\title{
La Ictiofauna de los
}

Yacimientos Arqueológicos

del Noroeste de la Península lbérica

Eduardo González Gómez de Agüero

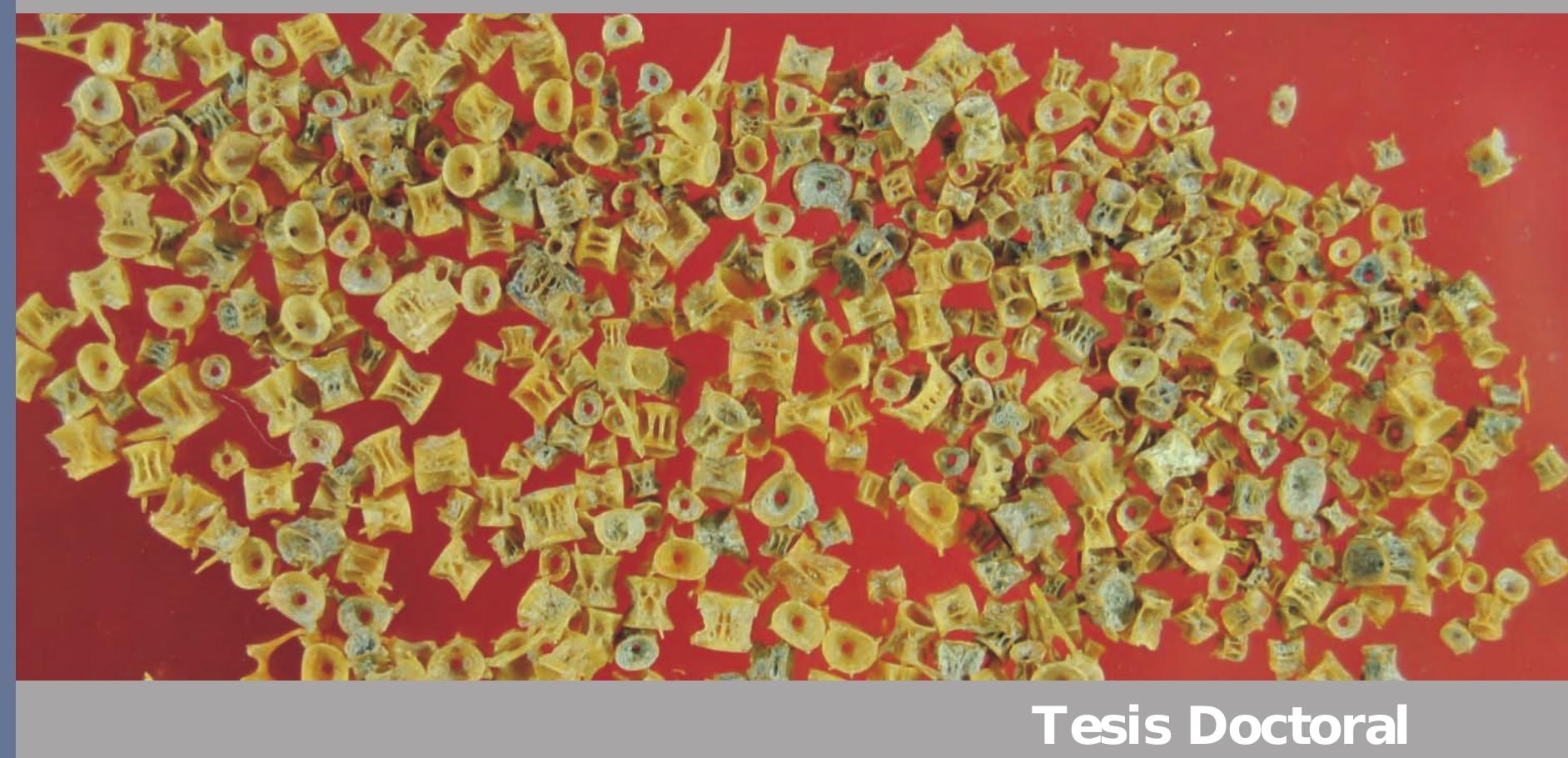

Universidad de León 2013 



\title{
LA ICTIOFAUNA DE LOS YACIMIENTOS ARQUEOLÓGICOS DEL NOROESTE DE LA PENÍNSUlA IBÉRICA
}

\section{Fishes in archaeological sites in the north-west of Iberian Peninsula}

\author{
Eduardo González Gómez de Agüero
}

Departamento de Historia

Universidad de León, 2013 

Tesis presentada para obtener el grado de Doctor por la Universidad de León por:

Eduardo González Gómez de Agüero

$\mathrm{V}^{\circ} \mathrm{B}^{\circ}$

Dr. Carlos Fernández Rodríguez

Director de Tesis 

A mis padres, Eduardo y Rosi A mi hermana, Cristina

A Nuria y a Iria 



\section{AGRADECIMIENTOS.}

En primer lugar, tengo que agradecer al Dr. Carlos Fernández Rodríguez el acogerme bajo su dirección, así como por su ayuda y guía, que han hecho posible el presente trabajo, aportando todo su saber, experiencia y prudencia que espero quede reflejada en el estudio.

Al Departamento de Historia de la Universidad de León, principalmente a los Dres. Federico Bernaldo de Quirós, Ana Neira Campos, Carlos Fernández Rodríguez y Natividad Fuertes Prieto, del Área de Prehistoria, cuyas instalaciones se utilizaron para el análisis y procesado de las muestras. Tengo que agradecer especialmente a la Dra. Natividad Fuertes Prieto todo el apoyo ofrecido desde que empezara mi carrera investigadora, así como por la ayuda prestada en la búsqueda bibliográfica y en la solución de diversos problemas que fueron surgiendo a la hora de realizar este trabajo.

A todos los estudiantes de la Licenciatura de Historia de la Universidad de León que durante estos años han pasado por el laboratorio de Prehistoria, por su colaboración en el procesado del material. Entre ellos hay que destacar especialmente a Juan Carlos Álvarez que en los últimos años ha sido uno más del equipo, colaborando en todos los proyectos que fueron surgiendo.

Al Dr. Xurxo Ayán Vila por ceder los materiales del Castro Grande de O Neixón, así como permitirme muestrear el conchero de este yacimiento e incluirme en su Equipo Técnico en las campañas de excavación de 2005, 2006 y 2007 . Además, tengo que agradecerle la confianza depositada en mí, así como su amistad y mostrarnos una manera diferente de hacer arqueología. Neixón fue una gran familia (United Neixón) de la que todos aprendimos mucho, por eso es necesario recordar a todos los miembros del Equipo Técnico: Leo, Muros, Álvaro, Jano, Pablo, Lucas, Sara, el Topo, Gago y Rafa, así como a Sonia, Noemí, Carlos de Rianxo y familia, por todo lo que me aportaron profesional y personalmente. Además del Equipo Técnico es necesario agradecer a los integrantes del Campo de Trabajo de las campañas de 2005, 2006 y 2007 por su colaboración en el procesado del material, como a toda la gente de la Parroquia de Nine por su acogida.

A Rafael Rodríguez Martínez, director de las excavaciones de A Lanzada en la campaña de 2010, por permitirme acceder al material de las últimas excavaciones, así como por la amistad que ha ido surgiendo desde los tiempos de O Neixón. 
A Roberto Aboal Fernández que cedió los materiales de Montealegre para su análisis, así como fotografías, planimetrías e informes para poder realizar el presente estudio.

A Emilio Ramil de AXA Arqueología por haberme facilitado el material de Area y del conchero de Punta Atalaia, permitiéndome realizar el muestreo y aportando toda la información y aparato gráfico que le fue solicitado. Del mismo modo agradecer a Eva Castro Vigo los materiales y la información del Solar 02 de Punta Atalaia.

A Elena Mosquera y Pablo Vaamonde de AMBIOTEC, que me facilitaron el acceso a los materiales de Taramancos, aportando toda la información gráfica y documental que le solicitamos para la elaboración del estudio.

A Raquel Casal y Francisco Acuña de la Universidade de Santiago de Compostela, que nos dejaron los materiales del Castelo da Rocha Forte para su estudio.

A Eduardo Ramil Rego, director del Museo de Prehistoria e Arqueoloxía de Vilalba, por todo lo que ha aportado, así como por la ayuda que nos ha prestado en todo este tiempo.

Por supuesto agradecer a mi familia todo el apoyo y comprensión que me han dado para la realización de este trabajo, sin su aportación no hubiera sido posible terminarlo. Especialmente a Nuria, por aguantarme todo este tiempo y por aceptar los sacrificios y el modo de vida que supone esta profesión.

A Víctor Bejega García todo, porque sin él no hubiera sido posible llegar a donde se ha llegado.

A todos ellos y alguno que se me habrá olvidado, si es así pedir perdón porque no ha sido intencionado, muchas gracias por todo, sin vuestra aportación no hubiera sido posible la finalización de este trabajo. Se que una simple cita es insuficiente para agradecer todos los apoyos recibidos durante los últimos años, espero que el resultado final compense vuestra aportación. 


\section{ÍNDICE}

Agradecimientos. .7

índice 9

I. Introducción: Objetivos y planteamientos .............................................15

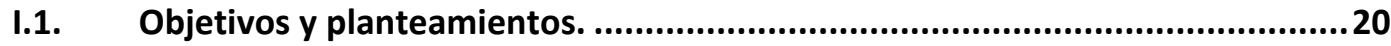

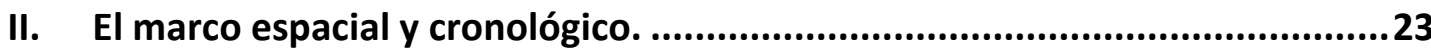

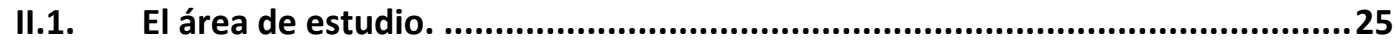

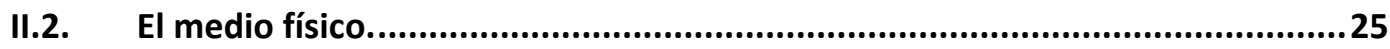

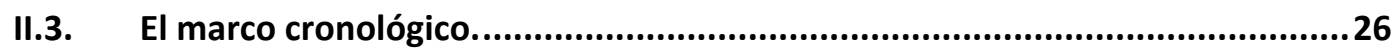

II.3.1. La Cultura Castreña del Noroeste. .................................................................................. 27

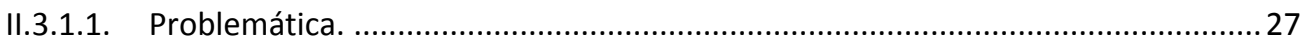

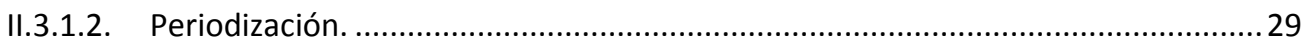

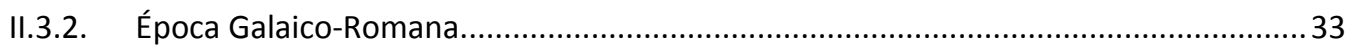

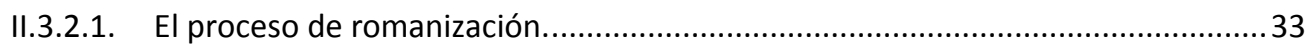

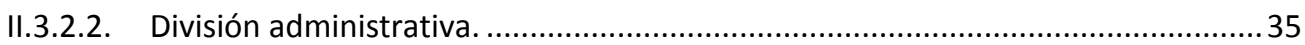

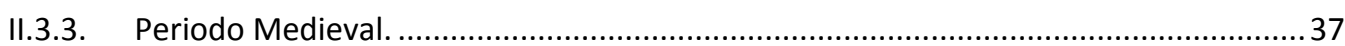

II.3.3.1. La Tardoantigüedad y la Alta Edad Media.........................................................37

II.3.3.2. La Plena y Baja Edad Media en Galicia. .............................................................. 39

II.4. Las condiciones del mar. .................................................................41

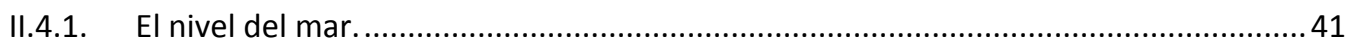

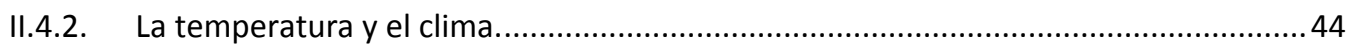

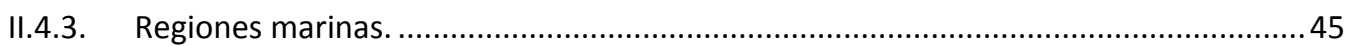

III. La ictioarqueología en el noroeste peninsular. ......................................47

III.1. La pesca en los estudios arqueológicos hasta la década de 1970. ...................50

III.1.1. La década de 1920: los concheros y la explotación del medio marino........................52

III.1.2. La posguerra y el abandono de los análisis. ............................................................55

III.2. El comienzo de la Ictioarqueología: la década de 1970 ................................58

III.2.1. Los primeros estudios ictioarqueológicos............................................................59

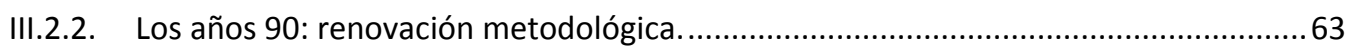

IV. Material y Métodos...................................................................................67

IV.1. Obtención y tratamiento de las muestras. ......................................................69

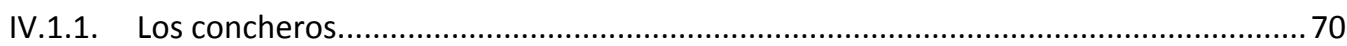

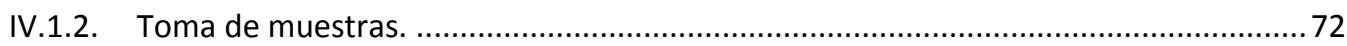

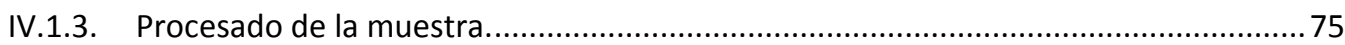

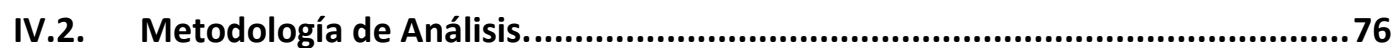

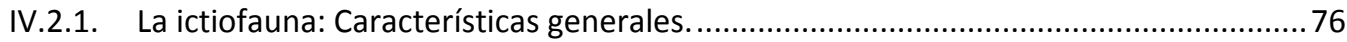

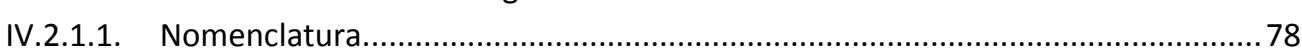

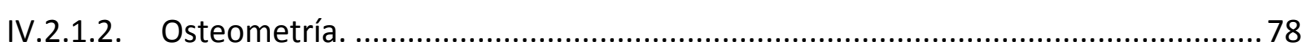

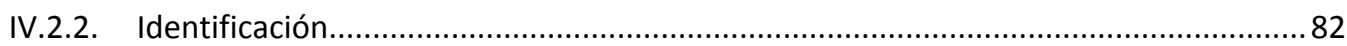

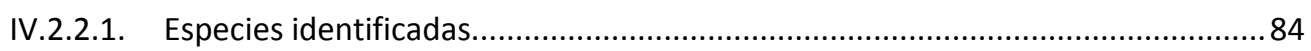

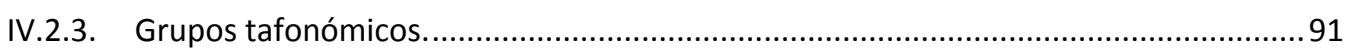




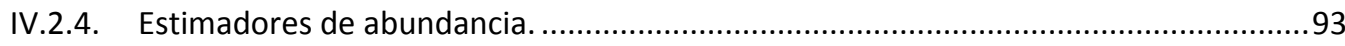

IV.2.4.1. Número de Restos (NR) ...................................................................... 93

IV.2.4.2. Número Mínimo de Individuos (NMI) ........................................................... 94

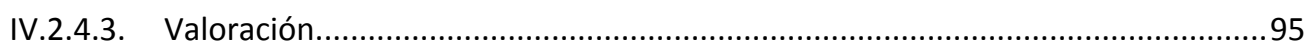

V. Análisis de los yacimientos. ........................................................................97

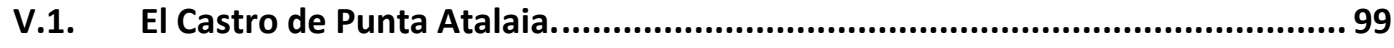

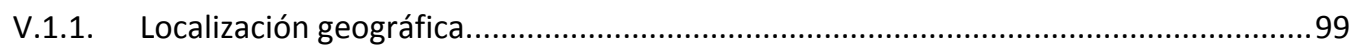

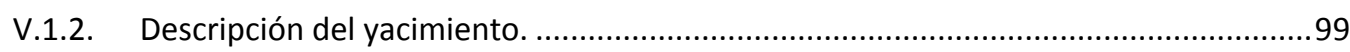

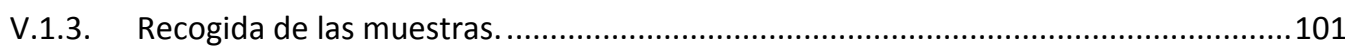

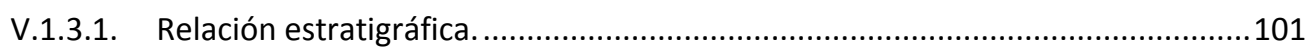

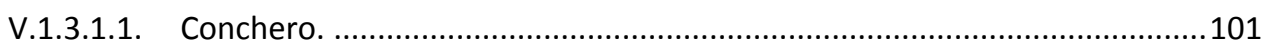

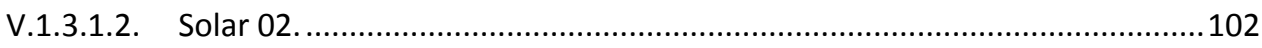

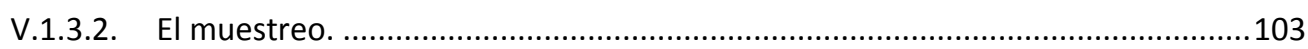

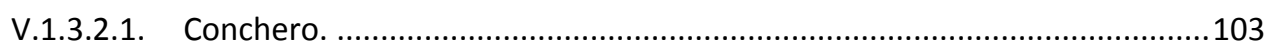

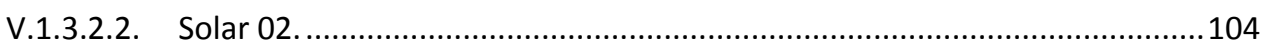

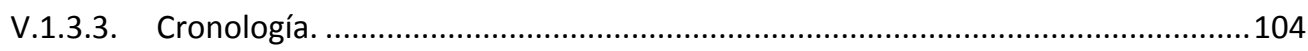

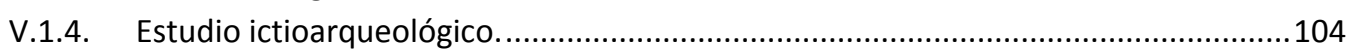

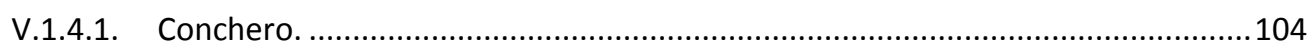

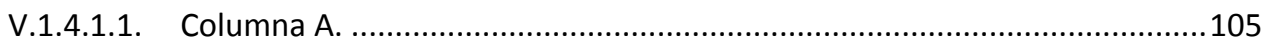

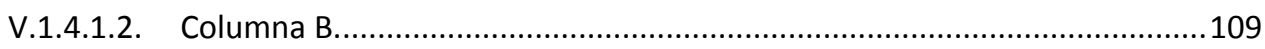

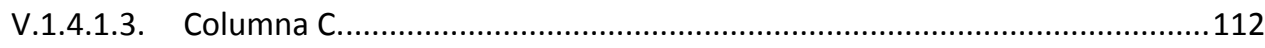

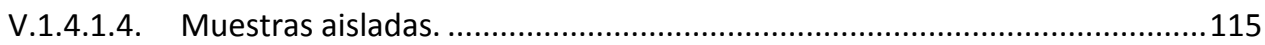

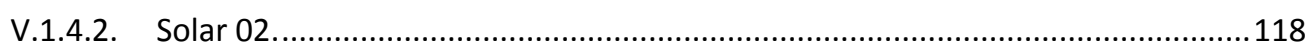

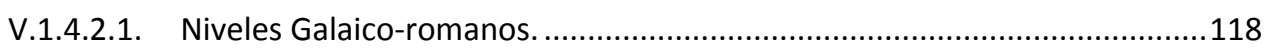

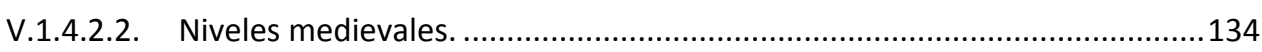

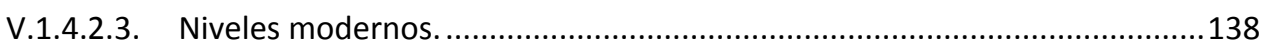

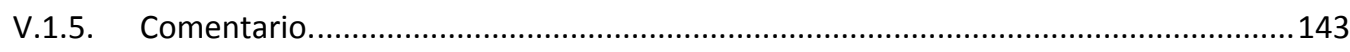

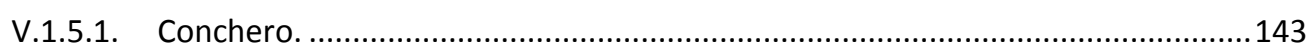

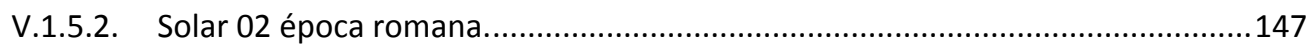

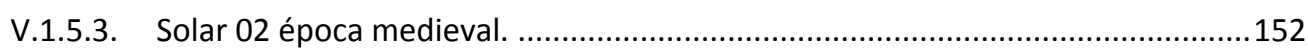

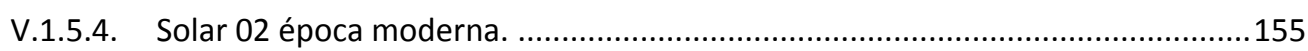

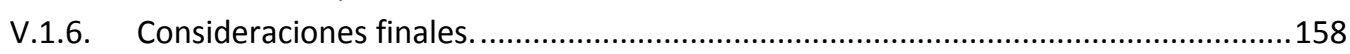

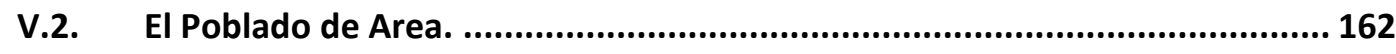

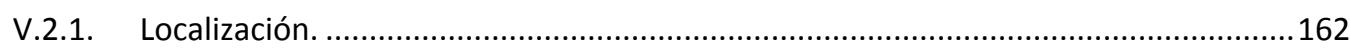

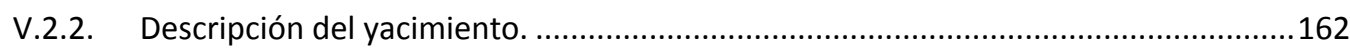

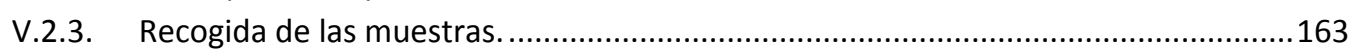

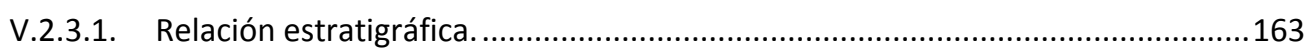

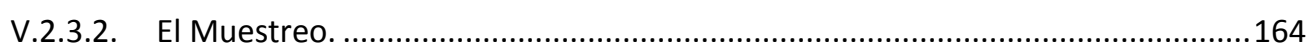

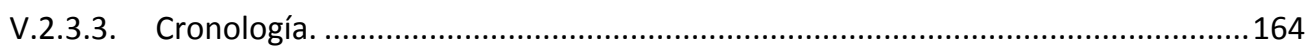

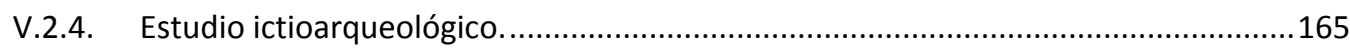

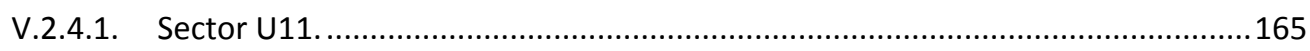

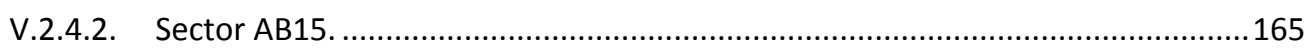

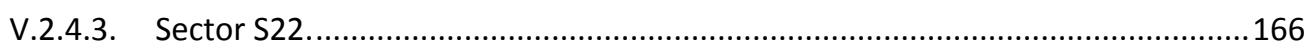

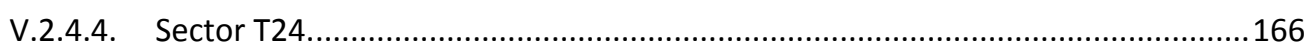

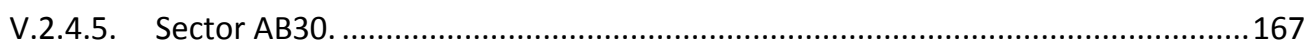

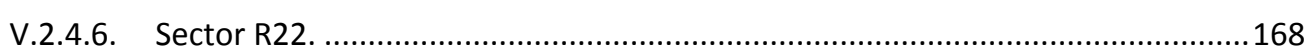

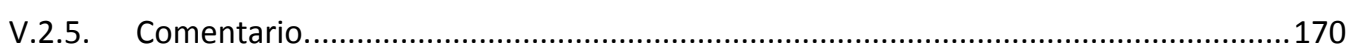




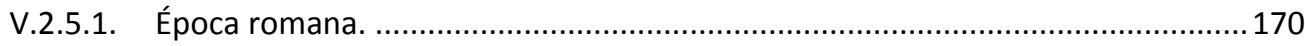

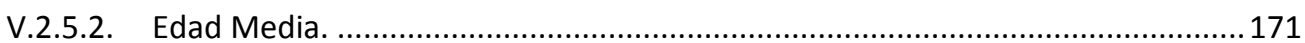

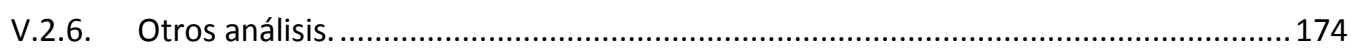

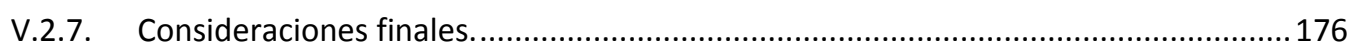

V.3. Taramancos. ................................................................................... 179

V.3.1. Localización geográfica. .................................................................................. 179

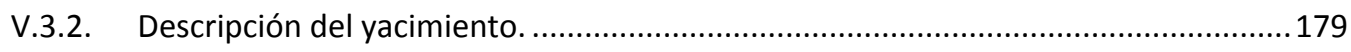

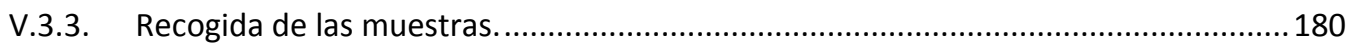

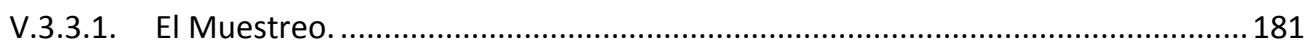

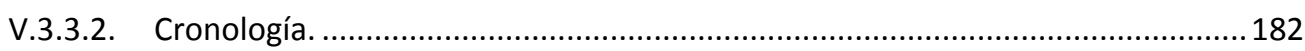

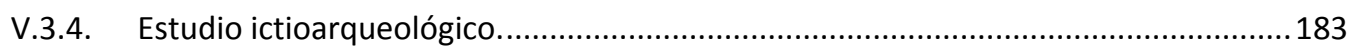

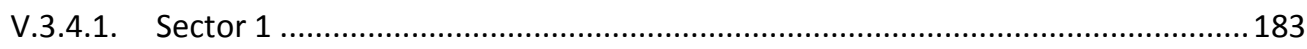

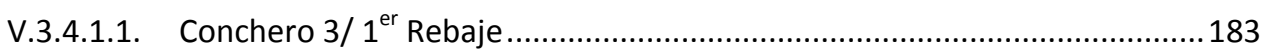

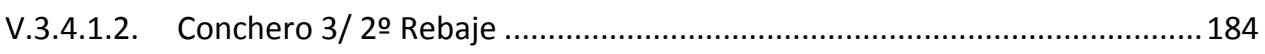

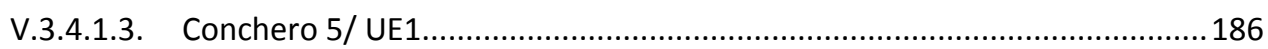

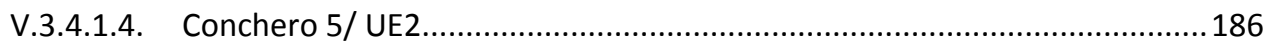

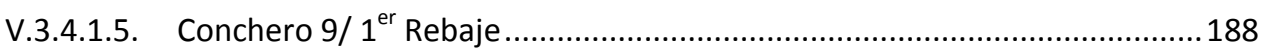

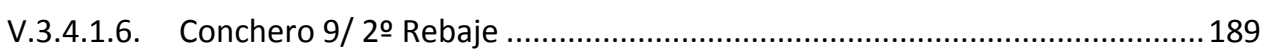

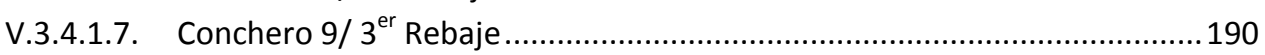

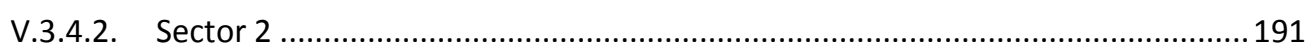

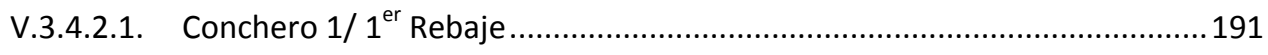

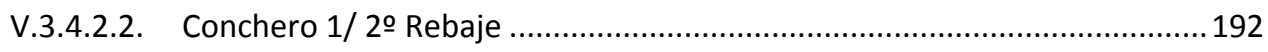

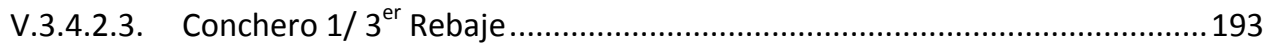

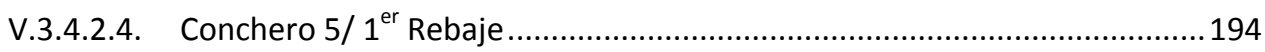

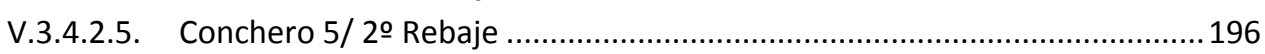

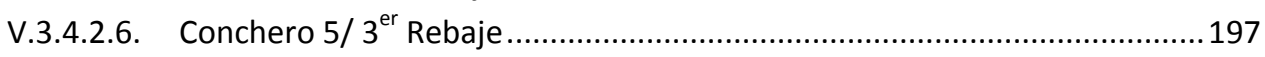

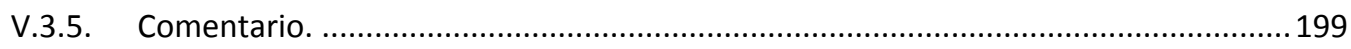

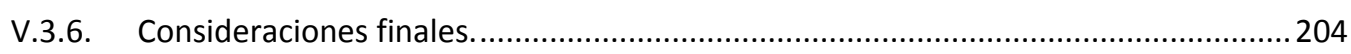

V.4. El Castro Grande de O Neixón. ............................................................ 207

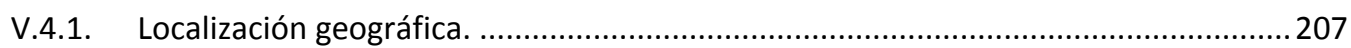

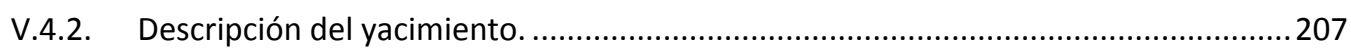

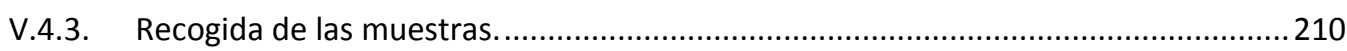

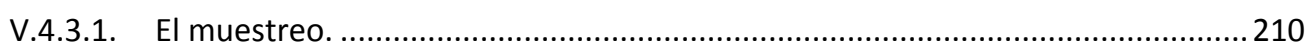

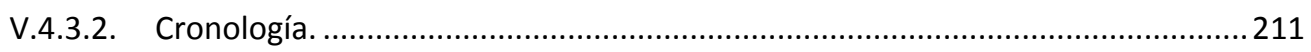

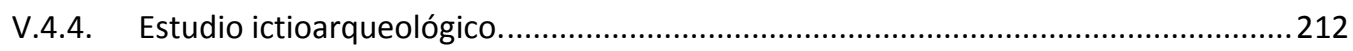

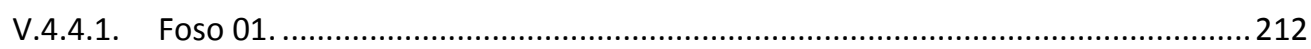

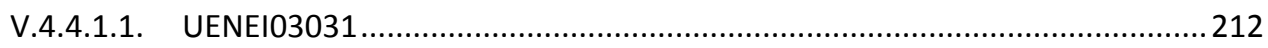

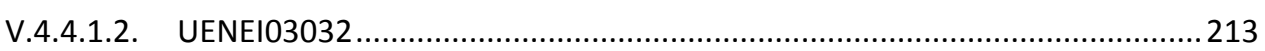

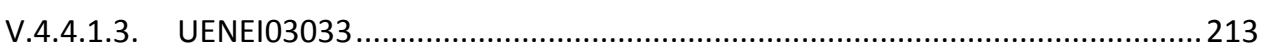

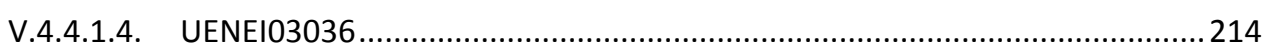

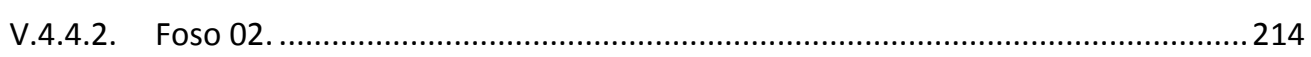

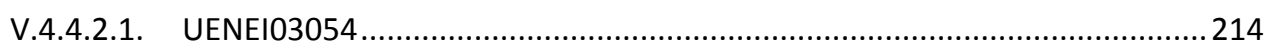

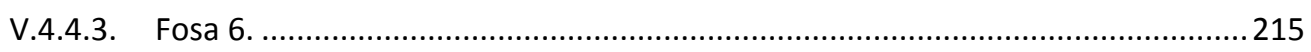

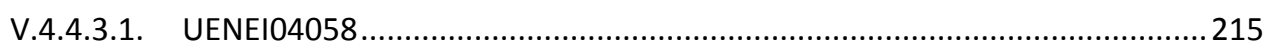

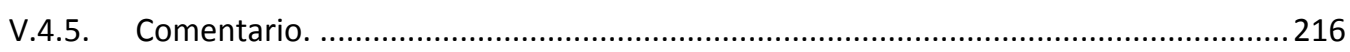

V.5. El Poblado de A Lanzada. .................................................................... 221

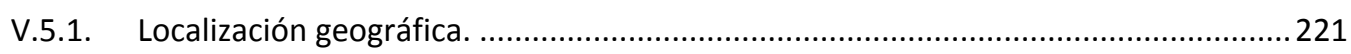

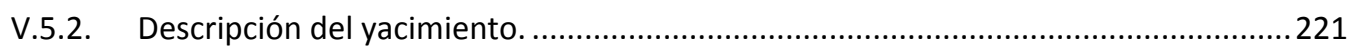




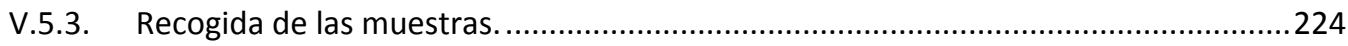

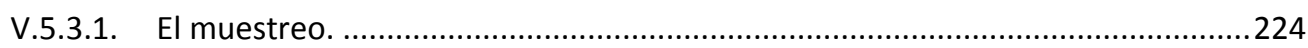

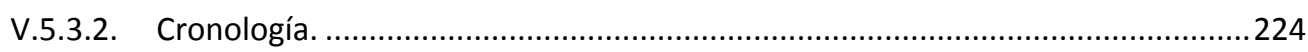

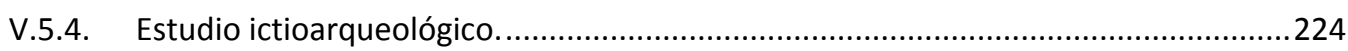

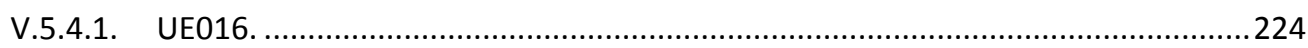

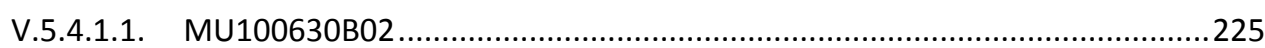

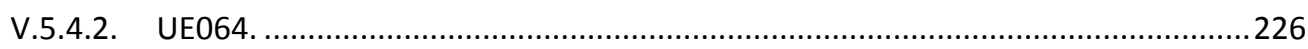

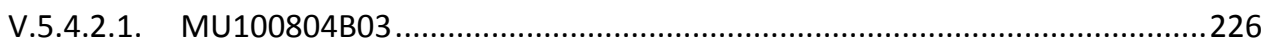

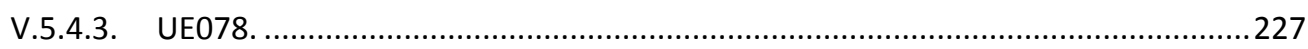

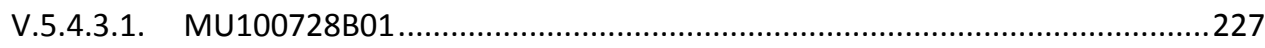

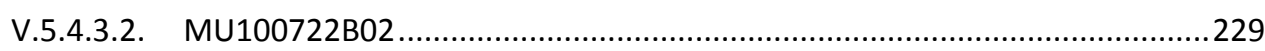

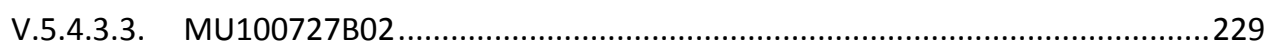

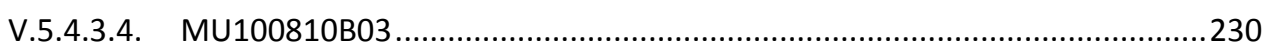

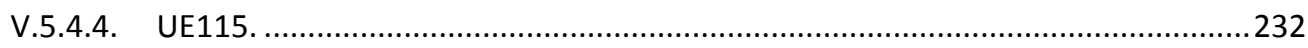

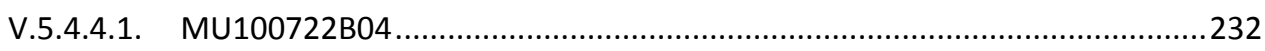

V.5.4.5. UE152.

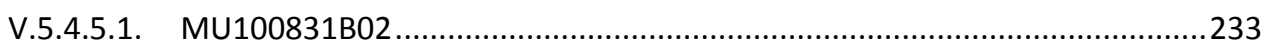

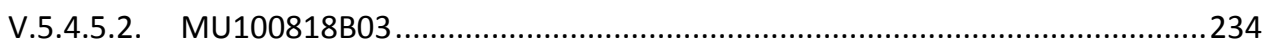

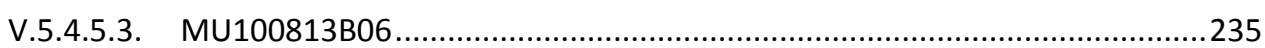

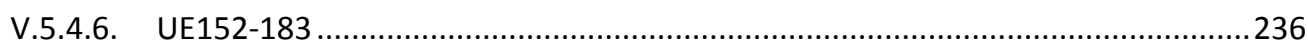

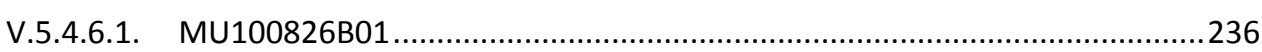

V.5.4.7. UE183.

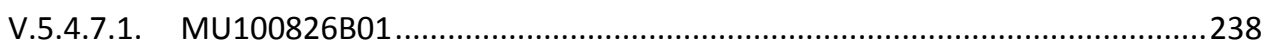

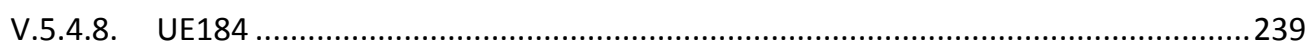

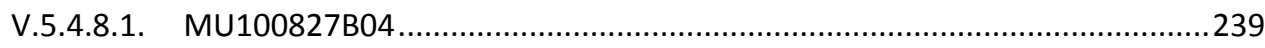

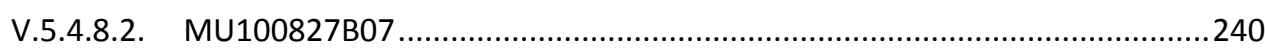

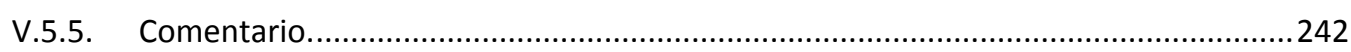

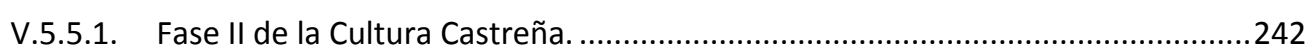

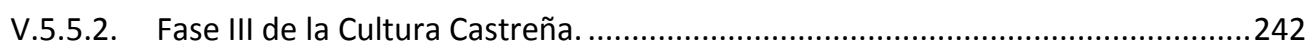

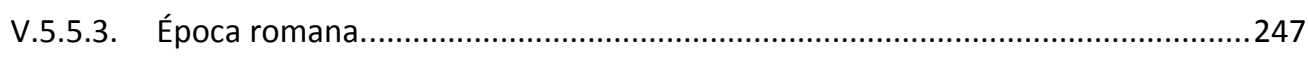

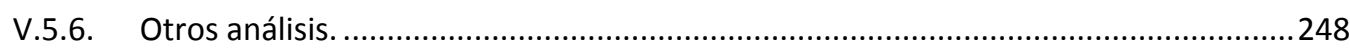

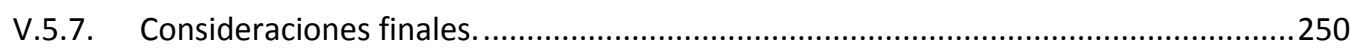

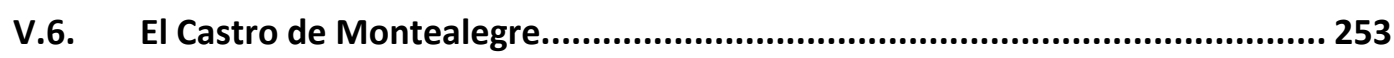

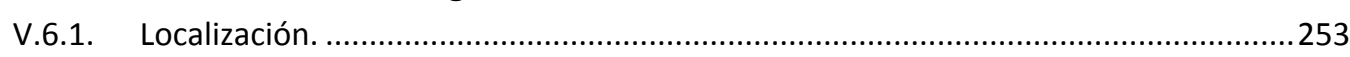

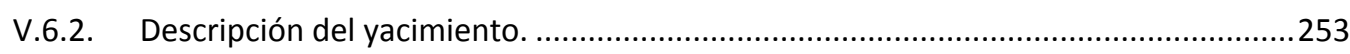

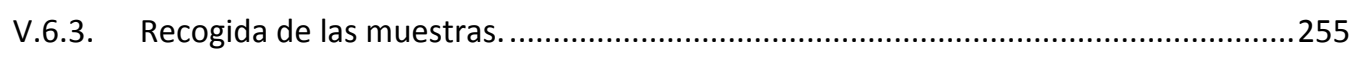

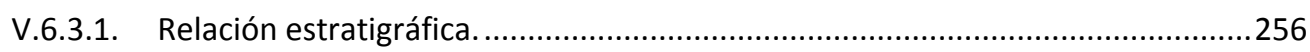

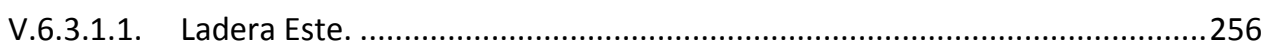

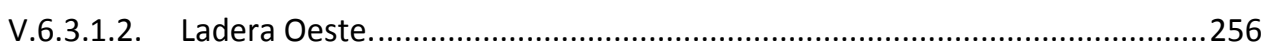

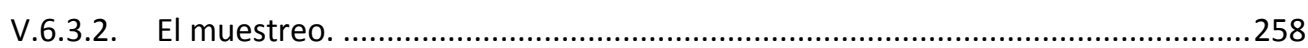

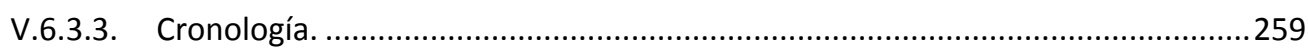

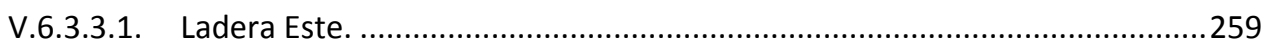

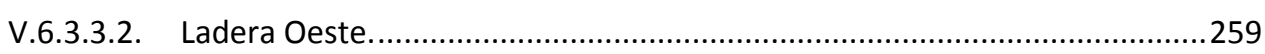

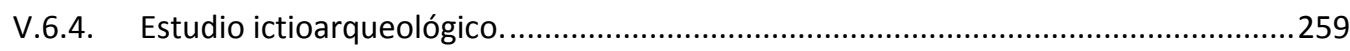

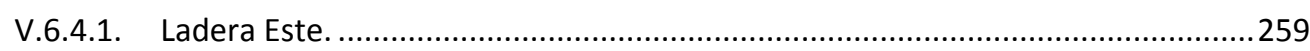

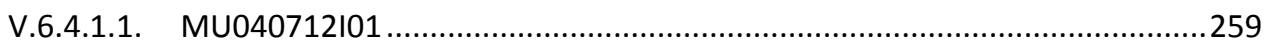

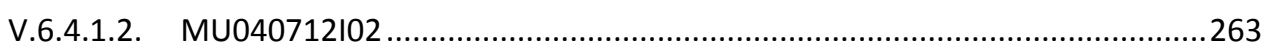

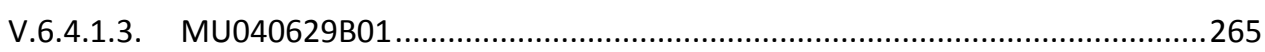


V.6.4.1.4. MU040426I01 267

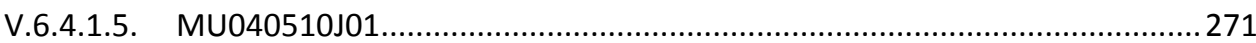

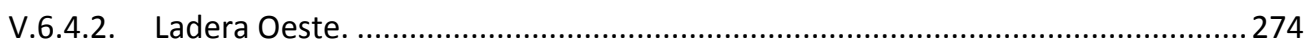

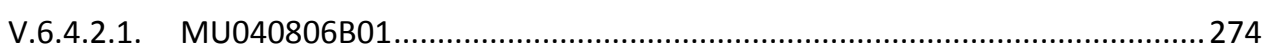

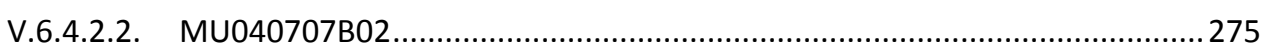

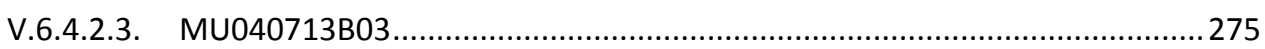

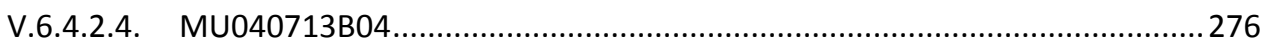

V.6.5. Utensilios de pesca documentados en el yacimiento. ..........................................276

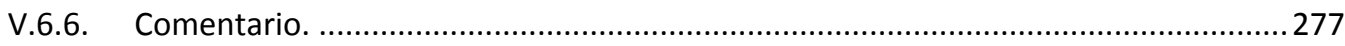

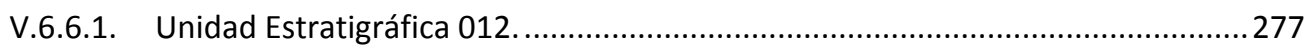

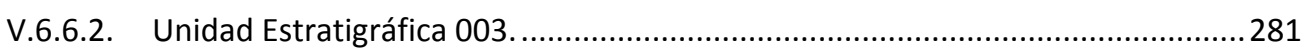

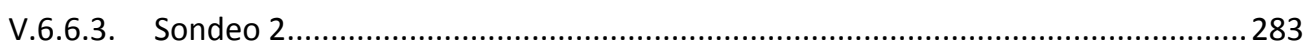

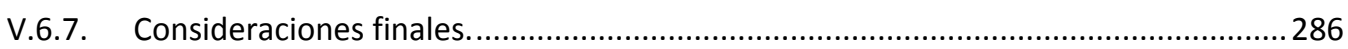

V.7. El Castro de Punta do Muiño do Vento..................................................28 288

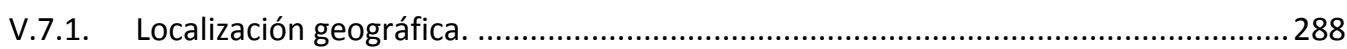

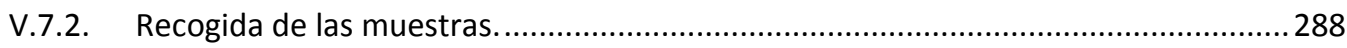

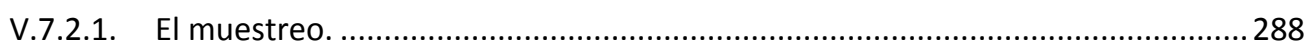

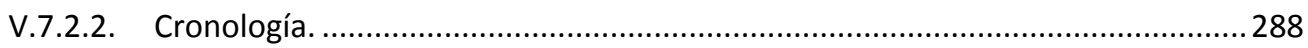

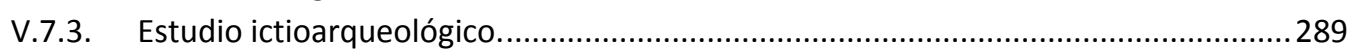

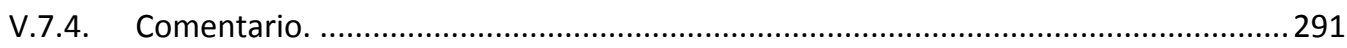

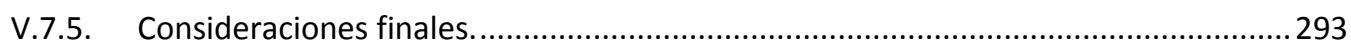

V.8. Castelo da Rocha Forte. ................................................................... 295

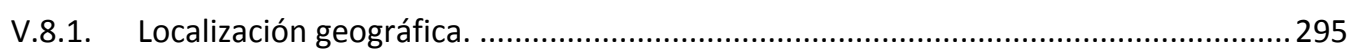

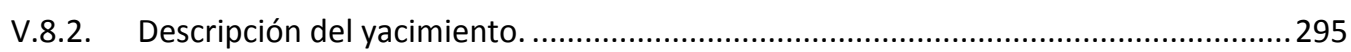

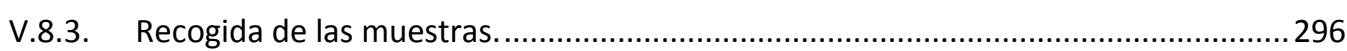

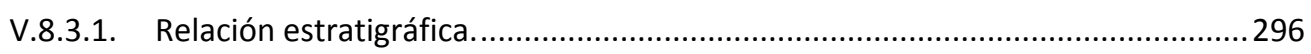

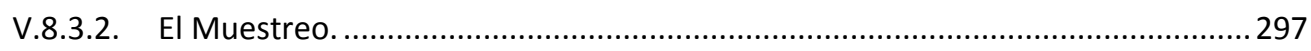

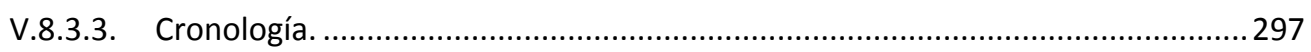

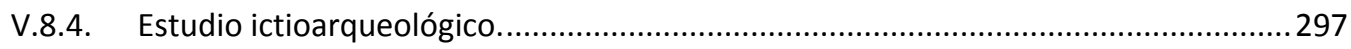

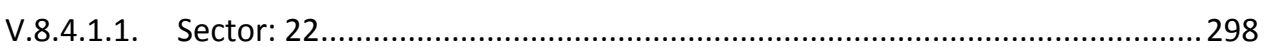

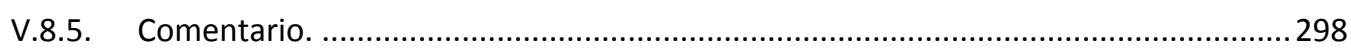

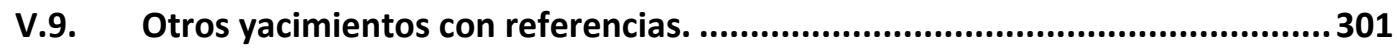

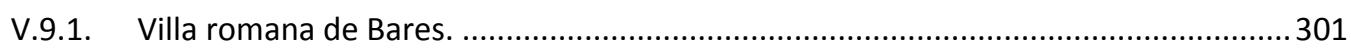

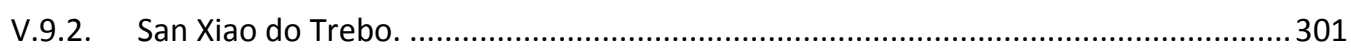

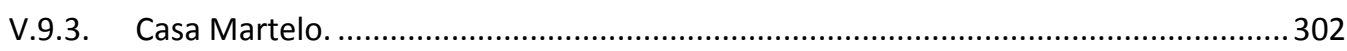

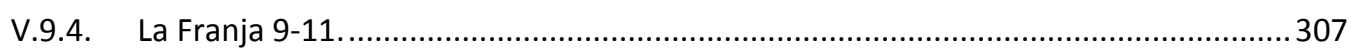

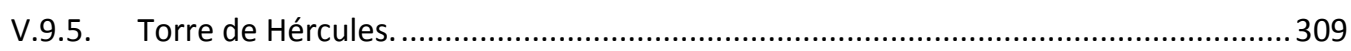

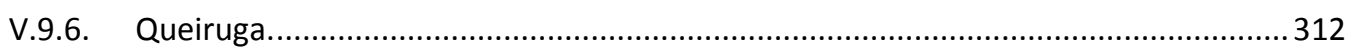

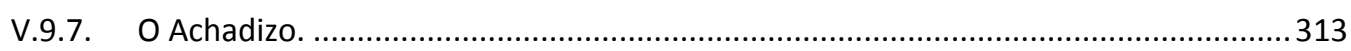

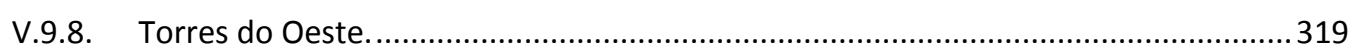

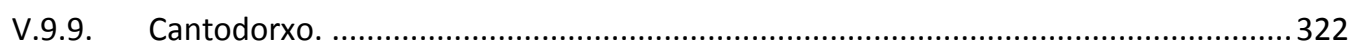

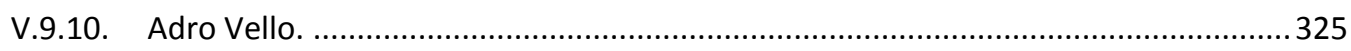

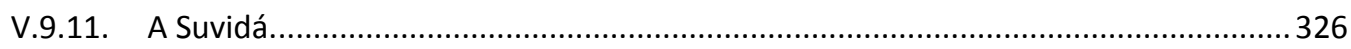

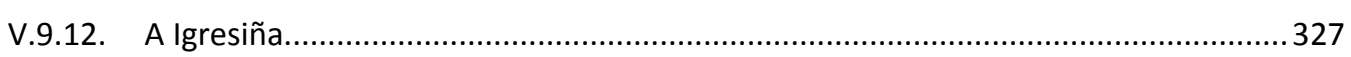

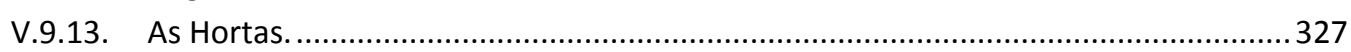

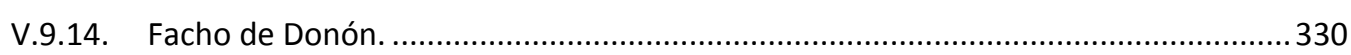

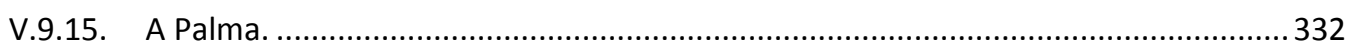

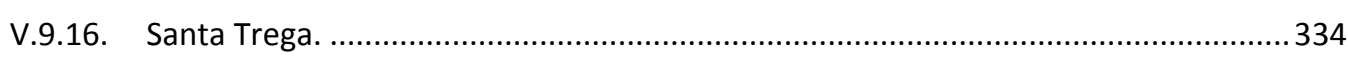




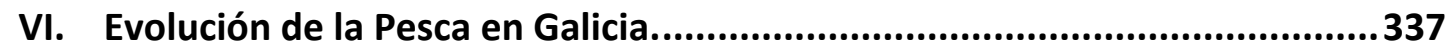

VI.1. La pesca en la Cultura castreña...................................................................... 339

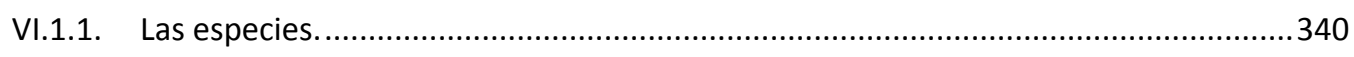

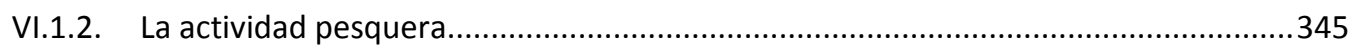

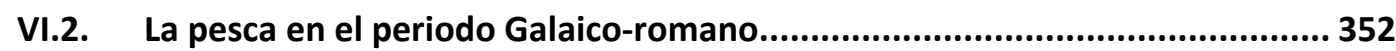

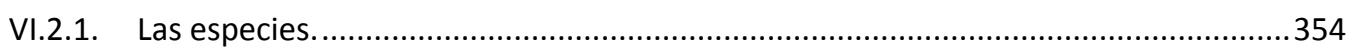

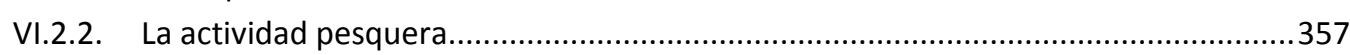

VI.3. La pesca en el Mundo Medieval y Moderno.................................................... 365

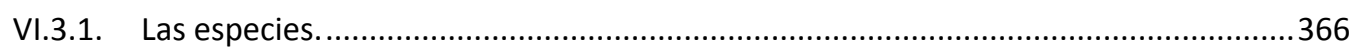

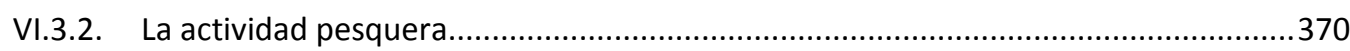

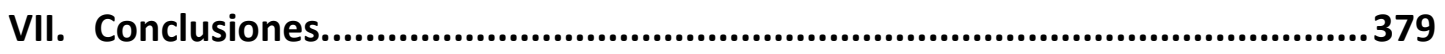

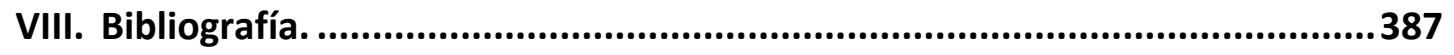

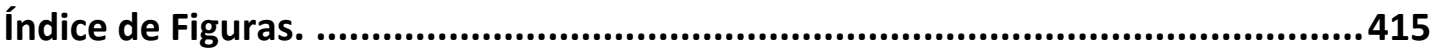

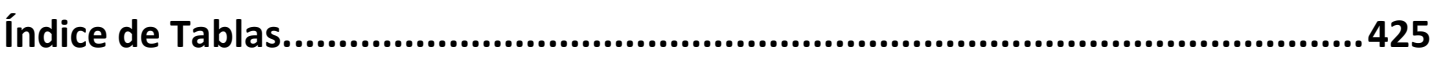

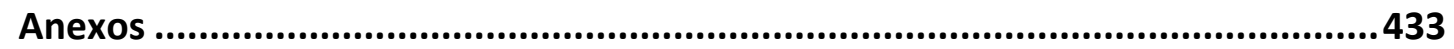




\section{INTRODUCCIÓN: OBJETIVOS Y PLANTEAMIENTOS}



La pesca es una de las actividades económicas más importantes en la Galicia de los últimos siglos. Esto ha ocasionado que la mayor parte de los historiadores y arqueólogos atribuyan a esta actividad un papel fundamental en las sociedades pretéritas que ocuparon el noroeste de la Península Ibérica. Además, la aparición de grandes depósitos de conchas, en los cuales era habitual recuperar espinas de pez y objetos relacionados con la pesca, no hizo sino agrandar el mito de la pesca antigua en Galicia. Sin embargo, pese al papel relevante que se le atribuía, no fue habitual la realización de estudios que intentaran definir la importancia de real de esta actividad, y cómo se desarrolló en las diferentes sociedades que ocuparon el litoral hasta la actualidad. Como veremos en el primer capítulo de este trabajo, durante el siglo XIX y la mayor parte del siglo XX la literatura arqueológica se limita a atribuir a la pesca un papel propio de la sociedad costera gallega actual y de las características reflejadas en los textos clásicos. Este vacío en el estudio de los restos faunísticos de peces estaba originado por diversos motivos, no siendo un fenómeno aislado. La ausencia de análisis supone un problema común a toda la fauna arqueológica, si bien en relación con la ictiofauna la problemática se ve agravada al tratarse habitualmente de restos mucho más frágiles y de menores dimensiones. Este aspecto ha ocasionado en muchos casos una incorrecta o nula recogida de las muestras en los yacimientos, limitando y adulterando los resultados que se pueden obtener del análisis faunístico.

No será hasta la década de 1970 cuando este panorama cambie ligeramente con la publicación de diversos análisis realizados por Vázquez Varela. Estos trabajos ofrecen un nuevo punto de vista que abandona la literalidad de los textos clásicos, dando comienzo al desarrollo de la ictioarqueología en Galicia. El punto álgido de estos estudios en el Noroeste tendrá lugar en la década de 1990, culminando en el 2003 con la defensa de la Tesis Doctoral de Ferré Álvarez en la Facultad de Biología de la Universidad de Santiago de Compostela. Desde este momento la investigación ictioarqueológica fue desapareciendo de las publicaciones arqueológicas referentes al noroeste ibérico.

Dentro de este marco, y ante la necesidad de retomar los estudios arqueoictiológicos en el noroeste, se ha desarrollado el presente trabajo. Uno de los principales problemas a los que nos enfrentamos a la hora de afrontar nuestro proyecto de investigación fue la recuperación de materiales y su representatividad. Por todo ello el primero de los objetivos que nos propusimos fue intentar sistematizar la recogida de muestras de modo que fuera una práctica habitual en los yacimientos arqueológicos. La mayor parte de los restos de pez documentados en yacimientos gallegos proceden de los depósitos denominados concheros. Por este motivo, la metodología de muestreo utilizada para el presente trabajo es fruto de una intensa actividad de recogida de muestras realizada en los últimos años y que ya se apuntaba en nuestra Tesina de Licenciatura, defendida en el año 2009 en la Facultad de Filosofía y Letras de la Universidad de León. Con esto no pretendemos que este sistema tenga un carácter definitivo o único, simplemente lo consideramos como un punto de partida desde el que se pueda formular 
nuevas propuestas que permitan resultados más adecuados. Para ello creemos básica la comunicación entre zooarqueólogos y arqueólogos, de modo que se puedan aunar experiencias que nos permitan superar los problemas metodológicos y avanzar en los diferentes ámbitos de esta investigación. Prácticamente la totalidad de los yacimientos inéditos que se presentan en las siguientes páginas han sido muestreados por nosotros, o bien siguiendo nuestras pautas.

El otro de los puntos de partida del presente trabajo fue hacer una revisión de los datos conocidos hasta la fecha añadiendo los resultados de los nuevos estudios. Con ello pretendíamos obtener una visión de conjunto de la pesca en el noroeste, definiendo, hasta donde fuera posible, las particularidades de cada periodo y la existencia de cambios a lo largo del tiempo, analizando las causas que los produjeron. Durante este trabajo nos encontramos con toda una serie de problemáticas: La mayor parte de los estudios no realizados por nosotros presentaban ausencia de ciertos datos como el peso y el volumen de sedimento procesado, vaguedad cronológica y ausencia de contexto arqueológico. En cuanto a los nuevos conjuntos, la imprecisión cronológica sigue siendo uno de los principales problemas, estando muy vinculada al método de excavación realizado y a la ausencia de análisis de otras evidencias arqueológicas. También fue un inconveniente la falta de información arqueoictiológica existente para algunas fases.

Sin embargo, una característica común a todos los periodos es la adscripción geográfica de la mayor parte de las muestras a una determinada zona geográfica. De este modo, para la Cultura Castreña únicamente tenemos yacimientos en las Rías Bajas, mientras que del periodo medieval los datos se concentran en la Costa Cantábrica. Pese a esto, consideramos oportuno incluir todos los datos que tenemos desde época prerromana hasta la Edad Moderna, ya que consideramos que es una oportunidad para completar los análisis anteriores con los nuevos resultados, y de este modo observar los cambios en la pesca en un amplio marco cronológico.

El poder desarrollar este estudio ha sido una tarea que ha ocupado varios años, siendo necesario muestrear una parte de los yacimientos que aquí se presentan, ya que todos han sido excavados en los últimos 6-7 años, así como realizar una colección comparativa de referencia. Somos conscientes de la existencia de otros análisis deben llevarse a cabo, sin embargo consideramos que las siguientes páginas suponen un importante paso para la ictioarqueología del noroeste, así como para el conocimiento de la pesca antigua en Galicia.

El área geográfica de nuestro estudio se restringe principalmente al territorio de la actual Galicia debido a que es el área en la que llevamos trabajando varios años, así como por proceder todos los materiales de yacimientos situados en esta Comunidad Autónoma. Pese a esto sabemos de lo artificial de esta división y más cuando se tratan periodos tan dispares entre sí. El Castelo da Rocha Forte es el único yacimiento interior con el que 
contamos. El resto de muestras proceden de asentamientos litorales, lo que supone un problema para periodos como el romano o el medieval, ya que el comercio con zonas interiores va a ser un factor decisivo en la explotación pesquera y en el desarrollo de las industrias relacionadas con ella.

En relación con la estructura del trabajo, se ha dividido en ocho grandes bloques. En el primero de los capítulos se definirán los objetivos y planteamientos del presente trabajo, mientras que en el segundo se realizará un encuadre cronológico y espacial del estudio. Además, también se ha incluido un breve apartado sobre las condiciones del mar en el cambio de era para el noroeste, ya que va a tener cierta relevancia en esta actividad económica.

El tercero es una revisión bibliográfica de los estudios de ictiofaunas arqueológicas en el territorio de la actual Galicia. Esta historiografía de la investigación ictioarqueológica no pretende ser exhaustiva, aunque sí recoger los trabajos más destacados para caracterizar el desarrollo en el noroeste durante los últimos cien años. El capítulo partirá de los primeros datos y referencias de comienzos del siglo XX, hasta llegar a las últimas publicaciones, distinguiendo un primer periodo que abarcaría desde las primeras referencias a la explotación de los recursos marinos hasta los años 70 del siglo XX, momento en que se produce el ya referido impulso a las investigaciones ictioarqueológicas en el noroeste con los trabajos de Vázquez Varela y que viene a definir una segunda fase que llega hasta la actualidad. Se ha decido centrar la revisión en el territorio de la actual Comunidad Autónoma de Galicia por diversos motivos: 1) Los yacimientos que hemos estudiado se localizan en este territorio; 2) Aunque las líneas de investigación van a estar influidas por corrientes desarrolladas en otros puntos de la península, prácticamente la totalidad de los estudios fueron llevados a cabo por investigadores vinculados a esta comunidad.

El cuarto de los capítulos se ha dedicado a exponer brevemente la metodología utilizada en las analíticas, desde la recogida de las muestras en el yacimiento hasta el análisis de los restos. Prestaremos una mayor atención a los concheros debido a que la mayor parte del material aquí estudiado procede de este tipo de depósitos. En este contexto, el muestreo va a ocupar un papel importante en el desarrollo de la metodología debido a la influencia que tiene la recogidad e las muestras en la representatividad de los conjuntos.

El quinto bloque resulta el de mayor extensión, presentándose los resultados obtenidos en los diferentes yacimientos estudiados. En primer lugar nos ocuparemos de aquellos que han sido estudiados por nosotros, ordenados siguiendo su disposición a lo largo de la costa, de norte a sur, teniendo en cuenta que alguno de los mismos presenta materiales de diferentes cronologías. En el apartado correspondiente a cada yacimiento se expondrá su localización geográfica y una breve descripción del mismo. Posteriormente se 
definirá la estrategia de muestreo empleada y el contexto estratigráfico de las muestras, para pasar a la presentación de los resultados obtenidos en el análisis ictiológico. Por último se realizará una breve interpretación del yacimiento a partir de la información presentada y, de existir, se comentarán los datos de estudios anteriores. En el último apartado se expondrán los análisis de otros yacimientos estudiados por distintos autores, ordenados también conforme a su disposición geográfica de norte a sur.

En el capítulo seis se presentan unas conclusiones generales de cada periodo, atendiendo tanto a aspectos taxonómicos como históricos. A la hora de realizar unas conclusiones finales, siempre que sea posible, se tendrá en cuenta la cronología de los depósitos para poder determinar variaciones diacrónicas en la explotación pesquera. El capítulo se encuentra subdividido en tres grandes bloques que se corresponden con cada periodo estudiado: el primero se dedicará a la Cultura Castreña del Noroeste; el segundo a la Época romana, haciendo referencia tanto a instalaciones salazoneras como a otros asentamientos; el último de los apartados se dedicara a la Edad Media y a la Edad Moderna.

Para concluir el trabajo hemos realizado unas conclusiones finales en las que resaltaremos los aspectos más significativos, teniendo presente que el capítulo seis, en conjunto, supone en sí mismo las conclusiones a nuestro estudio. El último de los bloques correspondería a la bibliografía consultada para la realización del presente trabajo.

Para terminar, se adjunta un anexo con todos los datos biométricos por especie y yacimiento correspondientes a los materiales analizados.

\section{I.1. OBJETIVOS Y PLANTEAMIENTOS.}

El parcial desarrollo de los análisis ictioarqueológicos en el noroeste peninsular, así como la falta de continuidad en los mismos, ha supuesto un problema a la hora de estudiar la actividad pesquera en esta área. Por este motivo, el principal objetivo del presente trabajo es realizar una revisión de los yacimientos estudiados hasta la fecha y aportar nueva información. De este modo, pretendemos contribuir al conocimiento de las sociedades que ocuparon la actual Galicia entre el siglo V a.C. y el XVII d.C. Abordaremos el papel que desempeñó la pesca en estas economías, así como los aspectos sociales y técnicos que implica esta práctica, si bien somos conscientes de la dificultad que suponen estos últimos objetivos debido a la falta de datos, principalmente para algunos periodos.

El estudio de periodos (principalmente desde la Edad Media) con documentación escrita, nos planteó el problema de la gran cantidad de información documental con la que se cuenta. Por este motivo, y ante la imposibilidad de abarcar un estudio arqueozoológico y documental, decidimos centrarnos principalmente en la información aportada por el registro faunístico, si bien tendremos en cuenta estudios documentales sobre la pesca, ya 
que consideramos que pueden aportar información que no es posible obtener a partir de los datos arqueológicos, principalmente en periodos como el medieval.

Otro de los problemas que se nos planteó fue la representatividad de los restos y su recuperación en los yacimientos. Por este motivo, entre los objetivos que se plantearon estaba el de sistematizar una metodología de muestreo que permitiera la recuperación de los restos de manera sencilla y ordenada, sin que supusiera un problema para los arqueólogos debido a su complejidad, y además que resultara lo más representativa posible. Estos principios de muestreo se han realizado partiendo de los trabajos de diversos investigadores (Desse y Desse, 1988: 70; Wheeler y Jones, 1989: 49; Juan-Muns et alii, 1991: 85; Claassen, 1998; Dupont, 2006), adaptándolos a nuestra experiencia en los yacimientos del noroeste (Bejega García et alii, 2010). La mayor parte de las piezas óseas se documentaron en los depósitos conocidos como "concheros", por lo que en un principio estas pautas de muestreo se centraron más en este tipo de acumulaciones; sin embargo, el principal problema de recuperación de estos restos se encuentra cuando no aparecen grandes acumulaciones, por lo que también se adaptaron las estrategias de muestreo a estas circunstancias.

Por otro lado, nos marcamos como objetivo más conciso valorar el papel que jugó la pesca en las sociedades del pasado. Anteriores trabajos plantean la posibilidad de que la pesca tuviera una notable importancia en las economías costeras desde época castreña, si bien con la romanización se produce un aumento de las capturas, lo que sugeriría un mayor desarrollo de las artes de pesca (Vázquez Varela, 1998). Otros autores señalan un panorama similar, aunque cuestionan que en época castreña la pesca desempeñara un papel primordial dentro de estas economías de subsistencia (Ferré y Rey, 1998; Ferré, 2003). Dentro de este objetivo principal, consideramos necesario definir las características de la actividad pesquera en cada periodo, así como determinar las especies capturadas y sus implicaciones socio-económicas y técnicas para su captura. Partiendo de los estudios realizados hasta la fecha (Vázquez Varela, 1976; 1978; 1980; 1983; 1984; Vázquez Varela et alii, 1993; Vázquez Varela, 1998; Ferré y Rey, 1998; Ferré, 2003), se pueden explicitar las siguientes características para los diferentes periodos:

-Periodo prerromano: Explotación de especies del entorno inmediato al asentamiento, tanto de sustrato arenoso como rocoso, formando parte de una economía de subsistencia. La presencia de especies carnívoras indicaría su captura mediante líneas de anzuelos desde la costa o con embarcaciones cerca de ella. La ausencia de peces pelágicos reflejaría la ausencia de redes, si bien algunos autores defienden su utilización durante este periodo (Vázquez Varela, 1998). Se capturan principalmente besugos, fanecas y doradas, sin que se detecten evidencias de conservación si exceptuamos el caso de O Achadizo (Ferré et alii, 1996). 
-Época romana: Presencia de las primeras factorías conserveras en el noroeste, detectándose presencia de comercio de productos marinos hacia zonas del interior. Importante utilización de las redes para desarrollar la actividad pesquera destinada a estas factorías, capturando principalmente sardina y chicharro. Se van a ampliar las áreas de captación tanto en horizontal como en vertical. Por otro lado, en los castros se detecta una explotación pesquera similar a la del periodo anterior, capturándose especies como dorada, pargo, faneca y maragota.

-Edad Media: Se produce un aumento del número de taxones identificados, al tiempo que una diversificación y especialización en los útiles de pesca y en las capturas. Progresivamente las flotas se alejan de la costa, aumentando la profundidad de las capturas. Se detecta además un comercio de pescado fresco hacia el interior, formado principalmente por lubina, jurel, maragota, besugo y abadejo. Por otro lado, se va a desarrollar una industria pesquera especializada en la captura y tratamiento por medio del secado y la salazón de tres especies: sardina, merluza y congrio. Esta trilogía supone la base de la actividad pesquera medieval en Galicia.

Siguiendo la línea abierta para los moluscos por otros investigadores (Martínez Cortizas y Vázquez Varela, 2002), así como por nosotros en la tesina de licenciatura (González Gómez de Agüero, 2009), consideramos oportuno valorar posibles variaciones climáticas y medioambientales a través de las especies capturadas. Ciertas especies de moluscos y de peces son muy sensibles a cambios de salinidad y temperatura, por lo que pueden servir como indicadores de cambios medioambientales. En este sentido, los estudios realizados han documentado la presencia de especies como Stramonita haemastoma, así como la abundancia de Sparus aurata o Pagrus pagrus, en yacimientos datados entre el periodo castreño y el medieval siendo actualmente escasos en las costas gallegas, sugiriendo un progresivo enfriamiento de las aguas costeras entre el siglo I-XIII d.C. (Martínez Cortizas y Vázquez Varela, 2002; Ferré, 2003). Además, la incorporación de este tipo de variantes puede permitirnos explicar la presencia o ausencia de ciertas especies, así como intentar definir los límites del determinismo biológico en la economía pesquera. 
II. EL MARCO ESPACIAL Y CRONOLÓGICO. 



\section{II.1. El ÁREA DE ESTUDIO.}

A la hora de realizar un trabajo de este tipo, siempre se plantea la necesidad de establecer unos límites temporales y espaciales ante la posibilidad de que el estudio se vuelva inabarcable. En nuestro caso, hemos decidido centrarnos únicamente en los yacimientos situados en la actual Comunidad Autónoma de Galicia. Somos conscientes de la escasa validez que presentan las fronteras actuales a la hora de analizar las sociedades del pasado, sin embargo hemos tomado esta decisión por tres motivos principales: 1) La mayor parte de los yacimientos que hemos estudiado, así como de los que tenemos datos publicados en el noroeste, proceden de yacimientos localizados en esta comunidad. No obstante, y como resulta lógico, se harán referencias a otros estudios sobre ictiofaunas del noroeste peninsular situados fuera de los límites que hemos establecido. 2) El amplio abanico cronológico que abarcaba nuestro estudio dificultaba considerablemente la definición de un espacio físico con asentamientos coherentes culturalmente sin que se ampliara de manera sustancial el ámbito de análisis. Además, el estudio de un área determinada en diferentes períodicos históricos puede ser un punto de vista interesante a la hora de observar las distintas influencias que afectan a las poblaciones asentadas en ese espacio físico. 3) La desigual distribución a lo largo de la costa de los yacimientos estudiados supone igualmente un problema a la hora de establecer unas conclusiones generales. Sin embargo, la inclusión de yacimientos pertenecientes a dos ámbitos geográficos diferenciados, como son la costa cantábrica y la atlántica, puede ser un buen punto de partida para reconocer diferencias culturales e influencias del medio físico en las actividades económicas.

\section{II.2. EL MEDIO FÍSICO.}

La actual Comunidad Autónoma de Galicia se localiza en el extremo noroeste de la península Ibérica, con una superficie de $29.365 \mathrm{~km}^{2}$. Limita al norte con el Mar Cantábrico, y al oeste con el Océano Atlántico, con una longitud total de costa de $1.498 \mathrm{~km}$. Al sur, el Río Miño sirve de frontera con Portugal; por el este el Macizo Galaico-Leonés la separa de Asturias, León y Zamora. Presenta una altitud media de 500-600 m, aunque asciende desde el mar hasta los 1.600-2.100 m de altitud en las zonas montañosas. Este espacio físico presenta un relieve fragmentado con múltiples fallas y bloques elevados o hundidos, configurando un paisaje de sierras graníticas y cubetas rellenas de sedimentos cuaternarios. De norte a sur recorre el territorio una cordillera prelitoral, formando las Sierras Centrales o Dorsal Gallega que actúa como divisoria entre las aguas del Miño y los demás ríos atlánticos, creando un corredor en esta dirección. Al este se encuentran las Sierras Orientales y Surorientales, con una mayor cota que la Dorsal Gallega. Al norte se encuentran las Tierras Llanas, que coinciden en gran medida con la cuenca del Miño (Pagés Valcarlos y Vidal Romaní, 1998). 
El litoral presenta un perfil irregular, predominantemente rocoso y abrupto, con playas arenosas que pueden englobarse en cuatro tipos: ensenada entre acantilados, playas-dunas, estuarios y rías. La costa norte presenta una morfología recortada y acantilada, destacando la presencia de entrantes costeros. Se pueden diferenciar dos tramos, uno occidental muy recortado, y otro oriental que se transforma en un tramo recto con una rasa costera elevada y largas playas, similar al resto de la costa cantábrica (Lorenzo et alii, 2003). La costa atlántica se caracteriza por la presencia de los sistemas de la red de drenaje de la Galicia Occidental, las Rías, que confieren un perfil irregular a la línea costera (Pagés Valcarlos, 2000). La plataforma continental presenta una anchura de 40-60 km, jugando un papel muy importante en la explotación marina.

\section{II.3. EL MARCO CRONOLÓGICO.}

La mayoría de los yacimientos en los que se documentan restos de ictiofauna corresponden a periodos posteriores a la I Edad del Hierro. El primer testimonio faunísitico de pesca en la prehistoria del noroeste procede del yacimiento de Reiro (Arteixo) en la provincia de A Coruña. En 1968, los trabajos realizados por una empresa arenera en las proximidades de la playa de Barrañán, dejaron al descubierto toda una serie de materiales líticos y faunísticos adscribibles al mesolítico, entre los que destacan la abundante presencia de restos de pez (Ramil Soneira, 1973). De este conjunto hemos podido estudiar cuatro centros vertebrales depositados en el Museo de Prehistoria e Arqueoloxía de Vilalba. Este estaría formado por dos vértebras caudales y una precaudal de Pargo (Pagrus pagrus), así como una vértebra que no nos fue posible identificar debido a su mal estado de conservación.

Además de estas evidencias directas, contamos con otras indirectas que indicarían actividad pesquera en la prehistoria del noroeste. De este modo, durante el campaniforme se habrían utilizado espinas de pez para la decoración de la cerámica (Salanova y Prieto, 2011).

Por último, pertenecientes a la Edad del Bronce, contamos con cuatro restos óseos de ictiofauna en el conchero de Guidoiro Areoso (Illa de Arousa, Pontevedra) (Rey García, 2011), aunque desconocemos las especies a las que pertenecen.

Todas estas evidencias reflejan la práctica habitual y continuada de la actividad pesquera en el noroeste, por lo menos desde el mesolítico, si bien lo exiguo del registro no permite profundizar en su estudio. Debido a ello hemos centrado el trabajo en asentamientos posteriores al siglo $\mathrm{V}$ a.C. Por otro lado, hemos establecido el otro límite temporal en el siglo XVI d.C. debido a la ausencia de restos de momentos posteriores. 
Por lo tanto, en el presente estudio se analizará la actividad pesquera en tres grandes periodos, la Edad del Hierro (ss. V-I a.C.), la Época romana (ss. I-V d.C.) y el periodo medieval y moderno (ss. VI-XVI d.C.).

\section{II.3.1. La Cultura Castreña del Noroeste.}

\section{II.3.1.1. PROBLEMÁtICA.}

Establecer unos límites territoriales para enmarcar el desarrollo de la conocida como Cultura Castreña es sumamente complicado debido al carácter diverso y fragmentado que presenta el noroeste peninsular a lo largo de la Edad del Hierro (González Ruibal, 2006-07). Pese a esta problemática, tradicionalmente se han incluido en el marco geográfico de su desarrollo los territorios de la actual Galicia, Norte de Portugal y las áreas occidentales de las provincias de Zamora, León y Asturias (Carballo Arceo, 1996; Calo Lourido, 1997). Pese a esta fragmentación y falta de unidad política y territorial, el noroeste de Portugal y suroeste de Galicia sí parece reflajar una realidad integrada y similar, mientras que para el interior se aprecian ciertas diferencias frente a este núcleo (Peña Santos, 1996; Carballo Arceo, 1996; González Ruibal, 2006-07).

Desde los primeros momentos de la investigación de la Edad del Hierro en el noroeste, se ha utilizado el castro como elemento caracterizador de este periodo (López Cuevillas, 1953; Acuña Castroviejo, 1977), siendo aplicado tradicionalmente este término a todo poblado fortificado localizado en altura y que se desarrolla durante este periodo (López Cuevillas, 1953). En los últimos años la utilización del término castro ha sido sometido a análisis por diferentes autores ante la larga perduración de este modelo de asentamiento (Carballo Arceo, 1996). Si bien las primeras referencias de poblados fortificados en el Noroeste se documentan en torno al siglo IX a.C., la ocupación y creación de nuevos asentamientos continuará en época romana, siendo en muchas ocasiones reocupados estos poblados en la Edad Media, fruto de la inestabilidad producida por las diferentes invasiones (Calo Lourido, 1997). Otro de los problemas que se plantea es la existencia de este tipo de poblados en otros lugares de la Península Ibérica, por lo que no se constituye en un elemento exclusivo de la cultura de la Edad del Hierro en el Noroeste (Calo Lourido, 1997).

El castro como asentamiento presenta ciertas particularidades según su situación geográfica, pudiendo diferenciarse varios tipos básicos (Carballo Arceo, 1996):

A- En la cumbre de un otero, loma o interfluvio. Dominan en altura el espacio circundante con pendientes bajas o medias. Fácilmente defendible.

B- En la ladera de un monte con pendiente suave o media en una línea de ruptura de pendientes: 
-Línea de pendientes más pronunciada en la parte baja.

-Línea de pendientes más pronunciada en la parte alta.

-Aprovechando un rellano.

C- En coto o cerro rodeado de fuertes pendientes por al menos tres de sus lados. Dominan visualmente todo el espacio circundante, con buenas condiciones defensivas.

D- En meandro de río, en una pequeña elevación a modo de espolón.

E- Situados en zonas llanas o ligeramente inclinadas, pueden aprovechar una pequeña elevación. No tienen buenas condiciones de defensa, pero pueden tener un amplio control visual.

F- En punta marina. Poseen buenas condiciones de defensa y una excelente posición estratégica. Este tipo de castro será al que prestemos mayor atención por ser donde se va a producir un aprovechamiento más intenso del medio marino. Entre los castros litorales podemos diferenciar dos modelos básicos según su posición respecto al mar (Romero Masiá, 1980):

A- Asentado en un promontorio que se interna en el mar y tiene las defensas en el istmo. Según la complejidad de sus defensas pueden diferenciarse tres tipos:

A1- Muralla como única defensa.

A2- Muralla y foso.

A3- Varias murallas con fosos intermedios en un número variable.

B- Formas redondeadas y bañados por el mar únicamente en la parte que no precisan defensas.

En cuanto a la relación de este tipo de asentamientos con el medio marino y su explotación, podemos diferenciar dos tipos (Rodríguez López y Fernández Rodríguez, 1996):

-Castros Litorales: enclaves en los que el mar se incluye en el territorio inmediato que lo rodea.

-Castros Sublitorales: situados en cimas y medias laderas a cierta distancia de la línea de costa, en relación con valles de comunicación y tierras interiores, pero con un claro aprovechamiento de los recursos del medio marino. 
Como consecuencia del debate surgido en torno al término castro, también se ha cuestionado la aplicación del término Cultura Castreña para referirse a las sociedades de la Edad de Hierro en el Noroeste Peninsular. Ante esta problemática, diferentes autores consideran que este término puede ser utilizado mientras no existan alternativas (Carballo Arceo, 1996), incluso sería correcta la utilización de término "castrexo" para referirse al "conjunto de conocimientos y comportamientos de las sociedades humanas que habitan en los castros" (Calo Lourido, 1997), pero siempre hay que tener en cuenta que el término Cultura Castreña no representa ningún tipo de unidad cultural, ya que significaría homogenizar una realidad múltiple (González Ruibal, 2006-07).

\section{II.3.1.2. PERIODIZACIÓN.}

La amplitud cronológica del periodo se ha demostrado poco efectiva a la hora de definir los elementos característicos de lo "castrexo" en el Noroeste de la Península Ibérica, por ello se ha intentado realizar una periodización que permita una mayor precisión a la hora de caracterizar esta cultura.

La primera periodización, y que, pese a la linformación limitada del momento, será la base sobre la que se asentarán el resto de clasificaciones realizadas hasta la actualidad (Calo Lourido, 1997), es la propuesta por Maluquer de Montes en 1975; en ella se establecerán cuatro fases diferentes que van desde su comienzo en el Bronce Final hasta la desaparición con la romanización: Castrexo I 700-500 a.C. (construcciones de material perecedero e influjos del SO de la Península); Castrexo II del 500 a.C. al siglo II a.C. (comienzan las casas de piedra circulares y los primeros contactos con el mundo romano); Castrexo III desde las incursiones de Décimo Bruto a las Guerras Cántabras; Castrexo IV desde Augusto hasta su desaparición con el proceso de romanización.

En 1983 se presentan nuevas propuestas de periodización; por un lado la de Fariña Busto, Arias Vilas y Romero Masiá (1983), articulando el periodo en tres fases: Formación, desde los siglos VII-V a.C. al siglo IV a.C. (momento de importaciones cerámicas); Castrexo Clásico, desde el siglo IV a.C. al siglo II a.C. (subdividida en dos fases, con gran desarrollo metalúrgico y cerámica estampillada, además de casas de barro y piedra); Castrexo Final, de finales del siglo II a.C. al cambio de Era, pudiendo llegar hasta mediados del siglo I d.C.

Ese mismo año Almeida (1983) propone una clasificación mucho más compleja basada en las características arquitectónicas, comenzando en el siglo IV a.C. con las construcciones en piedra, y finalizando en época Flavia: Castrexo Antigo (casas redondas con lareira central y sin vestíbulo); Castrexo Medio, desde César hasta Augusto (aparecen los vestíbulos y acabado más cuidado); Castrexo Recente, durante la Época Augustea (casas con construcciones adheridas); Castrexo Final, hasta Época Flavia (desaparición del vestíbulo, construcciones angulares y traslado de la lareira a un lateral). Los momentos anteriores los considera como precastreño o formativos. También para el Norte de 
Portugal y de estas mismas fechas es la periodización de Silva (1983/84), en la que plantea la existencia de tres fases partiendo del Bronce Final y finalizando con las reformas flavias del siglo I d.C.

Posteriormente Martíns (1990) propone una nueva periodización basándose en el registro de la cuenca media del Cádavo, añadiendo a las tres fases expuestas por otros autores una cuarta fase que iría desde época Flavia hasta el siglo III d.C., adelantando además el inicio hasta el comienzo del primer milenio a.C.

Una de las periodizaciones con más relevancia es la de Carballo Arceo (1996), ya que supone una síntesis de los trabajos anteriores contrastados con dataciones radiocarbónicas. Según este autor se pueden señalar tres fases diferentes:

-Fase Antigua (finales del s. IX a.C. al s. V a.C.): Proceso de sedentarización y formación de poblados fortificados ocupando cerros y espolones con buenas condiciones defensivas y buen dominio visual. Son castros de pequeñas dimensiones con casas circulares y de materiales perecederos, barro y piedra.

-Fase Media (ss. V-VI a.C. al s. II a.C.): Se produce un abandono de los castros del periodo anterior con peor control estratégico, constatándose un vuelco hacia el valle para maximizar los recursos agropecuarios como respuesta a un aumento de población. Se duplican los recintos, perviviendo construcciones de barro, aunque predominan las de piedra tanto de planta circular como ovalada.

-Fase Final (s. II a.C.- s. I d.C.): Abandono de alguno de los castros y surgimiento de otros nuevos, produciéndose una concentración de la población en determinados lugares. Aparece una clara jerarquización de castros. Las construcciones siguen siendo circulares y ovaladas, con vestíbulo, y se asocian formando "complejos familiares". Este tipo de estructura desaparecerá a lo largo del siglo I d.C. abandonándose muchos de estos poblados y desarrollándose las villas.

Otro modelo de periodización es la realizada por de la Peña Santos (Bello Diéguez y Peña Santos, 1995; Peña Santos, 1992; 1996; Peña Santos y Vázquez Varela, 1996). Como apunta el autor, esta propuesta es indicativa, ya que no es posible extenderla a todo el área geográfica donde se desarrolla la cultura castreña, pero seguramente tampoco sea tan siquiera extensible al ámbito galaico por las diferencias culturales que se han dectado en las diferentes áreas.

-Fase de formación (s. X - s. V a.C.): Se inicia con un proceso de sedentarización de las comunidades humanas en pequeños poblados situados en 
puntos fácilmente defendibles, con edificaciones de planta circular y de pequeño tamaño, manteniendo una cultura material similar a la del Bronce Final.

-Fase de desarrollo (s. V - mediados s. II a.C.): La fecha de inicio es referencial, ya que no existe ningún aspecto concreto que la valide excepto la suposición de la generalización del castro como modelo de asentamiento. Se empiezan a definir elementos característicos como las casas circulares de piedra, además de aparecer el torno lento y contactos comerciales con la meseta y la zona mediterránea.

-Fase castrexo-romana (mediados s. II a.C. - mediados s. I d.C.): Se producirá la incorporación del Noroeste al mundo romano, con la consiguiente reorganización del territorio, el abandono de algunos castros y la ocupación de otros nuevos de grandes dimensiones en claro interés por controlar determinadas zonas estratégicas. Se documenta la planta cuadrada y la agrupación de estructuras habitacionales. En este momento aparecen los rasgos considerados como más característicos del mundo castreño.

- Fase galaico-romana (finales s. I d.C. - s. III d.C.): Las reformas administrativas de época flavia, principalmente con la concesión del lus Latii, ocasionarán una lenta desestructuración del mundo castreño. Se producirá un abandono de un importante número de poblados y la aparición de las villae como modelo de explotación del territorio. En el occidente de Asturias, la costa cantábrica y en zonas del interior se producirá una continuidad en la ocupación de los poblados, además de la creación de nuevos asentamientos y reocupaciones de otros más antiguos.

A modo de síntesis de los esquemas planteados con anterioridad se encuentra el trabajo de Arias Vilas (2002), quien de nuevo plantea una división tripartita del periodo.

-Castrexo Inicial (ss. VIII/VII - s. V a.C.): Construcciones pétreas con otras de materiales perecederos.

-Castrexo Pleno (ss. V/IV a.C. - s. I d.C.): Estaría formado por varias subfases (ss. V-III a.C. con presencia de material de importación en la zona costera; s. II-I a.C. presencia de materiales romanos; s. I a.C. - s. I d.C. acentuación de la romanización, con mayor desarrollo de las artes plásticas).

-Castrexo Final (Finales del s. I d.C. - s. V d.C.): Pervive el castro como ocupación habitacional, pero convive con otros tipos de asentamientos de clara implantación romana, asimilando los modelos romanos y formando una Cultura Galaico-romana. 
La última de las propuestas de periodización formuladas es la de González Ruibal (2006-07), proponiendo una nueva periodización, proponiendo una división tripartita en la que pone en relación las diferentes fases con lo conocido en otras regiones europeas:

-Fase I (ca. 1000 a.C. - ca. 400 a.C.): Distingue dos subfases (1000 a.C. $825 / 800$ a.C. y $825 / 800$ a.C. -400 a.C.) pese a la similitud de los materiales entre el Bronce Final y el Hierro I, basándose en la generalización del castro y la desaparición de los asentamientos en Ilano. A partir del siglo VI a.C. se aprecian diferentes cambios fruto del comercio púnico. Este periodo coincidiría con Hallstatt A-D de Centroeuropa y con el Bronce Final y Hierro Antiguo en las Islas Británicas.

-Fase II (400 a.C. - 125/100 a.C.): Momento de intensificación de los procesos de la fase anterior, con una reorganización del área. En Europa equivaldría a la Segunda Edad del Hierro de La Tène A-C y al Hierro Medio de las Islas Británicas.

-Fase III (125/100 a.C. - 50/75 d.C.): Este periodo se caracteriza por la aparición de oppida con una reestructuración del territorio, además de cambios materiales y sociales. Dentro de esta fase distingue tres subfases:

$$
\begin{aligned}
& \text { - Fase III a (125 a.C. }-30 \text { a.C.) } \\
& \text { - Fase III b (30 a.C. }-20 \text { d.C.) } \\
& \text { - Fase III c (20 a.C. }-50 / 75 \text { d.C.) }
\end{aligned}
$$

Con posterioridad al 75 d.C. siguen perviviendo algunos castros hasta el siglo II d.C. Este periodo se correspondería con La Tène D en Centroeuropa y con la Edad de Hierro Tardía de las Islas Británicas.

A la hora de utilizar una u otra periodización debemos tener en cuenta los problemas y las limitaciones que cada una de las mismas presenta (González Ruibal, 200607). Pese a esto consideramos necesaria la utilización de un marco temporal y cultural en el que encuadrar los diferentes análisis, si bien aunque en muchos casos, como dice González Ruibal (2006-07), no contamos con cronologías absolutas, este tipo de periodizaciones nos puede permitir relacionar la información con otros yacimientos semejantes. La elección de una u otra periodización no supone un rechazo al resto, ya que creemos necesario tener en cuenta los trabajos realizados por otros autores, principalmente en los últimos años, como complemento que nos permita un mejor conocimiento de nuestro objeto de estudio. Además la debatida periodización de esta cultura, en constante evolución a la luz de las nuevas investigaciones, no es ajena a las problemáticas de carácter cronológico y espacial de este tipo de divisiones culturales geográfica y temporalmente tan amplias. Debido a esto hemos decidido utilizar la 
periodización propuesta por González Ruibal (2006-07), ya que es una de las últimas e introduce los avances producidos por las nuevas excavaciones, estudios de materiales y dataciones. Sin embargo, y como expusimos en las líneas anteriores, esto no supone un rechazo al resto de periodizaciones, por lo que tendremos en cuenta otras como la de Peña (1996) o Arias (2002).

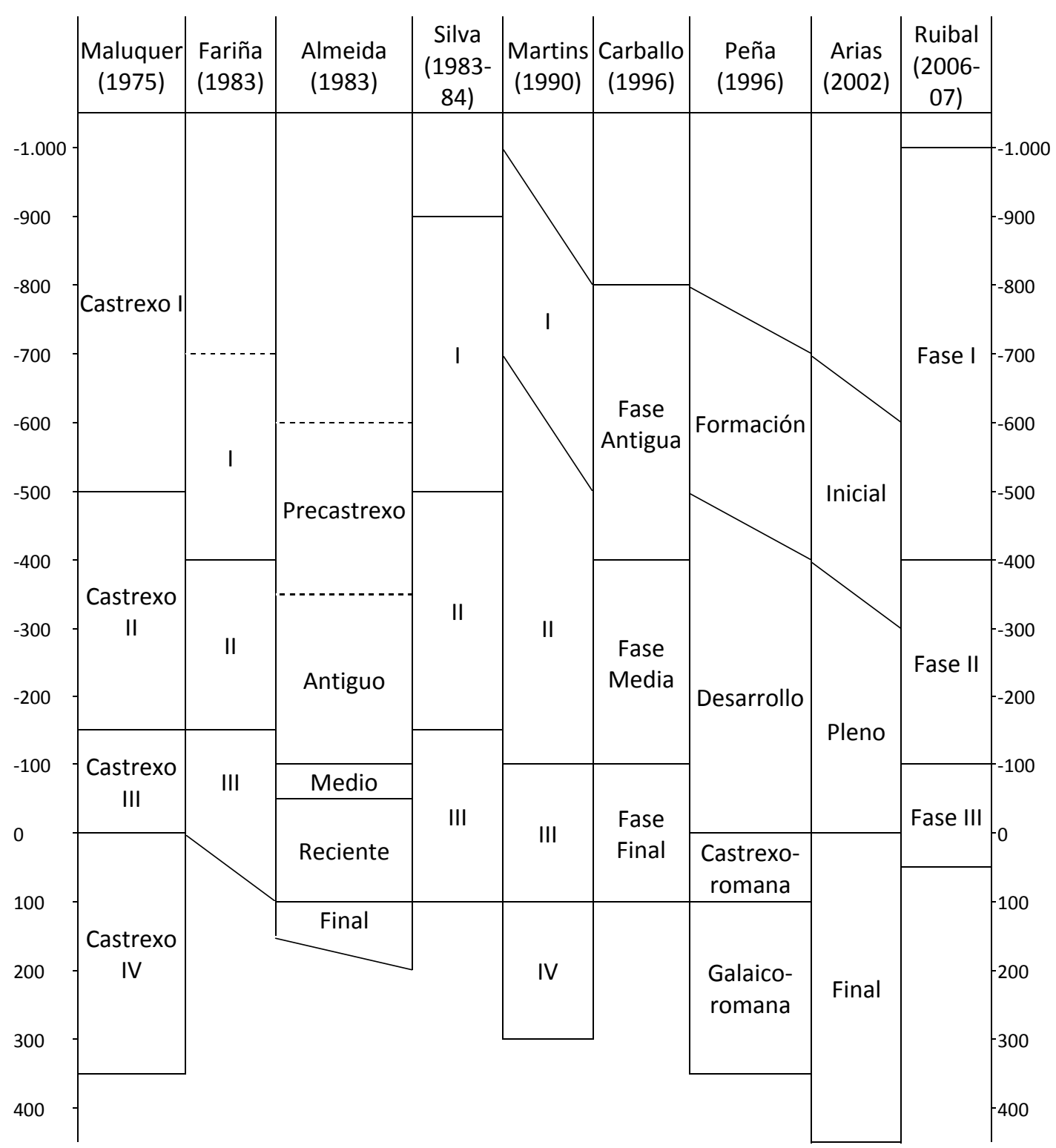

Fig. 1 Periodización de la Cultura Castreña según varios autores (Modificado de Carballo Arceo, 1996).

\section{II.3.2. ÉPOCA GALAico-Romana.}

\section{II.3.2.1. EL PROCESO DE ROMANIZACIÓN.}

Durante el siglo II a.C., en el contexto de las guerras lusitanas (139-138 a.C.), tendrán lugar las primeras expediciones militares de Roma contra los galaicos, en la denominada fase lusitana de la conquista de Gallaecia. El principal suceso lo constituye la 
expedición de Décimo Junio Bruto en el 137 a.C., que pasará el Duero sometiendo a los pueblos de la Lusitania, llegando a cruzar el río Limia llegando hasta el Miño. Esto supuso que el espacio entre el Duero y el Miño fuera explorado por los romanos, abriendo el camino a nuevos contactos con los pueblos indígenas y, supuestamente, el control de estos por parte de Roma (Arias Vilas, 1992; González García y Brañas Abad, 1995; Rodríguez Colmenero, 1996b). A finales del siglo II y comienzos del I a.C. se documentan las primeras evidencias arqueológicas de conquista romana, correspondiendo con algunos niveles de destrucción de castros del Norte de Portugal, además de intensificarse los contactos comerciales con el mundo romano (Arias Vilas, 1992).

A finales del siglo I a.C. será cuando se acentúe el valor económico del noroeste con la expedición de Publio Licinio Craso en busca del estaño y del plomo de las míticas "Cassitérides". En este momento se percibe una intensificación de las rutas comerciales y de los contactos con el mundo romano (Arias Vilas, 1992; González García y Brañas Abad, 1995).

Durante la Guerra Sertoriana se producirán nuevas campañas militares en territorio galaico, ya que Sertorio controlaba la Lusitania y la Celtiberia. En el 74 a.C. Perpenna, el lugarteniente de Sertorio, ocupará la población de Cales (Porto) (Arias Vilas, 1992; González García y Brañas Abad, 1995).

En el año 61-60 a.C., Julio César realizará otra expedición al noroeste en busca de prestigio y dinero para poder acceder al consulado. En esta expedición militar, pero también comercial, llegará hasta el Golfo Ártabro, percatándose de la riqueza minera de la zona, de la que ya tenía constancia por su anterior estancia en Hispania en el 68 a.C. como cuestor de C. Antistio Vetus, además de por su relación con el hijo de Publio Licinio Craso. En una primera fase procedió a la pacificación de los territorios lusitanos, haciendo varias incursiones al norte del Miño, aunque será en una posterior expedición marina cuando llegue al extremo Atlántico, posiblemente con fines comerciales. Desde este momento serán habituales los contactos con las zonas litorales atlánticas, finalizando la primera fase de la conquista del noroeste llamada lusitana (Arias Vilas, 1992; González García y Brañas Abad, 1995).

Todas estas expediciones no van a conseguir el control efectivo de Roma sobre el territorio, existiendo noticias de revueltas e insurrecciones. El control de todo el noroeste no será real hasta el fin de las Guerras Astur-Cántabras. Estas comenzaron el año 29 a.C., desarrollándose principalmente en los territorios asturleoneses y cántabros, mientras que la Gallaecia, que ya se encontraba más aculturada por los contactos anteriores, quedaba como base de operaciones en la retaguardia (Arias Vilas, 1992). Pese a esto se debieron registrar revueltas o sublevaciones, ya que varios castros de esta época presentan niveles de destrucción o abandono. Después de estas Guerras se producirá el control efectivo de Roma integrando definitivamente el noroeste en el sistema administrativo romano (Arias Vilas, 1992; González García y Brañas Abad, 1995; Rodríguez Colmenero, 1979). 


\section{II.3.2.2. DIVISIÓN ADMINISTRATIVA.}

En las primeras fases de conquista el Noroeste fue incluido en la provincia de Lusitania, hasta una fecha entre el 16 y el 13 a.C., una vez terminadas las Guerras AsturCántabras, cuando este territorio pasó a formar parte de la provincia Tarraconense, si bien como un conjunto diferenciado dentro de ésta, como apuntan las fuentes antiguas. Esta singularidad parece continuar presente, y en el 212 d.C. Caracalla crea la Provincia Nova Citerior Antoniniana, separada de la Tarraconense y asimilable al área galaica. Un siglo más tarde, en el año 305 a.C., Diocleciano reorganizará la estructura administrativa del Imperio, e incluirá el noroeste en la Prefectura de la Galia y en la Diócesis Hispana, formando una provincia independiente, la Gallaecia, que llega a ocupar su máxima extensión territorial, desde el Cantábrico hasta el Duero y del Atlántico al Sistema Ibérico (Arias Vilas, 1992; González García y Brañas Abad, 1995).

La organización básica interna es el Conventus, con una demarcación territorial determinada que centraliza en una capital aspectos fiscales, políticos, religiosos y militares, llegando a ser rastreados en algunos aspectos después de la caída del Imperio. Su administración dependía hasta los Flavios del Legatus Augusti pro praetore de Hispania, y posteriormente del Legatus iuriduci per Asturiae et Gallaecia, con un Procurator Asturiae et Gallaeciae por debajo de él. Además existía en cada Conventus toda una serie de funcionarios menores encargados de funciones auxiliares o subalternas (Arias Vilas, 1992).

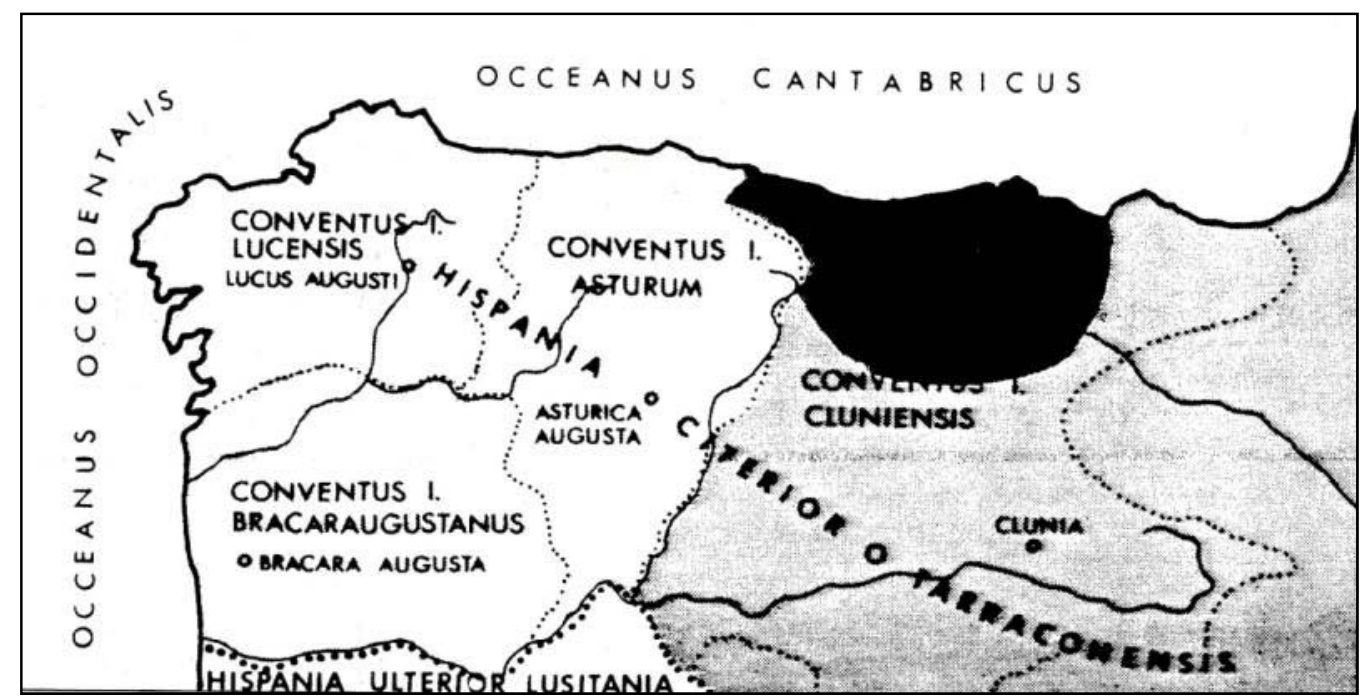

Fig. 2 División administrativa d el Noroeste en época romana. (Extraído de Arias, 1992).

El Noroeste estaba dividido en tres Conventus: el Conventus Lucensis con la capital en el actual Lugo y que abarcaría los territorios al norte de la Ría de Vigo hasta el curso medio del Navia, limitando al Este con los sistemas montañosos de Courel y Ancares; el Conventus Bracarensis o Bracaraugustanus con capital en Braga y situado al sur del Lucensis, limitando al sur con el Duero, y por el este hasta los ríos Túa y Sabor y las sierras de San Mamed y Queixa; el Conventus Asturicense o Asturum con capital en Astorga y que 
llegaría desde el Cantábrico hasta el Duero, limitando al Oeste con los Conventus Lucensis y Bracarensis y al este con el río Esla o el Cea (Santos Yanguas, 1985; Arias Vilas, 1992).

Con el proceso de romanización y la implantación de un nuevo modelo administrativo aparecerán nuevos sistemas de poblamiento, así como la pervivencia del modelo anterior. Según Pérez Losada (1996) pueden reconocerse dos tipos de asentamientos:

- Hábitat agrupado o conjunto: Destacan las Ciudades (urbes), que en el Noroeste se limitarán a las capitales augusteas: Bracara, Lucus y Asturica, cumpliendo funciones administrativas en amplios territorios. En los dos últimos casos parece haberse aprovechado un asentamiento militar previo (Rodríguez Colmenero, 1996a), mientras que Bracara parece responder a una selección en función de su posición estratégica.

Por otro lado se encontrarían los denominados por Pérez Losada (1996) como aglomerados secundarios, identificados con poblaciones con carácter urbano o protourbano de menor envergadura, en especial las denominadas ciudades flavias (Fernández Ochoa, 1993), como posiblemente Brigantium, Iria Flavia, Bergidum Flavium o Interamnium Flavium. Autores como Pérez Losada (1996) denominan a este tipo de asentamiento vici, si bien en su sentido más genérico, ya que según las fuentes clásicas (Moreno Martín, 1997) se trataría de asentamientos de pequeñas dimensiones y sin rasgos urbanos, dependientes de otra población, además de tener un carácter abierto y bien comunicado.

También pertenecerían a este grupo los castros, que seguirán siendo el principal tipo de asentamiento hasta el siglo II d.C. Posteriormente los castros continuarán teniendo gran importancia, y pese a que algunos se abandonan entre los siglos I y II d.C., en el siglo III-IV d.C., debido al clima de inestabilidad, se producirá una recuperación de los mismos, incluso surgiendo otros de nueva planta. En ellos se combinan elementos tradicionales, como la cerámica indígena o las casas circulares, con otros típicamente romanos, llegando su ocupación hasta el siglo VI d.C. Según algunos autores la ocupación de estos asentamientos refleja lugares complementarios de habitación o como refugio y asentamiento de guarniciones de carácter privado (Arias Vilas, 1992; González García y Brañas Abad, 1995).

-Hábitat familiar: Es el tipo de poblamiento más común junto al Castro, caracterizándose por su dispersión en el campo. Este tipo de asentamiento estaría formado por casas de campo vinculadas con la explotación de los recursos alimenticios, englobándose bajo el término de villae, aunque se desconoce la extensión y los tipos de explotación existentes. Estas villae 
tienen un carácter rural vinculado a grupos económicamente poderosos y se localizan en medios abiertos. Además de villae existen otros tipos de entidades productivas, como por ejemplo las factorías salazoneras (Arias Vilas, 1992; González García y Brañas Abad, 1995; Pérez Losada, 1996).

\section{II.3.3. Periodo Medieval.}

\section{II.3.3.1. LA TARDOANTIGÜEDAD Y LA ALTA EDAD MEDIA.}

En el 411 d.C. los pueblos germánicos se asentarán en la provincia tardorromana de Gallaecia, ocupando los suevos su parte occidental (Conventus de Lucus y Braga) y los Vándalos asdingos la oriental (Conventus de Asturica y cluniense) (Díaz Martínez, 1993). En el 419 d.C. Ios Suevos expulsarán a los Vándalos de Gallaecia situando su capital en Braga. A lo largo de esta fase parece existir una alianza militar entre Roma y los Suevos. Sin embargo esta situación cambiará en las décadas siguientes debido a la ocupación sueva de la bética fruto de los desplazamientos de los Vándalos hacia el norte de África (López Carreira, 2005).

Durante este periodo las ciudades van a mantener el sistema administrativo romano, presididas por un obispo y dirigidas por la oligarquía local. Sin embargo, existe una dualidad socio-económica entre los dos grupos de población. Por un lado se encuentras los suevos, que pretenden el dominio sobre Gallaecia, y por el otro los galaicoromanos, que buscan mantener sus medios de vida (Díaz Martínez, 1993). En el 449 d.C. con Requiario se produce la conversión sueva al catolicismo buscando la unidad entre estos dos grupos poblacionales. Sin embargo, se abre un periodo de inestabilidad interna que finalizará en el 456 d.C. con la intervención Visigoda. Después de la victoria de Teodorico sobre los suevos, el 5 de octubre de 456 d.C. a orillas del río Órbigo, il reino suevo seguirá existiendo bajo la órbita visigoda. No será hasta el 585 d.C. cuando Leovigildo intervenga militarmente en la política sueva con la escusa de problemas sucesorios para incorporar estos territorios a la administración visigoda. El territorio suevo se va a incorporar a esta monarquía como una provincia, volviendo poco después del 666 d.C. a ocupar el espacio de la antigua provincia bajo imperial de Gallaecia (López Carreira, 2005).

En el 711 d.C., con la victoria musulmana sobre las tropas de Rodrigo, se va a producir el desmantelamiento del reino visigodo. Los territorios peninsulares se van a incorporar al sistema musulmán, estableciendo gobernadores para el mejor control de las circunscripciones administrativas godas (Álvarez Álvarez, 1999: 17). Desde el siglo VIII d.C. Gallaecia se convierte en un territorio políticamente informe, lo que va a originar el desarrollo de toda una serie de poderes locales que controlan el territorio (Baliñas Pérez, 1990). No será hasta el siglo IX d.C., con el reinado de Alfonso II, cuando estos territorios de la actual Galicia se incorporen a la configuración estatal que había surgido en Asturias a principios del siglo VIII d.C., formando una adaptación del modelo socio-institucional 
visigótico a una nueva realidad social y política alejada del antiguo reino Visigodo de Toledo (Baliñas Pérez, 1990; López Carreira, 2005).

El nuevo sistema institucionalizado por Alfonso II va a generar una dualidad del poder, por un lado la Iglesia y por el otro la monarquía. Aprovechando las buenas relaciones con Carlomagno y el papado, va a romper los vínculos religiosos con Toledo y Braga. En sustitución va a aparecer una Iglesia vinculada al monarca asturiano y representada por Oviedo y Santiago de Compostela, orientada a la reconstrucción de los modelos góticos y relacionando a los asturianos como herederos de los mismos (Álvarez Álvarez, 1999: 20). Además se establecerá una corte estable en Oviedo, a semejanza del Imperio carolingio. Los contactos con el mundo francés y europeo se harán más patentes desde el reinado de Alfonso III (López Carreira, 2005).

A partir del siglo VII d.C. el mundo urbano va a pasar por un periodo de crisis, entrando en decadencia la ciudad como elemento administrativo, así como físicamente con el abandono de una parte de la población. Este vacío dejado por la ciudad será sustituido a la hora de articular una nueva administración por el monasterio. La unión Iglesia-monarquía, así como la tradición monástica gallega va a situar al monasterio como célula de explotación económica y propiedad de la tierra y de control ideológico (López Carreira, 2005).

A la muerte de Alfonso III la capital del Reino se traslada a León a causa de la lejanía de la frontera a la antigua capital ovetense. Este cambio no supone una ruptura con el modelo neogoticista, sino como una continuación ideológica y administrativa (Álvarez Álvarez, 1999: 24-25), si bien se va a ir creando un sistema con mayor complejidad social y política, de consolidación del poder señorial. Esto va a hacer que surjan tensiones entre la nobleza laica y la Iglesia por el poder. Durante todo el siglo X d.C. la monarquía leonesa va a estar sometida a un proceso de inestabilidad debido a los enfrentamientos por el poder entre diferentes facciones, siendo la Iglesia, con catedrales y monasterios, el único pilar estable de la monarquía durante todos los reinados (Álvarez Álvarez, 1999; López Carreira, 2005). Surgen los "territorios" como unidad administrativa básica, identificables con comarcas (López Carreira, 2005).

No será hasta el siglo XI d.C. con Vermudo III cuando tome forma el proceso feudal que se venía gestando durante todo el siglo anterior, sufriendo un proceso similar al desarrollado por los reinos Navarro y Franco, que van a tener una gran influencia en este momento sobre el territorio leonés, impulsando la reforma religiosa de Roma y Cluny (López Carreira, 2005). De hecho desde el siglo IX al XII d.C., el comercio va a estar dominado por gentes de origen Franco, principalmente centrado en los productos de lujo (Ferreira Priegue, 1990). Este fortalecimiento de la nobleza está muy ligado a la reorganización de los territorios, disolviendo comunidades aldeanas a través de la adquisición y concentración de la propiedad, fomentada desde la propia monarquía (Álvarez Álvarez, 1999: 70). 


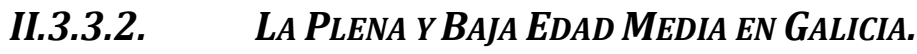

Durante la segunda mitad del siglo XI d.C., fruto de la consolidación del proceso feudal y de la influencia franca, se producirá un cambio de fase histórica que girará sobre tres aspectos (García Oro, 1977; Pallarés Méndez, 1991; Álvarez Borge, 2003; López Carreira, 2005):

-Cambios políticos: La administración cortesana de los siglos anteriores dará paso a la "Curia regis" como principal unidad de gobierno por influencia de la clerecía francesa, naciendo las Cortes. Predominio de la gran propiedad y el señorío jurisdiccional.

-Cambios religiosos: En este momento se producirá la desaparición del monacato pactualista y la diversidad normativa del monacato gallego por la imposición del rito romano bajo la unificación de la regla benedictina. El sistema de freguesías pertenecientes a una parroquia desaparece a favor de las parroquias reducidas con el objetivo de tener mayor contacto y control de la población. Por otro lado, la corona va a asumir un papel destacado convocando, dirigiendo y promulgando concilios.

-Eclosión del fenómeno urbano: Desde el siglo XII d.C. van a tomar forma los espacios urbanos, que darán origen a la burguesía. El nacimiento de los núcleos urbanos está muy ligado a un aumento de la población, al incremento de excedentes agrarios, al aumento de los intercambios y a las políticas regias que van a favorecer el crecimiento urbano, que se va a producir en tres ámbitos:

-Camino de Santiago: Este fenómeno se va a consolidar gracias a las peregrinaciones, floreciendo hasta el siglo XIV d.C., y en el que podemos diferenciar varios tipos de asentamientos (Passini, 1994):

-Aldeas: Muchas se desarrollan en la vecindad de monasterios ligados al Camino de Santiago, siendo el núcleo medieval más simple y cuyo eje lo constituye el camino.

-Núcleos urbanos: Pueden ser de tres tipos:

-Pequeños, de origen eclesiástico, monacal, señorial o real en los que el Camino es el eje de estas vías (como Cacabelos o Molinaseca).

-Medianos, formados por varias parroquias o burgos que pueden estar organizados de forma lineal en torno al Camino o asociado de formas más complejas. 
-Grandes núcleos urbanos anteriores al siglo XI bien por la existencia de un asentamiento romano $u$ originados en torno a un castillo.

-Ciudades episcopales: Se desarrollan desde finales del siglo XII a.C. entorno a las sedes episcopales (como Lugo, Ourense, Santiago) (Pallarés Méndez, 1991).

-Villas costeras: Obedecen a intereses regios tanto hacia las rutas de navegación que bordean las costas, y que ven cómo aumenta el tráfico de peregrinos y comerciantes, como para la explotación del medio marino (A Coruña, Ribadeo, Pontevedra, Noia) (Pallarés Méndez, 1991).

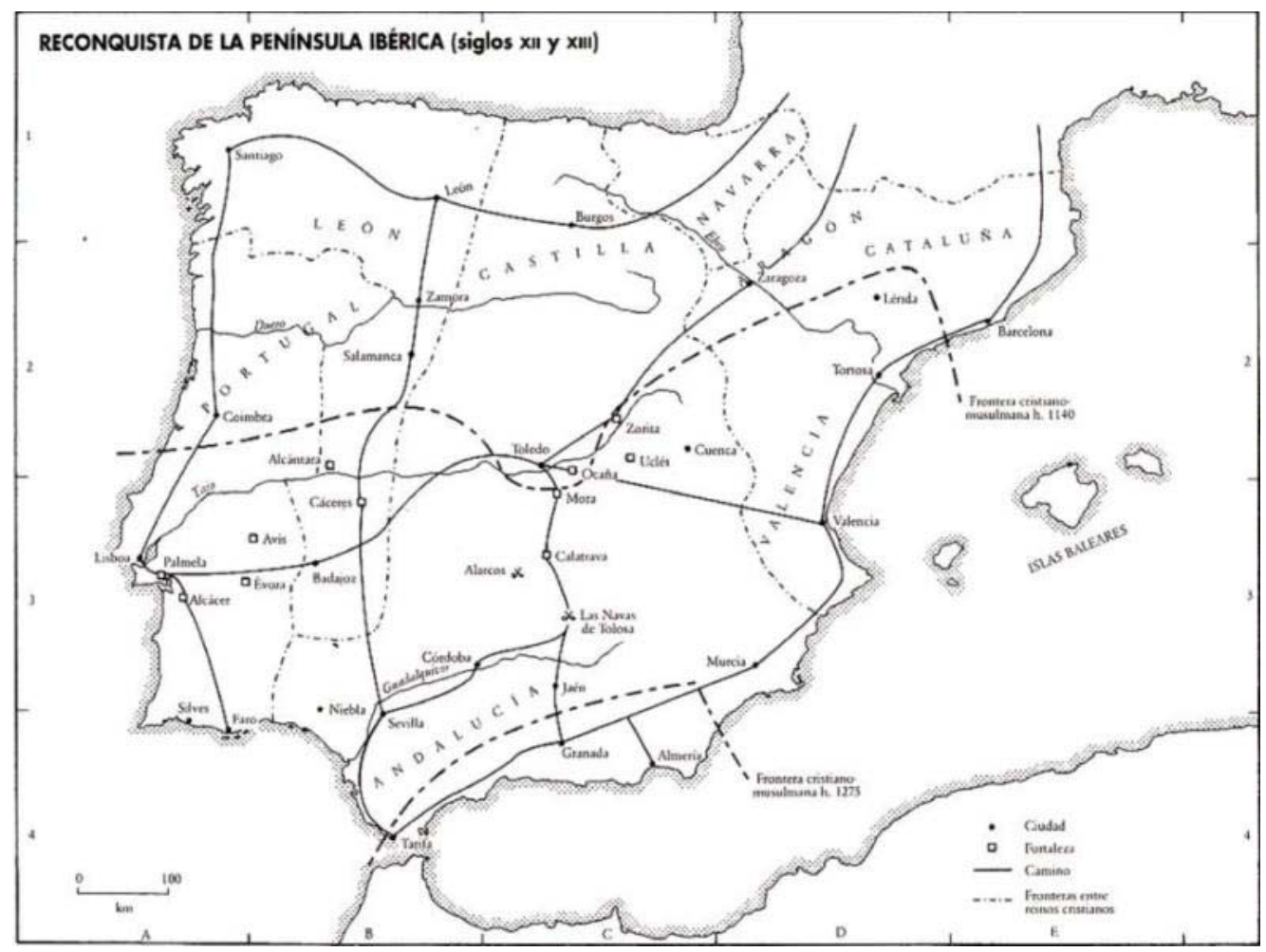

Fig. 3 División administrativa de la Península Ibérica durante el siglo XII y XIII (MacKay y Ditchburn, 1997).

Estos cambios socio-políticos se van a ver reflejados en los gobiernos de Fernando II y Alfonso VIII, cuando se va a fomentar la estructura eclesiástica, así como el apoyo a la nobleza condal y el fortalecimiento de la vida urbana. Este consenso social entre los sectores hegemónicos y la favorable coyuntura económica será la base sobre la que se asienten las bases del florecimiento cultural e institucional durante la Plena Edad Media (López Carreira, 2005).

La progresiva consolidación de la vida urbana y una coyuntura económica favorable van a llevar a las élites urbanas a reclamar poder político. Será ahora debido a este fenómeno cuando se concedan la mayor parte de las cartas forales, mediante las que se 
autorizará el nacimiento de nuevos núcleos. Por otro lado, la existencia de las ciudades y la creación de los concejos favorecieron el poder regio con la presencia en estos núcleos de los “Oficiales municipales” (García Oro, 1977; López Carreira, 2005).

Desde finales del siglo XIII d.C., el anterior periodo de desarrollo se verá truncado por una crisis a nivel europeo generada por los problemas agrarios y comerciales, lo que va a ocasionar una reducción del flujo jacobeo (Armas Castro, 1991). Por otro lado, la unión en 1230 d.C. de las Coronas de León y Castilla por parte de Fernando III, va a ocasionar la caída del grupo nobiliario gallego y se va a limitar la expansión urbana (Álvarez Álvarez, 1999; López Carreira, 2005).

Esta crisis va a reforzar la posición de la burguesía frente a las estructuras tradicionales, debido a que se trata de una crisis principalmente agraria. Esto va a ocasionar que durante el reinado de Pedro I el municipalismo gallego renazca. Sin embargo, con la muerte de este monarca en el 1369 d.C. la aristocracia castellana va a triunfar definitivamente sobre la nobleza gallega (García Oro, 1977; López Carreira, 2005). Desde el siglo XIV d.C. va a ir perdiendo poder el señorío territorial frente al jurisdiccional y territorial (García Oro, 1977). En este momento va a cobrar fuerza el movimiento proatlantistas, que busca la unión con el condado portugués, favoreciendo los contactos con este Reino y con Inglaterra (Menéndez Pidal, 1990; López Carreira, 2005). Desde las villas costeras se desarrollarán relaciones comerciales con los puertos de Gascuña, Flandes e Inglaterra (Ferreira Priegue, 1990).

En el siglo XV d.C. el territorio gallego estaba formado por un conglomerado de señoríos con una alta autonomía, en tanto que los concejos urbanos estaban supeditados a los prelados. El enfrentamiento generado desde los periodos anteriores entre núcleos urbanos y señores desembocará entre 1466-1469 en el movimiento de las "Irmandades", reclamando la legitimidad regia sobre la de los señores (García Oro, 1977; Álvarez Álvarez, 1990; Barros Guimeráns, 1991). Por otro lado, la Guerra de los 100 años y el enfrentamiento de Castilla con Portugal desencadenarán una limitación en el acceso al mar, tanto como fuente pesquera como en su papel de vía comercial (López Carreira, 2005).

\section{II.4. LAS CONDICIONES DEL MAR.}

\section{II.4.1. EL NIVEL DEL MAR.}

La presencia de unas especies frente a otras en un medio marino determinado, así como las actividades económicas desarrolladas por las diferentes comunidades humanas, van a estar condicionadas por diversas causas. Estos factores pueden ser de dos tipos: abióticos (profundidad, sustrato, temperatura, salinidad, humedad...) o bióticos (depredación, competición, parásitos...). 
La variación del nivel del mar es uno de los principales agentes que van a modificar el paisaje costero, influyendo en las especies representadas en las zonas próximas a los asentamientos y condicionando la accesibilidad a los recursos. Sin embargo, determinar las condiciones del mar hace 2000 años resulta complejo debido a las constantes fluctuaciones y a las variaciones de carácter local. Estas variaciones en el nivel del mar pueden ser de dos tipos: regresivas, correspondiente con la bajada del mismo; y transgresivas, que supondrían una subida.

Establecer unas curvas de nivel del mar presenta gran dificultad, tanto por los problemas de datación de los materiales, como por la imposibilidad de determinar el origen local o global de estos cambios (Alonso y Pagés, 2000). Debido a esto existen dos teorías acerca de la variación de los niveles marinos holocenos (Cearreta et alii, 1992; Rivas, 2000):

-Una serie de autores propone que el nivel del mar actual se alcanza hace 3.000-5.000 años y se mantiene más o menos estable.

-Otros autores defienden la existencia de una Transgresión Postglacial espasmódica, con fases transgresivas y regresivas.

Diversos estudios realizados en el litoral cantábrico sobre el nivel del mar en el Holoceno, indican para el cambio de era unos niveles similares a los actuales. Pese a esta tendencia general, se van a definir diferentes fases regresivas y transgresivas, si bien con cierto retraso en la zona occidental (Mary, 1992; Cearreta et alii, 1992; Rivas, 2000), debido al papel que van a jugar los efectos locales como la sedimentación en rías y estuarios, o los levantamientos epirogenéticos (Cearreta et alii, 1992; Rodríguez López y Fernández Rodríguez, 1996). Sin embargo la ausencia de evidencias claras de neotectónica haría aplicables los modelos definidos en diferentes puntos de la costa cantábrica para el resto del litoral (Rivas, 2000). Aceptando este principio, los resultados obtenidos por Edeso (1994) en su estudio de las Rías de Zarauz y Urumea nos pueden servir como modelo para la costa cantábrica:

-La primera Transgresión Flandriense o Herriko-Barra daría comienzo entre el $9000 \mathrm{BP}$ y el $7810 \pm 130 \mathrm{BP}$ hasta el $6000 \mathrm{BP}$, en este momento se produciría un aumento rápido del nivel del mar con algunas fases Transgresivas y Regresivas de corta duración. Esto se correspondería con lo observado en otros puntos cantábricos, con el nivel del mar unos 2-3 metros más alto que el actual (Mary, 1992; Cearreta et alii, 1992; Rivas, 2000).

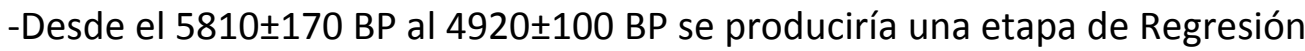
marina, con un nivel que se situaría por debajo del actual.

-La segunda pulsación Transgresiva -Durkenkiense, Xivares o Jaizquibel- se produciría entre el $4920 \pm 100 \mathrm{BP}$ y el $2740 \pm 90 \mathrm{BP}$, situándose el nivel del mar un metro por encima del actual, con valores similares a los observados en otros 
puntos, con una subida del nivel del mar de entre 0,5-1 metros (Mary, 1992; Rivas, 2000). Sería el segundo momento del Holoceno con el nivel marino más alto (Pérez Alberti et alii, 2009) En la Ría de Ares (A Coruña), se ha detectado una fase

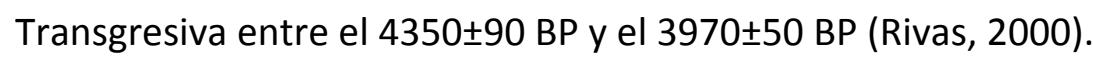

-Una segunda fase Regresiva llegará hasta el $1420 \pm$ BP, situando el nivel del mar en valores similares a los actuales o incluso inferiores. Será el momento de consolidación de las playas y estuarios. De este modo, para la turbera de Trengandín (Salas et alii, 1996), se detecta en torno al 2890 \pm 70 BP dos metros más bajo el nivel del mar. Sin embargo en el $2280 \pm 60$ BP en Corrubedo (A Coruña), el mar se situaría un metro por encima del actual (Salas et alii, 1996).

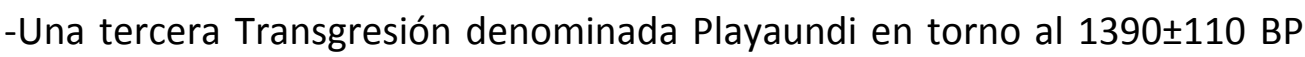
produciría la estabilización del nivel del mar, si bien debió de tener una incidencia muy limitada.

En cuanto a la costa Atlántica, los estudios son más escasos, siendo más difícil establecer una evolución de la costa debido a las particularidades de las Rías. Uno de los estudios que nos pueden servir para establecer una evolución en esta área es el realizado en las dunas de Hospital y Toralla en la Ría de Vigo (Martínez Cortizas y Costa Casais, 1997). Este trabajo, igual que lo observado para el Cantábrico, se plantea la sucesión de una serie de fases transgresivas-regresivas:

-La primera de estas Transgresiones se produciría antes del 2000 BP, y correspondería con la Transgresión Dunkerkiense o Xivares (3000-2000 BP). En este momento el nivel del mar sería similar al actual o bien ligeramente superior.

-Hacia el 1900 BP, y hasta el 1300 BP, se produciría la Regresión Wisant, con una disminución del nivel del mar.

-Se produciría una nueva fase Transgresiva entre 1500-1400 BP, si bien no alcanza el nivel de la primera de estas fases.

-Finalmente una fase Regresiva se producirá sobre el 1200-1100 BP.

Por otro lado, en la costa gallega se documentan asentamientos castreños y romanos que han sido afectados por la actividad marina. Esto ha llevado a considerar el periodo comprendido entre los siglos IV a.C. y V d.C., como una fase de estabilidad, con el nivel del mar 1-2 metros por debajo del actual (Rodríguez López y Fernández Rodríguez, 1996).

Como ya hemos comentado, las fluctuaciones experimentadas por el nivel del mar durante el Holoceno se ven condicionadas por factores diversos, que incluyen los niveles de sedimentación, la aportación fluvial, la altura e inclinación, etc, por lo que es complicado realizar una caracterización del mismo para toda la costa gallega. Sin embargo podemos observar que durante la Edad del Hierro, y hasta el cambio de Era, el nivel del 
mar debió ser ligeramente más alto que el actual $(0,5-2 \mathrm{~m})$ fruto de la Transgresión Durkenkiense, tanto en la costa cantábrica como en la Ría de Vigo. Posteriormente, y hasta el final del mundo romano, se produciría una fase Regresiva, con el nivel del mar ligeramente inferior al actual. En este momento se consolidará un sistema de playas, estuarios y acantilados muy parecido al actual. Durante el periodo medieval el nivel del mar debió de ascender ligeramente hasta posiciones actuales.

De forma paralela al nivel marino, también hay que tener en cuenta la acción de las mareas. Las mareas consisten en una variación del nivel del mar debido a la atracción que producen el sol y la luna sobre el agua. Durante cada día lunar (24 horas y 50 minutos) se producen dos pleamares y dos bajamares. Cuando coincide la luna con un punto de la tierra en un momento determinado, se produce una atracción de la masa de agua deformando la superficie, dando lugar a la pleamar. Por otro lado, en la cara opuesta, las fuerzas centrífugas hacen que se produzca otra pleamar de menor intensidad, por lo que cada 6 horas y 12 minutos tiene lugar este fenómeno (Lozano Cabo, 1978: 94-96; Fernández Román, 1998: 24-26). Además de la influencia que ejerce la luna sobre las aguas, también se produce una atracción por parte del sol. De este modo, cuando la acción de los dos astros se suman es más significativo el descenso del nivel del mar, dando lugar a las conocidas como mareas vivas o sicigia. Por otro lado, cuando esta atracción se contrarresta, se produce un descenso mínimo del nivel del mar, lo que se conoce como marea muerta o cuadratura. Esta acción tiene una gran importancia en la explotación del medio marino por parte de las comunidades humanas. El descenso del nivel del mar va a ampliar considerablemente la superficie de explotación, facilitando considerablemente labores como la de marisqueo. Por otro lado, esta sucesión de movimientos marinos puede ser utilizada para la captura de determinadas especies de peces.

\section{II.4.2. LA TEMPERATURA Y EL CLIMA.}

La temperatura del agua es uno de los factores que más influyen en la presencia de ciertas especies frente a otras. De este modo en la actualidad especies como Pagrus pagrus, Sparus aurata o Stramonita haemastoma, son muy escasas en las costas gallegas o han desaparecido de ellas, siendo habitual su presencia en los yacimientos arqueológicos (Ferré, 2003). La temperatura del mar se debe a diversas fuentes, como la energía del sol, la energía procedente del fondo del mar y del interior de la tierra, o por la energía desprendida de los efectos de condensación, entre otras. La temperatura del mar no es uniforme, variando entre mares y entre profundidades, dependiendo de su localización, ya que no son iguales los tiempos de insolación, así como a la topografía marina, las corrientes, los vientos o la pluviosidad (Lozano Cabo, 1978: 57-66).

Según los estudios geoquímicos podemos observar diversas oscilaciones considerando variables como la pluviosidad o las temperaturas de la superficie (Martínez Cortizas y Vázquez Varela, 2002; Ares et alii, 2008; Francés et alii, 2009): 
-Desde el 2700 BP hasta el 2200 BP, con el final del subboreal, se produce un enfriamiento de las aguas, si bien Rías como la de Vigo o la de Muros, no reflejan variaciones de la temperatura superiores a $1^{\circ} \mathrm{C}$ para la primera, y $0,5^{\circ} \mathrm{C}$ para la segunda. Las precipitaciones se situarían entre un $50-75 \%$ por debajo de las actuales.

-Hace 2200 años se produce el conocido como "periodo cálido romano", con un aumento de la temperatura, que van a ser similar a las actuales, y de las precipitaciones.

-A comienzos del siglo III d.C., y hasta finales del siglo IX d.C., se detecta un periodo más frío y árido, con un descenso de la temperatura del agua de $1^{\circ} \mathrm{C}$ en la Ría de Muros, y de $1,5^{\circ} \mathrm{C}$ en la de Vigo.

-Este periodo más frío finalizará en el siglo $X$ d.C. con el denominado "periodo cálido medieval", que presenta mayores precipitaciones.

-Desde el siglo XIV d.C. se va a producir un descenso de las temperaturas, dando paso al periodo conocido como la "pequeña edad del hielo". Esta consta de dos fases (fase 1: 1330-1650; fase 2: 1770-1850), y se va a producir un descenso de la temperatura de las aguas de entre $0,5-1^{\circ} \mathrm{C}$ respecto a periodos anteriores.

Del mismo modo, el estudio de la fauna de los diferentes yacimientos también nos indica un cambio en la temperatura del mar. La presencia de especies como Stramonita haemastoma en yacimientos datados entre el periodo castreño y el medieval, así como la abundancia de Sparus aurata o Pargus pargus, actualmente escasos en las costas gallegas, hacen plantear un progresivo enfriamiento de las aguas costeras entre el siglo I-XIII d.C. (Martínez Cortizas y Vázquez Varela, 2002; Ferré, 2003).

\section{II.4.3. REGIONES MARINAS.}

Otro de los factores abióticos que influyen en la fauna íctica, son las regiones marinas con sus diferentes profundidades y sustratos. La zona nerítica o béntica se extiende desde el supralitoral (zona que queda por encima del límite superior de marea), hasta la zona oceánica, donde termina la plataforma continental. Dentro de la zona nerítica se identifican diferentes pisos (Álvarez y Luque, 1981; Moreno, 1994; Gutiérrez Zugasti, 2005; 2009):

-Piso supralitoral: Zona que queda por encima de la zona de barrido de las olas y está sometida a una influencia directa de la humectación y de las salpicaduras.

-Piso mesolitoral o intermareal: Correspondería con la llamada plataforma costera o litoral, también conocida como eulitoral. Es la zona afectada por el barrido de las olas, comprendida entre la profundidad máxima y mínima de las mareas. Según su exposición a las mareas se pueden diferenciar tres franjas: 
-Alta: nunca permanece sumergida aunque está sometida al barrido de las olas.

-Media: nivel del balanceo de las mareas.

-Inferior: presenta inmersiones y emersiones alternantes, pero nunca sufre inmersiones prolongadas.

-Piso infralitoral: Junto con el intermareal correspondería a la plataforma continental. Queda delimitado en su parte superior por el límite de la marea baja, mientras el inferior lo está por la profundidad máxima de penetración de la luz. Este piso estaría formado por la zona de las laminarias (hasta los $30 \mathrm{~m}$ ), la zona coralífera (entre los 30-100 m) y la zona profunda (puede llegar hasta los $200 \mathrm{~m}$ ).

-Talud continental: Es la pendiente de caída de la plataforma continental hacia los grandes fondos.

-Zona abisal: Zona donde se encuentran las máximas profundidades, conformando la conocida como Región oceánica. Esta a su vez se divide en dos zonas: hasta los 200 m sería la Región pelágica; y desde esta hasta el fondo la Región batipelágica.

Además de la zonación litoral, hay que tener en cuenta el tipo de sustrato que conforma el entorno marino:

-Sustrato duro: sustrato rocoso; esqueletos de otros animales o vegetales. Este sustrato es el más propicio para ciertas especies de algas como fucus y laminarias, así como para diversos moluscos y crustáceos. Además va a servir de refugio a gran número de especies de peces.

-Sustrato blando: sedimento arenoso o fangoso. En los sustratos arenosos se suele encontrar vegetación de tipo herbácea, así como algunas especies de crustáceos y moluscos, si bien es normal que estos aparezcan enterrados o semienterrados en el sustrato. Según donde se localicen en el sustrato podemos diferenciar dos tipos de organismos:

-Epibiontes: organismos que viven sobre el fondo.

-Endobiontes: organismos que viven dentro del fondo.

Por otro lado, según los dominios oceánicos, y el lugar donde habiten las diferentes especies de peces se pueden diferenciar tres tipos, si bien numerosas especies varían de zona, incluso en el mismo día (Morales, 2008):

-Peces pelágicos, aquellos que habitan en la columna de agua.

-Peces demersales, especies que viven próximas al fondo.

-Peces bentónicos, viven sobre el fondo o enterrados en él. 


\section{LA ICTIOARQUEOLOGÍA EN EL NOROESTE PENINSULAR.}



El noroeste de la Península Ibérica se caracteriza por su estrecha vinculación con el mar, siendo la explotación de este uno de los principales motores económicos en la actualidad. Sin embargo, los estudios sobre la pesca en las sociedades pretéritas no han sido objeto de estudios continuados, principalmente en lo que a restos arqueológicos se refiere. Los análisis de ictiofaunas arqueológicas procedentes de yacimientos gallegos son escasos, han seguido un desarrollo discontinuo $y$ han estado influidos por factores de naturaleza muy diversa:

-Uno de los principales factores es la falta de una continuidad de los estudios arqueoictiológicos. Aspecto vinculado a la dificultad que supone el estudio de estas faunas debido al elevado número de especies potencialmente capturables, así como el elevado número de restos óseos que presentan. Los problemas del análisis de las ictiofaunas arqueológicas han ocasionado que en Galicia los estudios comiencen tarde. Además, la labor de estos autores se ha producido durante un limitado periodo de tiempo.

-Otro importante problema es la conservación de los restos en los yacimientos. Debido a las características de las piezas óseas de los peces, es una mínima parte del registro la que llega hasta nosotros, mientras la mayor parte es amortizada (Morales y Roselló, 2006). A este problema general hay que unir las particularidades del suelo gallego, con un $\mathrm{pH}$ ácido y un elevado drenaje, que favorece la destrucción de los restos faunísticos. Esto ha provocado que los conjuntos documentados se concentren en yacimientos costeros con presencia de concheros, donde los componentes calizos de las conchas neutralizan esta acidez.

-Por último, nos encontramos ante la habitual ausencia de una metodología de intervención y muestreo adecuada. Aspectos como la falta de cribado y flotación del sedimento extraído de los yacimientos arqueológicos, supone la pérdida de un número muy importante de restos. De este modo, su recogida queda vinculada a una visualización del material durante el proceso de excavación. A este problema hay que añadir la incorporación, en la arqueología de gestión, de personal sin los conocimientos mínimos para realizar estos trabajos, siendo más importante el fin de la intervención que su calidad técnica. Esto ocasiona pérdida de materiales, así como registros muy deficientes que no permiten en la mayoría de los casos una correcta contextualización de las muestras.

El desarrollo de los estudios arqueofaunísticos en Galicia ha pasado por dos momentos bien diferenciados, con la década de 1970 como punto de inflexión. Sin tratar de ser totalmente exhaustivos, vamos a ver el recorrido histórico que han tenido los estudios sobre ictiofaunas en nuestro ámbito de estudio. 


\section{III.1. LA PESCA EN LOS ESTUDIOS ARQUEOLÓGICOS HASTA LA DÉCADA DE 1970.}

Con las primeras obras generales sobre la Historia de Galicia en el siglo XIX, surge cierto interés por los restos arqueológicos (Acuña, 1996). Estos primeros trabajos van a estar muy vinculados a las corrientes románticas y neorrománticas, que van a reforzar la identidad propia buscando sus raíces en los celtas (Calo Lourido, 1997), lo que en muchos casos va a suponer una total indiferencia por otros periodos y en especial por los anteriores a lo que entonces se considera reflejo de lo celta (Fernández Rodríguez, 2000). Pese a este temprano interés por la arqueología, las publicaciones de este momento se limitan a incluir en el discurso cierta información, pero carecen tanto del apoyo de excavaciones y prospecciones como de estudios de materiales (Armada Pita, 2003/05). En este contexto van a producirse los primeros acercamientos a las acumulaciones de conchas, si bien no se va a realizar ningún análisis, y los restos óseos de peces van a quedar al margen. Sin embargo, el desarrollo de los estudios de los concheros va a ser el punto de partida de los futuros estudios ictioarqueológicos.

No será hasta las primeras décadas del siglo XX cuando comiencen las primeras excavaciones sistemáticas en los castros. Sin embargo, desde 1885 hasta 1916 la tónica general van a ser los estudios aislados realizados por aficionados vinculados a la vida cultural de las ciudades y reflejando una iniciativa individual (Ayán, 2006: 26). Una de las intervenciones más significativas de la época es la realizada por Ignacio Calvo en el Monte de Santa Trega (A Guardia), que se prolongará desde 1914 hasta 1923. Pese a que esta intervención se puede considerar bastante avanzada para la época (Acuña, 1996), no se va a prestar atención a los restos faunísticos. En la primera de las publicaciones con los resultados de sus trabajos, no hace ninguna referencia a la presencia de restos de pez, mientras que en el caso de los moluscos únicamente va a citar la presencia de concheros en las faldas del Monte de Santa Trega (Ignacio Calvo, 1914). Sin embargo, a la hora de interpretar el yacimiento, la pesca va a ocupar un papel muy importante:

"Las piedras curvas con alguna labor, de cuya forma, aunque sin labor, se encuentran varias dentro y fuera de las viviendas [...]. Los pescadores tenían sostenidas en cada dos de estas piedras salientes una vara larga, y colgando de ella, unos habían puesto sus redes para que secasen, y otros los pescados que preparaban para su salazón. Si los pobladores del Tecla se dedicaban a la pesca, ¿dónde y cómo secarían sus redes y pescados?" (Ignacio Calvo, 1914: 9).

"[...] La existencia de un pueblo, numeroso tal vez, pero sencillo, que entretenido en las rudas labores de la pesca, la caza y la agricultura, buscó en esta casi inaccesible montaña la tranquilidad que no podía tener en su antigua residencia [...]" (Ignacio Calvo, 1914: 12).

"[...] El canalillo, con cinco centímetros de fondo por 10 de ancho, estaba cubierto por losas de piedra y por tejas, estando sin duda 
destinado á dar paso á un líquido; y como el suelo es impermeable, ¿será insensato discurrir que esta caseta sería una especie de estanque, donde, ó conservasen vivos algunos pescados, ó los preparasen para su salazón?” (Ignacio Calvo, 1914: 13).

En posteriores campañas va a proceder a la excavación de parte del conchero sur, llegando hasta la roca base. En la memoria de las intervenciones, publicada en 1920 y 1924, el conchero va a tomar una mayor importancia, dedicando un apartado para hablar de él, haciendo también referencia a diversos restos de macromamíferos. Durante la excavación documentó dos anzuelos de bronce, aunque nada va a comentar con respecto a la presencia de ictiofauna:

"[...] Para deducir con absoluta certeza los datos más interesantes se exploró en la parte más lejana de las construcciones, llegando hasta el suelo nativo, y en las capas que no tenían señal de haber sido removidas se encontraron dos anzuelos de cobre, una fíbula de bronce y varios huesos de buey, dientes molares y colmillos de jabalí y un hueso de corza o de cabra. En lo explorado no se encontró utensilio alguno de piedra ni trozo de barro cocido [...]" (Ignacio Calvo, 1920: 28).

Llama la atención la descripción que hace el autor de un conchero basándose en los trabajos de autores escandinavos. En ella cita a las espinas de pescado como parte de estos depósitos y sin embargo no los documenta, o no los cita, entre los materiales recuperados en Santa Trega:

"[...] Al principio se les consideró como depósitos naturales de formación marina; pero los trabajos de algunos sabios escandinavos, especialmente Steenstrup y Worsaae, demostraron que eran núcleos de restos de comidas en las que mezclaban conchas, huesos de animales terrestres y espinas de pescado. Juntamente con estos restos de comida se hallaron algunos utensilios necesarios para la vida del hombre que vive en familia [...]" (Ignacio Calvo, 1920: 27).

A la hora de valorar estos restos faunísticos dentro de la economía de los habitantes del castro, se va a ver muy influido por los textos antiguos, así como por ciertos prejuicios. De este modo va a considerar que son la caza y la pesca las actividades de subsistencia fundamentales, la segunda reforzada por el hallazgo de los dos anzuelos: "[...] Hubo en este monte un núcleo importante de gente que con su ocupación habitual de la pesca compartían la de la caza y en algún modo la agricultura [...]" (Ignacio Calvo, 1920: 25). Las afirmaciones referidas a la pesca no las va a apoyar en la presencia de restos óseos o de utensilios relacionados con esta actividad, sino que las va a basar en una de las construcciones documentadas en la primera de sus campañas de excavación: "[...] La 
ocupación principal de los habitantes del Monte de Santa Tecla debió ser la caza y la pesca, dominando esta última, a juzgar por la construcción de una vivienda con un canalillo circular en todo el suelo [...]" (Ignacio Calvo, 1924: 17).

En resumen, podemos decir que todas estas aproximaciones a la actividad pesquera de la población del Castro de Santa Trega se basan en unas premisas en unas premisas a las que se adaptan los datos obtenidos en las diferentes campañas de excavación, muy alejado por tanto de una metodología científica que podamos considerar adecuada.

III.1.1. LA DÉCADA DE 1920: LOS CONCHEROS Y LA EXPLOTACIÓN DEL MEDIO MARINO.

No será hasta la década de 1920 cuando se empiecen a realizar los primeros estudios relacionados con la composición de los concheros. Sin embargo este nuevo interés por la fauna no conlleva un interés por los restos ictiológicos. La pesca seguirá ocupando un lugar importante dentro de las diferentes interpretaciones de las sociedades pretéritas, basándose en la mayoría de los casos en elementos vinculados con esta actividad: pesas y anzuelos. Esto se debe al incipiente interés por el estudio de los concheros, muy vinculado a la creciente aparición de depósitos con conchas en diferentes yacimientos europeos, y a la abundante presencia de materiales por sus condiciones de conservación. En esta fase, que llegará hasta el estallido de la Guerra Civil Española, podemos diferenciar dos líneas de investigación:

-La primera de estas corrientes, desarrollada por intelectuales jesuitas, parte de los trabajos realizados por Obermaier y el Conde de la Vega del Sella en la costa cantábrica. Estos estudios se van a realizar desde un enfoque histórico cultural, que va a surgir en Europa al finalizar la I Guerra Mundial. Esta corriente de investigación va a utilizar el "pico asturiense" como fósil guía, igual que sucedía en la zona cantábrica (Gutiérrez Zugasti, 2009). Además de este útil, en Galicia los concheros y algunas de las especies que en ellos aparecen son utilizados como fósil guía, tomando importancia el conchero como objeto de estudio. Del mismo modo, se va a realizar un esfuerzo importante por crear una secuencia cronológica de las diferentes culturas y definir sus áreas de difusión. La utilización de estos fósiles guías, así como el intento por crear una periodización cultural, es lo que va a llevar a la definición del "Asturiense gallego", motivado por las diferencias que se van a encontrar respecto al Asturiense cantábrico. Por primera vez en la literatura arqueológica del noroeste la fauna representada es citada por su nombre científico, si bien no se realizarán interpretaciones del papel que desempeñaron los conjuntos faunísticos en las sociedades que formaron los depósitos.

-Al mismo tiempo va a surgir una segunda línea de investigación que va a estar marcada por una óptica evolucionista. Esta corriente está vinculada a la Generación Nós y a la creación en 1923 del Seminario de Estudios Gallegos, en un 
intento de generar una ciencia gallega al nivel de la realizada en Europa (González Ruibal, 2006/07a). En este grupo va a ser muy fuerte el componente galleguista, pero también igualmente importante su posicionamiento conservador y católico, lo que les permitirá, a una buena parte de sus miembros, continuar con sus investigaciones después de la Guerra Civil (González Ruibal, 2006/07a), aun cuando ya no serán igual de fructíferos. Los análisis de concheros siguen siendo muy limitados y centrados en una enumeración de las especies presentes. Pese a esto, se empieza a valorar la importancia intrínseca de las conchas que forman los depósitos, así como su papel en las sociedades pretéritas, aunque no con una metodología adecuada.

El padre Eugenio Jalhay va a ser el representante más importante de la primera corriente. Sus trabajos le van a llevar a prospectar el entorno de A Guardia en busca de industrias líticas. Con ello pretendía encontrar nuevas pruebas que le permitieran asociar de forma más clara los concheros de la zona con las industrias que él considera Asturienses. Durante estos trabajos va a prospectar varios concheros y a recuperar un número importante de restos líticos. En la playa de A Guardia va a recoger varios cantos de cuarcita de forma puntiaguda, que asocia con los "picos asturienses". La ausencia de fauna antigua es achacada a la escasez de grutas naturales y la constitución del terreno que impediría la formación de cuevas y la fosilización de huesos y mariscos (Jalhay, 1928: 183). Además de estos picos, va a recoger cinco cantos con escotaduras laterales que identifica con pesas de red, citando además su presencia en otros yacimientos cercanos como Santa Trega y Camposancos:

"[...] Entre los picos hemos descubierto cinco pesos para redes, formados de pequeños cantos rodados con dos chaflanes laterales. Estos pesos han aparecido con alguna frecuencia en esta región, tanto en la población de Santa Tecla, como junto a la estación prehistórica de Camposancos [...]" (Jalhay, 1928: 182).

Debido a la presencia de estas piezas que se asemejan a pesas de red, va a considerar la pesca como la principal actividad de subsistencia de los antiguos habitantes de A Guardia:

"[...] Allí vivieron, dedicados a los humildes trabajos de la pesca, los más antiguos habitantes conocidos de la villa de La Guardia, predecesores en muchos siglos a los que habían de poblar el alto castro de Santa Tecla [...]" (Jalhay, 1928: 171-172).

La desconexión entre industrias líticas y concheros, unido a la adscripción que realizó Fontes en 1925 de la industria localizada en Pasaje de Camposancos, llevará al P. Eugenio Jalhay a plantear en el "Congreso de las Asociaciones Española y Portuguesa para el Progreso de las Ciencias" (celebrado en Barcelona en 1929), que el Asturiense gallego y portugués serían más antiguos que el cantábrico (Jalhay, 1929). Además va a empezar a 
reconocer la presencia de depósitos de conchas posteriores al Epipaleolítico, como las capas superiores del conchero de Santa Trega donde recuperó, ya en 1917, diversas piezas de metal entre las que se encontraban varios anzuelos:

"[...] En Santa Tecla he descubierto yo mismo en 1917 varios anzuelos y fíbulas de bronce, un cuchillito de hierro y muchos fragmentos de cerámica romana [...]" (Jalhay, 1929: 430).

En el ámbito de la otra corriente que va a dominar en la década de los 20 del siglo pasado, va a ser habitual la ausencia a referencias sobre la pesca. Esto se debe a la falta de restos que les permitan constatar esta actividad. Pese a que se va a introducir una metodología de excavación más depurada, con la publicación de perfiles estratigráficos, los métodos de recuperación no van a permitir constatar la presencia de peces en los yacimientos. Sebastián González García-Paz, en las excavaciones del castro de Baroña, va a recuperar varias piezas líticas que identifica con pesas de red:

"[...] Entre los objetos de piedra se incluyen los molinos de mano de ambos tipos, con mayor representación de los circulares, dos hachas pulimentadas, piedras de mariscar, pesos de red y un pequeño molde de fundición de forma de cuenco y pequeño tamaño [...]" (González García-Paz, 1933: 347).

Hecho que, una vez más, le lleva a considerar la pesca como una actividad básica de los habitantes del asentamiento, siendo además una labor que no presentaba dificultad:

"[...] Procurábanse siempre buscar lugar apropiado para hacer una vida fácil, cerca de campos fértiles o al pie del mar, donde la pesca era el mejor medio de vida [...]" (González García-Paz, 1933: 348).

Una excepción en el trato que van a recibir los restos de ictiofauna de los diferentes yacimientos arqueológicos es un artículo de Esmoris Recamán (1923) publicado en el Ideal Gallego. En él se ocupa de la historia de Finisterre, haciendo referencia a diferentes lugares singulares y leyendas, así como a diversos hallazgos arqueológicos. Entre estos, va a citar la presencia de un gran depósito de conchas en las proximidades de la playa de la Langosteira, así como restos de peces en un pozo al hacer una casa en la playa de Calafigueiras:

"[...] Al hacer la casa de Don Matías Canosa, situada en la calle real de esta villa, sobre la playa de Calafigueiras uno de los obreros notó que una de las partes del terreno presentaba menor resistencia: Había allí a manera de un pozo (de medio metro aproximadamente de diámetro) cegado con tierra y arena y en el que aparecieron varias vértebras de un pescado de grandes dimensiones, porque según me aseguró el señor Canosa, que es persona de muy buen criterio bien podía tener el cuerpo de la vértebra un grosor de siete 
u ocho centímetros. En el fondo de la excavación había mucha cantidad de grandes espinas también de pescado. "Parecía como si aquello fuesen restos de comida" [...]" (Esmoris Recamán, 1923).

Esta cita será una de las primeras referencias a restos óseos de ictiofauna en el noroeste peninsular.

\section{III.1.2. LA POSGUERRA Y EL ABANDONO DE LOS ANÁLISIS.}

El comienzo de la Guerra Civil va a truncar toda la labor investigadora que estaba realizando el Seminario de Estudios Gallegos, además de finalizar las relaciones con los investigadores portugueses (Acuña, 1996). Las consecuencias del conflicto bélico en España, así como la posterior Guerra Mundial, van a producir un estancamiento y abandono del interés por los concheros en el noroeste, principalmente en el estudio de los concheros. Los análisis de acumulaciones de conchas durante este periodo van a ser escasos. En 1944 se creará el Instituto Padre Sarmiento de Estudios Gallegos, donde tendrán cabida parte de los componentes del desaparecido Seminario de Estudios Gallegos, si bien no van a desarrollar una actividad investigadora con la importancia que habían alcanzado años antes (Acuña, 1996).

La intervención más importante realizada en un conchero en estos años, será la dirigida por Mergelina a finales de la década de los 30 en Santa Trega. Por un lado va a desvincular definitivamente las industrias líticas del yacimiento del Asturiense, a la vez que va a realizar un corte estratigráfico en el conchero de la puerta sur desarrollando una de las mejores intervenciones en un depósito de estas características hasta el momento (Mergelina, 1939/40). En cuanto a la pesca seguirán sin documentarse restos óseos, siendo las interpretaciones realizadas al respecto similares a las de fechas anteriores. Pero además, va a vincular de forma clara la pesca a una actividad propia de sociedades pobres y atrasadas, asociándola con las poblaciones pesqueras actuales:

"[...] Puede afirmarse son productos de gentes reducidas a una especial pobreza y por ende obligados a aceptar procedimientos en consonancia con el medio económico en que se situaron, por causas que ignoramos. Llegan a producir por todo ello y a mantener una supervivencia de formas primitivas, bien por arrastrarlas como algo tradicional (fenómeno extraño), bien por una misma situación, como creemos, pueda producir estados de cultura análogos a otros distanciados en el tiempo. [...] Esta afirmación puede parecer asombrosa, mas no debe olvidarse que si juntamente con estas manifestaciones, tenemos como coetáneas las pequeñas piedras horadadas y los pesos de red, hoy mismo se usan los rellos y los poutadas, y hoy mismo también, junto a un camino por donde chirría una carreta de ruedas macizas, pasa una carretera 
asfaltada, por donde corre veloz un automóvil [...]" (Mergelina, 1939-1940: 33).

Como hemos señalado, los restos de peces documentados son prácticamente nulos, y los restos de instrumentos de pesca escasos, lo que conlleva un cierto olvido de esta actividad en la mayoría de los artículos, mientras en otros se realiza una interpretación teñida de claros prejuicios.

No será hasta la década de los cincuenta cuando, en varias publicaciones generales sobre la economía castreña, la pesca comience a ser tenida en consideración. Estos trabajos están firmados por López Cuevillas: "El comercio y los medios de transporte de los pueblos castreños" (1955), "A Economía nos tempos da Cultura Castrexa" (1966), y por supuesto su obra clave: "La civilización céltica en Galicia" (1953). Sus interpretaciones van a basarse principalmente en las referencias que hacen los autores clásicos:

"[...] Gababa Polibio a fartura e boa calidade do peixe que se criaba nas costas lusitanas. lustino, á sua vez, asegura que o fluxo do Oceano faguía que os ríos da beiramar atlántica da Hispania estiveran cheos de pesca [...]" (López Cuevillas, 1966: 267).

También se van a tomar en cuenta los datos publicados sobre aparejos de pesca de diferentes yacimientos. A partir de estos restos, López Cuevillas diferencia dos momentos en la pesca del noroeste. El primero, conforme a los materiales de Camposancos, lo adscribe al Paleolítico, y estaría caracterizado por pequeñas piezas utilizadas como pesas de red. El segundo vinculado con los castros, donde se encontrarían pesos de redes más grandes, con presencia de anzuelos, y por lo tanto se refleja una mayor importancia de esta actividad. Pese a esta nueva perspectiva, la influencia de la etnigrafía va a seguir teniendo gran importancia, relacionando el mundo de los castros con la Galicia de su época:

"[...] Hai vestixios no noso país do exercicio da pesca que se remontan deica a industria paleolítica camposanquense, na que se atopan pedras de regular tamaño habilitadas, por meio de duas encetaduras no centro dos bordes, para serviren de pesos de grandes redes; e xa nos castros dos bordes, para serviren de pesos de grandes redes; e xa nos castros é frecuente o achádego de anzós, de aparelles para tranzar liñós, e sobre todo das pedriñas chamadas poutadas que aínda poden mirarse na bisbarra da Guardia, prendidas en determiñadas redes [...]" (López Cuevillas, 1966: 268).

Estas consideraciones sobre la pesca y los restos que se vinculan con esta actividad no van a cambiar en los años siguientes, aunque sí es cierto que según nos vamos aproximando a la década de los 70 algunos autores empiezan a darle a estas evidencias un 
nuevo tratamiento que será preludio del inicio de una nueva fase a mediados de esa década.

Uno de estos trabajos es la publicación de los resultados de la intervención en la necrópolis de “Adro Vello" por García Martínez y Vázquez Varela (1968). Dicho trabajo es un precedente de los primeros estudios sobre fauna realizados con una metodología científica moderna en Galicia. En este artículo, a la hora de interpretar los restos arqueológicos recuperados, se señala:

"La presencia de restos abundantes de mariscos, de algunos peces y de dientes de hervíboro, nos evidencian la práctica de la ofrenda funeraria de alimentos [...]" (García Martínez y Vázquez Varela, 1968: 570).

"Respecto a la alimentación observamos una gran importancia del marisqueo, junto con la pesca y cría de herbivoros" (García Martínez y Vázquez Varela, 1968: 571).

Otro ejemplo va a ser la intervención en el yacimiento de O Reiro. En su publicación se va a hacer referencia a la gran cantidad de restos de pez documentados, realizando además una identificación anatómica de los mismos, lo que es una excepción dentro de la literatura arqueológica del momento:

"[...] Muy abundante, aunque infinidad de trozos son irrecuperables.

Abundan los huesos de aves, micromamíferos y mamíferos; son muy abundantes las vértebras de peces [...]" (Ramil Soneira, 1973: 27).

E igual que veíamos en el artículo sobre la necrópolis de Adro Vello, la interpretación se realizará en base a los restos arqueológicos, teniendo en cuenta tanto restos animales como vegetales:

"[...] Podemos deducir que pese a su proximidad al mar no formaba parte de su alimentación los moluscos y sí que lo hacía de aves, mamíferos, peces y vegetales [...]" (Ramil Soneira, 1973: 30).

Desgraciadamente estos casos son excepciones, y en la mayoría de los artículos siguen predominando las interpretaciones apriorísticas y sin referencias a ictiofaunas. En 1971 se van a publicar los trabajos realizados por José Ma Luengo y Martínez en el Castro de Baroña. En este trabajo no se cita la presencia de ningún resto óseo de pez, y sin embargo se atribuye a la pesca la principal actividad de los habitantes del castro:

"[...] A juzgar por los hallazgos efectuados, el pueblo ocupador de este castro vivía principalmente de la pesca [...]" (Luengo y Martínez, 1971: 264). 
Cuando atribuye esta actividad a los hallazgos debe referirse a dos "agujas" de bronce que apunta que podrían ser anzuelos, por lo que la interpretación que realiza del yacimiento y de su actividad económica se basa únicamente en estos objetos:

"[...] Dos agujas de bronce, sin hondón de sección cuadrangular, tienen la punta rota y miden $35 \mathrm{~mm}$ de largo. Aparecieron, como se dijo, en la casa núm. IX. Cabe la posibilidad, por su forma, que fuesen las partes superiores de unos anzuelos [...]" (Luengo y Martínez, 1971: 253).

Como habíamos observado en trabajos anteriores, determinadas condiciones geográficas del yacimiento o los textos clásicos van a determinar la actividad del asentamiento, adaptando los datos a la conclusión apriorística.

\section{III.2. EL COMIENZO DE LA ICTIOARQUEOLOGÍA: LA DÉCADA DE 1970.}

El final de la década de los 60 y comienzo de los 70 del siglo XX va a suponer el desarrollo de los estudios ictioarqueológicos en Europa. Este cambio se va a producir principalmente por la aplicación de nuevas técnicas de excavación y cribado (Ferré, 2003). Uno de los principales autores va a ser Lepiksaar (1973, 1981-1983), que con toda una serie de trabajos a lo largo de la década de los 70 y los 80 va a ser considerado el padre de la disciplina (Clason, 1986). Sin embargo, la primera obra que va a plantear una metodología de recuperación y estudio aplicable a diferentes restos va a ser la de Casteel en 1976. La aparición de nuevos investigadores y los sucesivos avances metodológicos van a desembocar finalmente en la formación en los 80 del siglo XX del Fish Working Group del ICAZ.

En España, coincidiendo con el fin del aislamiento después de la Guerra Civil, se producirá la entrada de nuevas líneas de investigación provenientes del extranjero. Esto va a provocar que en los años setenta del siglo pasado se produzca un cambio importante en los estudios zooarqueológicos peninsulares. Este cambio viene marcado por los trabajos que van a realizar J. Boessneck y A. von Den Driesch en yacimientos de la Prehistoria Reciente, publicados en la serie Studien übe frühe Tierknochenfunde von der Iberischen Halbinsel (Fernández Rodríguez, 2000). Estos investigadores serán pioneros en los estudios de ictiofaunas arqueológicas en la Península Ibérica, principalmente de yacimientos de la mitad sur peninsular: Cabezo Redondo en Alicante (Von den Driesch y Boessneck, 1969), Cerro de la Virgen en Granada (Von den Driesch, 1972) o Cabezo de San Pedro en Huelva (Von den Driesch, 1973).

Además, a comienzos de esa misma década, la creación del laboratorio de arqueozoología de la Sociedad de Ciencias de Aranzadi de San Sebastián supondrá un gran impulso para este tipo de estudios. Bajo la dirección de J. Altuna se iniciará esta nueva línea de trabajo con la publicación de su tesis doctoral en 1972. Al mismo tiempo comenzarán a desarrollarse los trabajos de Arturo Morales, que realizará diversos estudios 
en el campo de la ictioarqueología, tanto a nivel metodológico (Morales y Roselund, 1979), como de análisis de yacimientos (Morales, 1979).

En Galicia, bajo la dirección del Instituto Padre Sarmiento de Estudios Gallegos por Bouza Brey en 1967, se abrirá la puerta de la sección de Arqueología y Prehistoria a un grupo de jóvenes universitarios: González Reboredo, Acuña Castroviejo, García Martínez, Carro Otero y Vázquez Varela, que formarán un núcleo inicial al que posteriormente se unirán otros investigadores (Calo Lourido, 1997). Por otro lado, la llegada a la Cátedra de Prehistoria de la Universidad de Santiago de Carlos Alonso del Real en 1955 favorecerá la relación con el Instituto Padre Sarmiento (Calo Lourido, 1997). En 1968 con la incorporación de Balil Illana a la Universidad de Santiago, se producirá un impulso de la investigación arqueológica en Galicia vinculada a la Universidad, que hasta el momento se había mantenido apartada de este ámbito, participando en la formación de nuevos arqueólogos y en el desarrollo de nuevas líneas de investigación (Acuña, 1996).

En cuanto a las investigaciones faunísticas, las nuevas corrientes se verán reflejadas en los trabajos realizados desde la Universidad de Santiago de Compostela por Vázquez Varela. Trabajos que se centrarán principalmente en la Cultura Castreña del Noroeste. Pese a que sus estudios económicos se van a centrar principalmente en el aprovechamiento de los recursos marinos, con estudios malacológicos e ictiológicos, también desarrollará y fomentará análisis paleobotánicos y macrofaunísticos, dentro de un proyecto más ambicioso que pretendía un acercamiento a la economía de subsistencia de las sociedades castreñas, tanto en poblaciones prerromanas como ya romanizadas (Fernández Rodríguez, 2000). Para realizar estos estudios arqueofaunísticos va contar con la colaboración de diferentes biólogos, pertenecientes al Departamento de Bioloxía Animal de la Universidad de Santiago, como J.S. Troncoso o V. Urgorri, en el caso de los estudios malacológicos, o José M. Rey Salgado en la investigación ictioarqueológica. Al mismo tiempo va a incorporar de forma crítica la información de las fuentes clásicas y de la antropología al discurso zooarqueológico.

\section{III.2.1. LOS PRIMEROS ESTUDIOS ICTIOARQUEOLÓGICOS.}

Desde comienzos de la década de 1970, la actividad investigadora de Vázquez Varela se va a centrar en los estudios arqueozoológicos, entre los que va a ocupar un papel preponderante el análisis de los recursos marinos, principalmente los malacológicos. En este sentido va a realizar el sondeo de diferentes concheros asociados a castros situados en las Rías Bajas. Estos muestreos pueden parecer hoy en día muy limitados metodológicamente, pero en aquel momento supusieron un gran avance en los estudios de la economía castreña, ya que por primera vez en Galicia se van a establecer unos principios de muestreo de concheros y posterior procesado de las muestras obtenidas:

"[...] Para estudiar la composición del conjunto formado por la acumulación de desechos alimenticios de los habitantes del 
poblado, tomamos varias muestras en varios puntos elegidos al azar y a diversas profundidades [...].

La muestra recogida fue mezclada y se procedió a cribarla con una malla fina, de forma que quedasen retenidos todos los restos de animales por pequeños que fueran, incluso las delgadas púas de los erizos. Posteriormente fueron lavados, secados, clasificados y contados [...]" (Vázquez Varela, 1975a: 501).

Estos trabajos van a desarrollar de manera notable los estudios arqueomalacológicos, abandonando la mera referencia a restos de moluscos en los yacimientos, y relacionando las especies con el medio para poder reconocer diferentes estrategias de recolección o incluso variaciones climáticas:

"[...] Alguno de los campos sobre los que se pueden obtener datos a través de los restos de peces y moluscos: 1.o Alimentación. 2. Técnicas y lugares de recolección y/o pesca. 3.o Distribución zoológica. 4. o Medio ambiente" (Vázquez Varela, 1975b: 291).

Los primeros estudios ictioarqueológicos van a estar muy ligados a estos sondeos en concheros. De este modo, el primer análisis de ictiofauna en un yacimiento gallego va a ser el publicado en 1975 en el marco del estudio del conchero de las Islas Cíes (Vázquez Varela, 1975b). En este trabajo se identifica un faringobranquial de Labrus bergylta, además de citarse un canto perforado que asocia a una pesa de red. Cotejando estos datos con la información antropológica va a llegar a la conclusión de que se utilizaba como técnica de pesca la línea de anzuelos. Esto va a suponer el primer intento por establecer una caracterización de la pesca relacionando los restos faunísticos y los aparejos, aunque tengan gran importancia los aspectos antropológicos:

"[...] En la prospección se encontró una pesa de red ovalada, hecha en piedra, de 35 grs., siendo éste el peso empleado actualmente para pescar la maragota a línea, por lo cual es muy probable que el citado lábrido haya sido capturado por este sistema [...]" (Vázquez Varela, 1975b: 294).

Aun cuando en este primer trabajo la presencia y el tratamiento de la ictiofauna resulta bastante anecdótica, en artículos posteriores presentará análisis más minuciosos. Así en un posterior trabajo (Vázquez Varela, 1976) va a realizar un estudio crítico de las diferentes fuentes que pueden ser utilizadas para el estudio de la pesca en la Cultura Castreña (artefactos, iconografía, fuentes literarias, restos paleontológicos), además de una reflexión sobre los métodos de recuperación empleados y la información que se puede obtener de los restos óseos de peces:

"[...] Dentro del conjunto faunístico tal vez el sector más descuidado en la recolección es el de los restos de peces [...]. Esto ha hecho que 
se hayan desperdiciado una serie de valiosos datos que nos hubiesen sido proporcionados por una depurada técnica de recogida de muestras y análisis.

Los restos de peces en los yacimientos prehistóricos, si son recogidos y estudiados con la metodología adecuada, pueden aportar valiosas informaciones sobre aspectos económicos, tecnológicos, culturales y ecológicos [...]". (Vázquez Varela, 1976: 84).

El material objeto de análisis en este trabajo va a proceder de varios yacimientos: $A$ Lanzada, A Suvidá, Islas Cíes y Castro de Donón, lo que le permite realizar una amplia caracterización de la pesca en la Cultura Castreña, tanto de especies como de técnicas de pesca. El estudio comparado de estos yacimientos con otras fuentes, le va a llevar a hablar de una actividad pesquera realizada en aguas próximas a la costa, tanto desde tierra como con pequeñas embarcaciones (Vázquez Varela, 1976: 86). Por otra parte, hay que señalar que el estudio arqueomalacológico de estos mismos yacimientos no se publicará hasta 1988 (Vázquez Varela, 1988).

Una estructura similar va a presentar en un posterior artículo, si bien va a ampliar algunos aspectos sobre las fuentes utilizadas y se añaden los resultados de los yacimientos de A Peneda y Santa Trega (Vázquez Varela, 1978).

Otros autores van a hacerse eco de las líneas de investigación abiertas por Vázquez Varela. Reflejo de ello será el estudio realizado por Cardero López (1980) en el castro de las Islas Cíes. Este autor realiza varias catas en el conchero, calculando unas dimensiones de $18 \mathrm{~m}$ de ancho y unos $30 \mathrm{~m}$ de largo. Según refiere su artículo, y ante la falta de medios para realizar una excavación estratigráfica, procedió al estudio de un talud a la mitad del conchero (Cardero López, 1980). Por lo tanto el muestreo parece haberse limitado a la recogida de materiales en un corte visible, lo que no se puede considerar metodológicamente correcto. También lleva a cabo una identificación de las especies de moluscos y el número de ejemplares de cada una, además de la toma de datos biométricos (Cardero López, 1980). Sin embargo para los peces se limita a hacer referencia a la abundancia y presencia de restos óseos, sin dar más información:

"[...] En el Concheiro aparecen en grandes cantidades restos animales (huesos, dientes, espinas, vértebras de pescado, conchas, etc.) [...]". (Cardero López, 1980: 346).

"[...] También se han hallado cinco fragmentos de la placa palatina de un pez semejante a la maragota y diversas vértebras aisladas de pescado [...]". (Cardero López, 1980: 348).

En la década de los 80 no se realizan nuevos sondeos en los concheros. Sin embargo van a publicarse una serie de artículos que sintetizan los resultados obtenidos en los 
muestreos realizados con anterioridad, a lo que se unirá la recuperación de la información de las antiguas excavaciones. En este momento se produce la ruptura definitiva con las corrientes interpretativas desarrolladas hasta la fecha en Galicia en relación con los aspectos económicos. Esta corriente se basaba en las fuentes literarias clásicas a la hora de definir la economía castreña, y los restos arqueológicos no se consideraban como complemento, sino como un elemento que venía a confirmar estos planteamientos (Vázquez Varela, 1980). Los estudios realizados en campos como la arqueobotánica y la arqueozoología, desarrollados por Vázquez Varela desde comienzos de la década de 1970, lleva a este autor a cuestionar la validez de la explicación tradicional, planteando unos nuevos parámetros interpretativos, algo que ya apuntaba en sus primeros trabajos (Vázquez Varela, 1976). En esta línea de definición interpretativa de los sistemas económicos, los recursos marinos adquieren una nueva dimensión, pasando de ser un elemento obviado, debido las escasas referencias presentes en las fuentes clásicas, a ser un elemento de considerable importancia:

"El mar era intensamente explotado por las comunidades litorales. Existía la pesca con redes y anzuelos desde embarcaciones y desde tierra firme y el marisqueo de crustáceos, equinodermos, bivalvos y gasterópodos propios de fondos fangosos, arenosos y rocosos de la zona intermareal. Este aporte es decisivo con relación a lo tradicional pues nos da una imagen de la ganadería totalmente diferente de la indicada en los textos y nos desvela un aspecto casi inédito hasta ahora, como es el de la importancia del mar en la economía de estas gentes" (Vázquez Varela, 1980: 201).

Algunos de los trabajos de síntesis publicados por Vázquez Varela en estos momentos son: "La economía Castreña al norte del Miño" (1980), "La alimentación y la cocina en la Cultura Castreña de Galicia" (1983) y "Los testimonios económicos", en el volumen titulado "Estudos de Cultura Castrexa e de Historia Antigua de Galicia" (1983). En conjunto, estos trabajos pueden considerarse como una actualización de los planteamientos publicados en 1966 por López Cuevillas sobre la economía castreña. El papel que ahora se le atribuye a los moluscos y a los peces en la dieta de las poblaciones costeras es mucho mayor, algo lógico si tenemos en cuenta el considerable aumento de los concheros estudiados y de la información obtenida de los mismos:

"[...] El mar era intensamente explotado por las comunidades litorales. Existía la pesca con redes y anzuelos desde embarcaciones y desde tierra firme [...]" (Vázquez Varela, 1980: 201).

Además va a llevar a cabo estudios tafonómicos, relacionando el bajo número de restos cefálicos, así como su deterioro, con la costumbre de masticar las cabezas:

"[...] Los huesos de la cabeza, a excepción de los maxilares de aquellas especies que los tienen fuertemente desarrollados tales 
como el pargo, la dorada, la maragota, etc., se presentan muy fragmentados lo que puede deberse en parte a su natural fragilidad y en parte a la práctica de masticarlos, costumbre todavía muy extendida en la actualidad en las zonas costeras de Galicia [...]" (Vázquez Varela, 1983: 395).

Entre estos trabajos de síntesis también tenemos que destacar el titulado "The fishing in the Castro's Culture" (1984), ya que va a suponer el dar a conocer estos estudios a nivel internacional, ya que hasta ahora únicamente se habían publicado en revistas locales.

En 1986 Hidalgo Cuñarro va a publicar otro trabajo de síntesis sobre el marisqueo y la pesca en la Cultura Castreña. En este artículo simplemente se limita a enumerar los yacimientos donde se localizan restos y las especies representadas. Tampoco se va a realizar ningún tipo de interpretación o aporte que incorpore nuevas hipótesis frente a las ya realizadas.

\section{III.2.2. LOS AÑOS 90: RENOVACIÓN METODOLÓGICA.}

Continuando la línea de investigación abierta por Vázquez Varela a comienzos de los años setenta, en la década de 1990 aparecerá una nueva generación de investigadores que llevarán a cabo una actualización metodológica, tanto analítica como interpretativa, de los estudios arqueofaunísticos. A esta nueva generación pertenecen investigadores como Carlos Fernández Rodríguez, cuyo trabajo ha contribuido decisivamente al conocimiento de la economía castreña y galaico-romana, en aspectos tan importantes como la caza o la ganadería entre otros, y que verán su máxima expresión en su Tesis Doctoral "Los macromamíferos en los yacimientos arqueológicos del noroeste peninsular: un estudio económico" (Fernández Rodríguez, 2000). Carlos Mạ Rodríguez López será el máximo exponente de esta generación en cuanto a la malacología, siendo el punto de partida de su labor investigadora el trabajo de Investigación de Tercer Ciclo, presentado en la Universidad de Santiago en 1992: "Nuevas aportaciones al estudio del aprovechamiento de los recursos marinos en los castros gallegos: el Castro de Cabo de Cruz". Por otro lado, M. Camino López y Ma del Carmen Ferré, bajo la dirección del profesor Rey Salgado y desde el Departamento de Bioloxía Animal de la Universidade de Santiago, realizarán una intensa labor de estudio de la ictiofauna, dando como resultado la presentación de la Tesis Doctoral de esta última investigadora, "Contribución al estudio de las ictiofaunas holocenas en Galicia", en 2003. Junto a los trabajos de esta nueva generación, es destacable la continuidad de Vázquez Varela, realizando en numerosas ocasiones trabajos conjuntos.

Esta nueva generación de zooarqueólogos, en lo que al estudio de los recursos marinos se refiere, se va a ver influida tanto en metodología de muestreo como de análisis, por los trabajos desarrollados fuera de nuestras fronteras por diferentes autores como Lepiksaar (1981-1983), J. Desse (1984), G. Desse (1984), Roselund y Morales (1984), 
Clason (1986); aunque el trabajo que más va a condicionar las futuras investigaciones ictioarqueológicas, es la Tesis de Licenciatura de Roselló Izquierdo: "Contribución al Atlas Osteológico de los Teleósteos Ibéricos I. Dentario y Articular", de 1988, y su posterior Tesis Doctoral: "Arqueoictiofaunas Ibéricas. Aproximación metodológica y bio-cultural", defendida en 1989 en la Facultad de Biología de la Universidad Autónoma de Madrid.

Será esta última generación la encargada de impulsar definitivamente el estudio de las ictiofaunas, muy vinculado al desarrollo de las técnicas de muestreo y estudio de los concheros. En unos pocos años se va a realizar una intensa labor investigadora, publicando la mayor parte de los trabajos con los que contamos en la actualidad sobre el aprovechamiento de recursos marinos, ganaderos y cinegéticos, indispensables para elaborar una interpretación económica de la Cultura Castreña y de la época Galaicoromana.

Dentro de los estudios ictiofaunísticos se van a diferenciar dos momentos bien definidos. El primero de ellos dará comienzo a iniciós de la década de los años 90 , con los análisis realizados por M. Camino López bajo la dirección de J.M. Rey Salgado. Pese a que la trayectoria investigadora de esta autora va a ser breve, y una parte de sus trabajos va a permanecer inédita, su labor supuso un paso muy importante en el desarrollo de los estudios de arqueoictiofaunas en el Noroeste. Sus trabajos incorporan una metodología mucho más precisa a la hora de identificar y contabilizar restos, del mismo modo que se van a empezar a tomar biometrías, lo que supone un salto cualitativo relevante respecto a los trabajos previos. Debido a su vinculación con el Departamento de Bioloxía de la Universidade de Santiago, en sus trabajos va a primar la vertiente bioecológica sobre la histórica.

Uno de los primeros trabajos que se van a desarrollar aplicando estos avances metodológicos, es el informe realizado de los restos de la campaña de mayo de 1991 del Castro de O Achadizo (Boiro, A Coruña) (Camino López, s.f.). En él, además de una breve descripción de la metodología utilizada, se van a desglosar las diferentes partes óseas identificadas por cada muestra, así como su número, lo que contrasta con los análisis anteriores donde únicamente se indicaban las especies representadas.

Por otro lado, se van a aplicar nuevos parámetros de muestreo en el estudio de los concheros, determinando el peso mínimo representativo de las muestras o diferenciando niveles. Además las muestras serán procesadas con una metodología más minuciosa, mediante un doble tamizando, primero con una criba de $1 / 4$ de pulgada y posteriormente con otra de $1 / 8$ pulgadas, para de este modo recuperar los restos de menor tamaño (Rodríguez López, 1992a).

En esta misma tendencia podemos incluir varios trabajos de síntesis sobre la pesca en la Galicia protohistórica. En 1991 (Camino López et alii, 1991) se va a presentar en la VIII Reunión Nacional sobre Cuaternario Ibérico, celebrada en Valencia, una comunicación sobre la ictiofauna de varios yacimientos gallegos, estableciendo dos líneas de 
investigación, una bioecológica y otra socio-económica. Otro de estos trabajos es publicado en 1993 (Vázquez Varela et alii, 1993), siendo el estudio más completo sobre la pesca en el mundo castreño, si tenemos en cuenta que va a cruzar tanto datos biológicos como útiles relacionados con esta actividad. Sin embargo, los yacimientos presentados van a ser pocos, y la metodología de recuperación de los materiales resulta poco precisa.

El segundo de estos periodos dará comienzo a mediados de la mismadécada de 1990, con el inicio de los análisis realizados por Ma.C. Ferré, también bajo la dirección de J.M. Rey desde el Departamento de Bioloxía Animal de la Universidade de Santiago, continuando con el trabajo y las líneas de investigación iniciadas por C. López. Este segundo momento se puede relacionar con la primera fase del proyecto de muestreo y análisis de concheros dirigido por Rodríguez López en 1993, proyecto subvencionado por la Xunta de Galicia, y avalado por el Departamento de Historia I de la Universidade de Santiago. La ictiofauna de los depósitos sondeados será estudiada por Ferré, siendo la base de su Tesis de Licenciatura (Ferré, 1996). Entre estos yacimientos se incluirán algunos ya estudiados por Vázquez Varela, lo que supone una revisión de los mismos aplicando los nuevos parámetros metodológicos y los nuevos enfoques interpretativos. En esta primera campaña se sondearán los castros de Queiruga (Porto do Son, A Coruña) y de Facho de Donón (Cangas de Morrazo, Pontevedra). En dicho proyecto, además del estudio de los materiales documentados en las labores de muestreo y del análisis sedimentológico para discriminar diferentes niveles, además de evaluar las modificaciones en el nivel del mar y llevar a cabo una estimación de la población que podría vivir en el Castro y la contribución de los recursos marinos a su dieta.

En 1994 se desarrollará la segunda fase de este proyecto, con el sondeo y muestreo de los concheros localizados en los castros de As Hortas (Islas Cíes, Pontevedra), Peneda del Viso (Redondela, Pontevedra), Punta de Cantodorxo (O Grove, Pontevedra) y Punta do Castro (San Cosme de Barreiros, Lugo). Las publicaciones relacionadas con los resultados obtenidos tienen además la particularidad de que se van a incluir los análisis de todos los materiales documentados en el conchero, mostrando la importancia y el potencial tiene un análisis pormenorizado de estos depósitos. De este proyecto saldrán a la luz diversos artículos de conjunto como el del yacimiento de Cantodorxo (Ferré et alii, 1996; Fernández Rodríguez et alii, 1998) o el de As Hortas (Ferré et alii, 1995; Rodríguez López et alii, 1996).

Estos sondeos van a servir para la realización de la primera Tesis de Licenciatura sobre ictioarqueología en Galicia, defendida por Mạ del Carmen Ferré Álvarez en 1996. En ella va a incluir los yacimientos de As Hortas, Cantodorxo, Queiruga, O Achadizo, Facho de Donón y Adro Vello. Este periodo finalizará en el año 2003 con la defensa de la Tesis Doctoral de esta autora, donde se presenta un panorama del aprovechamiento ictiológico de las sociedades costeras del Noroeste desde la Edad del Hierro hasta la Edad Moderna. Como ya comentamos, debido a la formación y vinculación académica de esta 
investigadora, en el enfoque de su investigación van a primar más los aspectos biológicos que los socio-económicos.

A lo largo de la segunda mitad de la década de los 90 se van a publicar un número importante de trabajos, entre los que consideramos que destacan principalmente dos. El primero de ellos es el titulado "O aproveitamento dos recursos mariños na prehistoria e a antigüedade de Galicia", de 1998. Este artículo se engloba en el marco de una monografía sobre la pesca en Galicia que analiza la evolución de esta actividad desde la Prehistoria hasta la actualidad. Únicamente se van a manejar restos arqueológicos para la Prehistoria y la Antigüedad, siendo un estudio principalmente documental. Por otro lado, ese mismo año se va a publicar el primer estudio evolutivo de la pesca desde Época Castreña hasta la Edad Media con base en los restos arqueoictiológicos (Ferré y Rey, 1998), recogiendo los escasos análisis realizados en aquel momento de ictiofaunas con una cronología posterior al periodo romano (Camino López et alii, 1991; Ferré y Rey, 1997).

Durante los últimos años de la década de 1990 y comienzos del siglo XXI, se produce un estancamiento en los estudios faunísticos del Noroeste (Fernández Rodríguez, 2005/06). Esta interrupción se ha dejado notar de manera importante en los estudios sobre las arqueictiofaunas gallegas, dando lugar a un vacío en la literatura arqueológica del siglo XXI. 
IV. Material y Métodos. 


\section{IV.1. OBTENCIÓN Y TRATAMIENTO DE LAS MUESTRAS.}

Durante mucho tiempo los restos faunísticos han ocupado un segundo plano de la bibliografía arqueológica. Como ya comentamos en el capítulo anterior, en la mayoría de las ocasiones son recuperados los restos visualmente más llamativos, quedando su selección en manos del azar o del criterio del arqueólogo. De hecho, es habitual idea de que los huesos más grandes, llamativos o más completos son los que más información aportan, dando lugar a la desaparición del registro de huesos de taxones de pequeño tamaño o de los restos fragmentados (Clason y Prummel, 1977; Morales Muñiz y Moreno Nuño, 1992; Fernández Rodríguez, 2000). Este problema que afecta a las faunas arqueológicas en general, se ve agravado en el caso de la ictiofauna debido a sus dimensiones y características óseas. La recuperación visual de los materiales y la inexistencia de cribado en las excavaciones arqueológicas, junto con el poco valor que se le da a estos restos, hacen que se pasen por alto un número muy significativo de elementos, que en algunos casos puede llegar a la totalidad del registro.

Los conjuntos estudiados en el presente trabajo proceden de diferentes yacimientos situados a lo largo de toda la costa gallega, representativos de un amplio abanico cronológico. La mayoría de las muestras se adscriben a asentamientos prerromanos, debido a la presencia de concheros que fueron tratados con una precisa metodología de análisis. Los concheros de O Neixón, Montealegre, A Lanzada y Punta Atalaia fueron muestreados siguiendo procedimientos similares, se tomaron varias columnas de muestras y se procesó todo el sedimento recogido. En el caso de O Neixón, los diferentes muestreos se completaron con el cribado de todo el sedimento procedente del conchero, lo que permitió recuperar la mayor parte de las piezas óseas.

En cuanto al conchero del Castro de Punta do Muiño do Vento, fue recogido en su totalidad pero sin que se conozca la ordenación seguida en su recuperación. Si bien las muestras son representativas del conjunto estudiado al no ser un muestreo selectivo, presenta problemas a la hora de evaluar posibles diferencias dentro del depósito.

En yacimientos de cronología romana y medieval, principalmente en lugares de interior, la recuperación del material se vuelve más complicada debido a problemas de registro, como comentaremos más adelante, y la ausencia de grandes acumulaciones. En los casos de las excavaciones en los asentamientos de Viveiro y Punta Atalaia la recuperación visual de las muestras se completó con la recogida del sedimento que englobaba a los restos. Esto nos permitió recuperar algunas espinas de pequeño tamaño, haciendo más representativa la muestra.

Caso aparte son los restos de Puente Castro, ya que fueron recogidos exclusivamente de forma visual, sin proceder a ningún muestreo ni cribado del sedimento. 


\section{IV.1.1. LOS CONCHEROS.}

Debido a que una parte importante de los restos fueron localizados en concheros, vamos a proceder a explicar brevemente las características y problemática que presentan estos depósitos.

Los primeros estudios sobre depósitos de conchas se remontan a la segunda mitad del siglo XIX, en los denominados "Køkkenmødding" de Dinamarca. Este término significa restos de cocina, y fue propuesto por el arqueólogo J.J.A. Worsae, el geólogo Fordhhammer y el zoólogo Steenstrup, miembros de la comisión designada por la Royal Society danesa en 1848 para estudiar estos depósitos (Bowdler, 2006).

En España, la generalización del término conchero frente al escandinavo Kjoekkenmoedding se remonta a la década de los años veinte del siglo pasado, si bien su origen parece retrotraerse al siglo XIX. Según el Conde de la Vega del Sella (1923) el primero en utilizar el término es Aquilino Padrón en el Boletín de la Sociedad Geográfica de 1877 refiriéndose a los depósitos de conchas existentes en las Canarias.

Tradicionalmente se ha denominado conchero a cualquier depósito con presencia de conchas, lo que provoca una gran confusión al no existir una estandarización de este concepto. Esto ocasiona que se considere conchero tanto un depósito donde las conchas suponen menos del $1 \%$ de su volumen, como otro que supere el $50 \%$.

La Real Academia Española de la Lengua (2001: 613) define conchero como un "depósito prehistórico de conchas y otros restos de moluscos y peces que servían de alimento a los hombres de aquellas edades. Generalmente se hallan a orillas del mar o de los ríos y cerca de las cuevas o cavernas". Esta definición es generalista y poco precisa, presentando toda una serie de limitaciones que no nos sirven para caracterizar estos depósitos. Quedan fuera una gran parte de acumulaciones de conchas que no se adscriben a periodos prehistóricos o que no están cerca de cuevas, además pueden no ser fruto de alimentación.

Clark (1976) va a definir conchero como "escombreras artificiales compuestas de una gran cantidad de fragmentos de huesos diversos y desperdicios, siempre llenos, como su nombre indica, de numerosas conchas".

Posteriormente Meighan (1980) va a precisar más las características, considerando conchero a cualquier depósito en el que la concha sea el elemento que predomine visualmente, lo que correspondería a más de un $30 \%$ de restos malacológicos, ya que el característico color blanco, y la mayor densidad pero menor volumen, del resto de componentes, hace que el depósito parezca estar compuesto exclusivamente de concha. Bowdler (2006) matizará aún más la definición y aumentará el porcentaje de conchas presentes, considerando conchero a todo depósito en el que representen más del $50 \%$ del peso total. 
La excesiva relatividad que presentan las definiciones, y las infinitas particularidades que presentan los concheros, hace necesario complementar la definición con una clasificación de los diferentes tipos de depósitos.

Meighan (1980) plantea una clasificación según las características culturales del grupo que creó el depósito:

-1. Concheros pertenecientes a sitios de cazadores-recolectores. Moluscos como alimento básico en la subsistencia, utilizados como recurso para sostener a la población en épocas de escasez.

-2. Concheros de economía mixta. La agricultura representa la fuente básica de alimentos, pero el mar proporciona el complemento proteínico.

-3. Concheros de actividad semicomercial. Los moluscos se utilizan tanto para consumo propio como para comercio de excedentes. Son producto de civilizaciones agrícolas altamente organizadas.

Otro tipo de clasificación es el propuesto por Widmer [1989, en Classen (1998)], según la presencia o no de artefactos y de otras actividades asociadas a las conchas:

-1. Shell midden site. Depósito de conchas para consumo alimenticio, sin presencia de otros artefactos.

-2. Shell midden. Depósito únicamente formado por conchas.

-3. Shell bearing midden site. Depósito de conchas para el consumo con restos de otras actividades.

-4. Shell bearing habitation site. Conchas utilizadas para la construcción.

Todas estas clasificaciones tienden a agrupar depósitos de conchas con unas morfologías muy diferentes, no siendo suficiente para una caracterización formal del conchero, aunque sí es cierto que la utilización de estas clasificaciones a nivel global nos puede dar información cultural sobre las poblaciones que lo formaron.

Por todo ello creemos que, a la hora de clasificar morfológicamente un depósito de conchas, es más adecuado el tipo de clasificación propuesto por Dupont (2006) para los concheros mesolíticos, basándose en la morfología y el volumen, con depósitos en positivo (Amas coquillier, Dépôt coquillier, Lit coquillier) o en estructuras en negativo (Lit coquillier de fossé, Lit coquillier de "fosse d'habitat", Dépôt coquillier de fosse de stockage ou autre).

A esta clasificación creemos necesario añadir una nueva categoría que englobe a todos aquellos restos no incorporados en la misma, como los restos aislados o en el interior de recipientes (Bejega García et alii, 2010). 


\section{IV.1.2.TOMA DE MUESTRAS.}

Lo más recomendable a la hora de estudiar un conchero sería el procesado total del mismo, pero esto se puede convertir en una labor ingente en el caso de depósitos de grandes dimensiones, siendo desproporcionado el esfuerzo invertido y los datos obtenidos (Bowdler, 2006). Diferentes autores consideran que, para determinar la composición de un conchero, es suficiente el procesado de pequeñas muestras, ya que los componentes de un nivel suelen ser bastante regulares en horizontal (Meighan, 1980; Ragir, 1988; Claassen, 1998). Por todo ello, a la hora analizar un conchero de grandes dimensiones, se procede a realizar diferentes muestreos, siendo recomendable la toma de varias muestras en horizontal de un mismo depósito para que el muestreo sea significativo (Dupont, 2006). La cantidad recogida de cada muestra debe estar en torno a los $2.000 \mathrm{~cm}^{3}$ o $2.000 \mathrm{gr}$. de peso, para que sea representativo del total del depósito, aunque hay autores que consideran más adecuadas muestras de entre 500 gr. y 2.500 gr. (Bowdler, 2006). Para otros el muestreo requiere muestras abundantes, pero pequeñas (Wheeler y Jones, 1989: 43).

Cuando nos encontramos con restos aislados el problema se acentúa. Unos inadecuados métodos de excavación y registro hacen que sea muy complicada la recuperación de estos restos. Por otro lado las grandes extensiones de terreno intervenidas y que potencialmente pueden contener restos ictiológicos complican aún más la recuperación. Sin duda estos problemas se podrían corregir con el cribado del total del sedimento extraído y una excavación más minuciosa y con recogida de sedimento en lugares sensibles como áreas de deposición de desperdicios, hogares o interior de estructuras.

No existe un único método de muestreo válido para todos los casos y depósitos (Juan-Muns et alii, 1991: 85). La estrategia de muestreo que sigamos debe ser flexible, adaptándose a las particularidades que presenta el depósito (Rodríguez López, 1993a; Claassen, 1998). Debido a esto, a la hora de realizar un muestreo hay que tener en cuenta dos cuestiones: 1) El muestreo debe ser representativo del depósito; 2) Cada yacimientos es único y requiere un muestreo propio (Wheeler y Jones, 1989: 40).

Debido a las características y problemas comunes que observamos a la hora de muestrear diferentes depósitos, hemos definido toda una serie de tipos de estrategias de muestreo que se adaptaran a las necesidades y características del depósito (Bejega García, 2009; González Gómez de Agüero, 2009; Bejega García et alii, 2010). A la hora de clasificar las técnicas de muestreo hemos utilizado las aplicadas a los análisis arqueobotánicos, adaptándolas a las características de las acumulaciones malacológicas e ictiológicas (Buxó, 1997; Burjachs et alii, 2003; Alonso Martínez et alii, 2003).

-Muestra de la totalidad del sedimento: se recoge toda la unidad estratigráfica con presencia de conchas o de huesos de peces. Este tipo de muestreo se desarrolla en aquellos depósitos de pequeño tamaño en los que no es 
posible realizar un muestreo o bien el análisis de todo el depósito no supone un esfuerzo superior a los resultados obtenibles.

-Columna de muestras: para el muestreo de depósitos de grandes dimensiones el método más recomendable es la columna de muestras. Con esta estrategia de muestreo obtenemos una frecuencia relativa de las variaciones relativas de la composición vertical del depósito, aunque una sola columna no es suficiente para tener una perspectiva global (Dupont, 2006). Con un único punto de muestreo se evaluarán diferencias verticales, pero carecemos de datos que permitan reconocer posibles variaciones horizontales. La separación entre las columnas de muestras debe adaptarse al tamaño del depósito, aunque hay autores que proponen una distancia de entre tres y seis metros, nunca pasando esta última porque la muestra dejaría de ser representativa (Claassen, 1998). Siempre que sea posible, la columna de muestras debe realizarse en un perfil, ya que de este modo podemos ver el desarrollo del depósito y podremos seleccionar los mejores lugares para realizar el muestreo (Meighan, 1980), aunque esto no quiere decir que no se deban muestrear varios perfiles.

La recogida de muestras en la columna tiene que realizarse siguiendo los diferentes niveles estratigráficos, siempre que sea posible. La porosidad de los depósitos y la actuación de los procesos tafonómicos, hacen que los componentes se entremezclen y parezcan uniformes, no permitiendo apreciar las posibles diferencias existentes (Waselkov, 1987). Este proceso es denominado TimeAveraging (Claassen, 1998; Gutiérrez Zugasti, 2005; Dupont, 2006). Sin embargo, un estudio más detallado del conchero va a permitir reconocer que está formado por diferentes echados individuales (Dupont, 2006). Por ello en estos casos es necesario hacer una división artificial del depósito en vertical, proceso que incluso sería recomendable en aquellos depósitos en que la estratigrafía parezca clara (Claassen, 1998; Dupont, 2006). La potencia de las diferentes muestras debe adaptarse a las características del conchero, aunque lo más recomendable, considerando la variabilidad que hemos podido constatar en los diferentes depósitos, sería de entre cinco y diez centímetros (Rodríguez López, 1993a; Bejega García et alii, 2010). La columna de muestras presenta el problema de que dificulta el estudio tafonómico e imposibilita el estudio microespacial, complicando el estudio paleoeconómico (Juan-Muns et alii, 1991: 85).

-Muestreo sistemático: método aleatorio utilizado para el muestreo en superficie de depósitos de conchas. Consiste en dividir la superficie en segmentos no superpuestos que a la vez serán subdivididos en 10 cuadrículas numeradas del 0 al 9. A la hora de proceder al muestreo, se recogerá el cuadro con el mismo número en todos los sectores. La subdivisión vertical se realiza siguiendo los estratos 
naturales o creando otros artificiales cada cierta profundidad (ver columna de muestras) (Ragir, 1988).

-Muestreo aislado: Muestra tomada en un depósito que, por diferentes razones, no puede tomarse en una columna de muestras. Implica la recogida del sedimento de una unidad estratigráfica en potencia.

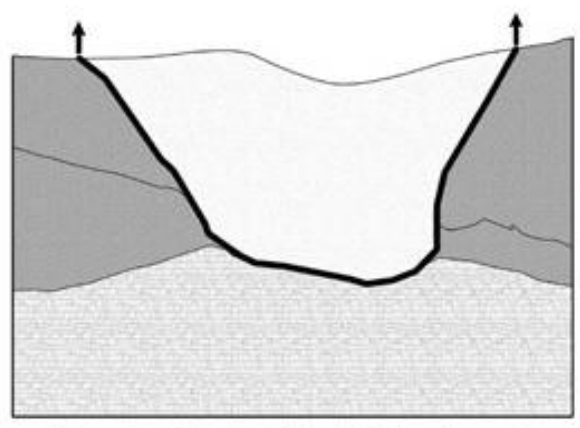

Muestra de la totalidad del sedimento

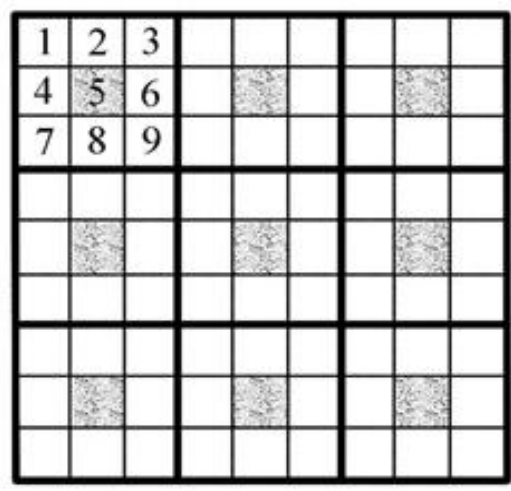

Muestreo sistemático

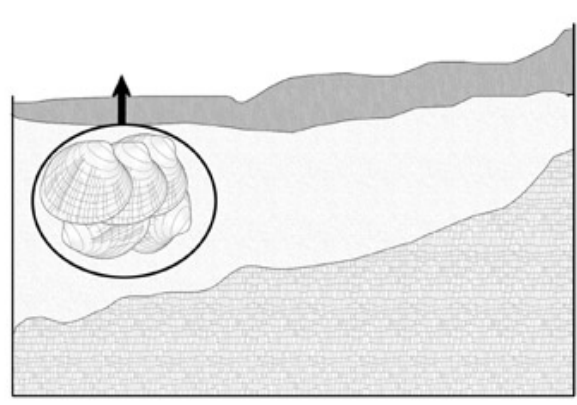

Muestra concentrada

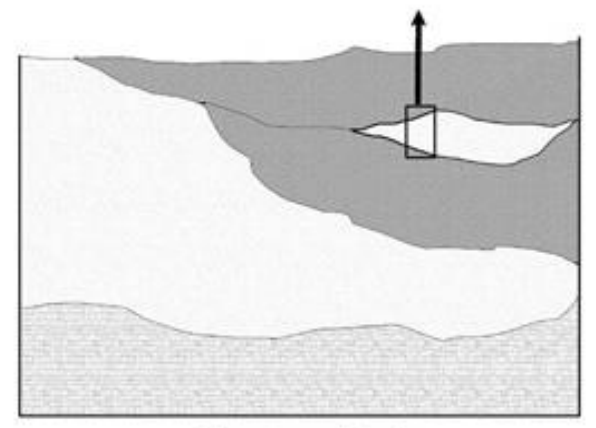

Muestreo aislado

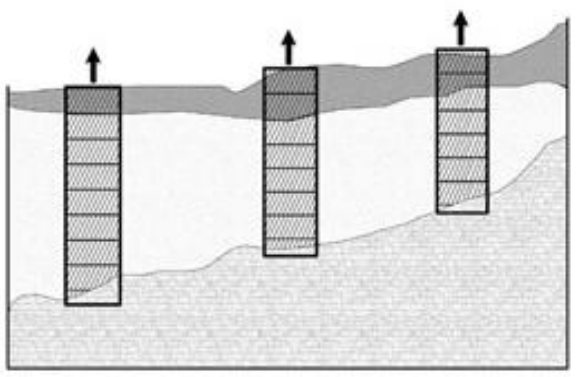

Columna de muestras

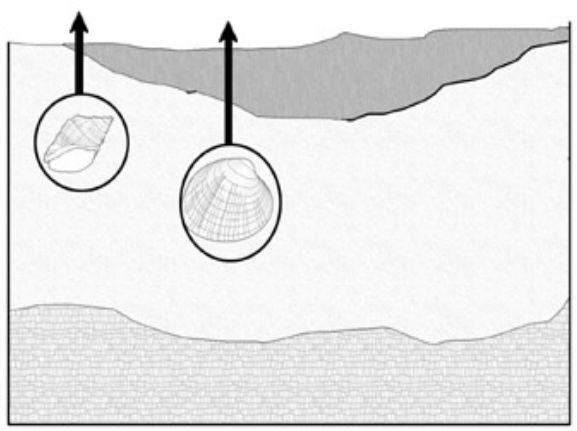

Muestra selectiva

Fig. 4 Sistemas de muestreo en concheros.

-Muestra selectiva: mediante este procedimiento se tiende a recoger aquellos restos más resistentes y mejor conservados o más llamativos. Este tipo de muestreo tiene el problema de que los pequeños fragmentos o las especies de pequeño tamaño no son recogidas (Morales Muñiz y Moreno Nuño, 1992, Dupont, 
2006). La representatividad de estas muestras respecto al conjunto del depósito es nula, ya que tiende a sobrevalorar todas aquellas piezas menos fracturadas o más llamativas, infravalorando o ignorando al resto. Pese a esto, puede ser útil a la hora de recuperar en el proceso de excavación restos aislados que complementen la información obtenida del muestreo.

-Muestra concentrada: se aplica a las áreas que presentan una acumulación de ciertas especies, o que suponen cierta variación visual en la composición respecto al resto del depósito, pero no tienen suficiente entidad para considerarlas como otra unidad estratigráfica. La muestra localizada implica la recogida del sedimento para su posterior tratamiento en el laboratorio. Debido a los problemas de recuperación que presenta la ictiofauna este debe ser el método utilizado en los casos de recogida manual (Desse y Desse, 1988: 70; Wheeler y Jones, 1989: 49), ya que pese a los problemas que presenta, ayuda a corregir los posibles errores de representatividad de la muestra.

Una vez descartado el análisis completo del sedimento, es necesaria la aplicación de un muestreo lo más correcto y completo posible, ya que problemas como la supuesta homogeneidad y la aparición de otros materiales pueden provocar errores en el análisis y pérdida de información (Bowdler, 2006). Para evitar esto, es necesaria la combinación de los diferentes métodos de muestreo, ya que no todos tienen la misma finalidad, por lo que mientras más amplia sea la variedad más posibilidades de análisis se nos van a presentar y una mayor flexibilidad que nos va a permitir adaptarnos a las características de cualquier tipo de yacimiento (Alonso Martínez et alii, 2003). También es importante complementar el proceso de muestreo con una excavación lo más correcta posible, en la que se aplique el cribado y flotación de sedimentos.

\section{IV.1.3.PROCESADO DE LA MUESTRA.}

Una vez en el laboratorio se procede al pesado y cubicado de cada muestra para poder calcular la representatividad de los diferentes restos zooarqueológicos frente al resto de materiales que componen el conchero. A la hora de realizar el muestreo es importante conservar todos los materiales que puedan aparecer, ya que sirve para caracterizar el depósito mediante las frecuencias de composición, así como para datar los distintos niveles. Posteriormente la totalidad de la muestra es cribada con agua para eliminar el sedimento más fino que contenga y que dificultaría la posterior tarea de tría. La malla que hemos utilizado para este primer proceso de tamizado tiene 0,8 $\mathrm{mm}$ de luz. Diferentes autores hablan de una malla de 1-2 mm (Desse y Desse, 1988: 70; Claassen, 1998), pero consideramos que con ese diámetro podríamos estar perdiendo información, puesto que determinados elementos de pequeño tamaño presentan menos posibilidades de ser recuperados, por este motivo hay autores que incluso proponen una malla de 0,5 mm (Waselkov, 1987; Juan-Muns et alii, 1991: 84). 
Una vez seca la muestra, y antes de su tría, se procede de nuevo a su cubicado y pesado para ver el porcentaje de muestra que corresponde a los elementos de menor tamaño. Posteriormente es otra vez tamizada, ahora en seco, con una malla de $1 \mathrm{~mm}$, hay autores que en este momento del proceso utilizan mallas entre $2 \mathrm{~mm}$ y $5 \mathrm{~mm}$ de luz (Ragir, 1988; Rodríguez López, 1992a; Ford, 1992; Claassen, 1998; Gutiérrez Zugasti, 2005; Bowdler, 2006; Dupont, 2006). La utilización de este tamaño de malla puede estar originando la pérdida de gran cantidad de restos de pequeño tamaño, y puesto que únicamente analizamos una parte del depósito es necesario conservar toda la información que sea posible, si bien todo dependerá del tipo de restos que conformen el depósito y el grado de fragmentación de los mismos. De la realización de este proceso diferenciamos dos tipos de restos en función de su tamaño:

-Muestra fina compuesta por elementos inferiores a $1 \mathrm{~mm}$; este sedimento fino será revisado para recuperar posibles restos de erizo, pez, micromoluscos u otras evidencias de actividad humana. Posteriormente se cubicará y pesará para tener constancia del porcentaje de muestra que representa. Este residuo se ha conservado para posibles análisis en el futuro.

-Muestra gruesa, donde se encuentran todos los restos mayores a $1 \mathrm{~mm}$, que fueron sometidos a un proceso de tría. Una vez separados, fueron pesados y en los casos en que fue posible cubicados por separado.

\section{IV.2. METOdología DE ANÁLISIS.}

\section{IV.2.1. LA ICTIOFAUNA: CARACTERÍSTICAS GENERALES.}

Pertenecientes a la Superclase de los peces encontramos un grupo de especies de vertebrados muy heterogéneo. Estas especies se caracterizan por tener un cuerpo continuo, en el que no hay separación entre las tres regiones, adaptado para moverse en el agua, un medio de gran densidad. La parte cefálica se extiende desde el extremo anterior hasta el borde del opérculo o la abertura branquial; desde este punto comenzaría el cuerpo hasta la abertura anal, donde se inicia la zona caudal, que llegaría al extremo posterior del individuo.

Los restos que nos vamos a encontrar en los diferentes yacimientos arqueológicos son principalmente los que conforman el esqueleto. Este esqueleto está formado por tres partes (Lozano Cabo, 1983):

-Esqueleto cefálico: formado por gran número de huesos. Está constituido principalmente por la caja craneana. Por debajo existe una serie de huesos suplementarios de origen dérmico que forman el opérculo, y el esqueleto visceral formado por una serie de arcos que forman la boca y el aparato respiratorio.

-Esqueleto de las aletas: puede ser de dos tipos: pares e impares. Las aletas pares corresponderían con las extremidades de los vertebrados, pudiendo ser 
pectorales o escapulares y ventrales o pelvianas. Las impares están formadas por el grupo de huesos que soportan los radios. Se encuentran colocadas en el plano sagital del cuerpo, pudiendo ser dorsales, caudales y anales.

-Columna vertebral: formada por un cierto número de vértebras característico de cada especie. Hay vértebras torácicas, en la que solo existe la apófisis espinosa y las transversales no se reúnen, y caudales, en las que además de la apófisis espinosa hay otra opuesta a ella constituida por la unión de las apófisis transversales.
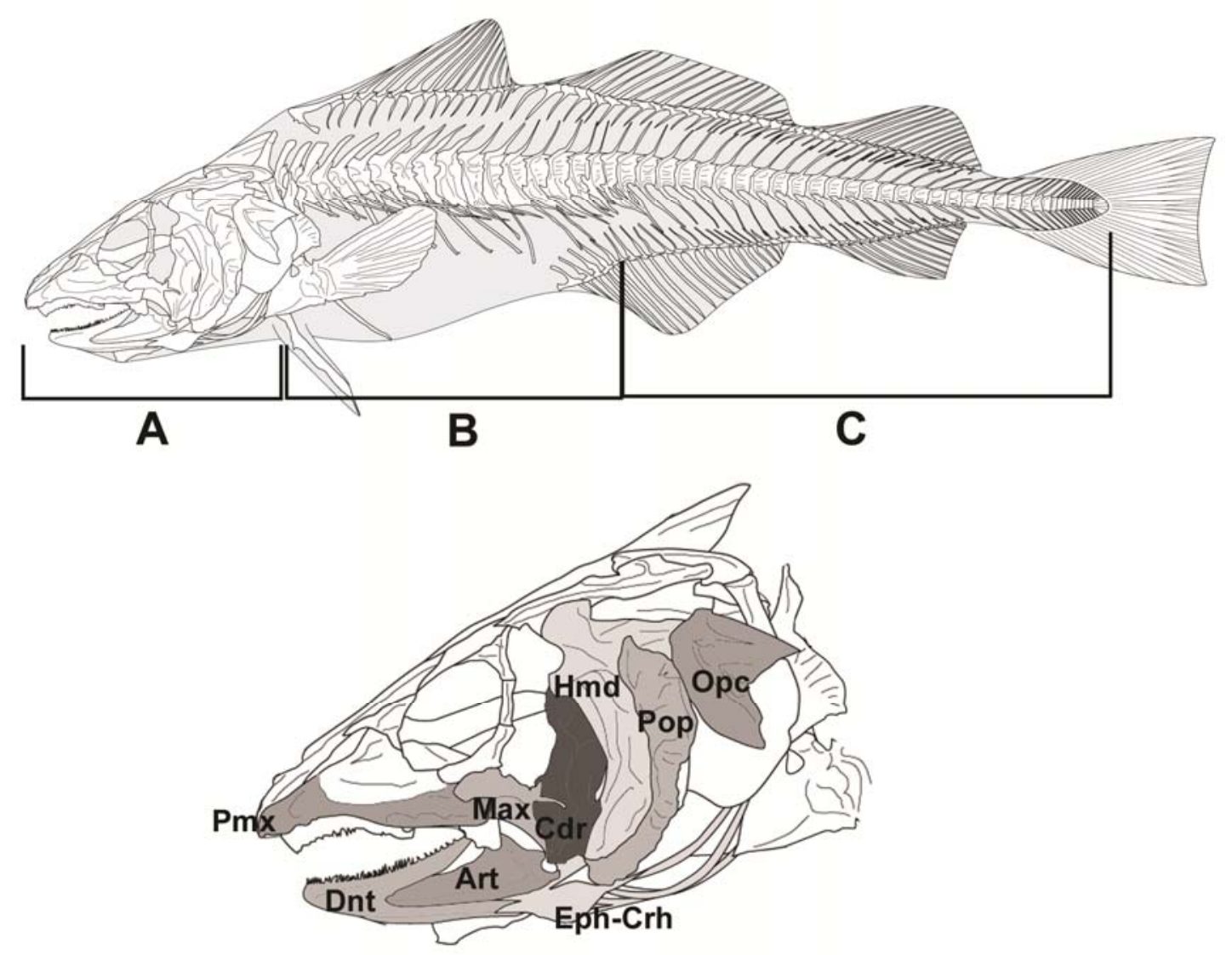

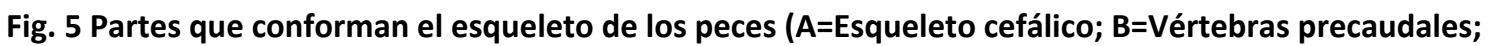
$C=$ Vértebras Caudales) y principales huesos cefálicos documentados en los yacimientos arqueológicos del Noroeste (Modificado de http://www.archeozoo.org/).

Además de los esqueléticos, también es común en los yacimientos encontrar otros tipos de restos. Aunque la superficie del cuerpo puede estar desnuda, lo más común es que se encuentre recubierta de formaciones especiales. Estas formaciones pueden ser de varios tipos: escamas de teleóstomos (ganoideas, cicloideas o tenoideas), dentículos dérmicos, característicos de condroicticios, u otros tipos de formaciones tegumentarias.

Dentro de la Superclase de los Peces, podemos diferenciar tres Clases: Agantos, Condroíctios y Osteíctios. Debido a sus características esqueléticas, así como a su 
importancia alimenticia, va a ser la Clase de los Osteíctios la que se encuentre mejor representada en los yacimientos arqueológicos.

\section{IV.2.1.1. NOMENCLATURA.}

La terminología utilizada para los diferentes huesos es la versión castellanizada del latín, propuesta por Roselló (1989), y basada en las directrices marcadas por la comunidad ictioarqueológica, recogidas por Lepiksaar (1981/83). Las abreviaturas son las utilizadas por Ferré (2003) y completadas por nosotros adecuándose a los restos documentados:

\begin{tabular}{ll|ll|ll} 
Basioccipital & Boc & Interopercular & lop & Supracleitro & Scl \\
Paraesfenoides & Psf & Dentario & Dnt & 1' Acantoriquia & Aca \\
Prevómer & Pvm & Articular & Art & Otolito & Oto \\
Vómer & Vom & Molar & Mol & Atlas & Atl \\
Premaxilar & Pmx & Faringobraquial & Fbr & Vértebra torácica & Tor \\
Maxilar & Max & Ceratobranquial & Cbr & Vértebra precaudal & Vpc \\
Palatino & Pal & Epihial & Eph & Vértebra caudal & Vca \\
Hiomandibular & $\mathrm{Hmd}$ & Ceratohial & Crh & Escamas & Esa \\
Cuadrado & Cdr & Urohial & Urh & Dentículo dérmico & Ddr \\
Opercular & Opc & Postemporal & Pst & Resto cefálico & Rce \\
Preopercular & Pop & Cleitro & Clt & Resto post-cefálico & Rpc
\end{tabular}

\section{IV.2.1.2. OSTEOMETRÍA.}

Una vez identificados los restos a nivel anatómico y taxonómico, se procedió a tomar los valores biométricos establecidos por diferentes autores. La toma de medidas se realizó con un calibre digital.

Para tomar las medidas básicas hemos seguido principalmente los parámetros establecidos por Morales y Roselund (1979; 1984), posteriormente completados por Roselló (1989) para piezas fragmentadas, y por Ferré (2003). Con el fin de simplificar las abreviaturas utilizadas para cada medida, se ha optado por utilizar el sistema empleado por Ferré (2003) asignándole a cada dato biométrico dentro de cada pieza un número. Por este motivo a continuación desarrollamos las claves numéricas y la descripción utilizadas por Ferré (2003) y las propuestas por Roselund y Morales (1984) y Roselló (1989):

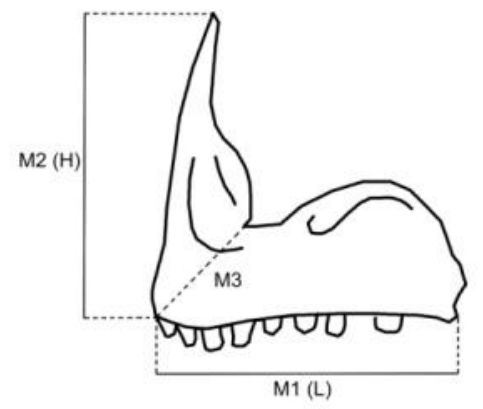

Premaxilar:

1 (L). Longitud del margen ventral

2 (H). Longitud del margen sinfísico 


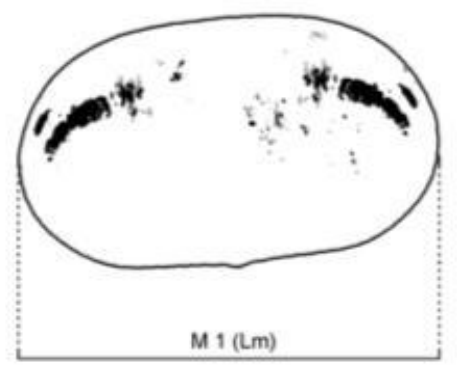

Gran molariforme:

1 (Lm). Longitud máxima

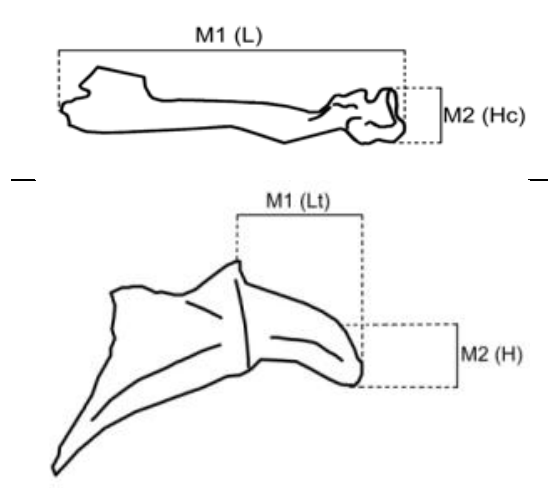

Maxilar:

1 (L). Longitud desde el proceso interno hasta la parte caudal

2 (Hc). Anchura del cuerpo maxilar

Palatino:

1 (Lt). Longitud desde el proceso maxilar hasta la parte subpterigoidea

$2(\mathrm{H})$. Anchura de la pieza

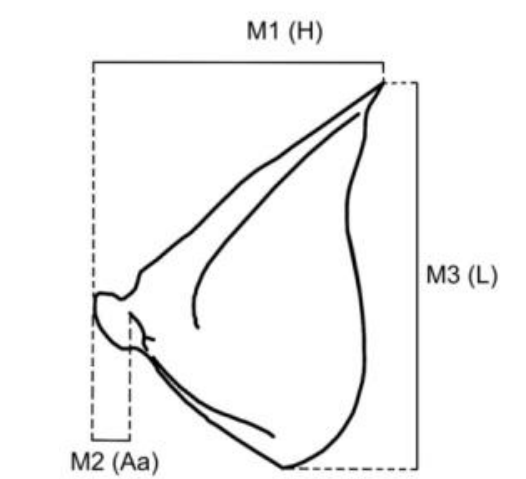

Cuadrado:

$1(\mathrm{H})$. Longitud desde el cóndilo lateral hasta el proceso preopercular

2 (Aa). Longitud desde el cóndilo medial hasta el cóndilo lateral

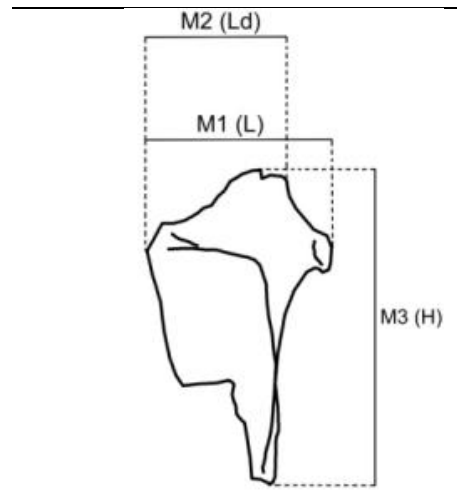

Hiomandibular:

1 (L). Longitud desde el proceso artículo-esfenoideo hasta el proceso artículo-opercular

2 (Ld). Longitud desde el proceso artículo-pteroideo hasta el proceso inferior

$3(\mathrm{H})$. Longitud desde el proceso artículo-pteroideo hasta la cresta preopercular

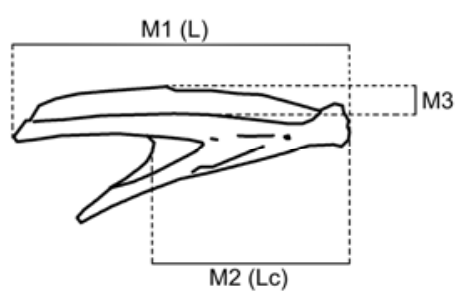

Dentario:

1 (L). Longitud desde la sínfisis hasta el proceso aboral superior 2 (LC). Longitud desde el margen inferior hasta la incisura posterior externa

3. Anchura de la pieza 


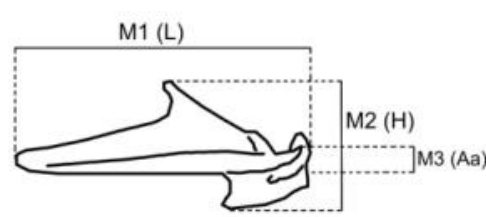

Articular:

1 (L). Longitud desde la facies cuadrado-articular hasta el proceso preopercular

2 (H). Longitud desde el proceso coronoides hasta el ángulo ventral anterior

3 (Aa). Anchura articular
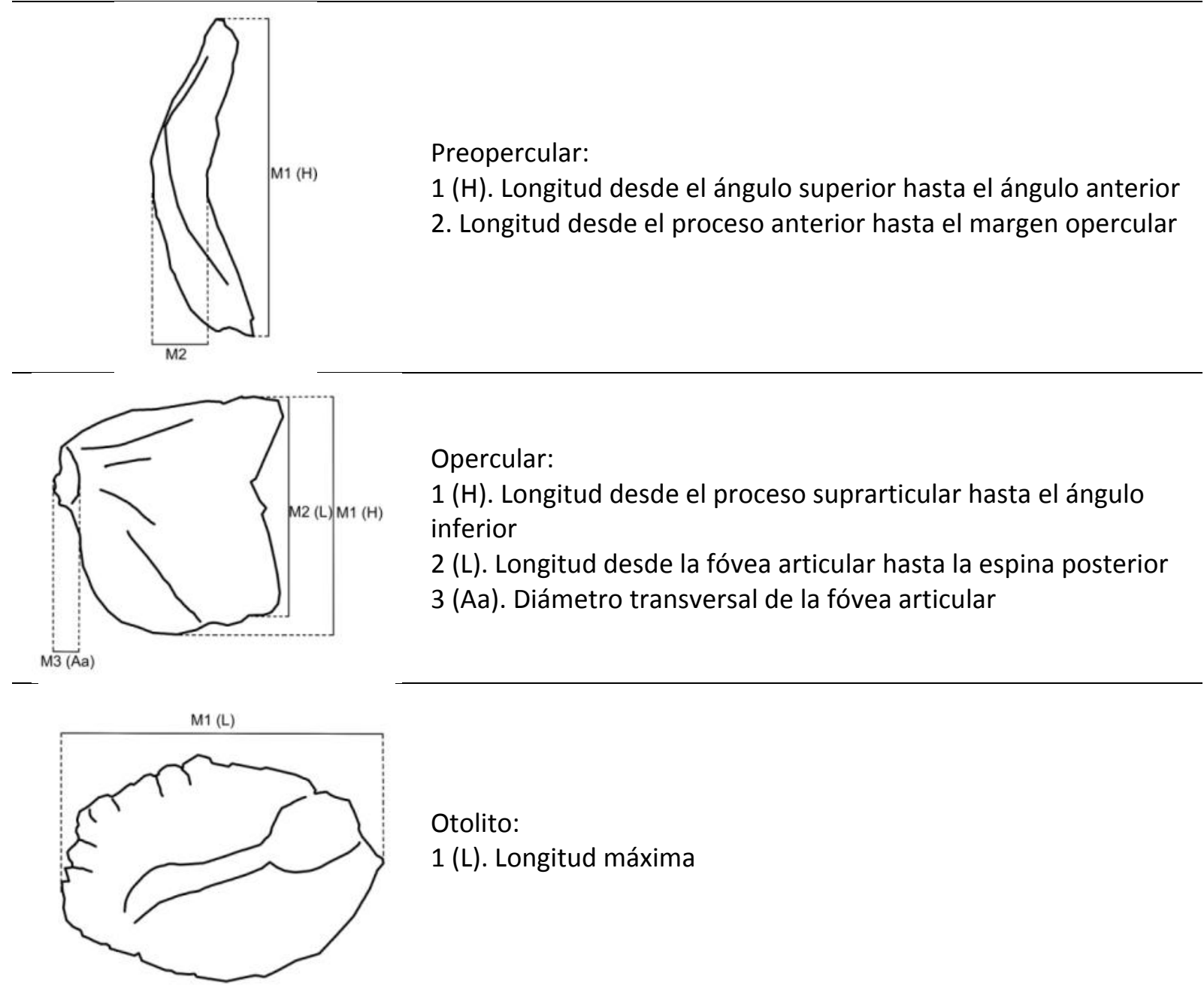

Otolito:

1 (L). Longitud máxima

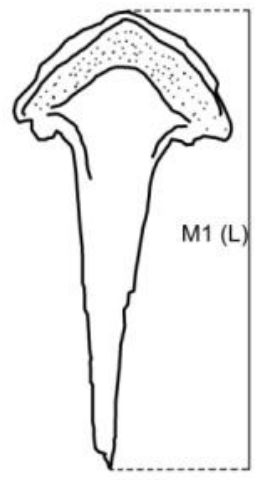

Vómer:

1 (L). Longitud máxima 


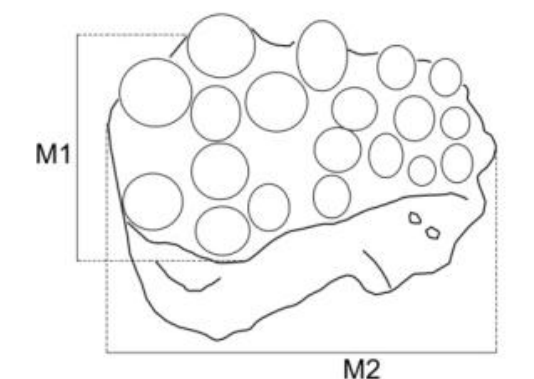

Faringobranquial:

1. Altura máxima

2. Longitud máxima

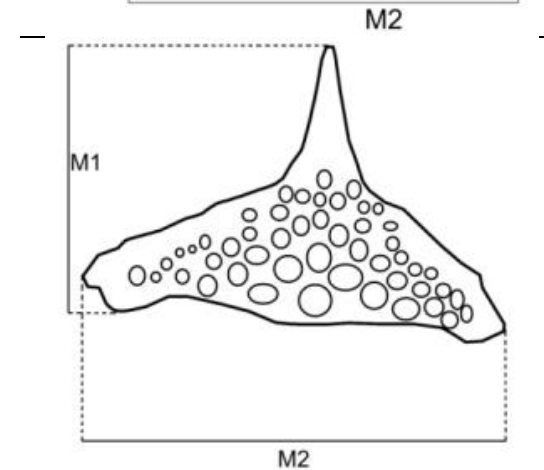

Ceratobranquial:

1. Altura máxima

2. Longitud máxima

Epihial:
1 (L). Longitud máxima
2 (H). Altura máxima

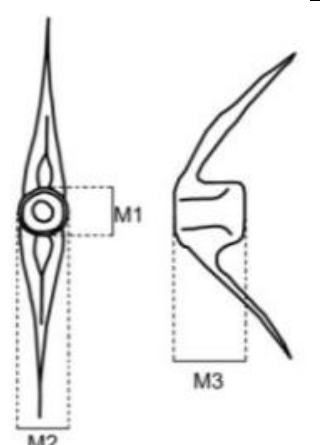

Vértebras:

1 (H). Altura máxima

2 (L). Longitud máxima

3. Diámetro antero-posterior máximo 


\section{IV.2.2. IDENTIFICACIÓN.}

La identificación es la correcta asignación de un resto a una serie de categorías: taxonómica, anatómica, cronológica... (Morales Muñiz, 1988: 456). La identificación se diferenciaría de la clasificación en que esta última busca el ordenamiento de las poblaciones en todos los niveles por medios inductivos, mientras que la identificación sitúa a los individuos en clases establecidas mediante métodos deductivos (Moreno, 1994). A la hora de realizar una identificación estamos asumiendo que los restos conservan suficientes características diagnósticas que nos permitan su identificación anatómica y taxonómica, dependiendo de sus características diagnósticas y del estado de conservación (Moreno, 1994).

Por otro lado la taxonomía se refiere al estudio teórico y práctico de la clasificación de los organismos, incluyendo sus bases, principios, procedimientos y fines. No todos los caracteres morfológicos valen a la hora de realizar una identificación taxonómica, ya que un carácter taxonómico se refiere únicamente al atributo por el que el miembro de un taxón podría deferir de un miembro de otro taxón (Martinell, 1982). La correcta asignación de un resto presenta toda una serie de complicaciones, ya que los restos animales presentan un gran variabilidad, por lo que a la hora de identificar hay que tener en cuenta diferentes factores (Morales Muñiz, 1988: 456-459): 1) La información que contiene el resto, ya que todos los elementos no poseen idéntica potencialidad para su identificación. Por otro lado el tamaño del hueso no incide en su correcta asignación. 2) El contexto zoocultural de la muestra a estudiar.

Realizar una correcta identificación es la base para una interpretación adecuada (Juan-Muns et alii, 1991: 87), pudiendo tener las consecuencias de una identificación errónea una gran repercusión al llevar a cabo una evaluación (Morales Muñiz, 1988). De este modo podemos precisar diferentes aspectos climáticos, de distribución de especies, zonas de explotación o preferencias de las comunidades humanas. Por ello a la hora de realizar la identificación de los restos, esta debe ser lo más precisa que sea posible, llegando a su asignación a nivel específico siempre que sea posible (Ferré, 2003: 6), aunque la imposibilidad de identificar todos los restos no implica una deficiente labor (Morales Muñiz, 1988: 68).

El proceso de identificación de los restos presenta toda una serie de limitaciones. Uno de los principales problemas que encontramos a la hora de asignar un resto es la fragmentación. La fragmentación es la separación física de los elementos diagnósticos (Moreno, 1994). En el caso de los peces este proceso comienza desde el mismo momento de su captura, acentuándose con la deposición y siguiendo hasta el proceso de excavación y procesado de la muestra, reduciendo las posibilidades de una identificación satisfactoria (Juan-Muns et alii, 1991: 89).

De entre los peces, los vertebrados son los mejor representados dentro del registro arqueológico debido a su mejor conservación. Sin embargo son los que mayor problema 
presentan a la hora de su identificación debido a la gran cantidad de especies y a la convergencia morfológica entre especies, géneros o familias que no tienen nada en común (Wheeler, 1978: 69; Desse y Desse, 1988: 71). Los huesos cefálicos son los que mayor diferencia morfológica presentan, siendo los huesos mandibulares (Maxilar, Premaxilar, Dentario, Articular y Cuadrado) los que más información aportan. Sin embargo, debido a su mayor osificación y su carácter masivo, son las vértebras los elementos que mejor representación tienen en los yacimientos arqueológicos (Wheeler, 1978: 69; Ryder, 1980; Desse y Desse, 1988: 71). Además de estos elementos, hay toda una serie de restos no esqueléticos que pueden ser identificados. Por un lado se encuentran los otolitos, formados por carbonato cálcico, que se encuentran localizados en el cráneo, siendo elementos de alto valor diagnóstico, además de servir para el cálculo de edad y periodo de captura. Los dientes aislados nos permiten una identificación a nivel de género o familia, siendo muy complicado identificar la especie. Por último, las escamas pueden ser identificables, incluso servir para el cálculo de edad, pero presentan una gran cantidad de problemas, ya que varían considerablemente su tamaño y su morfología según donde se encuentren situadas en el individuo (Wheeler, 1978: 70-71; Juan-Muns et alii, 1991: 88). Entre los restos del yacimiento de Viveiro se localizó un dentículo (escama placoidea) perteneciente a una raya (si bien no se ha podido identificarla a nivel de especie); los dentículos son escamas en punta presentes en los peces cartilaginosos, evolucionando en algunos casos hasta convertirse en espinas.

Además de la identificación taxonómica de las piezas, se ha contabilizado el número de restos en mal estado de conservación que no han podido ser identificados a nivel taxonómico. Este material se ha dividido en dos categorías según su localización anatómica: restos cefálicos para aquellos huesos que conforman la cabeza; restos postcefálicos para aquellos que conforman el cuerpo, incluyendo costillas, fragmentos de vértebras y radios de las aletas. En cuanto a las escamas, debido a su mal estado de conservación y la dificultad que supone su identificación específica, se han contabilizado (en aquellas muestras en las que se contaba con pocos restos) y pesado (cuando se tenía un volumen elevado).

El principal método para realizar la asignación taxonómica de un resto es la anatomía comparada, que permite la identificación de las piezas y su asignación a nivel de especie (Juan-Muns et alii, 1991: 87). Para realizar esta labor es imprescindible contar con una colección de referencia, ya que otros medios, como la utilización de atlas, proporcionan visiones estáticas y bidimensionales de elementos de una enorme variabilidad morfológica y muchas veces mal conservados (Wheeler, 1978: 69; Ryder, 1980: 393; Desse y Desse, 1988: 71; Morales Muñiz, 1988: 461). La colección comparativa debe contar con las especies propias del área y del periodo estudiado (Wheeler, 1978: 69; Ryder, 1980: 393; Desse y Desse, 1988: 71), si bien es recomendable que cuente con más ejemplares ante la posibilidad de aparecer especies no habituales (Morales Muñiz, 1988: 461), ya que estamos trabajando con depósitos antiguos, en los que la dispersión de 
especies no coincide con la actual, y donde además entra en juego la selección humana (Moreno, 1994). Por otro lado una colección comparativa debe contar con varios ejemplares de cada especie, siendo estos de diferentes tamaños y edades, ya que un ejemplar no es representativo de toda la variabilidad morfológica de las diferentes especies (Morales Muñiz, 1988: 461; Roselló, 1989: 11; Chaix y Méniel, 1996).

La identificación de los restos se ha realizado principalmente a partir de nuestra colección comparativa. En ella se incluyen principalmente las especies más habituales del Noroeste peninsular, contando en la mayoría de los casos con más de un ejemplar de diferente talla. Para la realización de la colección de referencia, se procedió a cocer los ejemplares durante unos minutos para eliminar las partes blandas. Posteriormente se introdujeron en agua con "Ariel" durante varios días con el fin de eliminar los restos de tejido. Una vez limpios fueron recuperados los restos esqueléticos e introducidos en acetona para eliminar la grasa que pudiera quedar (Davis y Payne, 2003). Somos conscientes de las limitaciones que puede presentar nuestra colección comparativa tanto a nivel de especies como de tallas, sin embargo hemos intentado subsanarlas con la utilización de otros medios.

Además de la colección comparativa se han utilizado diferentes recursos complementarios centrados en aquellas especies que nos presentaban mayores problemas. En primer lugar están los atlas osteológicos, aunque estos son escasos y con un número limitado de especies que en la mayoría de los casos quedan fuera de nuestro ámbito de estudio, señalando únicamente los huesos de mayor valor diagnóstico. Estos atlas no afrontan los diferentes problemas de identificación que presentan los restos arqueológicos. Por todo ello hemos utilizado varios atlas osteológicos aplicados a estudios arqueológicos presentes en diferentes tesis doctorales (Lepiksaar, 1981/83; Roselló, 1988; 1989; Cañas, 1992; Patón, 1993; Ferré, 2003). Además se han utilizado diferentes artículos especializados en determinadas familias o especies (Desse y Desse, 1983; Gállego y Mitjans, 1985; Nieves y Gállego, 1992; Sierra Aboal, 1994; Roselló Izquierdo y Morales Muñiz, 2005/2006; entre otros) y guías de peces para aspectos específicos como el hábitat (Rodríguez Solórzano et alii, 1983; Lozano Cabo, 1983; Pena, 2003; Fernández Román, 2006; entre otros).

\section{IV.2.2.1. ESPECIES IDENTIFICADAS.}

- Clase Agnatos.

Esta clase está representada en la actualidad por un único orden viviente, el de los ciclóstomos o petromizontes. Tienen el cuerpo anguiliforme, carecen de aletas pares y de escamas, no tienen mandíbulas (la boca está formada por una amplia ventosa). Pueden faltar los ojos o estar recubiertos de piel. Es completamente cartilaginoso. Una especie perteneciente a esta clase es la lamprea (Petromyzon marinus). 


\section{- Clase Condroíctios.}

Cuentan con un cuerpo fusiforme o aplanado, así como dos pares de aletas (formadas por ceratotiquias) pares y las pelvianas en posición abdominal, así como una cola heterocerca. La piel se encuentra cubierta de dentrículos dérmicos o desnuda. El esqueleto es cartilaginoso, aunque en ocasiones está endurecido por sales calizas.

\section{$\underline{\text { Fam. Rajidae }}$}

Nombre común: Rayas.

Familia representada en las costas gallegas por once especies. La cabeza se encuentra fusionada con el cuerpo, y cuentan en el pedúnculo caudal con un número elevado de dentrículos dérmicos. Se alimentan de moluscos y crustáceos. Habitan principalmente en fondos de arena o fango de la zona costera.

\section{- Clase Osteíctios.}

Tienen el cuerpo de diversas formas, aunque normalmente suele ser fusiforme, más o menos comprimido. El esqueleto se encuentra parcial o totalmente osificado, con las mandíbulas sostenidas por huesos membrana. Además cuentan con una piel cubierta de escamas. Pueden ser de dos subclases:

-Actionopterigios. Presentan las aletas pares sin lóbulos basales, y una aleta dorsal que puede escindirse. Esta subclase está formada por los superórdenes condrósteos, holósteos y teleósteos. Estos últimos presentan el esqueleto completamente osificado. Cuentan con la aleta caudal homocerca, así como la piel desnuda, cubierta con escamas cicloideas o tenoideas, o con espinas. Son los más numerosos.

-Coanoíctios. Presentan las extremidades pares pediculadas.

Fam. Anguilidae

Anguilla anguilla (Linné, 1758).

Nombre común: Anguila.

Especie catádroma, de fase larvaria pelágica y migradora. Gran parte de su vida adulta la pasa en aguas dulces o salobres. Se alimenta de crustáceos, moluscos y peces.

\section{$\underline{\text { Fam. Clupeidae }}$}

Sardina pilchardus (Walbaum, 1792).

Nombre común: Sardina.

Especie pelágica y gregaria formando grandes bancos que vive en zonas no muy alejadas de la costa. Se alimenta de crustáceos planctónicos, huevos y larvas de otros peces. Puede llegar a los $25 \mathrm{~cm}$. No le influye mucho la salinidad, por lo que es posible encontrarla en la desembocadura de los ríos. Es más sensible a los cambios de 
temperatura. Se aproxima a la costa en primavera y verano para realizar la puesta en aguas con una temperatura de entre 13-15 grados y a 20-25 m de profundidad. Los nuevos ejemplares suelen nacer entre noviembre-diciembre y marzo-abril. En otoño se alejan de la costa para permanecer en invierno en aguas más profundas.

\section{Fam. Engraulidae}

Engraulis encrasicholus (Linné, 1758).

Nombre común: Bocarte.

Especie pelágica y gregaria que forma grandes bancos. Puede llegar a los $20 \mathrm{~cm}$. Es un pez migrante que se acerca a la costa de julio a agosto para la reproducción, en aguas de 20 a 22 grados, alejándose posteriormente. Puede penetrar en la desembocadura de los ríos con la subida de la marea. Los juveniles durante el verano nadan en las costas, con el invierno se adentran en el mar a una mayor profundidad.

\section{Fam. Salmonidae}

Salmo salar (Linné, 1758).

Nombre común: Salmón.

Puede llegar a medir hasta 1,5 m y pesar $36 \mathrm{Kg}$. Especie que realiza grandes migraciones reproductoras. Es un pez marino, pero a comienzos de primavera (enero a junio) remonta los ríos de origen para realizar la puesta en su cabecera. La puesta suele ser en otoño. Los nuevos individuos se comportan como truchas entre uno y cinco años, edad a la que se adentran en el mar. Se alimentan de clupeidos, gádidos y crustáceos cuando se encuentran en el mar, no alimentándose en el periodo reproductor.

\section{Fam. Congridae}

Conger conger (Linné, 1758).

Nombre común: Congrio.

Especie bentónica que vive en fondos de piedras y cascajos entre 0 y $100 \mathrm{~m}$ de profundidad. Puede llegar a medir entre $2-3 \mathrm{~m}$ y superar los $50 \mathrm{~kg}$. La puesta se produce en los meses de verano, siendo un animal de actividad nocturna.

\section{Fam. Belonidae}

Belone belone (Linné, 1761).

Nombre común: Aguja.

Especie pelágica que se acerca a la costa de febrero a septiembre, formando grandes bancos para realizar la puesta. Puede alcanzar los $75 \mathrm{~cm}$ de longitud. Se alimenta de peces pequeños como sardinas o bocartes, por lo que es común que aparezca en el cerco destinado a la sardina. 


\section{$\underline{\text { Fam. Merlucciidae }}$}

Merluccius merluccius (Linné, 1758).

Nombre común: Merluza.

Especie demersal y batipelágica que vive en fondos de arena o cascajo desde los 100 hasta los $300 \mathrm{~m}$. Los ejemplares nuevos llegan a la costa durante el verano y en invierno vuelven a mayor profundidad. Se alimenta de otros peces, crustáceos y cefalópodos. Se reproducen a finales de invierno y primavera. Puede alcanzar los 1,3 m y pesar hasta $15 \mathrm{~kg}$.

\section{$\underline{\text { Fam. Gadidae }}$}

Pollachius pollachius (Linné, 1758).

Nombre común: Abadejo.

Especie demersal que habita en los fondos pedregosos hasta los $200 \mathrm{~m}$. La puesta se produce en la costa entre los meses de febrero a abril, donde viven los ejemplares jóvenes hasta que alcanzan la talla de $25 \mathrm{~cm}$, momento en el que se desplazan a zonas más profundas. Pueden llegar al metro de longitud y se alimentan de crustáceos, moluscos y crías de peces.

Trisopterus luscus (Linné, 1758).

Nombre común: Faneca.

Especie demersal de fondos rocosos y con algas. La puesta se produce entre abril y mayo cerca de la costa, donde los individuos jóvenes viven en pequeños bancos. Según van creciendo pueden descender hasta los $300 \mathrm{~m}$. Se alimentan de crustáceos y moluscos.

\section{$\underline{\text { Fam. Zeidae }}$}

Zeus faber (Linné, 1758).

Nombre común: Pez de San Pedro.

Pez demersal y solitario que vive desde la orilla del mar hasta una profundidad de $200 \mathrm{~m}$. Habita sobre fondos arenosos, si bien los ejemplares más pequeños se encuentran también en zonas de piedras o fango. A los cuatro años llega a la costa para la puesta, que se produce entre junio y agosto. Puede llegar a pesar 5-6 Kg y medir $50 \mathrm{~cm}$.

\section{$\underline{\text { Fam. Serranidae }}$}

Dicentrarchus labrax (Linné, 1758).

Nombre común: Lubina.

Especie demersal que habita en fondos de arena y de roca próximos al litoral. La puesta se produce de mayo a agosto cerca de las desembocaduras de los ríos. Los juveniles se encuentran en bancos en la desembocadura de los ríos, y cuando se hacen 
adultos se vuelven solitarios. Pueden llegar a medir hasta $1 \mathrm{~m}$ y pesar $12 \mathrm{Kg}$. Desde la última hora del atardecer hasta el anochecer se acerca a la costa a pocos centímetros del agua.

Polyprion americanus (Schneider, 1801).

Nombre común: Mero.

Especie bentónica de fondos rocosos con una profundidad entre los 100 y los 200 m. Es carnívoro, alimentándose principalmente de cefalópodos. La puesta es entre enero y abril. Cuando son jóvenes forman bancos de varios ejemplares, volviéndose con la edad peces solitarios.

\section{Fam. Sciaenidae}

Argyrosomus regius (Asso, 1801).

Nombre común: Corvina.

Especie bentónica de fondos arenosos entre los 10 y los $200 \mathrm{~m}$ de profundidad. Es una especie solitaria, que se agrupa en la reproducción, que se produce entre marzo y junio. Se alimenta tanto de otros peces como de crustáceos y cefalópodos.

\section{Fam. Carangidae}

Trachurus trachurus (T.E.Bowdich, 1825).

Nombre común: Chicharro.

Especie pelágica, vive en mar abierto, casi siempre lejos de la costa, en grandes bancos a una profundidad de entre 10 a $100 \mathrm{~m}$. En verano, cuando se produce la reproducción, es común que se acerquen más a la costa, pero en invierno bajan hasta los $500 \mathrm{~m}$. Puede llegar a alcanzar los $50 \mathrm{~cm}$. Es carnívoro, alimentándose principalmente de sardinas.

\section{Fam. Sparidae}

Dentex dentex (Linné, 1758).

Nombre común: Dentón.

Especie de zonas arenosas a una profundidad entre los 30 y $200 \mathrm{~m}$ de profundidad. La puesta se produce de marzo a mayo, momento en el que se encuentran más ejemplares en la costa.

Sparus aurata (Linné, 1758).

Nombre común: Dorada.

Esta especie habita en aguas poco profundas en grupos pequeños, tanto sobre fondo de piedra como de arena. Con el tiempo se hace solitaria. La reproducción se produce en otoño e invierno en aguas profundas. Aunque son peces marinos, pueden vivir 
en aguas salobres de lagunas litorales e internarse en los ríos. Puede llegar a medir hasta $70 \mathrm{~cm}$ de longitud. Se alimenta de crustáceos y moluscos.

Pagrus pagrus (Linné, 1758).

Nombre común: Pargo.

Especie demersal que durante el verano, momento de la reproducción, permanece en los fondos de arena y piedra superiores a $20 \mathrm{~m}$, bajando en invierno a profundidades de $100 \mathrm{~m}$. Puede llegar a medir hasta $75 \mathrm{~cm}$ de longitud. Se alimenta de crustáceos y moluscos, menos en primavera que son herbívoros.

Diplodus sargus (Linné, 1758).

Nombre común: Sargo.

Especie demersal de fondos rocosos de 2 a $50 \mathrm{~m}$ de profundidad. Los jóvenes forman bandas en aguas poco profundas de los arenales. Aumenta su presencia en la costa en verano cuando se acercan a deshovar. Las crías se suelen pescar en verano en las pozas de marea. Puede llegar a superar los $45 \mathrm{~cm}$ de longitud. Se alimenta de crustáceos, moluscos y equinodermos.

Diplodus vulgaris (E. Geoffrey Saint-Hilaire, 1817).

Nombre común: Mucharra.

Especie que no pasa los $20-25 \mathrm{~cm}$ de longitud. Vive en fondos pedregosos y de arena desde la costa hasta los $25 \mathrm{~m}$ de profundidad. El desove se produce en octubre. Se alimenta de crustáceos y moluscos.

Pagellus acarne (Risso, 1826).

Nombre común: Pancho picudo.

Especie demersal que habita en fondos de arena y fango desde los 25 a los $100 \mathrm{~m}$. La puesta se produce en julio y agosto, concentrándose los ejemplares jóvenes cerca del litoral.

Pagellus bogaraveo (Brünnich, 1768).

Nombre común: Besugo.

Especie demersal que habita en fondos de fango y cascajo, cerca de acantilados donde forma grupos numerosos entre 150-500 m de profundidad. Se alimenta de crustáceos, moluscos y peces de pequeño tamaño. La puesta se produce en febrero y marzo a más de $100 \mathrm{~m}$ de profundidad. Los ejemplares jóvenes viven cerca de la costa. Es una especie que acepta una salinidad entre 25-37\%. Cuando es adulto vive en las profundidades, en enero y febrero entre 400-500 m, descendiendo en marzo y ascendiendo a los 100-200 $\mathrm{m}$ en abril y mayo. Esto es debido a que en invierno la 
plataforma presenta menos salinidad, con unas temperaturas inferiores, mientras en primavera las aguas marinas invaden la plataforma.

Fam. Labridae

Labrus bergylta (Acanius, 1767).

Nombre común: Maragota.

Especie demersal que puede llegar a alcanzar los $60 \mathrm{~cm}$ de longitud y los 2-3 Kg de peso. Vive en zonas rocosas entre el metro y los $50 \mathrm{~m}$ de profundidad, en lugares con muchas algas. Se alimenta de moluscos, crustáceos y algas. La puesta se produce entre abril y mayo.

Symphodus (crenilabrus) melops (Linné, 1758).

Nombre común: Vellos, Serranos.

Especie demersal que no supera los $20 \mathrm{~cm}$ de longitud. Habita en aguas de un metro a $100 \mathrm{~m}$ de profundidad en zonas rocosas. La reproducción se produce en los meses de primavera. Durante el verano las crías, de $2-3 \mathrm{~cm}$, pueden ser pescadas en las pozas de marea.

\section{Fam. Ammodytudae}

Nombre común: Bolos.

Grupo de especies bentónicas de sustrato arenoso, en el cual se pasan gran parte del día enterrados. Pueden llegar a medir, dependiendo de la especie, hasta los 20 $35 \mathrm{~cm}$. La puesta se produce en invierno hasta comienzos de la primavera.

$\underline{\text { Fam. Scombridae }}$

Scomber scombrus (Linné, 1758).

Nombre común: Caballa.

Pez pelágico que vive en aguas profundas lejos de la costa. A final de la primavera forma grandes bancos que se acercan a la costa. En invierno desciende a zonas profundas dejando de comer. Se alimenta de otros peces. El periodo reproductivo se produce de mayo a julio.

Scomber japonicus (Houttuyn, 1782).

Nombre común: Estornino.

Especie pelágica similar a Scomber scombrus, si bien algo menos frecuente.

Fam. Thunnidae

Thunus thynnus (Linné, 1758).

Nombre común: Atún. 
Pez pelágico que nada en bancos pequeños en aguas con temperaturas superiores a los $10^{\circ} \mathrm{C}$. Se alimenta de otros peces. Durante el invierno vive en aguas atlánticas, no soportando grandes cambios de temperatura, siendo el periodo de acumulación de grasas. En marzo, con el desarrollo sexual, comienza la migración en elevadísimo número. La puesta se produce desde junio y la migración de retorno desde julio hasta agosto.

\section{Fam. Triglidae}

Trigla lyra (Linné, 1758).

Nombre común: Escacho.

Especie demersal que habita zonas de arena o fango a partir de los $40 \mathrm{~m}$ hasta los $700 \mathrm{~m}$ de profundidad. Puede llegar a medir hasta $60 \mathrm{~cm}$.

$\underline{\text { Fam. Mugilidae }}$

Nombre común: Múgiles.

Familia muy homogénea y por lo tanto de difícil identificación. Viven en la costa formando grandes bancos.

\section{IV.2.3. GRUPOS TAFONÓMICOS.}

Según la definición original de Efremov (1940) la Tafonomía sería la encargada de analizar e interpretar los procesos naturales que actúan sobre los organismos tras su muerte, sin tener en cuenta la intervención humana. Sin embargo desde la arqueología van ser los patrones culturales los que centren los análisis tafonómicos. En la tafonomía arqueológica, los factores darían comienzo desde el sacrificio del animal, la pesca en el caso de los peces, incluyendo los efectos del consumo, agentes atmosféricos, pisoteo, movimiento, alteraciones naturales... hasta la excavación (Wheeler y Jones, 1989: 61). Durante el proceso de excavación, la aplicación de uno y otro método de recuperación condicionan los restos recuperados, por lo que los conjuntos pueden reflejar un sesgo importante (Wheeler y Jones, 1989).

Los huesos de los peces son mucho más frágiles que los de otros animales, influyendo en su supervivencia tanto el trato recibido desde su captura, como el sedimento donde se depositan, desapareciendo el $80 \%$ de los huesos identificables (Wheeler y Jones, 1989), estando condicionado en gran medida por las diferencias de osificación de los taxones (Roselló, 1989: 592-605).

En 1987 Gautier va a proponer una clasificación de grupos tafonómicos enfocados al estudio de las faunas arqueológicas. Un grupo tafonómico engloba a todos aquellos restos animales que han seguido una historia tafonómica similar desde su muerte hasta su recuperación (Gautier, 1987). Siguiendo esta clasificación se pueden diferenciar seis grupos: 
1- Restos de consumo: incluiría los procesos de despiece hasta los restos de consumo.

2- Evidencias de manufacturas: estaría formado tanto por los objetos acabados como por los desperdicios de esta actividad.

3- Restos de esqueletos: individuos más o menos completos, sin ningún aprovechamiento aparente.

4- Intrusivos contemporáneos: restos no aportados intencionalmente por el ser humano, la llegada al depósito arqueológico se debe a la acción de agentes naturales.

5- Restos heredados: materiales aportados por la actividad humana desde niveles infrayacentes del propio yacimiento, o traídos desde otros depósitos por procesos naturales.

6- Intrusiones posteriores: restos que llegan al yacimiento mucho después de la formación del mismo.

La adscripción de los restos a cada uno de los diferentes grupos sigue unos criterios generales (Moreno Nuño, 1994):

-Contexto estratigráfico: debemos considerar las características generales de la unidad estratigráfica y de los demás elementos que la componen, comprobando si se trata de un taxón aislado o si aparece repetido en la muestra en un grado lo suficientemente amplio como para pensar en un aprovechamiento intencional.

-Estado de preservación: la presencia de un resto completo frente a una fragmentación generalizada o viceversa puede indicarnos una historia tafonómica diferente.

-Huellas o trazas sobre los restos.

-Distribución de las categorías de fragmentación de los restos: la existencia de representaciones anatómicas que aparecen de forma recurrente puede estar indicando la presencia de patrones vinculados a una actividad determinada.

-Tipo de organismo y sus características biológicas: el conocimiento del hábitat de determinadas especies puede ser indicativo de la presencia de algunos restos en el contexto arqueológico y de su función.

La adscripción de los restos a los diferentes grupos tafonómicos no siempre es clara, y por supuesto tampoco es unívoca, ya que en muchas ocasiones la actividad humana no deja huellas visibles que nos puedan indicar su utilización, a lo que se unen los efectos de los agentes no antrópicos, que pueden producir marcas y patrones similares a los producidos por la actividad antrópica. También pueden darse casos de adscripción a 
más de una de estas categorías, ya que algunos ejemplares pueden haber sido consumidos y posteriormente modificados para su uso como objetos (Moreno, 1994).

Además de la adscripción de los restos a uno de estos grupos tafonómicos existen toda una serie de elementos que nos pueden aportar información sobre la actividad humana. En este sentido se encuentra la representatividad anatómica de los diferentes taxones, así como las marcas de carnicería y de consumo (Wheeler y Jones, 1989: 61-78) que pueden indicar diferentes aspectos culturales (Morales Muñiz et alii, 2009).

\section{IV.2.4. ESTIMADORES DE ABUNDANCIA.}

El cálculo numérico de las muestras óseas pretende obtener un índice que nos permita la comparación y la estimación de los restos dentro de un yacimiento, sin que se persiga la reconstrucción de la composición original de la muestra depositada (Fernández Rodríguez, 2000: 80; Ferré, 2003: 30).

Han sido varios los índices propuestos y la metodología utilizada para su cálculo, sin que exista un consenso entre los diferentes investigadores. En nuestro caso utilizaremos tanto el Número de Restos (NR) como el Número Mínimo de Individuos (NMI), si bien daremos mayor peso al primero ante los problemas que presenta este segundo estimador a la hora de su cálculo en el conjunto ictiológico.

La agregación de las muestras se realizó a dos niveles. Primero por sector y unidad estratigráfica, y posteriormente una segunda agregación a nivel de yacimiento y de periodo, para de este modo poder evaluar diferencias entre asentamientos y entre diferentes épocas.

\section{IV.2.4.1. NÚMERO DE RESTOS (NR).}

El Número de Restos es un estimador extraído directamente de la muestra, obtenido de la contabilización de los fragmentos óseos asignables a una especie. Este estimador presenta toda una serie de problemas que han sido ampliamente tratados en la bibliografía zooarqueológica (Poplin, 1976; Klein \& Cruz-Uribe, 1984; Castaños Ugarte, 1984):

- El número de huesos es variable entre las diferentes especies, produciéndose una sobrevaloración de unas frente a las otras.

- Diferencias en el grado de conservación de las partes del esqueleto y entre individuos. Inciden variables como la edad, grado de osificación, tamaño, método de preparación para el consumo...

- Adquieren mayor importancia aquellas especies que son aprovechadas integralmente, frente a aquellas de las que se seleccionan ciertas partes.

- Índice muy sensible a la fragmentación. 
Al realizar el cálculo del NR hemos agrupado los elementos diagnósticos por taxón, mientras que los restos que no han sido identificados por su estado de conservación o escaso valor diagnóstico han sido agrupados en escamas, restos cefálicos y restos postcefálicos. En el caso de las vértebras diferenciaremos entre caudales y precaudales, y siempre que fue posible el atlas y las vértebras torácicas. Si bien, para el resto se hace muy difícil determinar a qué número de vértebra corresponde (Ferré, 2003: 31).

\section{IV.2.4.2. NÚMERO MÍNIMO DE INDIVIDUOS (NMI).}

El cálculo del Número Mínimo de Individuos es una estimación indirecta calculada a partir del NR. Consiste en calcular el número mínimo de individuos de cada taxón presente en la muestra analizada. Su utilización presenta toda una serie de problemas que han sido ampliamente tratados por diversos autores (Poplin, 1976; Klein y Cruz-Uribe, 1984; Castaños Ugarte, 1984; Roselló, 1989):

- Diferencias en las formas de calcularlo, lo que dificulta considerablemente la comparación entre muestras.

- Evolución de su cálculo, dejando anticuados los resultados antiguos.

- En ocasiones los bajos valores numéricos que proporciona no son representativos a nivel estimativo.

- Alta probabilidad de error en su cálculo.

- Sobrevaloración de la importancia de especies con representación limitada en la muestra.

En el caso de los estudios ictiofaunísticos, el cálculo se puede realizar con tres métodos diferentes (Roselló, 1989: 18-19; Ferré, 2003: 31):

- Cálculo convencional: Consiste en contabilizar cada elemento en derecho e izquierdo, tomando el número mayor. Sería necesario realizar el cálculo del NMI para cada tipo de hueso, siendo el número más alto el representativo de la especie. Una variante sería la introducida por Chaplin (1971), aplicando criterios de edad y tamaño.

- Cálculo de frecuencias: Los diferentes elementos serían agrupados por morfotipos y se calcula la frecuencia esperada para cada uno sobre el total de la serie obtenida de ejemplares actuales. Posteriormente se dividen los valores observados con los esperados.

-Cálculo de tamaños: Sería la cuantificación de los márgenes de variabilidad osteométrica para una determinada talla de pez y la aplicación de análisis de clusters para delimitar conjuntos que serían asimilados a individuos diferentes.

En el caso de la ictiofauna este cálculo es más complicado que en los mamíferos por el elevado número de partes y por su peor conservación. El elemento del esqueleto de los 
peces más representado en los yacimientos son las vértebras, sin embargo son el elemento más criticado a la hora de realizar el cálculo de NMI, siendo variable su número según la familia (Wheeler y Jones, 1989: 49-51).

Pese a los problemas que presenta la representatividad del NMI, se ha calculado este estimador mediante el método convencional, siguiendo a otros autores (Klein y CruzUribe, 1984; Roselló, 1989; Ferré, 2003). Consideramos que para una correcta interpretación de un depósito, es necesario contar con todos las variables posibles, obteniendo de este modo mejores resultados que utilizando de forma independiente los diferentes estimadores.

\section{IV.2.4.3. VALORACIÓN.}

Índice de Constancia: indica la probabilidad de encontrar una especie determinada.

$C=N A / N \times 100$

$\mathrm{NA}=$ número de muestras donde aparece la especie $\mathrm{A}$ (estratos)

$\mathrm{N}=$ número total de muestras (estratos)

Índice de Dominancia: equivale al \% e indica la abundancia relativa de los taxones en la muestra.

$D=M A / M \times 100$

$M A=$ número total de individuos de la especie $A$.

$\mathrm{M}=$ número total de individuos

La importancia real de las especies en la muestra como un todo vendrá determinada por el producto de los dos índices (IC x ID). 

V. ANÁlisis De los YACIMIENTOS. 



\section{V.1. El Castro de Punta atalaia.}

\section{V.1.1. LOCALIZACIÓN GEOGRÁFICA.}

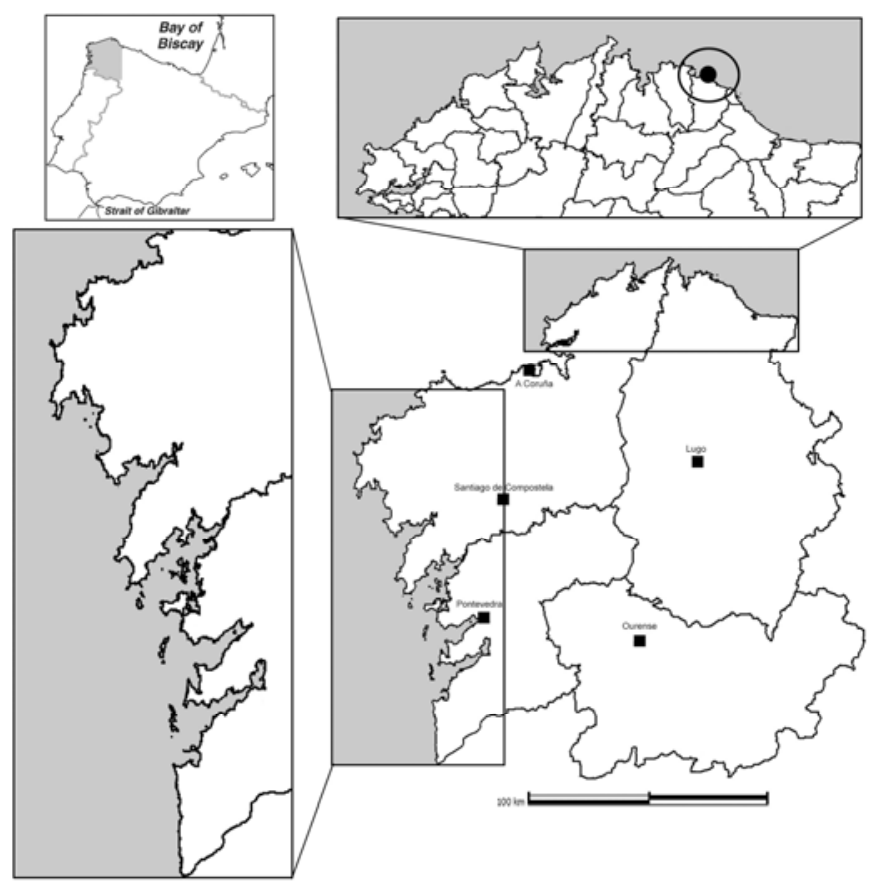

Fig. 6 Localización del yacimiento de Punta Atalaia.

El castro de Punta Atalaia se encuentra localizado en el Concello de Cervo (Lugo), en la población de San Cibrao, perteneciente a la parroquia de Lieiro. El asentamiento se sitúa en una península de perfil irregular que presenta una pendiente en dirección Oeste hacia un istmo que la comunica con la población de San Cibrao. Este istmo en la actualidad está formado por un banco de arena. Se desconoce la configuración de este espacio en el momento de ocupación del yacimiento, siendo lo más probable que la formación del istmo sea posterior a la fase más antigua de ocupación, y por lo tanto que la actual península fuera una isla (Ramil González, 2007). Al oeste del istmo de arena se sitúa el estuario de Lieiro, formado por la desembocadura del río Covo. Sus coordenadas son $7^{\circ} 26^{\prime} 14.25^{\prime \prime} \mathrm{W}$ y $43^{\circ} 41^{\prime} 59.94^{\prime \prime} \mathrm{N}^{1}$. Este asentamiento se correspondería con el modelo de un castro de tipo litoral.

\section{V.1.2. DESCRIPCIÓN DEL YACIMIENTO.}

El descubrimiento del castro de Punta Atalaia se produjo a finales del 2006, cuando se llevaban a cabo los desmontes, con medios mecánicos, para la construcción de un observatorio de fauna marina en las cercanías del Faro. Dichos trabajos pusieron al descubierto un nivel arqueológico en el que visualmente predominaban las conchas. Debido a la acción de las máquinas no fue posible estudiar el depósito en el área afectada por las obras. En el perfil originado por los trabajos de desmonte se pudo documentar un depósito de 1,95-1,85 m. de potencia y 8,5 m. de longitud en dirección sur-norte (Ramil González, 2007; 2009).

\footnotetext{
${ }^{1}$ Datum: ETRS89; Uso: 29; UTM: X 625.919/Y 4.839.738.
} 


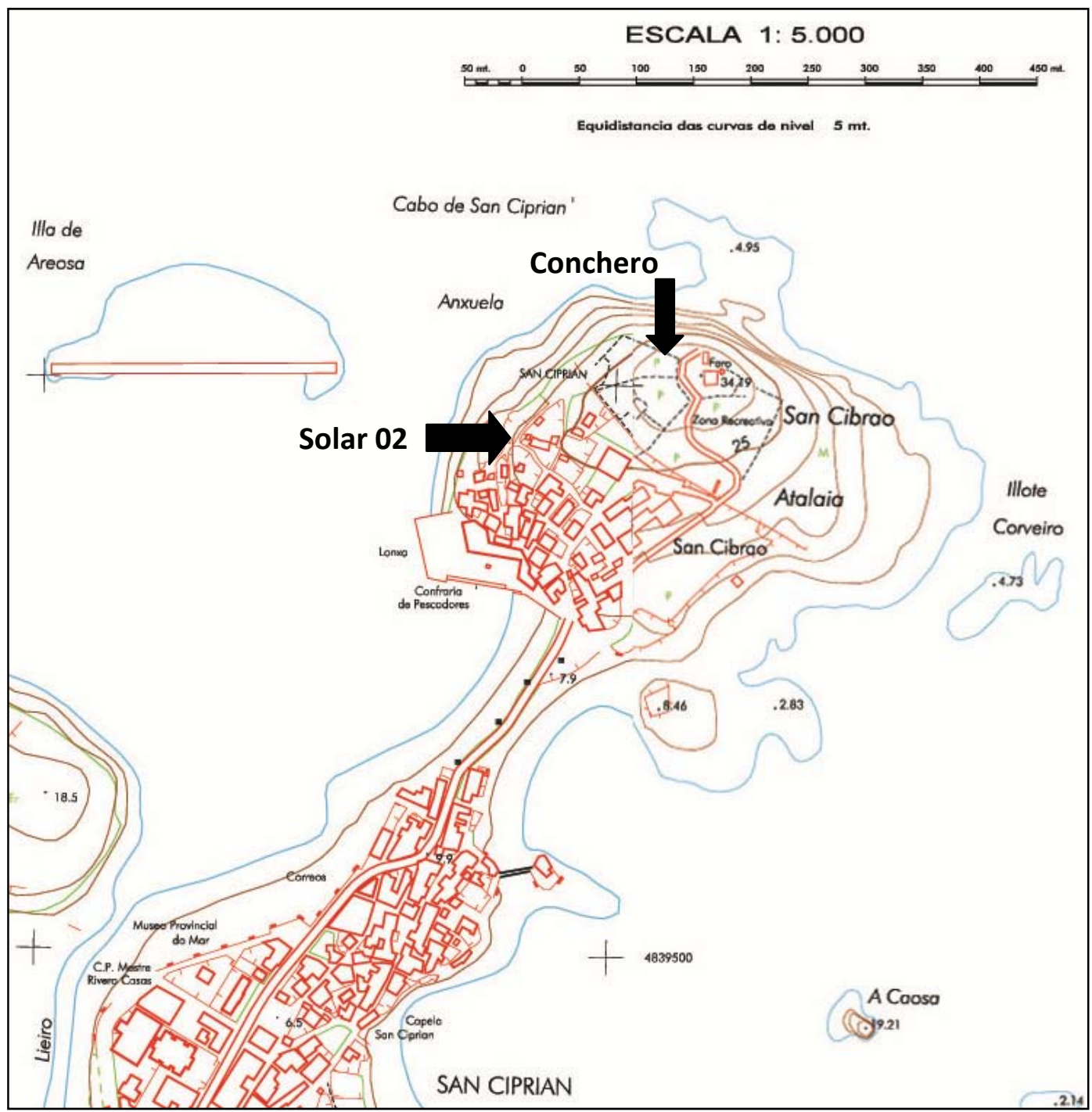

Fig. 7 Topográfico 1:5.000 de San Cibrao y localización de las intervenciones. (Extraído de http://sitga.xunta.es/sitga).

En los siguientes años, el proyecto de construcción de viviendas ha llevado a la realización de varias excavaciones y sondeos, centrados principalmente al oeste de la península, que han sacado a la luz una parte importante superficie del área habitacional, con una ocupación que va desde el periodo Galaico-romano hasta la actualidad (Sinde Váquez, 2008; Castro Vigo, 2008a; 2009; Cabrera Tilve, 2009).

De estas últimas campañas vamos a prestar atención a las excavaciones realizadas en el Solar 02, entre la Rúa Faro y la Rúa Atalaia, al oeste de la península. La parcela intervenida presentaba una superficie de $336 \mathrm{~m}^{2}$, dividida en 21 sondeos de $4 \times 4 \mathrm{~m}$ (Castro Vigo, 2008). En esta zona se documentaron varias estructuras circulares y ovales de época galaico-romana, así como alguna estructura medieval y reocupaciones modernas y contemporáneas (Castro Vigo, 2008). 


\section{V.1.3. RECOGIDA DE LAS MUESTRAS.}

Los materiales proceden de dos conjuntos bien definidos, por un lado del conchero documentado en la campaña de 2006 y 2007, y por el otro de una excavación en área realizada en el 2008 en una zona ocupacional con un amplio marco cronológico.

\section{V.1.3.1. RELACIÓN ESTRATIGRÁFICA.}

\section{V.1.3.1.1. Conchero.}

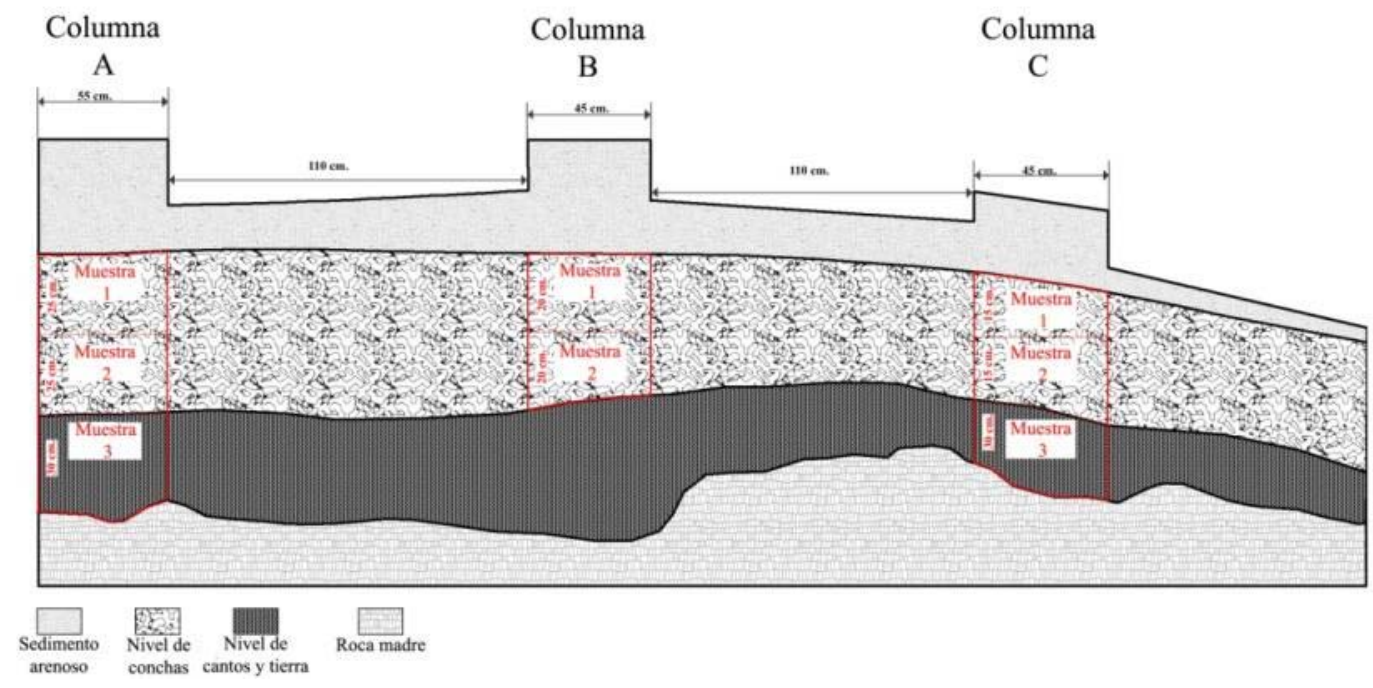

Fig. 8 Esquema del conchero y sistema de muestreo.

-Nivel 1: Nivel de duna formado por capas de colmatación de arena de playa.

Capa 1: Arena con raíces. Potencia entre $24-36 \mathrm{~cm}$.

Capa 2: Arena superficial de color blanco. Potencia de 10-20 cm.

Capa 3: Arena endurecida y húmeda, color Blanco grisáceo. Potencia entre $32-36 \mathrm{~cm}$.

-Nivel 2: Nivel arqueológico formado por las capas de acumulación antrópica de basura procedente del Castro de Punta Atalaia y donde visualmente predominan los restos de moluscos.

Capa 4: Tierra oscura con cantos, abundante cerámica, fragmentos de huesos y alguna concha. Potencia de $24-30 \mathrm{~cm}$.

Capa 5: Tierra de color claro, con abundantes restos de conchas, menos cerámica y huesos, así como escorias de hierro. Potencia entre $44-52 \mathrm{~cm}$.

Capa 6: Tierra muy negruzca, con escasas conchas, cerámica, y mucha escoria de hierro. Potencia entre 2-12 cm.

-Nivel 3: Substrato granítico, alterado por la extracción de piedra, posiblemente para las construcciones del Castro. 


\section{V.1.3.1.2. Solar 02.}

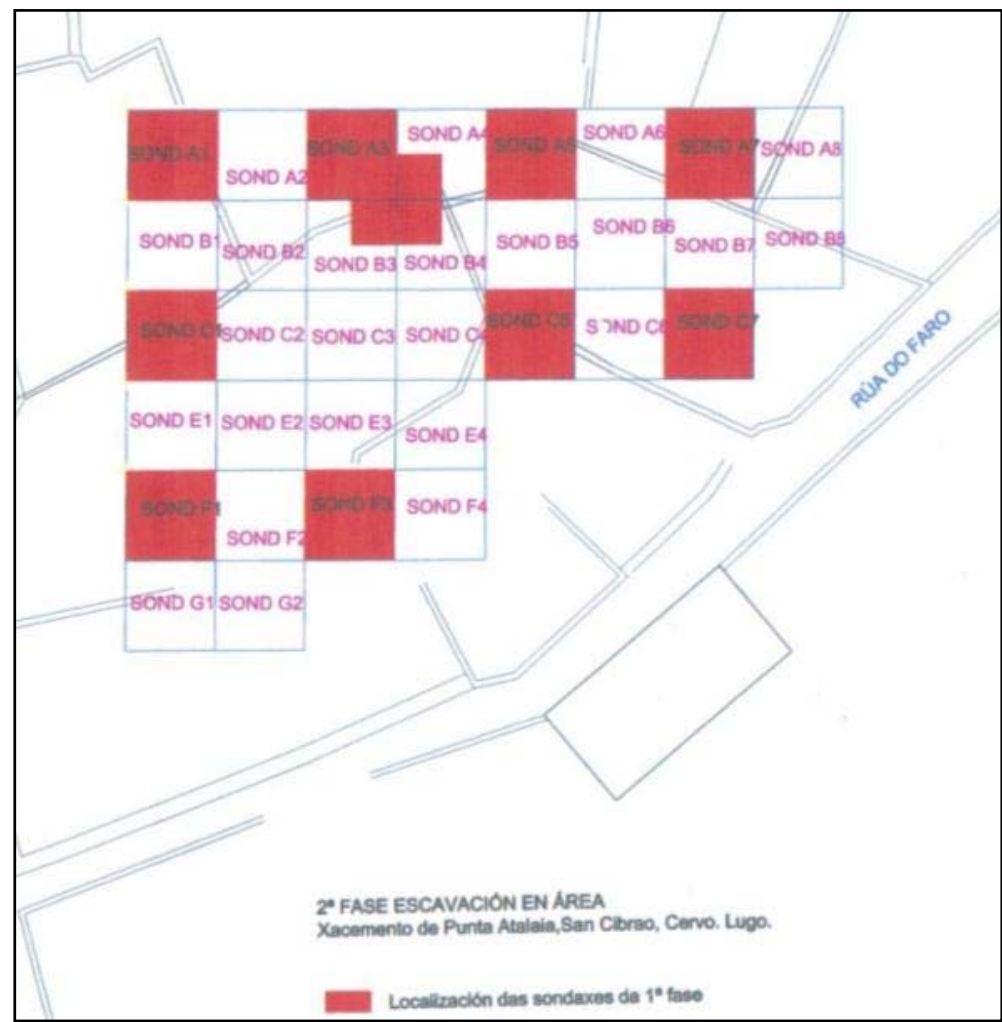

Fig. 9 Localización de los sondeos en el Solar 02 (Plano cedido por Eva Castro Vigo).

-Nivel 1: formado por capas de colmatación de arena de playa.

Capa 1: Nivel de arena clara sin material arqueológico que varía su espesor con pendiente oeste-este.

Capa 2: Arena más oscura que la anterior, presencia escasa de restos arqueológicos cerámicos, aunque sí se documentó gran cantidad de materiales orgánicos. La potencia varía igual que en la Capa 1.

-Nivel 2: nivel arqueológico formado por diferente número de capas según el sondeo.

Capa 3: Nivel color negro común en todos los sondeos. Es donde aparece la mayor parte del material galaico-romano.

Capa 4: Nivel común a todos los sondeos formado por el derrumbe de las estructuras. Cuenta con una potencia variable entre $0,20 \mathrm{~m}$ y $1,00 \mathrm{~m}$.

-Nivel 3: sustrato geológico alterado por la extracción de piedra. 


\section{V.1.3.2. EL MUESTREO.}

\section{V.1.3.2.1. Conchero.}

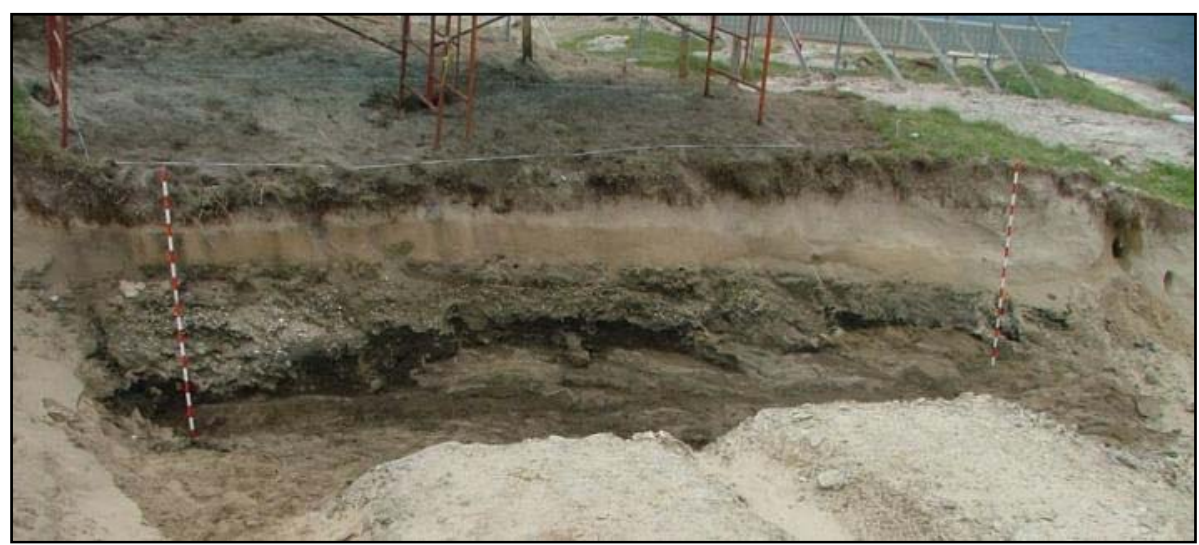

Fig. 10 Conchero de Punta Atalaia antes de la intervención arqueológica (Imagen cedida por Emilio Ramil).

El muestreo se realizó en el perfil oeste resultante de los trabajos de desmonte, procediendo a la toma de tres columnas de muestras, realizadas cada $110 \mathrm{~cm}$., con anchuras de $55 \mathrm{~cm}$. para la Columna A, y $45 \mathrm{~cm}$. para las Columnas B y C. A simple vista se podía apreciar en el Nivel 2 un depósito con predominancia de restos malacológicos que correspondería a parte de la Capa 4 y la Capa 5, del que se tomarían dos muestras equidistantes en cada columna. Por debajo de este nivel con conchas, se diferenciaba otro donde la presencia de restos de moluscos era muy escasa, el color del sedimento era más oscuro y había abundantes cantos, del que se tomó una muestra en las Columnas A y C. Este nivel se correspondería con la Capa 6 y la parte inferior de la Capa 5.

De la Columna A se tomaron tres muestras, las dos primeras de $25 \mathrm{~cm}$. de potencia y la tercera de $30 \mathrm{~cm}$.; para la Columna $B$ únicamente se tomaron dos muestras de $20 \mathrm{~cm}$. cada una; mientras que de la Columna $C$ se volvieron a tomar tres muestras, dos de $15 \mathrm{~cm}$. y una de 30 cm. (Fernández et alii, 2008; González Gómez de Agüero et alii, 2011).

Además de las columnas de muestras también se recogió el sustrato resultante de la limpieza del perfil en aquellos lugares donde se realizó el muestreo, si bien no ha sido incluido en este trabajo, y una recogida selectiva de algunos restos durante el proceso de excavación. El presente estudio ha sido realizado con las muestras obtenidas en las columnas, si bien se incluyen los datos de la recogida selectiva, aun cuando estas muestras no puedan considerarse representativas del depósito. 


\section{V.1.3.2.2. Solar 02 .}

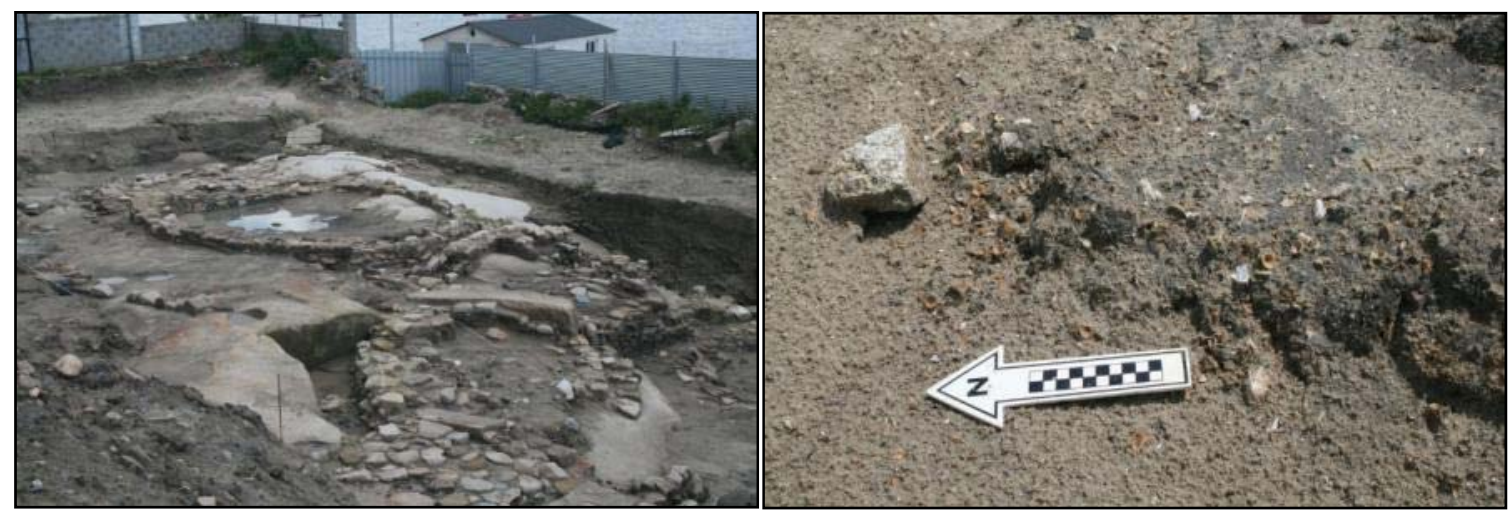

Fig. 11 Vista general del Solar 02 y acumulación de vértebras de Merluccius merluccius.

El muestreo del solar supuso mayores problemas, ya que si bien era abundante la presencia de material ictiológico y malacológico, no presentaba una densidad que permitiera hablar de una unidad estratigráfica ni de un conchero. Por este motivo, y ante la dificultad de recuperar los fragmentos de menor tamaño, se procedió a la toma de alguna muestra concentrada (SB/5-C3-N2; SB/5-C4-N2; SB/4-C5-N2; SF/1-C6-N3 y SC/1-C4N2) y de varias selectivas durante el proceso de excavación.

\section{V.1.3.3. CRONOLOGÍA.}

En el conchero se documentaron restos de cerámica galaico-romana (cerámica de tradición indígena, cerámica común romana y sigillata), que sugieren una cronología relativa de formación del depósito entre los siglos I-III d.C. (Ramil González, 2007; 2009).

En cuanto al Solar 02 se han localizado niveles Galaico-romanos (ss. I-III d.C.) para las capas del Nivel 02. Mientras que C-1, E-1 y F-1 parecen reflejar una ocupación medieval, confirmada por la recuperación de monedas de Alfonso X y Alfonso XI (Castro Vigo, 2008).

\section{V.1.4. ESTUDIO ICTIOARQUEOLÓGICO.}

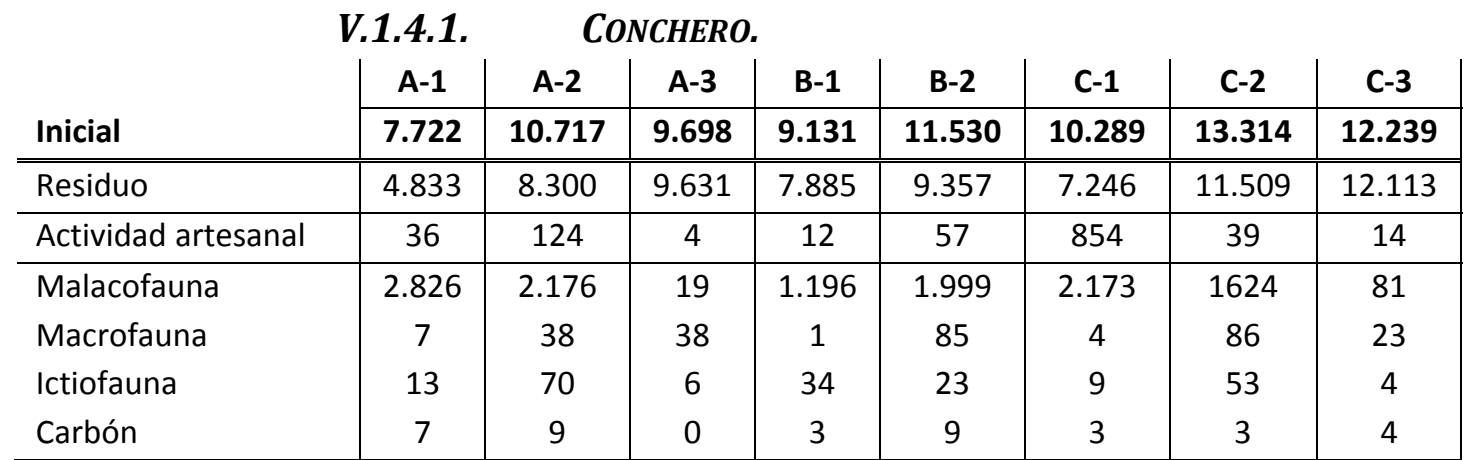

Tabla 1 Pesos iniciales (en gr.) del conchero por componentes. 


\section{V.1.4.1.1. Columna A.}

\section{Muestra A-1.}

\begin{tabular}{|c|c|c|c|c|c|c|c|c|c|c|c|c|}
\hline & $\begin{array}{l}\text { Pmx } \\
\text { (D/S) }\end{array}$ & $\begin{array}{c}\mathrm{Pal} \\
\text { (D/S) }\end{array}$ & $\begin{array}{c}\text { Cdr } \\
\text { (D/S) }\end{array}$ & Urh & Oto & Vpc & Vca & Rce & Rpc & Esa & NR & NMI \\
\hline Pollachius pollachius & & & & & & 2 & & & & & 2 & 1 \\
\hline Trisopterus luscus & & & & & & & 1 & & & & 1 & 1 \\
\hline Dicentrarchus labrax & & & & 1 & & & & & & & 1 & 1 \\
\hline Trachurus trachurus & & & & & & 1 & 3 & & & & 4 & 1 \\
\hline Pagellus acarne & & & & & & 1 & & & & & 1 & 1 \\
\hline Pagellus bogaraveo & & $1 / 0$ & $1 / 0$ & & 1 & & & & & & 3 & 1 \\
\hline Scomber japonicus & & & & & & & 2 & & & & 2 & 1 \\
\hline Indeterminado & 1 & & & & & 1 & 1 & 158 & 374 & $3 g r$. & 535 & \\
\hline TOTAL & 1 & 1 & 1 & 1 & 1 & 5 & 7 & 158 & 374 & & 549 & \\
\hline
\end{tabular}

En la Muestra A-1 se recuperaron 17 piezas óseas identificables pertenecientes a siete taxones. El conjunto lo completan 158 restos cefálicos y 374 post-cefálicos indeterminados, así como una elevada presencia de escamas. Las especies mejor representadas son Trachurus trachurus, con una vértebra precadual y tres vértebras caudales, y Pagellus bogaraveo, que cuenta con un palatino derecho, un cuadrado derecho y un otolito. Las seguiría Pollachius pollachius con dos vértebras precaudales, y Scomber japonicus con dos vértebras caudales. Por último, otro grupo de especies tiene una menor representación, estando formado por una vértebra caudal de Trisopterus luscus, una vértebra precadual de Pagellus acarne, y un urohial de Dicentrarchus labrax. Del mismo modo, contamos con un premaxilar, una vértebra precaudal y otra caudal que no han podido ser identificadas taxonómicamente.

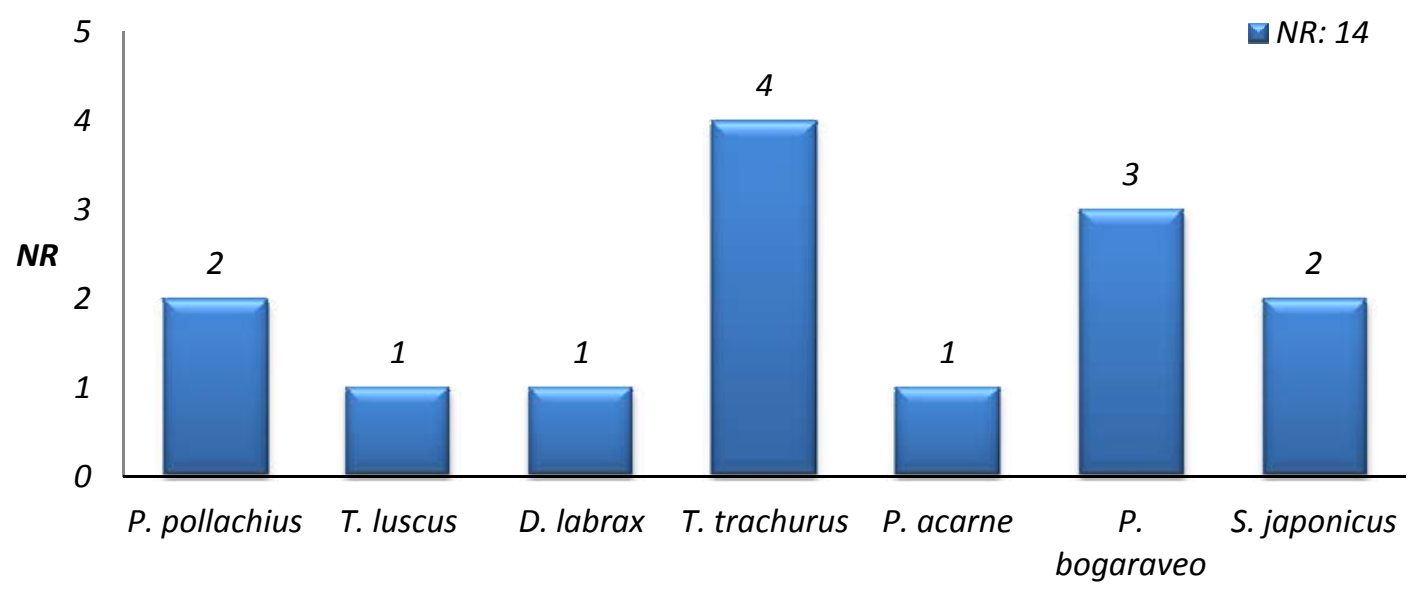

Fig. 12 Distribución de taxones identificados en la Muestra A-1 según el NR.

Tanto Trachurus trachurus como Pagellus bogaraveo son las especies mejor representadas en el conjunto, si bien no cuentan con un número destacado de piezas óseas que nos indique mayor importancia que el resto de especies. Las demás especies 
están representadas por dos (Pollachius pollachius y Scomber japonicus) o un único resto (Trisopterus luscus, Dicentrarchus labrax, Pagellus acarne).

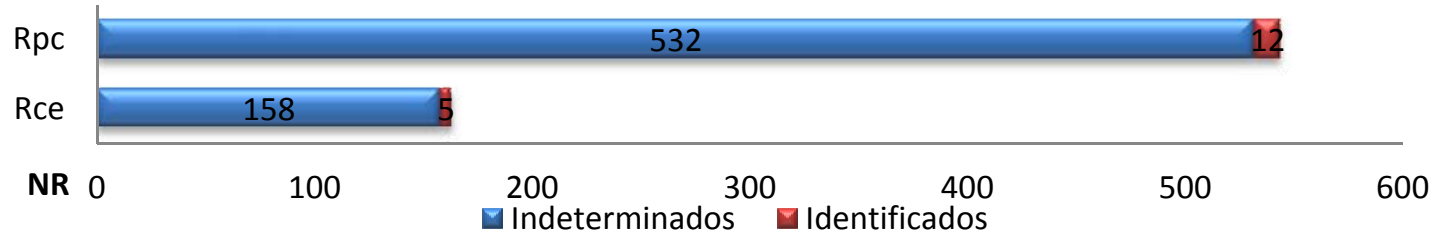

Fig. 13 Distribución esquelética de los restos ícticos de la Muestra A-1.

El número de restos indeterminados es muy elevado respecto al número de piezas óseas identificadas. Pese a esto se aprecia un predominio en los restos post-cefálicos, tanto entre los fragmentos indeterminados como las piezas óseas identificadas. Además la mayor parte de los restos cefálicos identificados pertenecen a una sola especie, Pagellus bogaraveo.

\section{Muestra A-2.}

\begin{tabular}{|c|c|c|c|c|c|c|c|c|c|c|c|c|c|c|c|c|c|c|c|c|}
\hline & $\begin{array}{l}P m x \\
\text { (D/S) }\end{array}$ & $\begin{array}{l}\operatorname{Max} \\
(\mathrm{D} / \mathrm{S})\end{array}$ & $\begin{array}{l}\text { Art } \\
\text { (D/S) }\end{array}$ & $\mathrm{Fbr}$ & $\mathrm{Cbr}$ & $\begin{array}{l}\text { Cdr } \\
\text { (D/S) }\end{array}$ & $\begin{array}{l}\text { Hmd } \\
\text { (D/S) }\end{array}$ & $\begin{array}{l}\text { Pop } \\
\text { (D/S) }\end{array}$ & $\begin{array}{c}\text { Pal } \\
\text { (D/S) }\end{array}$ & Eph & Crh & $\begin{array}{l}\text { Oto } \\
\text { (D/S) }\end{array}$ & $\mathrm{Vpc}$ & Atl & Vca & Rce & $\mathrm{Rpc}$ & Esa & NR & NMI \\
\hline Pollachius pollachius & & & & & & & & & & & & & & & 1 & & & & 1 & 1 \\
\hline Dicentrarchus labrax & & $0 / 1$ & & & & & & & & & 1 & & & & & & & & 2 & 1 \\
\hline Trachurus trachurus & & & & & & & & & & & & & & & 2 & & & & 2 & 1 \\
\hline Diplodus sargus & & & & & & & & & & & & & & & 1 & & & & 1 & 1 \\
\hline Pagellus acarne & & & & & & & & & & & & & 1 & & & & & & 1 & 1 \\
\hline Pagellus bogaraveo & & & & & & & & & & & & 1 & & & 1 & & & & 2 & 1 \\
\hline Pagrus pagrus & & & & & & & & & $1 / 0$ & & & & 1 & & 1 & & & & 3 & 1 \\
\hline Sparus aurata & & & & & & & $1 / 0$ & & & & & 1 & & & & & & & 2 & 1 \\
\hline Labrus bergylta & $1 / 1$ & & $0 / 1$ & 1 & 4 & $0 / 1$ & $1 / 0$ & $1 / 0$ & $2 / 0$ & 1 & & & 3 & 2 & 7 & & & & 26 & 4 \\
\hline Indeterminado & & & & & & 1 & & & & & & & & & & 498 & 841 & $6 \mathrm{gr}$. & 1340 & \\
\hline TOTAL & 2 & 1 & 1 & 1 & 4 & 2 & 2 & 1 & 3 & 1 & 1 & 2 & 5 & 2 & 13 & 498 & 841 & & 1380 & \\
\hline
\end{tabular}

En la Muestra A-2 se recuperaron 30 piezas óseas identificables pertenecientes a nueve taxones. El conjunto lo completarían 498 restos cefálicos y 841 post-cefálicos indeterminados, así como una elevada presencia de escamas. La especie con mayor número de restos es Labrus bergylta con dos premaxilares, un articular izquierdo, un faringobraquial, cuatro ceratobranquiales, un cuadrado izquierdo, un hiomandibular y un preopercular derecho, dos palatinos derechos, un epihial, tres vértebras precaudales, dos atlas y siete vértebras caudales. Además se ha podido identificar un palatino derecho, una vértebra precaudal y una caudal de Pagrus pagrus, un otolito y una vértebra caudal de Pagellus bogaraveo, dos vértebras caudales de Trachurus trachurus, un hiomandibular derecho y un otolito de Sparus aurata, así como un maxilar izquierdo y un ceratohial de Dicentrarchus labrax. Por último, las especies restantes únicamente cuentan con una pieza ósea identificada: una vértebra caudal de Pollachius pollachius y de Diplodus sargus, y una vértebra precaudual de Pagellus acarne. 


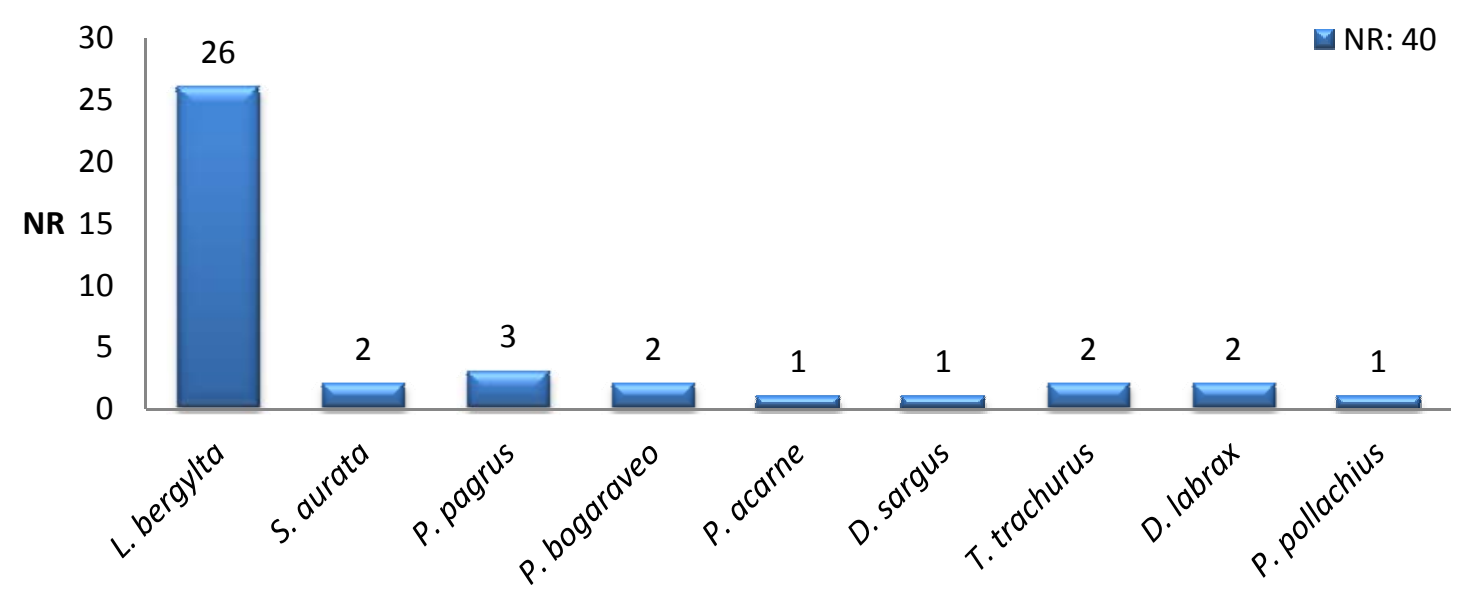

Fig. 14 Distribución de taxones identificados en la Muestra A-2 según el NR.

En esta muestra la especie dominante es Labrus bergylta, con un número elevado de restos, que refleja un NMI de cuatro ejemplares. Las demás especies cuentan con un número de restos muy inferior. Esta diferencia entre los distintos taxones es significativa al compararla con la Muestra 1 de la Columna A, en la que todas las especies presentaban un NR similar, y Labrus bergylta no estaba representada. Un grupo más o menos amplio estaría formado por cinco especies, representadas cada una por dos-tres restos. La mayor parte de estas especies ya se documentaron en la Muestra 1, aunque se incorporan dos especies nuevas: Pagrus pagrus y Sparus aurata. Por último, Pollachius pollachius, Diplodus sargus y Pagellus acarne cuentan con una representación mínima.

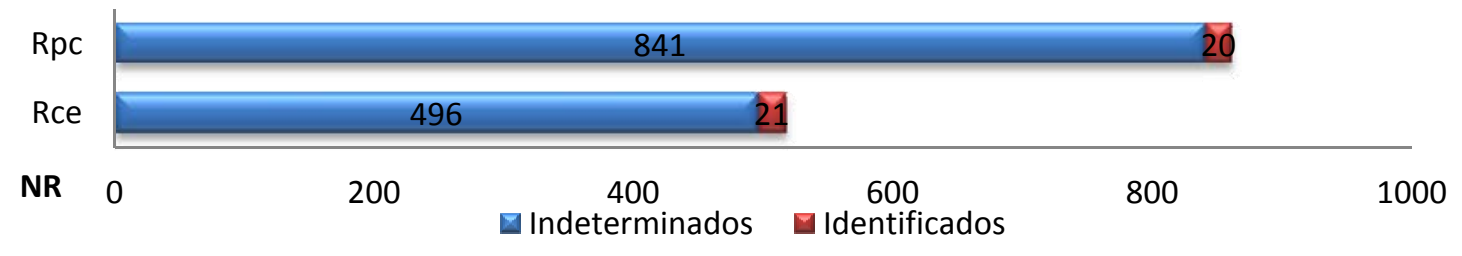

Fig. 15 Distribución esquelética de los restos ícticos de la Muestra A-2.

Igual que observábamos en la Muestra 1, el número de restos indeterminados es muy elevado respecto al número de piezas óseas identificadas. En este caso, la mayor parte de los restos no identificados pertenecen a fragmentos post-cefálicos, mientras que entre las piezas identificadas son ligeramente superiores los cefálicos, sin duda a causa de la abundante presencia de restos de Labrus bergylta. Otro elemento que aparece muy bien representado son las escamas, duplicando a las recuperadas en la Muestra 1, algo normal si tenemos en cuenta el mayor número de restos recuperados en esta muestra. 
Muestra A-3.

\begin{tabular}{lccccccc} 
& Vpc & Vca & Rce & Rpc & Esa & NR & NMI \\
\hline Labrus bergylta & & 2 & & & & $\mathbf{2}$ & 1 \\
Scomber japonicus & & 1 & & & & $\mathbf{1}$ & 1 \\
Pagellus bogaraveo & 1 & & & & & $\mathbf{1}$ & 1 \\
Indeterminado & & & 103 & 121 & 33 & $\mathbf{2 5 7}$ & \\
\hline \multicolumn{1}{c}{ TOTAL } & $\mathbf{1}$ & $\mathbf{3}$ & $\mathbf{1 0 3}$ & $\mathbf{1 2 1}$ & $\mathbf{3 3}$ & $\mathbf{2 6 1}$ &
\end{tabular}

Tabla 4 Relación de especies y representación ósea de la Muestra A-3.

La Muestra 3 corresponde al último nivel de la columna, sobre el sustrato geológico. En esta muestra se recuperaron cuatro piezas óseas identificables pertenecientes a tres taxones. El conjunto lo completarían 103 restos cefálicos, 121 postcefálicos indeterminados, así como 33 escamas. De esta muestra se han identificado dos vértebras caudales de Labrus bergylta, una vértebra caudal de Scomber japonicus y una vértebra precaudal de Pagellus bogaraveo. En este nivel no se apreciaban a simple vista restos de moluscos o peces, por lo que, como también se indicó en el análisis arqueomalacológico (González Gómez de Agüero, 2009), pueden reflejar bien procesos de percolación o bien su procedencia de una zona de contacto con los niveles superiores.

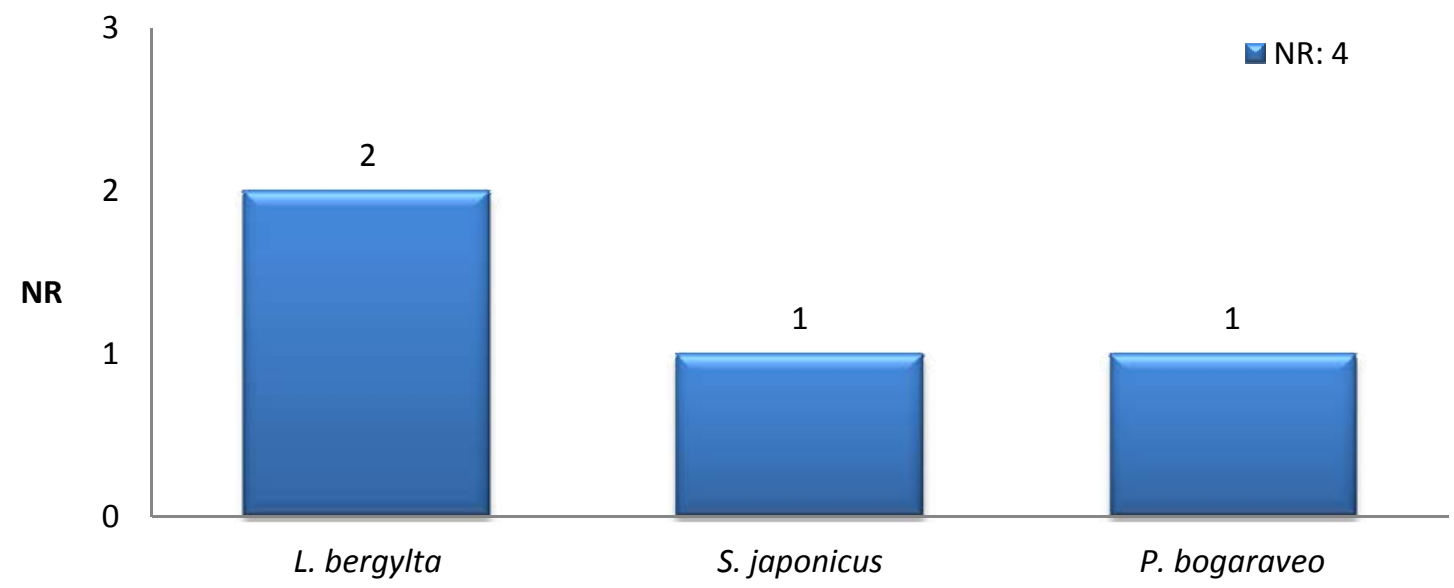

Fig. 16 Distribución de taxones identificados en la Muestra A-3 según el NR.

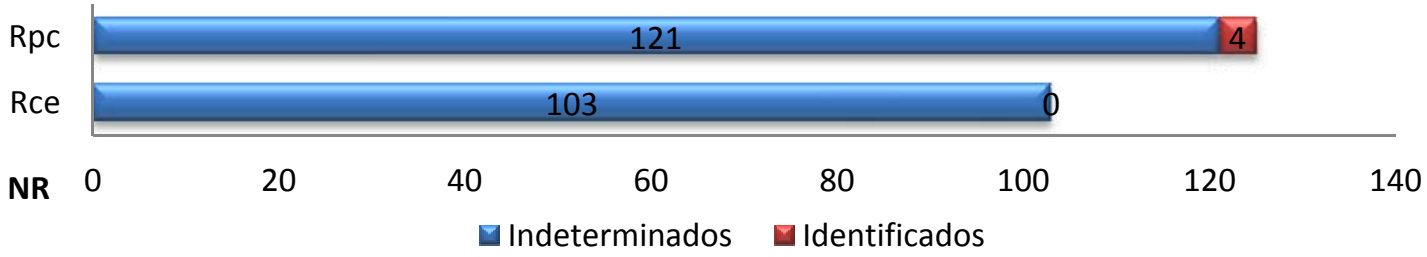

Fig. 17 Distribución esquelética de los restos ícticos de la Muestra A-3.

Como habíamos observado en las otras dos muestras, es abundante la presencia de restos indeterminados post-cefálicos y escamas. En cuanto a las piezas identificadas, todas se corresponden con centros vertebrales. 


\section{V.1.4.1.2. Columna B.}

\section{Muestra B-1.}

\begin{tabular}{|c|c|c|c|c|c|c|c|c|c|c|c|c|}
\hline & $\begin{array}{c}\text { Dnt } \\
\text { (D/S) }\end{array}$ & $\mathrm{Fbr}$ & $\begin{array}{c}\text { Pal } \\
\text { (D/S) }\end{array}$ & Oto & Vpc & Atl & Vca & Rce & Rpc & Esa & NR & NMI \\
\hline Sardina pilchardus & & & & & 1 & & & & & & 1 & 1 \\
\hline Salmo sp. & & & & & 1 & & & & & & 1 & 1 \\
\hline Pollachius pollachius & $0 / 1$ & & & 1 & & & 1 & & & & 3 & 1 \\
\hline Zeus faber & $1 / 0$ & & & & & & & & & & 1 & 1 \\
\hline Dicentrarchus labrax & & & & 1 & & & & & & & 1 & 1 \\
\hline Trachurus trachurus & & & & & 1 & & 3 & & & & 4 & 1 \\
\hline Pagrus pagrus & & & $1 / 0$ & & & 1 & 1 & & & & 3 & 1 \\
\hline Sparus aurata & & & & 1 & & & 1 & & & & 2 & 1 \\
\hline Labrus bergylta & & 2 & & & & 1 & & & & & 3 & 2 \\
\hline Scomber sp. & & & & & & & 1 & & & & 1 & 1 \\
\hline Scomber scombrus & & & & & & & 1 & & & & 1 & 1 \\
\hline Scomber japonicus & & & & & 3 & & & & & & 3 & 1 \\
\hline Indeterminado & & & & & & & 1 & 241 & 401 & 11 & 654 & \\
\hline TOTAL & 2 & 2 & 1 & 3 & 6 & 2 & 9 & 241 & 401 & 11 & 678 & \\
\hline
\end{tabular}

Tabla 5 Relación de especies y representación ósea de la Muestra B-1.

En la Muestra B-1 se recuperaron 25 piezas óseas identificables pertenecientes a 11 taxones. El conjunto lo completan 241 restos cefálicos y 401 post-cefálicos indeterminados, así como 11 escamas. Las especies con más restos son Pollachius pollachius con un dentario izquierdo, un otolito y una vértebra caudal; Pagrus pagrus con un palatino derecho, un atlas y una vértebra caudal; Labrus bergylta con dos faringobranquiales y un atlas; y Scomber japonicus con tres vértebras precaudales. Sparus aurata y Trachurus trachurus son las siguientes especies mejor representadas, con un otolito y una vértebra caudal para la primera y una vértebra precaudal y otra caudal para la segunda. Las piezas óseas documentadas para el resto de especies son: una vértebra precaudal de Sardina pilchardus y otra de Salmo sp., un dentario derecho de Zeus faber, un otolito de Dicentrarchus labrax, y sendas vértebras caudales de Scomber sp. y Scomber scombrus.

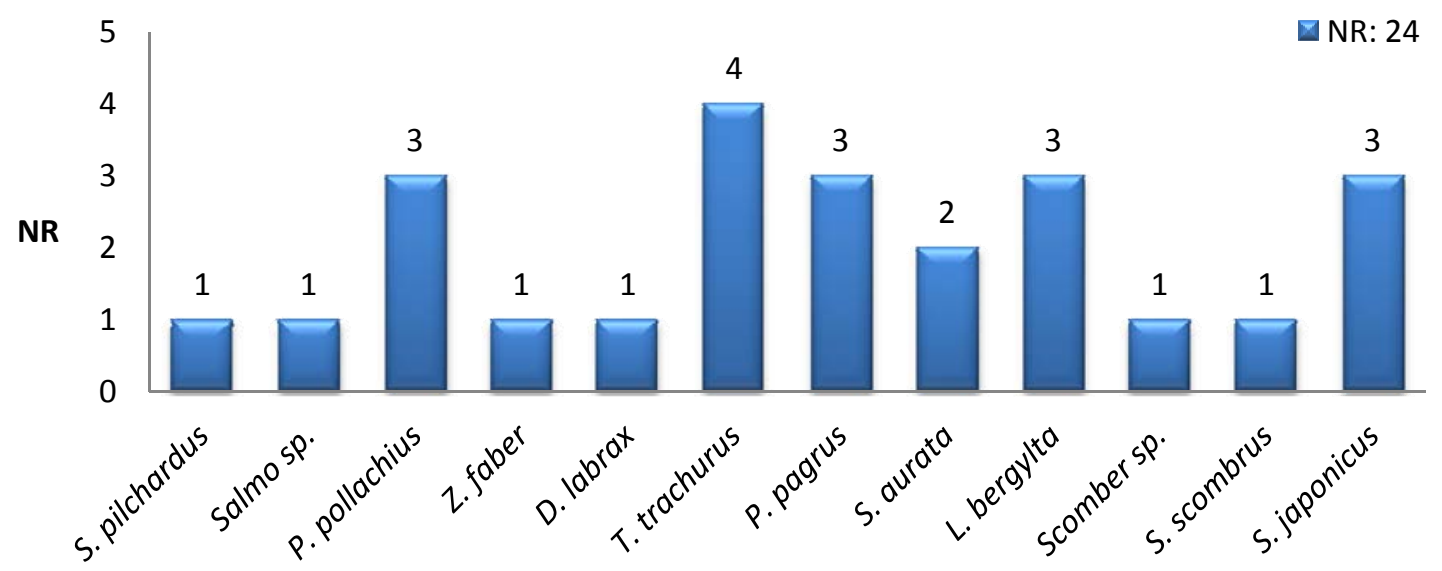

Fig. 18 Distribución de taxones identificados en la Muestra B-1 según el NR. 
Los taxones mejor representados serían Trachurus trachurus con cuatro restos, seguido de Pollachius pollachius, Pagrus pagrus, Labrus bergylta y Scomber japonicus con tres. El resto de especies tienen una presencia mínima con una o dos piezas óseas. En este grupo destaca la presencia de una vértebra precaudal de Salmo sp., especie de la que en yacimientos gallegos únicamente se había registrado una pieza vertebral en el Castro de $O$ Achadizo. Este taxón presenta un problema de conservación mayor que otras, ya que una gran parte del esqueleto es cartilaginoso, a lo que hay que unir los problemas de identificación específica. En nuestro caso lo hemos identificado como Salmo sp., ya que los centros vertebrales son similares entre las tres especies que habitan aguas peninsulares. Tradicionalmente un criterio de diferenciación ha sido la comparación de las longitudes vertebrales, considerando los ejemplares mayores de $9 \mathrm{~mm}$ como Salmo salar, mientras que medidas inferiores pueden corresponder a cualquiera de las especies. La longitud de esta vértebra $(4,7 \mathrm{~mm})$ no nos permite asegurar que sea Salmo salar, aunque así parece indicarlo la morfología y la distribución de las perforaciones laterales de la vértebra.

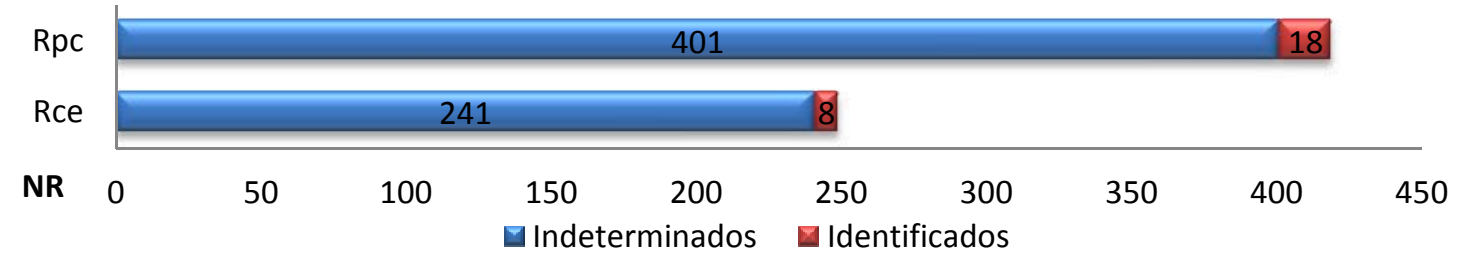

Fig. 19 Distribución esquelética de los restos ícticos de la Muestra B-1.

Como veíamos en las muestras de la Columna A, la proporción entre restos indeterminados e identificados es muy desigual. En este caso, la mayor parte de los restos pertenecen a fragmentos post-cefálicos. Sin embargo, el número de escamas es muy inferior teniendo en cuenta tanto las especies identificadas como los restos indeterminados, contrastando con lo observado en la Columna A.

\section{Muestra B-2.}

\begin{tabular}{|c|c|c|c|c|c|c|c|c|c|c|c|}
\hline & $\begin{array}{c}\mathrm{Cdr} \\
(\mathrm{D} / \mathrm{S})\end{array}$ & $\begin{array}{l}\text { Hmd } \\
\text { (D/S) }\end{array}$ & Cbr & Vpc & Atl & Vca & Rce & Rpc & Esa & NR & NMI \\
\hline Pagrus pagrus & $0 / 1$ & $0 / 1$ & & & & 4 & & & & 6 & 1 \\
\hline Labrus bergylta & & & 2 & 1 & 1 & 2 & & & & 6 & 2 \\
\hline Scomber japonicus & & $1 / 0$ & & & & & & & & 1 & 1 \\
\hline Indeterminado & & & & 1 & & 1 & 91 & 393 & 2 & 488 & \\
\hline TOTAL & 1 & 2 & 2 & 2 & 1 & 7 & 91 & 393 & 2 & 501 & \\
\hline
\end{tabular}

En la Muestra B-2 se recuperaron 15 piezas óseas identificables pertenecientes a tres taxones. El conjunto lo completan 91 restos cefálicos y 393 post-cefálicos indeterminados, además de dos escamas. Pagrus pagrus está representada por un cuadrado, un hiomandibular izquierdo y cuatro vértebras caudales. Labrus bergylta cuenta con dos ceratobranquiales, una vértebra precaudal, un atlas y dos vértebras caudales. La 
otra especie identificada es Scomber japonicus de la que se ha recuperado un hiomandibular derecho.

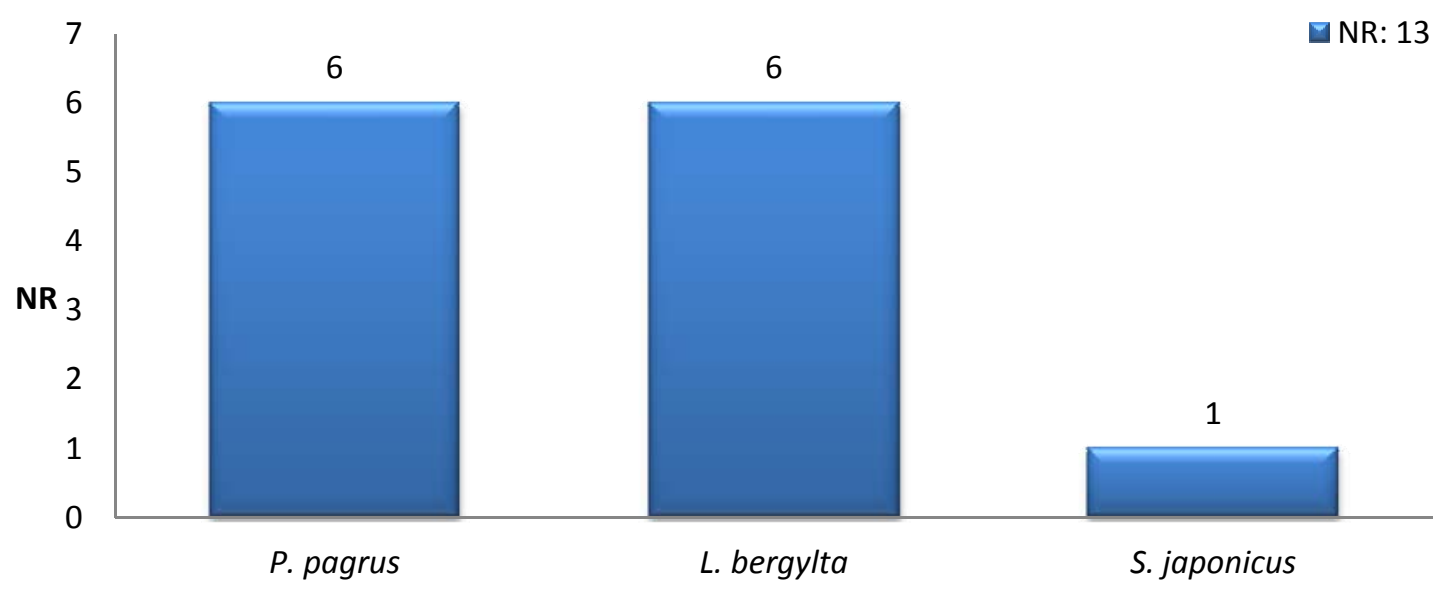

Fig. 20 Distribución de taxones identificados en la Muestra B-2 según el NR.

De las tres especies identificadas son Pagrus pagrus y Labrus bergy/ta las que presentan un mayor número de restos. En el caso de esta última especie ya observamos una alta representación en la Muestra 2 de la Columna A, mientras que Pagrus pagrus, ausente en la Muestra 1 de la Columna A, presenta un menor número de restos en las demás muestras. La otra especie identificada es Scomber japonicus, con una única pieza ósea.

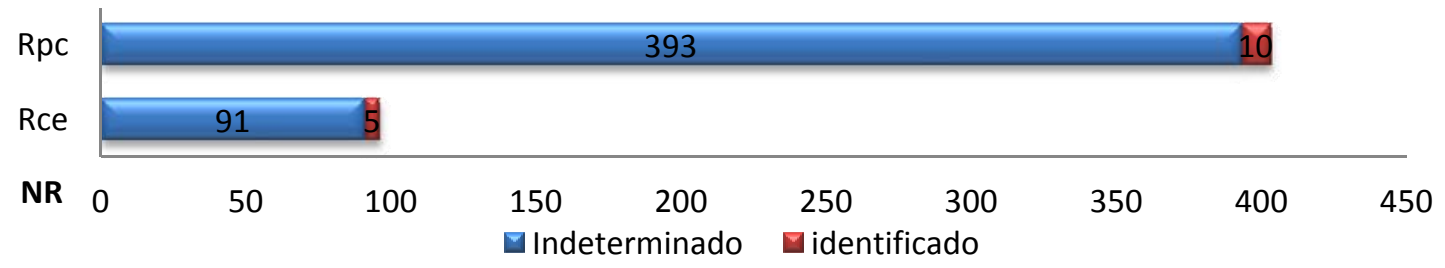

Fig. 21 Distribución esquelética de los restos ícticos de la Muestra B-2.

Al igual que en otras muestras, se han recuperado gran cantidad de fragmentos indeterminados, entre los que predominan los post-cefálicos. En cuanto a los restos identificados siguen predominando los post-cefálicos, aunque todas las especies documentadas cuentan con piezas cefálicas en el conjunto. Por otro lado, como sucedía en la Muestra 1 de la Columna B, las escamas son muy escasas, recuperándose únicamente dos. 


\section{V.1.4.1.3. Columna C.}

Muestra C-1.

\begin{tabular}{lcccccccccc} 
& $\begin{array}{c}\text { Pmx } \\
\text { (D/S) }\end{array}$ & $\begin{array}{c}\text { Pal } \\
\text { (D/S) }\end{array}$ & $\begin{array}{c}\text { Cdr } \\
\text { (D/S) }\end{array}$ & Vpc & Vca & Rce & Rpc & Esa & NR & NMI \\
\hline $\begin{array}{l}\text { Sardina pilchardus } \\
\text { Pollachius pollachius }\end{array}$ & & & $1 / 0$ & & 1 & & & & $\mathbf{2}$ & 1 \\
Pagellus acarne & & & & & 1 & & & & $\mathbf{1}$ & 1 \\
Pagrus pagrus & & & & & 1 & & & & $\mathbf{1}$ & 1 \\
Labrus bergylta & & & & 1 & & & & & $\mathbf{1}$ & 1 \\
Indeterminado & 1 & 1 & & 2 & & 72 & 232 & $7 g r$. & $\mathbf{3 0 8}$ & \\
\hline \hline \multicolumn{1}{c}{ TOTAL } & $\mathbf{1}$ & $\mathbf{1}$ & $\mathbf{1}$ & $\mathbf{4}$ & $\mathbf{3}$ & $\mathbf{7 2}$ & $\mathbf{2 3 2}$ & & $\mathbf{3 1 4}$
\end{tabular}

Tabla 7 Relación de especies y representación ósea de la Muestra C-1.

En la Muestra C-1 se recuperaron 10 piezas óseas identificables pertenecientes a cinco taxones. El conjunto lo completan 72 restos cefálicos y 232 post-cefálicos indeterminados, así como una elevada presencia de escamas. Se han recuperado una vértebra precaudal de Sardina pilchardus y otra de Labrus bergy/ta, un cuadrado derecho y una vértebra caudal de Pollachius pollachius y sendas vértebras caudales de Pagellus acarne y Pagrus pagrus.

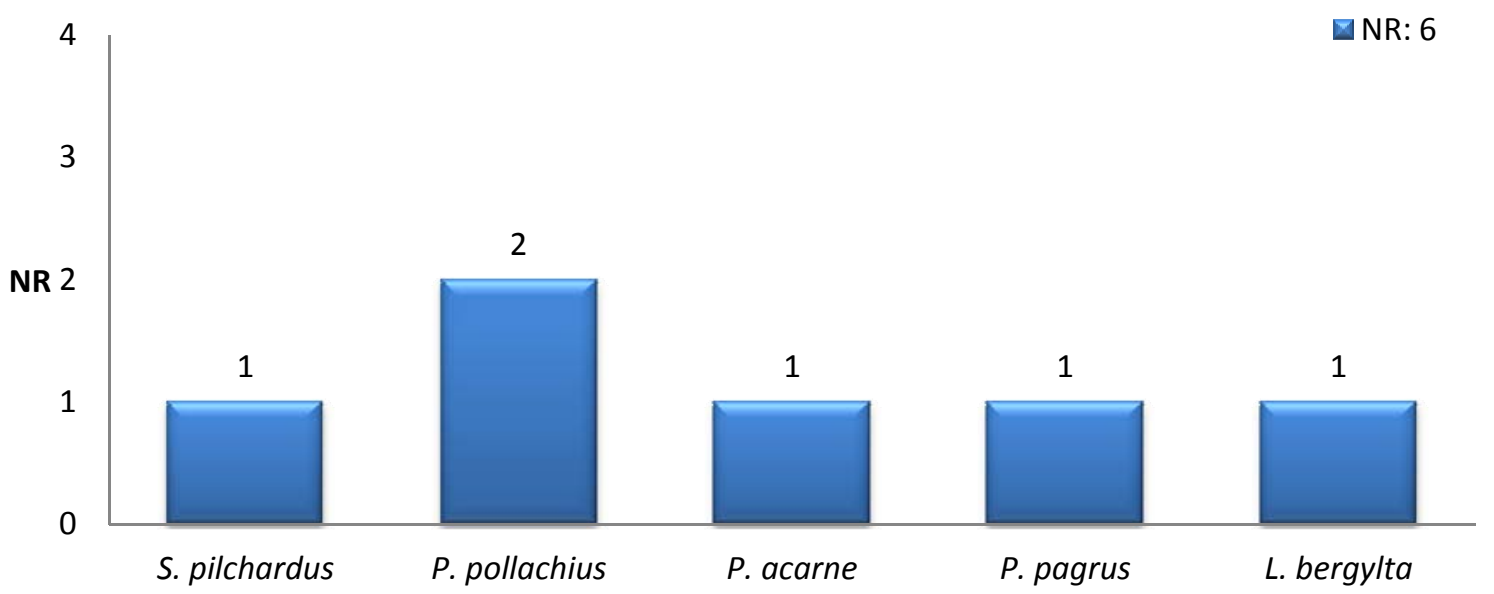

Fig. 22 Distribución de taxones identificados en la Muestra C-1 según el NR.

La presencia de ictiofauna en esta muestra es bastante reducida, con un número similar de restos para todos los taxones, si bien el $40 \%$ de las piezas óseas no han sido identificadas a nivel de especie.

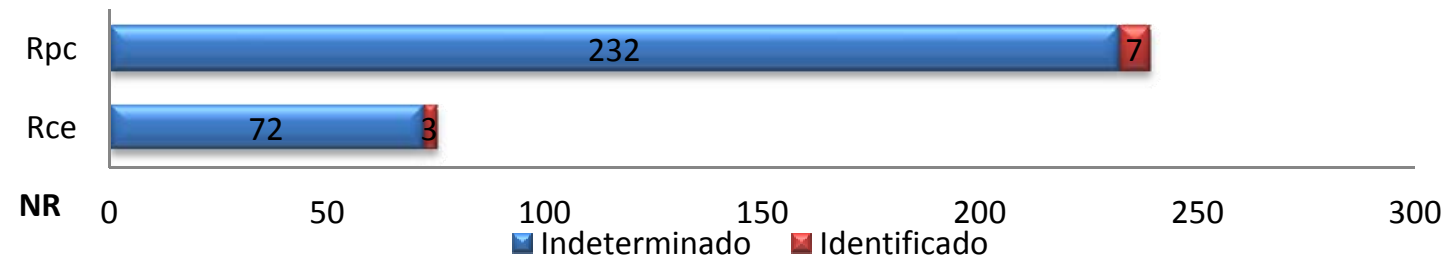

Fig. 23 Distribución esquelética de los restos ícticos de la Muestra C-1. 
Frente a la escasa presencia de restos identificables, se ha recuperado un número muy elevado de fragmentos indeterminados, entre los que predominan los restos postcefálicos frente a los cefálicos. Se ha recuperado también un gran número de escamas.

\section{Muestra C-2.}

\begin{tabular}{|c|c|c|c|c|c|c|c|c|c|c|c|c|c|c|}
\hline & $\begin{array}{l}\text { Pmx } \\
\text { (D/S) }\end{array}$ & $\begin{array}{l}\text { Dnt } \\
\text { (D/S) }\end{array}$ & $\begin{array}{l}\text { Cdr } \\
\text { (D/S) }\end{array}$ & $\begin{array}{l}\text { Pop } \\
\text { (D/S) }\end{array}$ & $\begin{array}{l}\text { Pal } \\
\text { (D/S) }\end{array}$ & $\begin{array}{c}\text { Eph } \\
\text { (D/S) }\end{array}$ & $\begin{array}{l}\text { Oto } \\
\text { (D/S) }\end{array}$ & Vpc & Vca & Rce & Rpc & Esa & NR & NMI \\
\hline Pollachius pollachius & & $0 / 1$ & & & & & & 2 & 1 & & & & 4 & 1 \\
\hline Pagellus acarne & & & & & & & & & 1 & & & & 1 & 1 \\
\hline Pagellus bogaraveo & & & & & & & 2 & & & & & & 2 & 1 \\
\hline Pagrus pagrus & & $1 / 0$ & $0 / 1$ & & & & & & & & & & 2 & 1 \\
\hline Labrus bergylta & $1 / 0$ & & & $0 / 1$ & & $0 / 1$ & & 1 & 3 & & & & 7 & 1 \\
\hline Scomber japonicus & & & & & & & & 1 & & & & & 1 & 1 \\
\hline Indeterminado & & & & & 2 & & & 2 & & 126 & 540 & $20 \mathrm{gr}$ & 670 & \\
\hline TOTAL & 1 & 2 & 1 & 1 & 2 & 1 & 2 & 6 & 5 & 126 & 540 & & 687 & \\
\hline
\end{tabular}

Tabla 8 Relación de especies y representación ósea de la Muestra C-2.

En la Muestra C-2 se recuperaron 21 piezas óseas identificables pertenecientes a seis taxones. El conjunto lo completan 126 restos cefálicos y 540 post-cefálicos indeterminados, así como una elevada presencia de escamas. Labrus bergy/ta cuenta con un premaxilar derecho, un preopercular y un epihial izquierdos, una vértebra precaudal y tres vértebras caudales. Pollachius pollachius está representado por un dentario izquierdo, dos vértebras precaudales y una vértebra caudal. De Pagellus bogaraveo se identificaron dos otolitos y de Pagrus pagrus un dentario derecho y un cuadrado izquierdo. Por último,se ha recuperado una vértebra caudal de Pagellus acarne, y otra precaudal de Scomber japonicus.

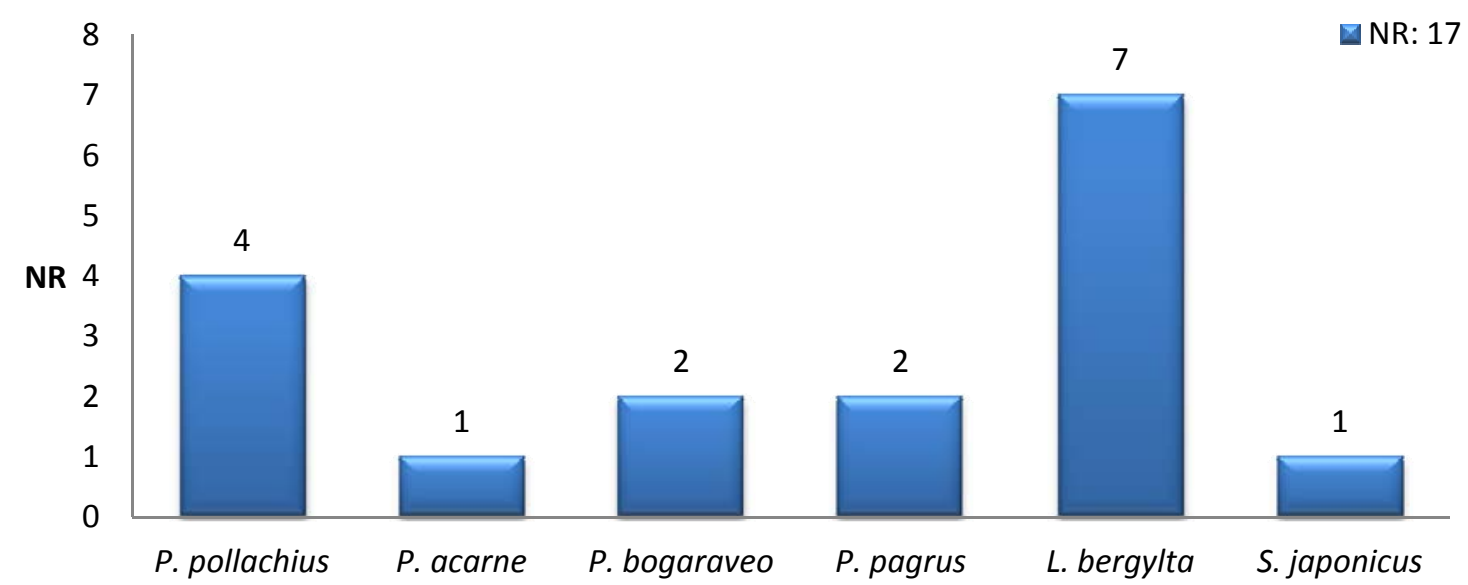

Fig. 24 Distribución de taxones identificados en la Muestra C-2 según el NR.

La especie con más restos identificados es Labrus bergy/ta, coincidiendo con lo observado en otras muestras como en B2 y A2. La siguiente especie mejor representada es Pollachius pollachius con cuatro restos. El resto de taxones están representados por una o dos piezas óseas. 


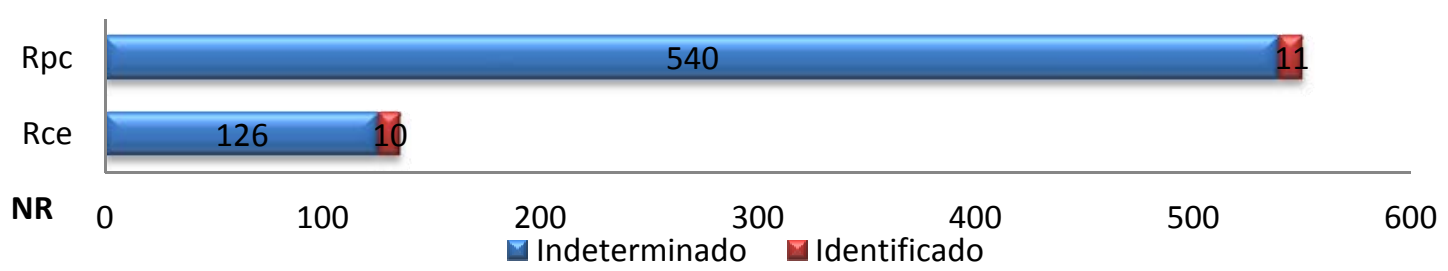

Fig. 25 Distribución esquelética de los restos ícticos de la Muestra C-2.

Hay un elevado número de fragmentos indeterminados, predominando los postcefálicos. En cuanto a los restos identificados, presentan valores similares tanto los cefálicos como los post-cefálicos. Esto mismo se observa en la Muestra A-2, donde también Labrus bergylta era la especie mejor representada, si bien con un mayor número de restos identificados. También se registró un elevado número de escamas, algo similar a lo documentado en las muestras de la Columna A y B.

\section{Muestra C-3.}

\begin{tabular}{lccccccc} 
& Vpc & Vca & Rce & Rpc & Esa & NR & NMI \\
\hline $\begin{array}{l}\text { Pagellus bogaraveo } \\
\text { Scomber japonicus }\end{array}$ & 1 & 1 & & & & $\mathbf{1}$ & 1 \\
Indeterminado & & & & & & $\mathbf{1}$ & 1 \\
\hline \multicolumn{1}{c}{ TOTAL } & $\mathbf{1}$ & $\mathbf{1}$ & $\mathbf{2 0}$ & $\mathbf{5 4}$ & $\mathbf{6 4}$ & $\mathbf{1 4 0}$ &
\end{tabular}

Tabla 9 Relación de especies y representación ósea de la Muestra C-3.

En la Muestra C-3 se recuperaron dos piezas óseas identificables pertenecientes a un taxón cada una: una vértebra caudal de Pagellus bogaraveo y otra precaudal de Scomber japonicus. El conjunto lo completan 20 restos cefálicos, 54 post-cefálicos indeterminados y 64 escamas. Esta muestra se localiza sobre el sustrato geológico, siendo escasa la presencia de material arqueológico.

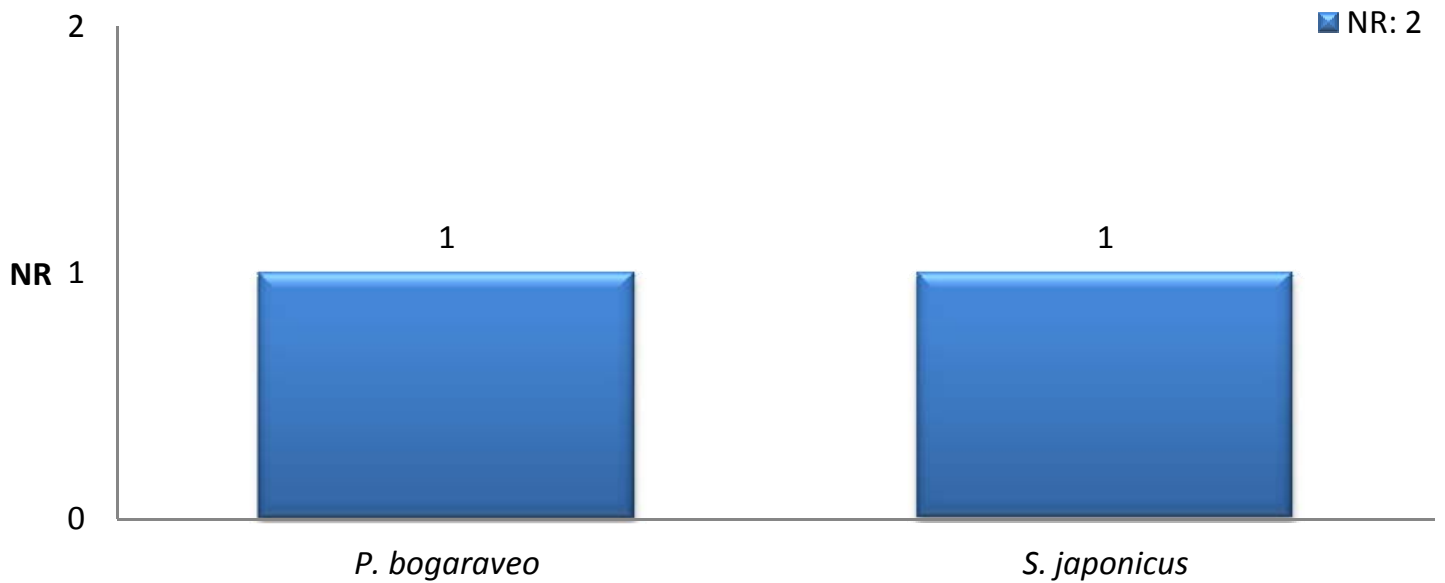

Fig. 26 Distribución de taxones identificados en la Muestra C-3 según el NR. 


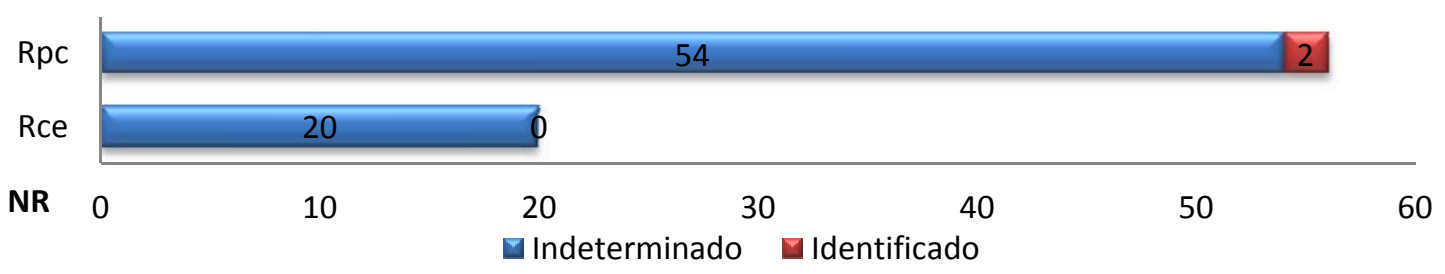

Fig. 27 Distribución esquelética de los restos ícticos de la Muestra C-3.

Predominan los restos post-cefálicos y, como se observaba en la muestra A-3, entre los restos identificados únicamente se han recuperado centros vertebrales. Teniendo en cuenta el bajo número de restos óseos documentado, llama la atención el importante volumen de escamas presente en la muestra.

\section{V.1.4.1.4. Muestras aisladas.}

N3-C4.

\begin{tabular}{lcccc} 
& Vpc & Esa & NR & NMI \\
\hline Sardina pilchardus & 1 & & $\mathbf{1}$ & 1 \\
Merluccius merluccius & 1 & & $\mathbf{1}$ & 1 \\
Scomber japonicus & 1 & & $\mathbf{1}$ & 1 \\
Indeterminado & & 4 & $\mathbf{4}$ & \\
\hline \hline \multicolumn{1}{c}{ TOTAL } & $\mathbf{3}$ & $\mathbf{4}$ & $\mathbf{7}$
\end{tabular}

Tabla 10 Relación de especies y representación ósea del Nivel 3-Capa 4.

Se identifican únicamente tres vértebras precaudales pertenecientes a otros tantos taxones. También se recuperó una vértebra precaudal de Merluccius merluccius, taxón no identificado en las demás muestras.

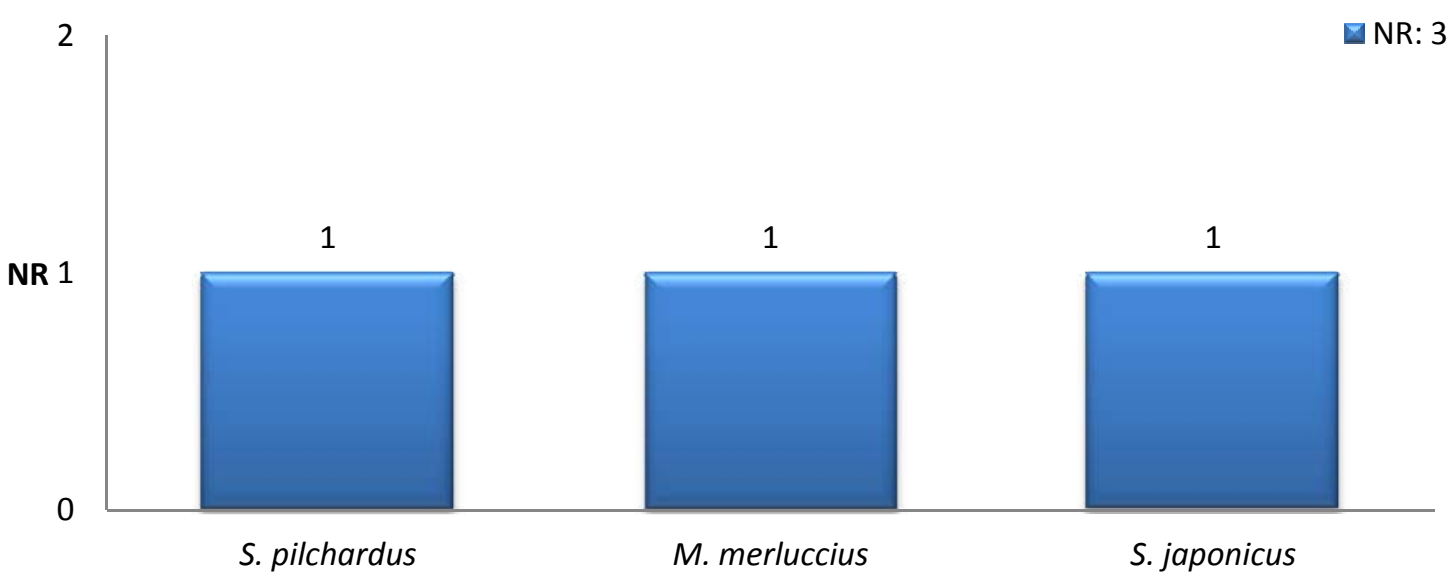

Fig. 28 Distribución de taxones identificados en el Nivel 3-Capa 4 según el NR. 
S1-N2-C5.

\begin{tabular}{|c|c|c|c|c|c|c|c|c|c|c|c|c|}
\hline & $\begin{array}{c}\text { Pmx } \\
\text { (D/S) }\end{array}$ & $\begin{array}{c}\text { Max } \\
(D / S)\end{array}$ & $\begin{array}{c}\text { Dnt } \\
\text { (D/S) }\end{array}$ & $\begin{array}{c}\text { Art } \\
\text { (D/S) }\end{array}$ & Cbr & $\begin{array}{l}\text { Hmd } \\
\text { (D/S) }\end{array}$ & Vpc & Vca & Rce & Rpc & NR & NMI \\
\hline Pollachius pollachius & $0 / 1$ & & $0 / 1$ & & & & 1 & 2 & & & 5 & 1 \\
\hline Pagrus pagrus & $2 / 0$ & $1 / 0$ & & $0 / 1$ & & & & & & & 4 & 2 \\
\hline Labrus bergylta & $1 / 0$ & & & & 7 & $1 / 0$ & & & & & 9 & 7 \\
\hline Scomber japonicus & & & & & & & & 1 & & & 1 & 1 \\
\hline Indeterminado & & & & & & & & & 17 & 17 & 43 & \\
\hline TOTAL & 4 & 1 & 1 & 1 & 7 & 1 & 1 & 3 & 17 & 17 & 62 & \\
\hline
\end{tabular}

Entre las muestras concentradas que se tomaron durante la excavación del área del conchero, esta es la que presenta un mayor número de restos identificables. Se contabilizan 19 restos pertenecientes a cuatro taxones, además de otros 17 restos cefálicos y 17 post-cefálicos cuya asignación específica no ha sido posible. Los primeros se corresponden con un premaxilar izquierdo, un dentario izquierdo, una vertebra precaudal y dos caudales de Pollachius pollachius; dos premaxilares, un maxilar derecho y un articular izquierdo de Pagrus pagrus; un premaxilar y un hiomandibular derecho, y siete ceratobranquiales de Labrus bergylta; y una vértebra caudal de Scomber japonicus.

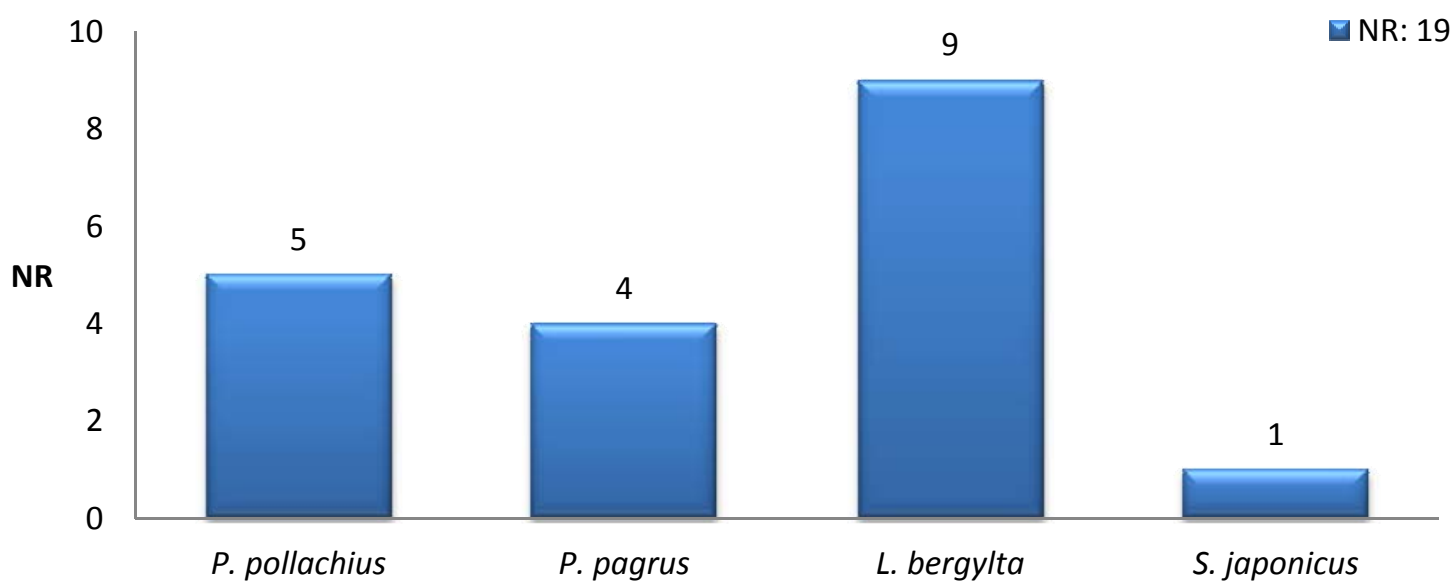

Fig. 29 Distribución de taxones identificados en el Sondeo 1-Nivel 2-Capa 5 según el NR.

La distribución de los taxones por número de restos presenta un esquema similar al observado en las columnas de muestras, siendo Labrus bergylta la especie principal, seguida de Pollachius pollachius y Pagrus pagrus con menos restos. Por último Scomber japonicus está representada por un solo resto.

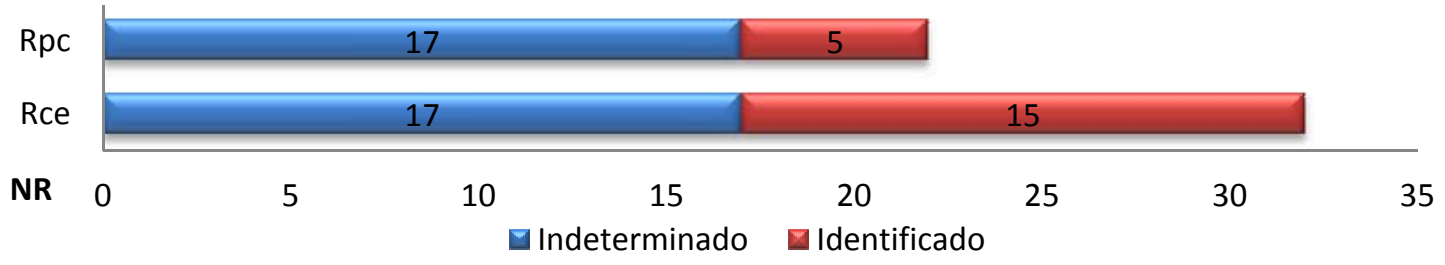

Fig. 30 Distribución esquelética de los restos ícticos del Sondeo 1-Nivel 2-Capa 5. 
Predominan los restos cefálicos sobre los post-cefálicos, si bien entre los indeterminados hay un equilibrio entre estos valores. Como ya habíamos observado en las Muestras A-2 y C-2, cuando Labrus bergylta es la especie mejor representada predominan los restos cefálicos. Esto se debe a la mayor osificación del cráneo de este taxón.

S2-N2-C4.

\begin{tabular}{cccc} 
& Cbr & NR & NMI \\
\hline Labrus bergylta & 1 & $\mathbf{1}$ & 1 \\
\hline \hline TOTAL & $\mathbf{1}$ & $\mathbf{1}$ &
\end{tabular}

Tabla 12 Relación de especies y representación ósea del Sondeo 2-Nivel 2-Capa 4.

Esta muestra cuenta únicamente con un resto correspondiente a un ceratobranquial de Labrus bergylta, que debido tanto a su tamaño, como a su forma llamativa, facilita su localización visual y su recuperación.

S2-N2-C5.

\begin{tabular}{lcccccc} 
& Pmx & Rce & Rpc & Esa & NR & NMI \\
& (D/S) & & & & & \\
\hline Pollachius pollachius & $1 / 0$ & & & & $\mathbf{1}$ & 1 \\
$\begin{array}{l}\text { Pagellus acarne } \\
\text { Indeterminado }\end{array}$ & $0 / 1$ & & & & $\mathbf{1}$ & 1 \\
\hline \hline \multicolumn{1}{c}{ TOTAL } & $\mathbf{2}$ & $\mathbf{8}$ & $\mathbf{3 0}$ & & $\mathbf{4 0}$ &
\end{tabular}

Tabla 13 Relación de especies y representación ósea del Sondeo 2-Nivel 2-Capa 5.

Se han documentados 2 restos identificables pertenecientes a 2 taxones diferentes, así como 8 restos cefálicos, 30 post-cefálicos y una importante presencia de escamas. El material identificado se corresponde con un premaxilar derecho de Pollachius pollachius y otro izquierdo de Pagellus acarne.

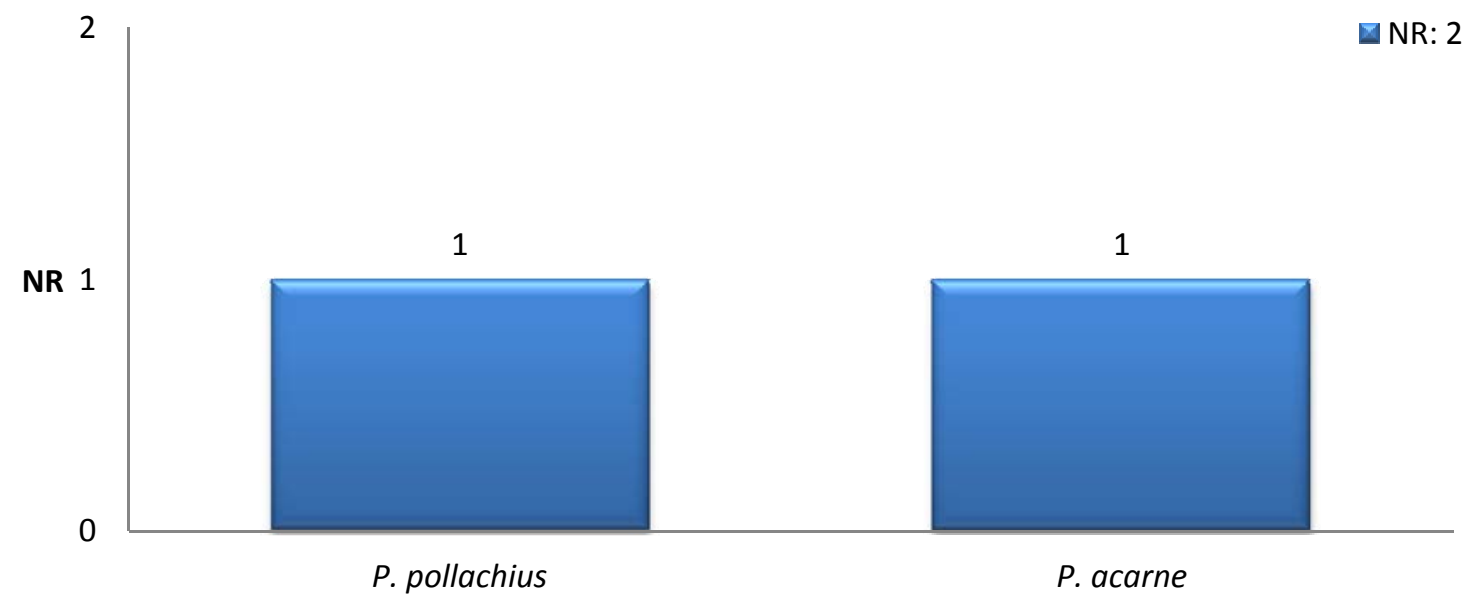

Fig. 31 Distribución de taxones identificados en el Sondeo 2-Nivel 2-Capa 5 según el NR. 


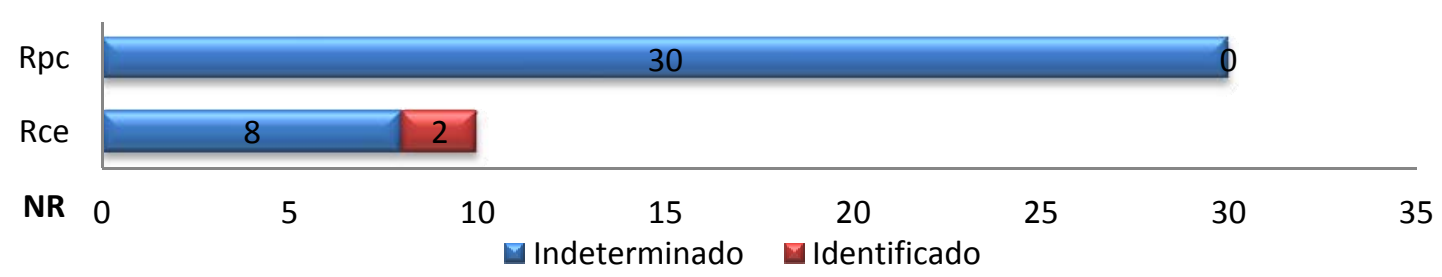

Fig. 32 Distribución esquelética de los restos ícticos del Sondeo 2-Nivel 2-Capa 5.

Entre los huesos indeterminados predominan los restos post-cefálicos, aunque identificables únicamente hay dos restos cefálicos.

S3-N2-C5.

\begin{tabular}{ccccc} 
& $\begin{array}{c}\text { Pmx } \\
(\mathbf{D} / \mathbf{S})\end{array}$ & $\mathbf{R p c}$ & NR & NMI \\
\hline Pagrus pagrus & $0 / 1$ & & $\mathbf{1}$ & 1 \\
Indeterminado & & 1 & $\mathbf{1}$ & \\
\hline \hline TOTAL & $\mathbf{1}$ & $\mathbf{1}$ & $\mathbf{2}$
\end{tabular}

Tabla 14 Relación de especies y representación ósea del Sondeo 3-Nivel 2-Capa 5.

Esta muestra cuenta únicamente con un resto correspondiente a un premaxilar izquierdo de Pagrus pagrus.

\section{V.1.4.2. SOLAR 02.}

\section{V.1.4.2.1. Niveles Galaico-romanos.}

$S A / 3-C 2-N 2$.

\begin{tabular}{cccc} 
& Vpc & NR & NMI \\
\hline Merluccius merluccius & 4 & $\mathbf{4}$ & 1 \\
\hline \hline TOTAL & $\mathbf{4}$ & $\mathbf{4}$ &
\end{tabular}

Tabla 15 Relación de especies y representación ósea del Sondeo A/3-Nivel 2-Capa 2.

En esta muestra únicamente se identificaron cuatro vértebras precaudales de Merluccius merluccius.

$S B / 4-C 2-N 2$

\begin{tabular}{|c|c|c|c|c|c|c|c|c|c|c|c|}
\hline & $\begin{array}{c}\text { Pmx } \\
\text { (D/S) }\end{array}$ & $\begin{array}{c}\text { Dnt } \\
\text { (D/S) }\end{array}$ & $\begin{array}{c}\text { Art } \\
\text { (D/S) }\end{array}$ & $\begin{array}{c}C d r \\
(D / S)\end{array}$ & Vpc & Vca & Rce & Rpc & Esa & NR & NMI \\
\hline Sardina pilchardus & & & $0 / 1$ & & 2 & & & & & 3 & 1 \\
\hline Pagellus acarne & & & & & 3 & 1 & & & & 4 & 1 \\
\hline Symphodus melops & $0 / 1$ & $0 / 1$ & & $0 / 1$ & & 1 & & & & 4 & 1 \\
\hline Indeterminado & & & & & & & 7 & 8 & 32 & 47 & \\
\hline TOTAL & 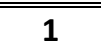 & 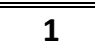 & 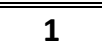 & $\overline{c 1}$ & 5 & 2 & 7 & 8 & 32 & 58 & \\
\hline
\end{tabular}

Tabla 16 Relación de especies y representación ósea del Sondeo B/4-Nivel 2-Capa 2.

La muestra está compuesta por 11 piezas óseas identificables pertenecientes a tres taxones, siete restos cefálicos y ocho post-cefálicos indeterminados, así como 32 escamas. Sardina pilchardus está representada por un articular izquierdo y dos vértebras 
precaudales. Pagellus acarne lo está por tres vértebras precaudales y una vértebra caudal. Por último, de Symphodus melops se ha podido identificar un premaxilar, un dentario y un cuadrado izquierdo, así como una vértebra caudal.

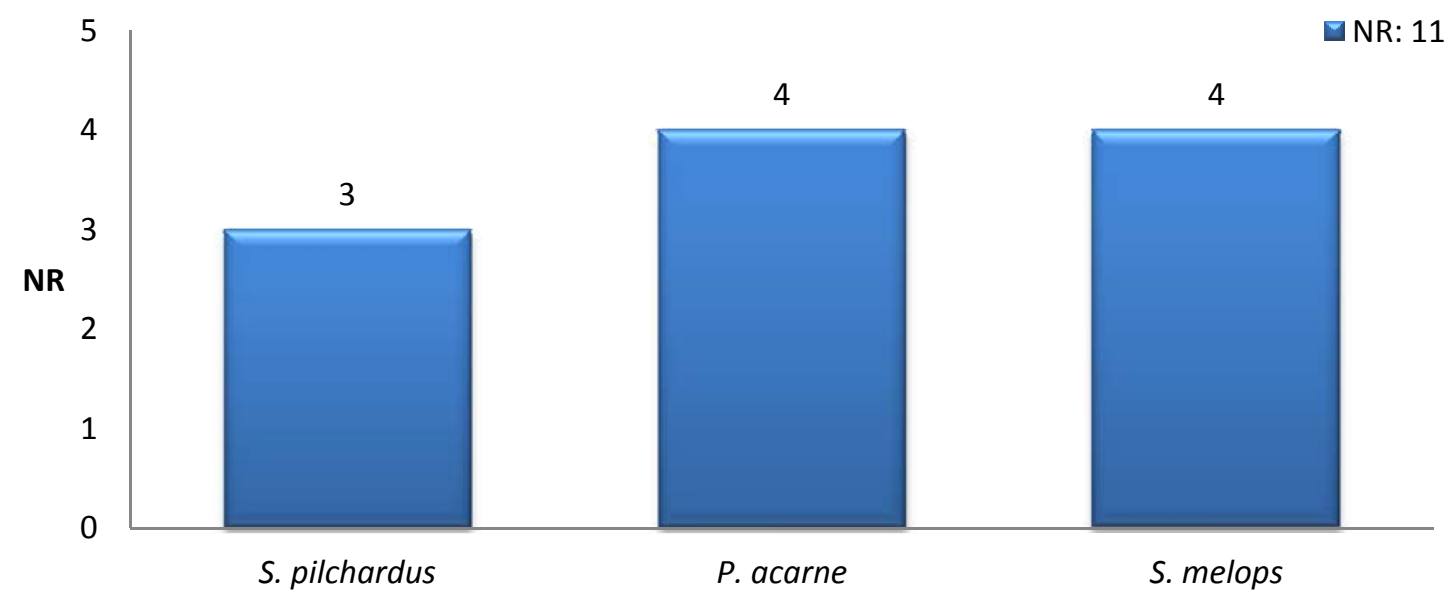

Fig. 33 Distribución de taxones identificados en el Sondeo B/4-Nivel 2-Capa 2 según el NR.

Todos los taxones identificados presentan un número similar de restos, si bien Pagellus acarne y Symphodus melops son ligeramente superiores a los de Sardina pilchardus.

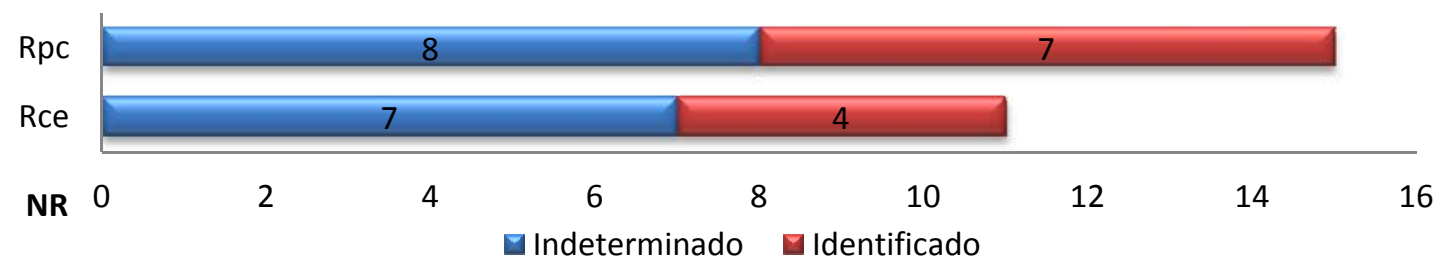

Fig. 34 Distribución esquelética de los restos ícticos del Sondeo B/4-Nivel 2-Capa 2.

Predominan los restos post-cefálicos frente a los cefálicos, tanto entre los restos indeterminados como entre los restos identificados. La mayor diferencia se aprecia en estos últimos, siendo mayor el número de restos post-cefálicos en todas las especies menos en Symphodus melops, donde predominan los cefálicos.

SA/2-C3-N2.

\begin{tabular}{lcccc} 
& $\begin{array}{c}\text { Dnt } \\
\text { (D/S) }\end{array}$ & Rce & NR & NMI \\
\hline $\begin{array}{l}\text { Merluccius merluccius } \\
\text { Indeterminado }\end{array}$ & $1 / 0$ & & $\mathbf{1}$ & 1 \\
\hline \hline & & 1 & $\mathbf{1}$ & \\
\hline TOTAL & $\mathbf{1}$ & $\mathbf{1}$ & $\mathbf{2}$
\end{tabular}

Tabla 17 Relación de especies y representación ósea del Sondeo A/2-Nivel 2-Capa 3.

Únicamente se recuperó un dentario derecho de Merluccius merluccius y un resto cefálico indeterminado. 
SA/4-C3-N2.

\begin{tabular}{lccccc} 
& Cbr & Vpc & Rpc & NR & NMI \\
\hline Merluccius merluccius & & 2 & & $\mathbf{2}$ & 1 \\
Labrus bergylta & 1 & & & $\mathbf{1}$ & 1 \\
Indeterminado & & & 1 & $\mathbf{1}$ & \\
\hline \hline \multicolumn{1}{c}{ TOTAL } & $\mathbf{1}$ & $\mathbf{2}$ & $\mathbf{1}$ & $\mathbf{4}$ &
\end{tabular}

Tabla 18 Relación de especies y representación ósea del Sondeo A/4-Nivel 2-Capa 3.

El conjunto lo conforman cuatro piezas óseas identificables pertenecientes a dos taxones y un resto postcefálico indeterminado. En esta muestra contamos con dos vértebras precaudales de Merluccius merluccius y un ceratobranquial de Labrus bergylta.

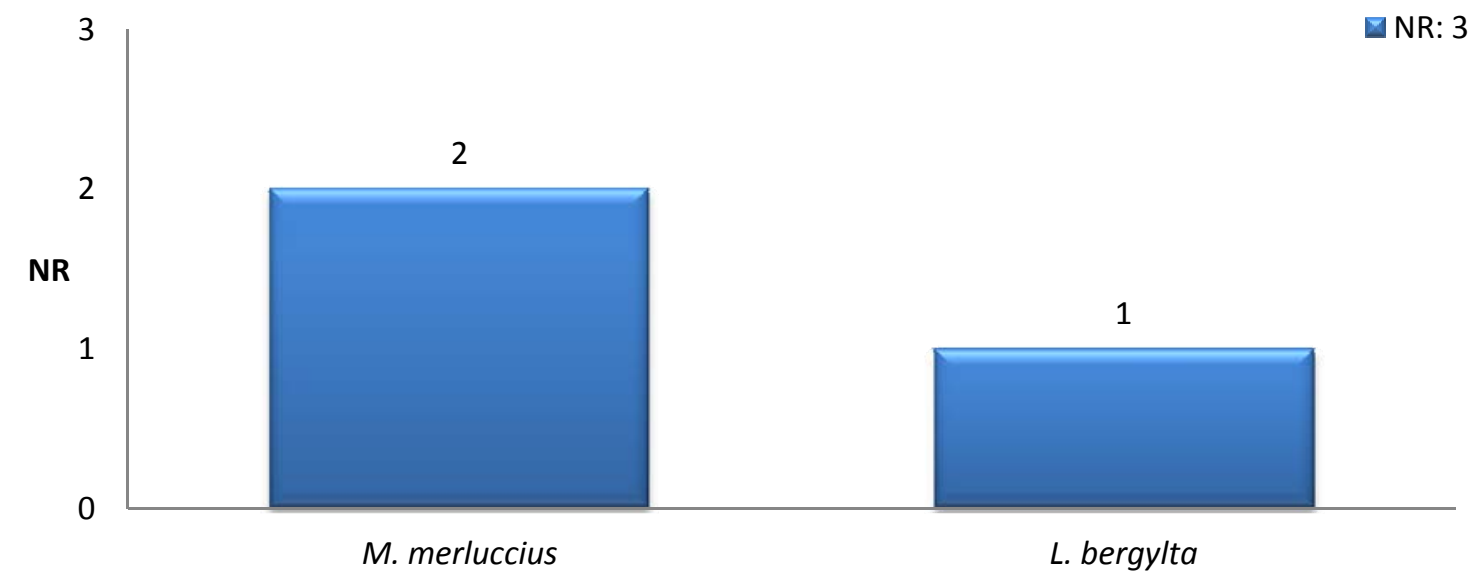

Fig. 35 Distribución de taxones identificados en el Sondeo A/4-Nivel 2-Capa 3 según el NR.

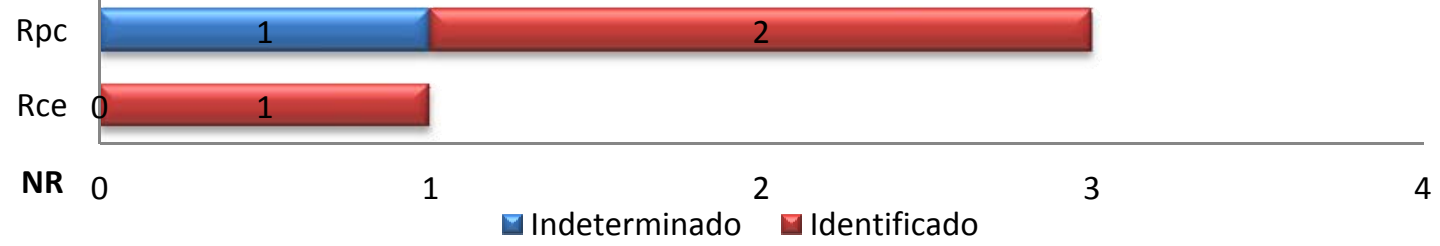

Fig. 36 Distribución esquelética de los restos ícticos del Sondeo A/4-Nivel 2-Capa 3.

Predominan los restos post-cefálicos, siendo Labrus bergylta la única especie de la que se han identificado restos cefálicos.

$S A / 5-C 3-N 2$.

\begin{tabular}{lccccccc} 
& $\begin{array}{c}\text { Dnt } \\
(\mathbf{D} / \mathbf{S})\end{array}$ & $\begin{array}{c}\text { Pmx } \\
\text { (D/S) }\end{array}$ & Vpc & Vca & Rce & NR & NMI \\
\hline Labrus bergylta & & $0 / 1$ & & & & $\mathbf{1}$ & 1 \\
$\begin{array}{l}\text { Merluccius merluccius } \\
\text { Indeterminado }\end{array}$ & $1 / 0$ & $1 / 1$ & 9 & 1 & & $\mathbf{1 3}$ & 1 \\
\hline \hline \multicolumn{1}{c}{ TOTAL } & $\mathbf{1}$ & $\mathbf{3}$ & $\mathbf{9}$ & $\mathbf{1}$ & $\mathbf{4}$ & $\mathbf{1 8}$ &
\end{tabular}

Tabla 19 Relación de especies y representación ósea del Sondeo A/5-Nivel 2-Capa 3. 
La muestra la componen 14 piezas óseas identificables pertenecientes a dos taxones, así como cuatro restos cefálicos indeterminados. De Labrus bergylta se ha identificado un premaxilar izquierdo, mientras que de Merluccius Merluccius un dentario derecho, un premaxilar derecho y otro izquierdo, nueve vértebras precaudales y una caudal.

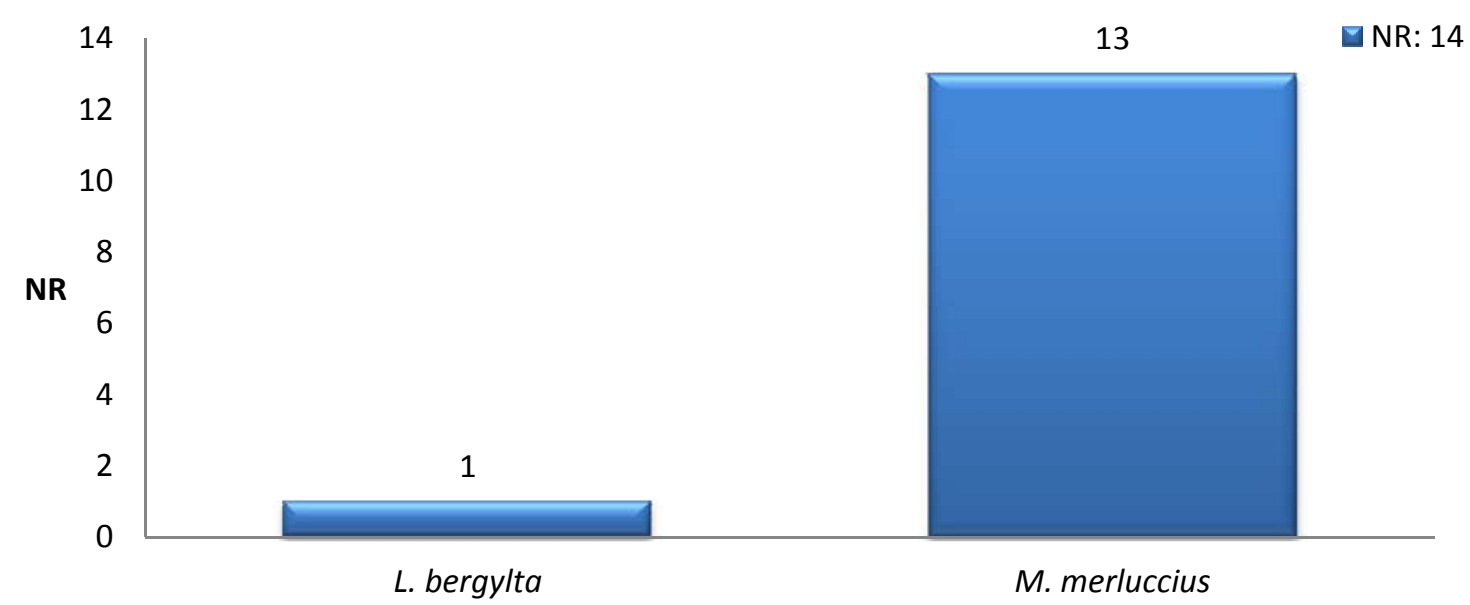

Fig. 37 Distribución de taxones identificados en el Sondeo A/4-Nivel 2-Capa 3 según el NR.

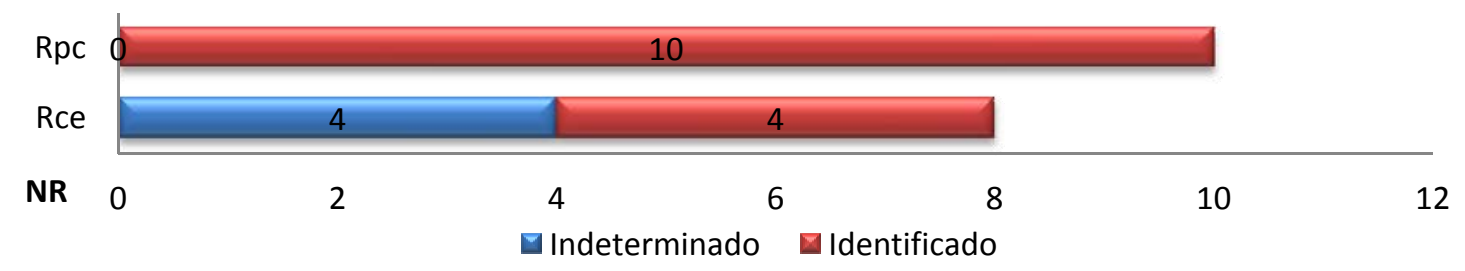

Fig. 38 Distribución esquelética de los restos ícticos del Sondeo A/4-Nivel 2-Capa 3.

Predominan los restos post-cefálicos, pertenecientes todos ellos a Merluccius merluccius. En cuanto a los restos cefálicos presentan un número similar a los postcefálicos, con el mismo número de restos indeterminados que de identificados.

\section{SA/6-C3-N2.}

\begin{tabular}{lcccc} 
& Vpc & Rpc & NR & NMI \\
\hline Merluccius merluccius & 1 & & $\mathbf{1}$ & 1 \\
Indeterminado & & 1 & $\mathbf{1}$ & \\
\hline \hline TOTAL & $\mathbf{1}$ & $\mathbf{1}$ & $\mathbf{2}$ &
\end{tabular}

Tabla 20 Relación de especies y representación ósea del Sondeo A/6-Nivel 2-Capa 3.

Únicamente se recuperó una vértebra precaudal de Merluccius merluccius y un resto post-cefálico indeterminado. 
SA/7-C3-N2.

\begin{tabular}{lccccccc} 
& $\begin{array}{c}\text { Art } \\
\text { (D/S) }\end{array}$ & $\begin{array}{c}\text { Dnt } \\
\text { (D/S) }\end{array}$ & Cbr & Eph & Rce & NR & NMI \\
\hline Merluccius merluccius & $0 / 1$ & $0 / 1$ & & 1 & & $\mathbf{3}$ & 1 \\
Labrus bergylta & & & 1 & & & $\mathbf{1}$ & 1 \\
Zeus faber & & & & 1 & & $\mathbf{1}$ & 1 \\
Indeterminado & & & & & 2 & $\mathbf{2}$ & \\
\hline \multicolumn{1}{c}{ TOTAL } & $\mathbf{1}$ & $\mathbf{1}$ & $\mathbf{1}$ & $\mathbf{2}$ & $\mathbf{2}$ & $\mathbf{7}$ &
\end{tabular}

Tabla 21 Relación de especies y representación ósea del Sondeo A/7-Nivel 2-Capa 3.

El conjunto está compuesto por 5 piezas óseas identificables pertenecientes a 3 taxones además de 7 restos cefálicos indeterminados. La especie a la que pertenece el mayor número de restos es Merluccius merluccius: un articular y un dentario izquierdo y un epihial. A Labrus bergylta le corresponde un ceratobranquial y a Zeus faber un epihial.

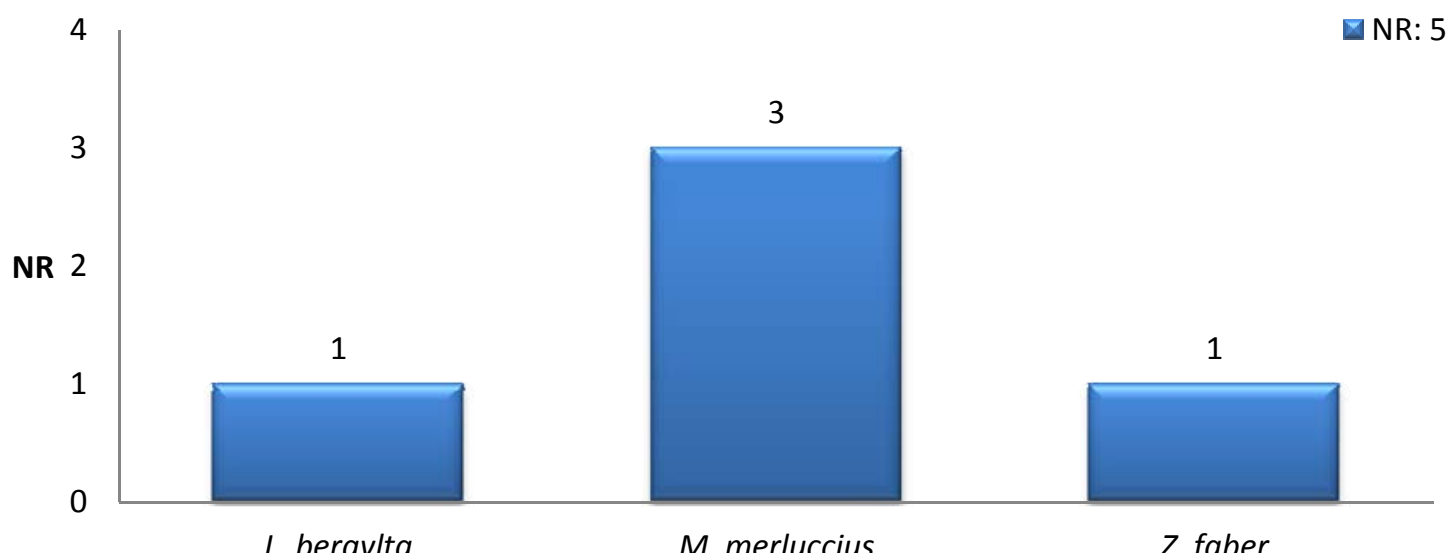

Fig. 39 Distribución de taxones identificados en el Sondeo A/7-Nivel 2-Capa 3 según el NR.

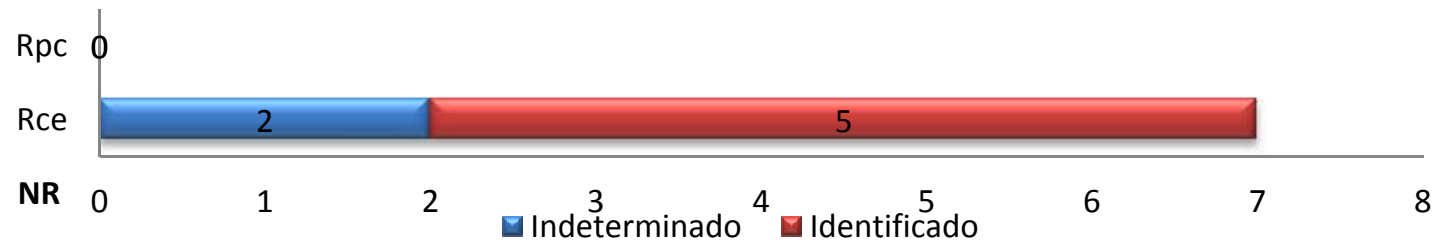

Fig. 40 Distribución esquelética de los restos ícticos del Sondeo A/7-Nivel 2-Capa 3.

Es significativa la ausencia de restos post-cefálicos, ya que suelen ser los más numerosos en las muestras analizadas de este yacimiento.

$S B / 3-C 3-N 2$.

\begin{tabular}{cccc} 
& Cbr & NR & NMI \\
\hline Labrus bergylta & 1 & $\mathbf{1}$ & 1 \\
\hline TOTAL & $\mathbf{1}$ & $\mathbf{1}$ &
\end{tabular}

Tabla 22 Relación de especies y representación ósea del Sondeo B/3-Nivel 2-Capa 3. 
Se ha recuperado un único resto identificado como ceratobranquial de Labrus bergylta.

$S B / 4-C 3-N 2$.

\begin{tabular}{lcccccc} 
& Fbr & Vpc & Vca & Rce & NR & NMI \\
\hline Merluccius merluccius & & 2 & 1 & & $\mathbf{3}$ & 1 \\
Pollachius pollachius & & 1 & & & $\mathbf{1}$ & 1 \\
Labrus bergylta & 1 & & & & $\mathbf{1}$ & 1 \\
Indeterminado & & & & 8 & $\mathbf{8}$ & \\
\hline \multicolumn{1}{c}{ TOTAL } & $\mathbf{1}$ & $\mathbf{3}$ & $\mathbf{1}$ & $\mathbf{8}$ & $\mathbf{1 3}$ &
\end{tabular}

Tabla 23 Relación de especies y representación ósea del Sondeo B/4-Nivel 2-Capa 3.

Conjunto formado por cinco piezas óseas identificables pertenecientes a tres taxones y ocho restos cefálicos indeterminados. Merluccius merluccius es el taxón mejor representado con una vértebra caudal y dos precaudales. A Pollachius pollachius corresponde una vértebra precaudal y a Labrus bergylta un faringobranquial. Además se recuperaron ocho restos cefálicos que no pudieron ser identificados por su estado de conservación.

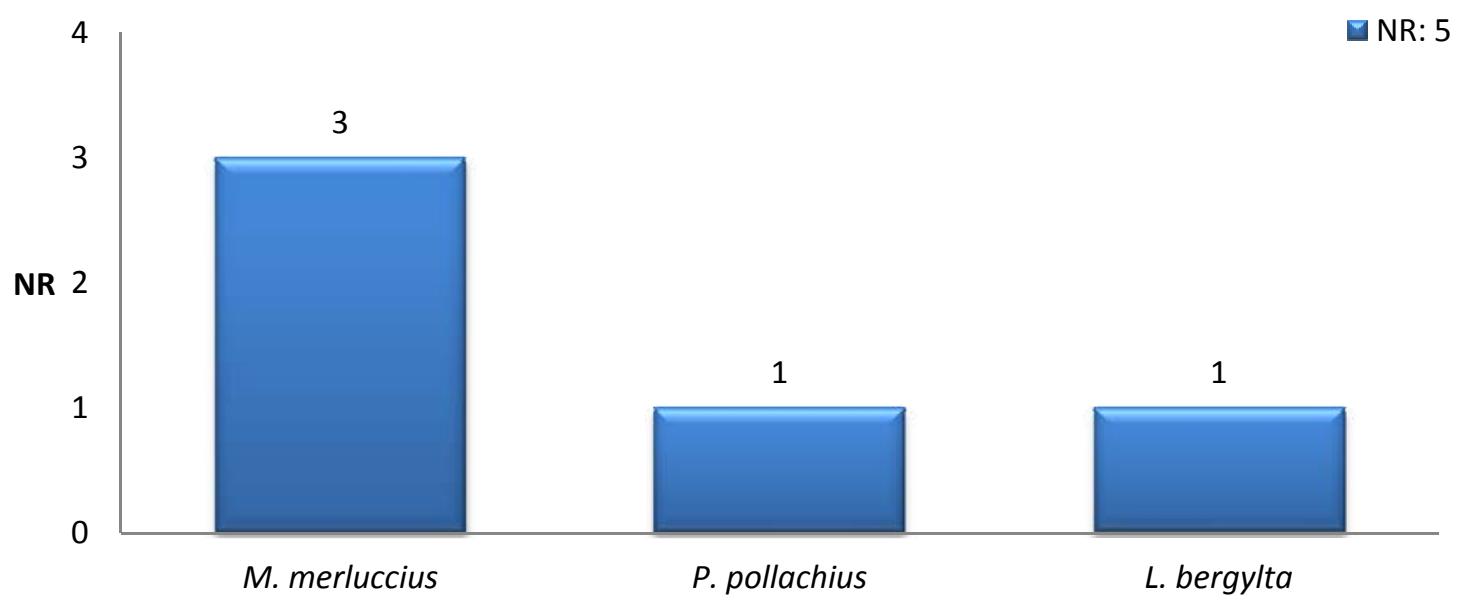

Fig. 41 Distribución de taxones identificados en el Sondeo B/4-Nivel 2-Capa 3 según el NR.

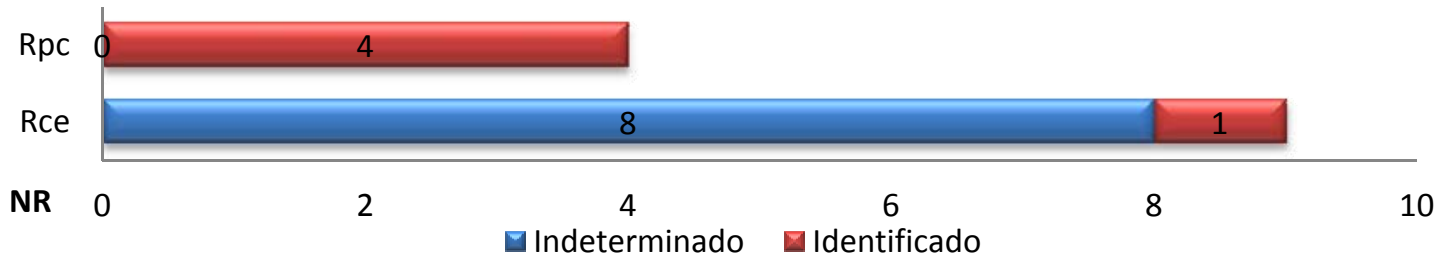

Fig. 42 Distribución esquelética de los restos ícticos del Sondeo B/4-Nivel 2-Capa 3.

Hay una mayor presencia de restos cefálicos, aunque tan solo uno ha podido ser identificado. Todos los restos post-cefálicos pertenecen a centros vertebrales. 
$S B / 5-C 3-N 2$.

\begin{tabular}{|c|c|c|c|c|c|c|c|c|c|c|}
\hline & $\begin{array}{c}\text { Pmx } \\
\text { (D/S) }\end{array}$ & $\begin{array}{c}\text { Art } \\
\text { (D/S) }\end{array}$ & $\begin{array}{c}\text { Cdr } \\
\text { (D/S) }\end{array}$ & Vpc & Vca & Rce & Rpc & Esa & NR & NMI \\
\hline Sardina pilchardus & & $1 / 0$ & $0 / 1$ & 14 & 3 & & & & 19 & 1 \\
\hline Trachurus trachurus & $1 / 1$ & & & 3 & 8 & & & & 13 & 1 \\
\hline Indeterminado & & & & & & 56 & 109 & 62 & 227 & \\
\hline TOTAL & 2 & 1 & 1 & 17 & 11 & 56 & 109 & 62 & 259 & \\
\hline
\end{tabular}

Tabla 24 Relación de especies y representación ósea del Sondeo B/5-Nivel 2-Capa 3.

La muestra está compuesta por 32 piezas óseas identificables pertenecientes a dos taxones, así como 56 restos cefálicos y 109 post-cefálicos indeterminados, y 62 escamas. La especie mejor representada es Sardina pilchardus con un articular derecho, un cuadrado izquierdo, catorce vértebras precaudales y tres caudales. La otra especie identificada es Trachurus trachurus con un premaxilar izquierdo y otro derecho, tres vértebras precaudales y ocho vértebras caudales. Además, se ha recogido un número importante de restos que no hemos podido identificar por su estado de conservación, pertenecientes tanto al cráneo como a diversas costillas. Destaca también la presencia de escamas.

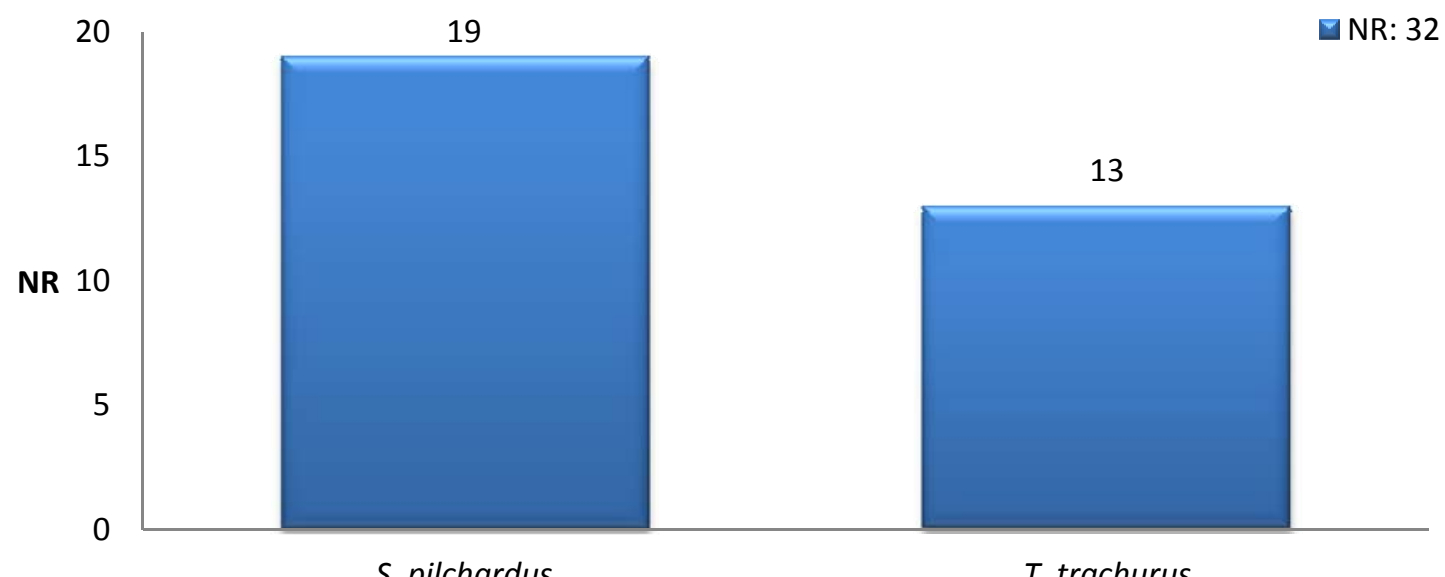
S. pilchardus
T. trachurus

Fig. 43 Distribución de taxones identificados en el Sondeo B/5-Nivel 2-Capa 3 según el NR.

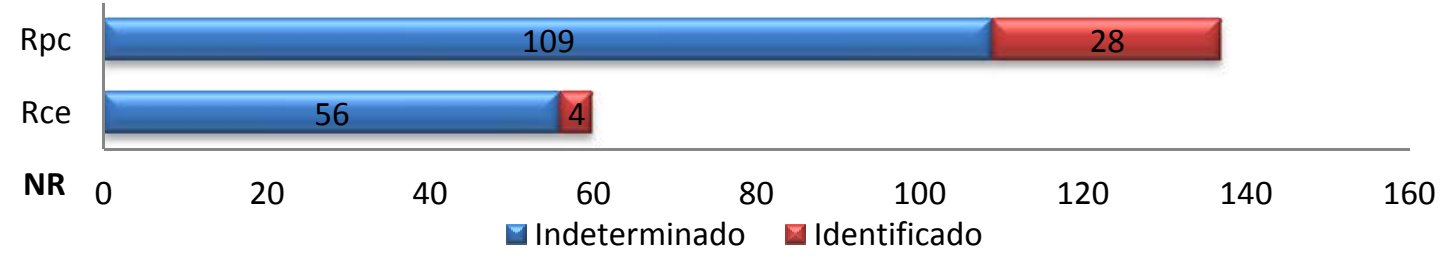

Fig. 44 Distribución esquelética de los restos ícticos del Sondeo B/5-Nivel 2-Capa 3.

Predominan los restos post-cefálicos, tanto entre los restos indeterminados como entre los identificados. Esto puede deberse a las diferencias de osificación, y por lo tanto de conservación de las diferentes partes esqueléticas de estas especies identificadas. 
$S B / 6-C 3-N 2$.

\begin{tabular}{ccccc} 
& Vpc & Vca & NR & NMI \\
\hline Merluccius merluccius & 1 & 1 & $\mathbf{2}$ & 1 \\
\hline \hline TOTAL & $\mathbf{1}$ & $\mathbf{1}$ & $\mathbf{2}$ &
\end{tabular}

Tabla 25 Relación de especies y representación ósea del Sondeo B/6-Nivel 2-Capa 3.

Se han recuperado dos restos, identificados como una vértebra precaudal y otra caudal de Merluccius merluccius.

SB/7-C3-N2.

\begin{tabular}{lcccc} 
& $\begin{array}{c}\text { Dnt } \\
\text { (D/S) }\end{array}$ & Vpc & NR & NMI \\
\hline Merluccius merluccius & & 1 & $\mathbf{1}$ & 1 \\
Zeusfaber & $0 / 1$ & & $\mathbf{1}$ & 1 \\
\hline \hline TOTAL & $\mathbf{1}$ & $\mathbf{1}$ & $\mathbf{2}$ &
\end{tabular}

Tabla 26 Relación de especies y representación ósea del Sondeo B/7-Nivel 2-Capa 3.

En esta muestra se recuperaron únicamente dos restos representativos de dos especies: una vértebra precaudal de Merluccius merluccius, y un dentario izquierdo de Zeus faber.

$S C / 2-C 3-N 2$.

\begin{tabular}{ccccc} 
& $\begin{array}{c}\text { Dnt } \\
\text { (D/S) }\end{array}$ & Vpc & NR & NMI \\
\hline Merluccius merluccius & $1 / 0$ & 3 & 4 & 1 \\
\hline \hline TOTAL & 1 & 3 & 4 &
\end{tabular}

Tabla 27 Relación de especies y representación ósea del Sondeo C/2-Nivel 2-Capa 3.

La muestra está formada por cuatro restos pertenecientes a Merluccius merluccius: un dentario derecho y tres vértebras precaudales.

$S C / 5-C 3-N 2$.

\begin{tabular}{ccccc} 
& Vpc & Rce & NR & NMI \\
\hline Merluccius merluccius & 1 & & $\mathbf{1}$ & 1 \\
Indeterminado & & 1 & $\mathbf{1}$ & \\
\hline \hline TOTAL & $\mathbf{1}$ & $\mathbf{1}$ & $\mathbf{2}$ &
\end{tabular}

Tabla 28 Relación de especies y representación ósea del Sondeo C/5-Nivel 2-Capa 3.

Conjunto formado por una vértebra precaudal de Merluccius merluccius, y un resto cefálico indeterminado.

$S C / 6-C 3-N 2$.

\begin{tabular}{ccccccc} 
& Vpc & Rce & Rpc & Esa & NR & NMI \\
\hline $\begin{array}{l}\text { Merluccius merluccius } \\
\text { Indeterminado }\end{array}$ & 1 & & & & $\mathbf{1}$ & 1 \\
\hline TOTAL & $\mathbf{1}$ & $\mathbf{2}$ & $\mathbf{3}$ & $\mathbf{3}$ & $\mathbf{9}$ &
\end{tabular}

Tabla 29 Relación de especies y representación ósea del Sondeo C/6-Nivel 2-Capa 3. 
Se ha reconocido la presencia de una vértebra precaudal de Merluccius merluccius, así como varios restos cefálicos y post-cefálicos indeterminados, y tres escamas.

$S C / 7-C 3-N 2$.

\begin{tabular}{cccc} 
& $\begin{array}{c}\text { Dnt } \\
\text { (D/S) }\end{array}$ & NR & NMI \\
\hline Pollachius pollachius & $0 / 1$ & 1 & 1 \\
\hline TOTAL & $\mathbf{1}$ & $\mathbf{1}$ &
\end{tabular}

Tabla 30 Relación de especies y representación ósea del Sondeo C/7-Nivel 2-Capa 3.

En esta muestra se recuperó exclusivamente un dentario izquierdo de Pollachius pollachius.

$S F / 3-C 3-N 2$.

\begin{tabular}{cccc} 
& $\begin{array}{c}\text { Dnt } \\
\text { (D/S) }\end{array}$ & NR & NMI \\
\hline Merluccius merluccius & $1 / 0$ & $\mathbf{1}$ & 1 \\
\hline \hline TOTAL & $\mathbf{1}$ & $\mathbf{1}$ &
\end{tabular}

Tabla 31 Relación de especies y representación ósea del Sondeo F/3-Nivel 2-Capa 3.

Únicamente se ha documentado un dentario derecho de Merluccius merluccius.

$S A / 1-C 4-N 2$.

\begin{tabular}{|c|c|c|c|c|c|c|}
\hline & Vpc & Atl & 1a Tor & Rce & NR & NMI \\
\hline Merluccius merluccius & 65 & 1 & 2 & & 68 & 2 \\
\hline Indeterminado & & & & 2 & 2 & \\
\hline TOTAL & 65 & 1 & 2 & 2 & 70 & \\
\hline
\end{tabular}

Tabla 32 Relación de especies y representación ósea del Sondeo A/1-Nivel 2-Capa 4.

La muestra incluye 68 vértebras de Merluccius merluccius, de las cuales sesenta y cinco son precaudales, un atlas y una vértebra torácica. Además, también hay dos restos cefálicos que no ha sido posible identificar a nivel de especie.

$S A / 3-C 4-N 2$.

\begin{tabular}{lcccccc} 
& $\begin{array}{c}\text { Dnt } \\
\text { (D/S) }\end{array}$ & Cbr & Atl & Vca & NR & NMI \\
\hline $\begin{array}{l}\text { Merluccius merluccius } \\
\text { Labrus bergylta }\end{array}$ & $1 / 0$ & & & & $\mathbf{1}$ & 1 \\
\begin{tabular}{l} 
Pagrus pagrus \\
\multicolumn{1}{c}{ TOTAL }
\end{tabular} & & 1 & & & $\mathbf{1}$ & 1 \\
\hline \hline
\end{tabular}

Tabla 33 Relación de especies y representación ósea del Sondeo A/3-Nivel 2-Capa 4.

Se han identificado 6 piezas óseas pertenecientes a 3 taxones. La especie mejor representada es Pagrus pagrus, con dos atlas y dos vértebras caudales. Merluccius merluccius con un dentario derecho y Labrus bergylta con un ceratobranquial, son las otras especies reconocidas. 


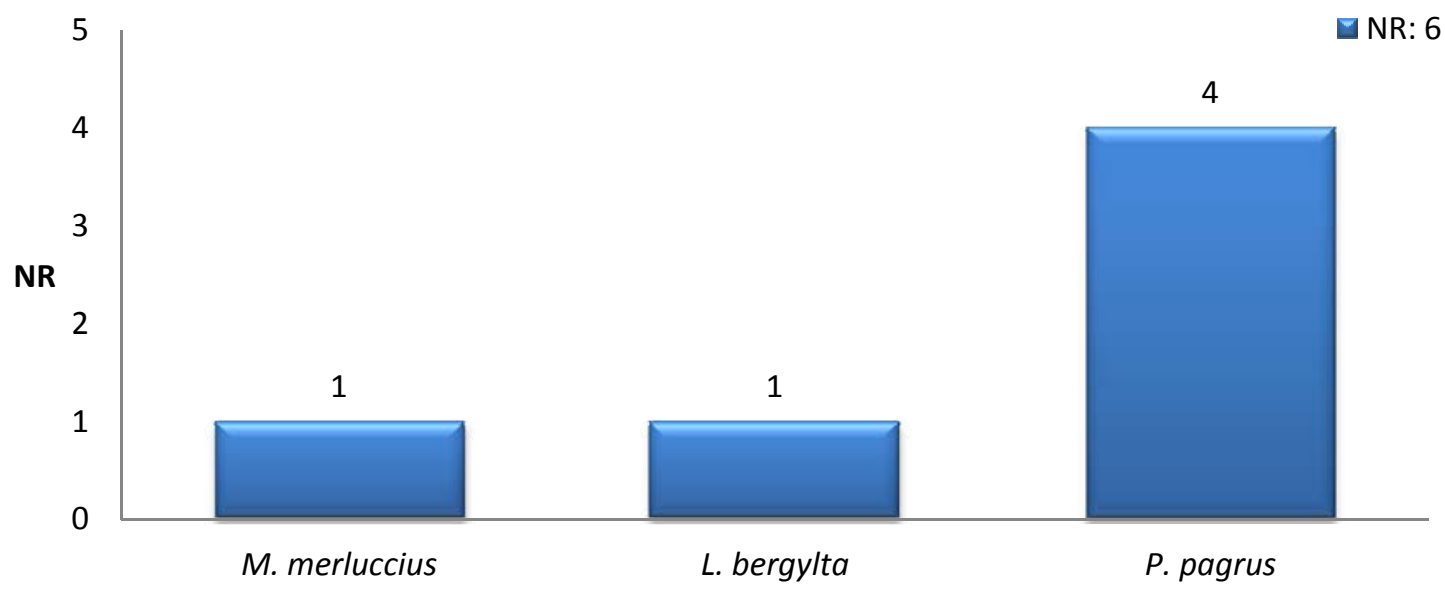

Fig. 45 Distribución de taxones identificados en el Sondeo A/3-Nivel 2-Capa 4 según el NR.

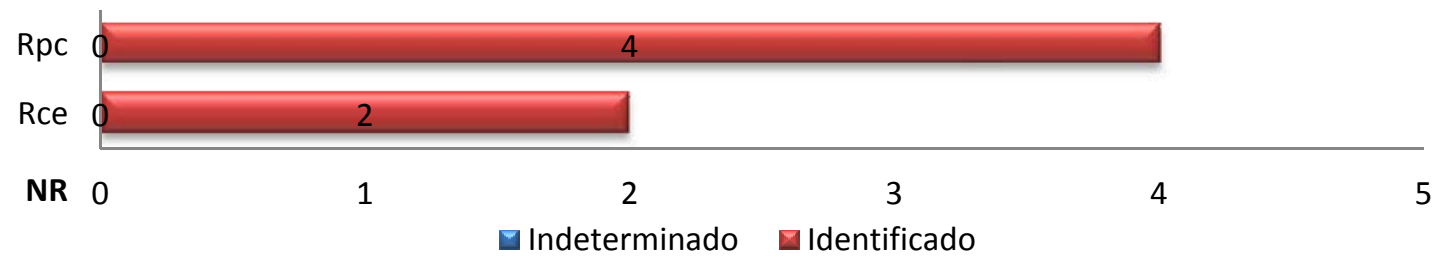

Fig. 46 Distribución esquelética de los restos ícticos del Sondeo A/3-Nivel 2-Capa 4.

Predominan los restos post-cefálicos, si bien estos pertenecen todos a Pagrus pagrus.

SA/4-C4-N2.

\begin{tabular}{cccc} 
& Vpc & NR & NMI \\
\hline Merluccius merluccius & 1 & 1 & 1 \\
\hline \hline TOTAL & 1 & 1 &
\end{tabular}

Tabla 34 Relación de especies y representación ósea del Sondeo A/4-Nivel 2-Capa 4.

Muestra con una vértebra precaudal de Merluccius merluccius.

\section{SA/5-C4-N2.}

\begin{tabular}{|c|c|c|c|c|c|c|c|}
\hline & $\begin{array}{c}\text { Art } \\
\text { (D/S) }\end{array}$ & Vpc & Rce & Rpc & Esa & NR & NMI \\
\hline Sardina pilchardus & $0 / 1$ & 3 & & & & 4 & 1 \\
\hline Indeterminado & & & 12 & 26 & $1 \mathrm{gr}$. & 38 & \\
\hline TOTAL & 1 & 3 & 12 & 26 & & 42 & \\
\hline
\end{tabular}

Tabla 35 Relación de especies y representación ósea del Sondeo A/5-Nivel 2-Capa 4.

El conjunto está compuesto por 4 piezas óseas identificables pertenecientes a un taxón, así como 12 restos cefálicos, 26 post-cefálicos indeterminados y un número importante de escamas. Sardina pilchardus es la única especie identificada, representada por un articular izquierdo y tres vértebras precaudales. 
$S B / 5-C 4-N 2$.

\begin{tabular}{lcccccccc} 
& $\begin{array}{c}\text { Cdr } \\
\text { (D/S) }\end{array}$ & $\begin{array}{c}\text { Hmd } \\
\text { (D/S) }\end{array}$ & Vpc & Rce & Rpc & Esa & NR & NMI \\
\hline $\begin{array}{l}\text { Sardina pilchardus } \\
\begin{array}{l}\text { Trachurus trachurus } \\
\text { Indeterminado }\end{array}\end{array}$ & $0 / 1$ & $0 / 1$ & & & & & $\mathbf{2}$ & $\mathbf{1}$ \\
\hline \hline TOTAL & $\mathbf{1}$ & $\mathbf{1}$ & $\mathbf{1 3}$ & $\mathbf{7}$ & $\mathbf{5 4}$ & $\mathbf{6}$ & $\mathbf{8 2}$ &
\end{tabular}

Tabla 36 Relación de especies y representación ósea del Sondeo B/5-Nivel 2-Capa 4.

La muestra la conforman 15 piezas óseas identificables pertenecientes a dos taxones, así como siete restos cefálicos, 54 post-cefálicos indeterminados y 6 escamas. De las dos especies presentes, la mejor representada es Sardina pilchardus con trece vértebras precaudales. A la otra especie, Trachurus trachurus, corresponden un cuadrado y un hiomandibular izquierdo.

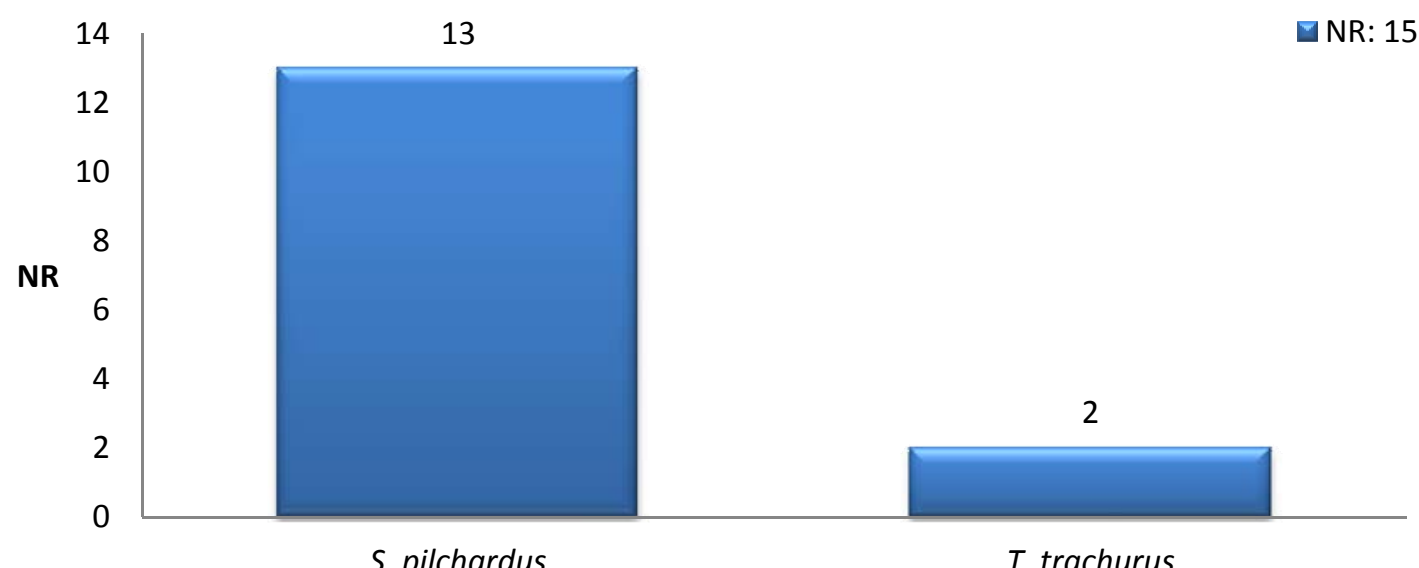

Fig. 47 Distribución de taxones identificados en el Sondeo B/5-Nivel 2-Capa 4 según el NR.

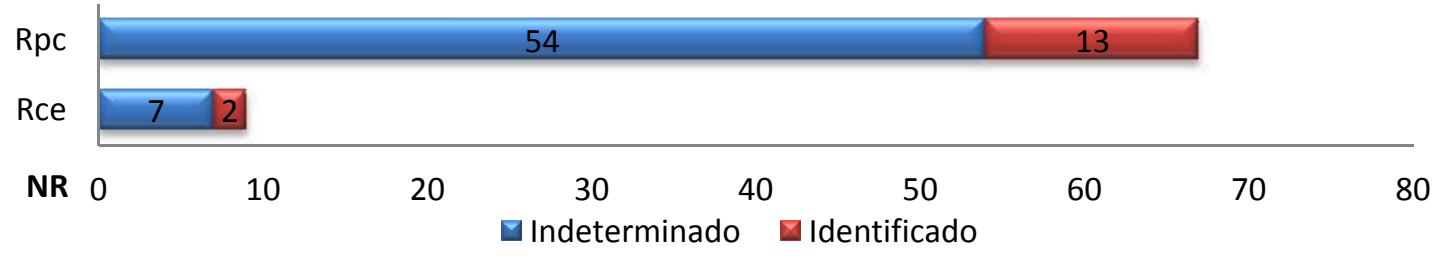

Fig. 48 Distribución esquelética de los restos ícticos del Sondeo B/5-Nivel 2-Capa 4.

Predominan los restos post-cefálicos, tanto entre los restos indeterminados como entre los identificados. Hay que tener en cuenta que los restos cefálicos pertenecen a una especie, mientras que los post-cefálicos se identifican con otra, que además es la mejor representada en la muestra.

$S B / 6-C 4-N 2$.

\begin{tabular}{rccc} 
& Rpc & NR & NMI \\
\hline Indeterminado & 5 & $\mathbf{5}$ \\
\hline \hline TOTAL & $\mathbf{5}$ & $\mathbf{5}$
\end{tabular}

Tabla 37 Relación de especies y representación ósea del Sondeo B/6-Nivel 2-Capa 4. 
Se han recuperado cinco restos post-cefálicos pertenecientes a diversas costillas no identificables a nivel de especie.

$S B / 8-C 4-N 2$.

\begin{tabular}{ccccc} 
& Cbr & Vpc & NR & NMI \\
\hline Merluccius merluccius & & 4 & $\mathbf{4}$ & 1 \\
Labrus bergylta & 1 & & $\mathbf{1}$ & 1 \\
\hline \hline TOTAL & $\mathbf{1}$ & $\mathbf{4}$ & $\mathbf{5}$ &
\end{tabular}

Tabla 38 Relación de especies y representación ósea del Sondeo B/8-Nivel 2-Capa 4.

En esta muestra se incluyen cuatro vértebras precaudales de Merluccius merluccius, así como un ceratobranquial de Labrus bergylta.

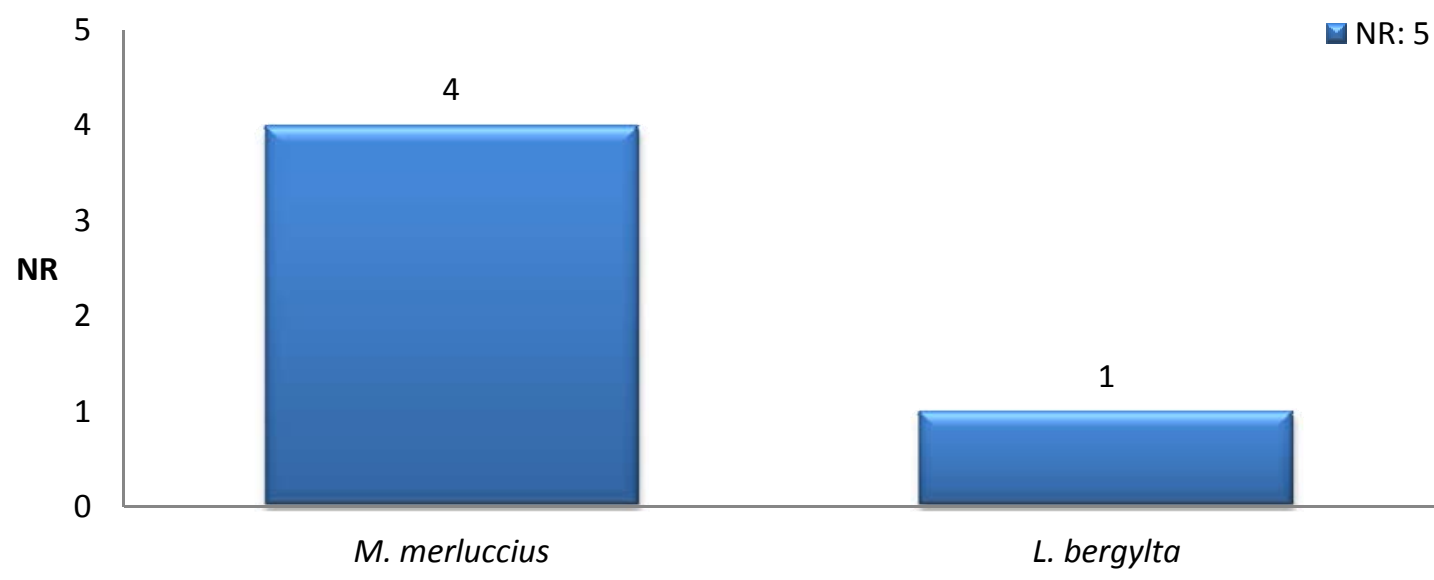

Fig. 49 Distribución de taxones identificados en el Sondeo B/8-Nivel 2-Capa 4 según el NR.

$S C / 2-C 4-N 2$.

\begin{tabular}{lcccccc} 
& Cbr & Oto & Vpc & Rpc & NR & NMI \\
\hline Merluccius merluccius & & & 6 & & $\mathbf{6}$ & 1 \\
Pagellus bogaraveo & & 1 & & & $\mathbf{1}$ & 1 \\
Labrus bergylta & 1 & & & & $\mathbf{1}$ & 1 \\
Indeterminado & & & 1 & 4 & $\mathbf{5}$ & \\
\hline \hline \multicolumn{1}{c}{ TOTAL } & $\mathbf{1}$ & $\mathbf{1}$ & $\mathbf{7}$ & $\mathbf{4}$ & $\mathbf{1 3}$
\end{tabular}

Tabla 39 Relación de especies y representación ósea del Sondeo C/2-Nivel 2-Capa 4.

La muestra está compuesta por ocho piezas óseas identificables pertenecientes a tres taxones y cuatro post-cefálicos indeterminados. La especie representada por un mayor número de restos es Merluccius merluccius con seis vértebras precaudales. De las otras dos especies únicamente se recuperó un ceratobranquial de Labrus bergylta y un otolito de Pagellus bogaraveo. 


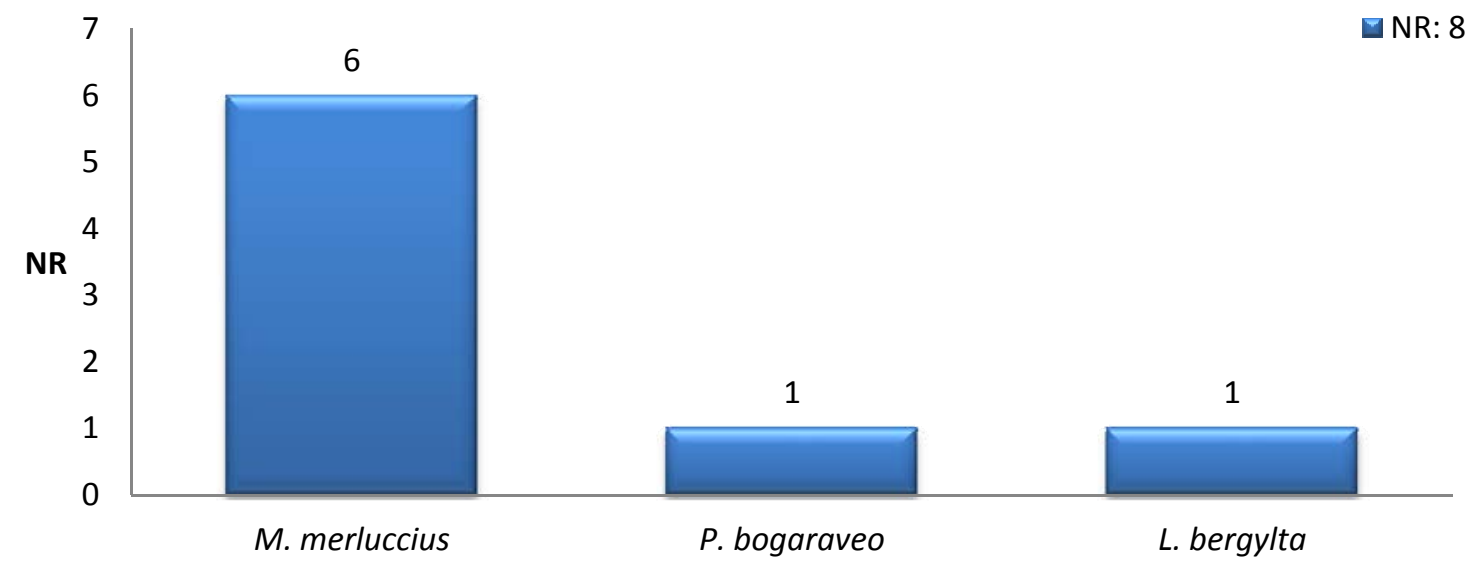

Fig. 50 Distribución de taxones identificados en el Sondeo C/2-Nivel 2-Capa 4 según el NR.

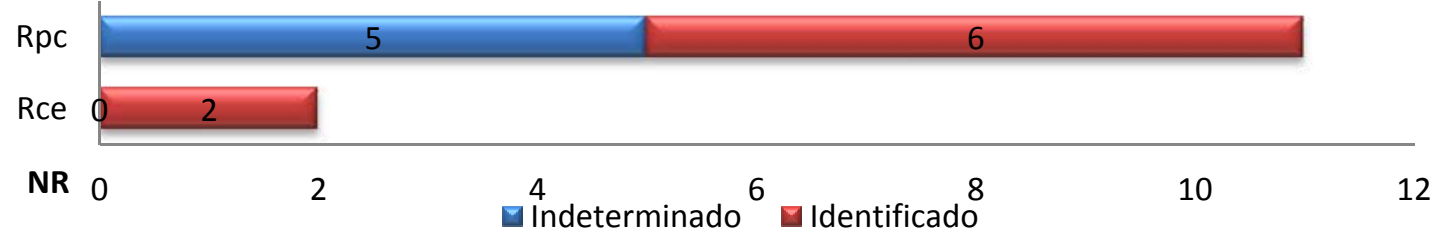

Fig. 51 Distribución esquelética de los restos ícticos del Sondeo C/2-Nivel 2-Capa 4.

Predominan los restos post-cefálicos, tanto entre los indeterminados como entre los identificados taxonómicamente. Hay que destacar que todos los restos post-cefálicos corresponden a Merluccius merluccius.

$S D / 1-C 4-N 2$.

\begin{tabular}{cccc} 
& Rpc & NR & NMI \\
\hline Indeterminado & 2 & $\mathbf{2}$ & \\
\hline \hline TOTAL & $\mathbf{2}$ & $\mathbf{2}$
\end{tabular}

Tabla 40 Relación de especies y representación ósea del Sondeo D/1-Nivel 2-Capa 4.

Presencia de dos restos post-cefálicos que no han podido ser identificados a nivel de especie debido a su fragmentación.

$S B / 4-C 5-N 2$.

\begin{tabular}{lcccccccccc} 
& $\begin{array}{c}\text { Pmx } \\
\text { (D/S) }\end{array}$ & $\begin{array}{c}\text { Art } \\
\text { (D/S) }\end{array}$ & $\begin{array}{c}\text { Cdr } \\
\text { (D/S) }\end{array}$ & Vpc & Vca & Rce & Rpc & Esa & NR & NMI \\
\hline Sardina pilchardus & & & & 4 & & & & & $\mathbf{4}$ & $\mathbf{1}$ \\
Trachurus trachurus & $2 / 1$ & $1 / 0$ & $1 / 0$ & 10 & 2 & & & & $\mathbf{1 7}$ & $\mathbf{2}$ \\
Scomber sp. & $1 / 0$ & & & & & & & & $\mathbf{1}$ & $\mathbf{1}$ \\
Scomber japonicus & & & & 1 & & & & & $\mathbf{1}$ & $\mathbf{1}$ \\
Scomber scombrus & & & & 1 & & & & & $\mathbf{1}$ & $\mathbf{1}$ \\
Indeterminado & & & & & & 13 & 30 & 48 & $\mathbf{9 1}$ & \\
\hline \multicolumn{1}{c}{ TOTAL } & $\mathbf{4}$ & $\mathbf{1}$ & $\mathbf{1}$ & $\mathbf{1 6}$ & $\mathbf{2}$ & $\mathbf{1 3}$ & $\mathbf{3 0}$ & $\mathbf{4 8}$ & $\mathbf{1 1 5}$
\end{tabular}

Tabla 41 Relación de especies y representación ósea del Sondeo B/4-Nivel 2-Capa 5. 
La muestra está compuesta por 24 piezas óseas identificables pertenecientes a cuatro taxones, así como 13 restos cefálicos y 30 post-cefálicos indeterminados, además de 48 escamas. Hay que destacar que todas las especies son pelágicas, siendo lo habitual en el resto de muestras la presencia de especies demersales. El taxón representado por un mayor volumen de restos es Trachurus trachurus: dos premaxilares derechos y uno izquierdo, un articular y un cuadrado derecho, diez vértebras precaudales, y dos caudales. La segunda especie mejor representada es Sardina pilchardus, con cuatro vértebras precaudales. Por último, contamos con una vértebra precaudal de Scomber japonicus y otra de Scomber scombrus, así como un premaxilar derecho de Scomber sp.

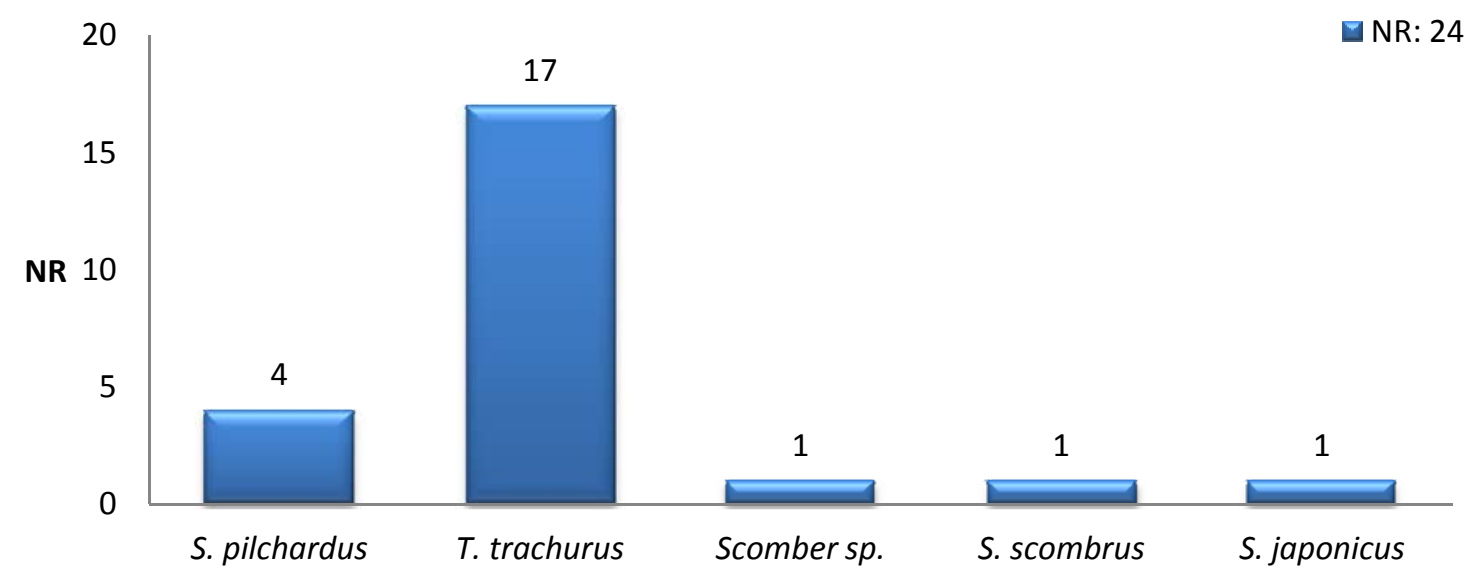

Fig. 52 Distribución de taxones identificados en el Sondeo B/4-Nivel 2-Capa 5 según el NR.

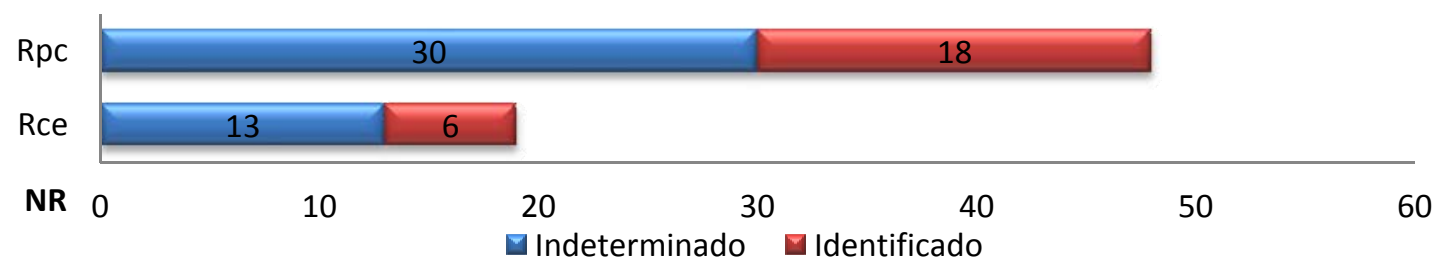

Fig. 53 Distribución esquelética de los restos ícticos del Sondeo B/4-Nivel 2-Capa 5.

Predominan los restos cefálicos, tanto indeterminados como identificados. Como habíamos observado en otras muestras, Trachurus trachurus aparece bien representada en cuanto a restos cefálicos.

$S C / 3-C 5-N 2$.

\begin{tabular}{cccc} 
& Vpc & NR & NMI \\
\hline Sardina pilchardus & 5 & $\mathbf{5}$ & 1 \\
\hline \hline TOTAL & $\mathbf{5}$ & $\mathbf{5}$ &
\end{tabular}

Tabla 42 Relación de especies y representación ósea del Sondeo C/3-Nivel 2-Capa 5.

Se han recuperado cinco vértebras precaudales de Sardina pilchardus. 
$S C / 6-C 5-N 2$.

\begin{tabular}{cccc} 
& Vpc & NR & NMI \\
\hline Merluccius merluccius & 1 & $\mathbf{1}$ & $\mathbf{1}$ \\
\hline \hline TOTAL & $\mathbf{1}$ & $\mathbf{1}$ &
\end{tabular}

Tabla 43 Relación de especies y representación ósea del Sondeo C/6-Nivel 2-Capa 5.

Presencia de una vértebra precaudal de Merluccius merluccius.

$S C / 1-C 6-N 3$.

\begin{tabular}{lccccc} 
& Pmx & Vpc & Rpc & NR & NMI \\
& (D/S) & & & & \\
\hline $\begin{array}{l}\text { Merluccius merluccius } \\
\text { Indeterminado }\end{array}$ & $0 / 1$ & 21 & & $\mathbf{2 2}$ & 1 \\
\hline \hline TOTAL & & & 1 & 1 & \\
\hline \hline
\end{tabular}

Tabla 44 Relación de especies y representación ósea del Sondeo C/1-Nivel 3-Capa 6.

En esta muestra se recuperaron 22 restos pertenecientes a Merluccius merluccius: con un premaxilar izquierdo y 21 vértebras precaudales. Además, se documentó un resto post-cefálico indeterminado.

$S C / 2-C 6-N 2$.

\begin{tabular}{lcccc} 
& $\begin{array}{c}\text { Art } \\
\text { (D/S) }\end{array}$ & Vpc & NR & NMI \\
\hline Merluccius merluccius & $1 / 0$ & 16 & $\mathbf{1 7}$ & 1 \\
\hline \hline TOTAL & $\mathbf{1}$ & $\mathbf{1 6}$ & $\mathbf{1 7}$ &
\end{tabular}

Tabla 45 Relación de especies y representación ósea del Sondeo C/2-Nivel 2-Capa 6.

En esta muestra se recuperaron diecisiete restos pertenecientes a la misma especie, Merluccius merluccius: un articular derecho y dieciséis vértebras precaudales.

SF/1-C6-N3.

\begin{tabular}{|c|c|c|c|c|c|c|c|c|c|c|c|c|c|c|}
\hline & $\begin{array}{l}\text { Pmx } \\
\text { (D/S) }\end{array}$ & $\begin{array}{l}\text { Max } \\
\text { (D/S) }\end{array}$ & $\begin{array}{c}\text { Dnt } \\
\text { (D/S) }\end{array}$ & $\begin{array}{c}\text { Art } \\
\text { (D/S) }\end{array}$ & $\begin{array}{c}\text { Opc } \\
\text { (D/S) }\end{array}$ & $\begin{array}{c}\text { Crh } \\
\text { (D/S) }\end{array}$ & Vpc & Atl & 12 Tor & Vca & Rce & Rpc & NR & NMI \\
\hline Merluccius merluccius & $1 / 0$ & $1 / 0$ & $1 / 0$ & & & $0 / 1$ & 65 & 2 & 2 & 1 & & & 74 & 2 \\
\hline Pagellus acarne & & & & & & & & & & 1 & & & 1 & 1 \\
\hline Pagellus bogaraveo & & & & & & & & & & 1 & & & 1 & 1 \\
\hline Labrus bergylta & $0 / 2$ & & & $1 / 0$ & $1 / 0$ & & 1 & & & & & & 5 & 2 \\
\hline Belone belone & & & $1 / 1$ & & & & & & & & & & 2 & 1 \\
\hline Indeterminado & & & & & & & & & & & 16 & 30 & 46 & \\
\hline TOTAL & 3 & 1 & 3 & 1 & 1 & 1 & 66 & 2 & 2 & 3 & 16 & 30 & 129 & \\
\hline
\end{tabular}

Tabla 46 Relación de especies y representación ósea del Sondeo F/1-Nivel 3-Capa 6.

Aunque esta muestra se ha adscrito al periodo romano, la representación faunística, así como la localización de esta capa, nos hace sospechar que pueda corresponder a época medieval. El conjunto lo componen 83 piezas óseas identificables pertenecientes a cinco taxones, 16 restos cefálicos y 30 post-cefálicos indeterminados. La 
especie mejor representada es Merluccius merluccius, a la que se han asignado un premaxilar, un maxilar y un dentario derecho, un ceratohial izquierdo, sesenta y cinco vértebras precaudales, dos atlas, dos vértebras torácicas y una vértebra caudal. La segunda especie en número de restos identificados es Labrus bergylta con dos premaxilares izquierdos, un articular y un opercular derecho y una vértebra precaudal. Dos dentarios, uno derecho y otro izquierdo, pertenecen a Belone belone. Por último, Pagellus acarne y Pagellus bogaraveo están representadas por sendas vértebras caudales.

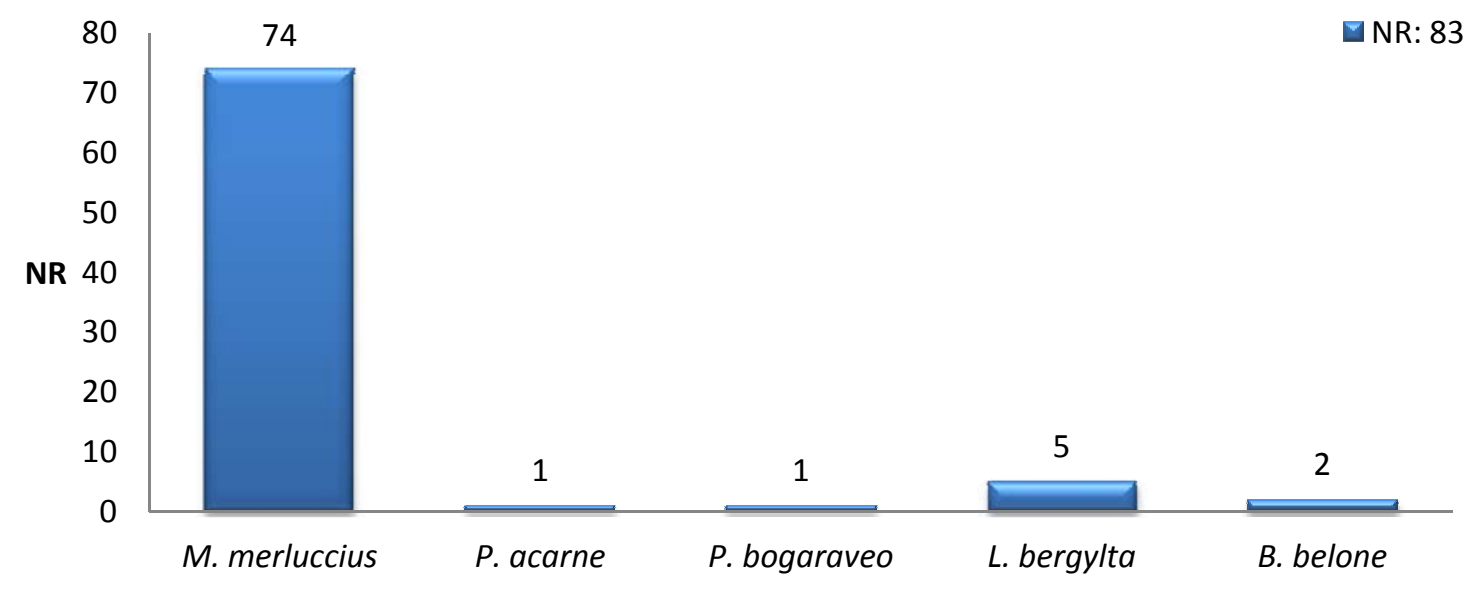

Fig. 54 Distribución de taxones identificados en el Sondeo F/1-Nivel 3-Capa 6 según el NR.

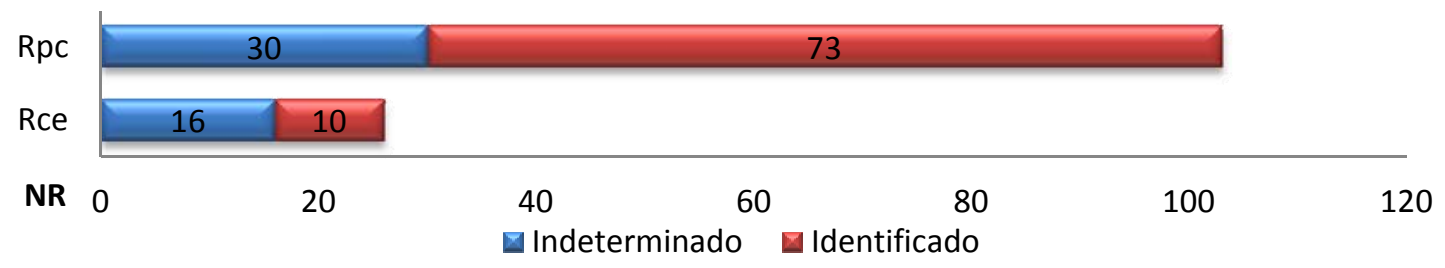

Fig. 55 Distribución esquelética de los restos ícticos del Sondeo F/1-Nivel 3-Capa 6.

Predominan los restos post-cefálicos, tanto entre las piezas identificadas como entre los fragmentos indeterminados. El elevado número de restos post-cefálicos identificados se debe al número de vértebras de Merluccius merluccius. Hay que destacar la ausencia de escamas.

SF/1-C8-N3.

\begin{tabular}{rccc} 
& $\begin{array}{c}\text { Hmd } \\
\text { (D/S) }\end{array}$ & NR & NMI \\
\hline Labrus bergylta & $1 / 0$ & $\mathbf{1}$ & 1 \\
\hline \hline TOTAL & $\mathbf{1}$ & $\mathbf{1}$ &
\end{tabular}

Tabla 47 Relación de especies y representación ósea del Sondeo F/1-Nivel 3-Capa 8.

Tan solo está presente un hiomandibular derecho de Labrus bergylta. 


\section{V.1.4.2.2. Niveles medievales.}

SC/1-C3-N2.

\begin{tabular}{|c|c|c|c|c|c|c|c|c|c|}
\hline & $\begin{array}{l}\text { Pmx } \\
\text { (D/S) }\end{array}$ & $\begin{array}{l}\text { Dnt } \\
\text { (D/S) }\end{array}$ & $\begin{array}{c}\text { Art } \\
\text { (D/S) }\end{array}$ & $\begin{array}{c}C d r \\
(D / S)\end{array}$ & Fbr & Vpc & Rce & NR & NMI \\
\hline Merluccius merluccius & $1 / 3$ & $2 / 1$ & $2 / 0$ & $0 / 1$ & & 32 & & 42 & 3 \\
\hline Labrus bergylta & & & & & 1 & & & 1 & 1 \\
\hline Indeterminado & & & & & & & 7 & 7 & \\
\hline
\end{tabular}

Tabla 48 Relación de especies y representación ósea del Sondeo C/1-Nivel 2-Capa 3.

En esta muestra se recuperaron 43 piezas óseas identificables pertenecientes a dos taxones. El conjunto lo completarían siete restos cefálicos indeterminados y siete escamas. Merluccius merluccius es la especie con más restos, habiéndose identificado un premaxilar derecho y tres izquierdos, dos dentarios derechos y uno izquierdo, dos articulares derechos, un cuadrado izquierdo y treinta y dos vértebras precaudales. La otra especie presente es Labrus bergylta representada por un faringobranquial.

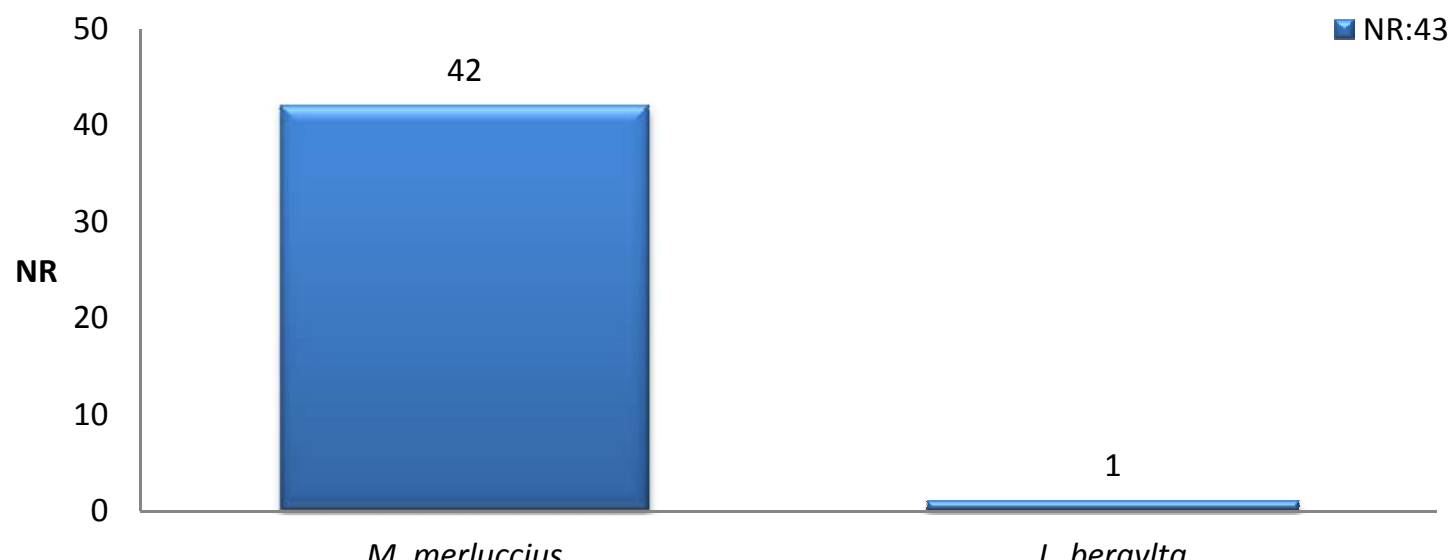

Fig. 56 Distribución de taxones identificados en el Sondeo C/1-Nivel 2-Capa 3 según el NR.

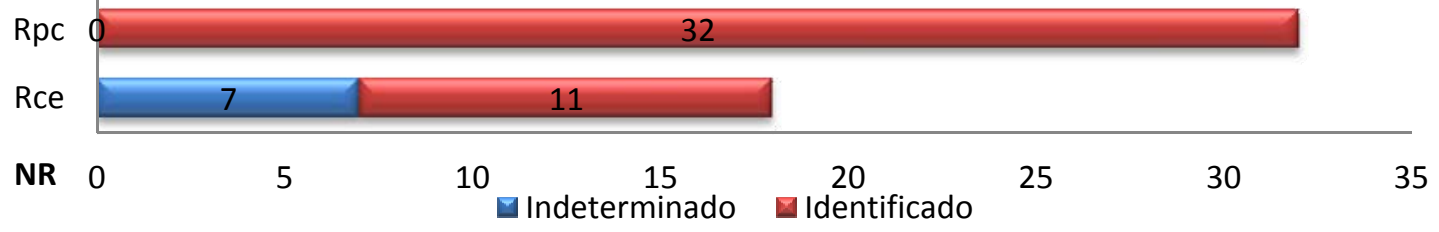

Fig. 57 Distribución esquelética de los restos ícticos del Sondeo C/1-Nivel 2-Capa 3.

Los restos más numerosos son los post-cefálicos, si bien identificados exclusivamente con vértebras precaudales de Merluccius merluccius. 
SF/1-C3-N2.

\begin{tabular}{|c|c|c|c|c|c|c|c|c|c|c|c|c|c|}
\hline & $\begin{array}{c}\text { Art } \\
(D / S)\end{array}$ & $\begin{array}{c}C d r \\
\text { (D/S) }\end{array}$ & $\begin{array}{l}\text { Hmd } \\
\text { (D/S) }\end{array}$ & $\begin{array}{c}\text { Pop } \\
\text { (D/S) }\end{array}$ & Pal & Vpc & Atl & Vca & Rce & Rpc & Esa & NR & NMI \\
\hline Conger conger & & & & & & 1 & & & & & & 1 & 1 \\
\hline Merluccius merluccius & $0 / 1$ & $0 / 1$ & $1 / 0$ & $0 / 1$ & 1 & 2 & 1 & & & & & 8 & 1 \\
\hline Trachurus trachurus & & & & & & & & 1 & & & & 1 & 1 \\
\hline Pagrus pagrus & & & & & & 1 & & & & & & 1 & 1 \\
\hline Indeterminado & & & & & & & & & 13 & 9 & 8 & 30 & \\
\hline TOTAL & 1 & 1 & 1 & 1 & 1 & 4 & 1 & 1 & 13 & 9 & 8 & 41 & \\
\hline
\end{tabular}

Tabla 49 Relación de especies y representación ósea del Sondeo F/1-Nivel 2-Capa 3.

La muestra cuenta con 11 piezas óseas identificables pertenecientes a cuatro taxones. El conjunto lo completan 13 restos cefálicos y nueve post-cefálicos indeterminados, así como ocho escamas. La especie mejor representada es Merluccius merluccius, con un articular, un preopercular y un cuadrado izquierdo, un hiomandibular derecho, un palatino, dos vértebras precaudales y un atlas. De Conger conger y Pagrus pagrus se han identificado sendas vértebras precaudales, y de Trachurus trachurus una vértebra caudal.

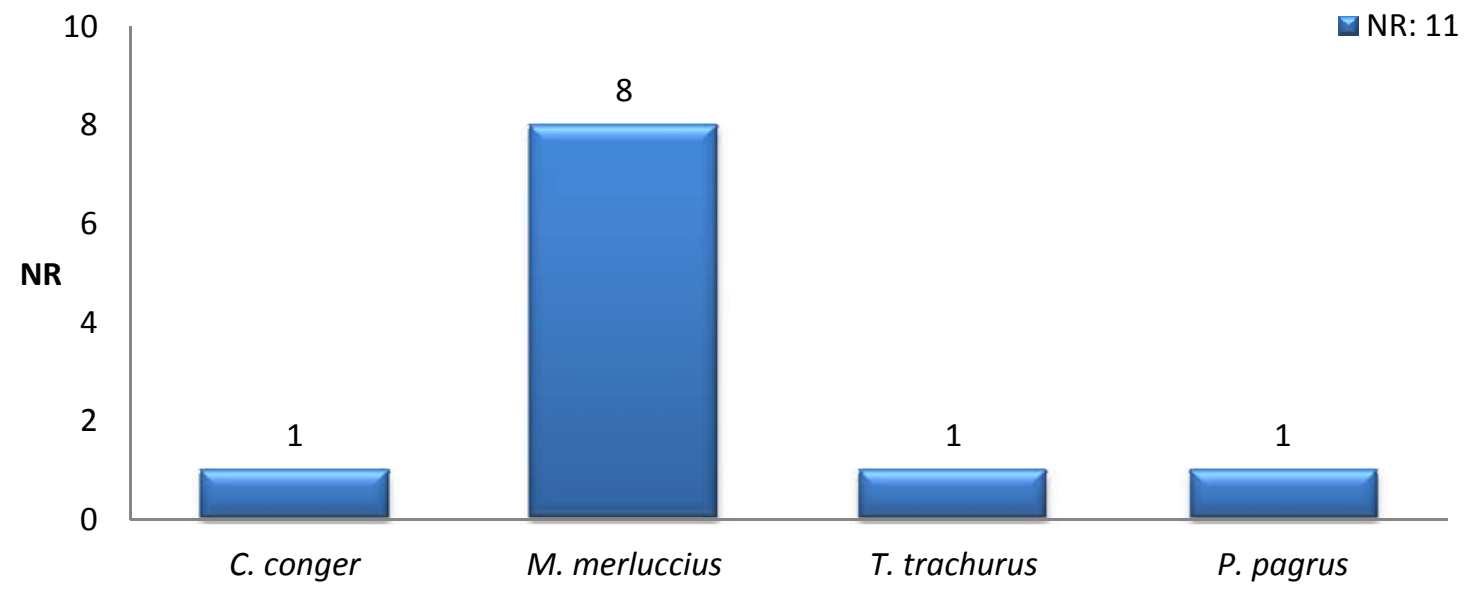

Fig. 58 Distribución de taxones identificados en el Sondeo F/1-Nivel 2-Capa 3 según el NR.

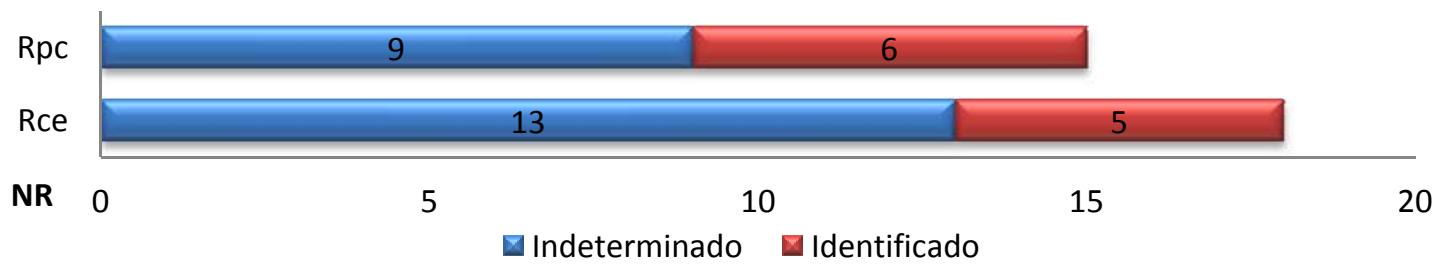

Fig. 59 Distribución esquelética de los restos ícticos del Sondeo F/1-Nivel 2-Capa 3.

Predominan los restos cefálicos, aunque entre los determinados van a ser ligeramente superiores los restos post-cefálicos, donde están representadas todas las especies presentes, mientras que únicamente se han reconocido restos cefálicos de Merluccius merluccius. 
$S C / 1-C 4-N 2$.

\begin{tabular}{|c|c|c|c|c|c|c|c|c|c|c|c|c|c|c|c|}
\hline & $\begin{array}{l}\text { Max } \\
\text { (D/S) }\end{array}$ & $\begin{array}{c}\text { Pmx } \\
\text { (D/S) }\end{array}$ & $\begin{array}{c}\text { Dnt } \\
\text { (D/S) }\end{array}$ & $\begin{array}{c}\text { Art } \\
(D / S)\end{array}$ & $\begin{array}{c}\mathrm{Cdr} \\
\text { (D/S) }\end{array}$ & $\begin{array}{l}\text { Crh } \\
\text { (D/S) }\end{array}$ & Pal & Vpc & Atl & Vca & Rce & Rpc & Esc & NR & NMI \\
\hline Merluccius merluccius & $0 / 3$ & $2 / 0$ & $1 / 0$ & $0 / 1$ & & $1 / 0$ & 1 & 199 & 6 & 2 & & & & 216 & 3 \\
\hline Conger conger & & & & & & & & 1 & & & & & & 1 & 1 \\
\hline Labrus bergylta & $1 / 0$ & & & & & & & 1 & & & & & & 2 & 1 \\
\hline Pagellus bogaraveo & & & & & & & & & & 1 & & & & 1 & 1 \\
\hline Sardina pilchardus & & & & & & & & 2 & & & & & & 2 & 1 \\
\hline Indeterminado & & & & & 1 & & & & & & 60 & 129 & $1 \mathrm{gr}$. & 190 & \\
\hline TOTAL & 4 & 2 & 1 & 1 & 1 & 1 & 1 & 203 & 6 & 3 & 60 & 129 & & 411 & \\
\hline
\end{tabular}

Tabla 50 Relación de especies y representación ósea del Sondeo C/1-Nivel 2-Capa 4.

Esta muestra incluye 222 piezas óseas identificables pertenecientes a cinco taxones. El conjunto lo completan 60 restos cefálicos y 129 post-cefálicos indeterminados, así como una elevada presencia de escamas. La especie de la que se han identificado más restos es Merluccius merluccius: tres maxilares y un articular izquierdos, dos premaxilares, un dentario y un ceratohial derechos, un palatino, ciento noventa y nueve vértebras precaduales, seis atlas y dos vértebras caudales. Labrus bergylta está representada por un maxilar derecho, una vértebra precaudal y Sardina pilchardus por dos vértebras precaduales. Con un único resto identificado se constata la presencia de Conger conger, una vértebra precadual y Pagellus bogaraveo, una vértebra caudal.

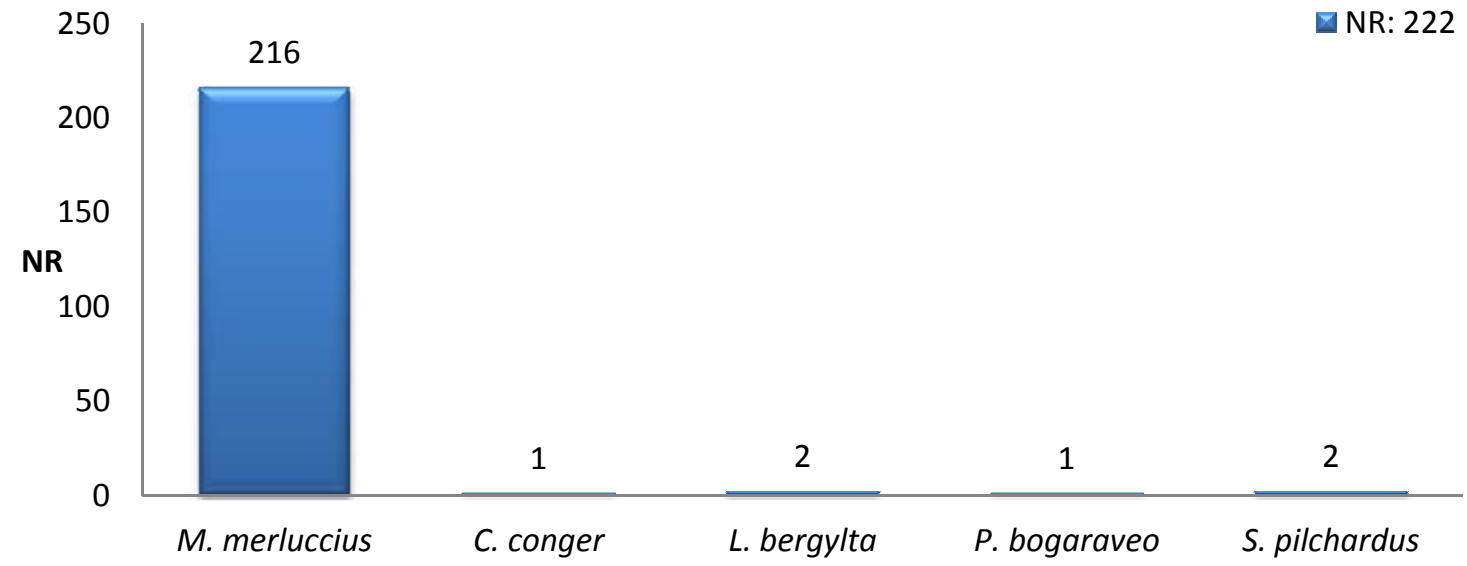

Fig. 60 Distribución de taxones identificados en el Sondeo C/1-Nivel 2-Capa 4 según el NR.

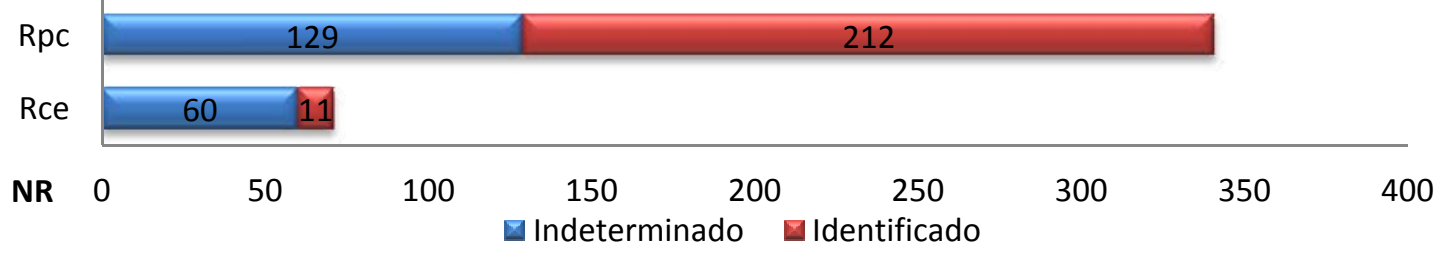

Fig. 61 Distribución esquelética de los restos ícticos del Sondeo C/1-Nivel 2-Capa 4. 
Predominan los restos post-cefálicos, tanto entre los restos indeterminados como entre los identificados, correspondiendo en su gran mayoría en este último grupo a Merluccius merluccius.

$S B / 1-C 5-N 2$.

\begin{tabular}{|c|c|c|c|c|c|c|c|c|c|c|c|c|c|c|c|c|c|c|}
\hline & $\begin{array}{l}P_{m x} \\
(D / S)\end{array}$ & $\begin{array}{l}\text { Max } \\
(D / S)\end{array}$ & $\begin{array}{l}\text { Dnt } \\
(D / S)\end{array}$ & $\begin{array}{l}\text { Art } \\
(\mathrm{D} / \mathrm{S})\end{array}$ & $\begin{array}{l}\mathrm{Cdr} \\
\text { (D/S) }\end{array}$ & $\begin{array}{l}\text { Hmd } \\
(D / S)\end{array}$ & $\begin{array}{l}\text { Crh } \\
(D / S)\end{array}$ & $\begin{array}{c}\mathrm{Pal} \\
(\mathrm{D} / \mathrm{S})\end{array}$ & $\begin{array}{l}\text { Vom } \\
(D / S)\end{array}$ & $V p c$ & Atl & 12 tor & Vca & Rce & $\mathrm{Rpc}$ & Esa & NR & NMI \\
\hline Sardina pilchardus & & & & & & & & & & & & & 1 & & & & 1 & 1 \\
\hline Merluccius merluccius & $5 / 11$ & $6 / 9$ & $6 / 3$ & $3 / 5$ & $1 / 2$ & $1 / 0$ & $2 / 3$ & $1 / 0$ & $1 / 0$ & 645 & 10 & 13 & 6 & & & & 733 & 13 \\
\hline Trachurus trachurus & & & & & & & & & & & & & 1 & & & & 1 & 1 \\
\hline Labrus bergylta & & & & & & & & & & & & 1 & & & & & 1 & 1 \\
\hline Indeterminado & & & & & & & & & & 1 & & & & 180 & 170 & 4 & 355 & \\
\hline TOTAL & 16 & 15 & 9 & 8 & 3 & 1 & 5 & 1 & 1 & 646 & 11 & 13 & 8 & 180 & 170 & 4 & 1091 & \\
\hline
\end{tabular}

Tabla 51 Relación de especies y representación ósea del Sondeo B/1-Nivel 2-Capa 5.

En esta muestra se recuperaron 737 piezas óseas identificables pertenecientes a cuatro taxones. El conjunto se completa con 180 restos cefálicos y 170 post-cefálicos indeterminados, así como cuatro escamas. Como habíamos visto en las anteriores muestras de época medieval, Merluccius merluccius es el taxón mejor representado, con cinco premaxilares derechos y 11 izquierdos, seis maxilares derechos y nueve izquierdos, seis dentarios derechos y tres izquierdos, tres articulares derechos y cinco izquierdos, un cuadrado derecho y dos izquierdos, un hiomandibular derecho, dos ceratohiales derechos y tres izquierdos, un palatino derecho, un vómer, seiscientas cuarenta y cinco vértebras precaduales, 10 atlas, 13 vértebras torácicas y seis caudales. Las demás especies estarían representadas por sendas vértebras caudales de Sardina pilchardus y de Trachurus trachurus y una vértebra torácica de Labrus bergy/ta.

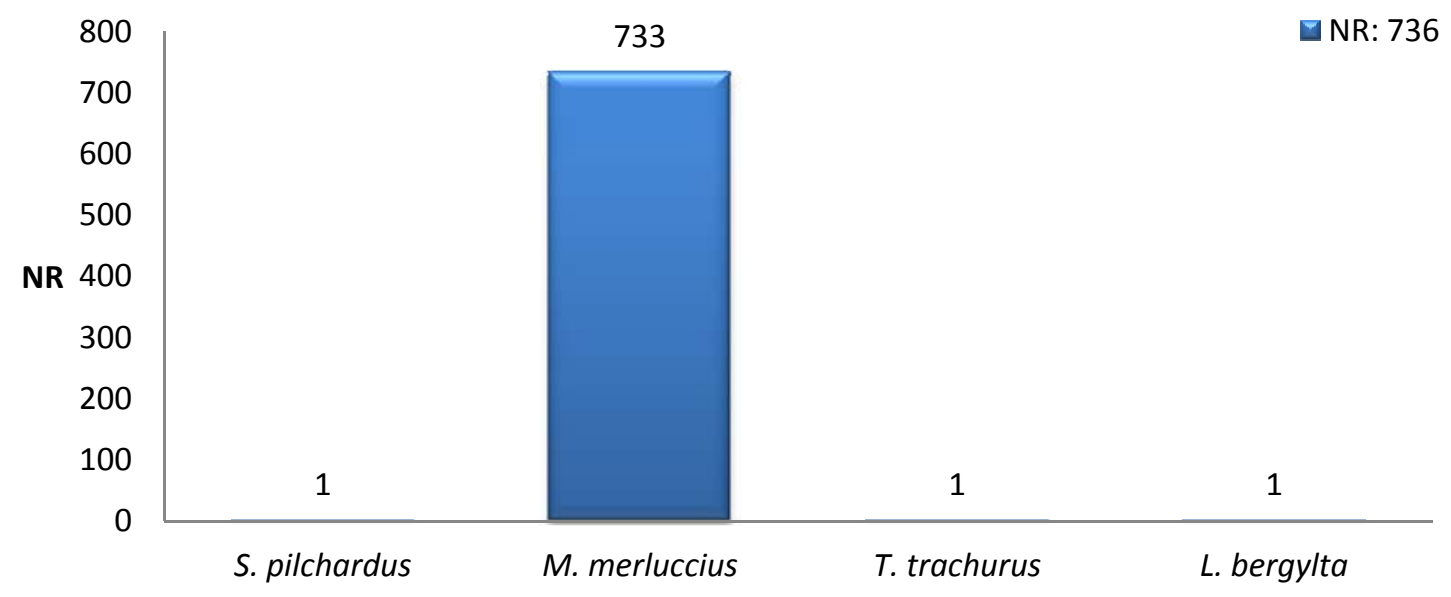

Fig. 62 Distribución de taxones identificados en el Sondeo B/1-Nivel 2-Capa 5 según el NR. 


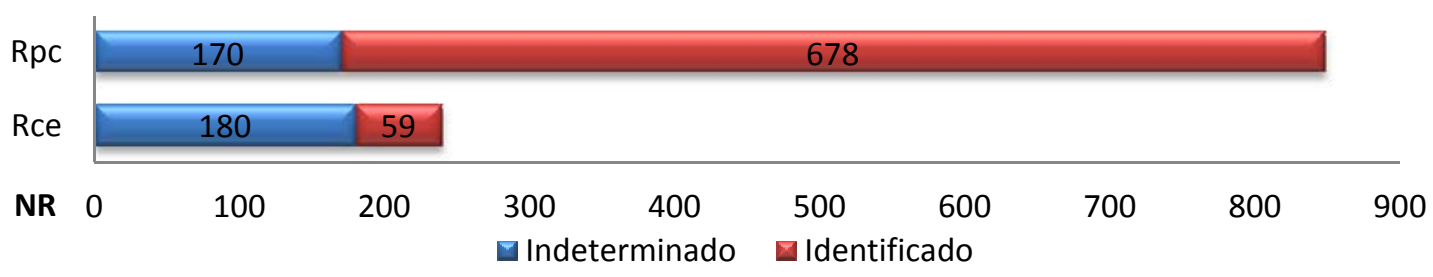

Fig. 63 Distribución esquelética de los restos ícticos del Sondeo B/1-Nivel 2-Capa 5.

Como en la muestra anterior predominan los restos post-cefálicos, correspondiendo en su gran mayoría a Merluccius merluccius.

$S F / 1-C 5-N 2$.

\begin{tabular}{cccc} 
& Cbr & NR & NMI \\
\hline Labrus bergylta & 1 & $\mathbf{1}$ & 1 \\
\hline \hline TOTAL & 1 & 1 &
\end{tabular}

Tabla 52 Relación de especies y representación ósea del Sondeo F/1-Nivel 2-Capa 5.

Esta muestra cuenta únicamente con un resto correspondiente a un ceratobranquial de Labrus bergy/ta.

\section{V.1.4.2.3. Niveles modernos.}

\section{$S A / 7-C 2-N 1$}

\begin{tabular}{lcccccccc} 
& Max & Pmx & & & & & \\
& (D/S) & (D/S) & Vpc & Atl & Rce & Rpc & NR & NMI \\
\hline $\begin{array}{l}\text { Merluccius merluccius } \\
\text { Zeusfaber }\end{array}$ & $0 / 2$ & $0 / 1$ & 150 & 4 & & & $\mathbf{1 5 7}$ & 4 \\
Indeterminado & & $0 / 1$ & & & & & $\mathbf{1}$ & 1 \\
\hline \hline \multicolumn{1}{c}{ TOTAL } & $\mathbf{2}$ & $\mathbf{2}$ & $\mathbf{1 5 0}$ & $\mathbf{4}$ & $\mathbf{8}$ & $\mathbf{2 7}$ & $\mathbf{1 9 3}$ &
\end{tabular}

Tabla 53 Relación de especies y representación ósea del Sondeo A-Nivel 1-Capa 2.

En esta muestra se recuperaron 158 piezas óseas identificables pertenecientes a dos taxones. El conjunto lo completarían ocho restos cefálicos y 27 post-cefálicos indeterminados. La mayor parte de las piezas óseas corresponde a Merluccius merluccius, con dos maxilares y un premaxilar izquierdos, 150 vértebras precaudales y cuatro atlas. EI otro taxón representado es Zeus faber que cuenta únicamente con un premaxilar izquierdo. 


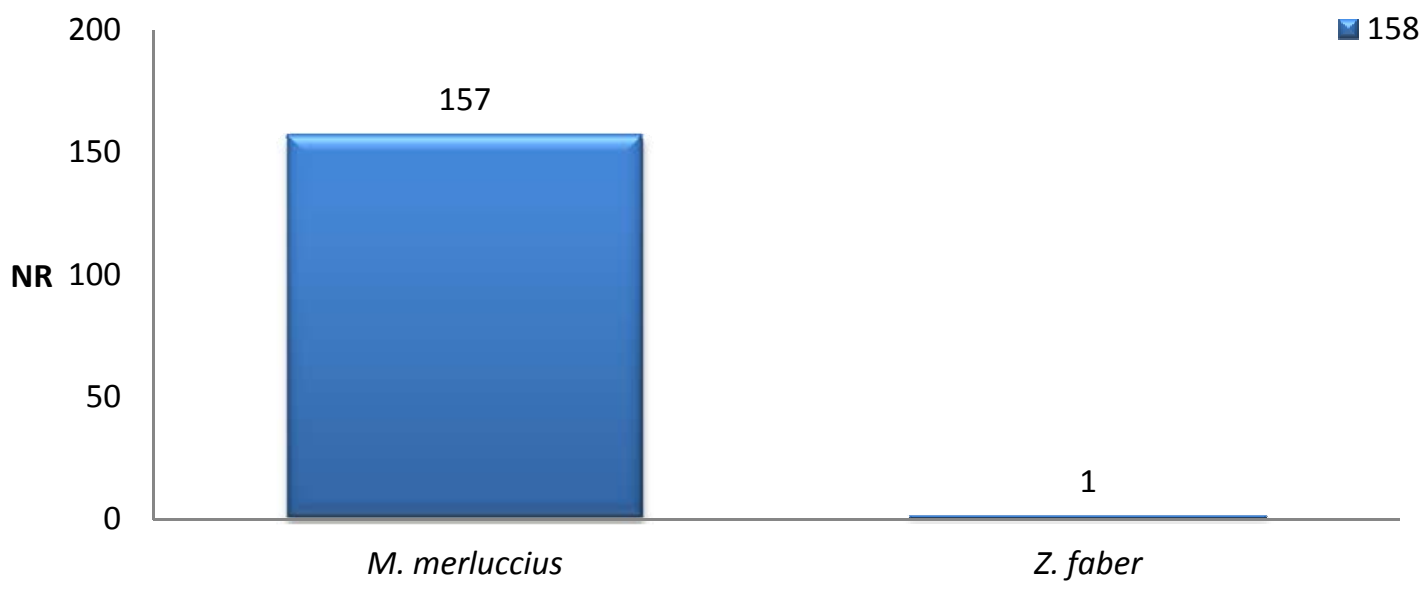

Fig. 64 Distribución de taxones identificados en el Sondeo A-Nivel 1-Capa 2 según el NR.

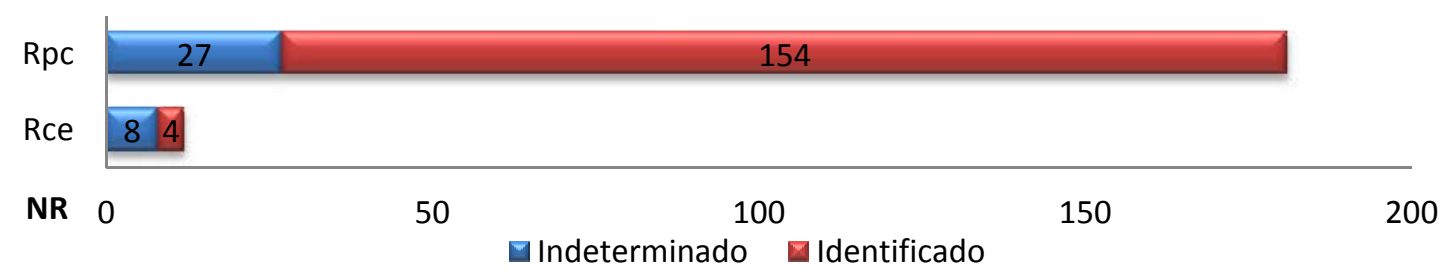

Fig. 65 Distribución esquelética de los restos ícticos del Sondeo A-Nivel 1-Capa 2.

Hay un predominio de restos post-cefálicos, tanto entre los restos indeterminados como entre los identificados taxonómicamente. Todos los restos post-cefálicos identificados se corresponden con centros vertebrales precaudales pertenecientes a Merluccius merluccius.

$S B / 1-C 2-N 1$

\begin{tabular}{cccc} 
& Rce & NR & NMI \\
\hline Indeterminado & 1 & $\mathbf{1}$ & \\
\hline TOTAL & $\mathbf{1}$ & $\mathbf{1}$
\end{tabular}

Tabla 54 Relación de especies y representación ósea del Sondeo B-Nivel 1-Capa 2.

Presencia de un único resto cefálico que no se ha podido identificar a nivel de especie debido a su deficiente estado de conservación.

\section{$S B / 5-C 2-N 1$}

\begin{tabular}{lcccccc} 
& $\begin{array}{c}\text { Dnt } \\
\text { (D/S) }\end{array}$ & Cbr & Vpc & Vca & NR & NMI \\
\hline Sardina pilchardus & & & & 1 & $\mathbf{1}$ & 1 \\
Merluccius merluccius & & & 1 & & $\mathbf{1}$ & 1 \\
Pollachius pollachius & $1 / 0$ & & & & $\mathbf{1}$ & 1 \\
Labrus bergylta & & 1 & & & $\mathbf{1}$ & 1 \\
\hline \hline \multicolumn{1}{c}{ TOTAL } & $\mathbf{1}$ & $\mathbf{1}$ & $\mathbf{1}$ & $\mathbf{1}$ & $\mathbf{4}$ &
\end{tabular}

Tabla 55 Relación de especies y representación ósea del Sondeo B-Nivel 1-Capa 2. 
Esta muestra cuenta únicamente con cuatro restos, pertenecientes cada uno de ellos a una especie diferente. De este modo Sardina pilchardus está representada por una vértebra caudal, Merluccius merluccius por una vértebra precadual, Pollachius pollachius por un dentario derecho, y Labrus bergylta por un ceratobranquial. En esta muestra no se documentaron ni restos indeterminados ni restos de escamas.

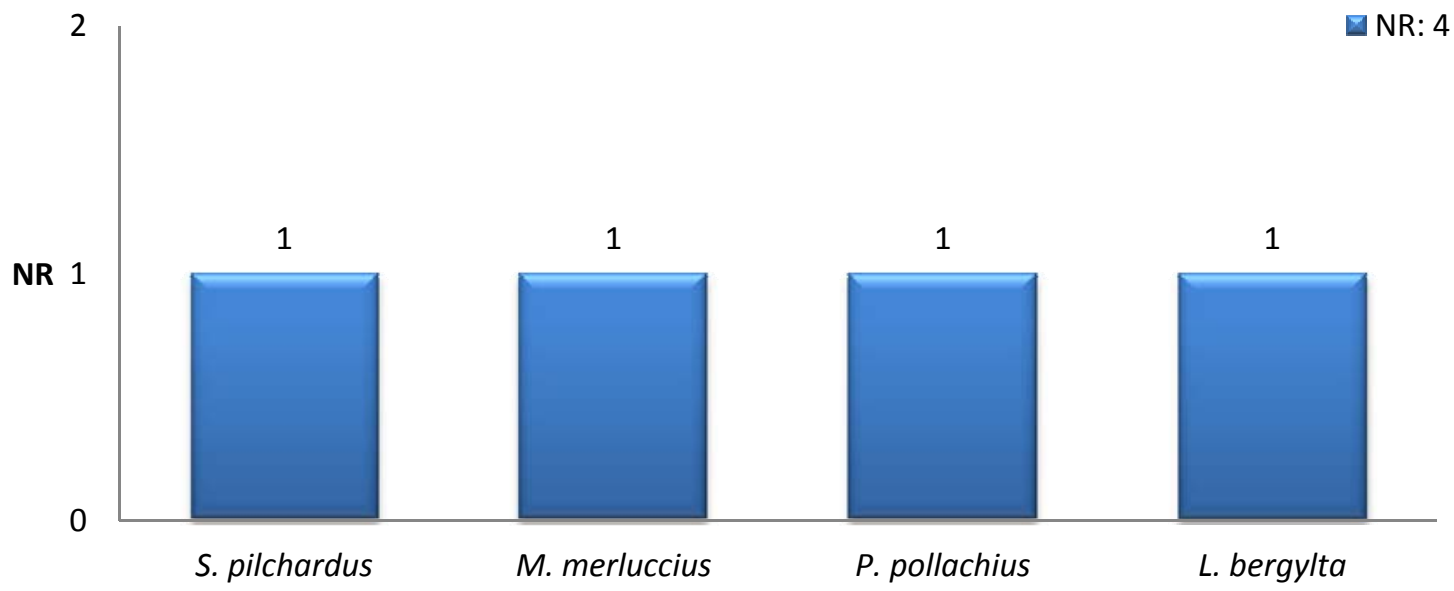

Fig. 66 Distribución de taxones identificados en el Sondeo B-Nivel 1-Capa 2 según el NR.

$S D / 1-C 2-N 1$

\begin{tabular}{|c|c|c|c|c|c|c|c|c|c|c|c|c|c|c|}
\hline & $\begin{array}{l}\text { Pmx } \\
\text { (D/S) }\end{array}$ & $\begin{array}{l}\text { Max } \\
\text { (D/S) }\end{array}$ & $\begin{array}{c}\text { Dnt } \\
(D / S)\end{array}$ & $\mathrm{Cbr}$ & $\begin{array}{l}\text { Pop } \\
\text { (D/S) }\end{array}$ & $\begin{array}{l}\text { Pal } \\
(\mathrm{D} / \mathrm{S})\end{array}$ & Vpc & Atl & Vca & Rce & Rpc & Esa & NR & NMI \\
\hline Sardina pilchardus & & & & & & & 2 & & & & & & 2 & 1 \\
\hline Merluccius merluccius & $0 / 1$ & & $0 / 2$ & & & & 111 & 2 & & & & & 116 & 2 \\
\hline Pagrus pagrus & $1 / 0$ & & & & & & & & & & & & 1 & 1 \\
\hline Sparus aurata & & & & & & $1 / 0$ & & & & & & & 1 & 1 \\
\hline Labrus bergylta & $0 / 2$ & $1 / 0$ & & 1 & $1 / 0$ & & & & 1 & & & & 6 & 2 \\
\hline Symphodus melops & & & & & & & & & 2 & & & & 2 & 1 \\
\hline Scomber scombrus & & & & & & & & & 1 & & & & 1 & 1 \\
\hline Indeterminado & & 1 & & & & & & & 1 & 16 & 77 & 33 & 128 & \\
\hline TOTAL & 4 & 2 & 2 & 1 & 1 & 1 & 113 & 2 & 5 & 16 & 77 & 33 & 257 & \\
\hline
\end{tabular}

Tabla 56 Relación de especies y representación ósea del Sondeo D/1-Nivel 1-Capa 2.

Esta muestra cuenta con 131 piezas óseas identificables pertenecientes a siete taxones. El conjunto lo completan 16 restos cefálicos, 77 post-cefálicos indeterminados y 33 escamas. La especie mejor representada es Merluccius merluccius con un premaxilar izquierdo, dos dentarios izquierdos, 111 vértebras precaudales y dos atlas. Le sigue en cuanto a número de restos Labrus bergylta con dos premaxilares izquierdos, un maxilar derecho, un ceratobranquial, un preopercular derecho y una vértebra caudal. Las demás especies están representadas por muy pocos restos: Sardina pilchardus por dos vértebras precaudales, Symphodus melops por dos vértebras caudales, Pagrus pagrus por un premaxilar derecho, Sparus aurata por un palatino derecho y Scomber scombrus por una vértebra caudal. 


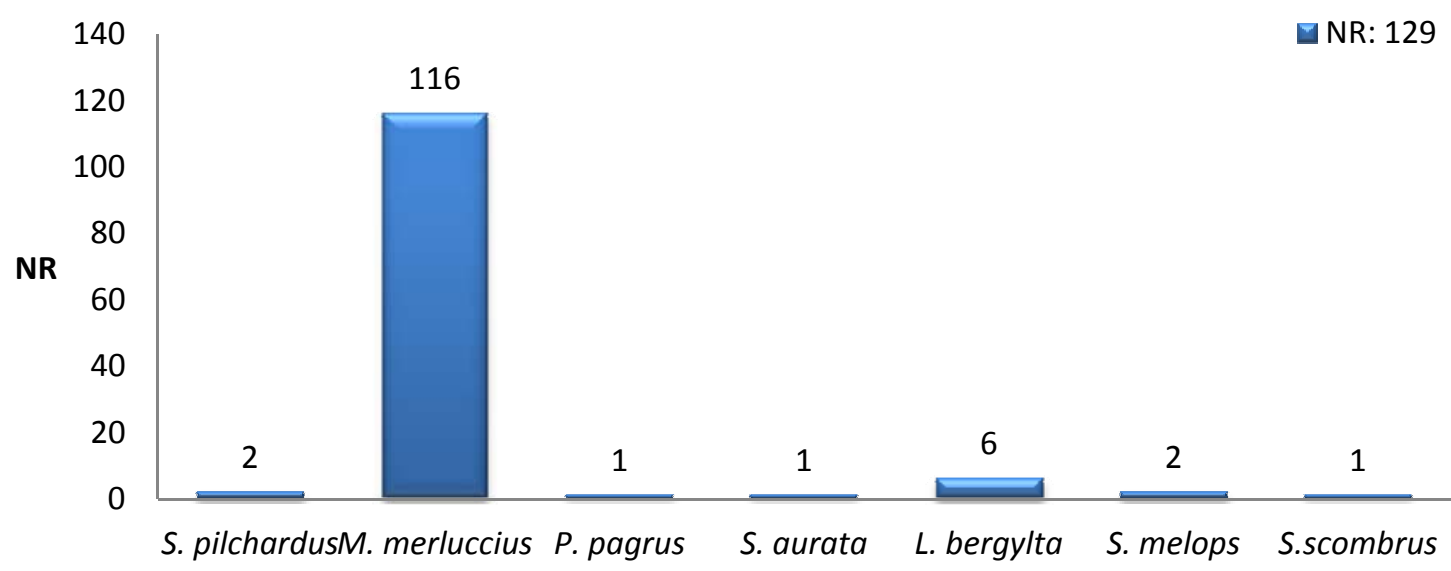

Fig. 67 Distribución de taxones identificados en el Sondeo D/1-Nivel 1-Capa 2 según el NR.

Merluccius merluccius es la especie mejor representada, superando considerablemente en número de restos a las demás. Le seguiría con una representación muy inferior Labrus bergylta. Ambas especies presentan el mismo NMI, debido a que en la primera predominan los centros vertebrales, mientras que en la segunda lo hacen los cefálicos. El resto de taxones tienen una representación mínima.

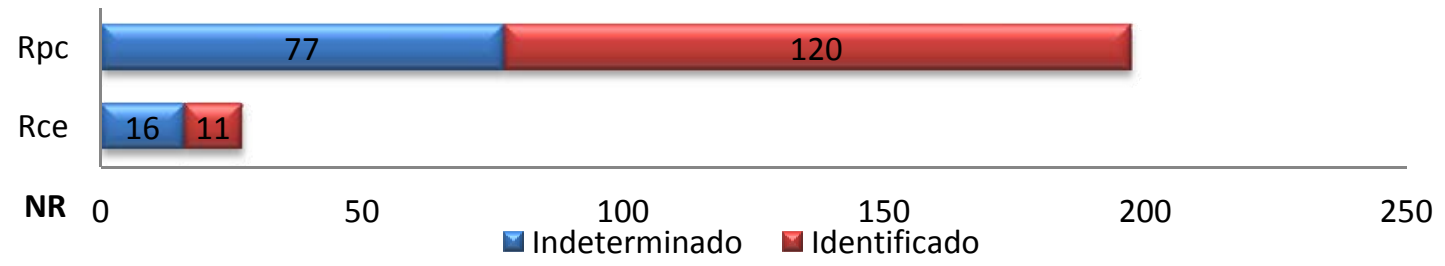

Fig. 68 Distribución esquelética de los restos ícticos del Sondeo D/1-Nivel 1-Capa 2.

Hay un predominio casi absoluto de los restos post-cefálicos frente a los cefálicos, tanto entre los fragmentos indeterminados como en las piezas identificadas. A este hecho contribuye decisivamente el elevado número de vértebras de Merluccius merluccius.

$S D / 2-C 2-N 1$

\begin{tabular}{|c|c|c|c|c|c|c|c|c|c|c|c|c|c|c|c|c|c|c|}
\hline & $\begin{array}{l}\text { Pmx } \\
\text { (D/S) }\end{array}$ & $\begin{array}{c}\text { Max } \\
\text { (D/S) }\end{array}$ & $\begin{array}{l}\text { Dnt } \\
\text { (D/S) }\end{array}$ & $\begin{array}{c}\text { Art } \\
\text { (D/S) }\end{array}$ & $\begin{array}{l}\text { Cdr } \\
\text { (D/S) }\end{array}$ & $\begin{array}{l}\text { Crh } \\
\text { (D/S) }\end{array}$ & $\begin{array}{l}\text { Pop } \\
\text { (D/S) }\end{array}$ & $\begin{array}{c}\mathrm{Pal} \\
\text { (D/S) }\end{array}$ & Oto & $\begin{array}{l}\text { Vom } \\
\text { (D/S) }\end{array}$ & $\mathrm{Vpc}$ & Atl & Vca & Rce & Rpc & Esa & NR & NMI \\
\hline Sardina pilchardus & & & & & & & & & & & 1 & & & & & & 1 & 1 \\
\hline Merluccius merluccius & $3 / 1$ & $3 / 2$ & $7 / 6$ & $4 / 4$ & $2 / 4$ & $3 / 2$ & $1 / 0$ & 8 & 1 & $2 / 3$ & 264 & 4 & 2 & & & & 326 & 7 \\
\hline Pollachius pollachius & & & $2 / 0$ & & & & & & & & & & & & & & 2 & 2 \\
\hline Scomber japonicus & & & & & & & & & & & 1 & & & & & & 1 & 1 \\
\hline Indeterminado & & & 4 & & & & & & & & & & & 947 & 332 & 82 & 1365 & \\
\hline TOTAL & 4 & 5 & 19 & 8 & 6 & 5 & 1 & 8 & 1 & 5 & 366 & 4 & 2 & 947 & 332 & 82 & 1695 & \\
\hline
\end{tabular}

Tabla 57 Relación de especies y representación ósea del Sondeo D/2-Nivel 1-Capa 2.

La muestra recuperada en este sondeo ha aportado 334 restos identificables, 947 restos cefálicos y 332 post-cefálicos indeterminados, además de 82 escamas, convirtiéndola en la muestra con el mayor número de piezas óseas, aunque únicamente se han identificado cuatro taxones. Como sucedía en la muestra anterior, la especie con más 
restos identificados es Merluccius merluccius, representada por cuatro premaxilares, cinco maxilares, trece dentarios, ocho articulares, seis cuadrados, cinco ceratohiales, un preopercular derecho, ocho palatinos, un otolito, cinco fragmentos de vómer, doscientas sesenta y cuatro vértebras precaudales, cuatro atlas y dos vértebras caudales. Las demás especies presenta un número muy bajo de restos con respecto a Merluccius merluccius: dos dentarios derechos de Pollachius pollachius, una vértebra precaudal de Sardina pilchardus y otra de Scomber japonicus.

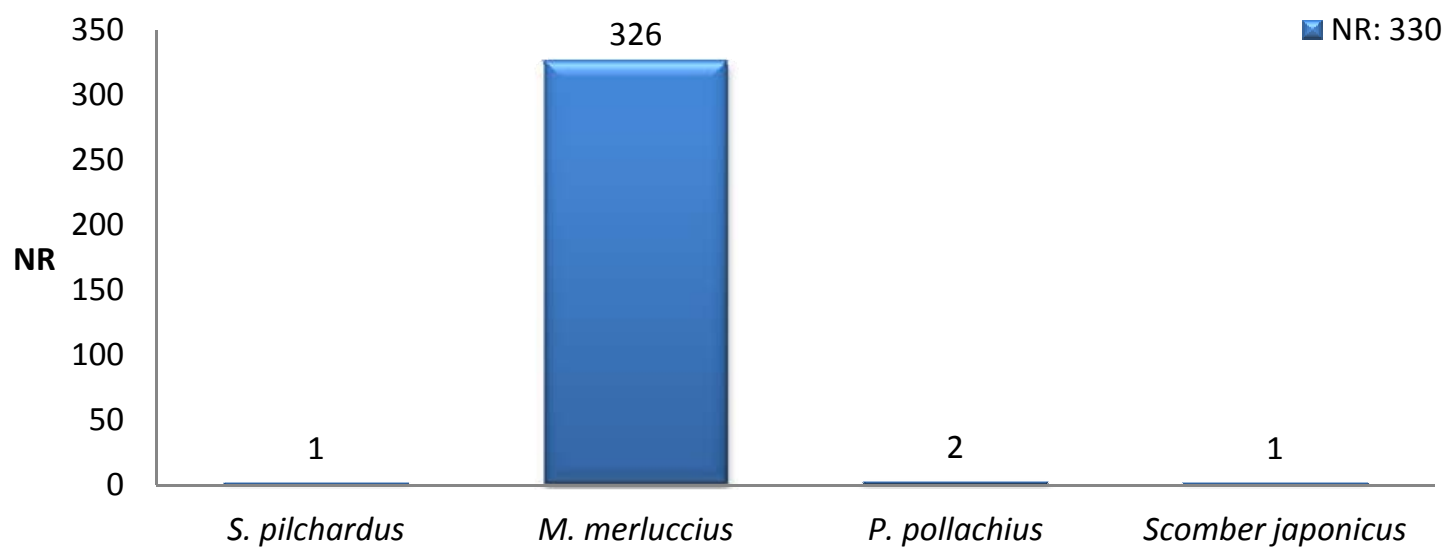

Fig. 69 Distribución de taxones identificados en el Sondeo D/2-Nivel 1-Capa 2 según el NR.

Merluccius merluccius es la especie mejor representada, al igual que se documentaba en la muestra anterior; su número supera ampliamente el documentado para las demás especies. La mayor presencia de piezas cefálicas hace que el NMI ascienda a siete ejemplares. Las demás especies presentan un número muy inferior de restos.

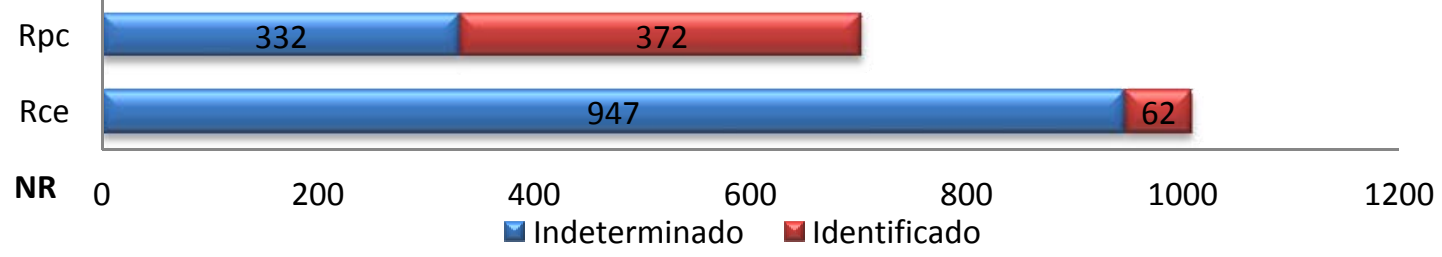

Fig. 70 Distribución esquelética de los restos ícticos del Sondeo D/2-Nivel 1-Capa 2.

Frente a lo observado en otras muestras, van a predominar los restos cefálicos no identificados frente a los post-cefálicos. En cuanto a las piezas óseas identificadas el predominio se invierte, lo que debemos relacionar con el alto número de centros vertebrales de Merluccius merluccius. En cuanto a los demás taxones, solamente en el caso de Pollachius pollachius se han documentado restos cefálicos.

$S F / 1-C 2-N 1$

\begin{tabular}{lccccc} 
& $\begin{array}{c}\text { Max } \\
\text { (D/S) }\end{array}$ & Vpc & Rpc & NR & NMI \\
\hline $\begin{array}{l}\text { Merluccius merluccius } \\
\text { Indeterminado }\end{array}$ & $1 / 0$ & 1 & & $\mathbf{2}$ & 1 \\
\hline \hline & & & 4 & $\mathbf{4}$ & \\
\hline \hline
\end{tabular}

Tabla 58 Relación de especies y representación ósea del Sondeo F/1-Nivel 1-Capa 2. 
Presencia de una única especie, Merluccius merluccius, representada por dos restos: un maxilar derecho y una vértebra precaudal. Además también se contabilizaron cuatro restos post-cefálicos que no pudieron ser asignados a ninguna especie, ya que se correspondían con fragmentos de espinas.

\section{V.1.5. COMEnTARIO.}

\section{V.1.5.1. CONCHERO.}

\section{Representación faunística.}

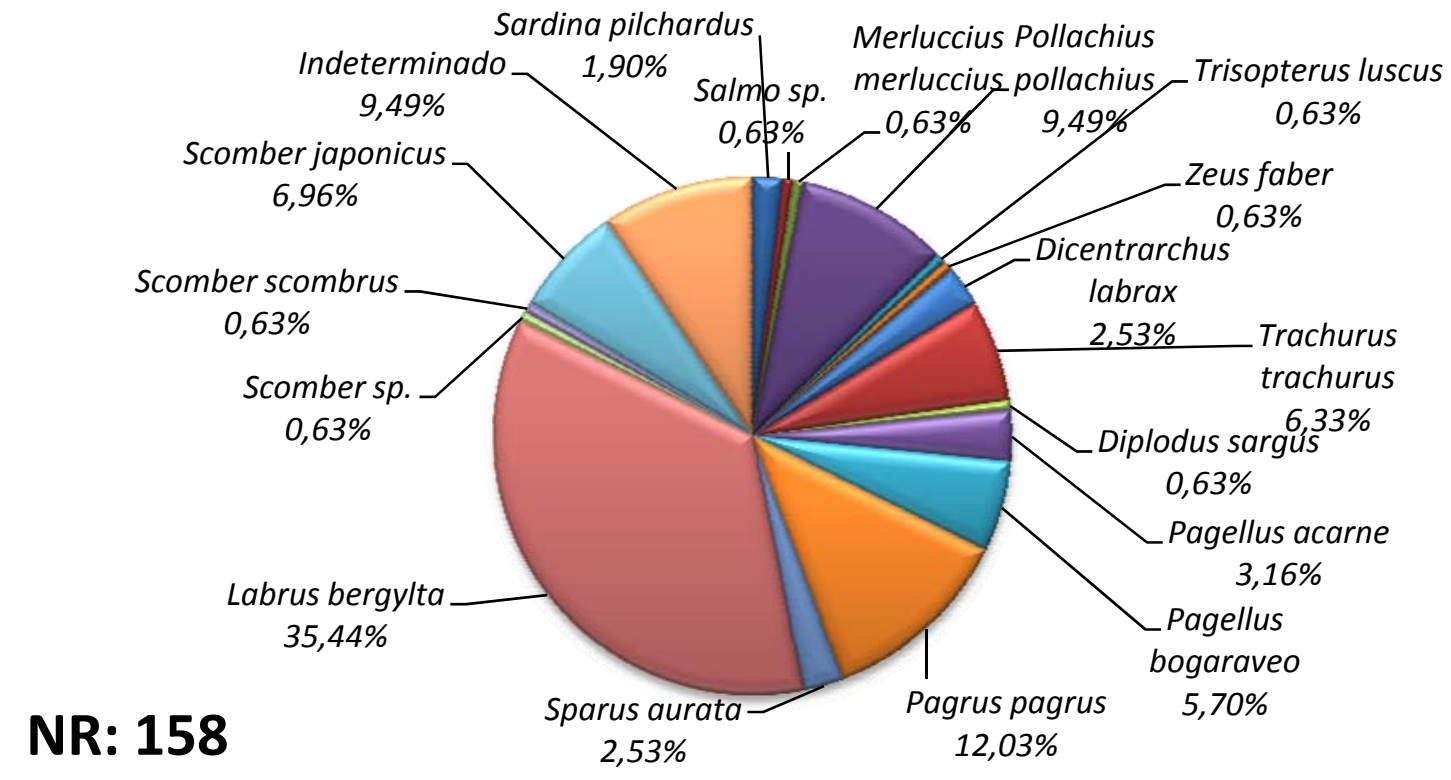

Fig. 71 Representatividad de los taxones identificados en el conchero según el NR.

\begin{tabular}{l|c|c|c|} 
& IC & ID & ICxID \\
\cline { 2 - 4 } Sardina pilchardus & 21,4 & 2,1 & 44,9 \\
Salmo sp. & 7,1 & 0,7 & 5 \\
Merluccius merluccius & 7,1 & 0,7 & 5 \\
Pollachius pollachius & 50 & 10,5 & 525 \\
Trisopterus luscus & 7,1 & 0,7 & 5 \\
Zeus faber & 7,1 & 0,7 & 5 \\
Dicentrarchus labrax & 21,4 & 2,8 & 59,9 \\
Trachurus trachurus & 21,4 & 7 & 149,8 \\
Diplodus sargus & 7,1 & 0,7 & 5 \\
Pagellus acarne & 28,5 & 3,5 & 99,8 \\
Pagellus bogaraveo & 35,7 & 6,3 & 224,9 \\
Pagrus pagrus & 50 & 13,3 & 665 \\
Sparus aurata & 14,3 & 2,8 & 40 \\
Labrus bergylta & 64,3 & 39,2 & 2520,6 \\
Scomber sp. & 7,1 & 0,7 & 5 \\
Scomber scombrus & 7,1 & 0,7 & 5 \\
Scomber japonicus & 57,1 & 7,7 & 439,7
\end{tabular}

Tabla 59 Índices de valoración. 
Aunque carecemos de dataciones absolutas para el conchero, parece que su formación se produciría durante un breve periodo de tiempo entre los siglos I y III d.C. (González Gómez de Agüero, 2009; González Gómez de Agüero et alii, 2011). Los datos proceden principalmente de las tres columnas del muestreo, aunque también se han añadido los restos de las muestras concentradas y selectivas. Estas últimas tienen el inconveniente de que no fueron realizadas aleatoriamente, quedando vinculada su recuperación a su localización visual por parte de los arqueólogos que realizaron la intervención. Pese a esto, nos pareció interesante añadirlas, ya que no variaban sustancialmente la relación de importancia de los diferentes taxones, pero sí incluían especies que no estaban presentes en las columnas de muestras. Basándonos en estos datos, podemos observar diferencias en la representatividad de los diferentes taxones:

-Especies principales: La especie mejor representada, con cerca del $40 \%$ de los restos, y presente en la mayor parte de las muestras tomadas en columna (solo se encuentra ausente en A-1 y C-3), es Labrus bergylta. Esta especie habita en zonas de roca con algas, siendo sedentaria y muy territorial, por lo que supondría un recurso estable y fácil de conseguir en la costa más cercana al yacimiento.

-Especies secundarias: Este grupo estaría formado por dos especies (Pollachius pollachius y Pagrus pagrus), con una gran diferencia tanto en lo que se refiere a su presencia en las diferentes muestras como en volumen de restos con respecto a Labrus bergy/ta. Los dos taxones están presentes en el mismo número de muestras, siendo muy similar el número de restos, si bien Pagrus pagrus está ligeramente mejor representado. Las dos especies son demersales, localizándose en fondos rocosos y arenosos. Pagrus pagrus habita cerca de la costa en verano, durante la reproducción, descendiendo en invierno por debajo de los $100 \mathrm{~m}$ de profundidad. En cuanto a Pollachius pollachius, los individuos jóvenes suelen encontrarse cerca de la costa, descendiendo a zonas más profundas a medida que van creciendo.

-Especies complementarias: Incluimos en esta categoría aquellas especies representadas por un número pequeño de restos y únicamente documentadas en una o dos muestras. Principalmente son especies demersales (Pagellus bogaraveo, Pagellus acarne, Dicentrarchus labrax y Sparus aurata), aunque es importante la presencia de especies pelágicas (Scomber scombrus, Trachurus trachurus y Sardina pilchardus).

-Especies anecdóticas: Incluimos en esta categoría a todas aquellas representadas por un resto. Este grupo estaría formado por Merluccius merluccius, Trisopterus luscus, Zeus faber, Diplodus sargus, Salmo sp. y Scomber scombrus. Si exceptuamos las dos últimas que son pelágicas, el resto de especies son demersales. En el caso de Scomber scombrus, sus similitudes con Scomber japonicus hacen posible una captura causal al realizar la pesca de esta última. Es significativo 
el caso de Salmo sp., ya que se ha recuperado un escaso número de restos de salmónidos en yacimientos castreños y galaico-romanos, pudiendo vincularse su captura a la migración anádroma que realiza esta especie. En este sentido, hay que tener en cuenta que en las cercanías del asentamiento se encuentra la desembocadura del río Covo. De Merluccius merluccius, únicamente se recuperó un resto en las muestras selectivas.

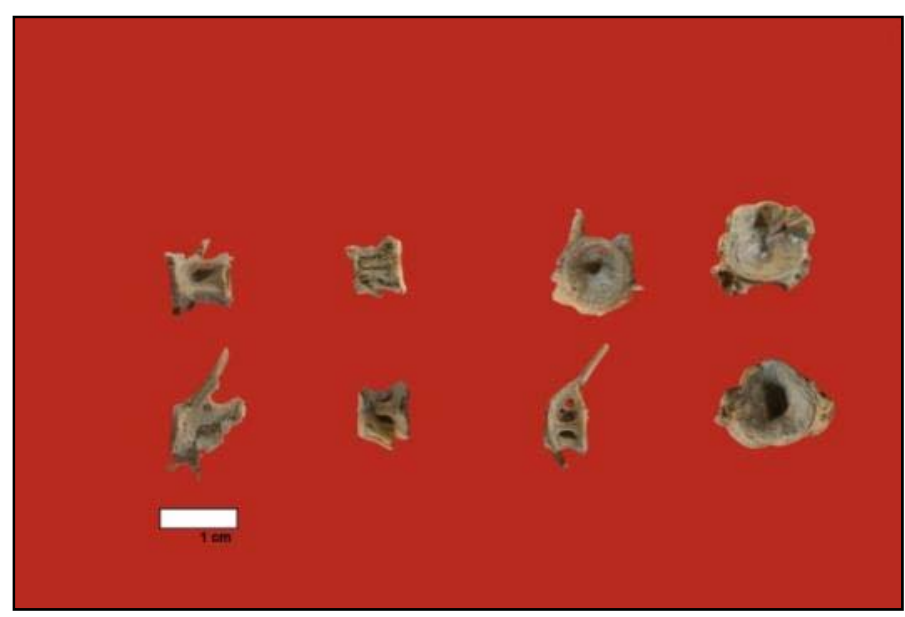

Fig. 72 Centros vertebrales de los principales taxones identificados.

Es interesante reseñar que en aquellas muestras donde Labrus bergylta presenta unos valores inferiores (A-1 ó B-1), además de existir una mayor variedad de taxones, son mayoritarias las especies con una marcada estacionalidad, como Trachurus trachurus, Pagellus bogaraveo o Scomber japonicus. Del mismo modo, las muestras en las que Labrus bergylta presenta un mayor número de restos coinciden mayoritariamente con aquellas donde también hay una mayor presencia de Paracentrotus lividus (González Gómez de Agüero, 2009). Como ya habíamos señalado en trabajos previos centrados en el estudio malacológico de este yacimiento (Fernández Rodríguez et alii, 2008; González Gómez de Agüero, 2009; González Gómez de Agüero et alii, 2011), esto puede deberse a factores estacionales, ya que las citadas especies ícticas suelen acercarse a la costa en primavera y verano, mientras que Paracentrotus lividus sería recogido entre el otoño y la primavera, periodo de desarrollo de las gónadas genitales, parte consumible de esta especie. De todos modos, hay que tener en cuenta que la división en muestras no se corresponde con niveles naturales, por lo que siempre hay que tomar estos datos con precaución, aunque sí es cierto que podemos observar ciertas tendencias que deben ser corroboradas con otros análisis como los de estacionalidad.

\section{Representatividad ósea.}

La presencia de restos cefálicos y post-cefálicos está bastante equilibrada, siendo en algunos casos mayoritarios los restos cefálicos. Las especies que presentan un mayor número de restos cefálicos son aquellas que presentan una mayor osificación de estos huesos (Roselló, 1989: 592-605). Es interesante el caso de Trachurus trachurus, ya que únicamente está representado por centros vertebrales, principalmente caudales, y sin embargo, en las muestras del solar 02 son numerosos los restos cefálicos. Esta especie es bastante grasa, siendo utilizada en algunos casos para su conserva. Quizás la presencia de 


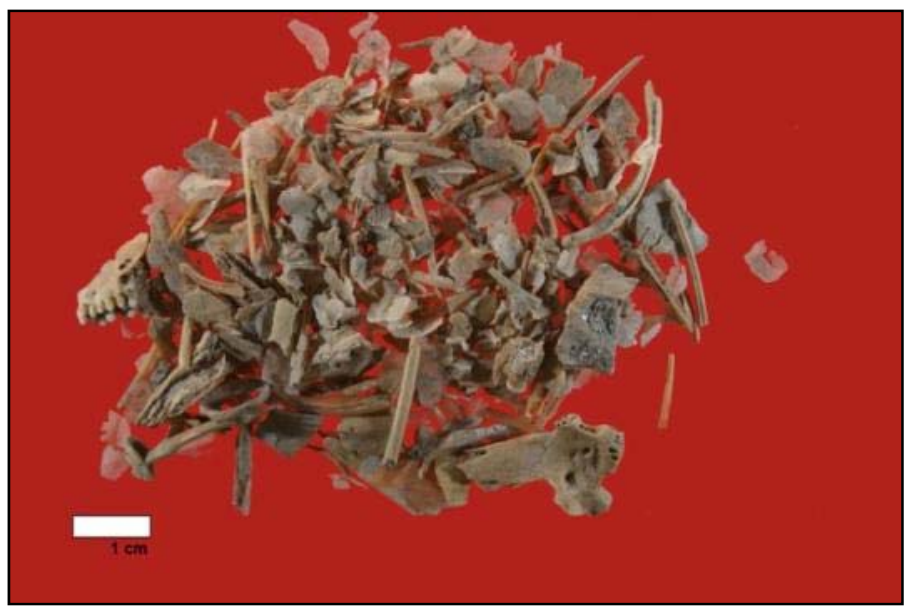

centros vertebrales de la cola en el conchero esté reflejando algún tipo de preparación del pez, bien para su conservación, bien para su consumo. En el caso de otras especies como Dicentrarchus labrax - Zeus faber se presenta el caso contrario, lo que puede deberse a la limpieza para su consumo.

Fig. 73 Restos de ictiofauna documentados en el conchero.

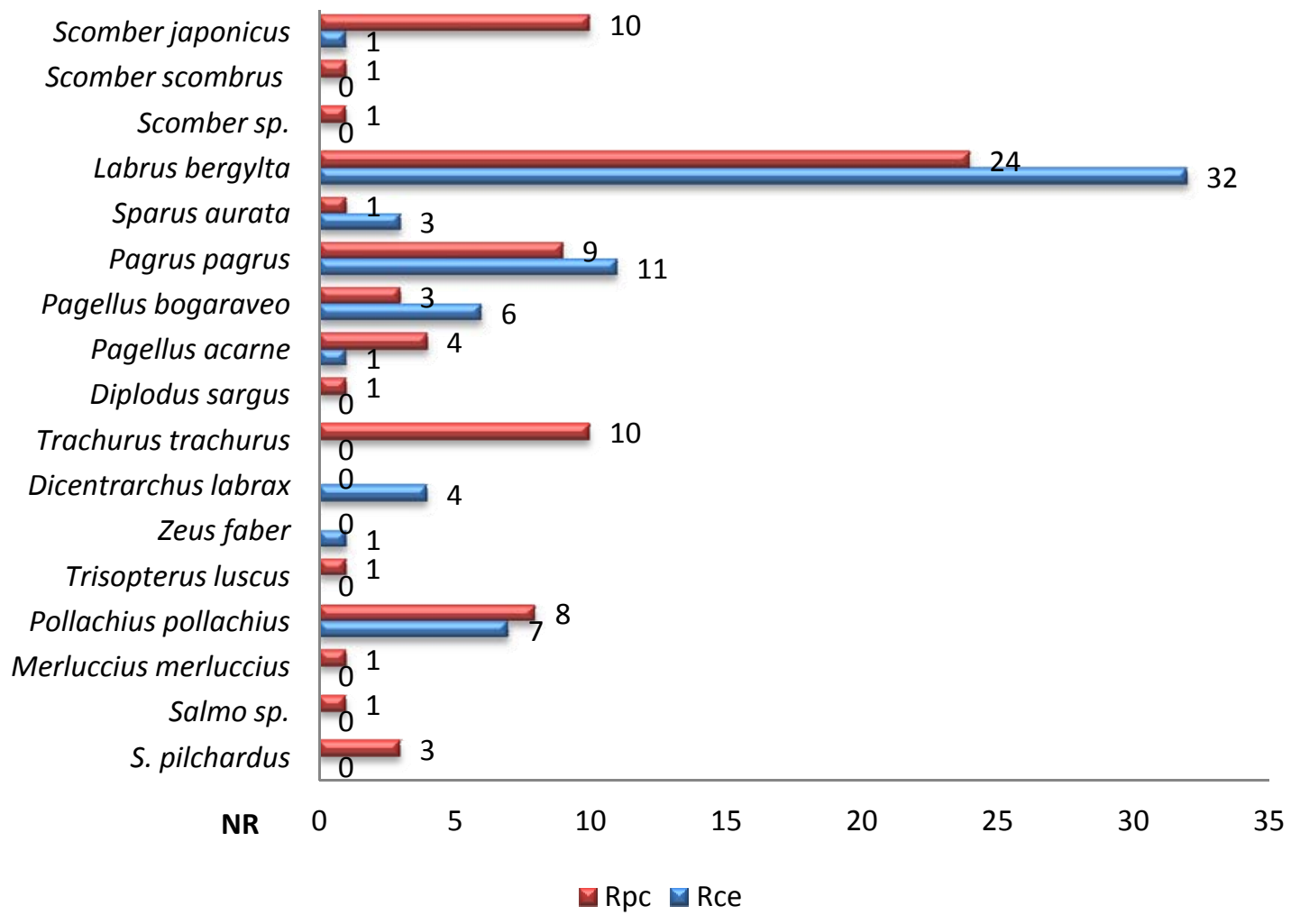

Fig. 74 Comparación numérica de los restos cefálicos y postcefálicos de los taxones identificados.

Aunque el número de restos identificables recuperados en el conchero no es muy numeroso, se cuenta con una gran cantidad de fragmentos que no ha sido posible identificar debido a su estado de fragmentación, así como un gran número de escamas, que sugieren que están llegando al asentamiento ejemplares completos, que son limpiados y procesados en el mismo. 


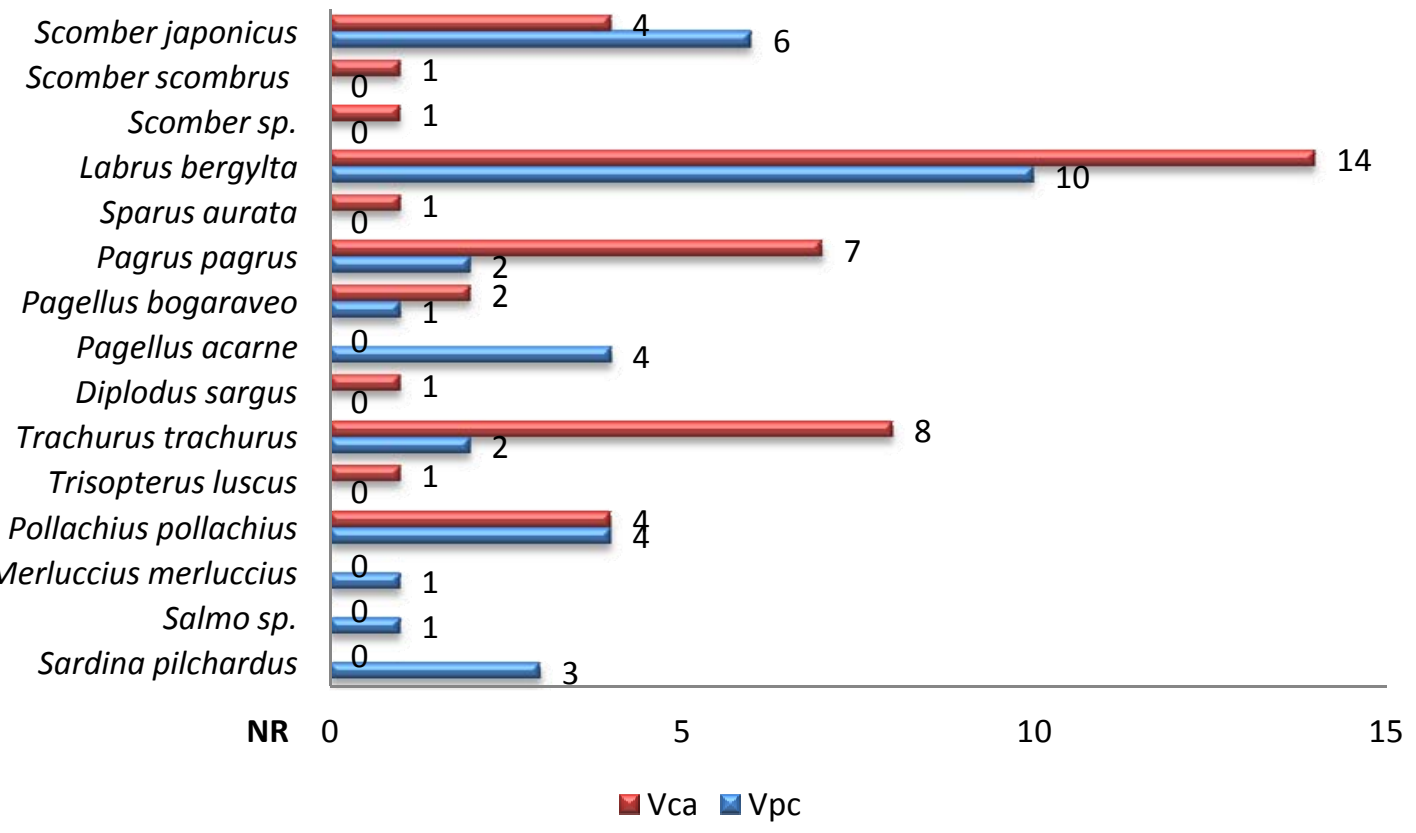

Fig. 75 Comparación numérica de las vértebras caudales y precaudales de los taxones identificados.

\section{V.1.5.2. SOLAR O2 ÉPOCA ROMANA.}

\section{Representación faunística.}

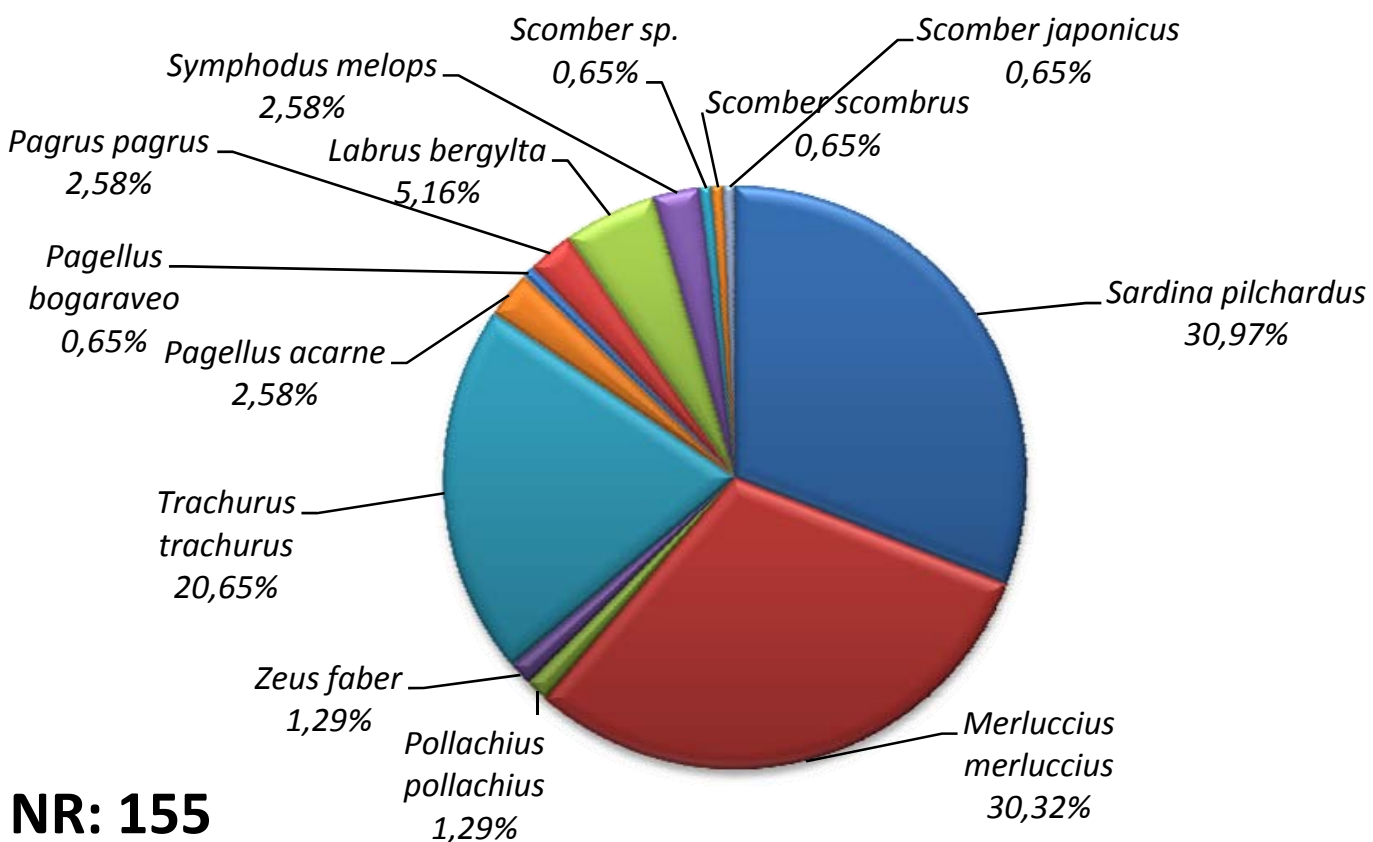

Fig. 76 Representatividad de los taxones de época romana identificados en el Solar 02 según el NR. 


\begin{tabular}{l|c|c|c|} 
& IC & ID & ICxID \\
\cline { 2 - 4 } Sardina pilchardus & 22,2 & 31 & 688,2 \\
Merluccius merluccius & 66,7 & 30,3 & 2021 \\
Pollachius pollachius & 7,4 & 1,3 & 9,6 \\
Zeus faber & 7,4 & 1,3 & 9,6 \\
Trachurus trachurus & 11,1 & 20,6 & 228,7 \\
Pagellus acarne & 3,7 & 2,6 & 9,6 \\
Pagellus bogaraveo & 3,7 & 0,6 & 2,2 \\
Pagrus pagrus & 3,7 & 2,6 & 9,6 \\
Labrus bergylta & 29,6 & 5,2 & 153,9 \\
Symphodus melops & 3,7 & 2,6 & 9,6 \\
Scomber sp. & 3,7 & 0,6 & 2,2 \\
Scomber scombrus & 3,7 & 0,6 & 2,2 \\
Scomber japonicus & 3,7 & 0,6 & 2,2
\end{tabular}

Tabla 60 Índices de valoración.

Las muestras analizadas se identificaron con muestras concentradas y selectivas realizadas durante el proceso de excavación del Solar 02. Debido a esto hemos constatado principalmente dos problemas:

-Se detecta un sesgo en las muestras; por ejemplo, Labrus bergy/ta está representada únicamente por huesos faríngeos, ya que estos son de buen tamaño y muy llamativos. Algo similar parece ocurrir con Merluccius merluccius, que aparece en muchas ocasiones como única especie de la muestra debido al mayor tamaño de los restos de su esqueleto frente a los de otras especies. Sin embargo, hay que tener en cuenta que otras especies como Sardina pilchardus o Trachurus trachurus, que presentan restos óseos de pequeño tamaño, están bien representadas. Por lo tanto aunque exista un sesgo al no recuperarse todos los restos presentes en el sedimento, el modelo de muestra concentrada ha permitido recuperar especies de pequeño tamaño haciéndolo menos significativo.

-El segundo de los problemas detectados es la adscripción cronológica: se ha realizado una asignación generalista de los restos de época romana, a falta de estudios de otros materiales o dataciones que permitan una mayor precisión cronológica. Asimismo se ha detectado que una serie de muestras, considerando los taxones documentados y la representatividad anatómica, tienen más similitud con lo observado en época medieval que romana. En estas muestras la especie dominante, con cerca del $90 \%$ de los restos, es Merluccius merluccius, que además aparece representada por restos cefálicos y vértebras precaudales, reflejo durante la Edad Media del tratamiento de los ejemplares de esta especie para su salado. Por este motivo, y por la ubicación de las muestras, hemos decidido no incluir en la valoración final (Fig. 72; Tabla 60) las muestras: SA/1-C4-N2, SC/1-C6-N3, SC/2-C6N2, SF/1-C6-N3. 
Pese a estos problemas, vamos a desglosar a continuación la representatividad de las diferentes especies:

-Especies principales: Tres especies suponen el $80 \%$ del conjunto. La especie más constante, y la segunda con más restos identificados es Merluccius merluccius, sin embargo debemos de tomar este dato con prudencia, debido a los problemas de adscripción que comentamos anteriormente. En la mayoría de las muestras en las que aparece esta especie, se constituye en la única representada. Como observamos en el conchero, Merluccius merluccius es capturada en época romana, del mismo modo que aparece recurrentemente en yacimientos castreños, sin embargo nunca presenta valores tan altos. No obstante, en el yacimiento romano de Casa Martelo (A Coruña) también se puede observar la importancia que alcanza esta especie (Capítulo V.9.3.).

Las siguientes especies mejor representadas son Sardina pilchardus y Trachururs trachurus. Su pesca va a ser habitual durante todo el periodo romano, principalmente para la elaboración de salsamentas. Ambas son pelágicas, siendo necesaria la utilización de redes para su captura, principalmente en el caso de Sardina pilchardus. Se suelen pescar en determinadas épocas del año, cuando se acercan a la costa. Es llamativo el número de restos de estos taxones documentado en este conjunto, mientras que en el conchero prácticamente no se encuentran representados. Este fenómeno puede deberse a diferentes factores como la estacionalidad, como comentamos en el apartado correspondiente al conchero, o podría también vincularse a las diferencias cronológicas entre ambos conjuntos, y por lo tanto ser reflejo de una evolución en las técnicas pesqueras y en el interés por diferentes especies desde una perspectiva diacrónica. Por último, también puede reflejar distintos tratamientos para su consumo, como parecen indicar las diferencias en la representación esquelética de los conjuntos del conchero y del solar $\mathbf{0 2}$, posiblemente también condicionados por factores cronológicos.

-Especies secundarias: En este grupo incluimos un amplio abanico de especies: Labrus bergylta, Pagrus pagrus, Pagellus acarne y Symphodus melops. La primera de ellas es la que está presente en un mayor número de muestras y la que se encuentra representada por un mayor número de restos. Sus características ya la comentamos anteriormente. Este grupo se asemeja mejor al documentado en el conchero; de hecho, Labrus bergylta y Pagrus pagrus, en las dos especies con más restos identificados. Tan solo Symphodus melops, no se se habñia identificado en el conchero. Todas las especies de este grupo son demersales.

-Especies anecdóticas: En esta categoría incluimos a todas aquellas de las que únicamente se contabilizan uno o dos restos. A este grupo pertenecen Pollachius pollachius, Zeus faber, Pagellus bogaraveo, Scomber sp. Es destacable los pocos restos recuperados de Pollachius pollachius, Pagellus bogaraveo y Scomber 
japonicus, ya que en el conchero estaban bien representadas, aunque únicamente la primera de ellas con cierta importancia en aquel depósito. Zeus faber y Scomber scombrus presentan valores similares a los reflejados en el conchero.

\section{Representatividad ósea.}

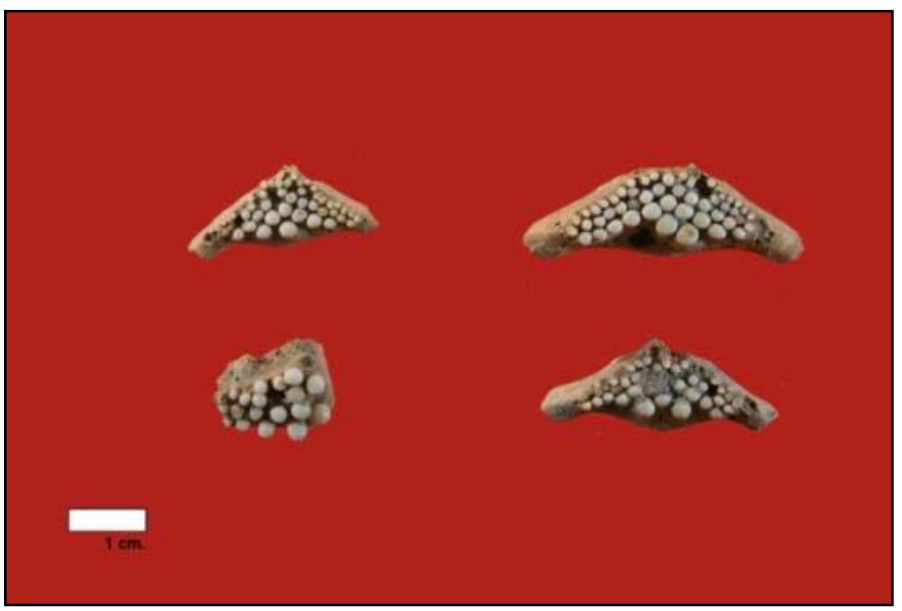

Como ya comentamos anteriormente, se observan ciertos patrones que nos indican un sesgo en el muestreo. Por un lado estaría la presencia únicamente de huesos faríngeos de Labrus bergylta, así como el elevado número de muestras donde únicamente se recuperaron restos de Meluccius merluccius. Por otro lado, también

Fig. 77 Faringobranquial y ceratobranquiales de Labrus hay que destacar la importancia de bergylta. la recogida de sedimento en torno a los materiales visualizados durante el proceso de excavación, ya que eso permitió recuperar un importante número de restos de pequeñas dimensiones, como las vértebras de Sardina pilchardus.

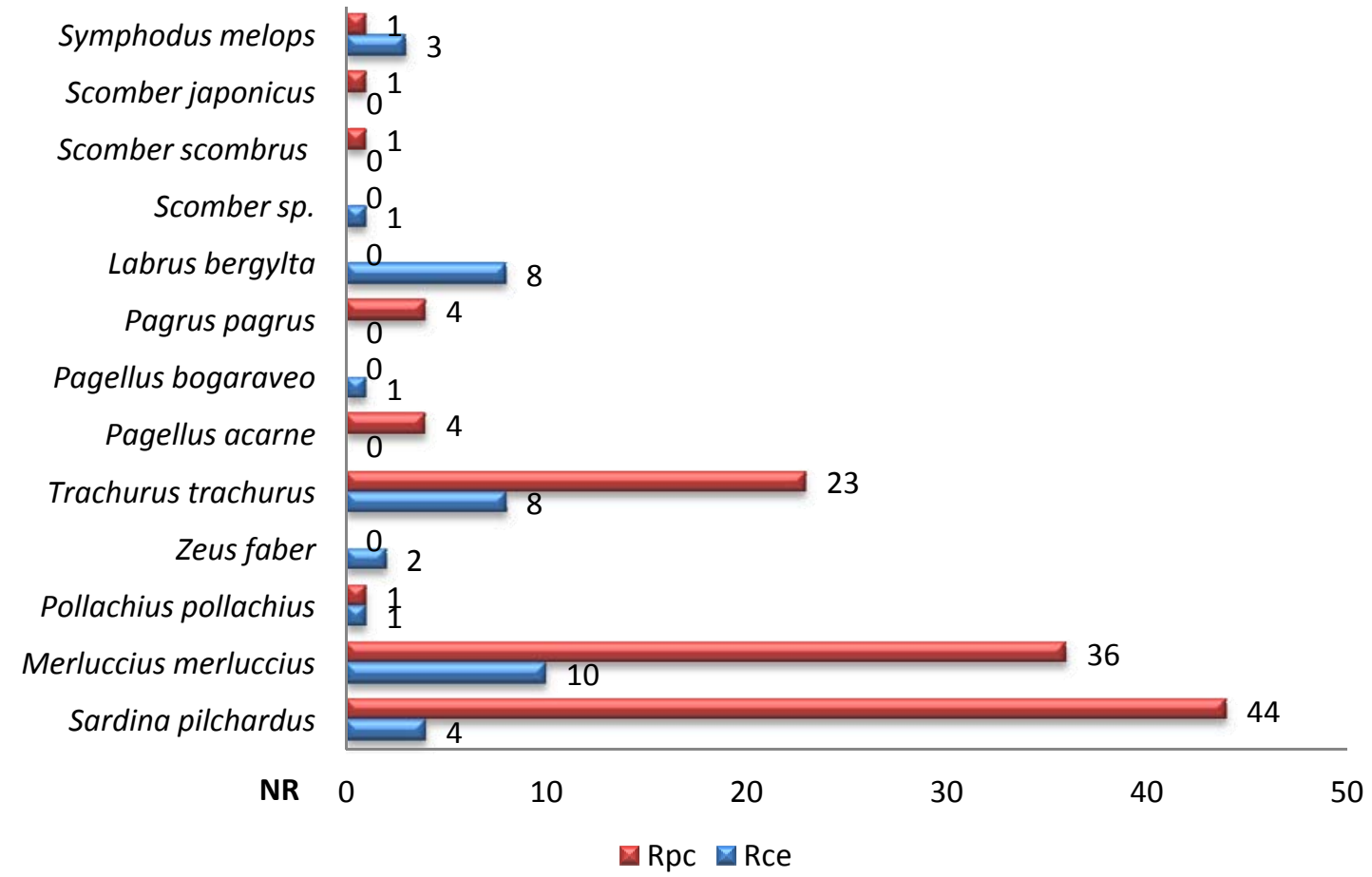

Fig. 78 Comparación numérica de los restos cefálicos y postcefálicos de los taxones identificados. 
Llama la atención la ausencia de restos cefálicos de Pagrus pagrus, ya que suelen ser más numerosos que los post-cefálicos, hecho que puede deberse al escaso número de restos identificados y al hecho de que todos aparecieran en la misma muestra.

Otro caso interesante es el de Trachurus trachurus, ya que hay un número importante de restos cefálicos, así como mayor presencia de vértebras precaudales que de vértebras caudales, principalmente en la muestra SB/4-C5-N2, frente a lo documentado en el conchero donde dominaban las vértebras caudales. Aunque los datos que tenemos son muy escasos, puede estar respondiendo a algún tipo de tratamiento de conservación. Algo similar podría ocurrir con los restos de Merluccius merluccius, especie representada principalmente por restos cefálicos y vértebras precaudales. Esta representación ósea de Merluccius merluccius va a ser habitual desde el siglo XIII-XIV d.C. en Galicia, reflejo de las técnicas de conserva empleadas. En cuanto a Sardina pilchardus, la escasa presencia de restos cefálicos es habitual en todos los yacimientos debido a la escasa osificación que presentan, así como a la posibilidad de ser consumidos. De todos modos, es significativa la mayor presencia de vértebras precaudales.

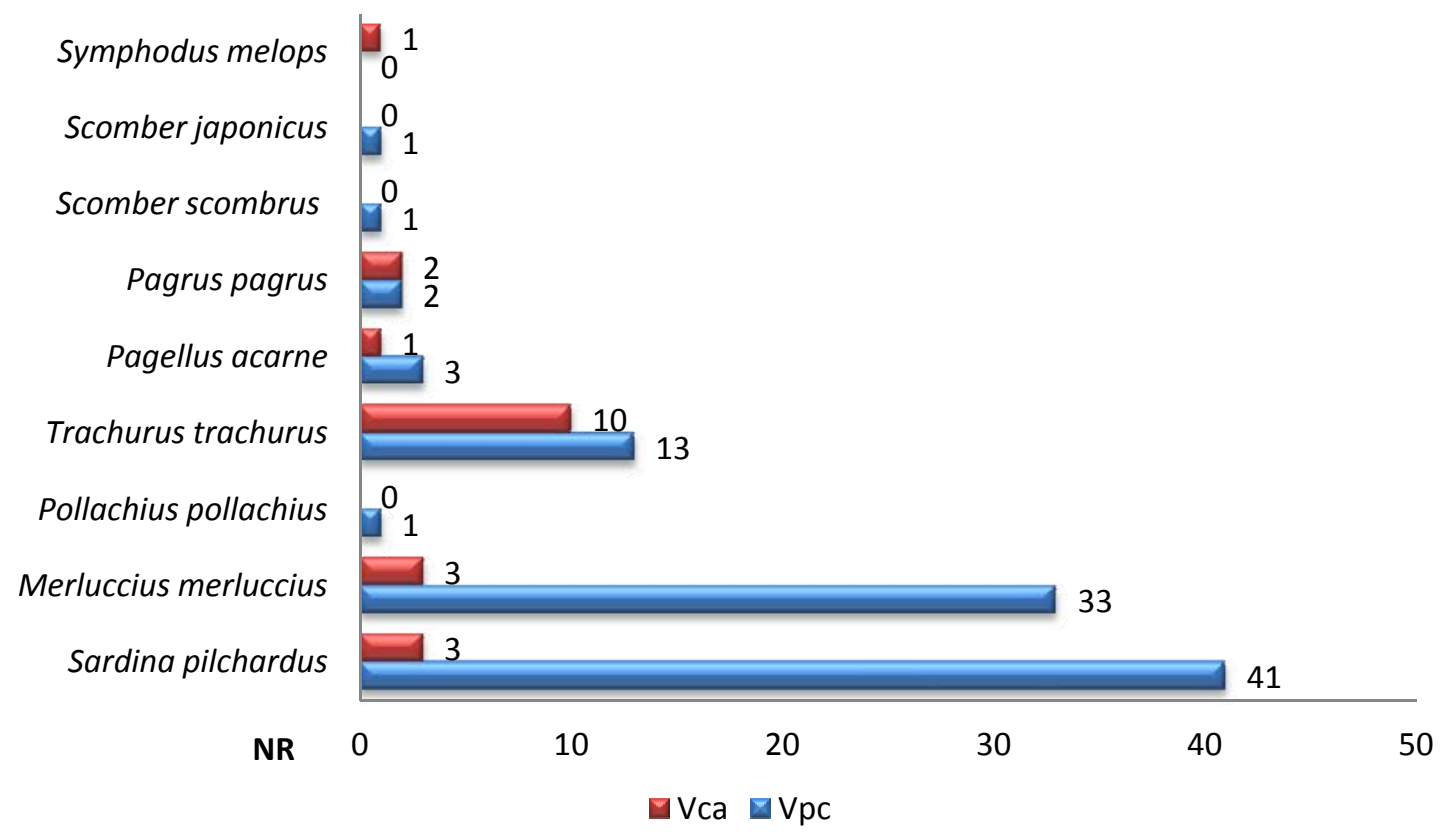

Fig. 79 Comparación numérica de las vértebras caudales y precaudales de los taxones identificados. 


\section{V.1.5.3. SOLAR O2 ÉPOCA MEDIEVAL.}

\section{Representación faunística.}

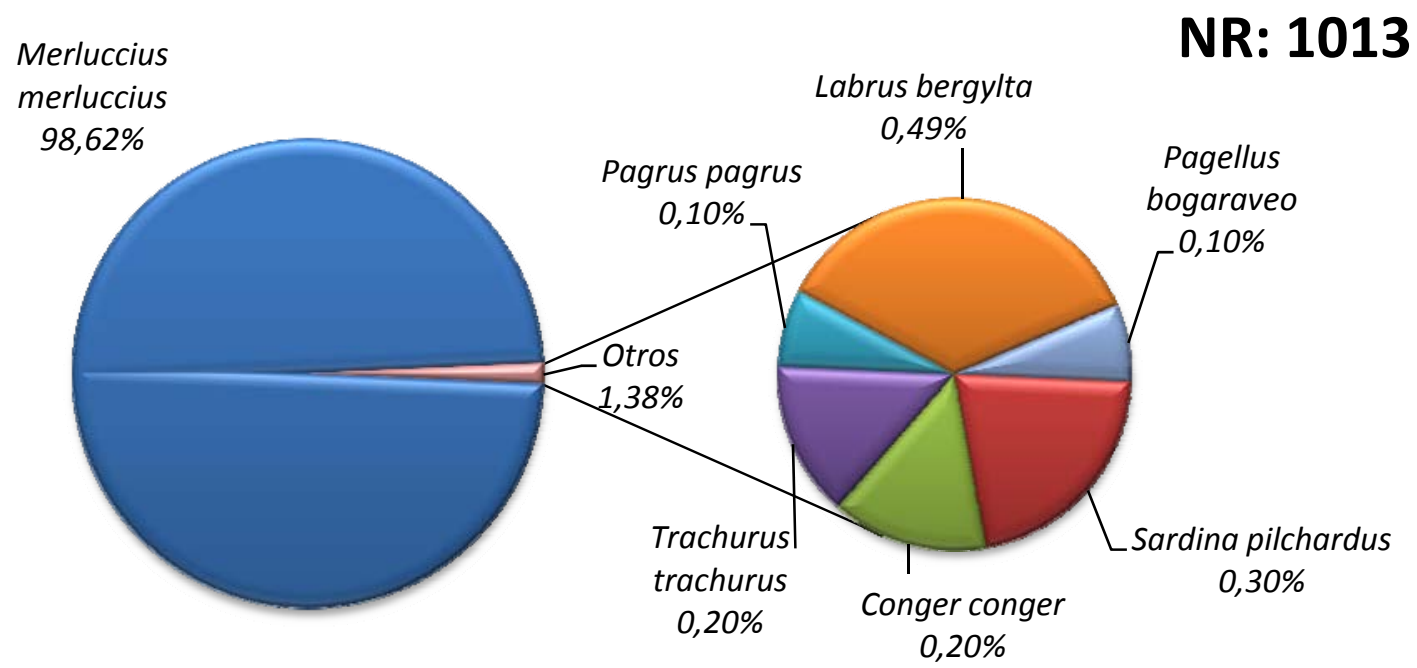

Fig. 80 Representatividad de los taxones de época medieval identificados en el Solar 02 según el $\mathbf{N R .}$

\begin{tabular}{l|c|c|c|} 
& IC & ID & ICxID \\
\cline { 2 - 4 } Sardina pilchardus & 40 & 0,3 & 12 \\
Conger conger & 40 & 0,2 & 8 \\
Merluccius merluccius & 80 & 98,6 & 7.888 \\
Trachurus trachurus & 40 & 0,2 & 8 \\
Pagrus pagrus & 20 & 0,1 & 2 \\
Labrus bergylta & 80 & 0,5 & 40 \\
Pagellus bogaraveo & 20 & 0,1 & 2
\end{tabular}

Tabla 61 Índices de valoración.

Todas las muestras adscritas a la Edad Media se corresponden con restos recuperados durante los sondeos y la excavación realizados en el Solar 02. La atribución cronológica se ha hecho de forma genérica a la Edad Media, puesto que carecemos de dataciones o de estudios de materiales, que puedan ayudar a precisar mejor su cronología. Los restos ictiológicos documentados son similares a los hallados en yacimientos gallegos situados en torno al siglo XIV-XV d.C. Además, se documentó una moneda de Alfonzo X y otra de Alfonso XI, por lo que es probable que el conjunto se sitúe entre los siglos XIII y XV d.C. A continuación vamos a comentar brevemente la distribución de los restos:

-Especies principales: Cerca del $99 \%$ de los restos se asignan a un único taxón, Merluccius merluccius. Esta especie no es muy habitual en los yacimientos de periodos anteriores, lo que, unido a sus condiciones biológicas, nos indicaría la presencia de nuevas técnicas pesqueras para su captura, que además permitirían realizarla a mayor lejanía de la costa. Merluccius merluccius va a tener mucha importancia al final de la Edad Media como producto de comercio y consumo (Ferreira Priegue, 1998; Ferré y Rey, 1998; Ferré, 2003), lo que explicaría que sea 
una especie representada por un alto número de restos, aunque hay que tener también en cuenta el tipo de muestreo realizado. De todos modos, la representación anatómica de esta especie nos hace pensar más en la realización de tratamientos conserveros para su posterior comercialización, que para el autoconsumo o consumo en fresco.

-Especies secundarias: En esta categoría destaca Labrus bergylta, ya que va a ser la especie con más restos después de Merluccius merluccius, aunque con valores muy alejados de esta. Este lábrido es sedentario y territorial, siendo habitual su presencia en las zonas rocosas con algas, y por lo tanto, en el entorno más inmediato al yacimiento. Ya vimos que era una especie muy importante desde época romana, manteniéndose en época medieval con cierta relevancia para el autoabastecimiento de la población local.

-Especies complementarias: Aunque las especies que incluimos en esta categoría presentan un número de restos muy similar a las especies anecdóticas, hemos decidido separarlas por las implicaciones que van a tener en la Edad Media. Sardina pilchardus y Conger conger completarían junto con Merluccius merluccius, la triada piscícola de la Edad Media gallega (Ferreira Priegue, 1998; Ferré, 2003). Estas tres especies van a suponer el eje sobre el que se va a desarrollar la actividad de los mareantes. Sin embargo, el número de restos recuperado es muy escaso, lo que nos plantea ciertos interrogantes en cuanto a la importancia real de las mismas en este yacimiento. Por un lado, puede ser reflejo del sesgo producido en el muestreo, aunque sería más difícil de explicar en el caso de Conger conger, cuyos restos son de gran talla y bastante osificados, similares a los de Merluccius merluccius. También es posible que sea reflejo del modo de preparación para la conserva de estas especies, ya que se transportarían los ejemplares completos (Cornide, 1788; Ferreira Priegue, 1998).

Por otro lado, aunque Trachurus trachurus no aparezca en las fuentes como una especie muy apreciada (Cornide, 1788; Ferreira Priegue, 1998), hemos decidido incluírla en este grupo debido a que es una de las mejor representadas, tanto en este yacimiento como en otros de la misma época (Ferré, 2003).

-Especies anecdóticas: Por último, un único resto ha permitido constatar la presencia de Pagrus pagrus y Pagellus bogaraveo. Ambas especies son espáridos que se acercan a la costa en determinadas épocas del año, pudiendo haber sido capturadas en las cercanías del yacimiento. En las muestras romanas se encontraban bien representadas, por lo que su presencia habría que relacionarla con un consumo de carácter local, similar al observado para Labrus bergylta, si bien estas especies son susceptibles de haber sido objeto de comercio de pescado fresco a corta distancia, hipótesis difícil de contrastar ante la ausencia de datos arqueoictiológicos en los yacimientos de interior. 


\section{Representatividad ósea.}

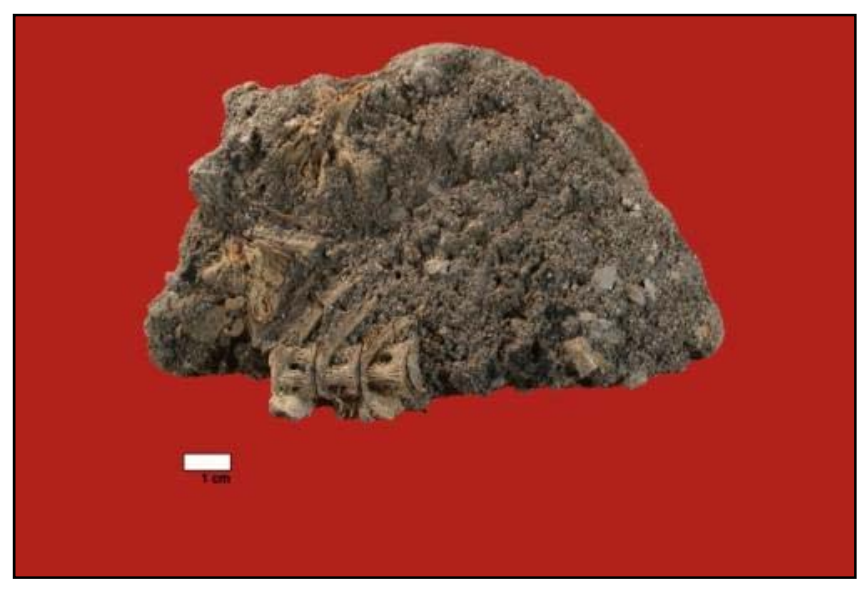

Fig. 81 Vértebras precaudales de Merluccius merluccius en conexión anatómica.

Las dos únicas especies representadas por restos cefálicos son Merluccius merluccius y Labrus bergylta. En cuanto a la primera, sus restos son de gran tamaño y con una alta osificación, y por lo tanto susceptibles de ser recuperados durante el proceso de excavación. Algo similar ocurre con el segundo de estos taxones, ya que está representado por dientes faríngeos, con una morfología muy particular. Por lo tanto, la ausencia de restos cefálicos del resto de especies puede reflejar los problemas de muestreo detectados y comentados anteriormente.

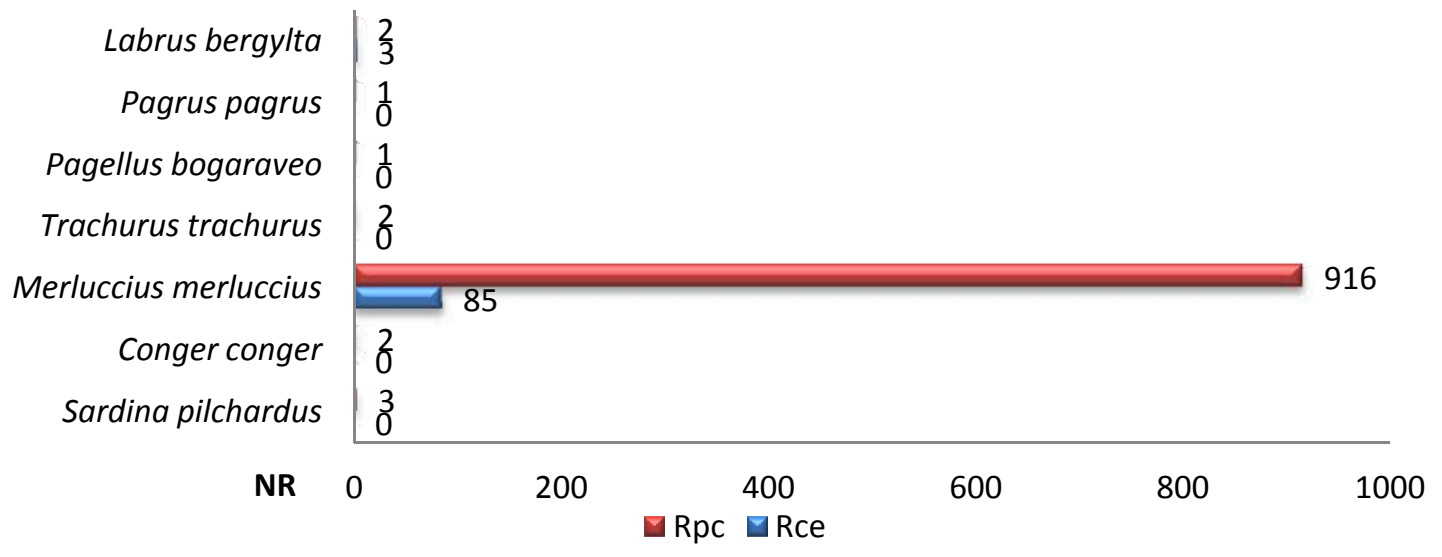

Fig. 82 Comparación numérica de los restos cefálicos y postcefálicos de los taxones identificados.

La especie a la que corresponden la mayor parte de los restos es Merluccius merluccius, representada principalmente por restos cefálicos y vértebras precaduales. Además, algunos de estos restos se presentaban en conexión anatómica. La presencia reiterada de los huesos de la cabeza y del cuerpo creemos que podría relacionarse con el procesado de los ejemplares de esta especie para la elaboración de conservas. Joseph Cornide (1788) describe el proceso empleado para secar la merluza, correspondiendo lo registrado por este autor con los restos documentados en este yacimiento. Según Cornide, los individuos eran descabezados y se eliminaba la columna hasta el ano, donde comienza la zona caudal. Posteriormente se ponían en pilas con sal gruesa durante seis días, y finalmente se secaba al aire durante ocho días. Por lo tanto, las vértebras caudales, que prácticamente no aparecen representadas en el yacimiento, serían comercializadas con el producto salado. 
En cuanto a las otras especies identificadas, el bajo número de restos y su poca representatividad, nos impide reconocer algún posible tipo de tratamiento conservero.

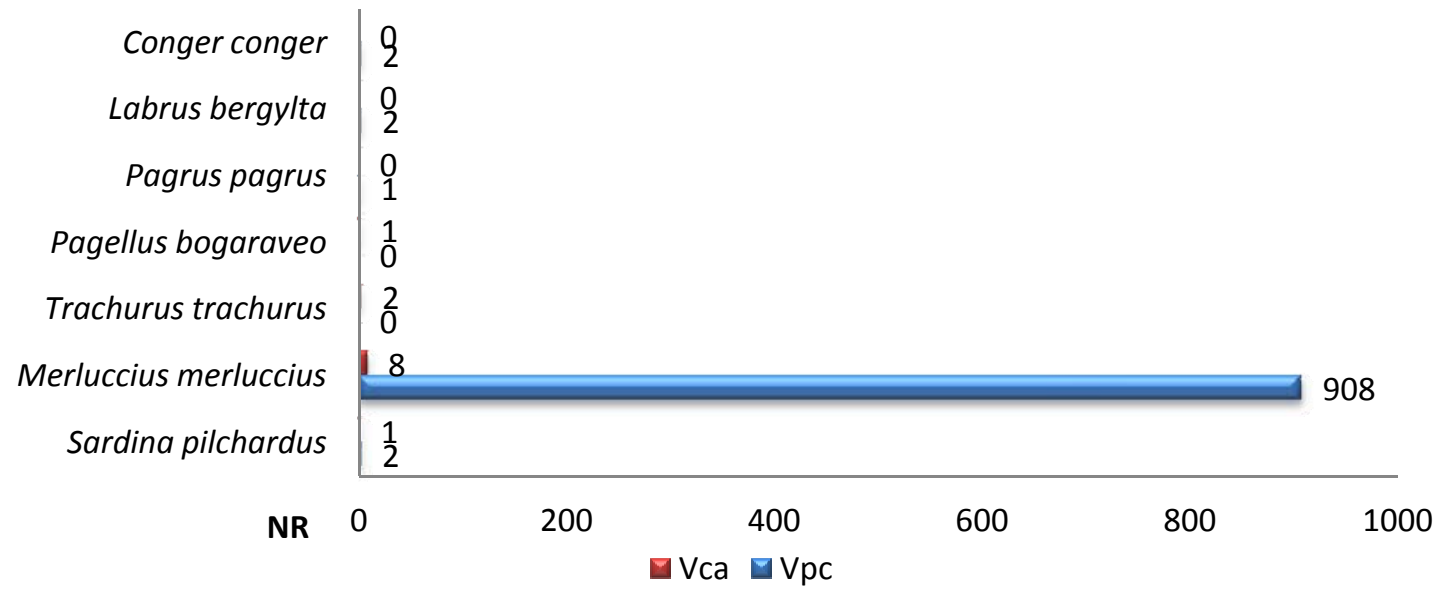

Fig. 83 Comparación numérica de las vértebras caudales y precaudales de los taxones identificados.

\section{V.1.5.4. SOLAR O2 ÉPOCA MODERNA.}

\section{Representación faunística.}

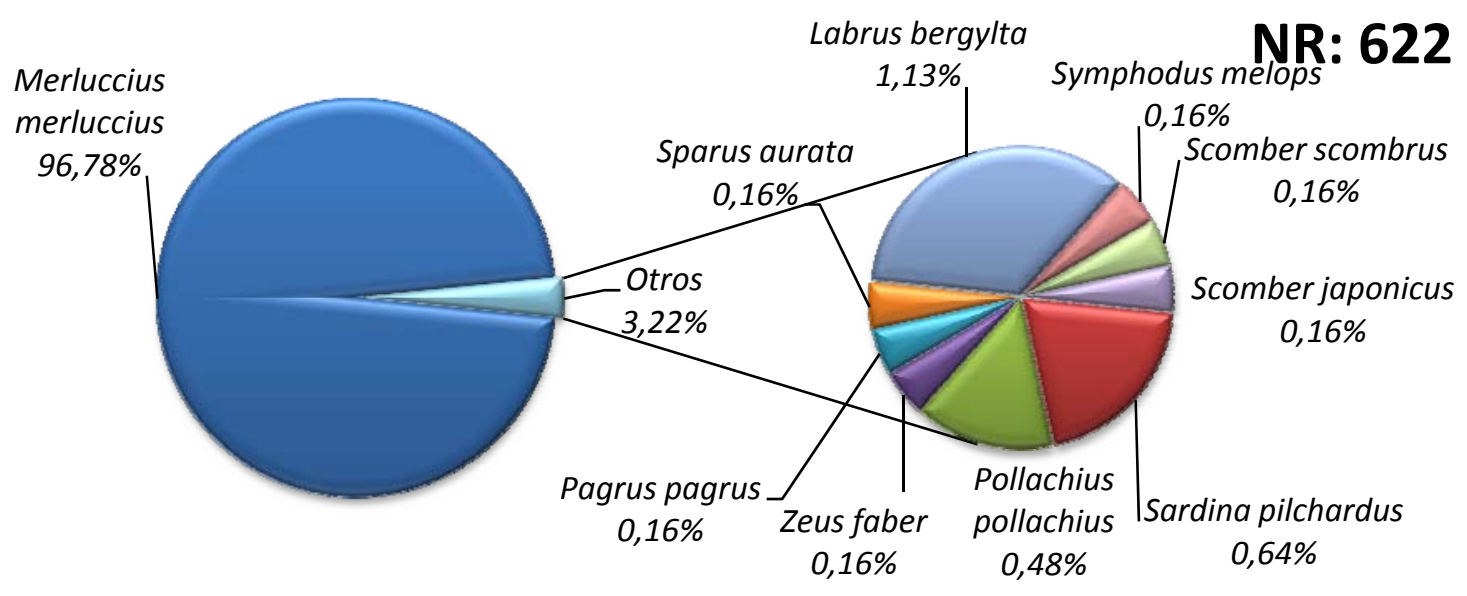

Fig. 84 Representatividad de los taxones de época moderna identificados en el Solar 02 según el NR.

\begin{tabular}{l|c|c|c|} 
& IC & ID & ICxID \\
\cline { 2 - 4 } Sardina pilchardus & 50 & 0,6 & 30 \\
Merluccius merluccius & 83,3 & 96,8 & 8063,4 \\
Pollachius pollachius & 33,3 & 0,5 & 16,7 \\
Zeus faber & 16,7 & 0,2 & 3,3 \\
Pagrus pagrus & 16,7 & 0,2 & 3,3 \\
Sparus aurata & 16,7 & 0,2 & 3,3 \\
Labrus bergylta & 33,3 & 1,1 & 36,6 \\
Symphodus melops & 16,7 & 0,2 & 3,3 \\
Scomber scombrus & 16,7 & 0,2 & 3,3 \\
Scomber japonicus & 16,7 & 0,2 & 3,3
\end{tabular}

Tabla 62 Índices de valoración. 
El conjunto de muestras asignadas a la Edad Moderna presentan unos problemas similares a los comentados para las muestras romanas y medievales del Solar 02. En este caso además hay que sumar la dudosa adscripción cronológica, ya que se recogieron del primer nivel de duna, sin estar asociadas a ninguna estructura de este periodo, y localizándose sobre el primer nivel arqueológico, por lo que podrían corresponder también a restos medievales. La distribución de las especies según su número de restos sería la siguiente:

-Especies principales: Como habíamos visto en el periodo medieval, el taxón del que se conservan más restos es Merluccius merluccius, con cerca del $97 \%$ de las piezas óseas. Asimismo, la importancia de la pesca y comercialización de productos derivados de esta especie va a ser relevante en el yacimiento. Los restos documentados siguen siendo principalmente cefálicos y vértebras precaudales, por lo que estaríamos de nuevo ante los desechos derivados de la manipulación de los individuos para su salado.

-Especies secundarias: Labrus bergy/ta sigue siendo la segunda especie con más restos, lo que la convierte en un recurso importante en la alimentación de la población local desde época romana.

-Especies complementarias: Como habíamos planteado para los restos medievales, se han diferenciado como especies complementarias aquellas con interés comercial en la época. Restos de Sardina pilchardus ya se habían identificado en el periodo anterior, presentando también ahora una problemática similar debido al escaso número de restos presente. El otro taxón es Pollachius pollachius que, aun cuando se hayan identificado pocos restos en este yacimiento como en otros del mismo periodo, según se desprende de las fuentes documentales era una especie de interés comercial, tratándose para su conservación igual que Merluccius merluccius (Cornide, 1788). Esto no parece que tenga relación con problemas de sesgo en los muestreos, ya que Pollachius pollachius presenta unas características óseas encuanto a tamaño y osificación similares a las de Merluccius merluccius, pudiendo deberse a otros motivos de índole económico o medioambiental.

-Especies anecdóticas: Por último, el número de especies representadas por un único resto es mayor que en el periodo medieval. De este modo, además de Pagrus pagrus, hay presencia de Sparus aurata, Zeus faber, Scomber japonicus, Scomber scombrus y Symphodus melops. Este conjunto es muy similar a las especies identificadas en el periodo romano. De nuevo estaríamos ante una explotación destinada al consumo local o al comercio a corta distancia, siendo posible que en algún caso su captura estuviera relacionada con aquellas de mayor valor comercial. 


\section{Representatividad ósea.}

Las especies para las que se han conservado restos cefálicos son aquellas que presentan una mayor osificación (Roselló, 1989: 592-605), principalmente de los huesos mandibulares, que a su vez son los mejor representados en estas muestras. Sin embargo, la ausencia de restos cefálicos de algunas especies, incluso de restos post-cefálicos, puede deberse a los problemas derivados del tipo de muestreo empleado, como ya comentamos anteriormente.

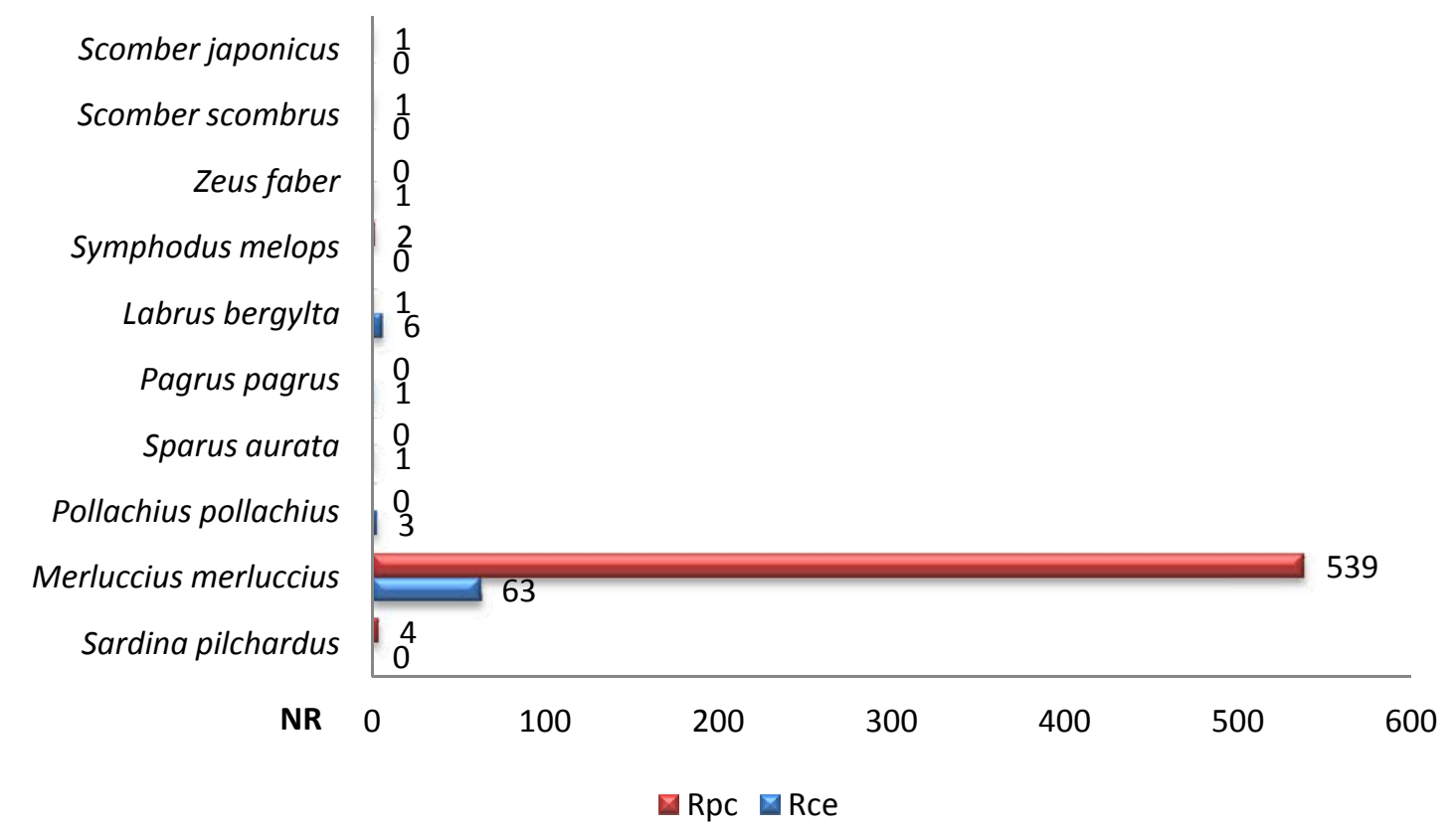

Fig. 85 Comparación numérica de los restos cefálicos y postcefálicos de los taxones identificados.

Como para la Edad Media, la especie a la que se asignan la mayoría de los restos es Merluccius merluccius, con una representación anatómica también similar a la vista para el periodo precedente. Por lo tanto consideramos que reflejarían la misma actividad conservera que comentamos en el apartado anterior.

Pollachius pollachius únicamente está representado por restos cefálicos, lo que podría referenciar un tratamiento similar al empleado para Merluccius merluccius, ya que como apunta Cornide (1788), esta especie contaba con cierto valor comercial y sería objeto del mismo tratamiento para su conservación. De todos modos, los pocos restos identificados nos impiden asegurar está práctica.

El limitado número de restos asignado al resto de especies, así como el sesgo detectado, nos impide valorar la aplicación de cualquier tipo de tratamiento para su consumo o conservación. 


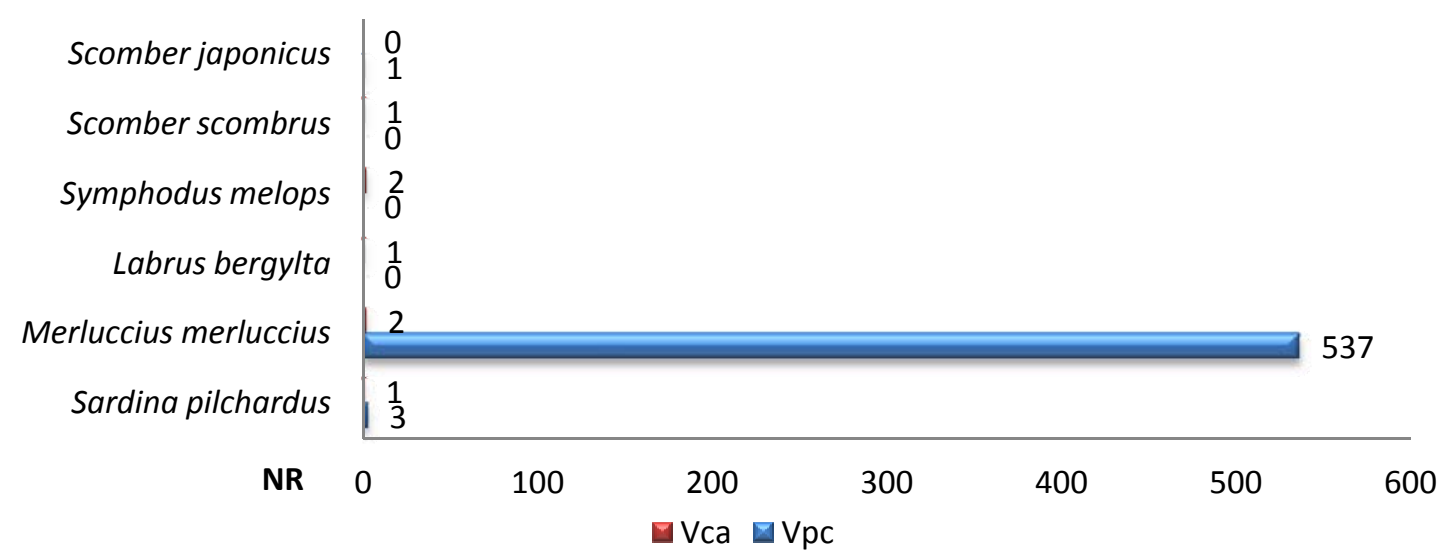

Fig. 86 Comparación numérica de las vértebras caudales y precaudales de los taxones identificados.

\section{V.1.6. CONSIDERACIONES FINALES.}

Durante la ocupación en época romana del yacimiento de Punta Atalaia parece que la explotación se ha centrado en especies localizadas en el entorno más inmediato, en la zona nerítica. Se explotarían tanto sustratos rocosos como arenosos, aunque van a ser las especies del primero las que tengan mayor importancia. En el estudio arqueomalacológico también pudimos constatar la preferencia por especies rocosas, llegando a suponer el $99 \%$ de la muestra (Fernández Rodríguez et alii, 2008; González Gómez de Agüero, 2009; González Gómez de Agüero et alii, 2011). La presencia de especies de zonas de arena y fango reaviva la cuestión referente a la presencia de playas y el istmo de arena, aunque es factible la pesca de estas especies en las cercanías del yacimiento por la situación del río Covo.

Parece existir cierta especialización en la captura de una especie, Labrus bergy/ta, que se va a convertir en el recurso principal. Esta especie es sedentaria y muy territorial, localizándose cerca de la costa, lo que podría explicar su importancia, ya que en un principio sería un recurso fácil de conseguir. Algo similar pudimos observar en el registro malacológico, donde Patella sp. supone el $82 \%$ del conjunto (Fernández Rodríguez et alii, 2008; González Gómez de Agüero, 2009; González Gómez de Agüero et alii, 2011).

En la zobna de poblado contamos con una serie de taxones, de carácter pelágico, que prácticamente no están representados en el conchero, pero que sin embargo, van a ser muy numerosos en el Solar 02. Además de las problemáticas que presentan estas especies, y que ya comentamos anteriormente, su presencia podría responder a factores estacionales. Especies pelágicas como Sardina pilchardus y Trachurus trachurus se acercan a la costa en primavera y verano, por lo que su captura se produce en momentos muy concretos. Por otro lado, estas especies forman grandes cardúmenes, por lo que su captura con redes produciría un gran rendimiento en poco tiempo. 
Otro motivo que puede explicar las diferencias taxonómicas de los conjuntos es la evolución de la actividad pesquera en el asentamiento. Pese a las particularidades que presenta el conchero, su composición es semejante a la constatada para los depósitos en otros yacimientos de cronología prerromana. Sin embargo, la fauna marina del Solar 02 tendría más relación con momentos más avanzados del dominio romano. A este respecto, hay que destacar el elevado número de restos de Merluccius merluccius identificados en el Solar 02. Esta especie es poco relevante en el mundo prerromano, igual que en el conchero de Punta Atalaia, y sin embargo parece que en el mundo romano va a cobrar cierta importancia, como se desprende de yacimientos como la Casa Martelo en A Coruña, datados entre el siglo II y III d.C. Por lo tanto, es probable que el proceso romanizador modifique los patrones de consumo y las técnicas de explotación atendiendo a nuevos gustos y necesidades. En este sentido es interesante ver el papel que jugó el asentamiento de Punta Atalaia, ya que parece corresponder a un puerto de cabotaje en la ruta cantábrica, y por lo tanto muy vinculado al comercio.

Ambos conjuntos, conchero y Solar 02, presentan una gran variedad de taxones, siendo los espáridos los que más especies aportan, aunque no van a ser los que más restos presenten. Los pescados blancos van a ser mucho más importantes que el azul en el conchero, aunque en general ambos presenten unos valores similares. En el mundo romano, la explotación de pescado azul cobra mucha importancia debido a la elaboración de salsamentas y conservas para su comercialización. En este caso, no estamos ante una estructura productiva, sino ante un poblado de tradición indígena, lo que explicaría las similitudes del conjunto con lo observado en yacimientos prerromanos. De todos modos, el pescado en el mundo romano, ya sea en conserva o fresco, va a jugar un papel muy importante en la dieta, principalmente de núcleos urbanos.

Por lo tanto, ¿qué papel está jugando la pesca en las actividades económicas del castro?, ¿'es autoconsumo o también existe comercio?. Parece clara la comercialización de moluscos desde los diferentes asentamientos costeros con el interior, principalmente de ostras, por lo que resulta lógico pensar que también existiría un comercio a pequeña escala de pescado, tanto fresco, a corta distancia, como en conserva. El problema para evaluar esta hipótesis es la práctica inexistencia de información ictiofaunísitica en los yacimientos de interior.

Por otro lado, también se nos plantea otra cuestión, y es la relación de estos asentamientos con las industrias salazoneras y las capturas de ciertas especies pelágicas. Estas últimas se producirían para un consumo o un comercio propio, o para abastecer a estas instalaciones. De todos modos, algunas especies, como Trachurus trachurus, parecen haber estado sometidas a tratamientos de conservación, aunque los restos con los que contamos son aún muy escasos. La presencia en el conchero únicamente de vértebras caudales, y en el Solar 02 principalmente de restos cefálicos y vértebras precaudales, nos recuerda a un patrón muy similar al observado durante la Edad Media y la Edad Moderna 
para el salado de Merluccius merluccius, realizándose también estos tratamientos en la Edad Moderna con los ejemplares más grandes de Trachurus trachurus (Cornide, 1788). La captura de estas especies pelágicas plantea a su vez el problema de su conservación, ya que durante un determinado periodo del año se consiguen capturar un número muy elevado de ejemplares, siendo necesario un consumo rápido o un tratamiento conservero.

Parece clara la utilización de redes para la pesca, así como diferentes aparejos con anzuelos. Es interesante la presencia de restos de Zeus faber, pez solitario que se encuentra entre la costa y los $200 \mathrm{~m}$ de profundidad; actualmente se pesca con artes de arrastre y con palangre. Su presencia en yacimientos romanos puede estar reflejando la aparición de nuevas artes o nuevos aparejos, que por un lado serían más productivos, y que por otro lado permitirían la captura de nuevas especies. De todos modos la ausencia de esta especie en yacimientos prerromanos puede estar vinculada a la ubicación de estos asentamientos. Los depósitos en los que tenemos restos de ictiofauna de la Edad del Hierro estudiada se sitúan en la costa atlántica, principalmente en el interior de las rías, mientras que los galaico-romanos se sitúan en zonas exteriores. Como pudimos constatar en la malacofauna (González Gómez de Agüero y Bejega García, 2011), y parece suceder también en la ictiofauna (Capítulo VI.1.1.), la situación del asentamiento va a influir en la fauna representada. Algo similar podemos decir para Pollachius pollachius, que en Punta Atalaia alcanza valores cercanos al 10\%, mientras que en época prerromana únicamente se documentó un resto en O Achadizo (Ferré et alii, 1996; Ferré, 2003).

Los salmónidos no suele ser muy habituales en los yacimientos del noroeste peninsular. Esto puede deberse a la fragilidad de los elementos anatómicos de especies como Salmo salar, en su mayor parte compuestos por cartílago. Por otro lado, tampoco parece que sea reflejo de una explotación sistemática del medio fluvial, sino que debe estar relacionado con pescas casuales en el mar en momentos de migración de estas especies.

Durante la Edad Media se pueden observar toda una serie de cambios sustanciales. De este modo, va a aparecer una importante industria de procesado y salado de Merluccius merluccius, seguramente desde la Baja Edad Media. Además, aunque el registro sea un poco exiguo, se van a capturar otras especies de importante valor comercial como Sardina pilchardus o Conger conger. Con estas especies se va a asentar la actividad pesquera de los mareantes, que aparecerán perfectamente conformados desde la primera mitad del siglo XIV (Ferreira Priegue, 1998; 2009). Estas Cofradías de mareantes son organizaciones colectivas que se van a especializar en la obtención de estas especies, incorporando nuevas artes de pesca que van a permitir aumentar las capturas, así como alejarse más de la costa (Ferreira Priegue, 1998; 2009). Ejemplo de la incorporación de estas mejoras técnicas, tanto a nivel de naves como de aparejos, es la abundancia de Merluccius merluccius, que en periodos anteriores aparece con un número más bajo. Sabemos que estas especies eran objeto de conservas, aunque únicamente hemos podido 
constatar la realización de esta actividad en una de las mismas, Merluccius merluccius, que además parece ser la que centra principalmente la actividad pesquera. Como ya comentamos con anterioridad, la presencia de vértebras precaudales y restos cefálicos sugiere que estamos ante el resultado del producto de la limpieza de los ejemplares para su salado, coincidiendo con la descripción que hace de este proceso Joseph Cornide (1788) en el siglo XVIII; práctica que, de ser correcta nuestra interpretación, se remontaría a la Edad Media.

Así mismo, encontramos un número variable de especies muy similares al constatado en el conjunto romano, si bien con un número menor de restos, tanto en términos relativos como absolutos. Esta pesca parece haberse realizado en el entorno del yacimiento, siendo la especie mejor representada Labrus bergylta. La captura de estas especies marcaría cierta continuidad desde el cambio de Era, siendo reflejo de la pesca realizada por los denominados desde la Edad Media como "pescadores". Estos no están organizados como los mareantes, y desarrollan su actividad cerca de la costa, utilizando pequeñas embarcaciones y artes y aparejos tradicionales como el trasmallo, la línea de anzuelos o el palangre (Ferreira Priegue, 1998; 2009). La productividad de esta actividad es muy escasa, y se destinaría mayoritariamente al autoconsumo, aunque también estaría enfocada al comercio de pescado fresco en los mercados más cercanos (Ferreira Priegue, 1998; 2009).

En cuanto al registro de la Edad Moderna, aunque varíen algunas de las especies, se puede seguir observando esta dualidad en cuanto a la economía pesquera.

En general parece que el pescado blanco es el que cobra una mayor importancia tanto el periodo medieval como moderno, bien por sus mejores condiciones para su salado y secado a la hora de comercializarlo, caso de Merluccius merluccius, Pollachius pollachius y Conger conger, como por ser un recurso de fácil acceso como Labrus bergylta o Pagrus pagrus. Sin embargo, especies de pescado azul como Trachurus trachurus o Sardina pilchardus, van a jugar también un papel significativo. Según las fuentes va a ser esta segunda la que cobre un papel fundamental durante este periodo (Cornide; 1788; Ferreira Priegue, 1998; 2009), sin embargo, los problemas de registro del yacimiento nos impiden constatar este aspecto. 


\section{V.2. El Poblado de AREA.}

\section{V.2.1. LOCALIZACIÓN.}

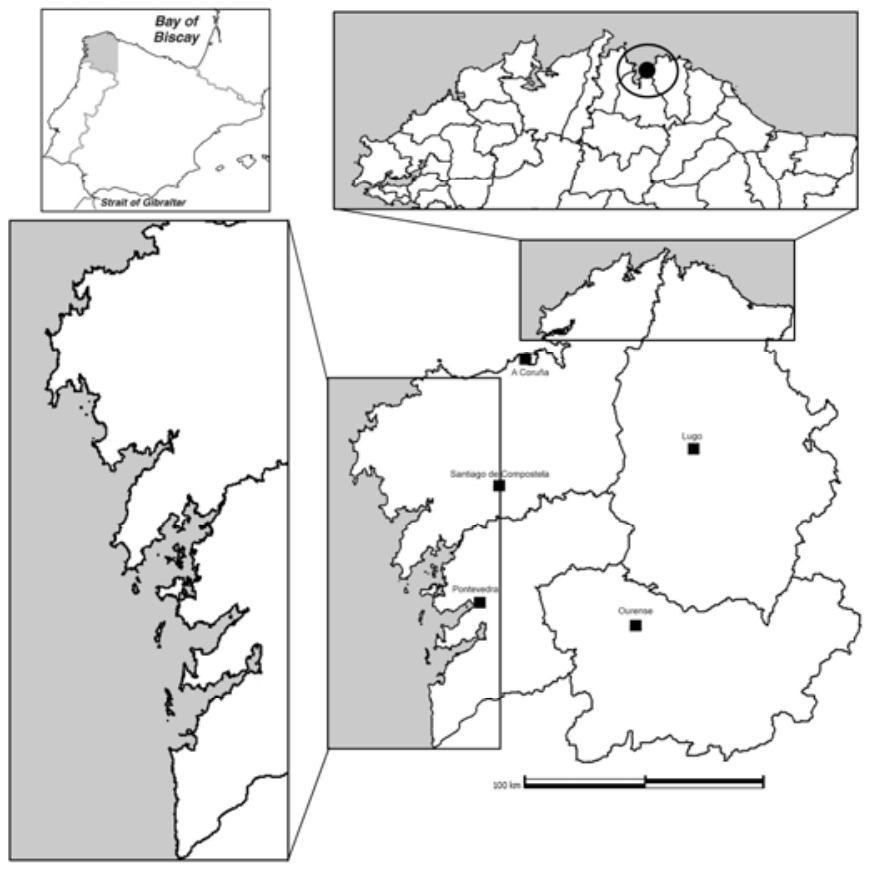

El yacimiento está localizado en Augadoce, parroquia de San Xiao de Faro, en el Concello de Viveiro, Lugo. Se sitúa en la playa de Area, que forma una ensenada en la boca de la Ría de Viveiro. Sus coordenadas geográficas son $7^{\circ} 34^{\prime} 34.88^{\prime \prime} \mathrm{W}$ y $43^{\circ}$ $41^{\prime} 42.08^{\prime \prime} N^{2}$. Podríamos adscribirlo a los yacimientos litorales.

Fig. 87 Localización del yacimiento de Area.

\section{V.2.2. DESCRIPCIÓN DEL YACIMIENTO.}

En 1951 unos temporales dejaron al descubierto en la playa de Area una serie de restos arqueológicos de época romana, que fueron señalados como pertenecientes a una factoría de salazón, con piletas recubiertas por opus signinum y la utilización de cuarto de bocel para las esquinas (Vázquez Seijas, 1952; Fernández Ochoa y Martínez Maganto, 1994).

El primer estudio de la fauna de este yacimiento procede de un basurero documentado en 1996 durante los trabajos realizados para la construcción del paseo marítimo (Ferré y Rey, 2001; Ferré, 2003). Aunque en un principio se pensó que estos restos podrían corresponder a época romana vinculados a la factoría de salazón, la cerámica asociada adscribe el depósito a la Baja Edad Media, entre los siglos XIV-XV d.C. (Ferré y Rey, 2001; Ferré, 2003).

En el 2007 se realizaron ocho catas con el objetivo de realizar una caracterización y delimitación del yacimiento (Ramil González, 2008). Con esta intervención se pudo confirmar la presencia de una villa romana tardía con una parte residencial y otra productiva destinada a la realización de salazones. Encima de esta villa, se registró un poblado medieval. La parte productiva de la villa se sitúa en la playa, mientras la zona residencial se ubica en una parcela contigua, donde también se localiza el asentamiento

\footnotetext{
${ }^{2}$ Datum: ETRS89; Uso: 29; UTM: X 614.723/Y 4.838.985.
} 
medieval (Ramil González, 2008). Durante el proceso de sondeos de este asentamiento prácticamente no se tocaron los niveles romanos por motivos de seguridad (Ramil González, 2008). Las cuadrículas excavadas tenían unas dimensiones de $3 \times 3 \mathrm{~m}$, excepto el cuadro 3 que era de $2 \times 2 \mathrm{~m}$.

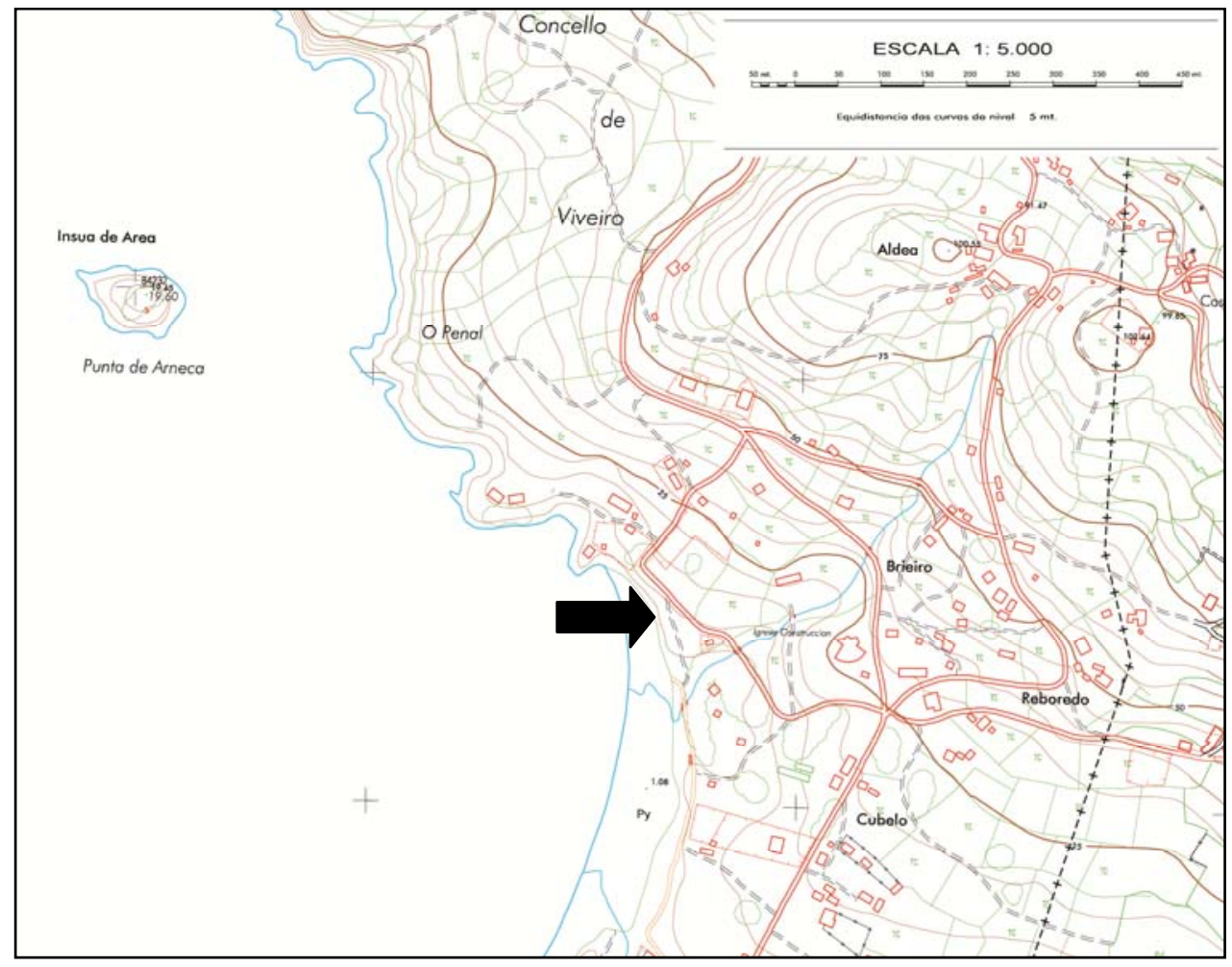

Fig. 88 Topográfico 1:5.000 de Area y localización de las intervenciones. (Extraído de http://sitga.xunta.es/sitga).

\section{V.2.3. RECOGIDA DE LAS MUESTRAS.}

Los materiales estudiados en el presente trabajo proceden todos ellos de las excavaciones realizadas en el año 2007. Además, se va a tener en cuenta a la hora de realizar una valoración general del yacimiento, los estudios realizados en las muestras del basurero descubierto en 1996.

\section{V.2.3.1. RELACIÓN ESTRATIGRÁFICA.}

-Nivel 1: Formado por dos capas modernas, una de sedimentación natural y otra de basura contemporánea. Ocupa toda la superficie del área excavada.

Capa 1: Colmatación de arena de playa con raíces del manto vegetal que cubre el yacimiento, con una potencia entre $10-14 \mathrm{~cm}$.

Capa 2: Restos de obra y basura contemporánea, con una potencia máxima de $23 \mathrm{~cm}$.

-Nivel 2: Nivel natural formado por capas de sedimentación de arena de playa. 
Capa 3: Arena de playa de color gris claro con una potencia entre $8-18 \mathrm{~cm}$.

Capa 4: Arena de playa de color gris oscuro con una potencia que varía entre $24-65 \mathrm{~cm}$.

-Nivel 3: Nivel que engloba la ocupación medieval, formado por una capa de tierra de color marrón oscuro y con derrumbes de piedra de los muros, con una potencia de 70 $74 \mathrm{~cm}$

Capa 5: Tierra de color oscuro con material variado: cerámica, huesos, conchas e hierros; tiene una potencia de $10-30 \mathrm{~cm}$.

-Nivel 4: Correspondiente a la ocupación romana, formado por dos capas.

Capa 6: Derrumbe de los muros romanos con una potencia de $90-95 \mathrm{~cm}$.

Capa 7: Tierra marrón oscura, con carbones.

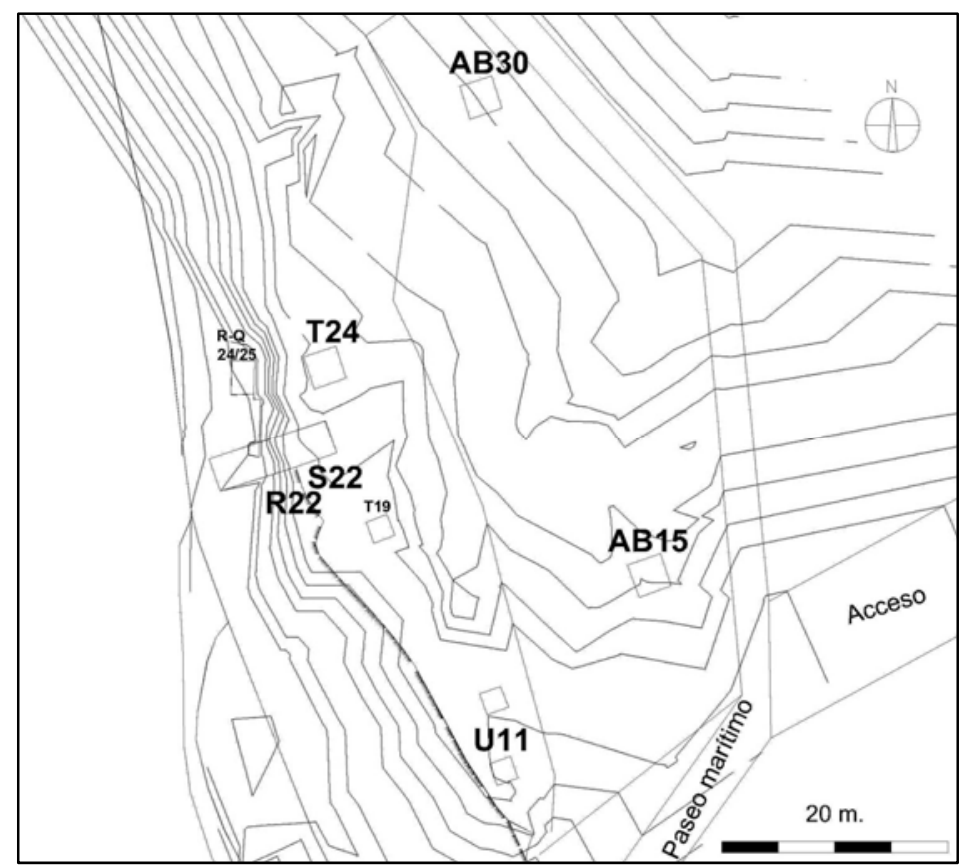

Fig. 89 Localización de los sondeos de 2007 en el poblado de Area (Plano facilitado por Emilio Ramil).

\section{V.2.3.2. EL MUESTREO.}

Aunque era abundante el material ictiológico y malacológico, este no formaba una aglomeración que permitiera definir una concentración en una unidad estratigráfica ni de un conchero. Por este motivo, y ante la dificultad de recuperar los fragmentos de menor tamaño, se procedió a la toma de varias muestras concentradas y alguna muestra selectiva, recogiendo los restos visibles y el sedimento del entorno.

\section{V.2.3.3. CRONOLOGÍA.}

Carecemos de una cronología precisa para las muestras, aunque se pueden adscribir a groso modo bien a época romana o bien a época medieval. En cuanto a los 
niveles romanos, se documentaron dos fragmentos de sigillata hispánica tardía en los niveles de contacto con la fase ocupacional medieval. Por lo que se refiere a los restos medievales, se documentaron una moneda del siglo XI d.C. y otra del siglo XV d.C. (Ramil González, 2008).

\section{V.2.4. ESTUDIO ICTIOARQUEOLÓGICO.}

\section{V.2.4.1. SECTOR U11.}

\section{Capa 3 (Colmatación natural).}

\begin{tabular}{cccc} 
& $\begin{array}{c}\text { Pmx } \\
\text { (D/S) }\end{array}$ & NR & NMI \\
\hline Merluccius merluccius & $1 / 0$ & $\mathbf{1}$ & 1 \\
\hline \hline TOTAL & $\mathbf{1}$ & $\mathbf{1}$ &
\end{tabular}

Tabla 63 Relación de especies y representación ósea de la Capa 3 del Sector U11.

Se ha documentado un único resto, un premaxilar derecho de Merluccius merluccius.

\section{V.2.4.2. SECTORAB15.}

Capa 3 (Colmatación natural).

\begin{tabular}{lcccc} 
& Vpc & Rce & NR & NMI \\
\hline Merluccius merluccius & 1 & & $\mathbf{1}$ & 1 \\
Indeterminado & & 1 & $\mathbf{1}$ & \\
\hline \hline \multicolumn{1}{c}{ TOTAL } & $\mathbf{1}$ & $\mathbf{1}$ & $\mathbf{2}$ &
\end{tabular}

Tabla 64 Relación de especies y representación ósea de la Capa 3 del Sector AB15.

En esta muestra únicamente se han recuperado una vértebra precaudal de Merluccius merluccius y un fragmento cefálico que no se ha podido identificar anatómicamente.

\section{Capa 4 (Edad Media).}

\begin{tabular}{lcccc} 
& Vpc & Rpc & NR & NMI \\
\hline Merluccius merluccius & 5 & & $\mathbf{5}$ & 1 \\
Indeterminado & & 4 & $\mathbf{4}$ & \\
\hline \hline TOTAL & $\mathbf{5}$ & $\mathbf{4}$ & $\mathbf{9}$ &
\end{tabular}

Tabla 65 Relación de especies y representación ósea de la Capa 4 del Sector AB15.

Presencia de cinco vértebras precaudales de Merluccius merluccius y cuatro restos post-cefálicos identificados como fragmentos de espina.

\section{Capa 5 (Periodo romano).}

\begin{tabular}{cccc} 
& $\begin{array}{c}\text { Pop } \\
\text { (D/S) }\end{array}$ & NR & NMI \\
\hline Zeus faber & $1 / 0$ & $\mathbf{1}$ & 1 \\
\hline \hline TOTAL & $\mathbf{1}$ & $\mathbf{1}$ &
\end{tabular}

Tabla 66 Relación de especies y representación ósea de la Capa 5 del Sector AB15. 
En la Capa 5 únicamente se recuperó un preopercular derecho de Zeus faber.

\section{V.2.4.3. SECTORS22.}

\section{Capa 5 (Edad Media).}

\begin{tabular}{lcccc} 
& Vca & Rpc & NR & NMI \\
\hline Dicentrarchus labrax & 4 & & $\mathbf{4}$ & 1 \\
Trachurus trachurus & 2 & & $\mathbf{2}$ & 1 \\
Indeterminado & & 3 & $\mathbf{3}$ & \\
\hline \multicolumn{1}{c}{ TOTAL } & $\mathbf{6}$ & $\mathbf{3}$ & $\mathbf{9}$
\end{tabular}

Tabla 67 Relación de especies y representación ósea de la Capa 5 del Sector S22.

Se recuperaron cuatro vértebras caudales de Dicentrarchus labrax y dos vértebras caudales de Trachurus trachurus. Además de estas piezas vertebrales, también se contabilizaron tres fragmentos post-cefálicos. Tanto Dicentrarchus labrax como Trachurus trachurus, están representados por un individuo para cada especie.

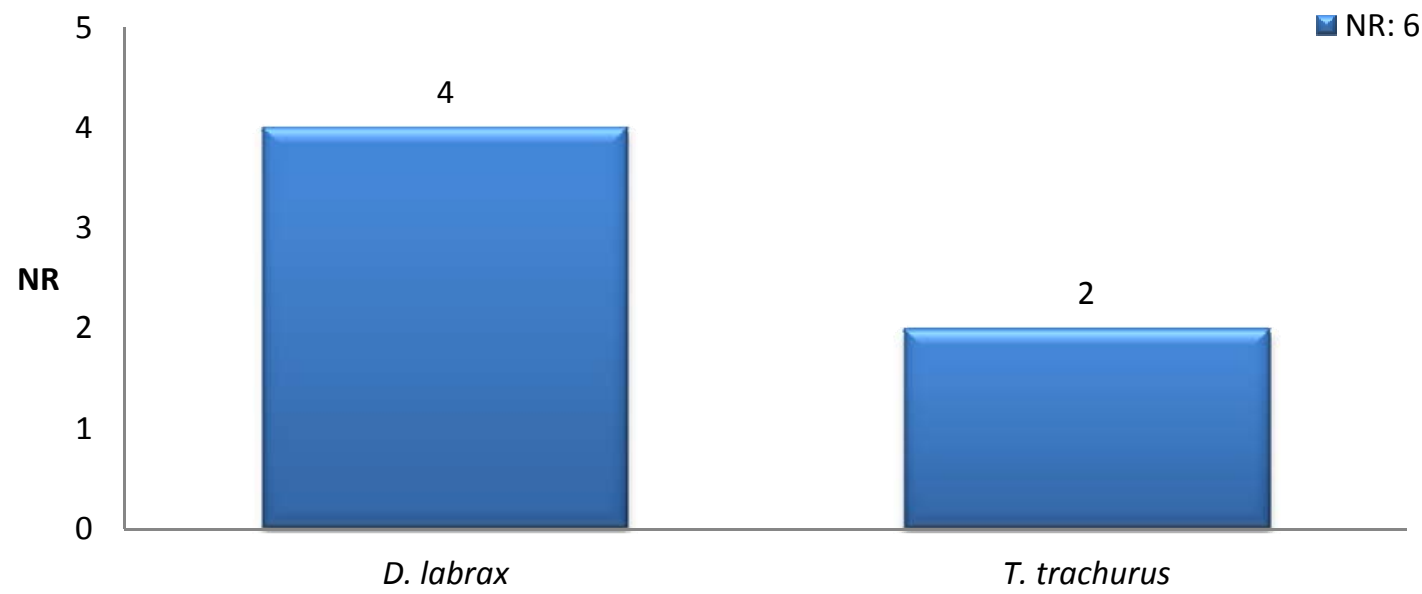

Fig. 90 Distribución de taxones identificados en la Capa 5 del Sector S22 según el NR.

\section{V.2.4.4. SECTORT24.}

\section{Capa 4 (Edad Media).}

\begin{tabular}{|c|c|c|c|c|c|c|c|c|c|}
\hline & $\begin{array}{l}\text { Max } \\
\text { (D/S) }\end{array}$ & $\begin{array}{l}\text { Pmx } \\
\text { (D/S) }\end{array}$ & $\begin{array}{l}\text { Dnt } \\
\text { (D/S) }\end{array}$ & Vpc & Rce & Rpc & Esa & NR & NMI \\
\hline Merluccius merluccius & $1 / 0$ & $0 / 4$ & $1 / 0$ & 6 & & & & 12 & 4 \\
\hline Indeterminado & & & & & 5 & 6 & 27 & 38 & \\
\hline TOTAL & 1 & 4 & 1 & 6 & 5 & 6 & & 50 & \\
\hline
\end{tabular}

Se identificó una única especie, Merluccius merluccius, representada por un maxilar derecho, cuatro premaxilares izquierdos, un dentario derecho y seis vértebras precaudales. 


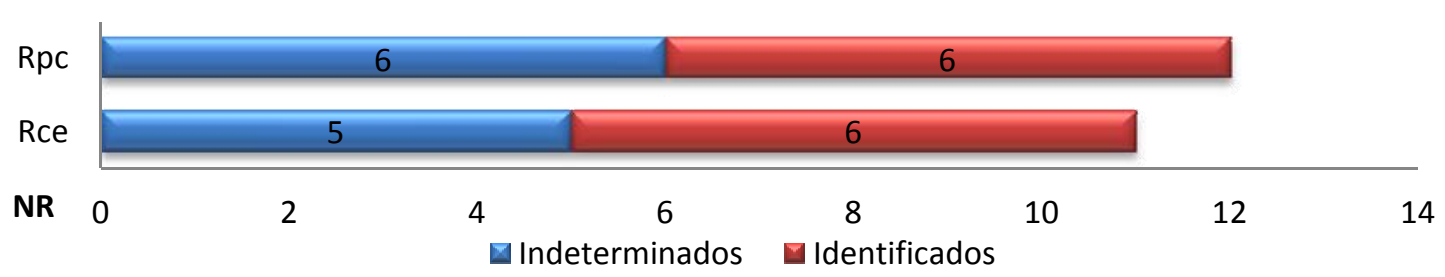

Fig. 91 Distribución esquelética de los restos ícticos de la Capa 4 del Sector T24.

Además de estos restos identificados, se recuperaron cinco fragmentos pertenecientes a la estructura cefálica y seis restos post-cefálicos. Entre los identificados, restos cefálicos y post-cefálicos presentan el mismo valor. Llama la atención la presencia de un elevado número de escamas, contrastando con otras muestras donde el número de especies o de restos es superior y no aparecen escamas.

\section{V.2.4.5. SECTORAB30.}

\section{Capa 4 (Edad Media).}

\begin{tabular}{|c|c|c|c|c|c|c|c|c|c|c|c|c|c|}
\hline & $\begin{array}{l}\text { Max } \\
\text { (D/S) }\end{array}$ & $\begin{array}{l}\text { Pmx } \\
\text { (D/S) }\end{array}$ & $\begin{array}{l}\text { Dnt } \\
\text { (D/S) }\end{array}$ & $\begin{array}{l}\text { Hmd } \\
\text { (D/S) }\end{array}$ & $\begin{array}{l}\text { Pop } \\
\text { (D/S) }\end{array}$ & $\begin{array}{l}\text { Opc } \\
\text { (D/S) }\end{array}$ & $\mathrm{Vpc}$ & Vca & Rce & Rpc & Esa & NR & NMI \\
\hline Merluccius merluccius & $1 / 2$ & $2 / 4$ & $1 / 3$ & $1 / 0$ & & $1 / 0$ & 40 & 1 & & & & 56 & 4 \\
\hline Pollachius pollachius & $1 / 0$ & & & & & & & & & & & 1 & 1 \\
\hline Pagellus bogaraveo & & & & & $0 / 1$ & & & & & & & 1 & 1 \\
\hline Pagellus acarne & & & & & & & & 1 & & & & 1 & 1 \\
\hline Trigla lyra & $1 / 0$ & & $1 / 0$ & $1 / 0$ & & $2 / 0$ & 3 & & & & & 8 & 2 \\
\hline Indeterminado & & & & & & & & & 162 & 61 & 47 & 270 & \\
\hline TOTAL & 5 & 6 & 5 & 2 & 1 & 2 & 43 & 2 & 162 & 61 & 47 & 337 & \\
\hline
\end{tabular}

Tabla 69 Relación de especies y representación ósea de la Capa 4 del Sector AB30.

En el Sondeo AB30, Capa 4, se recogió una de las muestras con mayor presencia de ictiofauna de todo el yacimiento. En ella se recuperaron tres maxilares, seis premaxilares, cinco dentarios, dos operculares, cuarenta vértebras precaudales y una vértebra caudal de Merluccius merluccius. Además también hemos identificado un maxilar derecho de Pollachius pollachius, un preopercular izquierdo de Pagellus bogaraveo y una vértebra caudal de Pagellus acarne. Por último Trigla lyra está representada por un maxilar, un dentario, un hiomandibular y dos operculares derechos, así como por tres vértebras precaudales. 


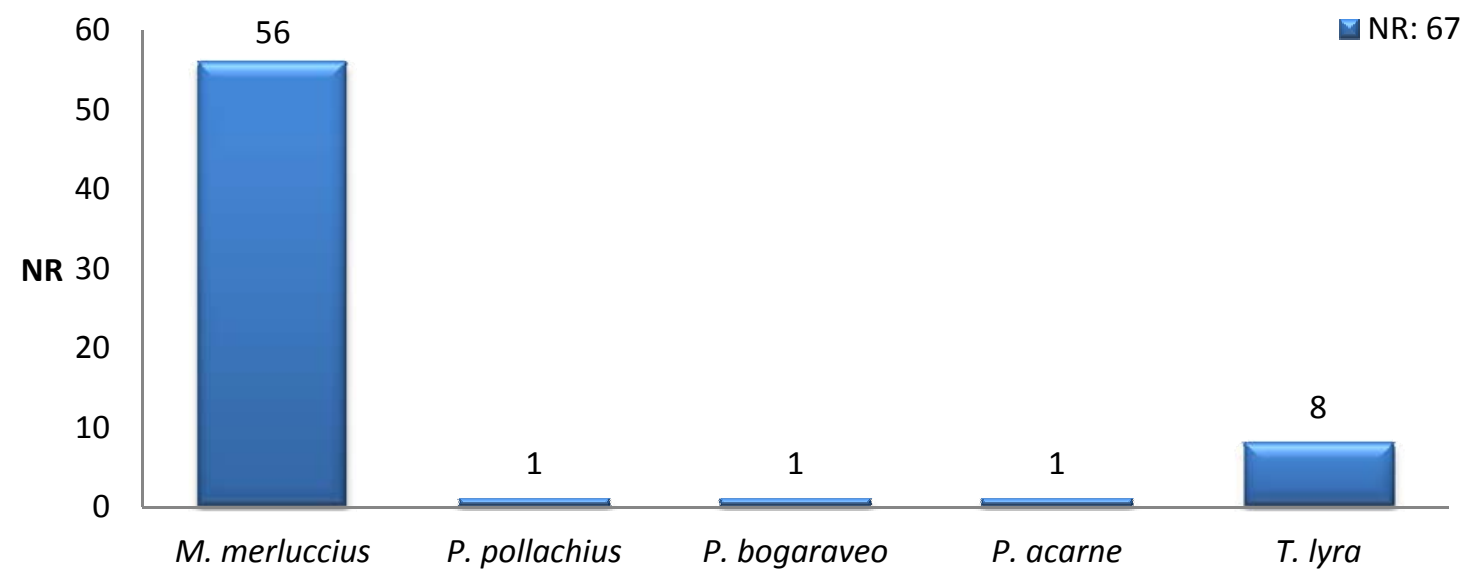

Fig. 92 Distribución de taxones identificados en la Capa 4 del Sector AB30 según el NR.

La especie mejor representada es Merluccius merluccius, tanto en NR (56) como en el NMI, con cuatro ejemplares. Le sigue Trigla lyra con ocho restos. Las demás especies están representadas por un solo resto.

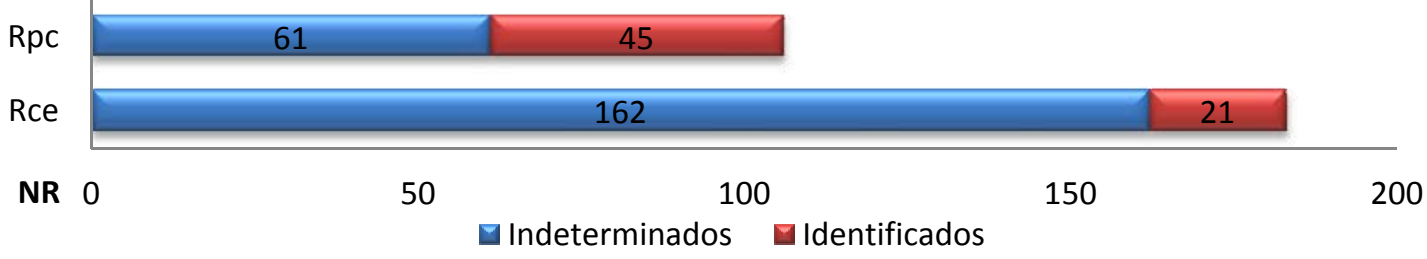

Fig. 93 Distribución esquelética de los restos ícticos de la Capa 4 del Sector AB30.

Entre los restos indeterminados, la mayor parte de las piezas óseas corresponden a fragmentos cefálicos, mientras que en los restos identificados a nivel de especie esto se invierte. Esta distribución no es la más habitual, como hemos documentado en otras muestras y en otros yacimientos, y sin embargo estas proporciones se repiten en las muestras con abundantes restos de Merluccius merluccius. La mayor presencia de restos cefálicos de Trigla lyra puede deberse a una mayor osificación de estos huesos que en otras especies.

\section{V.2.4.6. SECTOR R22.}

\section{Capa 5 (Periodo romano).}

\begin{tabular}{cccc} 
& Rce & NR & NMI \\
\hline Indeterminado & 1 & $\mathbf{1}$ & \\
\hline TOTAL & $\mathbf{1}$ & $\mathbf{1}$ &
\end{tabular}

Tabla 70 Relación de especies y representación ósea de la Capa 5 del Sector R22.

Presencia de un único resto cefálico que no se ha podido identificar anatómicamente. 


\section{Capa 6 (Periodo romano).}

\begin{tabular}{|c|c|c|c|c|c|c|c|c|c|c|c|c|c|}
\hline & $\begin{array}{l}\text { Max } \\
\text { (D/S) }\end{array}$ & $\begin{array}{l}\text { Pmx } \\
\text { (D/S) }\end{array}$ & $\begin{array}{c}\text { Dnt } \\
\text { (D/S) }\end{array}$ & $\begin{array}{c}C d r \\
\text { (D/S) }\end{array}$ & Pal & Vpc & Atl & Vca & Rce & Rpc & Esa & NR & NMI \\
\hline Merluccius merluccius & & $3 / 3$ & $0 / 1$ & $1 / 0$ & & 82 & 4 & 1 & & & & 95 & 4 \\
\hline Labrus bergylta & & & & & 1 & & & 1 & & & & 2 & 1 \\
\hline Sardina pilchardus & & & & & & 3 & & 1 & & & & 4 & 1 \\
\hline Engraulis encrasicholus & $1 / 0$ & & & & & & & & & & & 1 & 1 \\
\hline Pagellus bogaraveo & & & & & & 1 & & & & & & 1 & 1 \\
\hline Pagellus acarne & & & & & & 1 & & 1 & & & & 2 & 1 \\
\hline Zeus faber & $1 / 1$ & $2 / 2$ & & & & & & & & & & 6 & 2 \\
\hline Thunnus sp. & & & & & & & & 1 & & & & 1 & 1 \\
\hline Indeterminado & & & & & & & & & 134 & 85 & 110 & 329 & \\
\hline TOTAL & 3 & 8 & 1 & 1 & 1 & 87 & 4 & 5 & 134 & 85 & 110 & 439 & \\
\hline
\end{tabular}

Tabla 71 Relación de especies y representación ósea de la Capa 6 del Sector R22.

Esta es la muestra con más restos y con mayor variedad de especies de todo el yacimiento. En ella hemos podido recuperar seis premaxilares, un dentario izquierdo, un cuadrado derecho, ochenta y dos vértebras precaudales, cuatro atlas y dos vértebras caudales de Merluccius merluccius. También se han recuperado un palatino y una vértebra caudal de Labrus bergylta; tres vértebras precaudales y una caudal de Sardina pilchardus; un maxilar derecho de Engraulis encrasicholus; una vértebra precaudal de Pagellus bogaraveo; una vértebra precadual y una caudal de Pagellus acarne; y dos maxilares y cuatro premaxilares de Zeus faber.

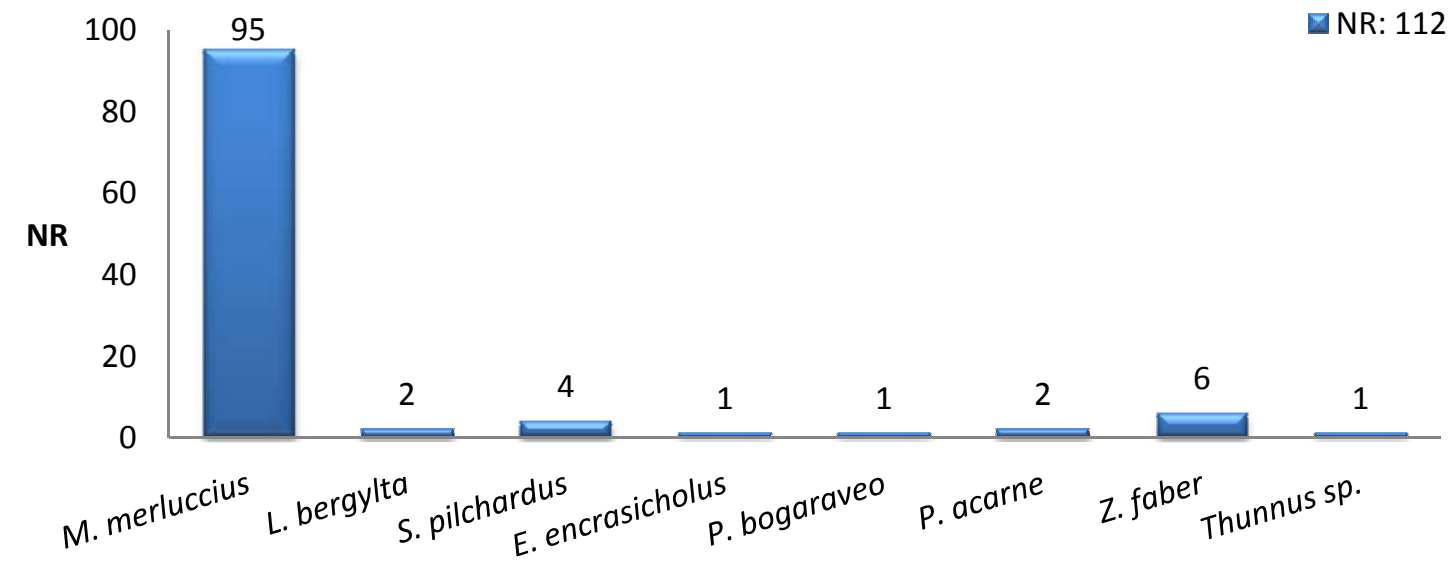

Fig. 94 Distribución de taxones identificados en la Capa 6 del Sector R22 según el NR.

La especie mejor representada es Merluccius merluccius con noventa y seis restos y cuatro individuos. Las demás especies están representadas por un número de restos muy inferior pudiendo distinguir dos grupos: el primero formado por Zeus faber y Sardina pilchardus, con seis y cuatro restos respectivamente. En cuanto a las demás especies, su presencia es mínima, con dos restos de Labrus bergylta y Pagellus acarne, y un único resto de Engraulis encrasicholus y Pagellus bogaraveo. 


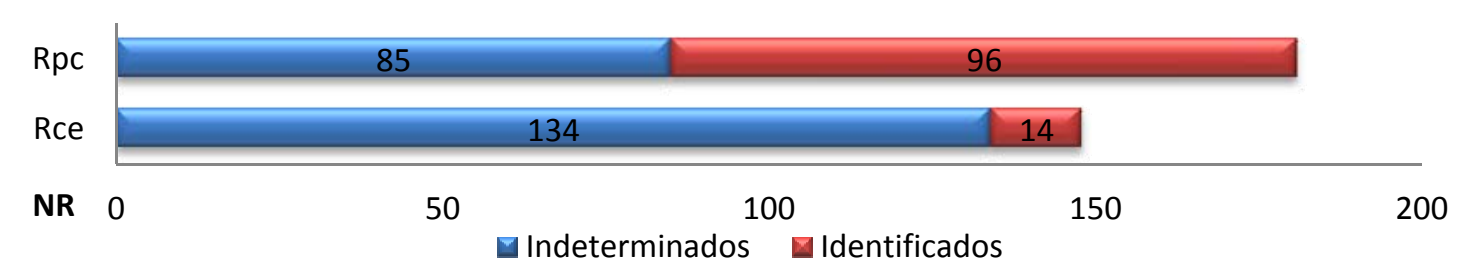

Fig. 95 Distribución esquelética de los restos ícticos de la Capa 6 del Sector R22.

Entre los restos indeterminados, la mayor parte de las piezas óseas se corresponde con fragmentos cefálicos, mientras que entre los identificados a nivel de especie esto se invierte. Esta distribución es similar a lo observado en muestras anteriores, por lo que puede deberse a las mismas causas ya referidas.

\section{V.2.5. COMENTARIO.}

\section{V.2.5.1. ÉPOCA ROMANA.}

De todas las muestras, únicamente tres han sido adscritas a la fase de ocupación romana. Sin embargo, las dos muestras del sondeo R22 creemos que pudieran pertenecer a época medieval. Las especies documentadas, así como su representatividad esquelética, se parecen más a lo documentado en época medieval que para los depósitos romanos. Además, estas muestras se recuperaron sobre un derrumbe de época romana y bajo otro de época medieval (Ramil González, 2008). Debido a esto hemos decidido no agregarla a ninguno de los dos periodos a la espera de que nuevos datos permitan una adscripción cronológica más precisa. En estas muestras predomina Merluccius merluccius, representada principalmente por vértebras precaudales y restos cefálicos, patrón seguramente vinculado a algún tratamiento de conservación, como veremos posteriormente en las muestras medievales.

Entre las demás especies cabe destacar la presencia de Sardina pilchardus, que no aparece en el resto de muestras, así como de Engraulis encrasichoius, identificada por primera vez para las costas gallegas. Del mismo modo también hay que destacar la presencia de una vértebra de Thunnus sp., ya que en Galicia únicamente se han identificado con anterioridad vértebras de esta familia en el yacimiento de la Edad Moderna de A Palma (Ferré, 2003). Por otro lado, Zeus faber sería la segunda especie mejor representada, y aunque la tenemos representada en yacimientos romanos, parece común en yacimientos medievales como la Torre de Hércules o las Torres do Oeste (Ferré, 2003).

Por lo tanto, la única muestra que parece corresponder con seguridad al periodo romano es la recuperada en AB15-C5. En esta se identificó un preopercular derecho de Zeus faber. Aunque como señalamos anteriormente, esta especie es abundante en los yacimientos medievales, también es común en los de época romana, como Punta Atalaia. 
La ausencia de restos de peces en la pileta excavada nos impide poner en relación estos restos con la industria de salazones, sin embargo no podemos descartar su vinculación, ya que se han identificado restos de esta especie en el interior de piletas de salazón en el yacimiento del istmo de Ceuta (Roselló Izquierdo, 1992).

\section{V.2.5.2. EDAD MEDIA.}

\section{Representación faunística.}

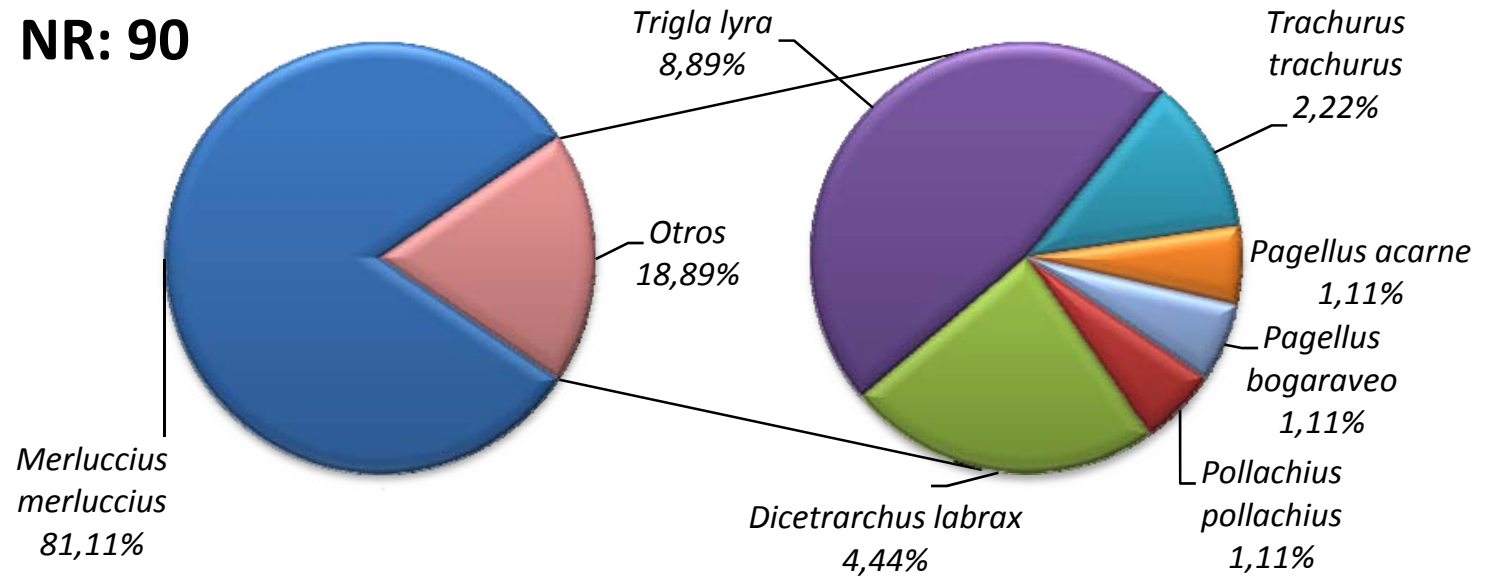

Fig. 96 Representatividad de los taxones de época medieval según el NR.

\begin{tabular}{l|c|c|c|} 
& IC & ID & ICxID \\
\cline { 2 - 4 } Merluccius merluccius & 80 & 81,1 & 6488 \\
Pollachius pollachius & 20 & 1,1 & 22 \\
Dicetrarchus labrax & 20 & 4,4 & 88 \\
Trachurus trachurus & 20 & 2,2 & 44 \\
Pagellus acarne & 20 & 1,1 & 22 \\
Pagellus bogaraveo & 20 & 1,1 & 22 \\
Trigla lyra & 20 & 8,8 & 176
\end{tabular}

Tabla 72 Índices de valoración.

A la hora de valorar los restos procedentes de la excavación realizada en 2007, debemos tener en cuenta varios aspectos. En primer lugar hay que considerar la imprecisión cronológica de las muestras, ya que todos los niveles medievales se sitúan entre el siglo XI y el XV d.C., sin precisar más la cronología de cada capa. De todos modos, ante la similitud faunística del conjunto con las muestras de 1996, podrían reflejar una cronología similar entorno al siglo XIV-XV.

Asimismo hay que tener en cuenta que las muestras, aunque se han agregado a nivel de yacimiento, proceden de sondeos situados en diferentes puntos. $Y$ tampoco hay que olvidar el hecho de que las muestras fueron recogidas de forma visual, sin una estrategia sistemática de muestreo, lo que en cierto modo explicaría el predominio de Merluccius merluccius, siendo mucho más escasos los restos de otras especies de menos dimensiones. Pese a todo esto vamos a exponer brevemente las características generales 
de las muestras procedentes de la excavación, y la importancia de los diferentes taxones presentes:

-Especies principales: Más del $80 \%$ de los restos pertenecen a una única especie, Merluccius merluccius. Su abundancia se debe a dos motivos fundamentales: en primer lugar, y como ya comentamos, el tipo de muestreo realizado tiende a recuperar los restos de mayor tamaño, lo que unido a la ausencia de cribado del sedimento, ocasiona la pérdida de un número importante de restos de un tamaño mucho menor y que no son percibidos de visu. El segundo de los factores es la gran importancia que va a adquirir esta especie en el comercio y consumo de pescado en la Europa cristiana en toda la Edad Media y Moderna. Teniendo en cuenta los restos anatómicos representados, podríamos hablar de un procesado de esta especie con fines comerciales, más que de un consumo local.

-Especies complementarias: Como especies complementarias incluimos al resto de taxones, ya que están todos representados por un número muy reducido de restos. La especie con más piezas óseas es Trigla lyra, que habita en fondos de arena y fango a profundidades mayores de los $40 \mathrm{~m}$. Es posible que su ausencia en yacimientos con una cronología más antigua se deba a la introducción durante la Edad Media de nuevas artes de pesca como el arrastre para la explotación de las especies mercantes. Trachurus trachurus es la única especie pelágica identificada en las muestras. Otras especies como Pagellus acarne, Pagellus bogaraveo y Dicentrarchus labrax, se pescarían cerca de la costa, principalmente en verano y con línea de anzuelos (Cornide, 1788). Tanto Pagellus bogaraveo como Pagellus acarne son habituales y muy importantes en la economía pesquera gallega desde la Edad del Hierro, si bien parece que pierden importancia en época medieval en Galicia frente a la que van a adquirir en otros puntos del Cantábrico, quizás al ser más abundante. En cuanto a Dicentrarchus labrax parece suceder lo contrario, siendo mayor su presencia en los yacimientos medievales. Por último Pollachius pollachius va a tener también cierta importancia comercial durante la Edad Media, aunque al recuperarse un único resto, no es posible valorar el papel de esta especie en la economía del asentamiento. Es probable que estas especies fueran fruto de una pesca realizada en el entorno más inmediato al yacimiento y enfocadas a un consumo local o a un comercio a corta distancia. Alguna de ellas, como Trigla lyra, quizás sean reflejo de una captura casual al realizar la pesca de otras especies como Merluccius merluccius.

\section{Representatividad ósea.}

La mayor parte de los restos documentados, tanto identificados como indeterminados, corresponden al esqueleto post-cefálico. Especies como Trigla lyra, Pagellus bogaraveo o Pollachius pollachius, presentan un número mayor de restos cefálicos, siendo en la última citada los únicos documentados. Esto puede deberse a la 
mayor osificación de determinados huesos de la cabeza, aunque también hay que tener en cuenta el bajo número de piezas que se han identificado.

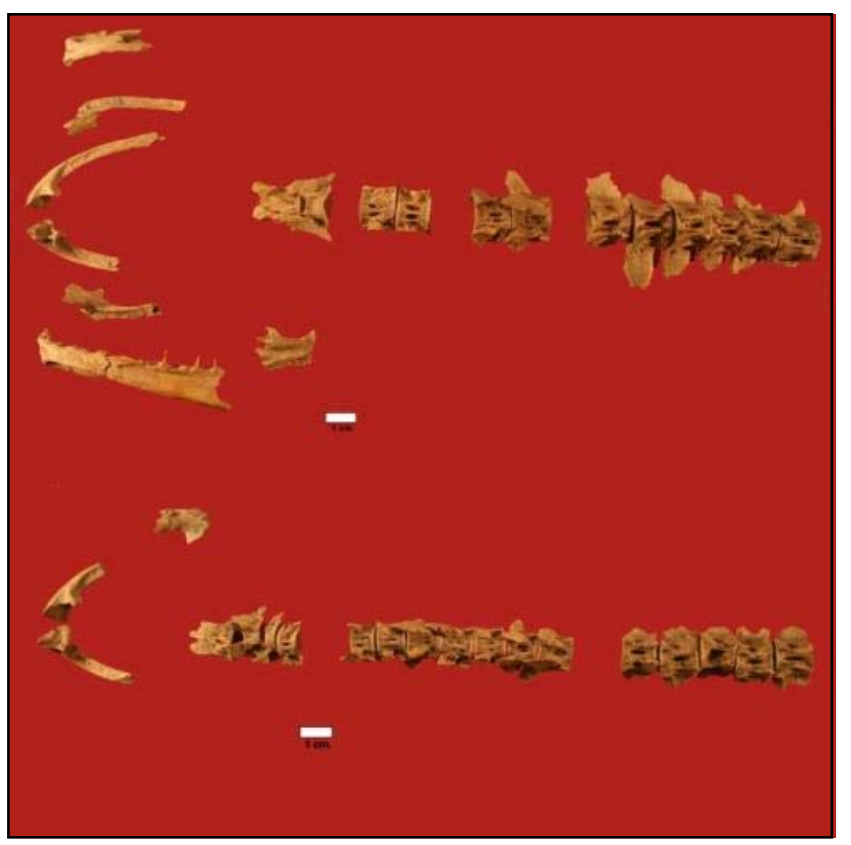

Fig. 97 Huesos cefálicos y vétebras precaudales de Merluccius merluccius.

En el caso de Merluccius merluccius, que es el taxón con mayor presencia, encontramos un número elevado de huesos cefálicos, así como casi exclusivamente vértebras precaudales. Este patrón parece corresponder con el procesado del animal para realizar su conservación. Según Joseph Cornide (1788), el tratamiento de esta especie para su secado se realiza cortándole la cabeza, abriéndola hasta el ano, y eliminando la espina. Si bien este tratado es casi de finales del siglo XVIII, los restos arqueológicos de este yacimiento reflejan, unos siglos antes, la utilización de una técnica similar a la descrita. De este modo las cabezas y vértebras precaudales quedarían en el lugar donde se realizan los trabajos de conservación, mientras que las vértebras caudales acompañarían al ejemplar hasta su destino de consumo.

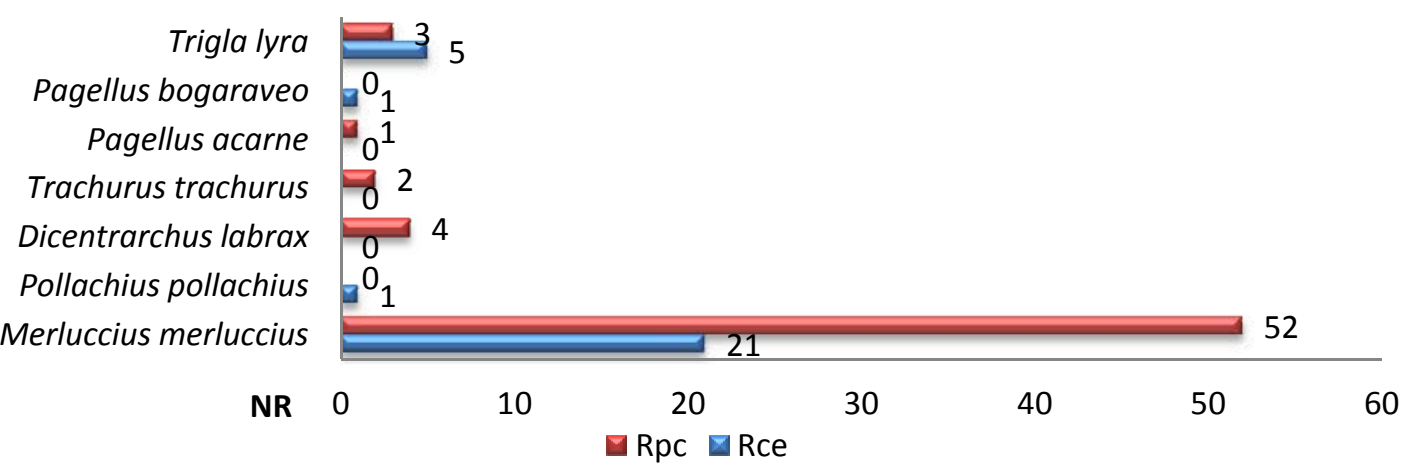

Fig. 98 Comparación numérica de los restos cefálicos y post-cefálicos de los taxones identificados.

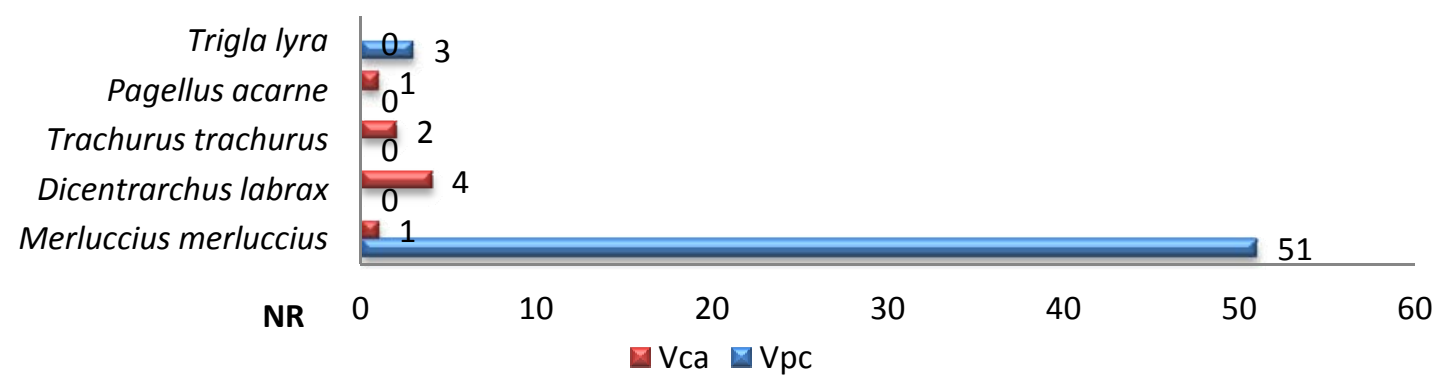

Fig. 99 Comparación numérica de las vértebras caudales y precaudales de los taxones identificados. 


\section{V.2.6. OTROS ANÁLISIS.}

\section{Localización y cronología.}

Los materiales fueron recuperados al realizar las obras del paseo marítimo, descubriendo un depósito con abundante cerámica, así como restos de macromamíferos, conchas y peces. El análisis de la cerámica sitúa los restos en el periodo Bajomedieval, entre los siglos XIV-XV d.C. (Ferré y Rey, 2001; Ferré, 2003).

\section{Estudio ictiológico.}

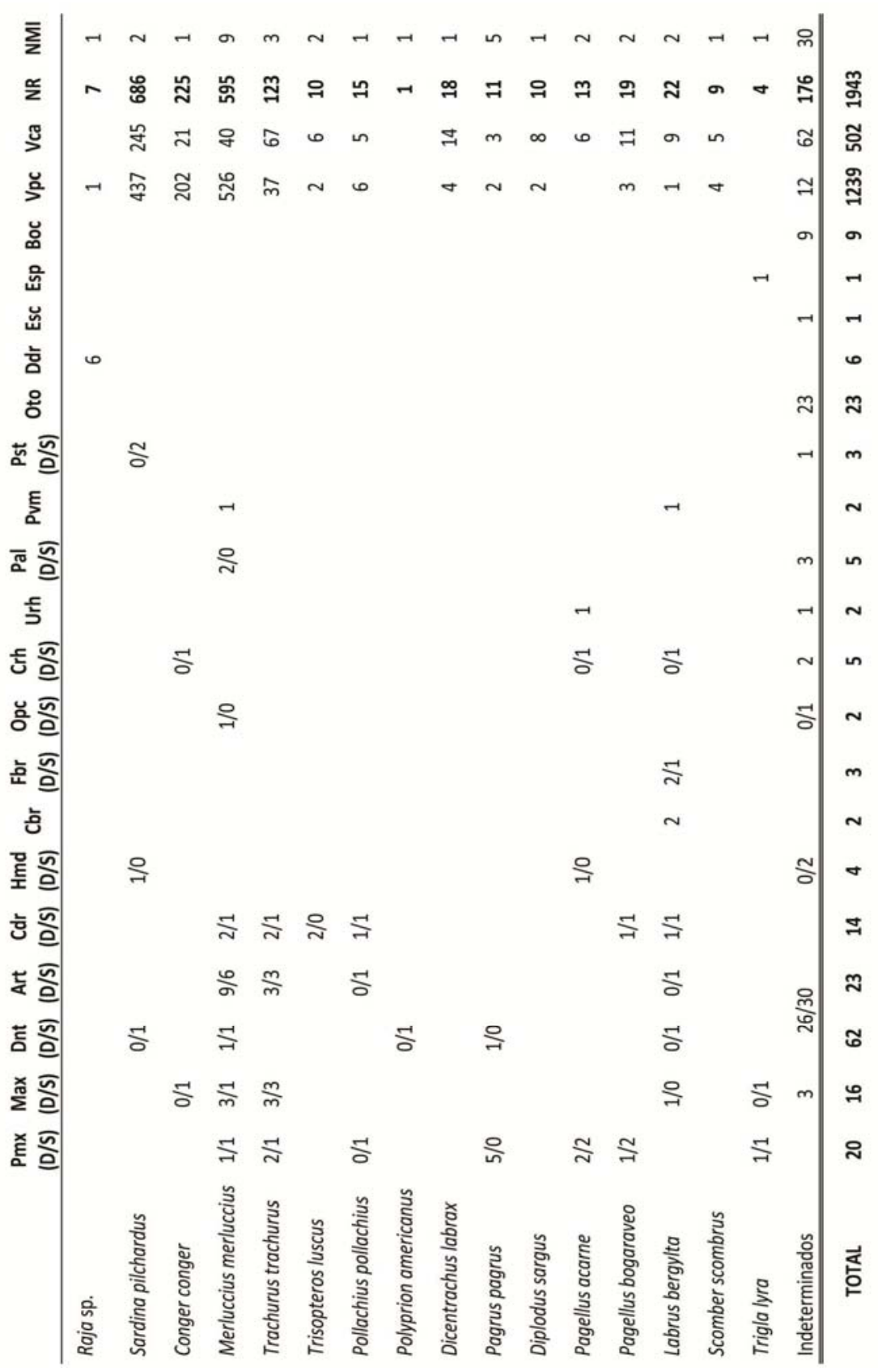

Tabla 73 Relación de especies y representación ósea del conchero (Datos extraídos de Ferré, 2003). 


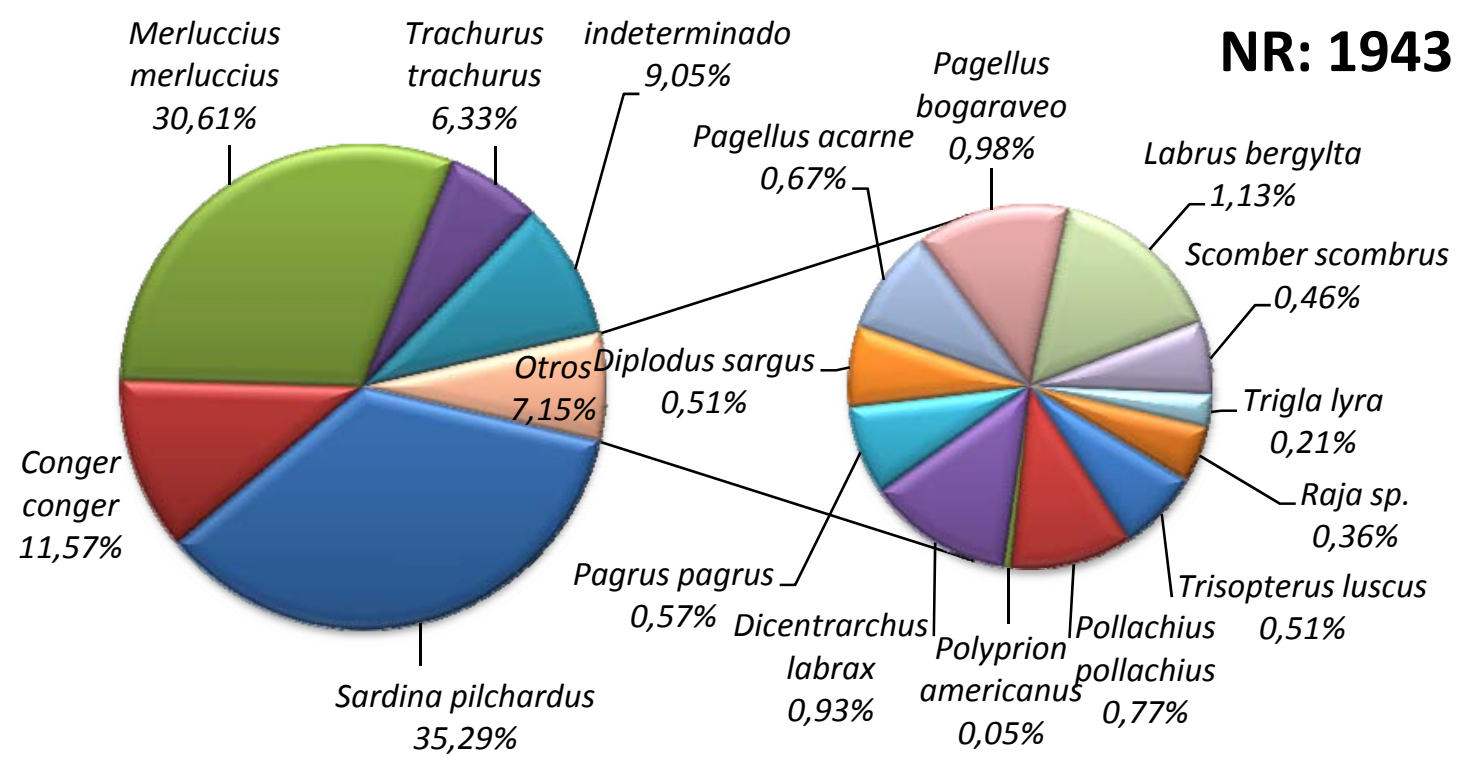

Fig. 100 Representatividad de los taxones identificados en el conchero según el NR.

Se identificaron quince especies de Osteictios y una de Condrictio. La presencia de Trigla lyra, supone la primera cita en los yacimientos del norte peninsular. Las especies mejor representadas son Sardina pilchardus, Merluccius merluccius y Conger conger (Ferré y Rey, 2001; Ferré, 2003).

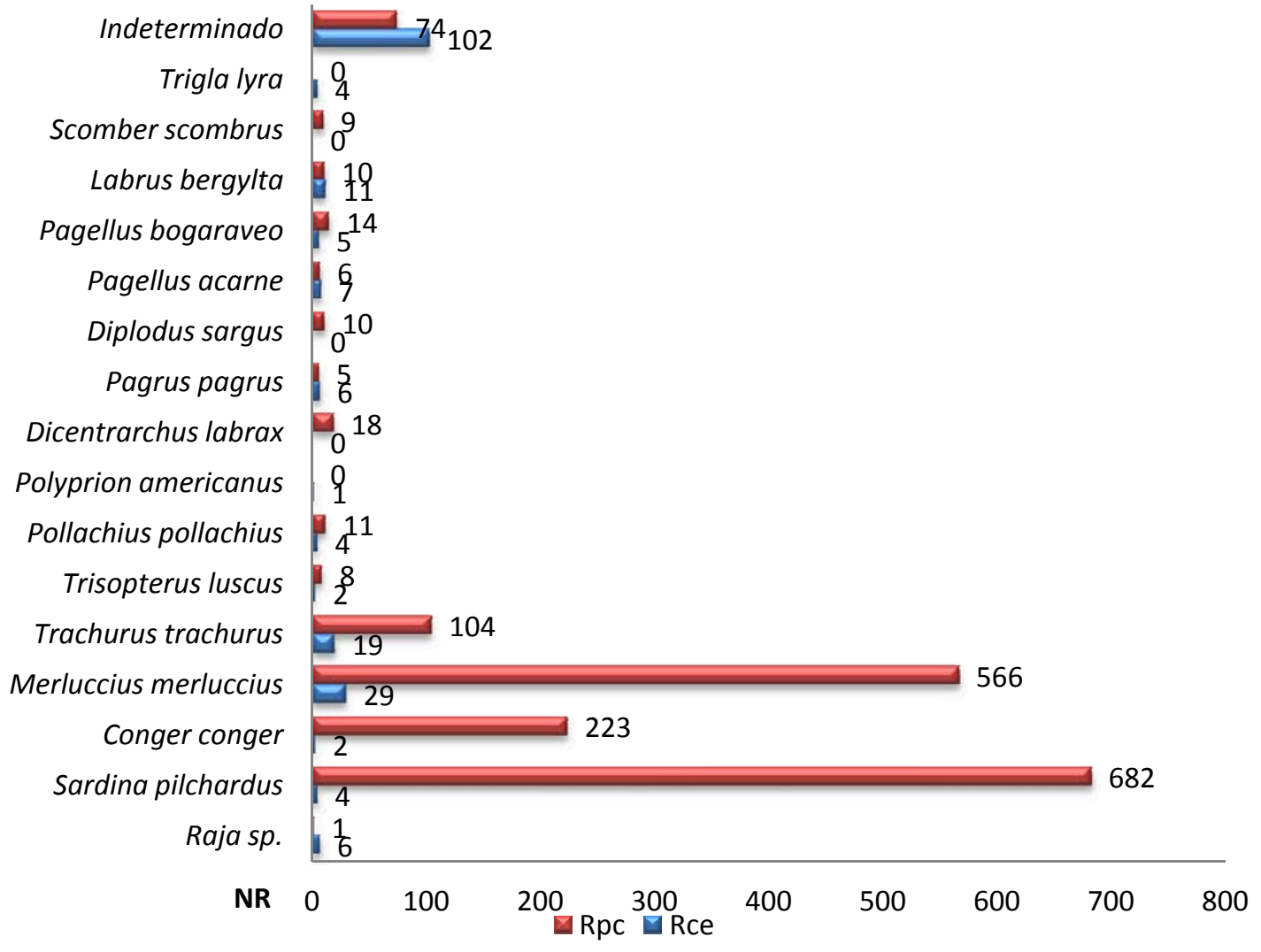

Fig. 101 Comparación numérica de los restos cefálicos y post-cefálicos de los taxones identificados. 


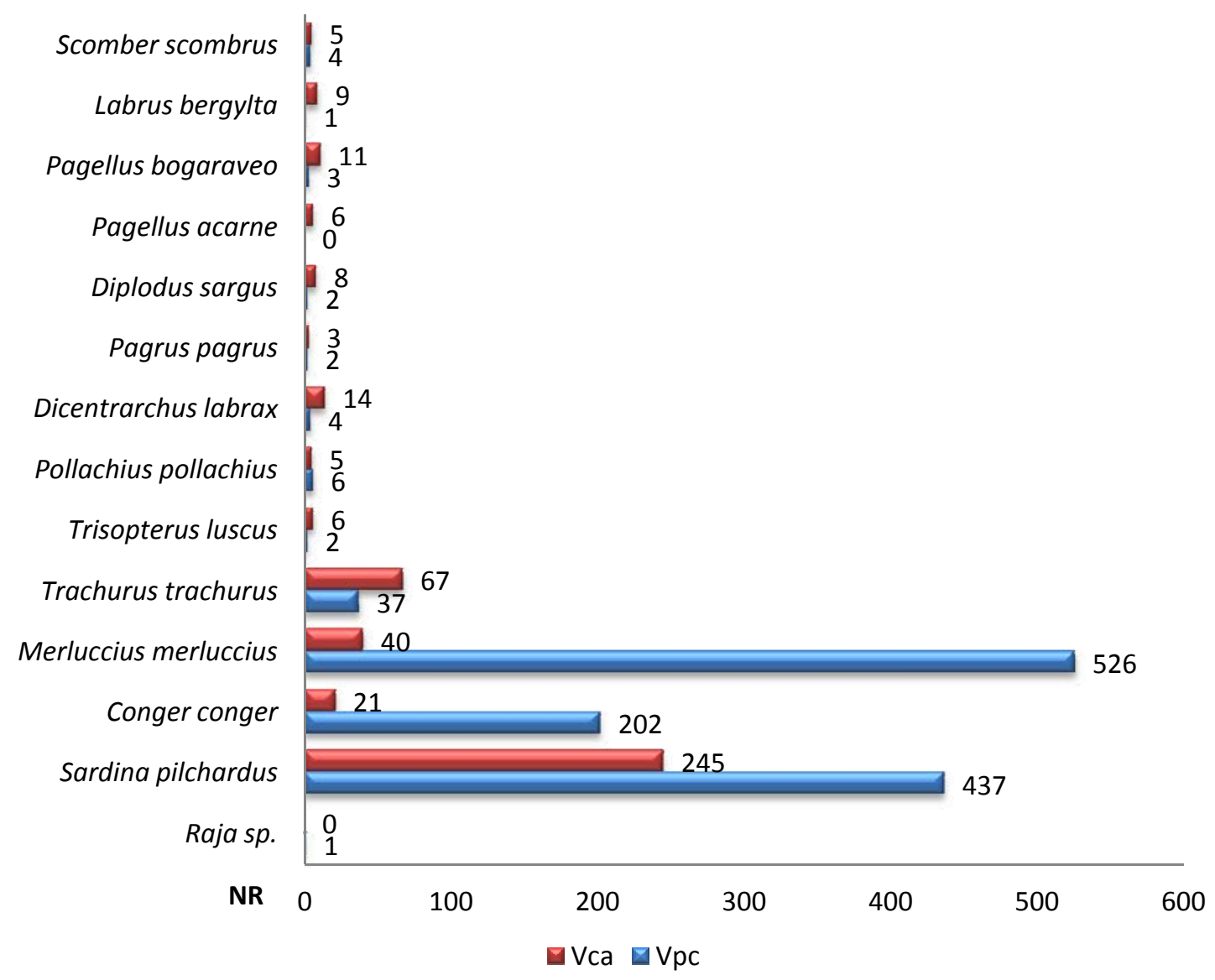

Fig. 102 Comparación numérica de las vértebras caudales y precaudales de los taxones identificados.

\section{V.2.7. CONSIDERACIONES FINALES.}

Como ya comentamoscon anterioridad, pese a que en la campaña de 2007 se excavó una pileta asociada a una posible instalación salazonera romana, los escasos restos recuperados nos impiden hacer cualquier tipo de valoración para esta fase de ocupación.

Sin embargo, para la ocupación medieval contamos con dos conjuntos bastante amplios, lo que al trabajar con ambos, nos va a permitir acercarnos a la actividad pesquera del poblado de Area durante este periodo. Al evaluar las muestras podemos diferenciar dos grupos de especies atendiendo al número de restos por el que están representadas. En el primero debemos incluir Sardina pilchardus, Merluccius merluccius, Conger conger y Trachurus trachurus. Su abundante presencia no es algo excepcional, ya que suele ser habitual en los yacimientos medievales, principalmente entre los siglos XIV-XVI d.C. Las tres primeras especies son objeto de una intensa actividad pesquera durante este periodo con fines comerciales. Esto, junto al volumen de restos recuperados y la representatividad anatómica, sugiere una pesca especializada en especies de alto interés comercial. Según las fuentes, su captura estaría prácticamente monopolizada por los mareantes, que aparecen en la primera mitad del siglo XIV; un grupo superior de profesionales dedicados a 
la pesca y que van a llevar a cabo una organización colectiva, copropietaria de nuevas artes de pesca, que les permite la captura de un mayor número de ejemplares (Ferreira Priegue, 1998; 2009).

En especies como Merluccius merluccius la representación anatómica documentada nos indica claramente la preparación de los ejemplares para su salado (Cornide, 1788; Ferreira Priegue, 1998). En las otras especies la aplicación de estos tratamientos conserveros no parecen estar tan claros; así Conger conger suele ser secado y raramente se sala, aunque también suele consumirse en fresco. Sardina pilchardus presenta mayores problemas de conservación, ya que hace falta mucha sal debido a su gran cantidad de grasa, procediendo para ello al eviscerado y eliminación de la cabeza (Ferreira Priegue, 1998; 2009). En el muestreo del paseo marítimo aparecen principalmente centros vertebrales (mayoritariamente vértebras precaudales) (Ferré, 1998; Ferré, 2003), lo que puede reflejar o bien su consumo en fresco o la aplicación de otros métodos de conservación, ya que no se corresponde con el proceso antes mecionado. Si para su salado es habitual la decapitación de los individuos, la ausencia de restos cefálicos es llamativa. Sin embargo esto puede estar vinculado a la extracción de saín, proceso que no se realizará mediante el prensado de la sardina salada hasta el siglo XVIII (Carrillo Boutureira, 1999), y que podría conllevar una importante alteración de los restos y por lo tanto una peor conservación.

Por lo tanto, en el poblado de Area se realizarían tareas de procesado y limpieza del pescado para su conserva, no siendo posible por el momento asegurar que en este lugar se realizaran las posteriores fases del proceso (Bejega García et alii, 2011). En Galicia únicamente un puerto en cada ría tenía el monopolio de carga y descarga, centralizando todo el tráfico local (Ferreira Priegue, 1991). Viveiro, concello al que actualmente pertenece el yacimiento, ostentó este privilegio desde las Cortes de Jerez en 1268 d.C., y en los siglos XIV-XV d.C. fué uno de los pocos centros exportadores de la costa cantábrica gallega (Ferreira Priegue, 1991). Es por lo tanto probable que el yacimiento que nos atañe hubiera formado parte de ese entramado comercial como centro productivo del asentamiento urbano principal.

Hay otros taxones, que aunque están representados por un número menor de restos, podrían estar vinculadas a la captura de las especies mercantes. Para las de menor valor comercial como Pollachius pollachius, la presencia absoluta de restos cefálicos y de vértebras precaudales y caudales es similar, lo que puede reflejar su consumo en fresco. Trigla lyra, Raia sp. o Polyprion americanus, especies bentónicas que prácticamente no se documentan en periodos anteriores, pueden ser reflejo de la introducción de nuevas artes de pesca, como el arrastre, para la explotación de las especies mercantes, principalmente Merluccius merluccius.

Caso aparte supone la presencia de Trachurus trachurus; si bien en las fuentes no es considerada de interés comercial, en los yacimientos medievales gallegos, como Torre de 
Hércules o el caso que nos ocupa, aparece representada por un volumen de restos muy importante. Según Cornide (1788) en el siglo XVIII d.C. los ejemplares más grandes de Trachurus trachurus suelen, por lo que es posible que esta especie tuviera una mayor importancia que la que se le atribuye, aunque sea a un nivel más local y no del gran comercio.

El segundo grupo de especies está representado por un número mucho menor de restos. Son mayoritariamente demersales y pueden ser pescadas cerca de la costa. Este grupo parece estar reflejando una pesca desarrollada en el entorno más inmediato al yacimiento, con una gran variedad de especies y con una representatividad muy modesta si se compara con la pesca mercante. Podría corresponderse, por lo tanto, con la actividad desarrollada por los denominados "pescadores". Estos no se encuentran organizados como los mareantes y desarrollan su actividad desde la costa o con pequeñas embarcaciones (Ferreira Priegue, 1998; 2009). Las artes de pesca serían las tradicionales como la línea, el palangre y el trasmallo, lo que no les permite realizar un número grande de capturas (Ferreira Priegue, 1998; 2009). Su pesca estaría enfocada tanto a servir de pescado fresco a los mercados, principalmente los más cercanos, como al autoconsumo (Ferreira Priegue, E., 1998). Esta actividad no sería económicamente muy importante, estando más próxima a una economía de subsistencia que de mercado (Bejega García et alii, 2011). 


\section{V.3. TARAMANCOS.}

\section{V.3.1. LOCALIZACIÓN GEOGRÁFICA.}

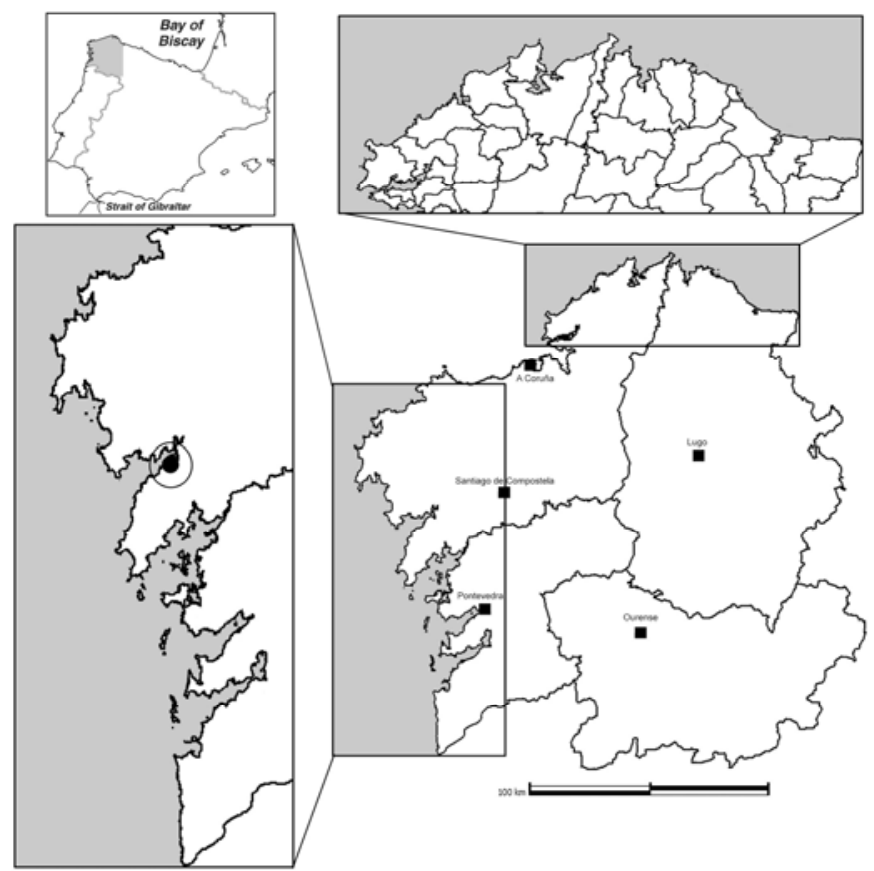

El yacimiento se localiza en Taramancos, Concello de Noia, A Coruña. Se sitúa en una pequeña elevación con amplia visibilidad de la ría y del entorno inmediato. Sus coordenadas son: $8^{\circ} 54^{\prime} 53.77^{\prime \prime} \mathrm{W}$ y $42^{\circ} 47^{\prime} 13.89^{\prime \prime} \mathrm{N}^{3}$. Se trataría de un yacimiento sublitoral.

Fig. 103 Localización del yacimiento de Taramancos.

\section{V.3.2. DESCRIPCIÓN DEL YACIMIENTO.}

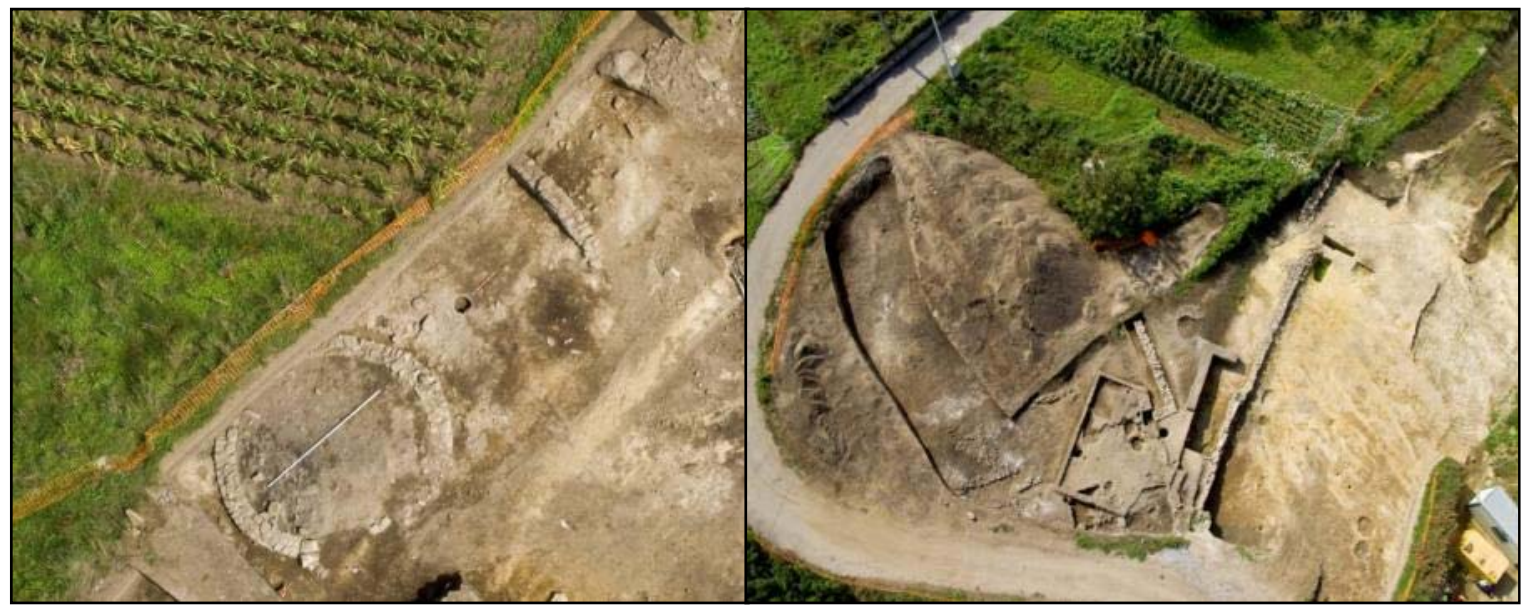

Fig. 104 Vistas general del área intervenida (Imágenes facilitadas por AMBIOTEC).

El movimiento de tierras realizado el año 2011 en Taramancos para la construcción del Corredor Brión-Noia puso al descubierto un yacimiento desconocido hasta la fecha. La intervención se centró en la superficie ocupada por la traza, sacando a la luz diversas estructuras circulares, construcciones de planta rectangular, fondos de cabañas, agujeros

\footnotetext{
${ }^{3}$ Datum: ETRS89; Uso: 29; UTM: X 506.957/Y 4.737.187.
} 
de poste y un petroglifo con cazoletas (Elena-Ambiotec, comunicación personal). Además de estas estructuras se documentó, en los Sectores 1 y 2, la presencia de 17 acumulaciones de conchas de diverso tamaño. Estas se encontraban sobre los derrumbes de estructuras anteriores, en muchos casos alterándolas.

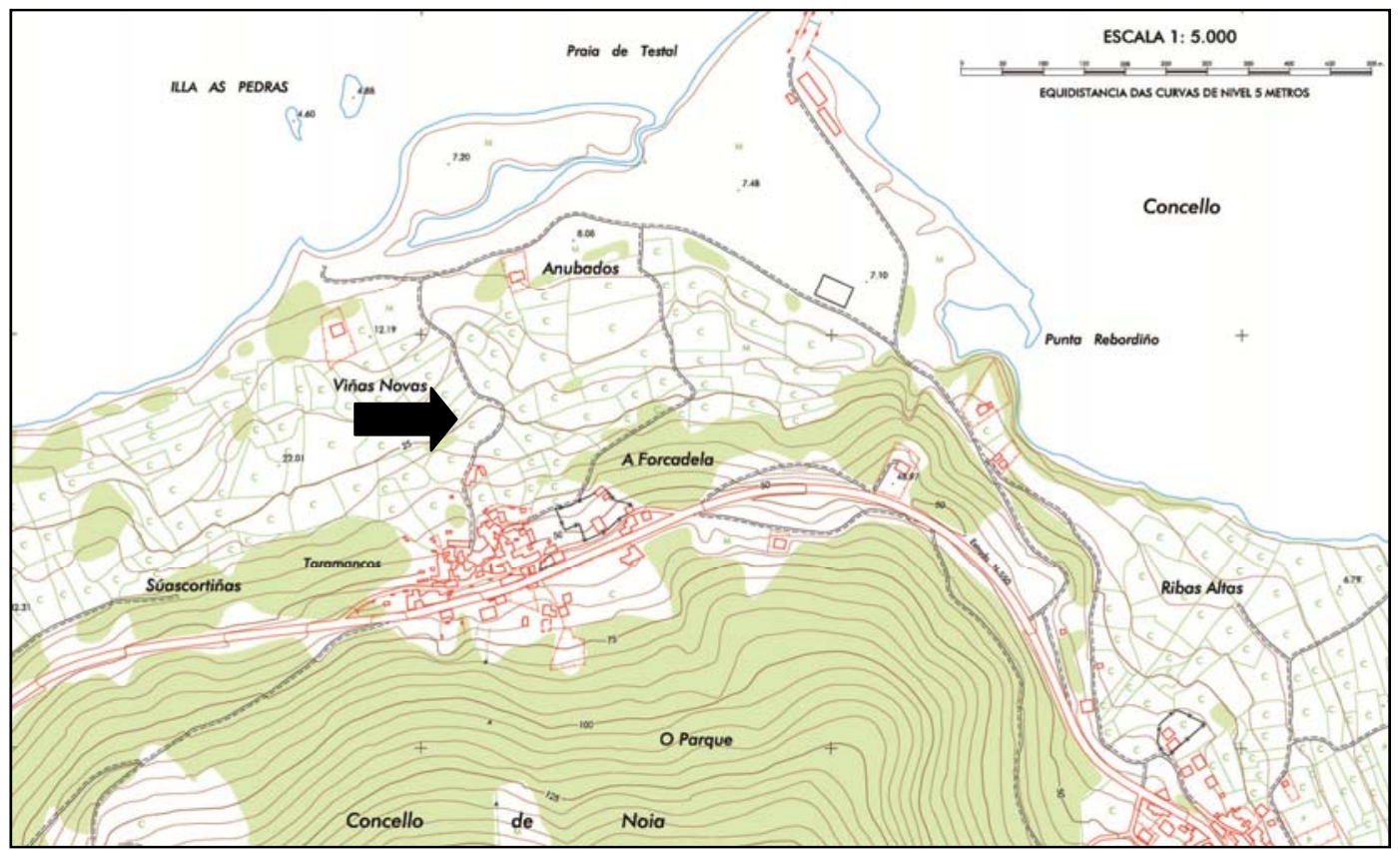

Fig. 105 Topográfico 1:5.000 de Taramancos y localización de las intervenciones. (Extraído de http://sitga.xunta.es/sitga).

\section{V.3.3. RECOGIDA DE LAS MUESTRAS.}

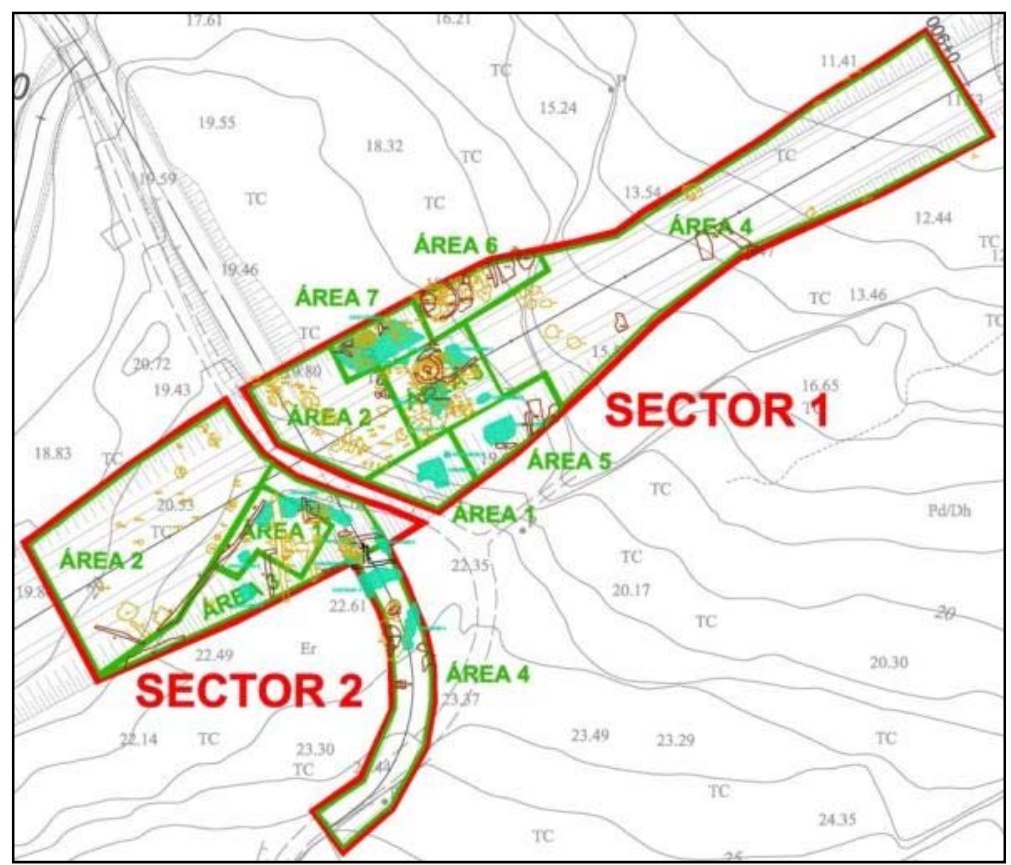

Fig. 106 Localización de los Sectores y Áreas (Plano facilitado por AMBIOTEC). 
De todos los concheros documentados se estudiaron únicamente muestras de cinco de ellos. Las muestras tenían un peso que en la mayoría de los casos se situaba entre los 5 y $10 \mathrm{Kg}$. Ante la homogeneidad que presentaba la muestra malacológica se decidió analizar de manera pormenorizada $2 \mathrm{Kg}$ de cada muestra, de donde se recuperaron todos los restos. En el caso de la ictiofauna, se decidió procesar las muestras en su totalidad, recuperando los elementos con alto valor diagnóstico.

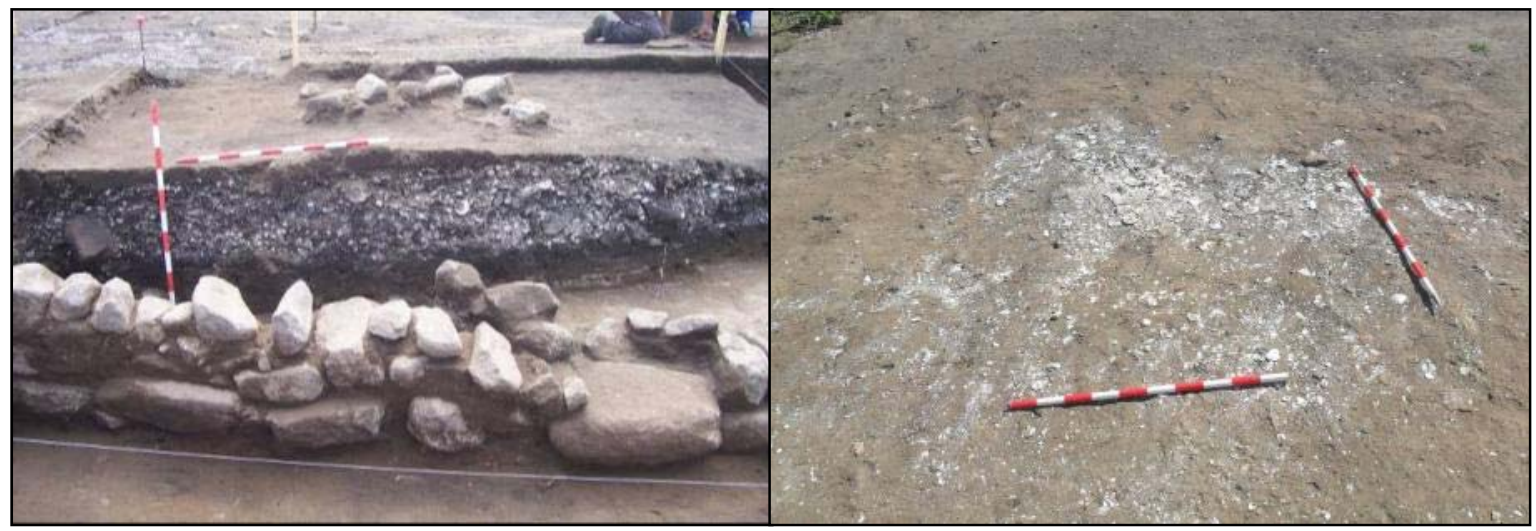

Fig. 107 Conchero 1 del Sector 2 y Conchero 3 del Sector 1. (Imágenes facilitadas por AMBIOTEC).

\section{V.3.3.1. EL MUESTREO.}

En el Sector 1 se estudiaron dos muestras procedentes de los Conchero 3 y $5 b$, mientras del Conchero 9 se analizaron tres muestras. Para el primero de estos concheros se tomó una columna de muestras, mientras que para los otros dos se realizaron muestreos aislados de forma aleatoria en cada UE.

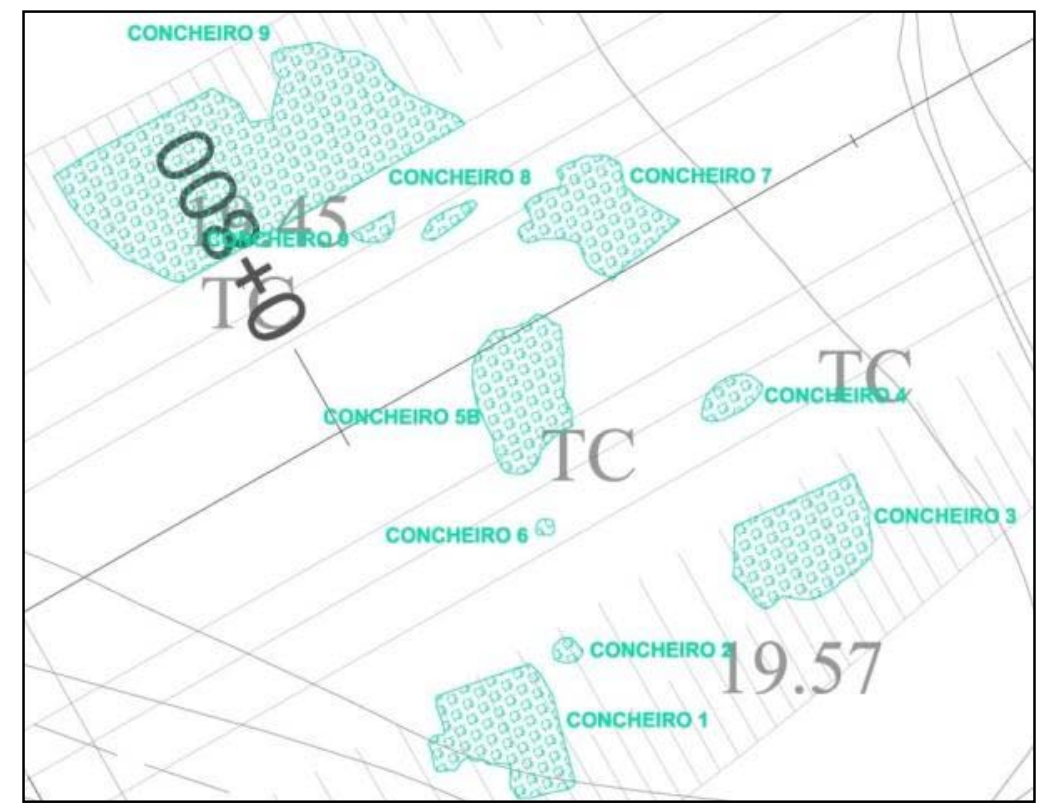

Fig. 108 Distribución de los Concheros del Sector 1 (Plano facilitado por AMBIOTEC). 
En cuanto al Sector 2, se han analizado los Concheros 1 y 5 . Del primero se realizaron tres columnas de muestreo de $20 \mathrm{~cm}$ de anchura realizando tres rebajes de 10 $\mathrm{cm}$. En el caso del Conchero 5 se realizaron tres muestreos aislados debido a la poca potencia que presentaba.

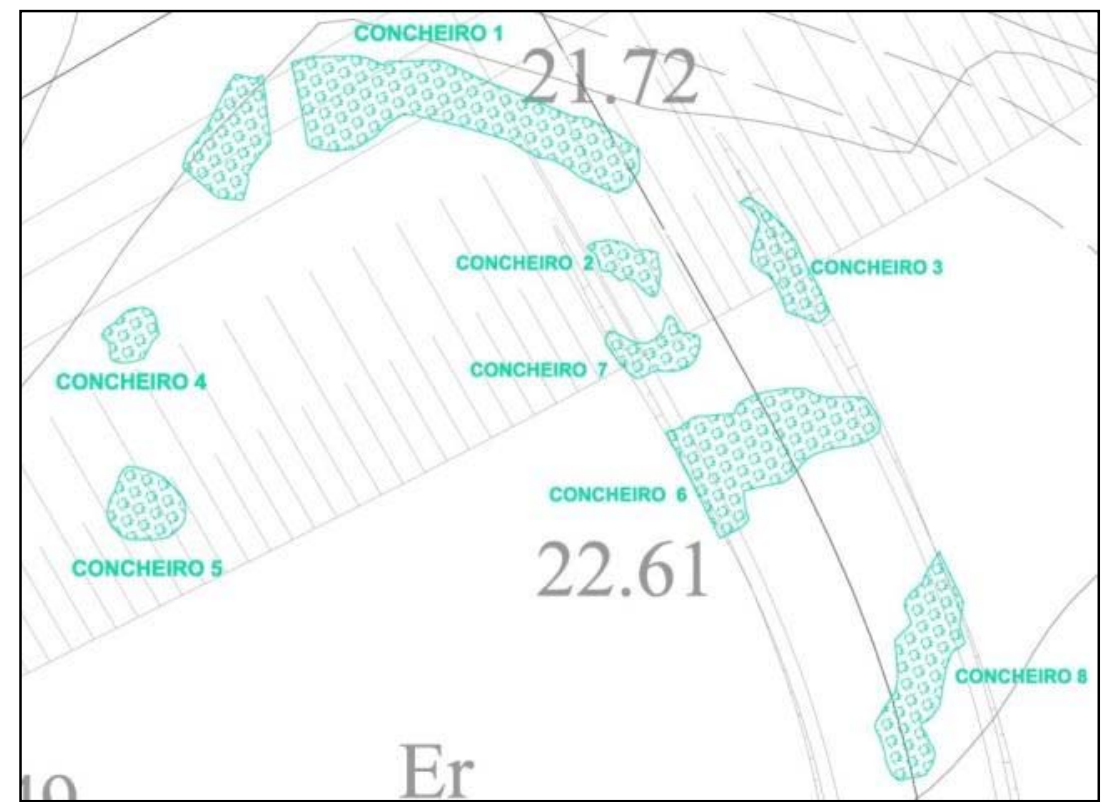

Fig. 109 Distribución de los Concheros del Sector 2 (Plano facilitado por AMBIOTEC).

\section{V.3.3.2. CRONOLOGÍA.}

Las cronologías del yacimiento son de momento provisionales, ya que los materiales están en proceso de estudio e inventario. La cerámica es muy heterogénea con piezas de la prehistoria reciente, de época castreña, romana y medieval, así como algún fragmento moderno y contemporáneo. La mayor parte de los restos cerámicos se situarían entre el Bronce Final y la Fase II-III de la Cultura Castreña.

Hay que destacar la recuperación de varios anzuelos de bronce y uno en hierro, si bien por el momento no tenemos constancia de su adscripción cronológica. En el Sector 2 se recuperaron varias monedas de época medieval.

Como ya comentamos, los cocheros se sitúan amortizando estructuras y sobre los derrumbes. Lo cual, unido a las características que presentan los depósitos, tanto en taxones presentes como en representaciones anatómicas, nos inclina a pensar en una cronología bajo medieval/moderna como más probable para la formación de estos depósitos. 


\section{V.3.4. ESTUDIO ICTIOARQUEOLÓGICO.}

\section{V.3.4.1. SECTOR 1}

\section{V.3.4.1.1. Conchero 3/ 1 ${ }^{\text {er }}$ Rebaje}

\begin{tabular}{l|c|c|}
\multirow{2}{*}{ Inicial } & cc. & gr. \\
\cline { 2 - 3 } \multicolumn{1}{c|}{} & $\mathbf{2 . 0 0 0}$ & $\mathbf{1 . 6 8 3}$ \\
\hline \hline Residuo & 500 & 847 \\
\hline Malacofauna & & 829,5 \\
Micromoluscos & & 1 \\
Ictiofauna & & 4 \\
Carbón & & 1,5 \\
\hline
\end{tabular}

Tabla 74 Pesos iniciales (en gr.) del $1^{\mathrm{er}}$ Rebaje del Conchero 3 por componentes.

\begin{tabular}{|c|c|c|c|c|c|c|c|c|c|c|c|c|c|c|c|c|c|c|}
\hline & $\begin{array}{c}C d r \\
(D / S)\end{array}$ & $\begin{array}{c}\text { Opc } \\
\text { (D/S) }\end{array}$ & $\begin{array}{l}\text { Pop } \\
\text { (D/S) }\end{array}$ & $\begin{array}{l}\text { Pmx } \\
(D / S)\end{array}$ & $\begin{array}{l}\text { Dnt } \\
(D / S)\end{array}$ & $\begin{array}{c}\text { Art } \\
\text { (D/S) }\end{array}$ & $\begin{array}{c}\text { Eph } \\
\text { (D/S) }\end{array}$ & $\begin{array}{l}\text { Pst } \\
(D / S)\end{array}$ & Atl & Oto & 1 Tor & Vpc & Vca & Rce & Rpc & Esa & NR & NMI \\
\hline Sardina pilchardus & $4 / 2$ & $0 / 1$ & $0 / 1$ & & & $3 / 3$ & & $1 / 1$ & 2 & & & 24 & 2 & & & & 44 & 4 \\
\hline Merluccius merluccius & & & $0 / 1$ & $4 / 2$ & $1 / 2$ & & $1 / 0$ & $1 / 1$ & 4 & 1 & 3 & 92 & 6 & & & & 119 & 4 \\
\hline Pagellus bogaraveo & & & & & & & & & & & & 1 & & & & & 1 & 1 \\
\hline Indeterminado & & & & & & & & & & & & & & 32 & 215 & 76 & 323 & \\
\hline TOTAL & 6 & 1 & 2 & 6 & 3 & 6 & 1 & 4 & 6 & 1 & 3 & 117 & 8 & 32 & 215 & 76 & 487 & \\
\hline
\end{tabular}

Tabla 75 Relación de especies y representación ósea del $1^{\mathrm{er}}$ Rebaje del Conchero 3.

La muestra íctica está formada por 164 piezas óseas identificables pertenecientes a tres taxones. Además se han recuperado 32 restos cefálicos y 215 post-cefálicos indeterminados y 76 escamas. La especie que cuenta con un mayor volumen de restos identificados es Merluccius merluccius, representada por un preopercular izquierdo, cuatro premaxilares derechos y dos izquierdos, un dentario derecho y dos izquierdos, un epihial derecho, un postemporal derecho y otro izquierdo, uno otolito, cuatro atlas, tres vértebras torácicas, noventa y dos precaudales y seis caudales. Le sigue Sardina pilchardus con cuatro cuadrados derechos y dos izquierdos, un opercular y un preopercular izquierdo, tres articulares derechos y otros tantos izquierdos, un postemporal derecho y otro izquierdo, dos atlas, veinticuatro vértebras precaudales y dos caudales. Por último se ha identificado un vértebra precaudal de Pagellus bogaraveo. 


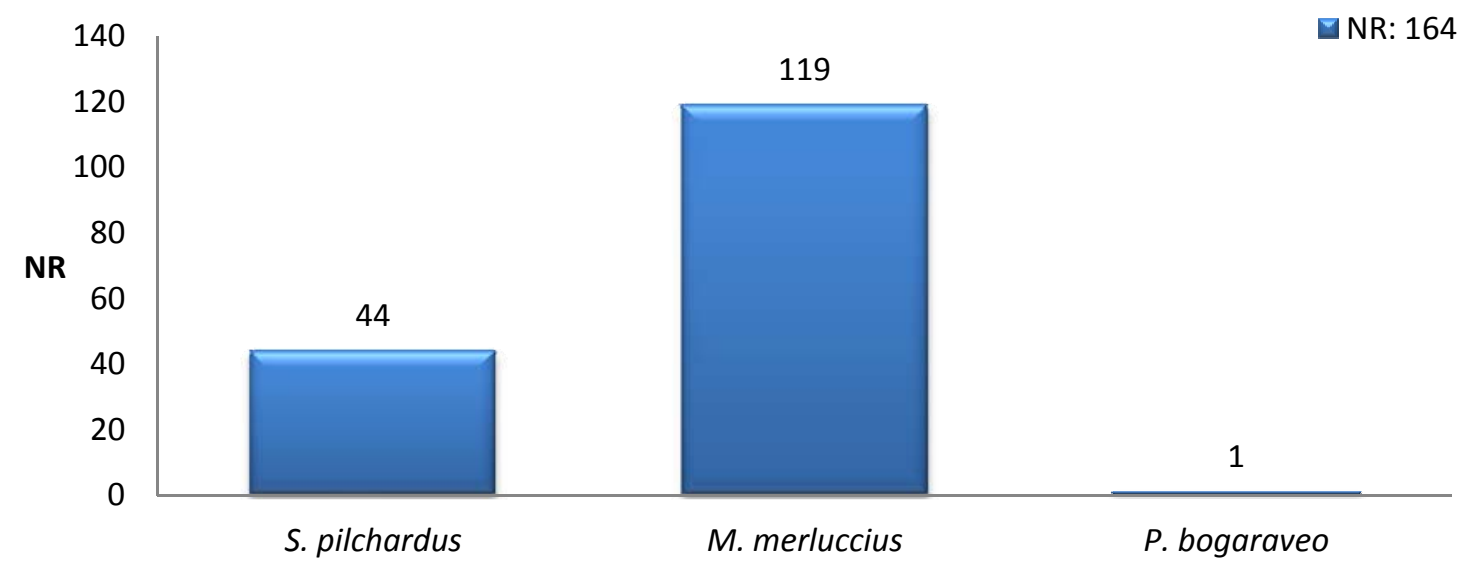

Fig. 110 Distribución de taxones identificados en el $1^{\mathrm{er}}$ Rebaje del Conchero 3 según el NR.

De los tres taxones identificados, a dos corresponden el mayor volumen de restos, siendo mínima la presencia de Pagellus bogaraveo. Más de un $70 \%$ de las piezas óseas identificadas pertenecen a una única especie, Merluccius merluccius. Sardina pilchardus sería la segunda especie mejor representada con un número significativo de restos, si bien no supone la mitad de los contabilizados para Merluccius merluccius.

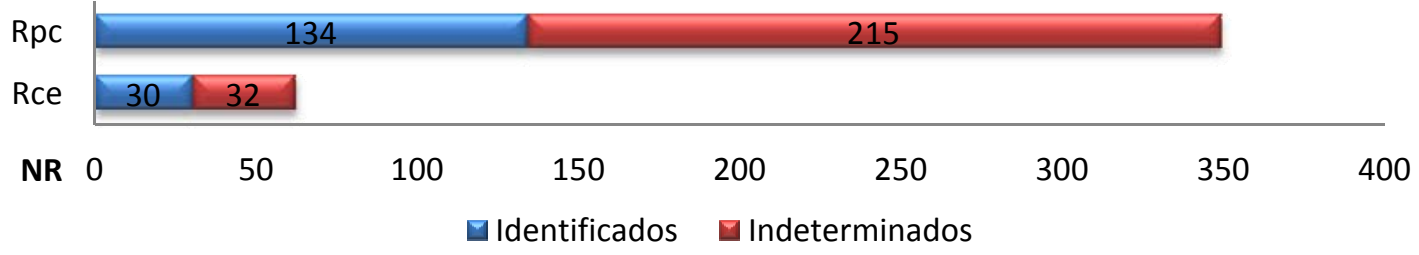

Fig. 111 Distribución esquelética de los restos ícticos del $1^{\mathrm{er}}$ Rebaje del Conchero 3.

Predominan los restos post-cefálicos, aunque los cefálicos están bien representados tanto entre los restos de Merluccius merluccius como, en menor medida, de Sardina pilchardus.

\section{V.3.4.1.2. Conchero 3/20 Rebaje}

\begin{tabular}{l|c|c|}
\multirow{2}{*}{\multicolumn{1}{c|}{ Inicial }} & cc. & gr. \\
\cline { 2 - 3 } & $\mathbf{2 . 0 0 0}$ & $\mathbf{1 . 9 6 4}$ \\
\hline \hline Residuo & 650 & 1.182 \\
\hline Cerámica & & 2 \\
\hline Malacofauna & & 776,5 \\
Micromoluscos & & 0,5 \\
Macrofauna & & 1 \\
Ictiofauna & & 1 \\
Carbón & & 1 \\
\hline
\end{tabular}

Tabla 76 Pesos iniciales (en gr.) del 20 Rebaje del Conchero 3 por componentes. 


\begin{tabular}{lccccccccccc} 
& $\begin{array}{c}\text { Pmx } \\
\text { (D/S) }\end{array}$ & $\begin{array}{c}\text { Dnt } \\
\text { (D/S) }\end{array}$ & $\begin{array}{c}\text { Max } \\
\text { (D/S) }\end{array}$ & $\begin{array}{c}\text { Art } \\
\text { (D/S) }\end{array}$ & Atl & Vpc & Vca & Rce & Esa & NR & NMI \\
\hline $\begin{array}{l}\text { Sardina pilchardus } \\
\begin{array}{l}\text { Merluccius merluccius } \\
\text { Indeterminado }\end{array}\end{array}$ & $2 / 3$ & $6 / 4$ & $2 / 2$ & & 1 & 55 & 1 & & & $\mathbf{7 7}$ & 6 \\
\multicolumn{1}{c}{ TOTAL } & 5 & $\mathbf{1 0}$ & $\mathbf{4}$ & $\mathbf{2}$ & $\mathbf{1}$ & $\mathbf{5 7}$ & $\mathbf{1}$ & $\mathbf{4}$ & $\mathbf{1 7}$ & $\mathbf{1 0 2}$
\end{tabular}

Tabla 77 Relación de especies y representación ósea del 2ํ Rebaje del Conchero 3.

En el 20 Rebaje del Conchero 3 se recuperaron 81 piezas óseas identificables pertenecientes a dos taxones, además de cuatro restos cefálicos indeterminados y 17 escamas. Merluccius merluccius es la especie representada por un mayor número de restos: dos premaxilares derechos y tres izquierdos, seis dentarios derechos y cuatro izquierdos, dos maxilares derechos y dos izquierdos, un atlas, cincuenta y cinco vértebras precaudales y una caudal. A la otra especie presente, Sardina pilchardus, se han adscritoun articular derecho y otro izquierdo, así como dos vértebras precaduales.

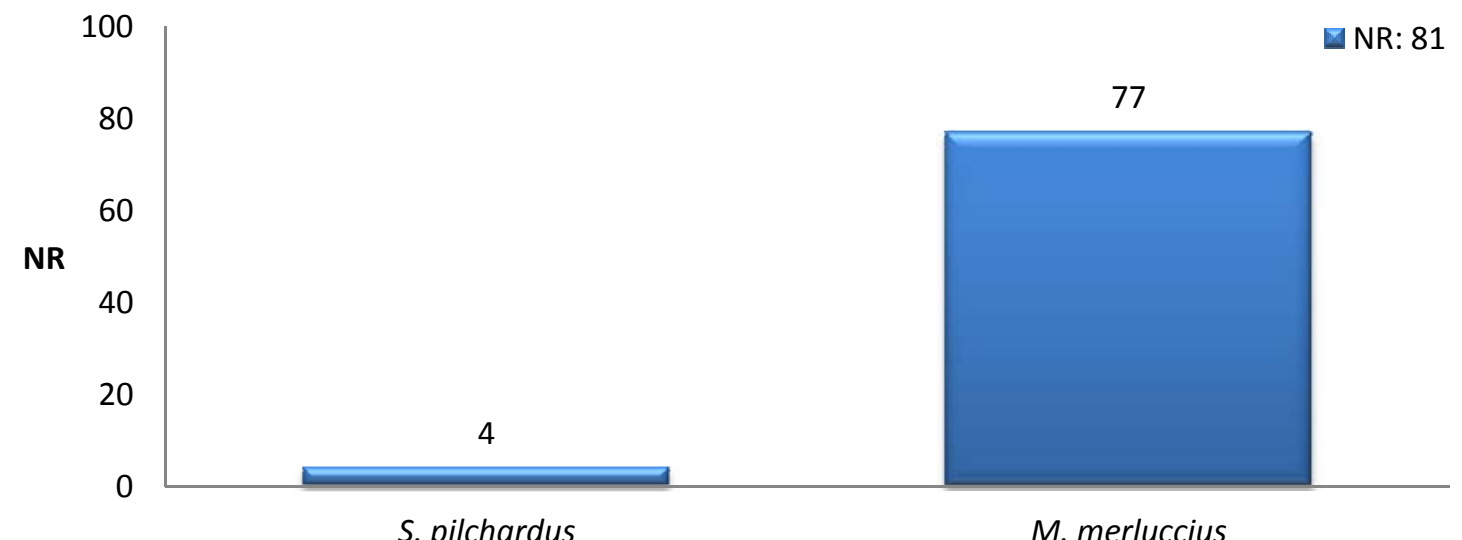

Fig. 112 Distribución de taxones identificados en el 2ำ Rebaje del Conchero 3 según el NR.

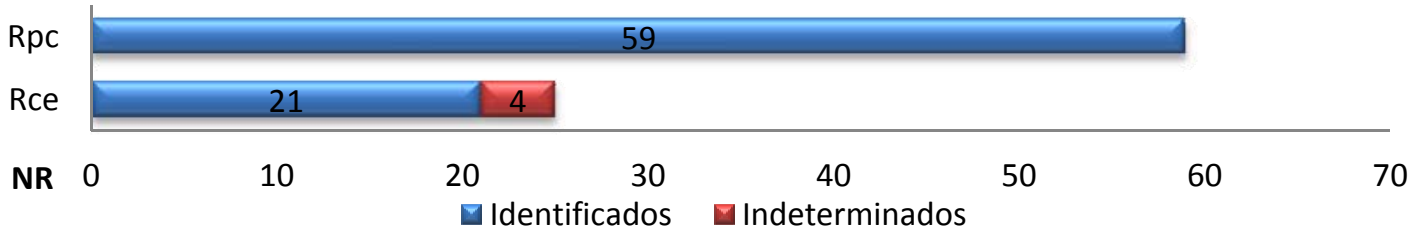

Fig. 113 Distribución esquelética de los restos ícticos del 2을 Rebaje del Conchero 3.

Los restos post-cefálicos siguen siendo los más numerosos, aunque no se han recuperado fragmentos indeterminados de esta categoría. Los restos cefálicos corresponden en su mayoría a Merluccius merluccius. 


\section{V.3.4.1.3. Conchero 5/ UE1}

\begin{tabular}{l|c|c|}
\multirow{2}{*}{ Inicial } & cc. & gr. \\
\cline { 2 - 3 } & $\mathbf{2 . 0 0 0}$ & $\mathbf{1 . 5 4 2}$ \\
\hline \hline Residuo & 200 & 715 \\
\hline Cerámica & & 32 \\
\hline Malacofauna & & 791 \\
Macrofauna & & 2 \\
Ictiofauna & & 1 \\
Carbón & & 1 \\
\hline
\end{tabular}

Tabla 78 Pesos iniciales (en gr.) de la UE 1 del Conchero 5 por componentes.

\begin{tabular}{cccccccccc} 
& $\begin{array}{c}\text { Pmx } \\
\text { (D/S) }\end{array}$ & $\begin{array}{c}\text { Dnt } \\
\text { (D/S) }\end{array}$ & $\begin{array}{c}\text { Max } \\
\text { (D/S) }\end{array}$ & Vpc & Vca & Rce & Esa & NR & NMI \\
\hline $\begin{array}{l}\text { Merluccius merluccius } \\
\text { Indeterminado }\end{array}$ & $1 / 0$ & $0 / 2$ & $1 / 0$ & 8 & 1 & & & 13 & 2 \\
\hline \hline TOTAL & & & & & 1 & 1 & 20 & $\mathbf{2 2}$ & \\
\hline \hline
\end{tabular}

Tabla 79 Relación de especies y representación ósea de la UE 1 del Conchero 5.

Esta muestra ha aportado 14 restos identificados pertenecientes a dos taxones, así como un resto cefálico y una vértebra caudal indeterminados y 20 escamas. La mayoría de las piezas óseas pertenecen a Merluccius merluccius: un premaxilar derecho, dos dentarios izquierdos, un maxilar derecho, ocho vértebras precaudales y una caudal.

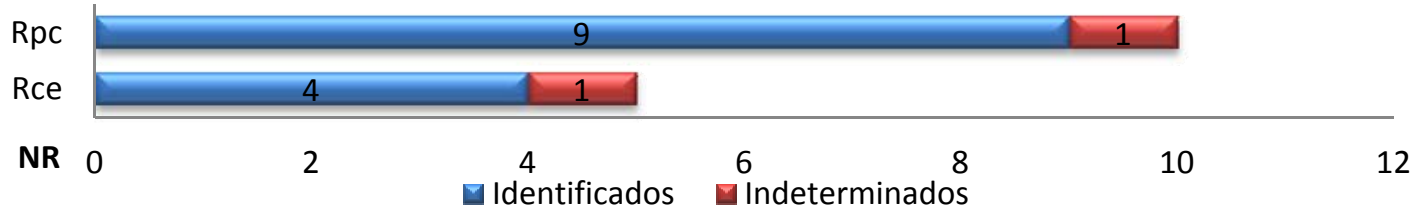

Fig. 114 Distribución esquelética de los restos ícticos de la UE 1 del Conchero 5.

La mayor parte de las piezas identificadas corresponden a restos post-cefálicos, perteneciendo todos los cefálicos a una única especie, Merluccius merluccius. La presencia de escamas y otros fragmentos indeterminados es muy baja.

\section{V.3.4.1.4. Conchero 5/ UE2}

\begin{tabular}{l|c|c|}
\multirow{2}{*}{\multicolumn{1}{c|}{ Inicial }} & cc. & gr. \\
\cline { 2 - 3 } & $\mathbf{2 . 0 0 0}$ & $\mathbf{1 . 8 9 6}$ \\
\hline \hline Residuo & 700 & 1.109 \\
\hline Cerámica & & 64 \\
\hline Malacofauna & & 717,5 \\
Micromoluscos & & 0,5 \\
Macrofauna & & 1 \\
Ictiofauna & & 3 \\
Carbón & & 1 \\
\hline
\end{tabular}

Tabla 80 Pesos iniciales (en gr.) de la UE 2 del Conchero 5 por componentes. 


\begin{tabular}{lcccccccccc} 
& $\begin{array}{c}\text { Pmx } \\
\text { (D/S) }\end{array}$ & $\begin{array}{c}\text { Dnt } \\
\text { (D/S) }\end{array}$ & $\begin{array}{c}\text { Max } \\
\text { (D/S) }\end{array}$ & Vpc & Vca & Rce & Rpc & Esa & NR & NMI \\
\hline Sardina pilchardus & & & & 2 & 5 & & & & $\mathbf{7}$ & 1 \\
$\begin{array}{l}\text { Merluccius merluccius } \\
\text { Indeterminado }\end{array}$ & $1 / 3$ & $0 / 2$ & $1 / 1$ & 5 & 1 & & & & $\mathbf{1 4}$ & 3 \\
\hline \multicolumn{1}{c}{ TOTAL } & $\mathbf{4}$ & $\mathbf{3}$ & $\mathbf{2}$ & $\mathbf{7}$ & $\mathbf{6}$ & $\mathbf{2}$ & $\mathbf{7}$ & $\mathbf{4 8}$ & $\mathbf{7 9}$ &
\end{tabular}

Tabla 81 Relación de especies y representación ósea de la UE 2 del Conchero 5.

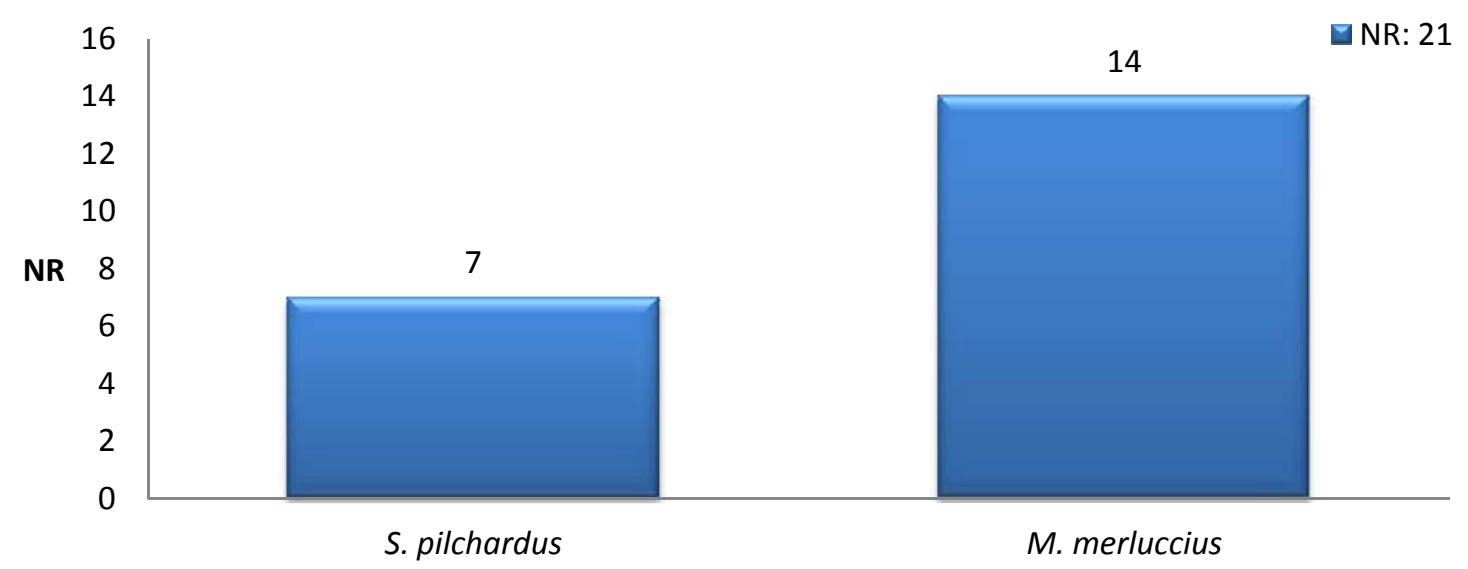

Fig. 115 Distribución de taxones identificados en la UE 2 del Conchero 5 según el NR.

La muestra íctica está compuesta por 22 piezas óseas identificables pertenecientes a dos taxones, además de dos restos cefálicos y siete post-cefálicos indeterminados, y 48 escamas. La especie mejor representada es Merluccius merluccius, de la que se han identificado un premaxilar derecho y tres izquierdos, 2 dentarios izquierdos, un maxilar derecho y uno izquierdo, cinco vértebras precaudales y una caudal. La otra especie presente es Sardina pilchardus, representada por dos vértebras precaudales y cinco caudales.

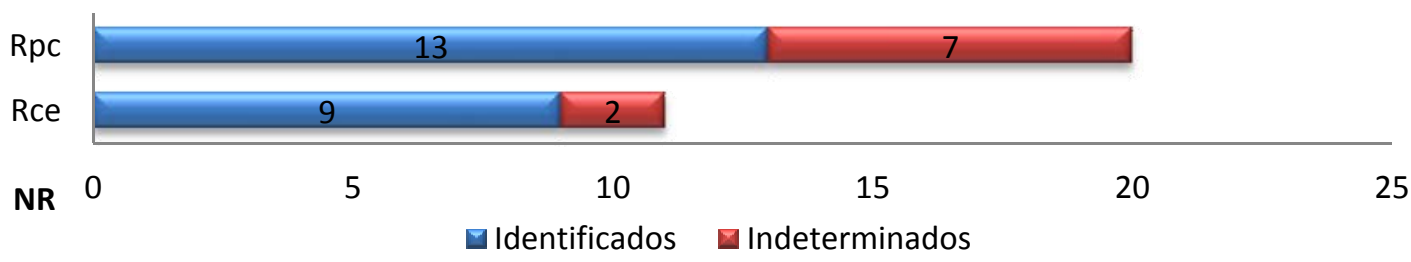

Fig. 116 Distribución esquelética de los restos ícticos de la UE 2 del Conchero 5.

Los restos más numerosos son los postcefálicos, aunque los cefálicos presentan un número similar si consideramos exclusivamente las piezas identificadas. La mayoría de los restos cefálicos corresponden a Merluccius merluccius. 


\section{V.3.4.1.5. Conchero 9/ 1er Rebaje}

\begin{tabular}{l|c|c|}
\multicolumn{1}{c|}{ Inicial } & cc. & gr. \\
\cline { 2 - 3 } \multicolumn{1}{c|}{} & $\mathbf{2 0 0 0}$ & $\mathbf{1 8 4 6}$ \\
\hline \hline Residuo & 600 & 1.226 \\
\hline Cerámica & & 15 \\
\hline Malacofauna & & 600 \\
Micromoluscos & & 1,5 \\
Ictiofauna & & 1,5 \\
Carbón & & 2 \\
\hline
\end{tabular}

Tabla 82 Pesos iniciales (en gr.) del $1^{\mathrm{er}}$ Rebaje del Conchero 9 por componentes.

\begin{tabular}{|c|c|c|c|c|c|c|c|c|c|c|}
\hline & $\begin{array}{c}\text { Max } \\
\text { (D/S) }\end{array}$ & Pal & $\begin{array}{c}\text { Art } \\
\text { (D/S) }\end{array}$ & $\begin{array}{c}\text { Pst } \\
\text { (D/S) }\end{array}$ & Vpc & Vca & Rce & Rpc & NR & NMI \\
\hline Sardina pilchardus & & & $1 / 0$ & & 3 & 1 & & & 5 & 1 \\
\hline Pagellus bogaraveo & & & & & & 1 & & & 1 & 1 \\
\hline Trisopterus luscus & $1 / 0$ & & & $1 / 1$ & 1 & 6 & & & 10 & 1 \\
\hline Indeterminado & & 1 & & & & & 6 & 6 & 13 & \\
\hline "TOTAL & 1 & 1 & 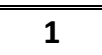 & 2 & 4 & 8 & 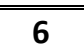 & 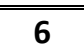 & 29 & \\
\hline
\end{tabular}

Tabla 83 Relación de especies y representación ósea del $1^{\mathrm{er}}$ Rebaje del Conchero 9.

El primer rebaje del Conchero 9 ha aportado 17 piezas óseas identificables pertenecientes a tres taxones, así como seis restos cefálicos y otros seis post-cefálicos indeterminados. Trisopterus luscus es la especie mejor representada: un maxilar derecho, un postemporal derecho y otro izquierdo, una vértebra precaudal y seis caudales. Sardina pilchardus cuenta con un articular derecho, tres vértebras precaduales y una caudal. La presencia de Pagellus bogaraveo está constatada por una única vértebra caudal.

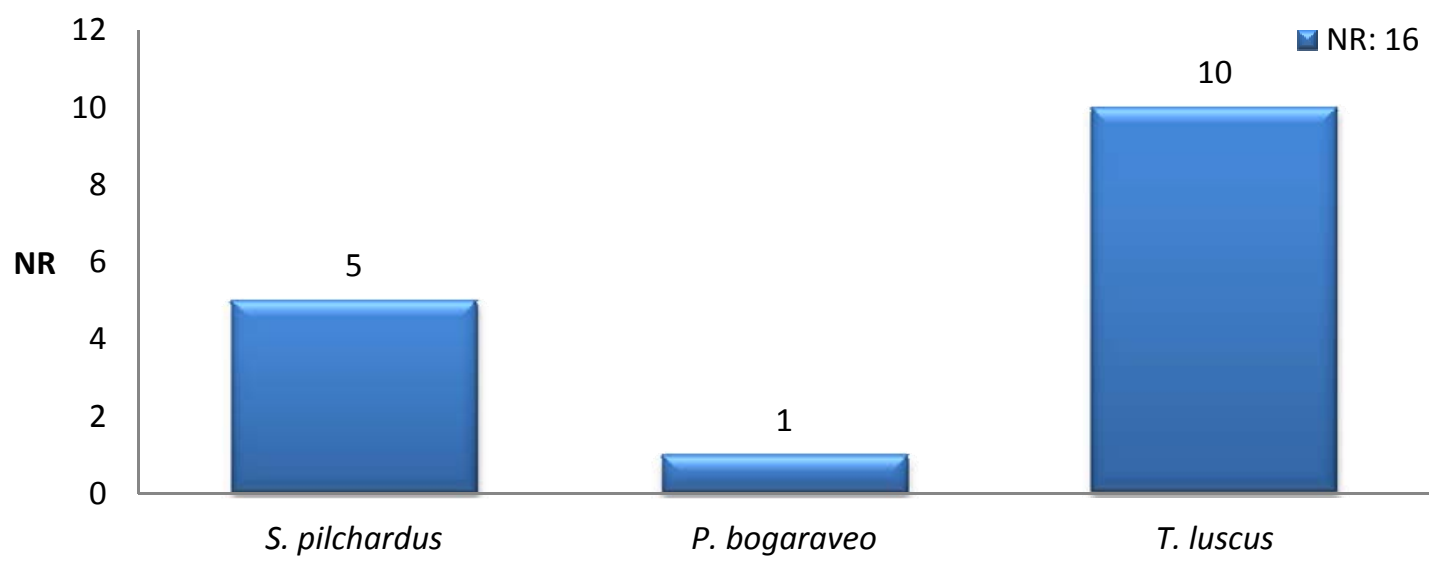

Fig. 117 Distribución de taxones identificados en el $1^{\mathrm{er}}$ Rebaje del Conchero 9 según el NR.

La especie mejor representada es Trisopterus luscus, seguida de Sardina pilchardus con la mitad de los restos que la anterior. Pagellus bogaraveo cuenta con una presencia mínima. 


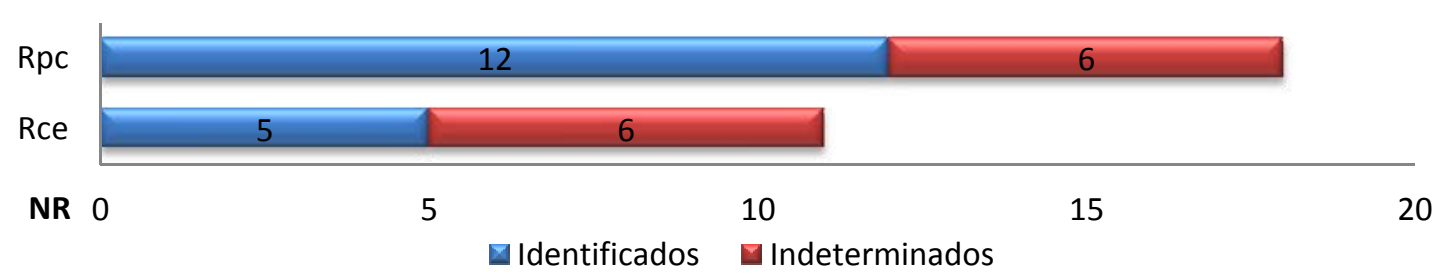

Fig. 118 Distribución esquelética de los restos ícticos del $1^{\mathrm{er}}$ Rebaje del Conchero 9.

Los restos post-cefálicos son los más numerosos, estando presentes en todas las especies identificadas. En cuanto a los cefálicos, únicamente están representados por Trisopterus luscus y Sardina pilchardus, aunque esta última con un único resto.

\section{V.3.4.1.6. Conchero 9/ 20 Rebaje}

\begin{tabular}{l|c|c|}
\multirow{2}{*}{\multicolumn{1}{c|}{ Inicial }} & cc. & gr. \\
\cline { 2 - 3 } & $\mathbf{2 . 0 0 0}$ & $\mathbf{1 . 9 1 2}$ \\
\hline \hline Residuo & 550 & 974 \\
\hline Cerámica & & 123 \\
\hline Malacofauna & & 751 \\
Micromoluscos & & 0,5 \\
Macrofauna & & 61 \\
Ictiofauna & & 1 \\
Carbón & & 2 \\
\hline
\end{tabular}

Tabla 84 Pesos iniciales (en gr.) del 20 Rebaje del Conchero 9 por componentes.

\begin{tabular}{|c|c|c|c|c|c|c|c|c|c|c|c|}
\hline & $\begin{array}{l}\text { Pal } \\
\text { (D/S) }\end{array}$ & $\begin{array}{l}\text { Opc } \\
\text { (D/S) }\end{array}$ & Oto & Atl & Vpc & Vca & Rce & Rpc & Esa & NR & NMI \\
\hline Sardina pilchardus & & $0 / 1$ & & 1 & 10 & & & & & 12 & 1 \\
\hline Dicentrarchus labrax & & & & & & 1 & & & & 1 & 1 \\
\hline Pagellus bogaraveo & $1 / 0$ & & 1 & & & & & & & 2 & 1 \\
\hline Indeterminado & & & & & & 1 & 12 & 17 & 75 & 105 & \\
\hline
\end{tabular}

Tabla 85 Relación de especies y representación ósea del 2ำ Rebaje del Conchero 9.

En la muestra del segundo de los rebajes del Conchero 9 se documentaron 16 piezas óseas identificables pertenecientes a tres taxones, además de 12 restos cefálicos, 17 post-cefálicos indeterminados y 75 escamas. Sardina pilchardus es la especie con más restos: un opercular izquierdo, un atlas y diez vértebras precaudales. El resto del conjunto lo forman Dicentrarchus labrax con una vértebra caudal y Pagellus bogaraveo con una palatino derecho y un otolito. 


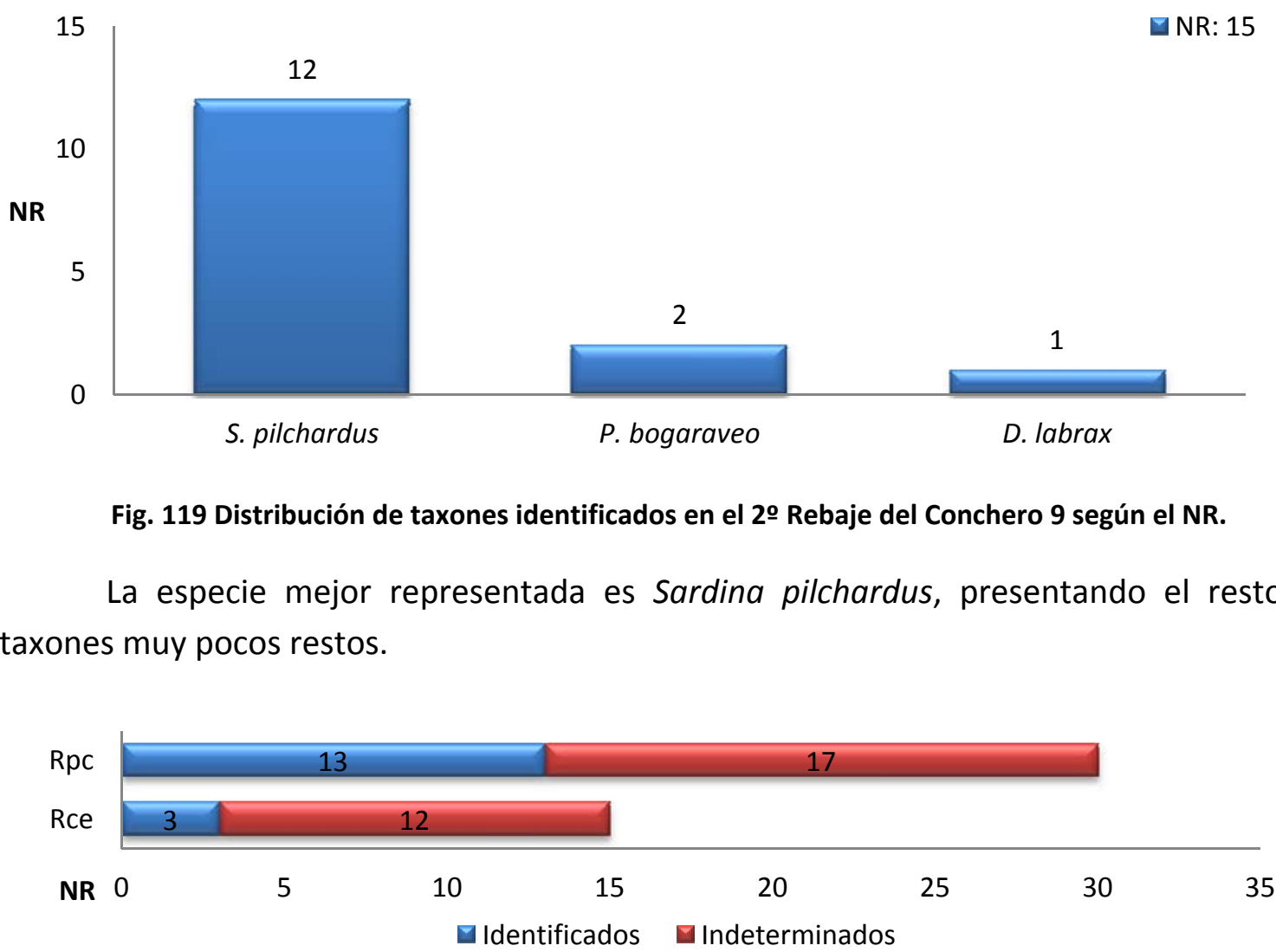

Fig. 120 Distribución esquelética de los restos ícticos del 20 Rebaje del Conchero 9.

Predominan los restos post-cefálicos, al igual que ya habíamos visto para las demás muestras. Pese a este bajo número de restos cefálicos, la representación de Pagellus bogaraveo se va a registrar únicamente en esta categoría.

\section{V.3.4.1.7. Conchero 9/ 3 er Rebaje}

\begin{tabular}{l|c|c|}
\multirow{2}{*}{\multicolumn{1}{c|}{ Inicial }} & cc. & gr. \\
\cline { 2 - 3 } & $\mathbf{8 0 0}$ & $\mathbf{4 2 0}$ \\
\hline \hline Residuo & 100 & 92 \\
\hline Malacofauna & & 327 \\
Ictiofauna & & 0,5 \\
Carbón & & 0,5 \\
\hline
\end{tabular}

Tabla 86 Pesos iniciales (en gr.) del $3^{\text {er }}$ Rebaje del Conchero 9 por componentes.

\begin{tabular}{ccccc} 
& Rce & Esa & NR & NMI \\
\hline Indeterminado & 2 & 4 & 6 & \\
\hline \hline TOTAL & 2 & 4 & 6
\end{tabular}

Tabla 87 Relación de especies y representación ósea del $3^{\text {er }}$ Rebaje del Conchero 9.

Esta muestra presentaba muy poco volumen, documentándose únicamente dos restos cefálicos indeterminados y cuatro escamas. 


\section{V.3.4.2. SECTOR 2}

\section{V.3.4.2.1. Conchero 1/ 1 ${ }^{\mathrm{er}}$ Rebaje}

\begin{tabular}{l|c|c|}
\multirow{2}{*}{ Inicial } & cc. & gr. \\
\cline { 2 - 3 } & $\mathbf{1 9 5 0}$ & $\mathbf{1 . 8 5 2}$ \\
\hline \hline Residuo & 450 & 916 \\
\hline Cerámica & & 8 \\
\hline Malacofauna & & 923 \\
Micromoluscos & & 0,5 \\
Macrofauna & & 0,5 \\
Ictiofauna & & 2 \\
Carbón & & 2 \\
\hline
\end{tabular}

Tabla 88 Pesos iniciales (en gr.) del $1^{\text {er }}$ Rebaje del Conchero 1 por componentes.

\begin{tabular}{|c|c|c|c|c|c|c|c|c|c|c|c|}
\hline & $\begin{array}{l}\text { Pmx } \\
(D / S)\end{array}$ & $\begin{array}{c}\text { Pal } \\
\text { (D/S) }\end{array}$ & $\begin{array}{c}\text { Eph } \\
\text { (D/S) }\end{array}$ & Atl & Vpc & Vca & Rce & Rpc & Esa & NR & NMI \\
\hline Sardina pilchardus & & & & & 12 & 3 & & & & 15 & 1 \\
\hline Merluccius merluccius & & & $1 / 0$ & & 1 & 1 & & & & 3 & 1 \\
\hline Pagellus bogaraveo & & $0 / 1$ & & 1 & & 2 & & & & 4 & 1 \\
\hline Trisopterus luscus & $0 / 1$ & & & & & & & & & 1 & 1 \\
\hline Indeterminado & & & & & & & 10 & 10 & 33 & 53 & \\
\hline TOTAL & 1 & 1 & 1 & 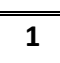 & 13 & 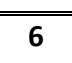 & 10 & 10 & 33 & 46 & \\
\hline
\end{tabular}

Tabla 89 Relación de especies y representación ósea del $1^{\mathrm{er}}$ Rebaje del Conchero 1.

La muestra incluía 23 piezas óseas identificables pertenecientes a cuatro taxones, 10 restos cefálicos y 10 post-cefálicos indeterminados, así como 33 escamas. Sardina pilchardus es la especie representada por un mayor número de restos: 12 vértebras precaudales y tres vértebras caudales. De Pagellus bogaraveo se identificaron un palatino izquierdo, un atlas y dos vértebras caudales. El resto del conjunto lo completan Merluccius merluccius con un ephilial derecho, una vértebra precaudal y otra caudal; y Trisopterus luscus con un premaxilar izquierdo.

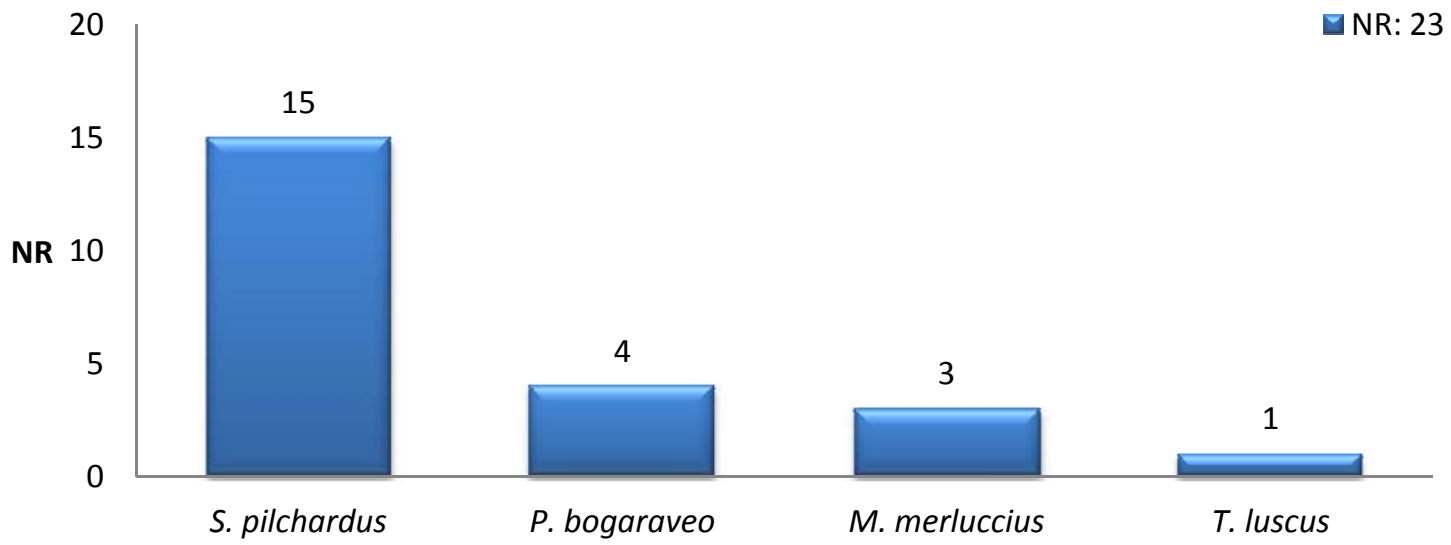

Fig. 121 Distribución de taxones identificados en el $1^{\text {er }}$ Rebaje del Conchero 1 según el NR. 
La especie con más piezas óseas identificadas es Sardina pilchardus. Como hemos visto en otras muestras, la mayor presencia de este taxón está acompañada de una mayor diversidad de especies. Este conjunto estaría compuesto además por Pagellus bogaraveo y Merluccius merluccius, así como Trisopterus luscus, si bien esta última especie con un único resto identificado.

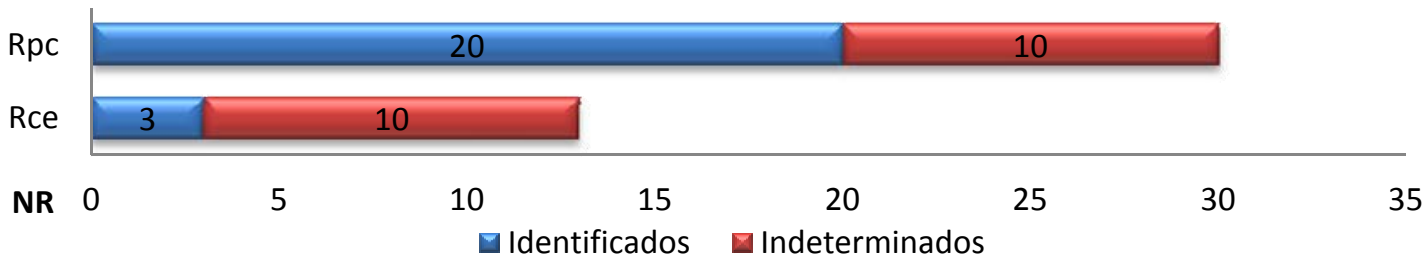

Fig. 122 Distribución esquelética de los restos ícticos del $1^{\mathrm{er}}$ Rebaje del Conchero 1.

Dominan los restos post-cefálicos, representados principalmente por las vértebras de Sardina pilchardus, de la que no se han reconocido piezas craneales. Los restos cefálicos están presentes en las demás especies.

\section{V.3.4.2.2. Conchero 1/ 2o Rebaje}

\begin{tabular}{l|c|c|}
\multirow{2}{*}{ Inicial } & cc. & gr. \\
\cline { 2 - 3 } & $\mathbf{2 . 0 0 0}$ & $\mathbf{1 . 7 9 0}$ \\
\hline \hline Residuo & 340 & 746 \\
\hline Cerámica & & 3 \\
\hline Malacofauna & & 1.032 \\
Micromoluscos & & 0,5 \\
Ictiofauna & & 0,5 \\
Carbón & & 8 \\
\hline
\end{tabular}

Tabla 90 Pesos iniciales (en gr.) del 20 Rebaje del Conchero 1 por componentes.

\begin{tabular}{lcccccccc} 
& Oto & Vpc & Vca & Rce & Rpc & Esa & NR & NMI \\
\hline Sardina pilchardus & & 2 & 1 & & & & $\mathbf{3}$ & 1 \\
Merluccius merluccius & & 2 & & & & & $\mathbf{2}$ & 1 \\
Trisopterus luscus & 1 & 1 & 1 & & & & $\mathbf{3}$ & 1 \\
Indeterminado & & 2 & & 1 & 3 & 5 & $\mathbf{1 1}$ & 1 \\
\hline \multicolumn{1}{c}{ TOTAL } & $\mathbf{1}$ & $\mathbf{7}$ & $\mathbf{2}$ & $\mathbf{1}$ & $\mathbf{3}$ & $\mathbf{5}$ & $\mathbf{1 9}$ &
\end{tabular}

Tabla 91 Relación de especies y representación ósea del 2ำ Rebaje del Conchero 1.

En el segundo rebaje del Conchero 1 se recuperaron 10 piezas óseas identificables pertenecientes a tres taxones, un resto cefálico y tres post-cefálicos indeterminados y cinco escamas. Las especies a las que corresponde un mayor número de restos son Sardina pilchardus con dos vértebras precaudales y una caudal; y Trisopterus luscus con un otolito, una vértebra precaudal y otra caudal. El conjunto lo completarían dos vértebras precaudales de Merluccius merluccius. 


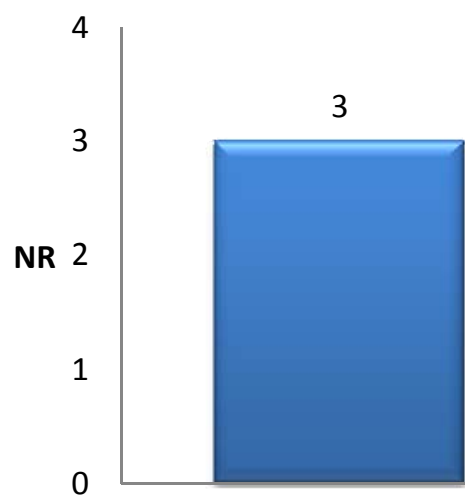

S. pilchardus

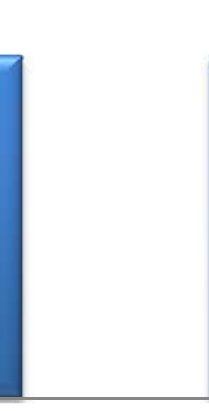

Fig. 123 Distribución de taxones identificados en el 20 Rebaje del Conchero 1 según el NR.

Los tres taxones identificados presentan unos valores muy similares, caracterizándose por su bajo número de restos.

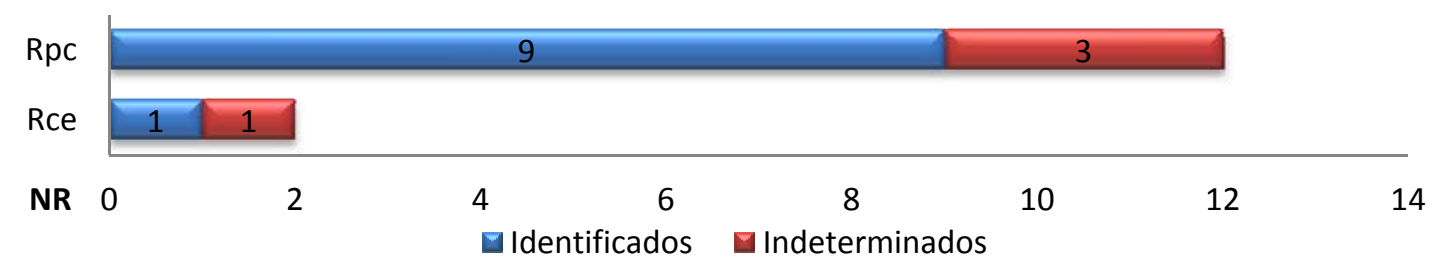

Fig. 124 Distribución esquelética de los restos ícticos del 2ㅇe Rebaje del Conchero 1.

Dominan los restos post-cefálicos frente los cefálicos, representados únicamente por un otolito de Trisopterus luscus y un fragmento indeterminado.

\section{V.3.4.2.3. Conchero 1/ 3 3er $^{\text {Rebaje }}$}

\begin{tabular}{l|c|c|}
\multirow{2}{*}{ Inicial } & cc. & gr. \\
\cline { 2 - 3 } \multicolumn{1}{c|}{} & $\mathbf{2 0 0 0}$ & $\mathbf{1 9 2 6}$ \\
\hline Residuo & 400 & 822 \\
\hline Cerámica & & 1 \\
\hline Malacofauna & & 1093 \\
Micromoluscos & & 0,5 \\
Macrofauna & & 0,5 \\
Ictiofauna & & 1 \\
Carbón & & 9 \\
\hline
\end{tabular}

Tabla 92 Pesos iniciales (en gr.) del $3^{\text {er }}$ Rebaje del Conchero 1 por componentes.

\begin{tabular}{lcccccc} 
& Vpc & Vca & Rpc & Esa & NR & NMI \\
\hline Sardina pilchardus & 3 & 3 & & & 6 & 1 \\
Pagellus acarne & & 1 & & & $\mathbf{1}$ & 1 \\
Indeterminado & & & 4 & 4 & $\mathbf{8}$ & \\
\hline \multicolumn{1}{c}{ TOTAL } & $\mathbf{3}$ & $\mathbf{4}$ & $\mathbf{4}$ & $\mathbf{4}$ & $\mathbf{1 5}$ &
\end{tabular}

Tabla 93 Relación de especies y representación ósea del $3^{\mathrm{er}}$ Rebaje del Conchero 1. 
El último rebaje del Conchero 1 ha aportado siete piezas óseas identificables pertenecientes a dos taxones, además de cuatro restos post-cefálicos indeterminados y cuatro escamas. La especie mejor representada es Sardina pilchardus con tres vértebras precaudales y otras tantas caudales. El otro taxón es Pagellus acarne, representado por una vértebra caudal.

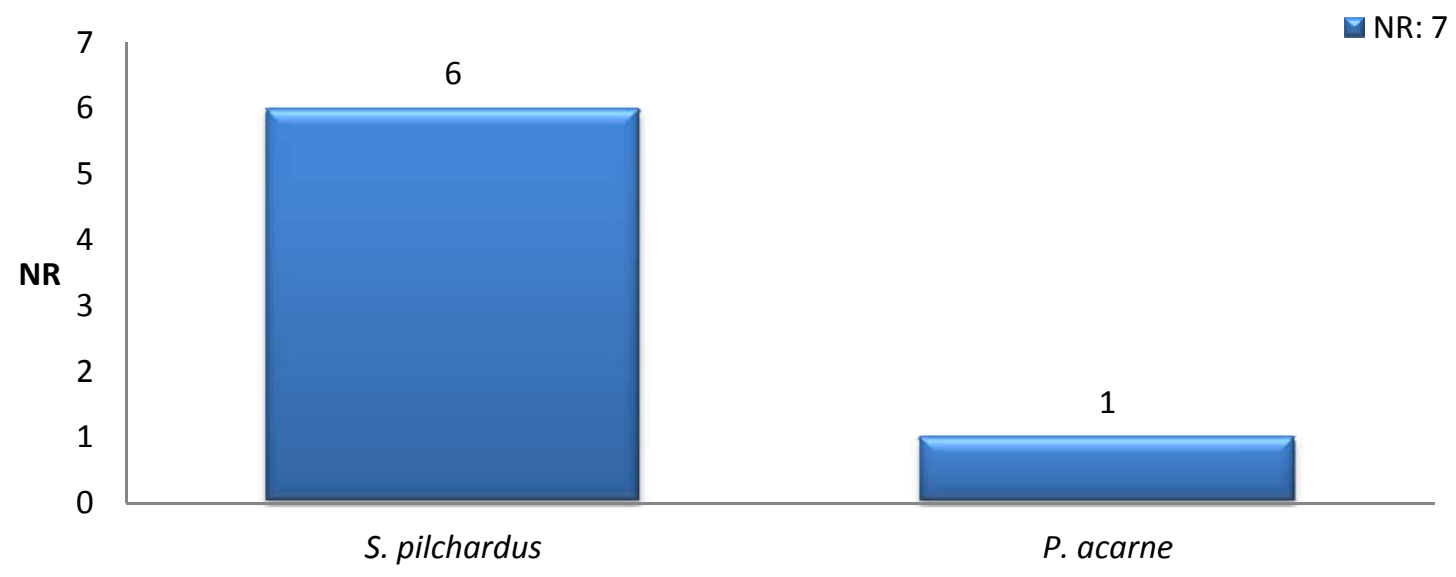

Fig. 125 Distribución de taxones identificados en el $3^{\text {er }}$ Rebaje del Conchero 1 según el NR.

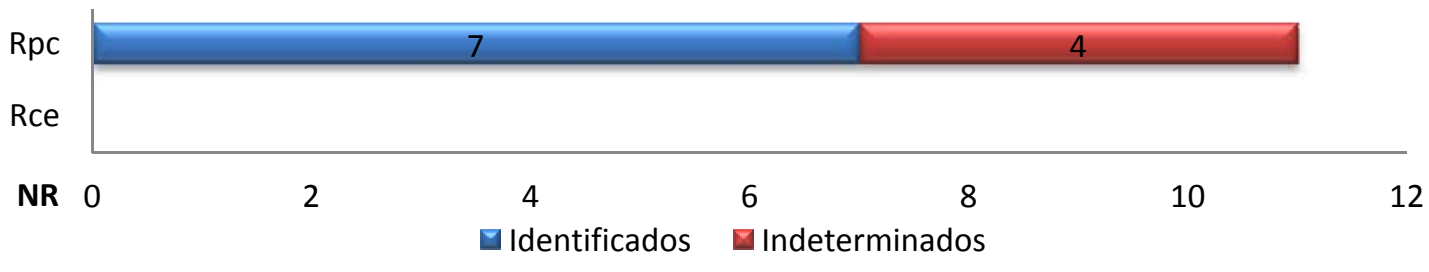

Fig. 126 Distribución esquelética de los restos ícticos del $3^{\text {er }}$ Rebaje del Conchero 1.

En esta muestra únicamente se recuperaron restos post-cefálicos, tanto identificables como entre los fragmentos indeterminados.

V.3.4.2.4. Conchero 5/ 1 ${ }^{\mathrm{er}}$ Rebaje

\begin{tabular}{l|c|c|}
\multirow{2}{*}{\multicolumn{1}{c|}{ Inicial }} & cc. & gr. \\
\cline { 2 - 3 } & $\mathbf{2 . 0 0 0}$ & $\mathbf{1 . 9 3 6}$ \\
\hline \hline Residuo & 800 & 1.509 \\
\hline Cerámica & & 6 \\
\hline Malacofauna & & 410 \\
Micromoluscos & & 1 \\
Macrofauna & & 2 \\
Ictiofauna & & 3 \\
Carbón & & 5 \\
\hline
\end{tabular}

Tabla 94 Pesos iniciales (en gr.) del $1^{\mathrm{er}}$ Rebaje del Conchero 5 por componentes. 


\begin{tabular}{|c|c|c|c|c|c|c|c|c|c|c|c|}
\hline & $\begin{array}{l}\text { Pop } \\
\text { (D/S) }\end{array}$ & Pst & $\begin{array}{c}\text { Pal } \\
\text { (D/S) }\end{array}$ & Atl & Vpc & Vca & Rce & Rpc & Esa & NR & NMI \\
\hline Sardina pilchardus & $1 / 0$ & & & & 23 & 14 & & & & 38 & 1 \\
\hline Merluccius merluccius & & 1 & & & 7 & & & & & 8 & 1 \\
\hline Pagellus acarne & & & & & & 2 & & & & 2 & 1 \\
\hline Pagellus bogaraveo & & & $1 / 0$ & 1 & & & & & & 2 & 1 \\
\hline Trisopterus luscus & & & & & 2 & 3 & & & & 5 & 1 \\
\hline Indeterminado & & & & & & & 6 & 79 & 38 & 123 & \\
\hline TOTAL & 1 & 1 & 1 & 1 & 32 & 19 & 6 & 79 & 38 & 178 & \\
\hline
\end{tabular}

Tabla 95 Relación de especies y representación ósea del $1^{\mathrm{er}}$ Rebaje del Conchero 5.

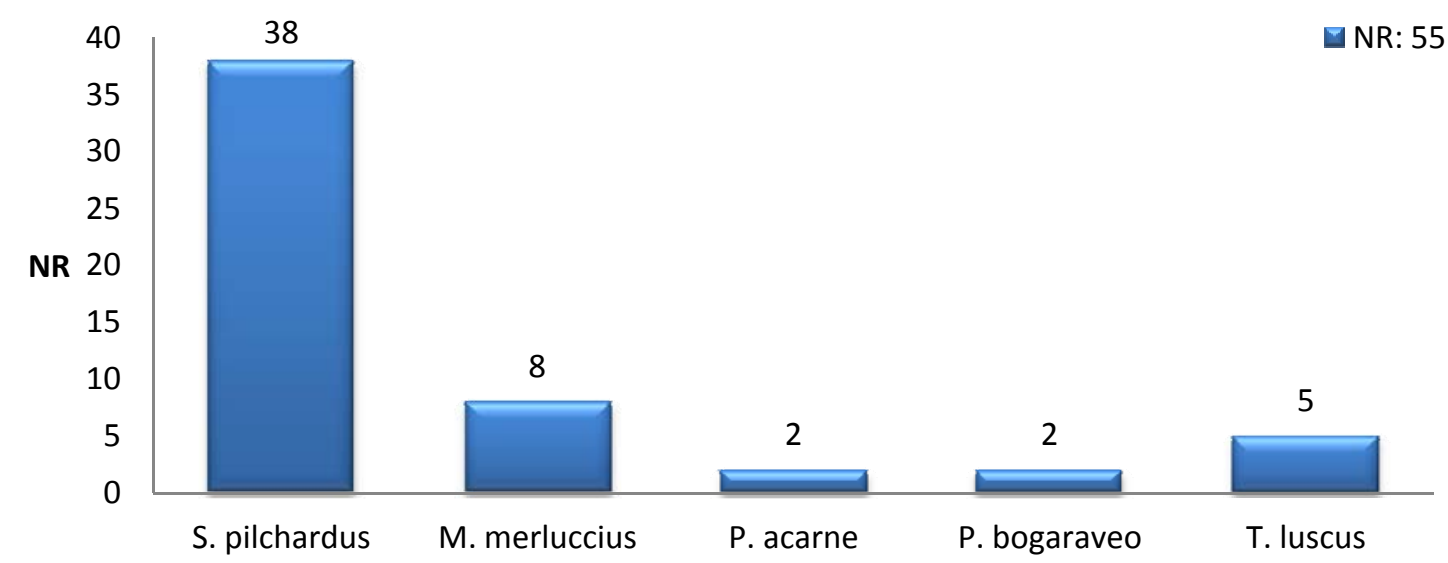

Fig. 127 Distribución de taxones identificados en el $1^{\mathrm{er}}$ Rebaje del Conchero 5 según el NR.

En el primer rebaje del Conchero 5 se pudieron recuperar 55 piezas óseas identificables pertenecientes a cinco taxones, seis restos cefálicos y 79 post-cefálicos indeterminados y 38 escamas. La especie mejor representada es Sardina pilchardus con un preopercular derecho, 23 vértebras precaudales y 14 vértebras caudales. Con un menor volumen de restos se encontraría Merluccius merluccius con un postemporal y siete vértebras precaudales; y Trisopterus luscus con dos vértebras precaudales y tres vértebras caudales. Por último, con una representación mínima contamos con un palatino derecho y un atlas de Pagellus bogaraveo, así como dos vértebras caudales de Pagellus acarne.

La especie que presenta más piezas identificadas es Sardina pilchardus, con un número de restos muy destacado sobre los demás taxones. Como observábamos en otras muestras del yacimiento, la mayor diversidad de especies se localiza en aquellos niveles con predominio de este taxón. Merluccius merluccius y Trisopterus luscus serían las siguientes especies con mejor representación, siendo muy pocos los restos documentados de Pagellus acarne y Pagellus bogaraveo. 


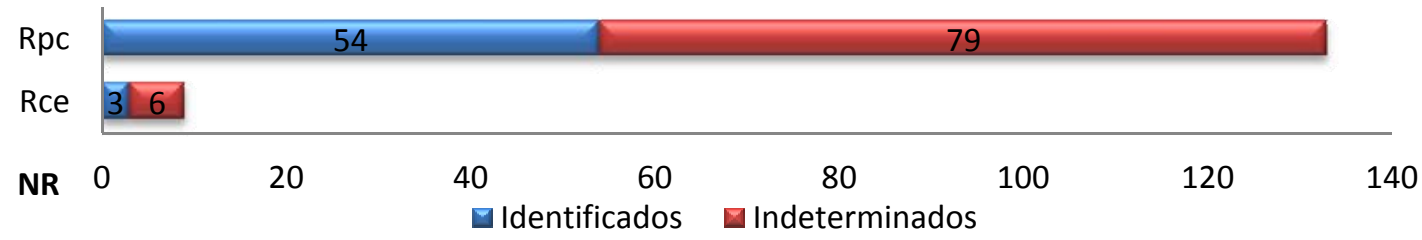

Fig. 128 Distribución esquelética de los restos ícticos del $1^{\mathrm{er}}$ Rebaje del Conchero 5.

Los restos post-cefálicos son los más numerosos, en parte debido a que la mayoría de los restos de Sardina pilchardus, la especie mejor representada, corresponden a vértebras. En cuanto a las piezas cefálicas, únicamente se han identificado tres taxones.

\section{V.3.4.2.5. Conchero 5/ 2o Rebaje}

\begin{tabular}{l|c|c|}
\multirow{2}{*}{ Inicial } & cc. & gr. \\
\cline { 2 - 3 } & $\mathbf{2 . 0 0 0}$ & $\mathbf{1 . 4 9 2}$ \\
\hline \hline Residuo & 200 & 637 \\
\hline Cerámica & & 2 \\
\hline Malacofauna & & 846 \\
Micromoluscos & & 1 \\
Macrofauna & & 1 \\
Ictiofauna & & 3 \\
Carbón & & 2 \\
\hline
\end{tabular}

Tabla 96 Pesos iniciales (en gr.) del 20 Rebaje del Conchero 5 por componentes.

\begin{tabular}{lccccccccc} 
& $\begin{array}{c}\text { Cdr } \\
\text { (D/S) }\end{array}$ & Atl & V & Vpc & Vca & Rpc & Esa & NR & NMI \\
\hline Sardina pilchardus & & 1 & & 5 & & & & $\mathbf{6}$ & 1 \\
Merluccius merluccius & & & 1 & 3 & 7 & & & $\mathbf{1 1}$ & 1 \\
Pagellus acarne & & & & & 1 & & & $\mathbf{1}$ & 1 \\
Pagellus bogaraveo & $0 / 1$ & & & & 2 & & & $\mathbf{3}$ & 1 \\
Indeterminado & & & & 3 & 2 & 80 & 35 & $\mathbf{1 2 0}$ & \\
\hline \multicolumn{1}{c}{ TOTAL } & $\mathbf{1}$ & $\mathbf{1}$ & $\mathbf{1}$ & $\mathbf{1 1}$ & $\mathbf{1 2}$ & $\mathbf{8 0}$ & $\mathbf{3 5}$ & $\mathbf{1 4 1}$ &
\end{tabular}

Tabla 97 Relación de especies y representación ósea del 2 Rebaje del Conchero 5.

La muestra incluye 26 piezas óseas identificables pertenecientes a cuatro taxones, 80 restos post-cefálicos indeterminados y 35 escamas. A Merluccius merluccius se le asignan la mayor parte de los restos: tres vértebras precaudales, siete caudales y una vértebra que no hemos podido precisar a qué parte correspondería debido a su mal estado de conservación. De Sardina pilchardus se han identificado un atlas y cinco vértebras precaudales, mientras Pagellus bogaraveo esta representada por un cuadrado izquierdo y dos vértebras caudales. Con una única vértebra caudal se ha constatado la presencia de Pagellus acarne. 


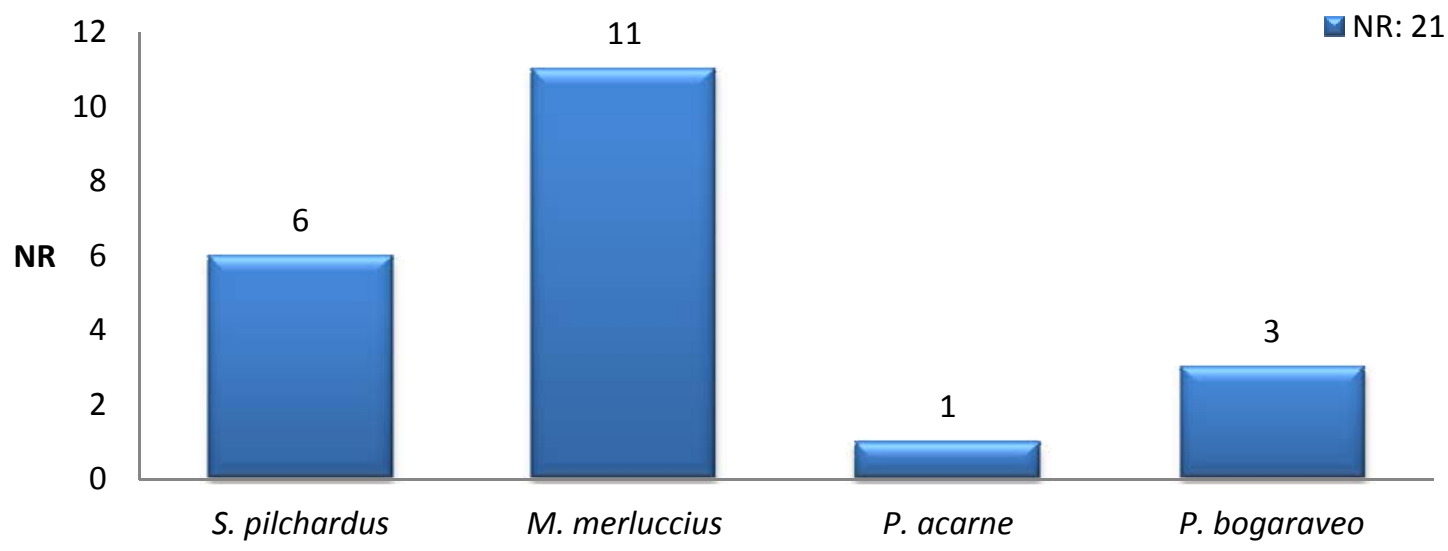

Fig. 129 Distribución de taxones identificados en el 20 Rebaje del Conchero 5 según el NR.

De nuevo las especies con más restos identificados son Merluccius merluccius y Sardina pilchardus, aspecto común a todas las muestras estudiadas en este yacimiento. A su vez, Pagellus bogaraveo y Pagellus acarne acompañan a estos taxones con una representación muy baja.

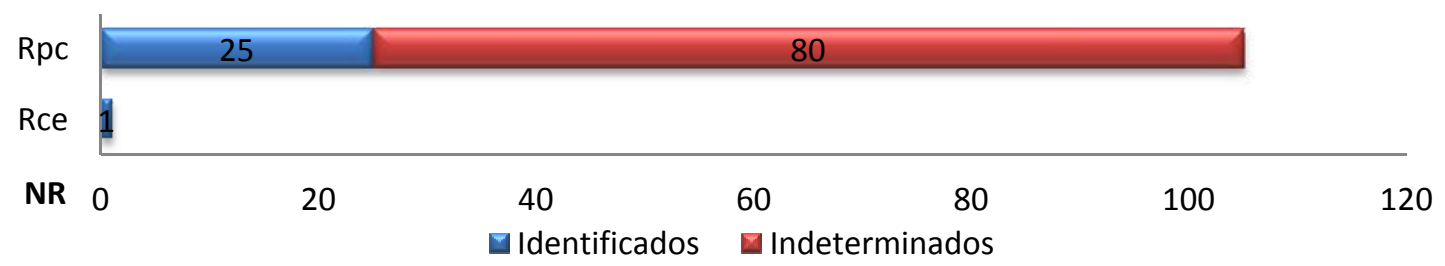

Fig. 130 Distribución esquelética de los restos ícticos del 2ำ Rebaje del Conchero 5.

Dominio claro de los restos post-cefálicos, identificándose un única pieza craneal perteneciente a Pagellus bogaraveo. Es destacable la ausencia de restos cefálicos de Merluccius merluccius, ya que suelen ser numerosos debido a su mayor osificación y tamaño.

\section{V.3.4.2.6. Conchero 5/ $3^{\text {er }}$ Rebaje}

\begin{tabular}{l|c|c|}
\multirow{2}{*}{\multicolumn{1}{c|}{ Inicial }} & cc. & gr. \\
\cline { 2 - 3 } & $\mathbf{2 . 0 0 0}$ & $\mathbf{2 . 0 0 6}$ \\
\hline \hline Residuo & 1.600 & 1.788 \\
\hline Cerámica & & 1 \\
\hline Malacofauna & & 213,5 \\
Ictiofauna & & 1,5 \\
Carbón & & 2 \\
\hline
\end{tabular}

Tabla 98 Pesos iniciales (en gr.) del $3^{\text {er }}$ Rebaje del Conchero 5 por componentes. 


\begin{tabular}{lccccccccc} 
& $\begin{array}{c}\text { Cdr } \\
\text { (D/S) }\end{array}$ & V & Vpc & Vca & Rce & Rpc & Esa & NR & NMI \\
\hline Sardina pilchardus & & & 15 & 10 & & & & $\mathbf{2 5}$ & $\mathbf{1}$ \\
Merluccius merluccius & & 1 & 1 & & & & & $\mathbf{2}$ & $\mathbf{1}$ \\
Pagellus bogaraveo & $0 / 1$ & & & 1 & & & & $\mathbf{2}$ & $\mathbf{1}$ \\
Trigla sp. & & & & 1 & & & & $\mathbf{1}$ & $\mathbf{1}$ \\
Ammodytidae & & & & 1 & & & & $\mathbf{1}$ & $\mathbf{1}$ \\
Indeterminado & & & & 1 & 4 & 42 & 29 & $\mathbf{7 6}$ & \\
\hline \multicolumn{1}{c}{$\quad$ TOTAL } & $\mathbf{1}$ & $\mathbf{1}$ & $\mathbf{1 6}$ & $\mathbf{1 4}$ & $\mathbf{4}$ & $\mathbf{4 2}$ & $\mathbf{2 9}$ & $\mathbf{1 0 7}$ &
\end{tabular}

Tabla 99 Relación de especies y representación ósea del $3^{\text {er }}$ Rebaje del Conchero 5.

En el último rebaje del Conchero 5 se pudieron recuperar 32 piezas óseas identificables pertenecientes a cinco taxones, además de cuatro restos cefálicos y 42 postcefálicos indeterminados y 29 escamas. Sardina pilchardus está representada por 15 vértebras precaudales y 10 caudales. El conjunto lo completarían Merluccius merluccius con una vértebra precaudal y otra que ha sido imposible asignar debido a su estado de conservación; Pagellus bogaraveo con un cuadrado izquierdo y una vértebra caudal; y Trigla sp. y Ammodytidae sp. con una vértebra precaudal cada una.

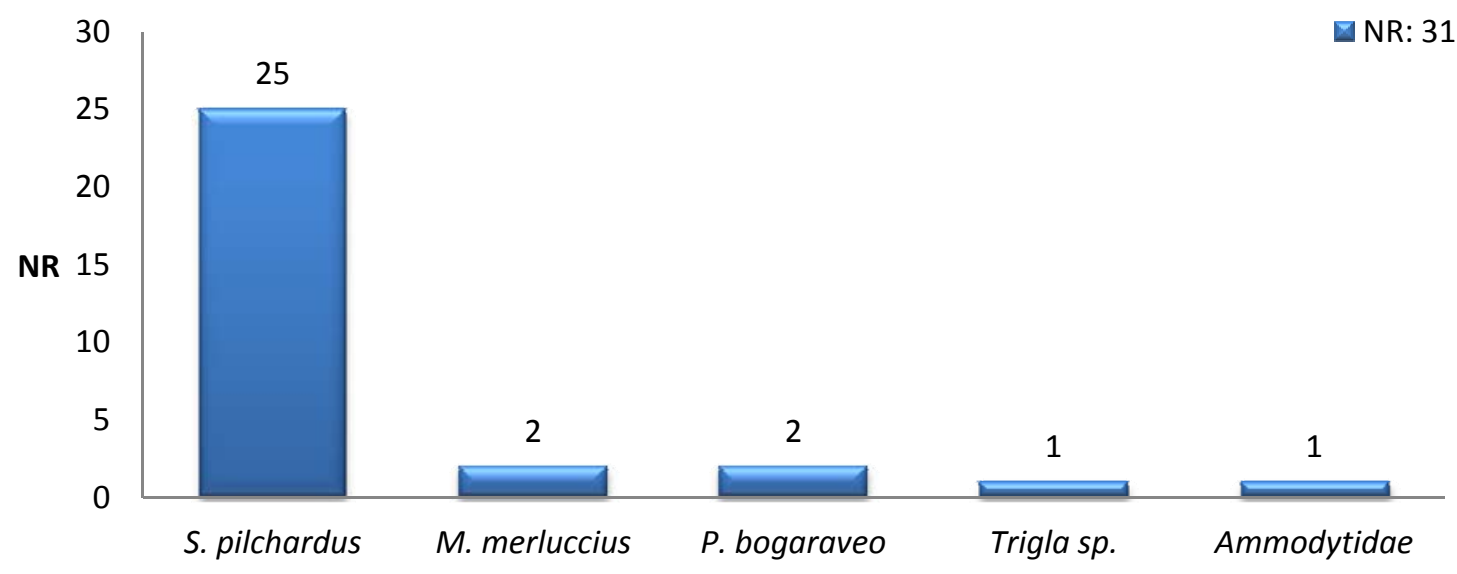

Fig. 131 Distribución de taxones identificados en el $3^{\text {er }}$ Rebaje del Conchero 5 según el NR.

El número de restos identificados de Sardina pilchardus es muy superior a la representación de los demás taxones, que que alcanza valores mínimos. Es destacable la presencia de una vértebra de Trigla sp., especie bentónica de zonas profundas, y de un ejemplar de la familia Ammodytidae. Los individuos de esta familia suelen vivir enterrados en suelos arenosos en la zona de mareas. 


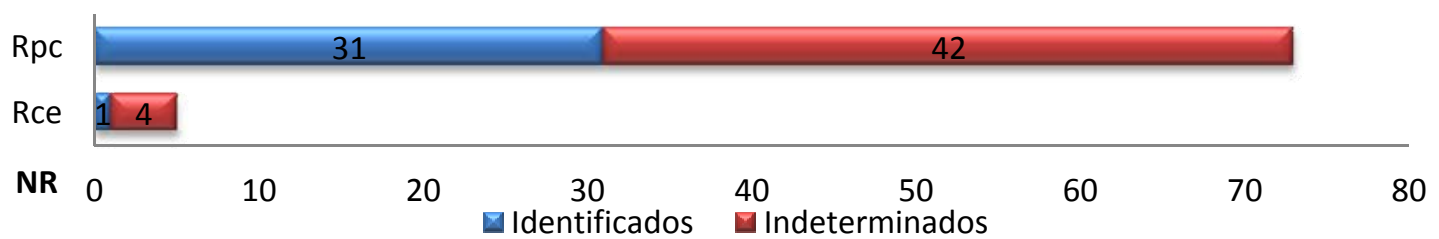

Fig. 132 Distribución esquelética de los restos ícticos del $3^{\text {er }}$ Rebaje del Conchero 5.

Predominio de los restos post-cefálicos tanto entre los identificados como entre los indeterminados. Como en la muestra anterior, están ausentes los restos cefálicos de Merluccius merluccius.

\section{V.3.5. Comentario.}

Ante la ausencia de datos cronológicos más precisos o de contextos diferentes que nos modifiquen sustancialmente la relación de las muestras, hemos decidido agrupar todos los datos a la hora de realizar una valoración. De todos modos sí hemos observado ciertas diferencias entre los sectores 1 y 2, con una mayor presencia de Merluccius merluccius en el primer sector, y de Sardina pilchardus en el segundo.

\section{Representación faunística.}

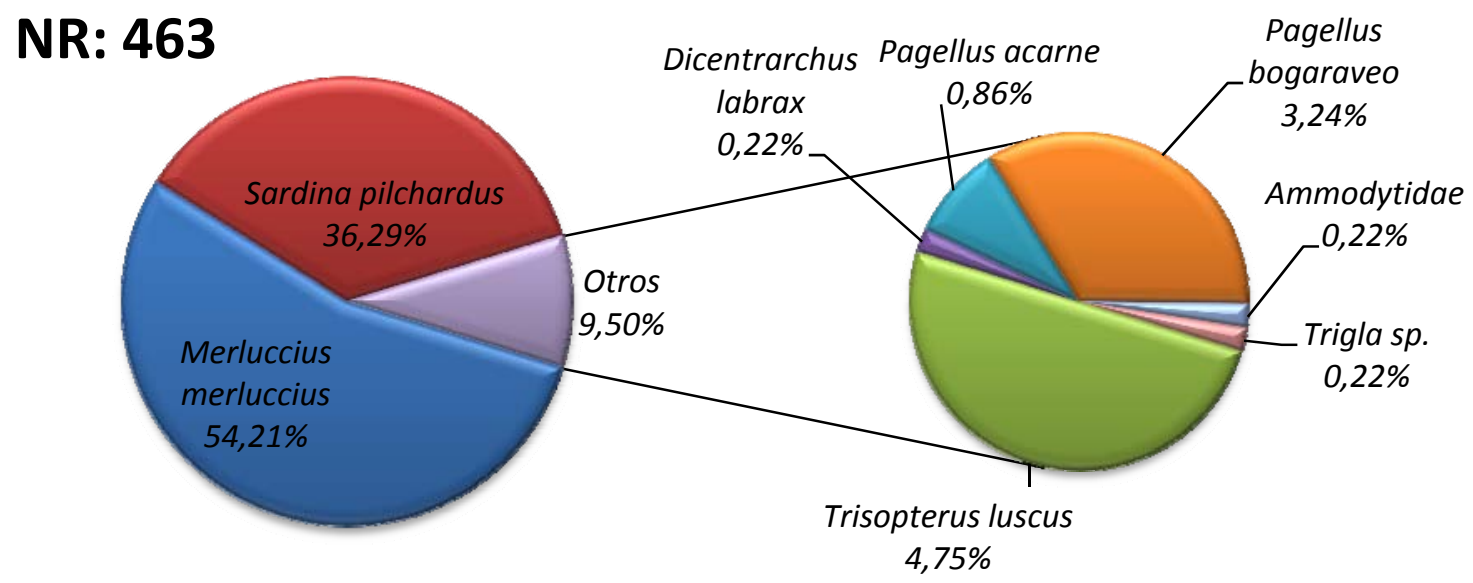

Fig. 133 Representatividad de los taxones identificados según el NR.

\begin{tabular}{l|c|c|c|} 
& IC & ID & ICxID \\
\cline { 2 - 4 } Sardina pilchardus & 84,6 & 36,2 & 3062,5 \\
Merluccius merluccius & 76,9 & 54,1 & 4160,3 \\
Trisopterus luscus & 38,5 & 4,7 & 181,0 \\
Dicentrarchus labrax & 7,7 & 0,2 & 1,5 \\
Pagellus acarne & 23,1 & 0,9 & 20,8 \\
Pagellus bogaraveo & 53,8 & 3,2 & 172,2 \\
Ammodytidae & 7,7 & 0,2 & 1,5 \\
Trigla sp. & 7,7 & 0,2 & 1,5
\end{tabular}

Tabla 100 Índices de valoración. 
Todas las muestras que se han procesado, presentan una gran homogeneidad respecto a los taxones identificados y a la importancia relativa de cada especie. A continuación vamos a exponer brevemente las características generales de las muestras y la importancia de los diferentes taxones presentes:

-Especies principales: El 90\% de los restos identificados pertenece a dos especies: Merluccius merluccius y Sardina pilchardus. Ambas especies van a jugar un papel fundamental en la economía medieval gallega, principalmente en el comercio a larga distancia. La representación anatómica de estas especies, así como la especialización en su captura, parecen indicar una explotación con fines comerciales.

-Especies complementarias: También se han recuperado otras especies, que, aunque cuentan con un menor número de restos, aparecen en varias muestras y presentan cierta importancia. Este grupo estaría formado por Trisopteros luscus, Pagellus bogaraveo y Paguellus acarne. Estos taxones son comunes en los yacimientos de fondo de Ría como veremos en el periodo prerromano (ver apartado VI.1.1.), lo que nos indicaría una captura en zonas próximas al yacimiento.

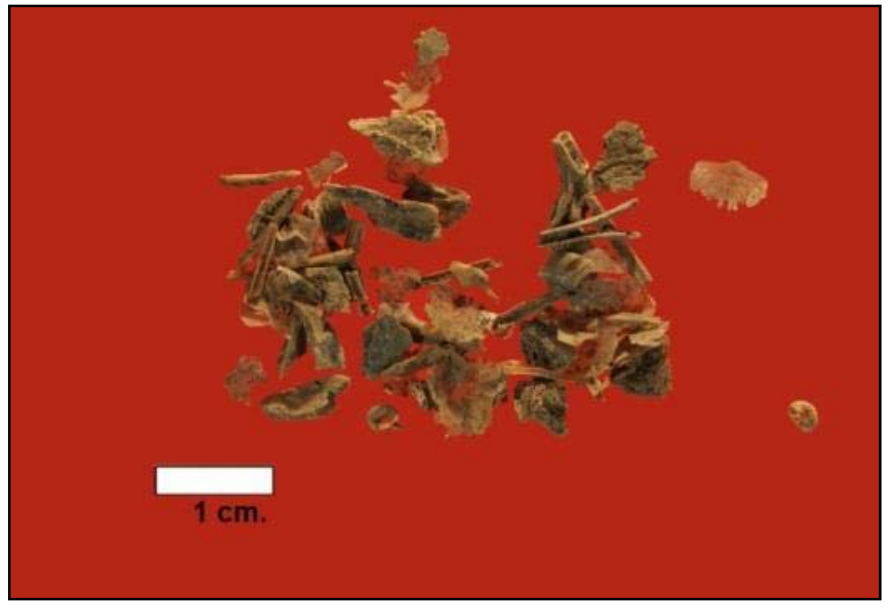

Fig. 134 Restos de ictiofauna del Sondeo 2, Capa 5, $3^{\text {er }}$ rebaje.
Es destacable el tamaño que presentan estos restos comparados con otros de la misma época, perteneciendo a ejemplares de pequeña talla, similares a los de época prerromana. Esto puede deberse a la captura de ejemplares jóvenes, que en estas especies, suelen ocupar zonas cercanas a la costa. Sin embargo, mientras en la Edad del Hierro sería debido a una pesca litoral, en el caso que nos ocupa podría estar relacionado con la captura de otras especies como Sardina pilchardus. En artes de pesca documentadas en la Ría de Noia con fechas anteriores al siglo XV, como la sacada o la traíña, las redes eran arrastradas con dornas y pinazas en el mar o con tracción animal y humana desde tierra (Ferreira Priegue, 1988: 140), lo que podría dar lugar a la captura de ejemplares de pequeño tamaño de algunas de estas especies, debido a los sacos tan tupidos que tenían (Fabeiro Gómez, 1990: 156). De hecho en la "Ordenanza de Pontevedra, autorizada de Real Aprobación en 9 de Abril de 1768" (Cornide, 1774: 90), se recoge la utilización de este arte para la pesca de besugos y fanecas, con mallas de dos dedos. 
Vca

Yacimientos castreños

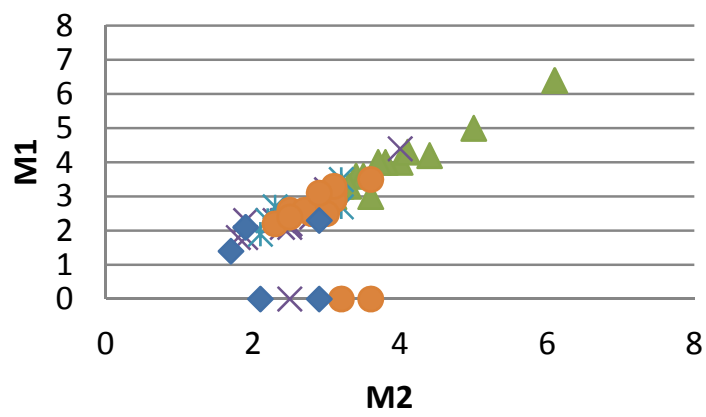

$\triangle \mathrm{IC}(14) \times \mathrm{MO}(15) * \operatorname{Par}(5) \bigcirc \mathrm{AL} 10(17) \diamond \mathrm{Ta}(5)$
Vca

Yacimientos medievales

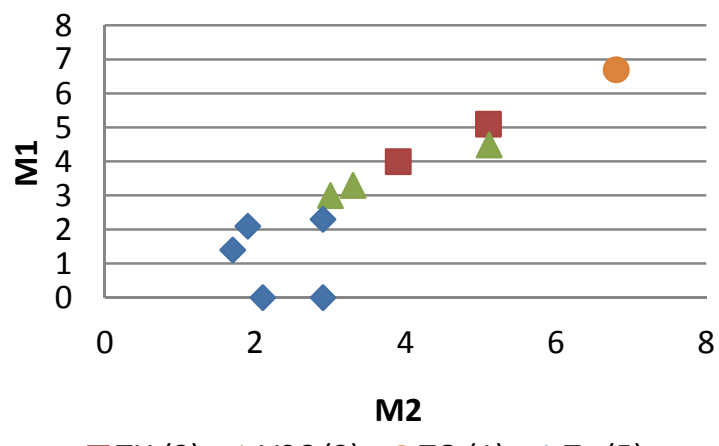

$\mathrm{TH}(2) \Delta \mathrm{V} 96(3) \circ \mathrm{TO}(1) \diamond \mathrm{Ta}(5)$

Fig. 135 Distribución biométrica $(\mathrm{mm}$.) de vértebras caudales de Pagellus bogaraveo en yacimientos castreños y de medievales (Ta=Taramancos; AL10= A Lanzada 2010; IC=Islas Cíes; MO=Montealegre; PAr=Punta Atalaia conchero; TH=Torre de Hércules; TO=Torres de Oeste; V96=Area 1996).

Vca

Yacimientos castreños

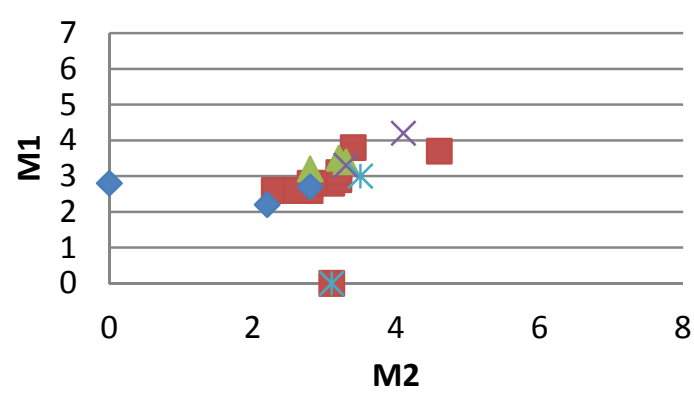

$\mathrm{AL}(10) \triangle \mathrm{OA}(3) \times \mathrm{IC}(2) * \mathrm{Pac}(2) \bullet \mathrm{TA}(3)$
Vca

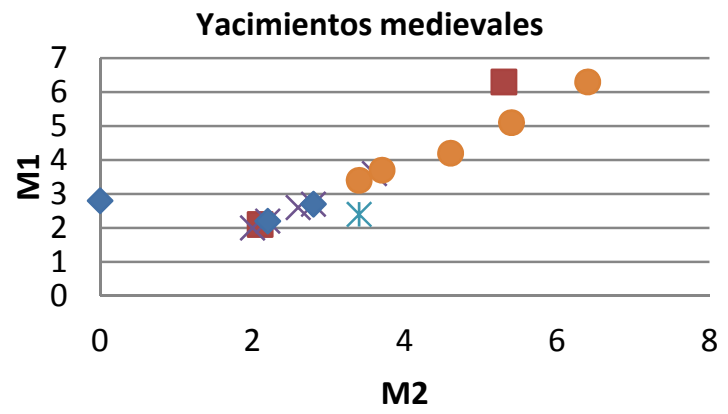

PA02 (02) ×V96 (5) $*$ TO (1) ○ TH (5) $\bullet$ TA (3)

Fig. 136 Distribución biométrica $(\mathrm{mm}$.) de vértebras caudales de Pagellus acarne en yacimientos castreños y medievales (Ta=Taramancos; AL10= A Lanzada 2010; IC=Islas Cíes; OA=O Achadizo; PAr=Punta Atalaia conchero; PA02= Punta Atalaia Solar 02; TH=Torre de Hércules; TO=Torres de Oeste; V96=Area 1996).

Vca

Yacimientos prerromanos y medievales

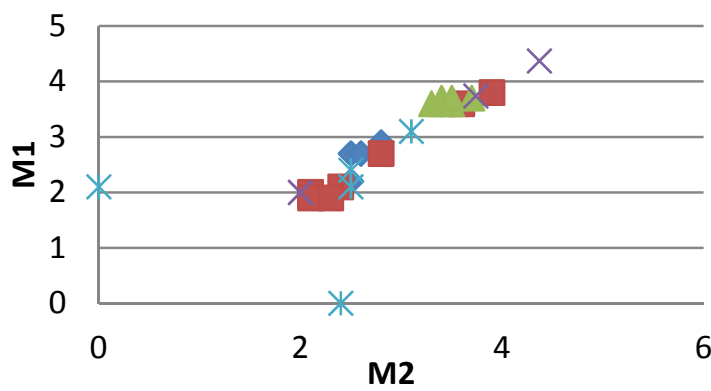

$\rightarrow \mathrm{MA}(6) \square \mathrm{MV}(7) \triangle \mathrm{AL}(6) \times \mathrm{V} 96(4) * \mathrm{Ta}(5)$
Fig. 137 Distribución biométrica de vértebras caudales de Trisopterus luscus en yacimientos medievales y prerromanos (Ta=Taramancos; AL10= A Lanzada 2010; MA=Montealegre; MV=Muiño do Vento; V96=Area96). 
En las Ordenanzas del pescado de la Villa de Noia, de 1589, aparece una relación de especies comercializadas y precios de las mismas (Fabeiro Gómez, 1990: 111). Hay que destacar la diferencia que hacen entre el besugo y el ollomol, tratada también por Cornide en el siglo XVIII. Según este autor el ollomol se identificaría con el "besugo de Laredo", que posiblemente se corresponda a Pagellus bogaraveo:

"...en su figura es parecido a una Dorada pequeña, de la que se diferencia en el color, porque el Besugo es ---- o pardusco por el lomo, y plateado por el cuerpo, y sus aletas tienen una tintura roxa, de estas las del lomo y vientre son espinosas, y sobre los juglares tienen una manchita negra como un realillo, la cabeza del Besugo es gruesa, carnosa, sus ojos grandes, la pupila negra, el iris plateado, su hocico mas romo que el del Besugo..." (Cornide, 1788: 40-41).

Al mismo tiempo habría el besugo gallego, que según apunta Cornide se correspondería con el Aligote de Gijón o el Pancho Pedrés de Luarca (Cornide, 1788: 42), pudiéndose relacionar con Pagellus acarne.

-Especies anecdóticas: En este último grupo recogemos toda una serie de taxones representados por un número mínimo de restos. Exceptuando a Dicentrarchus labrax, las demás especies son todas bentónicas. Este taxón va a jugar un papel importante en la Edad Media, tal y como se desprende del aumento del número de sus restos en otros yacimientos, quizás fruto del perfeccionamiento de las artes y aparejos de pesca. Respecto a Trigla sp., en el noroeste se documenta únicamente a partir de época medieval, pudiendo relacionarse sus capturas con la aplicación de artes de fondo este momento, incluso vinculadas a la pesca de algunas especies como Merluccius merluccius.

\section{Representatividad ósea.}

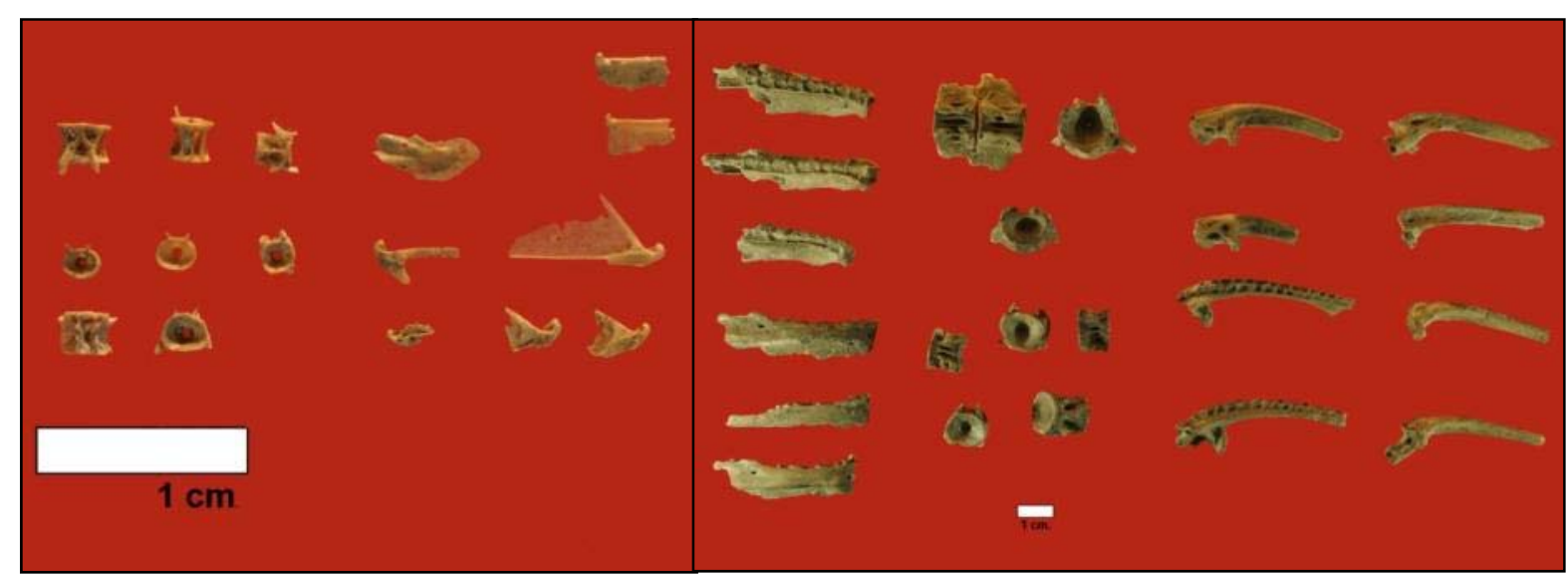

Fig. 138 Restos óseos de Sardina pilchardus (izquierda) y Merluccius merluccius (derecha). 
Sólo presentan restos cefálicos cuatro taxones, si bien van a ser superados por los restos post-cefálicos en todos los casos. En especies como Pagellus bogaraveo, Trisopterus luscus, y principalmente Merluccius merluccius, suele ser habitual la presencia de estos últimos en los yacimientos, posiblemente debido a la mayor osificación de estos huesos. En el caso de Sardina Pilchardus, sin ser excepcional, no suele ser tan habitual su identificación debido a su tamaño y mayor fragilidad. Para el resto de taxones hay que tener en cuenta los pocos restos recuperados.

En relación con la representación vertebral en todas las especies, exceptuando Sardina pilchardus y Merluccius merluccius, predominan las vértebras caudales, comportamiento similar a lo observado en otros yacimientos gallegos. En el caso de Merluccius merluccius, los restos más numerosos son los craneales y las vértebras precaudales, representación similar a la documentada en otros yacimientos medievales como Area o Punta Atalaia. Este patrón coincide con la descripción que realiza Joseph Cornide (1788) de la limpieza de esta especie para su conserva en sal, por lo que podríamos estar ante evidencias de estos procesados. Sardina pilchardus presenta una representación similar a la descrita para Merluccius merluccius, si bien en las descripciones que tenemos para su conserva incluyen el desechado de la cabeza y su evisceración, aunque no hablan de la eliminación de las vértebras (Cornide, 1774: 145; 1788: 93; Ferreira Priegue, 1988: 146). Esta distribución esquelética va a documentarse en otros yacimientos, principalmente desde época romana, como el Solar 02 de Punta Atalaia, y sobretodo medieval, si bien los datos con los que contamos nos impiden de momento hacer una valoración al respecto.

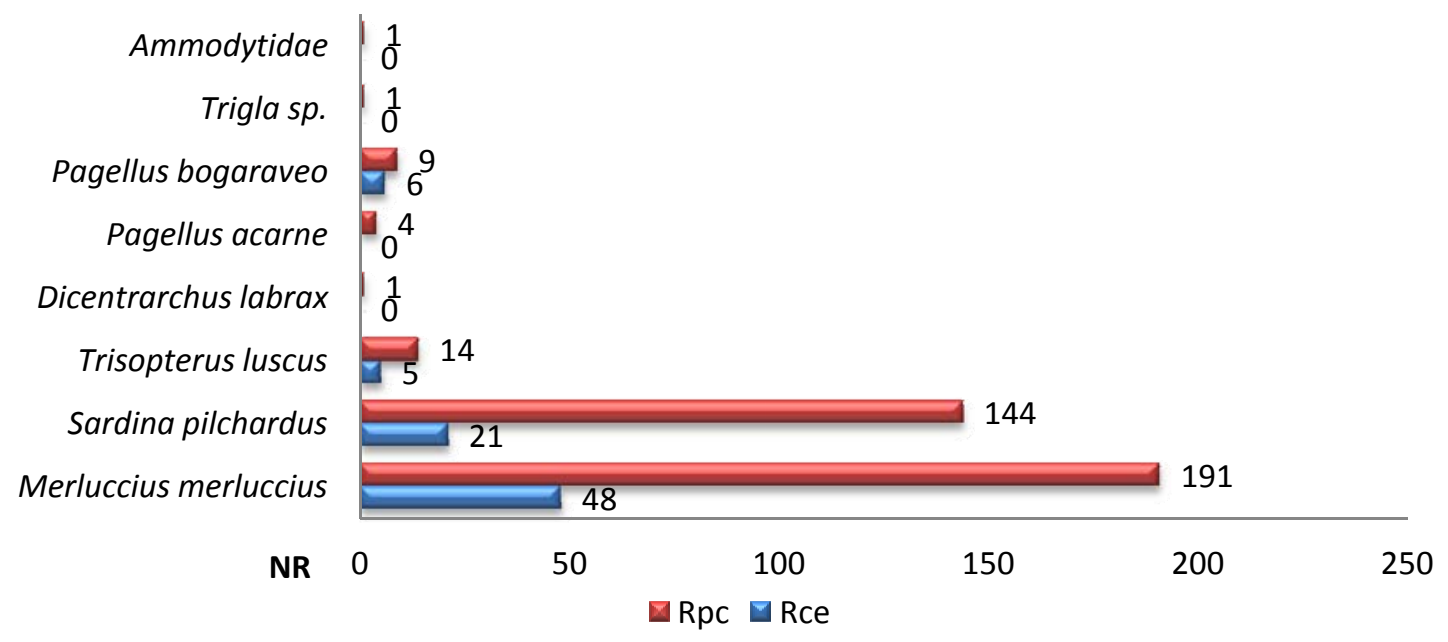

Fig. 139 Comparación numérica de los restos cefálicos y post-cefálicos de los diferentes taxones identificados. 


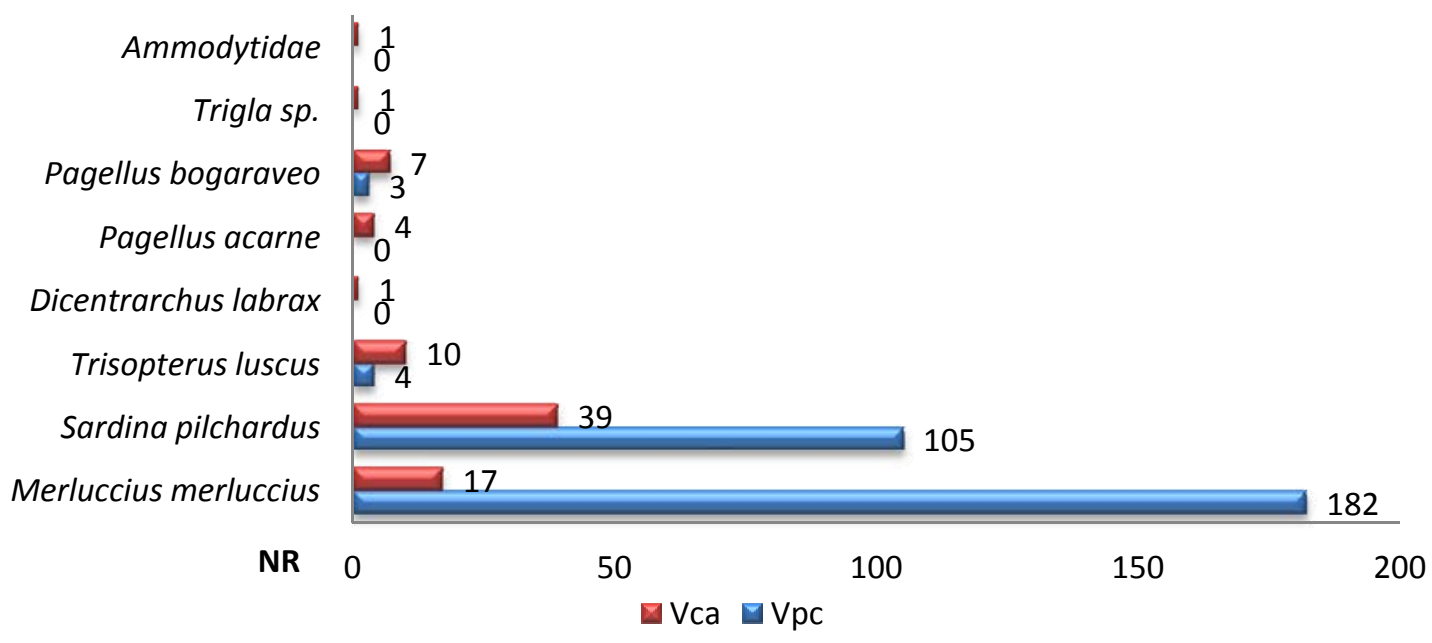

Fig. 140 Comparación numérica de las vértebras caudales y precaudales de los diferentes taxones identificados.

\section{V.3.6. CONSIDERACIONES FINALES.}

En Tramancos la pesca se centraría principalmente en especies demersales, aunque tan solo una de ellas, Merluccius merluccius, presenta una importancia significativa. Sin embargo, el otro taxón mejor representado, Sardina Pilchardus, va a ser pelágico, sin que se registren más especies de este dominio. También se han documentados varios taxones bentónicos, aun cuando estos van a tener importancia mínima dentro del conjunto. Teniendo en cuenta lo señalado, se parecia una especialización en las capturas centrada en dos especies: Merluccius merluccius y Sardina pilchardus. El análisis arqueomalacológico aportó unos resultados similares, con un marisqueo centrado en dos taxones: Ostrea edulis y Cerastoderma edule (Bejega et alii, 2012).

La importancia de la pesca de Sardina pilchardus en la zona de Noia queda perfectamente constatado en la documentación de la época, siendo muy apreciada en los mercados exteriores por su calidad (Ferreira Priegue, 1988: 134). La pesca de esta especie se realizaría con el jeito, la sacada y el cerco, desarrollándose de forma preferente en los meses de primavera y verano para salar y en otoño e invierno para ahumar (Cornide, 1774; 1788; Ferreira Priegue, 1988: 146). La otra especie importante es Merluccius merluccius, que si bien no parece haber tenido tanta relevancia como Sardina pilchardus, según parece era muy abundante en la Ría (Ferreira Priegue, 1988: 143) y de gran importancia económica como se desprende de los pagos de portazgo de las villas cercanas a Noia:

"Iten ha de auer el mayordomo el portaje de dez e seys duzenas de pixotas pequeñas que montan cient dozenas pequeñas e XII dineros e medio" (López Ferreiro, 1875: 122). 
Otras especies como Pagellus bogaraveo o Trisopterus luscus presentan un menor valor comercial, por lo menos a larga distancia. Su pesca se realizaría principalmente mediante el trasmallo (Ferreira Priegue, 1988: 139-140), aunque también podían ser capturadas con otros métodos como la sacada (Cornide, 1774: 90). En el caso de Pagellus bogaraveo, aunque no sea una especie apreciada de largo recorrido, sí parece que tenía gran demanda en los mercados de pescado fresco (Ferreira Priegue, 1988: 140). Como ya comentamos anteriormente, es probable que la captura de estas especies pueda estar vinculada a la pesca de Sardina pilchardus. Ambos son taxones abundantes en el fondo de ría, como se deduce tanto del registro de los yacimientos prerromanos como de la documentación medieval, estando especificados en los diezmos del Fuero de Noia:

"Iten ha de auer el mayordomo la meytad del diesmo de losque dan por enero e de los busugeyros e de las fanecas e de los otros" (López Ferreiro, 1875: 117).

La posibilidad de que se trate de una pesca casual no implica que sean desechados, pudiendo haber servido como alimento a la población local, así como de producto de comercio a corta distancia.
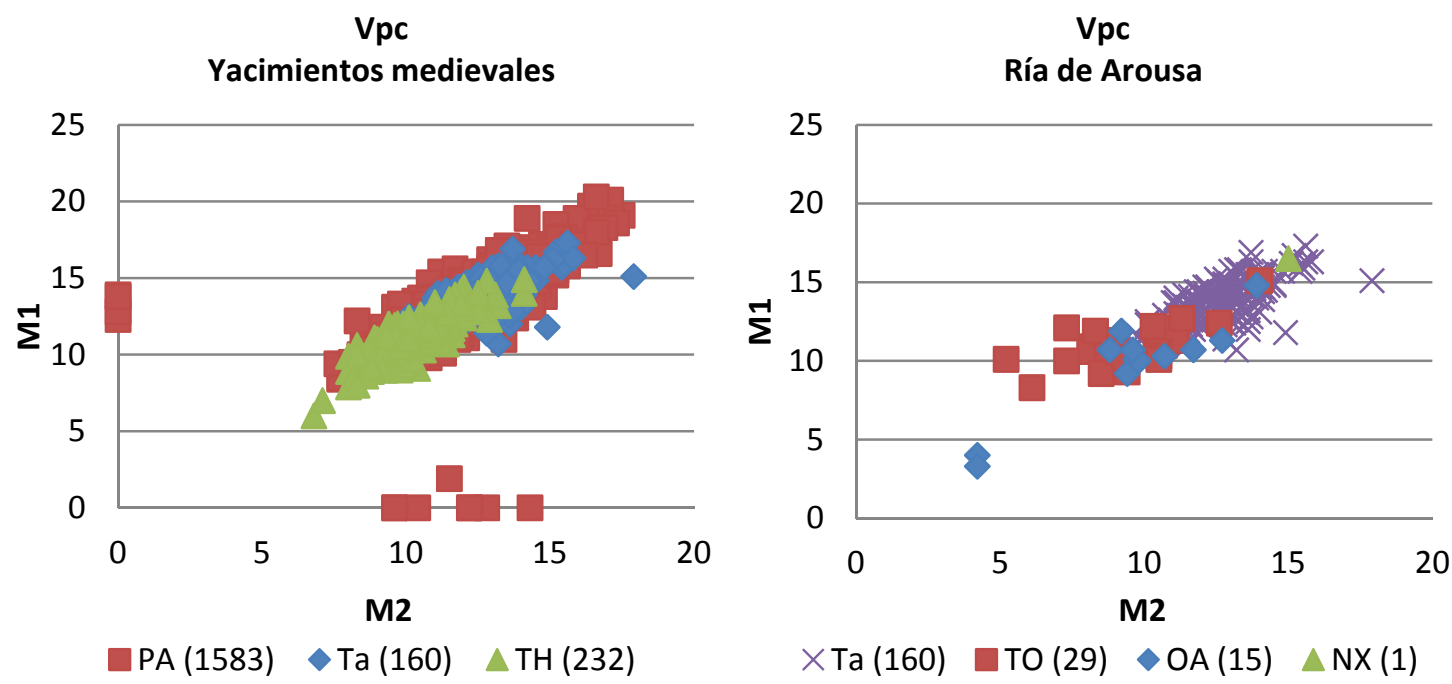

Fig. 141 Distribución biométrica de vértebras precaudales de Merluccius merluccius en yacimientos medievales y en la Ría de Arousa (Ta=Taramancos; NX=Neixón; OA=O Achadizo; PA=Punta Atalaia Solar 02; TH=Torre de Hércules; TO=Torres do Oeste).

El tamaño de los restos óseos de Merlucius merluccius de Taramancos parecen indicar la presencia de individuos de mayor talla que los documentados en el interior de rías como la de Arousa, con valores similares a los documentados en yacimientos medievales localizados fuera de las rías, quzás debido a unas mejores condiciones para el desarrollo de esta especie en las zonas exteriores. Esto nos hace plantear la posibilidad de 
que los ejemplares de Taramancos fueran capturados en zonas alejadas de la ría y no en el entorno inmediato, donde pudieron haber sido pescadas el resto de especies, si bien serían necesarios más datos para confirmar esta hipótesis.

La importancia comercial de Sardina pilchardus y Merluccius merluccius durante la Edad Media y Moderna, así como la representación esquelética de esta última especie nos hace pensar en la elaboración de conservas. Taramancos era puerto subsidiario de Noia, si bien desde 1434 el Arzobispado le va a otorgar el privilegio, mediante el pago de derechos al mayordomo arzobispal, de llevar las capturas a tierra en su propio puerto sin tener que descargar en Noia (Ferreira Priegue, 1988: 134):

"Iten ha de auer el mayordomo el portaje de los barcos que estodieren en Minortos e en Boa e eno Pereyro e en Taramancos e eno Oure, que andaren a pescar e a las ostras de que deuen dar por cada vez que fuere a la mar cada uno que pescado o sardinas o ostras traxier I soldo, o se auenir con el mayordomo de Noya por estos pescados e ostras e portajes por todo el año e por faseren portos en los dichos lugares con estos pescados e ostras e por los non constrener el mayordomo de Noya que vengan á la villa de Noya a faser puerto con estos pescados e ostras, por que se deuen auenir con el mayordomo de Noya" (López Ferreiro, 1875: 121).

Por otro lado, en Noia, las instalaciones conserveras se situaban en la periferia de la villa formando complejos industriales (Ferreira Priegue, 1988: 150), prohibiendose en las ordenanzas de 1589 el salado dentro de la villa:

"Iten hordenaron y mandaron que ning ${ }^{a}$ persona sea osado de salar en su casa ni azer pila de sardina ni de otra pesca alguna so pena de seiscientos maravedís y veinte días de carzel por la primera bez y por la segd ${ }^{a}$ millmrs. Y la dha sardina y pesca que le fuere allada perdida y por la tercera bez que le sea doblada la pena de los dos mil mrs. Y perdimiento de la dha sardina y pesca que ansi le fuere allada" (Fabeiro Gómez, 1990: 140).

La situación del yacimiento cerca la costa y ligeramente alejado de la población de Taramancos, podría responder a una de estas fábricas. Por lo tanto, es probable que estos depósitos correspondan a los desechos de alguna instalación conservera situada en las inmediaciones. 


\section{V.4. El Castro Grande de 0 Neixón.}

\section{V.4.1. LOCALIZACIÓN GEOGRÁFICA.}

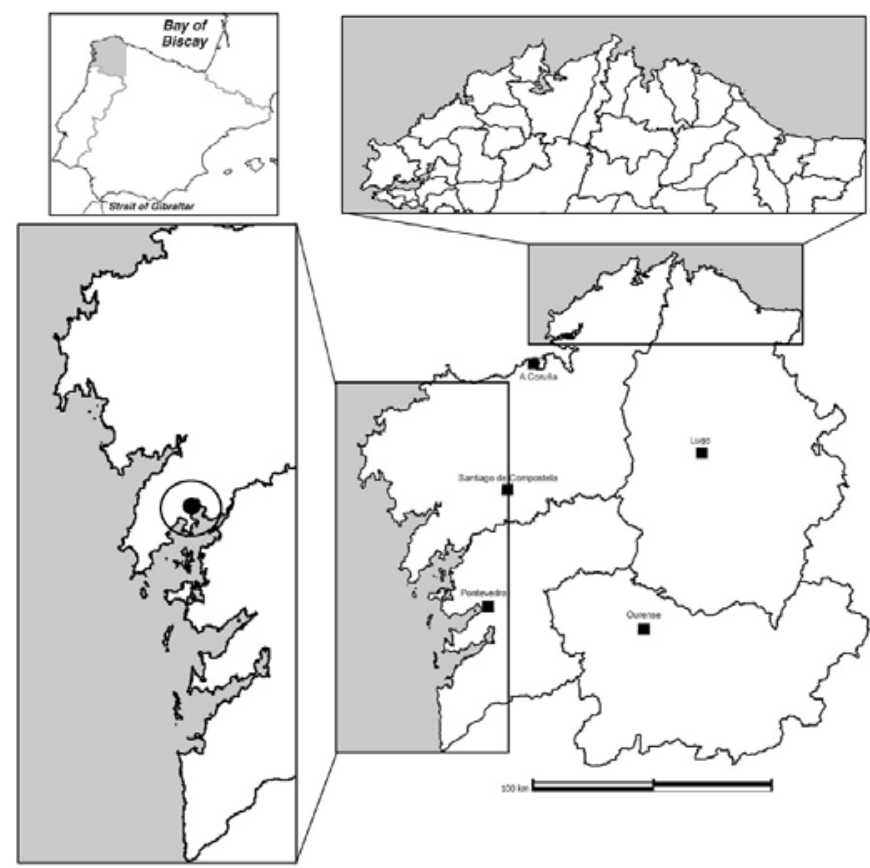

Fig. 142 Localización del Castro de 0 Neixón.

El Castro Grande de Neixón se localiza en la parroquia de Cespón, concello de Boiro, en la provincia de A Coruña. Está situado en la parte central y más elevada de la Punta de O Neixón, a unos $10 \mathrm{~m}$ sobre el nivel del mar e inmediato al Castro Pequeno, que ocupa el extremo norte de esta pequeña península. La Punta, a modo de espolón con una morfología en planta suave, se localiza en una ensenada, junto a la desembocadura de los ríos Grande y Beluso al fondo de la Ría de Arousa (Costa Casais, 2008). Sus coordenadas geográficas son $8^{\circ} 50^{\prime} 33.13^{\prime \prime}$ W y $42^{\circ} 39^{\prime} 49.25^{\prime \prime}$

$\mathrm{N}^{4}$. Esta localización nos permite catalogarlo como un castro de tipo litoral.

\section{V.4.2. DESCRIPCIÓN DEL YACIMIENTO.}

El Castro Grande tiene una morfología oval (95 m norte-sur; 105 m este-oeste), limitado por el norte con un parapeto de $7 \mathrm{~m}$ de altura y un foso que separa el complejo arqueológico del resto de la península, mientras por el este y el oeste lo delimitaría el mar (Ayán Vila et alii, 2005a).

Las primeras actuaciones arqueológicas conocidas en la península de O Neixón se remontan a la década de los años veinte del siglo pasado, con intervenciones dirigidas por López Cuevillas y Bouza Brey (1926/27). En ellas se excavó parte del Castro Pequeno, realizando en 1925 una zanja lineal en el parapeto para conocer su estratigrafía, descubriendo varios niveles con presencia de moluscos.

No será hasta la década de 1970 cuando se reanuden las excavaciones en el yacimiento. Bajo la dirección de A. Balil y Acuña Castroviejo (1970, 1971 y 1972), de Acuña Castroviejo y Caamaño Gesto (1973) y de Acuña Castroviejo (1974-1980). Estas intervenciones se centrarán en el Castro Pequeno, aunque también se excavará algún sector en el Castro Grande. De estos trabajos apenas se cuenta con alguna referencia al

\footnotetext{
${ }^{4}$ Datum ETRS89; Uso 29; UTM: X 512.905/Y 4.723.480
} 
Castro Pequeno (Acuña Castroviejo, 1976), mientras que del Grande solo hay publicados estudios puntuales de materiales determinados.

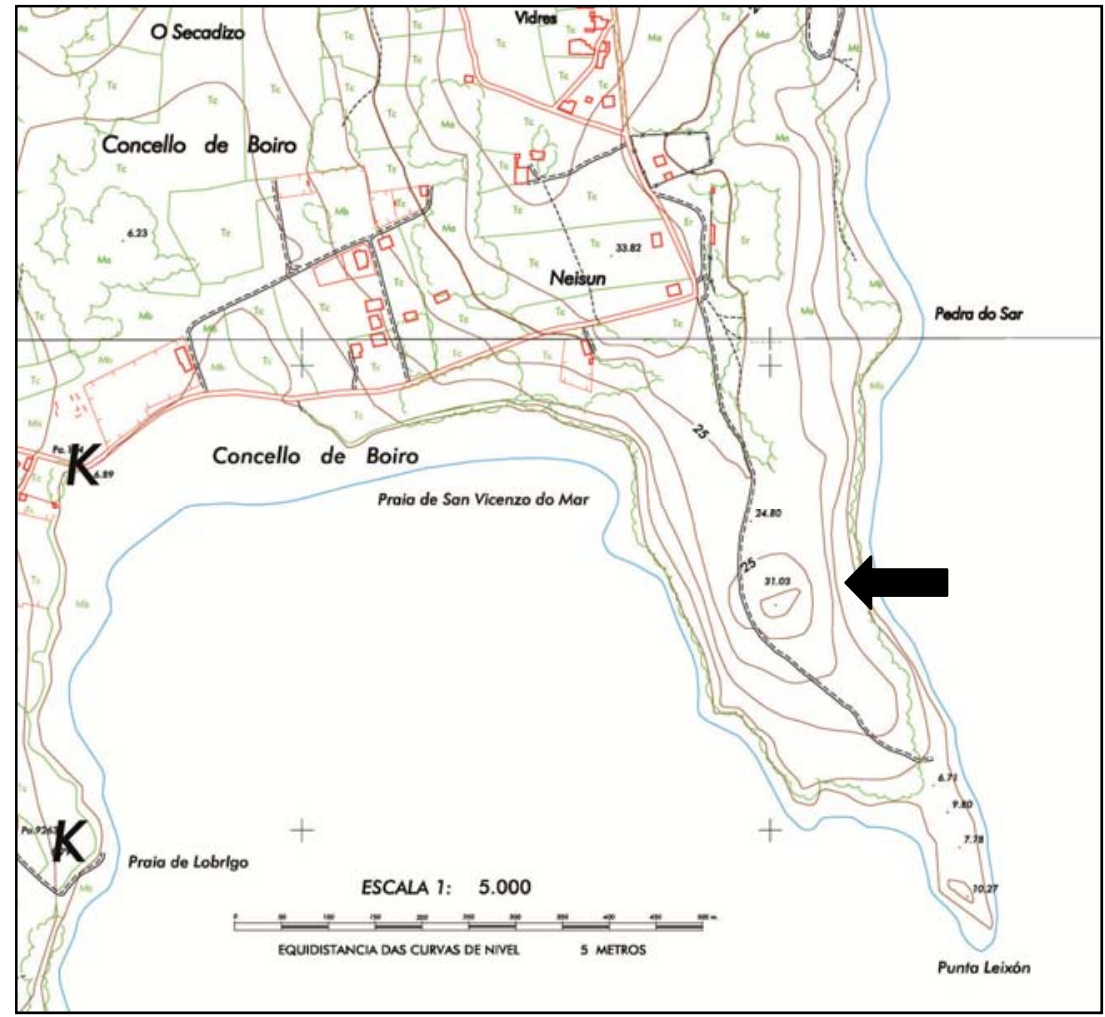

Fig. 143 Topográfico 1:5.000 de la Punta de O Neixón. (Extraído de http://sitga.xunta.es/sitga).

A finales de los años 90 (1996-1998) se producen nuevas intervenciones en los Castros de O Neixón, dirigidas por A. Concheiro Coello. En ellas se llevó a cabo una limpieza del castro Grande, definiendo las antiguas áreas de excavación y realizando una planimetría. En el desarrollo de una pequeña excavación se localizaron varias estructuras en mal estado de conservación, así como un vertedero de escombro de obra (Concheiro, 2008a).

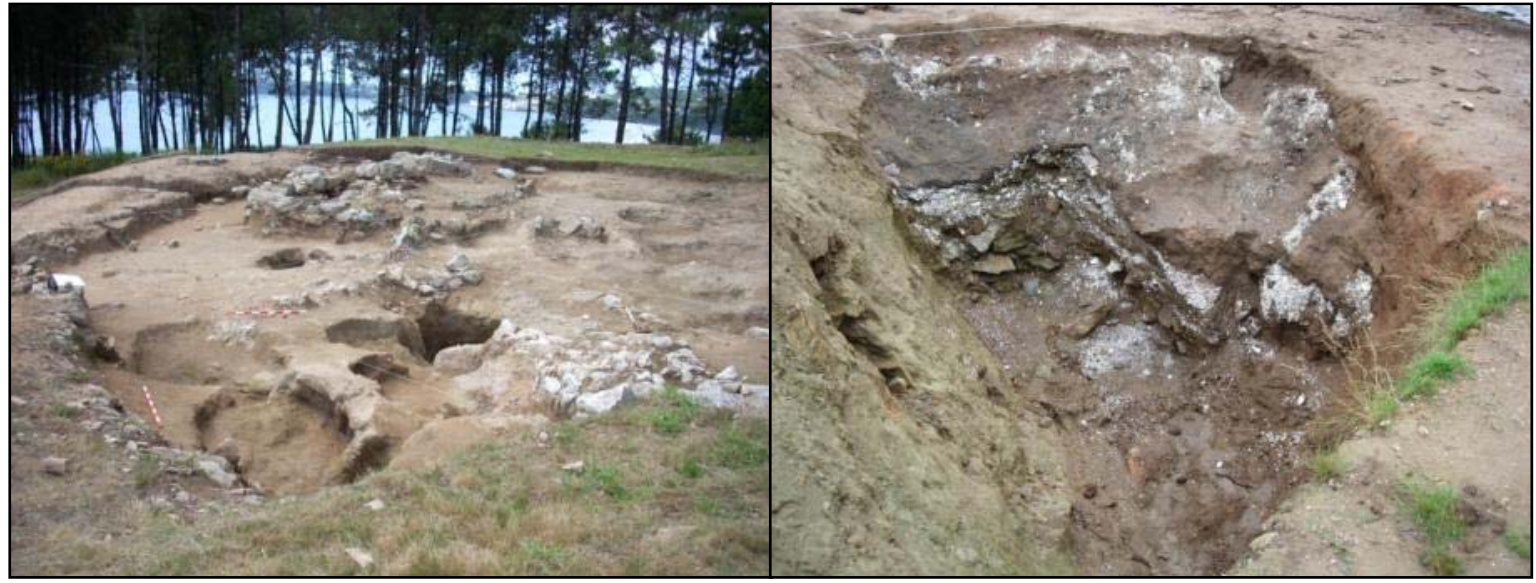

Fig. 144 Castro de 0 Neixón Grande: Sector 02 y conchero en el interior del foso (Imágenes facilitadas por Xurxo Ayán). 
En el 2003, y perdurando hasta el 2008, se reinician los trabajos de excavación en el Castro Grande con una serie de campañas anuales llevadas a cabo desde el Laboratorio de Patrimonio del Instituto de Estudos Galegos Padre Sarmiento (CSIC-Xunta de Galicia) y dirigidas por Xurxo Ayán Vila, fruto del Convenio firmado con el Excmo. Concello de Boiro y la Consellería de Familia, Xuventude e Voluntariado da Xunta de Galicia. Estas intervenciones, centradas principalmente en el Castro Grande, constataron una secuencia ocupacional desde el siglo IV a.C. hasta época bajoimperial (Ayán Vila et alii, 2005; 2008). En la Campaña de 2004 (Ayán Vila et alii, 2005b) se realizó una trinchera en el Sector 02 para evaluar la estratigrafía en el parapeto, lo que produjo el descubrimiento de un foso. Este foso se había rellenado mediante sucesivos echados, destacando un basurero cerámico y varios depósitos con conchas. En la campaña siguiente (2005) se procedió a la ampliación del sondeo, lo que permitió documentar una estructura de sección en $\mathrm{V}$, de $2,50 \mathrm{~m}$ de ancho y 2,70 m de profundidad (Ayán Vila et alii, 2008a). Además, al norte de este sector, se documentó otro tramo de foso, con varios echados aislados de conchas.

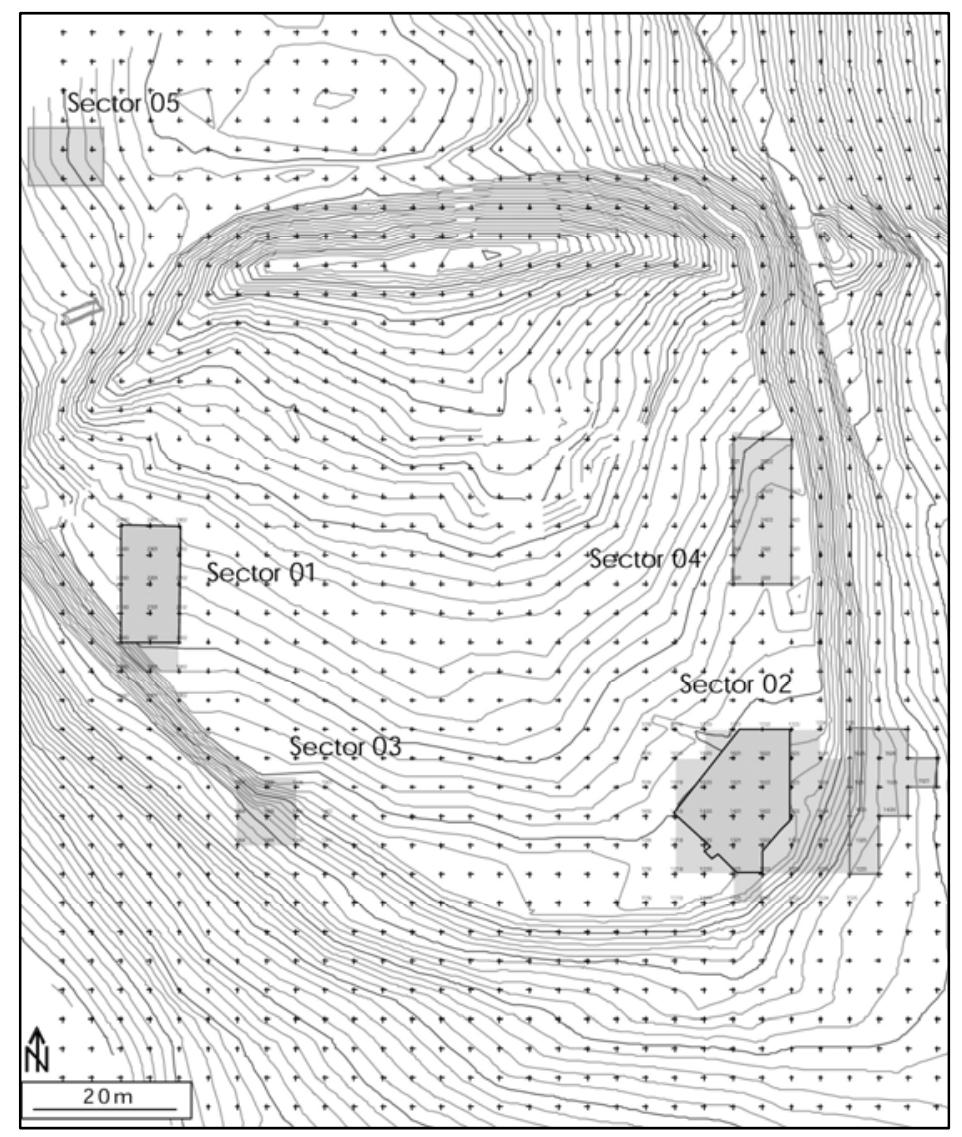

Fig. 145 Planimetría Castro de O Neixón Grande y localización de los sectores (Ayán et alii, 2008a).

En el año 2006 y 2007, se continuó la excavación en el Sector 02, documentando, además de una estructura circular en piedra de época romana y varios agujeros de poste, una serie de estructuras en negativo datadas entre los siglos IV y II a.C. (Ayán Vila et alii, 2008b). Estas fosas aparecieron colmatadas de material arqueológico, siendo interpretadas 
como silos de almacenamiento (Ayán Vila et alii, 2008b). En la Fosa 06 se documentó un pequeño depósito de conchas con unas dimensiones de 0,20 x 0,30 m.

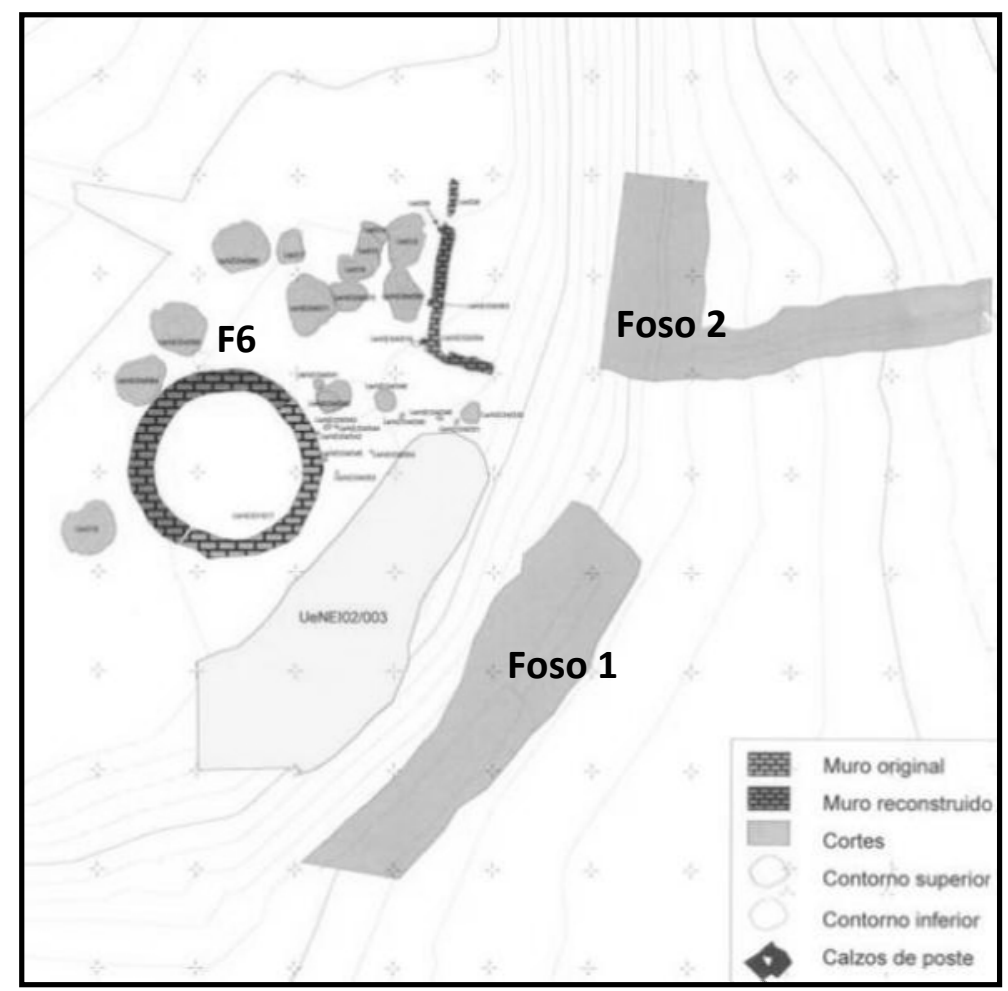

Fig. 146 Planimetría del Sector 02 del Castro Grande de 0 Neixón (Ayán et alii, 2008b).

\section{V.4.3. RECOGIDA DE LAS MUESTRAS.}

Los restos ictiológicos estudiados, fueron recogidos durante los trabajos arqueológicos realizados en las campañas de 2005, 2006 y 2007, vinculados a los diferentes echadizos con conchas documentados tanto en los fosos como en el Sector 02.

\section{V.4.3.1. EL MUESTREO.}

Las muestras de los fosos fueron recogidas durante la campaña de excavación de 2005, localizándose los restos ictiológicos en el conchero que rellenaba parte del Foso 01 y en uno de los echadizos de conchas del Foso 02. En el Foso 01 se documentó un conchero formado por varios niveles que rellenaban la mayor parte de su zona norte. Para la toma de las muestras se procedió a realizar una columna de 0,20 m de anchura y 0,70 m de altura que incluía las UE32 y UE33. Para la UE31, que quedaba fuera de la columna de muestras, se realizó un muestreo aislado. En la UE36 no se documentaron restos de moluscos, por lo que se realizó un muestreo selectivo. Hay que destacar que durante el proceso de excavación del foso se utilizó una criba de $10 \mathrm{~mm}$ para el procesado del sedimento, lo que permitió recuperar la mayor parte de los restos de peces aquí estudiados. 


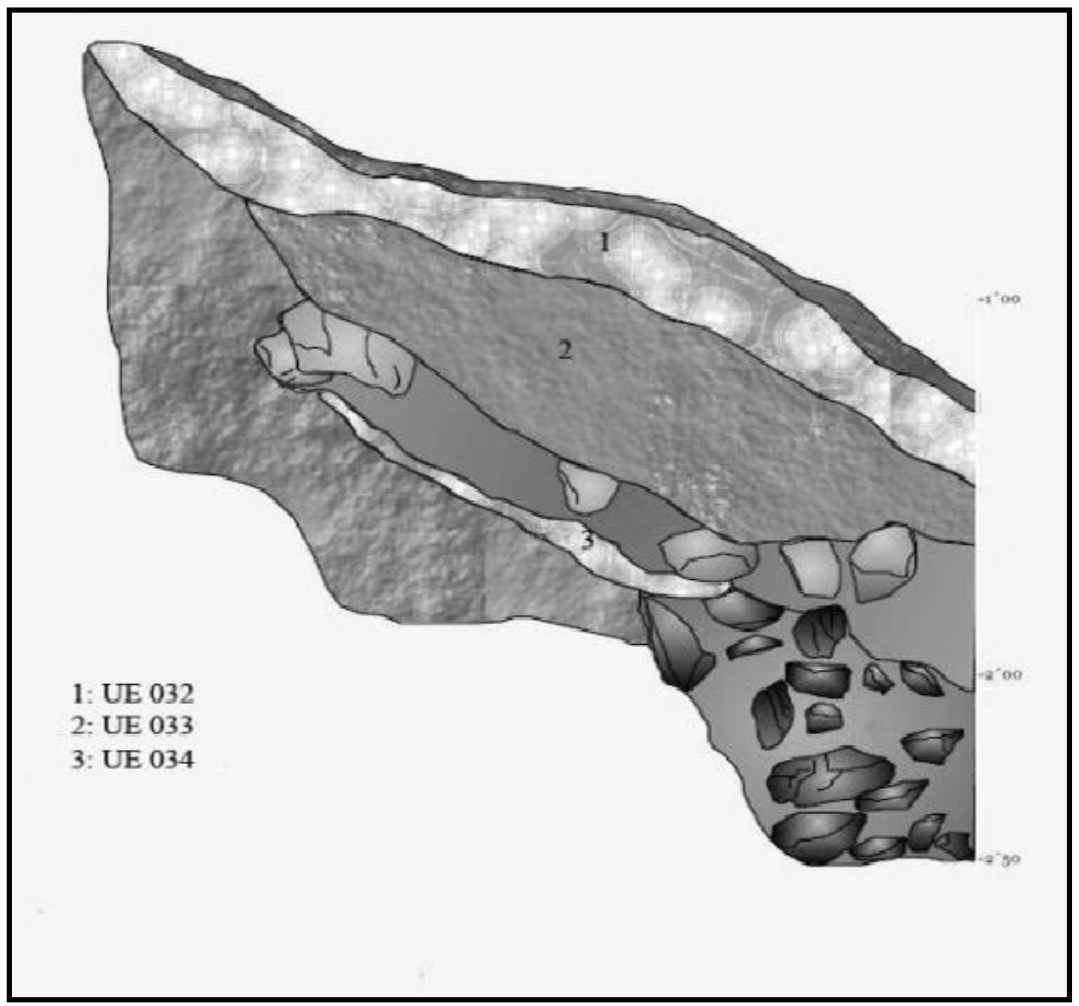

Fig. 148 Perfíl del Conchero localizado en el Foso 01 (Ayán et alii, 2008a).

En el Foso 02 se localizaron diversas bolsadas de conchas, considerando las pequeñas dimensiones de estos depósitos se procedió a recogerlos en su totalidad. En cuanto a las muestras de la Fosa 6 de la croa, el método de muestreo fue el mismo que para los restos del Foso 02.

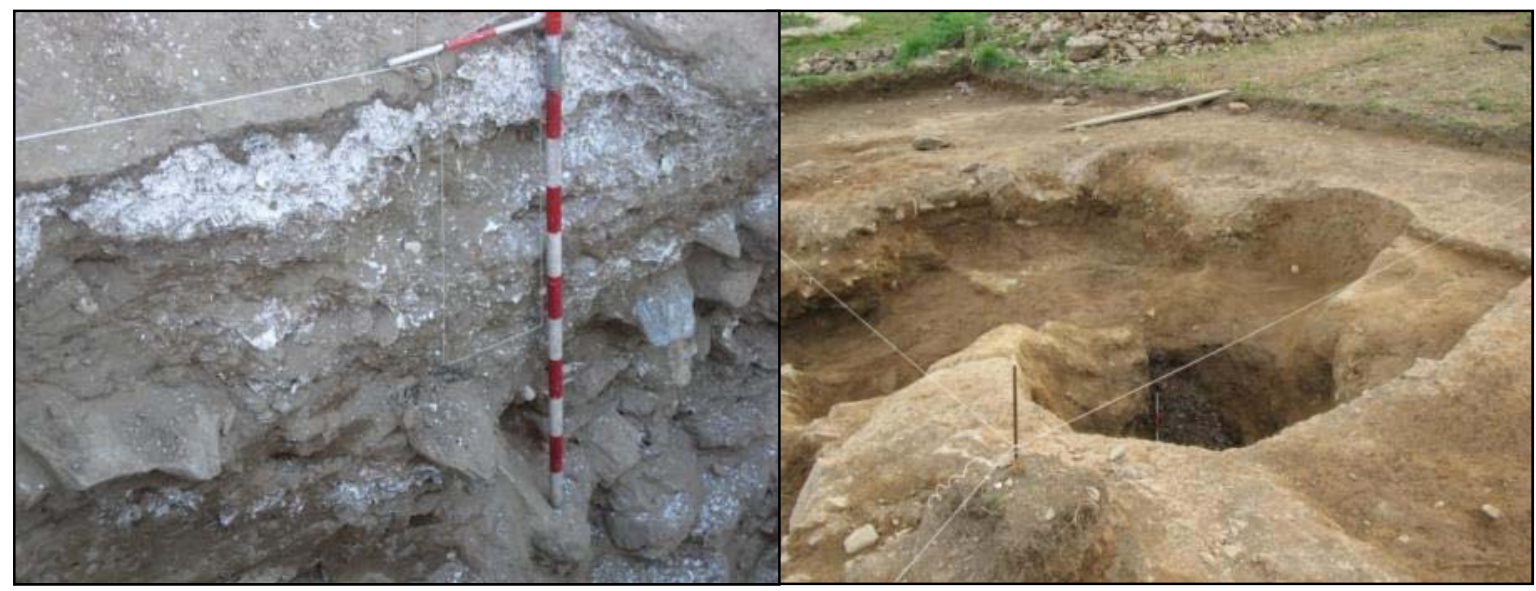

Fig. 147 Columna de muestras del conchero y fosa con restos de fauna marina (Imágenes facilitadas por Xurxo Ayán.

\section{V.4.3.2. CRONOLOGÍA.}

Los materiales documentados en los depósitos de conchas localizados en los fosos son adscribibles a la Fase II de la cultura castreña (Ayán Vila et alii, 2008a). Además en el Foso 01 apareció un vertedero cerámico que sellaba la estructura; estos materiales son 
adscribibles también a la Fase II, con jarras Toralla, ollas tipo Toralla, bordes exvasados y bordes marítimos (Ayán Vila et alii, 2008a: 106). Por todo ello podemos encuadrar los restos entre los siglos IV-II a.C. Las posteriores dataciones radiocarbónicas de materiales (hueso y carbón) confirmaron la cronología relativa anteriormente señalada (Parcero Oubiña y Ayán Vila, 2008).

En cuanto a la Fosa 06 documentada en el sector 2, los materiales son similares a los documentados en los fosos de la entrada sureste, por lo que se le puede atribuir una cronología similar (Ayán Vila et alii, 2008b: 173), ratificada de nuevo mediante dataciones radiocarbónicas (Parcero Oubiña y Ayán Vila, 2008).

\section{V.4.4. ESTUDIO ICTIOARQUEOLÓGICO.}

\section{V.4.4.1. Foso 01 .}

El depósito del Foso 01 corresponde a sucesivos vertidos en un breve periodo de tiempo con el fin de colmatar esta estructura, pudiendo observarse diferentes puntos de deposición (Ayán Vila et alii, 2008a: 111). Además, se ha planteado que los restos no se depositaran originalmente en este lugar y procedieran de otro vertedero primario (Bejega y Fernández, 2008; Bejega, 2009: 93).

\begin{tabular}{l|c|c|c}
\multirow{2}{*}{\multicolumn{1}{c|}{ Inicial }} & UE $\mathbf{0 3 1}$ & UE $\mathbf{0 3 2}$ & UE $\mathbf{0 3 3}$ \\
\cline { 2 - 4 } & $\mathbf{5 . 3 3 7}$ & $\mathbf{4 . 3 2 4 , 5}$ & $\mathbf{4 . 4 9 4}$ \\
\hline \hline Residuo & 2.564 & 1.937 & 3.559 \\
\hline Actividad artesanal & 12 & 0,5 & 1 \\
\hline Malacofauna & 2.751 & 2.379 & 933 \\
Macrofauna & 2 & 1 & \\
Ictiofauna & 2 & 3 & 1 \\
Carbón & 7 & 4 & 2 \\
\hline
\end{tabular}

Tabla 101 Pesos iniciales (en gr.) del conchero por componentes.

\section{V.4.4.1.1. UENEI03031}

\section{Descripción de la unidad.}

Nivel poco compactado de color blanco debido al volumen de conchas que lo constituyen. Es el vertido de moluscos más reciente en el proceso de colmatación del foso. Destaca la presencia de almeja, ostra y mejillón, especies mezcladas con fragmentos cerámicos y restos óseos (Ayán Vila et alii, 2008a: 107).

Restos de ictiofauna.

\begin{tabular}{lccccc} 
& Mol & Vpc & Rce & NR & NMI \\
\hline Merluccius merluccius & & 1 & & $\mathbf{1}$ & 1 \\
Sparus aurata & 1 & & & $\mathbf{1}$ & 1 \\
Indeterminados & & & 8 & $\mathbf{8}$ & \\
\hline \multicolumn{1}{c}{ TOTAL } & $\mathbf{1}$ & $\mathbf{1}$ & $\mathbf{8}$ & $\mathbf{1 0}$ & $\mathbf{2}$
\end{tabular}

Tabla 102 Relación de especies y representación ósea de la UE031. 
La UE 031 es la que mayor número de restos de pez presenta de todas las muestras recogidas en los Fosos. En esta muestra se pudieron recuperar tres fragmentos pertenecientes a una misma vértebra precaudal de Merluccius merluccius, así como medio molariforme de Sparus aurata.

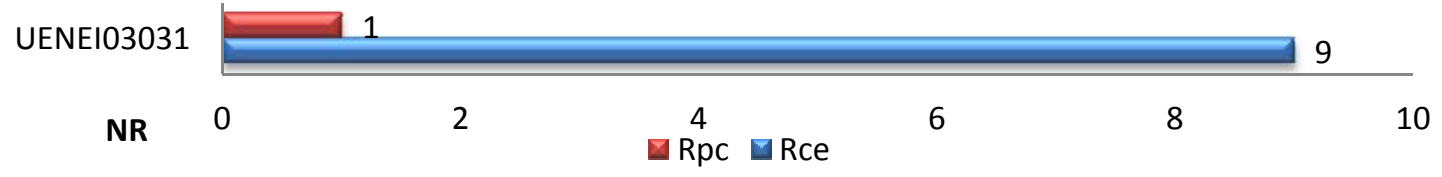

Fig. 149 Distribución esquelética de los restos ícticos de la UE031.

Además de estas piezas óseas se han podido recuperar ocho restos cefálicos, sin que se constatara ningún resto postcefálico ni escamas. Se trata de un hecho significativo, ya que en los depósitos castreños es habitual que predominen los restos post-cefálicos.

\section{V.4.4.1.2. UENEI03032}

\section{Descripción de la unidad.}

Nivel alargado y estrecho de tierra y conchas, con un buzamiento en dirección suroeste, de 2,50 $\mathrm{m}$ en el eje noreste-sureste, y 1,70 $\mathrm{m}$ de ancho máximo y 0,40 $\mathrm{m}$ de mínimo en el eje noroeste-sureste.

\section{Restos de ictiofauna.}

\begin{tabular}{ccl} 
& Rpc & NR \\
\hline Indeterminados & 2 & $\mathbf{2}$ \\
\hline \hline TOTAL & $\mathbf{2}$ & $\mathbf{2}$
\end{tabular}

Tabla 103 Relación de especies y representación ósea de la UE032.

Presencia de dos restos post-cefálicos, no siendo posible su identificación, ya que se encontraban en mal estado de conservación y formaban parte de las costillas. Es la única muestra de los Fosos en la que predominan los restos post-cefálicos.

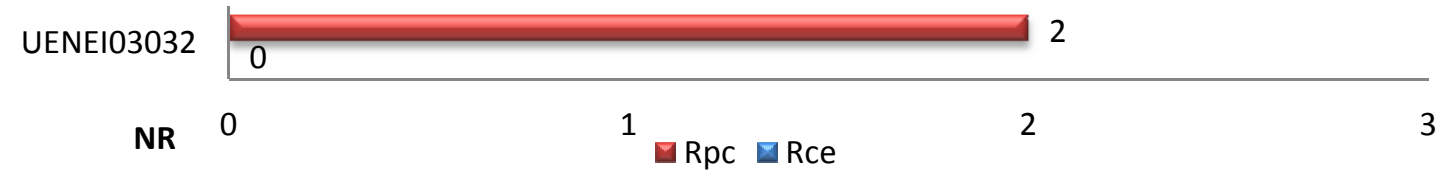

Fig. 150 Distribución esquelética de los restos ícticos de la UE032.

\section{V.4.4.1.3. UENEI03033}

\section{Descripción de la unidad.}

Segundo nivel de conchas identificado con un depósito compacto de color marrón oscuro, mezclado con conchas y pequeñas piedras, que presenta un notable buzamiento hacia el suroeste. Aparecen pequeñas tongadas alargadas constituidas por pequeñas 
gravas, y otras de tierra arenosa, amarillenta y muy compacta, que incluyen también restos malacológicos.

\section{Restos de ictiofauna.}

\begin{tabular}{ccc} 
& Rce & NR \\
\hline Indeterminados & 1 & $\mathbf{1}$ \\
\hline \hline TOTAL & $\mathbf{1}$ & $\mathbf{1}$
\end{tabular}

Tabla 104 Relación de especies y representación ósea de la UE033.

En este nivel únicamente se ha documentado un resto cefálico indeterminado.

\section{V.4.4.1.4. UENEI03036}

\section{Descripción de la unidad.}

Nivel de tierra marrón oscura en el que destaca la presencia de ocho bloques de esquisto de entre $0,30-0,40 \mathrm{~m}$ y pequeñas acumulaciones de grava de tamaño variable.

\section{Restos de ictiofauna.}

\begin{tabular}{cccc} 
& Cdr & NR & NMI \\
\hline Dicentrarchus labrax & 1 & $\mathbf{1}$ & 1 \\
\hline \hline TOTAL & $\mathbf{1}$ & $\mathbf{1}$ & $\mathbf{1}$
\end{tabular}

Tabla 105 Relación de especies y representación ósea de la UE036.

En esta unidad no se han documentado restos de moluscos, pero si se recuperó un cuadrado izquierdo de Dicentrarchus labrax en mal estado de conservación.

\section{V.4.4.2. Foso 02.}

Los depósitos del Foso 02 se identifican con pequeños vertidos aislados procedentes del consumo en un momento concreto (Bejega y Fernández, 2008; Bejega, 2009: 94).

\section{V.4.4.2.1. UENEI03054}

Descripción de la unidad.

Pequeño depósito de conchas de forma irregular en planta.

\begin{tabular}{l|c|}
\multirow{2}{*}{ Inicial } & UE 054 \\
\cline { 2 - 2 } $\mathbf{4 . 8 4 6}$ \\
\hline Residuo & 2.831 \\
\hline Malacofauna & 2.020 \\
Ictiofauna & 1 \\
Carbón & 3 \\
\hline
\end{tabular}

Tabla 106 Pesos iniciales (en gr.) de la UE 054 del Foso 02 por componentes.

\section{Restos de ictiofauna.}

\begin{tabular}{ccc} 
& Rce & NR \\
\hline Indeterminados & 1 & $\mathbf{1}$ \\
\hline \hline TOTAL & $\mathbf{1}$ & $\mathbf{1}$
\end{tabular}

Tabla 107 Relación de especies y representación ósea de la UE054. 
En este tramo de foso únicamente se han localizado restos de ictiofauna en la UE54, en la que pudimos documentar un diente coniforme de espárido.

\section{V.4.4.3. FOSA 6.}

\section{V.4.4.3.1. UENEI04058}

\section{Descripción de la unidad.}

Primer depósito de relleno, formado por tierra orgánica oscura con numerosos carbones. Abundante material cerámico indígena y varios fragmentos púnicos. En el extremo norte aparece un pequeño depósito de conchas con algún fragmento de hueso y abundantes carbones, además de varios fondos de vasijas indígenas.

\begin{tabular}{l|c|}
\multirow{2}{*}{ Inicial } & MU070823J02 \\
\cline { 2 - 2 } & $\mathbf{1 . 0 0 0}$ \\
\hline \hline Residuo & 700 \\
\hline Malacofauna & 299 \\
Ictiofauna & 1 \\
Carbón & 0,5 \\
\hline
\end{tabular}

Tabla 108 Pesos iniciales (en gr.) de la Fosa 06 por componentes.

\section{Restos de ictiofauna.}

\begin{tabular}{lccccccc} 
& Vpc & Vca & Rce & Rpc & Esa & NR & NMI \\
\hline Dicentrarchus labrax & & 1 & & & & $\mathbf{1}$ & 1 \\
Diplodus sargus & 1 & 1 & & & & $\mathbf{2}$ & 1 \\
Pagellus bogaraveo & & 1 & & & & $\mathbf{1}$ & 1 \\
Indeterminado & & & 4 & 34 & 4 & $\mathbf{4 2}$ & \\
\hline \multicolumn{1}{c}{ TOTAL } & $\mathbf{1}$ & $\mathbf{3}$ & $\mathbf{4}$ & $\mathbf{3 4}$ & $\mathbf{4}$ & $\mathbf{4 6}$ &
\end{tabular}

Tabla 109 Relación de especies y representación ósea de la UE058.

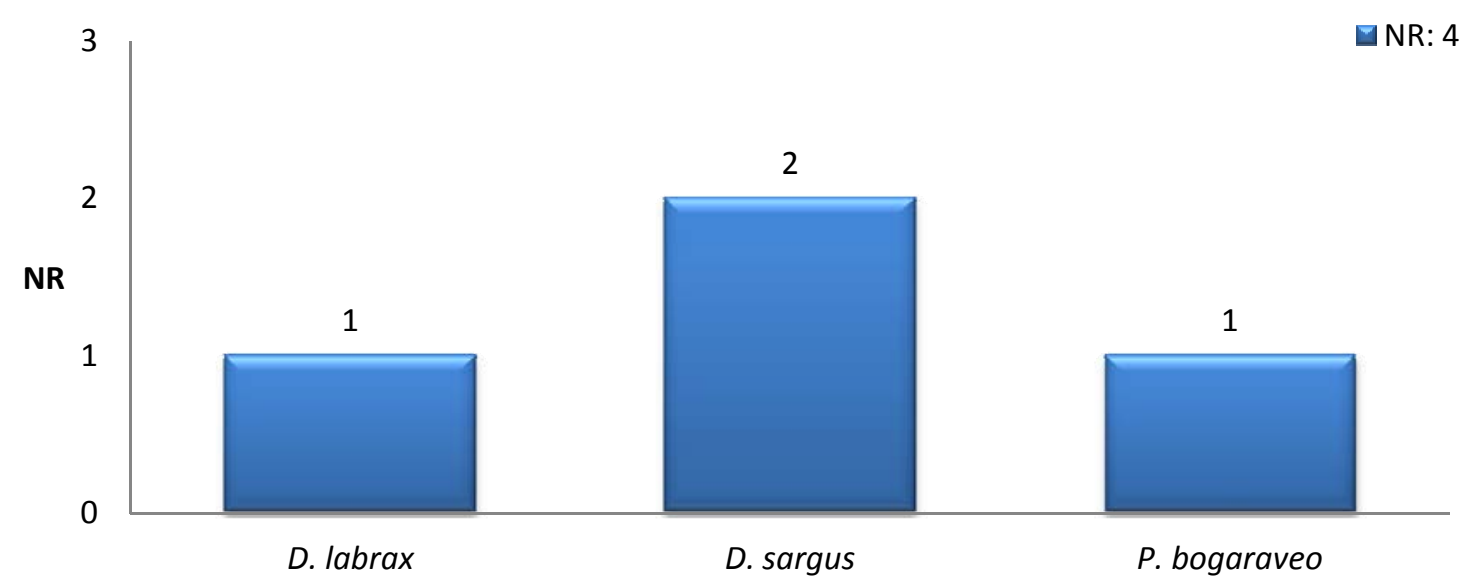

Fig. 151 Distribución de taxones identificados en la UE058 según el NR.

El depósito presentaba unas dimensiones de 0,30 x 0,20 m, pero a pesar de ser tan pequeño de aquí proceden la mayor parte de los restos de peces recuperados en el 
yacimiento. Esta muestra contenía una vértebra caudal de Pagellus bogaraveo, así como una vértebra precaudal y otra caudal de Diplodus sargus, especies que no habían sido documentadas en las demás muestras. También se ha recuperado una vértebra caudal de Dicentrarchus labrax, siendo el único taxón identificado tanto en esta unidad como en los fosos. Las tres especies identificadas son demersales, habitando en zonas arenosas con cascajos y rocas.

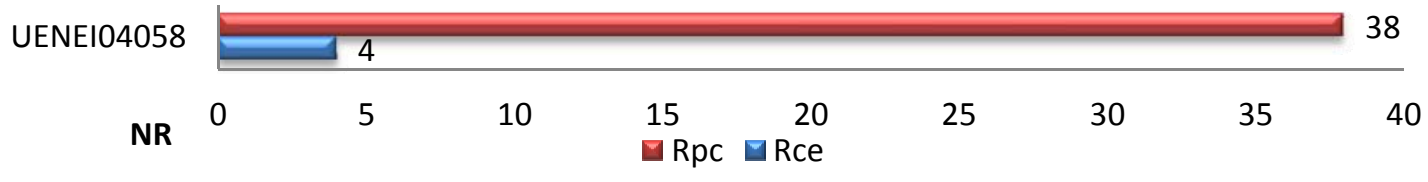

Fig. 152 Distribución esquelética de los restos ícticos de la UE058.

Predominan los elementos post-cefálicos con 38 restos, mientras que los cefálicos son únicamente cuatro y no han podido ser identificados a nivel de especie. Esto contrasta con lo observado en el Foso 01, donde destacaban los restos cefálicos. Por otro lado, es reseñable la presencia de escamas, que no aparecen en las otras zonas muestreadas del yacimiento.

\section{V.4.5. Comentario.}

Antes de realizar cualquier valoración, hay que tener en cuenta el bajo número de restos documentados pese a cribar todo el sedimento de los concheros. Este hecho va a condicionar lo expuesto en las siguientes líneas; lo que comentaremos será por tanto un primer acercamiento a partir de los datos disponibles.

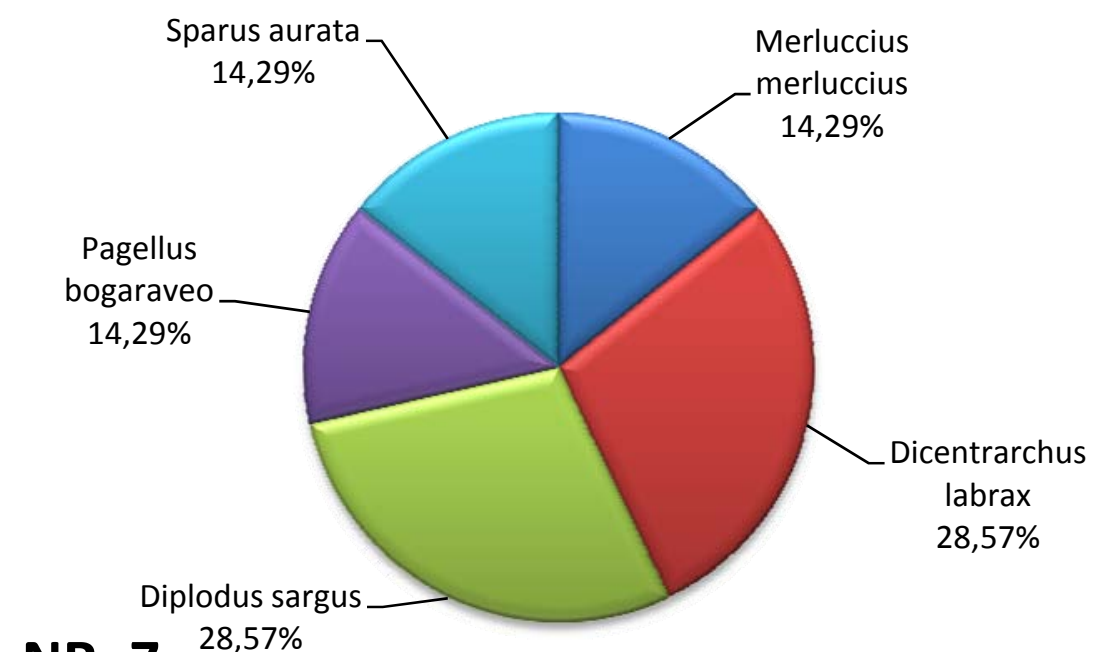

NR: 7

$$
28,57 \%
$$

Fig. 153 Representatividad de los taxones según el NR. 


\begin{tabular}{l|c|c|c|}
\multirow{2}{*}{ Sparus aurata } & IC & ID & ICxID \\
\cline { 2 - 4 } Merluccius merluccius & 16,7 & 14,3 & 238,8 \\
Pagellus bogaraveo & 16,7 & 14,3 & 238,8 \\
Diplodus sargus & 16,7 & 28,6 & 477,6 \\
Dicentrarchus labrax & 33,3 & 28,6 & 952,4
\end{tabular}

Tabla 110 Índices de valoración.

Las especies que predominan son las de la Familia Sparidae, tanto en variedad de taxones, como en número de restos. Suponen el $50 \%$ de los restos documentados, principalmente en la Fosa 06. Además, contamos con la presencia de un serránido, Dicentrarchus labrax, y de Merluccius merluccius. Estas especies no parecen haber tenido mucha importancia en este periodo, ya que en otros yacimientos con una cronología similar resultan también anecdóticas, al contrario que en época medieval, cuando van a tener mucha más importancia (Ferré, 2003). Los ejemplares de Dicentrarchus labrax puede adentrarse en agua dulce, siendo más habitual cuando se hacen adultos, habitando en las desembocaduras de los ríos, mientras que los juveniles ocuparían las aguas más internas de la ría.

Diplodus sargus tampoco es una especie muy habitual en los yacimientos prerromanos, aunque se han documentado restos tanto en Neixón como en Cantodorxo (Ferré et alii, 1996; Fernández Rodríguez et alii, 1998; Ferré, 2003). Algo similar se puede decir para Sparus aurata, aunque por los datos que tenemos para O Achadizo, esta especie parece ser muy abundante en el fondo de la ría (Ferré et alii, 1996). La presencia de Pagellus bogaraveo es más habitual en los yacimientos de esta cronología, siendo en todos ellos una de las especies con mayor número de evidencias.

Todas estas especies son demersales, propias de hábitats arenosos o fangosos y pedregosos. Estos taxones habitan en zonas cercanas a la costa, sea en determinados momentos del año o de manera más continua. En el entorno más inmediato al asentamiento encontramos zonas arenosas combinadas con otras rocosas (Costa Casais, 2008), hábitat preferido de estas especies. Por todo ello creemos que la actividad pesquera se realizaría en las inmediaciones del yacimiento. A este respecto, Merluccius merluccius puede plantear cierta problemática debido a que actualmente no se interna en aguas salobres, localizándose por debajo de los $30 \mathrm{~m}$ de profundidad, por lo que su presencia en el yacimiento podría estar reflejando cambios en el rango batimétrico y vital de esta especie, como apuntan algunos autores (Morales Muñiz et alii, 2009).

Se trataría de una pesca nerítica, que podría realizarse desde la costa o desde pequeñas embarcaciones. Conocer el arte de pesca empleado para la captura de estas 
especies es muy complicado, ya que son susceptibles de ser pescadas mediante diferentes métodos. El hecho de que todas estas especies sean carnívoras, no siendo necesaria la utilización de redes para su captura, nos sugiere una pesca con anzuelo. De todos modos no se pueden descartar otros sistemas como el trampeo en sus diferentes tipologías.

Al comparar los restos de ictiofauna de la zona de los Fosos y los recuperados en la croa, podemos observar algunas variaciones. En primer lugar, se aprecia una gran diferencia entre el volumen de sedimento procesado y los restos documentados, de tal manera que en la Fosa 06, que suponía una mínima parte del sedimento porcesado, se han recuperado más de la mitad de los restos de ictiofauna del yacimiento. Por otro lado, los restos identificados del Foso 01 pertenecen a ejemplares de unas dimensiones muy superiores a los de la Fosa 06, y a la mayoría de los restos documentados en otros yacimientos castreños.

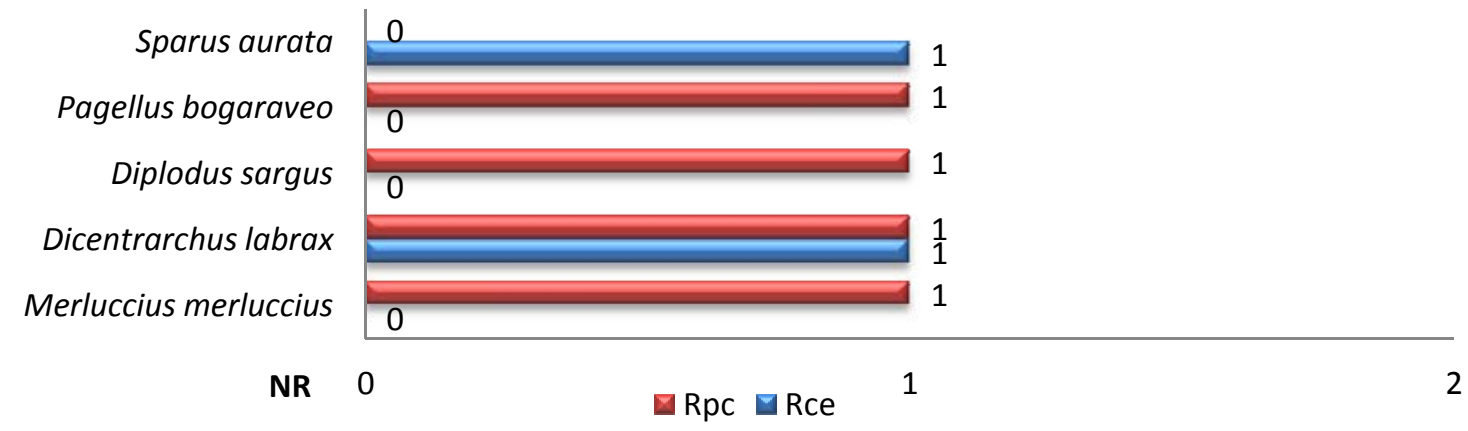

Fig. 154 Comparación numérica de los restos cefálicos y post-cefálicos de los diferentes taxones identificados.

A estas diferencias hay que añadir lo observado en cuanto a su identificación esquelética. La mayor parte de los huesos documentados en el Foso 01 corresponden con restos cefálicos, algo que contrasta con lo observado en la Fosa 06 o en otros yacimientos como Cantodorxo o Achadizo, donde predominan los restos post-cefálicos en la mayoría de especies. Del mismo modo, únicamente se van a conservar escamas en la Fosa 06. También es destacable la ausencia en ciertas unidades (UE 032; UE 033; UE 054) de restos identificables, recuperándose muy pocos fragmentos, principalmente de costillas.

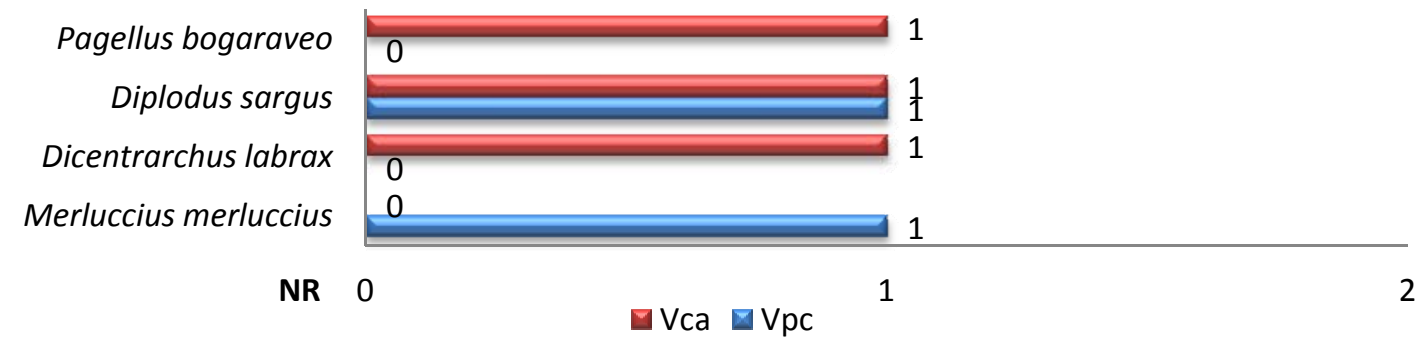

Fig. 155 Comparación numérica de las vértebras caudales y precaudales de los diferentes taxones identificados. 
Cdr

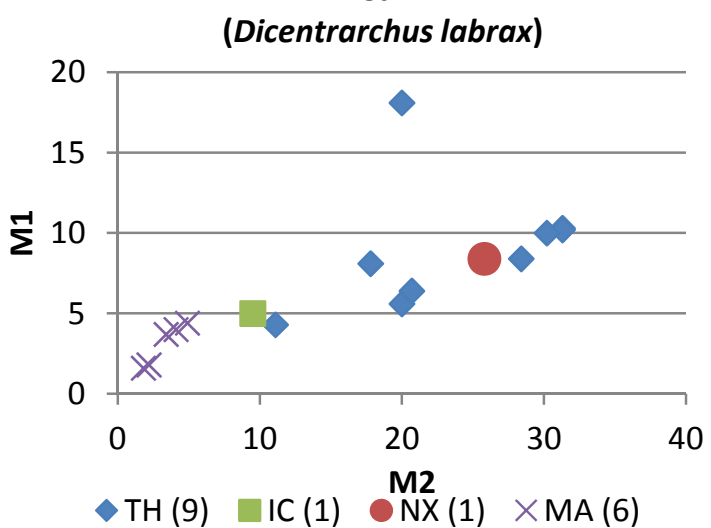

Vpc

(Diplodus sargus)

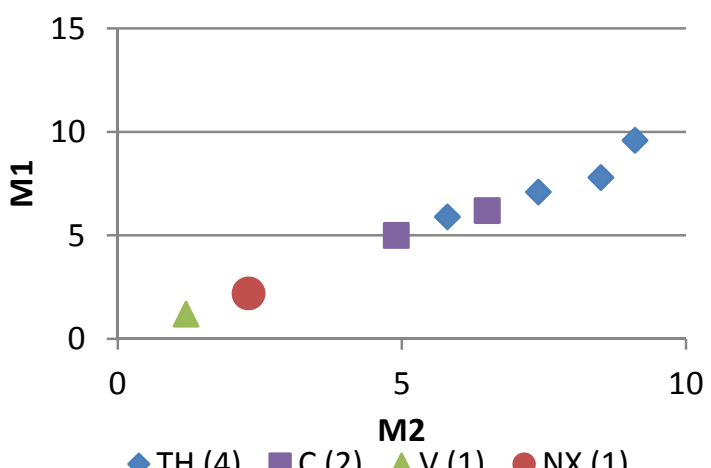

$\rightarrow \mathrm{TH}(4) \quad \mathrm{C}(2) \triangle \mathrm{V}(1) \quad \mathrm{NX}(1)$

Vca

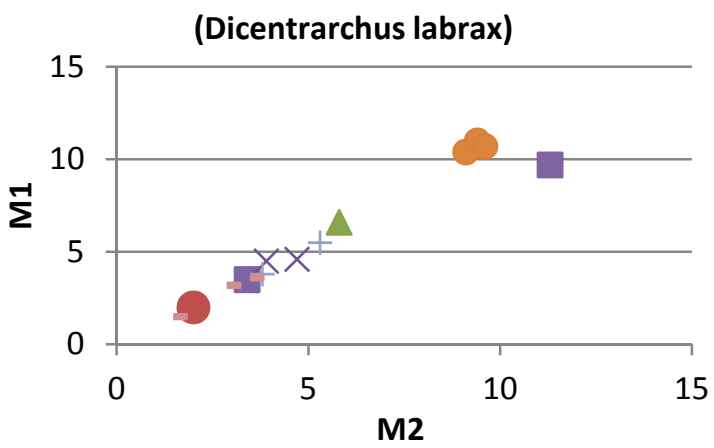

$\mathrm{V}(2) \quad \triangle O A(1) \quad \times I C(2) \quad \mathrm{NX}(1)$
Vpc

(Merluccius merluccius)

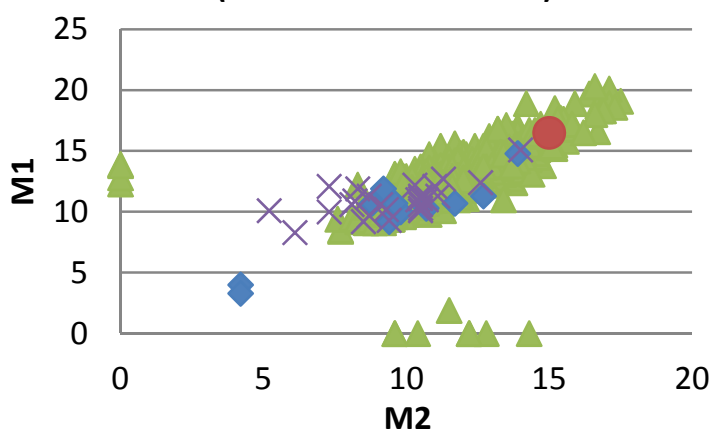

$\triangle \mathrm{PA}(1583) \diamond \mathrm{OA}(15) \times \mathrm{TO}(29) \bigcirc \mathrm{NX}(1)$

Vca

(Diplodus sargus)

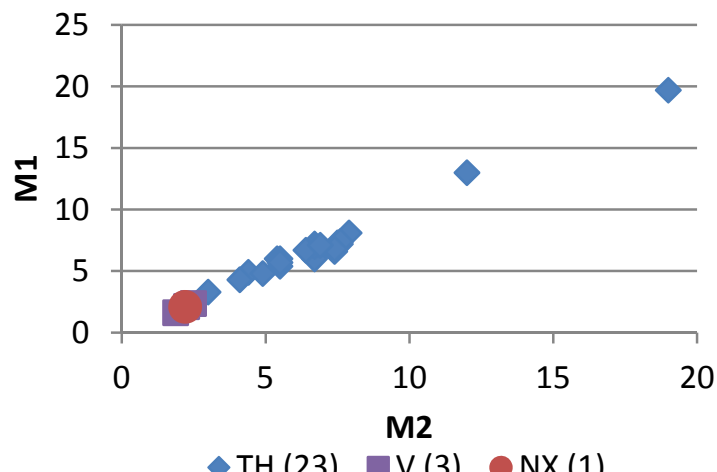

$\rightarrow \mathrm{TH}(23) \quad \mathrm{V}(3) \quad \mathrm{NX}(1)$

Vca

(Pagellus bogaraveo)

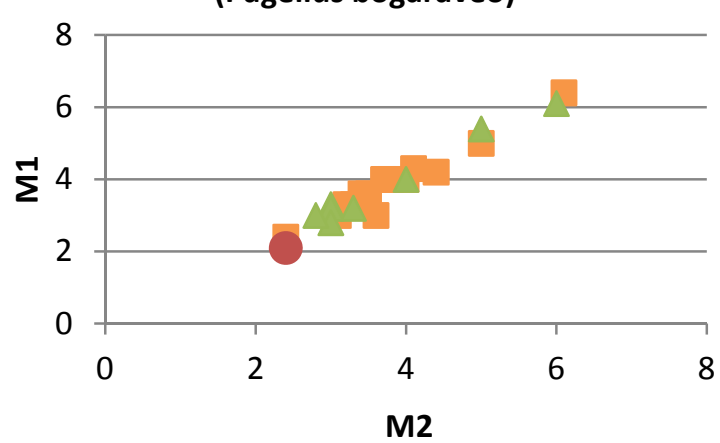

$\square \mathrm{IC}(14) \triangle \mathrm{C}(8) \quad \mathrm{NX}(1)$

Fig. 156 Distribución biométrica ( $\mathrm{mm}$.) de los taxones identificados en el Castro de $\mathrm{O}$ Neixón (NX) y Comparación con otros yacimientos gallegos citados en este trabajo (AR=Area; C=Cantodorxo; IC=Islas Cíes; MA=Montealegre; MV=Muiño do Vento; $O A=O$ Achadizo; PA=Punta Atalaia; TH=Torre de Hércules; TO=Torres de Oeste; V=Area96).

Además de estas diferencias de representatividad anatómica, existen variaciones en cuanto a las dimensiones óseas. Los huesos recuperados en el conchero del Foso 01 presentan tallas grandes, equiparables a las piezas de mayor tamaño recuperadas hasta la 
fecha en el noroeste. Por otro lado, en la Fosa 06, los centros vertebrales recuperados presentan unas tallas no muy elevadas, siendo el caso más significativo el de Dicentrarchus labrax, con restos en ambos conjuntos.

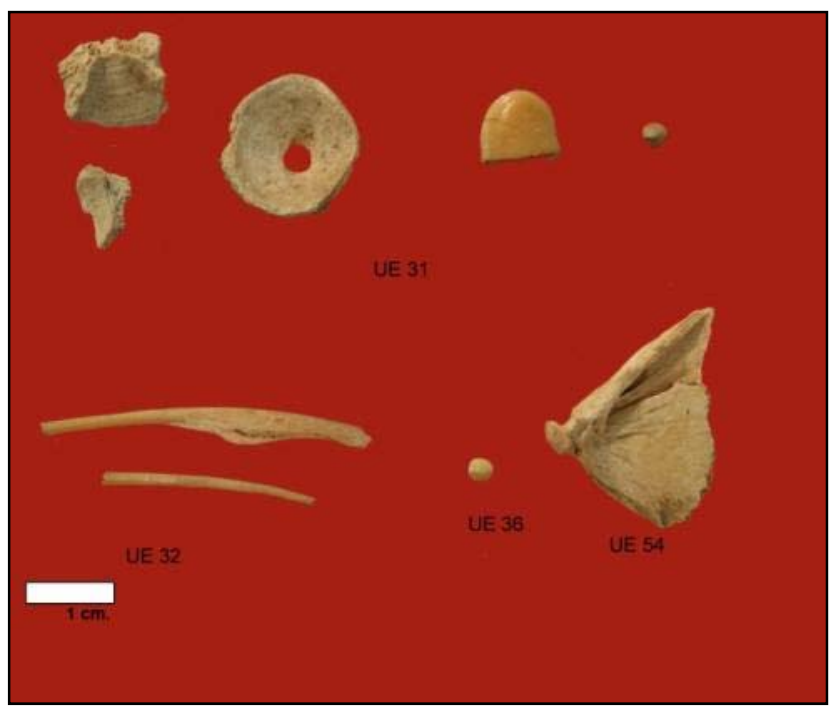

Fig. 157 Restos de ictiofauna del conchero del Foso 1.

El número tan escaso de restos recuperados, respecto al volumen de sedimento procesado, hace que nos planteemos diferentes cuestiones a la hora de valorar el conjunto. ¿Este fenómeno es reflejo de una escasa importancia de la pesca? o ¿son las características de los depósitos las que influyen en la poca representación de la ictiofauna?. Los diferentes echados identificados indican un proceso rápido de colmatación intencional en el Foso 01, que presentaría su sellado total a finales del siglo II a.C. (Ayán et alii, 2008a: 111). El origen de los diferentes echadizos de conchas podría provenir de otro vertedero mayor, mientras que los vertidos del Foso 02 corresponderían a fases de recolección-consumo (Bejega, 2009: 93-94; Fernández, 2008; Bejega y Fernández, 2008), algo similar a lo que se sucedería en la Fosa 06. Por otro lado, el estudio arqueomalacológico reveló variaciones en la importancia de las especies entre los diferentes vertidos, lo que nos puede indicar diferentes estadios estacionales (Bejega, 2009: 112-113). Pese a todo esto, parece claro que la pesca sería una actividad destinada al consumo local, dentro de un modelo de subsistencia.

Las variaciones en las tallas y en el número de restos de las diferentes muestras, puede estar reflejando una estacionalidad en las capturas. Los ejemplares adultos de Merluccius merluccius, o Dicentrarchus labrax, se acercan al litoral en determinadas épocas del año para la puesta, siendo posible su captura con pequeñas embarcaciones o desde la costa. Además, ejemplares adultos de Dicentrarchus labrax o Sparus aurata suelen internarse en aguas no salobres. Es posible que los diferentes vertidos correspondan a periodos concretos en los cuales se desarrollarían o no actividades pesqueras. La ausencia de escamas puede deberse a tratamientos previos al consumo, bien en fresco o para su conserva. Por lo tanto, estas se depositarían o bien fuera del yacimiento, o en otro punto del mismo no afectado por las intervenciones arqueológicas recientes. 


\section{V.5. El Poblado de A Lanzada.}

\section{V.5.1. LOCALIZACIÓN GEOGRÁFICA.}

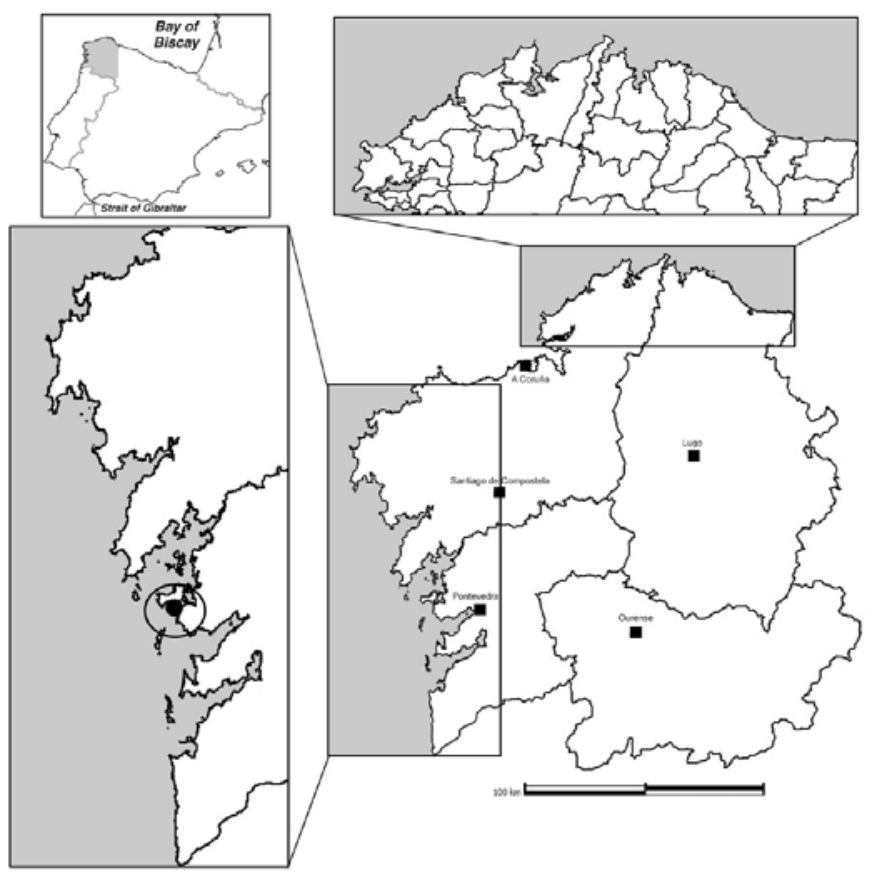

Fig. 158 Localización del yacimiento de A Lanzada.
El yacimiento de A Lanzada se localiza en la Parroquia de Noalla, Concello de Sanxenxo (Pontevedra). Se sitúa sobre un promontorio rocoso, conocido como Punta Lanzada o da Nosa Señora, que se introduce en el Océano Atlántico entre las playas de Areagorda y Foxos. Sus coordenadas geográficas son $8^{\circ} 52^{\prime} 30.45^{\prime \prime}$ W y $42^{\circ} 25^{\prime} 45.7^{\prime \prime}$ $\mathrm{N}^{5}$. El asentamiento se puede clasificar como litoral.

\section{V.5.2. DESCRIPCIÓN DEL YACIMIENTO.}

El espacio arqueológico de esta punta se estructura en tres áreas. Por un lado se encontrarían los restos de la fortaleza medieval del siglo $X$ d.C., situados en la punta del promontorio. La segunda de las zonas sería la conocida como O Campo, y que es donde se localizan las fases más antiguas de ocupación y las intervenciones aquí estudiadas. Por último, ya en el istmo, se encontraría el conocido como Sector exterior de A Lanzada, donde se han documentado diferentes enterramientos de época romana.

Las intervenciones sistemáticas en el yacimiento se remontan a la década de 1950, aunque ya anteriormente se tenía constancia del valor arqueológico del sitio (Rodríguez Martínez et alii, 2010; 2011). Las campañas de 1950 y 1951 van a ser dirigidas por Filgueira Valverde y Sánchez Cantón (Filgueira Valverde y Blanco Freijeiro, 1962), y se van a centrar tanto al Este del Campo da Lanzada, como en la necrópolis. Durante estas intervenciones se localiza un conchero con presencia de diversas especies de moluscos y equinodermos, así como espinas de peces (Filgueira Valverde y Blanco Freijeiro, 1962). Los únicos datos que conocemos respecto a las especies son los que se recogen en la bibliografía sobre estas intervenciones.

\footnotetext{
${ }^{5}$ Datum: ETRS89; Uso: 29; UTM: X 510.272/Y 4.697.457.
} 


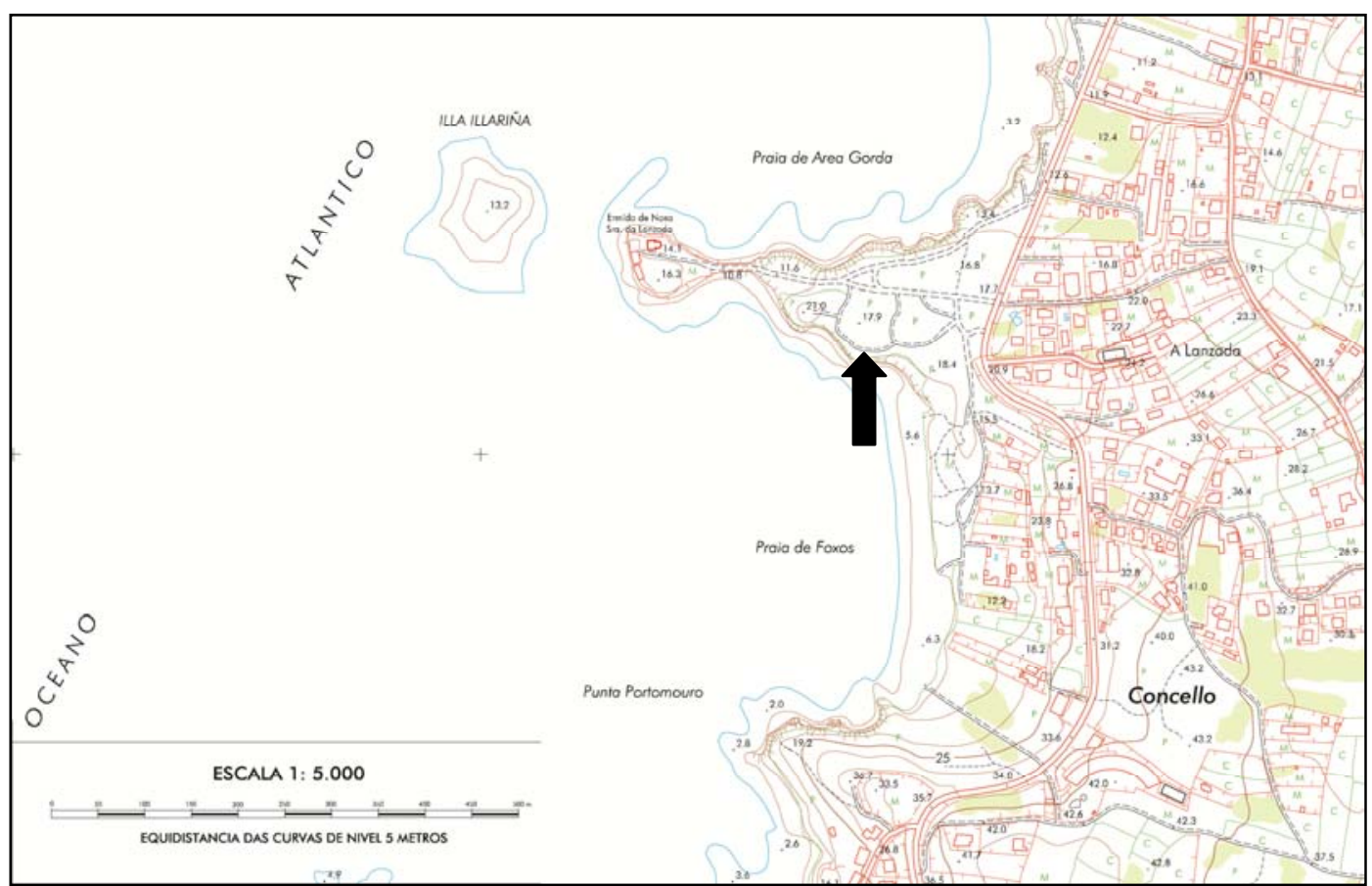

Fig. 159 Topográfico 1:5.000 de Punta Lanzada y localización de las intervenciones. (Extraído de http://sitga.xunta.es/sitga).

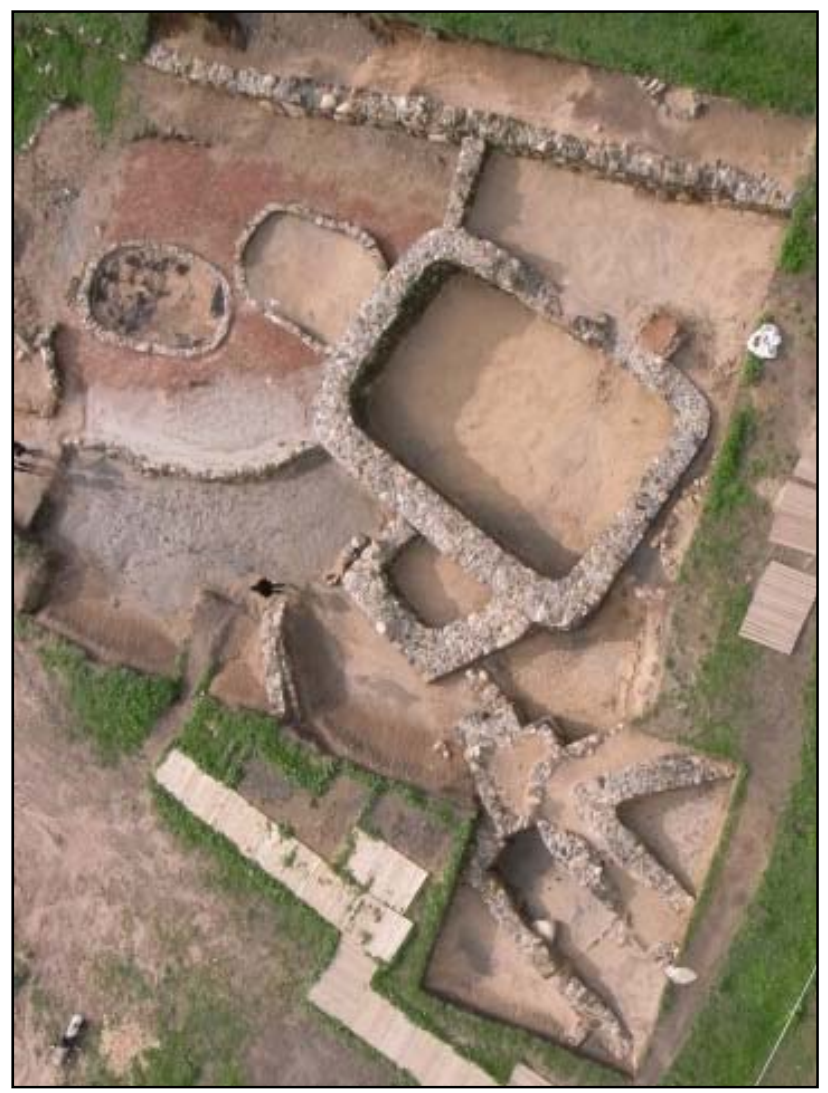

Fig. 160 Superficie excavada en la Campaña de 2010 (Imagen facilitada por Rafael Rodríguez).
A inicios de la década de los setenta se producen nuevas intervenciones promovidas por el Museo de Pontevedra, cosntatando una potencia estratigráfica de $4 \mathrm{~m}$ (Fariña Busto, 1974; 1975). Durante estas intervenciones se recuperaron diversos restos de fauna, estudiados por Vázquez Varela $(1973,1976,1984)$.

En 1977 y 1978, ante la aparición de nuevos enterramientos, se realizan nuevas campañas arqueológicas en el Sector Exterior (Suárez Otero y Fariña Busto, 1990). De estas campañas se han estudiado los restos de ictiofauna, formando parte de la Tesis Doctoral de Ferré (2003) y de macrofauna, también parte de una Tesis Doctoral (Fernández Rodríguez, 2000).

Entre 1980-1983 se realizaron varias campañas de urgencia dirigidas 
por de la Peña Santos. De estas excavaciones únicamente se publicaron los resultados de los restos de macromamíferos (Penedo Romero, 1986; 1988; Fernández Rodríguez, 2000).

Las últimas intervenciones llevadas a cabo son las efectuadas en el 2010 por la Diputación de Pontevedra y bajo la dirección de Rodríguez Martínez. En esta campaña se excavó una superficie de $628 \mathrm{~m}^{2}$, de los cuales parte correspondían al área intervenida durante los años 50 y los 70 del siglo pasado con el fin de precisar la estratigrafía (Rodríguez Martínez et alii, 2010). Por otro lado, también se pretendía la puesta en valor de las estructuras exhumadas (Rodríguez Martínez, 2010).

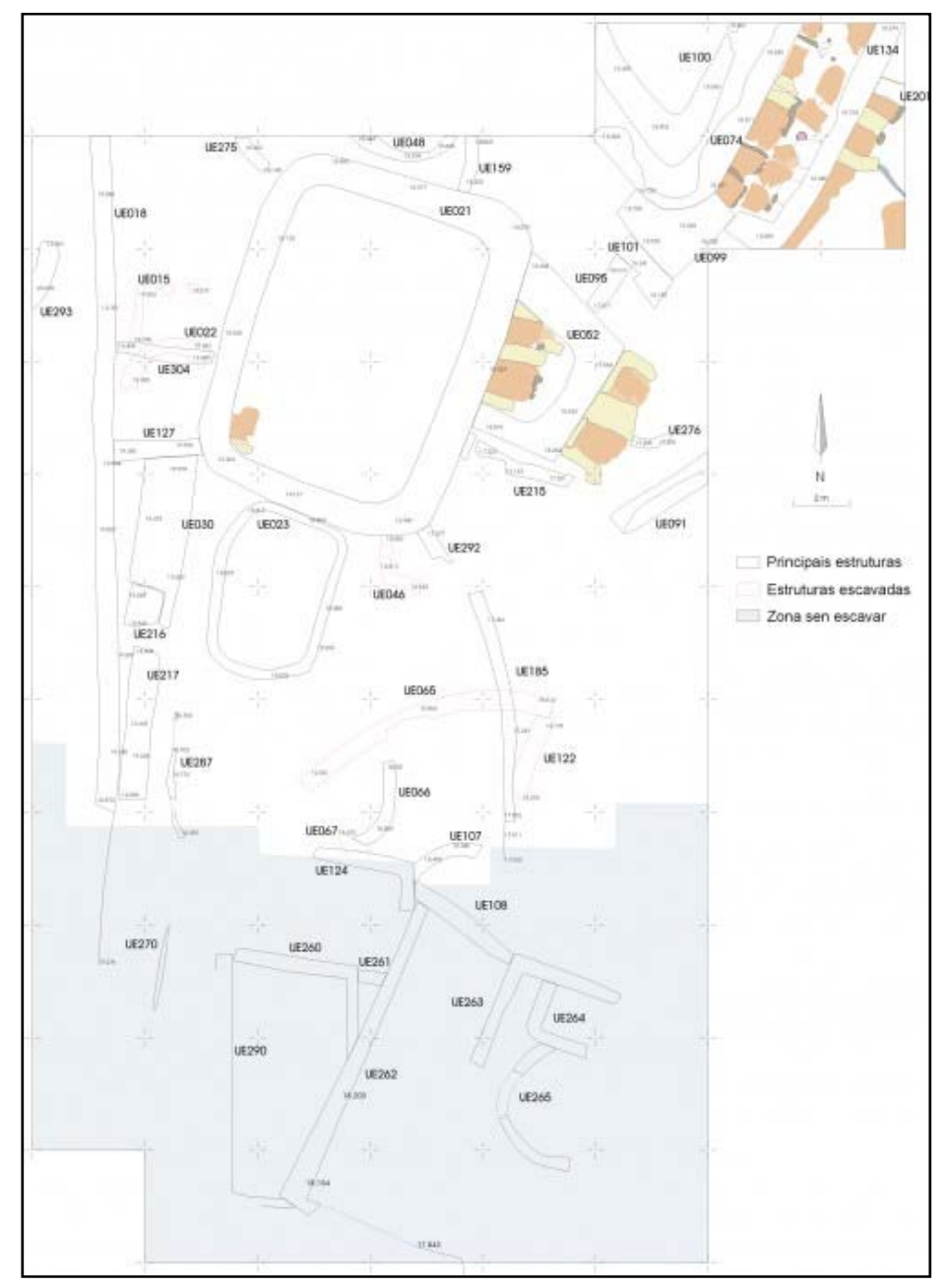

Fig. 161 Planimetría A Lanzada campaña de 2010 (Rodríguez Martínez, 2010).

Durante esta campaña se pudo constatar la ocupación del asentamiento desde el siglo IV-III a.C. al IV d.C., con varias reestructuraciones, tanto por motivos urbanísticos como productivos. En el siglo II a.C. se va a producir la construcción de instalaciones relacionadas con el tratamiento y conservación de productos marinos. Posteriormente se producirá una remodelación de este espacio, construyendo un gran almacén, aunque van a seguir funcionando estas instalaciones conserveras. En este momento también aparecerán nuevas estructuras habitacionales, así como distintos vertederos de moluscos (Rodríguez Martínez et alii, 2010; 2011). 
Con la influencia del mundo romano se articula de nuevo el espacio, desapareciendo estas instalaciones productivas y apareciendo estructuras con ángulos rectos (Rodríguez Martínez et alii, 2010; 2011).

\section{V.5.3. RECOGIDA DE LAS MUESTRAS.}

\section{V.5.3.1. EL MUESTREO.}

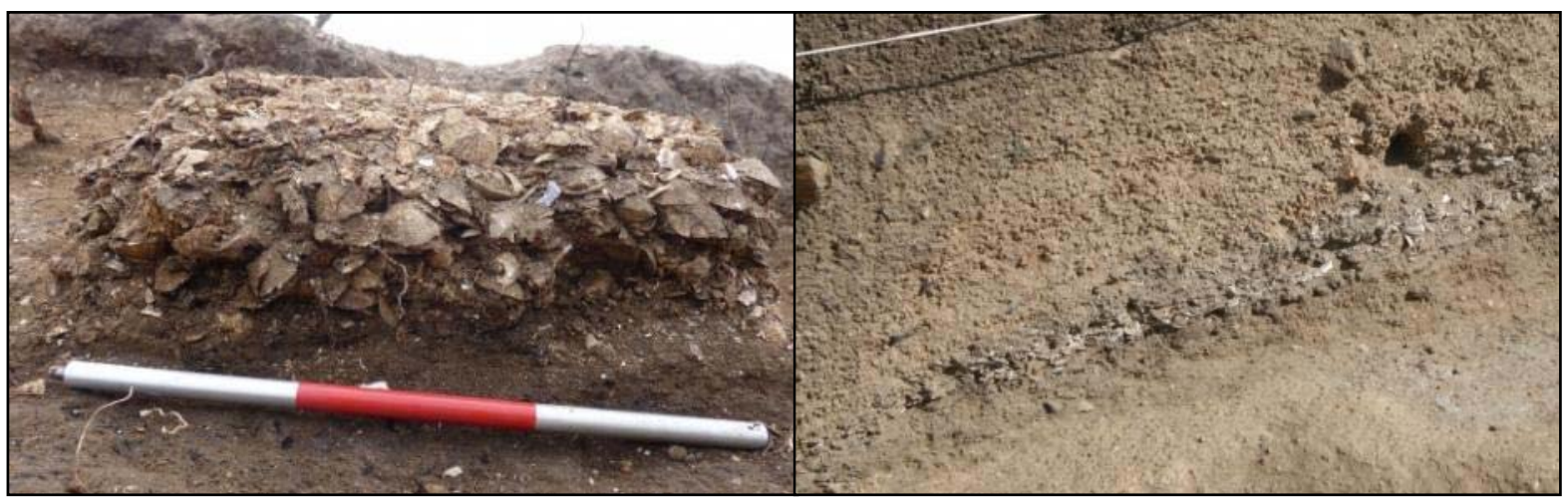

Fig. 162 Echadizos de conchas (Imágenes facilitadas por Rafael Rodríguez).

La ausencia de un depósito masivo con conchas, apareciendo diferentes niveles de escasa potencia, condicionó el tipo de muestreo realizado. Por este motivo se procedió a tomar diferentes muestras aislados y otras concentradas (Bejega García et alii, 2010). Dependiendo de la potencia de la unidad se tomaron una o varias muestras.

\section{V.5.3.2. CRONOLOGía.}

Según las diferentes excavaciones realizadas en A Lanzada, se ha constatado una ocupación que se iniciaría en el siglo VIII a.C., y que llegaría hasta el siglo X d.C. Durante este tiempo se produciría una ocupación continuada en el asentamiento, con un total de nueve fases de ocupación (Rodríguez Martínez et alii, 2010).

La mayoría de las muestras que hemos analizado, están relacionadas cronológica y estratigráficamente con las estructuras productivas, por lo que se sitúan en torno al siglo II a.C. También contamos con una muestra de época romana (UE115) datada a finales del siglo I d.C. o principios del siglo II. Por otro lado, la unidad 016 no presenta una cronología clara, por lo que si bien se incluirá en el trabajo, no se tendrá en cuenta al realizar la valoración global de los datos.

\section{V.5.4. ESTUDIO ICTIOARQUEOLÓGICO.}

\section{V.5.4.1. UE016.}

\section{Descripción de la unidad.}

Depósito de tierra color marrón, localizada en las UR.s 2643, 2644 y 2645. 


\begin{tabular}{l|c|c|}
\multirow{2}{*}{\multicolumn{1}{c|}{ Inicial }} & cc. & gr. \\
\cline { 2 - 3 } & $\mathbf{1 . 1 5 0}$ & $\mathbf{1 . 3 2 6}$ \\
\hline \hline Residuo & 600 & 977 \\
\hline Cerámica & & 6 \\
\hline Malacofauna & & 233 \\
Micromoluscos & & 1 \\
Equinodermos & & 6 \\
Crustáceos & & 16,5 \\
Indeterminado & & 0,5 \\
Macrofauna & & 81 \\
Ictiofauna & & 4 \\
Carbón & & 1 \\
\hline
\end{tabular}

Tabla 111 Pesos iniciales (en gr.) de la UE16 por componentes.

\section{V.5.4.1.1. MU100630B02}

\begin{tabular}{lcccccccc} 
& Vpc & Atl & Vca & Rce & Rpc & Esa & NR & NMI \\
\hline Pagrus pagrus & 1 & & & & & & $\mathbf{1}$ & 1 \\
Diplodus sargus & & 1 & & & & & $\mathbf{1}$ & 1 \\
Pagellus acarne & 1 & & 1 & & & & $\mathbf{2}$ & 1 \\
Pagellus bogaraveo & 1 & & & & & & $\mathbf{1}$ & 1 \\
Symphodus melops & & & 2 & & & & $\mathbf{2}$ & 1 \\
Indeterminado & & 1 & 1 & 26 & 27 & 1 & $\mathbf{5 6}$ & \\
\hline \multicolumn{1}{c}{ TOTAL } & $\mathbf{3}$ & $\mathbf{2}$ & $\mathbf{4}$ & $\mathbf{2 6}$ & $\mathbf{2 7}$ & $\mathbf{1}$ & $\mathbf{6 3}$ &
\end{tabular}

Tabla 112 Relación de especies y representación ósea de MU100630B02.

En esta muestra se han identificado dos vértebras caudales de Symphodus melops, así como una vértebra precaudal y una caudal de Pagellus acarne. Con menor número de restos, están presentes Pagrus pagrus y Pagellus bogaraveo con una vértebra precaudal cada uno, y Diplodus sargus con un atlas.

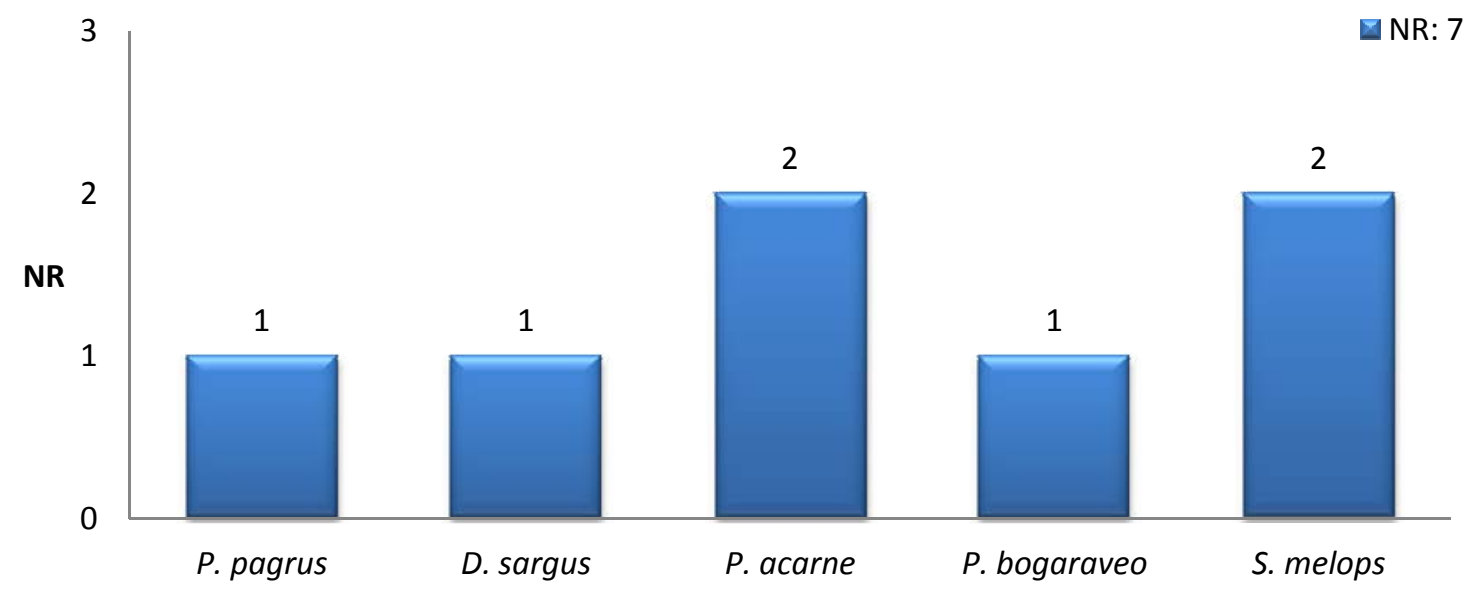

Fig. 163 Distribución de taxones identificados en MU100630B02 según el NR. 


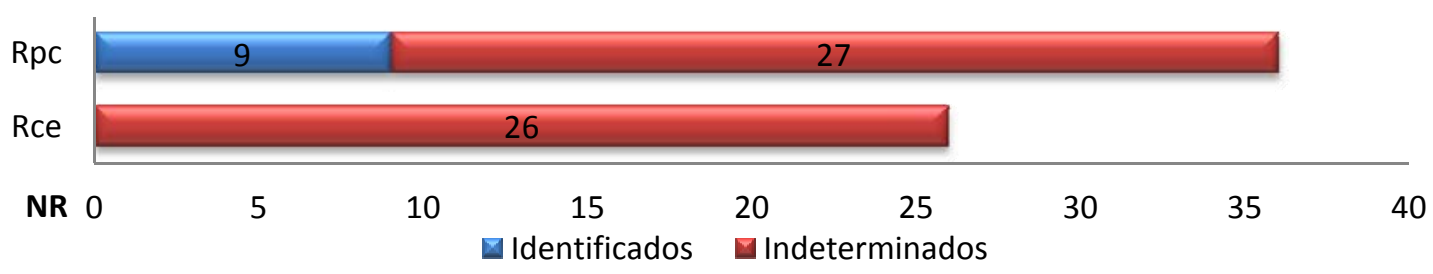

Fig. 164 Distribución esquelética de los restos ícticos de MU100630B02.

Todos los restos que hemos podido identificar a nivel anatómico pertenecen al esqueleto postcefálico. Sin embargo el número de restos indeterminados es similar para restos cefálicos y post-cefálicos. Únicamente se recuperó una escama.

\section{V.5.4.2. UE064.}

\section{Descripción de la unidad.}

Estrato de color marrón amarillento, de granulometría media, gravas. Compactación media. Se superpone el muro de una cabaña desmantelada (UE066) y sobre él estaba una estructura lineal de clara cronología romana (UE 065). Los materiales asociados son castrexos y algún fragmento de ánfora de tradición púnica. La datación de la estructura amortizada se realizó por este depósito (s II a.C.), lo que lo dataría en torno a los ss. I a.C. - I d.C. Se localiza en la UR 2543.

\begin{tabular}{l|c|c|}
\multirow{2}{*}{\multicolumn{1}{c|}{ Inicial }} & cc. & gr. \\
\cline { 2 - 3 } & $\mathbf{1 . 3 0 0}$ & $\mathbf{1 . 2 4 1}$ \\
\hline \hline Residuo & 1.050 & 1.081 \\
\hline Cerámica & & 15 \\
\hline Malacofauna & & 64,5 \\
Micromoluscos & & 4 \\
Equinodermos & & 1 \\
Crustáceos & & 1,5 \\
Macrofauna & & 71 \\
Ictiofauna & & 1 \\
Carbón & & 1,5 \\
\hline \multicolumn{2}{l|}{}
\end{tabular}

Tabla 113 Pesos iniciales (en gr.) de la UE064 por componentes.

\section{V.5.4.2.1. MU100804B03}

\begin{tabular}{ccccccc} 
& Vca & Rce & Rpc & Esa & NR & NMI \\
\hline $\begin{array}{c}\text { Labrus bergylta } \\
\text { Indeterminado }\end{array}$ & 1 & & & & $\mathbf{1}$ & 1 \\
\hline \hline TOTAL & $\mathbf{1}$ & $\mathbf{5}$ & $\mathbf{1 9}$ & $\mathbf{6}$ & $\mathbf{3 1}$ &
\end{tabular}

Tabla 114 Relación de especies y representación ósea de MU100804B03.

Se ha identificado únicamente una vértebra caudal de Labrus bergy/ta. 


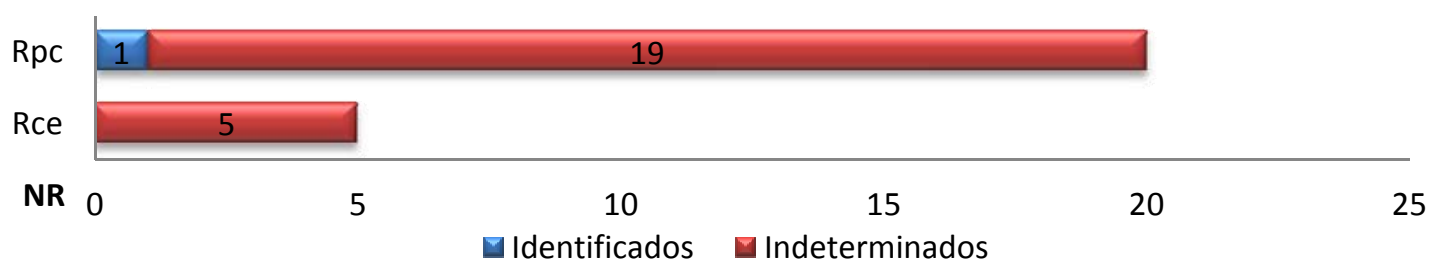

Fig. 165 Distribución esquelética de los restos ícticos de MU100804B03.

Entre las piezas óseas indeterminadas predominan los restos post-cefálicos con diecinueve fragmentos sobre los cefálicos. En cuanto a los restos identificados, la muestra únicamente contenía una vértebra.

\section{V.5.4.3. UE078.}

\section{Descripción de la unidad.}

Nivel escasamente compactado, compuesto por tierra, conchas, huesos y abundante material cerámico (cerámica castreña típica del Hierro II, ollas y jarras Toralla, bordes aristados, estampillas, etc... y algún material de importación de clara filiación púnica procedente de la zona del actual Cádiz).

\begin{tabular}{|c|c|c|c|c|c|c|c|c|}
\hline \multirow[b]{3}{*}{ Inicial } & \multicolumn{2}{|c|}{ MU100728B01 } & \multicolumn{2}{|c|}{ MU100722B02 } & \multicolumn{2}{|c|}{ MU100727B02 } & \multicolumn{2}{|c|}{ MU100810B03 } \\
\hline & cC. & gr. & CC. & gr. & cc. & gr. & cc. & gr. \\
\hline & 2.350 & 5.184 & 1.550 & 1.285 & 200 & 242 & 1.900 & 1.386 \\
\hline Residuo & 2.200 & 5.100 & 750 & 719 & 100 & 225 & 1.700 & 1.131 \\
\hline Cerámica & & 16 & & 16 & & 1 & & 125 \\
\hline Malacofauna & & 34 & & 454 & & 7 & & 62 \\
\hline Micromoluscos & & 1,5 & & 2 & & & & 1 \\
\hline Equinodermos & & 3 & & 1 & & 0,5 & & 1 \\
\hline Crustáceos & & 5 & & 6,5 & & 0,5 & & 8,5 \\
\hline Indeterminado & & 0,5 & & 2 & & & & \\
\hline Macrofauna & & 16 & & 80 & & 5 & & 39 \\
\hline Ictiofauna & & 7 & & 3,5 & & 2 & & 14 \\
\hline Microfauna & & 1,5 & & 0,5 & & 0,5 & & \\
\hline Carbón & & 1,5 & & 1 & & 0,5 & & 4 \\
\hline
\end{tabular}

Tabla 115 Pesos iniciales (en gr.) de las muestras de la UE 078 por componentes.

\section{V.5.4.3.1. MU100728B01}

\begin{tabular}{lcccccccccc} 
& $\begin{array}{c}\text { Pal } \\
\text { (D/S) }\end{array}$ & $\begin{array}{c}\text { Eph } \\
\text { (D/S) }\end{array}$ & Vpc & Atl & Vca & Rce & Rpc & Esa & NR & NMI \\
\hline $\begin{array}{l}\text { Trisopterus luscus } \\
\text { Trachurus trachurus }\end{array}$ & & & 1 & & & & & & $\mathbf{1}$ & 1 \\
Pagellus sp. & & & 1 & & & & & & $\mathbf{1}$ & 1 \\
Pagellus bogaraveo & & & 2 & & 2 & & & & $\mathbf{4}$ & 1 \\
Labrus bergylta & $1 / 0$ & $0 / 1$ & 2 & 1 & 2 & & & & $\mathbf{7}$ & 1 \\
Symphodus melops & & & 3 & & 5 & & & & $\mathbf{8}$ & 1 \\
Indeterminado & & & 2 & & & 74 & 88 & 4 & $\mathbf{1 6 6}$ & \\
\hline \multicolumn{1}{c}{ TOTAL } & $\mathbf{1}$ & $\mathbf{1}$ & $\mathbf{1 1}$ & $\mathbf{1}$ & $\mathbf{1 2}$ & $\mathbf{7 4}$ & $\mathbf{8 8}$ & $\mathbf{4}$ & $\mathbf{1 9 0}$ &
\end{tabular}

Fig. 166 Relación de especies y representación ósea de MU100728B01. 
En esta muestra se han identificado tres vértebras precaudales y cinco caudales de Symphodus melops. Una de las vértebras precaudales se encontraba afectada por acción del fuego. También se han recuperado un palatino derecho, un epihial izquierdo, dos vértebras precaudales, un atlas y dos vértebras caudales de Labrus bergylta. Con una menor representación se encontraría Pagellus bogaraveo, con dos vértebras caudales y dos precaudales, y Trachurus trachurus, para la que se han reconocido tres vértebras caudales. Por último Trisopterus luscus y un ejemplar del género Pagellus, ambos representados con una vértebra precadual.

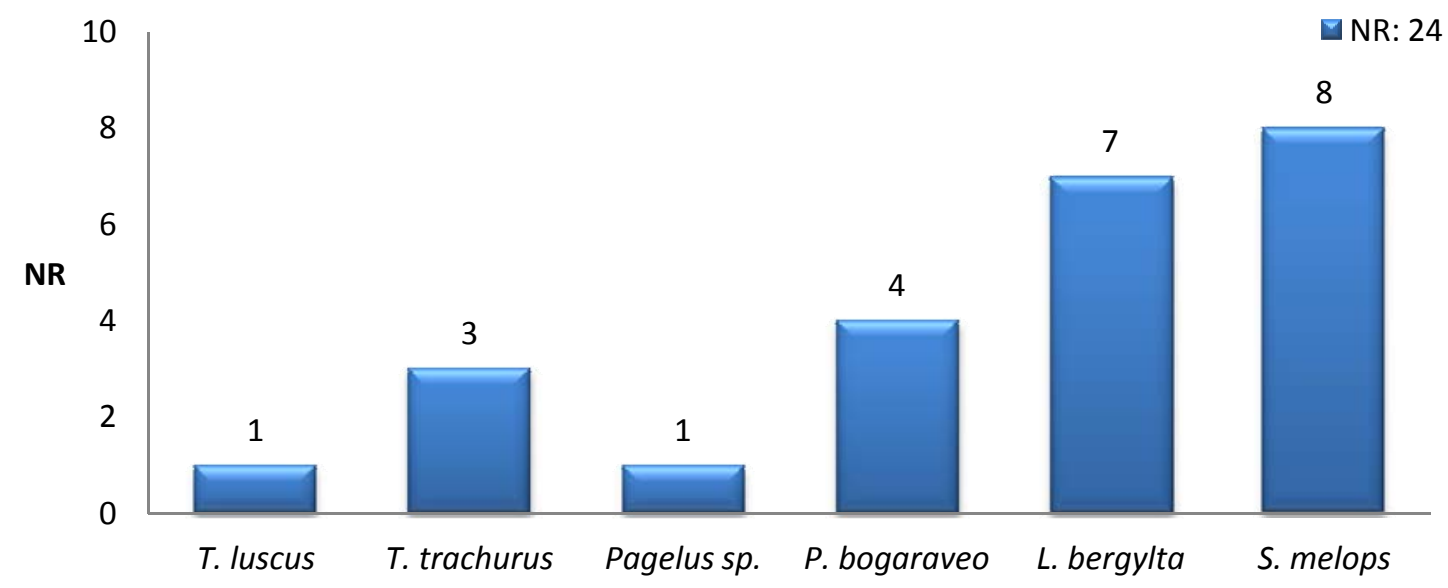

Fig. 167 Distribución de taxones identificasdos en MU100728B01 según el NR.

Entre las especies representadas podemos realizar tres grupos según el número de restos identificados en la muestra. En el primero estarían Labrus bergylta y Symphodus melops, ambas especies pertenecientes a la Familia de los Lábridos. Le seguirían en un segundo grupo Pagellus bogaraveo y Trachurus trachurus. Finalmente, resulta anecdótica la presencia de Trisopterus luscus. A excepción de Trachurus trachurus, que es pelágica, el resto de especies son todas demersales.

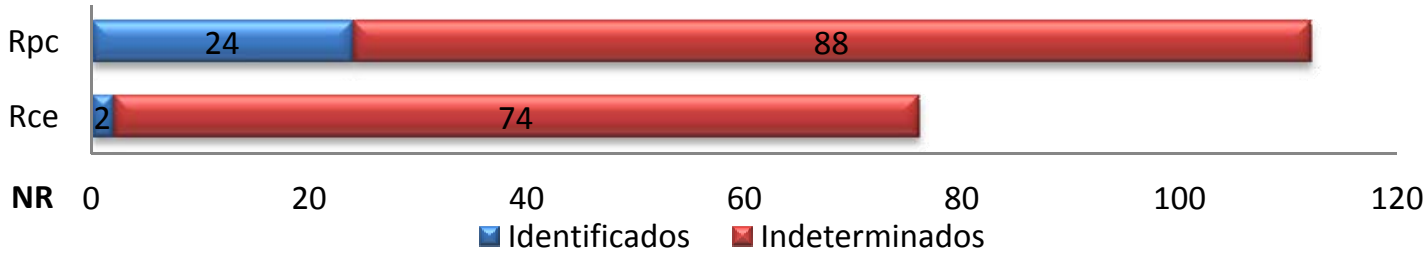

Fig. 168 Distribución esquelética de los restos ícticos de MU100728B01.

Tanto entre los restos identificados como en los indeterminados predominan las piezas esqueléticas postcefálicas. En el caso de los identificados anatómicamente, el número de piezas cefálicas es muy escaso, tan solo dos, siendo ambas de la misma especie, Labrus bergylta. 


\begin{tabular}{lcccccccc}
$\begin{array}{l}\text { V.5.4.3.2. } \\
\text { MU100722B02 }\end{array}$ & & & & & \\
& $\begin{array}{l}\text { Max } \\
\text { (D/S) }\end{array}$ & $\begin{array}{c}\text { Art } \\
\text { (D/S) }\end{array}$ & Vpc & Rce & Rpc & NR & NMI \\
\hline $\begin{array}{l}\text { Pagrus pagrus } \\
\text { Symphodus melops }\end{array}$ & $0 / 1$ & $0 / 1$ & & & & $\mathbf{2}$ & 1 \\
Indeterminado & & & 1 & & & $\mathbf{1}$ & 1 \\
\hline \hline TOTAL & $\mathbf{1}$ & $\mathbf{1}$ & $\mathbf{1}$ & $\mathbf{1 2}$ & $\mathbf{6}$ & $\mathbf{2 1}$ &
\end{tabular}

Tabla 116 Relación de especies y representación ósea de MU100722B02.

Presencia de un maxilar y un articular izquierdos de Pagrus pagrus, y una vértebra precaudal de Symphodus melops.

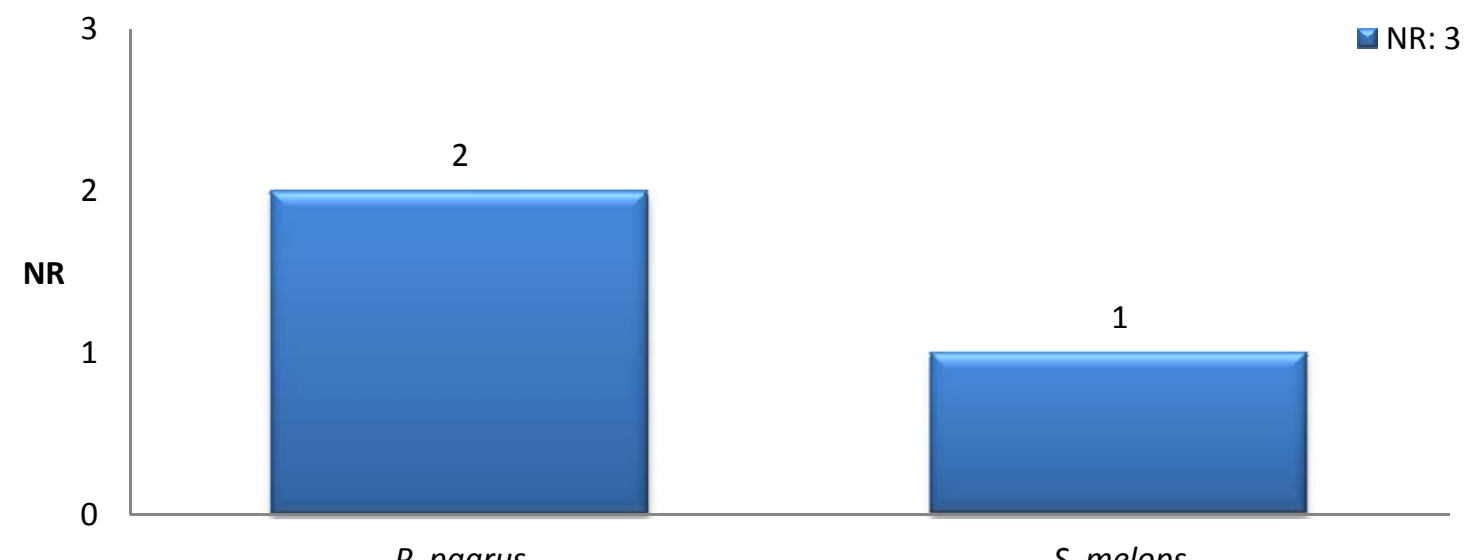
P. pagrus
S. melops

Fig. 169 Distribución de taxones identificados en MU100722B02 según el NR.

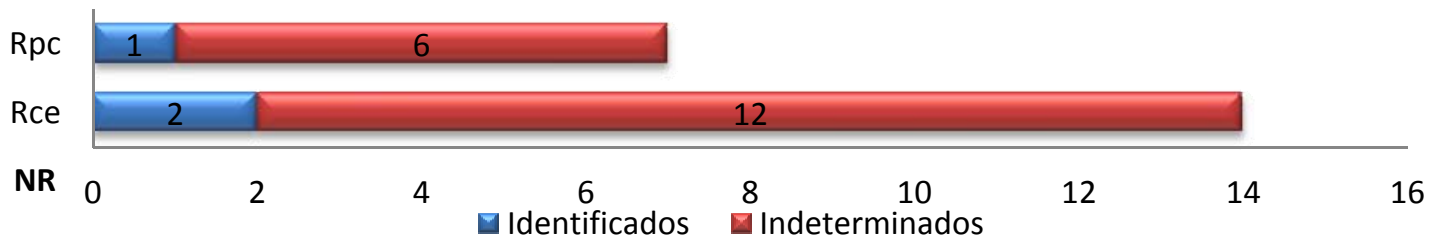

Fig. 170 Distribución esquelética de los restos ícticos de MU100722B02.

Frente a lo observado en otras muestras, va a ser mayor el número de restos cefálicos que el de post-cefálicos, tanto en restos identificados como indeterminados.

\section{V.5.4.3.3. MU100727B02}

\begin{tabular}{lcccccccc} 
& Fbr & Pop & Vpc & Vca & Rce & Rpc & NR & NMI \\
\hline Trisopterus luscus & & & 1 & & & & $\mathbf{1}$ & 1 \\
Diplodus sargus & 1 & & & & & & $\mathbf{1}$ & 1 \\
Symphodus melops & & & 1 & 1 & & & $\mathbf{2}$ & 1 \\
Indeterminado & & 1 & 1 & & 2 & 25 & $\mathbf{2 9}$ & \\
\hline \hline \multicolumn{1}{c}{ TOTAL } & $\mathbf{1}$ & $\mathbf{1}$ & $\mathbf{3}$ & $\mathbf{1}$ & $\mathbf{2}$ & $\mathbf{2 5}$ & $\mathbf{3 3}$ &
\end{tabular}

Tabla 117 Relación de especies y representación ósea de MU100727B02. 
Presencia de una vértebra precaudal y una caudal de Symphodus melops, además de un faringobranquial de Diplodus sargus y una vértebra precaudal de Trisopterus luscus.

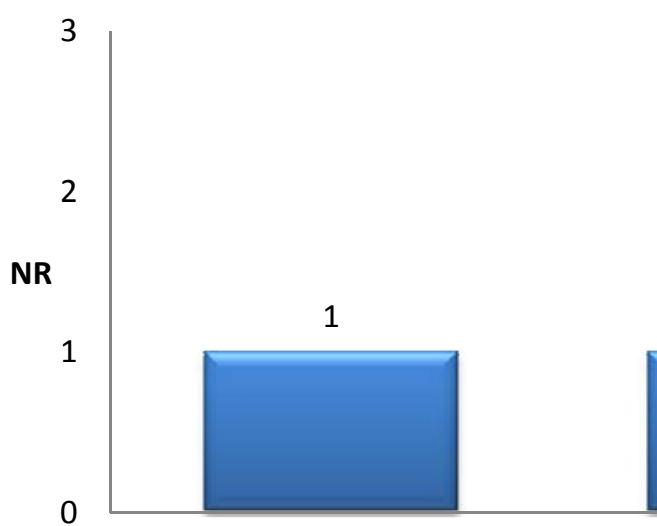

T. luscus

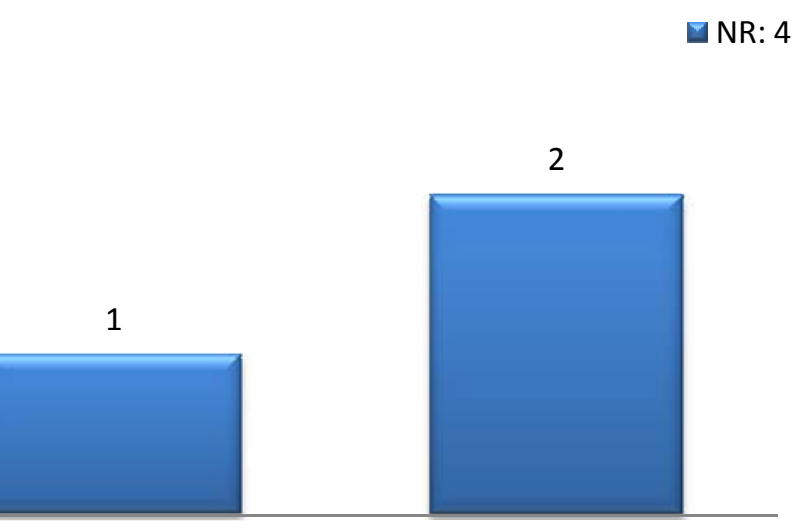

D. sargus

S. melops

Fig. 171 Distribución de taxones identificados en MU100727B02 según el NR.

La especie mejor representada es Symphodus melops con dos restos. Tanto Trisopterus luscus como Diplodus sargus cuentan con un resto cada una.

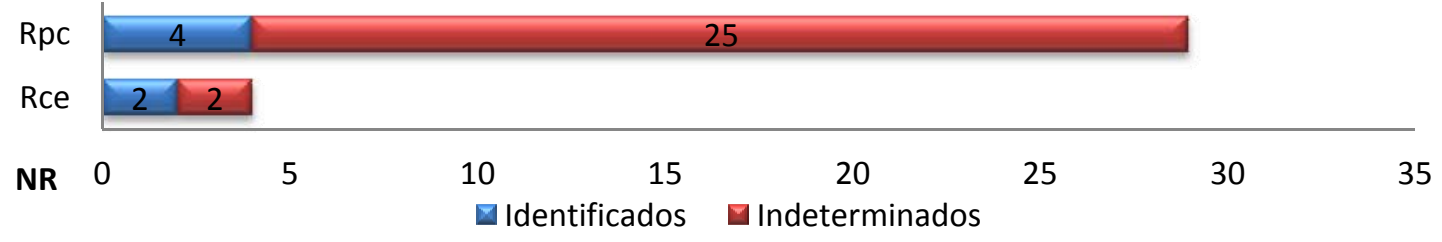

Fig. 172 Distribución esquelética de los restos ícticos de MU100727B02.

Predominan los restos post-cefálicos, siendo muy escasos los cefálicos recuperados, tanto entre los restos identificados como en los indeterminados.

\section{V.5.4.3.4. MU100810B03}

\begin{tabular}{|c|c|c|c|c|c|c|c|c|c|c|c|}
\hline & $\begin{array}{c}\text { Pmx } \\
\text { (D/S) }\end{array}$ & Cbr & $\begin{array}{l}\mathrm{Hmd} \\
(\mathrm{D} / \mathrm{S})\end{array}$ & $\begin{array}{c}\text { Pal } \\
\text { (D/S) }\end{array}$ & Vpc & Vca & Rce & Rpc & Esa & NR & NMI \\
\hline Trisopterus luscus & & & & & 2 & & & & & 2 & 1 \\
\hline Trachurus trachurus & & & & & 7 & 16 & & & & 23 & 1 \\
\hline Pagrus pagrus & & & & & & 2 & & & & 2 & 1 \\
\hline Diplodus sargus & & & & & 2 & & & & & 2 & 1 \\
\hline Pagellus sp. & $0 / 1$ & & & & & & & & & 1 & 1 \\
\hline Pagellus acarne & $0 / 1$ & & & & & & & & & 1 & 1 \\
\hline Pagellus bogaraveo & & & $0 / 1$ & $0 / 1$ & & 4 & & & & 6 & 1 \\
\hline Labrus bergy/ta & & & & & 2 & 5 & & & & 7 & 1 \\
\hline Symphodus melops & & 1 & & & 7 & 3 & & & & 11 & 1 \\
\hline Ammodytidae & & & & & 2 & & & & & 2 & 1 \\
\hline Scomber japonicus & & & & & 1 & & & & & 1 & 1 \\
\hline Indeterminado & & & & & 1 & 3 & 136 & 148 & 3 & 291 & \\
\hline TOTAL & 2 & 1 & 1 & 1 & 24 & 33 & 136 & 148 & 3 & $\overline{349}$ & \\
\hline
\end{tabular}


Es una de las muestras con mayor número de restos. La especie identificada con un mayor volumen de piezas óseas es Trachurus trachurus, con siete vértebras precaudales y dieciséis vértebras caudales. Le sigue en número de restos Symphodus melops con un ceratobranquial, siete vértebras precaudales y tres vértebras caudales. Con un número inferior de restos se encuentra Pagellus bogaraveo, con un hiomandibular y un palatino izquierdo y cuatro vértebras caudales; así como Labrus bergylta con dos vértebras precaudales y cinco vértebras caudales. El resto de especies estarían representadas por dos vértebras precaudales en el caso de Trisopterus luscus, Diplodus sargus y de un ejemplar de la Familia Ammodytidae. Dos vértebras caudales corresponden a Pagrus pagrus, mientras que una precaudal pertenece a Scomber japonicus. Por último se ha recuperado un premaxilar izquierdo de Pagellus acarne y otro de un ejemplar de Pagellus sp.

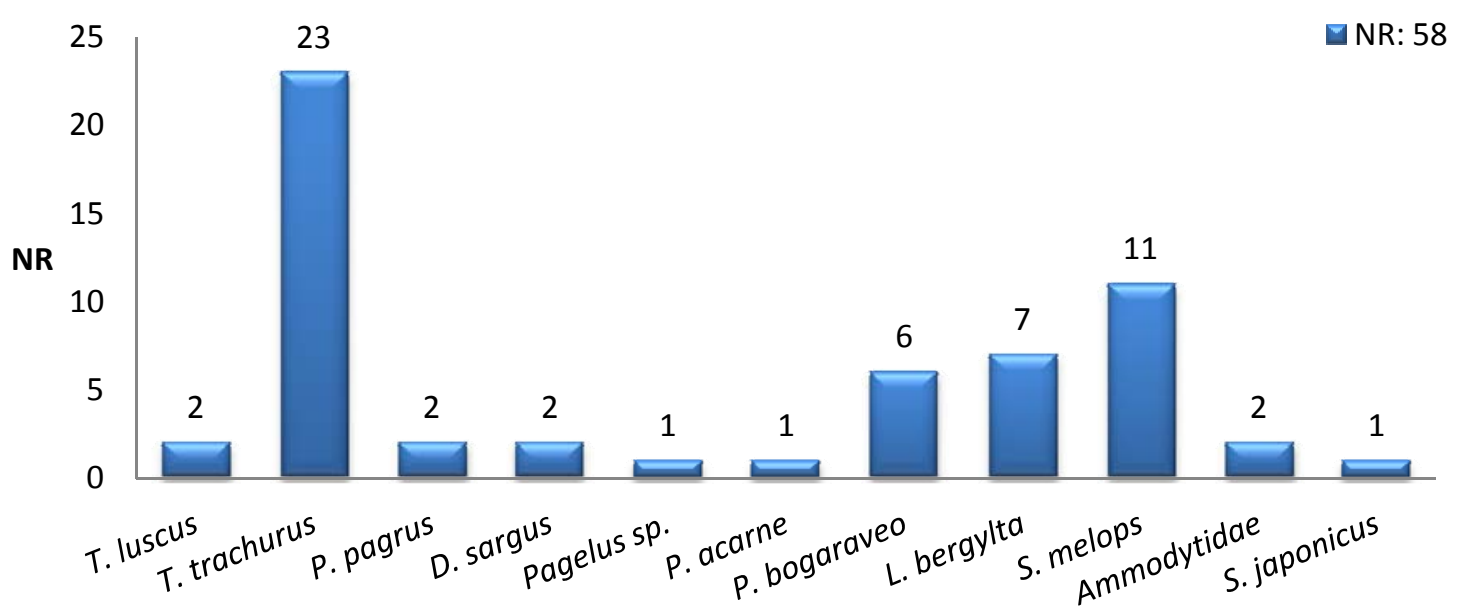

Fig. 173 Distribución de taxones identificados en MU100810B03 según el NR.

El taxón con mayor número de restos identificados es Trachurus trachurus, con más del doble de piezas óseas el siguiente en importancia. Además, frente a lo visto en las otras muestras, la especie mejor representada es pelágica. El siguiente grupo está formado de nuevo por especies demersales, destacando los Lábridos (Labrus bergylta y Symphodus melops), a los que acompaña Pagellus bogaraveo. Por último, hay un amplio abanico de especies con un número escaso de restos. La mayoría de ellas son demersales, a excepción de Scomber japonicus que es pelágica y la Familia Ammodytidae que son bentónicos. Esta Familia está formada por varias especies que tienen en común el que pasan la mayor parte del día enterradas en la arena.

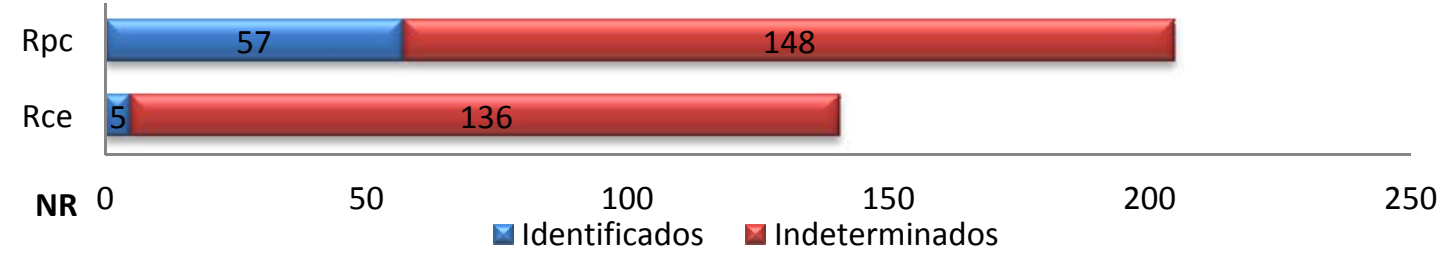

Fig. 174 Distribución esquelética de los restos ícticos de MU100810B03. 
Predominan los restos post-cefálicos, tanto entre los identificados como entre los indeterminados. Escaso número de escamas respecto al número de restos recuperados.

\section{V.5.4.4. UE115.}

\section{Descripción de la unidad.}

Tierra marrón oscura con abundantes inclusiones de conchas, presentando una compactación alta. Se documentan materiales de clara adscripción romana, sigillatas e imitaciones regionales de engobes rojos pompeyanos, pero se combinan con materiales indígenas de almacenaje. Cronológicamente encuadrable en el siglo I d.C. avanzado, quizás inicios del s. II d.C. Se localiza en las URs 2545 y 2445.

\begin{tabular}{l|c|c|}
\multirow{2}{*}{\multicolumn{1}{c|}{ Inicial }} & cc. & gr. \\
\cline { 2 - 3 } & $\mathbf{4 0 0}$ & $\mathbf{5 0 5}$ \\
\hline \hline Residuo & 350 & 483 \\
\hline Cerámica & & 1 \\
\hline Malacofauna & & 24,5 \\
Equinodermos & & 0,5 \\
Crustáceos & & 0,5 \\
Indeterminado & & 0,5 \\
Macrofauna & & 0,5 \\
Ictiofauna & & 0,5 \\
Carbón & & 0,5 \\
\hline
\end{tabular}

Tabla 119 Pesos iniciales (en gr.) de la UE115 por componentes.

\section{V.5.4.4.1. MU100722B04}

\begin{tabular}{lcccccc} 
& Vpc & Vca & Rce & Rpc & NR & NMI \\
\hline $\begin{array}{l}\text { Sardina pilchardus } \\
\text { Indeterminado }\end{array}$ & 2 & & & & $\mathbf{2}$ & 1 \\
\hline TOTAL & $\mathbf{2}$ & 1 & 3 & 6 & $\mathbf{1 0}$ & \\
\hline \hline
\end{tabular}

Tabla 120 Relación de especies y representación ósea de MU100722B04.

En esta muestra se han recuperado dos vértebras precaudales de Sardina pilchardus.

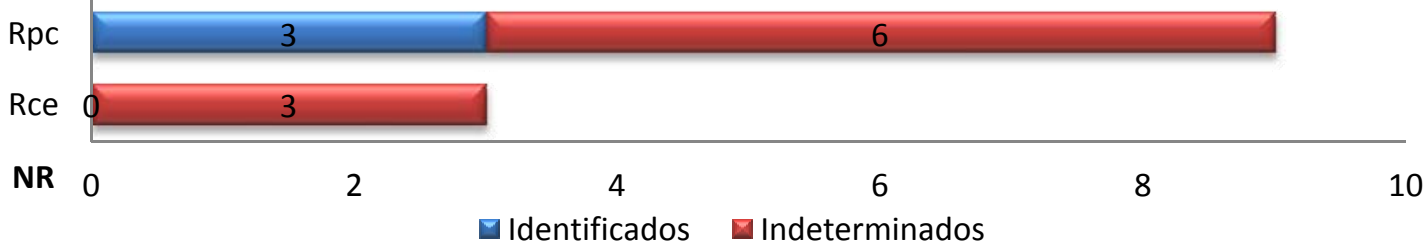

Fig. 175 Distribución esquelética de los restos ícticos de MU100722B04.

Presencia mayoritaria de restos post-cefálicos. En el caso de los restos identificados a nivel anatómico no se ha recuperado ninguno que pertenezca al esqueleto cefálico. 


\section{V.5.4.5. UE152.}

\section{Descripción de la unidad.}

Tierra marrón oscura con abundantísimas conchas. Delimitado por las estructuras (UEs) 018, 021 y 027. Además de conchas se documenta un importante volumen de materiales. Cronológicamente, atendiendo a lo que indican los materiales cerámicos, este depósito podría datarse en el siglo II a.C., pues aparecen Jarras Toralla y vasijas de almacenaje tipo Cíes que perviven hasta momentos iniciales de este siglo. URs 2940-41; $2840-41$ y $2740-41$.

\begin{tabular}{|c|c|c|c|c|c|c|}
\hline \multirow[b]{3}{*}{ Inicial } & \multicolumn{2}{|c|}{ MU100831B02 } & \multicolumn{2}{|c|}{ MU100818B03 } & \multicolumn{2}{|c|}{ MU100813B06 } \\
\hline & cc. & gr. & cc. & gr. & cc. & gr. \\
\hline & 5.750 & 6.093 & 1.150 & 988 & 5.100 & 5.660 \\
\hline Residuo & 2.650 & 3.962 & 950 & 430,5 & 3.670 & 4.965 \\
\hline Cerámica & & 60 & & & & 23 \\
\hline Inorgánico indeter. & & & & & & 36 \\
\hline Malacofauna & & 1769,5 & & 387 & & 455 \\
\hline Micromoluscos & & 4 & & & & \\
\hline Equinodermos & & 56 & & 164 & & 3 \\
\hline Crustáceos & & 52,5 & & 1 & & 19 \\
\hline Indeterminado & & 0,5 & & & & 1 \\
\hline Macrofauna & & 158 & & 2 & & 64 \\
\hline Ictiofauna & & 20 & & 0,5 & & 21 \\
\hline Microfauna & & 2 & & 0,5 & & 1,5 \\
\hline Carbón & & 8,5 & & 2,5 & & 14 \\
\hline
\end{tabular}

Tabla 121 Pesos iniciales (en gr.) de las muestras de la UE152 por componentes.

\section{V.5.4.5.1. MU100831B02}

\begin{tabular}{|c|c|c|c|c|c|c|c|c|c|c|c|c|}
\hline & $\begin{array}{l}\text { Pmx } \\
\text { (D/S) }\end{array}$ & $\mathrm{Cbr}$ & $\begin{array}{l}\text { Pop } \\
\text { (D/S) }\end{array}$ & $\begin{array}{c}\text { Pal } \\
\text { (D/S) }\end{array}$ & Urh & Vpc & Vca & Rce & Rpc & Esa & NR & NMI \\
\hline Trisopterus luscus & & & & & & 1 & 2 & & & & 3 & 1 \\
\hline Trachurus trachurus & & & & & & & 1 & & & & 1 & 1 \\
\hline Pagrus pagrus & $0 / 1$ & & & & 1 & & 1 & & & & 3 & 1 \\
\hline Diplodus sp. & & & & & & & 1 & & & & 1 & 1 \\
\hline Diplodus sargus & & & & & & & 1 & & & & 1 & 1 \\
\hline Pagellus acarne & & & & & & & 1 & & & & 1 & 1 \\
\hline Labrus bergy/ta & & & $1 / 0$ & $1 / 0$ & 1 & 2 & 3 & & & & 8 & 1 \\
\hline Symphodus melops & & 1 & & & & 1 & 4 & & & & 6 & 1 \\
\hline Scomber japonicus & & & & & & & 1 & & & & 1 & 1 \\
\hline Indeterminado & & & & & & 1 & 2 & 156 & 275 & 14 & 448 & \\
\hline TOTAL & 1 & 1 & 1 & 1 & 2 & 5 & 17 & 156 & 275 & 14 & 4473 & \\
\hline
\end{tabular}

Tabla 122 Relación de especies y representación ósea de MU100831B02.

La especie que presenta más restos identificados es Labrus bergy/ta: un preopercular y un palatino derecho, un urohial, dos vértebras precaudales y una vértebra caudal. En número le seguiría Symphodus melops con un ceratobranquial, una vértebra 
precaudal y cuatro caudales. Además se ha recuperado una vértebra precaudal y dos caudales de Trisopterus luscus; un premaxilar derecho, un urohial y una vértebra caudal de Pagrus pagrus; así como una vértebra caudal de Trachurus trachurus, Diplodus sargus, Pagellus acarne, Scomber japonicus y de algún ejemplar del género Diplodus.

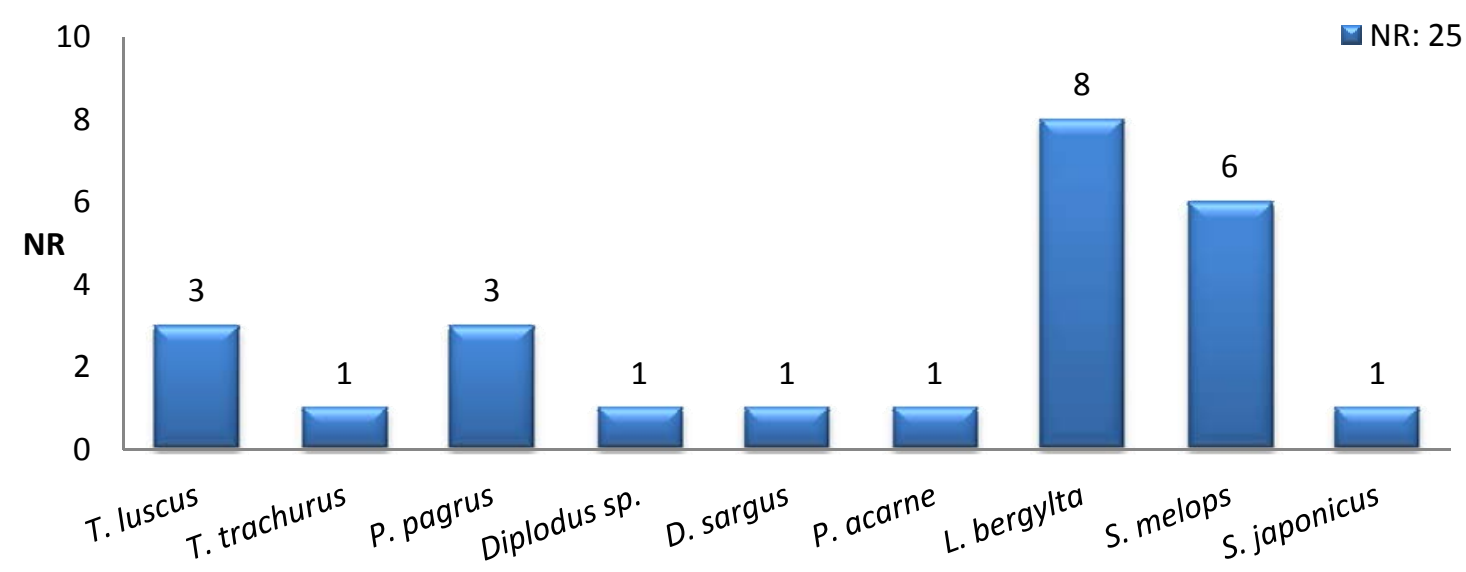

Fig. 176 Distribución de taxones identificados en MU100831B02 según el NR.

Según el número de restos que presentan las diferentes especies, podemos establecer tres grupos en importancia. El primero de ellos vuelve a estar formado por ejemplares de la Familia de los Lábridos, Labrus bergylta y Symphodus melops, configurando el $50 \%$ de la muestra. Le siguen en número de restos Trisopterus luscus y Pagrus pagrus con tres restos cada uno. Finalmente hay un amplio abanico de especies con una presencia mínima de restos: Trachurus Trachurus, Pagellus acarne, Scomber japonicus, Diplodus sargus y un ejemplar del género Diplodus.

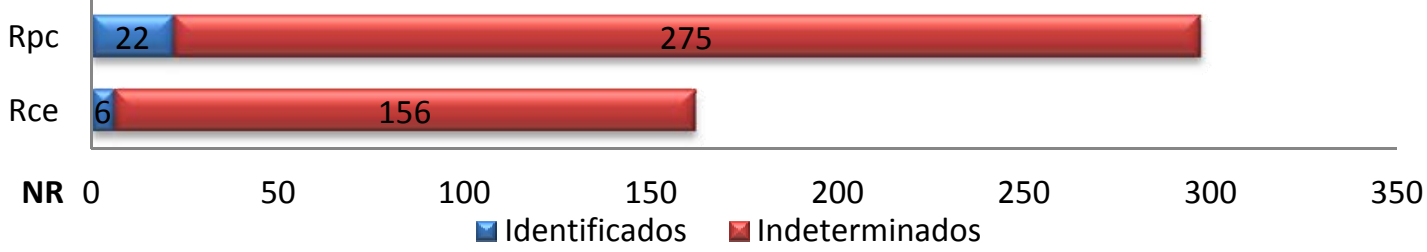

Fig. 177 Distribución esquelética de los restos ícticos de MU100831B02.

Se constata un mayor número de restos post-cefálicos que de cefálicos, tanto entre los restos óseos identificados como entre los indeterminados. Se han recuperado 14 escamas.

\section{V.5.4.5.2. MU100818B03}

\begin{tabular}{cccc} 
& Rpc & NR & NMI \\
\hline Indeterminado & 3 & $\mathbf{3}$ \\
\hline \hline TOTAL & $\mathbf{3}$ & $\mathbf{3}$
\end{tabular}

Tabla 123 Relación de especies y representación ósea de MU100818B03. 
Presencia de tres restos post-cefálicos indeterminados, correspondientes a costillas.

\begin{tabular}{|c|c|c|c|c|c|c|c|c|c|c|c|c|c|c|c|c|}
\hline \multicolumn{3}{|c|}{ V.5.4.5.3. } & \multicolumn{4}{|c|}{ MU100813B06 } & \multirow[b]{2}{*}{$\begin{array}{l}\text { Crh } \\
\text { (D/S) }\end{array}$} & \multirow[b]{2}{*}{$\begin{array}{c}\text { Eph } \\
\text { (D/S) }\end{array}$} & \multirow[b]{2}{*}{ Oto } & \multirow[b]{2}{*}{ Vpc } & \multirow[b]{2}{*}{ Vca } & \multirow[b]{2}{*}{ Rce } & \multirow[b]{2}{*}{ Rpc } & \multirow[b]{2}{*}{ Esa } & \multirow[b]{2}{*}{ NR } & \multirow[b]{2}{*}{ NMI } \\
\hline & $\begin{array}{l}\text { Pmx } \\
\text { (D/S) }\end{array}$ & $\begin{array}{c}\operatorname{Max} \\
(\mathrm{D} / \mathrm{S})\end{array}$ & $\begin{array}{l}\mathrm{Cdr} \\
(\mathrm{D} / \mathrm{S})\end{array}$ & $\begin{array}{l}\text { Hmd } \\
(\mathrm{D} / \mathrm{S})\end{array}$ & $\begin{array}{l}\text { Pop } \\
\text { (D/S) }\end{array}$ & $\begin{array}{c}\text { Pal } \\
\text { (D/S) }\end{array}$ & & & & & & & & & & \\
\hline Trisopterus luscus & & & & & & & & & & 1 & 1 & & & & 2 & 1 \\
\hline Trachurus trachurus & & & & & & & & & 1 & & 1 & & & & 2 & 1 \\
\hline Pagrus pagrus & $1 / 0$ & & & & $0 / 1$ & & $1 / 0$ & $1 / 0$ & & & 1 & & & & 5 & 1 \\
\hline Pagellus sp. & & & $0 / 1$ & & & & $1 / 0$ & & & & & & & & 2 & 1 \\
\hline Pagellus bogaraveo & & & & $0 / 1$ & & $1 / 0$ & & & & & 1 & & & & 3 & 1 \\
\hline Labrus bergylta & & & & & & $0 / 1$ & & & & & 1 & & & & 2 & 1 \\
\hline Symphodus melops & & & & & & & & & & 2 & 4 & & & & 6 & 1 \\
\hline Scomber japonicus & & & & & & & & & & & 2 & & & & 2 & 1 \\
\hline Scomber scombrus & & & & & & & & & & 1 & & & & & 1 & 1 \\
\hline Indeterminado & $0 / 1$ & $1 / 0$ & & & & $0 / 2$ & & & & 1 & 1 & 207 & 152 & 12 & 377 & \\
\hline TOTAL & 2 & 1 & 1 & 1 & 1 & 4 & 2 & 1 & 1 & 5 & 12 & 207 & 152 & 12 & 402 & \\
\hline
\end{tabular}

Tabla 124 Relación de especies y representación ósea de MU100813B06.

La especie con más restos identificados es Symphodus melops, con dos vértebras precaudales y cuatro caudales. Le sigue en representatividad Pagrus pagrus, con un premaxilar, un ceratohial y un epihial derechos, un preopercular izquierdo y una vértebra caudal. Pagellus bogaraveo está representado por un hiomandibular izquierdo, un palatino derecho y una vértebra caudal. Trisopterus luscus con una vértebra precaudal y una caudal. Trachurus trachurus cuenta con un otolito y una vértebra caudal, que presenta signos de aplastamiento. De Labrus bergy/ta se ha recuperado un palatino izquierdo y una vértebra caudal. De Scomber japonicus dos vértebras caudales y de Scomber scombrus una precaudal. Además se ha recuperado un cuadrado izquierdo y un ceratohial derecho de algún ejemplar del género Pagellus.

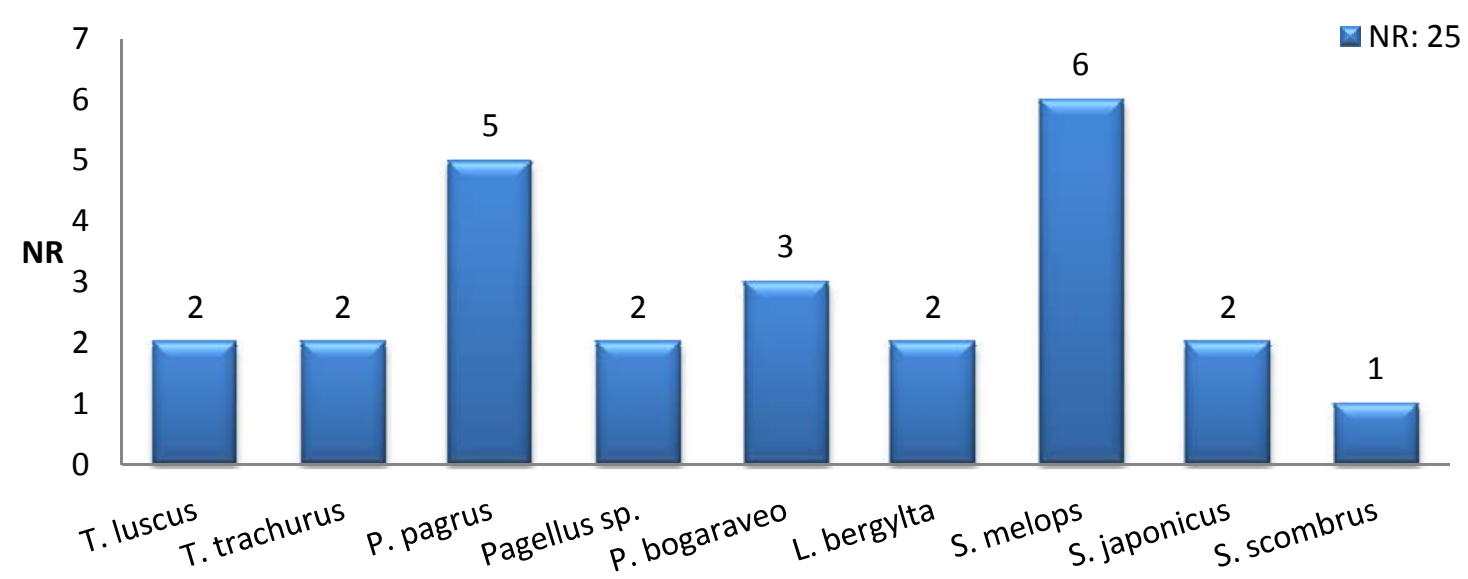

Fig. 178 Distribución de taxones identificados en MU100813B06 según el NR. 
Las especies que presentan el mayor número de restos identificados en la muestra son Pagrus pagrus y Symphodus melops. El segundo grupo en número de restos lo formarían un amplio abanico de taxones, entre los que destacan especies demersales como Pagellus bogaraveo, Trisopterus luscus y Labrus bergylta, o pelágicas como Trachurus trachurus, Scomber japonicus y Scomber scombrus.

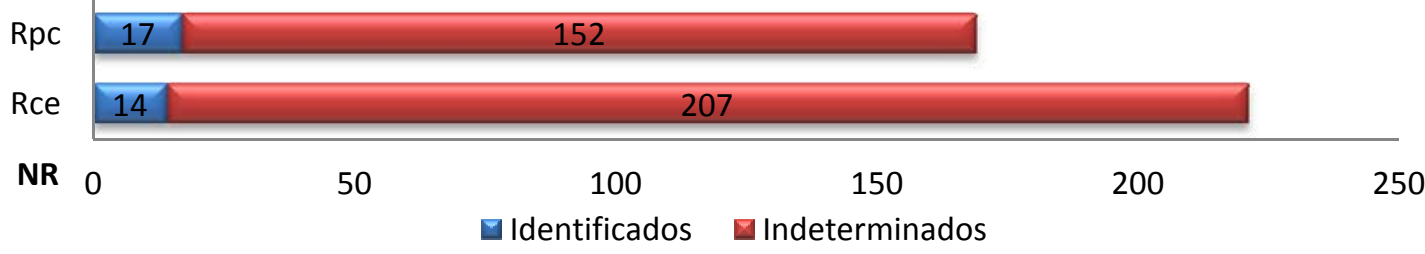

Fig. 179 Distribución esquelética de los restos ícticos de MU100813B06.

En esta muestra el mayor número de restos identificados anatómicamente corresponde a post-cefálicos; no obstante, el número de restos total es mayor en los cefálicos. Además, se recuperaron 12 escamas.

V.5.4.6.

UE152-183

\begin{tabular}{l|c|c|}
\multirow{2}{*}{\multicolumn{1}{c|}{ Inicial }} & cc. & gr. \\
\cline { 2 - 3 } & $\mathbf{6 . 9 5 0}$ & $\mathbf{7 . 4 1 8}$ \\
\hline \hline Residuo & 6.850 & 7.087 \\
\hline Manufacturas & & 58,5 \\
\hline Malacofauna & & 193,5 \\
Equinodermos & & 7 \\
Crustáceos & & 7,5 \\
Macrofauna & & 37,5 \\
Ictiofauna & & 9,5 \\
Microfauna & & 2 \\
Carbón & & 15,5 \\
\hline
\end{tabular}

Tabla 125 Pesos iniciales de la UE152-183 por componentes.

\section{V.5.4.6.1. MU100826B01}

\begin{tabular}{|c|c|c|c|c|c|c|c|c|c|c|c|c|c|c|}
\hline & $\begin{array}{l}\text { Dnt } \\
\text { (D/S) }\end{array}$ & $\mathrm{Fbr}$ & $\mathrm{Cbr}$ & $\begin{array}{l}\text { Hmd } \\
\text { (D/S) }\end{array}$ & $\begin{array}{c}\text { Crh } \\
\text { (D/S) }\end{array}$ & Oto & Vpc & Atl & Vca & Rce & Rpc & Esa & NR & NMI \\
\hline Trisopterus luscus & & & & & & & 2 & 1 & 3 & & & & 6 & 1 \\
\hline Trachurus trachurus & $0 / 1$ & & & & & & & & & & & & 1 & 1 \\
\hline Diplodus sargus & & & 1 & & & & & & & & & & 1 & 1 \\
\hline Pagellus acarne & & & & $1 / 0$ & & & & & & & & & 1 & 1 \\
\hline Pagellus bogaraveo & & & & & $1 / 0$ & & & & & & & & 1 & 1 \\
\hline Labrus bergylta & & 1 & & & & & & & & & & & 1 & 1 \\
\hline Symphodus melops & $0 / 1$ & & & $0 / 1$ & & & 1 & & & & & & 3 & 1 \\
\hline Scomber japonicus & & & & & & & 1 & & 1 & & & & 2 & 1 \\
\hline Indeterminado & & & & & & 2 & 1 & & & 39 & 78 & 1 & 121 & \\
\hline TOTAL & 2 & 1 & 1 & 2 & 1 & 2 & 5 & 1 & 4 & 39 & 78 & 1 & 137 & \\
\hline
\end{tabular}

Tabla 126 Relación de especies y representación ósea de MU100826B01. 
Trisopterus luscus se constituye como la especie mejor representada: dos vértebras precaudales, un atlas y tres vértebras caudales. La siguiente especie es Symphodus melops, de la que se han identificado un dentario y un hiomandibular izquierdo, y una vértebra precaudal. De Scomber japonicus se ha recuperado una vértebra precaudal y una caudal. Por último, con un único resto se encuentra Trachurus trachurus con un dentario izquierdo; Diplodus sargus con un ceratobranquial; Pagellus acarne con un hiomandibular derecho; Pagellus bogaraveo con un ceratohial derecho; y Labrus bergylta con un faringobranquial.

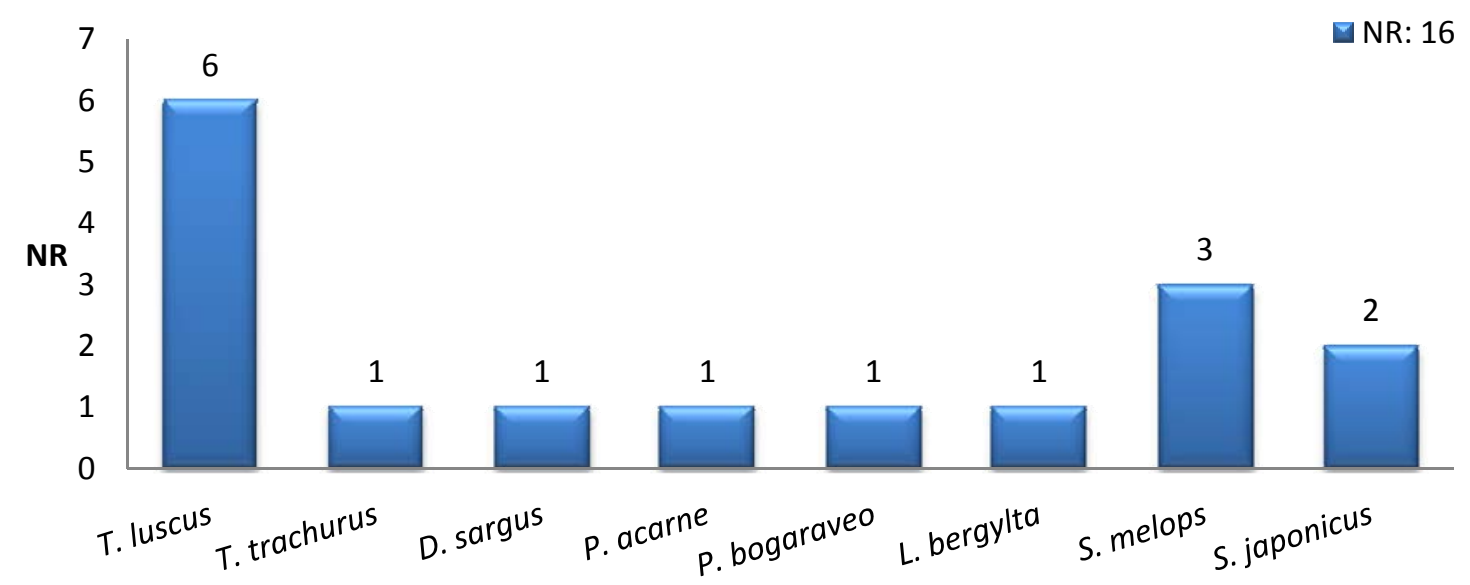

Fig. 180 Distribución de taxones identificados en MU100826B01 según el NR.

En esta muestra, el grupo con más restos identificados está costituído por una única especie, Trisopterus luscus. Los siguientes taxones mejor representados son Symphodus melops y Scomber japonicus. Por último, encontramos un tercer grupo formado por cinco especies con un único resto cada una. De todo el conjunto íctico, Trachurus trachurus sería la única especie pelágica.

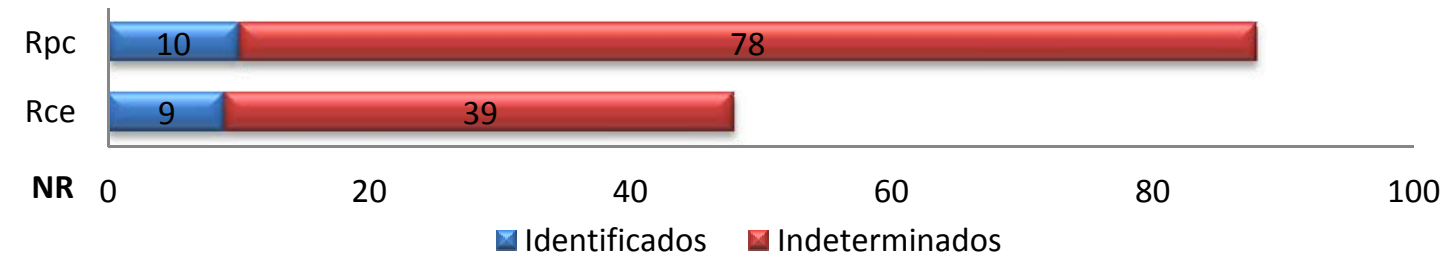

Fig. 181 Distribución esquelética de los restos ícticos de MU100826B01.

Aunque el número de restos identificados es similar entre los restos cefálicos y post-cefálicos, en el conjunto de indeterminados predominan estos segundos. Es destacable el bajo número de escamas en relación al volumen de piezas óseas. 


\section{V.5.4.7. UE183.}

\section{Descripción de la unidad.}

Nivel marrón, compacto y con una granulometría fina. Se documentan numerosos hallazgos de carbón y restos de bronce. Se localiza bajo la UE 152, ocupando el mismo espacio definido por la anterior. Los materiales cerámicos indican que se trata de un nivel del Hierro II, pero se hace difícil precisar más; quizás la aparición de una cuenta oculada de pasta vítrea permite situarlo entre los siglos V-III a.C.

\begin{tabular}{l|c|c|}
\multirow{2}{*}{\multicolumn{1}{c|}{ Inicial }} & cc. & gr. \\
\cline { 2 - 3 } & $\mathbf{7 0 0}$ & $\mathbf{7 1 4}$ \\
\hline \hline Residuo & 450 & 660 \\
\hline Malacofauna & & 44 \\
Micromoluscos & & 1 \\
Equinodermos & & 1 \\
Crustáceos & & 6 \\
Macrofauna & & 0,5 \\
Ictiofauna & & 0,5 \\
Microfauna & & 0,5 \\
Carbón & & 0,5 \\
\hline
\end{tabular}

Tabla 127 Pesos iniciales (en gr.) de la UE183 por componentes.

\section{V.5.4.7.1. MU100826B01}

\begin{tabular}{lcccccc} 
& Vpc & Rce & Rpc & Esa & NR & NMI \\
\hline $\begin{array}{l}\text { Symphodus melops } \\
\text { Indeterminado }\end{array}$ & 1 & & & & $\mathbf{1}$ & 1 \\
\hline \multicolumn{1}{c}{ TOTAL } & & 1 & 8 & 3 & $\mathbf{1 2}$ & \\
\hline \hline
\end{tabular}

Tabla 128 Relación de especies y representación ósea de MU100826B01.

En esta muestra únicamente se ha recuperado una vértebra precaudal de Symphodus melops.

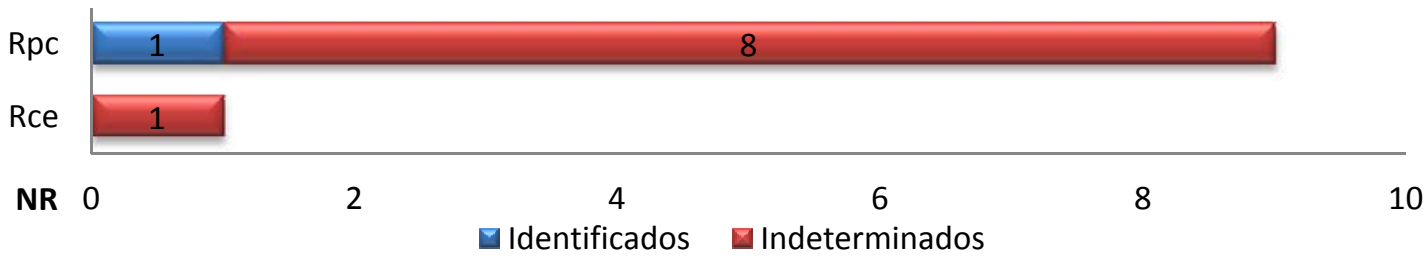

Fig. 182 Distribución esquelética de los restos ícticos de MU100826B01.

La mayor parte de los restos corresponden a elementos post-cefálicos, perteneciendo a esta parte del esqueleto la única pieza identificada anatómicamente. Únicamente se recuperó un resto cefálico y tres escamas. 


\section{V.5.4.8. UE184}

\section{Descripción de la unidad.}

Depósito de conchas, localizado en UR 2841. Se apoya sobre el muro UE021 (la gran cabaña o almacén), y bajo la UE 152. Su cronología se sitúa en torno al siglo II a.C.

\begin{tabular}{l|c|c|c|c|}
\multirow{2}{*}{\multicolumn{1}{c|}{ Inicial }} & \multicolumn{2}{|c|}{ MU100827B04 } & MU100827B07 \\
\cline { 2 - 5 } & $\mathbf{c c .}$ & $\mathbf{\text { gr. }}$ & cc. & gr. \\
\hline \hline Residuo & $\mathbf{4 . 5 0 0}$ & $\mathbf{3 . 6 8 4}$ & $\mathbf{8 . 7 0 0}$ & $\mathbf{4 . 8 6 7}$ \\
\hline Cerámica & & 34 & & 2 \\
\hline Malacofauna & & $1.781,5$ & & 3.658 \\
Micromoluscos & & 2 & & 0,5 \\
Equinodermos & & 28 & & 5 \\
Crustáceos & & 84,5 & & 27,5 \\
Indeterminado & & 11,5 & & 1 \\
Macrofauna & & 8 & & 11 \\
Ictiofauna & & 18 & & 23 \\
Microfauna & & 1,5 & & 0,5 \\
Carbón & 4,5 & & 4 \\
\hline
\end{tabular}

Tabla 129 Pesos iniciales (en gr.) de la UE184 por componentes.

\section{V.5.4.8.1. MU100827B04}

\begin{tabular}{|c|c|c|c|c|c|c|c|c|c|c|c|c|c|c|c|c|}
\hline & $\begin{array}{l}\text { Pmx } \\
\text { (D/S) }\end{array}$ & $\mathrm{Cbr}$ & $\begin{array}{l}\text { Cdr } \\
\text { (D/S) }\end{array}$ & $\begin{array}{l}\text { Hmd } \\
\text { (D/S) }\end{array}$ & $\begin{array}{l}\mathrm{Pal} \\
\text { (D/S) }\end{array}$ & $\begin{array}{l}\text { Eph } \\
\text { (D/S) }\end{array}$ & $\begin{array}{l}\text { Crh } \\
\text { (D/S) }\end{array}$ & Vpc & Atl & 19 Tor & Vca & Rce & Rpc & Esa & NR & NMI \\
\hline Conger conger & $0 / 1$ & & & & & & & & & & & & & & 1 & 1 \\
\hline Trachurus trachurus & & & & & & & & 2 & & & 14 & & & & 16 & 1 \\
\hline Pagellus acarne & & & & & & & & 3 & & & 3 & & & & 6 & 1 \\
\hline Pagellus bogaraveo & $0 / 1$ & & $0 / 1$ & & & & & 3 & & & 3 & & & & 8 & 1 \\
\hline Labrus bergylta & & & $1 / 0$ & $0 / 1$ & $1 / 0$ & $1 / 0$ & $1 / 0$ & 7 & & & 14 & & & & 25 & 1 \\
\hline Symphodus melops & & 1 & & & & $1 / 0$ & & 7 & 1 & 1 & 8 & & & & 19 & 1 \\
\hline Indeterminado & & & & & & & & & & & 3 & 200 & 183 & 3 & 389 & \\
\hline TOTAL & 2 & 1 & 1 & 1 & 1 & 2 & 1 & 22 & 1 & 1 & 45 & 200 & 183 & 3 & 464 & \\
\hline
\end{tabular}

Tabla 130 Relación de especies y representación ósea de MU100827B04.

Esta muestra es en la que se han recuperado un mayor número de restos ictiológicos. La especie mejor representada es Labrus bergylta con un hiomandibular izquierdo, un cuadrado, un palatino, un epihial y un ceratohial derecho, siete vértebras precaudales y 14 vértebras caudales. Una de las vértebras precaudales aparece serrada a la mitad. La siguiente especie con más restos es Symphodus melops, de la que se han recuperado un ceratobranquial, un epihial derecho, siete vértebras precaudales y ocho vértebras caudales. Trachurus trachurus está representada por dos vértebras precaudales y 14 caudales, siete de estas aplastadas. Ocho de las piezas óseas se han identificado como pertenecientes a Pagellus bogaraveo, con un premaxilar y un cuadrado izquierdo, así como tres vértebras precaudales, de la cual una está aplastada, y otras tantas caudales. También 
se han recuperado seis vértebras, tres precaudales y tres caudales, de Pagellus acarne. Por último se ha recuperado un premaxilar izquierdo de Conger conger, fracturado en dos fragmentos.

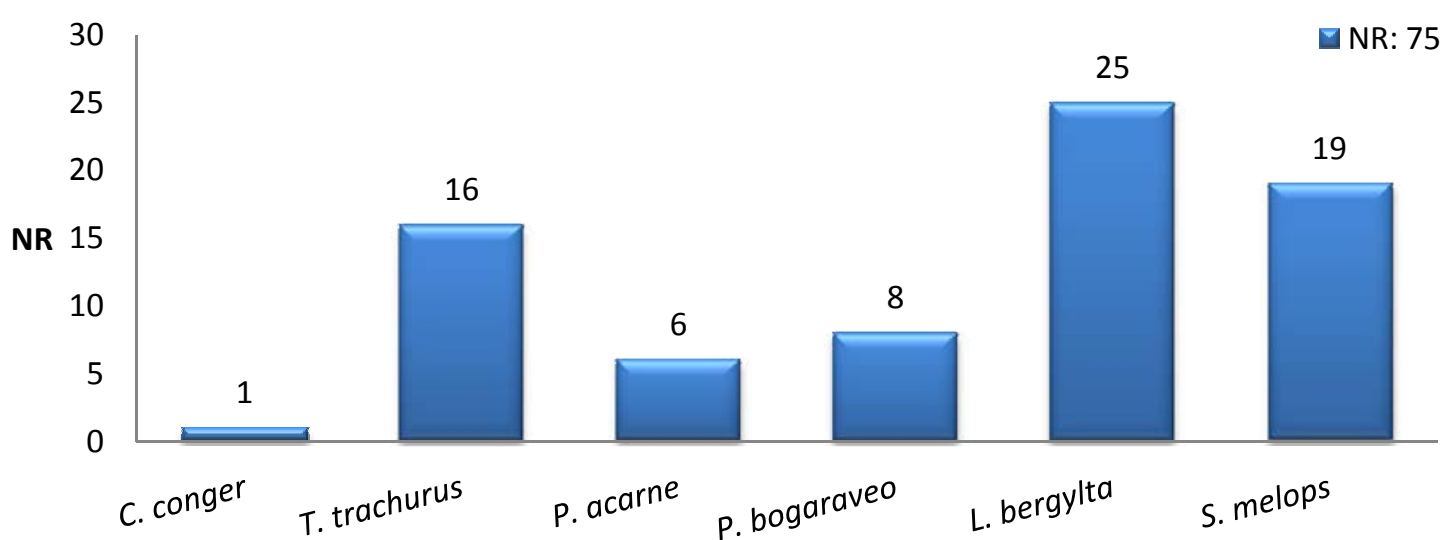

Fig. 183 Distribución de taxones identificados en MU100827B04 según el NR.

Esta muestra no es la que presenta más especies identificadas, aún cuando es la que cuenta con más restos. Tres serían los taxones que están mejor representados, dos lábridos (Labrus bergylta y Symphodus melops), y un carangido, (Trachurus trachurus). El segundo de los grupos estaría formado por Pagellus acarne y Pagellus bogaraveo. Por último, el tercer grupo estaría formado por un único resto de Conger conger.

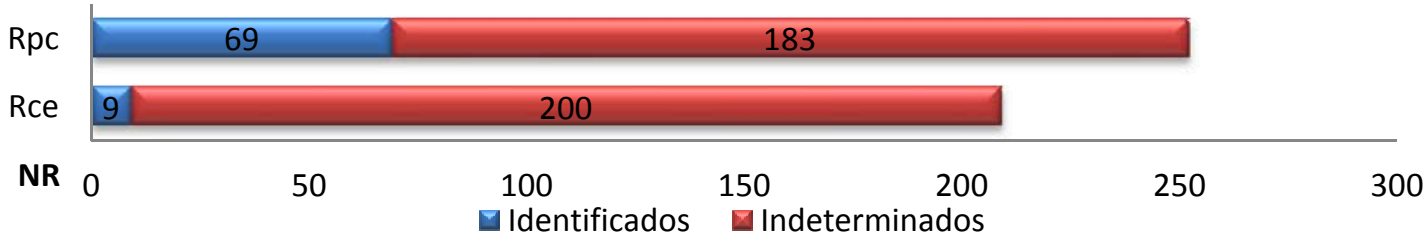

Fig. 184 Distribución esquelética de los restos ícticos de MU100827B04.

En cuanto a las piezas óseas identificadas, son una gran mayoría las post-cefálicas; sin embargo, entre los restos indeterminados hay mayor número de cefálicos. Respecto al cómputo global, es mayor el volumen de restos post-cefálicos que cefálicos. Como en muestras anteriores, es destacable las pocas escamas recuperadas.

V.5.4.8.2. MU100827B07

\begin{tabular}{|c|c|c|c|c|c|c|c|c|c|c|c|c|c|}
\hline & $\begin{array}{c}\text { Max } \\
(\mathrm{D} / \mathrm{S})\end{array}$ & Cbr & $\begin{array}{l}\text { Hmd } \\
(\mathrm{D} / \mathrm{S})\end{array}$ & $\begin{array}{c}\mathrm{Pal} \\
\text { (D/S) }\end{array}$ & $\begin{array}{c}\text { Eph } \\
\text { (D/S) }\end{array}$ & Vpc & Atl & Vca & Rce & $\mathrm{Rpc}$ & Esa & NR & NMI \\
\hline Trachurus trachurus & & & & & & & & 5 & & & & 5 & 1 \\
\hline Pagrus pagrus & $1 / 0$ & & & & & & & & & & & 1 & 1 \\
\hline Pagellus acarne & & & & $1 / 0$ & & & & 5 & & & & 6 & 1 \\
\hline Pagellus bogaraveo & & & & & $0 / 1$ & 4 & 1 & 7 & & & & 13 & 1 \\
\hline Labrus bergylta & & & $1 / 1$ & & $1 / 0$ & 6 & 2 & 7 & & & & 18 & 2 \\
\hline Symphodus melops & & 2 & & & $1 / 0$ & 9 & & 15 & & & & 27 & 2 \\
\hline Scomber japonicus & & & & & & & & 3 & & & & 3 & 1 \\
\hline Indeterminado & & & $1 / 0$ & & & & & & 202 & 153 & 6 & 362 & \\
\hline TOTAL & 1 & 2 & 3 & 1 & 3 & 19 & 3 & 42 & 202 & 153 & 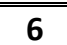 & 4335 & \\
\hline
\end{tabular}




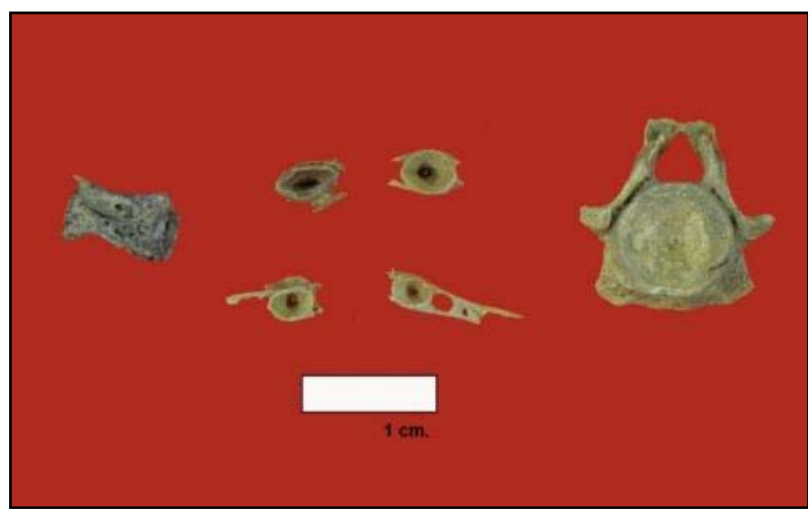

Fig. 185 Vértebras con marcas de corte y aplastamiento.
Esta es la segunda muestra con mayor número de restos. La especie que presenta más piezas identificadas es Symphodus melops, con dos ceratobranquiales, un epihial derecho, nueve vértebras precaudales, una de ellas aplastada, y 15 caudales, también una de ellas aplastada. La siguiente especie en número de restos recuperados es Labrus bergylta con un hiomandibular derecho y otro izquierdo, un epihial derecho, seis vértebras precaudales (una de ellas con marcas de corte), un atlas y siete caudales. Pagellus bogaraveo está representada por un epihial izquierdo, cuatro vértebras precaudales, una de ellas aplastada, un atlas y siete vértebras caudales, también una aplastada. Asimismo se han recuperado varios restos de Pagellus acarne: un palatino derecho y cinco vértebras caudales, una de ellas aplastada. De Trachurus trachurus se recuperaron cinco vértebras caudales, una de ellas aplastada. Por último, se han identificado tres vértebras caudales de Scomber japonicus, dos de ellas aplastadas, y un maxilar derecho de Pagrus pagrus.

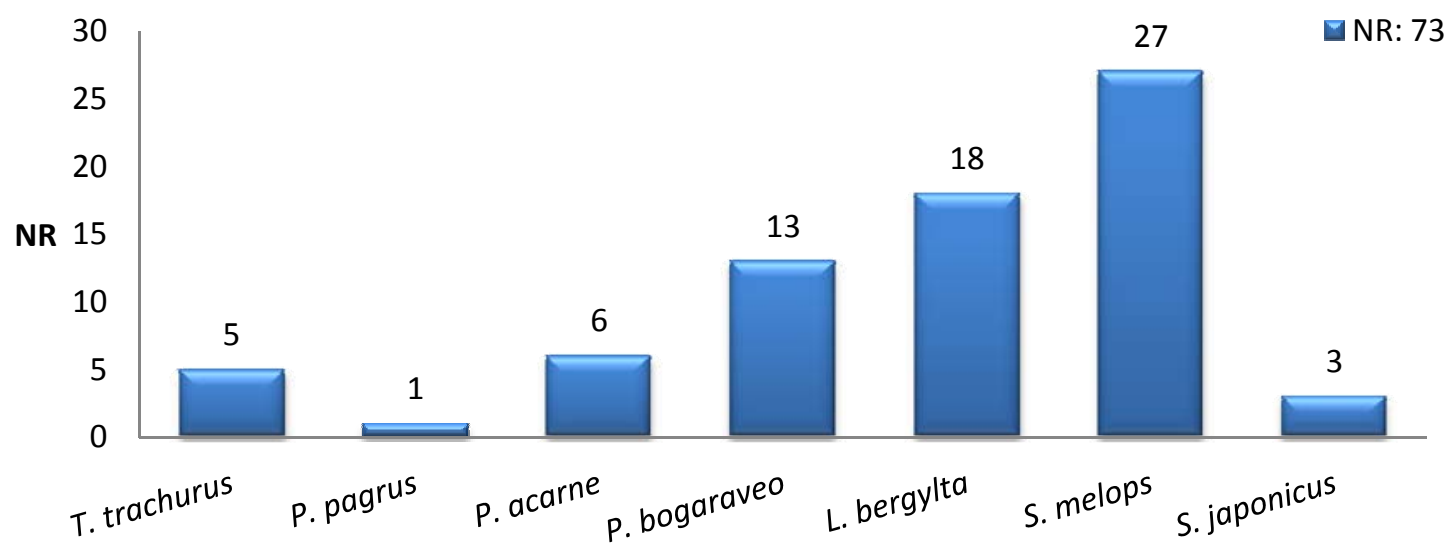

Fig. 186 Distribución de taxones identificados en MU100827B07 según el NR.

En el grupo de las especies principales o con mayor número de restos identificados, se encuentran Symphodus melops, que es la más abundante, seguida de Labrus bergylta y Pagellus bogaraveo. El segundo grupo está formado por dos especies, Trachurus trachurus y Pagellus acarne, la primera de ellas pelágica, mientras que la segunda sería demersal. Por último Scomber japonicus y Pagrus pagrus, esta última con un único resto. 


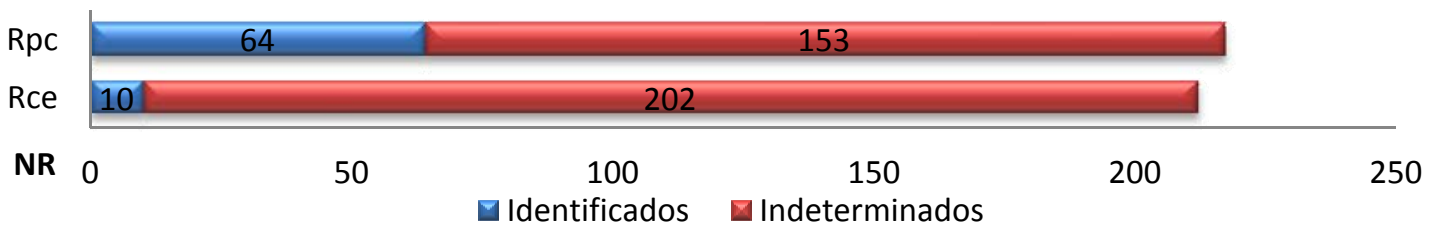

Fig. 187 Distribución esquelética de los restos ícticos de MU100827B07.

Como sucedía en la muestra anterior, predominan los restos post-cefálicos entre las piezas identificadas anatómicamente y en el cómputo global, aunque van a ser más los restos cefálicos indeterminados. Respecto a la presencia de escamas es válido lo apuntado para la muestra anterior.

\section{V.5.5. COMENTARIO.}

\section{V.5.5.1. FASE II dE LA CULTURA CASTREÑa.}

Los restos de peces más antiguos son los pertenecientes a la UE183, que correspondería a los siglos V-III a.C., coincidiendo cronológicamente con los datos publicados por Ferré (2003), y que proceden del sector exterior. En esta muestra únicamente se ha identificado una vértebra precaudal de Symphodus melops, así como algunos restos cefálicos, post-cefálicos y escamas indeterminados. Si bien esta especie no fue documentada en los análisis anteriores, presenta unas características similares a algunas especies identificadas en el citado estudio, como Labrus bergylta. Además, Symphodus melops va a ser muy numerosa en las muestras del siglo II a.C. Los escuetos datos con los que contamos de nuestro análisis nos impiden realizar una valoración de la explotación pesquera en este periodo, por lo que se comentará más adelante con los resultados derivados de estudios anteriores.

\section{V.5.5.2. FASE III DE la CULTURA CASTREÑa.}

\section{Representación faunística.}

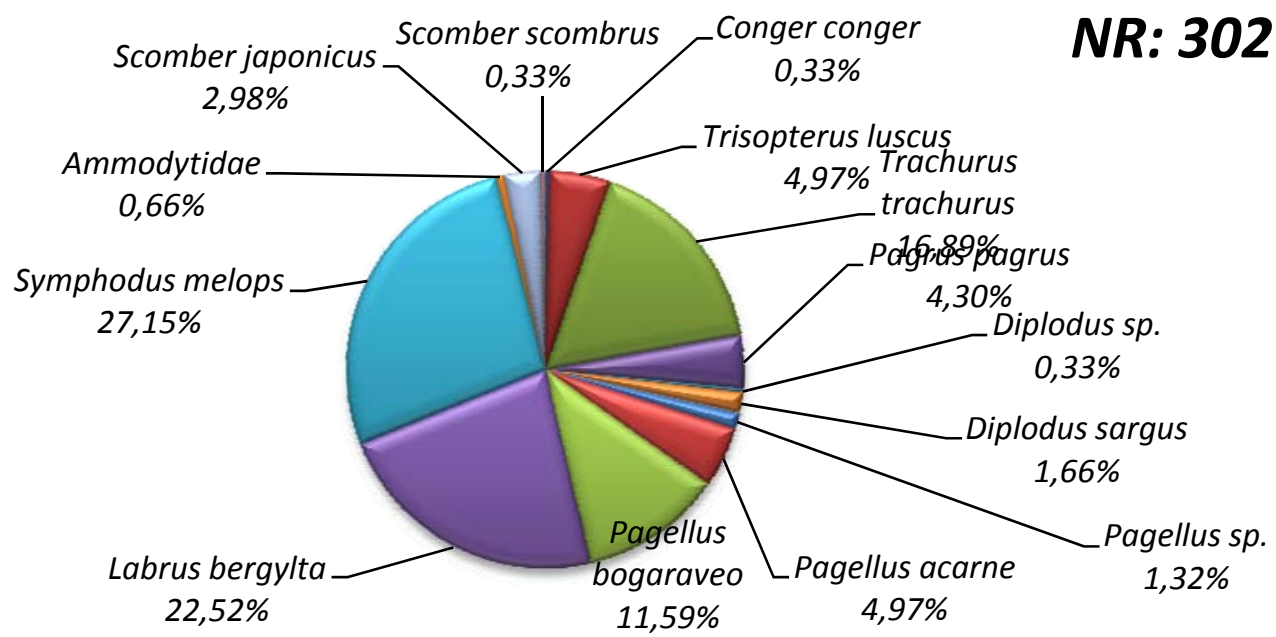

Fig. 188 Representatividad de los taxones según el NR. 


\begin{tabular}{l|c|c|c} 
& IC & ID & ICxID \\
\hline Conger conger & 11,1 & 0,3 & 3,3 \\
Trisopterus luscus & 66,7 & 5 & 333,5 \\
Trachurus trachurus & 77,8 & 16,9 & 1314,8 \\
Pagrus pagrus & 55,6 & 4,3 & 139,1 \\
Diplodus sp. & 11,1 & 0,3 & 3,33 \\
Diplodus sargus & 44,4 & 1,7 & 75,5 \\
Pagellus sp. & 33,3 & 1,3 & 43,3 \\
Pagellus acarne & 55,6 & 5 & 278 \\
Pagellus bogaraveo & 66,7 & 11,6 & 773,7 \\
Labrus bergylta & 77,8 & 22,5 & 1750,5 \\
Symphodus melops & 88,9 & 27,2 & 2418,1 \\
Ammodytidae & 11,1 & 0,7 & 7,8 \\
Scomber japonicus & 55,6 & 3 & 166,8 \\
Scomber scombrus & 11,1 & 0,3 & 3,3
\end{tabular}

Tabla 132 Índices de valoración.

Este conjunto está formado por nueve muestras pertenecientes a tres unidades estratigráficas: $078,152,184$. Debido a su coincidencia cronológica (a falta de dataciones más precisas), y las diferencias compositivas entre muestras, se ha decidido no agregarlas por unidad sino por periodo. Según parece, todas estas muestras se encuadran en el siglo II a.C., estando además asociadas a la colmatación de una gran estructura productiva con diversas piletas, que se ha relacionado con una industria salazonera (Rodríguez Martínez et alii, 2010). Según el número de restos identificados, podemos diferenciar un amplio abanico de especies con diferente representación:

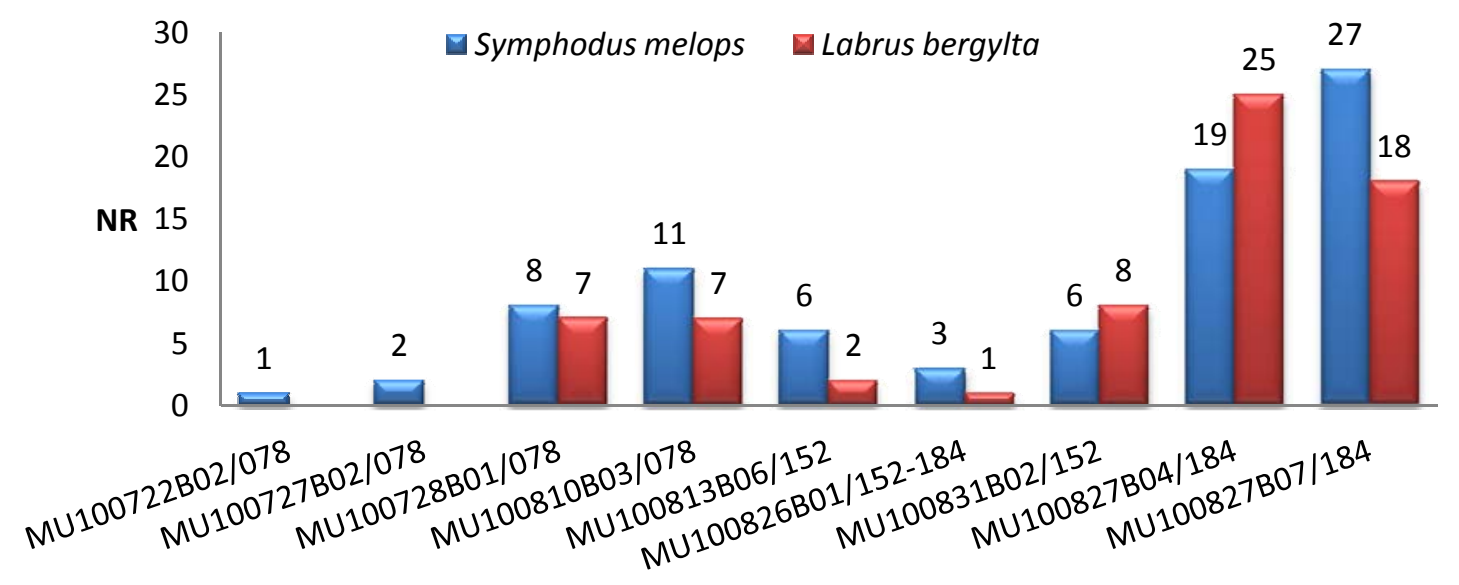

Fig. 189 Distribución del NR de Symphodus melops y Labrus bergylta en las diferentes muestras.

-Especies principales: Las especies que presentan un mayor número de restos pertenecen a la familia de los lábridos: Symphodus melops y Labrus bergylta. Además de suponer la mitad de los restos, van a aparecer representadas en casi todas las muestras, por lo que queda patente su importancia. Las dos especies son demersales, habitando en zonas rocosas. Son especies sedentarias y muy territoriales. Estas características podrían explicar la importancia que presentan, ya 
que son un recurso que se encontraría en las cercanías del yacimiento, además de no estar sujeto a variaciones migracionales y estacionales. Su captura se realizaría mediante las diferentes modalidades de pesca con anzuelo, aunque no se descarta la utilización de aparejos pasivos.

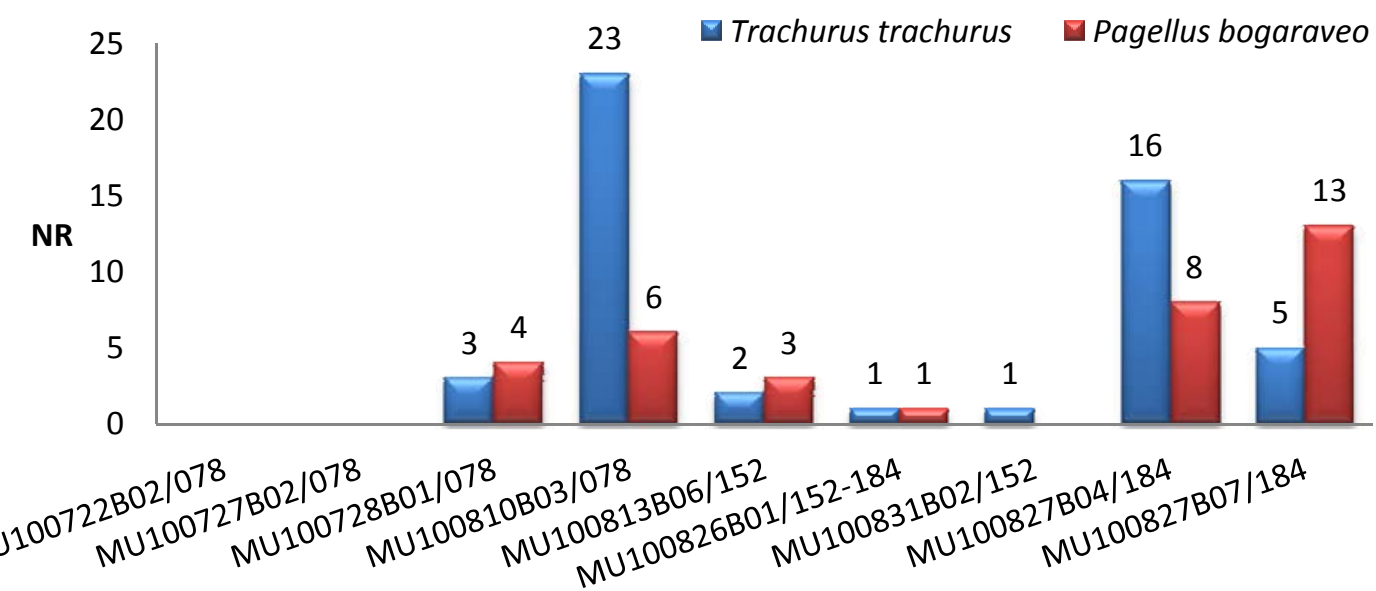

Fig. 190 Distribución del NR de Trachurus trachurus y Pagellus bogaraveo en las diferentes muestras.

-Especies secundarias: Con menos importancia encontramos dos especies de un marcado carácter estacional, siendo una de ellas pelágica (Trachurus trachurus) y la otra demersal (Pagellus bogaraveo). Ambas especies se acercan a la costa entre la primavera y el verano, descendiendo durante el invierno a profundidades inferiores a los $100 \mathrm{~m}$. Por lo tanto, su pesca estaría limitada a ciertas épocas del año, lo que también podría explicar este carácter secundario. Estas especies aparecen en más de la mitad de las muestras, lo que también es sintomático de su importancia. En el caso de Trachurus trachurus, observamos que sus máximos se centran en dos muestras, en las que resulta la especie mayoritaria (MU100810B03; MU100827B04). Este modelo refleja su condición de recurso estacional, con pescas abundantes en momentos puntuales.

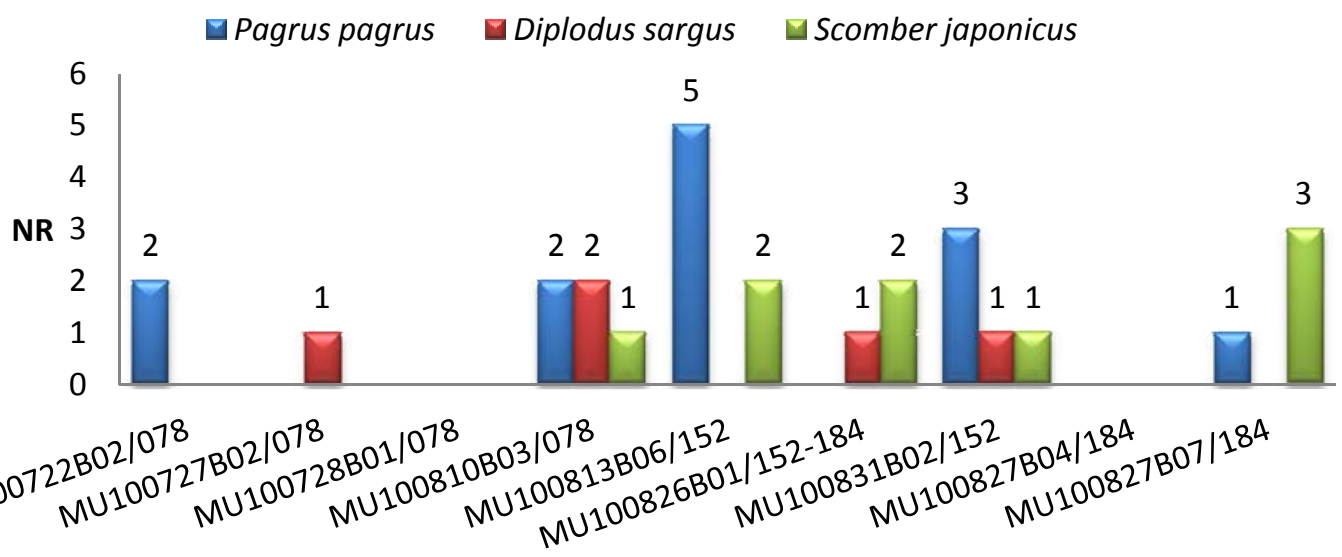

Fig. 191 Distribución del NR de Pagrus pagrus, Diplodus sargus y Scomber japonicus en las diferentes muestras. 
-Especies complementarias: En esta categoría se incluyen un amplio grupo de taxones con una representatividad inferior al $5 \%$. La familia que presenta mayor número de especies y de restos es la de los espáridos (Pagellus acarne, Pagrus pagrus, Diplodus sargus), seguida de los gádidos (Trisopterus luscus) y los escómbridos (Scomber japonicus). Exceptuando esta última, que es pelágica, las demás especies son todas demersales, pudiendo encontrarse en zonas arenosas o de cascajo, por lo que su captura se realizaría en las inmediaciones del yacimiento.

Aunque la distribución de especies es muy variable, cada una de ellas está presente al menos en la mitad de las muestras. En el caso de Scomber japonicus, su presencia únicamente se detecta cuando aparece Trachurus trachurus, alcanzando sus valores máximos en las muestras con menos restos de esta segunda especie. Del mismo modo, las muestras donde aparece Trachurus trachurus, son las que mayor variedad de especies presentan. Trisopterus luscus será la especie mejor representada en la muestra MU100826B01, coincidiendo con los mínimos de las especies principales y secundarias. Los máximos de Pagellus acarne van a coincidir con los máximos detectados en Pagellus bogaraveo. Todo esto puede estar reflejando una intensificación de la actividad pesquera en primavera y verano. Especies como Pagellus acarne, Scomber japonicus o Pagrus pagrus, son migradoras, acercándose a la costa en diferentes momentos del año coincidiendo con el periodo reproductivo. Por lo tanto es posible que estas variaciones estén sujetas a la mayor presencia de unas u otras especies según el periodo estacional. Su captura puede realizarse mediante la pesca con anzuelo en sus diferentes variantes, aunque especies como Scomber japonicus suelen ser pescadas con redes.

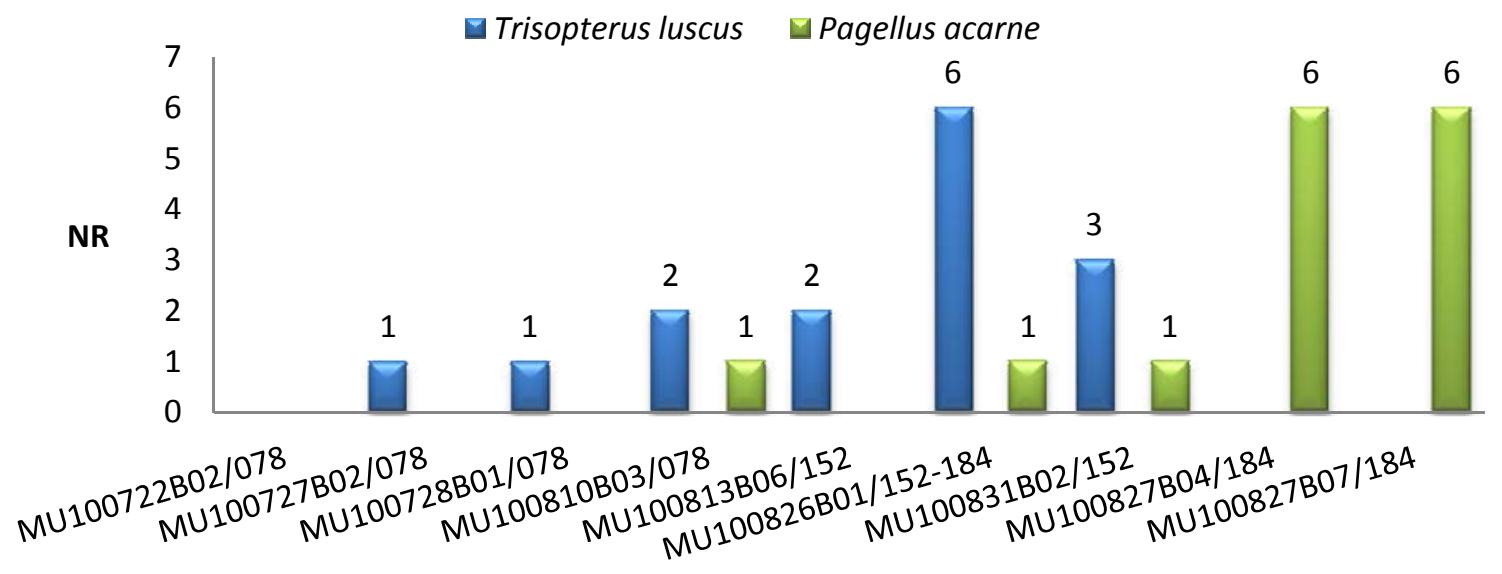

Fig. 192 Distribución del NR de Trisopterus luscus y Pagellus acarne en las diferentes muestras.

-Especies minoritarias: En este grupo incluimos a aquellas especies que tienen una representatividad inferior al 1\%. Estaría formado por Scomber scombrus, Conger conger y por la Familia Ammodytidae. Encontramos representadas una especie pelágica, una demersal y una bentónica. La presencia de Scomber scombrus 
puede deberse a una captura vinculada a la pesca de Scomber japonicus, ya que son especies con unas características similares. En cuanto a Conger conger, su escaso número presenta mayores problemas, ya que en las muestras estudiadas por Ferré (2003) era la especie mejor representada. Por último, la Familia Ammodytidae está formada por diversas especies que viven enterradas en el sustrato arenoso, pudiendo deberse su captura a la realización de actividades de marisqueo.

La totalidad de las especies son susceptibles de haber servido como alimento. Mayores dudas pueden suscitar las dos vértebras de la Familia Ammodytidae, ya que su captura puede no ser intencional y estar relacionada con las actividades de marisqueo realizadas en la playa. Además, es la primera vez que se identifica esta familia en yacimientos gallegos, por lo que podrían ser especies o bien difíciles de capturar o bien poco apreciadas para su consumo. Pese a esto tampoco se podría descartar ni su aprovechamiento alimenticio, ni su utilización como cebo.

\section{Representatividad ósea.}

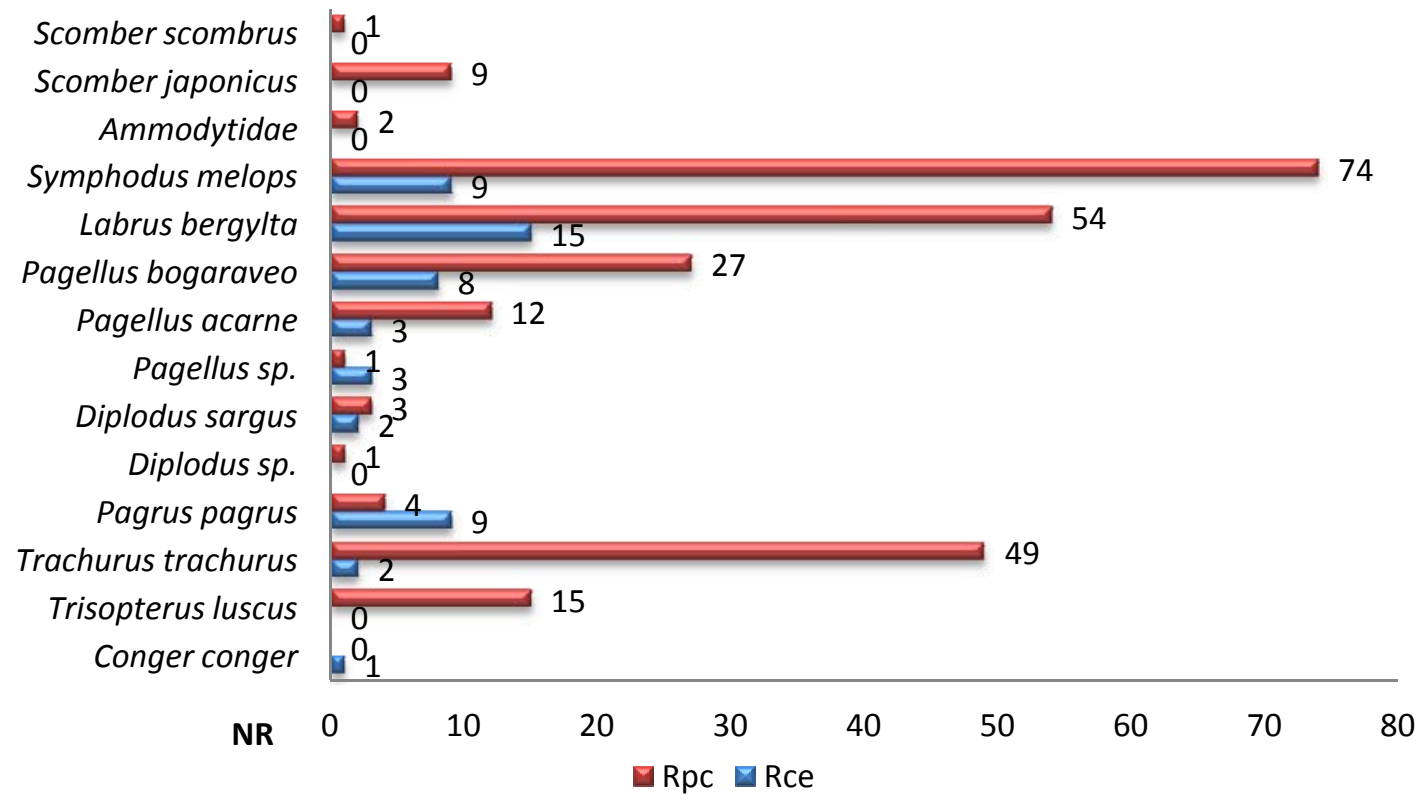

Fig. 193 Comparación numérica de los restos cefálicos y post-cefálicos de los diferentes taxones identificados.

La mayoría de los restos, tanto identificados como indeterminados, corresponden a huesos post-cefálicos. Los únicos casos en que es mayor el número de restos cefálicos son en Pagrus pagrus y Conger conger, pudiendo vincularse a diferencias de osificación. Por otro lado, los escómbridos y Trisopterus luscus no presentan restos cefálicos. En este caso, carecemos de más datos que nos puedan indicar si reflejan tratamientos del pescado o es un problema relacionado con la representatividad de las muestras. El número de escamas es muy bajo, no siendo así el número de restos indeterminados, por todo ello, es posible que el desescamado se estuviera realizando en otra zona distinta del yacimiento. 


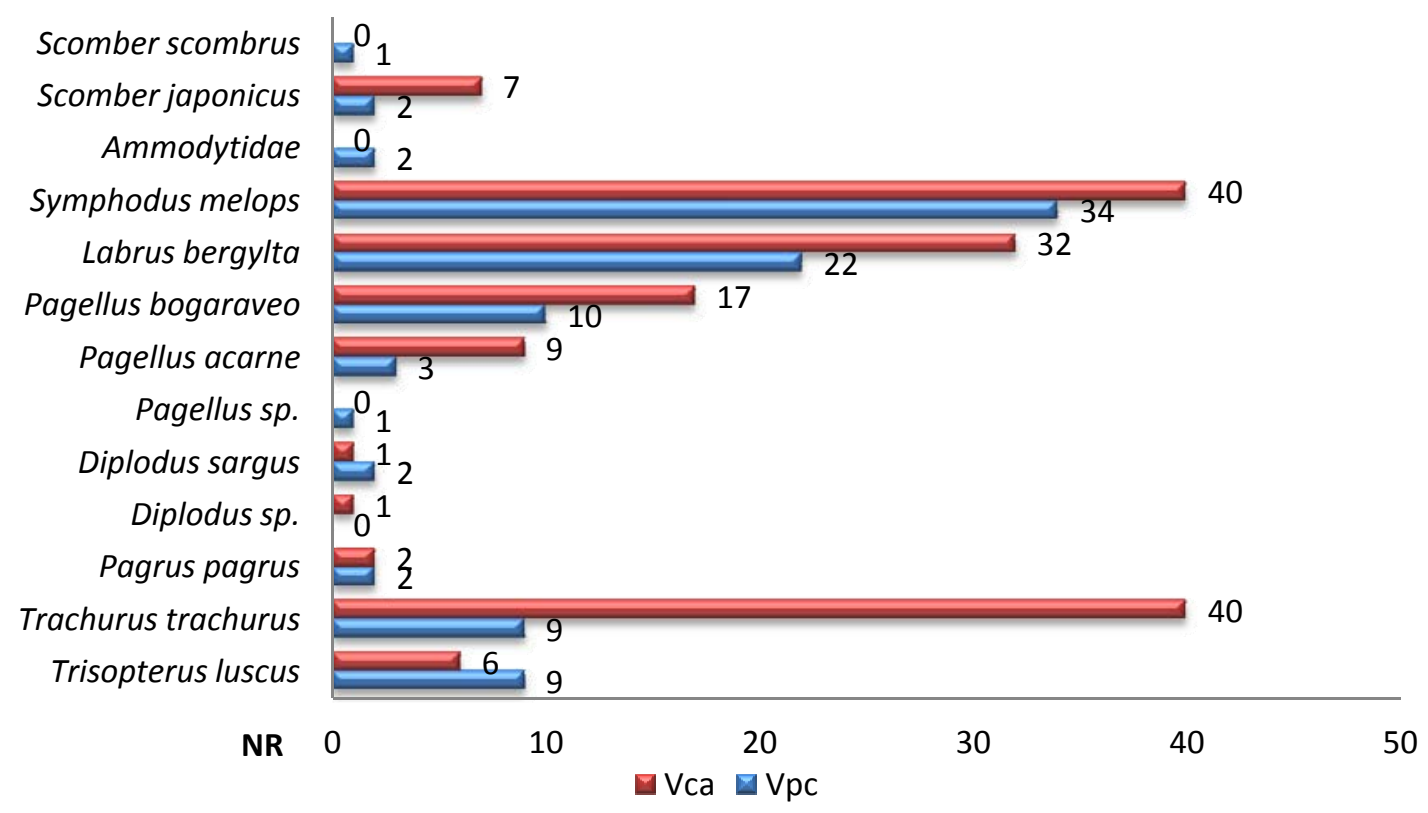

Fig. 194 Comparación numérica de las vértebras caudales y precaudales de los diferentes taxones identificados.

En cuanto a los centros vertebrales, predominan los caudales en casi todas las especies, aunque los precaudales están bien representados. Por este motivo no observamos ningún elemento que nos sugiera un procesado del pescado mediante el que se separasen las vértebras del cuerpo de las caudales o de la cabeza. Lo que sin embargo no descartaría otras actividades como el fileteado.

\section{V.5.5.3. ÉPOCA ROMANA.}

De época romana únicamente contamos con las muestras procedentes de la UE065 y de la UE115. La muestra de la primera de estas unidades correspondería a los siglos I a.C.-I d.C., presentando únicamente una vértebra caudal de Labrus bergylta, además de varios restos indeterminados: cinco restos cefálicos, 19 post-cefálicos y seis escamas.

La UE115 está datada a finales del siglo I d.C.-principios del siglo II d.C., y de ella proceden dos vértebras precaudales de Sardina pilchardus así como una vértebra caudal, tres restos cefálicos y seis post-cefálicos indeterminados.

Es complicado realizar una valoración de la pesca en época romana con tan exiguo registro. Labrus bergylta fue ya identificada por Vázquez Varela $(1976 ; 1978 ; 1984)$ para las fases romanas del yacimiento, y como veíamos es una especie común en la explotación del asentamiento desde épocas antiguas. Es significativa la presencia de Sardina pilchardus, ya que no ha sido identificada en periodos anteriores de ocupación del yacimiento. 


\section{V.5.6. OTROS ANÁLISIS.}

\section{Estudio Ictiológico.}

Los primeros estudios de ictiofauna de este yacimiento los realizó Vázquez Varela (1976; 1978; 1984), con materiales procedentes de las excavaciones realizadas a comienzos de la década de 1970. Las muestras fueron recogidas de un perfil de las excavaciones del Museo de Pontevedra, donde se documentaron 12 estratos (desde periodos muy tempranos de la Cultura Castreña, hasta momentos avanzados de la romanización). Sin embargo, en la presentación de los resultados del análisis, se van a unificar todas las muestras en dos grupos (niveles prerromanos y niveles romanos), sin especificar su marco cronológico concreto. Tampoco se indica el número de restos pertenecientes a cada especie.

\begin{tabular}{|c|c|c|c|c|c|c|}
\hline & \multicolumn{4}{|c|}{ Vázquez Varela } & \multirow{3}{*}{$\begin{array}{l}\text { Camino et alii } \\
\qquad 1991 \text { (NR) } \\
\text { V a.C.-V d.C. }\end{array}$} & \multirow{3}{*}{$\begin{array}{l}\text { Vázquez Varela et alii } \\
\qquad 1993 \text { (NMI) } \\
\text { V a.C.-V d.C. }\end{array}$} \\
\hline & \multicolumn{2}{|c|}{ 1976/1978 } & \multicolumn{2}{|c|}{1984} & & \\
\hline & Castreño & Romano & Castreño & Romano & & \\
\hline C. conger & & & & & & 1 \\
\hline Gadidae sp. & & & & & & 2 \\
\hline M. merluccius & $*$ & & $*$ & & & 1 \\
\hline A. regius & & & & & & 1 \\
\hline D. labrax & & $*$ & & $*$ & & 1 \\
\hline T. trachurus & $*$ & & $*$ & & & 1 \\
\hline Sparidae sp. & & & & & $1 \operatorname{Art}(d)$ & \\
\hline D. vulgaris & & & & & & 1 \\
\hline S. aurata & $*$ & $*$ & $*$ & $*$ & & \\
\hline P. pagrus & & & $*$ & & $\begin{array}{l}2 \operatorname{Pmx}(\mathrm{s}) \\
1 \mathrm{Pmx}(\mathrm{d})\end{array}$ & 4 \\
\hline P. acarne & & & & & & 1 \\
\hline L. bergy/ta & $*$ & $*$ & $*$ & $*$ & $\begin{array}{c}2 \mathrm{Fbr} ; 2 \mathrm{Hmd} \\
(\mathrm{s}) ; \\
1 \mathrm{Pvm}\end{array}$ & 6 \\
\hline S. melops & $*$ & & $*$ & & & \\
\hline S. scombrus & & & & & & 1 \\
\hline Motella sp. & & & $*$ & & & \\
\hline Indeterminado & & & & & 26 & \\
\hline
\end{tabular}

Tabla 133 Cuadro comparativo de los primeros estudios realizados sobre ictiofauna de A Lanzada.

A principios de los años 90, Vázquez Varela publica junto con M. Camino y J.M. Rey nuevos datos de A Lanzada (Camino López et alii, 1991; Vázquez Varela et alii, 1993), si bien no conocemos ni la procedencia concreta de los materiales ni la campaña a la que corresponden, aunque les atribuye una cronología entre el siglo $V$ a.C. al V. d.C.

El estudio más completo con el que contamos es el realizado por Ferré (2003), con una cronología para los restos comprendida entre los siglos V-III a.C. Los materiales 
estudiados proceden de la campaña de excavación realizada en 1977 y 1978 en el sector exterior.

En este conjunto predominan los centros vertebrales frente a los restos cefálicos, excepto en Pagrus pagrus, con valores similares y siendo la especie más numerosa. El conjunto lo forman cuatro especies y varios restos identificados a únicamente a nivel de género.

\begin{tabular}{|c|c|c|c|c|c|c|c|c|c|c|c|}
\hline & $\begin{array}{l}\text { Pmx } \\
\text { (D/S) }\end{array}$ & $\begin{array}{l}\text { Max } \\
\text { (D/S) }\end{array}$ & $\begin{array}{l}\text { Dnt } \\
\text { (D/S) }\end{array}$ & $\begin{array}{l}\text { Art } \\
\text { (D/S) }\end{array}$ & $\begin{array}{l}\text { Hmd } \\
\text { (D/S) }\end{array}$ & Pvm & Cbr & Vpc & Vca & NR & NMI \\
\hline C.conger & & & & & & & & 3 & 4 & 7 & 1 \\
\hline M. merluccius & & & & & & & & 1 & & 1 & 1 \\
\hline Gadidae sp. & & & & & & & & 1 & & 1 & 1 \\
\hline P. pagrus & $1 / 4$ & & & $0 / 1$ & $1 / 1$ & & & 1 & 6 & 15 & 4 \\
\hline Sparidae sp. & & & $0 / 1$ & & & & & & & 1 & 1 \\
\hline L. bergy/ta & & & & & & & 3 & 3 & 3 & 9 & 1 \\
\hline Indeterminados & & $0 / 1$ & & & $0 / 1$ & 1 & & 4 & 1 & 8 & 1 \\
\hline TOTAL & 5 & 1 & 1 & 1 & 3 & 1 & 3 & 13 & 14 & 42 & \\
\hline
\end{tabular}

Tabla 134 Relación de especies y representación ósea del Sector exterior de A Lanzada (Datos tomados de Ferré, 2003).

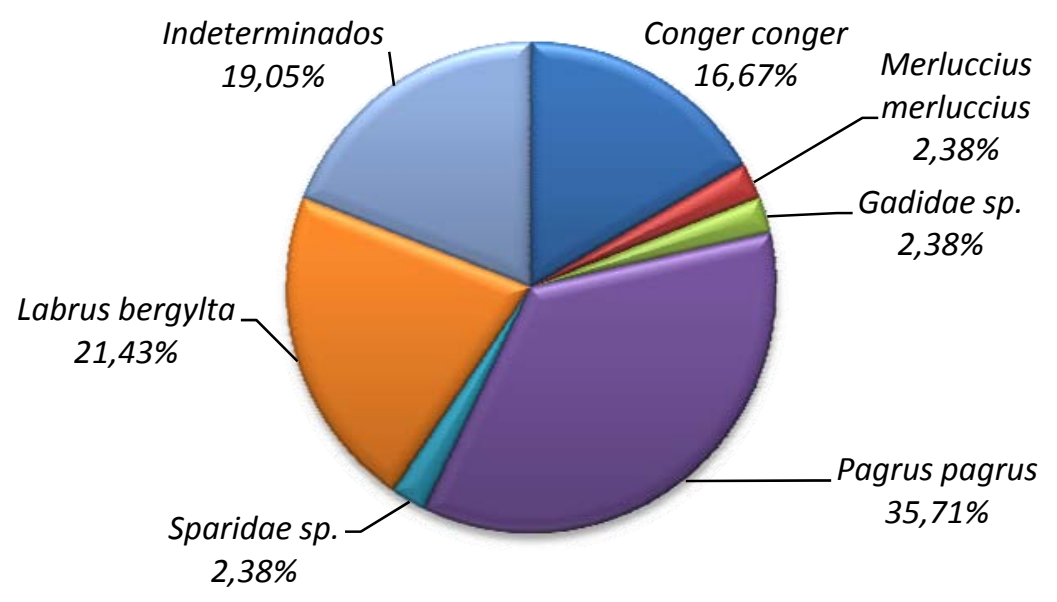

NR: 42

Fig. 195 Representatividad de los taxones según el NR.

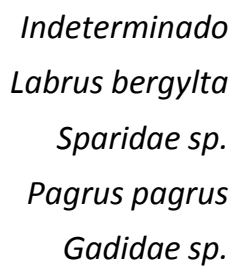

Merluccius merluccius

Conger conger

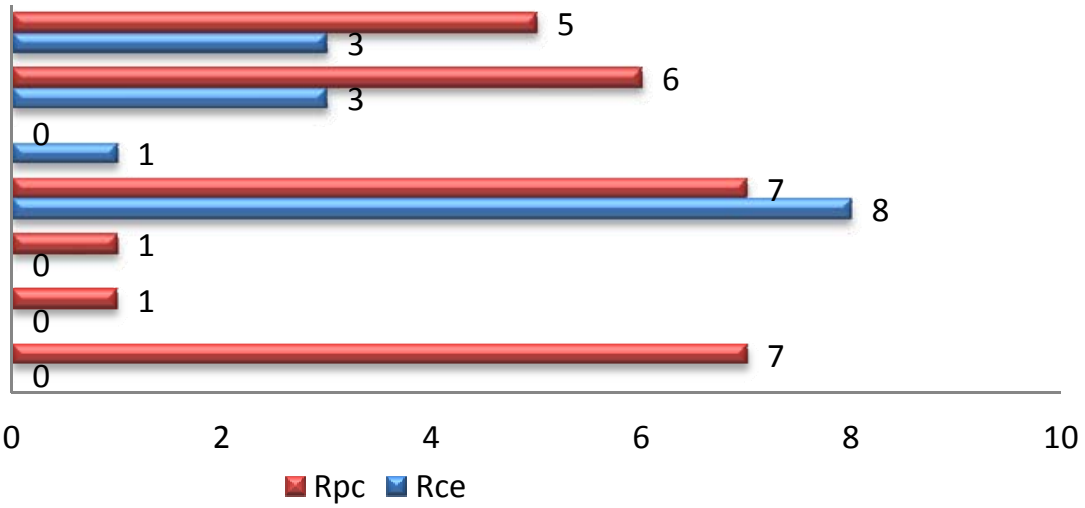

Fig. 196 Comparación numérica de los restos cefálicos y post-cefálicos de los taxones identificados. 


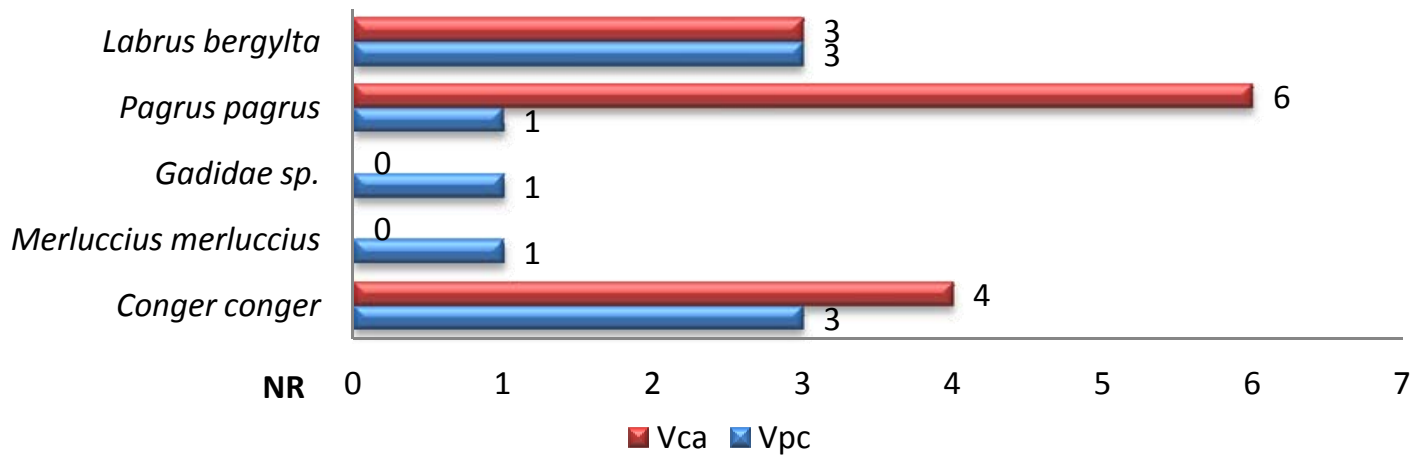

Fig. 197 Comparación numérica de las vértebras caudales y precaudales de los taxones identificados.

\section{V.5.7. CONSIDERACIONES FINALES.}

Del asentamiento de A Lanzada contamos con dos conjuntos bien diferenciados, tanto cronológicamente como en su localización. El conjunto más antiguo correspondería al sector exterior, adscribiéndose a la Fase II de la Cultura Castreña, entre los siglos V y III a.C. En esta muestra se recuperaron un pequeño grupo de especies con pocos restos. Todas las especies son demersales, más o menos sedentarias, y propias de zonas de roca o cascajo. Además, predomina el pescado blanco.

Sin embargo, en las muestras de O Campo, pertenecientes al siglo II a.C., el panorama es muy diferente. Dentro de la Fase III se amplía el abanico de especies, cobrando gran importancia las especies pelágicas, alcanzando el pescado azul y semigraso valores similares al del pescado blanco. Las especies migradoras van a suponer un recurso muy importante, lo que estaría relacionado con una pesca condicionada fuertemente por la estacionalidad. Si en las muestras de la Fase II Pagrus pagrus era la especie mejor representada seguida de Conger conger y Labrus bergylta, desde el siglo II a.C. únicamente esta última va a seguir siendo una de las especies principales, las otras dos pasarán a formar parte de los recursos complementarios o minoritarios.

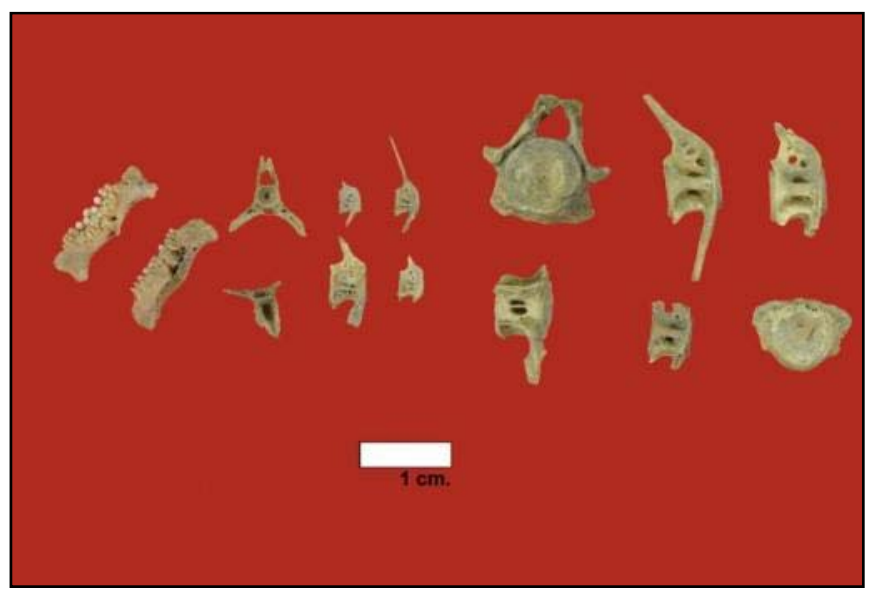

Fig. 198 Restos óseos de Symphodus melops y Labrus bergylta.
Ante la importancia de los lábridos en ambos conjuntos, llama la atención la no aparición de Symphodus melops en las muestras del sector exterior. Sin embargo, la presencia de esta especie las muestras de las últimas intervenciones puede indicar que su ausencia se deba a otros factores que no se corresponden directamente con la práctica de su captura, como puede ser una recogida poco minuciosa de las muestras, 
factores estacionales, etc...

Como veíamos en las muestras de O Campo, entre las piezas óseas de Pagrus pagrus predominan las cefálicas, principalmente de la boca, lo que seguramente está reflejando una cuestión de preservación de los restos.

Todas estas especies serían pescadas con anzuelo, trampas, etc... desde la costa o con pequeñas embarcaciones, respondiendo a una explotación enfocada al autoconsumo. En las excavaciones antiguas se recuperó un anzuelo de $45 \mathrm{~mm}$, que se adecuaría perfectamente a la pesca de estas especies (Vázquez Varela et alii, 1993).

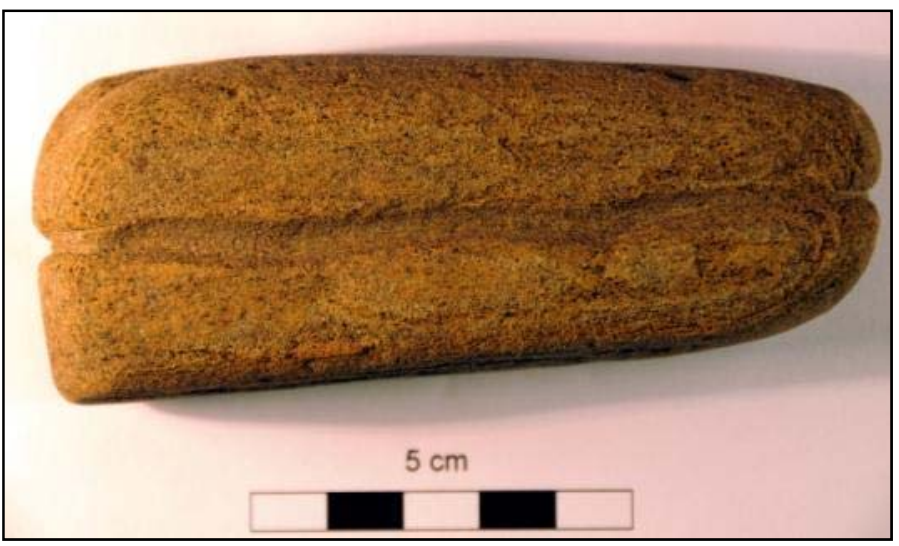

Fig. 199 Posible pesa de red recuperada en la intervención de 2010 (Rodríguez Martínez, 2010).
Entre el siglo III a.C. y el II a.C., detectamos una serie de diferencias en las especies identificadas, que nos sugieren cambios en las artes de pesca. El cambio más significativo va a ser la presencia de especies pelágicas, siendo Trachurus trachurus una de las especies mejor representadas. Su pesca suele realizarse habitualmente con artes de red, lo que supondría un cambio sustancial en relación con las técnicas empleadas en el periodo anterior.

Durante las últimas intervenciones, se recuperaron varias pesas de piedra que podrían asociarse con esta utilización de redes.

Por otro lado, también se va a ampliar el abanico de especies capturadas. Mientras que la pesca se centra principalmente en dos especies de lábridos, lo que puede ser explicado por su carácter sedentario y territorial, las especies migradoras desempeñarían un papel secundario. Este mismo modelo se ha observado en otros yacimientos del mismo periodo, como en Montealegre.

Es abundante la presencia de restos cefálicos, por lo que estarían siendo depositados ejemplares más o menos completos. La presencia de escamas es poco numerosa, quizás por un desescamado en otros puntos del yacimiento.

La aparición de una gran estructura productiva, con diversas piletas, y con una cronología del siglo II a.C., podría responder a una industria salazonera (Rodríguez Martínez et alii, 2010; 2011). El problema se nos presenta al relacionar la ictiofauna documentada con las actividades desarrolladas, ya que no apareció asociada a las cubetas vacías. Sin embargo, podemos hablar de la aparición de una serie de especies (Trachurus trachurus, Scomber scombrus, Scomber japonicus) de alto contenido graso, que serían susceptibles de ser empleadas para la elaboración de salazones. Con esta misma 


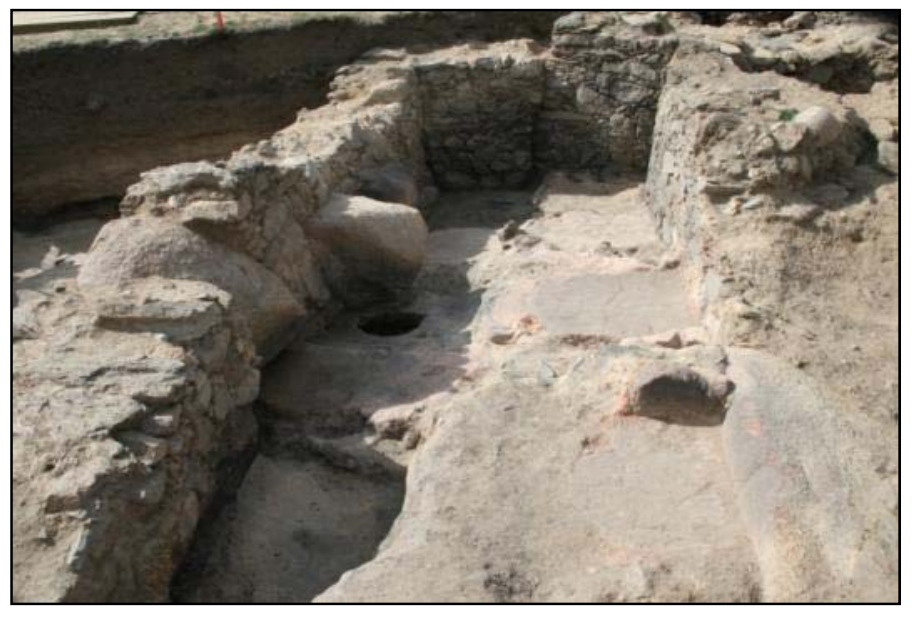

Fig. 200 Detalle de varias piletas de la estructura productiva.

cronología, en el sur peninsular se detecta una gran diversidad en las especies utilizadas, aunque van a emplearse principalmente escómbridos de talla intermedia y jureles para la realización de salazones (García Vargas, 2006; Morales Muñiz y Roselló Izquierdo, 2006; García Vargas y Bernal Casasola, 2009). Sin embargo, en nuestro caso la referida falta de asociación entre piletas y muestras analizadas complica la identificación de la actividad desarrollada, y en el supuesto de ser salsamentas, qué tipo de especies se estarían utilizando.

El resto de taxones parecen haber servido para el consumo local, sin que se aprecie ningún patrón de despiece específico que pueda indicar alguna técnica de procesado. Por lo tanto, podemos hablar de una pesca local, seguramente de subsistencia a la que se incorporan nuevas artes de pesca. Sin embargo, no podemos descartar la presencia de una pesca destinada al procesado y comercialización de derivados del pescado. Es posible que este cambio en la producción venga influenciado por el contacto con pueblos mediterráneos. 


\section{V.6. El CASTro de Montealegre.}

\section{V.6.1. LOCALIZACIÓN.}

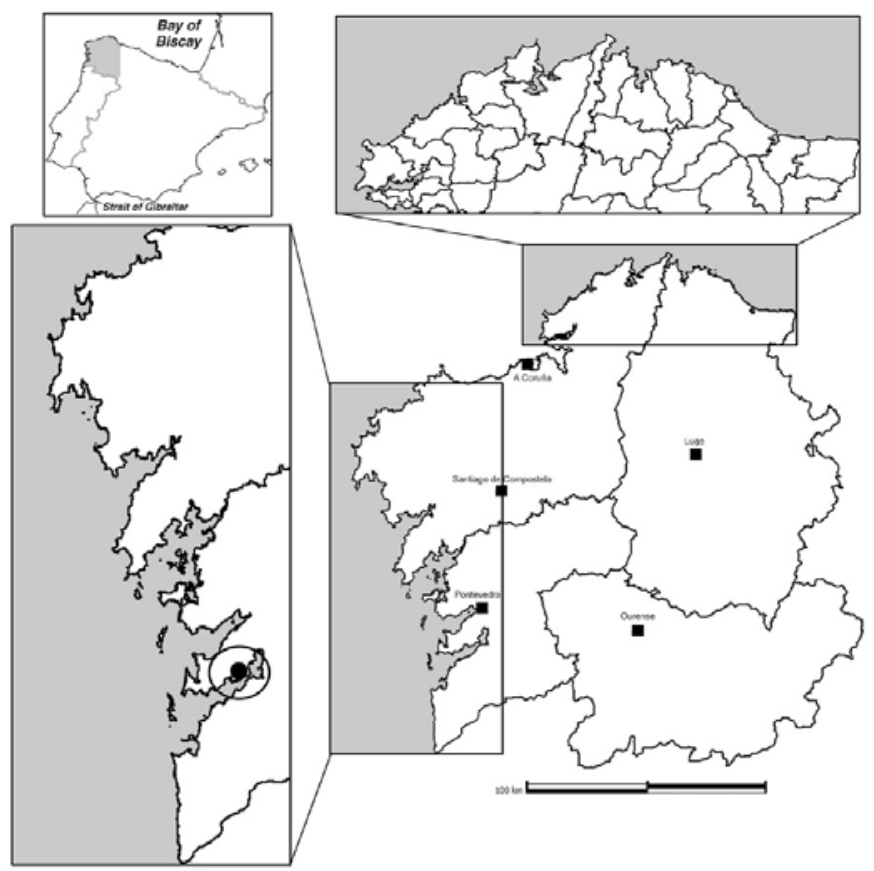

El Castro de Montealegre se localiza en Domaio, Concello de Moaña, Pontevedra. Está situado en la Península del Morrazo, en la parte más estrecha de la ría de Vigo, teniendo una gran visibilidad sobre la misma. El castro se asienta sobre un espolón de la Sierra del Morrazo, algo alejado de la línea de costa actual. Sus coordenadas geográficas son $8^{\circ} 40^{\prime} 13.59^{\prime \prime} \mathrm{W}$ y $42^{\circ} 17^{\prime} 34.98^{\prime \prime} \mathrm{N}^{6}$. Este castro lo podemos incluir dentro de los de tipo sublitoral.

Fig. 201 Localización del yacimiento de Montealegre.

\section{V.6.2. DESCRIPCIÓN DEL YACIMIENTO.}

El yacimiento se asienta sobre un espolón bastante estrecho y con mucha pendiente, por lo que el poblamiento se va a realizar en diversas terrazas desde la parte más alta del monte. Únicamente se han documentado estructuras defensivas en su ladera norte, la parte más accesible, aunque las sucesivas alteraciones de la ladera sur podrían haber dificultado su localización (Criado Boado et alii, 2003: 72; Aboal Fernández y Castro Hierro, 2006b: 91).

Las primeras intervenciones se remontan a 1925 y 1926, dirigidas por Losada Diéguez, en las que se va a documentar un gran conchero y varias estructuras circulares de piedra. Los materiales llevaron a datar el asentamiento en la II Edad del Hierro (Losada y Diéguez, 1927). Posteriormente, en 1930, se realizaría una nueva excavación en el castro, ahora dirigida por Mergelina. De esta intervención no existe ninguna publicación, quedando únicamente recogida en una documentación manuscrita de González GarciaPaz, que se encuentra depositada en el Museo de Pontevedra (Ayán Vila, 2006: 31-36).

En la década de 1970, Vázquez Varela realizó un sondeo en la ladera sur con la finalidad de llevar a cabo un estudio arqueomalacológico, cuyos resultados fueron publicados junto a los de A Peneda do Viso (Vázquez Varela, 1975).

\footnotetext{
${ }^{6}$ Datum: ETRS89; Uso: 29; UTM: X 527.168/Y 4.682.367.
} 


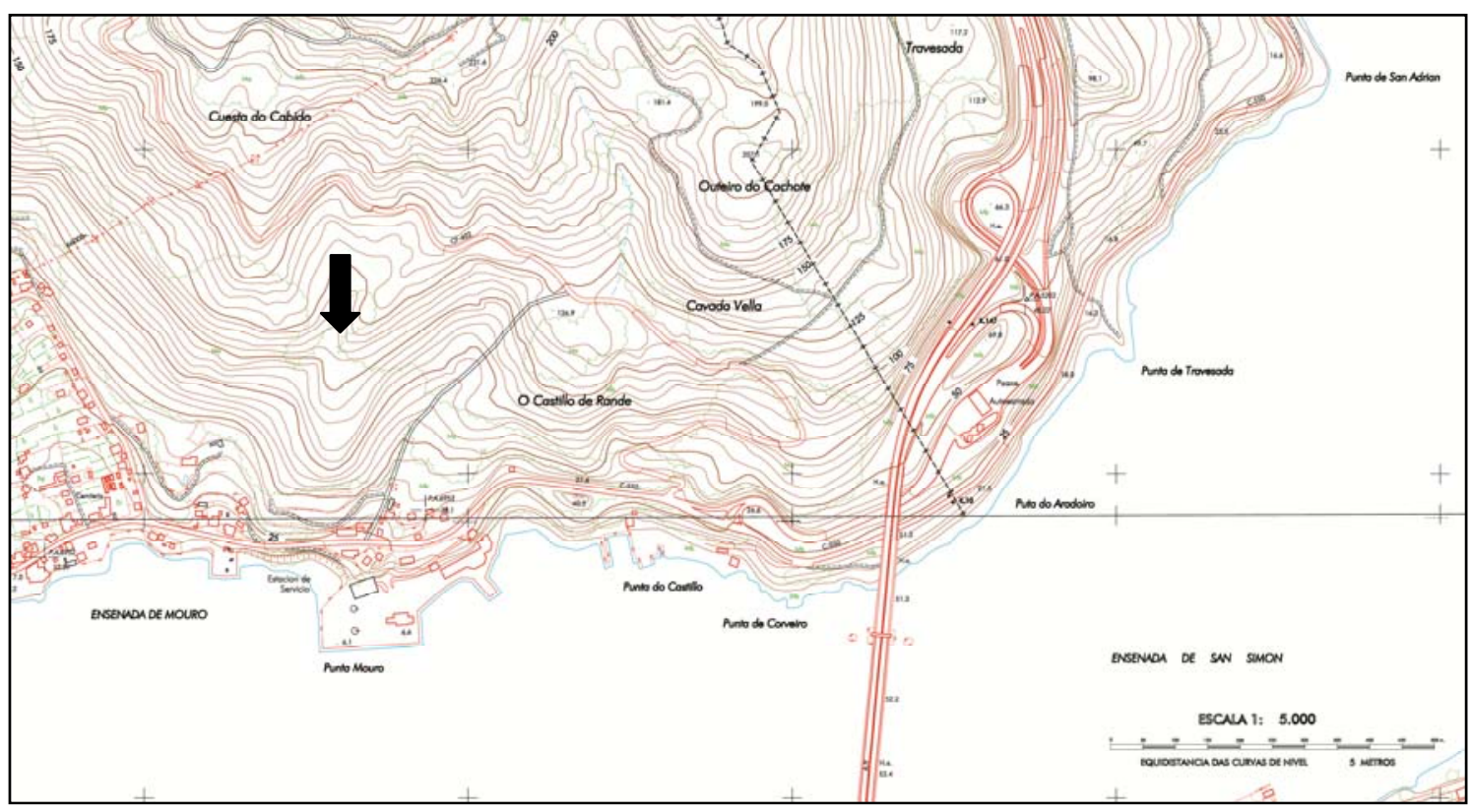

Fig. 202 Topográfico 1:5.000 de Montealegre y localización de las intervenciones. (Extraído de http://sitga.xunta.es/sitga).

No será hasta 2003 cuando se vuelvan a realizar excavaciones sistemáticas en el yacimiento, momento en el que fueron recogidas las muestras analizadas en el presente trabajo. En ese año, y con motivo de la construcción del corredor del Morrazo, se hizo

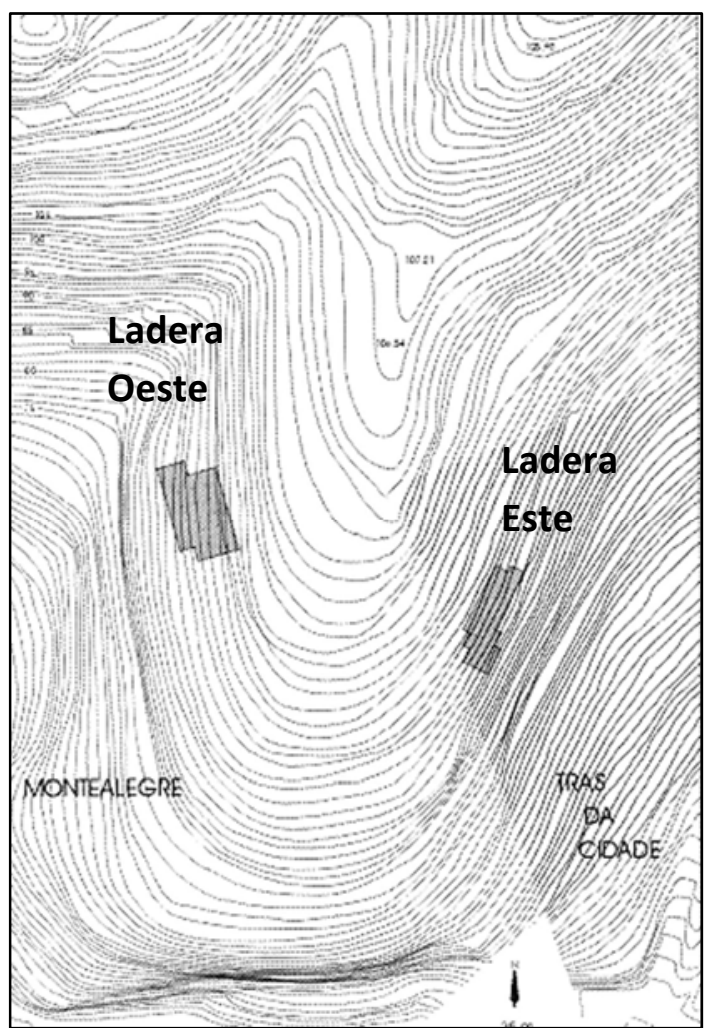

Fig. 203 Localización de las intervenciones de 2004 (Aboal Rodríguez y Castro Hierro, 2006b). necesaria la intervención arqueológica en la ladera este y en la ladera oeste de dicho espolón, afectadas por el túnel que atraviesa de lado a lado el monte donde se asienta el castro. Esta intervención fue realizada por el Laboratorio de Arqueoloxía del Paisaxe do Instituto de Estudos Galegos Padre Sarmiento, bajo la dirección de Roberto Aboal Fernández. La primera intervención se remonta a septiembre-octubre de 2003, en la que se procedió a excavar $232 \mathrm{~m}^{2}$ de la ladera oeste, así como a realizar varios sondeos en la ladera este (Aboal Rodríguez y Castro Hierro, 2006a: 81; 2006b: 93), en concreto tres con unas dimensiones de $2 \times 2 \mathrm{~m}, 5 \times 2 \mathrm{~m}$ y $2 \times 2 \mathrm{~m}$, situados de sur a norte (Aboal Rodríguez $y$ Castro Hierro, 2006b: 118).

En 2004 se intervino de nuevo en la ladera este, en una superficie de $248 \mathrm{~m}^{2}$, a escasos metros de las excavaciones realizadas 
en los años 20 por Losada Diéguez (Aboal Rodríguez y Castro Hierro, 2006a:81; 2006b: 93).

En la ladera oeste se localizó una zona de habitación con una amplia cronología. En ella se han documentado materiales atribuibles a la primera Edad del Hierro (ss. VIII-V a.C.), aunque no es posible asociarlas a ninguna de las estructuras documentadas. También se han registrado materiales de la Fase II de la Cultura Castreña (ss. IV-II a.C.) relacionados con una cabaña oval. Las estructuras mejor conservadas son las realizadas en torno al siglo I d.C., ya en época romana (Aboal Rodríguez y Castro Hierro, 2006b).

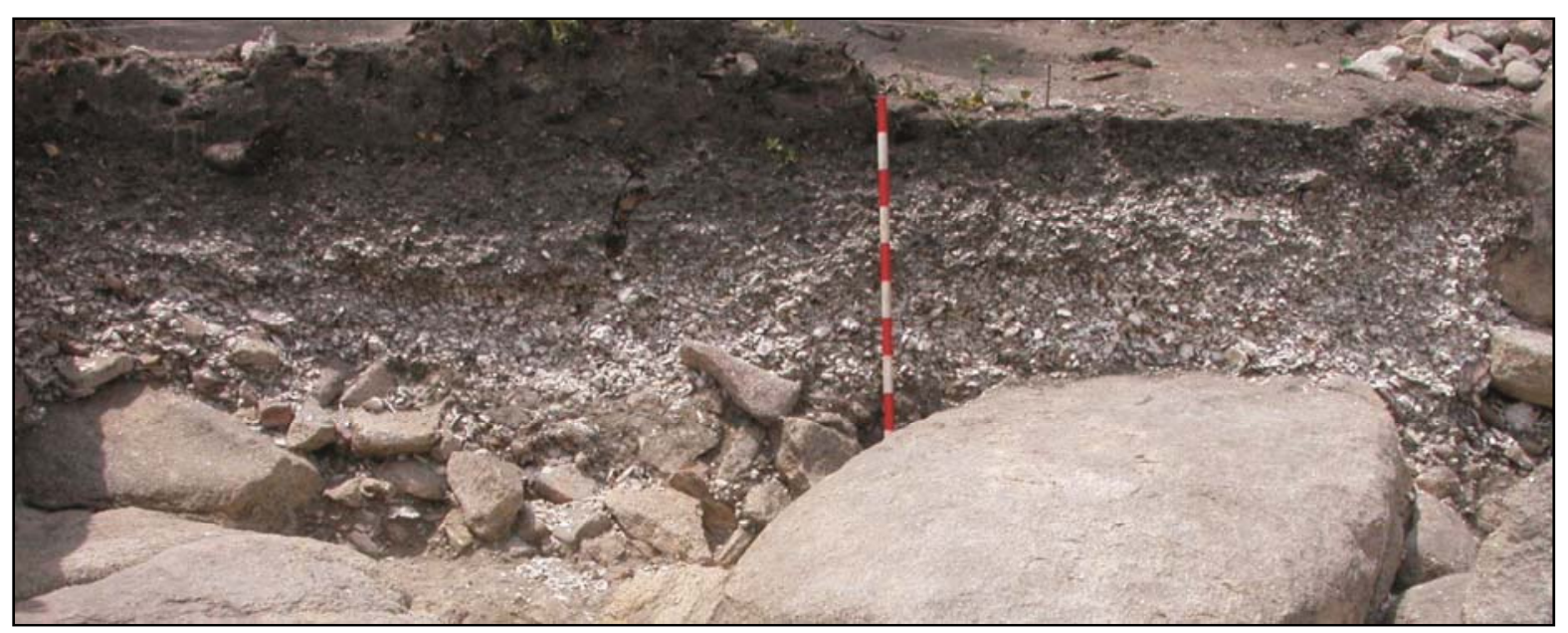

Fig. 204 Conchero de la ladera Este (Imagen facilitada por Roberto Aboal y Virginia Castro).

En la ladera este, únicamente se registraron evidencias de actividades antrópicas como trabajos de cantería o acumulaciones de desperdicios alimenticios con la presencia de un conchero de grandes dimensiones que ocuparía una extensión de $34 \mathrm{~m}^{2}$ del área de intervención, aunque en su totalidad podría ocupar unos 80-85 $\mathrm{m}^{2}$. En el mismo lugar se han documentado varios tramos de posibles canales y un muro a los pies del conchero que podría servir como estructura de contención. Los restos recuperados de este depósito apuntan un marco cronológico situado entre el siglo IV a.C. y el I d.C., aunque el grueso de los materiales sugiere que el conchero se habría acumulado entre el siglo II y el I a.C. (Aboal Rodríguez y Castro Hierro, 2006b).

\section{V.6.3. RECOGIDA DE LAS MUESTRAS.}

Los restos de ictiofauna analizados en este trabajo proceden de los sondeos realizados en 2003, tanto en la ladera este, donde se localiza un conchero de grandes dimensiones, como en la oeste, con varios echadizos entre diferentes estancias. Además también se analizarán los materiales recuperados en las muestras tomadas en el 2004 en la excavación en área de la ladera este. 


\section{V.6.3.1. RELACIÓN ESTRATIGRÁFICA}

En la relación estratigráfica únicamente trataremos aquellas unidades de las que se nos facilitaron muestras para analizar, así como de otras unidades que tienen una relación directa con las muestras con las que se elaboró este estudio.

\section{V.6.3.1.1. Ladera Este.}

\section{Sondeos.}

Sondeo 2: Alcanza una profundad máxima de $1,40 \mathrm{~m}$, siendo el fondo de granito. Debajo de la capa vegetal se identificó un conchero con una altura 0,70 m, que va perdiendo potencia en el sentido descendente de la ladera (Aboal Rodríguez y Castro Hierro, 2006b: 118).

\section{Excavación.}

-UEMTA04003: Depósito de tierra negra mezclada con conchas que cubre la UEMTA04012. Su potencia aumenta en el sentido de la pendiente (desde 0,09 m hasta los 0,85 m) (Aboal Rodríguez y Castro Hierro, 2006b: 122-123).

-UEMTA04012: Depósito constituido principalmente por conchas. Tiene una potencia que oscila entre $0,15 \mathrm{~m}$ y $0,93 \mathrm{~m}$, aumentando en sentido de la pendiente. Se encuentra apoyado directamente sobre la roca (Aboal Rodríguez y Castro Hierro, 2006b: 123).

-UEMTA04014: Estructura documentada en la parte sur del área de excavación delimitando el depósito de conchas. Es una construcción realizada con piedras de pequeño y mediano tamaño. La orientación es norte-sur con unas dimensiones de 8,30 $\mathrm{m}$ de largo y una altura entre $0,90-0,50 \mathrm{~m}$. No aparecieron restos de conchas al otro lado de este muro (Aboal Rodríguez y Castro Hierro, 2006b: 124).

\section{V.6.3.1.2. Ladera Oeste.}

Construcción C. Cabaña de planta ovalada: Estructura de habitación de forma oval de la que solamente se conservan en buen estado los muros de su lado norte y este (Aboal Rodríguez y Castro Hierro, 2006b: 104-105).

-UEMTA03045: Depósito de tierra de carácter postdeposicional que rellenaba a la estructura $C$.

-UEMTA03064: Nivel de tierra con conchas bajo UEMTA03045.

-UEMTA03022: Derrumbe con material abundante de los siglos II-I a.C., aunque mezclado con material anterior. Está cubierto por UEMTA03064.

-UEMTA03106: Nivel de quemado bajo UEMTA03022.

-UEMTA03145: Segundo nivel de derrumbe bajo UEMTA03106. 
-UEMTA03173-174: Posible pavimento.

-UEMTA03179: Depósito de tierra que habilita una superficie llana bajo UEMTA03173 y 174.

-UEMTA03235: Nivel de tierra con conchas que rellena las grietas de la roca, bajo UEMTA03179.

-Espacio E: Espacio entre cabañas que parece que funcionaba como eje vertebrador de esta zona en el primer momento de ocupación (Aboal Rodríguez y Castro Hierro, 2006b: 110-111).

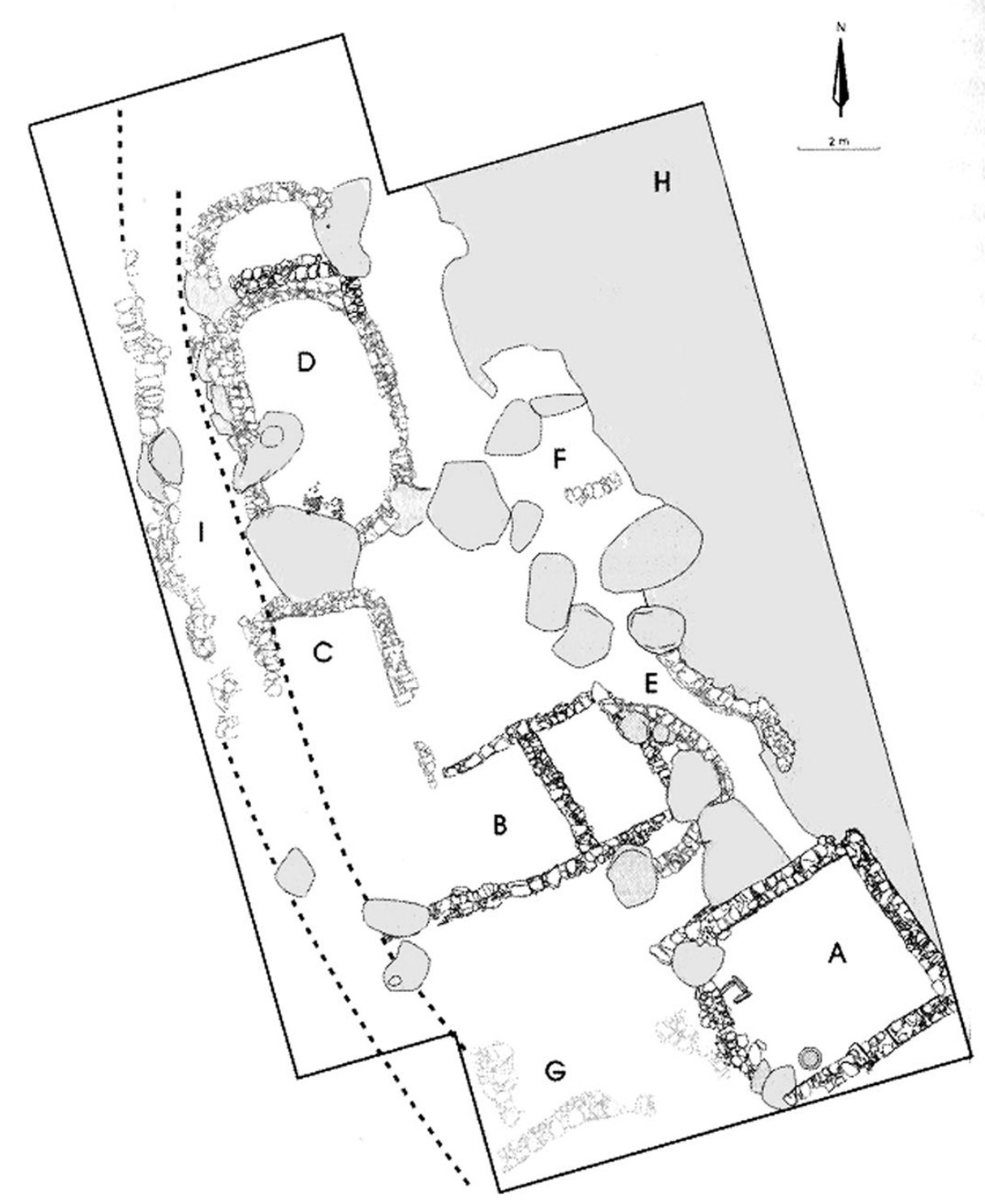

Fig. 205 Planimetría de la Ladera Oeste (Aboal Rodríguez y Castro Hierro, 2006) 


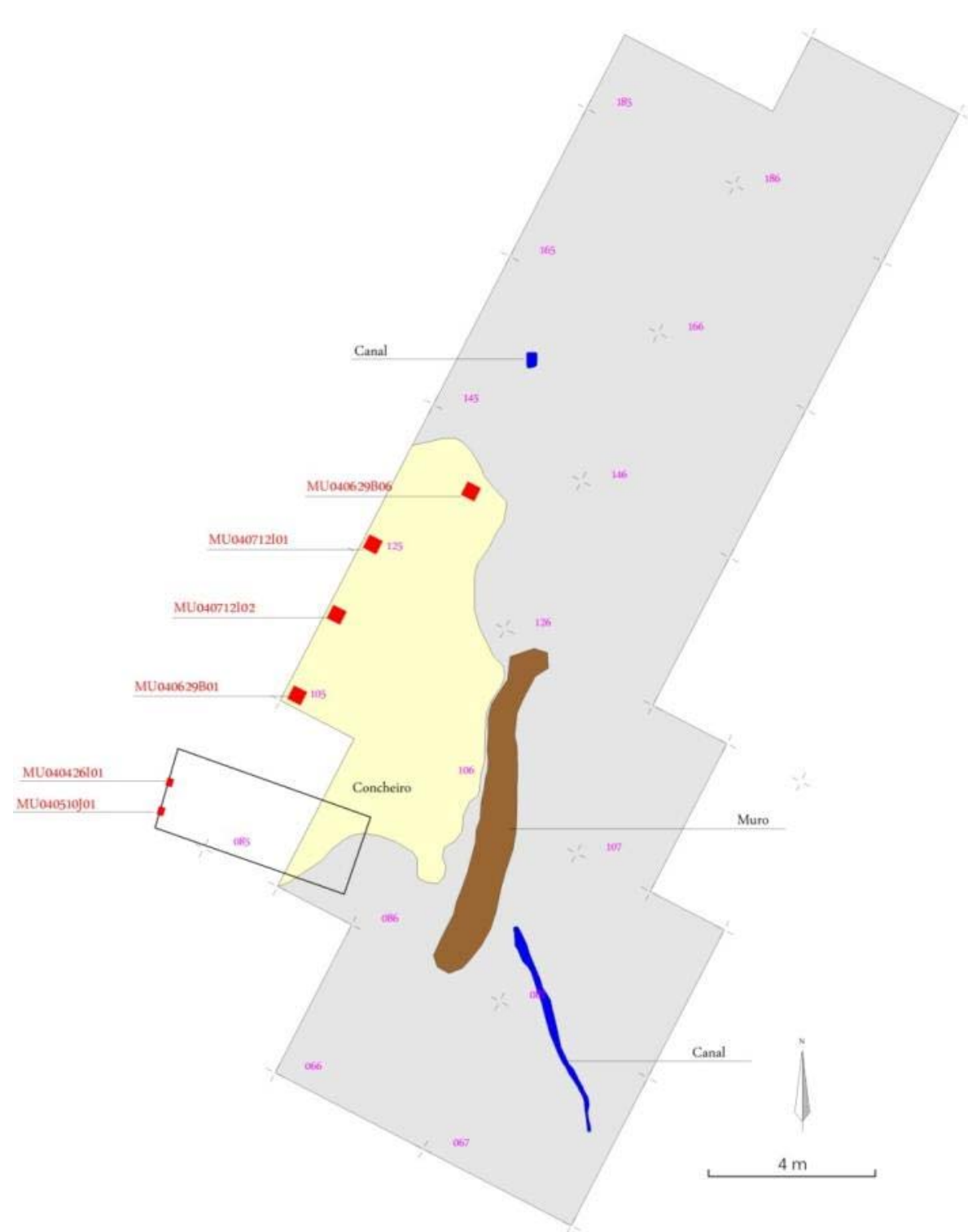

V.6.3.2. EL MUESTREO.

Fig. 206 Localización de los muestreos en la ladera Este (Imagen facilitada por Aboal Rodríguez y

Castro Hierro).

Durante los sondeos realizados en 2003 se recogieron tres columnas de muestras en la ladera este, dos de ellas en el perfil noroeste del Sondeo 2, mientras la tercera procede de la esquina suroeste de la UEMTA012 (UR105). Por otro lado, se recogieron varias muestras en diferentes echadizos localizados entre las estructuras de la ladera oeste. En la campaña de 2004, cuando se realizó la intervención en área de la ladera este, se recogieron dos columnas de muestras en el perfil noreste del conchero y un muestreo puntual en la parte noreste del conchero (UEMTA012-UR125), aunque esta muestra no ha sido procesada. 


\section{V.6.3.3. CRONOLOGÍA.}

\section{V.6.3.3.1. Ladera Este.}

Las muestras MU040510J01 y MU040426I01 aparecieron asociadas a cerámica estampillada, restos de ánfora tipos Harltern 70 y Dressel $1 \mathrm{~A}$, así como una moneda de Augusto de la ceca de Ébora, lo que permite adscribir el depósito a la Fase III de la Cultura Castreña (ss. III-I a.C.).

Por otro lado, las muestras MU040629B01, MU040712101 y MU040712102 se corresponden con dos niveles identificados en la excavación. El primero de ellos es la UEMTA04003, que presenta un número elevado de ánfora, así como vidrio y diferente material metálico que adscribiría el nivel a los siglos II a.C.-I d.C. El otro nivel sería la UEMTA04012, en la que se documentó gran cantidad de material cerámico, así como piezas metálicas y líticas. Sin embargo este nivel presenta mayores problemas, ya que no contamos con la referencia a materiales coordenados que permitan concretar posibles diferencias temporales dentro del depósito, que cuenta con un amplio marco cronológico (desde el siglo IV a.C. al siglo I d.C., con mayor presencia de materiales del siglo II a.C.-I d.C.). No obstante podemos decir que el conchero se situaría en la transición entre la Fase Il y la Fase III de la Cultura Castreña.

\section{V.6.3.3.2. Ladera Oeste.}

La ladera oeste presenta mayores problemas a la hora de datar los depósitos. Las muestras MU040713B03 y MU040713B04 fueron recogidas de la UEMTA03064, que cubre el derrumbe de la estructura C. La UEMTA03045, que cubre al echado de conchas, presenta materiales tanto del Hierro I como del Hierro II. En cuanto al derrumbe, se documentaron materiales pertenecientes principalmente a los siglos II-I a.C., aunque también hay materiales más antiguos (Aboal Rodríguez y Castro Hierro, 2006b: 104).

La muestra MU040806B01, recogida en la UEMTA03235, presentaba materiales pertenecientes al Hierro I (Aboal Rodríguez y Castro Hierro, 2006b: 105).

En cuanto a la muestra MU040707B02, son mayores los problemas para su datación, ya que desconocemos su origen exacto dentro del Espacio E.

\section{V.6.4. ESTUDIO ICTIOARQUEOLÓGICO.}

\section{V.6.4.1. LADERA ESTE.}

\section{V.6.4.1.1. MU040712I01}

Muestra tomada en: UEMTA04003 y UEMTA04012

Dimensiones: $83 \times 15 \times 13 \mathrm{~cm}$

Método de muestreo: bolsas tomadas de arriba hacia abajo cada $20 \mathrm{~cm}$. 
№ Bolsas: 8

Observaciones: Las bolsas 01 y 02 se corresponden a la UE003. El resto se asignan a la UE012.

\begin{tabular}{l|c|c|c|c|c|c|c|c|} 
& $\mathbf{M U / 0 1}$ & $\mathbf{M U / 0 2}$ & $\mathbf{M U / 0 3}$ & $\mathbf{M U} / \mathbf{0 4}$ & $\mathbf{M U} / \mathbf{0 5}$ & $\mathbf{M U} / \mathbf{0 6}$ & $\mathbf{M U} / \mathbf{0 7}$ & $\mathbf{M U / 0 8}$ \\
\cline { 2 - 9 } \multicolumn{1}{c}{ Inicial } & $\mathbf{2 . 0 7 8}$ & $\mathbf{2 . 2 5 8}$ & $\mathbf{1 . 3 3 0}$ & $\mathbf{1 . 9 9 7}$ & $\mathbf{2 . 1 2 3}$ & $\mathbf{2 . 4 6 9}$ & $\mathbf{2 . 5 1 3}$ & $\mathbf{1 . 7 8 0}$ \\
\hline \hline Residuo & 603 & 659 & 106 & 211 & 144 & 247 & 275,5 & 389 \\
\hline Cerámica & 10 & 0,5 & 2,5 & 3,5 & 1 & 7 & 1 & \\
\hline Malacofauna & $1.462,5$ & 1.555 & $1.156,5$ & 1.749 & 1.951 & 2.178 & $2.126,5$ & $1.399,5$ \\
Macrofauna & 3 & 16 & 3 & 7 & 21,5 & 8,5 & 36 & 7 \\
Ictiofauna & 1 & 1 & 1 & 0,5 & 1 & 1 & 1,5 & 0,5 \\
Carbón & 1 & 1,5 & 1 & 1 & 1,5 & 1,5 & 2 & 1 \\
Indeterminado & 1 & 1 & 1 & 1 & 1 & 1 & 1,5 & 0,5 \\
\hline
\end{tabular}

Tabla 135 Pesos (en gr.) iniciales de MU040712I01 por componentes.

\begin{tabular}{lccccccc} 
MU040712I01/01 & Vpc & Vca & Rce & Rpc & Esa & NR & NMI \\
\hline Sardina pilchardus & 1 & 2 & & & & $\mathbf{3}$ & 1 \\
$\begin{array}{l}\text { Dicentrarchus labrax } \\
\text { Indeterminado }\end{array}$ & & 2 & & & & $\mathbf{2}$ & 1 \\
\hline \hline & & & 12 & 34 & 4 & $\mathbf{5 0}$ & \\
\hline \hline TOTAL & $\mathbf{1}$ & $\mathbf{4}$ & $\mathbf{1 2}$ & $\mathbf{3 4}$ & $\mathbf{4}$ & $\mathbf{5 5}$ &
\end{tabular}

Tabla 136 Relación de especies y representación ósea de MU040712101/01.

En la Muestra 1 solamente se han podido identificar dos especies, Sardina pilchardus y Dicentrarchus labrax. Sardina pilchardus está representada por una vértebra precaudal y dos vértebras caudales, mientras que Dicentrarchus labrax por dos vértebras caudales.

\begin{tabular}{lcccccc} 
MU040712I01/02 & Vca & Rce & Rpc & Esa & NR & NMI \\
\hline Sardina pilchardus & 3 & & & & $\mathbf{3}$ & 1 \\
Pagellus bogaraveo & 2 & & & & $\mathbf{2}$ & 1 \\
Indeterminado & & 12 & 36 & 5 & $\mathbf{5 3}$ & \\
\hline \hline \multicolumn{1}{c}{ TOTAL } & $\mathbf{5}$ & $\mathbf{1 2}$ & $\mathbf{3 6}$ & $\mathbf{5}$ & $\mathbf{5 8}$ &
\end{tabular}

Tabla 137 Relación de especies y representación ósea de MU040712101/02.

En la Muestra 2 se mantiene la presencia de Sardina pilchardus con tres vértebras caudales. Por otro lado, va a desaparecer Dicentrarchus labrax, apareciendo ahora Pagellus bogaraveo, representada también por dos vértebras caudales.

\begin{tabular}{lccccccc} 
Mu040712I01/03 & Vpc & Vca & Rce & Rpc & Esa & NR & NMI \\
\hline Sardina pilchardus & & 2 & & & & $\mathbf{2}$ & 1 \\
Merluccius merluccius & 1 & 1 & & & & $\mathbf{2}$ & 1 \\
Dicentrarchus labrax & & 1 & & & & $\mathbf{1}$ & 1 \\
Labrus bergylta & 1 & & & & & $\mathbf{1}$ & 1 \\
Indeterminado & & & 11 & 6 & 6 & $\mathbf{2 3}$ & \\
\hline \multicolumn{1}{c}{ TOTAL } & $\mathbf{2}$ & $\mathbf{4}$ & $\mathbf{1 1}$ & $\mathbf{6}$ & $\mathbf{6}$ & $\mathbf{2 9}$ &
\end{tabular}

Tabla 138 Relación de especies y representación ósea de MU040712101/03. 
La Muestra 3 es la que presenta mayor número de restos y de especies dentro de la columna. Las especies con más restos son Sardina pilchardus, con dos vértebras caudales, y Merluccius merluccius, con una vértebra precaudal y otra caudal. También se ha identificado Dicentrarchus labrax, que vuelve a documentarse con una vértebra caudal, y Labrus bergy/ta con una vértebra precaudal.

\begin{tabular}{cccccc} 
MU040712I01/04 & Vca & Rpc & Esa & NR & NMI \\
\hline Indeterminado & 1 & 4 & 2 & 7 & \\
\hline \hline TOTAL & 1 & 4 & 2 & 7 &
\end{tabular}

Tabla 139 Relación de especies y representación ósea de MU040712101/04.

\begin{tabular}{lccccccc} 
Mu040712I01/05 & Vpc & Vca & Rce & Rpc & Esa & NR & NMI \\
\hline $\begin{array}{l}\text { Labrus bergylta } \\
\text { Indeterminado }\end{array}$ & 1 & & & & $\mathbf{1}$ & $\mathbf{1}$ \\
\hline \hline TOTAL & & & 7 & 1 & $\mathbf{8}$ & \\
\hline \hline
\end{tabular}

Tabla 140 Relación de especies y representación ósea de MU040712101/05.

De la Muestra 5 tan solo procede una vértebra caudal de Labrus bergylta, especie que ya había sido documentada en la muestra 3.

\begin{tabular}{lccccc} 
MU040712I01/06 & Vpc & Vca & Esa & NR & NMI \\
\hline Sardina pilchardus & 1 & & & $\mathbf{1}$ & 1 \\
Pagellus bogaraveo & & 1 & & $\mathbf{1}$ & 1 \\
Indeterminado & & & 3 & $\mathbf{3}$ & \\
\hline \hline \multicolumn{1}{c}{ TOTAL } & $\mathbf{1}$ & $\mathbf{1}$ & $\mathbf{3}$ & $\mathbf{5}$ &
\end{tabular}

Tabla 141 Relación de especies y representación ósea de MU040712101/06.

La Muestra 6 aporta de nuevo restos de Sardina pilchardus y Pagellus bogaraveo como en la Muestra 2, aunque en este caso representadas únicamente por una vértebra precaudal y otra caudal respectivamente.

\begin{tabular}{cccccc} 
MU040712101/07 & Rce & Rpc & Esa & NR & NMI \\
\hline Indeterminado & 1 & 5 & 1 & $\mathbf{7}$ & \\
\hline \hline TOTAL & $\mathbf{1}$ & $\mathbf{5}$ & $\mathbf{1}$ & $\mathbf{7}$
\end{tabular}

Tabla 142 Relación de especies y representación ósea de MU040712101/07.

\begin{tabular}{ccccc} 
MU040712I01/08 & Rce & Rpc & NR & NMI \\
\hline Indeterminado & 1 & 2 & 3 & \\
\hline \hline TOTAL & $\mathbf{1}$ & $\mathbf{2}$ & $\mathbf{3}$ &
\end{tabular}

Tabla 143 Relación de especies y representación ósea de MU040712101/08.

En las Muestras 4, 7 y 8 no se ha documentado ningún resto identificable a nivel de especie, aunque sí se ha recuperado algún fragmento indeterminado. 


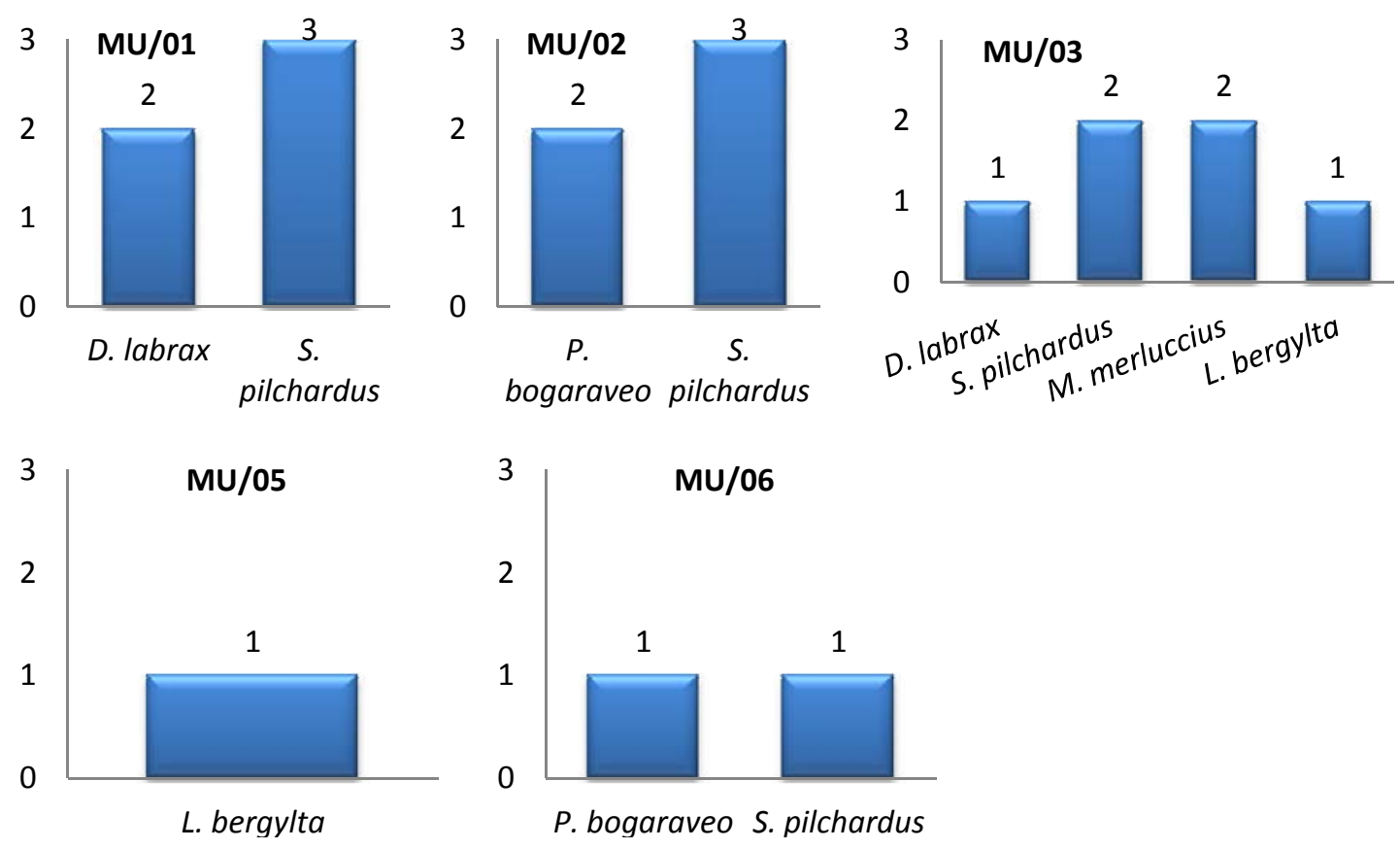

Fig. 207 Distribución de taxones identificados en MU040712101 por muestras según el NR.

El mayor número de especies y de restos se concentran en las tres primeras muestras, llegando a ser anecdótica la presencia de ictiofauna en el resto. En cuanto a las especies identificadas, podemos observar que Sardina pilchardus es la mejor representada en número de restos en las diferentes muestras.

Seguidamente se encontrarían dos especies demersales: Dicentrarchus labrax y Pagellus bogaraveo, que además no coinciden en ninguna de las muestras. En último lugar se encontrarían Merluccius merluccius y Labrus bergylta con dos restos cada una.

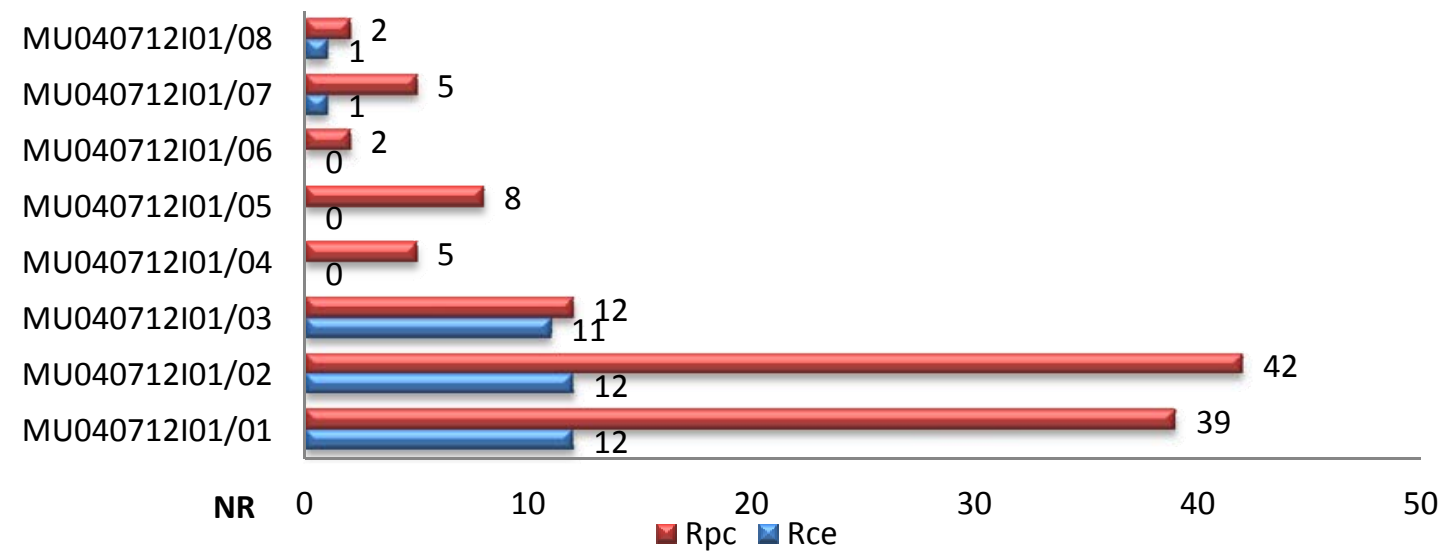

Fig. 208 Distribución esquelética de los restos ícticos de MU040712101.

En todas las muestras predominan los elementos post-cefálicos sobre los cefálicos, tanto entre los restos identificados como entre los indeterminados. Es significativa la ausencia de elementos cefálicos entre los restos identificados, documentándose 
únicamente piezas vertebrales. Del mismo modo también es reseñable la mayor presencia de vértebras caudales en todas las especies identificadas. Entre los no identificados destaca el predominio de restos cefálicos en las tres primeras muestras, en las que también encontramos mayor número de especies, desapareciendo prácticamente en las demás muestras. Algo similar podemos observar en relación a la presencia de escamas.

\section{V.6.4.1.2. MU040712I02}

Muestra tomada en: UEMTA04003 y UEMTA04012

Dimensiones: $58 \times 15 \times 15 \mathrm{~cm}$

Método de muestreo: bolsas tomadas de arriba hacia abajo cada $18 \mathrm{~cm}$.

№ Bolsas: 6

Observaciones: Las bolsas 01, 02 y 03 se corresponden a la UE003. El resto se corresponden con la UE012.

\begin{tabular}{l|c|c|c|c|c|c|} 
& $\mathbf{M U / 0 1}$ & $\mathbf{M U} / \mathbf{0 2}$ & $\mathbf{M U} / \mathbf{0 3}$ & $\mathbf{M U} / \mathbf{0 4}$ & $\mathbf{M U} / 05$ & $\mathbf{M U / 0 6}$ \\
\cline { 2 - 7 } \multicolumn{1}{c}{ Inicial } & $\mathbf{1 . 9 1 8}$ & $\mathbf{2 . 0 1 7}$ & $\mathbf{1 . 7 7 4}$ & $\mathbf{1 . 4 4 3}$ & $\mathbf{1 . 2 4 8}$ & $\mathbf{1 . 3 4 2}$ \\
\hline \hline Residuo & 1.051 & 1.032 & 545 & 197 & 152 & 237 \\
\hline Cerámica & 1 & 2 & 3 & 0,5 & & 2 \\
\hline Malacofauna & 876 & 977,5 & 1.225 & $1.263,5$ & $1.078,5$ & 1.110 \\
Macrofauna & 7 & 5 & 5 & 5 & 33 & 8 \\
Ictiofauna & 2 & 1,5 & 1 & 1 & 1 & 1 \\
Carbón & 1,5 & 2 & 1,5 & 1 & 1.5 & 1,5 \\
\hline
\end{tabular}

Tabla 144 Pesos (en gr.) iniciales de MU040712102 por componentes.

\begin{tabular}{lccccccc} 
Mu040712102/01 & Vpc & Vca & Rce & Rpc & Esa & NR & NMI \\
\hline Sardina pilchardus & 1 & 1 & & & & $\mathbf{2}$ & 1 \\
Trisopterus luscus & 1 & & & & & $\mathbf{1}$ & 1 \\
Pagellus bogaraveo & & 1 & & & & $\mathbf{1}$ & 1 \\
Indeterminado & & & 3 & 9 & 1 & $\mathbf{1 3}$ & \\
\hline \multicolumn{1}{c}{ TOTAL } & $\mathbf{2}$ & $\mathbf{2}$ & $\mathbf{3}$ & $\mathbf{9}$ & $\mathbf{1}$ & $\mathbf{1 7}$ &
\end{tabular}

Tabla 145 Relación de especies y representación ósea de MU040712102/01.

En la Muestra 1 se han identificado tres especies. La representada por un mayor número de restos es Sardina pilchardus, con una vértebra precaudal y otra caudal. Además se ha recuperado una vértebra precaudal de Trisopterus luscus y una caudal de Pagellus bogaraveo.

\begin{tabular}{lccccccc} 
Mu040712102/02 & Vpc & Vca & Rce & Rpc & Esa & NR & NMI \\
\hline Trisopterus luscus & 1 & & & & & $\mathbf{1}$ & 1 \\
Pagellus bogaraveo & & 2 & & & & $\mathbf{2}$ & 1 \\
Indeterminado & 1 & & 1 & 3 & 3 & $\mathbf{8}$ & \\
\hline \hline \multicolumn{1}{c}{ TOTAL } & $\mathbf{2}$ & $\mathbf{2}$ & $\mathbf{1}$ & $\mathbf{3}$ & $\mathbf{3}$ & $\mathbf{1 1}$ &
\end{tabular}

Tabla 146 Relación de especies y representación ósea de MU040712102/02.

En la Muestra 2 se constatan las mismas especies representadas en la anterior muestra, a excepción de Sardina pilchardus que desaparece. Se ha podido identificar una vértebra precaudal de Trisopterus luscus y dos vértebras caudales de Pagellus bogaraveo. 


\begin{tabular}{lcccccc} 
MU040712I02/03 & Vpc & Vca & Rpc & Esa & NR & NMI \\
\hline Sardina pilchardus & & 1 & & & $\mathbf{1}$ & 1 \\
Diplodus sargus & 1 & & & & $\mathbf{1}$ & 1 \\
Labrus bergylta & 1 & & & & $\mathbf{1}$ & 1 \\
Indeterminado & & & $\mathbf{7}$ & $\mathbf{1}$ & $\mathbf{8}$ & \\
\hline \multicolumn{1}{c}{ TOTAL } & $\mathbf{2}$ & $\mathbf{1}$ & $\mathbf{7}$ & $\mathbf{1}$ & $\mathbf{1 1}$
\end{tabular}

Tabla 147 Relación de especies y representación ósea de MU040712102/03.

En la Muestra 3, vuelve a aparecer Sardina pilchardus con una vértebra caudal, y desaparecen las especies que la acompañaban en las muestras anteriores. En su lugar se ha identificado una vértebra precaudal de Diplodus sargus y otra de Labrus bergylta.

\begin{tabular}{clllll} 
MU040712102/04 & Vpc & Rpc & Esa & NR & NMI \\
\hline $\begin{array}{l}\text { Diplodus sargus } \\
\text { Indeterminado }\end{array}$ & 1 & & & $\mathbf{1}$ & 1 \\
\hline \hline TOTAL & $\mathbf{1}$ & $\mathbf{2}$ & $\mathbf{1}$ & $\mathbf{4}$ &
\end{tabular}

Tabla 148 Relación de especies y representación ósea de MU040712102/04.

En la Muestra 4 únicamente se registra una vértebra precaudal de Diplodus sargus.

\begin{tabular}{lcccccc} 
Mu040712102/05 & Vpc & Vca & Rce & Rpc & NR & NMI \\
\hline $\begin{array}{l}\text { Sardina pilchardus } \\
\text { Indeterminado }\end{array}$ & 3 & 4 & & & $\mathbf{7}$ & 1 \\
\hline \hline TOTAL & & & 3 & 11 & $\mathbf{1 4}$ & \\
\hline \hline & $\mathbf{3}$ & $\mathbf{4}$ & $\mathbf{3}$ & $\mathbf{1 1}$ & $\mathbf{2 1}$ &
\end{tabular}

Tabla 149 Relación de especies y representación ósea de MU040712102/05.

Por último, la Muestra 5 agrupa el mayor número de restos de toda la columna, tres vértebras precaudales y cuatro caudales, todas ellas de Sardina pilchardus.
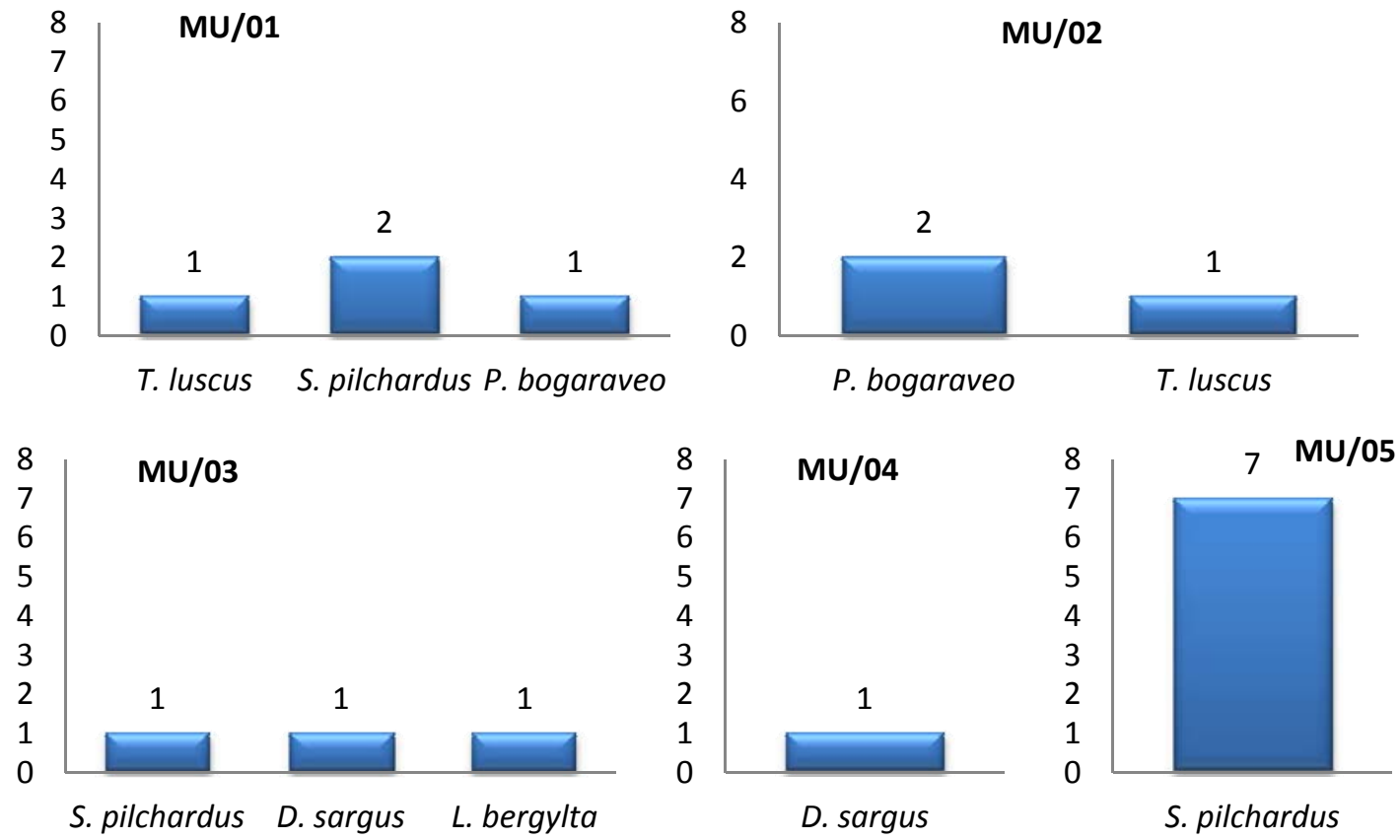

Fig. 209 Distribución de taxones identificados en MU040712102 por muestras según el NR. 
La especie mejor representada es pelágica, Sardina pilchardus, que se encuentra representada en tres de las muestras, con un total de 10 restos. Es destacable la Muestra 5, donde se observa la mayor concentración de restos, todos de este taxón.

Las demás especies representadas son todas demersales: Pagellus bogaraveo, Trisopterus lucus, Diplodus sargus y por último Labrus bergylta. Se constata la presencia de dos especies no identificadas en la columna anterior, Trisopterus luscus y Diplodus sargus. Hay que destacar que Diplodus sargus no coincide en ninguna muestra ni con Trisopterus luscus ni con Pagellus bogaraveo, especies que aparecen asociadas en las muestras de esta columna.

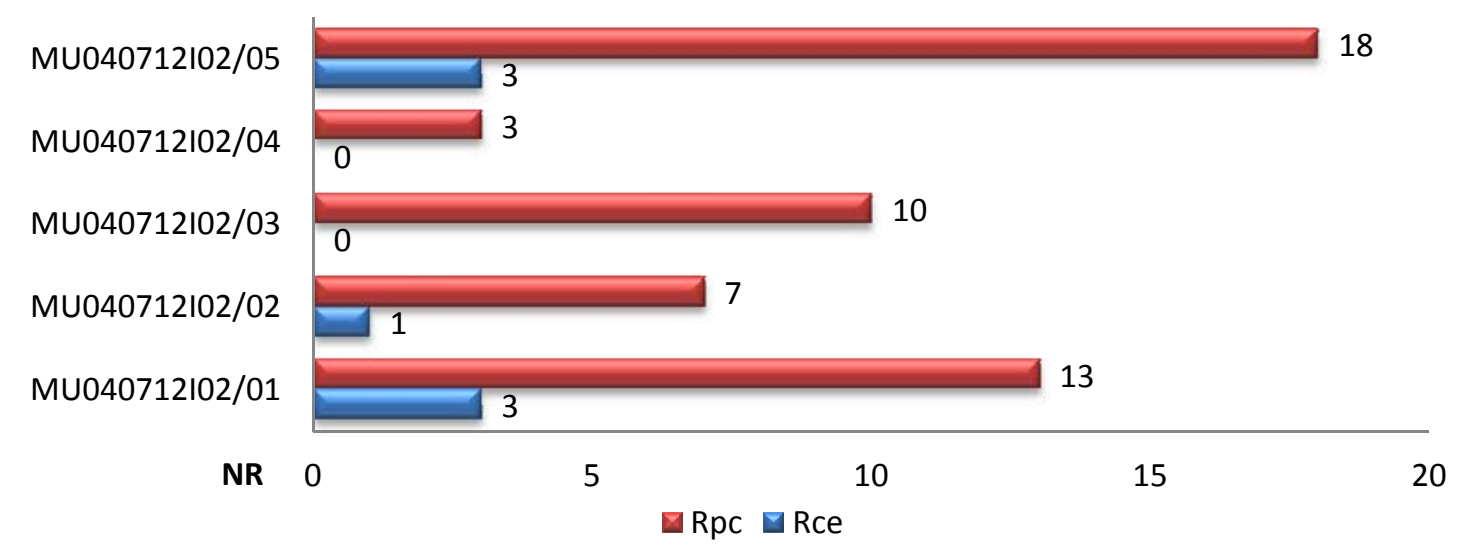

Fig. 210 Distribución esquelética de los restos ícticos de MU040712102.

Predominan los restos post-cefálicos frente a los cefálicos en todas las muestras, llegando estos últimos a no estar presentes en las Muestras 3 y 4 . Del mismo modo la presencia de escamas es muy escasa en toda la columna. Entre los restos identificados a nivel de especie no se ha recuperado ningún cefálico, siendo en su totalidad piezas vertebrales.

\section{V.6.4.1.3. MU040629B01}

Muestra tomada en: UEMTA04012

Localización: Esquina suroeste de la UE012 (UR105)

Dimensiones: $40 \times 20 \times 20 \mathrm{~cm}$

Método de muestreo: Columna de muestras.

№ Bolsas: 3

Observaciones: Por encima se documentó un nivel de derrumbe de cascote pequeño cubierto por un depósito de tierra con conchas (UE003). El depósito se apoya directamente sobre la roca. 


\begin{tabular}{l|c|c|c|}
\multirow{2}{*}{\multicolumn{1}{c|}{ Inicial }} & $\mathbf{M U / 0 1}$ & $\mathbf{M U / 0 2}$ & $\mathbf{M U / 0 3}$ \\
\cline { 2 - 4 } & $\mathbf{5 . 7 0 3}$ & $\mathbf{5 . 5 4 7}$ & $\mathbf{4 . 4 9 2}$ \\
\hline \hline Residuo & 982 & 1.010 & 1.064 \\
\hline Cerámica & 7 & 2 & 9 \\
Metal & 26 & & \\
\hline Malacofauna & 4.675 & 4.523 & $3.370,5$ \\
Macrofauna & 13 & 9 & 18,5 \\
Ictiofauna & 4,5 & 2,5 & 1,5 \\
Carbón & 4 & 4 & 3 \\
Indeterminado & 1 & 1 & \\
\hline
\end{tabular}

Tabla 150 Pesos (en gr.) iniciales de MU040629B01 por componentes.

\begin{tabular}{lcccccccc} 
Mu040629B01/01 & Oto & Vpc & Vca & Rce & Rpc & Esa & NR & NMI \\
\hline Trisopterus luscus & 1 & & & & & & $\mathbf{1}$ & 1 \\
$\begin{array}{l}\text { Pagellus bogaraveo } \\
\text { Indeterminado }\end{array}$ & & & 1 & & & & $\mathbf{1}$ & 1 \\
\hline \multicolumn{1}{c}{ TOTAL } & $\mathbf{1}$ & $\mathbf{1}$ & $\mathbf{1}$ & $\mathbf{1 5}$ & $\mathbf{1 6}$ & $\mathbf{3}$ & $\mathbf{3 7}$ &
\end{tabular}

Tabla 151 Relación de especies y representación ósea de MU040629B01/01.

En la Muestra 1 se han identificado dos especies representadas cada una por un resto: Trisopterus luscus por un otolito, y Pagellus bogaraveo por una vértebra caudal.

\begin{tabular}{lccccc} 
MU040629B01/02 & Vca & Rce & Rpc & NR & NMI \\
\hline Trisopterus luscus & 1 & & & $\mathbf{1}$ & 1 \\
Dicentrarchus labrax & 1 & & & $\mathbf{1}$ & 1 \\
Indeterminado & & 6 & 6 & $\mathbf{1 2}$ & \\
\hline \hline \multicolumn{1}{c}{ TOTAL } & $\mathbf{2}$ & $\mathbf{6}$ & $\mathbf{6}$ & $\mathbf{1 4}$ &
\end{tabular}

Tabla 152 Relación de especies y representación ósea de MU040629B01/02.

La Muestra 2 también presenta únicamente dos especies, Trisopterus luscus y Dicentrarchus labrax, representadas por una vértebra caudal cada una.

\begin{tabular}{lcccccc} 
MU040629B01/03 & Vpc & Vca & Rce & Rpc & NR & NMI \\
\hline Trisopterus luscus & 2 & & & & $\mathbf{2}$ & 1 \\
Sparus aurata & & 1 & & & $\mathbf{1}$ & 1 \\
Indeterminado & & & 4 & 3 & $\mathbf{7}$ & \\
\hline \hline \multicolumn{1}{c}{ TOTAL } & $\mathbf{2}$ & $\mathbf{1}$ & $\mathbf{4}$ & $\mathbf{3}$ & $\mathbf{1 0}$
\end{tabular}

Tabla 153 Relación de especies y representación ósea de MU040629B01/03.

La Muestra 3 es la que cuenta con un mayor número de restos identificados a nivel de especie, con dos vértebras precaudales de Trisopterus luscus y una vértebra caudal de Sparus aurata. 

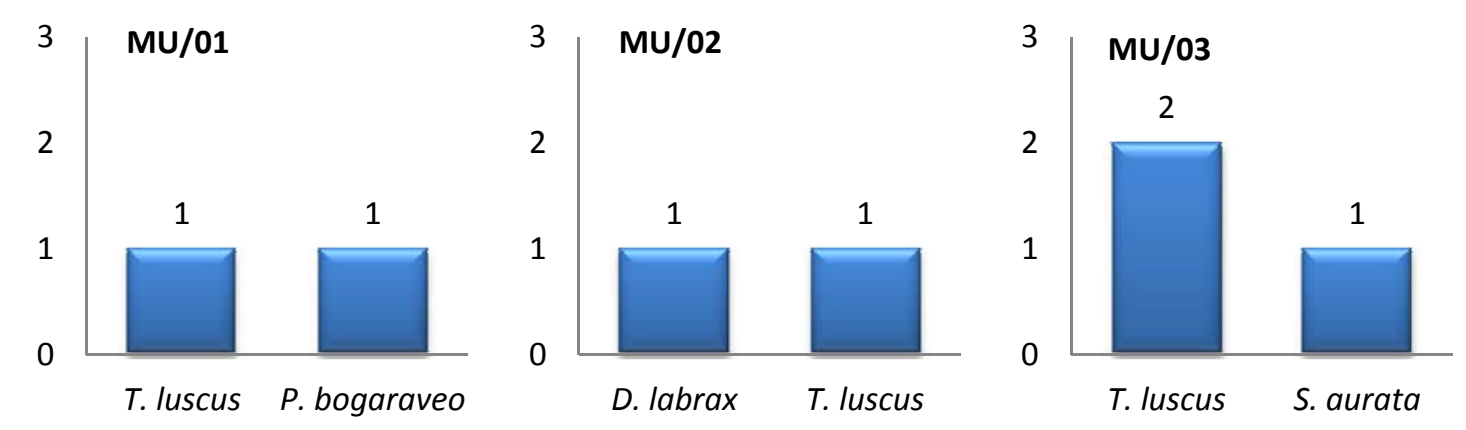

Fig. 211 Distribución de taxones identificados en MU040629B01 por muestras según el NR.

La especie mejor representada es Trisopterus luscus, que aparece en todas las muestras con un total de cuatro restos. Las demás especies aparece cada una en una muestra diferente, representadas únicamente por un resto.

Dicentrarchus labrax y Pagellus bogaraveo siguen apareciendo asiduamente, aunque sin coincidir en la misma muestra. Se ha documentado un resto de Sparus aurata, especie que no había sido identificada en las columnas anteriores.

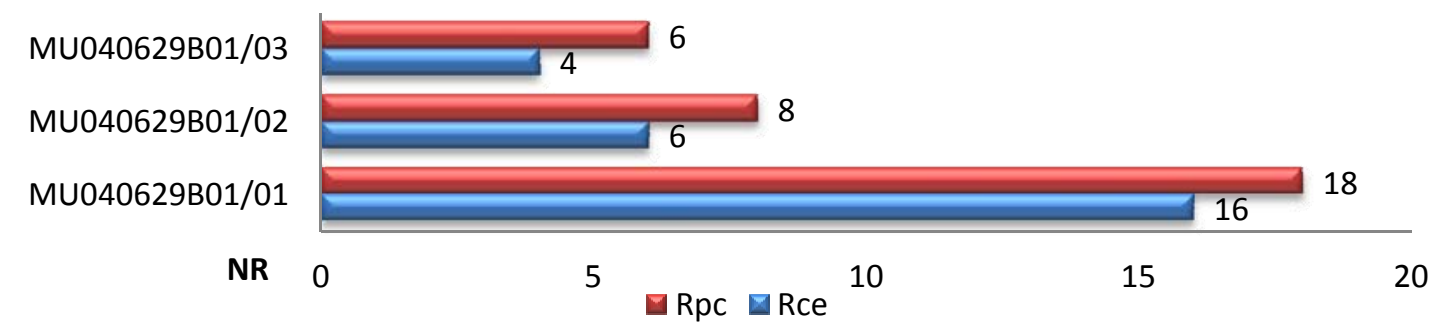

Fig. 212 Distribución esquelética de los restos ícticos de MU040629B01.

Los restos no identificados a nivel de especie son principalmente post-cefálicos. Tan solo se han recuperado escamas en la primera muestra, coincidiendo con el mayor número de restos documentados. En cuanto a los restos identificados a nivel de especie, siguen siendo casi exclusivamente post-cefálicos, con presencia de un solo resto cefálico en la Muestra 1.

\section{V.6.4.1.4. MU040426I01}

Muestra tomada en: UEMTA04012

Localización: Perfil Sondeo 2

Dimensiones: $20 \times 30 \times 60 \mathrm{~cm}$

Método de muestreo: Columna de muestras

№ Bolsas: 6 (tomadas cada $10 \mathrm{~cm}$ de arriba hacia abajo)

Observaciones: Depósito de conchas cubierto por un depósito de tierra mezclada con conchas y apoyado directamente sobre la roca. 


\begin{tabular}{l|c|c|c|c|c|c|} 
& $\mathbf{M U / 0 1}$ & $\mathbf{M U / 0 2}$ & $\mathbf{M U / 0 3}$ & $\mathbf{M U / 0 4}$ & $\mathbf{M U / 0 5}$ & $\mathbf{M U / 0 6}$ \\
\cline { 2 - 7 } \multicolumn{1}{c}{ Inicial } & $\mathbf{3 . 2 0 2}$ & $\mathbf{3 . 6 4 9}$ & $\mathbf{3 . 5 7 1}$ & $\mathbf{3 . 2 1 9}$ & $\mathbf{3 . 2 3 5}$ & $\mathbf{2 . 5 8 5}$ \\
\hline \hline Residuo & 577 & 831 & 827 & $\mathbf{7 2 8}$ & 1.266 & 567 \\
\hline Cerámica & & & 3 & 1 & 5 & 2 \\
\hline Malacofauna & $2.542,5$ & $2.303,5$ & $2.738,5$ & $2.602,5$ & 2.617 & 1.998 \\
Macrofauna & 10 & 2 & 3 & 1,5 & 2,5 & 2 \\
Ictiofauna & 2,5 & 3 & 4,5 & 3 & 1,5 & 2 \\
Carbón & 4 & 3 & 4 & 3,5 & 2,5 & 2,5 \\
Indeterminado & & 1 & & & & \\
\hline
\end{tabular}

Tabla 154 Pesos (en gr.) iniciales de MU040426I01 por componentes.

\begin{tabular}{lcccccc} 
MU040426I01/01 & Vpc & Rce & Rpc & Esa & NR & NMI \\
\hline Trisopterus luscus & 3 & & & & $\mathbf{3}$ & 1 \\
Indeterminado & & 7 & 11 & 3 & $\mathbf{2 1}$ & \\
\hline \hline TOTAL & $\mathbf{3}$ & $\mathbf{7}$ & $\mathbf{1 1}$ & $\mathbf{3}$ & $\mathbf{2 4}$ &
\end{tabular}

Tabla 155 Relación de especies y representación ósea de MU040426I01/01.

En la Muestra 1 se identificaron únicamente tres vértebras precaudales de Trisopterus luscus.

\begin{tabular}{lccccccccc} 
Mu040426I01/02 & Oto & Vpc & Atl & Vca & Rce & Rpc & Esa & NR & NMI \\
\hline Trisopterus luscus & 1 & 2 & & & & & & $\mathbf{3}$ & 1 \\
Dicentrarchus labrax & & 1 & & & & & & $\mathbf{1}$ & 1 \\
Diplodus sargus & & & 1 & & & & & $\mathbf{1}$ & 1 \\
Pagellus bogaraveo & & & & 1 & & & & $\mathbf{1}$ & 1 \\
Scomber sp & & & & 1 & & & & $\mathbf{1}$ & 1 \\
Indeterminado & 1 & & & & 13 & 34 & 5 & $\mathbf{5 3}$ & \\
\hline \hline \multicolumn{1}{c}{ TOTAL } & $\mathbf{2}$ & $\mathbf{3}$ & $\mathbf{1}$ & $\mathbf{2}$ & $\mathbf{1 3}$ & $\mathbf{3 4}$ & $\mathbf{5}$ & $\mathbf{6 0}$ &
\end{tabular}

Tabla 156 Relación de especies y representación ósea de MU040426I01/02.

La Muestra 2 cuenta con cinco especies identificadas. La que presenta mayor número de restos es Trisopterus luscus, con un otolito y dos vértebras precaudales. Los demás taxones están representados por un único resto, así de Dicentrarchus labrax una vértebra precaudal, de Diplodus sargus un atlas, mientras que de Pagellus bogaraveo y Scomber sp. una vértebra caudal de cada una.

\begin{tabular}{lccccccccccc} 
Mu040426I01/03 & $\begin{array}{c}\text { Dnt } \\
\text { (D/S) }\end{array}$ & $\begin{array}{c}\text { Art } \\
\text { (D/S) }\end{array}$ & Pal & $\begin{array}{c}\text { Pop } \\
\text { (D/S) }\end{array}$ & Vpc & Vca & Rce & Rpc & Esa & NR & NMI \\
\hline $\begin{array}{l}\text { Sardina pilchardus } \\
\text { Trisopterus luscus }\end{array}$ & & & & & & 1 & & & & $\mathbf{1}$ & 1 \\
Dicentrarchus labrax & & & & $0 / 1$ & & 1 & & & & $\mathbf{2}$ & 1 \\
$\begin{array}{l}\text { Diplodus sargus } \\
\text { Pagellus bogaraveo }\end{array}$ & $1 / 0$ & & & & & & & & & $\mathbf{1}$ & 1 \\
Indeterminado & $1 / 0$ & & & & & 2 & & & & $\mathbf{3}$ & 1 \\
\hline \multicolumn{1}{c}{ TOTAL } & $\mathbf{2}$ & $\mathbf{1}$ & $\mathbf{1}$ & $\mathbf{1}$ & $\mathbf{4}$ & $\mathbf{9}$ & $\mathbf{1 8}$ & $\mathbf{4 2}$ & $\mathbf{5}$ & $\mathbf{8 3}$ &
\end{tabular}

Tabla 157 Relación de especies y representación ósea de MU040426I01/03. 
La Muestra 3, además de contar con el mismo número de especies, va a aportar un número mayor de restos. La especie mejor representada sigue siendo Trisopterus luscus, con tres vértebras precaudales y una caudal. Le siguen en número de restos Pagellus bogaraveo, con un dentario derecho y dos vértebras caudales, y Dicentrarchus labrax con un preopercular izquierdo y una vértebra caudal. Por último, Sardina pilchardus con una vértebra caudal y Diplodus sargus con un dentario derecho.

\begin{tabular}{lccccccc} 
MU040426I01/04 & Vpc & Vca & Rce & Rpc & Esa & NR & NMI \\
\hline Sardina pilchardus & & 1 & & & & $\mathbf{1}$ & 1 \\
Trisopterus luscus & 2 & & & & & $\mathbf{2}$ & 1 \\
Sparus aurata & & 1 & & & & $\mathbf{1}$ & 1 \\
Indeterminado & 1 & 3 & 13 & 41 & 1 & $\mathbf{5 9}$ & \\
\hline \hline \multicolumn{1}{c}{ TOTAL } & $\mathbf{3}$ & $\mathbf{5}$ & $\mathbf{1 3}$ & $\mathbf{4 1}$ & $\mathbf{1}$ & $\mathbf{6 3}$ &
\end{tabular}

Tabla 158 Relación de especies y representación ósea de MU040426I01/04.

En la Muestra 4 la especie con más restos identificados es de nuevo Trisopterus luscus, con dos vértebras precaudales. El conjunto se completa con una vértebra caudal de Sardina pilchardus y otra de Sparus aurata.

\begin{tabular}{lcccccccc} 
MU040426I01/05 & Oto & Vpc & Vca & Rce & Rpc & Esa & NR & NMI \\
\hline Sardina pilchardus & & & 1 & & & & $\mathbf{1}$ & 1 \\
Trisopterus luscus & 1 & 1 & 1 & & & & $\mathbf{3}$ & 1 \\
Indeterminado & & & 1 & 6 & 15 & 3 & $\mathbf{2 5}$ & \\
\hline \hline TOTAL & $\mathbf{1}$ & $\mathbf{1}$ & $\mathbf{3}$ & $\mathbf{6}$ & $\mathbf{1 5}$ & $\mathbf{3}$ & $\mathbf{2 9}$ &
\end{tabular}

Tabla 159 Relación de especies y representación ósea de MU040426101/05.

En la Muestra 5 desciende tanto el número de restos como las especies identificadas. Trisopterus luscus sigue siendo la que alcanza una mayor representación, con un otolito, una vértebra precaudal y otra caudal. La otra especie identificada es Sardina pilchardus con una vértebra caudal.

\begin{tabular}{lcccccccc} 
Mu040426I01/06 & $\begin{array}{c}\text { Pmx } \\
\text { (D/S) }\end{array}$ & Vpc & Vca & Rce & Rpc & Esa & NR & NMI \\
\hline Sardina pilchardus & & 1 & & & & & $\mathbf{1}$ & 1 \\
Trisopterus luscus & & 1 & & & & & $\mathbf{1}$ & 1 \\
$\begin{array}{l}\text { Diplodus sargus } \\
\text { Indeterminado }\end{array}$ & 1 & & 1 & & & & $\mathbf{1}$ & 1 \\
\hline \hline & & & & 13 & 18 & 3 & $\mathbf{3 5}$ & \\
\hline TOTAL & $\mathbf{1}$ & $\mathbf{2}$ & $\mathbf{1}$ & $\mathbf{1 3}$ & $\mathbf{1 8}$ & $\mathbf{3}$ & $\mathbf{3 8}$ &
\end{tabular}

Tabla 160 Relación de especies y representación ósea de MU040426I01/06.

En la Muestra 6 se documenta Sardina pilchardus y Trisopterus luscus con una vértebra precaudal cada una, y Diplodus sargus con una vértebra caudal. 

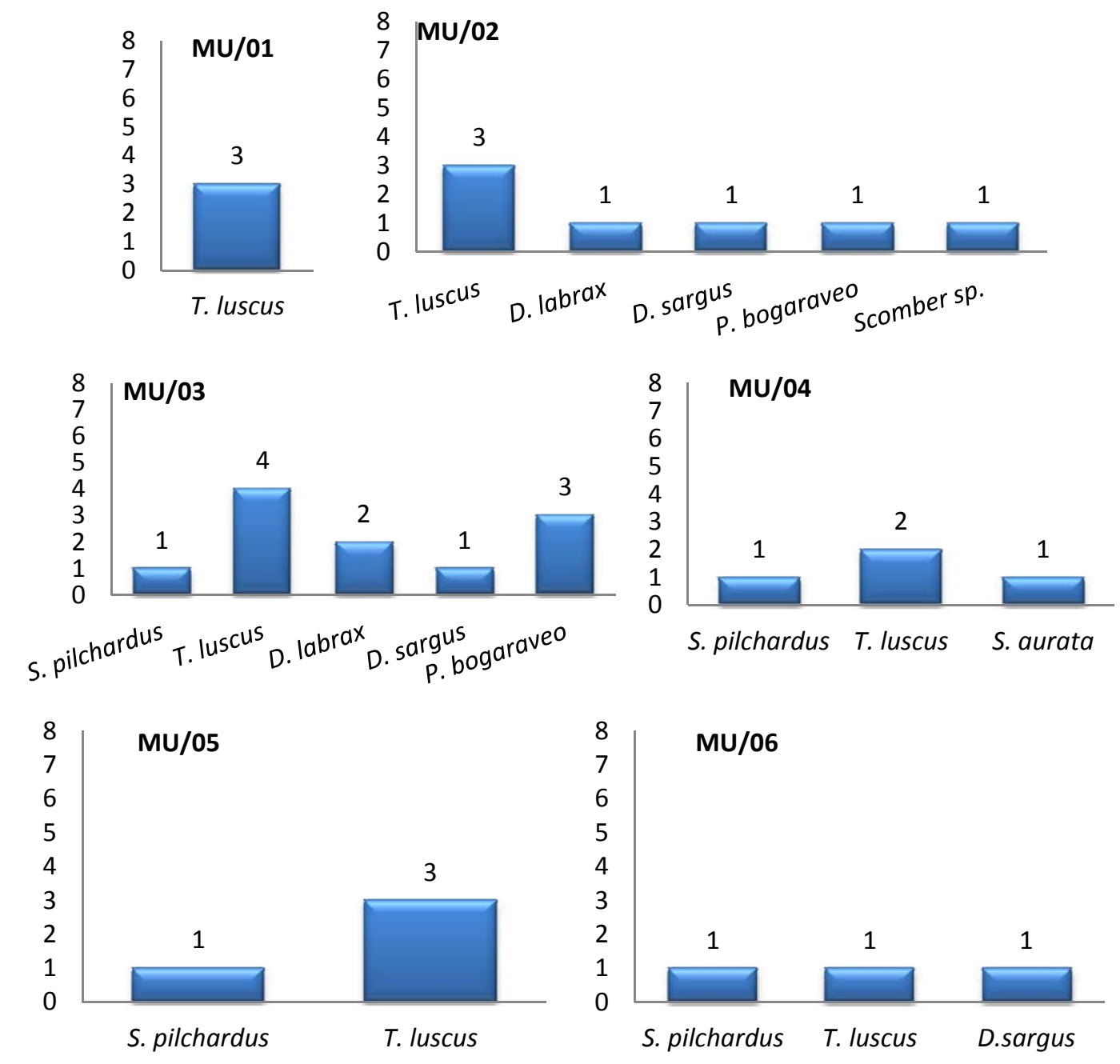

Fig. 213 Distribución de taxones identificados en MU040426I01 por muestras según el NR.

El mayor número de restos identificados se encuentra en la Muestra 3, siendo menor el número de restos documentados en las muestras de los extremos de la columna. La especie con mejor representación y con mayor número de restos es Trisopterus luscus, que aparece en todas las muestras, con un total de quince restos. Le siguen Sardina pilchardus, con cuatro restos repartidos en las cuatro últimas muestras de la columna, y Pagellus bogaraveo, también con cuatro restos, que se concentra en las Muestras 2 y 3. Con menor representación está Diplodus sargus, con tres restos en tres muestras, y Dicentrarchus labrax representado por tres restos en dos muestras. Hay que indicar que Dicentrarchus labrax y Pagellus bogaraveo, así como Diplodus sargus, coinciden en las mismas muestras, algo que no se había documentado en el resto de columnas. Por último, con tan solo un resto identificado para cada una están Scomber sp. y Sparus aurata. 


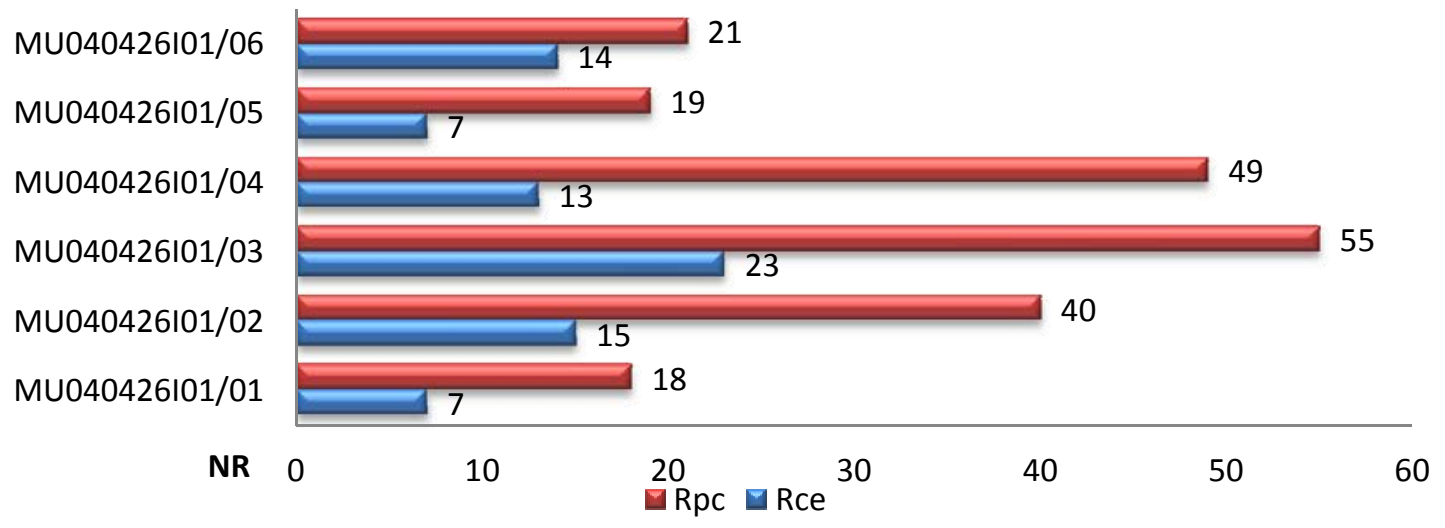

Fig. 214 Distribución esquelética de los restos ícticos de MU040426I01.

Como habíamos visto en la mayoría de las muestras ya analizadas, predominan los restos post-cefálicos frente a los cefálicos. Por lo que se refiere a los restos identificados a nivel de especie sigue siendo mayor el número de post-cefálicos, aunque se han recuperado un mayor número de piezas cefálicas, lo que contrasta con los escasos restos documentados en las demás columnas. La mayor concentración de restos indeterminados se produce en las muestras localizadas en la parte media de la columna, lo que no resulta sorprendente si tenemos en cuenta que tabién son las muestras donde más especies y restos identificados se habían recuperado. Esta relación también se aprecia en las escamas que, aunque en número escaso, aparecen en la totalidad de las muestras.

\section{V.6.4.1.5. MU040510J01}

Muestra tomada en: UEMTA04012

Localización: Perfil del Sondeo 2

Dimensiones: $50 \times 60 \times 40 \mathrm{~cm}$

Método de muestreo: Columna de muestras

№ Bolsas: 4 (tomadas cada $10 \mathrm{~cm}$ de arriba hacia abajo)

Observaciones: Depósito de conchas cubierto por un depósito de tierra mezclada con conchas y apoyado directamente sobre la roca.

\begin{tabular}{l|c|c|c|c|}
\multirow{2}{*}{\multicolumn{1}{c|}{ Inicial }} & $\mathbf{M U / 0 1}$ & $\mathbf{M U / 0 2}$ & $\mathbf{M U / 0 3}$ & $\mathbf{M U / 0 4}$ \\
\cline { 2 - 5 } & $\mathbf{3 . 6 4 2}$ & $\mathbf{3 . 2 5 3}$ & $\mathbf{3 . 2 1 4}$ & $\mathbf{5 . 0 6 2}$ \\
\hline \hline Residuo & 799 & 907,7 & $\mathbf{7 1 0 , 1}$ & $\mathbf{2 . 0 5 9 , 5}$ \\
\hline Cerámica & 1 & 1 & 4,5 & 3 \\
\hline Malacofauna & 2.831 & $2.336,8$ & $2.489,1$ & 2.981 \\
Macrofauna & 1,5 & & 0,5 & 1 \\
Ictiofauna & 6 & 3,5 & 4 & 9 \\
Carbón & 2,5 & 3,5 & 2,8 & 3,5 \\
Indeterminado & 1 & 0,5 & 3 & 5 \\
\hline
\end{tabular}

Tabla 161 Pesos (en gr.) iniciales de MU040510J01 por componentes. 


\begin{tabular}{lcccccccccc} 
Mu040510J01/01 & $\begin{array}{c}\text { Art } \\
\text { (D/S) }\end{array}$ & $\begin{array}{c}\text { Eph } \\
\text { (D/S) }\end{array}$ & Cbr & Vpc & Vca & Rce & Rpc & Esa & NR & NMI \\
\hline Trisopterus luscus & & $0 / 1$ & & 5 & 2 & & & & $\mathbf{8}$ & 1 \\
Dicentrarchus labrax & & & & & 1 & & & & $\mathbf{1}$ & 1 \\
Diplodus sargus & & $0 / 1$ & 1 & & & & & & $\mathbf{2}$ & 1 \\
Sparus aurata & & & & 1 & & & & & $\mathbf{1}$ & 1 \\
Pagellus bogaraveo & & & & & 2 & & & & $\mathbf{2}$ & 2 \\
Scomber scombrus & & & & & 1 & & & & $\mathbf{1}$ & 1 \\
Indeterminado & $0 / 1$ & & & & 2 & 6 & 51 & 5 & $\mathbf{6 5}$ & \\
\hline \hline \multicolumn{1}{c}{ TOTAL } & $\mathbf{1}$ & $\mathbf{2}$ & $\mathbf{1}$ & $\mathbf{6}$ & $\mathbf{8}$ & $\mathbf{6}$ & $\mathbf{5 1}$ & $\mathbf{5}$ & $\mathbf{8 0}$ &
\end{tabular}

Tabla 162 Relación de especies y representación ósea de MU040510J01/01.

En la Muestra 1 la especie representada por un mayor número de restos es Trisopterus luscus: un epihial izquierdo, cinco vértebras precaudales y dos vértebras caudales. Los otros taxones alcanzan una representación mucho menor: un epihial izquierdo y un ceratobranquial de Diplodus sargus, dos vértebras caudales de Pagellus bogaraveo, una vértebra caudal de Dicentrarchus labrax, otra vértebra caudal de Scomber scombrus y una vértebra precaudal de Sparus aurata.

\begin{tabular}{lcccccccc} 
MU040510J01/02 & Vpc & Atl & Vca & Rce & Rpc & Esa & NR & NMI \\
\hline Trisopterus luscus & 2 & 1 & 1 & & & & $\mathbf{4}$ & 1 \\
Sparus aurata & & & 1 & & & & $\mathbf{1}$ & 1 \\
Pagellus bogaraveo & & & 1 & & & & $\mathbf{1}$ & 1 \\
Indeterminado & 1 & & 1 & 15 & 30 & 16 & $\mathbf{6 3}$ & \\
\hline \multicolumn{1}{c}{ TOTAL } & $\mathbf{3}$ & $\mathbf{1}$ & $\mathbf{4}$ & $\mathbf{1 5}$ & $\mathbf{3 0}$ & $\mathbf{1 6}$ & $\mathbf{6 9}$ &
\end{tabular}

Tabla 163 Relación de especies y representación ósea de MU040510J01/02.

En la Muestra 2 Trisopterus luscus sigue siendo la especie mejor representada con dos vértebras precaudales, un atlas y una vértebra caudal. Además también se identificó una vértebra caudal de Sparus aurata y otra de Pagellus bogaraveo.

\begin{tabular}{lcccccccc} 
Mu040510J01/03 & $\begin{array}{c}\text { Pmx } \\
\text { (D/S) }\end{array}$ & Vpc & Vca & Rce & Rpc & Esa & NR & NMI \\
\hline Trisopterus luscus & & 3 & 1 & & & & $\mathbf{4}$ & 1 \\
Pagellus bogaraveo & $1 / 0$ & & 1 & & & & $\mathbf{2}$ & 1 \\
Scomber sp. & $1 / 0$ & & & & & & $\mathbf{1}$ & 1 \\
Scomber scombrus & & & 1 & & & & $\mathbf{1}$ & 1 \\
Indeterminado & & 1 & 5 & 10 & 50 & $\mathbf{7}$ & $\mathbf{7 3}$ & \\
\hline \hline \multicolumn{1}{c}{ TOTAL } & $\mathbf{2}$ & $\mathbf{4}$ & $\mathbf{8}$ & $\mathbf{1 0}$ & $\mathbf{5 0}$ & $\mathbf{7}$ & $\mathbf{8 1}$ &
\end{tabular}

Tabla 164 Relación de especies y representación ósea de MU040510J01/03.

De la Muestra 3 proceden tres vértebras precaudales y una caudal de Trisopteros luscus. En número de restos le sigue Pagellus bogaraveo, con un premaxilar derecho y una 
vértebra caudal. Además también se identificó una vértebra caudal de Scomber scombrus y un premaxilar derecho de Scomber sp.

\begin{tabular}{lccccccccc} 
Mu040510J01/04 & $\begin{array}{c}\text { Dnt } \\
\text { (D/S) }\end{array}$ & Oto & Vpc & Vca & Rce & Rpc & Esa & NR & NMI \\
\hline Trisopterus luscus & $0 / 1$ & 1 & 5 & 1 & & & & $\mathbf{8}$ & 1 \\
$\begin{array}{l}\text { Dicentrarchus labrax } \\
\text { Pagellus bogaraveo }\end{array}$ & & & 1 & & & & & $\mathbf{1}$ & 1 \\
Indeterminado & & 1 & 4 & 1 & 12 & 117 & 13 & $\mathbf{1 4 9}$ & \\
\hline \hline & & & & 2 & & & & $\mathbf{2}$ & 1 \\
\hline TOTAL & $\mathbf{1}$ & $\mathbf{2}$ & $\mathbf{1 0}$ & $\mathbf{4}$ & $\mathbf{1 2}$ & $\mathbf{1 1 7}$ & $\mathbf{1 3}$ & $\mathbf{1 6 0}$ &
\end{tabular}

Tabla 165 Relación de especies y representación ósea de MU040510J01/04.

La Muestra 4 se ha comportado de forma similar a la 1, con el mismo número de restos de Trisopterus luscus: un dentario izquierdo, un otolito, cinco vértebras precaudales y una vértebra caudal. El resto del conjunto está formado por una vértebra precaudal de Dicentrarchus labrax y dos vértebras caudales de Pagellus bogaraveo.
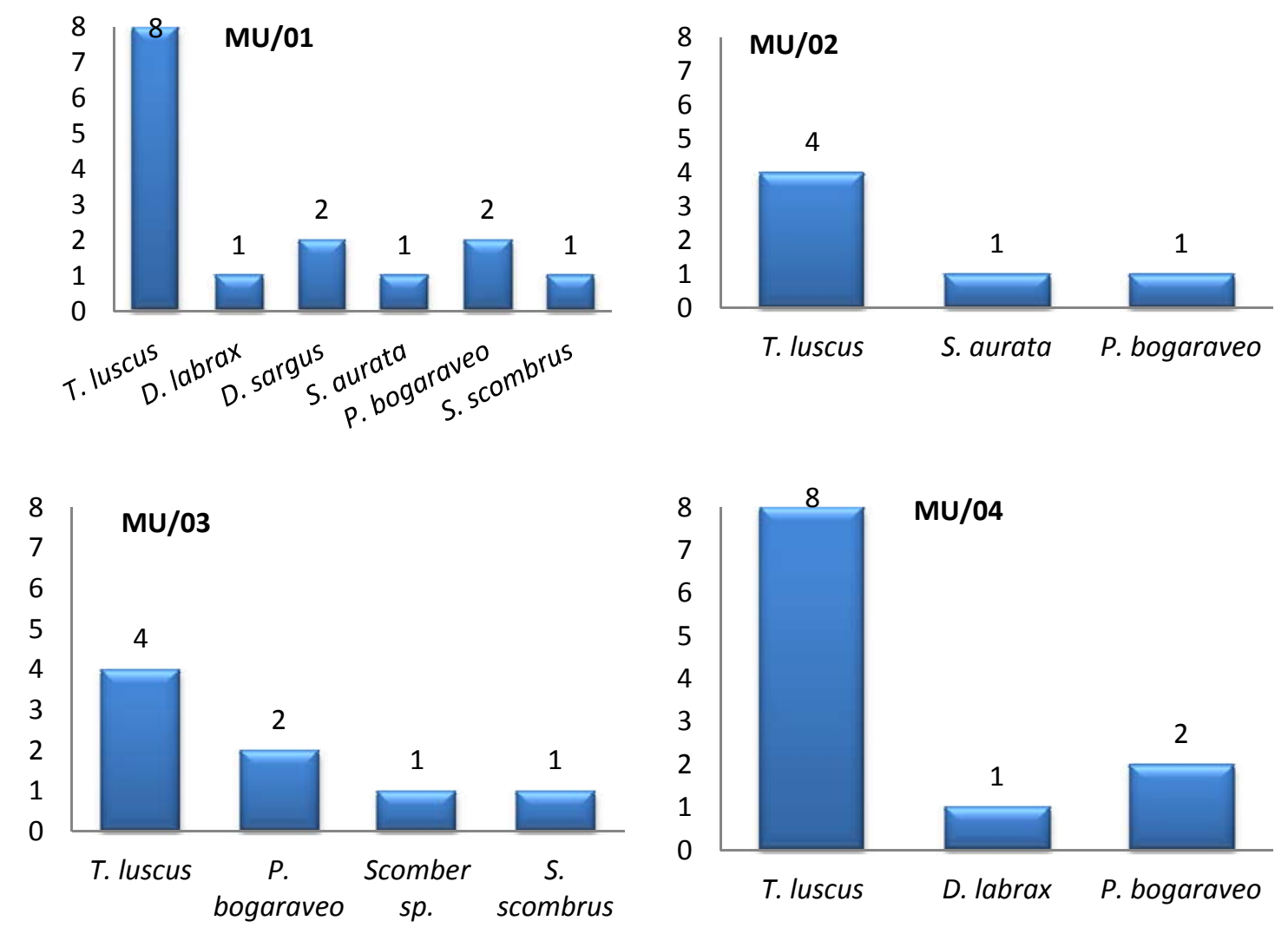

Fig. 215 Distribución de taxones identificados en MU040510J01 por muestras según el NR.

El mayor número de restos se concentra en las Muestras 1 y 4 . Trisopterus luscus es la especie mejor representada, estando presente en todas las muestras. Le seguiría en importancia Pagellus bogaraveo, con siete restos repartidos entre todas las muestras. Después de estas dos especies principales encontraríamos un grupo más variable de 
especies con pocos restos y que no aparecen en todas las muestras. Este grupo estaría formado por Dicentrarchus labrax, Diplodus sargus, Sparus aurata y Scomber scombrus.

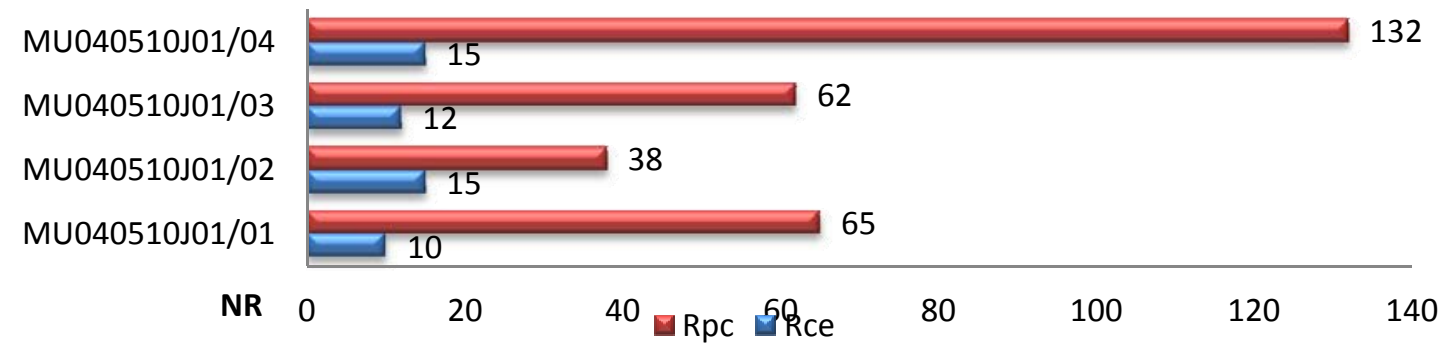

Fig. 216 Distribución esquelética de los restos ícticos de MU040510J01.

Al igual que habíamos observado en las otras columnas, predominan los restos post-cefálicos, siendo más abundantes en aquellos niveles donde hay mayor número de restos identificables. Destaca especialmente la presencia de escamas, documentándose un mayor número en aquellas muestras con menos restos.

\section{V.6.4.2. LADERA OESTE.}

\section{V.6.4.2.1. MU040806B01}

Muestra tomada en UEMTA03235. Se trataría de una muestra de la totalidad del sedimento que se encontraba rellenando las grietas de la roca bajo la estructura C.

\begin{tabular}{l|c}
\multirow{2}{*}{\multicolumn{1}{c|}{ Inicial }} & MU040806B01 \\
\cline { 2 - 2 } & $\mathbf{3 . 0 5 0}$ \\
\hline \hline Residuo & 1.257 \\
\hline Cerámica & 4 \\
Metal & 4 \\
\hline Malacofauna & $1.746,5$ \\
Macrofauna & 1,5 \\
Ictiofauna & 2 \\
Carbón & 6 \\
Indeterminado & 1 \\
\hline
\end{tabular}

Tabla 166 Pesos (en gr.) iniciales de MU040806B01 por componentes.

\begin{tabular}{lccccc} 
Mu040806B01 & $\begin{array}{c}\text { Hmd } \\
\text { (D/S) }\end{array}$ & Rce & Rpc & NR & NMI \\
\hline $\begin{array}{l}\text { Scomber scombrus } \\
\text { Indeterminado }\end{array}$ & $1 / 0$ & & & $\mathbf{1}$ & 1 \\
\hline \hline TOTAL & $\mathbf{1}$ & $\mathbf{5}$ & $\mathbf{2 4}$ & $\mathbf{3 0}$ &
\end{tabular}

Tabla 167 Relación de especies y representación ósea de MU040806B01.

En la muestra se registraron 30 restos óseos de peces, aunque únicamente se ha podido identificar un hiomandibular derecho a nivel de especie. Esta pieza craneal corresponde a un ejemplar de Scomber scombrus. El resto de huesos se identifican 
principalmente con elementos post-cefálicos, mientras que las piezas cefálicas serían cinco. Destaca la ausencia de escamas.

\section{V.6.4.2.2. MU040707B02}

Muestra tomada en UEMTA03069. Muestra aislada en el espacio E.

\begin{tabular}{l|c|}
\multirow{2}{*}{ Inicial } & MU040707B02 \\
\cline { 2 - 2 } & $\mathbf{6 6 5}$ \\
\hline \hline Residuo & 465 \\
\hline Cerámica & 3 \\
\hline Malacofauna & 178 \\
Ictiofauna & 0,5 \\
Carbón & 0,5 \\
\hline
\end{tabular}

Tabla 168 Pesos (en gr.) iniciales de MU040707B02 por componentes.

\begin{tabular}{lcccccc} 
MU040707B02 & Vca & Rce & Rpc & Esa & NR & NMI \\
\hline $\begin{array}{l}\text { Pagellus bogaraveo } \\
\text { Indeterminado }\end{array}$ & 1 & & & & $\mathbf{1}$ & 1 \\
\hline \hline TOTAL & & 1 & 16 & 1 & $\mathbf{1 8}$ & \\
\hline
\end{tabular}

Tabla 169 Relación de especies y representación ósea de MU040707B02.

En esta muestra se ha podido identificar una vértebra caudal de Pagellus bogaraveo. El resto del conjunto incluye 16 fragmentos post-cefálicos y una pieza cefálica. También se ha recuperado una escama.

\section{V.6.4.2.3. MU040713B03}

Muestra tomada en UEMTA03064. Se trata de un muestreo aislado en un depósito de tierra con conchas localizado en el interior de la estructura $\mathrm{C}$.

\begin{tabular}{l|c|}
\multirow{2}{*}{\multicolumn{1}{c|}{ Inicial }} & MU040713B03 \\
\cline { 2 - 2 } & $\mathbf{2 . 9 1 6}$ \\
\hline \hline Residuo & 1.577 \\
\hline Cerámica & 4 \\
\hline Malacofauna & $1.321,5$ \\
Macrofauna & 5 \\
Ictiofauna & 1 \\
Carbón & 0,5 \\
Indeterminado & 2,5 \\
Microfauna & 0,5 \\
\hline
\end{tabular}

Tabla 170 Pesos (en gr.) iniciales de MU040713B03 por componentes.

\begin{tabular}{ccccc} 
MU040713B03 & Vpc & Rce & NR & NMI \\
\hline Indeterminado & 1 & 2 & $\mathbf{3}$ & \\
\hline \hline TOTAL & $\mathbf{1}$ & $\mathbf{2}$ & $\mathbf{3}$ &
\end{tabular}

Tabla 171 Relación de especies y representación ósea de MU040713B03. 
Durante el procesado de esta muestra no se ha podido identificar ningún resto a nivel de especie, aunque se recuperó una vértebra precaudal en un estado de conservación aceptable. Además, se recuperaron dos fragmentos cefálicos, sin documentarse la presencia de escamas ni de restos post-cefálicos.

\section{V.6.4.2.4. MU040713B04}

Muestra tomada en UEMTA03064. Se trata de un muestreo aislado en un depósito de tierra con conchas localizado en el interior de la estructura C.

\begin{tabular}{l|c|}
\multirow{2}{*}{\multicolumn{1}{c|}{ Inicial }} & MU040713B04 \\
\cline { 2 - 2 } & $\mathbf{3 . 0 1 8}$ \\
\hline Residuo & 1.244 \\
\hline Cerámica & 5 \\
\hline Malacofauna & $1.737,5$ \\
Macrofauna & 2,5 \\
Ictiofauna & 2 \\
Carbón & 3,5 \\
\hline
\end{tabular}

Tabla 172 Pesos (en gr.) iniciales de MU040713B04 por componentes.

\begin{tabular}{cccccc} 
MU040713B04 & Vca & Rpc & Esa & NR & NMI \\
\hline Indeterminado & 1 & 3 & 1 & $\mathbf{5}$ & \\
\hline \hline TOTAL & $\mathbf{1}$ & $\mathbf{3}$ & $\mathbf{1}$ & $\mathbf{5}$
\end{tabular}

Tabla 173 Relación de especies y representación ósea de MU040713B04.

Esta muestra es similar a la anterior, con una vértebra, en este caso caudal, que no hemos podido identificar a nivel de especie, y tres restos post-cefálicos. Además se ha recuperado una escama. La ausencia de restos cefálicos o su escaso número, es un aspecto que ya habíamos documentado en la mayor parte de las muestras de este yacimiento.

\section{V.6.5. UTENSILIOS DE PESCA DOCUMENTADOS EN EL YACIMIENTO.}

Durante la intervención arqueológica se recuperaron varios objetos relacionados con la actividad pesquera. De la ladera este proceden dos anzuelos de bronce, uno de ellos exhumado en el Sondeo 2 y el otro en la excavación en área (Criado Boado et alii, 2003: 66; Aboal et alii, 2006: 267):

-PZMTA01/j005, vástago de sección circular, sin anilla. Punta saliente y arpón largo. Buen estado de conservación.

-PZMTA04/j050, pieza peor conservada que la anterior, vástago de sección circular y también sin anilla. Punta saliente y arpón largo.

Además, también se recuperaron nueve pesas que podrían estar relacionadas con la utilización de redes. Cuatro de ellas se documentaron en la ladera este (dos en UE003, una en UE012, y otra sobre el afloramiento rocoso), mientras que las cinco restantes eran de la ladera oeste (dos en los depósitos postdeposicionales de la Estructura G, una en el 


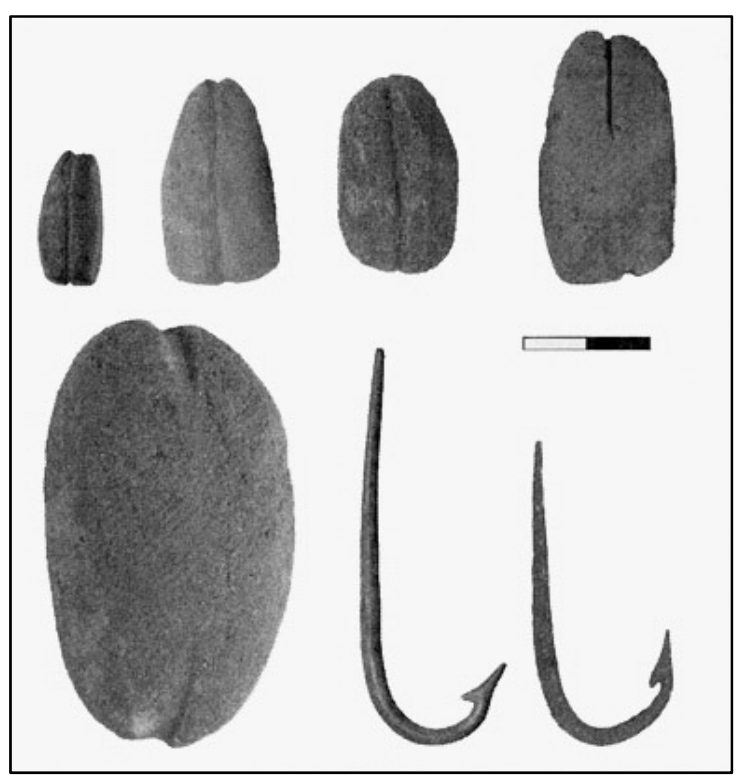

Fig. 217 Útiles de pesca documentados en Montelaegre (Aboal et alii, 2006).

nivel de uso de la Estructura D y otra en el relleno de esta misma estructura) (Cancela Cereijo, 2006: 226-227). La mayoría de las piezas estaban realizadas sobre cantos rodados de granito, estando únicamente un par de ellas realizadas en caliza. Todas las piezas muestran un tratamiento de regularización de la superficie mediante pulido, así como una acanaladura longitudinal que fue tallada en los extremos opuestos. Según su tamaño y peso se establecieron varios grupos (Cancela Cereijo, 2006: 226):

-Dos piezas de granito de forma oval, de $7 \mathrm{~cm}$ de largo y entre 4,5-5 $\mathrm{cm}$ de ancho. Grosor de 2,5-3 cm. Peso de 163 gr y $113 \mathrm{gr}$. Acanaladuras en los extremos.

-Cinco piezas de granito con forma entre ovalada y piriforme. Dimensiones entre 4,5-5 cm de largo, 2-3,3 cm de ancho, grosor entre 2 y 1,5 cm. Peso entre 3612 gr. Acanaladuras longitudinales alrededor de la pieza.

-Dos pesas de caliza piriformes de 2,5 cm de largo y entre 2-1,5 cm de ancho y $2 \mathrm{~cm}$ de grosor. Peso entre 1-3 gr. Con acanaladura en los extremos de la pieza.

\section{V.6.6. Comentario.}

\section{V.6.6.1. UNIDAD ESTRATIGRÁFICA 012.}

\section{Representación faunística.}

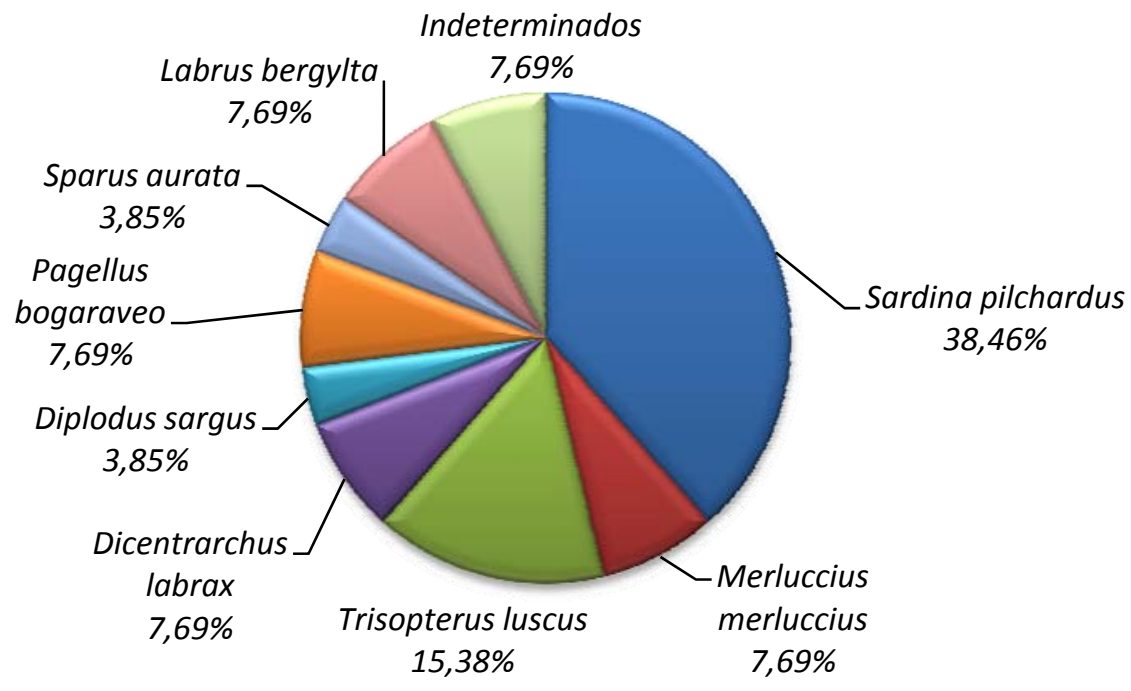

Fig. 218 Representatividad de los taxones según el NR. 


\begin{tabular}{l|c|c|c|} 
& IC & ID & ICxID \\
\cline { 2 - 4 } Sardina pilchardus & 27,3 & 41,7 & 1138,4 \\
Merluccius merluccius & 9,1 & 8,3 & 75,5 \\
Dicentrarchus labrax & 18,2 & 8,3 & 151,1 \\
Labrus bergylta & 18,2 & 8,3 & 151,1 \\
Pagellus bogaraveo & 18,2 & 8,3 & 151,1 \\
Diplodus sargus & 9,1 & 4,2 & 38,2 \\
Trisopterus luscus & 27,3 & 16,7 & 455,9 \\
Sparus aurata & 9,1 & 4,2 & 38,2
\end{tabular}

Tabla 174 Índices de valoración.

La UE 012 correspondería al nivel más antiguo de deposición del conchero, si bien no contamos con una adscripción cronológica precisa, abarcando un amplio periodo desde el siglo IV a.C. al I d.C. Pese al volumen de sedimento procesado (32 Kg.), el número de restos es muy bajo (26 restos), lo que hace difícil realizar una caracterización de la actividad pesquera. Pese a esto, podemos observar la presencia de una serie de especies con diferente importancia:

-Especies principales: La especie que presenta un mayor número de restos es Sardina pilchardus. Su pesca va a estar muy relacionada con dos factores, por un lado la estacionalidad, y por otro la utilización de redes. Los cardúmenes de esta especie se acercan a la costa en primavera y verano, introduciéndose en las rías. Debido a esto, consideramos que su aparición en el registro de Montealegre refleja una pesca estacional desarrollada en una época determinada del año. Este hecho también explicaría su presencia únicamente en algunos niveles, siendo lo más llamativo su ausencia en la columna MU040629B01.

Por otro lado, la pesca de estos cupleidos se realizaría casi exclusivamente con redes, si bien no podemos definir exactamente con qué tipo de arte.

-Especies secundarias: A este grupo adscribimos únicamente Trisopterus luscus. Pese a ser la segunda especie con mayor número de restos identificados, estos se concentran en la columna MU040629B01, en la que no se recuperaron restos de Sardina pilchardus. La ausencia de una cronología concreta para las diferentes muestras, hace sumamente complicado poder explicar este aspecto. Podríamos encontrarnos frente a muestras de diferentes periodos cronológicos. Sin embargo, también es posible el reflejo de factores estacionales, ya que esta especie se acerca a la costa entre abril y mayo para la reproducción. De todos modos, los individuos juveniles pueden localizarse en zonas de arena cerca de la costa, por lo que su captura se podría haber producido en las cercanías del yacimiento.

-Especies complementarias: En este grupo incluimos un grupo de seis especies representadas por uno o dos restos. Se trata principalmente de espáridos (Pagellus bogaraveo, Diplodus sargus y Sparus aurata), aunque también lo 
conforman serránidos (Dicentrarchus labrax), lábridos (Labrus bergylta) y gádidos (Merluccius merluccius). Todas son especies demersales, siendo posible su pesca cerca de la costa. Su presencia en las muestras es complementaria a las especies principales y a la secundaria, apareciendo rara vez dos de ellas juntas. Especies como Pagellus bogaraveo son migradoras, por lo que su aproximación al litoral se produce en primavera, algo similar a lo comentado para Sardina pilchardus, vinculándose por tanto su captura a determinadas épocas del año. El caso contrario sería Labrus bergylta, especie muy territorial y sedentaria. Su presencia es habitual en los yacimientos gallegos de este periodo, por lo que su bajo número habría que relacionarlo con las condiciones físicas de la ría en el entorno del yacimiento. También es interesante el caso de Merluccius merluccius, ya que no suele ser muy habitual en yacimientos castreños, del mismo modo que hoy en día no es posible encontrarla en el interior de las rías ni cerca de la costa.

Todas estas especies son susceptibles de haber sido consumidas, sin que existan elementos que nos indiquen una posible intrusión o un uso diferente.

\section{Representatividad ósea.}

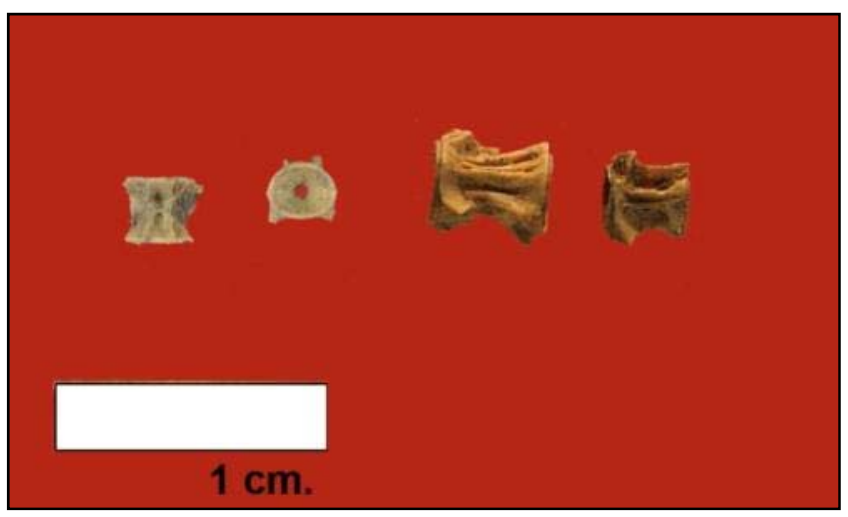

Fig. 219 Vértebras de Sardina pilchardus y Trisopterus luscus.

Es llamativa la presencia casi única de piezas post-cefálicas, identificándose únicamente un otolito de Trisopterus luscus. En cuanto a los restos no identificados taxonómicamente, también son mayoritarios los fragmentos postcefálicos. En las especies documentadas, la posibilidad de encontrar restos cefálicos y postcefálicos parece ser bastante similar (Roselló, 1989: 592-605). De hecho, entre los espáridos, dentario y premaxilar son más resistentes que las vértebras (Roselló, 1989: 592-605). Por este motivo consideramos que lo aquí documentado puede ser debido a algún patrón de procesado previo al consumo. En el mismo sentido, es significativa la escasa presencia de escamas, que aun cuando sea bajo el número de ejemplares constatado, su representación sigue siendo muy exigua. Tanto la ausencia de restos cefálicos como de escamas, puede estar vinculada a la limpieza de los ejemplares, que conllevaría un descabezamiento y la eliminación de la mayor parte de las escamas. La ausencia de estas partes en los concheros nos sugiere que este procesado primario se realizaría en otro lugar, ya fuera en otra zona del asentamiento o en la misma costa al realizar las capturas. 


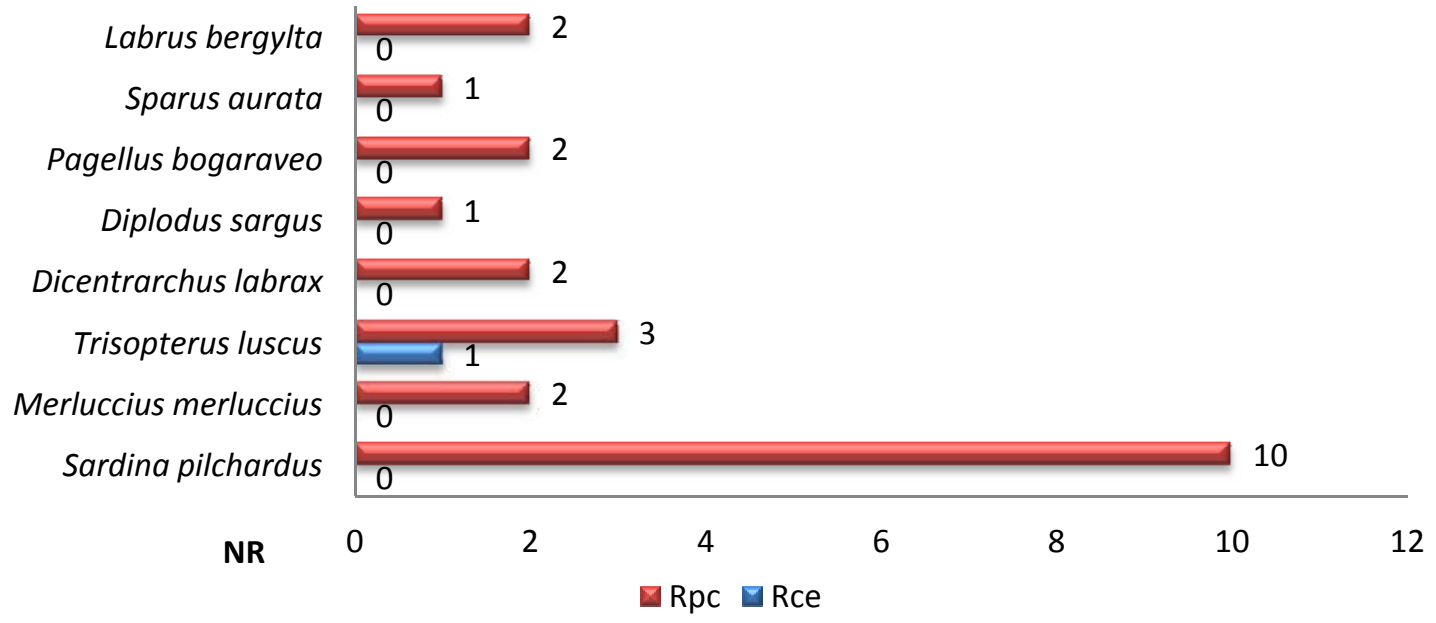

Fig. 220 Comparación numérica de los restos cefálicos y postcefálicos de los diferentes taxones identificados.

Es destacable la ausencia de restos identificables en ciertas muestras, como por ejemplo las 7 y 8 de la columna MU040712101, donde únicamente se recuperaron huesos pertenecientes a las costillas o alguna escama.

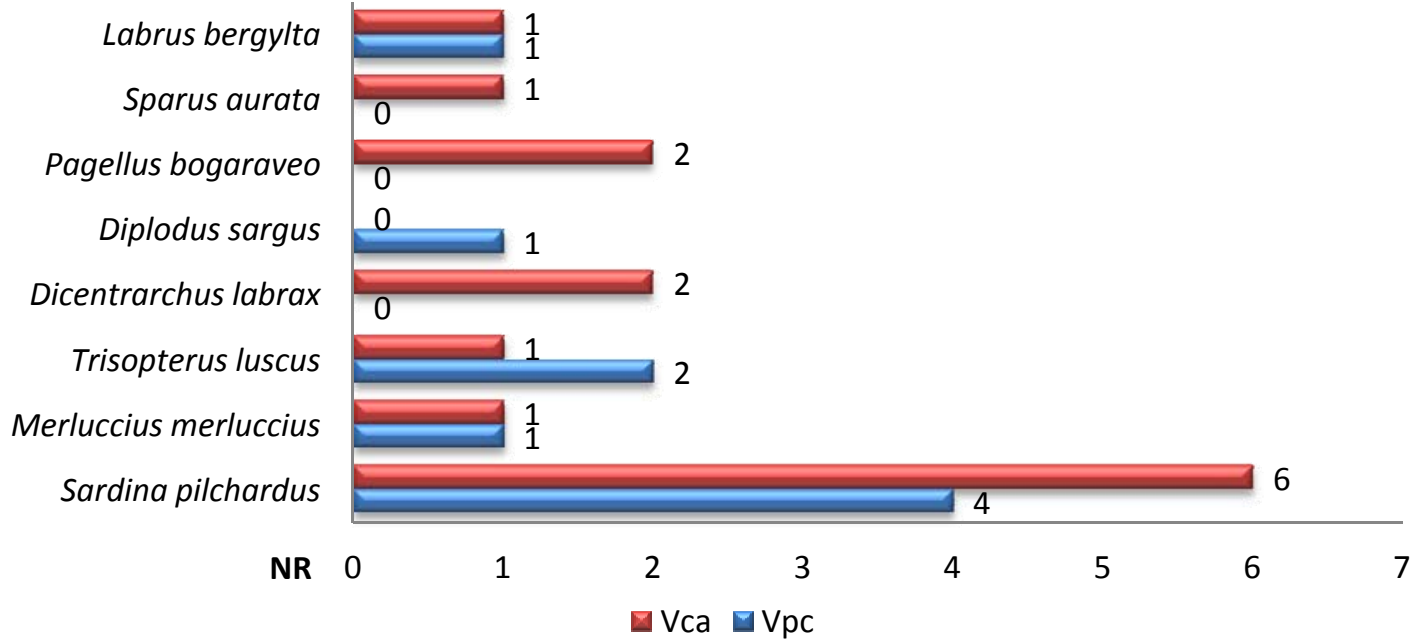

Fig. 221 Comparación numérica de las vértebras caudales y precaudales de los diferentes taxones identificados. 


\section{V.6.6.2. UNIDAD ESTRATIGRÁFICA 003.}

\section{Representación faunística.}

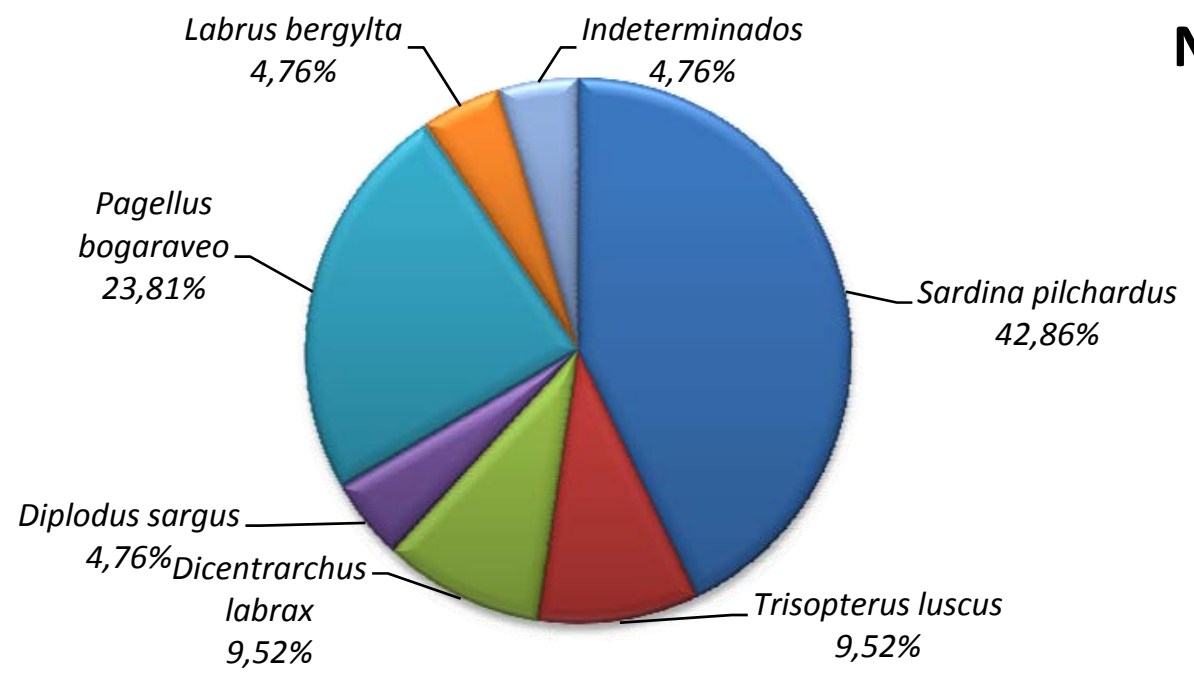

NR: 21

Fig. 222 Representatividad de los taxones según el NR.

\begin{tabular}{l|c|c|c|} 
& IC & ID & ICxID \\
\cline { 2 - 4 } Sardina pilchardus & 80 & 45 & 3600 \\
Dicentrarchus labrax & 20 & 10 & 200 \\
Pagellus bogaraveo & 80 & 25 & 2000 \\
Trisopterus luscus & 40 & 10 & 400 \\
Diplodus sargus & 20 & 5 & 100 \\
Labrus bergylta & 20 & 5 & 100
\end{tabular}

Tabla 175 Índices de valoración.

La UE003, localizada sobre UE012, tiene una cronología comprendida entre el siglo II a.C. y el I d.C. La unidad presentaba un importante volumen de sedimento, pudiendo haberse formado este nivel por arrastre de los materiales situados en la parte alta del conchero. El número de restos es similar al documentado en la UE012, aunque el número de muestras es menor. Los restos de cada especie se repartirían de la siguiente manera:

-Especies principales: Como en la unidad estratigráfica anterior, la especie mejor representada es Sardina pilchardus, con casi la mitad de los restos. El número de piezas óseas va a ser similar al de la UE012. Por lo tanto, creemos que su pesca estaría condicionada a las migraciones estacionales que realiza esta especie, realizándose esta por medio de redes.

Se ha identificado en todas las muestras menos en la MU040712102/02, si bien siempre con un escaso número de restos.

-Especies secundarias: En este caso la segunda especie con más restos y mayor presencia es Pagellus bogaraveo. Esta especie demersal ocupa zonas fangosas y de cascajo, por lo que podría ser capturada en las cercanías del 
yacimiento. Pero su captura tendría un carácter estacional, ya que desciende a zonas profundas durante el invierno. En consecuencia, nos encontramos con que las dos especies principales se caracterizan por sus ritmos estacionales, condicionando en consecuencia la actividad pesquera. Por otro lado en la columna MU040712102 su presencia está ligada a Trisopterus luscus, no apareciendo asociado en ninguna de estas columnas a Dicentrarchus labrax.

-Especies complementarias: Por último, nos encontramos de nuevo con un grupo diverso de especies, si bien en esta ocasión en menor cantidad. Las diferentes familias representadas van a distribuirse equitativamente: una especie de espáridos (Diplodus sargus), de serránidos (Dicentrarchus labrax), de lábridos (Labrus bergy/ta) y de gádidos (Trisopterus luscus). De nuevo se trata de especies demersales que pueden ser pescadas desde la costa y que habitarían en un medio similar al que se puede encontrar hoy en día en el entorno del yacimiento.

A igual que veíamos con anterioridad, todas las especies habrían servido como alimento.

\section{Representatividad ósea.}

Entre los restos identificados únicamente se recuperaron centros vertebrales. Por otro lado, entre los no identificados, se recuperaron más huesos post-cefálicos, aunque aumentó la presencia de restos cefálicos. Algo similar podemos decir para las escamas: aunque siguen siendo muy escasas, su número se ha incrementado. Por lo tanto nos encontramos con la misma situación que observamos en la UE012 y que, como en la UE anterior, podría relacionarse con los diversos procesos de tratamiento del pescado previos al consumo.

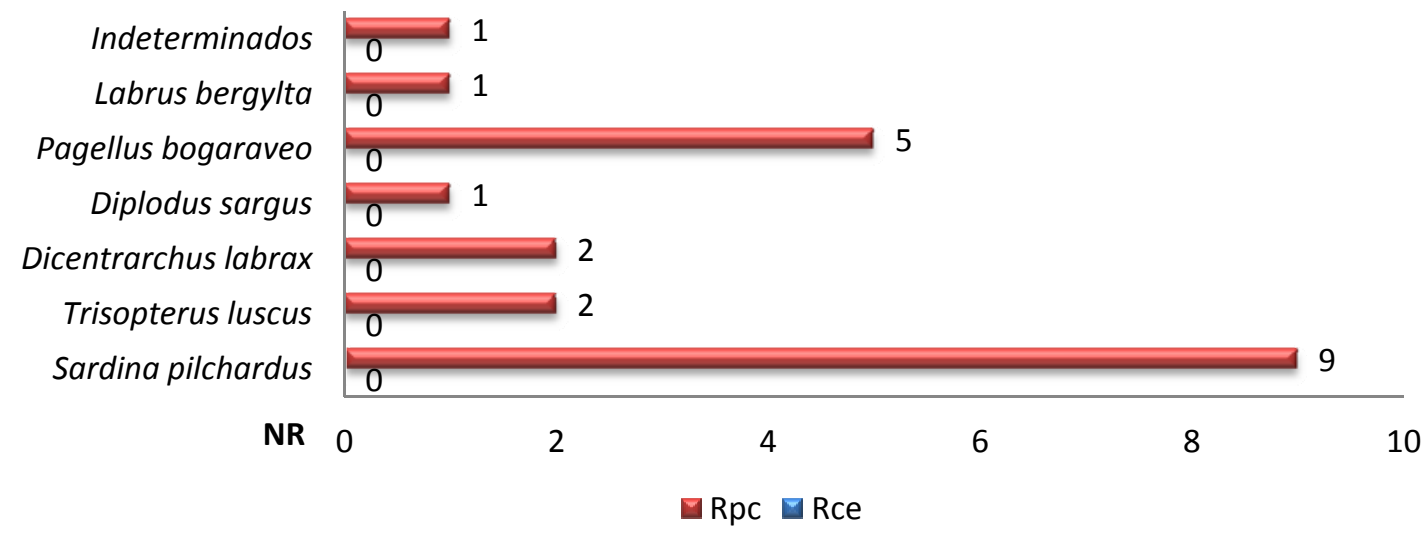

Fig. 223 Comparación numérica de los restos cefálicos y post-cefálicos de los taxones identificados.

De nuevo contamos con un exiguo registro que nos impide valorar correctamente la existencia de algún patrón vinculado a tratamientos de despiece o conservación. Sin embargo, y comparándolo con los resultados obtenidos en la UE012, se observa que 
Pagellus bogaraveo y Dicentrarchus labrax están representados en UE003 únicamente por vértebras caudales.

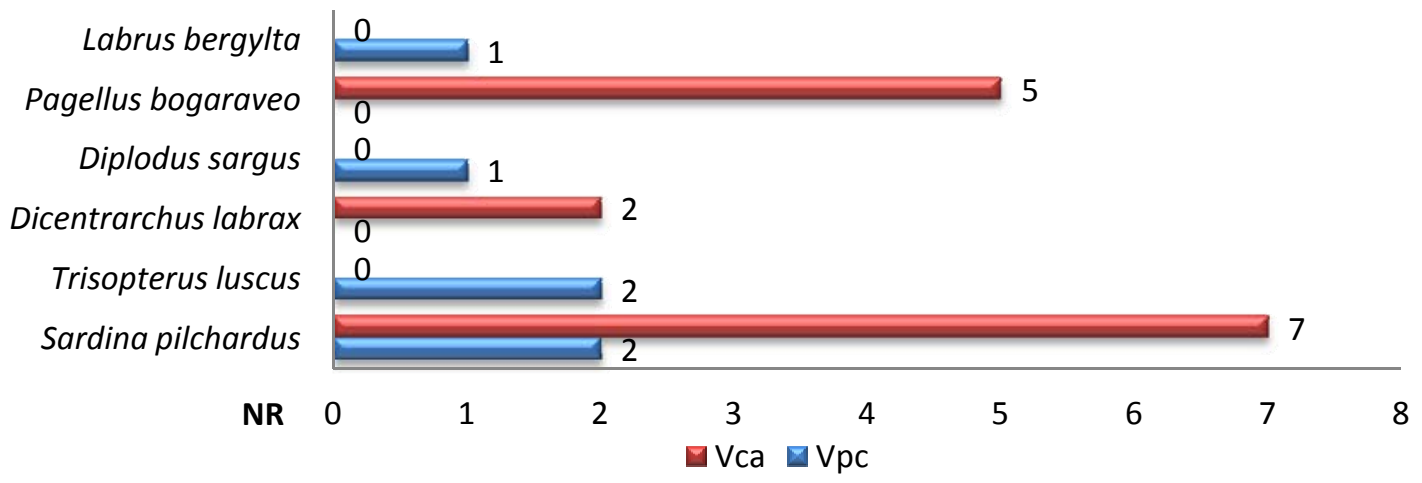

Fig. 224 Comparación numérica de las vértebras caudales y precaudales de los taxones identificados.

\section{V.6.6.3. SONDEO 2.}

\section{Representación faunística.}

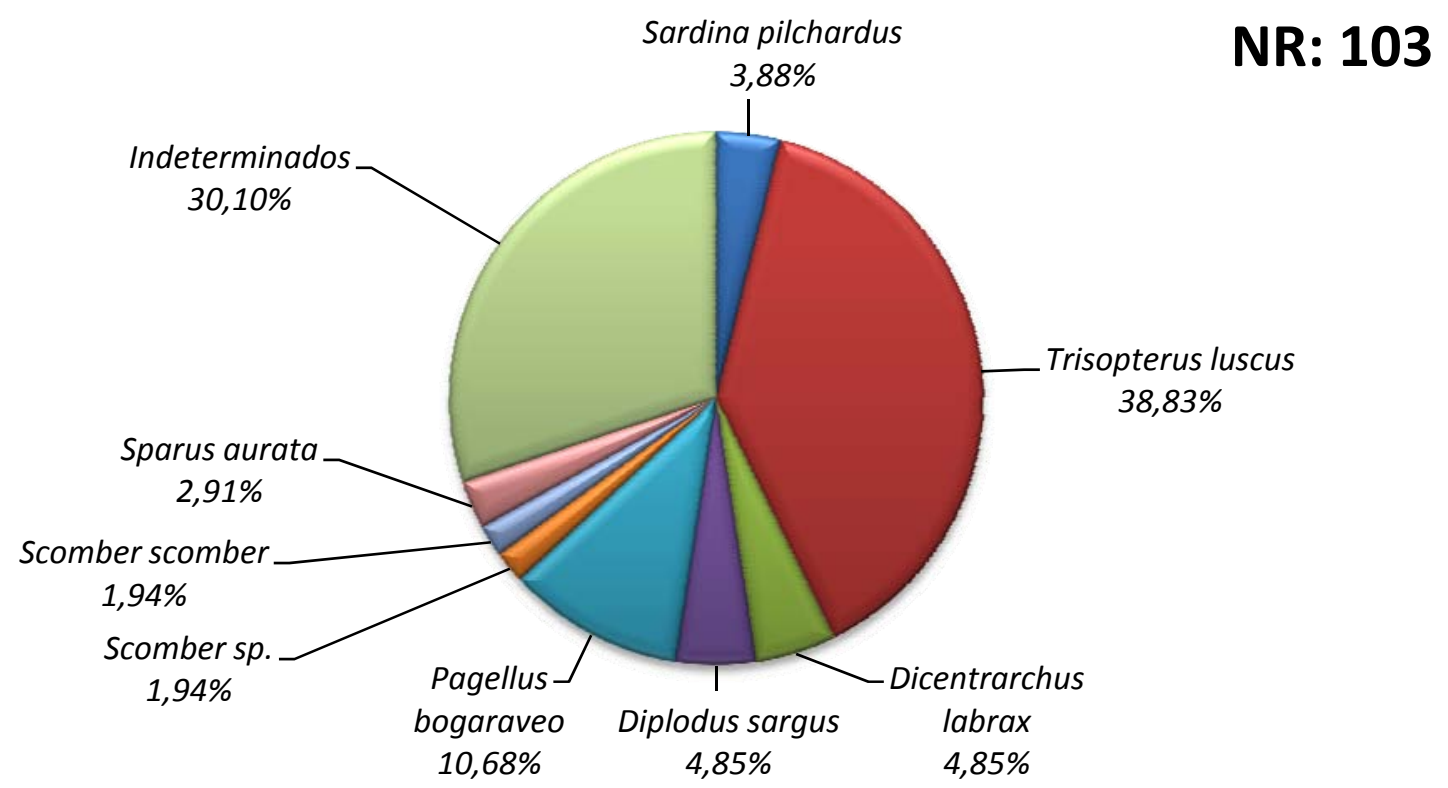

Fig. 225 Representatividad de los taxones según el NR.

\begin{tabular}{l|c|c|c|} 
& IC & ID & ICxID \\
\cline { 2 - 4 } Trisopterus luscus & 100 & 55,6 & 5560 \\
Dicentrarchus labrax & 40 & 6,9 & 276 \\
Diplodus sargus & 40 & 6,9 & 276 \\
Pagellus bogaraveo & 60 & 15,3 & 918 \\
Scomber sp. & 20 & 2,8 & 56 \\
Sardina pilchardus & 40 & 5,6 & 224 \\
Sparus aurata & 30 & 4,2 & 126 \\
Scomber scombrus & 20 & 2,8 & 56
\end{tabular}


Las muestras del Sondeo 2 se adscriben a una cronología comprendida entre los siglos III-I a.C. En un principio es similar a la establecida en el resto de columnas, aunque hemos observado cambios sustanciales en la composición faunística. De nuevo, la imprecisión cronológica y estratigráfica del depósito impide realizar una valoración más pormenorizada de los diferentes conjuntos. La distribución de las especies es la siguiente:

-Especies principales: De nuevo apreciamos que la mitad de los restos pertenecen a una única especie. En este caso, además con un número más elevado de piezas óseas que en los conjuntos anteriores. De este modo Trisopterus luscus sería la especie mejor representada en el yacimiento. Suele ocupar fondos rocosos con algas, aunque es posible encontrar bancos de juveniles en zonas arenosas. Por lo tanto su captura es probable que se produjera en las cercanías del asentamiento, no siendo necesario el empleo de artes muy complejas. Sus restos aparecieron en todas las muestras del sondeo 2 , siendo también muy importante su presencia en las otras columnas, como habíamos visto anteriormente.

-Especies secundarias: Pagellus bogaraveo formaría de nuevo este grupo, si bien hay que tener en cuenta que un $30 \%$ del total de los restos recuperados no ha podido ser identificado taxonómicamente. Como vemos, las especies con proceso migratorio más marcado siguen teniendo un papel importante dentro del conjunto. Su pesca también se realizaría en las cercanías del yacimiento, siendo similares las artes empleadas en su captura a las utilizadas para Trisopterus luscus. Su presencia se va a centrar principalmente en la columna MU040510J01, mientras que en la columna MU040426I01 solo se encuentra en las Muestras 02 y 03.

-Especies complementarias: En esta categoría se incluyen las demás especies documentadas. La familia mejor representada en cuanto a especies y número de restos es la de los espáridos (Sparus aurata; Diplodus sargus), aunque también están presentes otras: serránidos (Dicentrarchus labrax), escómbridos (Scomber scombrus) y cupleidos (Sardina pilchardus). Basicamente son las mismas especies que formaban el grupo de complementarias en los otros conjuntos, a excepción de las dos últimas. La presencia de Sardina pilchardus se restringe a la mitad inferior de la columna MU040426101, que coincide con las muestras en las que no se han documentado restos de Pagellus bogaraveo. En el caso de Scomber scombrus, únicamente se documentó un resto en la ladera oeste, con una problemática peculiar que comentaremos más adelante. Esta especie también es estacional, acercándose a la costa a finales de primavera. Aunque suele ser pesca con redes, puede ser capturada con anzuelo desde pequeñas embarcaciones. Los restos parecen responder a una actividad alimenticia. 


\section{Representatividad ósea.}

Frente a lo observado en los otros conjuntos, es importante la representación de restos cefálicos, siendo los más numerosos en algunas especies como Diplodus sargus. Los únicos taxones para los que no se han identificado restos cefálicos son Sparus aurata y Sardina pilchardus. El registro de Sparus aurata contrasta con lo observado en otros yacimientos como el de O Achadizo (Ferré, 2003), donde los restos cefálicos son los predominantes. En cuanto a la ausencia de restos cefálicos de Sardina pilchardus, puede deberse tanto a una mayor dificultad a la hora de su preservación debido a que son más frágiles que los de otras especies, como a su consumo, favorecido también por este aspecto. El predominio de los restos post-cefálicos, tanto en indeterminados como en identificados, es normal si tenemos en cuenta la mejor conservación de estas partes anatómicas (Roselló, 1989: 592-605).

En definitiva, observamos que en este depósito se están depositando individuos bastante completos. Este hecho también lo corrobora la mayor presencia de escamas y de restos indeterminados como costillas, radios o fragmentos de cráneo.

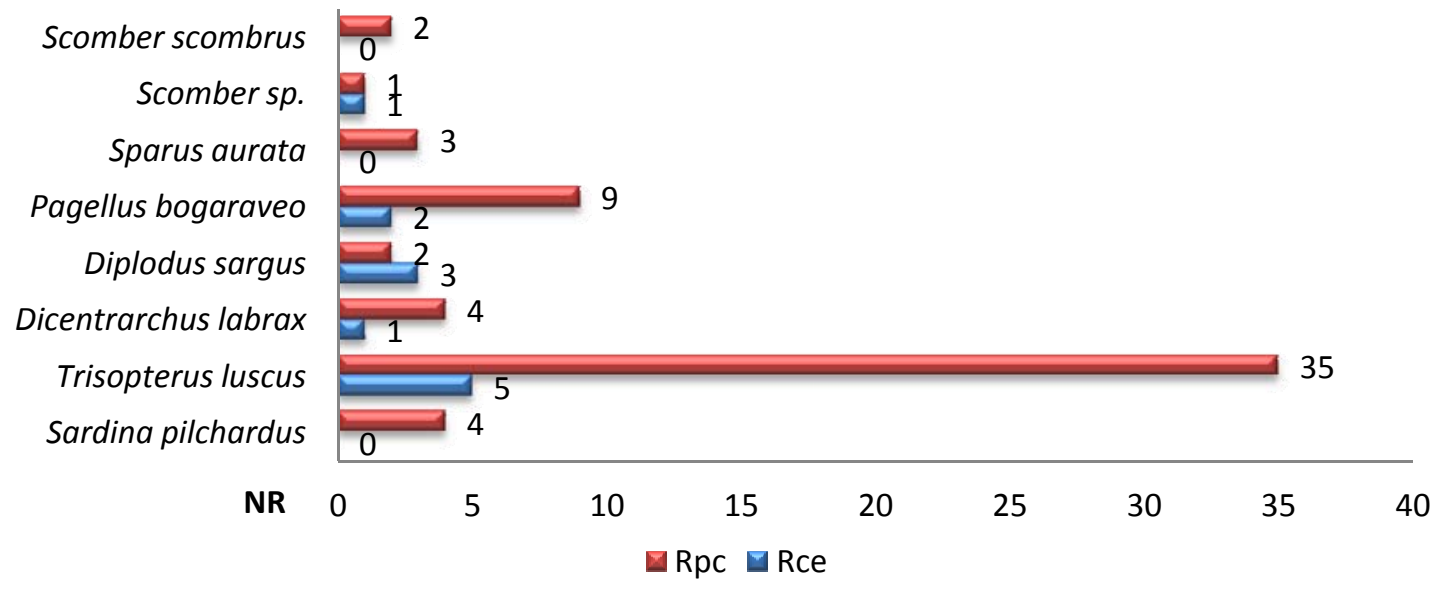

Fig. 226 Comparación numérica de los restos cefálicos y post-cefálicos de los taxones identificados.

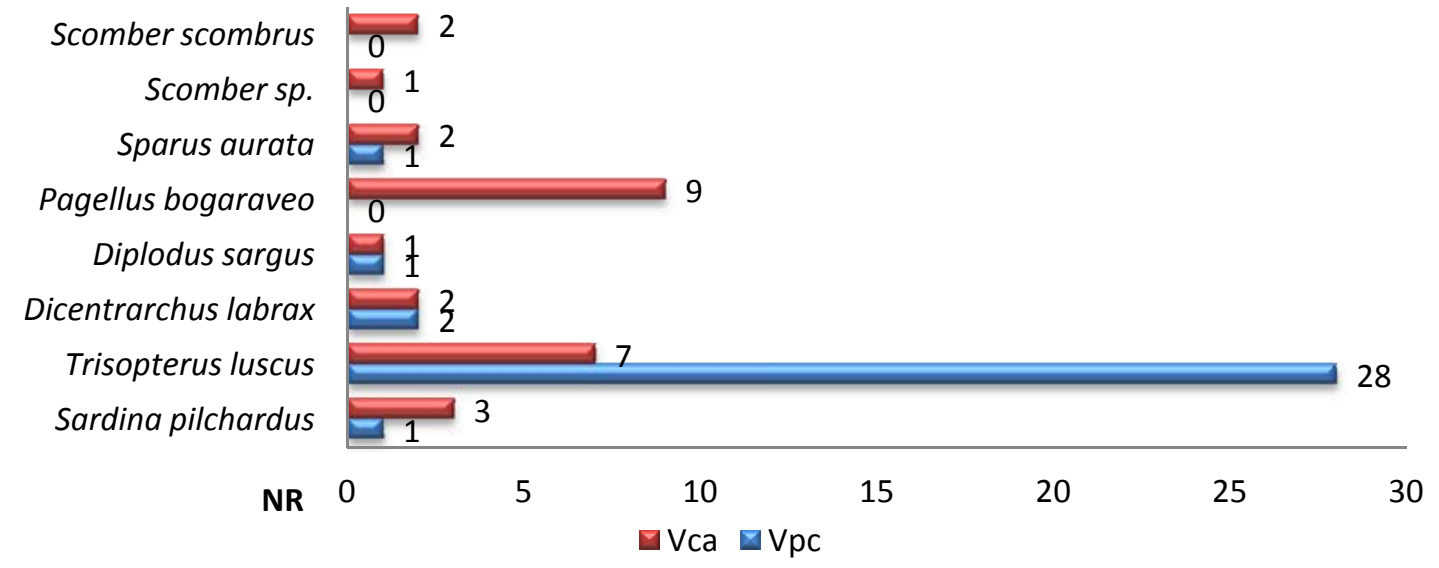

Fig. 227 Comparación numérica de las vértebras caudales y precaudales de los taxones identificados. 
En cuanto a los centros vertebrales, van a predominar los caudales, algo que ya habíamos visto en los demás conjuntos, sin que de modo general se pueda observar ningún patrón. Sin embargo, sí es significativa la presencia únicamente de vértebras caudales de algunas especies en todos los conjuntos, como es el caso de Pagellus bogaraveo (una de las especies con mayor representación), cuando además de este taxón únicamente se han identificado dos restos cefálicos. Algo similar se puede decir para Scomber scombrus, aunque sus restos son muy pocos para poder establecer algún patrón.

\section{V.6.7. CONSIDERACIONES FINALES.}

Los restos ictiológicos más antiguos del yacimiento proceden de la muestra MU040806B01, datados en la transición de la I Edad del Hierro a la II Edad del Hierro, lo que la convierte en la referencia a ictiofauna más antigua para la Cultura Castreña. La muestra es sumamente pequeña, aportando exclusivamente un hiomandibular de Scomber scombrus, y 29 restos indeterminados. Al mismo tiempo, esta muestra presenta una serie de problemas, que van desde su localización rellenando una grieta, a su adscripción cronológica y a la especie identificada. Según diferentes autores, en fases prerromanas no se utilizarían redes para la pesca (Vázquez Varela et alii, 1993; Ferré y Rey, 1998; Ferré, 2003), y esta especie, aunque no deba ser necesariamente pescada con este arte, suele ser capturada de este modo. De todos modos, la falta de un mayor volumen de restos identificables impide realizar una caracterización de la pesca durante este momento. Por lo tanto, debemos tener cuidado al valorar esta muestra y esperar a contar con más datos que clarifiquen lo expuesto.

Según los taxones, y los restos recuperados, podemos diferenciar dos conjuntos en la ladera este, con unas características propias. Por un lado se las columnas MU040629B01, MU040712I01 y MU040712I02, y por otro las columnas MU040510J01 y MU040426101. La falta de dataciones más precisas no nos permite corroborar la relación existente entre las diferencias detectadas en los depósitos y su adscripción cronológica. La excavación del conchero se realizó de forma masiva, al considerar únicamente la existencia de dos unidades estratigráficas según la mayor o menor presencia de sedimento, sin tener en cuenta la estratigrafía interna de estas acumulaciones de echadizos. Al procesar las muestras hemos identificado la presencia de tres niveles (UE003 y UE012a-UE012b) según la cantidad de sedimento inorgánico. Un análisis de dispersión de los materiales podría ayudar a aclarar mínimamente este problema, aunque sin duda una excavación y registro por capas (Bejega García et alii, 2010) es la única forma de leer correctamente estos depósitos. De todos modos, creemos que estas diferencias que hemos detectado reflejan episodios de formación en periodos cronológicamente diferentes.

Pese a que la familia de los espáridos es la que más especies aporta, no va a ser la que presente esté representada por un mayor volumen de restos. La actividad pesquera se va a centrar principalmente en tres especies: Trisopterus luscus, Sardina pilchardus y Pagellus bogaraveo. Por lo tanto, la pesca va a verse sujeta a un marcado carácter 
estacional, centrada principalmente en los meses de verano y primavera. El hecho de que Trisopterus luscus sea demersal, y no tenga un carácter estacional tan marcado como Sardina pilchardus o Pagellus bogaraveo, puede explicar que sea la especie numéricamente más importante en el registro. El aprovechamiento de las especies pelágicas en la Península Ibérica parece haber cumplido un papel secundario hasta la llegada de los pueblos del Mediterráneo oriental, a lo que hay que sumar el hecho de que las especies demersales son mucho más regulares (Morales, 2008).

Es posible que existieran periodos en los que no se realizarían actividades pesqueras, y sin embargo se consumiría pescado tratado para su conservación. Este fenómeno podría quedar reflejado en el registro mediante muestras con pocos restos, de los cuales la mayoría son indeterminados. De todos modos, para confirmar esta hipótesis, además de precisar mejor la época de captura de cada especie sería necesario realizar estudios de edad y estacionalidad.

Aunque va a primar el pescado blanco, los pescados azules y semigrasos también tienen un importante papel. Por el número de restos que hemos documentado, parece que estamos ante una explotación de subsistencia en la que el pescado, aunque importante, no sería un producto prioritario. Todas las especies parecen haber servido para el consumo en el asentamiento. Los peces serían descabezados, parcial o totalmente, y descamados antes de entrar en el yacimiento por lo visto en las columnas MU040629B01, MU040712I01 y MU040712I02. Sin embargo, en el sondeo 02 parece que sí llegaron peces parcialmente completos. Aunque no podemos asegurar la realización de conservas, no descartamos su presencia, si bien se destinarían al autoconsumo.

Parece seguro el empleo de artes de red, como sugiere la documentación de especies pelágicas y gregarias como Sardina pilchardus, y la recuperación de pesas en niveles del siglo II a.C. Estas pesas son de tres tipos, según su tamaño y morfología, pero ¿pertenecen todas a pesas de red o pueden pertenecer a otras artes? Seguramente tengamos que relacionarlas con diferentes aparejos, desde redes a pesca con anzuelo o nasas. En el conchero también se recuperaron dos anzuelos de tipo "J". La variedad de especies que pueden ser pescadas con estos anzuelos es muy amplia y las identificadas en las muestras analizadas se incluyen entre ellas. Por lo tanto parece clara la utilización de este elemento, bien con caña, bien con palangres o con líneas de anzuelos. 


\section{V.7. El Castro de Punta do Muiño do Vento.}

\section{V.7.1. LOCALIZACIÓN GEOGRÁFICA.}

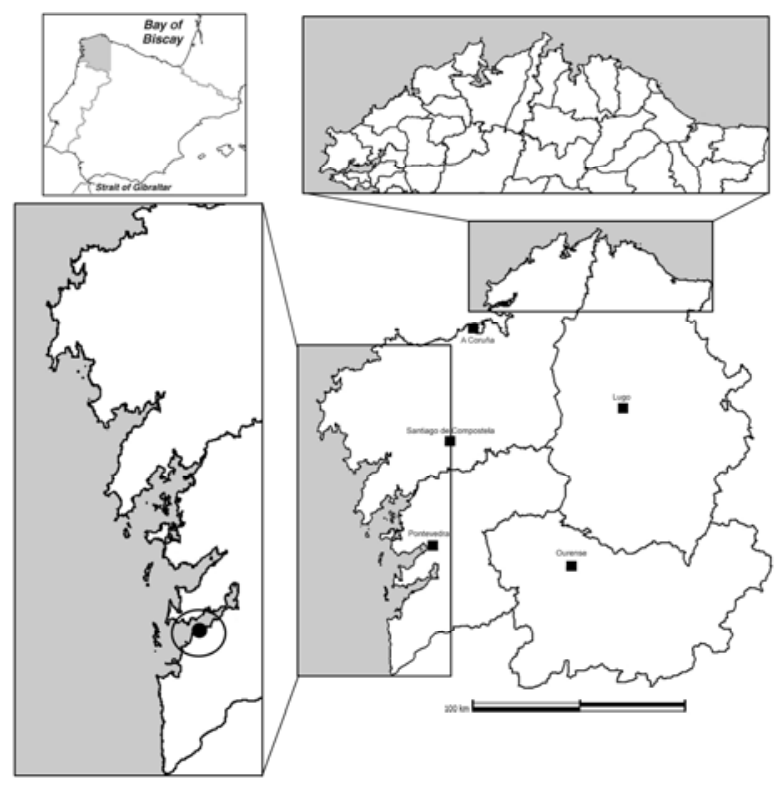

Fig. 228 Localización del yacimiento de Punta do Muiño do Vento.
Yacimiento localizado en la parroquia de Santa Baia de Alcabre, en el Concello de Vigo. Se sitúa en un pequeño promontorio que se adentra en el mar. Sus coordenadas son $8^{\circ} 46^{\prime} 11.96^{\prime \prime} \mathrm{W}$ y $42^{\circ} 13^{\prime}$ 27.57" $\mathrm{N}^{7}$.Se trataría de un castro de tipo litoral.

\section{V.7.2. RECOGIDA DE LAS MUESTRAS.}

\section{V.7.2.1. EL MUESTREO.}

El conchero fue recogido en su totalidad de forma masiva, separado en diferentes bolsas numeradas, aunque desconocemos la posición concreta dentro del depósito de cada una de ellas. Pese a que este método de recogida no es el más adecuado, el muestreo sí es representativo, ya que las muestras se recogieron de forma aleatoria y no selectiva. Para este trabajo únicamente se ha analizado una muestra, si bien esta contaba con un importante volumen de sedimento.

\section{V.7.2.2. CRONOLOGÍA.}

Este yacimiento está funcionando desde los siglos VI-V a.C. como puerto comercial, abandonándose en el siglo II a.C. por el oppidum de Vigo. El conchero fue localizado sobre el poblado abandonado, recuperándose restos de Haltern 70, Dressel 18/Mañá C y Terra sigilata itálica, por lo que se podría datar en la Fase III de la Cultura Castreña (González Ruibal, 2006/07b: 302; 340).

\footnotetext{
${ }^{7}$ Datum: ETRS89; Uso: 29; UTM: X 518.982/Y 4.745.462.
} 


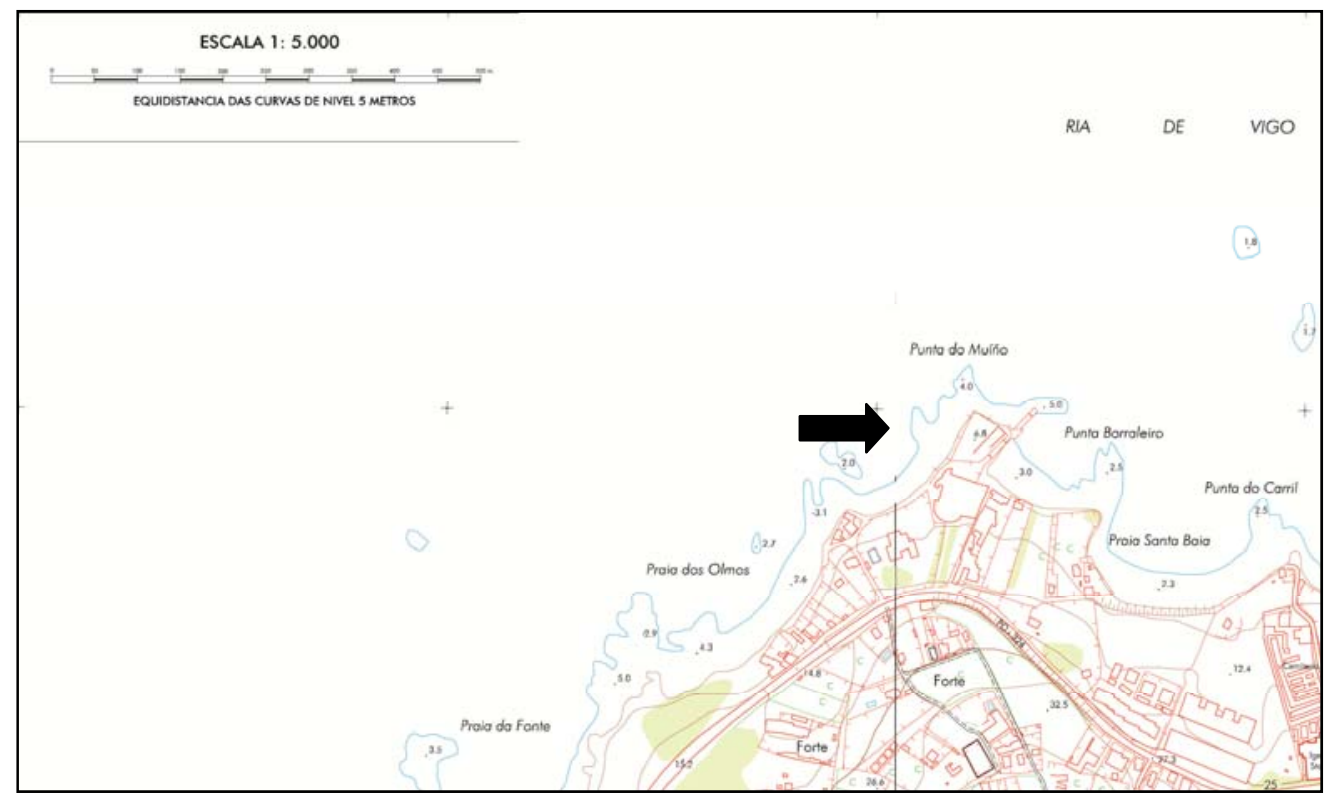

Fig. 229 Topográfico 1:5.000 de Punta do Muiño y localización de las intervenciones. (Extraído de http://sitga.xunta.es/sitga).

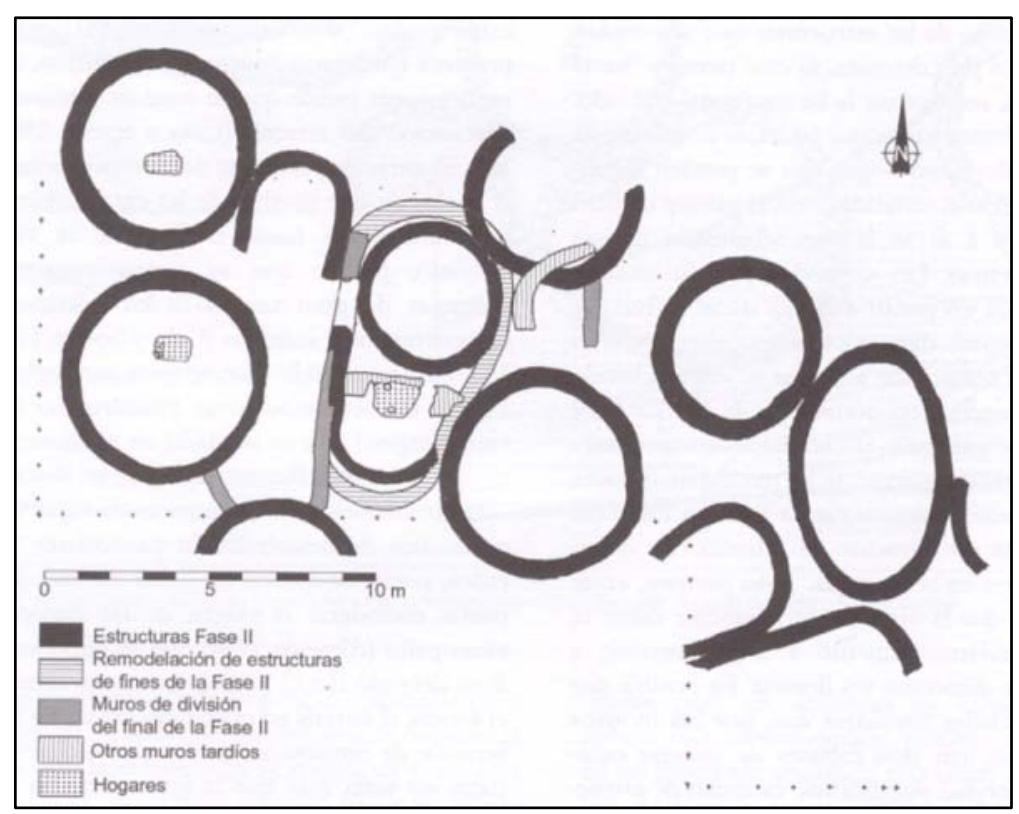

Fig. 230 Planimetría del Castro de Punta do Muiño do Vento (González Ruibal, 2006/07).

\section{V.7.3. ESTUDIO ICTIOARQUEOLÓGICO.}

\begin{tabular}{l|c|}
\multirow{2}{*}{\multicolumn{1}{c|}{ Inicial }} & gr. \\
\cline { 2 - 2 } & $\mathbf{2 1 . 4 6 0}$ \\
\hline Residuo & 17.565 \\
\hline Cerámica & 127,5 \\
\hline Malacofauna & $4.327,5$ \\
Macrofauna & 141,5 \\
Ictiofauna & 24,5 \\
Carbón & 18,5 \\
\hline
\end{tabular}

Tabla 177 Pesos (en gr.) iniciales por componentes. 


\begin{tabular}{|c|c|c|c|c|c|c|c|c|c|c|c|c|c|c|}
\hline & $\begin{array}{l}\text { Pmx } \\
\text { (D/S) }\end{array}$ & $\begin{array}{l}\text { Max } \\
\text { (D/S) }\end{array}$ & $\begin{array}{c}\text { Dnt } \\
\text { (D/S) }\end{array}$ & $\mathrm{Cbr}$ & $\begin{array}{l}\text { Cdr } \\
\text { (D/S) }\end{array}$ & $\begin{array}{l}\text { Pal } \\
\text { (D/S) }\end{array}$ & $\begin{array}{l}\text { Oto } \\
\text { (D/S) }\end{array}$ & Vpc & Vca & Rce & Rpc & Esa & NR & NMI \\
\hline Sardina pilchardus & & & & & & & & 8 & 6 & & & & 14 & 1 \\
\hline Merluccius merluccius & & & & & & & & & 1 & & & & 1 & 1 \\
\hline Trisopterus luscus & & & & & & & 2 & 1 & 9 & & & & 12 & 1 \\
\hline Dicentrarchus labrax & & & & & & & & 1 & 5 & & & & 6 & 1 \\
\hline Diplodus sargus & $0 / 1$ & & $1 / 0$ & 4 & $0 / 1$ & $1 / 0$ & & & 2 & & & & 10 & 4 \\
\hline Diplodus vulgaris & & & & & & & & & 1 & & & & 1 & 1 \\
\hline Pagellus bogaraveo & $0 / 1$ & $1 / 0$ & & & $1 / 0$ & $1 / 0$ & & 2 & 5 & & & & 11 & 1 \\
\hline Scomber scombrus & & & & & & & & & 1 & & & & 1 & 1 \\
\hline Scomber japonicus & & & & & & & & & 1 & & & & 1 & 1 \\
\hline Indeterminado & & & & & & & & & 4 & 79 & 274 & $12 \mathrm{gr}$ & 357 & \\
\hline TOTAL & 2 & 1 & 1 & 4 & 2 & 2 & 2 & 12 & 35 & 79 & 274 & & 414 & \\
\hline
\end{tabular}

En la muestra se han identificado nueve taxones con diferente representación. El que más restos presenta es Sardina pilchardus, con ocho vértebras precaudales y seis vértebras caudales. A continuación se sitúan Trisopterus luscus, con dos otolitos, una vértebra precaudal y nueve vértebras caudales; Diplodus sargus, con un premaxilar izquierdo, un dentario derecho, cuatro ceratobranquiales, un cuadrado derecho, un palatino derecho y dos vértebras caudales, y Pagellus bogaraveo, con un premaxilar izquierdo, un maxilar derecho, un cuadrado derecho, un palatino derecho, dos vértebras precaudales y cinco vértebras caudales. Dicentrarchus labrax está representada por una vértebra precaudal y cinco vértebras caudales. Por último, contaríamos con cuatro especies (Merluccius merluccius, Diplodus vulgaris, Scomber scombrus y Scomber japonicus) representadas únicamente por una vértebra caudal.

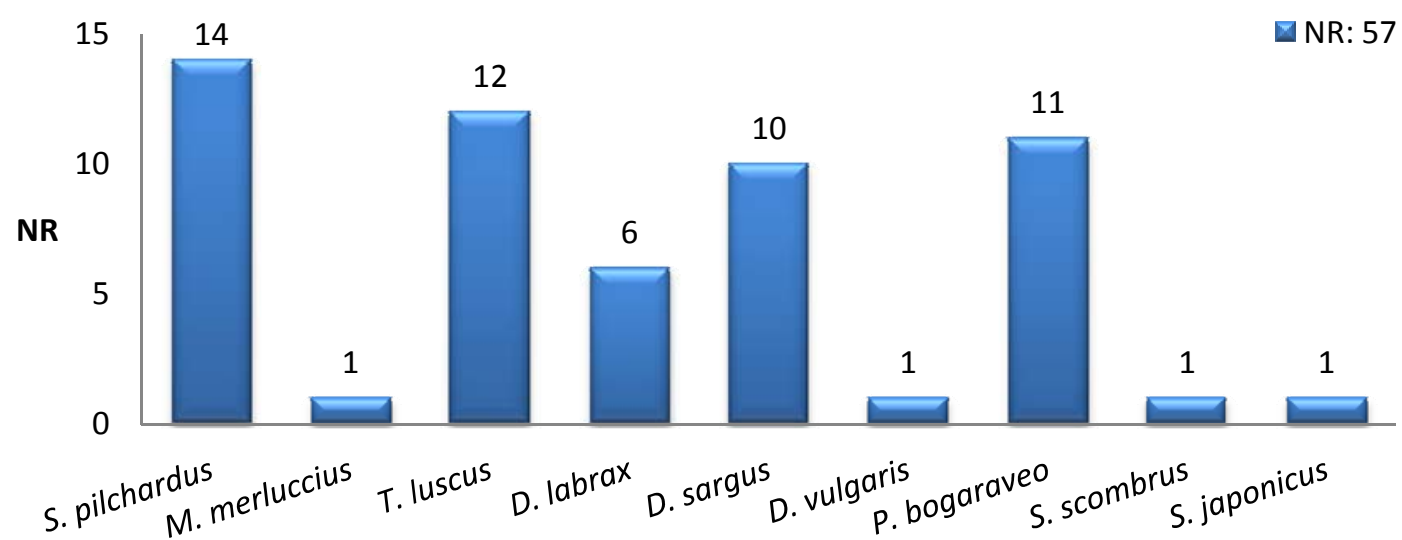

Fig. 231 Distribución de taxones identificados según el NR.

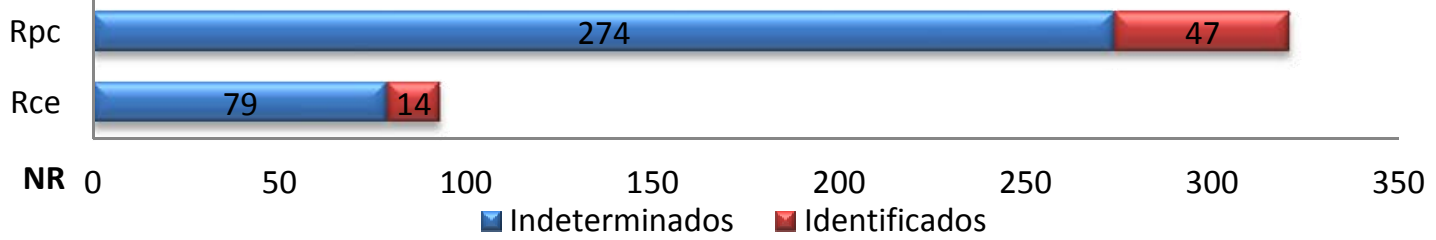

Fig. 232 Distribución esquelética de los restos ícticos. 
La mayor parte de los restos óseos documentados pertenecen a restos postcefálicos, tanto entre los identificados a nivel de especie como entre los indeterminados. Los huesos cefálicos que hemos identificado pertenecen casi en su totalidad a un grupo muy reducido de taxones. La mayoría de los restos se identifican con centros vertebrales, principalmente con vértebras caudales. Es destacable el elevado número de escamas recuperadas.

\section{V.7.4. COMENTARio.}

\section{Representación faunística.}

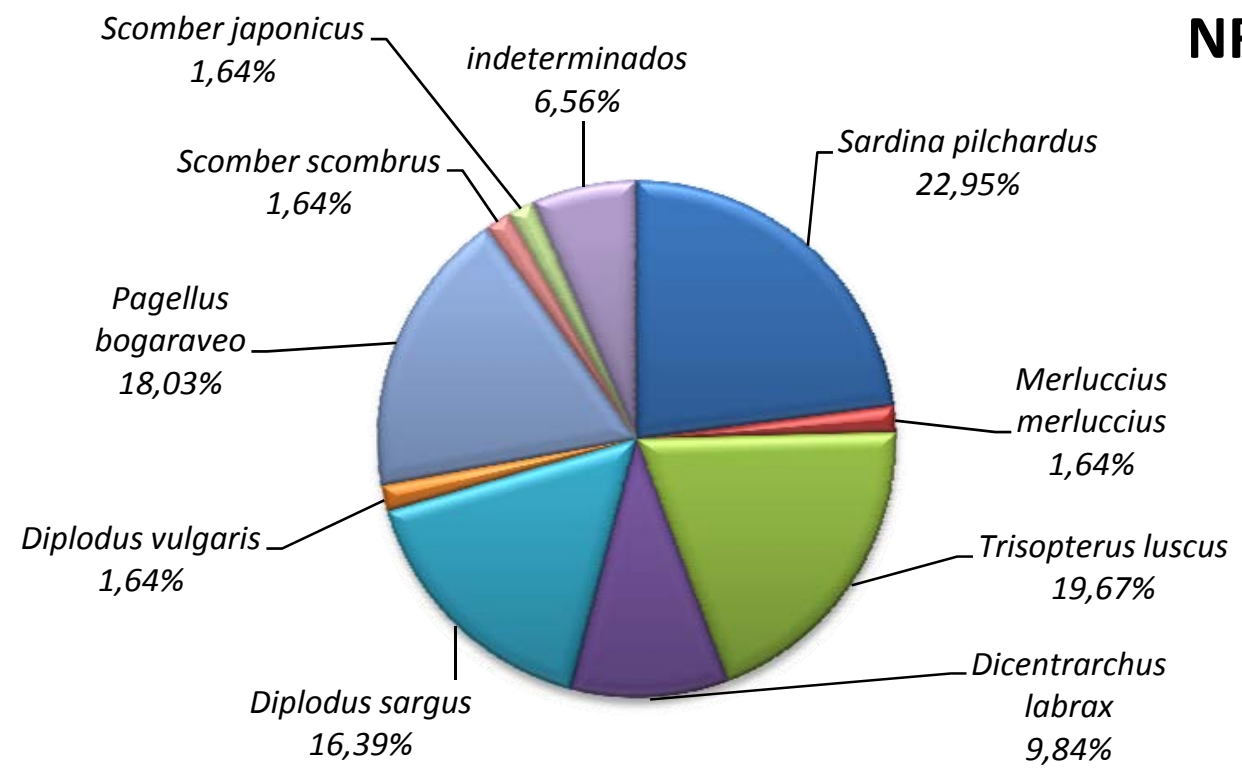

Fig. 233 Representatividad de los taxones según el NR.

Pese a que únicamente contamos con una muestra analizada para este yacimiento, la presencia de un número más o menos representativo de restos ictioarqueológicos nos permite observar algunas diferencias en cuanto a la representación de los diferentes taxones:

-Especies principales: La especie mejor representada es Sardina pilchardus, aunque no muestra grandes diferencias con otros taxones representados en la muestra. Su presencia en el interior de las rías y cerca de la costa se produciría entre la primavera y el verano, debido a las migraciones estacionales que realiza. Por lo tanto, su captura se centraría principalmente en determinadas épocas del año, empleando redes para su captura.

Dentro de este grupo también encontraríamos un gádido (Trisopterus luscus) y dos espáridos (Pagellus bogaraveo y Diplodus sargus). Todas estas especies son demersales, de fondos arenosos y con cascajo, siendo posible su captura en el entorno más inmediato al yacimiento. Se trata de especies carnívoras, por lo que pudieron haber sido pescadas con anzuelos cerca de la costa. Las que 
alcanzan mayor importancia son Trisopterus luscus y Pagellus bogaraveo, con menor carácter estacional la primera de ellas, mientras que la segunda únicamente está presente en el litoral en ciertas épocas del año.

-Especies complementarias: Grupo formado únicamente por una especie, Dicentrarchus labrax. Su presencia no suele ser muy habitual en los yacimientos anteriores al periodo medieval. Este taxón es carnívoro por lo que, igual que pasaba con alguna de las especies principales, puede ser capturado con anzuelos desde la costa o en pequeñas embarcaciones.

-Especies anecdóticas: Por último agrupamos aquellas especies que presentan valores mínimos, en esta ocasión Diplodus vulgaris, Merluccius merluccius, Scomber scombrus y Scomber japonicus. La primera de ellas es demersal y pudo haberse capturado cerca de la costa, quizás en relación con la pesca de Diplodus sargus, especie muy similar. Sin embargo, el resto de especies presenta una mayor problemática. Los escómbridos son pelágicos $y$, aunque suelen ser capturadas con redes, su pesca pudo haberse realizado con anzuelo desde embarcaciones, lo que también explicaría el escaso número de restos que las representan. Por otro lado, Merluccius merluccius no suele ser muy abundante en los yacimientos castreños, aunque aparece de forma regual.

\section{Representatividad ósea.}

La mayor parte de los restos se corresponden con elementos post-cefálicos, tanto entre los huesos identificados como entre los indeterminados. Los restos cefálicos no son muy numerosos y pertenecen a tres especies: Pagellus bogaraveo, Trisopterus luscus y Diplodus sargus. Esta última especie es la única que presenta un mayor número de restos cefálicos que vertebrales. En especies como Sardina pilchardus, o los escómbridos, la ausencia de restos cefálicos puede estar respondiendo a una menor osificación de estos huesos, lo que dificultaría su conservación. De todos modos, algo que parece ser común en los yacimientos castreños es la ausencia de restos cefálicos. También es llamativa la abundancia de escamas. Por lo tanto, esto nos indicaría la llegada al yacimiento de ejemplares completos de la mayoría de las especies, realizando en el mismo las tareas de limpieza del pescado. 


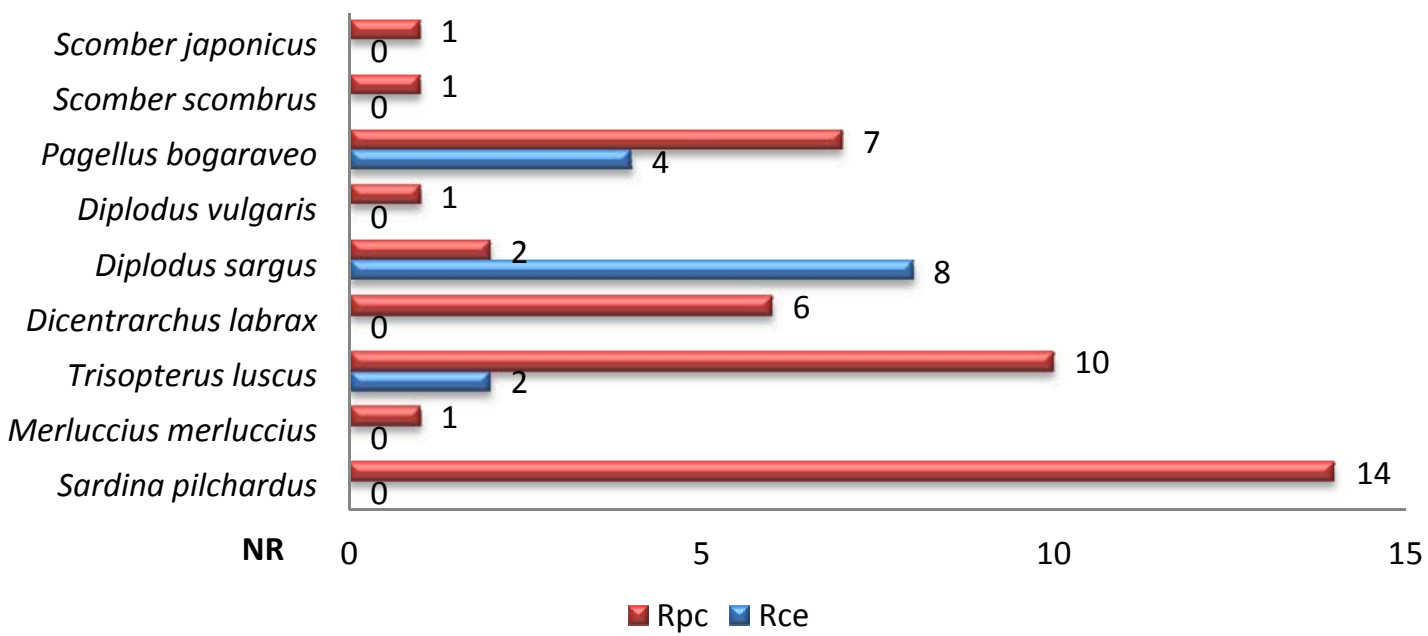

Fig. 234 Comparación numérica de los restos cefálicos y post-cefálicos de los diferentes taxones identificados.

A excepción de Sardina pilchardus, que presenta un mayor número de centros vertebrales precaudales, todas las especies están representadas principalmente por vértebras caudales. Lo exiguo del conjunto estudiado nos impide realizar una valoración respecto a la posibilidad de que existan tratamientos relacionados con la conserva del pescado.

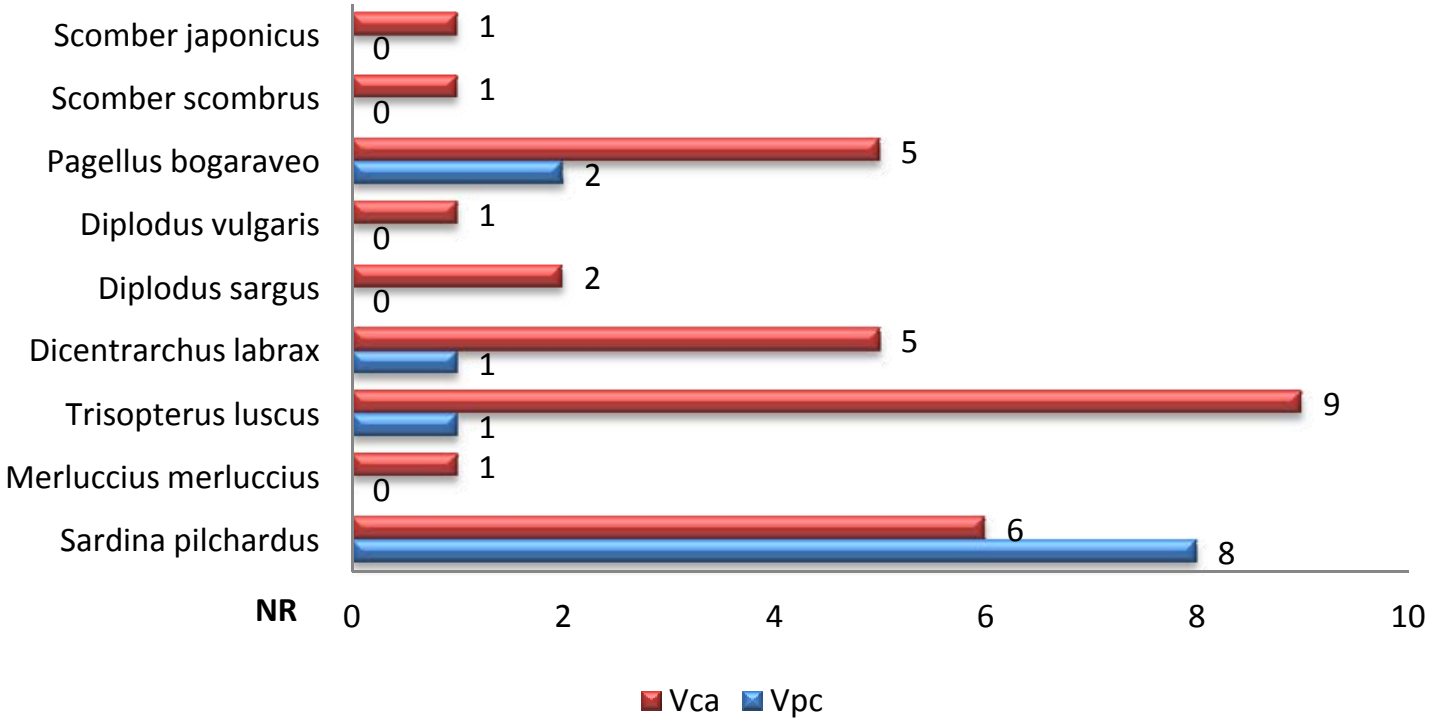

Fig. 235 Comparación numérica de las vértebras caudales y precaudales de los diferentes taxones identificados.

\section{V.7.5. CONSIDERACIONES FINALES.}

Respecto al volumen de sedimento procesado, los restos recuperados no son muy numerosos. Esto, junto a las características de las especies identificadas, nos hace pensar 
en una actividad destinada al autoconsumo, realizándose las capturas en las inmediaciones del yacimiento. La presencia de Sardina pilchardus indica la utilización de redes, aunque para la captura de las especies no sería necesario este método.

La mayoría de las especies mejor representadas dentro del conjunto van a ser migradoras, por lo que la estacionalidad va a suponer un factor muy importante. La actividad pesquera se intensificaría en la primavera y el verano, centrándose en unas especies determinadas. Aunque la mayor parte de los restos y de las especies pertenecen a pescado blanco, el pescado azul y semigraso va a tener cierta relevancia, de hecho de las tres especies con más restos, dos van a pertenecer a este grupo. La presencia en la costa de especies como Dicentrarchus labrax, Trisopterus luscus y Diplodus sargus es más constante, lo que explicaría que juntas alcancen el $46 \%$ de los restos. Su presencia a lo largo de todo el año supone un recurso estable y menos variable que el de las especies migradoras. Sin embargo, estas especies van a aumentar su número en las épocas de reproducción, que principalmente se produce en primavera y verano. 


\section{V.8. CASTElO DA ROCHA FoRTE.}

\section{V.8.1. LOCALIZACIÓN GEOGRÁFICA.}

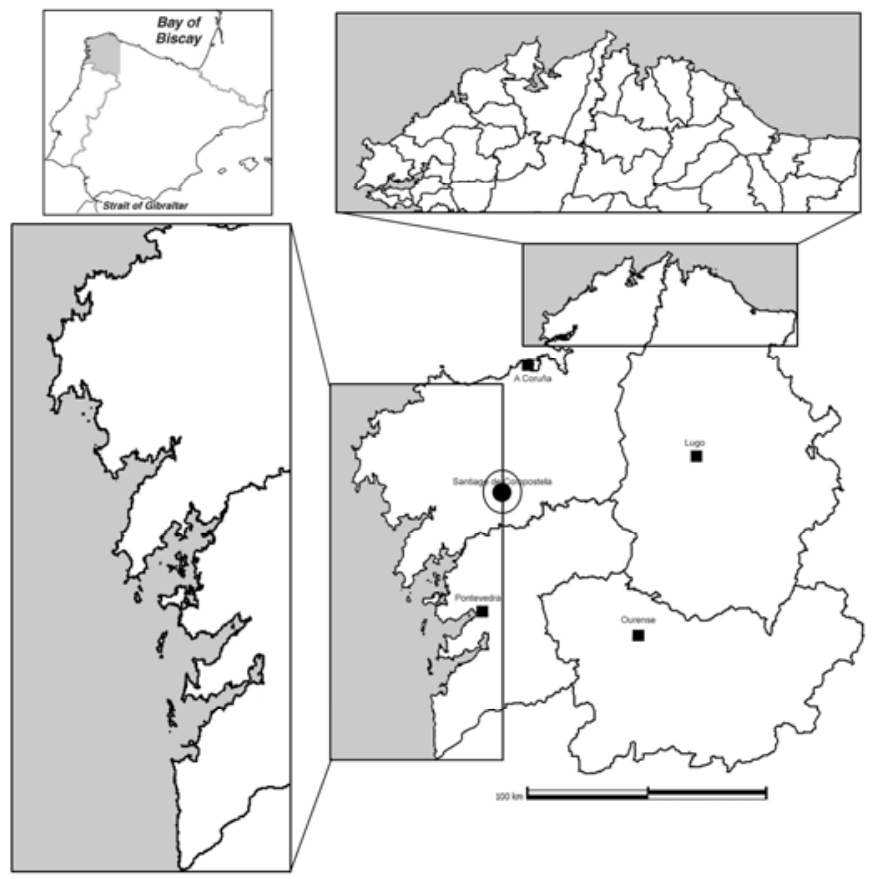

La Fortaleza de A Rocha Forte está localizada en la parroquia de Santa María de Conxo, perteneciente al Concello de Santiago de Compostela. Se sitúa en un promontorio donde confluyen el regato de Vilar con el río Sar, rodeando sus lados Este y Norte (Casal García y Acuña Castroviejo, 2007), en las coordenadas $8^{\circ} 34^{\prime} 23.84^{\prime \prime} \mathrm{W}$ y $42^{\circ}$ $51^{\prime} 39.08 " \mathrm{~N}^{8}$.

Fig. 236 Localización del yacimiento del Castelo da Rocha.

\section{V.8.2. DESCRIPCIÓN DEL YACIMIENTO.}

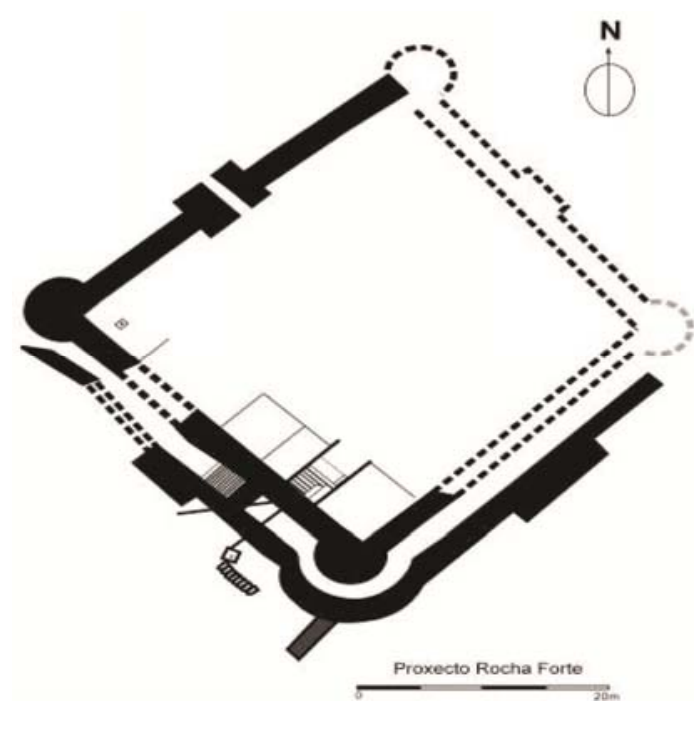

Fig. 237 Reconstrucción de la planta del Castillo (Casal García et alii, 2007).
El Castillo fue concebido como un complejo residencial y militar a las afueras de Santiago de Compostela, fruto de las crecientes tensiones entre el Concello y el señorío del Arzobispado. El nombramiento de Juan Arias como arzobispo de Santiago (1238-1266) lleva a un reforzamiento del poder señorial del arzobispado, construyendo esta fortaleza para controlar el acceso a la ciudad desde Padrón (Casal García y Acuña Castroviejo, 2007). En 1466, durante el conflicto irmandiño fue destruído, desmantelando parte del edificio para construir otras estructuras (Casal García y Acuña Castroviejo, 2007; Casal García et alii, 2007).

La fortaleza presenta una planta cuadrada con una superficie de $3.500 \mathrm{~m}^{2}$ con cuatro torres

\footnotetext{
${ }^{8}$ Datum: ETRS89; Uso: 29; UTM: X 534.859/Y 4.745.451.
} 
circulares en las esquinas. La entrada, con dos torreones a sus flancos, está situada al Oeste. En el interior de la muralla, y adosada a esta, se encuentra una escalinata que desciende a una estructura abovedada. Durante el siglo XIV sufrirá varias reformas, construyendo una barbacana en la zona Este y Sur del recinto (Casal García y Acuña Castroviejo, 2007; Casal García et alii, 2007).

Se han desarrollado diversas campañas desde el año 2002 (Casal García et alii, 2004), realizadas por el equipo de investigación Arqueopat GI-1533 de la Universidade de Santiago de Compostela, dirigido por Casal García y Acuña Castroviejo (Casal García et alii, 2007).

\section{V.8.3. RECOGIDA DE LAS MUESTRAS.}

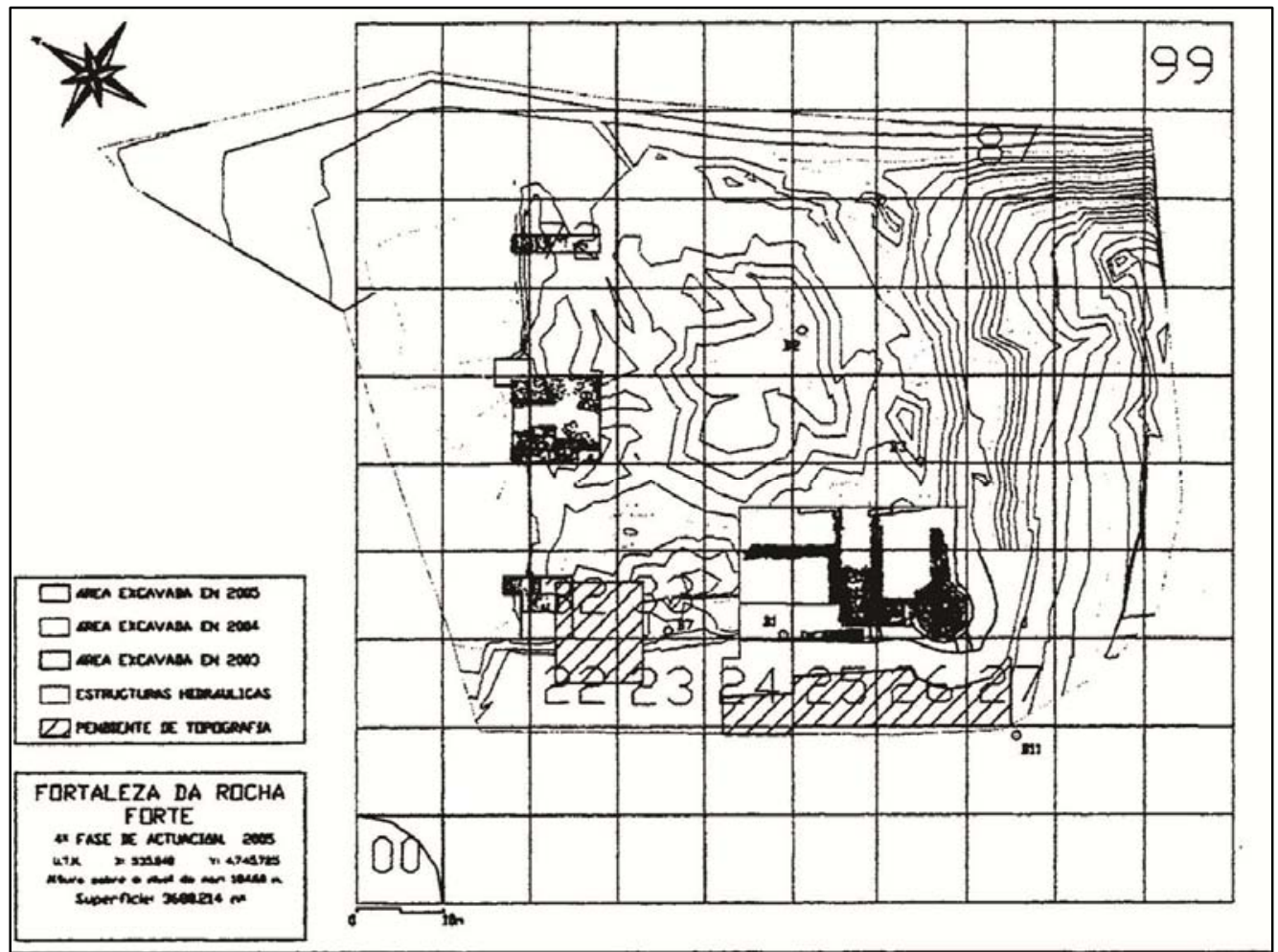

Fig. 238 Localización de los sectores intervenidos entre las campañas de 2002 y 2005 (Casal García et alii, 2006).

Los materiales ictiofaunísticos recogidos en este trabajo proceden de las excavaciones desarrolladas en los años 2004 (Casal García et alii, 2005) y 2005 (Casal García et alii, 2006).

\section{V.8.3.1. RELACIÓN ESTRATIGRÁFICA.}

Sector 22/23: Nivel de relleno al exterior del recinto fortificado entre la torre suroeste y la barbacana. En este tramo la barbacana se abre hacia el suroeste para rodear 
el torreón. La presencia en este espacio de la mayor parte de los materiales y su homogeneidad hacen pensar en aportes procedentes del exterior del Castillo (Casal García et alii, 2006; 2007). En él, en la UE 217, se encontraron el $90 \%$ de los restos óseos y malacológicos (García et alii, 2006).

\section{V.8.3.2. EL MUESTREO.}

Las muestras fueron recogidas durante el proceso de excavación mediante un muestreo selectivo. Esto puede explicar la presencia de piezas óseas de un tamaño importante y de alto valor diagnóstico. Las escamas documentadas en la UE 217 proceden del sedimento que rellenaba una valva de Ostrea edulis. Este sedimento fue cribado, recuperando las escamas, así como varios restos de Mytilus sp. y Venerupis pullastra, dos especies no registradas en el proceso de excavación. Ese hallazgo lo que refleja es que pueden haberse dejado de recuperar restos ícticos de especies de pequeñas dimensiones que pudieran estar presentes.

\section{V.8.3.3. CRonología.}

Tanto la documentación de la época, como los materiales documentados nos apuntan a que la ocupación presenta una cronología que va desde el siglo XIII al XV d.C., produciéndose en el siglo XIV d.C. diversas reformas como la construcción de la barbacana junto a la cual se documentaron estos restos faunísticos (Casal García y Acuña Castroviejo, 2007).

\section{V.8.4. ESTUDIO ICTIOARQUEOLÓGICO.}

UE502

\begin{tabular}{cccc} 
& Vca & NR & NMI \\
\hline Merluccius merluccius & 1 & $\mathbf{1}$ & 1 \\
\hline TOTAL & $\mathbf{1}$ & $\mathbf{1}$ &
\end{tabular}

Tabla 179 Relación de especies y representación ósea de la UE 502.

Presencia de una única vértebra caudal de Merluccius merluccius. Aunque está prácticamente completa, presenta un mal estado de conservación.

UE516

\begin{tabular}{cccc} 
& Vpc & NR & NMI \\
\hline Indeterminado & 1 & $\mathbf{1}$ & 1 \\
\hline TOTAL & $\mathbf{1}$ & $\mathbf{1}$ &
\end{tabular}

Tabla 180 Relación de especies y representación ósea de la UE 516.

Vértebra precaudal de gran tamaño y en buen estado de conservación, si bien no ha podido ser identificada a nivel de especie. 


\section{V.8.4.1.1. Sector: 22}

UE226

\begin{tabular}{rccc} 
& $\begin{array}{c}\text { Eph } \\
\text { (D/S) }\end{array}$ & NR & NMI \\
\hline Conger conger & $0 / 1$ & $\mathbf{1}$ & 1 \\
\hline \hline TOTAL & $\mathbf{1}$ & $\mathbf{1}$ &
\end{tabular}

Tabla 181 Relación de especies y representación ósea de la UE 226.

Epihial de Conger conger fragmentado. La limpieza de la fractura, así como su dirección nos hace pensar en un corte fruto de labores de limpieza del ejemplar.

UE217

\begin{tabular}{cccc} 
& Esc & NR & NMI \\
\hline Indeterminado & 6 & $\mathbf{6}$ & 1 \\
\hline \hline TOTAL & $\mathbf{6}$ & $\mathbf{6}$ &
\end{tabular}

Tabla 182 Relación de especies y representación ósea de la UE 217.

Presencia de seis escamas en el sedimento recuperado del interior de una valva de Ostrea edulis.

\section{V.8.5. COMEnTARio.}

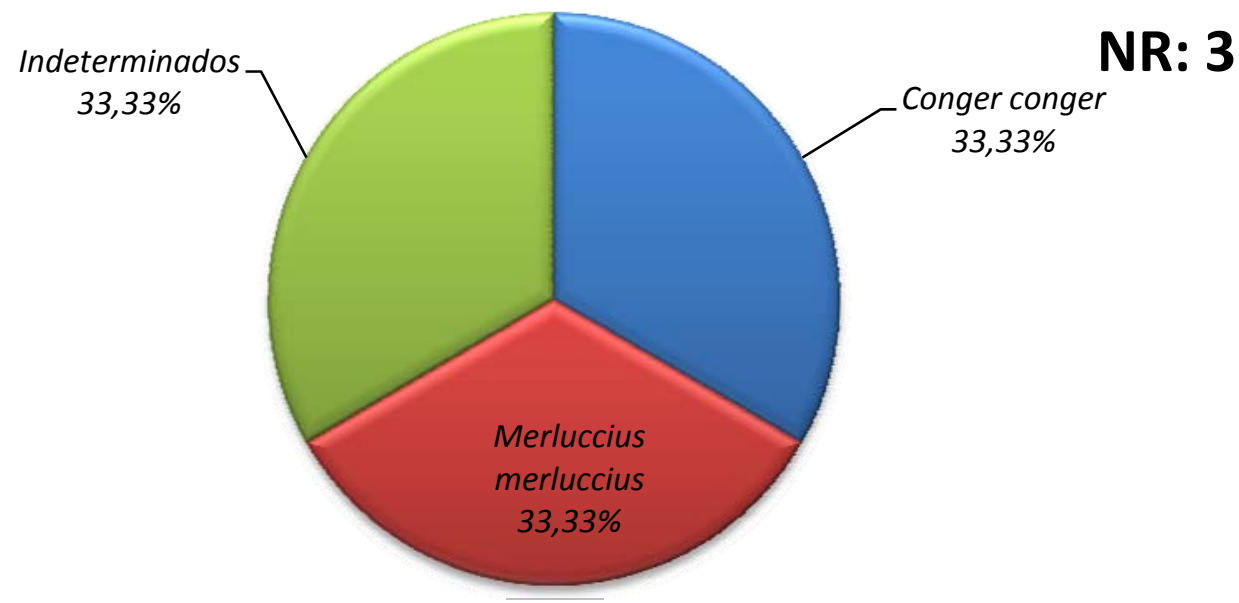

Fig. 239 Representatividad de los taxones según el NR.

La muestra ictiofaunística recuperada en el yacimiento medieval de A Rocha Forte es poco significativa. Sin embargo presenta una gran importancia debido a que es uno de los pocos yacimientos interiores con restos de peces que tenemos en el noroeste, además del papel socio-político que jugó el Castelo. Pese a que estamos ante un yacimiento de interior, donde los restos de fauna marina son inferiores a los documentados en zonas costeras, la recuperación de una muestra tan exigua estaría relacionada con una inadecuada estrategia de recuperación de estos materiales. Todas las piezas anatómicas recuperadas, presentan un tamaño lo suficientemente grande como para ser visualizadas 
durante el proceso de excavación. Sin embargo, carecemos de restos de pequeño tamaño, bien sean costillas, restos cefálicos o piezas óseas de especies de dimensiones reducidas, fenómeno sintomático de muestreos sesgados debido a la aplicación de metodologías inadecuadas. Otro aspecto que viene a corroborar este hecho es la recuperación de varias escamas en el sedimento que rellenaba una valva de Ostrea edulis. Junto a las escamas aparecieron pequeños restos de otras especies de moluscos, lo que indica que la variedad de estos era mayor, no limitándose al par de especies recogidas durante el proceso de excavación.

Tanto Merluccius merluccius como Conger Conger tienen gran importancia durante la Edad Media, como queda reflejado en diversos yacimientos costeros como Punta Atalaia, Area o Torre de Hércules, así como en yacimientos interiores como el Castro de los Judíos, localizado a las afueras de León (Avello y Sánchez-Lafuente, 2001). En cuanto a la documentación referente a Santiago de Compostela, también está atestiguada su presencia, tanto frescas como en conserva (Suárez, 1950). Según el folio 87 del Tumbo Vermello de Don Lope de Mendoza, el Castelo da Rocha Forte tiene los derechos sobre determinadas mercancías de productos marinos que pasasen por la Ciudad de Santiago, como son la merluza, la sardina, el congrio y el pescado fresco, que según parece llegaría desde Rianxo (López Ferreiro, 1875: 117; Rodríguez González, 1995: 129):

"De cualquier bestia que partiere de los puertos de Gallizia et pasare por entre la cibdad de Santiago e el Tambere de cada carga de pescadas ha de aver una pescada la mejor, ede la carga de los pulpos dos de los mejores o cuatro pequenos; e de la carga de las Rayas dos grandes o quatro pequeñas; e de la carga de las sardinas viente sardinas, quier frescas, quier saladas; e de la tonina un palmo della que sea de la yjada e una mano en ancho. Et todos pagan estos derechos saluo los vecinos de Santiago. Et he sabido que dan en Renta cada año por estos derechos a vasco lopes de cordido vuestro alcalde et tenedor que agora es de la dicha casa mill e dosientos mrs. De moneda vieja e ocho millares de sardina salada. Et en esto non se incluye el pescado fresco que viene de Rianjo a la dicha cibdad que queda para el dicho alcayde..."

Partiendo de esta información, una de las rutas que podría haber seguido el pescado desde la costa hasta Santiago de Compostela es ascendiendo el río Ulla, lugar donde está situado el yacimiento de Torres do Oeste, del cual también se cuenta con información de ictiofauna (Ferré, 2003).

Además de estar representadas en Torres do Oeste las dos especies presentes en Rocha Forte, lógico al ser dos especies tan comunes en los yacimientos del periodo. La presencia de una vértebra caudal en Rocha Forte no permite determinar si serían 
ejemplares frescos o tratadas para su conservación. Por otro lado, el tamaño de las vértebras se situaría por debajo de la media documentada en Torres del Oeste.

Vca

(Merluccius merluccius)

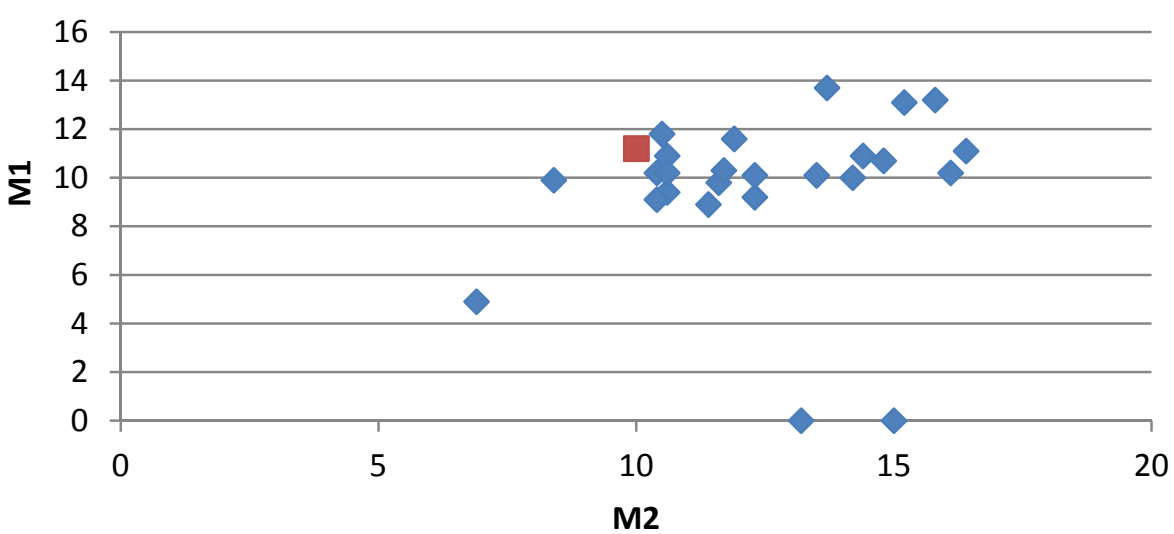

$\rightarrow \mathrm{TO}(25) \square \mathrm{RF}(1)$

Fig. 240 Distribución biométricas (en mm.) de las vértebras caudales de Torres del Oeste (TO) y el Castelo da Rocha Forte (RF).

Por lo que se refiere al epihial de Conger conger, presenta una fractura que podría corresponder con marcas de corte para la eliminación de la cabeza. Pese a que es difícil saber si esas labores de limpieza se realizaron en el yacimiento o en otro lugar, cabiendo la posibilidad de que puedan responder a tratamientos para su conservación.

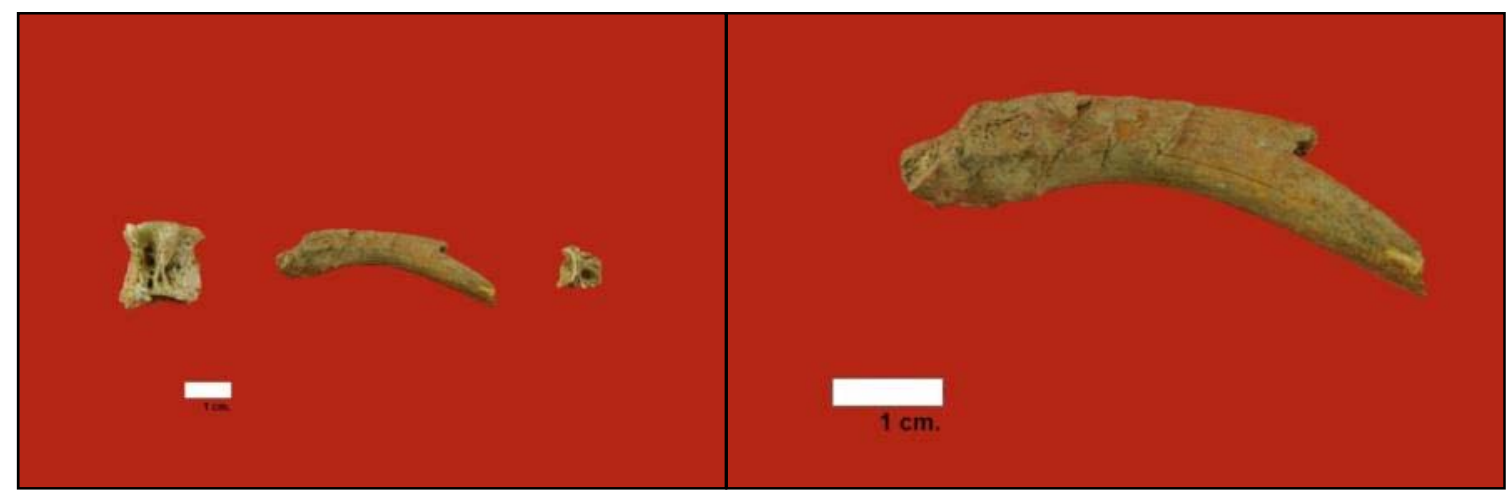

Fig. 241 Restos ícticos documentados en el Castelo da Rocha y epihial de Conger conger con marcas de corte.

La parquedad del registro ictiológico hace muy complicado realizar una valoración del comercio y consumo de pescado en el Castelo da Rocha Forte, así como en la ciudad de Santiago de Compostela. Esperamos que nuevos hallazgos puedan ampliar el registro para poder caracterizar el papel de este producto en la dieta de esta población y de sus habitantes durante los siglos finales de la Edad Media. 


\section{V.9. OTROS YACIMIENTOS CON REFERENCIAS.}

\section{V.9.1. Villa ROMANA DE BARES.}

\section{Localización y cronología.}

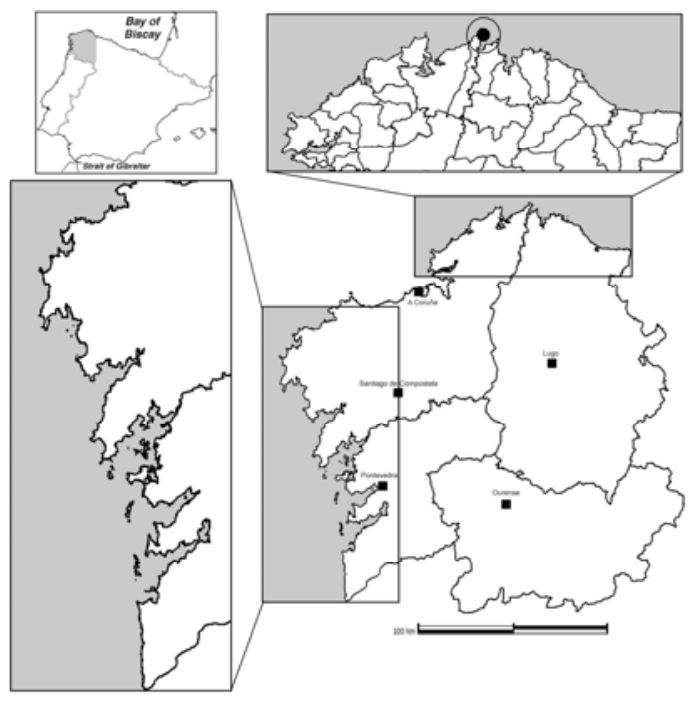

Fig. 242 Localización de la Villa romana de Bares.
Esta villa romana se localiza en el lugar conocido como Eirexa-Vella o A Torre, sobre la playa de Bares en el Concello de Mañón, A Coruña. Sus coordenadas geográficas son $43^{\circ} 47^{\prime} 30^{\prime \prime}$ norte y $7^{\circ} 40^{\prime} 08^{\prime \prime}$ oeste. Los materiales proceden de la intervención realizada en 1997 financiada por la Dirección Xeral do Patrimonio Cultural. Se realizaron 32 catas de $2 \times 2 \mathrm{~m}^{2}$ distribuidos en cinco sectores a lo largo del yacimiento. El yacimiento presenta una amplia cronología que va desde el siglo IV al XVIII d.C., superponiéndose diferentes momentos culturales con una villa tardo-romana, una necrópolis de inhumación y la iglesia parroquial de Bares (Ramil González, 2003). Los restos ictiológicos se documentaron en el nivel tardo-romano vinculado con la villa costera (Fernández Rodríguez, 1998; 2003).

\section{Estudio Ictiológico.}

Únicamente se recuperaron tres vértebras de Mugilidae sp., sin que se pudiera precisar la especie concreta. Además también se recuperaron dos fragmentos indeterminados. Estos restos, junto A Suvidá, se constituyen en una de las evidencias más antiguas de la pesca de Mugilidae en el Noroeste (Fernández Rodríguez, 1998; 2003).

\begin{tabular}{lccccc} 
& Vpc & Vca & Rpc & NR & MNI \\
\hline Mugilidae sp. & 1 & 2 & & $\mathbf{3}$ & 1 \\
Indeterminados & & & 2 & $\mathbf{2}$ & \\
\hline \hline TOTAL & $\mathbf{1}$ & $\mathbf{2}$ & $\mathbf{2}$ & $\mathbf{5}$ &
\end{tabular}

Tabla 183 Relación de especies y representación ósea de la Villa de Bares.

\section{V.9.2. SAN XiaO do Trebo.}

\section{Localización y cronología.}

Yacimiento situado en San Xiao do Trebo, en el Concello de Cariño. Durante los trabajos de restauración de la ermita, salió a la luz un depósito con una alta densidad de conchas. Según la mayor parte de la cerámica encontrada, este conchero se adscribe a la Alta Edad Media. Las muestras de ictiofauna proceden de una recogida selectiva de los 


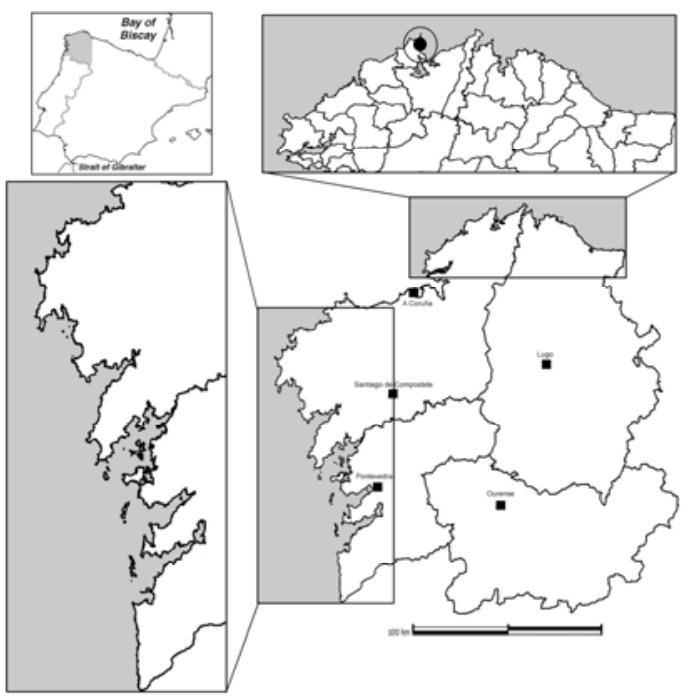

Fig. 243 Localización del yacimiento de San Xiao do Trebo. arqueólogos y del cribado de una muestra malacológica (Ramil Gónzález y Picos Brage, 2002). De este yacimiento únicamente contamos con citas de la presencia de restos de ictiofauna, sin precisar la identificación anatómica y taxonómica de la mayoría de los restos (Rodríguez López, 2002).

\section{Estudio Ictiológico.}

En este trabajo únicamente se presentan los resultados preliminares. Se recuperaron 89 restos óseos, de los cuales 11 pertenecían a la cabeza, 22 restos a espinas y radios, 49 al tronco y 7 indeterminados. En el análisis publicado se identificaron dos restos de Labrus bergylta, además de constatar la presencia de lábridos, espáridos y escómbridos, aunque no se especifican las especies (Rodríguez López, 2002).

\begin{tabular}{l|c} 
& $\mathrm{NR}$ \\
\hline Labrus bergylta & 2 \\
\hline Labridae & $*$ \\
\hline Sparidae & 1 \\
\hline Scombridae & 1
\end{tabular}

Tabla 184 Especies y familias representadas.

\section{V.9.3. CASa Martelo.}

\section{Localización y cronología.}

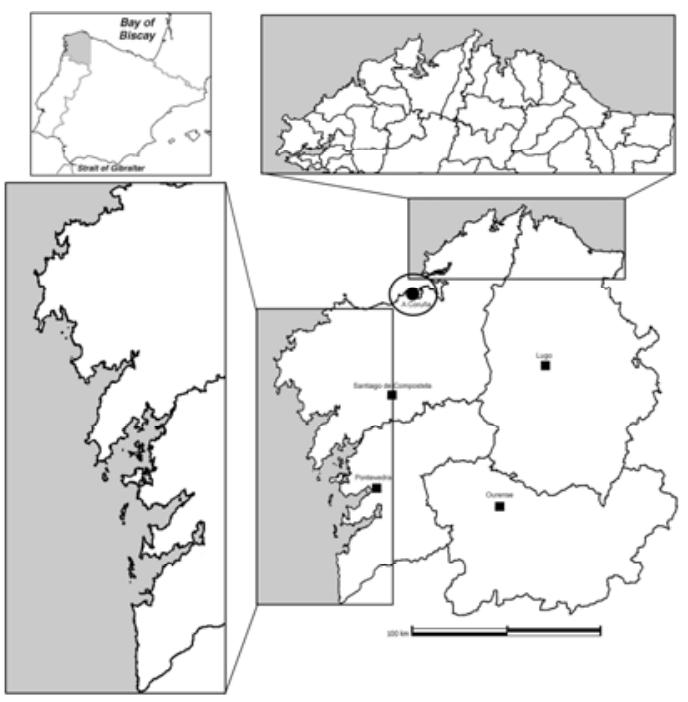

Fig. 244 Localización del yacimiento de Casa Martelo.
Solar de la Ciudad de A Coruña situado en la calle de La Franja excavado en dos fases, la primera de ella correspondió a un seguimiento de las obras dirigida por J.Ma Bello Diéguez, y a la segunda la apertura de $17 \mathrm{~m}^{2}$, dirigida por M. Lestón Gómez (1991).

Durante el primero de los seguimientos se documentó un pavimento romano muy alterado por construcciones más recientes, así como un muro de mampostería asentado sobre una duna datado en época alto imperial (Bello Diéguez, 1994). En los niveles suprayacentes se documentó un vertedero conformado por abundantes restos cerámicos, 
constructivos, metálicos y orgánicos que tendría una cronología que abarca los siglos II-IV d.C. (Nivel 2) (Bello Diéguez, 1994; Castro Paredes et alii, 2000; Vázquez Martínez, 2000). La disposición horizontal de los restos se ha interpretado como el resultado de una deposición lenta de los mismos. Por encima de este nivel de vertidos se sitúa otra capa (Nivel 1), también de relleno, que incluía abundante material cerámico romano pero en el que también se localizan piezas de otros periodos culturales más recientes, así como un canal de desagüe que procedía de un pozo negro situado en el interior del edificio (Lestón Gómez, 1991).

\section{Estudio Ictiológico.}

La especie mejor representada es Labrus bergylta seguida de Merluccius merluccius, acompañadas por un grupo de otras siete especies. Pese al bajo número de restos la diversidad específica es alta. Se detecta una preferencia por el hábitat costero, lo que indicaría una pesca basada principalmente en la utilización de distintas artes de anzuelo. No obstante, la presencia de especies gregarias tales como Trachurus trachurus, y Dicetranchus labrax, son indicativas de una pesca ejercitada mediante el empleo de redes (Ferré, s.f.).

\begin{tabular}{lccccccc} 
NIVEL 1 & Pmx & Dnt & Urh & Vpc & Vca & NR & MNI \\
\hline Merlucius merluccius & 1 & 1 & & 3 & 2 & $\mathbf{7}$ & 1 \\
Sparus aurata & 1 & & & & & $\mathbf{1}$ & 1 \\
Indeterminados & & & 1 & & & $\mathbf{1}$ & \\
\hline \multicolumn{1}{c}{ TOTAL } & $\mathbf{2}$ & $\mathbf{1}$ & $\mathbf{1}$ & $\mathbf{3}$ & $\mathbf{2}$ & $\mathbf{9}$ &
\end{tabular}

Tabla 185 Relación de especies y representación ósea del Nivel 1.

El primer nivel correspondería a una capa de relleno con materiales romanos junto con otros más modernos. En él se pudieron identificar siete restos de Merluccius merluccius y uno de Sparus aurata.

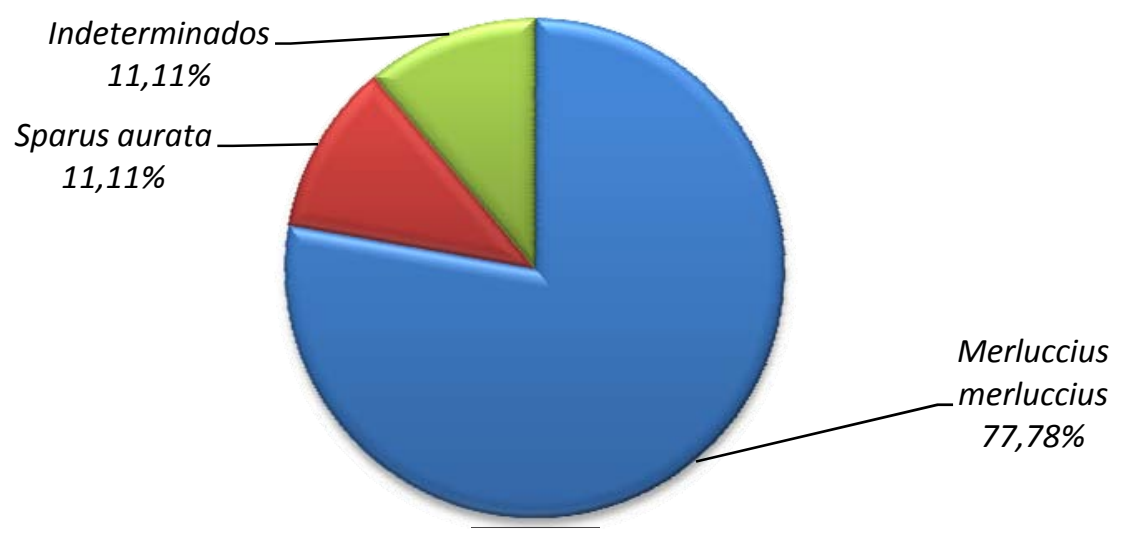

NR: 9

Fig. 245 Representatividad de los taxones según el NR. 


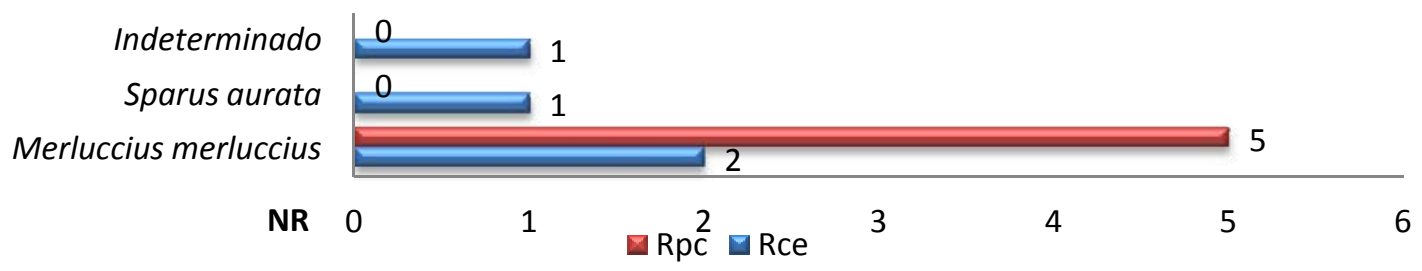

Fig. 246 Comparación numérica de los restos cefálicos y postcefálicos de los taxones identificados.

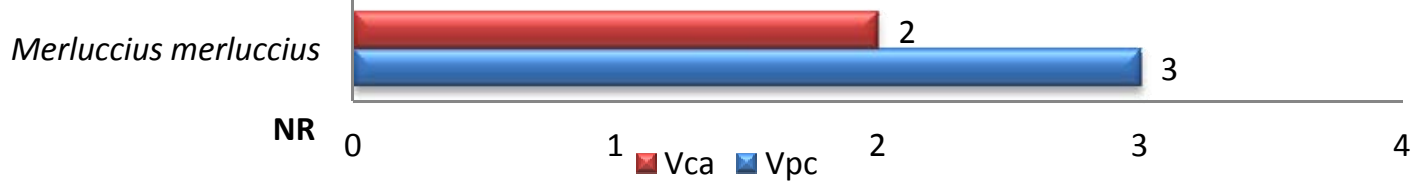

Fig. 247 Comparación numérica de las vértebras caudales y precaudales de los taxones identificados.

\begin{tabular}{lcccccccccc}
\multicolumn{1}{c}{ NIVEL 1/2 } & Pmx & Max & Dnt & Art & Cbr & Pvm & Vpc & Vca & NR & MNI \\
\hline M.merluccius & & & & 2 & & & 2 & & $\mathbf{4}$ & 2 \\
T.trachurus & & & & & & & & 1 & $\mathbf{1}$ & 1 \\
D.labrax & & & & & & & & 1 & $\mathbf{1}$ & 1 \\
Sparus aurata & 1 & & & & & & & & $\mathbf{1}$ & 1 \\
Pagrus pagrus & 2 & 1 & 1 & & & & & 1 & $\mathbf{5}$ & 2 \\
Labrus bergylta & & & & & \multirow{2}{*}{11} & 1 & & & $\mathbf{1 2}$ & 11 \\
Sparidae & 1 & & & & & & & & $\mathbf{1}$ & 1 \\
Indeterminados & & & & & & & 1 & & $\mathbf{1}$ & \\
\hline \multicolumn{1}{c}{ TOTAL } & $\mathbf{4}$ & $\mathbf{1}$ & $\mathbf{1}$ & $\mathbf{2}$ & $\mathbf{1 1}$ & $\mathbf{1}$ & $\mathbf{3}$ & $\mathbf{3}$ & $\mathbf{2 6}$ &
\end{tabular}

Tabla 186 Relación de especies y representación ósea del Nivel 1/2.

La muestra del Nivel 1/2 corresponde a la zona de contacto entre los dos niveles detectados. El conjunto lo formarían cuatro restos de Merluccius merluccius, uno de Trachurus trachurus, Dicetranchus labrax y Sparus aurata; cinco restos de Pagrus pagrus y doce de Labrus bergylta.

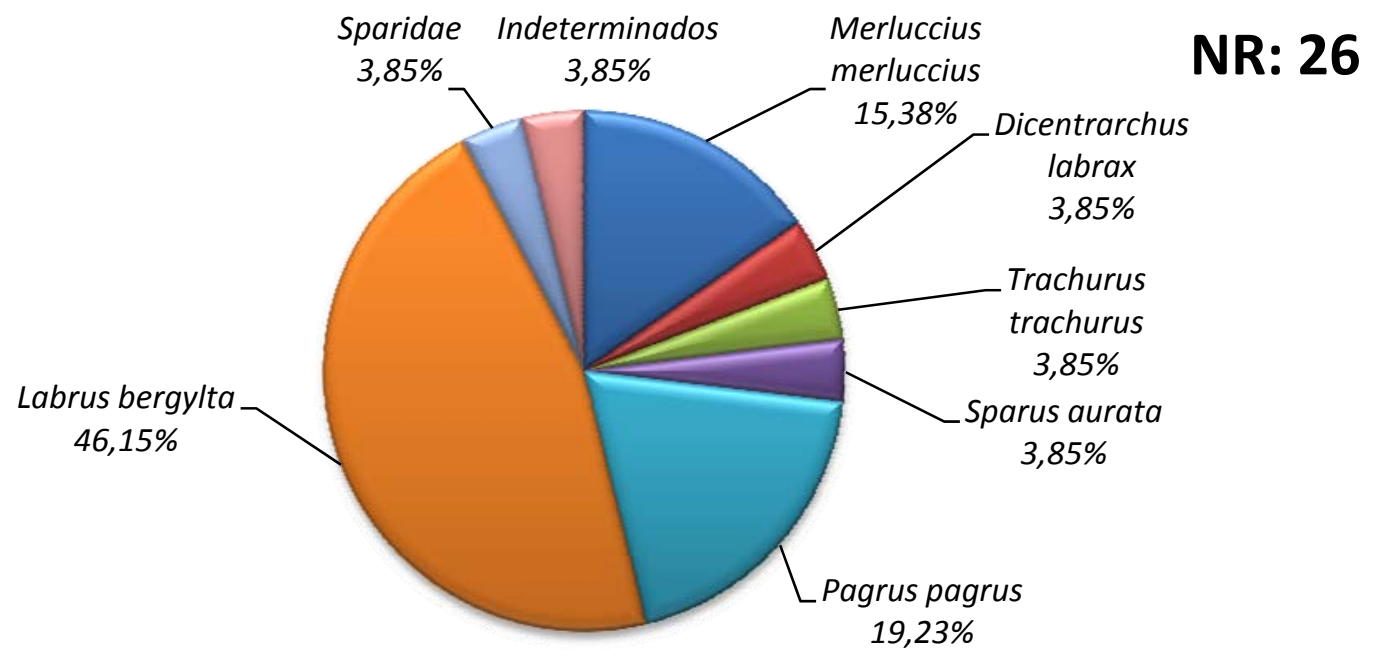

Fig. 248 Representatividad de los taxones según el NR. 


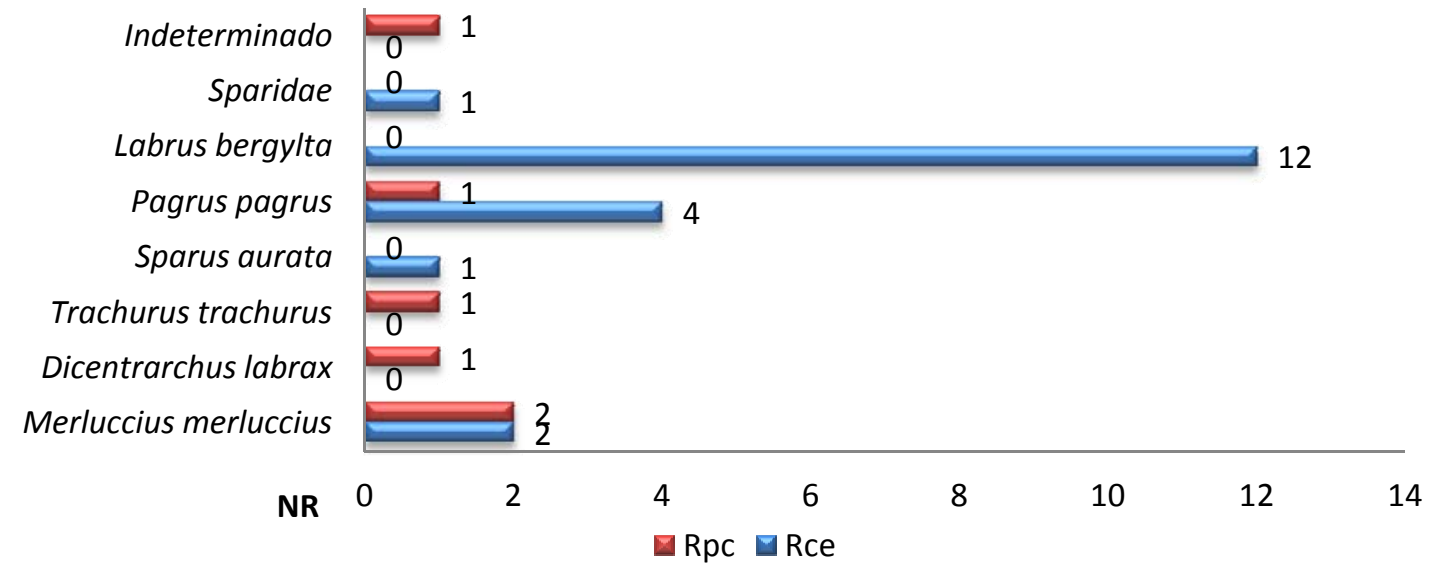

Fig. 249 Comparación numérica de los restos cefálicos y post-cefálicos de los taxones identificados.

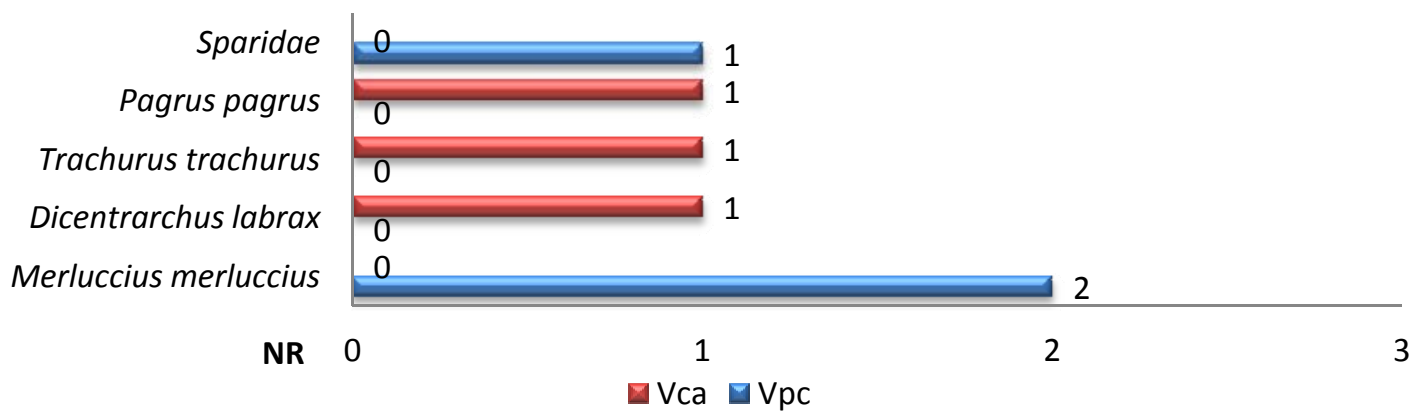

Fig. 250 Comparación numérica de las vértebras caudales y precaudales de los taxones identificados.

\begin{tabular}{|c|c|c|c|c|c|c|c|c|c|c|c|c|c|c|}
\hline NIVEL 2 & Pmx & Max & Dnt & Art & Mol & Cbr & Pop & Op & Hmd & Psf & Vpc & Vca & NR & MNI \\
\hline M. merluccius & 2 & 4 & 1 & 1 & & & & & & & 5 & 1 & 14 & 4 \\
\hline Conger conger & & 2 & & & & & & & & & 1 & & 3 & 2 \\
\hline Trachurus trachurus & & 1 & & & & & & & & & & & 1 & 1 \\
\hline Dicentrarchus labrax & & & & & & & & & & & & 1 & 1 & 1 \\
\hline Zeus faber & & 2 & 1 & 1 & & & & & 2 & & & & 6 & 2 \\
\hline Diplodus vulgaris & & & 1 & & & & & & & & & & 1 & 1 \\
\hline Sparus aurata & 2 & & 1 & & 1 & & & & & & & 1 & 5 & 2 \\
\hline Pagrus pagrus & & & & 1 & & & & & & & & 1 & 2 & 1 \\
\hline Labrus bergylta & & 1 & & & & 11 & & & 1 & & 3 & 1 & 17 & 11 \\
\hline Sparidae & & & 2 & & & & & & & & & & 2 & 1 \\
\hline Labridae & & & & & & & 1 & & & & & & 1 & 1 \\
\hline Indeterminados & & 3 & 1 & & & & & 1 & 1 & 1 & 1 & 2 & 10 & \\
\hline TOTAL & 4 & 13 & 7 & 3 & 1 & 11 & 1 & 1 & 4 & 1 & 10 & 7 & 63 & \\
\hline
\end{tabular}

El Nivel 2 corresponde propiamente al periodo romano. La especie que ha diso identificada por un mayor número de restos es Labrus bergylta con 17, seguida por Merluccius merluccius con 14. Las demás especies que componen la muestra son Zeus faber con seis piezas óseas, Sparus aurata con cinco, Conger conger con tres y Pagrus pagrus con dos. Representadas por un único resto contamos con Trachurus trachurus, Dicentrarchus labrax y Diplodus vulgaris. 


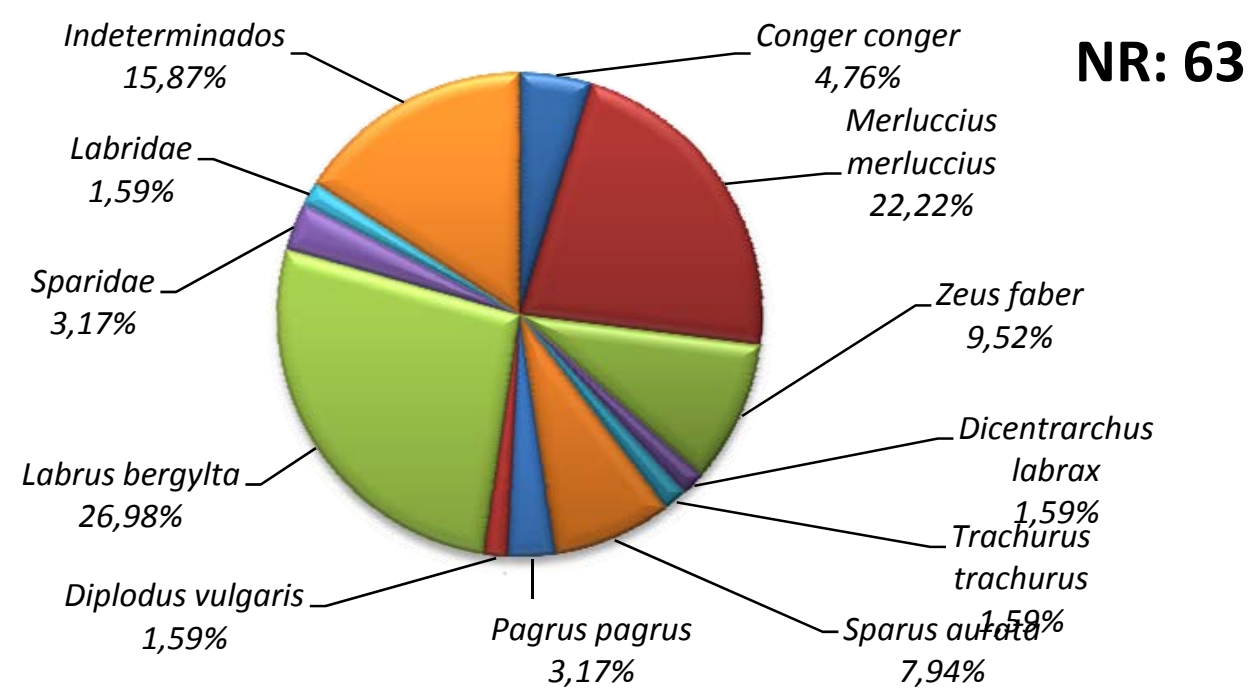

Fig. 251 Representatividad de los taxones según el NR.

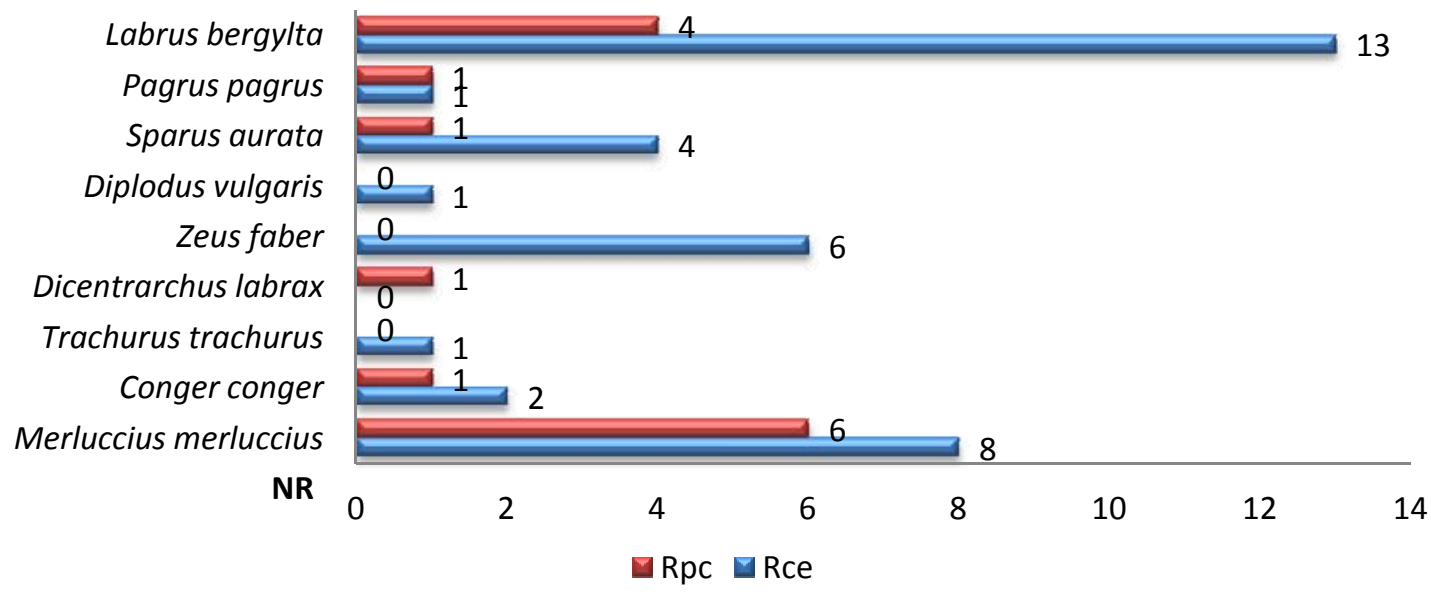

Fig. 252 Comparación numérica de los restos cefálicos y post-cefálicos de los taxones identificados.

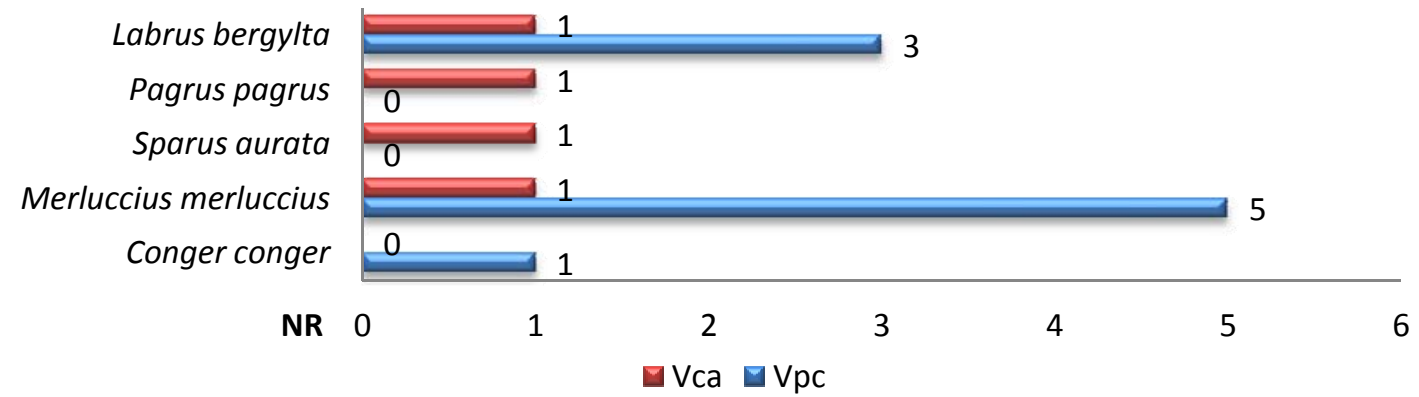

Fig. 253 Comparación numérica de las vértebras caudales y precaudales de los taxones identificados. 


\section{V.9.4. LA Franja 9-11.}

\section{Localización y cronología.}

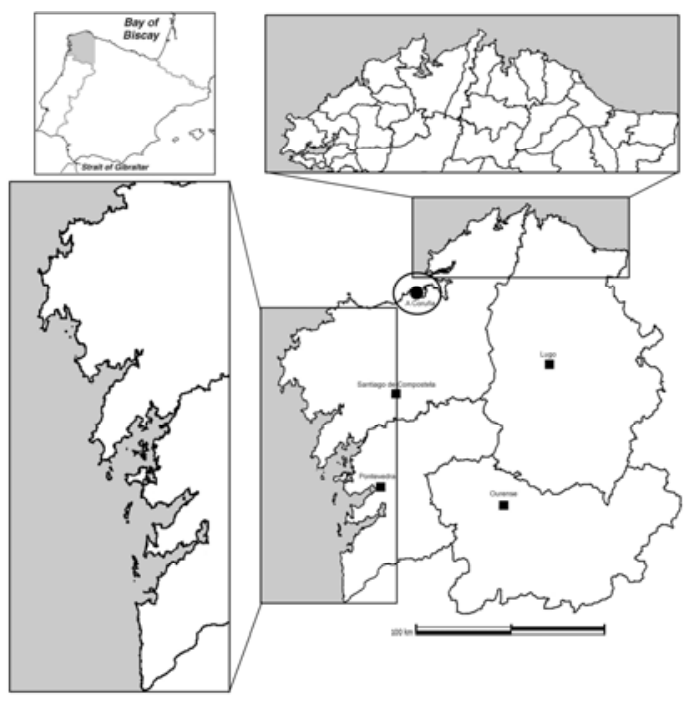

Fig. 254 Localización La Franja 9-11.

Excavación realizada en la Calle a Franja 911 en la Ciudad de A Coruña, cerca de Casa Martelo, limitando la parcela prácticamente limitando con el mar (Vázquez Gómez, 1996). La superficie intervenida presentaba una superficie de $81 \mathrm{~m}^{2}$. Se realizaron dos catas de $2 \times 2 \mathrm{~m}$, una denominada $\mathrm{C} 1$ al sureste del solar y la $\mathrm{C} 2$ en el oeste (Vázquez Gómez, 1996). La estratigrafía está formada por tres niveles: 1) formado por tierra marrón y piedras con material medieval y romano; 2) tierra negra de $30 \mathrm{~cm}$ de espesor con tégula y cerámica romana; 3) arena de playa sobre la que se asientan las estructuras. Se localizó una estructura en forma de $U$ con la abertura hacia el oeste (Vázquez Gómez, 1996).

El estudio ictioarqueológico fue realizado por M. Camino López y J.M. Rey Salgado, documentándose los materiales en la cata $\mathrm{C} 2$ en el nivel 2. Pese a que el yacimiento presenta una amplia cronología, desde el cambio de era al siglo $\mathrm{V}$ d.C., la estructura parece ser anterior al siglo III d.C., momento en el que se abandonaría y empezaría a acumularse los restos que conformarán el basurero (Vázquez Gómez, 1996).

\section{Estudio Ictiológico.}

La especie mejor representada es Labrus bergylta con 15 restos, seguida por Diplodus sargus con ocho, y Merluccius merluccius con uno. Además se recuperaron cinco restos no identificados a nivel de especie y que pertenecerían a lábridos y espáridos, así como seis restos indeterminados. Predominan las especies costeras y sedentarias, por lo que se pudieron capturar en las cercanías de la costa.

\begin{tabular}{lcccccccccc} 
& Dnt & Hmd & Pal & Fbr & Psf & Pst & Scl & V & NR & MNI \\
\hline Diplodus sp. & & & & & & & & 2 & $\mathbf{2}$ & 1 \\
Diplodus sargus & 1 & & 2 & & & & & 2 & $\mathbf{5}$ & 2 \\
Labrus bergylta & & 2 & & 6 & 1 & 2 & 1 & & $\mathbf{1 2}$ & 6 \\
\hline \hline TOTAL & $\mathbf{1}$ & $\mathbf{2}$ & $\mathbf{2}$ & $\mathbf{6}$ & $\mathbf{1}$ & $\mathbf{2}$ & $\mathbf{1}$ & $\mathbf{4}$ & $\mathbf{1 9}$ &
\end{tabular}

Tabla 188 Relación de especies y representación ósea de C2 "tierra parda bajo muro transversal”. 


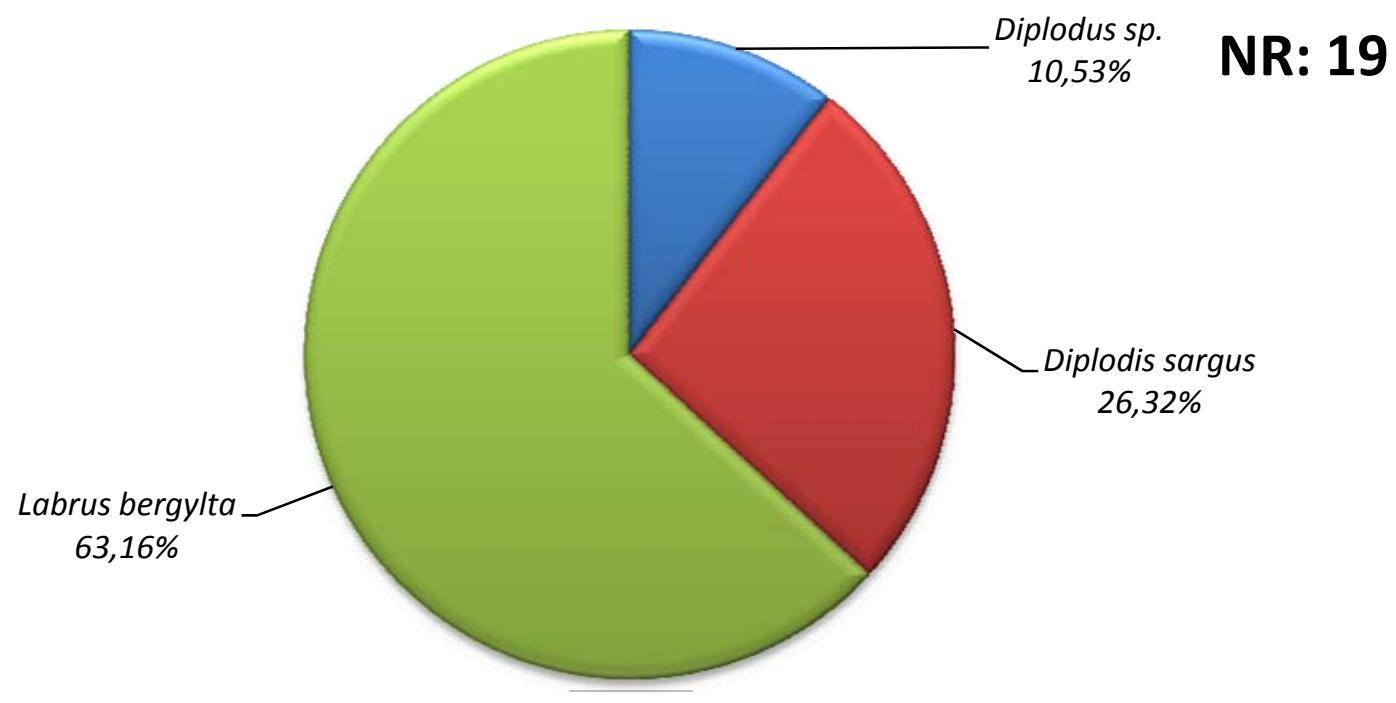

Fig. 255 Representatividad de los taxones según el NR.

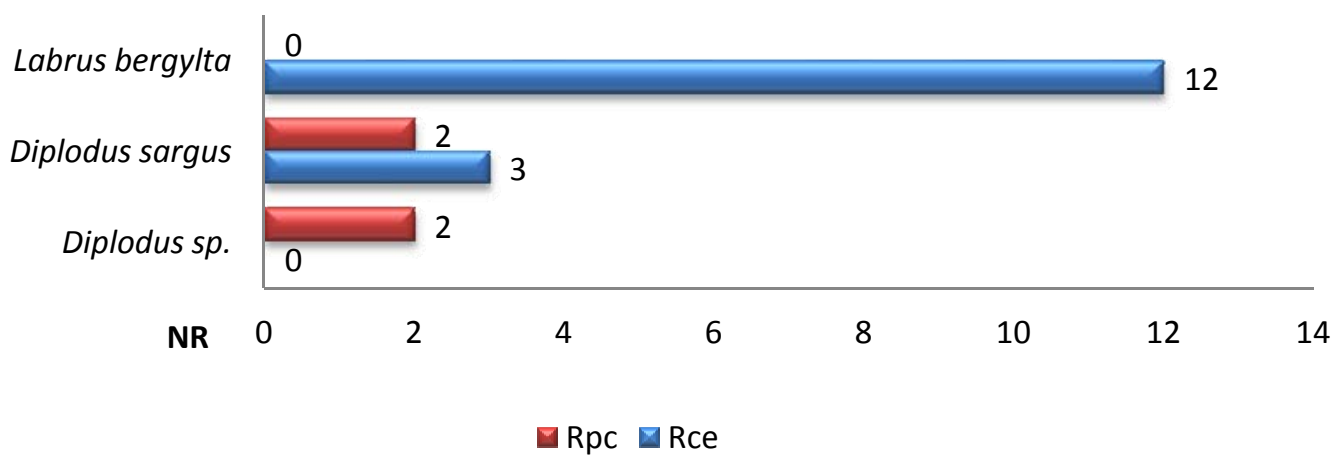

Fig. 256 Comparación numérica de los restos cefálicos y postcefálicos de los taxones identificados.

\begin{tabular}{cccc} 
& Fbr & NR & MNI \\
\hline Labrus bergylta & 2 & $\mathbf{2}$ & 2 \\
\hline \hline TOTAL & $\mathbf{2}$ & $\mathbf{2}$ &
\end{tabular}

Tabla 189 Relación de especies y representación ósea de C2 "Tierra negra".

\begin{tabular}{lcccc} 
& Pmx & Aca & NR & MNI \\
\hline Diplodus sp. & 1 & & $\mathbf{1}$ & 1 \\
Merluccius merluccius & & 1 & $\mathbf{1}$ & 1 \\
\hline \hline \multicolumn{1}{c}{ TOTAL } & $\mathbf{1}$ & $\mathbf{1}$ & $\mathbf{1}$ &
\end{tabular}

Tabla 190 Relación de especies y representación ósea de C2 "Tierra negra debajo del muro". 


\section{V.9.5. TORRE DE HÉRCULES.}

Localización y cronología.

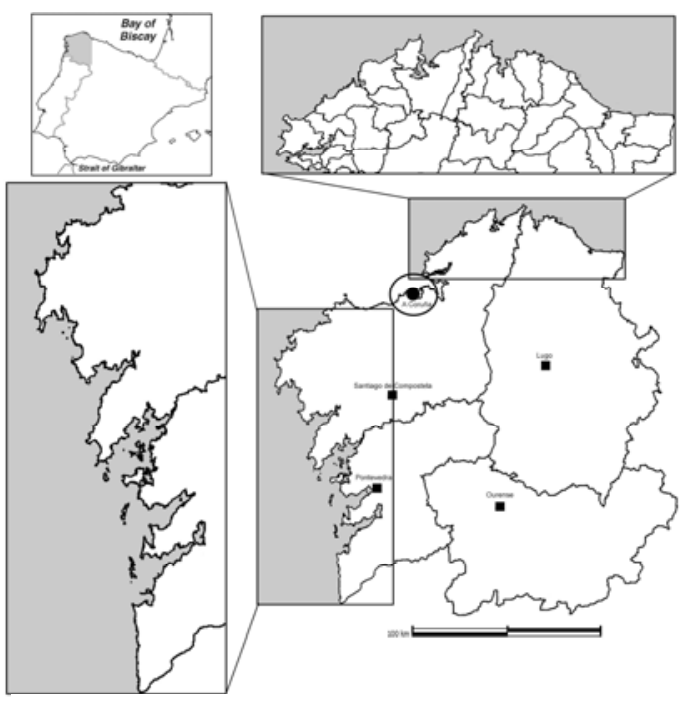

Fig. 257 Localización de la Torre de Hércules.
Se sitúa en la entrada de la Ría de A Coruña entre las ensenadas de Punta Hermida y As Lagoas. Sus coordenadas son $8^{\circ} 25^{\prime} 42^{\prime \prime} \mathrm{W}$ y $43^{\circ} 23^{\prime} 13^{\prime \prime} \mathrm{N}$. Los restos proceden de las excavaciones realizadas en los alrededores del Faro, que pusieron de manifiesto nuevas estructuras (Bello et alii, 2008). Los restos recuperados seguramente fueron acumulados entre los siglos X-XI al XIII d.C. De este yacimientos los únicos estudios con los que contamos fueron realizados por Ma.C. Ferré y J.M. Rey (1997), formando parte de la Tesis Doctoral de Ferré (2003).

\section{Estudio Ictiológico.}

Se han identificado 18 especies de peces, procediendo todas de aguas marinas, a excepción de Anguilla anguilla que puede venir de aguas estuarinas. Labrus bergylta es la mejor representada, tanto en NR como en NMI. Le sigue en abundancia Merluccius merluccius, Dicentrarchus labrax y Conger conger. La abundancia de estas especies puede estar vinculada a las pesquerías enfocadas a su comercio mediante el secado y la salazón. Tanto Dicentrarchus labrax, como Argyrosomus regius y Polyprion americanus pudieron haber sido utilizados como pago de tributos relacionados con la función de vigilancia de la torre debido a su gran aprecio (Ferré y Rey, 1997; Ferré, 2003).

Todos los restos de ictiofauna aparecieron asociados a las cocinas del emplazamiento defensivo. El conjunto está formado por 2.348 restos distribuídos en 18 taxones. Las especies mejor representadas son: Labrus bergylta con 567 piezas óseas, Merluccius merluccius 417, Dicetranchus labrax 325, Conger conger 295 y Trachurus trachurus 241. Con una menor representación se sitúa Pollachius pollachius con 79 restos, Pagrus pagrus 75, Diplodus vulgaris 49, Diplodus sargus 25 y 21 de Zeus faber y Mugilidae sp. respectivamente. El conjunto lo completarían Sparus aurata con 19 piezas óseas, Pagellus acarne con 14, Anguilla anguilla 11, Scomber japonicus ocho, Symphodus melops siete, Polypron americanus seis, Argyrosomus regius cinco y dos restos de Pagellus bogaraveo y Gadidae sp. respectivamente. 


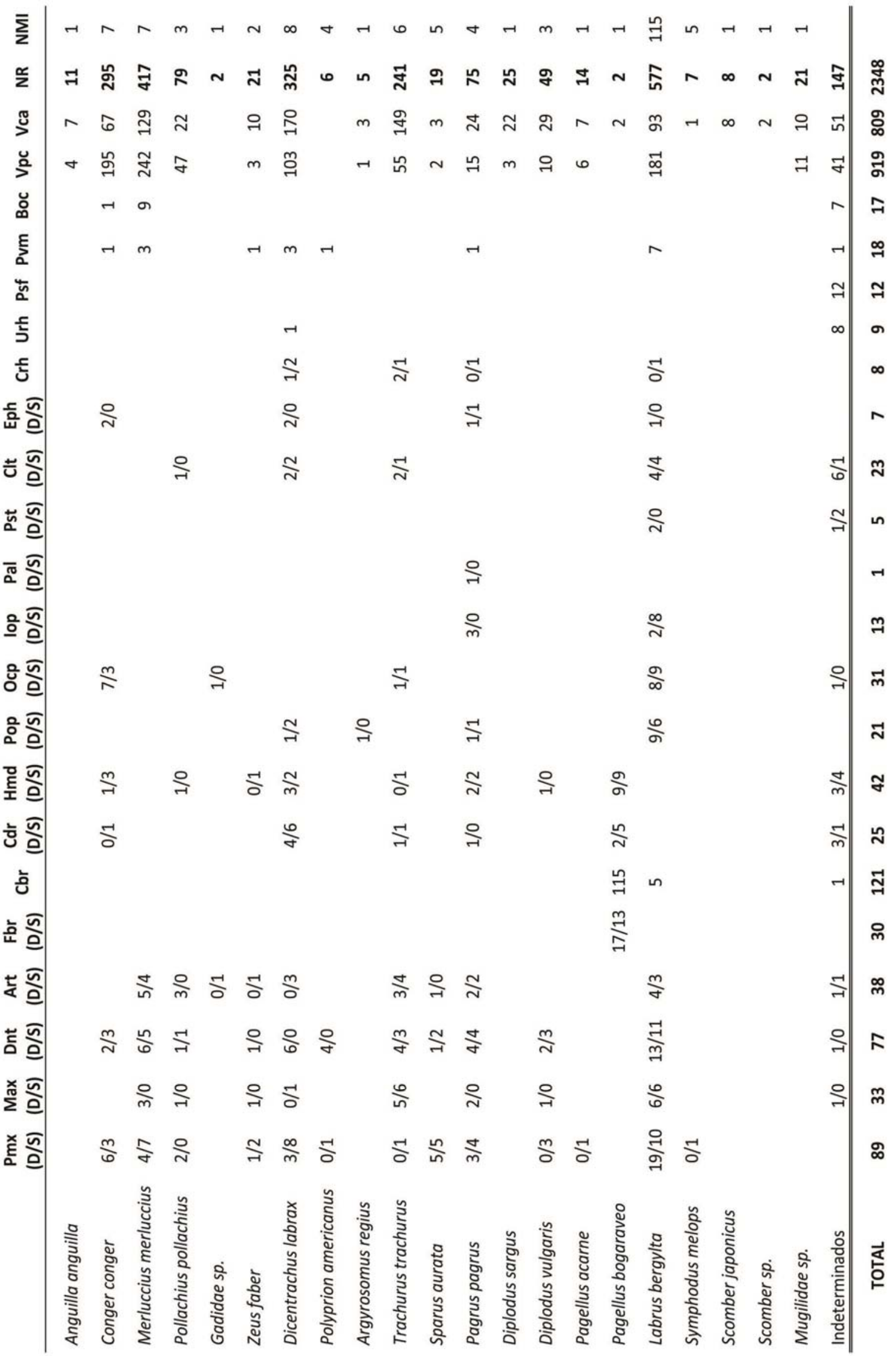

Tabla 191 Relación de especies y representación ósea. 


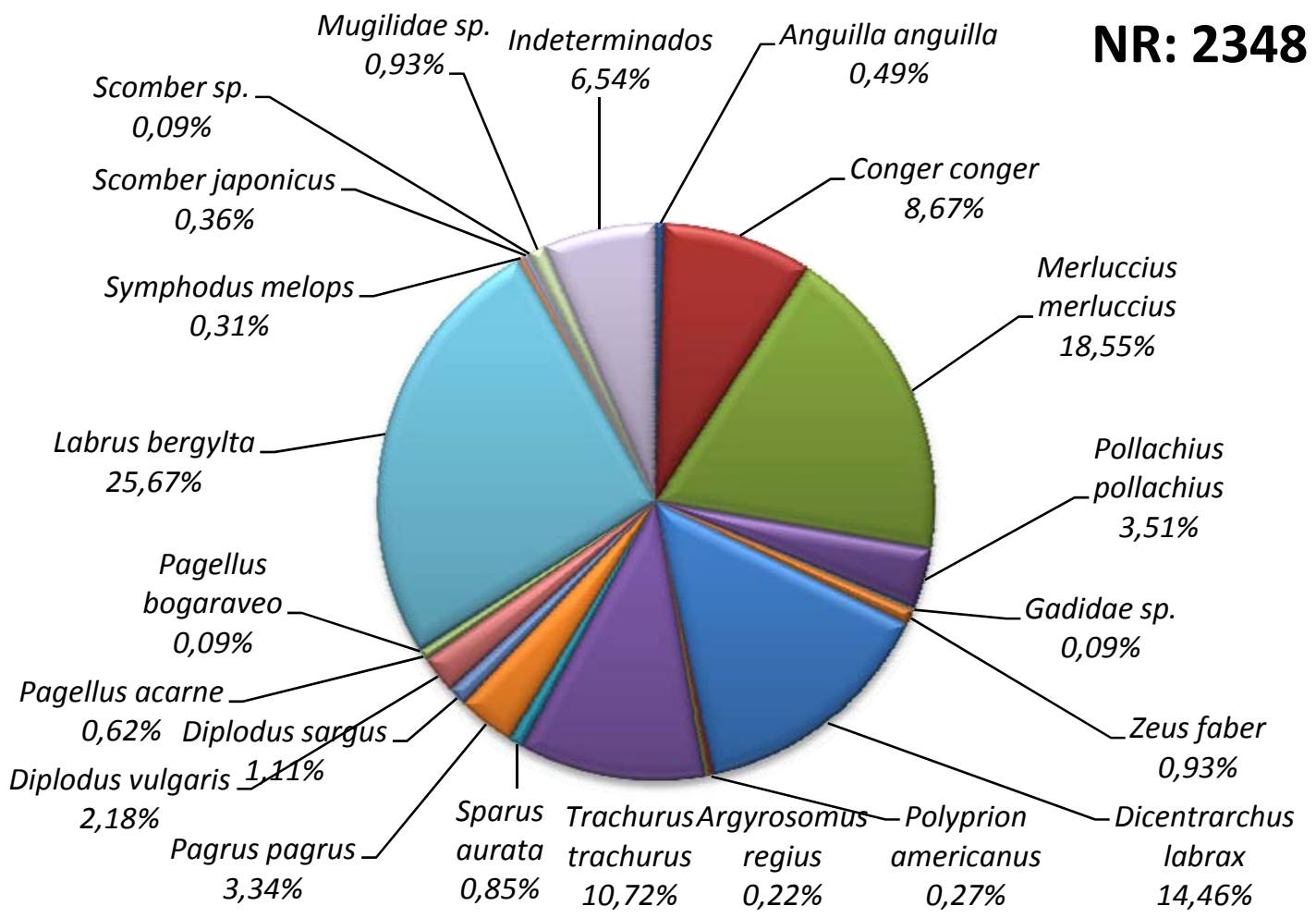

Fig. 258 Representatividad de los taxones según el NR.

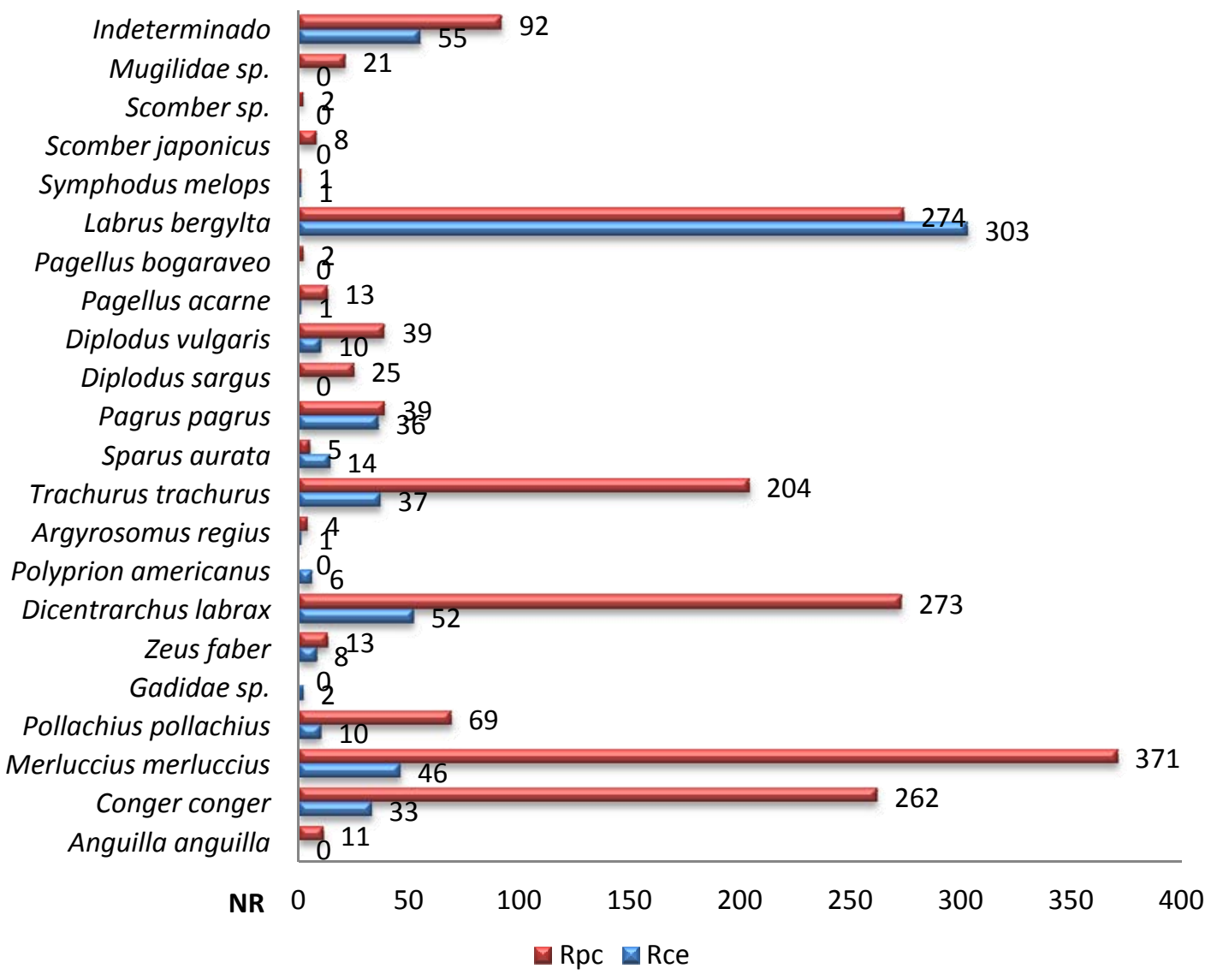

Fig. 259 Comparación numérica de los restos cefálicos y post-cefálicos de los taxones identificados. 


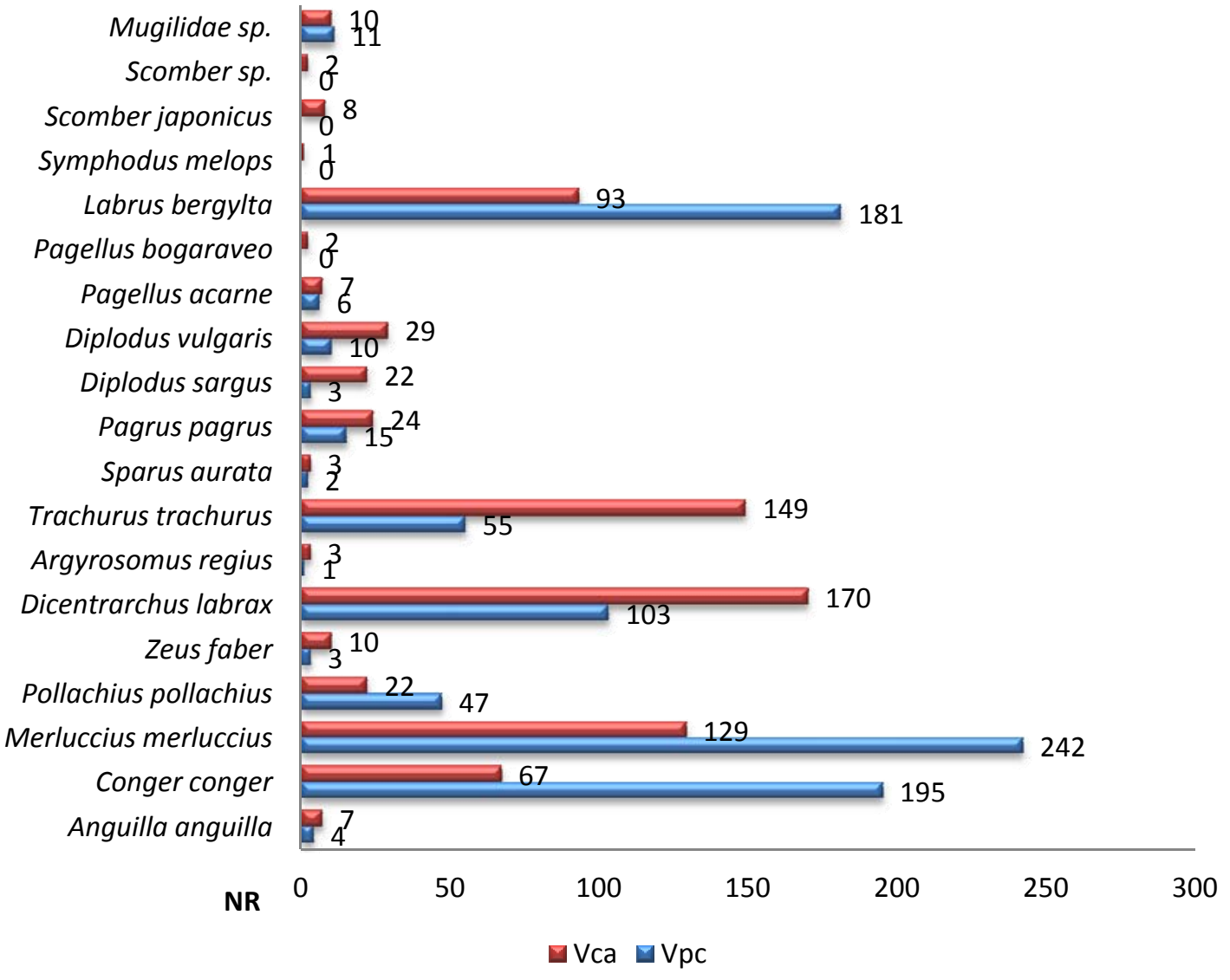

Fig. 260 Comparación numérica de las vértebras caudales y precaudales de los taxones identificados.

\section{V.9.6. QUEIRUGA.}

\section{Localización y cronología.}

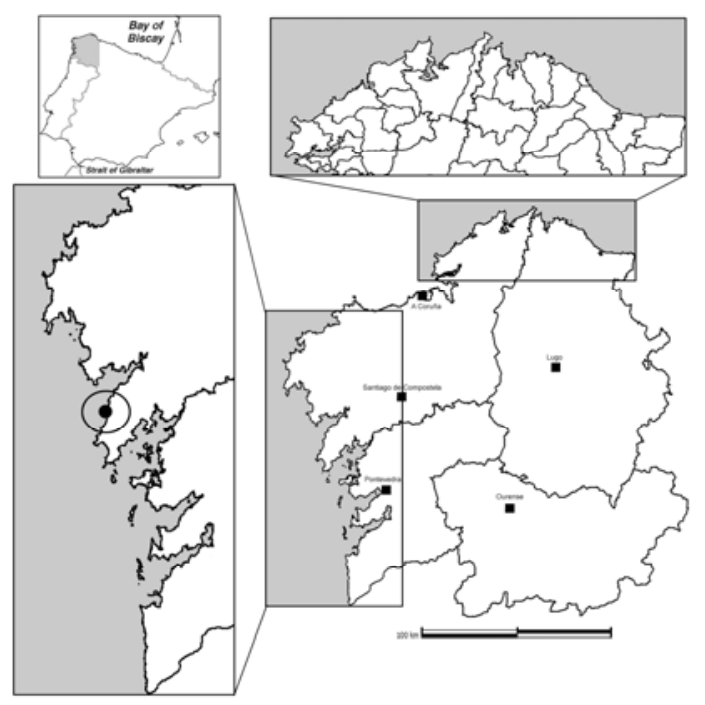

Fig. 261 Localización del Castro de Queiruga.

Castro situado en un promontorio rocoso en la orilla sur de la Ría de Noia, al sureste del Castro de Baroña. Se localiza en la parroquia de San Esteban de Queiruga, Concello de Porto do Son, A Coruña. Sus coordenadas son $9^{\circ} 02^{\prime} 20^{\prime \prime} \mathrm{W}$ y $42^{\circ} 40^{\prime} 12^{\prime \prime} \mathrm{N}$. Los restos proceden de las capas 1 y 3 del sondeo realizado por Rodríguez López en 1992. La primera capa presenta una potencia de 0,50 $\mathrm{m}$, y se caracteriza por la abundancia de materia orgánica. La segunda capa de 0,07-0,18 $\mathrm{m}$ con tierra oscura y escasos restos de ictiofauna. La capa tres sería de conchero, seguido de la capa cuatro que se apoya sobre la roca. Los materiales asociados datarían el 
depósito entre los siglos III-I a.C. Estos datos únicamente se encuentran recogidos en la Tesis de Licenciatura y la Tesis Doctoral de Ma.C. Ferré (1996; 2003).

\section{Estudio Ictiológico.}

La muestra la componían seis restos de Labrus bergylta, lo que indica una explotación del medio rocoso más cercano al yacimiento.

\begin{tabular}{ccccccc} 
& $\begin{array}{c}\mathrm{Cbr} \\
(\mathrm{D} / \mathrm{S})\end{array}$ & $\begin{array}{c}\mathrm{Cdr} \\
(\mathrm{D} / \mathrm{S})\end{array}$ & Vpc & Vca & NR & NMI \\
\hline Labrus bergylta & $0 / 1$ & $1 / 0$ & 2 & 2 & 6 & 1 \\
\hline \hline TOTAL & 1 & 1 & 2 & 2 & 6 &
\end{tabular}

Tabla 192 Relación de especies y representación ósea.

Labrus bergylta

NR $\quad 0$

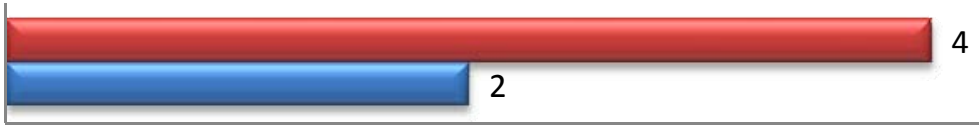

1

4
2

$\square \mathrm{Rpc} \square \mathrm{Rce}$

5

Fig. 262 Comparación numérica de los restos cefálicos y postcefálicos del taxón identificado.

\section{V.9.7. O ACHADIZo.}

\section{Localización y cronología.}

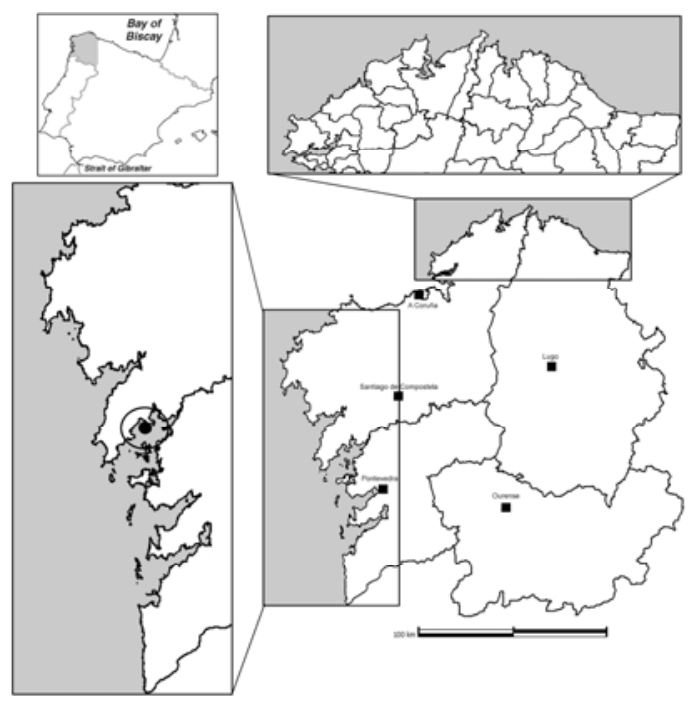

Fig. 263 Localización del Castro de O Achadizo.

Yacimiento situado en la margen derecha de la Ría de Arousa, en la Parroquia de Santa María de O Castro, Concello de Boiro, A Coruña. Sus coordenadas son $8^{\circ} 53^{\prime} 16^{\prime \prime} \mathrm{W}$ y $42^{\circ}$ $36^{\prime} 40^{\prime \prime} \mathrm{N}$. Los primeros estudios de ictiofauna realizados en $\mathrm{O}$ Achadizo corresponden a Camino López, que realiza el primer informe valorativo de la campaña de 1991 (s.f.), así como diversos trabajos con J.M. Vázquez Varela y J.M. Rey (Camino López et alii, 1991; Vázquez Varela et alii, 1993). Un segundo estudio fue realizado por Ma.C. Ferré, incorporando los restos documentados en las campañas realizadas entre 1991-1994, apareciendo en varios trabajos (Ferré, 1996; 2003; Ferré et alii, 1996). Estos datos también fueron publicados por Conchero Coello (2008) como parte de la memoria de las citadas excavaciones. 
Los restos estudiados por Ferré corresponden a las excavaciones de urgencia realizadas por A. Concheiro entre 1991 y 1994, y están adscritos a las siguientes fases: Fase IV formada por una capa de tierra vegetal, conchero y un nivel de destrucción que correspondería a época galaico-romana (Ferré et alii, 1996); Fase III constituída por el conchero " $A$ " con unas dataciones de 2174 \pm 35 BP, CSIC-1314 (Rubinos Pérez et alii, 1999; Concheiro Coello, 2008); Fase II compuesta por un conchero asociado a una zona de restos quemados, y con unas dataciones de $2441 \pm 44$ BP, CSIC-1314; 2307 \pm 29 BP, CSIC-1309 (Rubinos Pérez et alii, 1999; Concheiro Coello, 2008).

Estudio Ictiológico.

\begin{tabular}{|c|c|c|c|}
\hline . & $\begin{array}{c}\text { Camino López et alii, } 1991 \\
\text { (NR) }\end{array}$ & $\begin{array}{l}\text { Camino López, s.f. } \\
\text { (NR) }\end{array}$ & $\begin{array}{l}\text { Vázquez Varela et alii, } 1993 \\
\text { (NMI) }\end{array}$ \\
\hline Trisopterus luscus & $1 \mathrm{Pmx}(\mathrm{S})$ & $\begin{array}{l}11 \text { V; } 1 \text { Pvm; } 1 \\
\text { Max; } 1 \text { Pmx }\end{array}$ & 8 \\
\hline Sparus aurata & $1 \mathrm{Mol}$ & & 1 \\
\hline Diplodus vulgaris & & & 1 \\
\hline Pagellus bogaraveo & & $3 \mathrm{~V}$ & 2 \\
\hline Pagellus acarne & & $4 \mathrm{~V} ; 1 \mathrm{Boc}$ & 3 \\
\hline Pagellus sp. & & $5 \mathrm{~V} ; 1 \mathrm{Cdr}$ & 4 \\
\hline Dentex dentex & & & 1 \\
\hline Sparidae & & $3 \mathrm{~V}$ & 3 \\
\hline Merluccius merluccius & & $1 \mathrm{~V}$ & 1 \\
\hline Gadidae & & 7 V; 1 Pst; 1 Psf & 4 \\
\hline Labrus bergylta & & $2 \mathrm{~V} ; 1 \mathrm{Fbr}$ & 2 \\
\hline Simphodus melops & & $1 \mathrm{~V} ; 1$ Psf & 2 \\
\hline Trachurus trachurus & & $1 \mathrm{~V} ; 1 \mathrm{Pvm}$ & 2 \\
\hline Scomber scombrus & & & 1 \\
\hline Serránidae & & 1 Pop & \\
\hline Indeterminado & 46 & & 11 \\
\hline
\end{tabular}

Tabla 193 Cuadro comparativo de los primeros estudios realizados sobre ictiofauna de O Achadizo.

En los trabajos de M.C. Ferré, se han identificado 14 especies. Destacan los espáridos, principalmente Sparus aurata, predominando los restos cefálicos. En las demás especies dominan los centros vertebrales, destacando en cuanto a número de restos Merluccius merluccius y Trisopterus luscus. 


\begin{tabular}{|c|c|c|c|c|c|c|c|c|c|c|c|c|c|c|c|}
\hline Nivel II & $\begin{array}{l}\text { Pmx } \\
\text { (D/S) }\end{array}$ & $\begin{array}{c}\text { Max } \\
\text { (D/S) }\end{array}$ & $\begin{array}{c}\text { Dnt } \\
\text { (D/S) }\end{array}$ & Mol & $\begin{array}{l}\mathrm{Cdr} \\
\mathrm{D} / \mathrm{S})\end{array}$ & $\mathrm{Cbr}$ & $\begin{array}{c}\text { Opc } \\
\text { (D/S) }\end{array}$ & $\begin{array}{l}\text { Pop } \\
\text { (D/S) }\end{array}$ & Pvm & Psf & Urh & Vpc & Vca & NR & NMI \\
\hline Conger conger & & & & & & & & & & & & 1 & & 1 & 1 \\
\hline Merluccius merluccius & & & & & & & & & & & & 4 & 2 & 6 & 1 \\
\hline Trisopterus luscus & & & & & & & & & & & & 17 & 42 & 59 & 1 \\
\hline Sparus aurata & $8 / 3$ & $1 / 0$ & $6 / 2$ & 13 & $1 / 1$ & & & & & & & 1 & 2 & 38 & 8 \\
\hline Pagellus acarne & & & & & & & & & 1 & & & 1 & 2 & 4 & 1 \\
\hline Pagellus bogaraveo & & & & & $1 / 1$ & & & & & & & 17 & 56 & 75 & 1 \\
\hline Pagrus pagrus & & & & & & & & & & & & 10 & & 10 & 1 \\
\hline Labrus bergylta & & & & & & 1 & & & & & & & 1 & 2 & 1 \\
\hline Symphodus melops & & & $0 / 1$ & & & & & & & 1 & & & & 2 & 1 \\
\hline Indeterminados & & & & & & & $1 / 0$ & $1 / 0$ & & 1 & 1 & & 5 & 9 & \\
\hline TOTAL & 11 & 1 & 9 & 13 & 4 & 1 & 1 & 1 & 1 & 2 & 1 & 51 & 110 & 206 & \\
\hline
\end{tabular}

Tabla 194 Relación de especies y representación ósea del Nivel II.

El Nivel Il se corresponde con las muestras más antiguas d el Castro de O Achadizo. Las especies mejor representadas son Pagellus bogaraveo con 75 restos, Trisopterus luscus con 59 y Sparus aurata con 38. El conjunto se completa con la presencia de Merluccius merluccius con seis piezas óseas, Pagellus acarne con cuatro, Labrus bergylta y Symphodus melops con dos cada una y Conger conger con un resto.

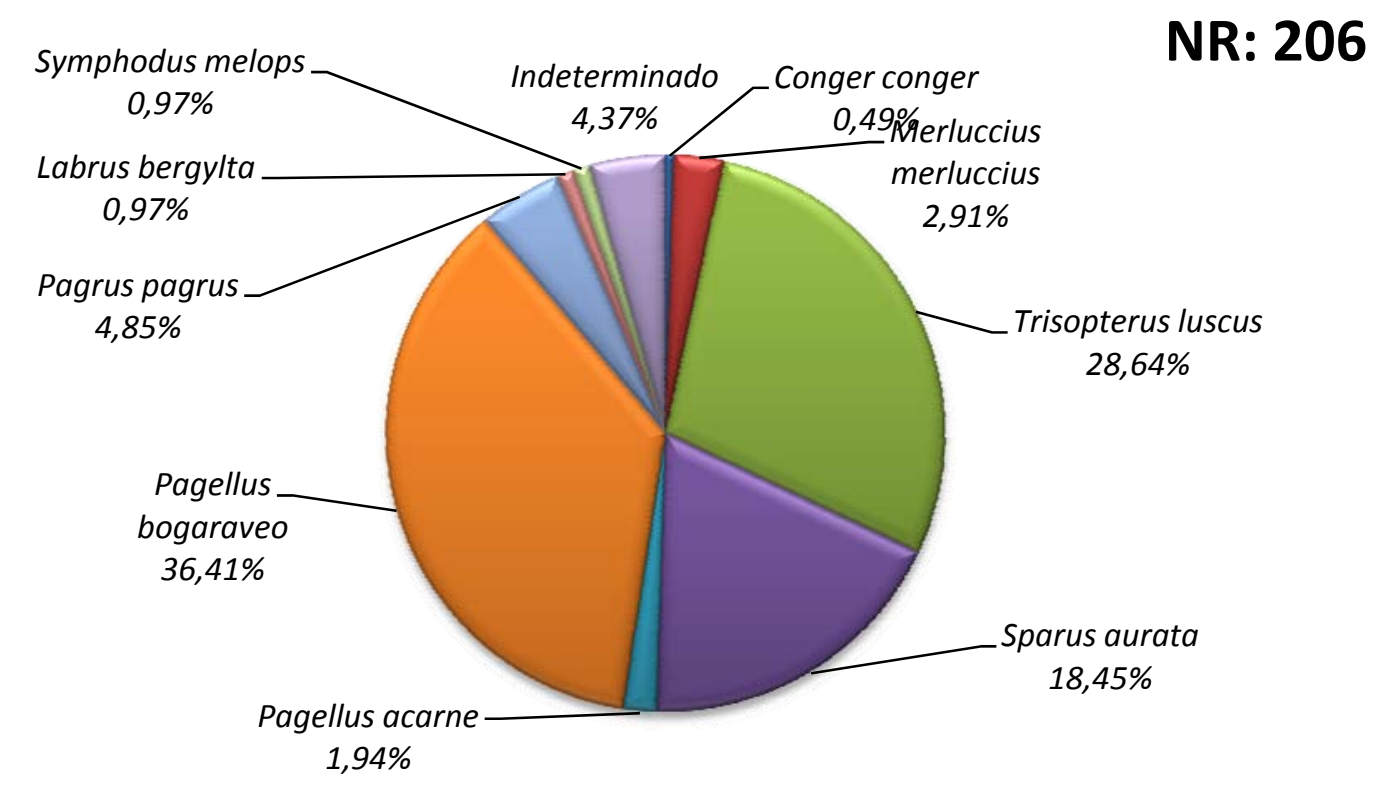

Fig. 264 Representatividad de los taxones según el NR. 


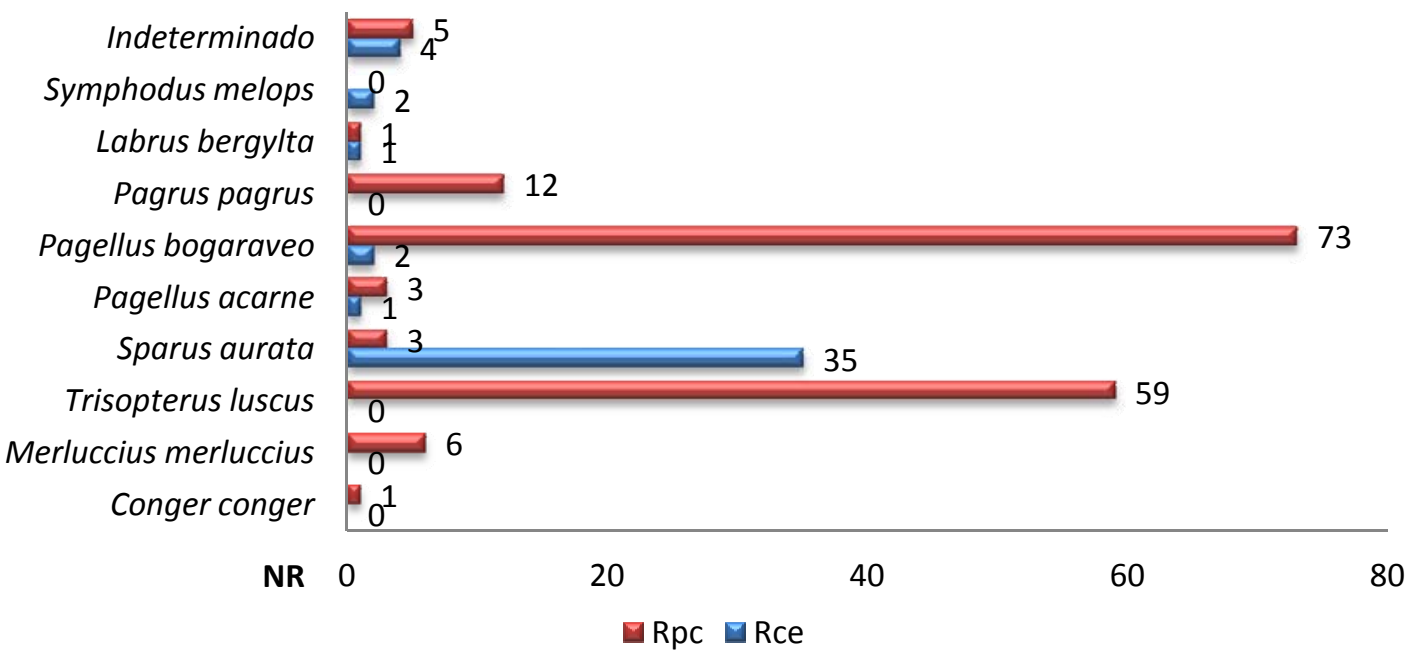

Fig. 265 Comparación numérica de los restos cefálicos y postcefálicos de los taxones identificados.

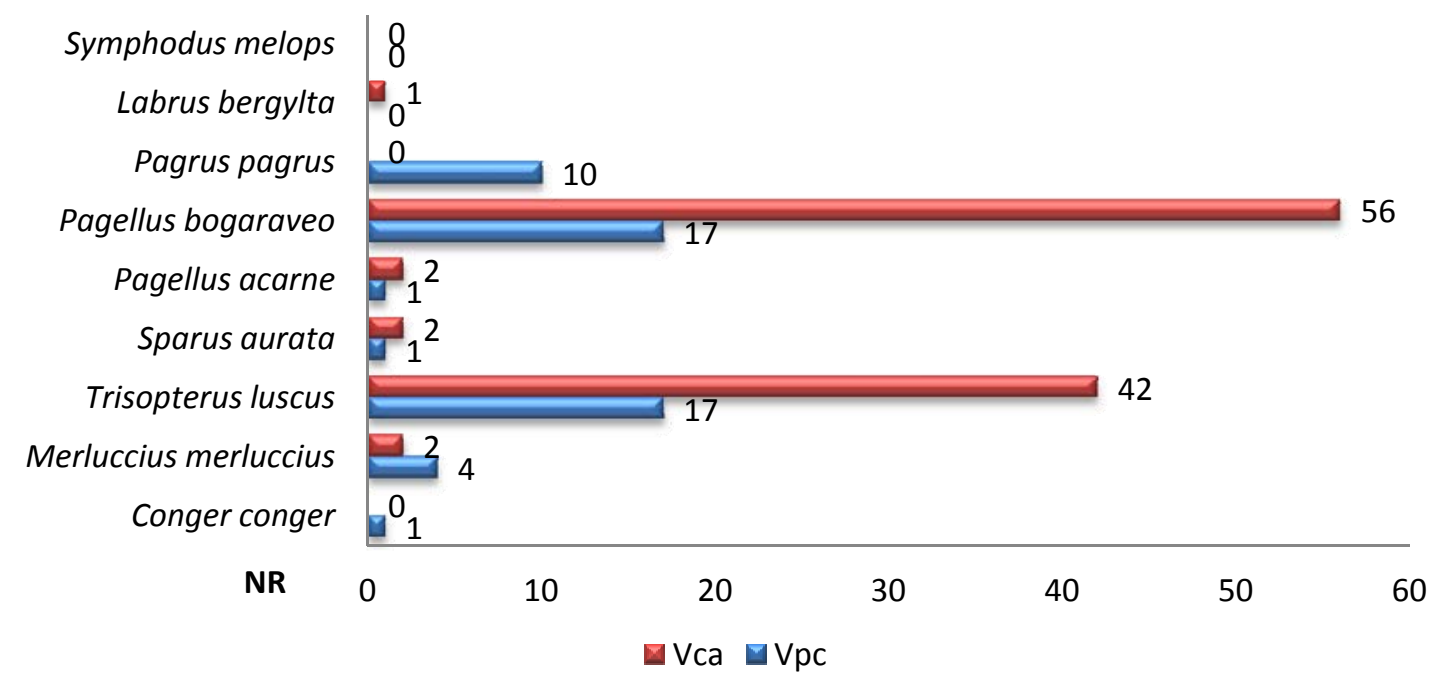

Fig. 266 Comparación numérica de las vértebras caudales y precaudales de los taxones identificados.

\begin{tabular}{|c|c|c|c|c|c|c|c|c|c|c|c|c|}
\hline Nivel III & $\begin{array}{c}\text { Pmx } \\
\text { (D/S) }\end{array}$ & $\begin{array}{c}\text { Max } \\
\text { (D/S) }\end{array}$ & $\begin{array}{c}\text { Art } \\
\text { (D/S) }\end{array}$ & $\begin{array}{c}\text { Dnt } \\
\text { (D/S) }\end{array}$ & Mol & $\begin{array}{c}C d r \\
\text { (D/S) }\end{array}$ & Boc & Pvm & Vpc & Vca & NR & NMI \\
\hline Salmo salar & & & & & & & & & 1 & & 1 & 1 \\
\hline Merluccius merluccius & & & & & & & & & 10 & 4 & 14 & 1 \\
\hline Trisopterus luscus & $0 / 1$ & $0 / 2$ & & & & & & 1 & 7 & 5 & 16 & 2 \\
\hline Pollachius pollachius & $1 / 0$ & & & & & & & & & & 1 & 1 \\
\hline Trachurus trachurus & & & & & & & & 1 & & 2 & 3 & 1 \\
\hline Sparus aurata & $2 / 8$ & & $0 / 1$ & $4 / 6$ & 6 & & & & & & 27 & 8 \\
\hline Pagellus bogaraveo & & & & & & $1 / 0$ & & & & 2 & 3 & 1 \\
\hline Pagrus pagrus & & & & & & & 1 & & 2 & & 5 & 1 \\
\hline Labrus bergylta & & & & & & & & & & 1 & 1 & 1 \\
\hline Symphodus melops & & & & & & & & & 1 & & 1 & 1 \\
\hline Indeterminados & & & & & & & 1 & & & & 1 & \\
\hline TOTAL & 13 & 3 & 1 & 10 & 6 & 1 & 2 & 2 & 21 & 14 & 73 & \\
\hline
\end{tabular}


En el Nivel III se observan ciertos cambios respecto al anterior depósito. La especie mejor representada es Sparus aurata con 27 restos seguida de Trisopterus luscus con 16 y Merluccius merluccius con 14. Las demás especies identificadas son Pagrus pagrus con cinco restos, Trachurus trachurus y Pagellus bogaraveo con tres cada uno y Salmo salar, Pollachius pollachius, Labrus bergylta y Symphodus melops con un resto.

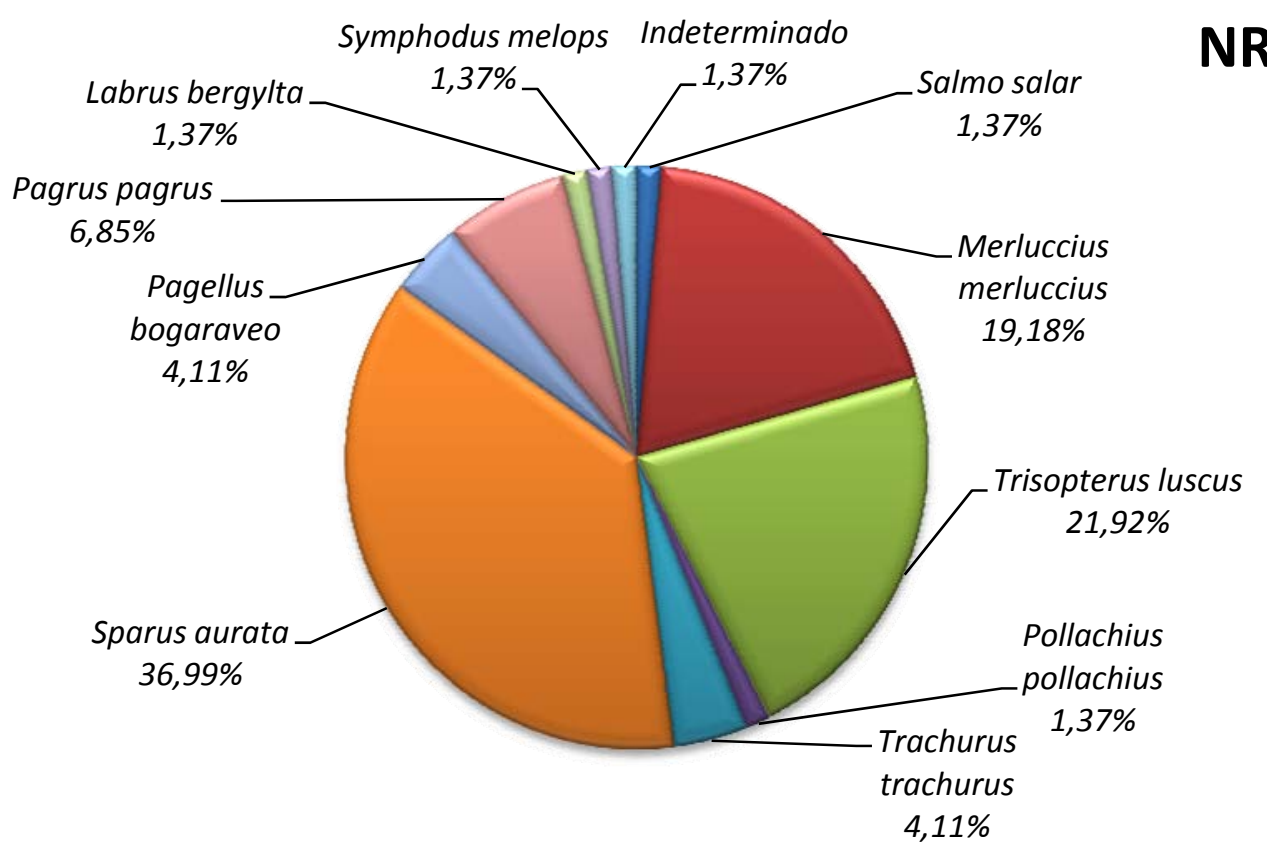

Fig. 267 Representatividad de los taxones según el NR.

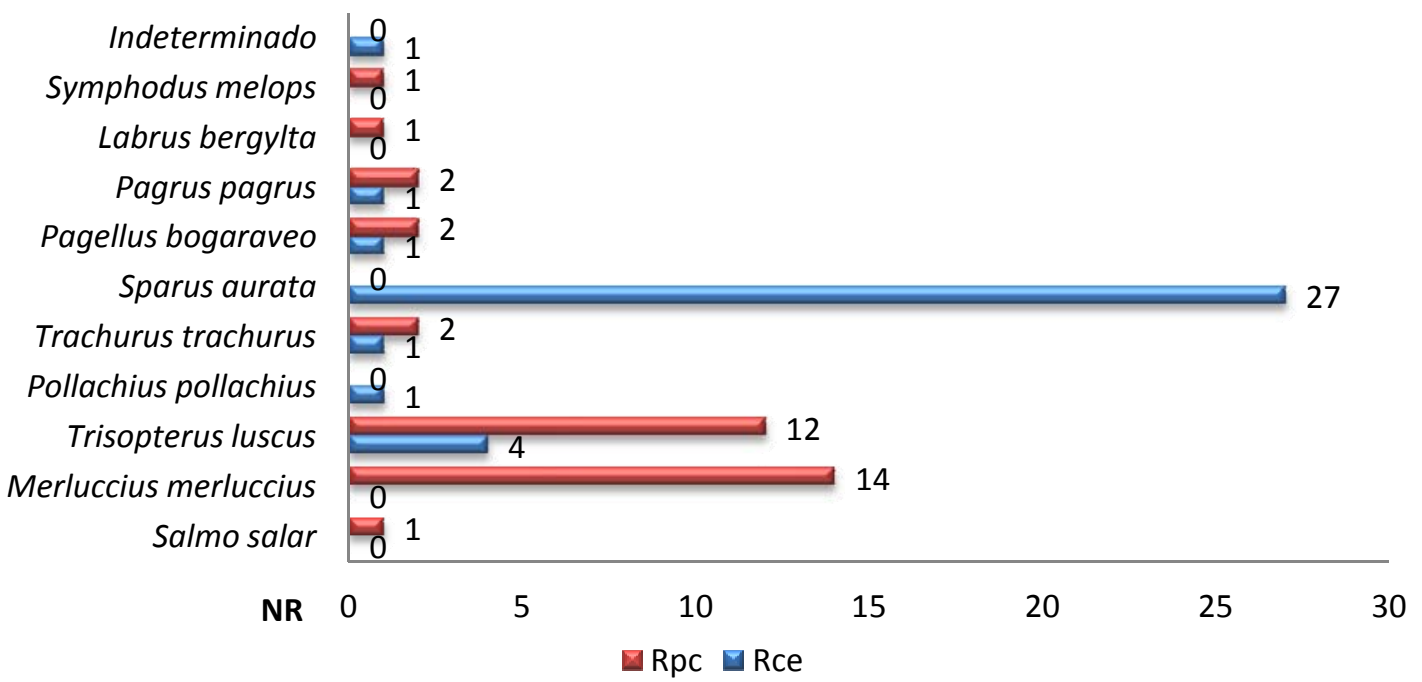

Fig. 268 Comparación numérica de los restos cefálicos y post-cefálicos de los taxones identificados. 


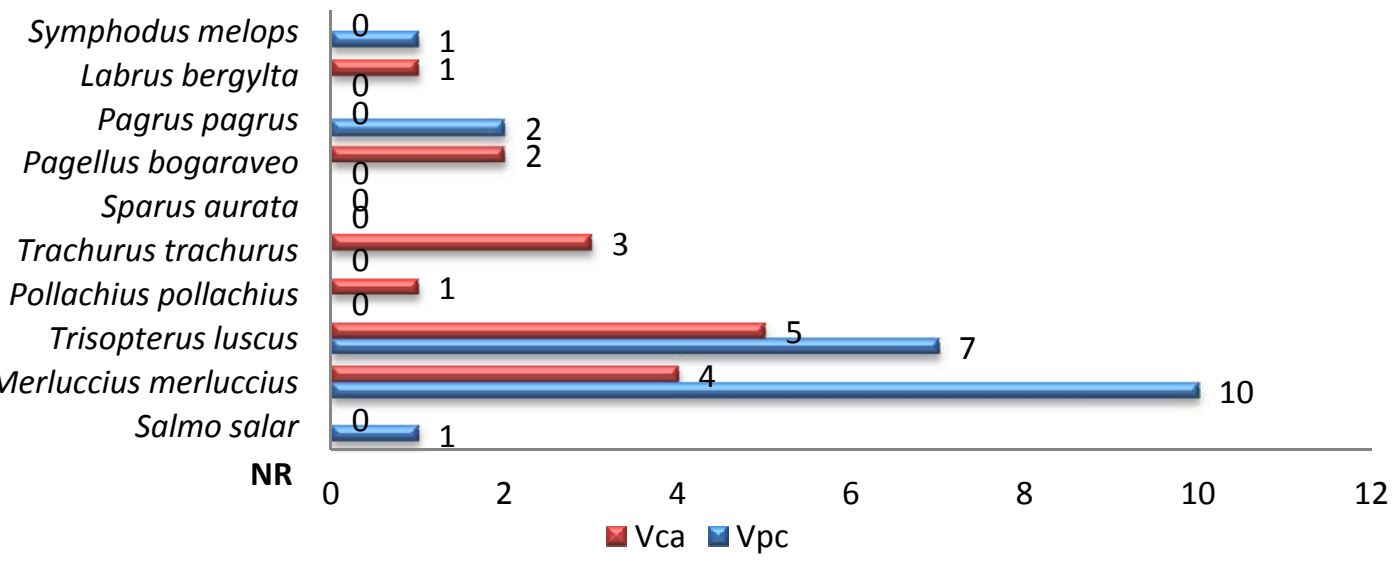

Fig. 269 Comparación numérica de las vértebras caudales y precaudales de los taxones identificados.

\begin{tabular}{|c|c|c|c|c|c|c|c|c|c|c|c|c|c|c|}
\hline Nivel IV & $\begin{array}{c}\mathrm{Pmx} \\
\text { (D/S) }\end{array}$ & $\begin{array}{c}\text { Max } \\
\text { (D/S) }\end{array}$ & $\begin{array}{c}\text { Art } \\
\text { (D/S) }\end{array}$ & $\begin{array}{c}\text { Dnt } \\
\text { (D/S) }\end{array}$ & Mol & $\begin{array}{c}\text { Cdr } \\
\text { (D/S) }\end{array}$ & $\begin{array}{l}\text { Hmd } \\
\text { (D/S) }\end{array}$ & $\begin{array}{c}\text { Opc } \\
\text { (D/S) }\end{array}$ & $\begin{array}{c}\text { Pst } \\
\text { (D/S) }\end{array}$ & $\begin{array}{c}\text { Crh } \\
\text { (D/S) }\end{array}$ & Vpc & Vca & NR & NM \\
\hline Trisopterus luscus & & & & & & & & & & & 7 & 4 & 11 & 1 \\
\hline Dicentrachus labrax & & & & & & & & & & & & 1 & 1 & 1 \\
\hline Polyprion americanus & & & & $1 / 0$ & & & & & & & & & 1 & 1 \\
\hline Trachurus trachurus & & & & & & & & & & & & 1 & 1 & 1 \\
\hline Sparus aurata & $16 / 18$ & $2 / 0$ & $4 / 3$ & $16 / 13$ & 4 & $2 / 1$ & $1 / 1$ & $2 / 1$ & $0 / 2$ & $1 / 0$ & 1 & 3 & 91 & 18 \\
\hline Dentex dentex & & & & & & & & & & & & 1 & 1 & 1 \\
\hline Pagellus acarne & & & & & & & & & & & & 2 & 2 & 1 \\
\hline Pagellus bogaraveo & & & & & & & & & & & & 2 & 2 & 1 \\
\hline Labrus bergy/ta & & & & & & & & & & & & 1 & 1 & 1 \\
\hline TOTAL & 34 & 2 & 7 & 30 & 4 & 3 & 2 & 3 & 2 & 1 & 8 & 15 & 111 & \\
\hline
\end{tabular}

El Nivel IV corresponde a fases galaico-romanas, variando considerablemente la composición de la muestra respecto a los conjuntos anteriores. La especie con más restos identificados en Sparus aurata con 91 restos. La segunda especie mejor representada es Trisopterus luscus con 11 piezas óseas. El conjunto lo completa Pagellus acarne y Pagellus bogaraveo con dos vértebras cada una, y Dicentrarchus labrax, Polyprion americanus, Trachurus trachurus, Dentex dentex y Labrus bergylta con un resto.

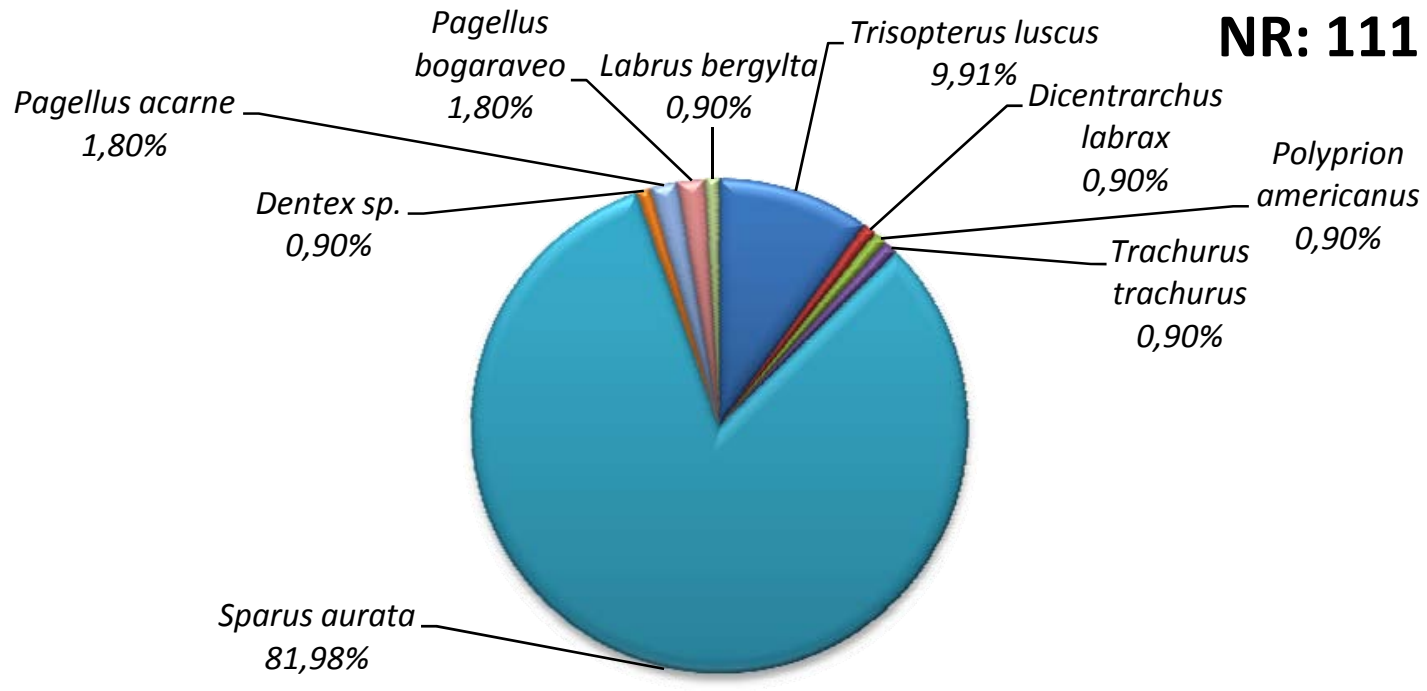

Fig. 270 Representatividad de los taxones según el NR. 


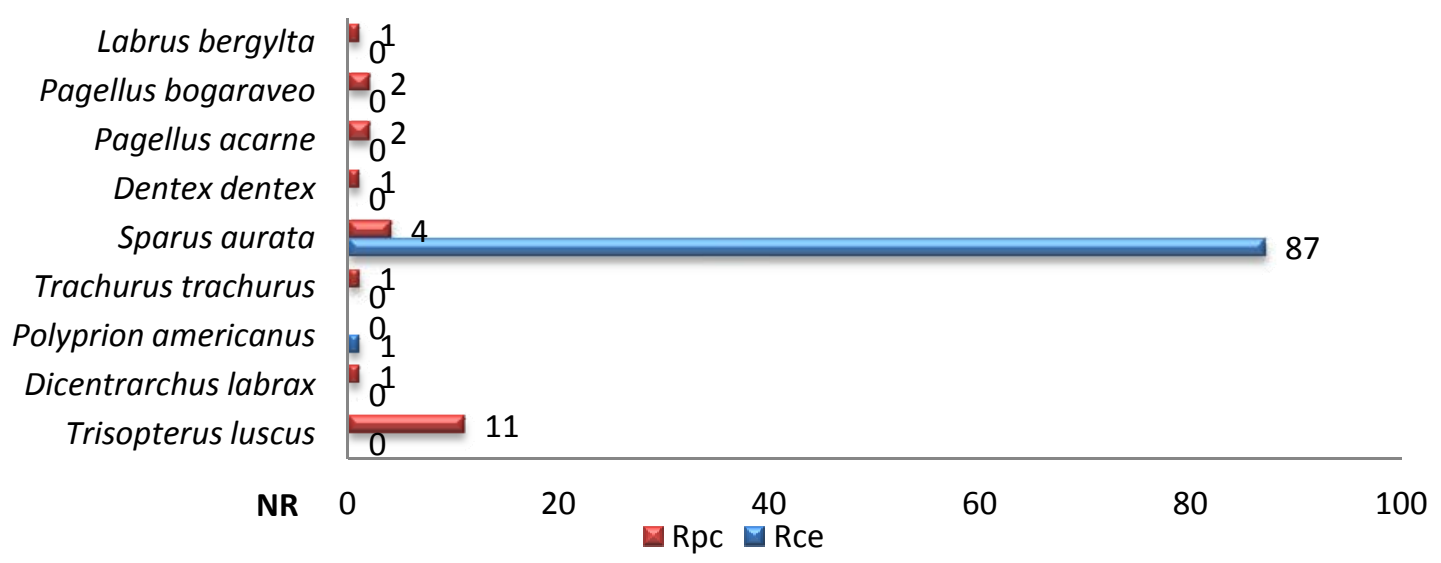

Fig. 271 Comparación numérica de los restos cefálicos y postcefálicos de los taxones identificados.

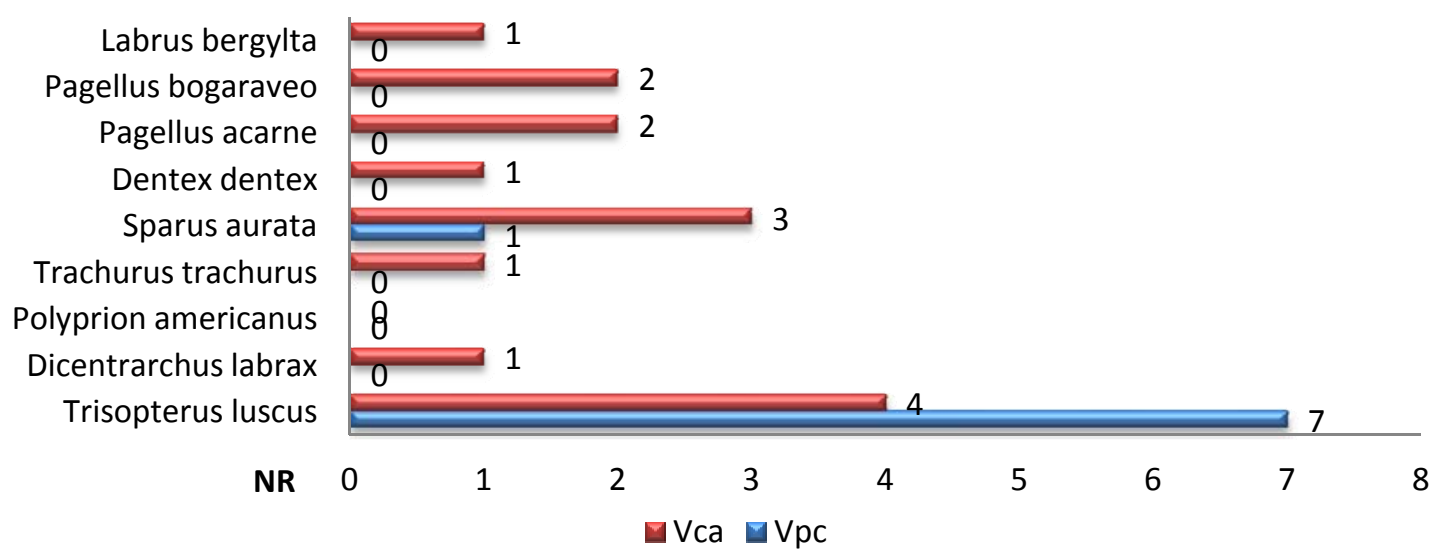

Fig. 272 Comparación numérica de las vértebras caudales y precaudales de los taxones identificados.

\section{V.9.8. TORRES DO OESTE.}

\section{Localización y cronología.}

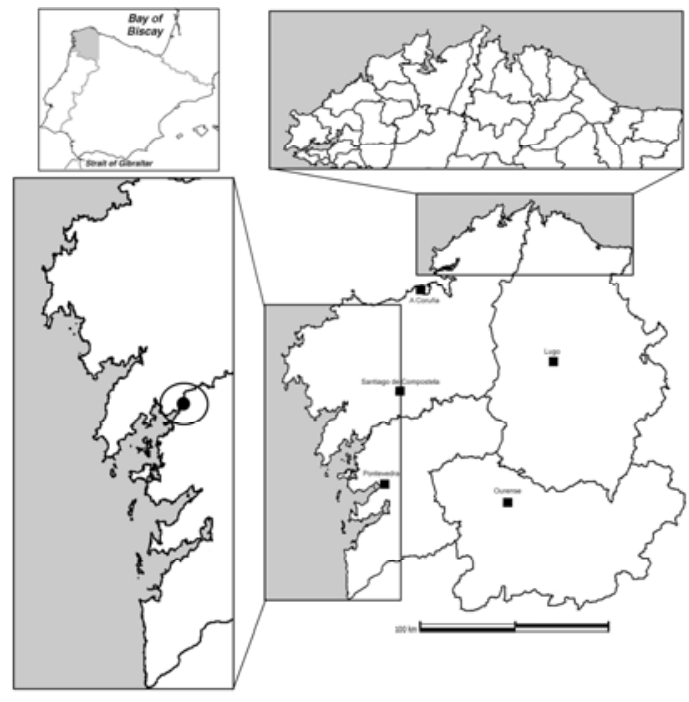

Fig. 273 Localización de Torres del Oeste.

Fortaleza medieval localizada en la margen izquierda del Río Ulla, cerca de su desembocadura, en la localidad de Catoira. Sus coordenadas son $8^{\circ} 43^{\prime} 26^{\prime \prime} \mathrm{W}$ y $42^{\circ} 40^{\prime}$ $39^{\prime \prime} \mathrm{N}$. El yacimiento está formado por un castro costero arrasado por la construcción de una fortaleza medieval. En primer lugar la fortaleza sirvió como defensa frente a los piratas, mientras que posteriormente pasó a controlar el tráfico comercial por la vía fluvial (Ferré, 2003).

Los análisis corresponden a las muestras tomadas en la campaña de 1989 con 
materiales adscritos a la Edad Media, entre el siglo XIII y XV d.C. (Ferré, 2003). De este yacimiento contamos con dos análisis, el primero de ellos fue realizado por M. Camino López, J.M. Vázquez Varela y J.M. Rey (1991), mientras que el segundo de ellos aparece en la Tesis Doctoral de Ma..C. Ferré Álvarez (2003). Ámbos estudios permanecen inéditos.

\section{Estudio Ictiológico.}

\begin{tabular}{l|c} 
& $\mathrm{NR}$ \\
\hline Conger conger & $1 \mathrm{Dnt}(\mathrm{D})$ \\
\hline Gadidae sp. & $1 \mathrm{Pmx}(\mathrm{S})$ \\
\hline Pagrus pagrus & $1 \mathrm{Pmx}(\mathrm{D})$ \\
\hline Sparus aurata & $1 \mathrm{Dnt}(\mathrm{S}) ; 1 \mathrm{Mol}$ \\
\hline Labrus bergylta & 1 Pmx (D); 1 Pmx (S); 1 Fbr 1 Cbr \\
\hline Indeterminados & 57
\end{tabular}

Tabla 197 Relación de especies y representación ósea del estudio de M. Camino López, J.M. Vázquez Varela y J.M. Rey (1991).

Se han identificado nueve taxones, a pesar del alto grado de deterioro de los restos. Merluccius merluccius es la especie mejor representada. La presencia de especies de gran tamaño, como Zeus faber y Argyrosomus regius, sugiere que pudieran servir de pago del portazgo (Ferré, 2003).

\begin{tabular}{|c|c|c|c|c|c|c|c|c|c|c|c|c|c|c|}
\hline & $\begin{array}{l}\text { Pmx } \\
\text { (D/S) }\end{array}$ & $\begin{array}{l}\text { Max } \\
\text { (D/S) }\end{array}$ & $\begin{array}{l}\text { Dnt } \\
\text { (D/S) }\end{array}$ & $\begin{array}{l}\text { Art } \\
\text { (D/S) }\end{array}$ & $\begin{array}{l}\text { Hmd } \\
\text { (D/S) }\end{array}$ & Mol & $\mathrm{Cbr}$ & $\begin{array}{l}\text { Eph } \\
\text { (D/S) }\end{array}$ & $\begin{array}{l}\text { Crh } \\
\text { (D/S) }\end{array}$ & Psf & Vpc & Vca & NR & NMI \\
\hline Conger conger & & $0 / 1$ & & $1 / 0$ & & & & $1 / 0$ & $1 / 0$ & & & & 4 & 1 \\
\hline M. merluccius & & $0 / 1$ & & & $1 / 0$ & & & & & & 18 & 28 & 48 & 1 \\
\hline Zeus faber & $1 / 0$ & & & & & & & & & & & & 1 & 1 \\
\hline Serranidae sp. & & $1 / 0$ & & & & & & & & & & & 1 & 1 \\
\hline A. regius & $1 / 0$ & & & & & & & & & & & & 1 & 1 \\
\hline Sparus aurata & & & $1 / 0$ & & & 1 & & & & & & & 2 & 1 \\
\hline Pagrus pagrus & $1 / 0$ & & & & & & & & & & & & 1 & 1 \\
\hline Pagellus acarne & & & & & & & & & & & & 1 & 1 & 1 \\
\hline P. bogaraveo & & & & & & & & & & & 1 & & 1 & 1 \\
\hline Sparidae sp. & & $1 / 0$ & & & & & & & & & & & 1 & 1 \\
\hline Labrus bergylta & $2 / 0$ & & & & $0 / 1$ & & 1 & & & & & & 4 & 2 \\
\hline Mugilidae sp. & & & & & & & & & & & 1 & & 1 & 1 \\
\hline Indeterminados & & & $1 / 0$ & & & & & & & 1 & & 2 & 4 & 1 \\
\hline TOTAL & 5 & 4 & 2 & 1 & 2 & 1 & 1 & $\overline{c 1}$ & 1 & 1 & 20 & 31 & 70 & \\
\hline
\end{tabular}

Más de la mitad de los restos identificados pertenecen a Merluccius merluccius. Otras especies que componen la muestra son Conger conger y Labrus bergy/ta con cuatro restos cada una, además de Sparus aurata con dos. El conjunto lo completarían Zeus faber, Argyrosomus regius, Pagrus pagrus, Pagellus acarne, Pagellus bogaraveo, Mugilidae sp, Sparidae sp. y Serranidae sp. con un resto cada una. 


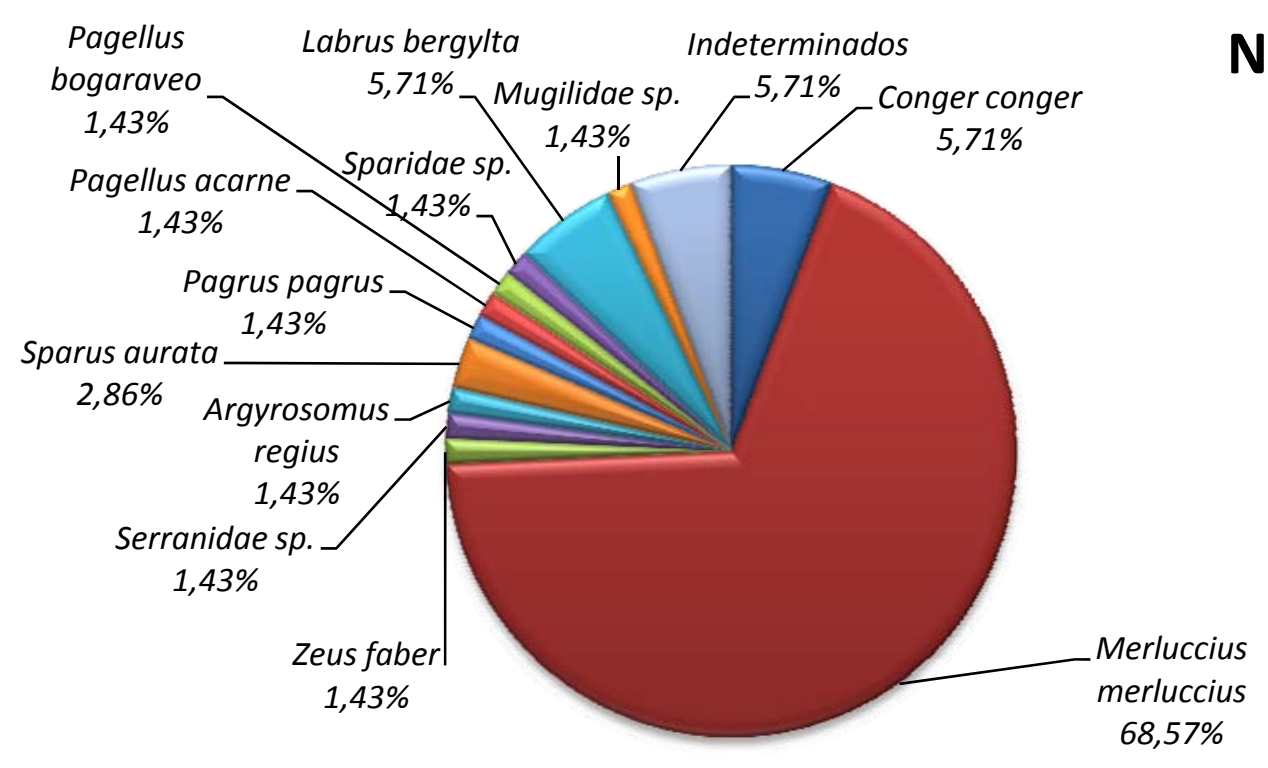

Fig. 274 Representatividad de los taxones según el NR.

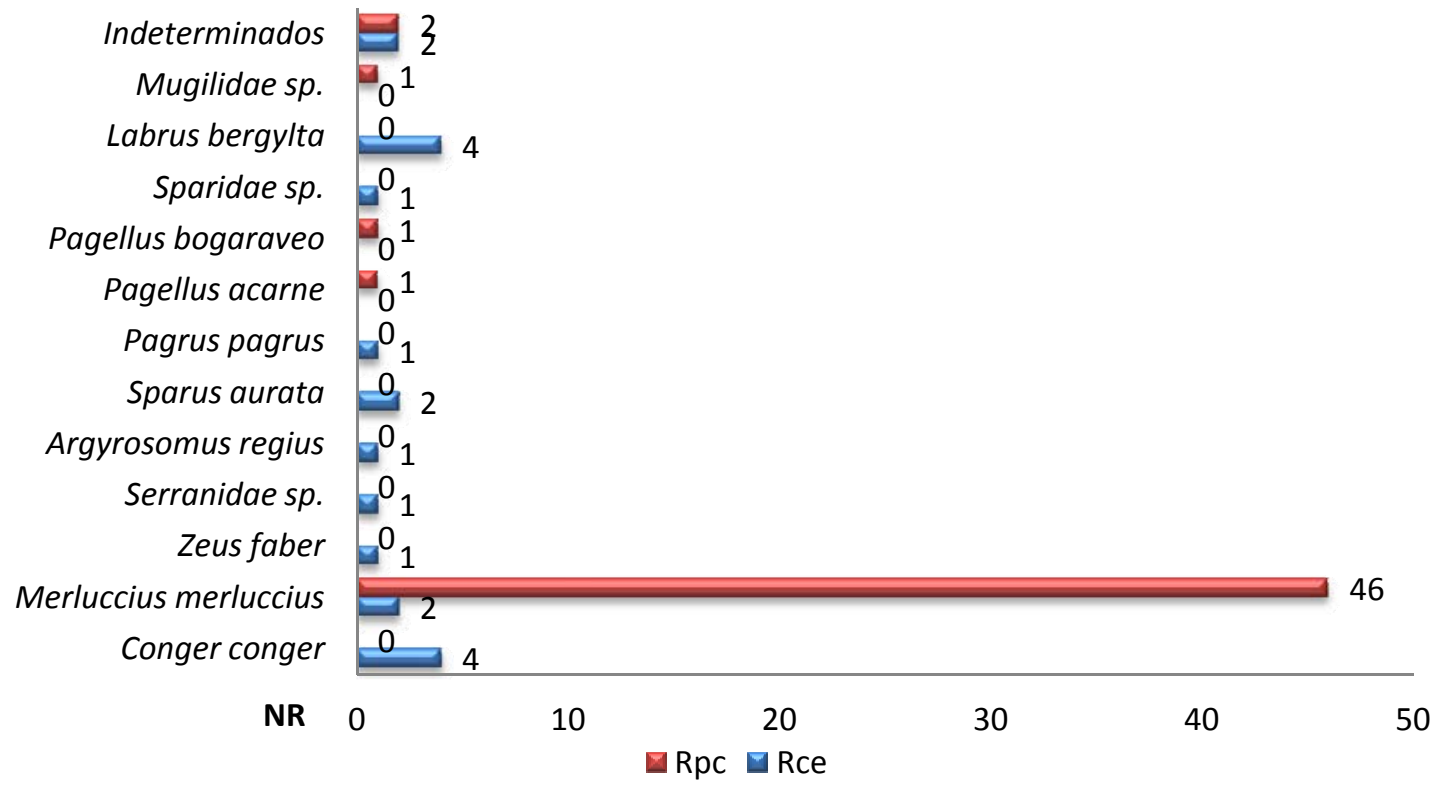

Fig. 275 Comparación numérica de los restos cefálicos y postcefálicos de los taxones identificados.

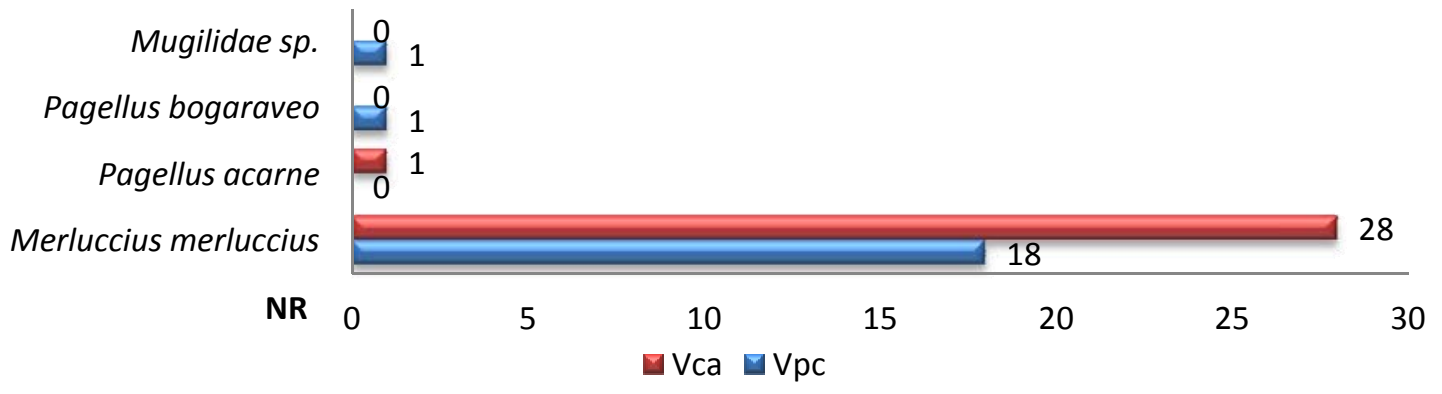

Fig. 276 Comparación numérica de las vértebras caudales y precaudales de los taxones identificados. 


\section{V.9.9. CantodorXo.}

Localización y cronología.

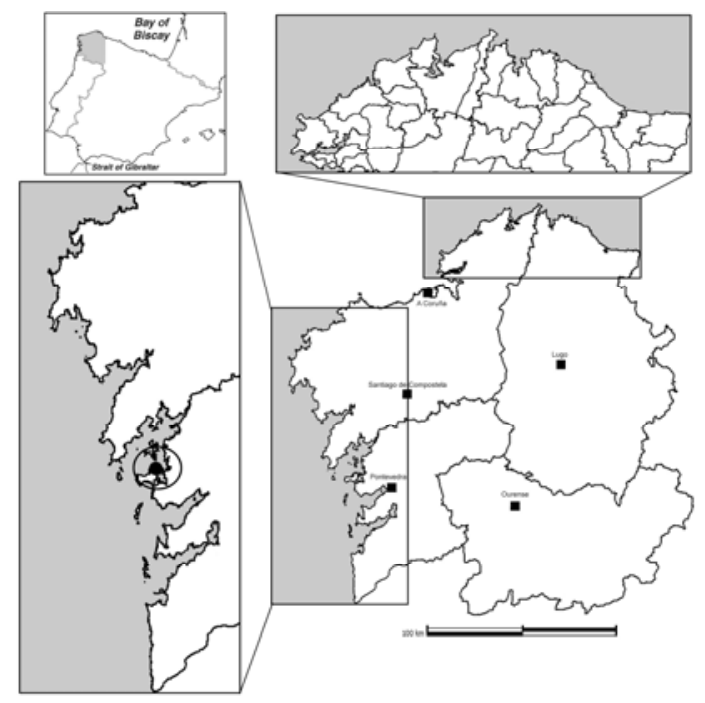

Fig. 277 Localización del Castro de Cantodorxo.

Yacimiento localizado en la Península de O Grove, al suroeste de la Ría de Arousa. Pertenece a la parroquia de San Martín de O Grove, Concello de O Grove en Pontevedra. Sus coordenadas son $8^{\circ} 52^{\prime} 15^{\prime \prime} \mathrm{W}$ y $42^{\circ} 30^{\prime} 04^{\prime \prime} \mathrm{N}$. Los materiales proceden de los sondeos realizados por Rodríguez López en 1993. El perfil norte está formado por tres capas: 1a de $0,80 \mathrm{~m}$ de potencia con materiales de distinta procedencia; 2a capa de 0,30 m que sería el conchero; 3 a de 0,40 m formado por materiales turbosos. En cuanto al perfil Oeste se aprecian diferencias: 1a capa de 0,35 m similar a la primera del perfil norte; $2^{a}$ nivel de $0,70 \mathrm{~m}$ que constituye el conchero; 3a capa de 0,32 m de color amarillo y con material cerámico; 4a capa similar a la tercera del perfil norte. La cerámica recuperada situaría el depósito entre los siglos IV-II a.C. Los resultados del estudio ictiológico han sido publicados en varios trabajos (Ferré, 1996; 2003; Ferré et alii, 1996; Fernández Rodríguez et alii, 1998).

\section{Estudio Ictiológico.}

Las especies documentadas en ambos perfiles son similares, salvo la presencia de Anguilla anguilla y Diplodus sargus en el perfil norte. Predominan los restos de Labrus bergylta, seguida de Pagrus pagrus. Preponderancia de los espáridos. La mayoría de las especies, menos Sparus aurata, presentan mayor número de restos post-cefálicos (Ferré, 2003).

\begin{tabular}{lcccccccccc} 
PERFIL NORTE & $\begin{array}{c}\text { Pmx } \\
\text { (D/S) }\end{array}$ & $\begin{array}{c}\text { Dnt } \\
\text { (D/S) }\end{array}$ & $\begin{array}{c}\text { Cdr } \\
\text { (D/S) }\end{array}$ & Cbr & Pvm & Boc & Vpc & Vca & NR & NMI \\
\hline Anguilla anguilla & & & & & & & & 1 & $\mathbf{1}$ & 1 \\
Gadidae sp. & & & & & & & 5 & & $\mathbf{5}$ & 1 \\
Trisopterus luscus & & & $1 / 0$ & & & & 1 & & $\mathbf{2}$ & 1 \\
Diplodus sargus & & & & & & & 2 & & $\mathbf{2}$ & 1 \\
Pagellus acarne & & & & & & & & 1 & $\mathbf{1}$ & 1 \\
Pagellus bogaraveo & & & & & & & 2 & 5 & $\mathbf{7}$ & 1 \\
Pagrus pagrus & $1 / 0$ & & & & & & 3 & 5 & $\mathbf{9}$ & 1 \\
Sparus aurata & $1 / 0$ & $0 / 2$ & & & & & & & $\mathbf{3}$ & 2 \\
Labrus bergylta & & & $1 / 0$ & 2 & & & 5 & 3 & $\mathbf{1 1}$ & 2 \\
Indeterminados & & & & & 1 & 1 & 3 & & $\mathbf{5}$ & 1 \\
\hline \multicolumn{1}{c}{ TOTAL } & $\mathbf{2}$ & $\mathbf{2}$ & $\mathbf{2}$ & $\mathbf{2}$ & $\mathbf{1}$ & $\mathbf{1}$ & $\mathbf{2 1}$ & $\mathbf{1 5}$ & $\mathbf{4 6}$ &
\end{tabular}

Tabla 199 Relación de especies y representación ósea del perfil norte de Cantodorxo. 
Las especies identificadas con más restos son Labrus bergylta con 11, Pagrus pagrus con nueve, Pagellus bogaraveo con siete y Gadidae sp. con cinco. El conjunto se completa con la presencia de Sparus aurata con tres restos, Trisopterus luscus y Diplodus sargus con dos piezas cada una, y con un resto Anguilla anguilla y Pagellus acarne.

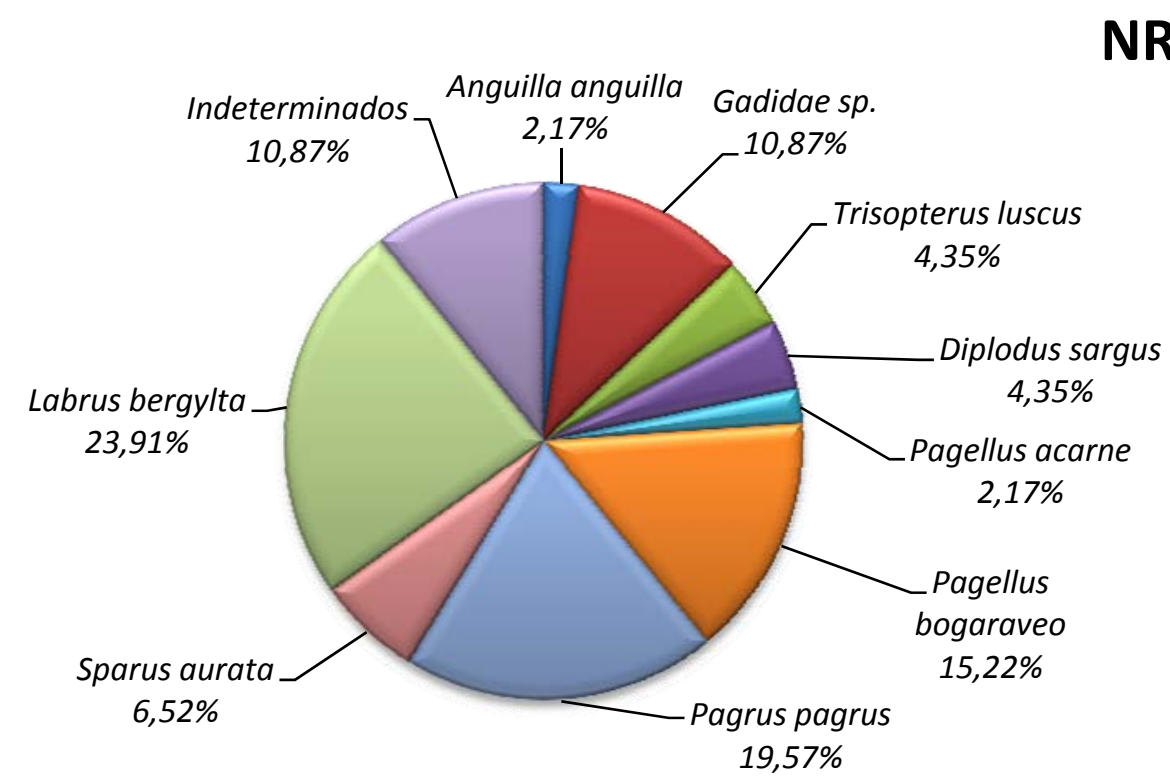

Fig. 278 Representatividad de los taxones según el NR.

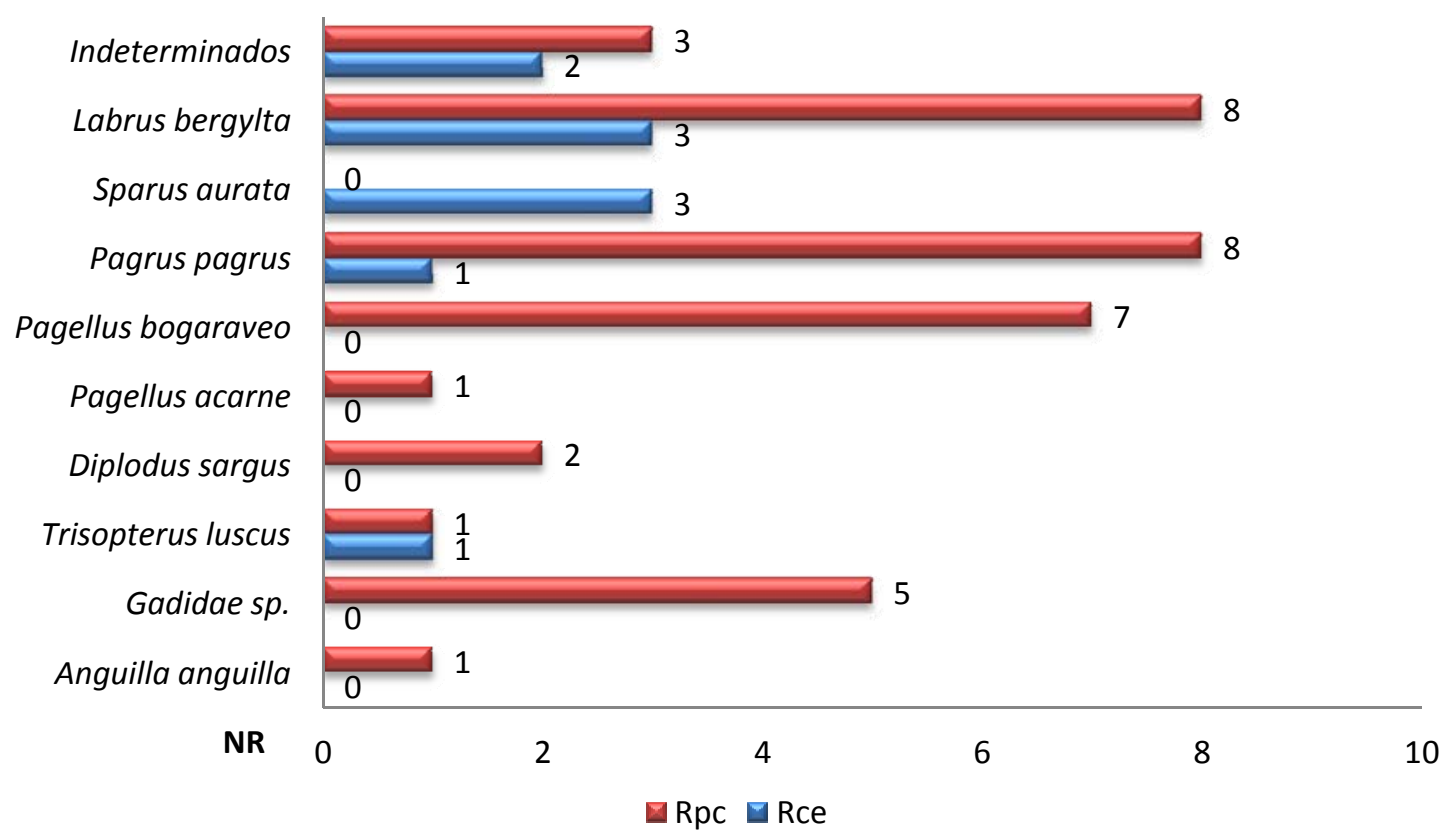

Fig. 279 Comparación numérica de los restos cefálicos y postcefálicos de los taxones identificados. 


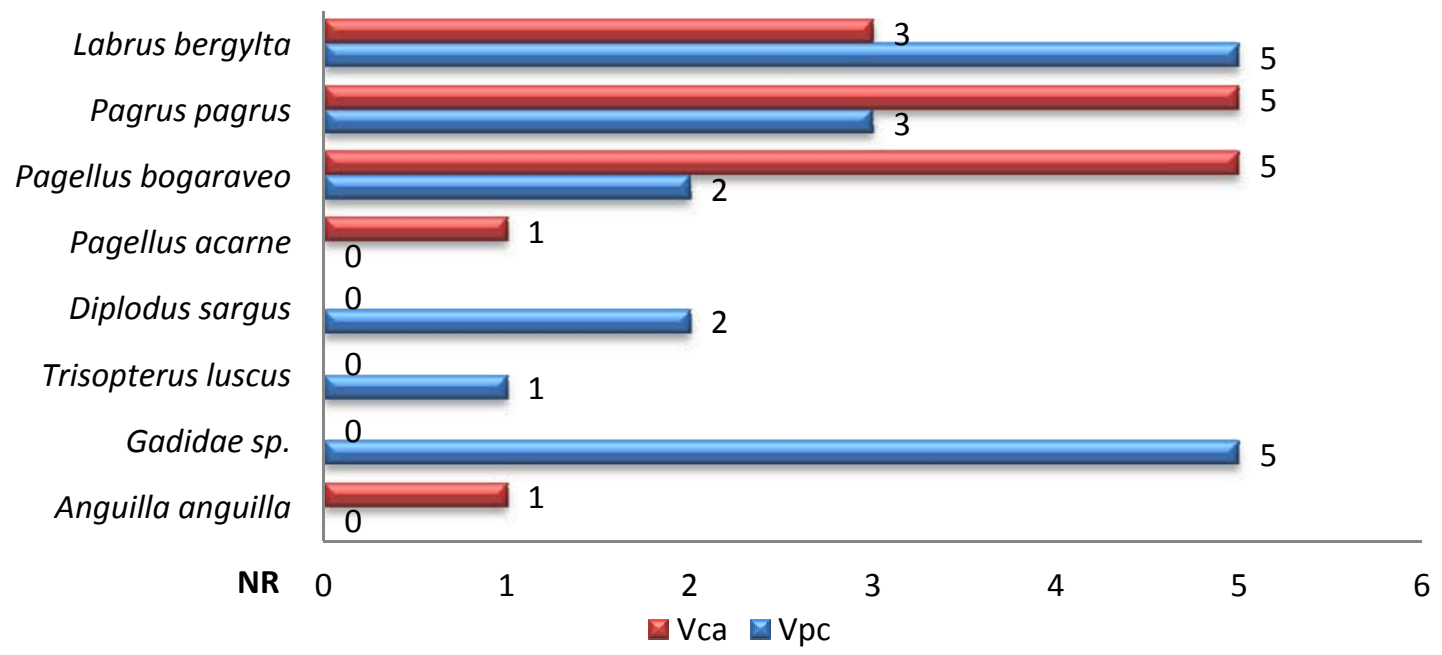

Fig. 280 Comparación numérica de las vértebras caudales y precaudales de los taxones identificados.

\begin{tabular}{|c|c|c|c|c|c|c|c|c|}
\hline PERFIL OESTE & $\begin{array}{c}\text { Pmx } \\
(D / S)\end{array}$ & $\begin{array}{c}\text { Max } \\
\text { (D/S) }\end{array}$ & $\begin{array}{c}\text { Fbr } \\
(D / S)\end{array}$ & Boc & Vpc & Vca & NR & NMI \\
\hline Gadidae sp. & & & & & 1 & & 1 & 1 \\
\hline Trisopterus Iuscus & & $0 / 1$ & & & 8 & & 9 & 1 \\
\hline Pagellus acarne & & & & & & 1 & 1 & 1 \\
\hline Pagellus bogaraveo & & & & & & 4 & 4 & 1 \\
\hline Pagrus pagrus & & & & & & 2 & 2 & 1 \\
\hline Sparus aurata & $0 / 1$ & & & & & & 1 & 1 \\
\hline Labrus bergylta & & & $0 / 1$ & & 1 & 1 & 3 & 1 \\
\hline Indeterminados & & & & 2 & & 2 & 4 & 1 \\
\hline TOTAL & 1 & 1 & 1 & 2 & 10 & 10 & 25 & \\
\hline
\end{tabular}

En el perfil oeste las especies con más restos identificados son Trisopterus luscus con nueve, Pagellus bogaraveo con cuatro y Labrus bergylta con tres. El conjunto se completaría con dos restos de Pagrus pagrus y uno de Gadidae sp., Pagellus acarne y Sparus aurata.

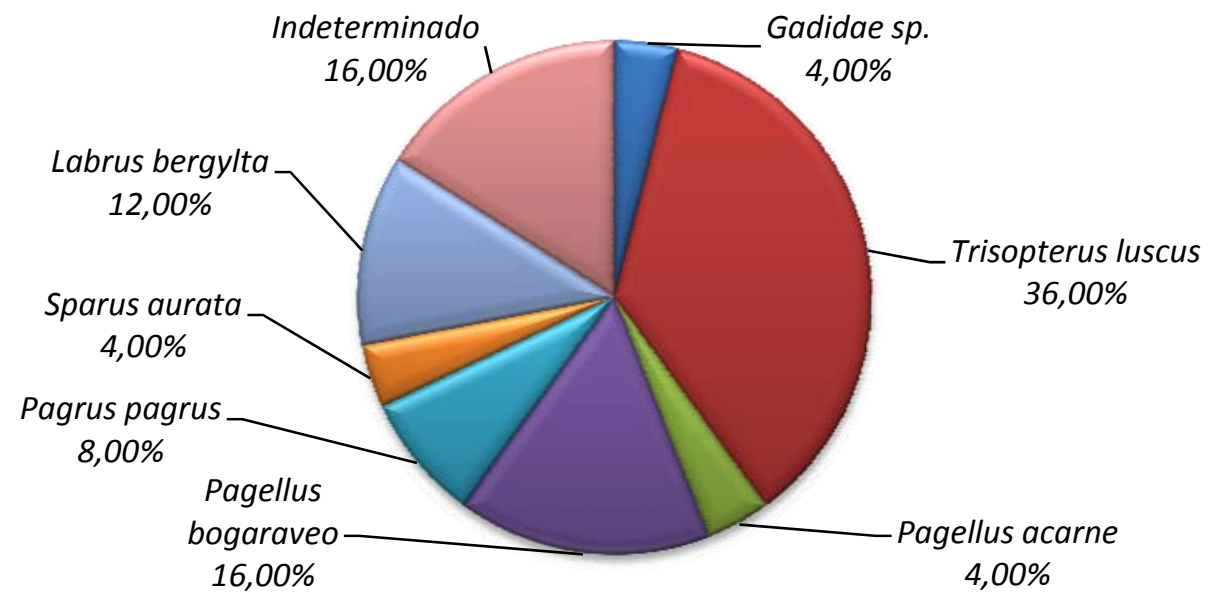

Fig. 281 Representatividad de los taxones según el NR. 


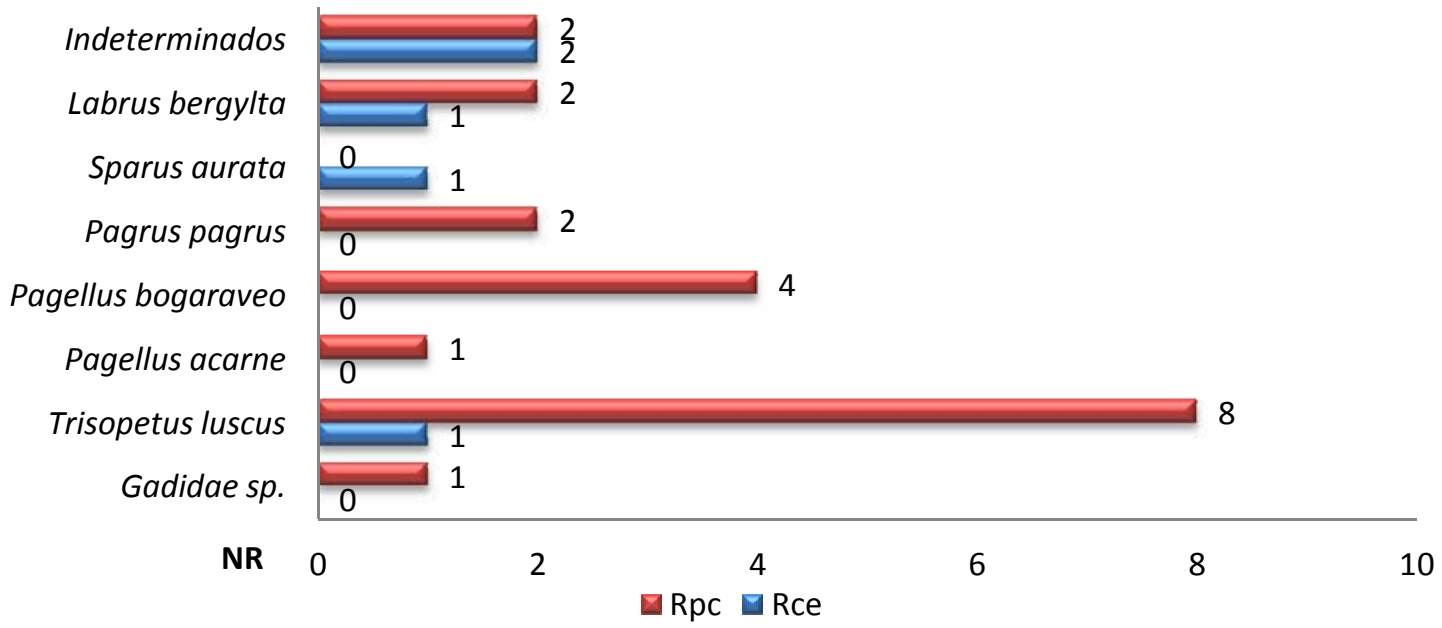

Fig. 282 Comparación numérica de los restos cefálicos y postcefálicos de los diferentes taxones.

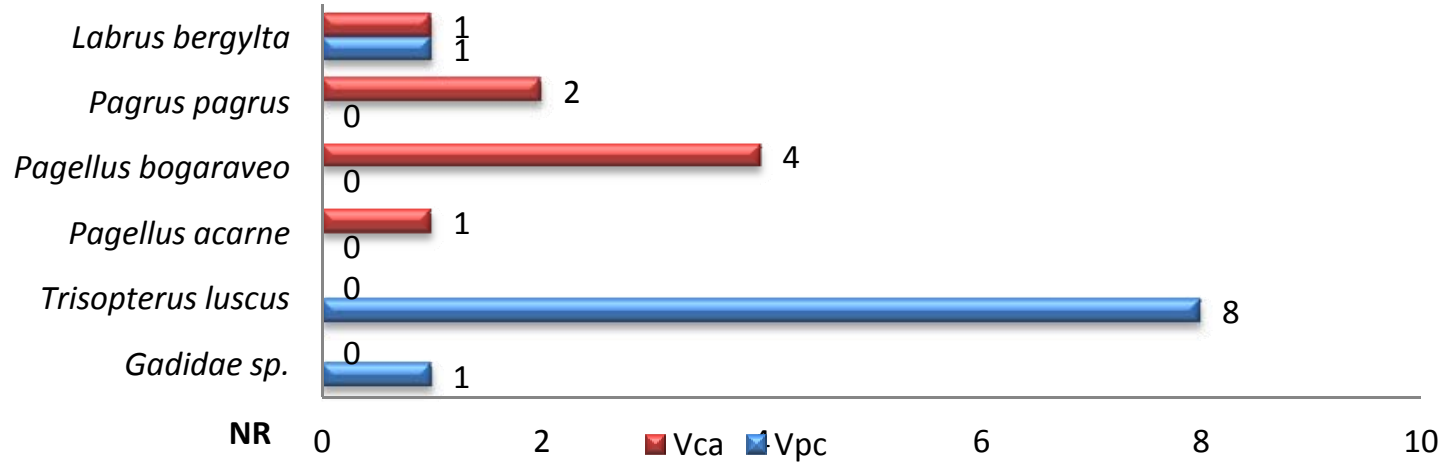

Fig. 283 Comparación numérica de las vértebras caudales y precaudales de los diferentes taxones.

\section{V.9.10. AdRo Vello.}

\section{Localización y cronología.}

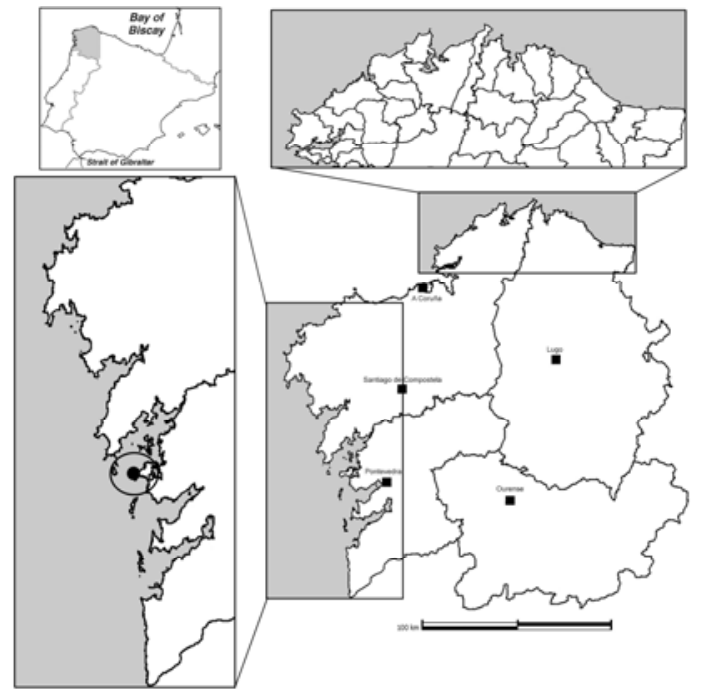

Fig. 284 Localización de Adro Vello.
Yacimiento situado en la playa de "O Carreiro", en el noroeste de la península de $\mathrm{O}$ Grove. Hay dos conjuntos claramente diferenciados: una villa romana con piletas de salazón (de donde proceden las muestras), y una necrópolis medieval y moderna que ocupa este espacio después de la destrucción de la villa (Carro, 1987; 1991). Los datos del análisis ictioarqueológico únicamente se encuentran en la Tesis de Licenciatura y la Tesis Doctoral de Ma..C. Ferré (1996; 2003). 


\section{Estudio Ictiológico.}

Únicamente se ha constatado la presencia de Sardina pilchardus y de Trachurus trachurus, siendo más importante la presencia de la primera, tanto en restos cefálicos como post-cefálicos (Ferré, 1996; 2003).

\begin{tabular}{|c|c|c|c|c|c|c|c|c|c|c|c|c|c|c|}
\hline & $\begin{array}{l}\text { Max } \\
\text { (D/S) }\end{array}$ & $\begin{array}{l}\text { Dnt } \\
\text { (D/S) }\end{array}$ & $\begin{array}{l}\text { Pop } \\
\text { (D/S) }\end{array}$ & $\begin{array}{l}\text { Opc } \\
\text { (D/S) }\end{array}$ & $\begin{array}{l}\text { Cdr } \\
\text { (D/S) }\end{array}$ & $\begin{array}{l}\text { Hmd } \\
\text { (D/S) }\end{array}$ & $\begin{array}{l}\text { Pst } \\
\text { (D/S) }\end{array}$ & $\begin{array}{c}\mathrm{Clt} \\
(\mathrm{D} / \mathrm{S})\end{array}$ & Psf & Boc & $\mathrm{Vpc}$ & Vca & NR & NMI \\
\hline $\begin{array}{l}\text { Sardina } \\
\text { pilchardus }\end{array}$ & $21 / 36$ & $16 / 14$ & $34 / 34$ & $55 / 71$ & $3 / 3$ & $39 / 52$ & $0 / 13$ & $45 / 61$ & 93 & 44 & 354 & 1006 & 2004 & 71 \\
\hline $\begin{array}{l}\text { Trachurus } \\
\text { trachurus }\end{array}$ & & & & & & & & & & & 7 & 2 & 9 & 1 \\
\hline TOTAL & 57 & 30 & 68 & 126 & 6 & 91 & 13 & 106 & 93 & 44 & 361 & 1008 & 2013 & \\
\hline
\end{tabular}

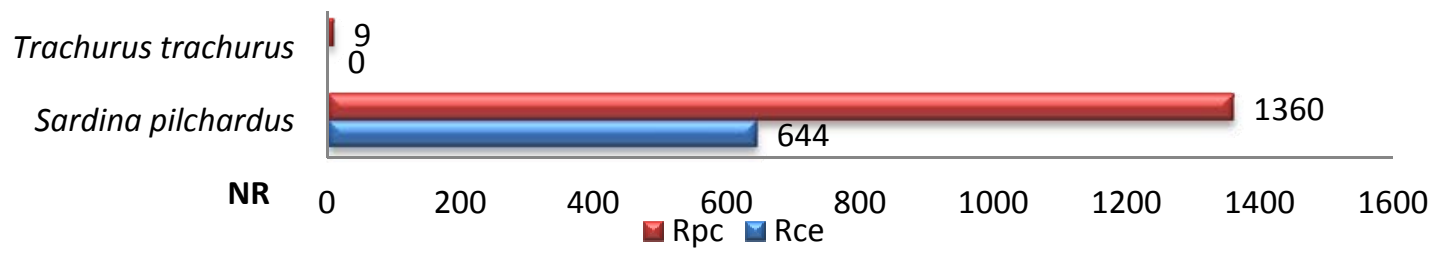

Fig. 285 Comparación numérica de los restos cefálicos y postcefálicos de los taxones identificados.

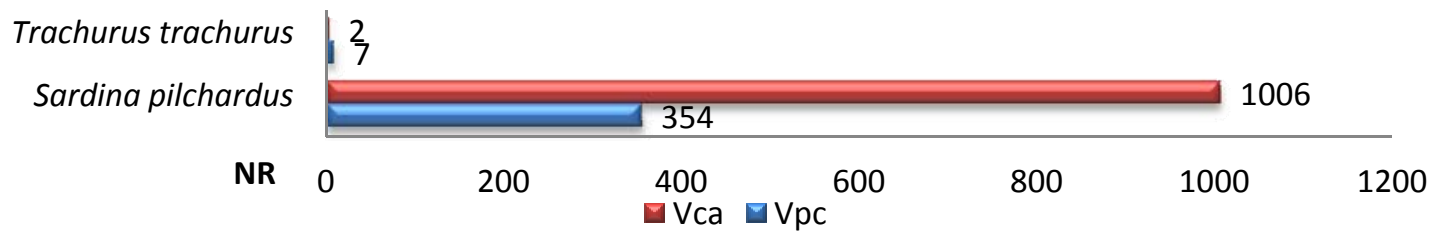

Fig. 286 Comparación numérica de las vértebras caudales y precaudales de los taxones identificados.

\section{V.9.11. A SUVIDÁ.}

\section{Localización y cronología.}

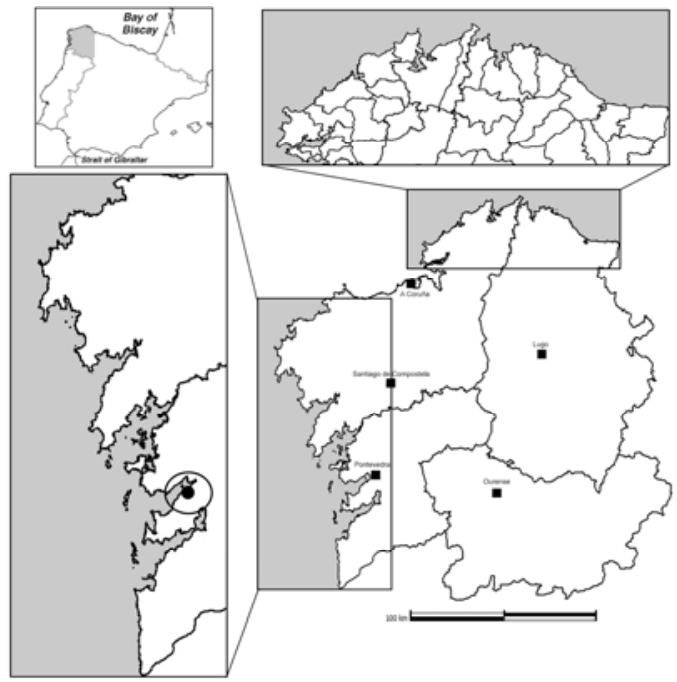

Castro situado en Mogor, en una colina cerca de la costa en el interior de la Ría de Pontevedra. Los materiales proceden de un sondeo realizado por Vázquez Varela, y se adscriben a las fases romanizadas de la Cultura Castreña. Las reseñas que hay de este análisis se localizan en obras generales sobre la pesca en la Cultura Castreña, sin aportar el número de restos identificados (Vázquez Varela, 1976; 1978; 1984).

Fig. 287 Localización del Castro de A Suvidá. 


\section{Estudio Ictiológico.}

Únicamente se cita la presencia de Mugil sp., si bien desconocemos el número de restos recuperados y su representación anatómica.

\begin{tabular}{c|c|c|c} 
& \multicolumn{3}{|c}{ Vázquez Varela } \\
& 1976 & 1978 & 1984 \\
\hline Mugil sp. & $*$ & $*$ & $*$
\end{tabular}

Tabla 202 Relación de especies identificadas en A Suvidá.

\section{V.9.12. A IGRESIÑNA.}

\section{Localización y cronología.}

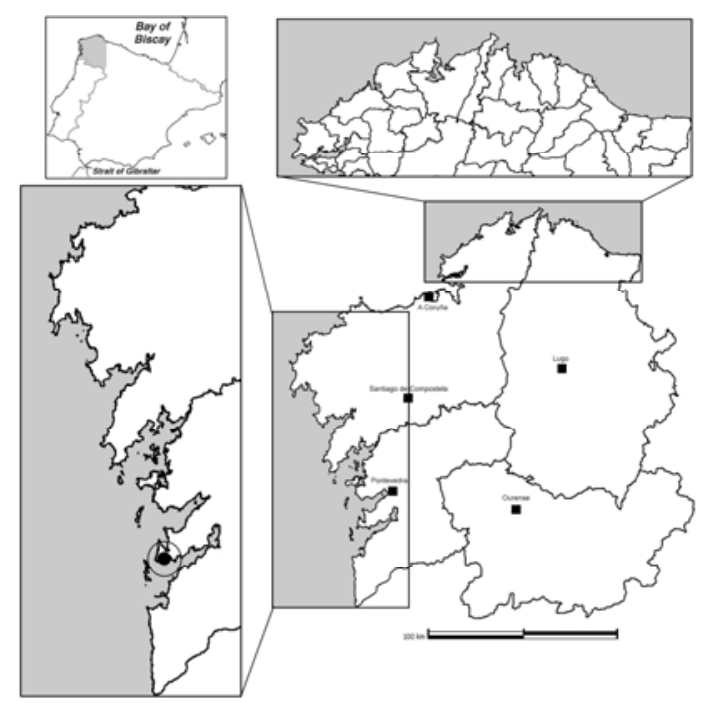

Fig. 288 Localización de Igresiña.

Yacimiento situado en Nerga, provincia de Pontevedra. Sus coordenadas son $8^{\circ} 50^{\prime} 55^{\prime \prime}$ W y $42^{\circ} 15^{\prime} 38^{\prime \prime} \mathrm{N}$. Durante las intervenciones allí realizadas se constató la presencia de un tanque de salazón y una dependencia anexa. El tanque tiene unas dimensiones de $2,9 \times 2,4 \mathrm{~m}$ y una altura de $1,15 \mathrm{~m}$. Presenta una cronología comprendida entre los siglos I-IV d.C. (Currás, 2007).

Los materiales ictioarqueológicos de este yacimiento proceden del sedimento alojado en el interior de una diáfisis de macrofauna. Esta muestra procede de las excavaciones realizadas en 1996 en la duna

costera (Fernández Rodríguez, 2000; Ferré, 2003).

\section{Estudio Ictiológico.}

El conjunto recuperado de Igresiña lo componían únicamente tres piezas óseas de Sardina pilchardus.

\begin{tabular}{ccccc} 
& Opc & V & NR & NMI \\
\hline Sardina pilchardus & 1 & 2 & 3 & 1 \\
\hline \hline TOTAL & $\mathbf{1}$ & $\mathbf{2}$ & $\mathbf{3}$ &
\end{tabular}

Tabla 203 Relación de especies y representación ósea de Igresiña.

\section{V.9.13. As HoRTAS.}

\section{Localización y cronología.}

Castro situado en la ladera sureste del Monte del Faro, en la Isla do Medio en las Islas Cíes, coordenadas $8^{\circ} 54^{\prime} 45^{\prime \prime}$ W y $42^{\circ} 12^{\prime} 53^{\prime \prime} \mathrm{N}$. Su conchero tiene una dimensión de 


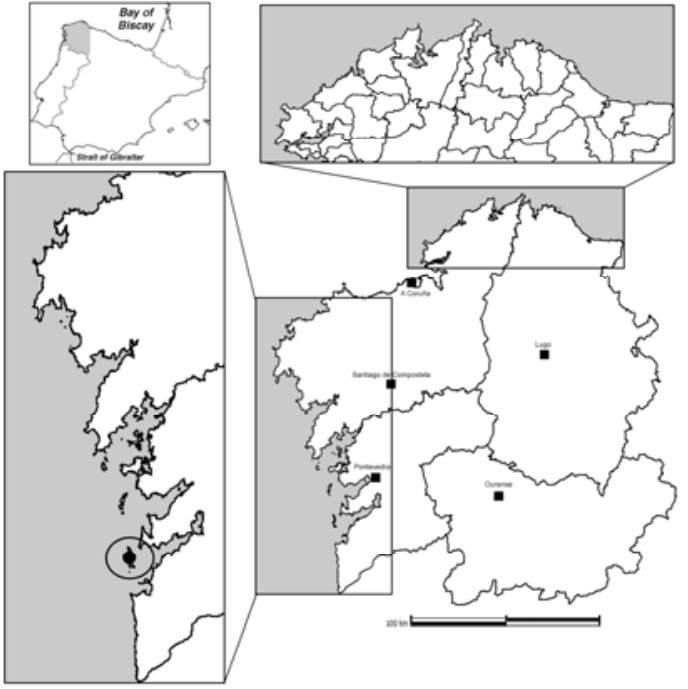

Fig. 289 Localización del Castro de As Hortas.

60 m en dirección noreste-sureste y 31 m en dirección suroeste-noreste. Los primeros estudios de ictiofauna de este yacimiento son los realizados por Vázquez Varela (1975; 1976; 1978; 1984), si bien desconocemos el lugar exacto donde se recogieron las muestras, así como del tipo de muestreo realizado. Estos estudios se van a limitar a citar la presencia de ciertas especies. De este mismo momento es el trabajo de Cardero López (1980), citando simplemente la presencia de ictiofauna.

Un segundo grupo de estudios son los de sondeos en concheros gallegos realizado por Rodríguez López en 1993. Durante esta campaña se sondeó en el conchero diferenciándose dos niveles. El primer nivel de 0,300,42 m está formado por un revuelto de materiales, donde aparecieron dos únicos restos de peces. El segundo de los niveles tiene una potencia de 0,40 m. El conchero se adscribe a la Fase II de la Cultura Castreña entre los siglos IV-II a.C. De estos trabajos saldrían a la luz diversas publicaciones (Ferré et alii, 1995; Rodríguez et alii, 1996; Ferré, 1996; 2003).

\section{Estudio Ictiológico.}

\begin{tabular}{l|c|c|c|c} 
& \multicolumn{4}{|c}{ Vázquez Varela } \\
& 1975 & 1976 & 1978 & 1984 \\
\hline Labrus bergylta & $*$ & $*$ & $*$ & $*$ \\
\hline Dicentrarchus labrax & & $*$ & $*$ &
\end{tabular}

Tabla 204 Relación de especies identificadas por Vázquez Varela en As Hortas.

\begin{tabular}{|c|c|c|c|c|c|c|c|c|c|c|c|}
\hline & $\begin{array}{c}\text { Pmx } \\
\text { (D/S) }\end{array}$ & $\begin{array}{c}\text { Max } \\
(D / S)\end{array}$ & $\begin{array}{c}\text { Dnt } \\
\text { (D/S) }\end{array}$ & $\begin{array}{c}C d r \\
(D / S)\end{array}$ & $\begin{array}{l}\text { Hmd } \\
(\mathrm{D} / \mathrm{S})\end{array}$ & Boc & Psf & Vpc & Vca & NR & NMI \\
\hline Merluccius merluccius & & & & & & & & & 3 & 3 & 1 \\
\hline Trisopterus luscus & & & & & & & & 2 & 3 & 5 & 1 \\
\hline Dicentrachus labrax & & & & & & & & 1 & 1 & 2 & 1 \\
\hline Trachurus trachurus & & & & & & & & 1 & 3 & 4 & 1 \\
\hline Pagrus pagrus & $3 / 1$ & $0 / 1$ & & & & & & 2 & 6 & 13 & 3 \\
\hline Diplodus sargus & $0 / 1$ & & $1 / 0$ & & & & & & & 2 & 1 \\
\hline Diplodus vulgaris & & & & & & & & 1 & 1 & 2 & 1 \\
\hline Pagellus acarne & & & & & & & & 3 & 3 & 6 & 1 \\
\hline Pagellus bogaraveo & & & & & & & & 2 & 15 & 17 & 1 \\
\hline Labrus bergylta & & $0 / 1$ & & & $1 / 0$ & & & 5 & 7 & 14 & 1 \\
\hline Scomber scombrus & & & & & & & & & 1 & 1 & 1 \\
\hline Scomber japonicus & & & & & & & & 12 & 24 & 36 & 1 \\
\hline Indeterminados & & $0 / 1$ & & $3 / 1$ & & 9 & 1 & 2 & 3 & 20 & 1 \\
\hline TOTAL & 5 & 3 & 1 & 4 & 1 & 9 & 1 & 31 & 70 & 125 & \\
\hline
\end{tabular}

Tabla 205 Relación de especies y representación ósea de As Hortas. 
Predominan los centros vertebrales frente a los huesos del cráneo. Destaca la abundancia de espáridos, y de lábridos de fondos rocosos. También se documentan tres especies pelágicas como Trachurus trachurus, Scomber scombrus y Scomber japonicus, propias de aguas batidas y oxigenadas (Rodríguez López et alii, 1996; Ferré, 2003).

La especie de la que más restos se han identificado es Scomber japonicus con 36 restos. A este taxón lo acompañan Pagellus bogaraveo con 17 restos, Labrus bergylta con 14 y Pagrus pagrus con 13. El conjunto lo completan Pagellus acarne con seis piezas óseas, Trachurus trachurus cuatro, Merluccius merluccius tres, Dicentrarchus labrax, Diplodus sargus y Diplodus vulgaris con dos piezas cada una, y un resto de Scomber scombrus.

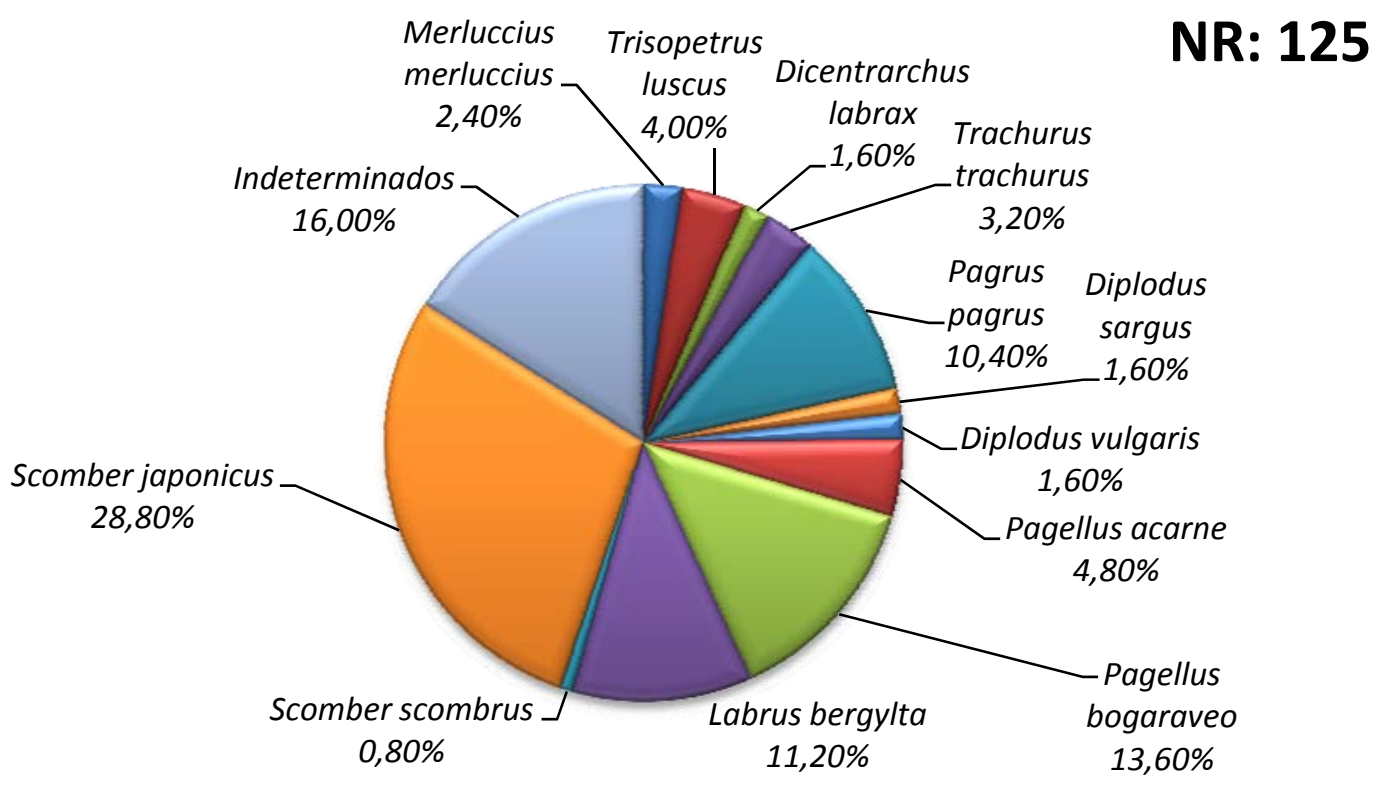

Fig. 290 Representatividad de los taxones según el NR.

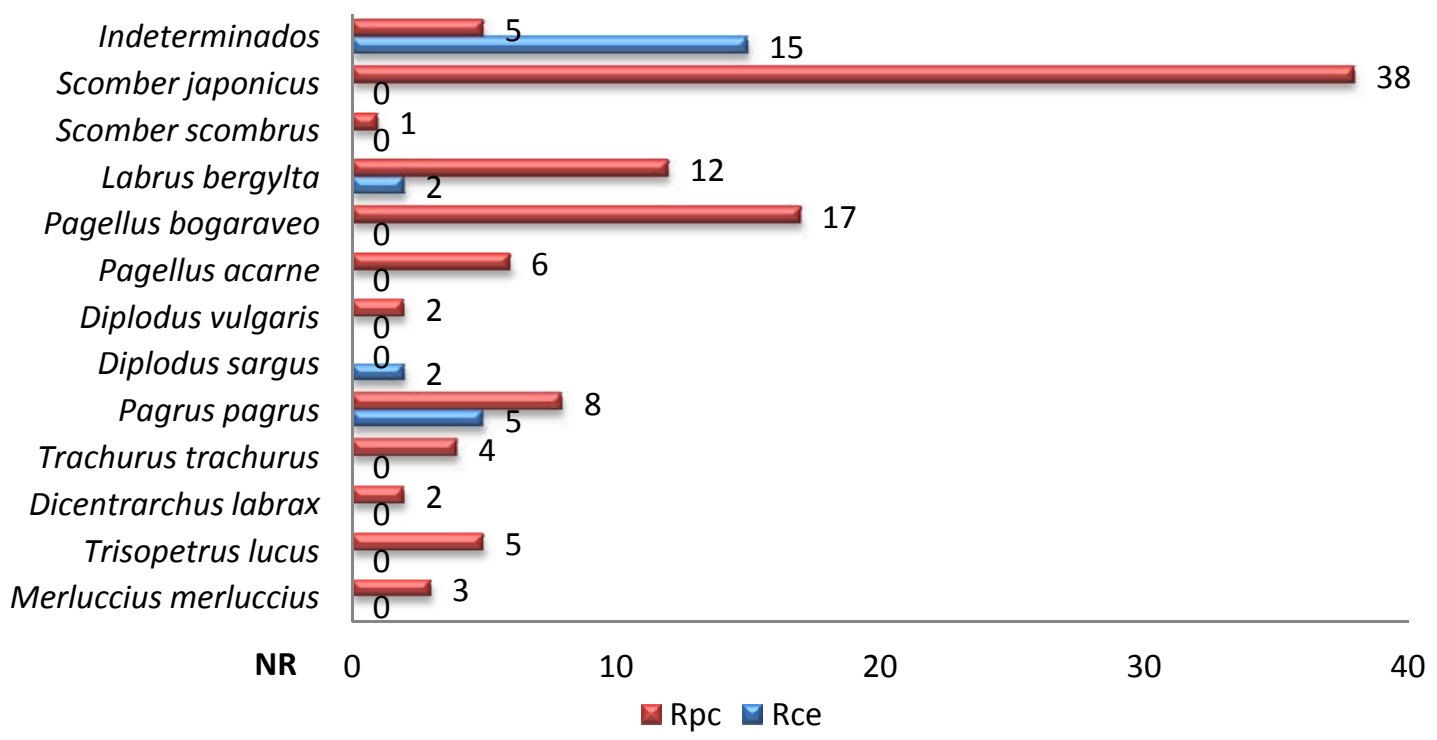

Fig. 291 Comparación numérica de los restos cefálicos y postcefálicos de los diferentes taxones identificados. 


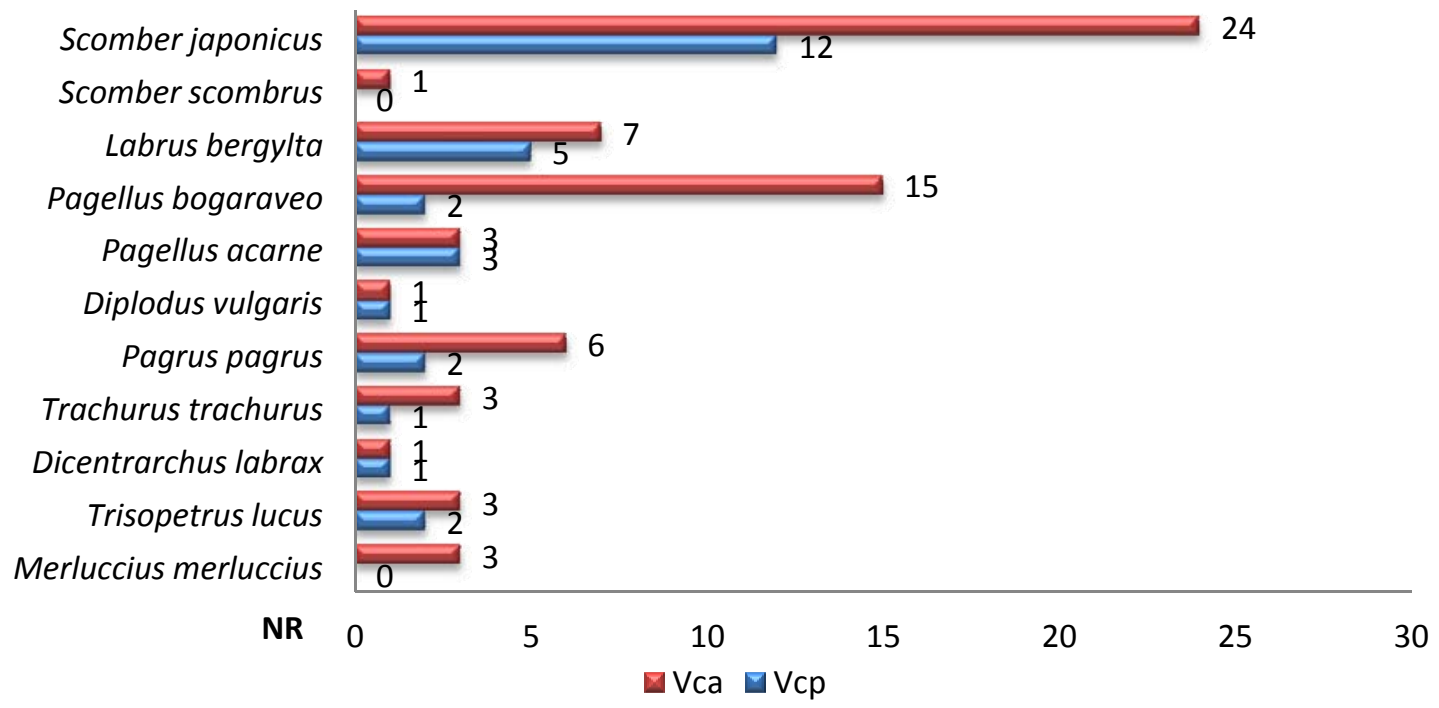

Fig. 292 Comparación numérica de las vértebras caudales y precaudales de los diferentes taxones identificados.

\section{V.9.14. FACHO DE DONÓN.}

\section{Localización y cronología.}

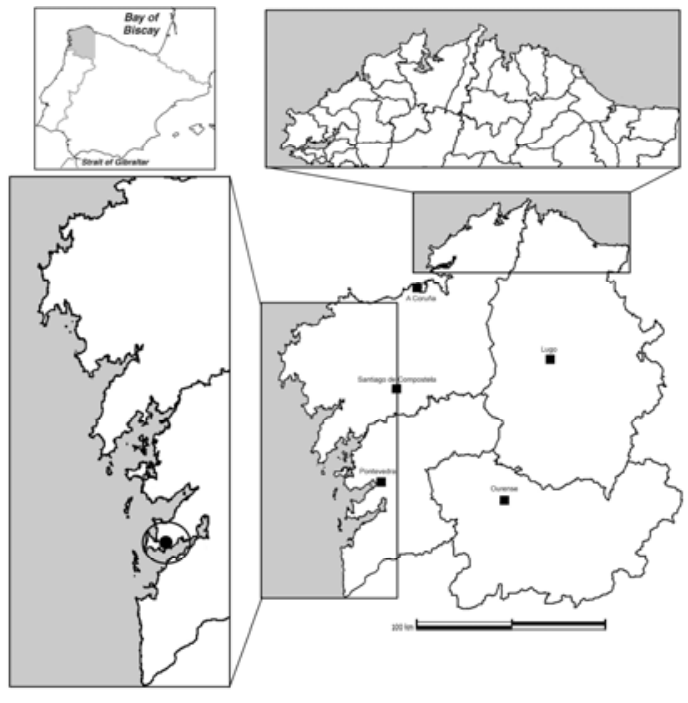

Fig. 293 Localización del Castro del Facho de Donón.
Castro localizado en la parroquia de Hío, perteneciente a Cangas do Morrazo (Pontevedra). Se encuentra próximo a la boca de la Ría de Vigo, con las coordenadas $8^{\circ} 51^{\prime}$ $36^{\prime \prime}$ W y $42^{\circ} 16^{\prime} 40^{\prime \prime}$ N. Los estudios arqueoictiológicos sobre $\mathrm{O}$ Facho de Donón se desarrollaron en tres momentos bien definidos. El primero de ellos corresponde con los estudios de Vázquez Varela (1976; 1978; 1984), el segundo estarían realizados por Camino López junto con J.M. Rey y Vázquez Varela (Camino López et alii, 1991; Vázquez Varela et alii, 1993), mientras el último de los momentos correspondería a los trabajos de M.C. Ferré (1996; 2003).

El trabajo más completo corresponde a esta última investigadora. Los materiales de este estudio proceden de un conchero situado en su ladera Oeste, en el que en 1992 Rodríguez López realizó un sondeo. Este conchero tiene una capa superficial de 0,30 m de coloración oscura, y una segunda capa de 0,55 m, siendo su composición mayoritariamente de conchas. El estudio de la cerámica lo sitúa entre los siglos I a.C. y II d.C. (Ferré, 2003). 


\section{Estudio Ictiológico.}

\begin{tabular}{l|c|c|c|c|c} 
& \multicolumn{2}{|c|}{ Vázquez Varela } & Camino López et alii, & Vázquez Varela et alii, \\
& 1976 & 1978 & 1984 & $1991(\mathrm{NR})$ & 1993 (NR) \\
\hline Labrus bergylta & $*$ & $*$ & $*$ & $1 \mathrm{Cbr}$ & 1 \\
\hline Pagrus pagrus & $*$ & $*$ & $*$ & & 1 \\
\hline Sparus aurata & $*$ & $*$ & $*$ & $1 \mathrm{Dnt}(\mathrm{D})$ & 1 \\
\hline Dicentrarchus labrax & $*$ & $*$ & $*$ & & 1 \\
\hline Pagellus acarne & & & & & 1 \\
\hline Diplodus sargus/vulgaris & & & & $1 \mathrm{Pmx}(\mathrm{S})$ & 1 \\
\hline Sparidae & & & & $1 \mathrm{Mol}$ & 1 \\
\hline Antonogadus macrophthalmus & & & & & 7
\end{tabular}

Tabla 206 Cuadro comparativo de los primeros estudios realizados en el Facho de Donón.

Restos documentados en un único nivel, con seis especies representadas propias de Ría, a excepción de Trachurus trachurus más propio de aguas abiertas. Predominio de los espáridos (Ferré, 1996; 2003).

\begin{tabular}{lcccccccc} 
& $\begin{array}{c}\text { Pmx } \\
\text { (D/S) }\end{array}$ & $\begin{array}{c}\text { Dnt } \\
\text { (D/S) }\end{array}$ & Mol & Cbr & Vpc & Vca & NR & NMI \\
\hline Trisopterus luscus & & & & & 1 & & $\mathbf{1}$ & 1 \\
Trachurus trachurus & & & & & & 1 & $\mathbf{1}$ & 1 \\
Sparus aurata & & $0 / 1$ & 1 & & & & $\mathbf{2}$ & 1 \\
Pagrus pagrus & $0 / 1$ & & & & & & $\mathbf{1}$ & 1 \\
Pagellus sp. & & & & & & 1 & $\mathbf{1}$ & 1 \\
Labrus bergylta & & & & 1 & & & $\mathbf{1}$ & 1 \\
Indeterminados & & & & & & 3 & $\mathbf{3}$ & \\
\hline \hline \multicolumn{1}{c}{ TOTAL } & $\mathbf{1}$ & $\mathbf{1}$ & $\mathbf{1}$ & $\mathbf{1}$ & $\mathbf{1}$ & $\mathbf{5}$ & $\mathbf{1 0}$ &
\end{tabular}

Tabla 207 Relación de especies y representación ósea del Facho de Donón según Ferré (1996; 2003).

La muestra está compuesta por dos restos de Sparus aurata y una pieza de Trisopterus luscus, Trachurus trachurus, Pagrus pagrus, Pagellus sp. y Labrus bergylta.

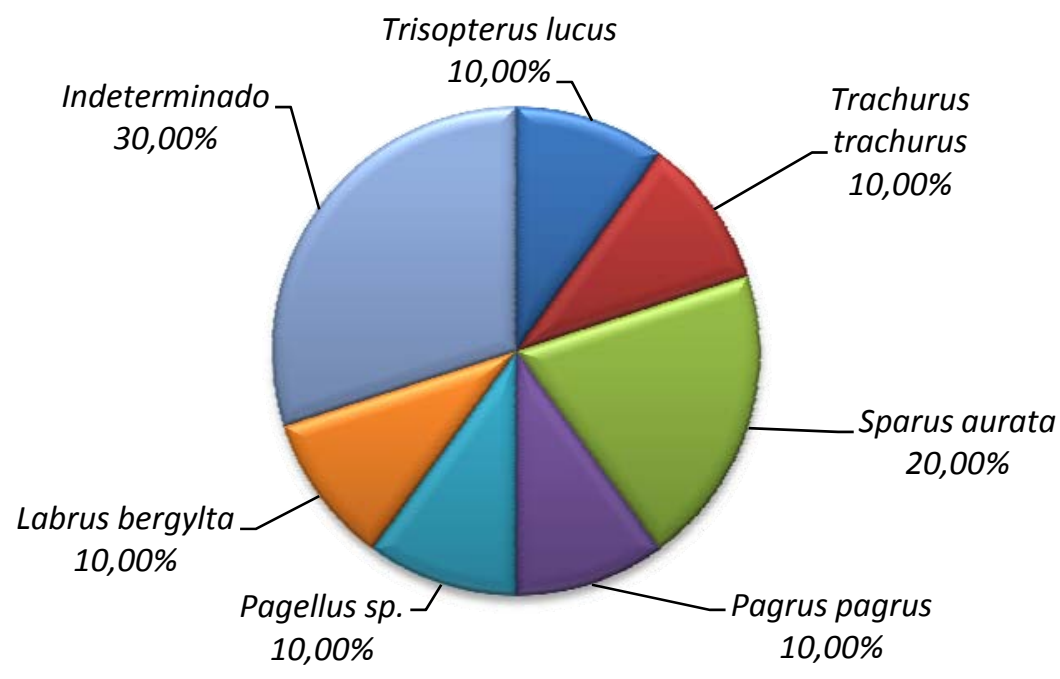

NR: 10

Fig. 294 Representatividad de los taxones según el NR. 


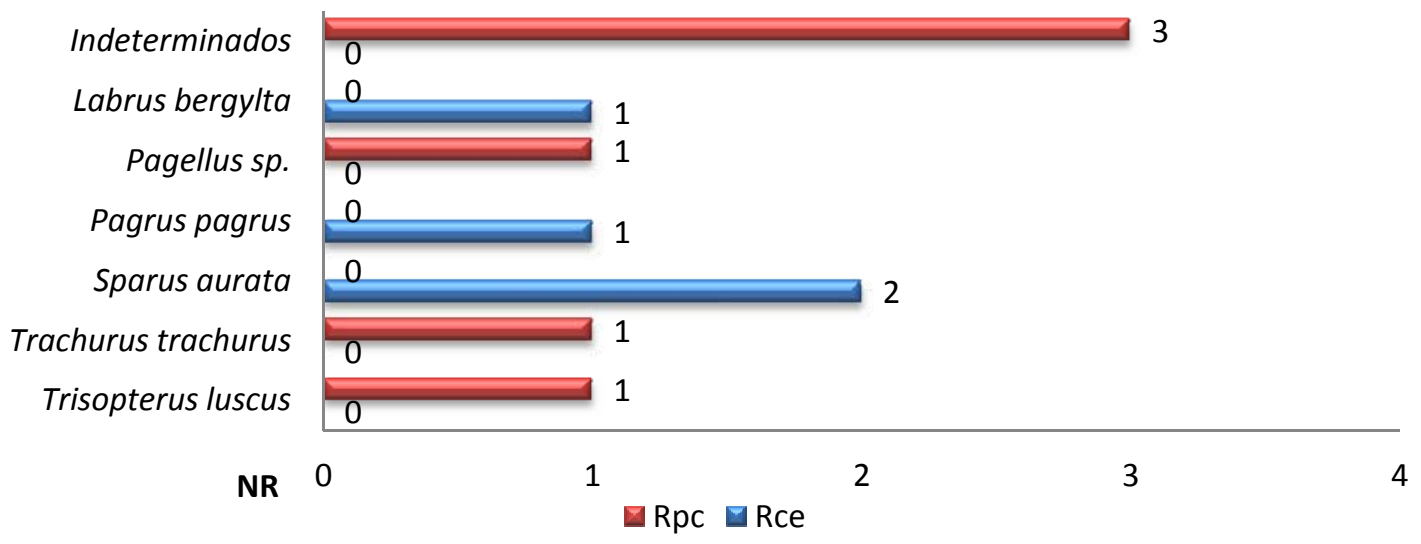

Fig. 295 Comparación numérica de los restos cefálicos y postcefálicos de los taxones identificados.

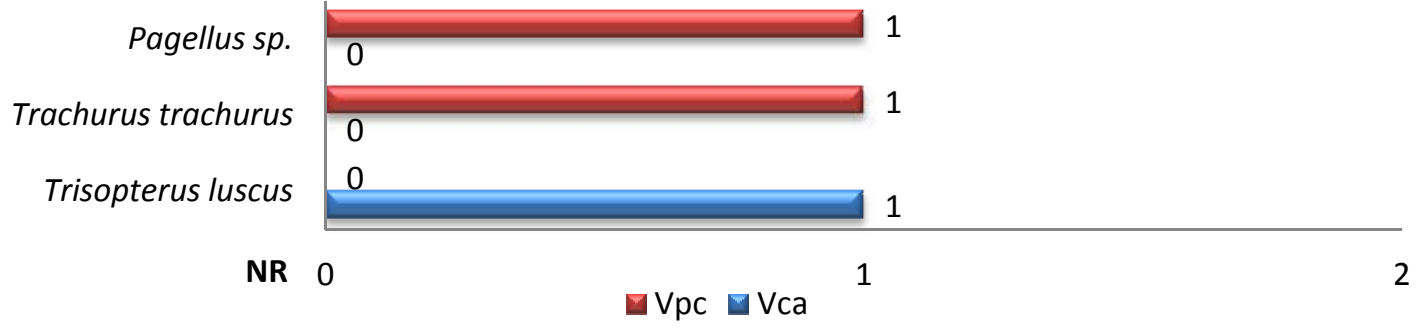

Fig. 296 Comparación numérica de las vértebras caudales y precaudales de los taxones identificados.

\section{V.9.15. A PALMA.}

\section{Localización y cronología.}

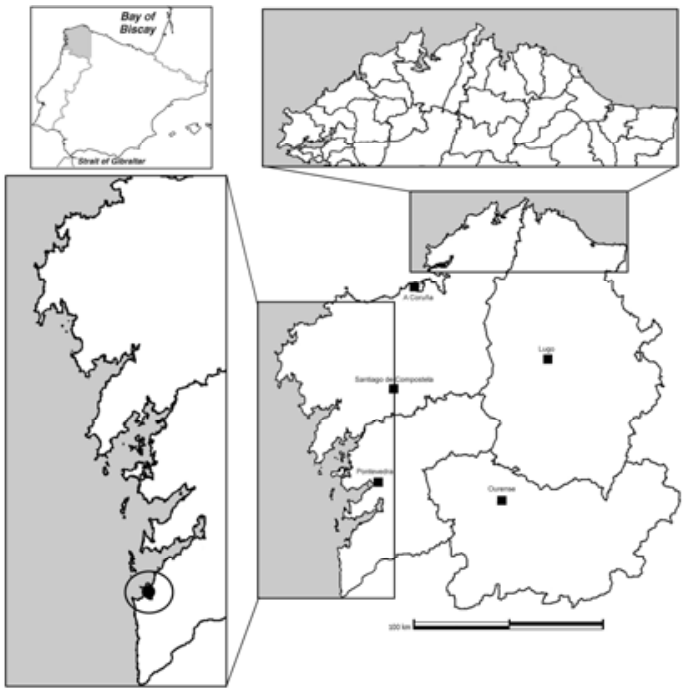

Fig. 297 Localización del yacimiento de A Palma.

Yacimiento situado junto al castillo en Baiona, Pontevedra. El material ictiológico procede de las excavaciones realizadas por $\mathrm{V}$. Caramés. Las muestras fueron objeto de un proceso selectivo que llevó a no recuperar algunos materiales como una abundante presencia de restos de moluscos (Fernández Rodríguez, 1992). Los restos de fauna se localizaban en dos niveles estratigráficamente bien diferenciados, correspondiéndose con distintas deposiciones de materiales de desecho en una zona utilizada como vertedero. Ambos niveles presentan una cronología similar adscrita a los siglos XVI y XVII d.C., según se desprende de los estudios 
de otras evidencias arqueológicas. Los restos ícticos proceden del Nivel 2. El único estudio con el que contamos se encuentra en la Tesis Doctoral de Mạ.C. Ferré (2003).

\section{Estudio Ictiológico.}

Destaca la presencia de una vértebra caudal de Condrictio, que si bien son comunes en los yacimientos Holocenos del sur peninsular, son muy raros en el Noroeste. Esta pieza presentaba el contorno pulimentado y estaba perforada, lo que induce a considerar que ha sido utilizada como colgante. Las demás especies son demersales comunes en otros yacimientos. También se recuperó una vértebra de Thunnus thunnus, tratándose del primer registro de esta especie en el noroeste (Ferré, 2003).

\begin{tabular}{lccccccc} 
& $\begin{array}{c}\text { Pmx } \\
\text { (D/S) }\end{array}$ & $\begin{array}{c}\text { Dnt } \\
\text { (D/S) }\end{array}$ & Fbr & Vpc & Vca & NR & NMI \\
\hline Condrictios & & & & & 1 & $\mathbf{1}$ & 1 \\
Merluccius merluccius & & $5 / 3$ & & 14 & 23 & $\mathbf{4 5}$ & 5 \\
Dicentrachus labrax & $1 / 1$ & & & & & $\mathbf{2}$ & 1 \\
Labrus bergylta & & & 1 & & & $\mathbf{1}$ & 1 \\
Thunnus thynnus & & & & 2 & & $\mathbf{2}$ & 1 \\
Indeterminado & 2 & & & & & $\mathbf{2}$ & 2 \\
\hline \multicolumn{1}{c}{ Total } & $\mathbf{4}$ & $\mathbf{8}$ & $\mathbf{1}$ & $\mathbf{1 6}$ & $\mathbf{2 4}$ & $\mathbf{5 3}$ &
\end{tabular}

Tabla 208 Relación de especies y representación ósea de A Palma.

La especie representada con un mayor número de restos es Merluccius merluccius con 45. Completan el conjunto dos piezas óseas de Thunnus tuynnus y Dicentranchus labrax, así como un resto de Labrus bergylta y de Condrictio.

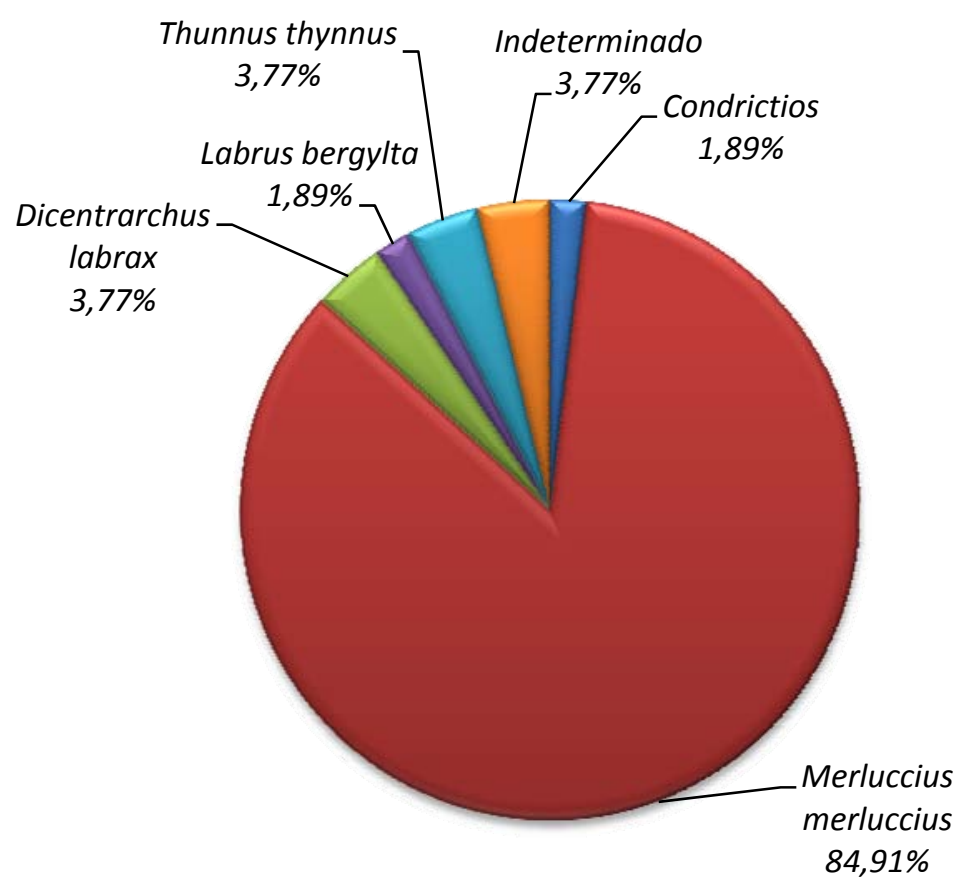

NR: 53

Fig. 298 Representatividad de los taxones según el NR. 


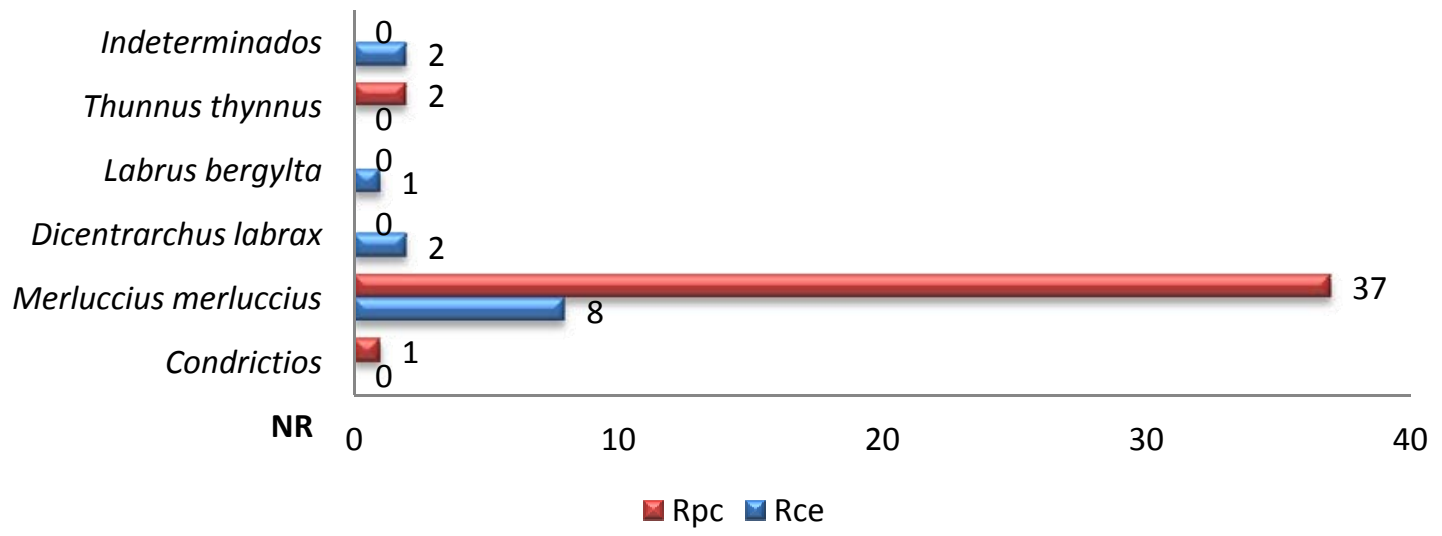

Fig. 299 Comparación numérica de los restos cefálicos y postcefálicos de los diferentes taxones identificados.

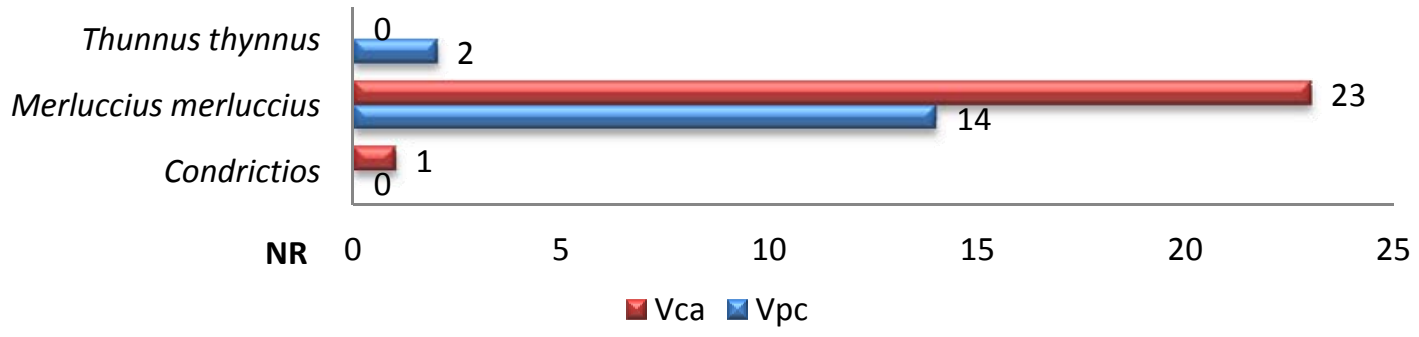

Fig. 300 Comparación numérica de las vértebras caudales y precaudales de los diferentes taxones identificados.

\section{V.9.16. SANTA Trega.}

\section{Localización y cronología.}

Yacimiento situado en la población de A Guardia, provincia de Pontevedra, en el

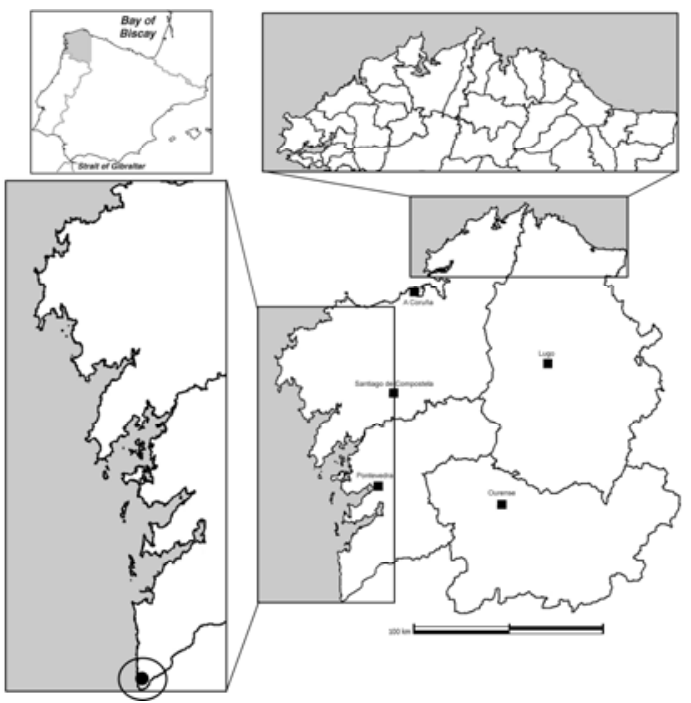

Fig. 301 Localización del Castro de Santa Trega. monte Santa Trega. Sus coordenadas son $8^{\circ} 52^{\prime}$ $14^{\prime \prime} \mathrm{W}$ y $41^{\circ} 53^{\prime} 15^{\prime \prime} \mathrm{N}$. La muestra procede de una prospección en la ladera que da hacia el río. Se le asigna una cronología del siglo I d.C. (Vázquez Varela et alii, 1993). La primera referencia a este conjunto corresponde a Vázquez Varela (1978) en una obra general sobre la pesca en la Cultura Castreña, si bien únicamente identifica una especie y no aporta el número de restos. De la década de los 90 contamos con estudios más completos, realizados por Camino López y J.M. Rey, junto a Vázquez Varela (Camino López et alii, 1991; Vázquez Varela et alii, 1993). 


\section{Estudio Ictiológico.}

\begin{tabular}{|c|c|c|c|}
\hline & $\begin{array}{c}\text { Vázquez Varela, } \\
1978\end{array}$ & $\begin{array}{l}\text { Camino López et alii, } 1991 \\
\text { (NR) }\end{array}$ & $\begin{array}{l}\text { Vázquez Varela et alii, } 1993 \\
\text { (NR) }\end{array}$ \\
\hline Dicentrarchus labrax & $*$ & & 1 \\
\hline Diplodus sargus/vulgaris & & 1 Dnt (S) & 1 \\
\hline Gadidae & & & 1 \\
\hline Labrus bergylta & & & 1 \\
\hline Indeterminado & & 9 & 6 \\
\hline
\end{tabular}

Tabla 209 Cuadro comparativo de los estudios realizados sobre la ictiofauna de Santa Trega.

Los restos recuperados en Santa Trega son muy escasos. En esta muestra se han identificado cuatro especies (Dicentrarchus labrax, Diplodus sp., Gadidae sp. y Labrus bergy/ta) representadas por un resto cada una. 



\section{VI.Evolución de la Pesca en Galicia.}





\section{VI.1. LA PESCA EN LA CULTURA CASTREÑA.}

Aunque el mayor número de yacimientos con restos de peces se adscriben cronológicamente a este periodo, se presentan una serie de problemas que van a dificultar el hacer una caracterización de la actividad pesquera durante la Cultura Castreña. En primer lugar todos los yacimientos se sitúan en las Rías Baixas, área geográfica con unas características muy determinadas dentro de la denominada "Cultura Castreña" (Peña Santos, 1996; Carballo Arceo, 1996; González Ruibal, 2006-07; Ayán Vila, 2012), lo que impide que las conclusiones que se alcancen puedan hacerse extensibles para toda el área galaica. Además, la mayoría de las muestras estudiadas se adscriben al periodo comprendido entre los siglos IV y I a.C. y principalmente en torno al siglo II a.C., sin que contemos con datos para momentos anteriores, y sean escasos para el cambio de Era. Este panorama se debe tanto al mayor interés que han despertado los yacimientos de las Rías Baixas, como a la mayor concentración de poblados litorales en torno al siglo II a.C.

Además de estos problemas, derivados en gran parte de las tendencias en la investigación, existen otros relacionados con la propia actividad arqueológica. Uno de estos es el relativo a la datación cronológica de las muestras. En la mayoría de los casos se parte de dataciones relativas derivadas de los materiales exhumados, siendo significativo el número de yacimientos en los que los materiales o bien no están estudiados, o bien no han sido publicados. Este problema, se agrava aún más en relación con nuestro objeto de estudio, ya que los restos ícticos se han recuperado en diferentes concheros que, en la mayoría de los casos, no han sido objeto de una excavación adecuada. Este incorrecto tratamiento de los depósitos de conchas ha ocasionado la mezcla irreversible de materiales, lo que hace imposible reconocer diferencias cronológicas dentro del depósito.

También relacionado con aspectos de cronología, los datos procedentes de estudios anteriores, tienden a agrupar los restos ictiológicos de la Edad del Hierro, sin diferenciar las distintas fases, y presentando en consecuenca lo que podemos definir como una estampa fija para un amplio marco cronológico, sin atender a detectar las posibles modificaciones que se hubieran producido en la obtención y consumo de los recursos ícticos marinos por parte de unas poblaciones que también experimentan cambios a lo largo del desarrollo de la Cultura Castreña del noroeste.

En los yacimientos que hemos estudiado, se ha procurado mantener la independencia de los diferentes conjuntos con cronologías similares. Los únicos yacimientos que cuentan con dataciones directamente relacionadas con los contextos de procedencia de los materiales que hemos analizado, son el de O Neixón Grande (Parcero Oubiña y Ayán Vila, 2008), O Achadizo (Rubinos Pérez et alii, 1999; Concheiro Coello, 2008) y A Lanzada (Rodríguez Martínez et alii, 2010).

Otro de los problemas existentes va a estar relacionado con la metodología de recuperación de los restos. Habitualmente, en las excavaciones arqueológicas suele intervenir personal no cualificado en esta disciplina, pero además, una parte significativa 
de los profesionales desconoce la metodología más adecuada para recuperar de forma adecuada este material tan específico. Realidad que, junto a otras causas de índole económica, ha llevado a que ni se cribe ni se flote sedimento en muchos yacimientos, quedando la recuperación de restos óseos de peces vinculada a la casualidad: aparición de piezas de gran tamaño; presencia de grandes acumulaciones de espinas; muestreos para otros estudios como los arqueomalacológicos...

A la problemática de la recuperación, hay que unir la de la conservación. La conservación de los huesos de los peces depende en gran medida del grado de osificación, edad del individuo, especie... A estas características propias del objeto de estudio, hay que unir las características del suelo en las costas gallegas, muy ácido, dificultando la preservación de los restos.

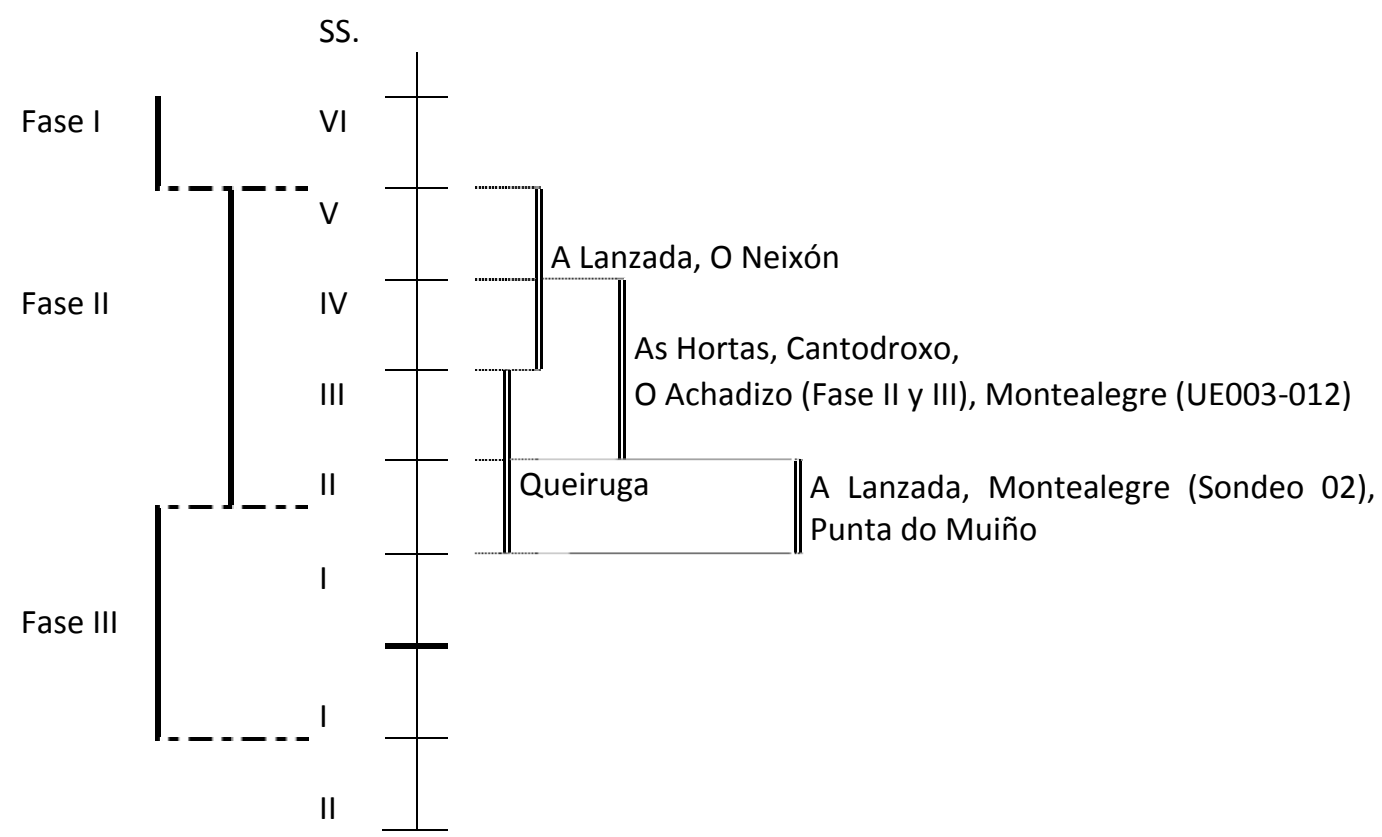

Pese a toda esta problemática, vamos a intentar definir algunos patrones que parecen comunes a los diferentes yacimientos. Siempre teniendo presente la parcialidad de los restos recuperados, y la imprecisión cronológica de muchas de las muestras.

\section{VI.1.1.LAS ESPECIES.}

En los yacimientos anteriores al cambio de Era encontramos una amplia variedad de especies, 20 en total, aunque su presencia va a ser muy desigual. Existe un grupo de tres especies que son las que están representadas por un mayor número de restos y en prácticamente todos los yacimientos. Son Pagellus bogaraveo y Trisopterus luscus, además de Labrus bergylta, cuya importancia se restringe a los yacimientos en torno a la boca de las rías. Se trata de especies demersales y carnívoras, pudiendo encontrarse cerca de la costa. El único taxón con un marcado carácter estacional es Pagellus bogaraveo, ya que durante el invierno desciende a zonas profundas. Este esquema parece coincidir con el obtenido de otros estudios (Vázquez Varela et alii, 1993; Ferré y Rey, 1998). 


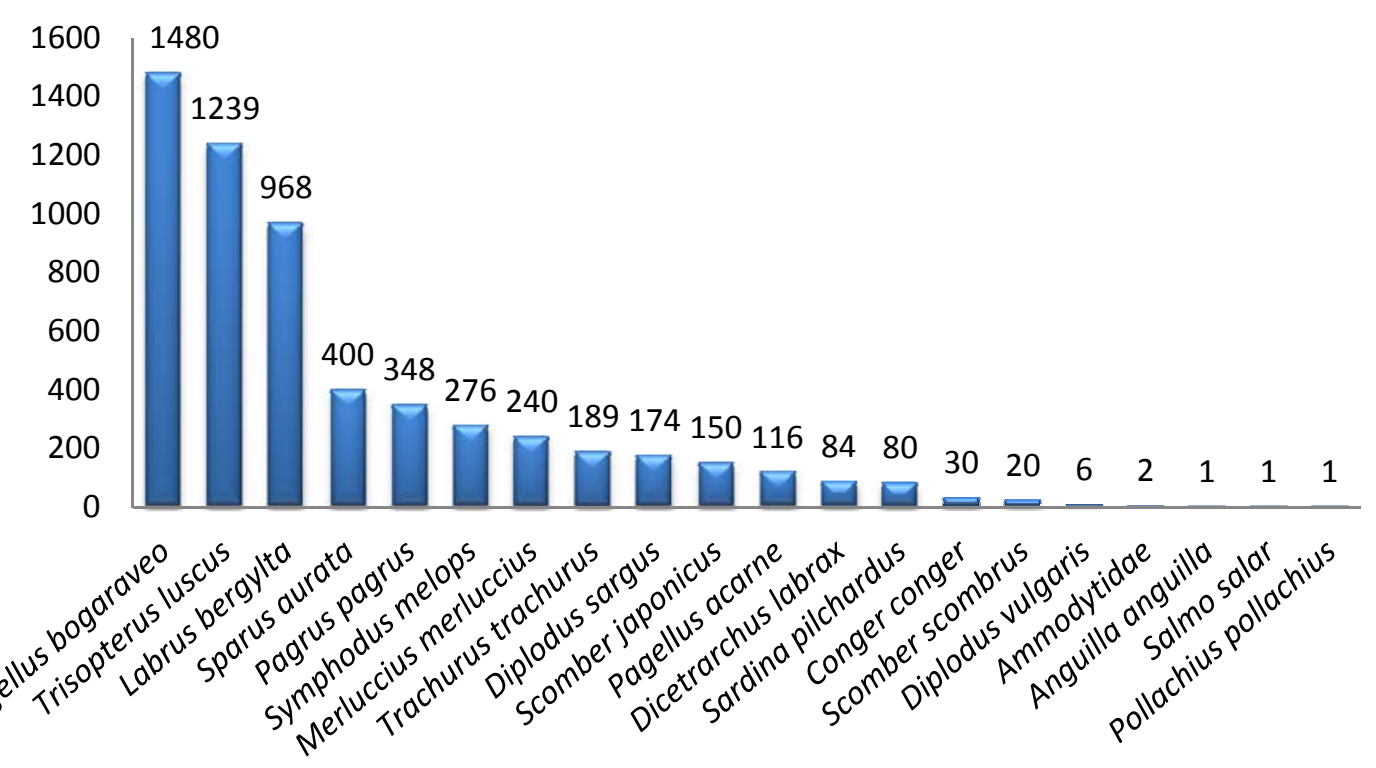

Fig. 302 Importancia de las especies a partir del cálculo del ICxID de los yacimientos prerromanos.

Con mucha menos importancia encontramos un grupo muy variado formado por 10 especies. Su presencia va a estar muy vinculada a la localización del yacimiento, así como seguramente a la cronología del mismo. De todos modos, se observan algunas características que plantean una serie de interrogantes no fácilmente solucionables. Especies como Symphodus melops y Sardina pilchardus, que cuentan con restos óseos de pequeño tamaño, no se habían identificado en los estudios anteriores, salvo la primera de ellas en O Achadizo. El caso de Symphodus melops puede explicarse por el tipo de yacimientos estudiados, que en su mayoría se sitúan en el interior de las rías, apareciendo con importancia en un yacimiento de mar abierto, A Lanzada.

En cuanto a Sardina pilchardus el problema es mucho más complejo. Hemos identificado esta especie en dos yacimientos de la Ría de Vigo, con una cronología en torno a los siglos II-I a.C. Su ausencia en el resto de yacimientos puede plantear interrogantes en cuanto a la metodología de recuperación utilizada, pudiendo haberse perdido los restos menor tamaño; sin embargo en yacimientos como el de A Lanzada, con una metodología igual a la de Montealegre o Muiño do Vento, no se recuperaron restos de esta especie que sí se documentó en los niveles romanos. El problema se complica más si tenemos en cuenta las implicaciones tecnológicas que supone la aparición de esta especie. Su captura se realizaría con redes, por lo que su presencia indicaría que estas artes solo se aplicarían en esta ría, aunque tampoco puede descartarse que los depósitos reflejen diferentes momentos cronológicos. Esperamos que nuevos análisis y nuevos datos puedan aclarar esta problemática.

Problemática similar es la reflejada por la presencia de especies como Trachurus trachurus y Scomber sp. Ambas son pelágicas y, aunque pueden ser pescadas con anzuelo, habitualmente su captura se produce mediante redes. En algunos yacimientos su presencia 
es muy importante, caso de A Lanzada o As Hortas, por lo que es probable que se utilizaran redes para su captura; sin embargo su escaso número en otros yacimientos, como Muiño do Vento o Montealegre, plantea más dudas acerca del empleo de estas artes, aunque como vimos es probable que ya se utilizara para especies como Sardina pilchardus.

Scomber japonicus, así como Sparus aurata y Pagrus pagrus, son especies que no son muy abundantes actualmente en las costas de Galicia. Sin embargo, aparecen bien representadas en los yacimientos de este periodo. Quizás el caso más significativo es el de Scomber japonicus, ya que presenta un número mayor de restos que Scomber scombrus, especie muy similar y que actualmente es la predominante en las aguas gallegas. Por lo tanto, parece que estos datos vienen a confirmar lo observado con otras especies de moluscos como Stramonita haemastoma (Martínez Cortizas y Vázquez Varela, 2002; González Gómez de Agüero, 2009), reflejando que durante la segunda mitad del I milenio a.C. la temperatura del agua es más alta que en la actualidad.

Merluccius merluccius es, por diversos motivos, otra especie problemática. En primer lugar hay que decir que, igual que Sparus aurata, presenta sus valores máximos únicamente en el castro de $O$ Achadizo, ya que lo habitual es que, aun cuando cuenta con representación en todos los yacimientos, no alcance valores muy elevados. Actualmente, Merluccius merluccius es una especie mesopelágica que no penetra en aguas salobres, por lo que, como apuntan algunos autores (Morales Muñiz et alii, 2009), su pesca en el interior de las rías indicaría un rango batimétrico y vital más amplio en tiempos pretéritos. Su captura en época castreña respondería a presencia en el interior de las rías, aunque el escaso número de restos reflejaría una pesca casual, quizás reflejo de que su aproximación a la costa no fuera muy habitual, ni de la existencia de una tecnología pesquera adecuada para su captura en grandes cantidades como va a suceder en la Edad Media.

Por último encontramos ocho especies que solo se documentan en uno o dos yacimientos y con muy pocos restos. La representada por un mayor número de piezas óseas es Conger conger, procedentes en su mayoría al sector exterior de A Lanzada. En las excavaciones de 2010 únicamente se ha recuperado un resto de esta especie pese a que la localización del asentamiento, así como el medio físico del mismo, sería propicio para su captura. Por este motivo, su presencia parece responder más a un hecho casual qué a una pesca sistematizada, similar a lo indicado para Merluccius merluccius.

La presencia de estos taxones que hemos definido como anecdóticos puede estar condicionada por diversos motivos. En primer lugar, Anguilla anguilla o Salmo salar son especies migradoras, la primera de migración catádroma y la segunda anádroma, por lo que parte de su vida la pasan en el mar y el resto transcurre en aguas dulces. Hasta la fecha carecemos de datos ictioarqueológicos que reflejen una pesca fluvial en los asentamientos de la Edad del Hierro en Galicia. Este hecho, junto con su escasa representación, lleva a considerar una pesca realizada en el mar, donde su captura se puede relacionar con las migraciones que realizan, aunque no resultarían presas 
habituales. Por otro lado, hay que comentar los problemas de conservación de los restos de Salmo salar debido a la escasa osificación que presentan.

Otras especies, como Diplodus vulgaris o Scomber scombrus, pueden estar vinculadas a la captura de otras muy similares como Diplodus sargus y Scomber japonicus, siendo más numerosas estas últimas quizás reflejando su predominio en este momento.

También es llamativa la ausencia de Pollachius pollachius, aunque puede estar relacionado con la mayor dificultad de su captura o su menor presencia por la temperatura del mar. Por último, los restos de la Familia Ammodytidae, como ya comentamos en el apartado de A Lanzada, pueden indicar una captura casual.

Pese a que hasta ahora hemos desarrollado de forma global la importancia de las especies según el número de restos, podemos observar que su relevancia va a cambiar según la localización del yacimiento. Por este motivo procederemos a comentar su distribución a lo largo de las diferentes rías. Para las gráficas se ha utilizado el Índice de Dominancia para ver la importancia que adquiere cada especie dentro de la ría, ya que consideramos que utilizar el Número de Restos puede distorsionar los datos debido al desigual tamaño de los conjuntos.

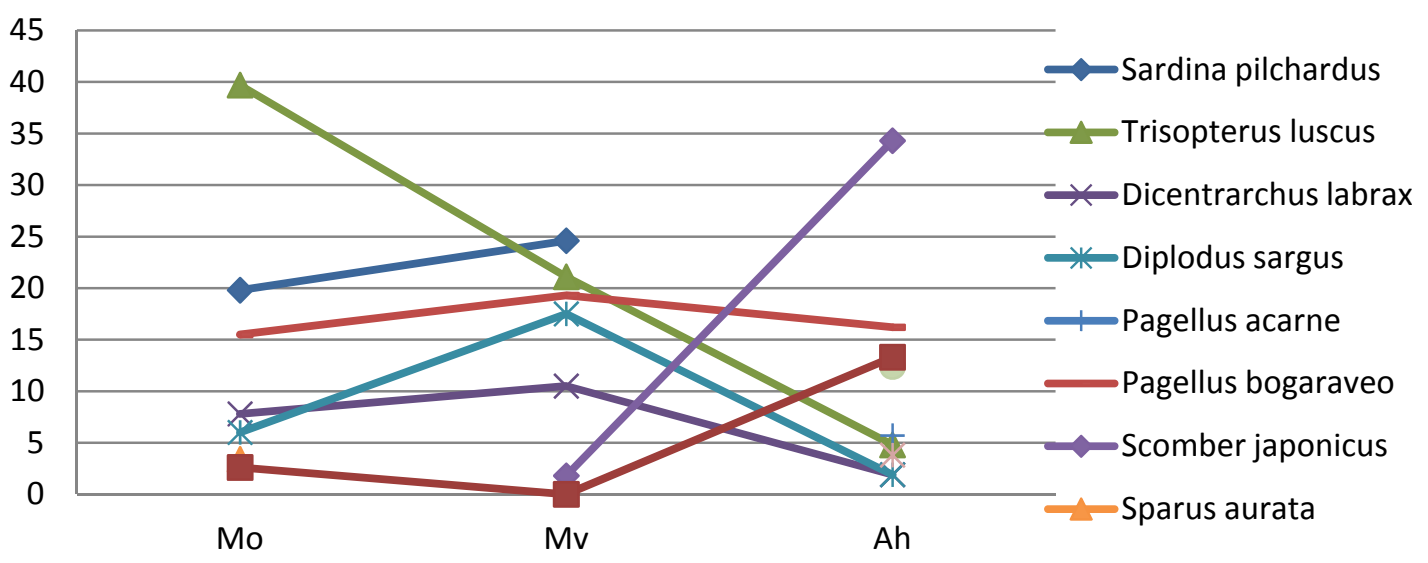

Fig. 303 Distribución de los principales taxones en la Ría de Vigo según la situación del yacimiento (De fondo de ría a zonas exteriores: Mo=Montealegre; Mv=Muiño do Vento; Ah=As Hortas).

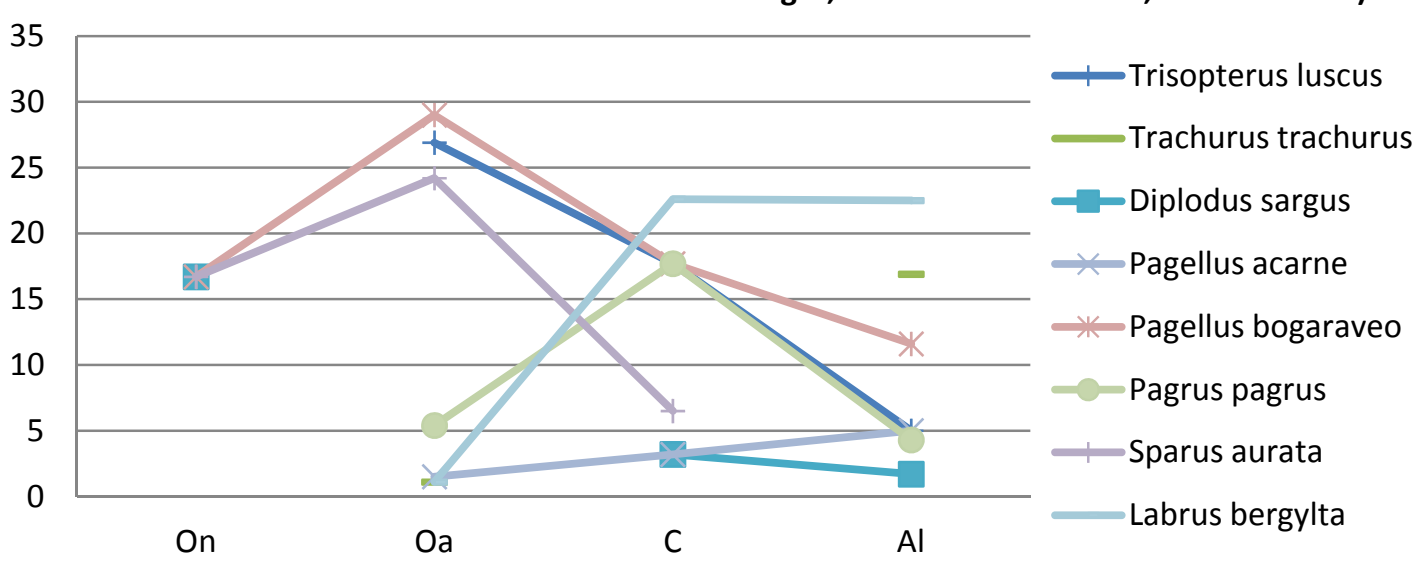

Fig. 304 Distribución de los principales taxones en la Ría de Arousa según la situación del yacimiento (De fondo de ría a zonas exteriores: On=O Neixón; Oa=O Achadizo; C=Cantodorxo; Al= A Lanzada). 
Pagellus bogaraveo va a estar presente en todos los yacimientos, independientemente de donde estén situados, aunque va a cobrar mayor importancia en aquellos localizados en las zonas medias de las rías. Sin embargo, no va a ser en ninguno de ellos la especie principal, salvo en la Fase II de O Achadizo. Una distribución similar, aunque para una especie con menor representatividad, se observa para Pagellus acarne. Trisopterus luscus, otra de las especies mejor representadas, va a estar también presente en casi todos los yacimientos, pero va a tener mayor importancia en aquellos situados en el interior de las rías, pasando a un papel muy secundario en los situados al exterior como As Hortas o A Lanzada. Además, en los yacimientos de la zona media y del fondo de ría, va a ser una de las especies mejor representadas, incluso mayoritarias. La presencia de Trisopterus luscus va a ser inversa a la de Labrus bergylta, que va a ir ganando en importancia según nos acercamos al exterior de la ría. De hecho, va a ocupar el papel que desempeñaba Trisopterus luscus en los yacimientos del interior, llegando a ser una de las especies principales. Es probable que el carácter sedentario de estas especies, principalmente de Labrus bergy/ta, las convierta en un recurso principal, al ser estable su presencia en el medio.

En el caso de Sardina pilchardus, ya comentamos anteriormente la problemática que presenta, aunque se puede apreciar que va adquiriendo más importancia según nos alejamos del fondo de ría. Este comportamiento es similar al que presenta Scomber japonicus, que va a tener una mayor representación en los yacimientos según nos acercamos a las zonas exteriores, siendo la especie más importante en As Hortas. Es interesante el hecho de que en Montealegre, situado casi al fondo de la Ría de Vigo, no se encuentre Scomber japonicus y sí Scomber scombrus, con una presencia anecdótica en el resto de yacimientos o incluso ausente. Trachurus trachurus es otra especie pelágica, que se va a localizar principalmente en los yacimientos exteriores, algo lógico si tenemos en cuenta que es un taxón que se encuentra en mar abierto.

Cuando aparecen estas especies suelen alcanzar una importancia significativa dentro del conjunto, seguramente debido a que forman grandes cardumes que facilitarían la captura de un número elevado de individuos por medio de redes. Por otro lado, la presencia de estas especies se localiza principalmente en la Ría de Vigo y en A Lanzada, documentándose en la ría de Arousa únicamente tres piezas de Trachurus trachurus en $\mathrm{O}$ Achadizo, lo que podría estar relacionado con factores cronológicos como evaluaremos más adelante.

Pagrus pagrus se ha documentado principalmente en los yacimientos situados en la mitad exterior de las rías, alcanzando sus mayores valores en aquellos asentamientos localizados en mar abierto, como As Hortas y A Lanzada. En el caso de este último, aunque en las muestras del 2010 no tenga mucha importancia, en el sector exterior fue la especie mejor representada. Con otras especies sucede lo contrario, como los casos de Sparus aurata o Dicentratchus labrax. Ambas, aunque con muy poca importancia, salvo Sparus 
aurata en $\mathrm{O}$ Achadizo, van a estar presentes principalmente en el fondo de la ría; además son eurihalinas, por lo que se pueden adentrar en zonas con aguas dulces.

En resumen, se aprecia que las especies capturadas van a depender en gran medida de la localización del yacimiento y de su entorno físico, ocasionando que unos taxones sean sustituidos por otros según la situación del asentamiento.

\section{VI.1.2.LA ACTIVIDAD PESQUERA.}

\section{Siglos V-II a.C.}

Como ya comentamos, los restos más antiguos de peces documentamos para la Cultura Castreña son los de la muestra MU040806B01 de Montealegre, adscribidles al Hierro I. Sin embargo, debido a su poca representatividad, así como a los problemas cronológicos que presenta el depósito, creemos que deben ser consideradaos con precaución por el momento.

Para la Fase II de la Cultura Castreña, únicamente contamos con cuatro yacimientos que presenten una cronología clara: el sector exterior de A Lanzada, con una cronología entre los siglos V y III a.C. (Ferré, 2003); las muestras de O Neixón, con dataciones de C-14 que sitúan tanto el Foso 01 como la Fosa 06 hacia los siglos IV y III a.C. (Parcero Oubiña y Ayán Vila, 2008); la Fase II de O Achadizo con dataciones que encuadran el depósito en torno al siglo V a.C. (Ferré et alii, 1996; Concheiro Coello, 2008a); y Cantodorxo con una cronología del IV-II a.C. (Ferré et alii, 1996; Fernández Rodríguez et alii, 1998).

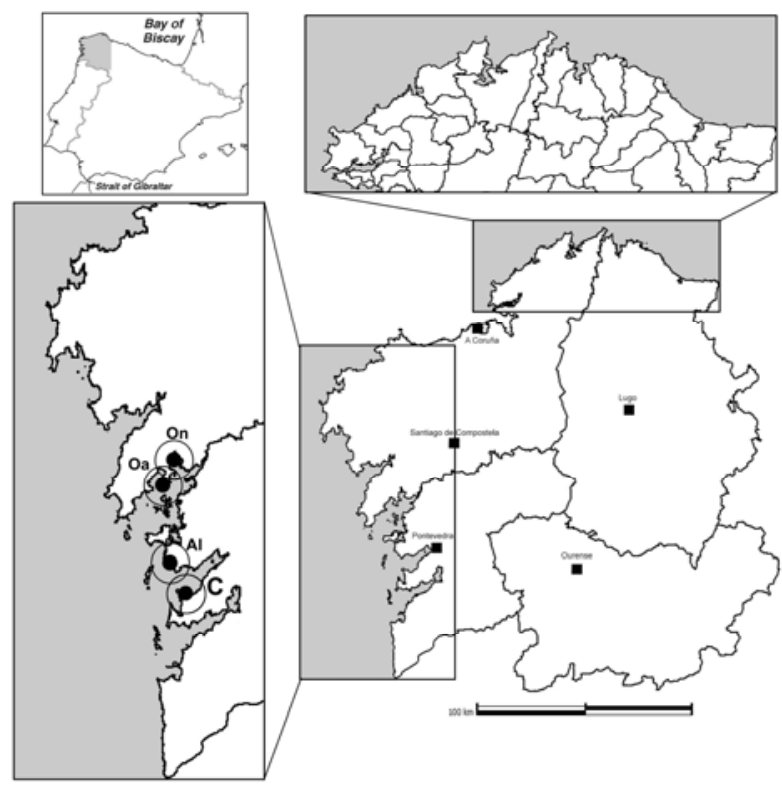

Fig. 305 Localización de los yacimientos con muestras del Siglo V-II a.C.

\begin{tabular}{l|c|c|c|c|} 
& On & OA II & Al & C \\
\cline { 2 - 5 } $\begin{array}{l}\text { Anguilla anguilla } \\
\text { Conger conger }\end{array}$ & & 1 & 7 & \\
$\begin{array}{l}\text { Gadidae sp. } \\
\text { Merluccius merluccius }\end{array}$ & 1 & 6 & 1 & \\
$\begin{array}{l}\text { Dicentrarchus labrax } \\
\text { Trisopterus luscus }\end{array}$ & 2 & & & \\
Diplodus sargus & 1 & 59 & & 11 \\
Sparus aurata & 1 & 38 & & 4 \\
Pagrus pagrus & & 10 & 15 & 11 \\
Pagellus acarne & & 4 & & 2 \\
Pagellus bogaraveo & 1 & 75 & & 11 \\
Labrus bergylta & & 2 & 9 & 14 \\
Symphodus melops & & 2 & & \\
\hline \hline \multicolumn{1}{c|}{ TOTAL } & $\mathbf{6}$ & $\mathbf{1 9 7}$ & $\mathbf{3 3}$ & $\mathbf{6 2}$
\end{tabular}

Tabla 210 NR de los diferentes taxones identificados en yacimientos del siglo V-Il a.C. (On=O Neixón; Oall=Nivel II de O Achadizo; Al=A Lanzada; C=Cantodorxo).

Los conjuntos de estos yacimientos se caracterizan en primer lugar por los pocos restos recuperados, aunque no tenemos constancia del volumen de sedimento procesado 
ni en el sector exterior de A Lanzada ni en O Achadizo. En O Neixón se procesaron $20 \mathrm{Kg}$ de sedimento, recuperándose únicamente siete restos anatómicamente identificables, lo que resulta una proporción menor a un resto por $\mathrm{Kg}$.

En estos conjuntos predominan los centros vertebrales, siendo muy pocos los restos cefálicos recuperados. Además, en O Neixón es llamativa la ausencia en la mayor parte de las muestras tanto de escamas como de costillas, el esqueleto de las aletas o fragmentos del cráneo. El único taxón representado exclusivamente por restos cefálicos es Sparus aurata, tanto en $\mathrm{O}$ Neixón como en $\mathrm{O}$ Achadizo, lo que puede responder al procesado de los individuos para su tratamiento conservero (Ferré et alii, 1996; Ferré, 2003).

La poca importancia que parece haber tenido la pesca en esta fase puede no ser más que una continuación de la escasa práctica de esta actividad detectada desde el segundo milenio en la Península Ibérica. En ese momento se van a producir una serie de cambios en las estrategias de subsistencia, desapareciendo los modos de vida indígena basados en la recolección y consolidándose los sistemas productivos (Roselló, 1989; Morales y Roselló, 2006). Algo similar se ha detectado en los castros del Noroeste respecto a las actividades cinegéticas, siendo muy pocos los restos de animales salvajes documentados (Ramil Rego y Fernández Rodríguez, 1999; Fernández Rodríguez, 2000). De hecho, en el noroeste desde el II milenio se va a producir una intensificación de las actividades productivas (González Ruibal, 2006/07a: 79), llegando a momentos máximos en la II Edad del Hierro con el descenso de los asentamientos a zonas de valle, así como con un aumento de la deforestación (González Ruibal, 2006/07b: 291). En el sur peninsular este patrón cambiará en la Edad del Hierro con la aparición de asentamientos fenicios y púnicos (Morales y Roselló, 2006).

En cuanto a las capturas, estos yacimientos se caracterizan por haber aportado un pequeño abanico de especies. La familia mejor representada va a ser la de los espáridos, quizás debido a que presenta el mayor número de especies en las costas gallegas. Otras familias como gádidos o lábridos van a estar también bien representadas en cuanto a número de restos, aunque no de especies. La mayor presencia de gádidos como Trisopterus luscus, o lábridos como Labrus bergylta, va a depender de la posición del yacimiento en el litoral, como vimos en el apartado anterior. Todas estas especies son demersales, carnívoras y se pueden encontrar cerca de la costa. Es llamativa la ausencia de especies pelágicas con un marcado carácter estacional como Scomber japonicus o Trachurus trachurus, que sí están presentes en depósitos con una cronología más moderna. Por lo tanto, estaríamos ante una pesca nerítica, con una tecnología muy simple ya que estas especies se pueden apresar desde la costa o desde embarcaciones sin necesidad de alejarse demasiado.

Debido a las especies representadas y al escaso número de restos recuperados, pensamos que la pesca se habría realizado mediante la utilización de anzuelos, con un 
rendimiento escaso, propio de economías de subsistencia. En el sector exterior de $A$ Lanzada se recuperó un anzuelo de tipo "J" en bronce, de 4,5 cm de longitud (Vázquez Varela et alii, 1993). En el Conchero B de O Achadizo (de donde procede la muestra adscrita al momento que nos ocuap) se documentó otro anzuelo de bronce con unas características similares (Concheiro Coello, 2008). Estos anzuelos servirían para capturar las especies representadas en el conjunto; de hecho, son adecuados para la captura de una gran cantidad de especies con diferentes características y tallas (Morales, 2008).

\section{Siglos II a.C.-I d.C.}

\begin{tabular}{l|c|c|c|c|c|} 
& Mo & Mv & Oa III & Al & Q \\
\cline { 2 - 6 } $\begin{array}{l}\text { Salmo salar } \\
\text { Sardina pilchardus }\end{array}$ & 23 & 14 & & & \\
$\begin{array}{l}\text { Conger conger } \\
\text { Merluccius }\end{array}$ & & & & 1 & \\
merluccius & 2 & 1 & 14 & & \\
Trisopterus luscus & 46 & 12 & 16 & 15 & \\
Pollachius pollachius & & & 1 & & \\
Dicentrarchus labrax & 9 & 6 & & & \\
Trachurus trachurus & & & 3 & 51 & \\
Diplodus sp. & & & & 1 & \\
Diplodus sargus & 7 & 10 & & 5 & \\
Diplodus vulgaris & & 1 & & & \\
Sparus aurata & 4 & & 27 & & \\
Pagrus pagrus & & & 5 & 13 & \\
Pagellus sp. & & & & 4 & \\
Pagellus acarne & & & & 15 & \\
Pagellus bogaraveo & 18 & 11 & 3 & 35 & \\
Labrus bergylta & 3 & & 1 & 68 & 6 \\
Symphodus melops & & & 1 & 82 & \\
Ammodytidae & & & & 2 & \\
Scomber sp. & 2 & & & & \\
Scomber scombrus & 2 & 1 & & 1 & \\
Scomber japonicus & & 1 & & 9 & \\
\hline \hline \multicolumn{1}{|c|}{ TOTAL } & $\mathbf{1 1 6}$ & $\mathbf{5 7}$ & $\mathbf{7 2}$ & $\mathbf{3 0 2}$ & $\mathbf{6}$
\end{tabular}

Tabla 211 NR de los diferentes taxones identificados en yacimientos del siglo II a.C.-I d.C. (Mo=Montealegre; Mv=Muiño do Vento; OallI=Nivel III de O Achadizo; Al=A Lanzada; FD=Facho de Donón; $\mathrm{Q}=$ Queiruga).

Los yacimientos que han sido objeto de análisis con una cronología entre el siglo II a.C. y el cambio de Era son: Montealegre (pese a los problemas de datación comentados en el apartado correspondiente); A Lanzada (las dataciones de las muestras las sitúan en el siglo II a.C.) (Rodríguez Martínez et alii, 2010); la Fase III de O Achadizo (siglo II a.C.) (Ferré et alii, 1996; Concheiro Coello, 2008a); el Castro de Punta do Muiño do Vento (siglos II-I a.C.); y Queiruga (siglo III-I a.C.) (Ferré, 1996; 2003). Por representación taxonómica As 


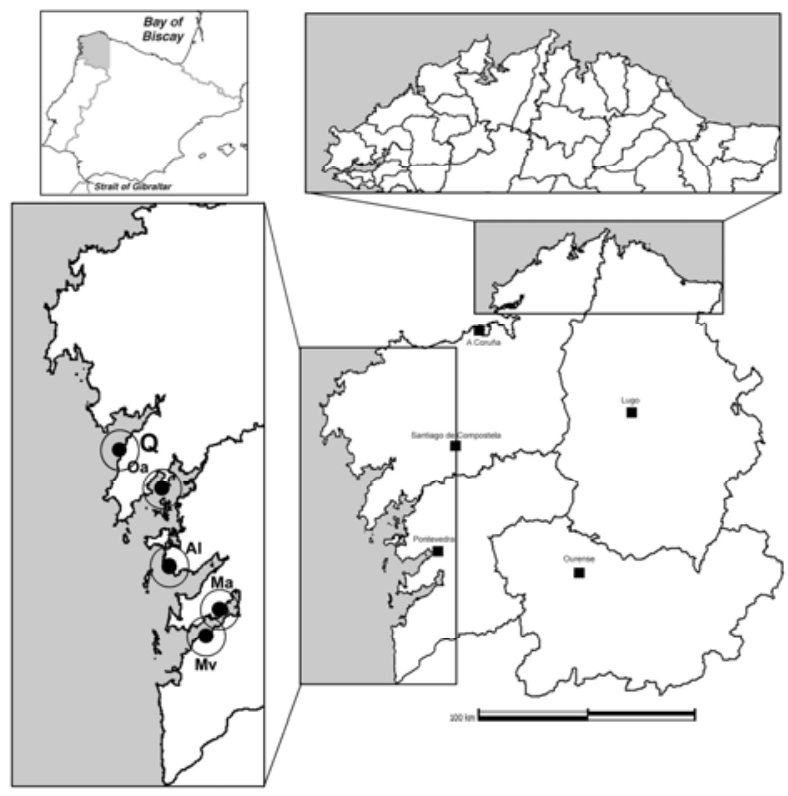

Fig. 306 Localización de los yacimientos con muestras del Siglo II a.C.-I d.C.

Hortas podría adscribirse a este mismo marco temporal, sin embargo debido a su poca precisión cronológica hemos decidido no incluírlo en el análisis.

Respecto a la fase anterior, podemos observar una serie de diferencias. En primer lugar, se percibe un aumento del abanico de especies capturadas, así como cambios en la importancia de las mismas. Aunque el número de restos identificados no es muy elevado, se aprecia un aumento de la proporción entre sedimento procesado y restos recuperados. Así, en el conchero de Montealegre se recuperaron 1,1 restos por cada $\mathrm{Kg}, 3$ en el sondeo 02 de Montelagre, 2,8 en Punta do Muiño do Vento y en A Lanzada 8,2 restos por $\mathrm{Kg}$. A la vez se puede apreciar un aumento de los restos cefálicos (menos en el conchero de Montealegre, quizás debido a diferencias cronológicas, ya que también es el que menos restos por Kg presenta), así como escamas, radios de las aletas, costillas y fragmentos de cráneo. Estos aspectos nos pueden estar indicando un aumento de la actividad pesquera, y por lo tanto un incremento del consumo de pescado, que ganaría importancia en la dieta. Además también puede estar reflejando cambios en el modo de procesar los ejemplares capturados, bien por la realización de tratamientos de conservación, bien por la llegada de más ejemplares completos al yacimiento.

\begin{tabular}{l|c|c|c|} 
& NR & Peso total & NR/Kg \\
\cline { 2 - 4 } A Lanzada & 302 & 36,807 & 8,2 \\
O Neixón & 7 & 20,001 & 0,3 \\
Montealegre 1 & 47 & 42,032 & 1,1 \\
Montealegre 2 & 103 & 34,63 & 3 \\
Muiño do Vento & 61 & 21,46 & 2,8
\end{tabular}

Tabla 212 NR de ictiofauna recuperado por $\mathrm{Kg}$ de sedimento procesado.

En cuanto a las especies capturadas, los espáridos siguen siendo la familia mejor representada, aunque va a cambiar la importancia de las especies. Se va a seguir constatando la presencia de especies carnívoras y demersales, si bien van a aparecer las pelágicas con un marcado carácter estacional, como Sardina pilchardus, Trachurus trachurus, Scomber sp. Estas especies se caracterizan por poder ser capturadas cerca de la costa, si bien en determinados momentos del año. En el caso de A Lanzada, los máximos de Trachurus trachurus se concentran en dos muestras, lo que puede estar reflejando esta pesca estacional. Esto, junto al hecho de que formen grandes cardúmenes, nos lleva a 
considerar la aparición de nuevas técnicas de pesca. Lo que se confirmaría por la aparición de Sardina pilchardus en varios yacimientos de este periodo. Estas especies van a jugar un papel muy importante entre las capturadas, si bien en pocos casos van a ocupar un puesto principal. Por lo tanto, podemos hablar de una intensificación de la pesca en determinadas épocas del año, coincidiendo con el momento de llegada de estas especies al litoral, en primavera y verano.

Parece haber una especialización en la captura de ciertos taxones, existiendo unas especies principales, uno o dos taxones, unas especies secundarias con tres o cuatro, y un amplio abanico de especies complementarias. En ciertas ocasiones estas últimas corresponden a especies con características similares a las mejor representadas, debiéndose su menor presencia a una mayor dificultad para su captura o por encontrarse peor representadas en el medio.

Los anzuelos seguirían siendo utilizados para la pesca de la mayoría de las especie; y han sido documentados en yacimientos como Montealegre o Santa Trega (Vázquez Varela et alii, 1993; Aboal et alii, 2006). Suelen presentar la punta recta o saliente, ejerciendo menor fuerza de anclaje y siendo más difícil la captura de la pieza (García Alonso, 1981/82). Por lo tanto estaríamos ante aparejos poco productivos, y que en cierto modo pueden explicar la poca presencia de especies como Dicentrarchus labrax, que presentan mucha resistencia a su captura (Rodríguez Pantoja, 2006) y que sin embargo van a ser muy importantes en periodos posteriores como el medieval (Ferré y Rey, 1998; Ferré, 2003).

Como ya apuntábamos anteriormente, se va a documentar la aparición de una nueva tecnología pesquera. Según parece, en este periodo se incorporarían redes para la pesca, por lo menos de determinadas especies como Sardina pilchardus, Trachurus trachurus o Scomber sp. En este periodo se han recuperado varios cantos trabajados que han podido servir como pesas de red. A este respecto existe cierta polémica, ya que hay autores que defienden que podrían responder a pesos para diferentes aparejos como la línea de anzuelos (Vázquez Varela et alii, 1993; Ferré y Rey, 1998). Estas piezas presentan unas características muy diferentes en cuanto a peso y forma, así como a localización de las escotaduras y tipo de las mismas. Según la localización de las escotaduras podemos diferenciar tres tipos de pesas: 1) Escotaduras transversales; 2) Escotaduras longitudinales; 3) Canal longitudinal. El primero de estos tipos sería similar a los documentados en yacimientos como Santa Trega o Vigo (Vázquez Varela et alii, 1993), mientras que los dos últimos han sido documentados en Montealegre (Cancela Cereijo, 2006: 226-227), Baroña (Vázquez Varela et alii, 1993) o A Lanzada (Rodríguez Martínez et alii, 2010).

Esta problemática también se ha planteado en otras áreas geográficas, de este modo, estudios realizados sobre poblaciones del sur de Sudamérica, sugieren que los cantos con muescas longitudinales serían utilizados para la pesca con línea de anzuelos, mientras que las muescas transversales se utilizarían para la pesca con redes (Tórres, 
2007). Algo similar es defendido para el noroeste de la Península Ibérica (Vázquez Varela et alii, 1993), apuntando que las piezas piriformes con canal longitudinal serían más adecuadas para la línea de anzuelos que para la red. Según otros autores (De Pinho y Lanhas, 1971) las piezas de menor tamaño formarían parte de la pesca en línea, mientras que las más grandes servirían para fijar las redes en sus extremos. Lo cierto es que es necesario un estudio de conjunto de todas las piezas líticas aparentemente relacionadas con la pesca, para intentar definir su funcionalidad.

Pese a esta problemática, es probable que en este momento se estén utilizando redes para la pesca, y aunque es complicado concretar las artes utilizadas, algunas como el trasmallo parecen las más lógicas si tenemos en cuenta que no necesitan de una excesiva mano de obra y es altamente productiva con especies pelágicas como Sardina pilchardus, Trachurus trachurus y Scomber sp. (Morales, 2008). De todos modos, es llamativa la ausencia de agujas y de lanzaderas, habituales en otras áreas peninsulares (García Alonso, 1981/82), quizás debido a una incorrecta identificación de los utensilios o a su fabricación en materiales perecederos como la madera. Además de la posible aparición de las artes de red, el aumento de las especies capturadas puede estar evidenciando el empleo de nuevos aparejos como el palangre de fondo, también reflejado por la aparición de estas pesas que pudieron ser utilizadas como lastre.

Desde el siglo II a.C. se detectan una serie de cambios sociales y materiales en las sociedades del noroeste. Por un lado se va a producir una concentración de la población en oppida situados en montes prominentes que controlan puntos clave del paisaje (González Ruibal, 2006/07b: 348). Pero además se va a detectar un apogeo de la orfebrería, la escultura, la cantería, la expansión de la siderurgia y una mayor homogenización alfarera, haciéndose más complejas las relaciones de poder en las comunidades del noroeste (González Ruibal, 2006/07). Por otro lado, aunque desde finales del siglo III a mediados del II a.C. se detecta una interrupción de flujo comercial púnico con el noroeste, desde mediados del siglo II hasta mediados del I a.C., van a reaparecer con más vigor estas relaciones comerciales, pudiendo albergar incluso población procedente de las ciudades del estrecho (González Ruibal et alii, 2007; 2010).

El aumento de la población en sí mismo supone una causa que justifica la intensificación de las actividades productivas para satisfacer el crecimiento de la demanda. Sin embargo, la evolución que podemos observar en la pesca y en el tratamiento de las capturas puede encuadrarse perfectamente en los cambios que desde el siglo II a.C. se detectan en el noroeste peninsular. El aumento de la pesca en este momento coincide con un cambio en la alimentación, como parece indicar el aumento de los recipientes cerámicos con formas abiertas frente a los recipientes cerrados del periodo anterior (González Ruibal, 2006/07b: 494). Este mismo proceso se puede apreciar en la zona del Estrecho a partir del siglo III a.C., con un mayor consumo de alimentos sólidos y una dieta más variada (Niveau de Villedary y Campanella, 2006: 675). Uno de los cambios que se 
habrían producido en este momento es la mayor ingesta de productos pesqueros. Es posible que el interés que adquiere la ictiofauna en la dieta esté vinculado a un cambio en su valoración social, en relación con la influencia cultural mediterránea, en la que el pescado ocupa una posición muy importante a nivel social y alimenticio (Niveau de Villedary, 2006; Niveau de Villedary y Campanella, 2006). En nuestro ámbito de estudio, este hecho se vería reflejado en la progresiva especialización en las capturas de determinadas especies, así como en la pesca de especies pelágicas y su procesado, como veremos posteriormente.

La presencia de ejemplares más o menos completos en los yacimientos indica variaciones sustanciales en el tratamiento del pescado dentro de los asentamientos. Parecen estarse reflejando nuevas formas de consumo de los alimentos, así como una profesionalización de la actividad pesquera vinculada a la intensificación de las capturas y a la aparición de nuevas artes.

Después de lo apuntado hasta el momento hay que señalar la limitada distribución de los productos pesqueros, circunscribiéndose a castros litorales o sublitorales. Este fenómeno puede deberse a varias razones: 1 ) La deficiente recuperación de los materiales en las excavaciones puede ocasionar la pérdida de estos restos, del mismo modo que los procesos tafonómicos intervienen decisivamente en su conservación. 2) Las influencias foráneas serían más intensas en las zonas costeras, de hecho, mientras más nos alejemos de la costa menor número de materiales de importación llegan (González Ruibal, 2006/07). 3) Lo más probable, a tenor de los datos que tenemos hasta la fecha, es que la explotación del medio marino tuviera un desarrollo local, de autoconsumo. Sin embargo, casos como el de A Lanzada plantean la aparición de un nuevo papel para la pesca como bien comercial, siendo un aspecto habitual desde el cambio de era. La pesca no sería un recurso de gran importancia en el noroeste hasta el siglo II a.C., momento en el que progresivamente irá ganando mayor predominio. Esto tampoco quiere decir que no supusiera una importante fuente alimenticia en las zonas costeras, aunque jugando un papel secundario.

En el área del estrecho se detecta un aumento de la actividad pesquera durante el primer milenio a.C. fruto de las influencias de las culturas del oriente mediterráneo (Morales y Roselló, 2006). Del mismo modo, los peces pelágicos parecen haber tenido un papel muy secundario durante la Protohistoria, alcanzando una significativa relevancia con las colonizaciones de estos pueblos (Morales y Roselló, 2006; Morales, 2008). La aparición de nuevas artes de pesca en el noroeste se puede englobar en los cambios producidos en este periodo, pero es posible que puedan existir influencias externas. Estas modificaciones en el modelo pesquero pueden deberse al impulso comercial con el sur peninsular, produciéndose de forma más tardía en el área gallega el fenómeno que desde inicios del primer milenio se detecta en la zona del estrecho.

Si bien es posible que la aparición de nuevos conocimientos técnicos para la pesca esté influida por los contactos tardopúnicos, de momento es más complicado establecer la 
relación existente entre este nuevo modelo de explotación y los comerciantes mediterráneos. Algunas de las causas que comentábamos anteriormente para los cambios que se producen en el noroeste durante la Fase III de la Cultura Castreña pueden ser válidas para explicar estos cambios.

La pesca de especies pelágicas tiene el inconveniente de tener que procesar los ejemplares para su conservación en momentos de excedentes, y buscar alternativas en los años de escasez (Morales, 2008). Evidencias claras de tratamientos de conservación únicamente se han documentado en el yacimiento de $\mathrm{O}$ Achadizo y en $\mathrm{A}$ Lanzada. En $\mathrm{O}$ Achadizo (Ferré, 2003) se recuperaron un gran número de restos de Sparus aurata, predominando en las tres fases documentadas los cefálicos frente a los post-cefálicos (Ferré et alii, 1996). En el yacimiento de A Lanzada, las excavaciones realizadas en 2010 han sacado a la luz una estructura productiva del siglo II a.C., formada por varias piletas, que se abandonaría con la llegada de Roma (Rodríguez Martínez et alii, 2010). Se ha planteado la posibilidad de que sea una fábrica de salazones, siendo el ejemplo más antiguo en Galicia de tratamiento industrial de pescado. Los restos ictioarqueológicos sí plantean una mayor intensidad pesquera que en otros yacimientos, apareciendo especies susceptibles de ser utilizadas en estas industrias. De todos modos, la desconexión entre estos restos y la citada estructura nos impide por el momento hacer ninguna valoración respecto a los productos elaborados, aunque la fauna recuperada encajaría bastante bien en lo observado en otras factorías del estrecho.

En resumen, el modelo de capturas parece corresponder en la mayoría de los casos más con lo observado en la Fase II que con lo que veremos en época romana, aunque casos como el de Montealegre, seguramente más cerca del cambio de era, ya apuntan lo que se aprecia en depósitos como el de Punta Atalaia o el nivel IV de O Achadizo. Por lo tanto, estaríamos ante un fenómeno de intensificación que seguramente tenga que relacionarse con un progresivo aumento del consumo de pescado y quizás a un mayor interés por este producto como ocurrirá en la sociedad galaico-romana desde el cambio de Era.

\section{VI.2. LA PESCA EN EL PERIODO GALAICO-ROMANO.}

El registro que tenemos para época romana es muy exiguo, ya que contamos con pocos yacimientos y pocos restos. Esto supone un problema mayor si tenemos en cuenta la gran variedad de modelos de asentamiento que aparecen en este periodo, con realidades socio-culturales y económicas diferentes. No va a jugar el mismo papel un asentamiento urbano que un castro o un vicus, que a su vez difieren de la importancia socio-económico de una factoría. A este problema hay también que sumar la imprecisión en las cronologías para los depósitos de este periodo que hemos analizado. 


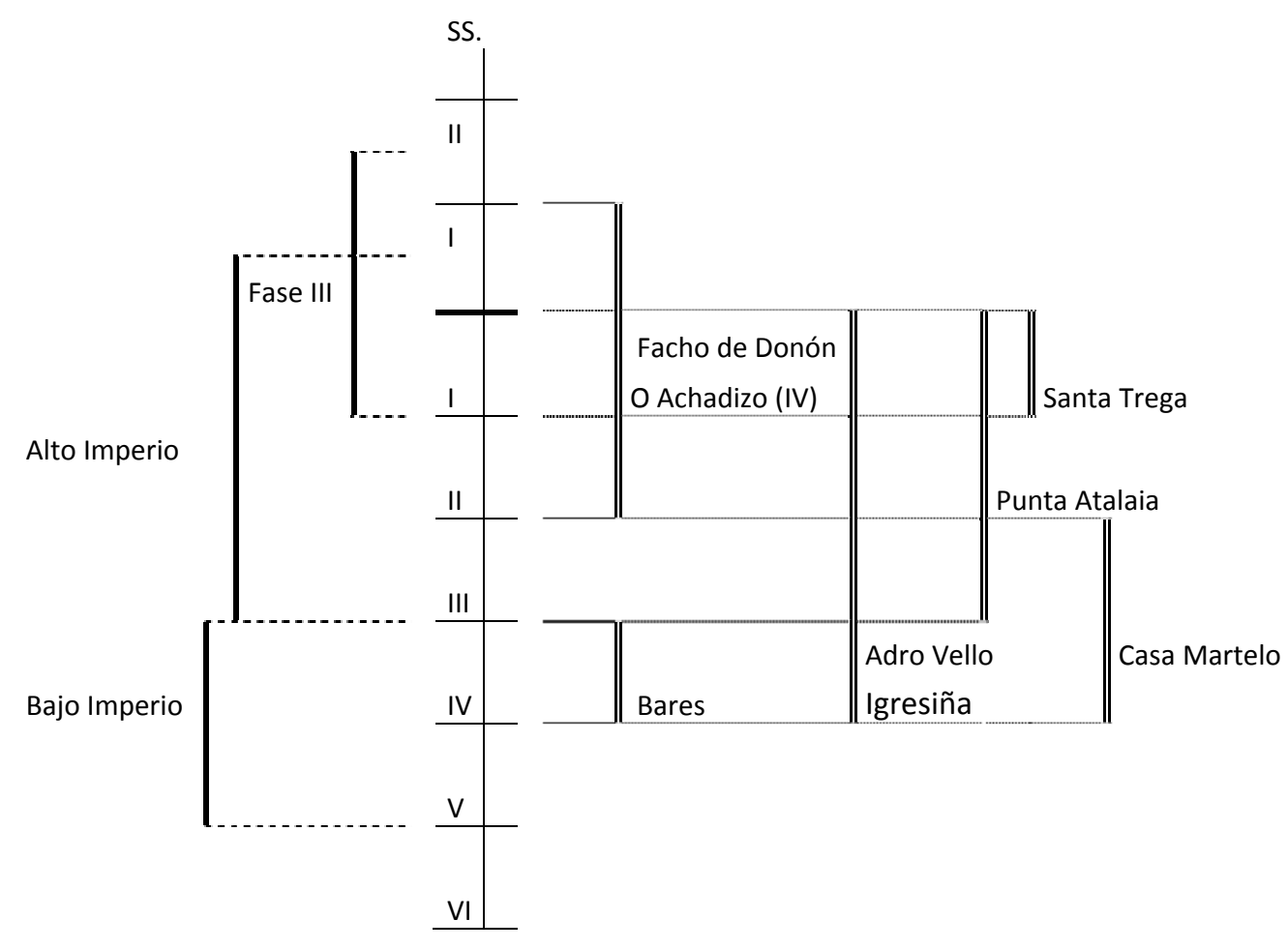

Otro de los problemas que nos hemos encontrado es el registro de los materiales. La ausencia de cribas, la desidia en la recuperación de restos materiales por parte de algunos arqueólogos, así como la necesidad de una mayor generalización de los estudios faunísticos con el análisis de las muestras recogidas, hace que sean muy pocos los yacimientos con restos de peces estudiados hasta la fecha en el noroeste. Estos problemas en la metodología de excavación, así como la casi total ausencia de dataciones en los concheros y de estudios de otros materiales asociados, hace que estos conjuntos se caractericen por una gran imprecisión cronológica. De este modo, conjuntos como el de Santa Trega platean serias dudas sobre su representatividad. A todos estos problemas derivados de la actividad arqueológica, hay que sumar la dificultad de conservación que presentan estos restos orgánicos, y que ya comentamos anteriormente.

Hay que tener en cuenta, a la hora de intentar sistematizar un modelo pesquero en el noroeste durante el periodo romano, la situación de los yacimientos, ya que todos, a excepción de O Achadizo, están situados en zonas de mar abierto. En este sentido, algunas de las diferencias que observamos respecto al mundo prerromano, como la representación de las especies, pueden estar condicionadas por este hecho. Además vamos a contar con la presencia de asentamientos cantábricos, zona para la cual no disponemos de información de las fases anteriores.

Pese a los problemas señalados, vamos a indicar algunas características referentes a la pesca en el periodo romano, así como a poner de manifiesto las diferencias más significativas respecto al periodo anterior. 


\section{VI.2.1. LAS ESPECIES.}

Para el mundo romano se aprecian ciertas diferencias en cuanto a la representatividad de las especies entre nuestros análisis y los trabajos de otros autores (Vázquez Varela et alii, 1993; Ferré y Rey, 1998). Lo que puede deberse a los pocos datos con los que se contaba, así como la incorporación de un yacimiento con un registro bastante completo como el de Punta Atalaia.

En los yacimientos de época romana para los que tenemos datos se han podido identificar un total de diecinueve especies. Esto supone un número similar de taxones que el constatado en época prerromana, aunque algunos no estaban presentes en los yacimientos del periodo anterior (Zeus faber, Polyprion americanus, Mugilidae sp.). Su presencia puede estar indicando cambios en las artes y aparejos de pesca con la incorporación de estos territorios a la administración romana y al nuevo sistema económico.

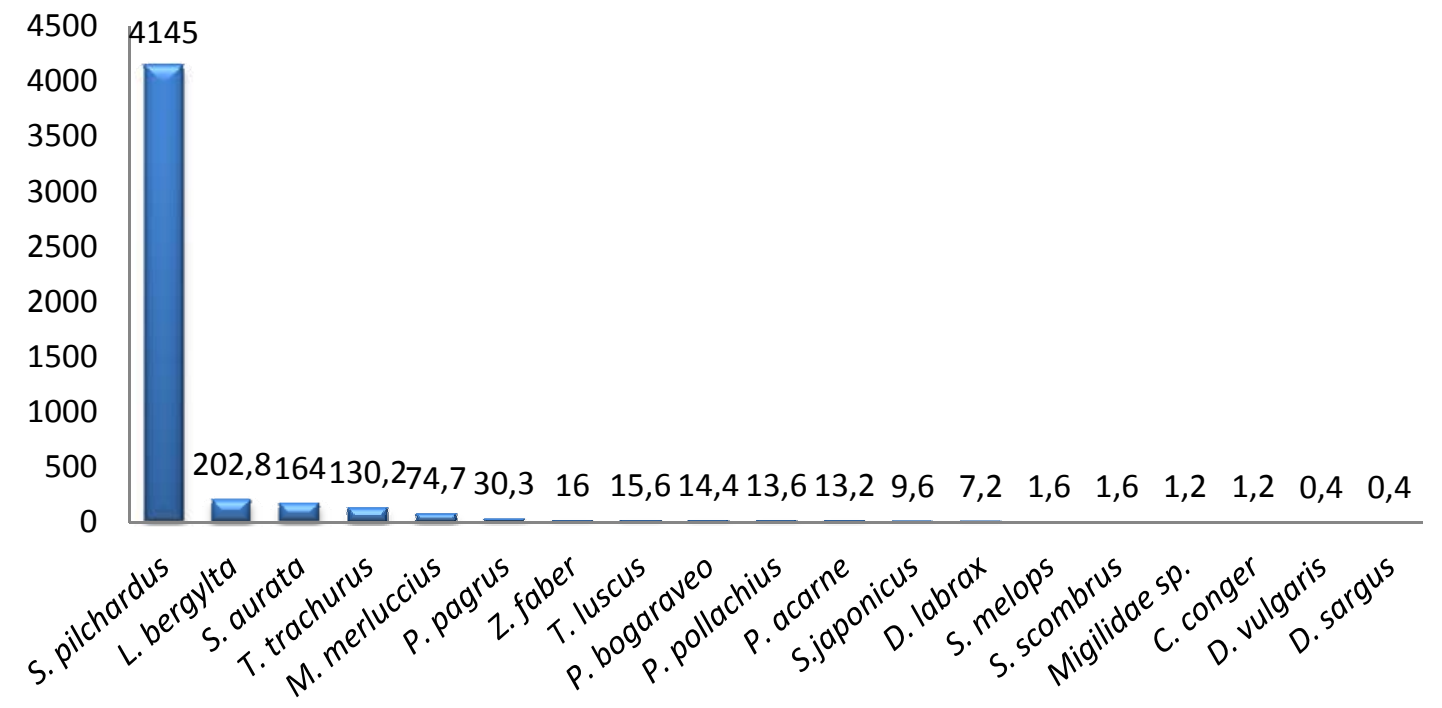

Fig. 307 Importancia de las especies a partir del cálculo del ICxID de los yacimientos de época romana.

La especie que mayor número de restos presenta para este periodo es Sardina pilchardus, aunque va a estar sobrevalorada por el registro de Adro Vello. Este yacimiento tiene unas características diferentes al resto de conjuntos estudiados, ya que se corresponde con unas instalaciones industriales para el procesado de peces, y por lo tanto está enfocado a la producción y comercio de productos derivados del pescado. Según parece, durante los siglos II y III d.C. se van a utilizar en diversas zonas peninsulares especies de pequeño tamaño, como Sardina pilchardus, para la producción de salsamentas (García Vargas, 2006). Este esquema parece adaptarse bien a lo observado en este yacimiento, así como en el de A Igresiña (Ferré, 2003: 260), lo que explicaría el elevado número de restos que de Sardina pilchardus se han documentado.

Algo similar puede decirse en relación con la captura de especies pelágicas, que si bien parece haber sufrido una intensificación en época romana, este aumento estaría 
vinculado principalmente con factorías conserveras, ya que no son tan numerosos los restos documentados en los yacimientos tipo castro. De todos modos, taxones como Trachurus trachurus y Scomber sp. sí parece que hayan jugado un papel más importante en los asentamientos que en las instalaciones industriales, por lo menos en lo que a la mariña lucense corresponde, aunque aún son escasos los datos disponibles. Scomber japonicus sigue siendo más numeroso que Scomber scombrus, algo que también se puede observar en la fauna localizada en diferentes industrias de salazón y ánforas en el sur de la Península Ibérica (García Vargas, 2006) y de la costa cantábrica (Morales Muñiz y Roselló Izquierdo, 2008).

Sparus aurata, Labrus bergylta y Trachurus trachurus son los taxones representados por más restos después de Sardina pilchardus. Labrus bergylta ya era una especie con gran importancia en los yacimientos de la zona exterior de la ría en el periodo prerromano, mientras que Trachurus trachurus, que solo estaba presente en estos poblados exteriores, va a aumentar considerablemente su importancia.

Es significativo el descenso en importancia de especies como Trisopterus luscus y sobre todo Pagellus bogaraveo con respecto a lo visto antes del cambio de era. Aunque hay que tomar esta apreciación con prudencia, debido a que estos taxones tenían una mayor importancia en los yacimientos prerromanos situados en el interior de las rías, y casi no tenemos datos para esta época romana, es significativo el hecho que estas dos especies presenten un elevado número de restos en las fases más antiguas de O Achadizo, y sin embargo sean muy pocos los recuperados del registro de la ocupación romanizada.

Pagellus bogaraveo quizás sea el caso más llamativo, ya que era una especie común a todos los yacimientos y con cierta importancia en las muestras estudiadas. En principio, estas ausencias pueden estar vinculadas a cambios en el medio o en las costumbres gastronómicas, pero en otros yacimientos cantábricos de época romana como La Plaza del Marqués en Gijón (Morales Muñiz et alii, 1992; 1994) o Iruña-Veleia (Morales Muñiz y Roselló Izquierdo, 2008) se ha identificado Pagellus erythrinus como una de las especies mayoritarias. Este taxón presenta unas características gastronómicas similares a Pagellus bogaraveo, por lo que quizás el descenso en los yacimientos costeros deba relacionarse con factores socio-económicos propios de la cultura romana, de modo que estas especies serían objeto de comercio con las comunidades del interior. Un fenómeno similar hemos detectado en el caso de Ostrea edulis, que si bien es habitual documentarla en castros litorales en época prerromana, con el mundo romano su consumo se va a centrar principalmente en asentamientos del interior (Vázquez Varela, 1996; Fernández Rodríguez y Fuertes Prieto, 2003; Fuertes Prieto y Fernández Rodríguez, 2010; Bejega García et alii, e.p.). De todos modos serían necesarios más datos de yacimientos interiores que permitieran confirmar esta hipótesis relativa al comercio de determinados productos piscícolas hacia núcleos urbanos interiores. 
Frente al descenso absoluto en la presencia de estos taxones, otros, como en el caso de Pagrus pagrus, mantienen unos porcentajes similares o incluso, como Sparus aurata, van a ver incrementada su importancia relativa.

Dicentrarchus labrax va a estar presente en más de la mitad de los yacimientos, aunque su escaso número concuerda con lo observado durante el periodo anterior. Esta especie parece que era muy apreciada en el mundo romano, llegando a criarse en cautividad (Rodríguez Pantoja, 2006), sin embargo, su captura no debía de ser sencilla debido a su resistencia (Rodríguez Pantoja, 2006).

Pollachius pollachius es una de las especies que más aumenta su importancia en época romana, con presencia en Punta Atalaia y en el yacimiento romano de Plaza del Marqués en Gijón (Morales Muñiz et alii, 1992; 1994). La concentración de los restos de esta especie en la Costa Cantábrica y la ausencia de muestras ictiofaunísticas en yacimientos prerromanos en esta zona, nos impide valorar si la pesca de esta especie ya era habitual en esta área o si, por el contrario, va a convertirse en una especie más importante con la romanización, sea por aprecio gastronómico, cambios en las condiciones del mar o por la aparición de nuevas técnicas pesqueras.

Un proceso similar se detecta en el caso de Merluccius merluccius. Su presencia en yacimientos prerromanos no supone un número elevado de restos, y sin embargo en el periodo romano su importancia relativa va a aumentar considerablemente. Igual que pasaba con Pollachius pollachius, van a ser los yacimientos cantábricos los que mayor número de restos de esta especie aportan. Si bien el Solar 02 de Punta Atalaia planteaba ciertas dudas relacionadas con la datación de las muestras, otros yacimientos, como Casa Martelo en A Coruña, presentan una clara cronología romana. A este respecto resultan también interesantes las diferencias en la representación anatómica de Merluccius merluccius en los diferentes yacimientos. En los prerromanos es destacable la ausencia de restos cefálicos, mientras que aunque predominan las vértebras precaudales, su presencia está bastante equilibrada con las caudales. En las muestras de época romana es muy numerosa la presencia de huesos cefálico, al tiempo que las vértebras precaudales son muy superiores a las caudales. Esta representación anatómica va a ser habitual en las factorías medievales gallegas desde el siglo XIII d.C., vinculadas al procesado de Merluccius merluccius para su salado. Quizás, este sistema de conserva ya sea utilizado en época romana, quedando en desuso en las costas gallegas con el fin de este periodo debido a la desestructuración que se produce del mercado. La necesidad de grandes cantidades de sal, la presencia de una flota estable y preparada, así como un mercado que absorba la producción son factores que han podido influir tanto en su abandono como en su posterior recuperación en la Plena Edad Media.

Finalmente hay un grupo variable de especies que aparecen de forma aislada, representadas por un bajo número de restos. Como sucedía en el mundo castreño, la pesca de estas especies puede vincularse más a una captura casual que sistemática. De 
este modo Salmo sp. (como ya comentamos, es posible que se trate de Salmo salar) podría haber sido pescado en el mar cuando se produce la migración de esta especie para su reproducción. En relación con esta especie, no hay que olvidar los ya comentados problemas de conservación de sus restos, lo que indudablemente ha debido influir en su representatividad.

La captura de Scomber scombrus puede vincularse con la de Scomber japonicus, de similares características etológicas, pero con menor presencia en los registro analizados.

Como apuntábamos más arriba, en estos yacimientos romanos se ha documentado dos especies de las que no teníamos constancia en momentos anteriores, pero que sí van a ser más comunes en la Edad Media: Zeus faber y Polyprion americanus, que van a plantear algunos interrogantes debido a sus características. Ambas son especies solitarias, carnívoras y que suelen vivir en aguas profundas, por lo que es normal que su representación se limite a un número pequeño de restos. En el caso de Zeus faber, suele ser capturado con palangres y artes de cerco o arrastre, y según parece era apreciado en ciudades del sur peninsular como Gadir (Rodríguez Pantoja, 2006). En nuestro caso, y al igual que comentamos para Pollachius pollachius y Merluccius merluccius, su pesca se va a centrar principalmente en el norte de Galicia, siendo también una de las especies más importantes en Casa Martelo. Polyprion americanus es una especie bentónica y solitaria que ocupa profundidades entre los 100 y los 200 m, su pesca se realiza principalmente con palangres de fondo. Su aparición por primera vez en el registro gallego en época romana puede ser reflejo de la aparición de nuevas técnicas pesqueras.

Es llamativa la total ausencia de Conger conger, especie que aparecía con cierta asiduidad en los yacimientos castreños, principalmente en los de la Fase II. Su presencia, no obstante, sí está documentada en otros yacimientos romanos del Cantábrico como Iruña-Veleia (Morales Muñiz y Roselló Izquierdo, 2008).

La importante presencia de Sparus aurata, Pagrus pagrus y Scomber japonicus sugiere unas condiciones marinas muy similares a las registradas en el mundo prerromano. Al igual que también parecen indicarlo algunas especies de moluscos como Stramonita haemastoma, presente en diversos yacimientos como Punta Atalaia (González Gómez de Agüero, 2009) o Punta do Castro (Ramil Rego et alii, 1995). Además, en el yacimiento de la Plaza del Marqués (Gijón) se ha recuperado un premaxilar de Dentex gibousus, actualmente inexistente en el cantábrico y propia de aguas más cálidas (Morales et alii, 1992; 1994). Todo esto apunta que la temperatura del agua sería mayor que en la actualidad.

\section{VI.2.2. LA ACTIVIDAD PESQUERA.}

Con la incorporación del noroeste peninsular al sistema administrativo y económico romano, se va a producir un cambio sustancial en los modelos de ocupación del territorio, del mismo modo que se detectan cambios significativos en los modelos económicos (Arias 
Vilas, 1992; González García y Brañas Abad, 1995; Rodríguez Colmenero, 1979). Este proceso lleva asociada la diversificación de los asentamientos. Hasta la fecha únicamente contamos con restos de peces procedentes de dos tipos de yacimientos, presentando características muy diferentes. Por un lado contamos con estudios ictiarqueológicos de dos instalaciones salazoneras, mientras que por otro disponemos de información relacionada con diversos asentamientos habitacionales tanto de tradición indígena como propiamente romanos. Debido a las sustanciales diferencias que presentan estos dos tipos de asentamientos, hemos decidido analizarlos en apartados independientes.

\section{Instalaciones industriales.}

Las instalaciones industriales de época romana, destinadas al tratamiento de pescado, abundan a lo largo de la costa gallega. La mayor concentración se localiza en las Rías Bajas, y aunque esto puede ser debido a la existencia de un número mayor de estudios en esta zona (Fernández Ochoa y Martínez Maganto, 1994; Currás, 2007), hay que tener en cuenta las condiciones favorables que presentan las rías para el aprovisionamiento y desarrollo de este tipo de industrias, así como la posible existencia de industrias de salazones prerromanas (caso de A Lazada) y una tradición de contactos con los pueblos mediterráneos en periodos anteriores.

Según parece, el periodo de máximo apogeo de estos centros se produce durante el periodo Altoimperial, asociados en la mayoría de los casos a asentamientos castreños, con pequeños núcleos de producción, y enfocadas al comercio local y regional (Fernández Ochoa y Martínez Maganto, 1994; Currás, 2007). Desde el siglo III d.C. se producirá una caída de la producción, manteniéndose en las villas marítimas si bien enfocada al autoconsumo y al comercio con el entorno (Fernández Ochoa y Martínez Maganto, 1994; Currás, 2007).

\begin{tabular}{|c|c|c|c|c|c|}
\hline Yacimiento & Localización & Provincia & Cronología & Descripción & Bibliografía \\
\hline O Cocho & $\begin{array}{c}\text { Punta } \\
\text { Borralleiro }\end{array}$ & Pontevedra & III-IV d.C. & $\begin{array}{c}\text { Muros que unen en ángulo recto y } \\
\text { que delimitan un espacio interior. Al } \\
\text { oeste otros muros conforman } \\
\text { diferentes habitáculos. El piso y los } \\
\text { laterales revestidos de opus } \\
\text { signinum. }\end{array}$ & $\begin{array}{c}\text { Hidalgo y } \\
\text { Rodríguez, } \\
1995\end{array}$ \\
\hline O Fiunchal & Alcabre & Pontevedra & III-V d.C. & $\begin{array}{c}\text { Presencia de tres estanques de } \\
\text { planta rectangular. Únicamente se } \\
\text { excavó uno completamente, con } \\
\text { unas dimensiones de 1,6 x 2,7 m. }\end{array}$ & $\begin{array}{c}\text { Castro, } \\
1992 / 1993\end{array}$ \\
\hline $\begin{array}{c}\text { Marqués de } \\
\text { Valladares }\end{array}$ & Vigo & Pontevedra & I-IV d.C. & $\begin{array}{c}\text { Factoría de planta rectangular. En el } \\
\text { interior aparecen cinco pilas } \\
\text { recubiertas de opus signinum en } \\
\text { forma de L en trono a un patio } \\
\text { interior. }\end{array}$ & $\begin{array}{c}\text { Torres, Castro } \\
\text { y Prieto, } 2007\end{array}$ \\
\hline Igresiña & Nerga & Pontevedra & I-IV d.C. & $\begin{array}{c}\text { Presencia de un tanque de salazón y } \\
\text { una dependencia anexa. El tanque }\end{array}$ & Currás, 2007 \\
\hline
\end{tabular}




\begin{tabular}{|c|c|c|c|c|c|}
\hline & & & & $\begin{array}{l}\text { tiene unas dimensiones de } 2,9 \times 2,4 \\
\text { m y una altura de } 1,15 \mathrm{~m} .\end{array}$ & \\
\hline A Pescadoira & Bueu & Pontevedra & I-III d.C. & $\begin{array}{l}\text { Conjunto industrial formado por una } \\
\text { factoría de salazón, un horno de } \\
\text { ánforas y un taller de cerámica } \\
\text { común. Factoría formada por una } \\
\text { batería en L de seis pilas en torno a } \\
\text { un patio interno. Tienen un tamaño } \\
\text { de } 3,25 \text { × 2,75 m. El interior está } \\
\text { recubierto de opus signinum. }\end{array}$ & Currás, 2007 \\
\hline Adro Vello & O Grove & Pontevedra & I-III d.C. & $\begin{array}{l}\text { Presencia de una pileta con revoco y } \\
\text { restos de peces. Presenta unas } \\
\text { dimensiones de } 1,5 \times 1,5 \times 1,5 \mathrm{~m} \text {. Al } \\
\text { oeste de esta estructura aparecen } \\
\text { otras dos pilas de un tamaño similar. }\end{array}$ & $\begin{array}{l}\text { Carro, 1987; } \\
1991\end{array}$ \\
\hline $\begin{array}{l}\text { Vilagarcía de } \\
\text { Arousa }\end{array}$ & $\begin{array}{c}\text { Vilagarcía de } \\
\text { Arousa }\end{array}$ & Pontevedra & & $\begin{array}{l}\text { Presencia de varias piletas en la } \\
\text { construcción del puerto. }\end{array}$ & Bouza, 1957 \\
\hline Cariño & Cariño & A Coruña & & $\begin{array}{l}\text { Presencia de siete cetáreas cubiertos } \\
\text { por una techumbre. }\end{array}$ & Naveiro, 1991 \\
\hline Espasante & Espasante & A Coruña & & $\begin{array}{l}\text { Diez piletas revestidas de opus } \\
\text { signinum. }\end{array}$ & $\begin{array}{l}\text { Maciñeira, } \\
1947\end{array}$ \\
\hline Bares & Bares & A Coruña & & $\begin{array}{l}\text { Presencia de varias piletas con } \\
\text { ángulos interiores redondeados y } \\
\text { revocado de opus signinum. }\end{array}$ & $\begin{array}{l}\text { Maciñeira, } \\
\text { 1947; Ramil } \\
\text { González, } \\
2003\end{array}$ \\
\hline Area & Viveiro & Lugo & & $\begin{array}{c}\text { Presencia de piletas } \\
\text { impermeabilizadas con opus } \\
\text { signinum y cuarto de bocel en las } \\
\text { juntas. }\end{array}$ & $\begin{array}{c}\text { Vázquez Seijas, } \\
\text { 1952; Ramil, } \\
2008\end{array}$ \\
\hline
\end{tabular}

Tabla 213 Instalaciones salazoneras de época romana documentadas en Galicia.

Pese al importante número de factorías romanas localizadas en Galicia, no es frecuente encontrar restos de fauna marina en estos yacimientos (Fernández Ochoa y Martínez Maganto, 1994), lo que podría deberse al aprovechamiento integral de los individuos (carne salada; sangre y vísceras para salsas; espinas para harina de pescado) (Fernández Ochoa y Martínez Maganto, 1994; Martínez Maganto, 1992a). Sin embargo, en varias instalaciones salazoneras, tanto gallegas (Ferré, 2003; Currás, 2007) como del círculo del estrecho (Roselló Izquierdo, 1989; Morales Muñiz y Roselló Izquierdo, 1990; Roselló Izquierdo, 1992; García Vargas y Bernal Casasola, 2009), se ha recuperado un volumen importante de restos de pescado. En la mayoría de los casos la aplicación de una metodología de recuperación poco adecuada ocasiona la pérdida de este material. Ejemplo de este posible problema metodológico sería el yacimiento de Igresiña, ya que los restos ícticos se documentaron en el sedimento presente en el interior de un hueso de macromamífero, y no durante el proceso de excavación (Fernández Rodríguez, 2000; Ferré, 2003).

De todas las instalaciones industriales documentadas en Galicia, únicamente tenemos un registro ictiológico amplio y representativo en Adro Vello (Ferré, 2003). Otros yacimientos con referencias serían Igresiña, con tres restos de Sardina pilchardus 
(Fernández Rodríguez, 2000; Ferré, 2003), así como una cita de la presencia de restos de peces en conexión anatómica en las instalaciones de Marqués de Valladares (Torres et alii, 2007; Currás, 2007). De las excavaciones realizadas en 2008 en la factoría de Area (Viveiro), contamos con un amplio registro ictioarqueológico para el periodo medieval, sin embargo, para época romana únicamente se ha indentificado un preopercular derecho de Zeus faber, sin que haya constancia de la presencia de restos de peces en la pileta excavada. En la Villa Romana de Bares también se recuperaron algunos restos de Mugilidae sp. (Fernández Rodríguez, 2003).

La ausencia de información faunística, así como la desconexión entre los restos ictiológicos y las estructuras productivas, nos impide realizar una interpretación de los diferentes salsamenta realizados en la Gallaecia romana, así como de sus implicaciones económicas, tecnológicas o sociales. Según se desprende de los textos antiguos, la salsa de mayor calidad está realizada con caballas (Maganto, 1992a). La presencia de Scomber sp. en los conjuntos estudiados no es muy numerosa, aunque tampoco sería un motivo para descartar la producción de salsas de calidad, como afirman algunos autores (Currás, 2007). Hay que tener en cuenta que la mayor parte de la información ictioarqueológica disponible procede de asentamientos castreños, donde si hay constancia de la pesca de esta especie, y no de factorías salazoneras.

\begin{tabular}{c|cc} 
& Av & I \\
\cline { 2 - 3 } Sardina pilchardus & 2004 & 3 \\
Trachurus trachurus & 9 & \\
\hline Total & $\mathbf{2 0 1 3}$ & $\mathbf{3}$
\end{tabular}

Tabla 214 NR de los diferentes taxones identificados en yacimientos de época romana (Av=Adro Vello; I=A Igresiña).

El conjunto de Adro Vello refleja la utilización de ejemplares completos de Sardina pilchardus, así como de cuerpos de Trachurus trachurus, aunque en mucha menor medida, pudiendo deberse a la utilización de individuos troceados. Conforme a las referencias que tenemos de Marqués de Valladares (Torres et alii, 2007; Currás, 2007), también se estarían utilizando animales prácticamente completos. Esta "receta" puede asociarse mejor con las salsas denominadas allex y liquamen, de menor calidad que el garum, que eran consumidas principalmente por las clases bajas. Para su elaboración se utilizaban los residuos de otras salsas, así como peces enteros de pequeño tamaño, pudiendo utilizarse una gran diversidad de especies (Martínez Maganto, 1992a).

En el sur peninsular se detecta desde finales del siglo II d.C. y principios del III, la incorporación principalmente de sardinas y boquerones, debido al menor coste de su captura y procesado, y como respuesta a una popularización de estos productos entre la población urbana y los establecimientos militares desde época de Augusto (García Vargas, 2006), así como a una sobreexplotación de los bancos de escómbridos y una descapitalización de estas industrias (García Vargas y Bernal Casasola, 2009). Un ejemplo de la utilización de Sardina pilchardus para la elaboración de salsas estaría reflejado por el 
ontenido de un ánfora tardo-romana localizada en el Foro de Tarraco (Morales Muñiz y Roselló Izquierdo, 1989). Quizás Adro Vello, y puede que Igresiña, respondan a este mismo proceso, y estemos ante la evidencia de producciones para el consumo regional aunque, como ya comentamos, la ausencia de más datos nos impide evaluar correctamente las producciones de las factorías galaicas.

Las industrias de salazón con una cronología comprendida entre el siglo I d.C. y el III suelen estar asentadas en las cercanías de algún asentamiento tipo castro (Fernández Ochoa y Martínez Maganto, 1994; Torres et alii, 2007; Currás, 2007). Esto ha sido vinculado por algunos autores al trabajo de la población indígena en estas instalaciones, como sucedería en el caso de Vigo (Torres et alii, 2007). El surgimiento de estas factorías, y su abastecimiento por parte de la población local, supone un cambio sustancial respecto al periodo anterior. Se introduce el factor comercial que va a ser el que regule totalmente la producción, pasando a un segundo plano las condiciones del medio, ya que se va a buscar la explotación de unas especies muy concretas, y además en grandes cantidades.

\section{Yacimientos habitacionales.}

El número de restos identificados taxonómicamente no es muy elevado en estos yacimientos, en el caso del conchero de Punta Atalaia la proporción es de dos restos por cada kilo de sedimento procesado. Sin embargo, en este mismo yacimiento se ha recuperado un número muy elevado de fragmentos de costillas, escamas, radios y piezas del cráneo, contrastando claramente con lo observado en los depósitos prerromanos, donde este tipo de evidencias no resultan muy numerosas.

Que la densidad de restos identificados sea similar a los yacimientos prerromanos, creemos que no responde a las mismas causas. Con la incorporación a la administración romana parece que se produce una intensificación de la explotación del medio marino reflejada, por ejemplo en la aparición de industrias salazoneras. Es probable que este incremento de la actividad pesquera se esté produciendo también en los asentamientos de tradición indígena, lo que podría explicar el elevado número de fragmentos cefálicos y post-cefálicos indeterminados que se han recuperado, lo que a su vez contrasta con los pocos centros vertebrales o cefálicos identificados.

Según parece, en época romana es habitual la utilización de las espinas para la elaboración de harinas de pescado (Fernández Ochoa y Martínez Maganto, 1994; Bernal, 2007; Currás, 2007; Torres et alii, 2007), como por ejemplo sucede en el Conjunto industrial I de la c/ San Nicolás 3-5 en Algeciras (Bernal, 2007). Tenemos constancia de que durante las excavaciones de Punta Atalaia se recuperaron un número importante de molinos, por lo que puede ser que parte de vértebras y cráneos fueran utilizados con este fin, lo que explicaría el desequilibrio entre restos. De todos modos esto no deja de ser una hipótesis que la ausencia de análisis en las zonas de uso de estas piezas impide confirmar, siendo un aspecto interesante evaluar en futuras excavaciones y análisis. 
Los espáridos siendo la familia representada por un mayor número de especies, si bien van a perder relevancia respecto al periodo prerromano, principalmente Pagellus bogaraveo. Por el contrario, se va producir un aumento de especies pelágicas, como Sardina pilchardus y Trachurus trachurus. Pese a la importancia de estas últimas, las demersales van a acaparar la mayor parte de las capturas. La estacionalidad sigue siendo un factor muy importante, acentuándose con la mayor relevancia de especies migradoras.

Esta posibilidad aparece reflejada en textos de la época; así Opiano señala que en primavera se pescaría el día entero ante la abundancia de peces en la costa (Rodríguez Pantoja, 2006). Sin embargo el resto del año es probable que la actividad pesquera se siguiera realizando, aunque en menor medida, como también recoge Opiano (Rodríguez Pantoja, 2006), con capturas de especies como Pollachius pollachius que suele ser más frecuente en los meses más fríos (Morales et alii, 1992; 1994), o Labrus bergylta que es sedentaria.

Sardina pilchardus

Salmo salar

Conger conger

Merluccius merluccius

Gadidae sp.

Pollachius pollachius

Trisopterus luscus

Dicetrarchus labrax

Polyprion americanus

Trachurus trachurus

Diplodus sp.

Diplodus sargus

Diplodus vulgaris

Dentex dentex

Pagellus sp.

Pagellus acarne

Pagellus bogaraveo

Pagrus pagrus

Sparus aurata

Labrus bergylta

Symphodus melops

Scomber sp.

Scomber japonicus

Scomber scombrus

Zeus faber

Mugilidae sp.

TOTAL

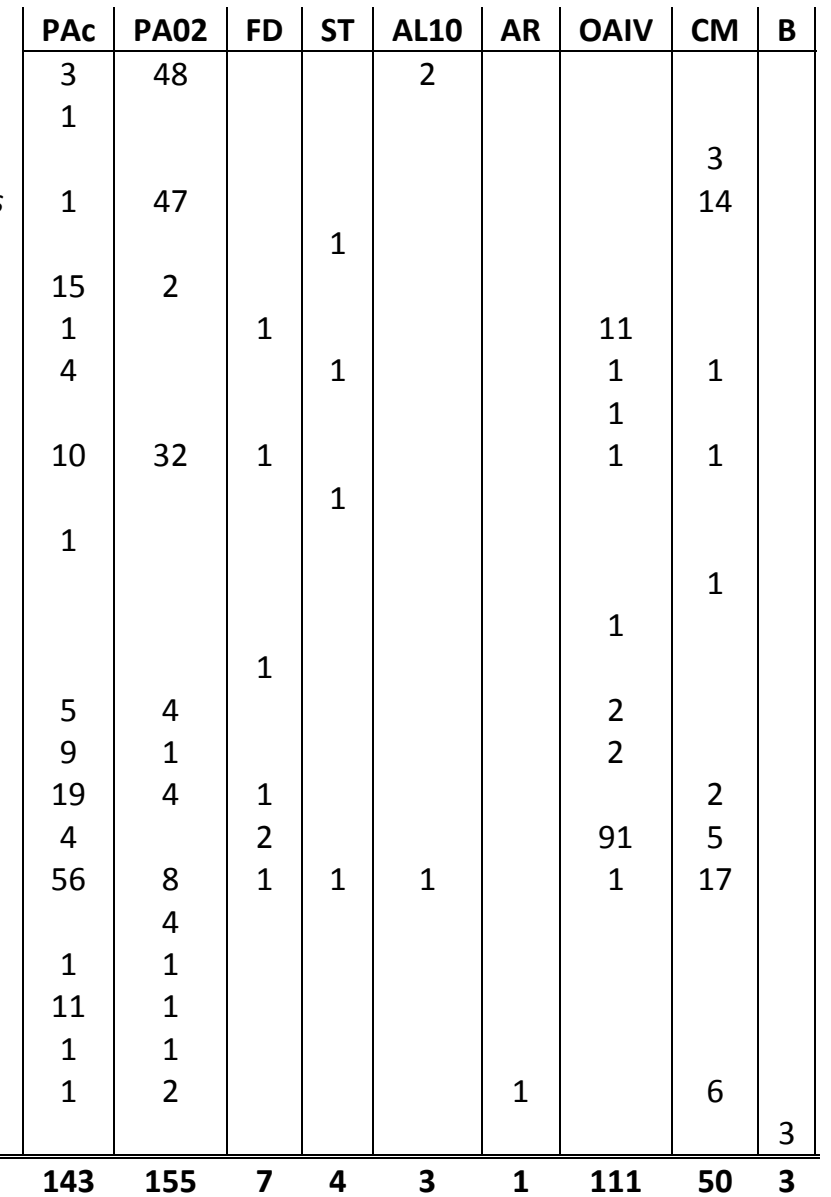

Tabla 215 NR de los diferentes taxones identificados en yacimientos de época romana (PAc=Punta Atalaia conchero; PA02=Punta Atalaia Sector 02; Fd= Facho de Donón; St=Santa Trega; Al=A Lanzada; AR=Area;

OalV=Nivel IV O Achadizo; CM=Casa Martelo; B=Villa de Bares). 


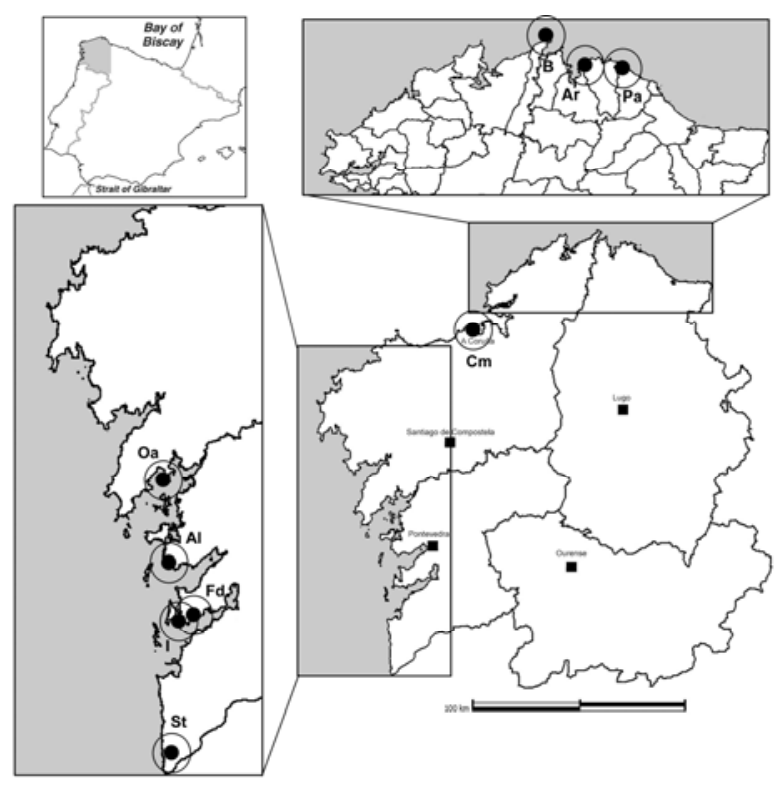

Fig. 308 Localización de los yacimientos con muestras de época romana.

Pese a la escasez de datos disponibles, y a la presencia de registros parciales como los de Facho de Donón o Santa Trega, parece que existe una especialización en la captura de una especie principal, con valores cercanos al $50 \%$ del volumen total de las identificaciones, o incluso superando este porcentaje, como en la Fase IV de O Achadizo.

Este esquema no se detecta solamente en castros, sino que también se reconoce en otros asentamiento de nueva creación, tal y como se puede observar en Casa Martelo (Brigantium). Este modelo de una única especie principal representada por un alto porcentaje de los restos identificados, también se refleja en la explotación de moluscos en yacimientos como Punta Atalaia, Punta dos Prados o Santa Trega (Vázquez Varela y Rodríguez López, 1995; 1995/96; Fernández Rodríguez y Rodríguez López, 1996; González Gómez de Agüero, 2009; Fernández Rodríguez et alii, e.p.). En el caso de los moluscos planteábamos la posibilidad de su vinculación con una actividad de comercio hacia zonas de interior, ya que se observaba un descenso de determinadas especies en las costas, como Ostrea edulis o Ruditapes decussatus, que van a registrarse en yacimientos como Lugo, Astorga o León (Vázquez Varela, 1996; Fernández Rodríguez y Fuertes Prieto, 2003; Fuertes Prieto y Fernández Rodríguez, 2010; Bejega García et alii, e.p.).

Para la ictiofauna, en el noroeste carecemos de información de zonas alejadas de la costa que nos puedan indicar algo similar a lo observado en la malacofauna. Sin embargo, no se puede descartar la posibilidad de que determinadas especies se estén comercializando con otros puntos, como comentábamos anteriormente, considerando que el pescado es un producto de consumo muy importante en la sociedad romana, principalmente en el mundo urbano. Su llegada a estos centros de consumo pudo ser tanto en fresco como en conserva. Tenemos constancia del comercio de pescado fresco en diferentes puntos del imperio (Rodrígez Pantoja, 2006; Blázquez Martínez, 2006), por lo que no sería tan extraño que en el noroeste peninsular también existieran redes comerciales de estos productos. En Iruña-Veleia (Morales Muñiz y Roselló Izquierdo, 2008) se ha recuperado un número importante de restos de ictiofauna, siendo las especies mejor representadas Scomber japonicus y Pagellus erythrinus.

Otra cuestión que se nos plantea es la relación que van a tener estos asentamientos con las factorías de salazón. Como ya comentamos, hay autores que hablan 
de la posibilidad que los habitantes de los castros sean los que trabajen en las instalaciones fabriles, ya que durante época altoimperial estas instalaciones aparecen asociadas a asentamientos de tipo indígena (Fernández Ochoa y Martínez Maganto, 1994; Torres et alii, 2007; Currás, 2007). Es interesante la relación que pudiera existir entre centros productivos y castros ya que, además de mano de obra, estos podrían realizar parte de las actividades pesqueras necesarias para abastecer a estas industrias conserveras de la materia prima para su funcionamiento. Esto explicaría también el predominio de una única especie, así como el descenso en el número de restos de especies importantes durante el periodo anterior como Pagellus sp., así como de las diferentes especies pelágicas.

Diversas pilas estudiadas tanto en el Mediterráneo como en el Atlántico, señalan a estas especies pelágicas como base para las salazones (García Vargas, 2006); de hecho, en la factoría localizada en el istmo de Ceuta, la fauna documentada es muy similar a la de los castros galaicos, con Pagrus pagrus, Zeus faber o Scomber japonicus entre otros (Roselló, 1992). Por lo tanto, además de una actividad pesquera enfocada al autoconsumo, es probable que exista otra con fines comerciales, tanto hacia las factorías como para abastecer los mercados interiores.

En los castros, el único caso en que parece documentarse el tratamiento de una especie para su conserva es Sparus aurata en O Achadizo. Los restos recuperados son exclusivamente cefálicos, siendo esta una práctica que se constata desde el siglo $V$ a.C. en este yacimiento. También en el conchero de Punta Atalaia, se documentaron únicamente restos del esqueleto caudal de Trachurus trachurus; mientras en la excavación del Sondeo 02, eran mayoritarias las piezas óseas cefálicos y los centros vertebrales precaudales de la misma especie.

El desarrollo de una gran demanda de pescado, así como de sus productos derivados, implica un importante volumen de capturas, muy superior a lo detectado en fases anteriores cuando todo parece indicar que es una actividad enfocada al autoconsumo.

A partir de los datos ictioarqueológicos obtenidos en el noroeste, así como de la información de las fuentes escritas y de los registros en otras áreas peninsulares, podemos hablar de la aparición de una nueva tecnología pesquera, tanto con red como con anzuelo, que explicaría la presencia de especies no documentadas anteriormente como Zeus faber o Polyprion americanus. En este sentido, estas nuevas artes y aparejos podrían explicar el aumento de las capturas de Merluccius merluccius. Posiblemente se esté reflejando el desarrollo de una pesca de fondo y más alejada de la costa que en periodos anteriores; de hecho, las fuentes clásicas hablan de pesca tanto litoral como de altura (Rodríguez Pantoja, 2006). Técnicas como el palangre o la línea de anzuelos, tanto de fondo como de superficie, serían utilizadas para conseguir una alta productividad, ya que dan buenos rendimientos en aquellos lugares donde no es posible utilizar redes y con especies que no se capturan con cerco (Martínez Maganto, 1992b; Rodríguez Pantoja, 2006). Actualmente 
estos aparejos se emplean en la pesca de, entre otras, Pagellus bogaraveo, Pagellus acarne, Zeus faber o Polyprion americanus.

Como veíamos, parece que la utilización de redes en el noroeste se puede intuir desde el siglo II a.C. Sin embargo, en época romana es probable que se incorporen nuevas artes que permitan un mayor volumen de capturas con menores costes tanto físicos como económicos, y de este modo abastecer a la industria salazonera y a los mercados interiores (Martínez Maganto, 1992b; Rodríguez Pantoja, 2006; García Vargas y Bernal Casasola, 2009). Estas artes estarían destinadas principalmente a la captura de especies pelágicas como Sardina pilchardus, Trachurus trachurus o Scomber sp.

\section{VI.3. LA PESCA EN El Mundo Medieval y Moderno.}

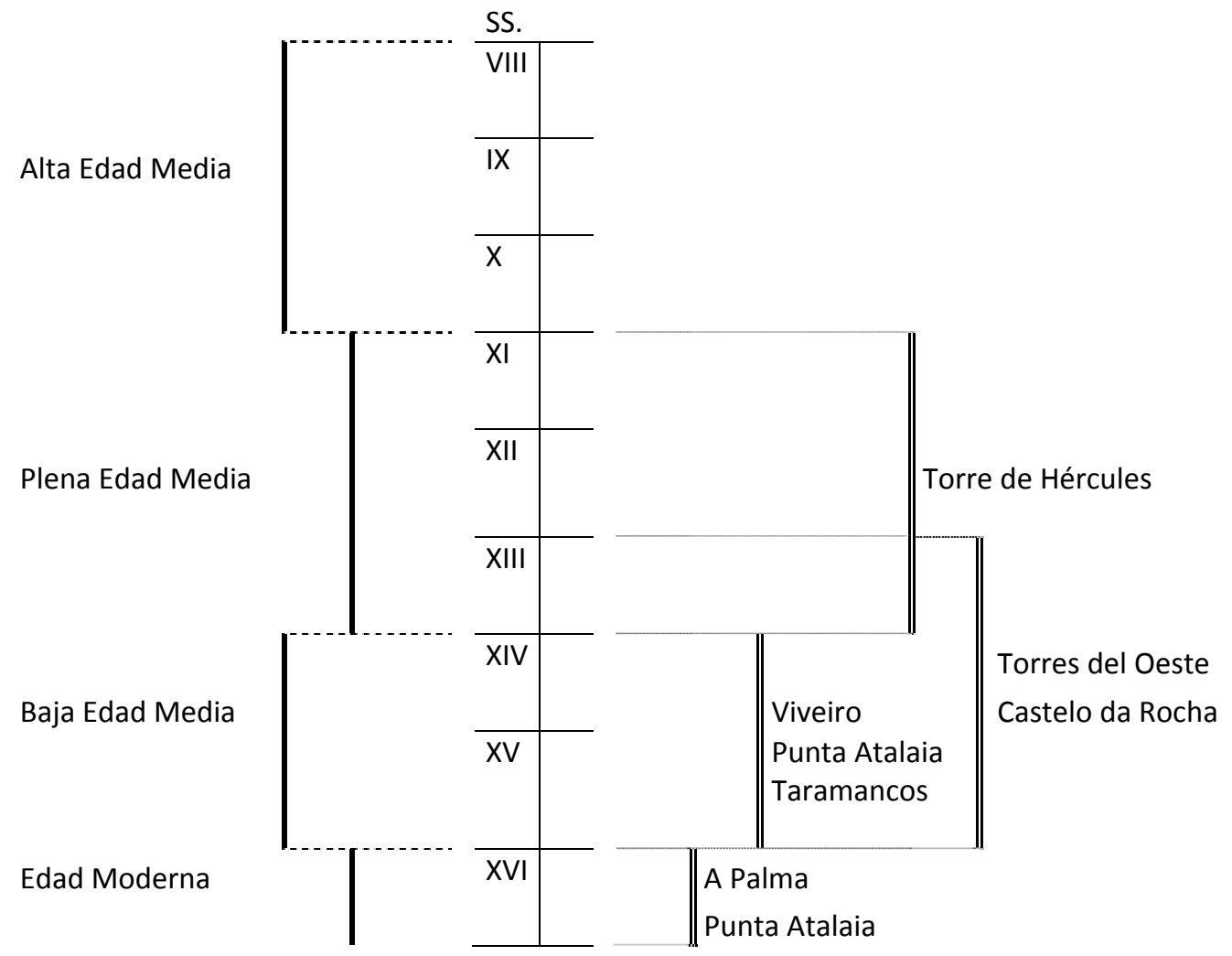

Son diversos los yacimientos medievales que han aportado información, abarcando un amplio abanico cronológico que va desde la Plena Edad Media hasta el comienzo de la Edad Moderna. Sin embargo, el número de yacimientos representativos de cada fase va a ser muy reducido, a lo que debemos sumar los mismos problemas cronológicos detectados también para los periodos precedentes.

Tanto por el número de restos recuperados como la representación taxonómica, parece que tanto la Torre de Hércules como las Torres do Oeste conservan un registro bastante completo. Por otro lado, los conjuntos procedentes de los sondeos de Area y de la excavación del solar 02 de Punta Atalaia, a pesar de su difusa cronología, se componen casi de forma exclusiva de restos de gran tamaño pertenecientes a una especie. El caso 
más significativo de selección de materiales por su tamaño es el Castello da Rocha Forte. Por el contrario, el yacimiento que presenta una mejor representación es el de Taramancos, ya que la acumulación de conchas formando depósitos más o menos homogéneos, permitió la realización de muestreos exhaustivos.

La mayoría de los yacimientos se sitúan en la costa cantábrica, aunque también contamos con tres en la costa Atlántica, dos de interior de ría y otro de mar abierto. Asimismo se dispone de información de un sitio de interior.

\section{VI.3.1.LAS ESPECIES.}

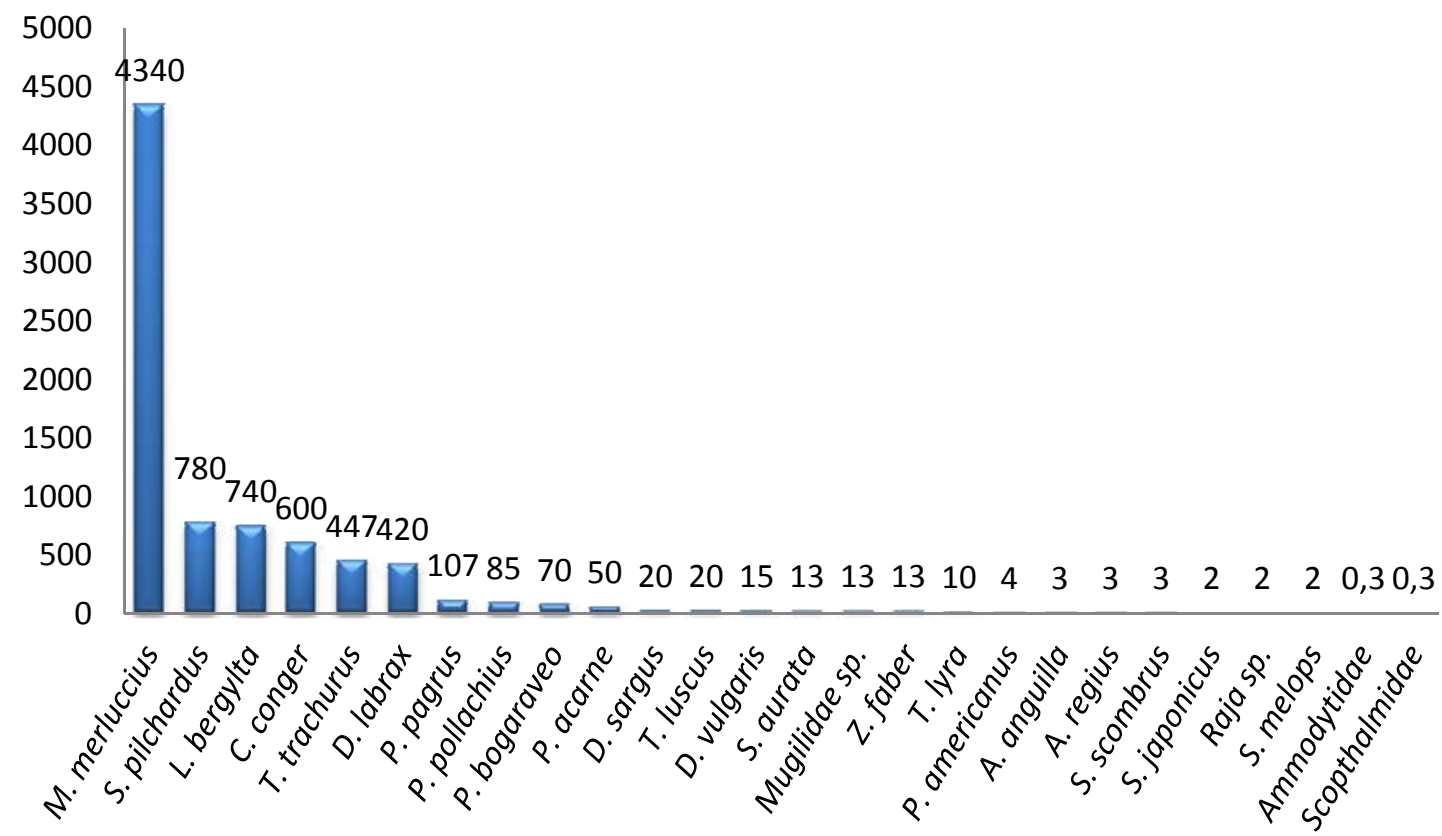

Fig. 309 Importancia de las especies a partir del cálculo del ICxID de los yacimientos medievales.

En los yacimientos medievales se han podido identificar veintiséis especies, con algunos taxones que van a tener ahora su primera presencia en el registro del noroeste. Entre estos, cabe destacar diversos restos de Raia sp., que serán los primeros restos de peces cartilaginosos documentados en Galicia, y que solo se han identificado en el yacimiento de Area.

En este mismo contexto se puede explicar el predominio de los restos de Merluccius merluccius frente a las demás especies. Este taxón va a estar presente en todos los yacimientos del periodo, siendo además en la mayoría de ellos la especie más abundante, principalmente desde el siglo XIII d.C. Es una especie demersal-batipelágica que habita en la plataforma continental entre los 30 y los $500 \mathrm{~m}$ de profundidad. Suele aparecer en los yacimientos prerromanos, si bien siempre con un número muy pequeño de restos, lo que sugiere una pesca no sistemática. Sin embargo, en la Edad Media, la aparición de nuevos tipos de embarcación y de nuevas artes de pesca, permitió aumentar sus capturas. Pese a los pocos datos que tenemos para época romana, parece que en este 
periodo en la costa cantábrica se va a producir un aumento de las capturas de esta especie, si bien sin alcanzar la importancia que tendrá en época medieval.

Según Ferreira (1988), la pesca de Merluccius merluccius se realizaría en el interior de las rías, lo que también parecen atestiguar los restos documentados en yacimientos castreños como O Achadizo, O Neixón o Montealegre, los dos últimos localizados cerca del fondo de la ría. Sin embargo, en la actualidad esta especie no se interna en aguas salobres, ni por encima de los $30 \mathrm{~m}$ (Morales Muñiz et alii, 2009). Por lo tanto, nuestros datos vienen a incidir en lo señalado por algunos autores, que indican un cambio en el rango batimétrico y vital de esta especie fruto de su sobreexplotación (Morales Muñiz et alii, 2009).

La presencia de taxones como Trigla lyra, Polyprion americanus y Argyrosamus regius, que no han documentado en periodos anteriores, estaría vinculada a estas nuevas técnicas que van a permitir explotar medios a los que antes no era posible acceder. Estas especies se caracterizan por ser solitarias, bentónicas y encontrarse a profundidades por encima de los 30-40 m. Por lo tanto, es posible que la aparición de artes de fondo y de arrastre haya provocado una paulatina sobreexplotación, tanto por la sobrepesca, como por las alteraciones del fondo marino. A este respecto, son significativas las referencias documentales a la oposición en Galicia a prácticas como el espinel (Ferreira Priegue, 1988: 142) o la jabrega (Cornide, 1774), que ocasionarían daños en el fondo y en la fauna marina. Según algunos autores, estas alteraciones de los fondos influirían en el desarrollo de algunas especies (Lozano Cabo, 1983: 331).

Conger conger, al igual que Merluccius merluccius, va a incrementar considerablemente su importancia frente a lo documentado en contextos romanos y castreños. Hecho vinculado tanto con la aparición de nuevos conocimientos técnicos como con su importancia como especie comercial. Su pesca se va a realizar principalmente para su conserva mediante el secado con fines comerciales, capturándose tanto cerca de la costa como a mayor distancia de la misma (Cornide, 1788).

Sardina Pilchardus completa la triada piscícola medieval, si bien su presencia no va a ser muy numerosa en los yacimientos de este periodo, aun cuando sea uno de los referentes según la documentación. Esta aparente contradicción con el registro arqueológico podemos relacionarla con varios aspectos: en primer lugar, el problema metodológico de recuperación de los restos de menor tamaño, que ya hemos comentado reiteradamente. Otra de las causas es el tratamiento que recibe esta especie, ya que hasta el siglo XVIII es habitual el seccionado de la cabeza y de las vísceras, de las que se extrae el saín, y la conservación del resto su en sal o ahumado, por lo que existiría un aprovechamiento integral de los individuos (Cornide, 1774; 1788; Ferreira Priegue, 1998; 2009). A partir del siglo XVIII fue más habitual la utilización del método catalán, preparando en conserva la sardina entera (Cornide, 1774; 1788; Ferreira Priegue, 1998; 2009). 
Su captura se produciría principalmente en el interior de las rías, muy vinculada a la estacionalidad, ya que es a finales del invierno cuando se acercan a la costa, momento en el que se captura para su salado, mientras que la sardina de diciembre y enero se reservaría para el ahumado debido a su menor contenido en grasa (Cornide, 1774; Ferreira Priegue, 1988). Para su pesca se utilizaban artes de deriva como el jeito, aunque desde el siglo XV se imponen artes de arrastre, como la sacada o el cerco (Ferreira Priegue, 1998; 2009).

Trachurus trachurus es otra especie pelágica que va a mantener su importancia desde época romana, incluso llegando a alcanzar en alguno de los yacimientos estudiados una mayor presencia que Sardina pilchardus. El número de restos identificado es bastante numeroso, si bien se restringe a los yacimientos medievales, no apareciendo en los de Edad Moderna. No obstante, el número de yacimientos de este periodo estudiados es muy reducido, por lo que la valoración de esta información es muy compleja; aun así, podría estarse reflejando la poca estimación bromatológica de la que se hace eco Cornide (1788) en el siglo XVIII. Ya sea para un consumo local o para su comercialización, la pesca de esta especie durante la Edad Media tiene una importancia muy superior a la de otras destinadas al consumo local y de mercados cercanos.

Labrus bergylta también parece que va a mantener cierta importancia. Ya vimos en época romana que esta especie presentaba más restos en los asentamientos castreños situados en las zonas de mar abierto. Durante la Edad Media va a ser la especie más importante en la mayoría de los yacimientos costeros tras las especies mercantes; incluso en las Torres do Oeste, situado en un medio poco favorable para esta especie, es el taxón mejor representado después de Merluccius merluccius. Sin embargo, en la documentación esta especie no aparece entre las más apreciadas gastronómicamente, por lo que es posible que sea fruto de consumo por parte de las poblaciones marineras y clases populares.

La menor representación de otras especies con mayor interés gastronómico, como Pagellus sp. o Pagrus pagrus, puede que refleje una actividad de comercio con el interior. Además, estas especies se caracterizan por unos hábitos migratorios que las aproximan a las costas tan solo en determinados momentos del año, mientras que Labrus bergylta es una especie sedentaria que se encuentra presente durante todo el año en el litoral.

Es llamativo el descenso en número de restos que va a experimentar Pagellus bogaraveo respecto a lo documentado en el mundo prerromano. Desde el cambio de Era hasta la Edad Moderna, esta especie presenta un importante descenso tanto en el número de restos como en representatividad dentro de los yacimientos. Sin embargo, según las fuentes, es una especie muy apreciada gastronómicamente, siendo muy explotada en la costa cantábrica (García Fajardo y Fernández Pérez, 1993: 65; Bielza, 1996). Aunque no se pueden obviar aspectos medioambientales, ejemplos como el de Taramancos nos lleva a considerar que el descenso de este taxón en los yacimientos litorales puede estar 
vinculado a su comercialización. Desde época romana se van a establecer rutas comerciales con territorios interiores, siendo esta una especie de gran aprecio bromatológico, como ya indicamos. De hecho, en la regulación comercial de Santiago de Compostela del siglo XII aparece citada junto a otras con gran importancia como la merluza, el pulpo o las ostras (Suárez, 1950: 467-470). En los Fueros de Noia del siglo XV también se establece diezmo para la pesca de besugo en enero (López Ferreiro, 1875: 117), incluso existen topónimos costeros como "Besugueira", como en el entorno de San Cibrao (Carrillo Boutureira, 1999), que en principio sugieren la presencia de ejemplares de esta especie. Del mismo modo, en el libro de cuentas del Real Monasterio de Santa María de El Paular en Madrid, se documenta a finales del siglo XVI d.C. importantes compras de ejemplares de esta especie, principalmente en los meses de diciembre y enero (Bielza, 1996).

Para especies como Trisopterus luscus, que presentan una baja representatividad, sería necesario contar con más datos en zonas de interior de ría, ya que en el época castreña es donde más importancia alcanzaba frente a las zonas exteriores, donde era mayor el número de restos de Labrus bergylta. De hecho en Taramancos si se han recuperado bastantes restos de Trisopterus luscus.

En relación con los periodos anteriores, es significativo el aumento de la representatividad de Dicentrarchus labrax, posiblemente vinculado a la mejora en la tecnología pesquera. Además contrasta con la presencia en época castreña únicamente en yacimientos de interior de ría, mientras que en la Edad Media se localizan en yacimientos exteriores, aunque vinculados a rías como la de Viveiro o A Coruña. Algo similar se apreciaba ya en época romana, al estar presente en yacimientos situados en zonas exteriores, cerca de desembocaduras, como es el caso de Punta Atalaia o Santa Trega.

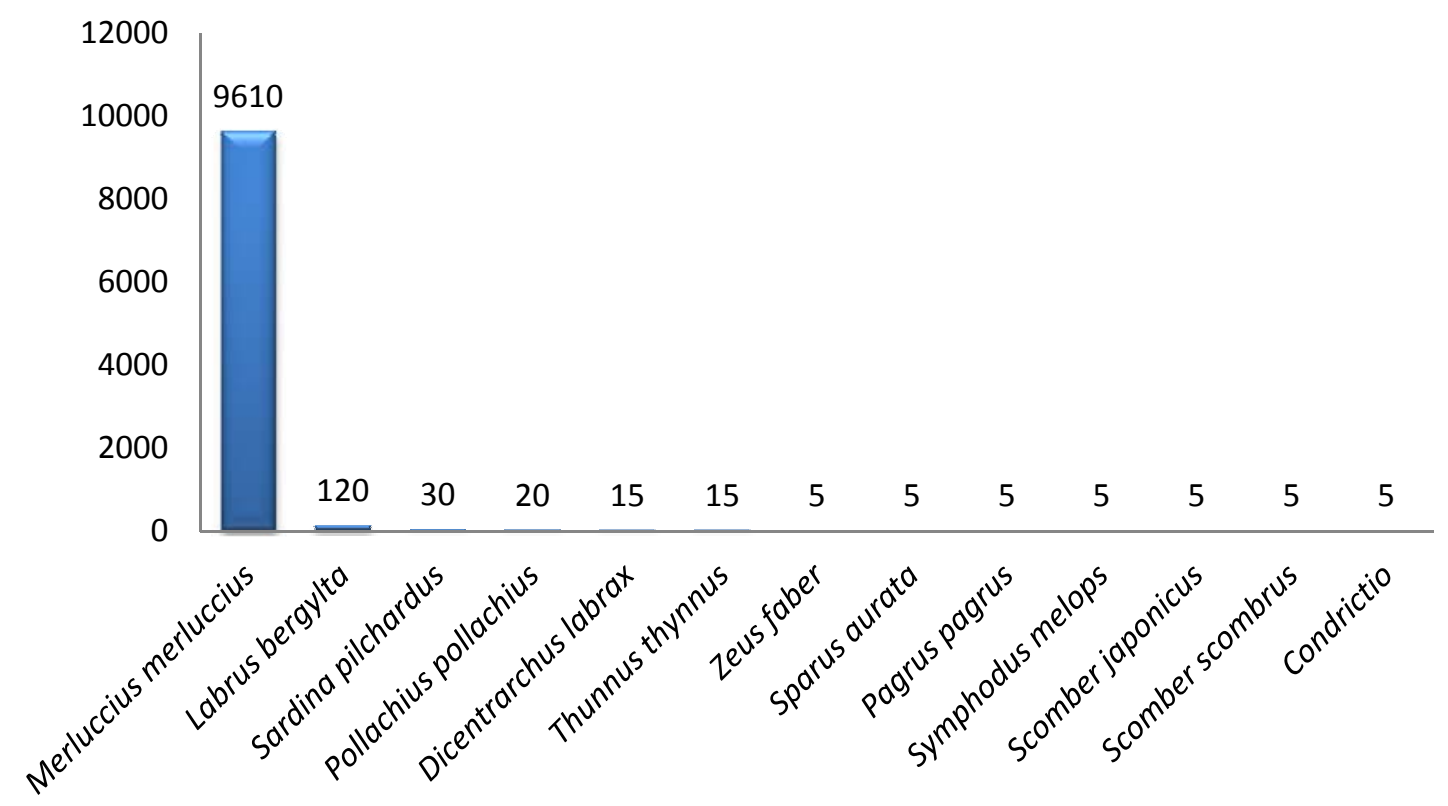

Fig. 310 Importancia de las especies a partir del cálculo del ICxID de los yacimientos modernos. 
En el registro de la Edad Moderna se percibe una distribución de las especies muy similar a la observada en la Edad Media, si bien es llamativa la ausencia de ciertos taxones como Conger conger o Trachurus trachurus, aunque las pocas muestras con las que contamos para este periodo hacen difícil realizar una valoración al respecto.

También es reseñable la presencia de Thunnus thynnus en el yacimiento de A Palma, única que tenemos en Galicia para esta especie hasta el momento, sin descartar la posibilidad de que sea fruto de transacciones comerciales (Ferré, 2003). No obstante, debemos recordar que un resto de una vértebra de Thunnus sp. se ha identificado en un nivel supuestamente romano de Area, aunque no se ha podido identificar la especie debido a su estado de fragmentación. La presencia de Condrictios indica una continuidad en las capturas de estos peces al menos desde el siglo XIV-XV.

Tanto en la Edad Media como en la Edad Moderna se observa una disminución en la importancia de Sparus aurata, Pagrus pagrus, y Scomber sp. respecto a los periodos anteriores. De hecho, Cornide (1788) señala la escasa presencia de Scomber japonicus en Galicia, especie que era habitual durante el periodo castreño y romano, con valores superiores a Scomber scombrus. En los yacimientos medievales y modernos ambas presentan unos porcentajes similares y muy bajos. La progresiva ausencia de estas especies resulta coincidente con lo que sucede con moluscos como Stramonita haemastoma, que desde el siglo $\mathrm{X}$ d.C. resulta muy escasa en las costas gallegas (Rodríguez López, 2002; Bejega García et alii, 2011), no siendo ya citada por Cornide (1788) en el siglo XVIII.

Desde finales del siglo XIV se produce un cambio en la temperatura, al iniciarse el periodo conocido como "la Pequeña Edad del Hielo", que se reflejaría en un descenso de $1^{\circ}-1,5^{\circ} \mathrm{C}$ en la temperatura del mar (Francés et alii, 2009). Quizás las modificaciones en la presencia de estas especies estén en relación con este cambio climático, que si bien parece responder a un proceso paulatino desde el final del Imperio Romano hasta el siglo XVIIXVIII (Martínez Cortizas y Vázquez Varela, 2002), puede coincidir en el siglo XIV cuando la variación paulatina en estas especies alcanza su punto de inflexión.

\section{VI.3.2.LA ACTIVIDAD PESQUERA.}

De la Alta Edad Media únicamente se dispone de un análisis muy parcial de los restos recuperados en el conchero de San Xiao de Trebo, en Cariño (A Coruña) (Rodríguez López, 2002). El depósito apareció asociado a una ermita, y únicamente hay constancia de la presencia de Labrus bergylta, así como de espáridos y escómbridos (Rodríguez López, 2002). Aunque no se han facilitado más datos que permitan concretar las características de la pesca en el yacimiento durante la Alta Edad Media, las especies y las familias referenciadas podrían encajar en el modelo expuesto por algunos autores para el momento que nos ocupa (Ferreira Priegue, 1998; 2009; Carrillo Bouteira, 1999). 
Sin embargo desde, la Plena Edad Media hasta el comienzo de la Edad Moderna contamos con una mayor variedad de yacimientos, asentados en diferentes puntos del litoral, si bien la mitad de ellos se localizan en la costa cantábrica.

\section{Plena Edad Media (ss. XI-XIII d.C.).}

Desde el siglo XI d.C. se van a ir desarrollando diversas poblaciones urbanas que van a incrementar la demanda de pescado para consumo. Además, durante la Edad Media la Iglesia va a imponer cerca de 140 días al año de abstinencia, estando prohibido el consumo de carne (Carrillo Bouteira, 1999). Estos dos factores serán algunos de los que estimulen la actividad pesquera en las zonas de costa, así como el comercio con el interior.

\begin{tabular}{l|c|} 
& TH \\
\cline { 2 - 2 } Anguilla anguilla & 11 \\
Conger conger & 295 \\
Merluccius merluccius & 417 \\
Pollachius pollachius & 79 \\
Gadidae sp. & 2 \\
Zeus faber & 21 \\
Dicentrarchus labrax & 325 \\
Polyprion americanus & 6 \\
Argyrosomus regius & 5 \\
Trachurus trachurus & 241 \\
Sparus aurata & 19 \\
Pagrus pagrus & 75 \\
Diplodus sargus & 25 \\
Diplodus vulgaris & 49 \\
Pagellus acarne & 14 \\
Pagellus bogaraveo & 2 \\
Labrus bergylta & 577 \\
Symphodus melops & 7 \\
Scomber japonicus & 8 \\
Scomber sp. & 2 \\
Mugilidae sp. & 21 \\
\hline \hline & $\mathbf{2}$ \\
\hline TOTAL & 2201
\end{tabular}

Tabla 216 NR de los diferentes taxones identificados en yacimientos del siglo XI-XIII d.C. (TH=Torre de Hércules).

Asignados a este marco cronológico únicamente se dispone de muestras de un yacimiento, si bien su análisis permite apreciar ciertas diferencias con momentos anteriores y posteriores. El conjunto está formado por restos asociados a las cocinas de la fortificación militar del Castro del Faro, en la actual Torre de Hércules (A Coruña) (Bello et alii, 2008). Según Ferré (Ferré y Rey, 1997; Ferré, 2003) la presencia de ciertas especies podrían responder al pago de tributos, como el portazgo, relacionados con la torre-faro. De todos modos, aunque así fuera, la presencia de los restos en relación con estructuras domésticas de cocina indicaría un uso alimenticio de estas especies por los ocupantes de este espacio militar.

En primer lugar, se observa por lo menos desde la Plena Edad Media una importante presencia de Merluccius merluccius y Conger conger, especies que van a ser de 
gran importancia a lo largo de toda la Edad Media y Moderna, principalmente la primera de ellas. Este esquema parece ser similar al documentado en el Castillo de Curiel (Peñaferruz, Gijón), donde desde el siglo X-XI d.C. se documenta un número importante de restos de ictiofauna en el que Merluccius merluccius y Conger conger juegan un papel muy importante, frente a lo documentado en la fase anterior (Gutiérrez González, 2003; Gutiérrez González, 2008). También es interesante el número de espáridos identificado en este yacimiento, como Sparus aurata, Diplodus sargus o Spondyliosoma cantharus (Gutiérrez González, 2003), ya que no suelen ser muy abundantes en los yacimientos costeros que hemos analizado, por lo que se podría estar reflejando un comercio hacia el interior de las especies más apreciadas, como ya apuntamos en el apartado anterior para Pagellus bogaraveo, entre otras.

Otro ejemplo de comercio con el interior es el Castro de los Judíos (González Gómez de Agüero et alii, 2011), situado en las cercanías de la ciudad de León, antigua sede regia. La presencia de restos de Merluccius merluccius y Conger Conger constatan los intercambios entre las zonas costeras y el interior, así como la importancia del pescado marino en los núcleos urbanos y la aparición de intermediarios para la comercialización de estos productos altamente perecederos, que ya se documentan en Santiago de Compostela en el siglo XII d.C. (Ferreira Priegue, 1998; 2009). En relación al Castro de los Judíos, hay que destacar la presencia de estos restos en la segunda fase de ocupación, posterior al siglo $\mathrm{XI}$, algo similar a lo registrado para la malacofauna marina (González Gómez de Agüero et alii, 2010), y que podría ser reflejo de un mayor desarrollo comercial entre las diferentes áreas, así como de las pesquerías litorales a partir del siglo X-XI d.C.

La representación esquelética de Merluccius merluccius de la Torre de Hércules incluye tanto restos cefálicos como vértebras precaudales y caudales; mientras que en el caso del Castro de los Judíos las vértebras corresponden al cuerpo del animal. Como veremos, esta representación esquelética difiere considerablemente de lo observado en momentos posteriores relacionados con la elaboración de conservas, por lo que consideramos dos posibilidades. La primera, la utilización de otro sistema de conserva diferente al de momentos posteriores, ya que en el siglo XII en la Historia Compostelana se hace referencia a la presencia de merluza tanto fresca como salada (Ferreira Priegue, 1998). La segunda posibilidad es la del consumo en fresco. En el caso de la Torre de Hércules el consumo en fresco de pescado no supone ningún problema, lo que también parece reflejarse en el alto número de taxones presentes, ya que se encuentra junto al mar. El yacimiento leonés plantea dudas debido a su considerable distancia respecto a la costa, aunque existe documentación de la época que habla del comercio de pescado fresco (Riesta Méndez, 2007: 136; Álvarez Fernández, 2009). De todos modos, parece que el coste del transporte, así como la escasez de sal, suponía una traba para el comercio de los excedentes pesqueros, generalizándose el secado al aire como método de conserva (Ferreira Priegue, 1998). Según parece, en este momento lo más común es la conserva de Merluccius merluccius mediante este método (Ferreira Priegue, 1988: 142). 
Quizá esta sea la clave para entender la representación esquelética documentada, ya que el secado puede estar relacionado con otro sistema de procesado. Este se realizaría abriendo y limpiando los ejemplares, sin eliminar el esqueleto, y aplicando cortes en el cuerpo para facilitar el proceso. Una vez preparados los ejemplares, se estiran y se colocan en las "cabrias", formadas por entramados de troncos horizontales y verticales. Este método es similar al empleado para Conger conger (Ferreira Priegue, 1988: 144) a lo largo de la Edad Media, perviviendo en la actualidad en Muxía (A Coruña).

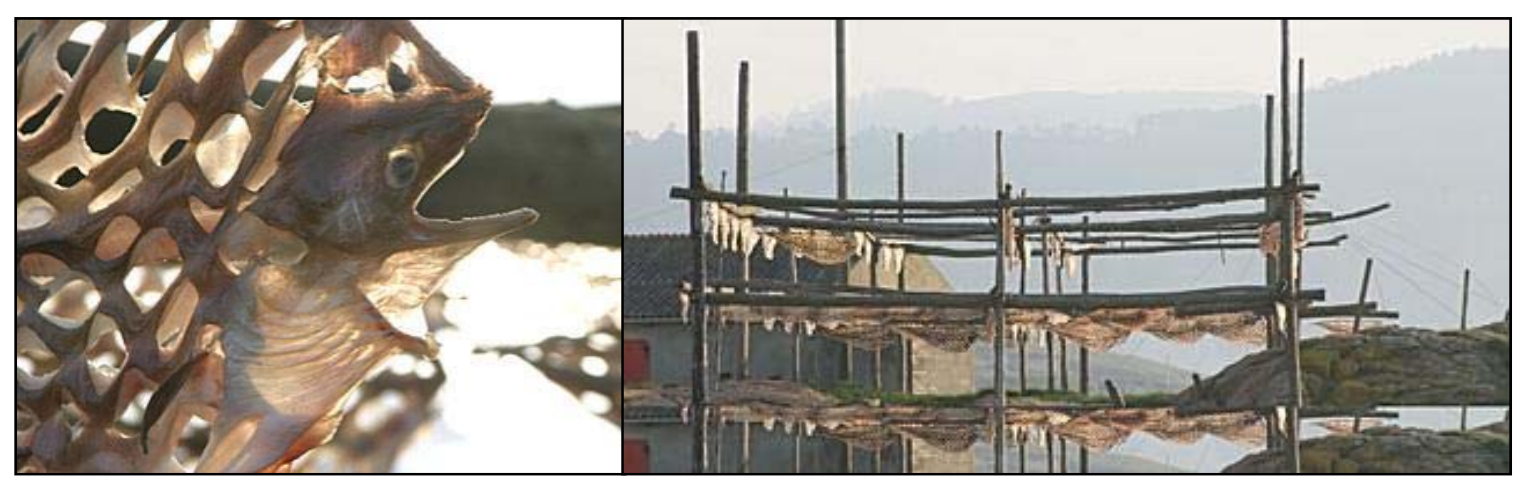

Fig. 311 Detalle del proceso de secado de Conger conger y cabrias de Muxía. (Fotos: ELMUNDO.es “Congrio seco: El pescado que es manjar en Aragón" 15/1/2012).

Anguilla anguilla y Salmo salar eran especies muy apreciadas en la época (Ferreira Priegue, 1998; Carrillo Boutureira, 1999; Riesta Méndez, 2007), pudiendo pescarse tanto en ambientes fluviales como marinos, por lo que se deduce tanto de la toponimia como de la documentación (Carrillo Boutureira, 1999). Ejemplo de ello serían los restos de Anguilla anguilla en la Torre de Hércules y Salmo salar en el Castro de los Judíos de León.

A partir de las especies representadas puede reconocerse la aparición de nuevas artes y estrategias de pesca, que a rasgos generales serán similares a las del periodo posterior. La presencia de Polyprion americanus y Argyrosomus regius indicarían el empleo de artes y aparejos de fondo a profundidades mayores de $30 \mathrm{~m}$; algo que también se intuye por el alto volumen de restos de Merluccius merluccius. Estas especies durante el periodo romano o no se documentan o aparecen con valores muy pequeños. Al mismo tiempo, se seguiría practicando una pesca más tradicional en la zona litoral, centrada principalmente en las familias de lábridos y espáridos.

La importancia de especies migratorias, que se acercan a la costa en primavera y verano, parece confirmar la intensificación pesquera estacional de la que hablan algunos autores, principalmente desde el siglo XII d.C. con el fin de las incursiones normandas y sarracenas (Ferreira Priegue, 1998). Así mismo, desde este momento va a ser muy importante la influencia de los navegantes gascones en todas las nuevas comunidades marítimas del norte peninsular (Ferreira Priegue, 2005). Con anterioridad al siglo XII d.C. van a empezar a surgir y a desarrollarse las villas marineras en Galicia, a las que Ilegan sobre todo barcos gascones que traen nuevas prácticas, técnicas y costumbres marinas (Ferreira Priegue, 2005). 


\section{Baja Edad Media (ss. XIII-XV d.C.).}

\begin{tabular}{|c|c|c|c|c|c|c|}
\hline & TO & TA & AR97 & AR07 & PA02 & RF \\
\hline Sardina pilchardus & & 168 & 686 & & 3 & \\
\hline Conger conger & 4 & & 225 & & 2 & 1 \\
\hline Merluccius merluccius & 48 & 251 & 595 & 73 & 999 & 1 \\
\hline Serranidae sp. & 1 & & & & & \\
\hline Pollachius pollachius & & & 15 & 1 & & \\
\hline Trisopterus luscus & & 22 & 10 & & & \\
\hline Zeus faber & 1 & & & & & \\
\hline Dicentrarchus labrax & & 1 & 18 & 4 & & \\
\hline Polyprion americanus & & & 1 & & & \\
\hline Argyrosomus regius & 1 & & & & & \\
\hline Trachurus trachurus & & & 123 & 2 & 2 & \\
\hline Sparidae sp. & 1 & & & & & \\
\hline Sparus aurata & 2 & & & & & \\
\hline Pagrus pagrus & 1 & & 11 & & 1 & \\
\hline Diplodus sargus & & & 10 & & & \\
\hline Pagellus acarne & 1 & 4 & 13 & 1 & & \\
\hline Pagellus bogaraveo & 1 & 15 & 19 & 1 & 1 & \\
\hline Labrus bergylta & 4 & & 22 & & 5 & \\
\hline Scomber scombrus & & & 9 & & & \\
\hline Mugilidae sp. & 1 & & & & & \\
\hline Trigla lyra & & & 4 & 8 & & \\
\hline Trigla $s p$ & & 1 & & & & \\
\hline Ammodytidae & & 1 & & & & \\
\hline Raia sp. & & & 7 & & & \\
\hline $\begin{array}{ll}\text { TOTAL } \\
\end{array}$ & 66 & 463 & 1768 & 90 & 1013 & 2 \\
\hline
\end{tabular}

Tabla 217 NR de los diferentes taxones identificados en yacimientos del siglo XIII-XV d.C. (To=Torres de Oeste; Ta=Taramancos; Ar97=Area 1997; Ar07=Area campaña de 2007; Pa02=Punta Atalaia Sondeo 02; $\mathbf{R f}=$ Castelo da Rocha Forte).

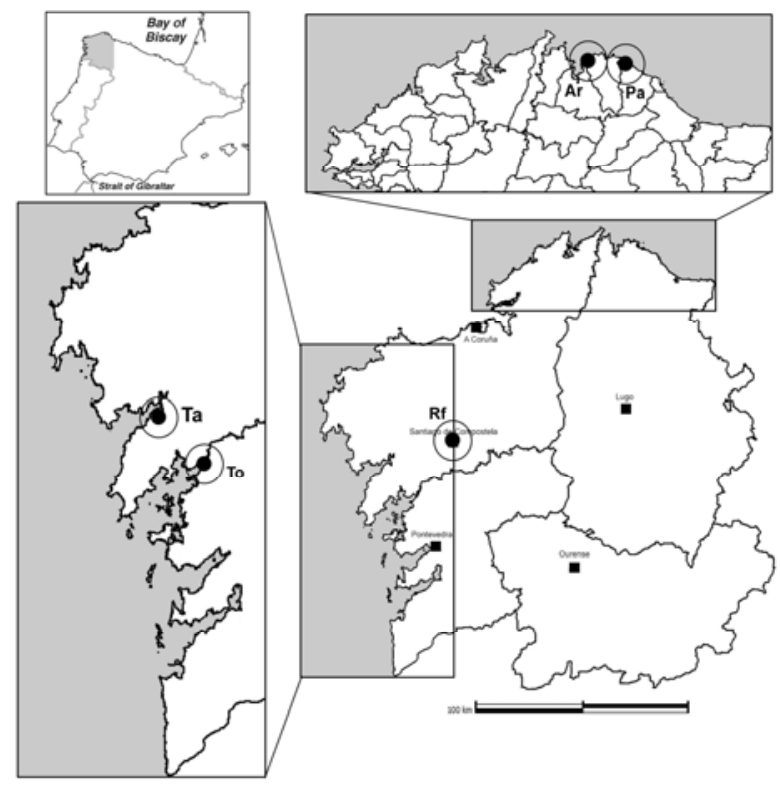

Fig. 312 Localización de los yacimientos con muestras de los siglos XIII-XV d.C.

Galicia (Ferreira Priegue, 2005).
A partir del siglo XIII d.C. el desarrollo urbano y comercial que se venía produciendo desde el periodo anterior, va a llevar asociado un incremento en la presión sobre ciertos productos, como el pescado y la sal, lo que va a ocasionar un mayor control de los mismos por los monarcas, así como la aparición de nuevas estructuras productivas enfocadas al comercio, observándose sus consecuencias desde mediados del siglo XIV d.C. (Ferreira Priegue, 1998; 2009). Es a partir de este momento cuando va a despegar el comercio bretón, factor decisivo para la exportación de pescado y la producción de conservas en 
Para este periodo contamos con una mejor representación de yacimientos, aun cuando sigue siendo muy reducida. Según parece, tanto Area (Viveiro) como Punta Atalaia (San Cibrao) corresponden a dos asentamientos relacionados con la industria conservera, vinculados tanto a la comercialización exterior como al consumo local de pescado. Un papel similar debió tener Taramancos (Noia), pero en este caso en el las Rías Baixas. Por otro lado, Torres do Oeste (Catoira) sería un enclave militar, así como de control del tráfico comercial a través del Río Ulla hacia Santiago de Compostela, de donde contamos con los restos del Castelo da Rocha Forte.

El registro arqueológico muestra una especialización en la pesca, centrada en unas pocas especies representadas por un número alto de restos, al tiempo que también hay un amplio abanico de especies con pocos restos. Todos los yacimientos presentan importantes concentraciones de restos ictiológicos: en el depósito muestreado en 1997 en Area hay una densidad de 17,7 restos por $\mathrm{Kg}$ de sedimento procesado, mientras que en Taramancos es de 8,4. Estos valores son muy superiores a los observados en yacimientos romanos y por supuesto castreños (salvo Adro Vello con 1000 restos por Kg y A Lanzada con 8,2, aunque ambos pertenecen a yacimientos con instalaciones industriales). Esta densidad es reflejo de la importancia que adquiere la pesca a lo largo de la Edad Media.

Merluccius merluccius, Conger conger y Sardina pilchardus son los taxones representados por el número más elevado de restos; principalmente la primera de ellas, quizás fruto del sistema de conserva detectado. Desde el siglo XIV d.C. se va a tener constancia de la aparición de cofradías de pescadores, aunque no será hasta el siglo XV d.C. cuando, vinculadas a estas, aparezcan los mareantes (Ferreira Priegue, 2009). Estos grupos de pescadores, especializados en la captura de las especies antes citadas, van a estar organizado en torno a las cofradías, siendo los encargados de la pesca y del procesado y distribución de los productos (Ferreira Priegue, 1998). Estos primeros mareantes van a incorporar nuevas técnicas pesqueras, como la "sacada", para especies como Sardina pilchardus o Merluccius merluccius, aunque para la primera de ellas se va a utilizar principalmente el cerco desde el siglo XV (Ferreira Priegue, 2009).

La representación esquelética de Conger conger y Sardina pilchardus presenta más dudas a la hora de constatar el sistema de conserva recogido en las fuentes. Sin embargo, el sistema de preparación de Merluccius merluccius parece más claro, siendo similar al descrito por Cornide (1788) para el siglo XVIII, y que es probable que comience a ser utilizado ya en la Baja Edad Media. Según este autor, el sistema de salado aplicado en Galicia en Pollachius pollachius y Merluccius merluccius es similar al realizado para Gadus morhua en Terranova (Cornide, 1788), siendo ya detectado en el siglo XI d.C. en las Islas Británicas para esta última especie (Serjeantson y Woolgar, 2006). Las muestras de Merluccius merluccius documentadas en el Solar 02 de Punta Atalaia y en Casa Martelo, de época romana, presentan una representación similar a la de este periodo. De momento son pocos los datos de los que disponemos, pero no podemos descartar que este método 
de conserva ya fuera practicado en el periodo romano, aunque es posible que cayera en desuso en Galicia y no se recuperase hasta la Baja Edad Media. Desde el siglo XIII d.C., además de los cambios productivos y comerciales del pescado, se va a producir una mejora en el abastecimiento de sal (Ferreira Priegue, 1998), lo que seguramente favoreció el desarrollo de esta técnica de conserva.

El procesado del pescado se realizaría en la costa, ya que parece que los caladeros no se encontraban muy lejos del litoral (Ferreira Priegue, 2009); lo que explicaría el importante número de restos de Merluccius merluccius en yacimientos como Area o Punta Atalaia, en los que es posible que se hubieran realizado trabajos de limpieza del pescado. En el caso de Area, los restos se encuentran a pie de playa, en una zona alejada del núcleo urbano de Viveiro; mientras que en Punta Atalaia, los restos también se concentran en una zona marginal de la península donde se emplaza el yacimiento, cerca del pueblo antiguo y del puerto, y donde se exhumaron únicamente unas pequeñas estructuras de época medieval. Por lo tanto, ambos casos pueden responder a lugares de desembarque de la carga y procesado de la misma, fuera de los núcleos urbanos. En el caso de Taramancos, los restos se recuperaron alejados de la costa, pudiendo responder a una instalación conservera.

Pese a que estos tres taxones van a ser los que centran la actividad pesquera de los mareantes, hay una serie de especies que, aunque no tengan una gran representatividad, es posible que también estén vinculadas a la actividad de estos grupos. Así, Trigla lyra, Polyprion americanus y Argyrosomus regius podrían ser capturadas mediante las nuevas artes, ya que prácticamente no se documentan en periodos anteriores a la Edad Media. Trachurus trachurus, a la que las fuentes no presentan como una especie muy apreciada gastronómicamente, alcanza valores importantes en las muestras, lo que cuestiona las valoraciones documentales e incrementa el interés real por esta especie, aunque esto no implique que no pudiera ser una comida poco valorada.

Hay también un grupo muy amplio de especies demersales que pueden ser pescadas cerca de la costa, reflejando una actividad pesquera similar a la realizada desde siglos antes. La captura de estas especies la realizan los denominados "pescadores", particulares o vasallos de señoríos, no organizados en gremios, que actúan tanto desde botes como desde tierra con artes de pesca muy sencillas, como el trasmallo o el palangre (Ferreira Priegue, 1998). De todos modos, también hay en la documentación referencias a la pesca por parte de estos grupos de especies mercantes, como Merluccius merluccius o Conger conger, si bien en pequeñas cantidades y muchas veces vendidas a los mareantes (Ferreira Priegue, 1998; 2009). Las capturas de este grupo irían destinadas al autoconsumo y a la venta de pescado fresco en los mercados, tanto locales como del interior.

La representación taxonómica de la ictiofauna recuperada en Torres do Oeste puede aportar una evidencia bastante directa del comercio de productos relacionados con la pesca en el mar, ya que nos encontramos en un enclave situado a la orilla del río Ulla y 
relacionado con el control comercial hacia la ciudad de Santiago de Compostela. En primer lugar se refleja el comercio de pescado fresco de especies como Merluccius merluccius, ya que aparecen tanto restos cefálicos como vértebras caudales, que son las más numerosas, que corroborarían la documentación de la época (López Ferreiro, 1875; Suárez, 1950). Las tallas de esta especie en este yacimiento son individuos más pequeños que los documentados en las instalaciones industriales de la época, lo que podría estar indicando un comercio en fresco de los ejemplares de menor talla, reservando los mayores para su salado.

Por otro lado, también queda patente la llegada de pescados procedentes de las zonas más abiertas de la ría, como Labrus bergylta, que ocuparía principalmente áreas exteriores como ya hemos visto. De hecho, en la Ría de Arousa el único puerto con derechos de descarga es el de Padrón (Ferreira Priegue, 1988: 134-135). Además, esta es la segunda especie en cuanto al número de restos identificados, algo similar a lo observado en los otros yacimientos, si bien en este es más llamativo al no encontrarse en un medio propicio, por lo que es posible que sea pescada en grandes cantidades y quizás destinada al consumo por las clases populares.

También es interesante la alta variedad de especies marinas identificadas en este yacimiento, aunque estén representadas por pocos restos, prueba de la gran variedad de pescados que son comercializados. Es llamativa la ausencia de especies pelágicas como Trachurus trachurus, Scomber sp. o Sardina pilchardus, principalmente la primera de ellas ante la abundancia registrada en los yacimientos de la costa cantábrica, quizás como reflejo de un mayor número de capturas de esta especie en la costa norte. Por su parte, la ausencia de Sardina pilchardus puede deberse a otros motivos de índole comercial, ya que parece que en el interior de las rías la actividad principal de los mareantes era la pesca de esta especie.

\section{Edad Moderna.}

En cuanto a los primeros momentos de la Edad Moderna, los datos disponibles son muy exiguos. De todos modos, se observa una explotación muy similar a la desarrollada en los siglos anteriores. Durante la primera mitad del siglo XVI se produce una crisis debido al retroceso de los mercados mediterráneos, así como un descenso de la presencia de sardina (Ferreira Priegue, 1998). Sin embargo, la falta de precisión cronológica, así como la escasez de registros, impide detectar estos problemas en los yacimientos arqueológicos.

En relación a las muestras estudiadas, es destacable la ausencia de especies como Trachurus trachurus, muy abundante en los yacimientos de la Baja Edad Media, así como de Pagellus sp. Ya indicamos que Trachurus trachurus estaba ausente de Torres do Oeste, también situado en la costa Atlántica, como A Palma, lo que podría confirmar su pesca principalmente en la costa cantábrica. También hay que destacar la presencia en este 
último yacimiento de dos vértebras de Thunnus thynnus, lo que reflejaría contactos comerciales e intercambios con la zona del sur peninsular.

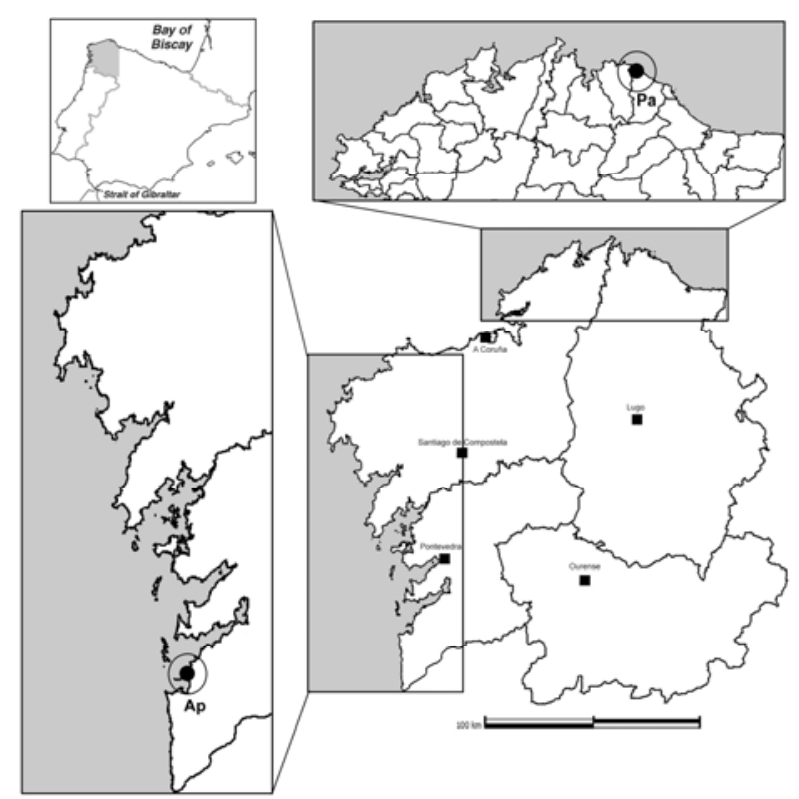

Fig. 313 Localización de los yacimientos con muestras de época moderna.

\begin{tabular}{|c|c|c|}
\hline & AP & PA02 \\
\hline Condrictio & 1 & \\
\hline Sardina pilchardus & & 4 \\
\hline Merluccius merluccius & 45 & 602 \\
\hline Pollachius pollachius & & 3 \\
\hline Zeus faber & & 1 \\
\hline Dicentrarchus labrax & 2 & \\
\hline Sparus aurata & & 1 \\
\hline Pagrus pagrus & & 1 \\
\hline Labrus bergylta & 1 & 7 \\
\hline Symphodus melops & & 1 \\
\hline Scomber japonicus & & 1 \\
\hline Scomber scombrus & & 1 \\
\hline Thunnus thynnus & 2 & \\
\hline
\end{tabular}

Tabla 218 NR de los diferentes taxones identificados en yacimientos de época moderna (Ap=A Palma; Pa02=Punta Atalaia Sondeo 02).

En cuanto a las técnicas pesqueras, se van a seguir utilizando las mismas que en el periodo anterior, si bien debido a la crisis del XVI se van a empezar a controlar las artes de pesca, principalmente las nuevas y más agresivas, estableciéndose días inhábiles para la pesca (Ferreira Priegue, 1998). 
VII. ConClusiones. 

La realización de este trabajo supone la primera revisión global de los datos arqueictiológicos gallegos desde el 2003, año en el que M.C. Ferré defendió su Tesis Doctoral. Por lo tanto el presente estudio viene a rellenar el vacío dejado por la ictioarqueología en la literatura arqueológica gallega durante los últimos años, con la incorporación de diversos estudios inéditos, así como con la revisión de los análisis anteriores.

Uno de los principales problemas que nos hemos encontrado a la hora de su realización es la representatividad de las muestras. En el presente trabajo exponemos una metodología de excavación y muestreo de concheros con la que llevamos varios años trabajando, y que ya enunciamos en nuestra Tesina de Licenciatura en 2009, si bien la habíamos aplicado casi exclusivamente a los estudios arqueomalacológicos.

El volumen que presentan los concheros protohistóricos y galaico-romanos, y las amplias superficies excavadas, suponen un gran problema a la hora de su estudio, debido al enorme esfuerzo que supondría el procesado de todo ese material. Del mismo modo, el almacenaje de la totalidad del depósito para futuras analíticas generaría multiples inconvenientes. Debido a esta problemática, se decidió sistematizar diferentes tipos de muestreo que de una forma flexible pudieran ser utilizados en depósitos de variadas características. Este sistema no pretende ser definitivo, sino una herramienta práctica que se pueda ir perfeccionando para conseguir un mejor método de intervención en estos depósitos y su aplicación por arqueólogos sin una cualificación específica en este ámbito de la investigación.

Consideramos que estos dos requisitos se han alcanzado con nuestro sistema de muestreo, como queda patente en la representatividad ósea de los diferentes yacimientos, y con la realización de muestreos (caso de los yacimientos de Montealegre o el de A Lanzada) por el personal de la excavación sin que exista un sesgo en las muestras estudiadas. Pese a todo, somos conscientes que al analizar únicamente determinadas muestras de un conjunto mucho más amplio, se está perdiendo información, principalmente en lo que a ictiofauna se refiere; por este motivo creemos que la utilización de cribas en los yacimientos para el procesado del sedimento debería de ser una práctica habitual en las excavaciones arqueológicas.

En O Neixón durante la campaña de 2005 se cribó todo el sedimento del Foso 01, recuperando diversos restos de pez, cuando no habían sido documentados peces en el año 2004 durante la excavación de una parte del mismo foso y que no fue cribada. Otro caso paradigmático es el de Area, donde llama la atención el bajo número de restos de especies de pequeño tamaño en la excavación de 2007, cuando no se cribó, frente a los resultados del depósito sondeado en 1996, de donde se cribó todo el sedimento recogido. Por otro lado, los casos de Montealegre y de Punta Atalaia vienen a confirmar que es posible realizar muestreos minuciosos en la "arqueología de gestión", sin que eso suponga 
problemas a la hora de finalizar la obra. Por todo ello hemos considerado adecuado, a la hora de presentar los datos de los yacimientos, informar del tipo de muestreo realizado y el volumen o peso de sedimento procesado, ya que ayuda a comprender la importancia y la representatividad del conjunto.

Otro aspecto a tener en cuenta es la existencia de ciertos periodos mejor estudiados que otros. En el presente trabajo se han presentado 21 yacimientos en un abanico cronológico que abarca más de 20 siglos, lo que supone un registro muy pequeño para ciertos periodos y para ciertas zonas. Sin duda, uno de los principales retos para el futuro es conseguir rellenar esos vacíos, algo que en gran medida depende de la recuperación de los restos ícticos a los que debe acompañar una correcta datación de los mismos, un gran problema a la hora de realizar este tipo de estudios como ya comentamos en los capítulos precedentes. De todos modos, los datos obtenidos han servido para un primer acercamiento a la evolución de la actividad pesquera en el noroeste peninsular.

Tradicionalmente, en la literatura arqueológica gallega se ha atribuido un papel preponderante a la pesca durante la Cultura Castreña dentro de las actividades económicas. Es posible que esto se deba a la estrecha vinculación existente entre arqueología y nacionalismo en el origen de la disciplina en Galicia (Ayán Vila, 2012: 40 y ss.), que asocia ciertos aspectos de las comunidades locales con las sociedades del pasado, definiendo una entidad cultural propia y con una larga tradición. En este mismo sentido, jugaría un papel importante el desarrollo que en época Contemporánea ha tenido esta actividad en las poblaciones marineras de Galicia. Por otro lado, también han tenido mucho que ver las interpretaciones literales de los textos clásicos, en los que se ensalza la cantidad y calidad del pescado y marisco de las costas de la Gallaecia.

Sin embargo, una vez analizados los restos ictiológicos de los yacimientos parece que nos encontramos ante un panorama muy diferente. La variedad de especies, así como el número de restos, no parece ser muy elevado, por lo que replanteamos la idea de ese papel principal que se le atribuía a la pesca, identificándose más con un recurso complementario, algo que parece ser habitual en las sociedades de la Edad del Hierro en la Península Ibérica. Somos conscientes de los pocos yacimientos asignados a la Fase II de la Cultura Castreña, aunque la mayor parte de los conjuntos tienen un denominador común: los materiales proceden de concheros, donde, en teoría, el carbonato cálcico de las conchas permite una mejor conservación de los materiales. Lo que desde luego parece claro durante este periodo es el carácter de autoconsumo que tendría esta actividad. Sin embargo, consideramos que este modelo no es común a todo el periodo castreño, y a lo largo del siglo II a.C. se detectan ciertos cambios que anuncian un nuevo modelo que aparece perfectamente conformado a partir del cambio de Era.

Estudios anteriores hablan de la incorporación del noroeste a la administración romana como punto de inflexión para la pesca. Entonces se habrían producido cambios 
técnicos con la incorporación de redes para la captura de taxones pelágicos, lo que facilitaría la captura de Sardina pilchardus, así como la introducción de un nuevo sistema productivo con la aparición de industrias salazoneras. El estudio de nuevos yacimientos y la revisión de otros ya conocidos, así como el análisis de los conjuntos por periodos cronológicos, nos ha llevado a replantearnos estas hipótesis, adelantando en más de un siglo estos cambios en el sistema de explotación pesquera. Conforme a estos nuevos datos, a lo largo del siglo II a.C. se va a producir un aumento del número de restos y de taxones recuperados en los yacimientos, documentándose una serie de especies pelágicas que no aparecían con anterioridad, entre las que se encuentra Sardina pilchardus. Por otro lado las excavaciones de 2010 en A Lanzada han sacado a la luz una estructura que podría corresponderse con una instalación para el procesado y conservación de pescado.

El aumento de las capturas podría deberse en gran medida a los procesos demográficos y socio-políticos que tendrán lugar en este momento, sin embargo este proceso parece englobarse en una coyuntura mucho más compleja. Desde mediados del siglo II a.C. se detecta en la cultura material una intensificación comercial con las poblaciones del sur peninsular, pudiendo haber comerciantes tardopúnicos más o menos estables en el noroeste. En cuanto a la pesca, con la llegada de estos comerciantes a diferentes puntos de la actual Andalucía y de Portugal se detectan cambios similares a los observados en el ámbito castreño, por lo que estos dos aspectos podrían estar relacionados. De todos modos, todavía falta evaluar el impacto real que pudieron haber tenido estas innovaciones en la relación entre los pescadores y el medio merino, así como el cambio económico que supuso dentro de la dinámica socio-política de las Rías Baixas en ese momento. Hasta la fecha, y a excepción del caso de A Lanzada, no se dispone de ninguna otra información que nos haga pensar en un modelo alejado del autoconsumo, aunque no podemos descartar que en el futuro se obtengan nuevas evidencias al respecto.

Con la implantación de la administración romana todas estas innovaciones se van a consolidar, surgiendo una autentica industria pesquera, con especialización en ciertas especies y multitud de centros industriales a lo largo de toda la costa. Este panorama no va a ser exclusivo de la Gallaecia, sino que va a ser común a toda la Península Ibérica, principalmente en aquellos lugares con una riqueza pesquera importante como el círculo del estrecho.

En cuanto a la explotación pesquera en el ámbito indígena castreño son interesantes dos aspectos: 1) La especialización en un taxón representado por un elevado número de restos, una característica ya observada en la malacofauna. Podría estar reflejando una mayor presión sobre el medio, aumentando el número de capturas de aquellas especies que tuvieran mayor presencia y presentaran un menor esfuerzo para su captura. Junto a esto, es probable que esté actuando un factor tan relevante en el periodo romano como es el comercio. 2) El segundo aspecto de interés es precisamente la relación 
existente entre los yacimientos indígenas costeros y el entramado productivo y comercial de época romana. Hasta el siglo III d.C. parece existir un vínculo entre castros e industrias salazoneras, siendo muy pocos los restos de especies pelágicas como Sardina pilchardus o Trachurus trachurus en los primeros, y abundantes en los segundos. También hay que tener en cuenta el comercio interior de pescado fresco o tratado. En el caso de los moluscos están claras estas relaciones comerciales, pero no tanto con el pescado, ya que carecemos de datos de yacimientos del interior. Sin embargo, la escasa presencia de ciertas especies como Pagellus bogaraveo en los yacimientos costeros de este periodo, frente a su importante presencia en periodos anteriores, y su interés gastronómico, llevan a plantear la posibilidad de un comercio con el interior de ciertas especies con gran demanda. Por lo tanto, igual que hay constancia de la existencia de asentamientos centrados en la explotación minera, es probable que existan castros costeros dedicados en parte a la explotación del medio marino, bien para servir los mercados interiores, bien para abastecer a la industria salazonera.

Durante los siglos siguientes hay un importante vacío en el registro ictioarqueológico que nos impide evaluar de forma precisa tanto los posibles cambios que se producen en relación con el sistema de explotación pesquera como los cambios que se van a producir durante la Plena y la Baja Edad Media. Desde el siglo XI d.C., con el inicio del desarrollo urbano, se detecta una importante actividad pesquera y de comercio de ciertas especies con el interior. En este sentido, hay que destacar un cambio en los taxones capturados, vinculándose a dos motivos: en primer lugar por la aparición de Merluccius merluccius, Conger conger y Sardina pilchardus como especies principales, sentando las bases de lo que será la industria pesquera gallega a lo largo de toda la Baja Edad Media y la Edad Moderna; en segundo por la presencia de otras especies como Polyprion americanus y Argyrosomus regius, que reflejarían la aplicación de nuevas artes de pesca más productivas.

Este repunte de la actividad pesquera parece estar relacionada con el Camino de Santiago y el contacto de los reinos del norte peninsular con el mundo ruropeo, especialmente con el franco, llegando grupos de gascones a las costas, convirtiéndose en los impulsores de esta nueva realidad.

El gran momento de la explotación pesquera en la Edad media gallega se va a producir en el siglo XIV con la aparición de las cofradías de mareantes, que consolidarán el modelo pesquero documentado desde la Plena Edad Media. Uno de los factores que parecen haber tenido un papel importante es el abastecimiento de sal, ya que en momentos anteriores este producto resultaba escaso, siendo más regular su comercio desde el siglo XIII. Esta mejoría va a reflejarse en el registro arqueológico con un cambio en el sistema conservero de Merluccius merluccius, que empieza a ser salada y secada de modo similar al empleado para el bacalao en Terranova y en las Islas Británicas. 
Paralelamente a esta actividad pesquera, con un claro fin comercial y exportador, va a mantenerse un modelo pesquero similar al detectado desde época castreña, con escasos rendimientos, realizado desde la costa o con pequeñas embarcaciones, y dedicado al autoconsumo y al comercio a corta distancia. De nuevo el impulso pesquero se va a ver condicionado por el contacto con otras áreas. Esta vez no será con el sur peninsular, sino que parece responder más a los contactos con el mundo Británico y del Norte de Europa desde el siglo XIII-XIV d.C.

Una constante desde la época castreña hasta la Edad Media parece ser el condicionamiento biológico y la situación geográfica del asentamiento, por dos motivos fundamentes: 1) La pesca se realiza en las inmediaciones de los asentamientos; 2) Las condiciones del entorno favorecen el desarrollo de unas especies frente a otras. Sin embargo, partiendo de esta base, el determinismo biológico quedaría limitado por el carácter antrópico de las capturas. Parece existir una especialización en la pesca de ciertas especies a lo largo de todo el marco cronológico, supeditadas en gran medida a factores económicos. De este modo, se persigue capturar especies que supongan menos esfuerzo y que tengan mayor rendimiento económico. Por ejemplo, durante el periodo castreño la presencia de un número importante de restos de especies más o menos sedentarias, como Trisopterus luscus o Labrus bergylta, supone la explotación de una fuente estable de recursos, que se localiza cerca de los yacimientos y que puede ser capturadas con poco esfuerzo. En época romana se aprecia un descenso en el número de restos de especies como Pagellus bogaraveo, muy abundante en los siglos anteriores, o el desarrollo de una pesca industrial de otras como Sardina pilchardus, claramente ambos aspectos supeditados a motivos económicos. El reflejo de la importancia económica de la pesca se hará más evidente desde el siglo XIV d.C., cuando se empiecen a alejar más las flotas buscando especies concretas con gran valor bromatológico, siendo menor el determinismo biológico y mayor el control antrópico.

Los análisis ictioarqueológicos juegan un papel muy importante en los estudios sobre problemas actuales como la sobrepesca y el cambio climático, ya que aportan información de periodos en los que no se tienen estadísticas y que de otro modo no se podrían obtener. En este sentido, en este trabajo hemos podido constatar una evolución en la temperatura de las aguas gallegas desde el siglo II a.C. al siglo XVI d.C. La presencia de un mayor número de restos de Scomber japonicus, propia de zonas tropicales, que de Scomber scombrus, especie predominante actualmente en Galicia, indica unas aguas más cálidas en época castreña y romana; mientras que en la Edad Media, principalmente desde el siglo XIII-XIV d.C., la práctica desaparición de Scomber japonicus apunta a un enfriamiento de las msimas. Este esquema parece coincidir con lo observado en determinados moluscos, como Stramonita haemastoma, y en otros estudios climáticos. De hecho desde el siglo XIII d.C. y hasta mediados del siglo XIX d.C. se va a producir en Europa un periodo frío conocido como la "Pequeña Edad del Hielo", seguramente causante de la 
desaparición de Stramonita haemastoma y del descenso en las capturas de Scomber japonicus en las costas de Galicia.

No vamos a extendernos más sobre estas cuestiones, ya que han sido tratadas con mayor detalle en los capítulos anteriores, y resultaríamos repetitivos. Somos conscientes de la potencialidad que todavía presentan estos conjuntos, por lo que no se puede considerar, ni mucho menos, que el tema esté cerrado. Nuestra principal pretensión era revisar los datos que ya existían y actualizarlos con el análisis de nuevos yacimientos. Esperamos que esto haya servido para avanzar en un campo todavía porco conocido y tan poco aprovechado como es la ictioarqueología en el noroeste peninsular. Del mismo modo, esperamos que este trabajo sirva de punto de partida para futuros estudios y nuevos análisis. 


\section{BIBLIOGRAFÍA.}



ABOAL FERNÁNDEZ, R.; CASTRO HIERRO, V. (2006a): “Contexto da intervención”. En Aboal Fernández, R. y Castro Hierro, V. (Coord.): O Castro de Montelaegre. Moaña, Pontevedra. Editorial Toxosoutos, Serie Keltia, 37. Noia: 79-84.

ABOAL FERNÁNDEZ, R.; CASTRO HIERRO, V. (2006b): “Avance de resultados da campaña de excavación arqueológica (2003-2004)”. En Aboal Fernández, R. y Castro Hierro, V. (Coord.): 0 Castro de Montelaegre. Moaña, Pontevedra. Editorial Toxosoutos, Serie Keltia, 37. Noia: 87-142.

ABOAL FERNÁNDEZ, R.; CASTRO HIERRO, V.; GOZÁLEZ RUIBAL, A.; RODRÍGUEZ MARTÍNEZ, R. (2006): "5.6. Outros obxectos". En Aboal Fernández, R. y Castro Hierro, V. (Coord.): O Castro de Montelaegre. Moaña, Pontevedra. Editorial Toxosoutos, Serie Keltia, 37. Noia: 261-274.

ACUÑA CASTROVIEJO, F. (1976): "Excavaciones en el Castro de O Neixón. Campaña de 1976". Noticiario Arqueológico Hispánico. Prehistoria, 5: 325-330.

ACUÑA CASTROVIEJO, F. (1996): "Historiografía e investigación de la Cultura Castreña en Galicia”. En J.M. Hidalgo Cuñarro (Coord.): A Cultura Castrexa galega a debate. Instituto de Estudios Tudenses, Tui: 25-39.

ALMEIDA, C.A.F. DE (1983). "Cultura castreja: evoluçao e problemática”. Arqueologia, 8: 70-74.

ALONSO MARTÍNEZ, N.; JUAN-TRESSERRAS, J.; RODRÍGUEZ-ARIZA, M.O.; ROVIRA BUENDÍA, N. (2003): "Muestreo arqueobotánico de yacimientos al aire libre y en medio seco". La recogida de muestras en arqueobotánica: objetivos y propuestas metodológicas. Museu d’Arqueologia de Catalunya: 31-48.

ALONSO, A.; PAGÉS, J.L. (2000): "El registro sedimentario del final del cuaternario en el litoral noroeste de la Península Ibérica. Márgenes Cantábrico y Atlántico". Revista de la Sociedad Geológica de España, 13 (1): 17-29.

ÁLVAREZ ÁlVAREZ, E. (1990): "El papel del Conde de Lemos en el levantamiento Irmandiño". Galicia en la Edad Media. Sociedad Española de Estudios Medievales, Madrid: 277-286.

Álvarez ÁlvareZ, C. (coord.) (1999): Edad Media. La Historia de León, Tomo II. Universidad de León, Diario de León.

ÁlVAReZ bORGE, I. (2003): La Plena Edad Media. Siglos XII-XIII. Historia de España $3^{\text {er }}$ milenio. Editorial Síntesis, Madrid.

ÁLVAREZ FERNÁNDEZ, M. (2009): "Abastecimiento y consumo de pescado en Oviedo a finales de la Edad media". La pesca en la Edad Media. Monografías de la Sociedad Española de Estudios Medievales, № 1: 71-86. 
ÁLVAREZ SÁNCHEZ, J.; LUQUE del VILLAR, A.A. (1981): Reseñas malacológicas I. Métodos de recogida, preparación y conservación de moluscos. Sociedad Española de Malacología, Madrid.

ARES, A.; REY, D.; RUBIO, B.; MOHAMED, K.; BERNABEU, A.; VILAS, F. (2008): "Reconstrucción paleoclimática de la plataforma continental gallega basada en datos geoquímicos y magnéticos". Geogaceta, 44: 87-90.

ARMAS CASTRO, J. (1991): "La crisis del siglo XIV". Historia de Galicia, Tomo II, Baja Edad Media y comienzos de la Edad Moderna. Faro de Vigo: 369-388.

ARIAS VILAS, F. (1992): A romanización de Galicia. Historia de Galicia 4. Edicións A Nosa Terra. Vigo.

ARIAS VILAS, F. (2002): "Las fases de la Cultura Castreña en Galicia: un debate abierto". En Blas Cortina, M.A. de; Villa Valdés, A. (Ed.): Los poblados fortificados del noroeste de la Península Ibérica: Formación y desarrollo de la Cultura Castreña. Coloquios de Arqueología en la cuenca del Navia. Homenaje al Prof. Dr. José Manuel González y Fernández-Valles. Navia: 127-138.

ARMADA PITA, X.-L. (2003/05): “Los orígenes de la arqueología universitaria en Galicia”. En Cabrera Valdés, V. y Ayarzagüena Sanz, M. (Eds.): El nacimiento de la Prehistoria y de la Arqueología científica. Archaia, Vol. 3-5: 257-265.

AVELLO ÁlVAREZ, J.L.; SÁNCHEZ-LAFUENTE PÉREZ, J. (2001): “Excavaciones en el poblado del Castro de los Judíos, Puente Castro, León. Campañas 1999-2000", Lancia, 4: 221-227.

AYÁN VILA, X. (2006): “A citania de Montealegre na xénese da arqueoloxía galeguista”. En Aboal Fernández, R. y Castro Hierro, V. (Coord.): O Castro de Montelaegre. Moaña, Pontevedra. Editorial Toxosoutos, Serie Keltia, 37 17-53.

AYÁN VILA, X. (2012): Casa, familia y comunidad en la Edad del Hierro del NW. Tesis Doctoral. Universidade de Santiago de Compostela, Inédita.

AYÁN VILA, X.; GIANOTTI GARCÍA, C.; RODRÍGUEZ MARTÍNEZ, R.; GONZÁLEZ PÉREZ, L.; ARIZAGA CASTRO, A. (2005a): "Avance de resultados da escavación arqueolóxica no Castro Grande de Neixón. Campaña de 2003". En Ayán Vila (coord.): Os Castros de Neixón. Boiro, A Coruña. Editorial Tosoxoutos, Serie Keltia, 30: 127-161.

AYÁN VILA, X.; GONZÁLEZ RUIBAL, A.; GONZÁLEZ PÉREZ, L.; ARIZAGA CASTRO, A. (2005b): "Avance de resultados da escavación arqueolóxica no Castro Grande de O Neixón. Campaña de 2004". En Ayán Vila (coord.). Os Castros de Neixón. Boiro, A Coruña. Editorial Toxosoutos, Serie Keltia, 30: 165-229.

AYÁN VILA, X.; GONZÁLEZ PÉREZ, L.; FRANCO FDZ., M.A.; LAIINO PIÑEIRO, A.; BEJEGA GARCÍA, V.; GONZÁLEZ GÓMEZ DE A., E.; MOLEDO SANTIAGO, X.; ARIZAGA CASTRO, A. (2008a): “Escavación arqueolóxica no Castro Grande de Neixón: campaña 2005. 
Síntese de resultados". En Ayán Vila (coord.) Os Castros de Neixón II. Editorial Tosoxoutos. Serie Keltia, 40: 99-139.

AYÁN VILA, X.; GONZÁLEZ PÉREZ, L.; FRANCO FDZ, M.A.; LAÍÑO PIÑEIRO, A.; BEJEGA GARCÍA, V.; GONZÁLEZ GÓMEZ DE A., E.; MOLEDO SANTIAGO, X.; ARIZAGA CASTRO, A. (2008b): "Escavación arqueolóxica no Castro Grande de Neixón: campaña 2006. Síntese de resultados". En Ayán Vila (Coord.) Os Castros de Neixón II. Editorial Toxosoutos. Serie Keltia, № 40: 143-191.

BALIÑAS PÉREZ, C. (1990): “En los orígenes de un ecosistema social: La Galicia del siglo VIII". Galicia en la Edad Media. Sociedad Española de Estudios Medievales, Madrid: 25-38.

BAÑÓN DÍAZ, R. (2009): "Variacións na diversidade e abundancia ictiolóxica mariña en Galicia por efectos do cambio climático". En Pérez, V., Muñuzuri, Fernández Cañamero, M. y Gómez Gesteira, J.L. (Eds.): Evidencias e impactos do cambio climático em Galicia. Xunta de Galicia, Consellería de Medio Ambiente e Desenvolvemento Sostible. Vigo: 355-371.

BARROS GUIMERÁNS, C. (1991): "La revuelta de los Irmandiños". Historia de Galicia, Tomo II, Baja Edad Media y comienzos de la Edad Moderna. Faro de Vigo: 441-460.

BEJEGA GARCÍA, V. (2009): El aprovechamiento de los recursos marinos en el Castro Grande de $\mathbf{O}$ Neixón (Boiro, A Coruña): un análisis arqueomalacológico. Tesina de Licenciatura. Universidad de León. Inédita.

BEJEGA GARCÍA, V.; FERNÁNDEZ RODRÍGUEZ, C. (2008): “O aproveitamiento dos recursos mariños no Castro Grande d'O Neixón". En Ayán Vila (coord.) Os Castros de Neixón II. Editorial Toxosoutos. Serie Keltia. № 40: 195-222.

BEJEGA GARCÍA, V.; GONZÁLEZ GÓMEZ DE AGÜERO, E.; FERNÁNDEZ RODRÍGUEZ, C.; ÁLVAREZ GARCÍA, J.C. (2010): "Los concheros de O Neixón (Boiro, A Coruña) y Punta Atalaia (San Cibrao, Lugo): Una propuesta de muestreo y excavación de depósitos de la Edad del Hierro y Época Romana en Galicia”. En González Gómez de Agüero, E.; Bejega García, V.; Fernández Rodríguez, C.; Fuertes Prieto, N. (Coord.). Actas de la I Reunión de Arqueomalacología de la Península Ibérica, Férvedes, 6: 33-42.

BEJEGA GARCÍA, V.; GONZÁLEZ GÓMEZ DE AGÜERO, E.; FERNÁNDEZ RODRÍGUEZ, C. (2011): "Pesca y Marisqueo en el yacimiento de Area (Viveiro, Lugo)". En Ramil Rego, E. y Fernández Rodríguez, C. (ed.): 2 Congreso Internacional de Arqueología de Vilalba, Férvedes, 7: 255-263.

BEJEGA GARCÍA, V.; GONZÁLEZ GÓMEZ DE AGÜERO, E.; FERNÁNDEZ RODRÍGUEZ, C. (2012): Informe Arqueomalacológico y Arqueoictiológico de Taramancos. 2012/03/Ta. Informe Inédito.

BELLO DIÉGUEZ, J.Mạ (1994): La Coruña romana y altomedieval. S. I-XII. Vía Láctea y Concello de A Coruña. Concello de A Coruña. 
BELLO DIÉGUEZ, J.Mạ; PEÑA SANTOS, A. DE LA (1995): Historia de Galicia, Tomo I. Galicia na Prehistoria. Vía Láctea Editorial, A Coruña.

BELLO DIÉGUEZ, J.Mạ.; SANJURJO SÁNCHEZ, J.; FERNÁNDEZ MOSQUERA, D. (2008) “Los niveles medievales de la Torre de Hércules: Caracterización arqueológica y datación mediante TL y OSL". En Ramil Rego, E. (ed.): 1 Congreso Internacional de Arqueología de Vilalba, Férvedes, 5: 453-464.

BERNAL, D. (2007): “Algo más que garum. Nuevas perspectivas sobre la producción de las cetariae hispanas al hilo de las excavaciones en C/San Nicolás (Algeciras, Cádiz)". En Lagostera, Bernal y Arévalo: CETARIAE 2005, Salsas y salazones de pescado en occidente durante la antigüedad. Actas del Congreso Internacional (Cádiz, 7-9 noviembre 2005). BAR Internacional Series 1686: 93-107.

BIELZA, Mo.J. (1996): "El pescado en la dieta de los Cartujos de El Paular en el siglo XVI". Archaeofauna, 5: 65-77.

BLÁZQUEZ MARTÍNEZ, J.M. (2006): "La pesca en la Antigüedad y sus factores económicos". Historia de la pesca en el ámbito del estrecho. I Conferencia Internacional. Junta de Andalucía, Consejería de agricultura y pesca, Vol. 1: 17-36.

BOUZA BREY, F. (1957) "O Castro da Alobre e os contactos antre a Bretaña e a Galiza na época romana”. Homaxe a F. López Cuevillas. Santiago: 73-110.

BOWDLER, S. (2006): "Mollusk and other shells". En Balme, J. y Paterson, A. (eds.): Archaeology in practice. A student guide to archaeological analyses. Blackwell publishing: 316-337.

BURJACHS, F.; LÓPEZ SÁEZ, J.A.; IRIARTE, M.J. (2003): “Metodología arqueopalinológica". La recogida de muestras en arqueobotánica: objetivos y propuestas metodológicas. Museu d’Arqueologia de Catalunya: 11-18.

BUXÓ, R. (1997): Arqueología de las plantas. Crítica, Barcelona.

CABRERA TILVE, I. (2009): "Excavación en área nunha parcela en solo urbano, no xacemento Punta Atalaia, no contorno da rúa do Faro de San Cibrao, Cervo". Actuacións Arqueolóxicas. Ano 2007. Xunta de Galicia: 156-157.

CALO LOURIDO, F. (1997): A Cultura Castrexa. Historia de Galicia 3. Edicións A Nosa Terra, (2a edición). Vigo.

CALVO Y SÁNCHEZ, I. (1914): "Exploraciones arqueológicas. Citanias gallegas". Revista de Archivos, Bibliotecas y Museos, XXXI: 1-15.

CALVO Y SÁNCHEZ, I. (1920): "Monte de Santa Tecla. La Guardia (Pontevedra). Exploraciones arqueológicas verificadas en los años 1914 a 1920". Tip. de la Revista de Archivos, Bibliotecas y Museos. 
CALVO Y SÁNCHEZ, I. (1924): “Monte de Santa Tecla en Galicia. Memoria de los trabajos realizados en 1922-23". Junta Superior de Excavaciones y Antigüedades, Memoria no 62. Edición especial de la "Sociedad Pro-Monte", La Guardia.

CAMINO LÓPEZ, M. (s.f.): La ictiofauna asociada al yacimiento arqueológico del Castro de "O Achadizo", Cabo de Cruz. Campaña de Mayo de 1991. Informe inédito.

CAMINO LÓPEZ, M.; VÁZQUEZ VARELA, J.M.; REY, J.M. (1991): “Aportación al conocimiento de la ictiofauna asociada a yacimientos Holocenos costeros de Galicia". Comunicación presentada en la VIII Reunión Nacional sobre Cuaternario Ibérico (Valencia, Septiembre 1991). Inédito.

CANCELA CEREIJO, C. (2006): “5.3. Material lítico”. En Aboal Fernández, R. y Castro Hierro, V. (Coord.): O Castro de Montelaegre. Moaña, Pontevedra. Editorial Toxosoutos, Serie Keltia, 37: 205-234.

CAÑAS DÍAZ, J.M. (1992): Contribución al Atlas Osteológico de los Teleósteos Ibéricos II. Osteología comparada de los Lábridos Ibéricos. Tesis Doctoral. Departamento de Biología, Facultad de Ciencias, Universidad Autónoma de Madrid. Inédito.

CARBALLO ARCEO, L.X. (1996): “Os Castros Galegos: Espacio e arquitectura". Gallaecia 14/15: 309-351.

CARDERO LÓPEZ, J.L. (1980): "Breve estudio arqueológico de las Islas Cies". Museo y Archivo Histórico Diocesano, III: 339-373.

CARRILLO BOUTUREIRA, (1999): "La actividad pesquera en la Galicia de los ss. IX-XIII, a través de la diplomática medieval y la toponimia actual". Anuario Brigantino, 22: 105-134.

CARRO, X. (1987): “Xacemento antropo-arqueolóxico de Adro-Vello (San Vicenzo do Grove, Pontevedra)". Arqueoloxía. Informes, 1. Campaña 1987. Xunta de Galicia: 86-92.

CARRO, X. (1991): "Adro Vello (S. Vicenzo do Grove, Pontevedra)". Arqueoloxía. Informes, 2. Campaña 1988. Xunta de Galicia: 93-99.

CASAL, R.; ACUÑA, F.; VIDAL, L.; RODRÍGUEZ, A.; NODAR, C. (2004): “La fortaleza de "La Rocha Forte" (Santiago de Compostela): Trabajos arqueológicos 2002-2003". Gallaecia, 23: 195-204.

CASAL, R.; ACUÑA, F.; VIDAL, L.; NODAR, C.; RODRÍGUEZ, A.; ALLES, Mà.J. (2005): “La fortaleza de A Rocha Forte (Santiago de Compostela. Campaña de 2004". Gallaecia, 24: 193-218.

CASAL, R.; ACUÑA, F.; MARTÍNEZ, J.R.; SANTAMARÍA, G. (2006): “Fortaleza medieval de A Rocha Forte (Santiago de Compostela). Campaña de 2005". Gallaecia, 25: 147-171. 
CASAL, R.; ACUÑA, F.; MARTíNEZ, J.R.; SANTAMARIA, G. (2007): "V campaña de intervención no Castelo da Rocha Forte (Santiago de Compostela). Novas preliminares da actuación no ano 2006". Gallaecia, 26: 163-184.

CASAL, R.; ACUÑA, F. (2007): "La Arqueología de la fortaleza medieval de Rocha Forte (Santiago de Compostela)". En Mercedes López-Mayan Navarrete y Carlos J. Galbán Malagón (Coord.): Del documento escrito a la evidencia material. Actas del I Encuentro Compostelano de Arqueología medieval. Santiago de Compostela. Ed. Lóstrego: 87-114.

CASTAÑOS UGARTE, P. (1984). "Algunas observaciones acerca del Número de Restos (NR) y del Número Mínimo de Individuos (NMI) en los estudios de arqueozoología". Kobie, XIV: 319-322.

CASTRO, J.C. (1992/1993) "Intervención arqueolóxica no xacemento romano de "O Fiunchal”. (Alcabre, Vigo)" Castrelos, 5-6: 71-83.

CASTRO PAREDES, I.; INSUA LIÑARES, Mạ.; LÓPEZ PÉREZ, Mạ.C. (2003): “Aportaciones a la Arqueología urbana de A Coruña: La Casa Martelo a través de sus materiales". Brigantium, 14. Museo Arqueolóxico e Histórico da Coruña: 225-243.

CASTRO VIGO, E. (2008a): Excavación arqueolóxica en área nunha parcela situada en solo urbano no xacemento arqueolóxico Punta Atalaia, no entorno da Rúa Atalaia e Rúa do Faro. San Cibrao, Cervo (Lugo). Informe valorativo. Inédito.

CASTRO VIGO, E. (2008b): "Sondaxes arqueolóxicas valorativas nunha parcela situada no entorno do xacemento arqueolóxico de Punta Atalaia San Cibrao-Cervo (Lugo)". En Ramil Rego, E. (ed.): 1 Congreso Internacional de Arqueología de Vilalba, Férvedes, 5: 477-483.

CASTRO VIGO, E. (2009): "Sondaxes valorativas nunha parcela en solo urbano, no contorno do xacemento de Punta Atalaia e rúa do faro de San Cibrao, Cervo". Actuacións Arqueolóxicas. Ano 2007. Xunta de Galicia: 154-155.

CASTEEL, R.W. (1976): Fish Remains in Archaeology and Paleo-environmetal studies. Academic press: 180.

CEARRETA, A.; EDESO, J.M.; UGARTE, F.M. (1992): "Cambios del nivel del mar durante el Cuaternario reciente en el Gofo de Bizkaia". Cearreta, A. y Ugarte, F.M. (ed.): The late Quaternary in the Western Pyrenean region. Servicio Editorial Universidad del País Vasco: 57-94.

CHAIX, L.; MÉNIEL, P. (1996): Éléments d'Archéozoologie. Editions Errance, Paris.

CHAPLIN, R.E. (1971): The study of animal bones from archaeological sites. Seminar Press, London.

CLAASSEN, CH. (1998): Shells. Cambridge University Press. 
CLARK, G.A. (1976): El Asturiense Cantábrico. Biblioteca Prehistórica Hispana, Vol. XIII. Madrid.

CLASON, A.T. (1986): "Fish and Archaeology". En Brinkhuizen y Clason: Fish and archeology. Studies in osteometry, taphonomy, seasonality and fishing methods. BAR International Series 294: 34-41.

CLASON, A.T., PRUMMEL, W. (1977): "Collecting, Sieving and Archaeozoological Research". Journal of Archaeological Science, 4: 171-175.

CONCHEIRO COELLO, A. (2008a): "As intervencións arqueolóxicas nos castros de Neixón, 1996-1998: primeiros pasos para a súa posta en valor". En Ayán Vila (coord.): Os Castros de Neixón II. Editorial Toxosoutos. Serie Keltia, 40: 59-72.

CONCHERO COELLO, A. (2008b): Castro do Achadizo. Cultura material. Economía. Subsistencia na Idade do Ferro. Memoria das escavacións 1991-1994. Cuaderno Cultural 11, Concello de Boiro.

CORNIDE, J. (1774): Memoria sobre la pesca de sardina en las costas de Galicia. Bibliotheca regia monacensis.

CORNIDE, J. (1788): Ensayo de una historia de los peces y otras producciones marinas de la costa de Galicia, arreglado al sistema del caballero Carlos Linneo. Con un tratado de las diversas pescas y de las redes y aparejos con que se practican. Madrid.

COSTA CASAIS, M. (2008): “Análise xeomorfolóxica da punta de Neixón: espazo natural e espazo antropizado". En Ayán Vila (coord.): Os Castros de Neixón II. Editorial Tosoxoutos. Serie Keltia, 40: 75-96.

CRIADO BOADO, F.; AMADO REINO, X.; ABOAL FERNÁNDEZ, R. (2003): Excavación arqueolóxica no Castro de Montealegre (Moaña, Pontevedra). Memoria Técnica. Informe inédito, Laboratorio de Patrimonio, Paleoambiente e Paisaxe.

CURRÁS, B. (2007): “Aportación al conocimiento de la industria de salazón en las Rías Baixas Gallegas". En Lagostera, Bernal y Arévalo: CETARIAE 2005, Salsas y salazones de pescado en occidente durante la antigüedad. Actas del Congreso Internacional (Cádiz, 7-9 noviembre 2005). BAR Internacional Series 1686: 135-149.

DAVIS, S.; PAYNE, S. (2003): "101 modos de tratar un erizo muerto: notas sobre la preparación de esqueletos desarticulados para uso zooarqueológico". Archaeofauna, 12: 203-211.

DE PINHO, D.; LANHAS, F. (1971): "Pesos de rede ou pesos de pedra com entalhes para pesca. Tentativa de sistematizaçao". II Congresso Nacional Arqueologia, Coimbra: 581-589. 
DESSE, G. (1984): "Nouvelle contribution à la diagnose des pièces rachiennes des poissons". En Desse-Berset, N. (ed.): 2émes Recontres dàrchèo-Ichtyalogie. Notes Monographies Techniques, 16: 25-40.

DESSE, G.; DESSE, J. (1983): “L'identification des vertèbres de poissons; applications au matériel issu de sites archéologiques et paléontologiques". Arch. Sc. Genève, 36 (2): 291-296.

DESSE, J. (1984): "Propositions pous une réalization collective d'un corpus: fiches d'identification et d'explotation métrique du squelette des poissons". En DesseBerset, N. (ed.): 2émes Recontres dàrchèo-Ichtyalogie. Notes Monographies Techniques, 16: 67-86.

DESSE, J.; DESSE, G. (1988): “Els Peixos”. Cota Cero 4: 70-74.

DÍAZ MARTÍNEZ, P.C. (1993): "El alcance de la ocupación Sueva de Gallaecia y el problema de la germanización". Galicia da romanidade á xermanización. Problemas históricos e culturais. Actas do encontró científico en homenaxe a Fermín Bouza Brey (1901-1973). Santiago de Compostela: 209-226.

DRIESCH, A. VON DEN; BOESSNECK, J. (1969): "Die fauna des "Cabezo Redondo" bei Villena (Prov. Alicante)". Studien über frühe Tierknochenfunde von der Iberischen Halbinsel, 1: 45-89.

DRIESCH, A. VON DEN (1972): "Osteoarchäologische Untersuchngen auf der Iberinsel Halbinsel". Studien über frühe Tierknochenfunde von der Iberischen Halbinsel, 3: 1267.

DRIESCH, A. VON DEN (1973): "Nahrungsreste tierischer Herkunft aus einer tartessischen und einer spätbronzezeitlichen bis iberischen Siedlung in Südspanien". Studien über frühe Tierknochenfunde von der Iberischen Halbinsel, 4: 9-31.

DUPONT C. (2006): La malacofaune de sites mésolithiques et néolithiques de la façade atlantique de la France. Contribution à l'économie et à l'identité culturelle des groupes concernés. BAR Internacional Series 1571.

EDESO, J.M. (1994): “El relleno holoceno de la depresión de Zarauz". Lurralde, 17: 115-152.

EFREMOV, I.A. (1940): "Taphonomy: a new branch of Paleontology". Pan-American Geologist, 74: 81-93.

ESMORIS RECAMÁN, F. (1923): "Recuerdos históricos de la villa de Finisterre". El Ideal Gallego, 8-IX-1923.

FABEIRO GÓMEZ, M. (1990): Páxinas Históricas de Noia. Edicións sementeira.

FARIÑA BUSTO, F. (1974): "A Lanzada: introducción histórica". Museo de Pontevedra, 28: 73-82. 
FARIÑA BUSTO, F. (1975): "Excavación de A Lanzada (Sanxenxo-Pontevedra); Informe preliminar de la campaña". Museo de Pontevedra, 29: 165-173.

FARIÑA BUSTO, F.; ARIAS VILAS, F.; ROMERO MASIÁ, A. (1983): "Panorámica general sobre la cultura castrexa". En G. Pereira Menaut (Ed.): Estudos de Cultura Castrexa e Historia Antiga de Galicia. Universidade de Santiago - Instituto de Estudios Gallegos Padre Sarmiento, Santiago: 87-127.

FERNÁNDEZ OCHOA, C. (1993): "La ciudad hispanorromana en los territorios septentrionales de la Península Ibérica". En M. Bendala Galán (Dir.): La ciudad hispanorromana. Ministerio de Cultura, Barcelona: 224-245.

FERNÁNDEZ OCHOA, C.; MARTÍNEZ MAGANTO, J. (1994): “Las industrias de salazón en el norte de la Península Ibérica en época romana. Nuevas aportaciones" Archivo Español de Arqueología, 67: 115-134.

FERNÁNDEZ RODRÍGUEZ, C. (1992): Análisis de los restos óseos. Proxecto de inventario xeral e estudo da cerámica decorada, análise dos restos óseos e estudo e catalogación numismática do xacemento moderno do Parque da Palma, Baiona. Informe Inédito.

FERNÁNDEZ RODRÍGUEZ, C. (1998): Restos óseos de macromamíferos. Eirexa Vella-Bares (A Coruña), 1997. Sercivio de Arqueometría, Universidad de Santiago. Informe Inédito.

FERNÁNDEZ RODRÍGUEZ, C. (2000): Los macromamíferos en los yacimientos arqueológicos del Noroeste peninsular: un estudio económico. En Tesis Doctorales de la Universidad de Santiago de Compostela, Edición en cd-rom. Universidade de Santiago de Compostela.

FERNÁNDEZ RODRÍGUEZ, C. (2003): “VI.3-Análise dos restos óseos análise da fauna mariña". En Ramil González, E. (2003): "Villa romana de Bares excavación arqueolóxica no xacemento Eirexa-Vella de Bares-Concello de Mañón (A Coruña). Campaña de 1997". Brigantium, 14. Museo Arqueolóxico e Histórico da Coruña: 218-222.

FERNÁNDEZ RODRÍGUEZ, C. (2005/06): "La arqueozoología en el noroeste de la Península Ibérica: historia de las investigaciones". Munibe (Antropología-Arkeologia), 57/1: 511-523.

FERNÁNDEZ RODRÍGUEZ, C. (2008): “Os macromamíferos do Castro Grande d'o Neixón. Campaña de 2005". En Ayán Vila (coord.): Os Castros de Neixón II. Edit. Toxosoutos, Serie Keltia, 40: 225-247.

FERNÁNDEZ RODRÍGUEZ, C.; FUERTES PRIETO, N. (2003): “Análisis de la fauna de Maestro Copín y San Salvador del Nido (León)". En Fernández Freire, B.E.: La época romana en León: aspectos arqueológicos. Arqueología Leonesa II: 201-231. 
FERNÁNDEZ RODRÍGUEZ, C.; RODRÍGUEZ LÓPEZ, C. (1996): "Nuevos datos acerca de los recursos económicos del poblado castreño de Santa Trega (A Guardia, Pontevedra)". Gallaecia, 14/15: 359-392.

FERNÁNDEZ RODRÍGUEZ, C.; RODRÍGUEZ LÓPEZ, C.; FERRÉ, C.; REY, J.M. (1998): “Sondeos en el conchero del Castro de Punta de Cantodorxo (O Grove, Pontevedra): Análisis zooarqueológico". Gallaecia, 17: 177-197.

FERNÁNDEZ RODRÍGUEZ, C.; GONZÁLEZ GÓMEZ DE AGÜERO, E.; BEJEGA GARCÍA, V. (2008): "Estudio del conchero del Castro de Punta Atalaia (San Cibrao, Lugo)". En Ramil Rego, E. (ed.): 1 Congreso Internacional de Arqueología de Vilalba, Férvedes, 5: 4352.

FERNÁNDEZ RODRÍGUEZ, C.; BEJEGA GARCÍA, V.; GONZÁLEZ GÓMEZ DE AGÜERO, E. (e.p.): "Shellfish gathering during the Iron Age and Roman times in the Northwest of the Iberian Peninsula". Comunicación presentada en Archaeomalacology Session, ICAZ Paris 2010.

FERNÁNDEZ ROMÁN, E. (2006): La pesca en el mar desde la costa. Ediciones Tutor, Madrid.

FERRÉ, M.C. (s.f.): Análisis de la muestra faunística recuperada en la casa Martelo (A coruña, Galicia). Informe inédito.

FERRÉ, M.C. (1996): Contribución al estudio de las ictiofaunas holocenas en Galicia. Análisis de los yacimientos de As Hortas, Cantodorxo, Queiruga, O Achadizo, Facho de Donón y Adro Vello. Tesis de Licenciatura. Universidade de Santiago de Compostela, Inédita.

FERRÉ, M.C. (2003): Contribución al estudio de la Arqueictiofauna Holocena en Galicia. Tesis Doctoral. Departamento de Bioloxía Animal, Universidade de Santiago de Compostela, Inédita.

FERRÉ, M.C.; REY, J.M. (1997): "Datos preliminares sobre la ictiofauna del yacimiento medieval de la Torre de Hércules (A Coruña)". En: Rodríguez Vidal (Eds): Cuaternario Ibérico. Huelva: 115-118.

FERRÉ, M.C.; REY, J.M. (1998): “La ictioarqueología en Galicia: evolución de la pesca desde el periodo castreño al medieval". XIV Jornadas de Paleontología y Medioambiente. Libro de Resúmenes. Tenerife: 71-74.

FERRÉ, M.C.; REY, J.M. (2001): “Análisis preliminar de la ictiofauna del yacimiento medieval de Area (Viveiro, Lugo)”. En: G. Meléndez; Z. Herrera; G. Delvene; B. Azanza (Eds.). Los Fósiles y la Paleogeografía. XVII Jornadas de Paleontología (SEP). Seminarios de Paleontología de Zaragoza, v. 5.1. Albarracín: 318-322.

FERRÉ, M.C.; REY, J.M.; VÁZQUEZ VARELA, J.M.; RODRÍGUEZ LÓPEZ, C. (1995): “Análisis preliminar de la ictiofauna de castro "As Hortas" (Isla del Faro, Islas Cíes, 
Pontevedra)". En: Aleixandre, T. y A. Pérez-González (Eds.): Reconstrucción de Paleoamientes y cambios climáticos durante el Cuaternario. Monografías 3, Centro de Ciencias Medioambientales, CSIC, Madrid: 437-441.

FERRÉ, C.; FERNÁNDEZ RODRÍGUEZ, C.; RODRÍGUEZ LÓPEZ, C. (1996): “Análisis de la fauna recuperada en el conchero del castro de Punta de Cantodorxo (O Grove, Pontevedra, Galicia)". Real Sociedad Española de Historia Natural, Tomo Extraordinario 125 Aniversario de Fundación (Actas XII Bienal R.S.E.H.N., Madrid, 1996): 205-207.

FERRÉ, M.C.; REY, J.M.; CONCHEIRO, A.; VÁZQUEZ VARELA, J.M. (1996): “Contribución al conocimiento ictiológico del Castro de "O Achadizo" (Cabo de Cruz, Coruña, Galicia)". En Ramil-Rego, P.; Fernández Rodríguez, C.; Rodríguez Guitián, M. (coord.): Biogeografía Pleistocena-Holocena de la Península Ibérica. Universidad de Santiago: 291-296.

FERREIRA PRIEGUE, E. (1988): Galicia en el comercio marítimo medieval. Universidad de Santiago de Compostela, Santiago de Compostela.

FERREIRA PRIEGUE, E. (1990): "El comercio de las villas costeras de Galicia en la Baja Edad Media". Galicia en la Edad Media. Sociedad Española de Estudios Medievales, Madrid: 247-264.

FERREIRA PRIEGUE, E. (1990): "Galicia en las rutas del comercio medieval". Historia de Galicia, Tomo II, Baja Edad Media y comienzos de la Edad Moderna. Faro de Vigo: 425-440.

FERREIRA PRIEGUE, E. (1998): “O desenvolvemento da actividade pesqueira desde a Alta Idade Media ó século XVII". Fernández Casanova, C. (Coord.): Historia da pesca en Galicia. Biblioteca de Divulgación, Serie Galicia, no 24. Universidade de Santiago de Compostela: 51-86.

FERREIRA PRIEGUE, E. (2005): "Galicia en la Marisma de Castilla. La dinámica de los intercambios mercantiles". En Arizaga Bolumburu, B.; Solórzano Telechea, J.A.: Ciudades y Villas portuarias del Atlántico en la Edad Media. Encuentros Internacionales del medievo, Nájera, 27-30 de julio de 2004: 165-186.

FERREIRA PRIEGUE, E. (2009): "Pesca y economía regional en Galicia”. La pesca en la Edad media, Madrid: 11-34.

FILGUEIRA VALVERDE, J.; BLANCO FREIJEIRO, A. (1962): "Excavaciones de La Lanzada". Noticiario Arqueológico Hispánico, V: 137-152.

FORD, P.J. (1992): "Interpreting the grain size distributions of Archaeological shell". En Stein, J. K. (ed.): Deciphering a Shell Miden. Academic Press, Inc.: 283-325.

FRANCÉS, G.; ALEJO, I.; BERNÁRDEZ, P.; DIZ, P.; GONZÁLEZ ÁLVAREZ, R.; GRIMALT, J.; MENA, A.; NOMBELA, M.A.; PEMA, L.; PÉREZ ARLUCEA, M.; PREGO, R. (2009): 
"Marco climático mariño de Galicia na era preindustrial: Variabilidade climática natural a escala milenaria e submilenaria". En Pérez, V., Muñuzuri, Fernández Cañamero, M. y Gómez Gesteira, J.L. (Eds.): Evidencias e impactos do cambio climático em Galicia. Xunta de Galicia, Consellería de Medio Ambiente e Desenvolvemento Sostible. Vigo: 249-270.

FUERTES PRIETO, N.; FERNÁNDEZ RODRIGUEZ, C. (2010): “El comercio y consumo de moluscos en Época Romana en Asturica Augusta (León)". En González Gómez de Agüero, E.; Bejega García, V.; Fernández Rodríguez, C.; Fuertes Prieto, N. (eds.): I Reunión de Arqueomalacología de la Península Ibérica, Férvedes, 6: 147-158.

GÁlLEGO, L.; MITJANS, G. (1985): “La diversificación de los Sparidae (Pises) basada en las fórmulas dentarias". Trazos, 3: 1-27.

GARCÍA ALONSO, F. (1981/82): “Ordenación tipológica del instrumental de pesca en bronce Ibero-romano". Pyrenae, 17-18: 315-328.

GARCÍA FAJARDO, I.; FERNÁNDEZ PÉREZ, J. (1993): "La pesca en la Historia de la España llustrada". En Sáñez Reguart, A.: Colección de producciones de los mares de España. Edición preparada por Isabel García Fajardo y Joaquín Fernández Pérez. Ministerio de Agricultura, Pesca y Alimentación: 37-83.

GARCÍA MARTÍNEZ, M.C.; VÁZQUEZ VARELA, J.M. (1968): "La necrópolis de Adro Vello (San Vicente de O Grove)". Compostellanum, vol. XIII, no 4: 563-571.

GARCÍA ORO, J. (1977): Galicia en la Baja Edad Media. Iglesia, Señorío y Nobleza. Bibliófilos gallegos, Biblioteca de Galicia XVII. Santiago de Compostela.

GARCÍA VARGAS, E. (2006): "Pesca y salazones en la Bética Altoimperial". Historia de la pesca en el ámbito del estrecho. I Conferencia Internacional. Junta de Andalucía, Consejería de agricultura y pesca, Vol. 2: 531-576.

GARCÍA VARGAS, E.; BERNAL CASASOLA, D. (2009): "Roma y la producción de garum, y salsamenta en la costa meridional de Hispania. Estado actual de la investigación". En Bernal Casasola, D (ed.): Arqueología de la pesca en el Estrecho de Gibraltar. De la Prehistoria al fin del Mundo Antiguo. Monografías del proyecto SAGENA 1: 133181.

GAUTIER, A. (1987): “Taphonomic groups: how and why?". Archaeozoologia, I: 47-52.

GONZÁLEZ GARCÍA, F.J.; BRAÑAS ABAD, R. (1995): Historia de Galicia, Tomo II. Galicia romana. Vía Láctea Editorial, $A$ Coruña.

GONZÁLEZ GARCÍA-PAZ, S. (1933): “Noticias de las exploraciones arqueológicas en los Castros de Borneiro y Baroña". Boletín de la Universidad de Santiago, 17: 323-351. 
GONZÁLEZ GÓMEZ DE AGÜERO, E. (2009): El marisqueo en los castros galaico-romanos de la costa cantábrica gallega: el conchero de Punta Atalaya (San Cibrao, Cervo, Lugo). Tesina de Licenciatura. Universidad de León. Inédita.

GONZÁLEZ GÓMEZ DE AGÜERO, E.; BEJEGA GARCíA, V. (2011): “Pesca y marisqueo en la Ría de Arousa (Galicia) durante la Cultura Castreña". OrJIA (coord.): II Jornadas de Jóvenes en Investigación Arqueológica (Madrid, 6, 7 y 8 de mayo de 2009), Tomo I. Libros Pórticos: 299-302.

GONZÁLEZ GÓMEZ DE AGÜERO, E.; BEJEGA GARCÍA, V.; FERNÁNDEZ RODRÍGUEZ, C. (2011): Informe arqueomalacológico e ictioarqueológico del Castro de los Judíos (León), Campañas 1999-2005. 2011/03/CJ. Informe inédito.

GONZÁLEZ GÓMEZ DE AGÜERO, E.; BEJEGA GARCÍA, V.; FERNÁNDEZ RODRÍGUEZ, C.; ÁLVAREZ GARCÍA, J.C. (2010): "La presencia de moluscos en un yacimiento judío durante la Edad Media: El Castro de los Judíos (Puente Castro, León)”. En González Gómez de Agüero, E.; Bejega García, V.; Fernández Rodríguez, C.; Fuertes Prieto, N. (eds.): I Reunión de Arqueomalacología de la Península Ibérica, Férvedes, 6: 159168.

GONZÁLEZ GÓMEZ DE AGÜERO, E.; BEJEGA GARCÍA, V.; FERNÁNDEZ RODRÍGUEZ, C.; ÁlVAREZ GARCÍA, J.C. (2011): "Marisqueo, pesca y forja en el castro de Punta Atalaia (San Cibrao, Lugo): Avance de resultados del conchero". En Ramil Rego, E. y Fernández Rodríguez, C. (eds.): 2 Congreso Internacional de Arqueología de Vilalba, Férvedes, 7: 17-26.

GONZÁLEZ RUIBAL, A. (2006-07a): Galaicos. Poder y comunidad en el Noroeste de la Península Ibérica (1200 a.C.-50 d.C.), Tomo I. Brigantium 18-19. Museo Arqueolóxico e Histórico da Coruña.

GONZÁLEZ RUIBAL, A. (2006-07b): Galaicos. Poder y comunidad en el Noroeste de la Península Ibérica (1200 a.C.-50 d.C.), Tomo II. Brigantium 18-19. Museo Arqueolóxico e Histórico da Coruña.

GONZÁLEZ RUIBAL, A.; RODRÍGUEZ MARTÍNEZ, R.; ABOAL FERNÁNDEZ, R.; CASTRO HIERRO, V. (2007): "Comercio Mediterráneo en el Castro de Montealegre (Pontevedra, Galicia). Siglo II a.C.-Inicios del siglo I d.C.". Archivo Español de Arqueología, vol. 80: 43-74.

GONZÁLEZ RUIBAL, A.; RODRÍGUEZ MARTíNEZ, R.; AYÁN VILA, X. (2010): “Buscando a los Púnicos en el Noroeste". Mainake, XXXII (1): 577-600.

GUTIÉRREZ GONZÁLEZ, Mạ.M. (2003): “Ictiofauna”. En Gutiérrez González J.A.: Peñaferruz (Gijón). El Castillo de Curiel y su territorio. Serie Patrimonio 7, VTP editorial, Gijón: 347-352.

GUTIÉRREZ GONZÁLEZ, J.A. (2008): “El Castillo de Curiel (Peñaferruz, Gijón). Un Castillo Altomedieval en Asturias”. En Álvarez Martínez, V.; González Álvarez, D.; Jimémez 
Chaparro, J.I. (Coord.): Actas de las I Jornadas de Arqueología en Asturias (abrilmayo de 2005). Universidad de Oviedo: 111-131.

GUTIÉRREZ ZUGASTI, F.I. (2005): La explotación de moluscos en la cuenca baja del río Asón (Cantabria, España) a inicios del Holoceno (10.000-5.000 BP) y su importancia en las comunidades humanas del Aziliense y del Mesolítico. Trabajo de Investigación de Doctorado. Departamento de Ciencias Históricas, Universidad de Cantabria. Inédito.

GUTIÉRREZ ZUGASTI, I. (2009): La explotación de moluscos y otros recursos litorales en la región cantábrica durante el Pleistoceno final y el Holoceno inicial. PUbliCan Ediciones de la Universidad de Cantabria, Santander.

HIDALGO CUÑARRO, J.M. (1986): “Pesca y marisqueo en Galicia durante la Cultura Castreña". Arqueología, 14: 110-113.

HIDALGO CUÑARRO, J.M.; RODRÍGUEZ, E. (1995): “Excavación arqueolóxica de urgencia na Praia do Cocho, Alcabre (Vigo, Pontevedra)", Arqueoloxía/Informes, campaña 1989, Santiago: 165-168.

JALHAY, E. (1928): "La estación Asturiense de La Guardia (Galicia)". Boletín de la Comisión Provincial de Monumentos Históricos y Artísticos de Orense, t. VIII, no 179: 169186.

JALHAY, E. (1929): "Un nuevo conchero prehistórico descubierto en Galicia”. Boletín de la Comisión Provincial de Monumentos Históricos y Artísticos de Orense, t. VIII, no 189: 425-431.

JUAN-MUNS i PLANS, N.; RODRIGO GARCÍA, M.J., RODRÍGUEZ SANTANA, C.G. (1991): “La ictiofauna de los yacimientos arqueológicos. Sus posibilidades en la reconstrucción paleoecológica y de interpretación paleoeconómica". En Asunción Villa (coord.): Arqueología. Consejo Superior de Investigaciones Científicas, Madrid: 83-99.

KLEIN, R.G.; CRUZ-URIBE, K. (1984): "The anaysis of animal remains from Archaeological Sites". Chicago University Press, Chicago.

LEPIKSAAR, J. (1973): "Tierknochen von westphönizischen und phonizisch beeintlubten Ansiedlungen im Südspanischen küstengebeit". Studien über frühe Tierknochenfunde von der Iberischen Halbinsel, 4: 32-36, 109-127.

LEPIKSAAR, J. (1981-83): Osteología I. Pisces. (Sin publicar): 65.

LESTÓN GÓMEZ, M. (1991): “Casa Martelo (A Coruña)”. Arqueoloxía Informes 2, Campaña 1988, Xunta de Galicia, A Coruña: 183-190.

LÓPEZ CARREIRA, A. (2005): O reino medieval de Galicia. Historia de Galicia 5. Edicións A Nosa Terra. Vigo. 
LÓPEZ CUEVILLAS, F. (1953): La civilización céltica en Galicia. Porto y Cía Editores, Santiago de Compostela.

LÓPEZ CUEVILLAS, F. (1955): "El comercio y los medios de transporte de los pueblos castreños". Cuadernos de Estudios Gallegos, tomo X, fascículo XXXI: 145-157.

LÓPEZ CUEVILLAS, F. (1966): “A Economía nos tempos da Cultura Castrexa”. Grial, 13: 216275.

LÓPEZ CUEVILLAS, F.; BOUZA BREY, F. (1926): “O Neixón". Boletín de la Real Academia Gallega. Año XXI, no 181: 1-11; 32-38; 56-61; 76-83; 103-108.

LÓPEZ FERREIRO, A. (1895): Fueros municiaples de Santiago y de su tierra. Tomo II. Imp. Y Enc. Del Seminacio C. Central, Santiago de Compostela.

LÓPEZ GARCÍA, J. (1927): La Citania de Santa Tecla o una ciudad prehistórica desenterrada. La Guardia, Casa Táboas.

LORENZO, F; ALONSO, A.; PAGÉS, J.L. (2003): “Evolución y erosión comparada de tres sistemas playa/flecha en las Rías de Ortigueira, O Barquero y Viveiro (Galicia, España)". Rev. C\&G., 17 (1-2): 75-89.

LOSADA y DIÉGUEZ (1927): "Excavaciones en Montealegre (Domayo) Provincia de Pontevedra". Memoria de la Junta Superior de Excavaciones y Antigüedades 90, Madrid.

LOZANO CABO (1978): Oceanografía, Biología y Pesca. Tomo 1. Ed. Paraninfo, Madrid.

LOZANO CABO (1983): Oceanografía, Biología y Pesca. Tomo 2. Ed. Paraninfo, Madrid.

LUENGO Y MARTÍNEZ, J.Mạ. (1971): "Excavaciones en el Castro Céltico de Baroña (La Coruña) (Campañas de 1969-1970)". Noticiario Arqueológico Hispánico, XVI: 245264.

MACIÑEIRA, F. (1947): Bares. Puerto hispánico de la primitiva navegación occidental. Santiago de Compostela.

MACKAY, A.; DITCHBURN, D. (1999): Atlas de Europa Medieval. Cátedra.

MALUQUER DE MOTES, J. (1975): “Formación y desarrollo de la cultura castreña". I Jornadas de Metodología Aplicada de las Ciencias Históricas. I. Prehistoria e Historia Antigua (Santiago, 1973). Universidade de Santiago: 269-284.

MARY, G. (1992): “La evolución del litoral Cantábrico durante el Holoceno”. Cearreta, A. y Ugarte, F.M. (ed.): The late Quaternary in the Western Pyrenean región. Servicio Editorial Universidad del País Vasco: 161-170.

MARTINELL, J. (1982): Reseñas malacológicas II. Clasificación, sistemática y taxonomía. Sociedad Española de Malacología, Madrid. 
MARTÍNEZ CORTIZAS, A.; COSTA CASAIS, M. (1997): "Indicios de variaciones del nivel del mar en la Ría de Vigo durante los últimos 3000 años". Gallaecia, 16: 23-47.

MARTÍNEZ CORTIZAS, A.; VÁZQUEZ VARELA, J.M. (2002): “El clima en la Galicia Romana: una aproximación interdisciplinar". Revista Real Academia Galega de Ciencias, Vol. XXI: 87-104.

MARTÍNEZ MAGANTO, J. (1992a): "Las salazones romanas: Aportes historiográficos de interés en Arqueozoología”. Archaeofauna, 1: 73-81.

MARTÍNEZ MAGANTO, J. (1992b): "Las técnicas de pesca en la antigüedad y su implicación económica en el abastecimiento de las industrias de salazón" CUPAUAM, 19: 219244.

MARTINS, M. (1990): “O poboamento proto-histórico e a romaniçazao da bacia do curso médio do Cávado". Cadernos de Arqueologia, monografías, 5. Braga.

MEIGHAN, C.W. (1980): "Los moluscos como restos alimenticios en los sitios arqueológicos". En Brothwell, D. y Higgs, E. (Ed.): Ciencia en Arqueología, Madrid, F.C.E.:427-434.

MENENDEZ PIDAL, F. (1990): "El origen inglés de las armas de Galicia". Galicia en la Edad Media. Sociedad Española de Estudios Medievales, Madrid: 15-24.

MERGELINA LUNA, C. (1939-40): “El seudo Asturiense de La Guardia (Pontevedra)". Boletín del Seminario de Estudios de Arte y Arqueología, VI: 23-33.

MORALES MUÑIZ, A. (1979): "Informe sobre los restos faunísticos de la cueva de Cuartamentero (Asturias)". Trabajos de Prehistoria, 36: 497-509.

MORALES MUÑIZ, A. (1984): "A study on the representativity and taxonomy of the fish faunas from two mousterian sites on northern Spain with special reference to the trout (Salmo trutta I., 1758)". In N. Desse-Berset (ed.): 2émes rencontres d'ArchéoIchthyologie. Notes et Monographies Téchniques, 16. Paris: 41-59.

MORALES MUÑIZ, A. (1988): "Identificación e identificabilidad: cuestiones básicas de metodología zooarqueológica". Espacio, Tiempo y Forma (Serie I, Prehistoria) t. I: 455-470.

MORALES MUÑIZ, A. (2008): "De los peces a las redes: Las artes de pesca desde una perspectiva arqueoictiológica". Arqueobios, Vol.2: 40-63.

MORALES MUÑIZ, A.; MORENO NUÑO, R. (1992): “Peña Negra (Alicante): Efectos de la selección apriorística de muestras en arqueozoología". Archaeofauna, 1: 1-10.

MORALES MUÑIZ, A.; ROSELUND, K. (1979): "Fish bone measurement. An Attempt to Standardize the Measuring of Fish Bones from Archaeological Sites". Steenstrupia: 1-48. 
MORALES MUÑIZ, A.; ROSELLÓ IZQUIERDO, E. (1989): “Informe sobre la fauna ictiológica recuperada en una àmfora tardo-romana del tipus Keay XXVI (Spatheion)". TED'A: Un abocador del segle $\mathbf{V}$ d.C. en el fórum provincial de Tàrraco. Tarragona: 324328.

MORALES MUÑIZ, A.; ROSELLÓ IZQUIERDO, E. (1990): "Puerto-6: consideraciones osteométricas y culturales de la ictiofauna. Huelva arqueológica, XII: 469-484.

MORALES MUÑIZ, A.; ROSELLÓ IZQUIERDO, E. (2006): "La pesca en la Antigüedad andaluza: una perspectiva biológica". Historia de la pesca en el ámbito del estrecho. I Conferencia Internacional. Junta de Andalucía, Consejería de agricultura y pesca, Vol. 1: 37-80.

MORALES MUÑIZ, A.; ROSELLÓ IZQUIERDO, E. (2008): “Iruña-Veleia (Álava, Spain): an overview of the fish remains from the domus at Pompeia Valentia". En Béarez, P.; Grouard, S. y Clavel, B.: Archéologie du poisson. 30 ans D'archéo-ichtyologie au CNRS. Hommage aux travaux de Jean Desse et Nathalie Desse-Berset. XXVIII rencontres internationales d'archéologie et d'historie d'Antibes. XIV ICAZ Fish remains working group meeting. éditions APDGA, Antibes: 219-236.

MORALES MUÑIZ, A.; ROSELLÓ IZQUIERDO, E.; MORENO NUÑO, R.; LIESAU, C. (1992): "Plaza del Marqués: aproximación arqueozoológica preliminar a la fauna recuperada en el asentamiento romano de Cimadevilla (Gijón, Asturias)". Boletín de Ciencias Naturales R.I.D.E.A., 42: 51-62.

MORALES MUÑIZ, A.; ROSELLÓ IZQUIEDO, E.; MORENO NUÑO, R.; LIESAU, C. (1994): “La fauna del yacimiento de la Plaza del Marqués". En Fernández Ochoa, C.: Una industria de salazón de época romana en la Plaza del Marqués (Gijón, Asturias): 175-204.

MORALES MUÑIZ, D.C.; ROSELLÓ IZQUIERDO, E.; MORALES MUÑIZ, A. (2009): "Pesquerías medievales hispanas: Las evidencias arqueofaunísitcas". La pesca en la Edad Media, Monografías de la Sociedad Española de Estudios Medievales, № I: 145-165.

MORENO MARTÍN, F. (1997): “Ocupación territorial hispano-romana. Los Vici: poblaciones rurales”. Espacio, Tiempo y Forma (Serie II, Historia Antigua), 10: 295-306.

MORENO NUÑO, R. (1994): Análisis Arqueomalacológicos en la Península Ibérica: Contribución Metodológica y Biocultural. Tesis Doctoral. Departamento de Biología, Facultad de Ciencias, Universidad Autónoma de Madrid. Inédito.

NAVEIRO, J. (1991): El comercio antiguo en el N.W. peninsular. Museo A Coruña.

NIEVES POU, M.; GÁLLEGO, L. (1992): “Anatomía Comparada de los dientes faringeos de los Lábridos (Osteichthyes, Labridae)". En Alemany, A. (ed.): Historia Natural, 91: 49-59. 
NIVEAU DE VILLEDARY Y MARIÑAS, A.M. (2006): “Ofrendas de peces y moluscos en la necrópolis púnica de Cádiz. Una aproximación". Historia de la pesca en el ámbito del estrecho. I Conferencia Internacional. Junta de Andalucía, Consejería de agricultura y pesca, Vol. 2: 599-632.

NIVEAU DE VILLEDARY Y MARIÑAS, A.M.; CAMPANELLA, L. (2006): "Finalmente a la mesa: El consumo de pescado en el mundo fenicio-púnico". Historia de la pesca en el ámbito del estrecho. I Conferencia Internacional. Junta de Andalucía, Consejería de agricultura y pesca, Vol. 2: 633-701.

PAGÉS VALCARLOS (2000): “Origen y evolución geomorfológica de las Rías Atlánticas de Galicia”. Rev. Soc. Geol. España, 13 (3-4): 393-403.

PAGÉS VALCARLOS, J.L.; VIDAL ROMANÍ, J.R. (1998): "Síntesis de la evolución geomorfológica de Galicia Occidental". Geogaceta, 23: 119-122.

PALLARES MÉNDEZ, Mạ.C. (1991): "Las ciudades y la sociedad feudal”. Historia de Galicia, Tomo II, Baja Edad Media y comienzos de la Edad Moderna. Faro de Vigo: 269288.

PARCERO OUBIÑA, C.; AYÁN VILA, X. (2008): "Datacións de C-14 do Castro Grande de Neixón)." En Ayán Vila (coord.): Os Castros de Neixón II. Editorial Tosoxoutos. Serie Keltia, 40: 331-340.

PASSINI, J. (1994): "El espacio urbano a lo largo del Camino de Santiago". El Camino de Santiago y la Articulación del Espacio Hispánico. XX Semana de Estudios Medievales, Estella, 26 a 30 de julio de 1993. Gobierno de Navarra, Pamplona: 247269.

PATÓN DOMíNGUEZ, D. (1993): Contribución al Atlas Osteológico de los Teleósteos III. Osteología comparada de los Mugilidos Ibéricos. Tesis Doctoral. Departamento de Biología, Facultad de Ciencias, Universidad Autónoma de Madrid. Inédito.

PENA ÁLVAREZ, J.C. (2003): Guía de los peces de consumo de León. Universidad de León.

PENEDO ROMERO, R. (1988): “Datos paleontológicos sobre la ganadería castreña en Galicia". Trabalhos de Antropología e Etnología, XXVIII (3-4): 325-340.

PENEDO ROMERO, R. (1989): "A fauna dos xacementos arqueolóxicos de Galicia". Arqueoloxía / Informes, 1 (Campañas 1987). Xunta de Galicia: 154-160.

PEÑA SANTOS, A. DE LA (1992): "El primer milenio a.C. en el área gallega. Génesis y desarrollo del mundo castreño a la luz de la arqueología". Actas del Congreso de Paleontología de la Península Ibérica (Madrid, 1989). Complutum, 2-3: 373-394.

PEÑA SANTOS, A. DE LA (1996): “A secuencia cultural do mundo castrexo galaico”. En J.M. Hidalgo Cuñarro (Coord.). A Cultura Castrexa galega a debate. Instituto de Estudios Tudenses, Tui: 63-103. 
PEÑA SANTOS, A. DE LA; VÁZQUEZ VARELA, J.M. (1996): “Aspectos de la génesis y evolución de la Cultura Castrexa de Galicia”.Complutum Extra, 6 (I): 255-262.

PÉREZ ALBERTI, A.; BLANCO CHAO, R.; OTERO OTERO, M.; MACÍAS GARCÍA, I.; LÓPEZ BEDOYA, J. (2009): "Cambios ambientais detectados na costa de Galicia durante o Plistoceno e Holoceno e dinámica actual”. En Pérez, V., Muñuzuri, Fernández Cañamero, M. y Gómez Gesteira, J.L. (Eds.): Evidencias e impactos do cambio climático em Galicia. Xunta de Galicia, Consellería de Medio Ambiente e Desenvolvemento Sostible. Vigo: 425-454.

PÉREZ LOSADA, F. (1996): "Hacia una definición de los asentamientos rurales en la Gallaecia: poblados (vici) y casas de campo (villae)". En C. Fernández Ochoa (Coord.): Los Finisterres atlánticos en la antigüedad. Epoca prerromana y romana. Ayuntamiento de Gijón, Madrid: 189-197.

POPLIN, F. (1976): “A propos du nombre de restes et du nombre d'individus dans les échantillons d'ossements". Cahiers du Centre de Recherches Préhistoriques, 5: 6174.

RAGIR, S. (1988): "Revisión de las técnicas de muestreo arqueológico". Métodos de campo en Arqueología, México, F.C.E.: 322-344.

RAMIL GONZÁLEZ, E. (2003): “Villa romana de Bares excavación arqueolóxica no xacemento Eirexa-Vella de Bares-Concello de Mañón (A Coruña). Campaña de 1997". Brigantium, 14. Museo Arqueolóxico e Histórico da Coruña: 185-224.

RAMIL GONZÁLEZ, E. (2007): Escavación arqueolóxica en área para valoración dun cuncheiro Galico-romano en Punta Atalaia, no entorno do faro de San Cibrao, Cervo (Lugo). Informe valorativo. Inédito.

RAMIL GONZÁLEZ, E. (2008): "Villa romana e poboado medieval de Area (Viveiro, Lugo)". En Rarmil Rego, E. (ed.): 1 Congreso Internacional de Arqueoloxía de Vilalba, Férvedes, 5: 487-492.

RAMIL GONZÁLEZ, E. (2009): “Excavación en área para valoración dun concheiro galaicoromano en Punta Atalaia, no contorno do faro de San Cibrao, Cervo". Actuacións Arqueolóxicas. Ano 2007. Xunta de Galicia: 152-153.

RAMIL REGO, E.; FERNÁNDEZ RODRÍGUEZ, C.; RODRÍGUEZ LÓPEZ, C.; LÓPEZ PÉREZ, C.; FERNÁNDEZ PINTOS, P. (1995): "El yacimiento de Punta do Castro (Reinante, Barreiros, Lugo). Materiales de superficie y perspectivas". Férvedes, 2: 87-115.

RAMIL REGO, P.; FERNÁNDEZ RODRÍGUEZ, C. (1999): “La explotación de los recursos alimenticios en el Noroeste Ibérico". En M.V. García Quintela: Mitología y mitos de la Hispania Prerromana, III. Ediciones Akal, 198, Madrid: 296-319.

RAMIL GONZÁLEZ, E.; PICOS BRAGE, F. (2002): A rehabilitación de la Capela de San Xiao de Trevo (Cariño, A Coruña). Deputación da Coruña. 
RAMIL SONEIRA, J.M. (1973): "Paradero de Reiro". Cuadernos de Estudios Gallegos, XXVIII: 23- 31.

REAL ACADÉMIA DE LA LENGUA (2001): Diccionario de la lengua española (22a ed.). Espasa-Calpe. Madrid.

REY GARCÍA, J.M. (2011): “Guidoiro Areoso (Illa de Arousa, Pontevedra): Un pequeño islote con una intensa ocupación entre el Neolítico final y la Edad del Bronce". En Prieto Martínez, Mạ. y Salanova, L. (Coord.): Las Comunidades Campaniformes en Galicia. Cambios sociales en el III y II milenios BC en el NW de la Península Ibérica. Diputación de Pontevedra: 201-210.

RIESTA MÉNDEZ, E. (2007): Los comido y los servido: Una aproximación a la alimentación en Asturias desde los primeros tiempos hasta la Edad Moderna. Ed. Trea.

RIVAS MANTECÓN, V. (2000): “Clima y nivel del mar: reconstrucción de las posiciones marinas cuaternarias a través de las evidencias en el litoral cantábrico". En García Cordón, J.C. (Coord.): La reconstrucción del clima en época preinstrumental (V reunión nacional de climatología). Servicio de publicaciones de la Universidad de Cantabria, Santander: 179-212.

RODRÍGUEZ COLMENERO, A. (1979): Augusto e Hispania. Conquista y organización del Norte peninsular. Deusto / Bilbao.

RODRÍGUEZ COLMENERO, A. (1996a): "El nacimiento de la ciudad en el Noroeste Hispánico". En VV.AA.: A Guerra en Galicia. O rural e o urbano na Historia de Galicia (III e IV Semanas Galegas de Historia). Asociación Galega de Historiadores, Santiago: 267-276.

RODRÍGUEZ COLMENERO, A. (1996b): "La integración de Gallaecia en los dominios romanos: fases de su conquista". En A. Rodríguez Colmenero (Coord.): Lvcvs Avgvsti. I. El amanecer de una ciudad. Fundación Pedro Barrié de la Maza, A Coruña: 245-263.

RODRÍGUEZ COLMENERO, A. (1996c): "Integración administrativa del NW peninsular en las estructuras romanas". En A. Rodríguez Colmenero (Coord.). Lvcvs Avgvsti. I. El amanecer de una ciudad. Fundación Pedro Barrié de la Maza, A Coruña: 265-300.

RODRÍGUEZ GONZÁLEZ, A. (ed.) (1995): O tumbo Vermello de Don Lope de Mendoza. IPSEG.CSIC. Santiago de Compostela MCMXCV.

RODRÍGUEZ LÓPEZ, C. (1992): Nuevas aportaciones al estudio del aprovechamiento de los recursos marinos en los castros gallegos: el Castro de Cabo de Cruz. Trabajo de Investigación de Tercer Ciclo. Departamento de Historia I, Universidade de Santiago. Inédito.

RODRÍGUEZ LÓPEZ, C. (1993a): “Unha aproximación ao estudio da explotación do mar na Prehistoria e Historia Antiga de Galicia a traves do analise dos concheiros" Historia 
Nova I: Contribución dos Xovenes Historiadores de Galicia. Asociación Galega de Historiadores: 5-14.

RODRÍGUEZ LÓPEZ, C. (1993b): Informe sobre la realización del proyecto: Sondaje y toma de muestras en los concheros de los castros de Queiruga y Facho de Donón. Dirección Xeral do Patrimonio Histórico e Documental. Xunta de Galicia. Inédito.

RODRÍGUEZ LÓPEZ, C. (1994): Informe sobre la realización del proyecto: toma de muestras en los concheros de los castros de Islas Cies, Peneda del Viso, Punta de Cantodorxo y Punta do Castro. Dirección Xeral do Patrimonio Histórico e Documental. Xunta de Galicia. Inédito.

RODRíGUEZ LÓPEZ, C. (2002): “Análise do conchero de San Xiao de Trevo”. En Ramil González, E. Y Picos Brage, F.: A rehabilitación de la Capela de San Xiao de Trevo (Cariño, A Coruña). Deputación da Coruña: 65-77.

RODRÍGUEZ LÓPEZ, C.; FERNÁNDEZ RODRÍGUEZ, C. (1996): “Una aproximación al estudio de los yacimientos castreños del litoral galaico: dimensiones ambientales y económicas". En Ramil-Rego, P.; Fernández Rodríguez, C.; Rodríguez Guitián, M. (coord.): Biogeografía Pleistocena-Holocena de la Península Ibérica. Universidad de Santiago: 363-375.

RODRÍGUEZ LÓPEZ, C.; FERNÁNDEZ RODRÍGUEZ, C.; VÁZQUEZ VARELA, J.M.; FERRÉ, M.C.; REY, J.M. (1996): "Nuevos datos acerca del aprovechamiento del medio natural en los yacimientos castreños del litoral galaico: el caso de las Islas Cies". Preactas del VI Coloquio Galaico-Minhoto. Ourense: 273-275.

RODRÍGUEZ MARTÍNEZ, R.; ABOAL FERNÁNDEZ, R.; CASTRO HIERRO, V.; CANCELA CEREIJO, C.; RODRÍGUEZ PAZ, A. (2010): Intervención arqueolóxica para a recuperación patrimonial do xacemento de A Lanzada (Sanxenxo, Pontevedra). Informe técnico inédito.

RODRÍGUEZ MARTÍNEZ, R.; ABOAL FERNÁNDEZ, R.; CASTRO HIERRO, V.; CANCELA CEREIJO, C.; AYÁN VILA, X. (2011): “Una posible factoría prerromana en el noroeste. Primeras valoraciones de la intervención en el Campo de A Lanzada (Sanxenxo, Pontevedra)". En Ramil Rego, E. y Fernández Rodríguez, C. (ed.): 2 Congreso Internacional de Arqueología de Vilalba, Férvedes, 7: 167-173.

RODRíGUEZ PANTOJA, M. (2006): "La pesca en los textos grecolatinos". Historia de la pesca en el ámbito del estrecho. I Conferencia Internacional. Junta de Andalucía, Consejería de agricultura y pesca, Vol. 1: 109-146.

RODRÍGUEZ SOLÓRZANO, M.; REGUEIRO, S.D.; GARRIDO, L.S. (1983): Guía dos peixes de Galicia. Vigo. Ed. Galaxia.

ROMERO MASÍA, A.M. (1980): "Asentamientos Castrexos costeiros no Norte de Galicia". Gallaecia, 6: 61-80. 
ROSELLÓ IZQUIERDO, E. (1988): Contribución al Atlas Osteológico de los Teleósteos Ibéricos. I. Dentario y Articular. Ediciones de la Universidad Autónoma de Madrid.

ROSELLÓ IZQUIERDO, E. (1989): Arqueoictiofaunas Ibéricas. Aproximación metodológica y Bio-cultural. Tesis Doctoral. Departamento de Biología, Facultad de Ciencias, Universidad Autónoma de Madrid. Inédito.

ROSELLÓ IZQUIERDO, E. (1992): "La ictiofauna recuperada en el istmo de Ceuta". Archaeofauna, 1: 23-32.

ROSELLÓ IZQUIERDO, E.; MORALES MUÑIZ, A. (2005/2006): “Ictiofaunas musterienses de la Península Ibérica: ¿Evidencias de pesca Neandertal?”. MUNIBE, 57: 183-195.

ROSENLUND, K.; MORALES, A. (1984): “Osteometría de osteictios: algunas consideraciones metológicas”. II Reunión Iberoamericana para la Conservación Zoológica de Vertebrados: 1-13.

RYDER, M.L. (1980): "Restos de peces y de otros animales acuáticos". En Brothwell, D. y Higgs, E. (Ed.): Ciencia en Arqueología, Madrid, F.C.E.: 384-405.

RUBINOS PÉREZ, A.; FÁBREGAS VALCARCE, R.; ALONSO MATHIAS, F.; CONCHEIRO COELLO, A. (1999): "Las fechas C-14 del Castro de O Achadizo (Boiro, A Coruña): Problemática de la calibración de conchas marinas". Trabajos de Prehistoria, 56 (1): 147-155.

SALAS, L.; REMONDO, J.; MARTíNEZ, P. (1996): "Cambios en el nivel del mar durante el Holoceno en el Cantábrico a partir del estudio de la turbera de Trengandín". En Grandal d'Anglade, A. y Pagés Valcarlos, J. (eds.): IV Reunión de Geomorfología. Sociedad Española de Geomorfología: 237-247.

SALANOVA, L.; PRIETO, Ma.P. (2011): “Una aproximación al empleo de la concha para decorar la cerámica campaniforme en Galicia”. En Prieto Martínez, Mạp. y Salanova, L. (Coord.): Las Comunidades Campaniformes en Galicia. Cambios sociales en el III y II milenios BC en el NW de la Península Ibérica. Diputación de Pontevedra: 297307.

SANTOS YANGUAS, J. (1985): Comunidades indígenas y administración romana en Hispania. Vitoria.

SERJEANTSON, D.; WOOLGAR, C.M. (2006) "Fish Consumption in Medieval England". En Woolgar, C.M.; Serjeantson, D. y Waldron, T.: Food in Medieval England. Diet and Nutrition. Oxford University press: 102-130.

SIERRA ABOAL, A. (1994): Sargos y doradas de las Rías Bajas. Diputación Provincial de Pontevedra, Vigo. 
SINDE VÁZQUEZ, A. (2008): Excavación en área nunha parcela situada en solo urbano no xacemento arqueolóxico Punta Atalaia, no entorno da Rúa do Faro de San Cibrao. Informe valorativo. Inédito.

SILVA, A.C.F. DA (1983/84): “A cultura castreja no Noroeste de Portugal: hábitat e cronologias". Portugália, nova série, IV/V: 121-129.

SUÁREZ, M. (trad.) (1950): Historia Compostelana, Santiago.

SUÁREZ OTERO, J Y FARIÑA BUSTO, F. (1990): “A Lanzada (Sanxenxo, Pontevedra), definición e interpretación de un yacimiento castreño atípico. Apuntes para un estudio de los intercambios protohistóricos en la costa atlántica peninsular". Madrider Mitteilungen, 31: 309-337.

TÓRRES, J. (2007): “¿Redes o líneas de pesca? El problema de la asignación morfofuncional de los pesos líticos y sus implicancias en las tácticas de pesca de los grupos del extremo Austral de Sudamérica". Magallania, 35(1): 53-70.

TORRES, C.; CASTRO, J.C.; PRIETO, S. (2007): “La factoría romana de salazón del yacimiento de "O Areal", Vigo (Galicia): Un complejo industrial salazonero Altoimperial". En Lagostera, Bernal y Arévalo: CETARIAE 2005, Salsas y salazones de pescado en occidente durante la antigüedad. Actas del Congreso Internacional (Cádiz, 7-9 noviembre 2005). BAR Internacional Series 1686: 475-485.

VÁZQUEZ GÓMEZ, X.L. (1996): “Excavación en la calle de la Franja 9-11. A Coruña”. Gallaecia, 14-15: 425-427.

VÁZQUEZ MARTÍNEZ, Ma.A. (2003): “Los vídrios de época romana procedentes de las actuaciones arqueológicas practicadas en 1988 en la Casa Martelo (A Coruña)". Brigantium, 14. Museo Arqueolóxico e Histórico da Coruña: 245-253.

VÁZQUEZ SEIJAS, M. (1952): "Factorías pesqueras en la playa de Area". Boletín de la Comisión Provincial de Monumentos Históricos y Artísticos de Lugo. Tomo V: 110114.

VÁZQUEZ VARELA, J.M. (1973): "Bases paleontológicas para el estudio de la ganadería de la cultura castreña”. Compostellanum, XVIII: 309-316.

VÁZQUEZ VARELA, J.M. (1975a): "El conchero del Castro de Queiruga (La Coruña)". Boletín del Seminario de Estudios de Arte y Arqueología de la Universidad de Valladolid, 40/41: 500-503.

VÁZQUEZ VARELA, J.M. (1975b): "Estudio del conchero protohistórico de las Islas Cíes". Actas de las I Jornadas de Metodología aplicada a las Ciencias Históricas. I Prehistoria e Historia Antigua. Santiago de Compostela: 291-295.

VÁZQUEZ VARELA, J.M. (1976): “Bases paleontológicas para el estudio de la pesca en la Cultura Castreña: Una investigación preliminar". Boletín Auriense, VI: 83-86. 
VÁZQUEZ VARELA, J.M. (1978): "La pesca en la Cultura Castreña de Galicia”. BRAÑA. Boletín de la Sociedad Gallega de Historia Natural: 79-90.

VÁZQUEZ VARELA, J.M. (1980): "La economía Castreña al Norte del Miño". Actas do Seminario de Arqueología do NO Penínsular, Vol. II, Guimarães: 197-204.

VÁZQUEZ VARELA, J.M. (1983a): "La alimentación y la cocina en la cultura castreña de Galicia” Studia Zamorensi, 4: 392-398.

VÁZQUEZ VARELA, J.M. (1983b): "Los testimonios económicos". Estudos de Cultura Castrexa e de Historia Antigua de Galicia. Santiago: 147-158.

VÁZQUEZ VARELA, J.M. (1984): "The fishing in the Castro's Culture". The Fishing Culture of the World. Akadémiai Kiado, Budapest: 435-445.

VÁZQUEZ VARELA, J.M. (1988): "El marisqueo en los castros de las rías gallegas". Coloquio de etnografía marítima: 209-219.

VÁZQUEZ VARELA, J.M. (1996): “Del mar al camino, del camino a la mesa: la fauna marina de las excavaciones arqueológicas de 1986, 1990 y 1991". En Rodríguez Colmenero, A. (coord.): Lucus Augusti. I. El amanecer de una ciudad. Fundación Pedro Barrié de la Maza, A Coruña: 107-122.

VÁZQUEZ VARELA, J.M. (1998): “O aproveitamento dos recursos mariños na prehistoria e a antigüedade de Galicia”. En Fernández Casanova (Coord.): Historia da Pesca en Galicia. Biblioteca de Divulgación, Serie Galicia, № 24, Universidad de Santiago de Compostela: 13-49.

VÁZQUEZ VARELA, J.M.; REY, J.M.; CAMINO, M. (1993): "La pesca en el mundo castreño y romano en Galicia". Galicia da romanidade á xermanización. Problemas históricos e culturais. Actas do encontró científico en homenaxe a Fermín Bouza Brey (19011973). Santiago de Compostela: 91-100.

VÁZQUEZ VARELA, J.M.; RODRÍGUEZ LÓPEZ, C. (1995): “Nuevas aportaciones metodológicas al estudio de los concheros castreños del noroeste de la Península Ibérica: El Castro de Punta dos Prados (Ortigueira, La Coruña, Galicia)". Zephyrus, XLVIII: 199-222.

VÁZQUEZ VARELA, J.M.; RODRÍGUEZ LÓPEZ, C. (1995/1996): “La fauna marina del Castro de Punta dos Prados (Espasante, Ortigueira, La Coruña)". Brigantium, 9: 75-106.

VÁZQUEZ VARELA, J.M.; RODRÍGUEZ LÓPEZ, C. (1999/2000): “El aprovechamiento de los recursos marinos en la prehistoria y la antigüedad de Galicia". Boletín do Museo Provincial de Lugo, IX: 335-365.

VEGA DEL SELLA, R.E. Conde de la (1923): El Asturiense. Nueva industria preneolítica. Serie Prehistórica, 27. Vol. 32, Museo Nacional de Ciencias Naturales, Madrid. 
WASELKOV, G.A. (1987): "Shellfish gathering and shell midden archaeology". En Schiffer, M.B. (ed.): Advances in archaeological method and theory, Vol. 10. Academic Press: 93-210.

WHEELER, A. (1978): "Problems of identification and interpretation os archaeological fish remains". En Brothwell, D.R.; Thomas, R.D.; Clutton.Brock, J.: Research problems in zooarchaeology. Unversity of London, Institute os Archaeology, Occasional publication no 3, London: 69-75.

WHEELER, A.; JONES, A. K.G. (1989): Fishes. Cambridge Manuals in Archaeology. Cambridge University Press.

WIDMER, R. (1989): "Archaeological Research Strategies in the Investigarion of ShellBearing Sites, a Florida Perspective". Paper delivered at the Annual Meeting of the Society for American Archaeology, Atlanta. 



\section{ÍNDICE DE FIGURAS.}

Fig. 1 Periodización de la Cultura Castreña según varios autores................................................................33

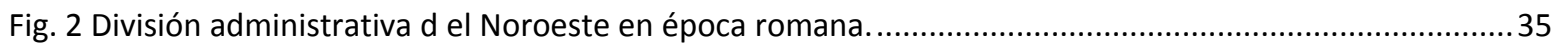

Fig. 3 División administrativa de la Península Ibérica durante el siglo XII y XIII ................................................40

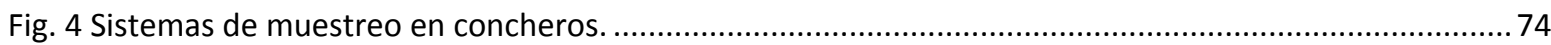

Fig. 5 Partes que conforman el esqueleto de los peces y principales huesos cefálicos documentados en los

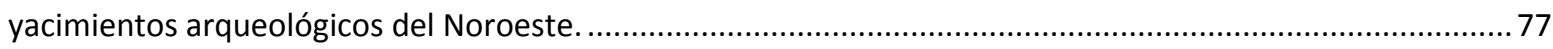

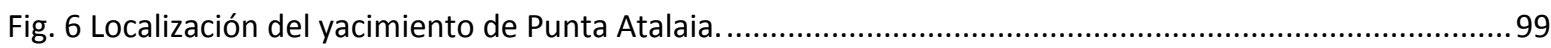

Fig. 7 Topográfico 1:5.000 de San Cibrao y localización de las intervenciones.............................................100

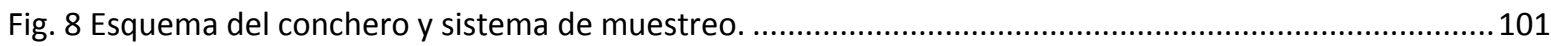

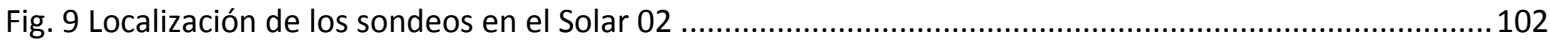

Fig. 10 Conchero de Punta Atalaia antes de la intervención arqueológica.......................................................103

Fig. 11 Vista general del Solar 02 y acumulación de vértebras de Merluccius merluccius................................104

Fig. 12 Distribución de taxones identificados en la Muestra A-1 según el NR. ................................................105

Fig. 13 Distribución esquelética de los restos ícticos de la Muestra A-1...........................................................106

Fig. 14 Distribución de taxones identificados en la Muestra A-2 según el NR. ...............................................107

Fig. 15 Distribución esquelética de los restos ícticos de la Muestra A-2 ..........................................................107

Fig. 16 Distribución de taxones identificados en la Muestra A-3 según el NR. ................................................108

Fig. 17 Distribución esquelética de los restos ícticos de la Muestra A-3.......................................................108

Fig. 18 Distribución de taxones identificados en la Muestra B-1 según el NR. ..............................................109

Fig. 19 Distribución esquelética de los restos ícticos de la Muestra B-1.......................................................110

Fig. 20 Distribución de taxones identificados en la Muestra B-2 según el NR. .............................................111

Fig. 21 Distribución esquelética de los restos ícticos de la Muestra B-2 …..................................................111

Fig. 22 Distribución de taxones identificados en la Muestra C-1 según el NR. ..............................................112

Fig. 23 Distribución esquelética de los restos ícticos de la Muestra C-1.....................................................112

Fig. 24 Distribución de taxones identificados en la Muestra C-2 según el NR. ...............................................113

Fig. 25 Distribución esquelética de los restos ícticos de la Muestra C-2 .........................................................114

Fig. 26 Distribución de taxones identificados en la Muestra C-3 según el NR. ...............................................114

Fig. 27 Distribución esquelética de los restos ícticos de la Muestra C-3.....................................................115

Fig. 28 Distribución de taxones identificados en el Nivel 3-Capa 4 según el NR............................................115

Fig. 29 Distribución de taxones identificados en el Sondeo 1-Nivel 2-Capa 5 según el NR.............................116

Fig. 30 Distribución esquelética de los restos ícticos del Sondeo 1-Nivel 2-Capa 5.........................................116

Fig. 31 Distribución de taxones identificados en el Sondeo 2-Nivel 2-Capa 5 según el NR..............................117

Fig. 32 Distribución esquelética de los restos ícticos del Sondeo 2-Nivel 2-Capa 5.........................................118 
Fig. 33 Distribución de taxones identificados en el Sondeo B/4-Nivel 2-Capa 2 según el NR. 119

Fig. 34 Distribución esquelética de los restos ícticos del Sondeo B/4-Nivel 2-Capa 2. 119

Fig. 35 Distribución de taxones identificados en el Sondeo A/4-Nivel 2-Capa 3 según el NR. 120

Fig. 36 Distribución esquelética de los restos ícticos del Sondeo A/4-Nivel 2-Capa 3. 120

Fig. 37 Distribución de taxones identificados en el Sondeo A/4-Nivel 2-Capa 3 según el NR. 121

Fig. 38 Distribución esquelética de los restos ícticos del Sondeo A/4-Nivel 2-Capa 3. 121

Fig. 39 Distribución de taxones identificados en el Sondeo A/7-Nivel 2-Capa 3 según el NR. 122

Fig. 40 Distribución esquelética de los restos ícticos del Sondeo A/7-Nivel 2-Capa 3. 122

Fig. 41 Distribución de taxones identificados en el Sondeo B/4-Nivel 2-Capa 3 según el NR. 123

Fig. 42 Distribución esquelética de los restos ícticos del Sondeo B/4-Nivel 2-Capa 3. 123

Fig. 43 Distribución de taxones identificados en el Sondeo B/5-Nivel 2-Capa 3 según el NR. 124

Fig. 44 Distribución esquelética de los restos ícticos del Sondeo B/5-Nivel 2-Capa 3. 124

Fig. 45 Distribución de taxones identificados en el Sondeo A/3-Nivel 2-Capa 4 según el NR. 127

Fig. 46 Distribución esquelética de los restos ícticos del Sondeo A/3-Nivel 2-Capa 4.

Fig. 47 Distribución de taxones identificados en el Sondeo B/5-Nivel 2-Capa 4 según el NR. 128

Fig. 48 Distribución esquelética de los restos ícticos del Sondeo B/5-Nivel 2-Capa 4. 128

Fig. 49 Distribución de taxones identificados en el Sondeo B/8-Nivel 2-Capa 4 según el NR. 129

Fig. 50 Distribución de taxones identificados en el Sondeo C/2-Nivel 2-Capa 4 según el NR. 130

Fig. 51 Distribución esquelética de los restos ícticos del Sondeo C/2-Nivel 2-Capa 4. 130

Fig. 52 Distribución de taxones identificados en el Sondeo B/4-Nivel 2-Capa 5 según el NR. 131

Fig. 53 Distribución esquelética de los restos ícticos del Sondeo B/4-Nivel 2-Capa 5. 131

Fig. 54 Distribución de taxones identificados en el Sondeo F/1-Nivel 3-Capa 6 según el NR. 133

Fig. 55 Distribución esquelética de los restos ícticos del Sondeo F/1-Nivel 3-Capa 6. 133

Fig. 56 Distribución de taxones identificados en el Sondeo C/1-Nivel 2-Capa 3 según el NR. 134

Fig. 57 Distribución esquelética de los restos ícticos del Sondeo C/1-Nivel 2-Capa 3 134

Fig. 58 Distribución de taxones identificados en el Sondeo F/1-Nivel 2-Capa 3 según el NR. 135

Fig. 59 Distribución esquelética de los restos ícticos del Sondeo F/1-Nivel 2-Capa 3. 135

Fig. 60 Distribución de taxones identificados en el Sondeo C/1-Nivel 2-Capa 4 según el NR. 136

Fig. 61 Distribución esquelética de los restos ícticos del Sondeo C/1-Nivel 2-Capa 4. 136

Fig. 62 Distribución de taxones identificados en el Sondeo B/1-Nivel 2-Capa 5 según el NR.

Fig. 63 Distribución esquelética de los restos ícticos del Sondeo B/1-Nivel 2-Capa 5.

Fig. 64 Distribución de taxones identificados en el Sondeo A-Nivel 1-Capa 2 según el NR 139

Fig. 65 Distribución esquelética de los restos ícticos del Sondeo A-Nivel 1-Capa 2. 139

Fig. 66 Distribución de taxones identificados en el Sondeo B-Nivel 1-Capa 2 según el NR 140 
Fig. 67 Distribución de taxones identificados en el Sondeo D/1-Nivel 1-Capa 2 según el NR. 141

Fig. 68 Distribución esquelética de los restos ícticos del Sondeo D/1-Nivel 1-Capa 2 ................................141

Fig. 69 Distribución de taxones identificados en el Sondeo D/2-Nivel 1-Capa 2 según el NR.........................142

Fig. 70 Distribución esquelética de los restos ícticos del Sondeo D/2-Nivel 1-Capa 2................................142

Fig. 71 Representatividad de los taxones identificados en el conchero según el NR................................143

Fig. 72 Centros vertebrales de los principales taxones identificados........................................................ 145

Fig. 74 Comparación numérica de los restos cefálicos y postcefálicos de los taxones identificados...............146

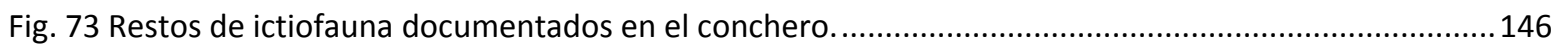

Fig. 75 Comparación numérica de las vértebras caudales y precaudales de los taxones identificados...........147

Fig. 76 Representatividad de los taxones de época romana identificados en el Solar 02 según el NR...........147

Fig. 78 Comparación numérica de los restos cefálicos y postcefálicos de los taxones identificados..............150

Fig. 77 Faringobranquial y ceratobranquiales de Labrus bergylta. ......................................................... 150

Fig. 79 Comparación numérica de las vértebras caudales y precaudales de los taxones identificados...........151

Fig. 80 Representatividad de los taxones de época medieval identificados en el Solar 02 según el NR. ........152

Fig. 82 Comparación numérica de los restos cefálicos y postcefálicos de los taxones identificados...............154

Fig. 81 Vértebras precaudales de Merluccius merluccius en conexión anatómica......................................154

Fig. 83 Comparación numérica de las vértebras caudales y precaudales de los taxones identificados...........155

Fig. 84 Representatividad de los taxones de época moderna identificados en el Solar 02 según el NR. ........155

Fig. 85 Comparación numérica de los restos cefálicos y postcefálicos de los taxones identificados...............157

Fig. 86 Comparación numérica de las vértebras caudales y precaudales de los taxones identificados...........158

Fig. 87 Localización del yacimiento de Area................................................................................ 162

Fig. 88 Topográfico 1:5.000 de Area y localización de las intervenciones.. ................................................163

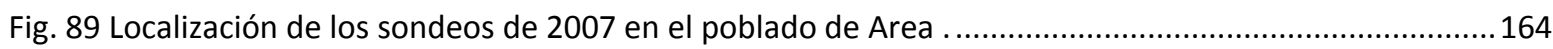

Fig. 90 Distribución de taxones identificados en la Capa 5 del Sector S22 según el NR................................166

Fig. 91 Distribución esquelética de los restos ícticos de la Capa 4 del Sector T24......................................167

Fig. 92 Distribución de taxones identificados en la Capa 4 del Sector AB30 según el NR............................168

Fig. 93 Distribución esquelética de los restos ícticos de la Capa 4 del Sector AB30....................................168

Fig. 94 Distribución de taxones identificados en la Capa 6 del Sector R22 según el NR. ..............................169

Fig. 95 Distribución esquelética de los restos ícticos de la Capa 6 del Sector R22 .....................................170

Fig. 96 Representatividad de los taxones de época medieval según el NR..............................................171

Fig. 98 Comparación numérica de los restos cefálicos y post-cefálicos de los taxones identificados. ............173

Fig. 99 Comparación numérica de las vértebras caudales y precaudales de los taxones identificados...........173

Fig. 97 Huesos cefálicos y vétebras precaudales de Merluccius merluccius. ...............................................173

Fig. 100 Representatividad de los taxones identificados en el conchero según el NR.................................175 
Fig. 101 Comparación numérica de los restos cefálicos y post-cefálicos de los taxones identificados. ..........175

Fig. 102 Comparación numérica de las vértebras caudales y precaudales de los taxones identificados.........176

Fig. 103 Localización del yacimiento de Taramancos.....................................................................179

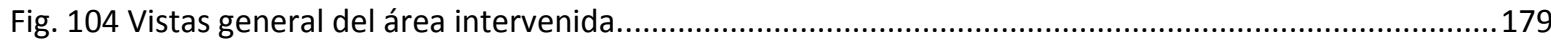

Fig. 105 Topográfico 1:5.000 de Taramancos y localización de las intervenciones. ....................................180

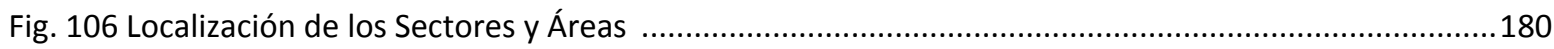

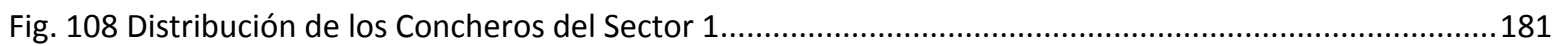

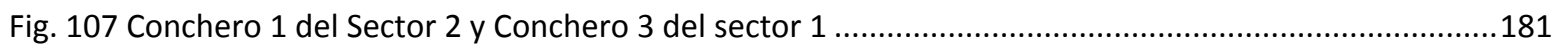

Fig. 109 Distribución de los Concheros del Sector 2 (Plano cedido por AMBIOTEC).....................................182

Fig. 110 Distribución de taxones identificados en el $1^{\text {er }}$ Rebaje del Conchero 3 según el NR........................184

Fig. 111 Distribución esquelética de los restos ícticos del $1^{\mathrm{er}}$ Rebaje del Conchero 3.................................184

Fig. 112 Distribución de taxones identificados en el 2ำ Rebaje del Conchero 3 según el NR. ........................185

Fig. 113 Distribución esquelética de los restos ícticos del 2o Rebaje del Conchero 3...................................185

Fig. 114 Distribución esquelética de los restos ícticos de la UE 1 del Conchero 5.....................................186

Fig. 115 Distribución de taxones identificados en la UE 2 del Conchero 5 según el NR..............................187

Fig. 116 Distribución esquelética de los restos ícticos de la UE 2 del Conchero 5.....................................187

Fig. 117 Distribución de taxones identificados en el $1^{\mathrm{er}}$ Rebaje del Conchero 9 según el NR.......................188

Fig. 118 Distribución esquelética de los restos ícticos del $1^{\mathrm{er}}$ Rebaje del Conchero 9. ...............................189

Fig. 119 Distribución de taxones identificados en el 2ㅇ Rebaje del Conchero 9 según el NR. .......................190

Fig. 120 Distribución esquelética de los restos ícticos del 2o Rebaje del Conchero 9...................................190

Fig. 121 Distribución de taxones identificados en el $1^{\mathrm{er}}$ Rebaje del Conchero 1 según el NR......................191

Fig. 122 Distribución esquelética de los restos ícticos del $1^{\mathrm{er}}$ Rebaje del Conchero 1 ..................................192

Fig. 123 Distribución de taxones identificados en el 2으. Rebaje del Conchero 1 según el NR........................193

Fig. 124 Distribución esquelética de los restos ícticos del 2o Rebaje del Conchero 1..................................193

Fig. 125 Distribución de taxones identificados en el $3^{\text {er }}$ Rebaje del Conchero 1 según el NR.......................194

Fig. 126 Distribución esquelética de los restos ícticos del $3^{\mathrm{er}}$ Rebaje del Conchero 1 .................................194

Fig. 127 Distribución de taxones identificados en el $1^{\text {er }}$ Rebaje del Conchero 5 según el NR........................195

Fig. 128 Distribución esquelética de los restos ícticos del $1^{\mathrm{er}}$ Rebaje del Conchero 5. .................................196

Fig. 129 Distribución de taxones identificados en el 2ㅇ Rebaje del Conchero 5 según el NR........................197

Fig. 130 Distribución esquelética de los restos ícticos del 2ㅇ Rebaje del Conchero 5..................................197

Fig. 131 Distribución de taxones identificados en el $3^{\text {er }}$ Rebaje del Conchero 5 según el NR.......................198

Fig. 132 Distribución esquelética de los restos ícticos del $3^{\mathrm{er}}$ Rebaje del Conchero 5.................................199

Fig. 133 Representatividad de los taxones identificados según el NR. ........................................................199

Fig. 134 Restos de ictiofauna del Sondeo 2, Capa 5, $3^{\text {er }}$ rebaje...............................................................200 
Fig. 135 Distribución biométrica $(\mathrm{mm}$.) de vértebras caudales de Pagellus bogaraveo en yacimientos castreños y de medievales

Fig. 136 Distribución biométrica $(\mathrm{mm}$.) de vértebras caudales de Pagellus acarne en yacimientos castreños y medievales.

Fig. 137 Distribución biométrica de vértebras caudales de Trisopterus luscus en yacimientos medievales y prerromanos.

Fig. 138 Restos óseos de Sardina pilchardus (izquierda) y Merluccius merluccius (derecha). .202

Fig. 139 Comparación numérica de los restos cefálicos y post-cefálicos de los diferentes taxones identificados.

Fig. 140 Comparación numérica de las vértebras caudales y precaudales de los diferentes taxones identificados. .204

Fig. 141 Distribución biométrica de vértebras precaudales de Merluccius merluccius en yacimientos medievales y en la Ría de Arousa..... 205

Fig. 142 Localización del Castro de O Neixón. 207

Fig. 143 Topográfico 1:5.000 de la Punta de O Neixón. 208

Fig. 144 Castro de O Neixón Grande: Sector 02 y conchero en el interior del foso 208

Fig. 145 Planimetría Castro de O Neixón Grande y localización de los sectores 209

Fig. 146 Planimetría del Sector 02 del Castro Grande de O Neixón 210

Fig. 147 Columna de muestras del conchero y fosa con restos de fauna marina. 211

Fig. 148 Perfíl del Conchero localizado en el Foso 01 211

Fig. 149 Distribución esquelética de los restos ícticos de la UE031. .213

Fig. 150 Distribución esquelética de los restos ícticos de la UE032. 213

Fig. 151 Distribución de taxones identificados en la UE058 según el NR. 215

Fig. 152 Distribución esquelética de los restos ícticos de la UE058. 216

Fig. 153 Representatividad de los taxones según el NR.

Fig. 154 Comparación numérica de los restos cefálicos y post-cefálicos de los diferentes taxones identificados.

Fig. 155 Comparación numérica de las vértebras caudales y precaudales de los diferentes taxones identificados.

Fig. 156 Distribución biométrica $(\mathrm{mm}$.) de los taxones identificados en el Castro de O Neixón (NX) y Comparación con otros yacimientos gallegos citados en este trabajo 219

Fig. 157 Restos de ictiofauna del conchero del Foso 1. 220

Fig. 158 Localización del yacimiento de A Lanzada. 221

Fig. 159 Topográfico 1:5.000 de Punta Lanzada y localización de las intervenciones.

Fig. 160 Superficie excavada en la Campaña de 2010

Fig. 161 Planimetría A Lanzada campaña de 2010

Fig. 162 Echadizos de conchas 
Fig. 163 Distribución de taxones identificados en MU100630B02 según el NR....................................225

Fig. 164 Distribución esquelética de los restos ícticos de MU100630B02 .............................................226

Fig. 165 Distribución esquelética de los restos ícticos de MU100804B03. ..............................................227

Fig. 166 Relación de especies y representación ósea de MU100728B01...............................................227

Fig. 167 Distribución de taxones identificasdos en MU100728B01 según el NR. ....................................228

Fig. 168 Distribución esquelética de los restos ícticos de MU100728B01. ................................................228

Fig. 169 Distribución de taxones identificados en MU100722B02 según el NR..........................................229

Fig. 170 Distribución esquelética de los restos ícticos de MU100722B02 ..............................................229

Fig. 171 Distribución de taxones identificados en MU100727B02 según el NR..........................................230

Fig. 172 Distribución esquelética de los restos ícticos de MU100727B02 ..............................................230

Fig. 173 Distribución de taxones identificados en MU100810B03 según el NR......................................231

Fig. 174 Distribución esquelética de los restos ícticos de MU100810B03. ................................................231

Fig. 175 Distribución esquelética de los restos ícticos de MU100722B04. .................................................232

Fig. 176 Distribución de taxones identificados en MU100831B02 según el NR........................................234

Fig. 177 Distribución esquelética de los restos ícticos de MU100831B02 .............................................234

Fig. 178 Distribución de taxones identificados en MU100813B06 según el NR.......................................235

Fig. 179 Distribución esquelética de los restos ícticos de MU100813B06.............................................236

Fig. 180 Distribución de taxones identificados en MU100826B01 según el NR......................................237

Fig. 181 Distribución esquelética de los restos ícticos de MU100826B01. ..............................................237

Fig. 182 Distribución esquelética de los restos ícticos de MU100826B01..............................................238

Fig. 183 Distribución de taxones identificados en MU100827B04 según el NR.......................................240

Fig. 184 Distribución esquelética de los restos ícticos de MU100827B04. ...............................................240

Fig. 186 Distribución de taxones identificados en MU100827B07 según el NR..........................................241

Fig. 185 Vértebras con marcas de corte y aplastamiento. ...................................................................241

Fig. 187 Distribución esquelética de los restos ícticos de MU100827B07. ................................................242

Fig. 188 Representatividad de los taxones según el NR. ...............................................................242

Fig. 189 Distribución del NR de Symphodus melops y Labrus bergylta en las diferentes muestras................243

Fig. 190 Distribución del NR de Trachurus trachurus y Pagellus bogaraveo en las diferentes muestras.........244

Fig. 191 Distribución del NR de Pagrus pagrus, Diplodus sargus y Scomber japonicus en las diferentes

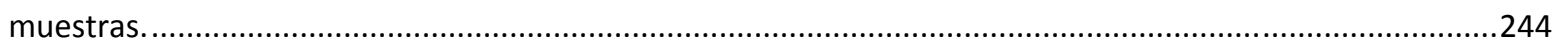

Fig. 192 Distribución del NR de Trisopterus luscus y Pagellus acarne en las diferentes muestras..................245

Fig. 193 Comparación numérica de los restos cefálicos y post-cefálicos de los diferentes taxones

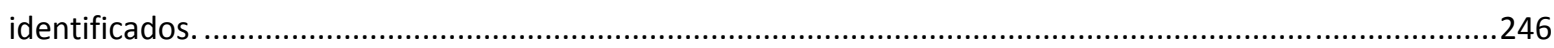

Fig. 194 Comparación numérica de las vértebras caudales y precaudales de los diferentes taxones identificados. 
Fig. 195 Representatividad de los taxones según el NR. 249

Fig. 196 Comparación numérica de los restos cefálicos y post-cefálicos de los taxones identificados. 249

Fig. 197 Comparación numérica de las vértebras caudales y precaudales de los taxones identificados 250

Fig. 198 Restos óseos de Symphodus melops y Labrus bergylta. 250

Fig. 199 Posible pesa de red recuperada en la intervención de 2010. .251

Fig. 200 Detalle de varias piletas de la estructura productiva. .252

Fig. 201 Localización del yacimiento de Montealegre. .253

Fig. 202 Topográfico 1:5.000 de Montealegre y localización de las intervenciones. .254

Fig. 203 Localización de las intervenciones de 2004 254

Fig. 204 Conchero de la ladera Este .255

Fig. 205 Planimetría de la Ladera Oeste. 257

Fig. 206 Localización de los muestreos en la ladera Este 258

Fig. 208 Distribución esquelética de los restos ícticos de MU040712101. 262

Fig. 207 Distribución de taxones identificados en MU040712101 por muestras según el NR. 262

Fig. 209 Distribución de taxones identificados en MU040712102 por muestras según el NR. .264

Fig. 210 Distribución esquelética de los restos ícticos de MU040712102. .265

Fig. 212 Distribución esquelética de los restos ícticos de MU040629B01. 267

Fig. 211 Distribución de taxones identificados en MU040629B01 por muestras según el NR .267

Fig. 213 Distribución de taxones identificados en MU040426I01 por muestras según el NR. .270

Fig. 214 Distribución esquelética de los restos ícticos de MU040426I01. 271

Fig. 215 Distribución de taxones identificados en MU040510J01 por muestras según el NR. .273

Fig. 216 Distribución esquelética de los restos ícticos de MU040510J01. .274

Fig. 218 Representatividad de los taxones según el NR. 277

Fig. 217 Útiles de pesca documentados en Montelaegre .277

Fig. 219 Vértebras de Sardina pilchardus y Trisopterus luscus. 279

Fig. 220 Comparación numérica de los restos cefálicos y postcefálicos de los diferentes taxones identificados. 280

Fig. 221 Comparación numérica de las vértebras caudales y precaudales de los diferentes taxones identificados.

Fig. 222 Representatividad de los taxones según el NR. 281

Fig. 223 Comparación numérica de los restos cefálicos y post-cefálicos de los taxones identificados. 282

Fig. 224 Comparación numérica de las vértebras caudales y precaudales de los taxones identificados....... 283

Fig. 225 Representatividad de los taxones según el NR. .283

Fig. 226 Comparación numérica de los restos cefálicos y post-cefálicos de los taxones identificados. 285

Fig. 227 Comparación numérica de las vértebras caudales y precaudales de los taxones identificados .285 
Fig. 228 Localización del yacimiento de Punta do Muiño do Vento.......................................................28

Fig. 229 Topográfico 1:5.000 de Punta do Muiño y localización de las intervenciones. ...............................289

Fig. 230 Planimetría del Castro de Punta do Muiño do Vento ..............................................................289

Fig. 231 Distribución de taxones identificados según el NR.............................................................290

Fig. 232 Distribución esquelética de los restos ícticos. ....................................................................290

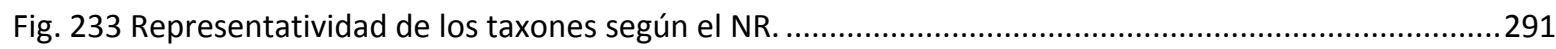

Fig. 234 Comparación numérica de los restos cefálicos y post-cefálicos de los diferentes taxones

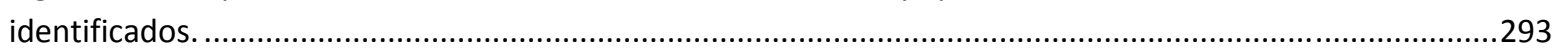

Fig. 235 Comparación numérica de las vértebras caudales y precaudales de los diferentes taxones

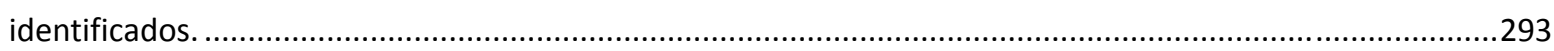

Fig. 236 Localización del yacimiento del Castelo da Rocha...............................................................295

Fig. 237 Reconstrucción de la planta del Castillo ..............................................................................295

Fig. 238 Localización de los sectores intervenidos entre las campañas de 2002 y 2005 (Casal García et alii,

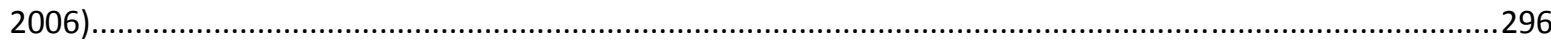

Fig. 239 Representatividad de los taxones según el NR.................................................................298

Fig. 240 Distribución biométricas (en mm.) de las vértebras caudales de Torres del Oeste (TO) y el Castelo da

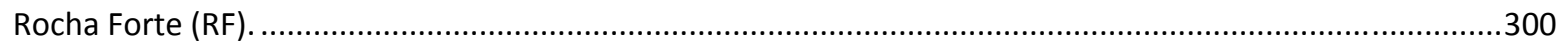

Fig. 241 Restos ícticos documentados en el Castelo da Rocha y epihial de Conger conger con marcas de corte. 300

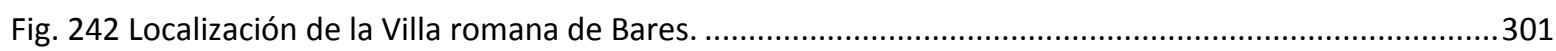

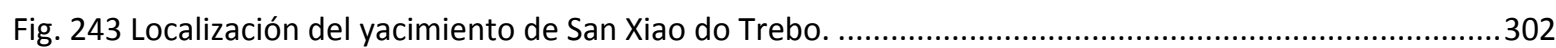

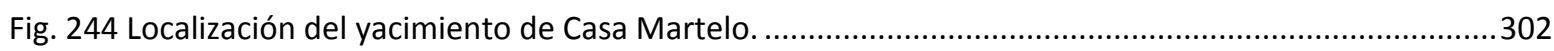

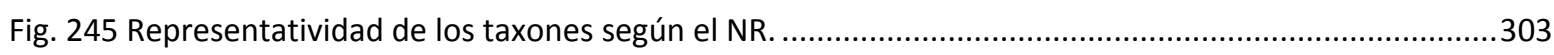

Fig. 246 Comparación numérica de los restos cefálicos y postcefálicos de los taxones identificados.............304

Fig. 247 Comparación numérica de las vértebras caudales y precaudales de los taxones identificados.........304

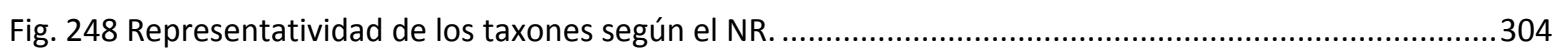

Fig. 249 Comparación numérica de los restos cefálicos y post-cefálicos de los taxones identificados. ..........305

Fig. 250 Comparación numérica de las vértebras caudales y precaudales de los taxones identificados.........305

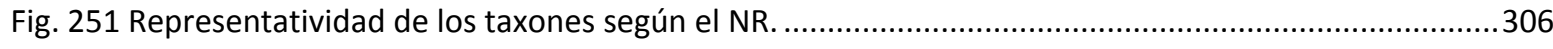

Fig. 252 Comparación numérica de los restos cefálicos y post-cefálicos de los taxones identificados. ..........306

Fig. 253 Comparación numérica de las vértebras caudales y precaudales de los taxones identificados.........306

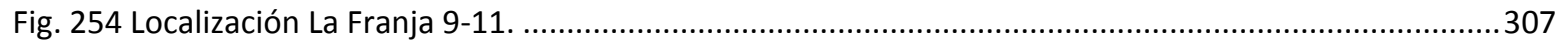

Fig. 255 Representatividad de los taxones según el NR. ..................................................................308

Fig. 256 Comparación numérica de los restos cefálicos y postcefálicos de los taxones identificados.............308

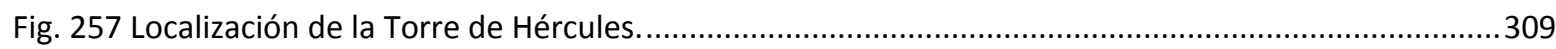

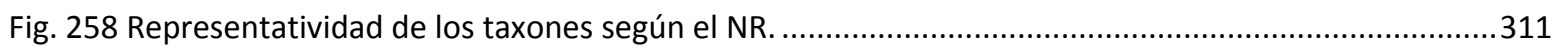


Fig. 259 Comparación numérica de los restos cefálicos y post-cefálicos de los taxones identificados. 311

Fig. 260 Comparación numérica de las vértebras caudales y precaudales de los taxones identificados 312

Fig. 261 Localización del Castro de Queiruga. 312

Fig. 262 Comparación numérica de los restos cefálicos y postcefálicos del taxón identificado. .313

Fig. 263 Localización del Castro de O Achadizo. 313

Fig. 264 Representatividad de los taxones según el NR. .315

Fig. 265 Comparación numérica de los restos cefálicos y postcefálicos de los taxones identificados. 316

Fig. 266 Comparación numérica de las vértebras caudales y precaudales de los taxones identificados. 316

Fig. 267 Representatividad de los taxones según el NR. 317

Fig. 268 Comparación numérica de los restos cefálicos y post-cefálicos de los taxones identificados. .317

Fig. 269 Comparación numérica de las vértebras caudales y precaudales de los taxones identificados .318

Fig. 270 Representatividad de los taxones según el NR. 318

Fig. 271 Comparación numérica de los restos cefálicos y postcefálicos de los taxones identificados. 319

Fig. 272 Comparación numérica de las vértebras caudales y precaudales de los taxones identificados. 319

Fig. 273 Localización de Torres del Oeste.

Fig. 274 Representatividad de los taxones según el NR.

Fig. 275 Comparación numérica de los restos cefálicos y postcefálicos de los taxones identificados. .321

Fig. 276 Comparación numérica de las vértebras caudales y precaudales de los taxones identificados.

Fig. 277 Localización del Castro de Cantodorxo.

Fig. 278 Representatividad de los taxones según el NR

Fig. 279 Comparación numérica de los restos cefálicos y postcefálicos de los taxones identificados. .323

Fig. 280 Comparación numérica de las vértebras caudales y precaudales de los taxones identificados .324

Fig. 281 Representatividad de los taxones según el NR. 324

Fig. 282 Comparación numérica de los restos cefálicos y postcefálicos de los diferentes taxones. .325

Fig. 283 Comparación numérica de las vértebras caudales y precaudales de los diferentes taxones. .325

Fig. 284 Localización de Adro Vello. 325

Fig. 285 Comparación numérica de los restos cefálicos y postcefálicos de los taxones identificados. .326

Fig. 286 Comparación numérica de las vértebras caudales y precaudales de los taxones identificados. .326

Fig. 287 Localización del Castro de A Suvidá. 326

Fig. 288 Localización de Igresiña. 327

Fig. 289 Localización del Castro de As Hortas. 328

Fig. 290 Representatividad de los taxones según el NR. .329

Fig. 291 Comparación numérica de los restos cefálicos y postcefálicos de los diferentes taxones identificados. 
Fig. 292 Comparación numérica de las vértebras caudales y precaudales de los diferentes taxones identificados.

Fig. 293 Localización del Castro del Facho de Donón. 330

Fig. 294 Representatividad de los taxones según el NR. 331

Fig. 295 Comparación numérica de los restos cefálicos y postcefálicos de los taxones identificados. 332

Fig. 296 Comparación numérica de las vértebras caudales y precaudales de los taxones identificados 332

Fig. 297 Localización del yacimiento de A Palma. 332

Fig. 298 Representatividad de los taxones según el NR. 333

Fig. 299 Comparación numérica de los restos cefálicos y postcefálicos de los diferentes taxones identificados.

Fig. 300 Comparación numérica de las vértebras caudales y precaudales de los diferentes taxones identificados.

Fig. 301 Localización del Castro de Santa Trega.

Fig. 302 Importancia de las especies a partir del cálculo del ICxID de los yacimientos prerromanos. 341

Fig. 303 Distribución de los principales taxones en la Ría de Vigo según la situación del yacimiento 343

Fig. 304 Distribución de los principales taxones en la Ría de Arousa según la situación del yacimiento 343

Fig. 305 Localización de los yacimientos con muestras del Siglo V-II a.C. 345

Fig. 306 Localización de los yacimientos con muestras del Siglo II a.C.-I d.C. 348

Fig. 307 Importancia de las especies a partir del cálculo del ICxID de los yacimientos de época romana.......354

Fig. 308 Localización de los yacimientos con muestras de época romana. 363

Fig. 309 Importancia de las especies a partir del cálculo del ICxID de los yacimientos medievales. 366

Fig. 310 Importancia de las especies a partir del cálculo del ICxID de los yacimientos modernos. 369

Fig. 311 Detalle del proceso de secado de Conger conger y cabrias de Muxía. ( 373

Fig. 312 Localización de los yacimientos con muestras de los siglos XIII-XV d.C.

Fig. 314 Localización de los yacimientos con muestras de época moderna. 


\section{ÍNDICE DE TABLAS.}

Tabla 1 Pesos iniciales (en gr.) del conchero por componentes. 104

Tabla 2 Relación de especies y representación ósea de la Muestra A-1 .................................................105

Tabla 3 Relación de especies y representación ósea de la Muestra A-2 ...............................................106

Tabla 4 Relación de especies y representación ósea de la Muestra A-3 ....................................................108

Tabla 5 Relación de especies y representación ósea de la Muestra B-1 ...................................................109

Tabla 6 Relación de especies y representación ósea de la Muestra B-2 .....................................................110

Tabla 7 Relación de especies y representación ósea de la Muestra C-1 .................................................112

Tabla 8 Relación de especies y representación ósea de la Muestra C-2 ...................................................113

Tabla 9 Relación de especies y representación ósea de la Muestra C-3 ......................................................114

Tabla 10 Relación de especies y representación ósea del Nivel 3-Capa 4. ...............................................115

Tabla 11 Relación de especies y representación ósea del Sondeo 1-Nivel 2-Capa 5..................................116

Tabla 12 Relación de especies y representación ósea del Sondeo 2-Nivel 2-Capa 4...................................117

Tabla 13 Relación de especies y representación ósea del Sondeo 2-Nivel 2-Capa 5...............................117

Tabla 14 Relación de especies y representación ósea del Sondeo 3-Nivel 2-Capa 5..................................118

Tabla 15 Relación de especies y representación ósea del Sondeo A/3-Nivel 2-Capa 2. ...............................118

Tabla 16 Relación de especies y representación ósea del Sondeo B/4-Nivel 2-Capa 2...............................118

Tabla 17 Relación de especies y representación ósea del Sondeo A/2-Nivel 2-Capa 3. ..............................119

Tabla 18 Relación de especies y representación ósea del Sondeo A/4-Nivel 2-Capa 3. ..............................120

Tabla 19 Relación de especies y representación ósea del Sondeo A/5-Nivel 2-Capa 3..............................120

Tabla 20 Relación de especies y representación ósea del Sondeo A/6-Nivel 2-Capa 3. ................................121

Tabla 21 Relación de especies y representación ósea del Sondeo A/7-Nivel 2-Capa 3................................122

Tabla 22 Relación de especies y representación ósea del Sondeo B/3-Nivel 2-Capa 3.................................122

Tabla 23 Relación de especies y representación ósea del Sondeo B/4-Nivel 2-Capa 3................................123

Tabla 24 Relación de especies y representación ósea del Sondeo B/5-Nivel 2-Capa 3...............................124

Tabla 25 Relación de especies y representación ósea del Sondeo B/6-Nivel 2-Capa 3..................................125

Tabla 26 Relación de especies y representación ósea del Sondeo B/7-Nivel 2-Capa 3.................................125

Tabla 27 Relación de especies y representación ósea del Sondeo C/2-Nivel 2-Capa 3.................................125

Tabla 28 Relación de especies y representación ósea del Sondeo C/5-Nivel 2-Capa 3..................................125

Tabla 29 Relación de especies y representación ósea del Sondeo C/6-Nivel 2-Capa 3..................................125

Tabla 30 Relación de especies y representación ósea del Sondeo C/7-Nivel 2-Capa 3.................................126

Tabla 31 Relación de especies y representación ósea del Sondeo F/3-Nivel 2-Capa 3..................................126

Tabla 32 Relación de especies y representación ósea del Sondeo A/1-Nivel 2-Capa 4...............................126 
Tabla 33 Relación de especies y representación ósea del Sondeo A/3-Nivel 2-Capa 4...............................126

Tabla 34 Relación de especies y representación ósea del Sondeo A/4-Nivel 2-Capa 4................................127

Tabla 35 Relación de especies y representación ósea del Sondeo A/5-Nivel 2-Capa 4................................127

Tabla 36 Relación de especies y representación ósea del Sondeo B/5-Nivel 2-Capa 4...............................128

Tabla 37 Relación de especies y representación ósea del Sondeo B/6-Nivel 2-Capa 4................................128

Tabla 38 Relación de especies y representación ósea del Sondeo B/8-Nivel 2-Capa 4..................................129

Tabla 39 Relación de especies y representación ósea del Sondeo C/2-Nivel 2-Capa 4................................129

Tabla 40 Relación de especies y representación ósea del Sondeo D/1-Nivel 2-Capa 4...............................130

Tabla 41 Relación de especies y representación ósea del Sondeo B/4-Nivel 2-Capa 5.................................130

Tabla 42 Relación de especies y representación ósea del Sondeo C/3-Nivel 2-Capa 5................................131

Tabla 43 Relación de especies y representación ósea del Sondeo C/6-Nivel 2-Capa 5................................132

Tabla 44 Relación de especies y representación ósea del Sondeo C/1-Nivel 3-Capa 6.................................132

Tabla 45 Relación de especies y representación ósea del Sondeo C/2-Nivel 2-Capa 6.................................132

Tabla 46 Relación de especies y representación ósea del Sondeo F/1-Nivel 3-Capa 6.................................132

Tabla 47 Relación de especies y representación ósea del Sondeo F/1-Nivel 3-Capa 8................................133

Tabla 48 Relación de especies y representación ósea del Sondeo C/1-Nivel 2-Capa 3................................134

Tabla 49 Relación de especies y representación ósea del Sondeo F/1-Nivel 2-Capa 3.................................135

Tabla 50 Relación de especies y representación ósea del Sondeo C/1-Nivel 2-Capa 4................................136

Tabla 51 Relación de especies y representación ósea del Sondeo B/1-Nivel 2-Capa 5................................137

Tabla 52 Relación de especies y representación ósea del Sondeo F/1-Nivel 2-Capa 5................................138

Tabla 53 Relación de especies y representación ósea del Sondeo A-Nivel 1-Capa 2.................................138

Tabla 54 Relación de especies y representación ósea del Sondeo B-Nivel 1-Capa 2. ...................................139

Tabla 55 Relación de especies y representación ósea del Sondeo B-Nivel 1-Capa 2 ....................................139

Tabla 56 Relación de especies y representación ósea del Sondeo D/1-Nivel 1-Capa 2. .............................140

Tabla 57 Relación de especies y representación ósea del Sondeo D/2-Nivel 1-Capa 2. ...............................141

Tabla 58 Relación de especies y representación ósea del Sondeo F/1-Nivel 1-Capa 2...............................142

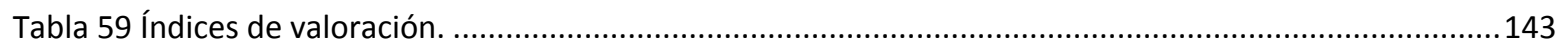

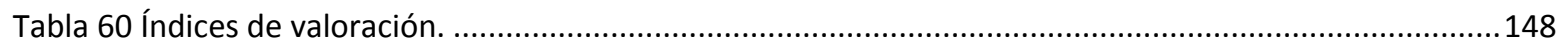

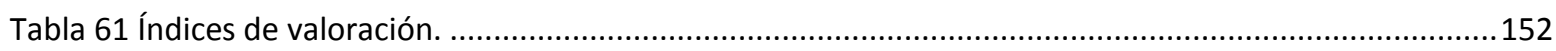

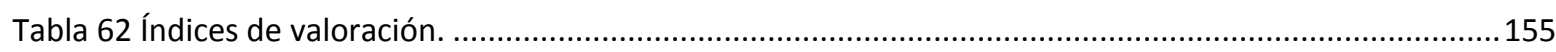

Tabla 63 Relación de especies y representación ósea de la Capa 3 del Sector U11....................................165

Tabla 64 Relación de especies y representación ósea de la Capa 3 del Sector AB15...................................165

Tabla 65 Relación de especies y representación ósea de la Capa 4 del Sector AB15.....................................165

Tabla 66 Relación de especies y representación ósea de la Capa 5 del Sector AB15....................................165 
Tabla 67 Relación de especies y representación ósea de la Capa 5 del Sector S22. 166

Tabla 68 Relación de especies y representación ósea de la Capa 4 del Sector T24. .166

Tabla 69 Relación de especies y representación ósea de la Capa 4 del Sector AB30. .167

Tabla 70 Relación de especies y representación ósea de la Capa 5 del Sector R22....... 168

Tabla 71 Relación de especies y representación ósea de la Capa 6 del Sector R22. .169

Tabla 72 Índices de valoración. 171

Tabla 73 Relación de especies y representación ósea del conchero. 174

Tabla 74 Pesos iniciales (en gr.) del $1^{\text {er }}$ Rebaje del Conchero 3 por componentes. 183

Tabla 75 Relación de especies y representación ósea del $1^{\text {er }}$ Rebaje del Conchero 3. 183

Tabla 76 Pesos iniciales (en gr.) del 2ㅇ Rebaje del Conchero 3 por componentes. 184

Tabla 77 Relación de especies y representación ósea del 2ํ Rebaje del Conchero 3. 185

Tabla 78 Pesos iniciales (en gr.) de la UE 1 del Conchero 5 por componentes. 186

Tabla 79 Relación de especies y representación ósea de la UE 1 del Conchero 5. 186

Tabla 80 Pesos iniciales (en gr.) de la UE 2 del Conchero 5 por componentes. 186

Tabla 81 Relación de especies y representación ósea de la UE 2 del Conchero 5. 187

Tabla 82 Pesos iniciales (en gr.) del $1^{\text {er }}$ Rebaje del Conchero 9 por componentes. 188

Tabla 83 Relación de especies y representación ósea del $1^{\mathrm{er}}$ Rebaje del Conchero 9. 188

Tabla 84 Pesos iniciales (en gr.) del 2 ㅇ Rebaje del Conchero 9 por componentes..... 189

Tabla 85 Relación de especies y representación ósea del 2ํㅡㄹebaje del Conchero 9. 189

Tabla 86 Pesos iniciales (en gr.) del $3^{\text {er }}$ Rebaje del Conchero 9 por componentes. 190

Tabla 87 Relación de especies y representación ósea del $3^{\text {er }}$ Rebaje del Conchero 9. 190

Tabla 88 Pesos iniciales (en gr.) del $1^{\text {er }}$ Rebaje del Conchero 1 por componentes. 191

Tabla 89 Relación de especies y representación ósea del $1^{\mathrm{er}}$ Rebaje del Conchero 1. ..191

Tabla 90 Pesos iniciales (en gr.) del 2을 Rebaje del Conchero 1 por componentes. 192

Tabla 91 Relación de especies y representación ósea del 2ํ Rebaje del Conchero 1. 192

Tabla 92 Pesos iniciales (en gr.) del $3^{\text {er }}$ Rebaje del Conchero 1 por componentes. 193

Tabla 93 Relación de especies y representación ósea del $3^{\mathrm{er}}$ Rebaje del Conchero 1. 193

Tabla 94 Pesos iniciales (en gr.) del $1^{\text {er }}$ Rebaje del Conchero 5 por componentes. .194

Tabla 95 Relación de especies y representación ósea del $1^{\mathrm{er}}$ Rebaje del Conchero 5. 195

Tabla 96 Pesos iniciales (en gr.) del 2ㅇ Rebaje del Conchero 5 por componentes. 196

Tabla 97 Relación de especies y representación ósea del 2 o Rebaje del Conchero 5. 196

Tabla 98 Pesos iniciales (en gr.) del $3^{\text {er }}$ Rebaje del Conchero 5 por componentes. 197

Tabla 99 Relación de especies y representación ósea del $3^{\text {er }}$ Rebaje del Conchero 5. 198

Tabla 100 Índices de valoración. 199 
Tabla 101 Pesos iniciales (en gr.) del conchero por componentes. . .212

Tabla 102 Relación de especies y representación ósea de la UE031. . .212

Tabla 103 Relación de especies y representación ósea de la UE032. .213

Tabla 104 Relación de especies y representación ósea de la UE033. 214

Tabla 105 Relación de especies y representación ósea de la UE036.

Tabla 106 Pesos iniciales (en gr.) de la UE 054 del Foso 02 por componentes.

Tabla 107 Relación de especies y representación ósea de la UE054.

Tabla 108 Pesos iniciales (en gr.) de la Fosa 06 por componentes.

Tabla 109 Relación de especies y representación ósea de la UE058.

Tabla 110 Índices de valoración. 217

Tabla 111 Pesos iniciales (en gr.) de la UE16 por componentes.

Tabla 112 Relación de especies y representación ósea de MU100630B02 _...............................................225

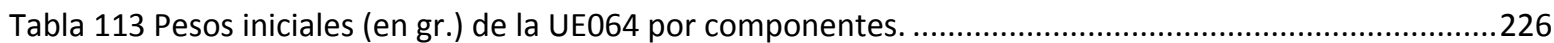

Tabla 114 Relación de especies y representación ósea de MU100804B03................................................226

Tabla 115 Pesos iniciales (en gr.) de las muestras de la UE 078 por componentes. ..................................227

Tabla 116 Relación de especies y representación ósea de MU100722B02 ..............................................229

Tabla 117 Relación de especies y representación ósea de MU100727B02 .............................................229

Tabla 118 Relación de especies y representación ósea de MU100810B03.............................................230

Tabla 119 Pesos iniciales (en gr.) de la UE115 por componentes. .........................................................232

Tabla 120 Relación de especies y representación ósea de MU100722B04...............................................232

Tabla 121 Pesos iniciales (en gr.) de las muestras de la UE152 por componentes. ...................................233

Tabla 122 Relación de especies y representación ósea de MU100831B02...............................................233

Tabla 123 Relación de especies y representación ósea de MU100818B03...............................................234

Tabla 124 Relación de especies y representación ósea de MU100813B06................................................235

Tabla 125 Pesos iniciales de la UE152-183 por componentes. ..................................................................236

Tabla 126 Relación de especies y representación ósea de MU100826B01.................................................236

Tabla 127 Pesos iniciales (en gr.) de la UE183 por componentes. ............................................................238

Tabla 128 Relación de especies y representación ósea de MU100826B01................................................238

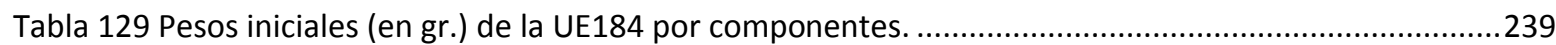

Tabla 130 Relación de especies y representación ósea de MU100827B04................................................239

Tabla 131 Relación de especies y representación ósea de MU100827B07.................................................240

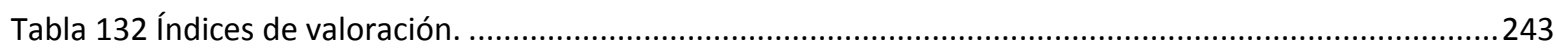

Tabla 133 Cuadro comparativo de los primeros estudios realizados sobre ictiofauna de A Lanzada.............248

Tabla 134 Relación de especies y representación ósea del Sector exterior de A Lanzada.............................249 
Tabla 135 Pesos (en gr.) iniciales de MU040712I01 por componentes. 260

Tabla 136 Relación de especies y representación ósea de MU040712101/01. 260

Tabla 137 Relación de especies y representación ósea de MU040712101/02. 260

Tabla 138 Relación de especies y representación ósea de MU040712101/03. 260

Tabla 139 Relación de especies y representación ósea de MU040712101/04. 261

Tabla 140 Relación de especies y representación ósea de MU040712I01/05. 261

Tabla 141 Relación de especies y representación ósea de MU040712I01/06. 261

Tabla 142 Relación de especies y representación ósea de MU040712101/07. 261

Tabla 143 Relación de especies y representación ósea de MU040712101/08. .261

Tabla 144 Pesos (en gr.) iniciales de MU040712102 por componentes. .263

Tabla 145 Relación de especies y representación ósea de MU040712I02/01. .263

Tabla 146 Relación de especies y representación ósea de MU040712102/02. 263

Tabla 147 Relación de especies y representación ósea de MU040712102/03. .264

Tabla 148 Relación de especies y representación ósea de MU040712102/04. 264

Tabla 149 Relación de especies y representación ósea de MU040712I02/05. .264

Tabla 150 Pesos (en gr.) iniciales de MU040629B01 por componentes. .266

Tabla 151 Relación de especies y representación ósea de MU040629B01/01. .266

Tabla 152 Relación de especies y representación ósea de MU040629B01/02. 266

Tabla 153 Relación de especies y representación ósea de MU040629B01/03. .266

Tabla 154 Pesos (en gr.) iniciales de MU040426I01 por componentes. 268

Tabla 155 Relación de especies y representación ósea de MU040426I01/01. 268

Tabla 156 Relación de especies y representación ósea de MU040426I01/02. 268

Tabla 157 Relación de especies y representación ósea de MU040426I01/03. .268

Tabla 158 Relación de especies y representación ósea de MU040426I01/04. .269

Tabla 159 Relación de especies y representación ósea de MU040426I01/05. 269

Tabla 160 Relación de especies y representación ósea de MU040426I01/06. .269

Tabla 161 Pesos (en gr.) iniciales de MU040510J01 por componentes. 271

Tabla 162 Relación de especies y representación ósea de MU040510J01/01. .272

Tabla 163 Relación de especies y representación ósea de MU040510J01/02. .272

Tabla 164 Relación de especies y representación ósea de MU040510J01/03. 272

Tabla 165 Relación de especies y representación ósea de MU040510J01/04. 273

Tabla 166 Pesos (en gr.) iniciales de MU040806B01 por componentes. ..... 274

Tabla 167 Relación de especies y representación ósea de MU040806B01. .274

Tabla 168 Pesos (en gr.) iniciales de MU040707B02 por componentes. 275 
Tabla 169 Relación de especies y representación ósea de MU040707B02..............................................275

Tabla 170 Pesos (en gr.) iniciales de MU040713B03 por componentes. ................................................275

Tabla 171 Relación de especies y representación ósea de MU040713B03................................................275

Tabla 172 Pesos (en gr.) iniciales de MU040713B04 por componentes. ...............................................276

Tabla 173 Relación de especies y representación ósea de MU040713B04.............................................276

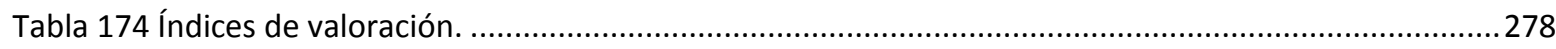

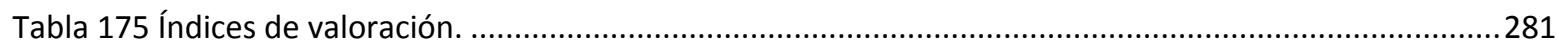

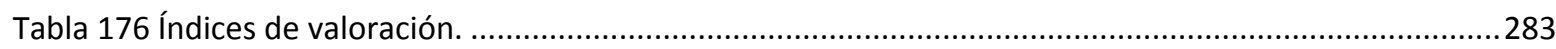

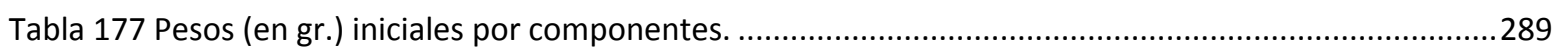

Tabla 178 Relación de especies y representación ósea.........................................................................290

Tabla 179 Relación de especies y representación ósea de la UE 502 ....................................................297

Tabla 180 Relación de especies y representación ósea de la UE 516........................................................297

Tabla 181 Relación de especies y representación ósea de la UE 226.........................................................298

Tabla 182 Relación de especies y representación ósea de la UE 217.....................................................298

Tabla 183 Relación de especies y representación ósea de la Villa de Bares. ............................................301

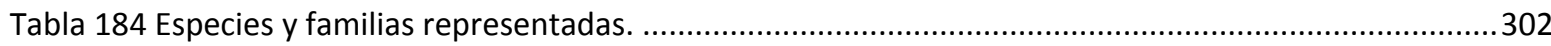

Tabla 185 Relación de especies y representación ósea del Nivel 1 ........................................................303

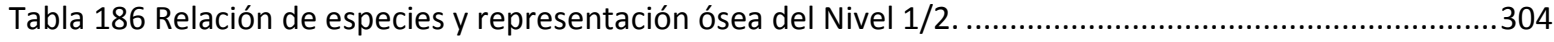

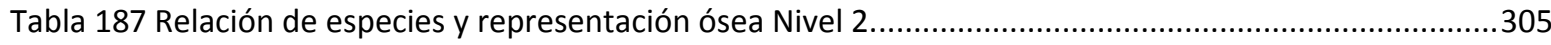

Tabla 188 Relación de especies y representación ósea de C2 “tierra parda bajo muro transversal”...............307

Tabla 189 Relación de especies y representación ósea de C2 "Tierra negra" .............................................308

Tabla 190 Relación de especies y representación ósea de C2 "Tierra negra debajo del muro". .....................308

Tabla 191 Relación de especies y representación ósea........................................................................310

Tabla 192 Relación de especies y representación ósea.........................................................................313

Tabla 193 Cuadro comparativo de los primeros estudios realizados sobre ictiofauna de O Achadizo............314

Tabla 194 Relación de especies y representación ósea del Nivel II........................................................315

Tabla 195 Relación de especies y representación ósea del Nivel III............................................................316

Tabla 196 Relación de especies y representación ósea del Nivel IV. .........................................................318

Tabla 197 Relación de especies y representación ósea del estudio de M. Camino López, J.M. Vázquez Varela y

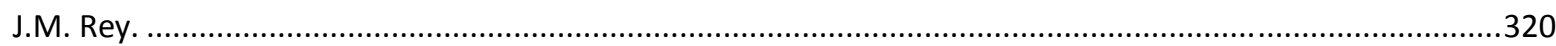

Tabla 198 Relación de especies y representación ósea de Torres del Oeste. ...............................................320

Tabla 199 Relación de especies y representación ósea del perfil norte de Cantodorxo................................322

Tabla 200 Relación de especies y representación ósea del perfil oeste de Cantodorxo................................324

Tabla 201 Relación de especies y representación ósea de Adro Vello.........................................................326 
Tabla 202 Relación de especies identificadas en A Suvidá.. .327

Tabla 203 Relación de especies y representación ósea de Igresiña. .327

Tabla 204 Relación de especies identificadas por Vázquez Varela en As Hortas. 328

Tabla 205 Relación de especies y representación ósea de As Hortas. 328

Tabla 206 Cuadro comparativo de los primeros estudios realizados en el Facho de Donón .331

Tabla 207 Relación de especies y representación ósea del Facho de Donón según Ferré. .331

Tabla 208 Relación de especies y representación ósea de A Palma. .333

Tabla 209 Cuadro comparativo de los estudios realizados sobre la ictiofauna de Santa Trega...... .335

Tabla 210 NR de los diferentes taxones identificados en yacimientos del siglo V-II a.C. .345

Tabla 211 NR de los diferentes taxones identificados en yacimientos del siglo II a.C.-I d.C. .347

Tabla 212 NR de ictiofauna recuperado por Kg de sedimento procesado. 348

Tabla 214 Instalaciones salazoneras de época romana documentadas en Galicia. .359

Tabla 215 NR de los diferentes taxones identificados en yacimientos de época romana...... 360

Tabla 216 NR de los diferentes taxones identificados en yacimientos de época romana .362

Tabla 217 NR de los diferentes taxones identificados en yacimientos del siglo XI-XIII d.C. .371

Tabla 218 NR de los diferentes taxones identificados en yacimientos del siglo XIII-XV d.C. .374

Tabla 219 NR de los diferentes taxones identificados en yacimientos de época moderna .378 

Anexos 



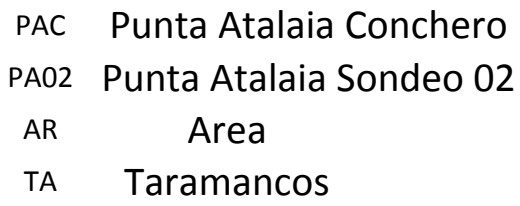

$\begin{array}{cl}\text { ON } & \text { O Neixón } \\ \text { AL } & \text { A Lanzada } \\ \text { Mo } & \text { Montealegre } \\ \text { MV } & \text { Muiño do Vento } \\ \text { RF } & \text { Rocha Forte }\end{array}$

\section{Sardina pilchardus}

\begin{tabular}{|c|c|c|c|c|c|c|c|c|c|c|c|c|c|}
\hline Yac. & Referencia & $\mathrm{D} / \mathrm{S}$ & Tipo & M1 & M2 & M3 & Yac. & Referencia & $D / S$ & Tipo & M1 & M2 & M3 \\
\hline TA & S1/Conchero 3/1R & $S$ & Art & & & 0,8 & PA02 & $\mathrm{S}-\mathrm{H} / \mathrm{C}-4$ & & $\mathrm{Vpc}$ & 1,9 & 2,4 & 2,1 \\
\hline TA & S1/Conchero 3/1R & $S$ & Art & & & 0,6 & PA02 & $\mathrm{S}-\mathrm{H} / \mathrm{C}-4$ & & $\mathrm{Vpc}$ & 1,9 & 2,3 & 2,3 \\
\hline TA & S1/Conchero 3/1R & $\mathrm{D}$ & Art & & & 0,8 & PA02 & $\mathrm{S}-\mathrm{H} / \mathrm{C}-4$ & & $\mathrm{Vpc}$ & 1,9 & 2,4 & 2,2 \\
\hline TA & S1/Conchero 3/1R & $\mathrm{D}$ & Art & 11,7 & 5,4 & 0,9 & PA02 & $\mathrm{S}-\mathrm{H} / \mathrm{C}-4$ & & $\mathrm{Vpc}$ & 1,7 & 2,1 & 1,9 \\
\hline TA & S1/Conchero 3/2R & $S$ & Art & & & 0,8 & PA02 & $\mathrm{S}-\mathrm{H} / \mathrm{C}-4$ & & $\mathrm{Vpc}$ & 2 & 2,4 & \\
\hline TA & S1/Conchero 3/2R & $\mathrm{D}$ & Art & & & 0,8 & PA02 & $\mathrm{S}-\mathrm{H} / \mathrm{C}-4$ & & Vpc & 1,7 & 2,4 & \\
\hline TA & S1/Conchero 9/1R & $\mathrm{D}$ & Art & & & 0,6 & PA02 & $\mathrm{S}-\mathrm{H} / \mathrm{C}-4$ & & $\mathrm{Vpc}$ & 1,7 & 2,2 & 2,1 \\
\hline PA02 & S-H/C-3 & S & $\mathrm{Cdr}$ & & 11 & & PA02 & $\mathrm{S}-\mathrm{H} / \mathrm{C}-4$ & & $\mathrm{Vpc}$ & 1,9 & 2,2 & \\
\hline TA & S1/Conchero 3/1R & D & $\mathrm{Cdr}$ & & 0,9 & & PA02 & $\mathrm{S}-\mathrm{H} / \mathrm{C}-4$ & & $\mathrm{Vpc}$ & 1,8 & 2,2 & 1,8 \\
\hline TA & S1/Conchero 3/1R & $\mathrm{D}$ & $\mathrm{Cdr}$ & & & 0,8 & PA02 & $\mathrm{S}-\mathrm{H} / \mathrm{C}-4$ & & $\mathrm{Vpc}$ & 1,8 & 1,8 & 1,9 \\
\hline TA & S1/Conchero 3/1R & $\mathrm{D}$ & $\mathrm{Cdr}$ & & & 1 & PA02 & $\mathrm{S}-\mathrm{H} / \mathrm{C}-4$ & & Vpc & 2,3 & 3,1 & 3,1 \\
\hline TA & S1/Conchero 3/1R & $\mathrm{D}$ & $\mathrm{Cdr}$ & & & 0,8 & PA02 & $\mathrm{S}-\mathrm{H} / \mathrm{C}-4$ & & $\mathrm{Vpc}$ & 1,9 & 2,5 & 2,2 \\
\hline TA & S1/Conchero 3/1R & $S$ & $\mathrm{Cdr}$ & & 0,8 & & PA02 & S-L/C-5 & & $\mathrm{Vpc}$ & 2 & 2,5 & 2,5 \\
\hline TA & S1/Conchero 3/1R & S & $\mathrm{Cdr}$ & & & 0,9 & PA02 & S-L/C-5 & & $\mathrm{Vpc}$ & 1,8 & 2,4 & 2,4 \\
\hline TA & S2/Conchero 5/2R & $S$ & $\mathrm{Cdr}$ & 6,5 & 1,6 & & PA02 & S-L/C-5 & & $\mathrm{Vpc}$ & 1,9 & 2 & 2,1 \\
\hline TA & S1/Conchero 3/1R & $S$ & Opc & & & 1,5 & PA02 & S-L/C-5 & & $\mathrm{Vpc}$ & 2 & 1,9 & 2 \\
\hline TA & S1/Conchero 9/2R & $S$ & Opc & & & 1,4 & PA02 & S-L/C-5 & & Vpc & 1,9 & 2,2 & \\
\hline PAC & B-1 & & $\mathrm{Vpc}$ & 2,3 & 3 & 2,7 & PA02 & S- $\tilde{N} / C-2$ & & $\mathrm{Vpc}$ & 1,9 & 2,4 & 2,6 \\
\hline PAC & C-1 & & Vpc & 1,3 & 1,6 & 1,5 & PA02 & S-Ñ/C-2 & & $\mathrm{Vpc}$ & 2,1 & 2,7 & 2,5 \\
\hline PAC & $N-3 / C-4$ & & $\mathrm{Vpc}$ & 2,2 & 2,9 & 2,7 & PA02 & $\mathrm{S}-\mathrm{O} / \mathrm{C}-2$ & & $\mathrm{Vpc}$ & 2,2 & 3 & 2,8 \\
\hline PA02 & $\mathrm{S}-3 / \mathrm{N}-2 / \mathrm{C}-4$ & & $\mathrm{Vpc}$ & 1,9 & 2 & 1,9 & AR & $\mathrm{S}-7 / \mathrm{C}-8 / \mathrm{N}-3$ & & $\mathrm{Vpc}$ & 2,1 & 2,9 & 2,6 \\
\hline PA02 & $\mathrm{S}-3 / \mathrm{N}-2 / \mathrm{C}-4$ & & $\mathrm{Vpc}$ & 1,5 & 1,5 & 1,3 & $A R$ & $S-7 / C-8 / N-3$ & & $\mathrm{Vpc}$ & 1,9 & 2,5 & 2,4 \\
\hline PA02 & $\mathrm{S}-3 / \mathrm{N}-2 / \mathrm{C}-4$ & & $\mathrm{Vpc}$ & 1,7 & 2 & 1,6 & AR & $S-7 / C-8 / N-3$ & & $\mathrm{Vpc}$ & & 2,5 & 2,4 \\
\hline PA02 & $S-5 / N-2 / C-4$ & & $\mathrm{Vpc}$ & 2 & 2,7 & 2,5 & TA & S1/Conchero 3/1R & & $\mathrm{Vpc}$ & 1,9 & 1,9 & 1,9 \\
\hline PA02 & $S-5 / N-2 / C-4$ & & $\mathrm{Vpc}$ & 1,9 & 2,2 & 2,2 & TA & S1/Conchero 3/1R & & $\mathrm{Vpc}$ & 1,6 & 2 & 1,8 \\
\hline PA02 & S-G/C-2 & & Vpc & 2,1 & 2,5 & 2,7 & TA & S1/Conchero 3/1R & & $\mathrm{Vpc}$ & 1,4 & 1,7 & 1,5 \\
\hline PA02 & S-G/C-2 & & $\mathrm{Vpc}$ & 1,8 & 2,2 & 2,1 & TA & S1/Conchero 3/1R & & Vpc & 1,4 & 2 & 1,9 \\
\hline PA02 & S-G/C-5 & & $\mathrm{Vpc}$ & 2 & 2,4 & 2,5 & TA & S1/Conchero 3/1R & & Vpc & 1,4 & & \\
\hline PA02 & S-G/C-5 & & $\mathrm{Vpc}$ & 1,8 & 2,6 & 2,4 & TA & S1/Conchero 3/1R & & $\mathrm{Vpc}$ & 1,9 & 2,4 & 2 \\
\hline PA02 & S-G/C-5 & & Vpc & 2,2 & 2,7 & 2,3 & TA & S1/Conchero 3/1R & & Vpc & 1,9 & 2,5 & 1,9 \\
\hline PA02 & S-G/C-5 & & $\mathrm{Vpc}$ & 1,7 & 2,1 & 1,9 & TA & S1/Conchero 3/1R & & $\mathrm{Vpc}$ & 1,1 & 1,7 & 1,5 \\
\hline PA02 & $\mathrm{S}-\mathrm{H} / \mathrm{C}-3$ & & $\mathrm{Vpc}$ & 2 & 2,3 & & TA & S1/Conchero 3/1R & & Vpc & & & 1,5 \\
\hline PA02 & $\mathrm{S}-\mathrm{H} / \mathrm{C}-3$ & & $\mathrm{Vpc}$ & 1,8 & 2,4 & 2,1 & TA & S1/Conchero 3/1R & & $\mathrm{Vpc}$ & 1,7 & 2,3 & 1,2 \\
\hline PA02 & $\mathrm{S}-\mathrm{H} / \mathrm{C}-3$ & & Vpc & 1,9 & 2,3 & 2,1 & TA & S1/Conchero 3/1R & & $\mathrm{Vpc}$ & 1,7 & 2,3 & 1,8 \\
\hline PA02 & $\mathrm{S}-\mathrm{H} / \mathrm{C}-3$ & & $\mathrm{Vpc}$ & 1,5 & 1,8 & 1,9 & TA & S1/Conchero 3/1R & & $\mathrm{Vpc}$ & 1,6 & 2 & 1,9 \\
\hline PA02 & $\mathrm{S}-\mathrm{H} / \mathrm{C}-3$ & & $\mathrm{Vpc}$ & & & 2,2 & TA & S1/Conchero 3/1R & & $\mathrm{Vpc}$ & 1,8 & 2,1 & 2 \\
\hline
\end{tabular}




\begin{tabular}{|c|c|c|c|c|c|c|c|c|c|c|c|}
\hline PA02 & $\mathrm{S}-\mathrm{H} / \mathrm{C}-3$ & $\mathrm{Vpc}$ & & & 2,5 & TA & S1/Conchero 3/1R & $V p c$ & 1,2 & 1,7 & 1,9 \\
\hline PA02 & $\mathrm{S}-\mathrm{H} / \mathrm{C}-3$ & $\mathrm{Vpc}$ & 2,1 & 2,7 & 2,7 & TA & S1/Conchero 3/1R & $\mathrm{Vpc}$ & 1,6 & 1,6 & 1,6 \\
\hline PA02 & $\mathrm{S}-\mathrm{H} / \mathrm{C}-3$ & $\mathrm{Vpc}$ & 2 & 2,4 & 2,5 & TA & S1/Conchero 3/1R & $V p c$ & 1,4 & 1,8 & 1,7 \\
\hline PA02 & $\mathrm{S}-\mathrm{H} / \mathrm{C}-3$ & $\mathrm{Vpc}$ & 2,1 & 2,7 & 2,4 & TA & S1/Conchero 3/1R & Vpc & 1,9 & 2,5 & \\
\hline PA02 & $\mathrm{S}-\mathrm{H} / \mathrm{C}-3$ & $\mathrm{Vpc}$ & 2,1 & 2,7 & & TA & S1/Conchero 3/1R & Vpc & 1,6 & 2 & 1,9 \\
\hline PA02 & $\mathrm{S}-\mathrm{H} / \mathrm{C}-3$ & $\mathrm{Vpc}$ & 2 & 2,6 & 2,5 & TA & S1/Conchero 3/1R & Vpc & 2,6 & & 2,3 \\
\hline PA02 & $\mathrm{S}-\mathrm{H} / \mathrm{C}-3$ & $\mathrm{Vpc}$ & 1,9 & 2,5 & 2,4 & TA & S1/Conchero 3/1R & Vpc & 1,8 & 2,3 & \\
\hline PA02 & $\mathrm{S}-\mathrm{H} / \mathrm{C}-3$ & $V p c$ & 2,1 & 2,5 & 2,2 & TA & S1/Conchero 3/1R & $V p c$ & 1,8 & 1,6 & 2 \\
\hline PA02 & $\mathrm{S}-\mathrm{H} / \mathrm{C}-3$ & $\mathrm{Vpc}$ & 2,1 & 2,2 & 2,5 & TA & S1/Conchero 3/1R & Vpc & 1,7 & 2,6 & 1,2 \\
\hline PA02 & $\mathrm{S}-\mathrm{H} / \mathrm{C}-4$ & $\mathrm{Vpc}$ & 2,2 & 2,9 & 2,7 & TA & S1/Conchero 3/1R & Vpc & 11,9 & 13,4 & 7 \\
\hline TA & S1/Conchero 3/2R & $\mathrm{Vpc}$ & 1,8 & 2,2 & 2,1 & TA & S2/Conchero 5/2R & Vpc & 2,3 & 2,9 & 3 \\
\hline TA & S1/Conchero 3/2R & $\mathrm{Vpc}$ & & & 1,5 & TA & S2/Conchero 5/2R & Vpc & 2,2 & 2,2 & 2,6 \\
\hline TA & S1/Conchero 9/2R & $\mathrm{Vpc}$ & 1,9 & 2,3 & 2,6 & TA & S2/Conchero 5/2R & Vpc & 2,2 & 2,6 & 2,8 \\
\hline TA & S1/Conchero 9/2R & Vpc & 1,9 & 2,6 & 2,3 & TA & S2/Conchero 5/2R & Vpc & 2,2 & 2,9 & 2,8 \\
\hline TA & S1/Conchero 9/2R & $\mathrm{Vpc}$ & 2,1 & 2,6 & 1,6 & TA & S2/Conchero 5/2R & Vpc & 2 & 2,7 & 2,4 \\
\hline TA & S1/Conchero 9/2R & $\mathrm{Vpc}$ & 1,9 & 2,6 & 2,4 & TA & S2/Conchero 5/2R & Vpc & 1,6 & 1,5 & 1,3 \\
\hline TA & S1/Conchero 9/2R & $\mathrm{Vpc}$ & 1,9 & 2,6 & 2,3 & TA & S2/Conchero 5/3R & $\mathrm{Vpc}$ & 2,4 & 2,9 & 2,3 \\
\hline TA & S1/Conchero 9/2R & $\mathrm{Vpc}$ & 2 & 2,4 & 2,4 & TA & S2/Conchero 5/3R & Vpc & 2,4 & 2,8 & 2,8 \\
\hline TA & S1/Conchero 9/2R & $\mathrm{Vpc}$ & 1,8 & 2,5 & 2,1 & TA & S2/Conchero 5/3R & Vpc & 2,3 & 3,3 & 3,1 \\
\hline TA & S1/Conchero 9/2R & Vpc & 1,9 & 2,4 & 2,4 & TA & S2/Conchero 5/3R & Vpc & 2,2 & 3,3 & 2,9 \\
\hline TA & S1/Conchero 9/2R & $\mathrm{Vpc}$ & 1,7 & 1,9 & 2,3 & TA & S2/Conchero 5/3R & $\mathrm{Vpc}$ & 2,5 & 3 & 2,8 \\
\hline TA & S1/Conchero 9/2R & Vpc & 1,6 & 1,7 & 1,9 & TA & S2/Conchero 5/3R & Vpc & 2,3 & 3 & 3 \\
\hline TA & S1/Conchero 9/2R & $\mathrm{Vpc}$ & 1,5 & 1,8 & 1,6 & TA & S2/Conchero 5/3R & Vpc & 1,9 & 2,4 & 2,2 \\
\hline TA & S1/Conchero 9/1R & $\mathrm{Vpc}$ & & & 1,9 & TA & S2/Conchero 5/3R & Vpc & 2,2 & 2,8 & 2,9 \\
\hline TA & S1/Conchero 9/1R & $\mathrm{Vpc}$ & 1,6 & 1,8 & 1,7 & TA & S2/Conchero 5/3R & $\mathrm{Vpc}$ & 2,1 & 2,9 & 2,9 \\
\hline TA & S1/Conchero 9/1R & Vpc & & & 2,3 & TA & S2/Conchero 5/3R & $\mathrm{Vpc}$ & 2,1 & 2,5 & 2,5 \\
\hline TA & S2/Conchero 1/1R & $\mathrm{Vpc}$ & 2,1 & 2,5 & 2,6 & TA & S2/Conchero 5/3R & $V p c$ & 2,4 & 3,2 & 3 \\
\hline TA & S2/Conchero 1/1R & $\mathrm{Vpc}$ & 1,8 & & 2,1 & TA & S2/Conchero 5/3R & Vpc & 2,2 & 2,8 & 2,6 \\
\hline TA & S2/Conchero 1/1R & $\mathrm{Vpc}$ & 1,7 & 2,3 & 2,2 & TA & S2/Conchero 5/3R & Vpc & 2,3 & 2,9 & \\
\hline TA & S2/Conchero 1/1R & $V p c$ & 1,4 & 1,7 & 1,7 & TA & S2/Conchero 5/3R & Vpc & 2,1 & 3,1 & \\
\hline TA & S2/Conchero 1/1R & Vpc & 1,6 & 2,1 & 1,9 & TA & S2/Conchero 5/3R & Vpc & 2,2 & 2,7 & \\
\hline TA & S2/Conchero 1/1R & $\mathrm{Vpc}$ & 1,7 & 2,1 & 1,9 & $\mathrm{AL}$ & M100722B04/115 & $V p c$ & 2 & 2,8 & \\
\hline TA & S2/Conchero 1/1R & Vpc & 2,1 & 2,7 & 2,5 & $\mathrm{AL}$ & M100722B04/115 & Vpc & 2 & 2,6 & \\
\hline TA & S2/Conchero 1/1R & $\mathrm{Vpc}$ & & & 2,4 & MO & MU040712I01/01 & Vpc & 1,2 & & 1,2 \\
\hline TA & S2/Conchero 1/1R & $\mathrm{Vpc}$ & 2,1 & 2,8 & & MO & MU040712J02/05 & Vpc & 1,1 & 1,4 & 1,3 \\
\hline TA & S2/Conchero 1/1R & $\mathrm{Vpc}$ & 1,6 & 2,2 & & MO & MU040712J02/05 & Vpc & 1 & 1,2 & 1,3 \\
\hline TA & S2/Conchero $1 / 2 \mathrm{R}$ & $\mathrm{Vpc}$ & 2,1 & 2,6 & 2,4 & MO & MU040712J02/01 & Vpc & 1,2 & 1,3 & 1,3 \\
\hline TA & S2/Conchero $1 / 2 \mathrm{R}$ & $\mathrm{Vpc}$ & 1,7 & 2,1 & 1,9 & MO & MU040426I01/06 & Vpc & 1,7 & 2 & 1,8 \\
\hline TA & S2/Conchero 1/3R & $\mathrm{Vpc}$ & 2 & 2,6 & 2,4 & MO & MU040712I01/06 & Vpc & 1,2 & & 1,3 \\
\hline TA & S2/Conchero 1/3R & $\mathrm{Vpc}$ & 1,5 & 2,1 & 1,5 & MO & MU040712J02/05 & Vpc & 1,2 & 1,3 & 1,2 \\
\hline TA & S2/Conchero $1 / 3 \mathrm{R}$ & $\mathrm{Vpc}$ & 1,8 & 2,1 & & MV & Muestra 1 & Vpc & 2 & 3 & 3 \\
\hline TA & S1/Conchero 5/UE2 & Vpc & 1,8 & 2,3 & 2,1 & MV & Muestra 1 & Vpc & 1,3 & 1,5 & 1,7 \\
\hline TA & S2/Conchero 5/1R & $\mathrm{Vpc}$ & 2,1 & 2,8 & 2,5 & MV & Muestra 1 & $\mathrm{Vpc}$ & & & 2,1 \\
\hline TA & S2/Conchero 5/1R & $\mathrm{Vpc}$ & & & 3,1 & MV & Muestra 1 & $\mathrm{Vpc}$ & 1,4 & 1,7 & \\
\hline TA & S2/Conchero 5/1R & $\mathrm{Vpc}$ & & & 2,5 & MV & Muestra 1 & $V p c$ & 1,9 & 2,5 & 2 \\
\hline
\end{tabular}




\begin{tabular}{|c|c|c|c|c|c|c|c|c|c|c|c|}
\hline TA & S2/Conchero 5/1R & $\mathrm{Vpc}$ & 2,2 & 2,8 & 2,8 & MV & Muestra 1 & $\mathrm{Vpc}$ & 1,9 & 2,4 & \\
\hline TA & S2/Conchero 5/1R & Vpc & 2,3 & 2,6 & 2,7 & MV & Muestra 1 & Vpc & 1,6 & 2,1 & 2 \\
\hline TA & S2/Conchero 5/1R & Vpc & 2 & 2,8 & 2,4 & MV & Muestra 1 & Vpc & 2,2 & 2,9 & 2,2 \\
\hline TA & S2/Conchero 5/1R & Vpc & 2 & 2,8 & 2,8 & PA02 & $S-D / C-5$ & Vca & 3,5 & 3 & 6,7 \\
\hline TA & S2/Conchero 5/1R & Vpc & 2,2 & 3 & 2,6 & PA02 & $\mathrm{S}-\mathrm{H} / \mathrm{C}-2$ & Vca & 1,8 & 1,8 & \\
\hline TA & S2/Conchero 5/1R & Vpc & 2,1 & 2,6 & 2,5 & PA02 & $\mathrm{S}-\mathrm{H} / \mathrm{C}-3$ & Vca & 2 & & \\
\hline TA & S2/Conchero 5/1R & Vpc & & & 2,6 & PA02 & $\mathrm{S}-\mathrm{H} / \mathrm{C}-3$ & Vca & 1,9 & 2 & 1,7 \\
\hline TA & S2/Conchero 5/1R & $\mathrm{Vpc}$ & 2,5 & 3,3 & 3 & PA02 & $\mathrm{S}-\mathrm{H} / \mathrm{C}-3$ & Vca & 1,9 & 2,4 & 2,4 \\
\hline TA & S2/Conchero 5/1R & $\mathrm{Vpc}$ & 2 & & 2,5 & $A R$ & S-7/C-8/N-3 & Vca & 1,9 & 1,9 & 1,9 \\
\hline TA & S2/Conchero 5/1R & $\mathrm{Vpc}$ & & 3 & & TA & S1/Conchero 3/1R & Vca & 1,3 & 1,4 & 1,6 \\
\hline TA & S2/Conchero 5/1R & $\mathrm{Vpc}$ & 2,2 & 2,6 & 2,2 & TA & S1/Conchero 3/1R & Vca & 1,9 & 2,1 & 2,2 \\
\hline TA & S2/Conchero 5/1R & Vpc & 2 & 2,7 & & TA & S1/Conchero 9/1R & Vca & & 1 & 1,1 \\
\hline TA & S2/Conchero 5/1R & $\mathrm{Vpc}$ & 1,3 & 1,8 & 1,6 & TA & S2/Conchero 1/1R & Vca & 2 & 1,6 & 1,4 \\
\hline TA & S2/Conchero 5/1R & Vpc & 1,6 & 1,8 & 2 & TA & S2/Conchero $1 / 1 \mathrm{R}$ & Vca & 2 & 2 & 2 \\
\hline TA & S2/Conchero 5/1R & Vpc & 1,5 & & 2,1 & TA & S2/Conchero $1 / 1 \mathrm{R}$ & Vca & 1,7 & 1,9 & 2,4 \\
\hline TA & S2/Conchero $1 / 2 \mathrm{R}$ & Vca & 2 & 1,8 & 2,1 & TA & S2/Conchero 5/3R & Vca & 2 & 2,4 & 2,7 \\
\hline TA & S2/Conchero 1/3R & Vca & 1,8 & 1,8 & 1,7 & TA & S2/Conchero 5/3R & Vca & 1,8 & 1,8 & 2,1 \\
\hline TA & S2/Conchero $1 / 3 \mathrm{R}$ & Vca & 1,5 & 1,8 & 1,9 & TA & S2/Conchero 5/3R & Vca & 1,8 & 1,9 & 1,6 \\
\hline TA & S2/Conchero 1/3R & Vca & 1,9 & 2,2 & 2,4 & TA & S2/Conchero 5/3R & Vca & 2 & 2,3 & 2,6 \\
\hline TA & S1/Conchero 5/UE2 & Vca & 1,8 & 1,5 & 1,8 & TA & S2/Conchero 5/3R & Vca & 2 & 2,3 & \\
\hline TA & S1/Conchero 5/UE2 & Vca & 2 & 2,1 & 2,5 & MO & MU040426I01/05 & Vca & 1,6 & 2 & 1,8 \\
\hline TA & S1/Conchero 5/UE2 & Vca & 1,9 & 2,1 & 2,4 & MO & MU040712J02/01 & Vca & 1,4 & 1,4 & 1,5 \\
\hline TA & S1/Conchero 5/UE2 & Vca & 2,2 & 1,9 & 2,2 & MO & MU040712J02/03 & Vca & 1,4 & 1,2 & 1,6 \\
\hline TA & S1/Conchero 5/UE2 & Vca & & & 2,3 & MO & MU040712J02/05 & Vca & 1,5 & 1,5 & 1,4 \\
\hline TA & S2/Conchero 5/1R & Vca & 2,3 & 2,8 & 3 & MO & MU040712J02/05 & Vca & 1,7 & 1,4 & 1,5 \\
\hline TA & S2/Conchero 5/1R & Vca & & & 3,6 & MO & MU040426I01/04 & Vca & 1,5 & 1,9 & 1,8 \\
\hline TA & S2/Conchero 5/1R & Vca & 2,5 & 2,7 & 2,7 & MO & MU040426I01/03 & Vca & 1,5 & 1,9 & 1,7 \\
\hline TA & S2/Conchero 5/1R & Vca & 1,9 & 1,9 & 2,2 & MO & MU040712I01/01 & Vca & 1,3 & 1,2 & 1,9 \\
\hline TA & S2/Conchero 5/1R & Vca & 2 & 2,2 & & MO & MU040712I01/01 & Vca & 1,4 & 1,5 & 1,5 \\
\hline TA & S2/Conchero 5/1R & Vca & 2,3 & 2,3 & 2,7 & MO & MU040712I01/02 & Vca & 1,3 & 1,8 & 1,5 \\
\hline TA & S2/Conchero 5/1R & Vca & 2,1 & 2,3 & 2,2 & MO & MU040712I01/02 & Vca & 1,3 & 1,2 & 1,3 \\
\hline TA & S2/Conchero 5/1R & Vca & 2,2 & 2,1 & 1,9 & MO & MU040712I01/02 & Vca & 1,2 & 1,4 & 1,2 \\
\hline TA & S2/Conchero 5/1R & Vca & 2,1 & 2,5 & 2,7 & MO & MU040712I01/03 & Vca & 1,6 & 1,5 & \\
\hline TA & S2/Conchero 5/1R & Vca & 2 & 2,2 & 2,1 & MO & MU040712I01/03 & Vca & 1,3 & 1,2 & 1,1 \\
\hline TA & S2/Conchero 5/1R & Vca & 2,6 & & 2,5 & MV & Muestra 1 & Vca & 2,1 & 2,8 & 2,4 \\
\hline TA & S2/Conchero 5/1R & Vca & 1,8 & 1,9 & 2 & MV & Muestra 1 & Vca & 1,6 & 15 & 2 \\
\hline TA & S2/Conchero 5/3R & Vca & 2,3 & 2,4 & 2,8 & MV & Muestra 1 & Vca & 2,1 & 2,8 & 2,4 \\
\hline TA & S2/Conchero 5/3R & Vca & 2,3 & 2,9 & 2,7 & MV & Muestra 1 & Vca & 1,3 & 1,7 & 1,7 \\
\hline TA & S2/Conchero 5/3R & Vca & 2,3 & 2,5 & 2,7 & MV & Muestra 1 & Vca & 1,9 & 1,9 & 2,3 \\
\hline TA & S2/Conchero 5/3R & Vca & 2,5 & 2,6 & 2,6 & MV & Muestra 1 & Vca & 1,7 & 1,5 & \\
\hline TA & S2/Conchero 5/3R & Vca & 2,3 & 2,4 & 2,5 & & & & & & \\
\hline
\end{tabular}


Conger conger

\begin{tabular}{|c|c|c|c|c|c|c|c|c|c|c|c|c|c|}
\hline Yac. & Referencia & $D / S$ & Tipo & M1 & M2 & M3 & Yac. & Referencia & $D / S$ & Tipo & M1 & M2 & M3 \\
\hline$A L$ & M100827B04/184 & $S$ & Pmx & 48,3 & 9,5 & 9,4 & PA02 & $S-R / C-3$ & & Vpc & 7,6 & 8 & 6,3 \\
\hline $\mathrm{RF}$ & 2005/22/UE226 & $S$ & Eph & 17,6 & 51,8 & & & & & & & & \\
\hline PA02 & $S-5 / N-2 / C-4$ & & Vpc & 9,8 & 12,1 & 6,9 & & & & & & & \\
\hline
\end{tabular}

\section{Merluccius merluccius}

\begin{tabular}{|c|c|c|c|c|c|c|c|c|c|c|c|c|c|}
\hline Yac. & Referencia & $\mathrm{D} / \mathrm{S}$ & Tipo & M1 & M2 & M3 & Yac. & Referencia & $D / S$ & Tipo & M1 & M2 & M3 \\
\hline PA02 & $\mathrm{S}-4 / \mathrm{N}-2 / \mathrm{C}-3$ & S & Art & 58,5 & & 9,9 & TA & S1/Conchero 3/1R & D & Eph & 13,3 & & \\
\hline PA02 & S-5/N-2/C-4 & S & Art & & & 12,1 & TA & S2/Conchero 1/1R & D & Eph & 9 & & \\
\hline PA02 & S-D/C-5 & S & Art & 6,9 & & & PA02 & S-5/N-2/C-4 & D & Crh & 60,8 & 19,2 & \\
\hline PA02 & $\mathrm{S}-\mathrm{O} / \mathrm{C}-2$ & S & Art & & & 8 & PA02 & $S-R / C-6$ & S & Crh & 53,8 & & \\
\hline PA02 & $\mathrm{S}-\mathrm{O} / \mathrm{C}-2$ & $S$ & Art & & & 7,2 & PA02 & $\mathrm{S}-3 / \mathrm{N}-2 / \mathrm{C}-3$ & D & Dnt & & & 8,4 \\
\hline PA02 & S-5/N-2/C-3 & $S$ & Cdr & & 14 & & PA02 & $\mathrm{S}-4 / \mathrm{N}-2 / \mathrm{C}-3$ & S & Dnt & & & 6,6 \\
\hline PA02 & $\mathrm{S}-\mathrm{O} / \mathrm{C}-2$ & S & Cdr & & 9,5 & & PA02 & $\mathrm{S}-5 / \mathrm{N}-2 / \mathrm{C}-3$ & D & Dnt & & & 8,4 \\
\hline PA02 & $\mathrm{S}-\mathrm{O} / \mathrm{C}-2$ & D & Cdr & & 11,3 & & PA02 & $\mathrm{S}-5 / \mathrm{N}-2 / \mathrm{C}-3$ & D & Dnt & & & 7,3 \\
\hline PA02 & $\mathrm{S}-\mathrm{O} / \mathrm{C}-2$ & S & $\mathrm{Cdr}$ & & 9,5 & & PA02 & $\mathrm{S}-5 / \mathrm{N}-2 / \mathrm{C}-3$ & S & Dnt & & & 8,3 \\
\hline PA02 & $\mathrm{S}-\mathrm{O} / \mathrm{C}-2$ & $S$ & Cdr & & 9,9 & & PA02 & $\mathrm{S}-5 / \mathrm{N}-2 / \mathrm{C}-4$ & D & Dnt & & 7,1 & \\
\hline PA02 & $\mathrm{S}-\mathrm{O} / \mathrm{C}-2$ & D & Cdr & & 10,6 & & PA02 & S-D/C-5 & S & Dnt & & 8 & \\
\hline PA02 & $S-R / C-3$ & S & $\mathrm{Cdr}$ & & 8,8 & & PA02 & $S-D / C-5$ & S & Dnt & & 7,3 & \\
\hline$A R$ & $S-7 / C-8 / N-3$ & D & $\mathrm{Cdr}$ & & 11,9 & & PA02 & S-D/C-5 & D & Dnt & & 8,1 & \\
\hline PA02 & S-D/C-5 & D & Dnt & & 8,5 & & PA02 & $\mathrm{S}-\mathrm{O} / \mathrm{C}-2$ & D & Max & & 10,3 & \\
\hline PA02 & $\mathrm{S}-\mathrm{O} / \mathrm{C}-2$ & S & Dnt & & & 8,1 & PA02 & $S-R / C-2$ & D & Max & & 7,7 & \\
\hline PA02 & $\mathrm{S}-\mathrm{O} / \mathrm{C}-2$ & $S$ & Dnt & & 6,9 & & PA02 & $S-R / C-6$ & D & Max & & & 10,4 \\
\hline PA02 & $\mathrm{S}-\mathrm{O} / \mathrm{C}-2$ & S & Dnt & & 6,8 & & AR & S-6/C-5/N-3 & S & Max & & 7,4 & \\
\hline PA02 & $\mathrm{S}-\mathrm{O} / \mathrm{C}-2$ & D & Dnt & & 8,6 & & AR & S-6/C-5/N-3 & D & Max & & 11,5 & \\
\hline PA02 & $\mathrm{S}-\mathrm{O} / \mathrm{C}-2$ & D & Dnt & & & 7,6 & AR & $S-5 / C-4 / N-3$ & D & Max & & 14,5 & \\
\hline PA02 & $\mathrm{S}-\mathrm{O} / \mathrm{C}-2$ & $\mathrm{D}$ & Dnt & & 7,8 & & TA & S1/Conchero 5b/UE2 & S & Max & & & 16,2 \\
\hline$A R$ & S-6/C-5/N-3 & S & Dnt & & & 8,4 & TA & S1/Conchero 5b/UE2 & D & Max & & & 15,8 \\
\hline$A R$ & $S-5 / C-4 / N-3$ & $\mathrm{D}$ & Dnt & & 8 & & TA & S1/Conchero 3/UE2 & S & Max & & & 10,3 \\
\hline AR & S-6/C-5/N-3 & $S$ & Dnt & & & 7,1 & TA & S1/Conchero 3/UE2 & D & Max & & & 8,2 \\
\hline$A R$ & S-6/C-5/N-3 & $S$ & Dnt & & & 9,5 & PA02 & $\mathrm{S}-3 / \mathrm{N}-2 / \mathrm{C}-3$ & D & Pmx & 13,6 & & 14,4 \\
\hline AR & $\mathrm{S}-7 / \mathrm{C}-8 / \mathrm{N}-3$ & $S$ & Dnt & & & 7,7 & PA02 & $\mathrm{S}-3 / \mathrm{N}-2 / \mathrm{C}-3$ & S & Pmx & & 14,2 & 12,5 \\
\hline TA & S1/Conchero 5b/UE1 & & Dnt & & & 13,3 & PA02 & $\mathrm{S}-4 / \mathrm{N}-1 / \mathrm{C}-2$ & S & Pmx & & 13,1 & 13,1 \\
\hline TA & S1/Conchero 5b/UE1 & & Dnt & & & 13,2 & PA02 & $\mathrm{S}-5 / \mathrm{N}-2 / \mathrm{C}-3$ & S & Pmx & & 9,7 & \\
\hline TA & S1/Conchero 3/UE1 & S & Dnt & & & 9 & PA02 & $\mathrm{S}-5 / \mathrm{N}-2 / \mathrm{C}-3$ & S & Pmx & & 15,3 & 15,9 \\
\hline TA & S1/Conchero 3/UE1 & S & Dnt & & & 8,6 & PA02 & $\mathrm{S}-5 / \mathrm{N}-2 / \mathrm{C}-3$ & D & Pmx & & 14,3 & 14,8 \\
\hline TA & S1/Conchero 3/UE2 & $S$ & Dnt & & 7,3 & & PA02 & $\mathrm{S}-5 / \mathrm{N}-2 / \mathrm{C}-3$ & S & Pmx & & 11,9 & 14,1 \\
\hline TA & S1/Conchero 3/UE2 & S & Dnt & & 7,3 & & PA02 & $\mathrm{S}-5 / \mathrm{N}-2 / \mathrm{C}-4$ & D & Pmx & 59 & 10,7 & 12,1 \\
\hline TA & S1/Conchero 3/UE2 & S & Dnt & & 9,1 & & PA02 & $\mathrm{S}-5 / \mathrm{N}-2 / \mathrm{C}-4$ & D & Pmx & & 10,3 & 14,2 \\
\hline TA & S1/Conchero 3/UE2 & $S$ & Dnt & & 8,1 & & PA02 & $\mathrm{S}-5 / \mathrm{N}-3 / \mathrm{C}-6$ & S & Pmx & & & 13,9 \\
\hline TA & S1/Conchero 3/UE2 & D & Dnt & & 8,1 & & PA02 & $S-D / C-5$ & S & Pmx & & 13,2 & 14,4 \\
\hline TA & S1/Conchero 3/UE2 & $\mathrm{D}$ & Dnt & & 7,9 & & PA02 & $S-D / C-5$ & D & Pmx & & 11,6 & 13,3 \\
\hline
\end{tabular}




\begin{tabular}{|c|c|c|c|c|c|c|c|c|c|c|c|c|c|}
\hline TA & S1/Conchero 3/UE2 & D & Dnt & & 9,7 & & PA02 & S-D/C-5 & D & Pmx & & 12,3 & 13,5 \\
\hline TA & S1/Conchero 3/UE2 & D & Dnt & & 7,6 & & PA02 & S-D/C-5 & $S$ & Pmx & & 12,7 & 13,8 \\
\hline TA & S1/Conchero 3/UE2 & D & Dnt & & 7,7 & & PA02 & S-D/C-5 & $S$ & Pmx & & 11,9 & 13,3 \\
\hline TA & S1/Conchero 3/UE2 & $\mathrm{D}$ & Dnt & 12,2 & 10,6 & & PA02 & S-D/C-5 & $S$ & Pmx & & 12,6 & 13,7 \\
\hline PA02 & $S-R / C-3$ & D & Hmd & 18 & 12,2 & 26,2 & PA02 & S-D/C-5 & D & Pmx & & 14,4 & 15,4 \\
\hline$A R$ & S-6/C-5/N-3 & S & $\mathrm{Hmd}$ & 17,8 & 12,3 & & PA02 & S-D/C-5 & $S$ & Pmx & & 10,7 & 11,8 \\
\hline PA02 & $\mathrm{S}-4 / \mathrm{N}-1 / \mathrm{C}-2$ & $S$ & Max & & 9,5 & & PA02 & S-D/C-5 & $S$ & Pmx & & 11,6 & 12,7 \\
\hline PA02 & $\mathrm{S}-4 / \mathrm{N}-1 / \mathrm{C}-2$ & $S$ & Max & & 9,9 & & PA02 & $S-D / C-5$ & $S$ & Pmx & & 10 & 11,8 \\
\hline PA02 & S-5/N-2/C-4 & $S$ & Max & & 9,1 & & PA02 & S-D/C-5 & $S$ & Pmx & & 14,2 & 15,5 \\
\hline PA02 & $\mathrm{S}-5 / \mathrm{N}-2 / \mathrm{C}-4$ & $S$ & Max & 99,3 & 14,1 & & PA02 & $S-D / C-5$ & $S$ & Pmx & & 13,1 & 13,9 \\
\hline PA02 & S-D/C-5 & D & Max & & 1,1 & & PA02 & S-D/C-5 & $S$ & Pmx & 66,2 & 12,5 & 13,5 \\
\hline PA02 & S-D/C-5 & $S$ & Max & & 10,6 & & PA02 & S-Ñ/C-2 & $S$ & Pmx & & 11,9 & 12,7 \\
\hline PA02 & S-D/C-5 & D & Max & & 9,7 & & PA02 & $\mathrm{S}-\mathrm{O} / \mathrm{C}-2$ & D & Pmx & & 12,7 & 12,6 \\
\hline PA02 & S-D/C-5 & $S$ & Max & & 9,9 & & PA02 & $\mathrm{S}-\mathrm{O} / \mathrm{C}-2$ & $S$ & Pmx & & 11,4 & 12,3 \\
\hline PA02 & S-D/C-5 & $S$ & Max & & 9,9 & & PA02 & $\mathrm{S}-\mathrm{O} / \mathrm{C}-2$ & D & Pmx & & 14 & 14,7 \\
\hline PA02 & S-D/C-5 & $S$ & Max & & 8 & & PA02 & S-R/C-6 & D & Pmx & & 11,1 & 11,5 \\
\hline PA02 & S-D/C-5 & $S$ & Max & & 9,4 & & $A R$ & $S-1 / C-3 / N-3$ & & Pmx & & 11,9 & \\
\hline PA02 & S-D/C-5 & $S$ & Max & & 9 & & AR & S-5/C-4/N-3 & $S$ & Pmx & & 13,6 & \\
\hline PA02 & S-D/C-5 & $S$ & Max & & 15,5 & 16,5 & $A R$ & $S-5 / C-4 / N-3$ & & Pmx & & 13,8 & \\
\hline PA02 & S-D/C-5 & $S$ & Max & 76,3 & 12 & & $A R$ & $S-5 / C-6 / N-3$ & $S$ & Pmx & & 10,1 & \\
\hline PA02 & S-D/C-5 & D & Max & & 32,7 & & AR & S-6/C-5/N-3 & $S$ & Pmx & & & 12,8 \\
\hline PA02 & S-D/C-5 & D & Max & & 8,7 & & $A R$ & S-6/C-5/N-3 & $S$ & Pmx & & & 12,7 \\
\hline PA02 & S-D/C-5 & D & Max & & 9,2 & & $A R$ & S-6/C-5/N-3 & $S$ & Pmx & & & 13 \\
\hline PA02 & S-D/C-5 & $S$ & Max & & 9,1 & & $A R$ & S-6/C-5/N-3 & D & Pmx & & & 13,7 \\
\hline PA02 & S-E/C-2 & D & Max & & 9,3 & & AR & $S-6 / C-5 / N-3$ & D & Pmx & & & 14,3 \\
\hline PA02 & $\mathrm{S}-\mathrm{O} / \mathrm{C}-2$ & S & Max & & 10,7 & & $A R$ & $S-7 / C-8 / N-3$ & $\mathrm{~S}$ & Pmx & & & 8,5 \\
\hline PA02 & $\mathrm{S}-\mathrm{O} / \mathrm{C}-2$ & $S$ & Max & & 8,5 & & AR & $S-7 / C-8 / N-3$ & & Pmx & & & 17,4 \\
\hline PA02 & $\mathrm{S}-\mathrm{O} / \mathrm{C}-2$ & D & Max & & 10,1 & & AR & $\mathrm{S}-7 / \mathrm{C}-8 / \mathrm{N}-3$ & & Pmx & & & 12,1 \\
\hline AR & $\mathrm{S}-7 / \mathrm{C}-8 / \mathrm{N}-3$ & $S$ & Pmx & & & 12,5 & PA02 & $\mathrm{S}-1 / \mathrm{N}-2 / \mathrm{C}-4$ & & Vpc & 10,5 & 10,9 & 9,9 \\
\hline$A R$ & $\mathrm{~S}-7 / \mathrm{C}-8 / \mathrm{N}-3$ & D & Pmx & & & 12,9 & PA02 & $S-1 / N-2 / C-4$ & & Vpc & & & 11,6 \\
\hline TA & S1/Conchero 5b/UE1 & $\mathrm{D}$ & Pmx & 36,6 & 17,5 & 12,7 & PA02 & $\mathrm{S}-1 / \mathrm{N}-2 / \mathrm{C}-4$ & & Vpc & & 12,3 & 10,5 \\
\hline TA & S1/Conchero 5b/UE2 & $S$ & Pmx & & 12 & 14,7 & PA02 & $\mathrm{S}-1 / \mathrm{N}-2 / \mathrm{C}-4$ & & Vpc & 10,8 & 13,6 & 6,9 \\
\hline TA & S1/Conchero 5b/UE2 & $\mathrm{S}$ & Pmx & & 9,6 & 15,9 & PA02 & $S-1 / N-2 / C-4$ & & $\mathrm{Vpc}$ & 12,2 & 13,1 & 11,1 \\
\hline TA & S1/Conchero 5b/UE2 & D & Pmx & & 11,4 & 15,6 & PA02 & $\mathrm{S}-1 / \mathrm{N}-2 / \mathrm{C}-4$ & & Vpc & 11,5 & 13,1 & 11,3 \\
\hline TA & S1/Conchero 3/UE1 & $S$ & Pmx & & & 13,6 & PA02 & $S-1 / N-2 / C-4$ & & Vpc & 11,1 & 11,8 & 10,9 \\
\hline TA & S1/Conchero 3/UE1 & $\mathrm{S}$ & Pmx & & & 12,4 & PA02 & $\mathrm{S}-1 / \mathrm{N}-2 / \mathrm{C}-4$ & & Vpc & 11,3 & 12,7 & 11,7 \\
\hline TA & S1/Conchero 3/UE1 & $\mathrm{D}$ & Pmx & & & 14,9 & PA02 & $S-1 / N-2 / C-4$ & & Vpc & 13,2 & 16,1 & 13,3 \\
\hline TA & S1/Conchero 3/UE1 & $\mathrm{D}$ & Pmx & & & 13,6 & PA02 & $S-1 / N-2 / C-4$ & & Vpc & 13,7 & 14,1 & \\
\hline TA & S1/Conchero 3/UE1 & $\mathrm{D}$ & Pmx & & & 11,6 & PA02 & $S-1 / N-2 / C-4$ & & Vpc & 9,6 & 10,4 & 8,2 \\
\hline TA & S1/Conchero 3/UE2 & D & Pmx & & 12,2 & 12,9 & PA02 & $\mathrm{S}-1 / \mathrm{N}-2 / \mathrm{C}-4$ & & Vpc & 11,2 & 12 & 11,3 \\
\hline TA & S1/Conchero 3/UE2 & D & Pmx & & 12,9 & 12,9 & PA02 & $\mathrm{S}-1 / \mathrm{N}-2 / \mathrm{C}-4$ & & Vpc & 12,2 & 13 & 12,4 \\
\hline TA & S1/Conchero 3/1R & D & Pst & 11,3 & & & PA02 & $S-1 / N-2 / C-4$ & & Vpc & 11,4 & 12,4 & 10,9 \\
\hline TA & S1/Conchero 3/1R & $\mathrm{S}$ & Pst & 9,5 & & & PA02 & $\mathrm{S}-1 / \mathrm{N}-2 / \mathrm{C}-4$ & & Vpc & 14 & 16,2 & 11 \\
\hline TA & S2/Conchero 5/1R & & Pst & 9 & & & PA02 & $\mathrm{S}-1 / \mathrm{N}-2 / \mathrm{C}-4$ & & Vpc & 14,3 & & 10,2 \\
\hline PA02 & S-E/C-4 & & Oto & 21,7 & 9 & & PA02 & $\mathrm{S}-1 / \mathrm{N}-2 / \mathrm{C}-4$ & & Vpc & 10,1 & 12,5 & 8,6 \\
\hline
\end{tabular}




\begin{tabular}{|c|c|c|c|c|c|c|c|c|c|c|c|c|}
\hline PA02 & $\mathrm{S}-\mathrm{O} / \mathrm{C}-2$ & & Oto & & 9,9 & & PA02 & $\mathrm{S}-1 / \mathrm{N}-2 / \mathrm{C}-4$ & Vpc & 14 & 16,3 & 8,6 \\
\hline PA02 & $S-5 / N-2 / C-4$ & & Pal & 23,1 & 6,7 & & PA02 & $\mathrm{S}-1 / \mathrm{N}-2 / \mathrm{C}-4$ & Vpc & 13,5 & 15,5 & 11,2 \\
\hline PA02 & S-D/C-5 & & Pal & 14,1 & 4 & & PA02 & $\mathrm{S}-1 / \mathrm{N}-2 / \mathrm{C}-4$ & Vpc & 13,5 & 13,8 & 12,5 \\
\hline PA02 & $\mathrm{S}-\mathrm{O} / \mathrm{C}-2$ & & Pal & 13,2 & 4,8 & & PA02 & $\mathrm{S}-1 / \mathrm{N}-2 / \mathrm{C}-4$ & Vpc & 9,9 & 12 & 9,1 \\
\hline PA02 & $\mathrm{S}-\mathrm{O} / \mathrm{C}-2$ & & Pal & & 4,7 & & PA02 & $\mathrm{S}-1 / \mathrm{N}-2 / \mathrm{C}-4$ & Vpc & 14,4 & 16,1 & 11,8 \\
\hline PA02 & $\mathrm{S}-\mathrm{O} / \mathrm{C}-2$ & & Pal & & 4,2 & & PA02 & $\mathrm{S}-1 / \mathrm{N}-2 / \mathrm{C}-4$ & Vpc & 11,2 & 13,6 & 10,6 \\
\hline PA02 & $\mathrm{S}-\mathrm{O} / \mathrm{C}-2$ & & Pal & & 1,7 & & PA02 & $\mathrm{S}-1 / \mathrm{N}-2 / \mathrm{C}-4$ & Vpc & 16,9 & 19,2 & 17,2 \\
\hline PA02 & $\mathrm{S}-\mathrm{O} / \mathrm{C}-2$ & & Pal & & 3,9 & & PA02 & $S-1 / N-2 / C-4$ & $V p c$ & 15,9 & 16,6 & 15,1 \\
\hline PA02 & $\mathrm{S}-\mathrm{O} / \mathrm{C}-2$ & & Pal & & 3,7 & & PA02 & $\mathrm{S}-1 / \mathrm{N}-2 / \mathrm{C}-4$ & Vpc & 12 & 12,6 & 12,3 \\
\hline PA02 & $\mathrm{S}-\mathrm{O} / \mathrm{C}-2$ & & Pal & 17,5 & 4,9 & & PA02 & $\mathrm{S}-1 / \mathrm{N}-2 / \mathrm{C}-4$ & Vpc & 9,7 & 10,2 & 8,1 \\
\hline PA02 & $S-R / C-3$ & & Pal & 13,4 & 2,9 & & PA02 & $\mathrm{S}-1 / \mathrm{N}-2 / \mathrm{C}-4$ & Vpc & 13,2 & 14,3 & 12,9 \\
\hline PA02 & S-D/C-5 & D & Vom & 19 & 11 & & PA02 & $\mathrm{S}-1 / \mathrm{N}-2 / \mathrm{C}-4$ & Vpc & 14,6 & 14,5 & 13,5 \\
\hline PA02 & $\mathrm{S}-\mathrm{O} / \mathrm{C}-2$ & $\mathrm{D}$ & Vom & 26,4 & & & PA02 & $\mathrm{S}-1 / \mathrm{N}-2 / \mathrm{C}-4$ & Vpc & 14,2 & 18,9 & 14,5 \\
\hline PA02 & $\mathrm{S}-\mathrm{O} / \mathrm{C}-2$ & $S$ & Vom & 21 & & & PA02 & $\mathrm{S}-1 / \mathrm{N}-2 / \mathrm{C}-4$ & Vpc & 13,3 & 13,4 & 14,3 \\
\hline PA02 & $\mathrm{S}-\mathrm{O} / \mathrm{C}-2$ & $S$ & Vom & 15 & & & PA02 & $\mathrm{S}-1 / \mathrm{N}-2 / \mathrm{C}-4$ & Vpc & 12,8 & & 11,4 \\
\hline PA02 & $\mathrm{S}-\mathrm{O} / \mathrm{C}-2$ & $S$ & Vom & 21 & & & PA02 & $\mathrm{S}-1 / \mathrm{N}-2 / \mathrm{C}-4$ & Vpc & 11,4 & 11,5 & 8,4 \\
\hline PAC & $\mathrm{N}-3 / \mathrm{C}-4$ & & $\mathrm{Vpc}$ & 10,2 & 11,7 & 8,5 & PA02 & $\mathrm{S}-1 / \mathrm{N}-2 / \mathrm{C}-4$ & Vpc & 14,9 & 16,6 & 15 \\
\hline PA02 & $\mathrm{S}-1 / \mathrm{N}-2 / \mathrm{C}-4$ & & $V p c$ & 12,2 & & 15,1 & PA02 & $\mathrm{S}-1 / \mathrm{N}-2 / \mathrm{C}-4$ & Vpc & 12,7 & 13,7 & 12,9 \\
\hline PA02 & $\mathrm{S}-1 / \mathrm{N}-2 / \mathrm{C}-4$ & & $\mathrm{Vpc}$ & & 12,8 & & PA02 & $\mathrm{S}-1 / \mathrm{N}-2 / \mathrm{C}-4$ & Vpc & 12,3 & 13,3 & 12,2 \\
\hline PA02 & $\mathrm{S}-1 / \mathrm{N}-2 / \mathrm{C}-4$ & & $V p c$ & & & 12,3 & PA02 & $S-1 / N-2 / C-4$ & $V p c$ & 13,4 & 14,7 & 10,9 \\
\hline PA02 & $\mathrm{S}-1 / \mathrm{N}-2 / \mathrm{C}-4$ & & $\mathrm{Vpc}$ & & 13,9 & 9,8 & PA02 & $\mathrm{S}-1 / \mathrm{N}-2 / \mathrm{C}-4$ & Vpc & 12 & 12,7 & 10,1 \\
\hline PA02 & $\mathrm{S}-1 / \mathrm{N}-2 / \mathrm{C}-4$ & & $\mathrm{Vpc}$ & & & 13,4 & PA02 & $\mathrm{S}-1 / \mathrm{N}-2 / \mathrm{C}-4$ & Vpc & 13,4 & 14,6 & 13 \\
\hline PA02 & $\mathrm{S}-1 / \mathrm{N}-2 / \mathrm{C}-4$ & & $V p c$ & 12,2 & & & PA02 & $\mathrm{S}-1 / \mathrm{N}-2 / \mathrm{C}-4$ & Vpc & 13,3 & 15,1 & 11,5 \\
\hline PA02 & $\mathrm{S}-1 / \mathrm{N}-2 / \mathrm{C}-4$ & & $\mathrm{Vpc}$ & & & 8,4 & PA02 & $\mathrm{S}-1 / \mathrm{N}-2 / \mathrm{C}-4$ & Vpc & 13,8 & 15,1 & 13,6 \\
\hline PA02 & $\mathrm{S}-1 / \mathrm{N}-2 / \mathrm{C}-4$ & & $\mathrm{Vpc}$ & 11,6 & 12,6 & 5,2 & PA02 & $\mathrm{S}-1 / \mathrm{N}-2 / \mathrm{C}-4$ & Vpc & 10,3 & 11,5 & 10,6 \\
\hline PA02 & $\mathrm{S}-1 / \mathrm{N}-2 / \mathrm{C}-4$ & & $\mathrm{Vpc}$ & 11,9 & 14,4 & 11,6 & PA02 & $\mathrm{S}-1 / \mathrm{N}-2 / \mathrm{C}-4$ & Vpc & 12,9 & 15,1 & 10,7 \\
\hline PA02 & $\mathrm{S}-1 / \mathrm{N}-2 / \mathrm{C}-4$ & & $\mathrm{Vpc}$ & 12,4 & 12,3 & 9,9 & PA02 & $\mathrm{S}-1 / \mathrm{N}-2 / \mathrm{C}-4$ & Vpc & 12 & 13,8 & 10,6 \\
\hline PA02 & $\mathrm{S}-1 / \mathrm{N}-2 / \mathrm{C}-4$ & & $\mathrm{Vpc}$ & 10,3 & 13,5 & 5,9 & PA02 & $\mathrm{S}-1 / \mathrm{N}-2 / \mathrm{C}-4$ & Vpc & 10,2 & 11,3 & 7,3 \\
\hline PA02 & $\mathrm{S}-1 / \mathrm{N}-2 / \mathrm{C}-4$ & & $\mathrm{Vpc}$ & 11,2 & 15,4 & 7,3 & PA02 & $\mathrm{S}-1 / \mathrm{N}-2 / \mathrm{C}-4$ & Vpc & 13,8 & 12,4 & 11,9 \\
\hline PA02 & $S-1 / N-2 / C-4$ & & $\mathrm{Vpc}$ & 10,5 & 12,6 & 7,1 & PA02 & $\mathrm{S}-1 / \mathrm{N}-2 / \mathrm{C}-4$ & Vpc & 13,4 & 15,1 & 11,3 \\
\hline PA02 & $S-1 / N-2 / C-4$ & & $\mathrm{Vpc}$ & 12,3 & 13,3 & 7,4 & PA02 & $S-1 / N-2 / C-4$ & Vpc & 16,8 & 19 & 15,3 \\
\hline PA02 & $S-1 / N-2 / C-4$ & & $\mathrm{Vpc}$ & 12,8 & 12,4 & 9,8 & PA02 & $\mathrm{S}-4 / \mathrm{N}-1 / \mathrm{C}-2$ & Vpc & 10,7 & 11,2 & 11 \\
\hline PA02 & $\mathrm{S}-1 / \mathrm{N}-2 / \mathrm{C}-4$ & & $\mathrm{Vpc}$ & 11,5 & 13,1 & 4,6 & PA02 & $\mathrm{S}-4 / \mathrm{N}-1 / \mathrm{C}-2$ & Vpc & 12,3 & 13,3 & 7,3 \\
\hline PA02 & $\mathrm{S}-4 / \mathrm{N}-1 / \mathrm{C}-2$ & & $\mathrm{Vpc}$ & 14,9 & 16 & 10,5 & PA02 & $\mathrm{S}-4 / \mathrm{N}-1 / \mathrm{C}-2$ & Vpc & 10,9 & 12 & 9,6 \\
\hline PA02 & $\mathrm{S}-4 / \mathrm{N}-1 / \mathrm{C}-2$ & & $\mathrm{Vpc}$ & 10 & 11,3 & 9,7 & PA02 & $\mathrm{S}-4 / \mathrm{N}-1 / \mathrm{C}-2$ & Vpc & 10,1 & 10,7 & 10,1 \\
\hline PA02 & $\mathrm{S}-4 / \mathrm{N}-1 / \mathrm{C}-2$ & & $\mathrm{Vpc}$ & & 13,8 & 11,6 & PA02 & $\mathrm{S}-4 / \mathrm{N}-1 / \mathrm{C}-2$ & $V p c$ & 10,2 & 11 & 9,1 \\
\hline PA02 & $\mathrm{S}-4 / \mathrm{N}-1 / \mathrm{C}-2$ & & $\mathrm{Vpc}$ & 11,4 & 12,9 & 11,2 & PA02 & $\mathrm{S}-4 / \mathrm{N}-1 / \mathrm{C}-2$ & Vpc & 10,9 & 12,2 & 9,4 \\
\hline PA02 & $\mathrm{S}-4 / \mathrm{N}-1 / \mathrm{C}-2$ & & $V p c$ & 10,4 & & 6,6 & PA02 & $\mathrm{S}-4 / \mathrm{N}-1 / \mathrm{C}-2$ & $V p c$ & 17,5 & 19,1 & 14,6 \\
\hline PA02 & $\mathrm{S}-4 / \mathrm{N}-1 / \mathrm{C}-2$ & & $V p c$ & 10,8 & 11,7 & 8,6 & PA02 & $\mathrm{S}-4 / \mathrm{N}-1 / \mathrm{C}-2$ & Vpc & 11,1 & 12,3 & 10,6 \\
\hline PA02 & $\mathrm{S}-4 / \mathrm{N}-1 / \mathrm{C}-2$ & & $\mathrm{Vpc}$ & 10,9 & 13,5 & 10,2 & PA02 & $\mathrm{S}-4 / \mathrm{N}-1 / \mathrm{C}-2$ & Vpc & 12,7 & 13,3 & 11,6 \\
\hline PA02 & $\mathrm{S}-4 / \mathrm{N}-1 / \mathrm{C}-2$ & & $\mathrm{Vpc}$ & 9,6 & 13,1 & 8,4 & PA02 & $\mathrm{S}-4 / \mathrm{N}-1 / \mathrm{C}-2$ & Vpc & 11,4 & 11,9 & 11,6 \\
\hline PA02 & $\mathrm{S}-4 / \mathrm{N}-1 / \mathrm{C}-2$ & & $\mathrm{Vpc}$ & 10,7 & 11,5 & 10,1 & PA02 & $\mathrm{S}-4 / \mathrm{N}-1 / \mathrm{C}-2$ & Vpc & 11 & 12,4 & 8,7 \\
\hline PA02 & $\mathrm{S}-4 / \mathrm{N}-1 / \mathrm{C}-2$ & & $V p c$ & 12,7 & 13,6 & & PA02 & $\mathrm{S}-4 / \mathrm{N}-1 / \mathrm{C}-2$ & $V p c$ & 10,8 & 12,8 & 8,2 \\
\hline PA02 & $\mathrm{S}-4 / \mathrm{N}-1 / \mathrm{C}-2$ & & $\mathrm{Vpc}$ & 11,2 & 13 & 10 & PA02 & $\mathrm{S}-4 / \mathrm{N}-1 / \mathrm{C}-2$ & Vpc & 10,9 & 11,8 & 10,4 \\
\hline PA02 & $\mathrm{S}-4 / \mathrm{N}-1 / \mathrm{C}-2$ & & $\mathrm{Vpc}$ & 11,2 & 12,5 & 9,2 & PA02 & $\mathrm{S}-4 / \mathrm{N}-1 / \mathrm{C}-2$ & Vpc & 11,5 & 12,5 & 12,3 \\
\hline
\end{tabular}




\begin{tabular}{|c|c|c|c|c|c|c|c|}
\hline PA02 & $\mathrm{S}-4 / \mathrm{N}-1 / \mathrm{C}-2$ & Vpc & 8,6 & 9,7 & 8 & PA02 & S-4/N-1/C-2 \\
\hline PA02 & $\mathrm{S}-4 / \mathrm{N}-1 / \mathrm{C}-2$ & Vpc & 8,5 & 9,9 & 7,1 & PA02 & S-4/N-1/C-2 \\
\hline PA02 & $S-1 / N-2 / C-4$ & Vpc & 9,5 & 10,4 & 8,8 & PA02 & $\mathrm{S}-4 / \mathrm{N}-1 / \mathrm{C}-2$ \\
\hline PA02 & $S-1 / N-2 / C-4$ & Vpc & 9,8 & 11,4 & 8,5 & PA02 & $\mathrm{S}-4 / \mathrm{N}-1 / \mathrm{C}-2$ \\
\hline PA02 & $S-1 / N-2 / C-4$ & Vpc & 12 & 13,7 & 11,3 & PA02 & $\mathrm{S}-4 / \mathrm{N}-1 / \mathrm{C}-2$ \\
\hline PA02 & $S-1 / N-2 / C-4$ & Vpc & 12,2 & 13,4 & 10,2 & PA02 & $\mathrm{S}-4 / \mathrm{N}-1 / \mathrm{C}-2$ \\
\hline PA02 & $\mathrm{S}-2 / \mathrm{N}-2 / \mathrm{C}-3$ & Vpc & 11,5 & 11,7 & 11,3 & PA02 & $\mathrm{S}-4 / \mathrm{N}-1 / \mathrm{C}-2$ \\
\hline PA02 & $\mathrm{S}-2 / \mathrm{N}-2 / \mathrm{C}-3$ & Vpc & 10,9 & 12 & 9,8 & PA02 & $\mathrm{S}-4 / \mathrm{N}-1 / \mathrm{C}-2$ \\
\hline PA02 & $\mathrm{S}-2 \mathrm{a} / \mathrm{N}-2 / \mathrm{C}-2$ & Vpc & & 13 & 10,4 & PA02 & $\mathrm{S}-4 / \mathrm{N}-1 / \mathrm{C}-2$ \\
\hline PA02 & S-2a/N-2/C-2 & Vpc & & 11,9 & & PA02 & $\mathrm{S}-4 / \mathrm{N}-1 / \mathrm{C}-2$ \\
\hline PA02 & $\mathrm{S}-3 / \mathrm{N}-2 / \mathrm{C}-3$ & Vpc & 11,1 & 11,9 & 10,8 & PA02 & $\mathrm{S}-4 / \mathrm{N}-1 / \mathrm{C}-2$ \\
\hline PA02 & $\mathrm{S}-3 / \mathrm{N}-2 / \mathrm{C}-3$ & Vpc & 16,4 & 19,7 & 12,3 & PA02 & $\mathrm{S}-4 / \mathrm{N}-1 / \mathrm{C}-2$ \\
\hline PA02 & $\mathrm{S}-3 / \mathrm{N}-2 / \mathrm{C}-3$ & Vpc & 11,3 & 12,1 & 11,7 & PA02 & $\mathrm{S}-4 / \mathrm{N}-1 / \mathrm{C}-2$ \\
\hline PA02 & $S-3 / N-2 / C-3$ & Vpc & 11,1 & 12,1 & 10,9 & PA02 & $\mathrm{S}-4 / \mathrm{N}-1 / \mathrm{C}-2$ \\
\hline PA02 & $S-3 / N-2 / C-3$ & $\mathrm{Vpc}$ & 10,8 & 11,3 & 10,4 & PA02 & $\mathrm{S}-4 / \mathrm{N}-1 / \mathrm{C}-2$ \\
\hline PA02 & $S-3 / N-2 / C-3$ & Vpc & 10,5 & 11,6 & 10,5 & PA02 & $\mathrm{S}-4 / \mathrm{N}-1 / \mathrm{C}-2$ \\
\hline PA02 & $\mathrm{S}-3 / \mathrm{N}-2 / \mathrm{C}-3$ & Vpc & 11,1 & 12,3 & 9,8 & PA02 & $\mathrm{S}-4 / \mathrm{N}-1 / \mathrm{C}-2$ \\
\hline PA02 & $S-3 / N-2 / C-3$ & Vpc & 10,7 & 12,8 & 6,1 & PA02 & $\mathrm{S}-4 / \mathrm{N}-1 / \mathrm{C}-2$ \\
\hline PA02 & $\mathrm{S}-3 / \mathrm{N}-2 / \mathrm{C}-3$ & Vpc & 14,1 & 15,7 & 12,3 & PA02 & $\mathrm{S}-4 / \mathrm{N}-1 / \mathrm{C}-2$ \\
\hline PA02 & $\mathrm{S}-4 / \mathrm{N}-1 / \mathrm{C}-2$ & Vpc & 11,2 & 11,8 & 10,3 & PA02 & $\mathrm{S}-4 / \mathrm{N}-1 / \mathrm{C}-2$ \\
\hline PA02 & $\mathrm{S}-4 / \mathrm{N}-1 / \mathrm{C}-2$ & Vpc & 11,3 & 11,6 & 11,8 & PA02 & $\mathrm{S}-4 / \mathrm{N}-1 / \mathrm{C}-2$ \\
\hline PA02 & $\mathrm{S}-4 / \mathrm{N}-1 / \mathrm{C}-2$ & Vpc & 11,5 & 12,5 & 11,2 & PA02 & $\mathrm{S}-4 / \mathrm{N}-1 / \mathrm{C}-2$ \\
\hline PA02 & $\mathrm{S}-4 / \mathrm{N}-1 / \mathrm{C}-2$ & Vpc & 11,4 & 12,9 & 10,3 & PA02 & $\mathrm{S}-4 / \mathrm{N}-1 / \mathrm{C}-2$ \\
\hline PA02 & $\mathrm{S}-4 / \mathrm{N}-1 / \mathrm{C}-2$ & Vpc & 10,2 & 12,4 & 8,5 & PA02 & $\mathrm{S}-4 / \mathrm{N}-1 / \mathrm{C}-2$ \\
\hline PA02 & $\mathrm{S}-4 / \mathrm{N}-1 / \mathrm{C}-2$ & Vpc & 11,4 & 12,5 & 10,7 & PA02 & $\mathrm{S}-4 / \mathrm{N}-1 / \mathrm{C}-2$ \\
\hline PA02 & $\mathrm{S}-4 / \mathrm{N}-1 / \mathrm{C}-2$ & Vpc & 10 & 12,5 & 9,2 & PA02 & $\mathrm{S}-4 / \mathrm{N}-1 / \mathrm{C}-2$ \\
\hline PA02 & $\mathrm{S}-4 / \mathrm{N}-1 / \mathrm{C}-2$ & Vpc & 9,6 & & 9,2 & PA02 & $\mathrm{S}-4 / \mathrm{N}-1 / \mathrm{C}-2$ \\
\hline PA02 & $\mathrm{S}-4 / \mathrm{N}-1 / \mathrm{C}-2$ & Vpc & 9,6 & 10,6 & 8,7 & PA02 & $\mathrm{S}-4 / \mathrm{N}-1 / \mathrm{C}-2$ \\
\hline PA02 & $\mathrm{S}-4 / \mathrm{N}-1 / \mathrm{C}-2$ & Vpc & 8,8 & 9,4 & 8,3 & PA02 & $\mathrm{S}-4 / \mathrm{N}-1 / \mathrm{C}-2$ \\
\hline PA02 & $\mathrm{S}-4 / \mathrm{N}-1 / \mathrm{C}-2$ & $\mathrm{Vpc}$ & 10,4 & 12,6 & 8,9 & PA02 & $\mathrm{S}-4 / \mathrm{N}-1 / \mathrm{C}-2$ \\
\hline PA02 & $\mathrm{S}-4 / \mathrm{N}-1 / \mathrm{C}-2$ & Vpc & 10,6 & 11,3 & 8,6 & PA02 & $\mathrm{S}-4 / \mathrm{N}-1 / \mathrm{C}-2$ \\
\hline PA02 & $\mathrm{S}-4 / \mathrm{N}-1 / \mathrm{C}-2$ & Vpc & 11,6 & 12,7 & 10,5 & PA02 & $\mathrm{S}-4 / \mathrm{N}-1 / \mathrm{C}-2$ \\
\hline PA02 & $\mathrm{S}-4 / \mathrm{N}-1 / \mathrm{C}-2$ & Vpc & 12,1 & 12,5 & 11,4 & PA02 & $\mathrm{S}-4 / \mathrm{N}-1 / \mathrm{C}-2$ \\
\hline PA02 & $\mathrm{S}-4 / \mathrm{N}-1 / \mathrm{C}-2$ & Vpc & 10,8 & 13,2 & 8,2 & PA02 & $\mathrm{S}-4 / \mathrm{N}-1 / \mathrm{C}-2$ \\
\hline PA02 & $\mathrm{S}-4 / \mathrm{N}-1 / \mathrm{C}-2$ & Vpc & 9,8 & 12,5 & 8,3 & PA02 & $\mathrm{S}-4 / \mathrm{N}-1 / \mathrm{C}-2$ \\
\hline PA02 & $\mathrm{S}-4 / \mathrm{N}-1 / \mathrm{C}-2$ & Vpc & 10,7 & 11,8 & 7,3 & PA02 & $\mathrm{S}-4 / \mathrm{N}-1 / \mathrm{C}-2$ \\
\hline PA02 & $\mathrm{S}-4 / \mathrm{N}-1 / \mathrm{C}-2$ & Vpc & 9,9 & 12,9 & 10 & PA02 & $\mathrm{S}-4 / \mathrm{N}-1 / \mathrm{C}-2$ \\
\hline PA02 & $\mathrm{S}-4 / \mathrm{N}-1 / \mathrm{C}-2$ & Vpc & & & 7,2 & PA02 & $\mathrm{S}-4 / \mathrm{N}-1 / \mathrm{C}-2$ \\
\hline PA02 & $\mathrm{S}-4 / \mathrm{N}-1 / \mathrm{C}-2$ & Vpc & 12,1 & 12,5 & 13,3 & PA02 & $\mathrm{S}-4 / \mathrm{N}-1 / \mathrm{C}-2$ \\
\hline PA02 & $\mathrm{S}-4 / \mathrm{N}-1 / \mathrm{C}-2$ & Vpc & 10,2 & 11,2 & 9,1 & PA02 & $\mathrm{S}-4 / \mathrm{N}-1 / \mathrm{C}-2$ \\
\hline PA02 & $\mathrm{S}-4 / \mathrm{N}-1 / \mathrm{C}-2$ & Vpc & 10,5 & 11,3 & 9,2 & PA02 & $\mathrm{S}-4 / \mathrm{N}-1 / \mathrm{C}-2$ \\
\hline PA02 & $\mathrm{S}-4 / \mathrm{N}-1 / \mathrm{C}-2$ & Vpc & 11,8 & 13 & 9,2 & PA02 & $\mathrm{S}-4 / \mathrm{N}-1 / \mathrm{C}-2$ \\
\hline PA02 & $\mathrm{S}-4 / \mathrm{N}-1 / \mathrm{C}-2$ & Vpc & & & 8,9 & PA02 & $\mathrm{S}-4 / \mathrm{N}-1 / \mathrm{C}-2$ \\
\hline PA02 & $\mathrm{S}-4 / \mathrm{N}-1 / \mathrm{C}-2$ & Vpc & 13,2 & 14,1 & 13,6 & PA02 & $\mathrm{S}-4 / \mathrm{N}-1 / \mathrm{C}-2$ \\
\hline PA02 & $\mathrm{S}-4 / \mathrm{N}-1 / \mathrm{C}-2$ & Vpc & 9,8 & 10,7 & 9,1 & PA02 & $\mathrm{S}-4 / \mathrm{N}-1 / \mathrm{C}-2$ \\
\hline
\end{tabular}

\begin{tabular}{|c|c|c|c|}
\hline oc & 12,6 & 14,8 & \\
\hline $\mathrm{Vpc}$ & 12,8 & 14,6 & 12,5 \\
\hline & 11,8 & 13,2 & 117 \\
\hline & 11,7 & 14,2 & \\
\hline & 10,3 & 12,4 & 48 \\
\hline & 11,6 & 13,3 & \\
\hline & 9,3 & 10 & \\
\hline & 8,5 & 10 & \\
\hline & & & \\
\hline & 8,7 & 9,7 & \\
\hline & 11,9 & 12,2 & 4 \\
\hline & 11,7 & 15,6 & \\
\hline & 8,6 & 9,7 & \\
\hline & 10,7 & 13 & \\
\hline & 8,3 & 12,2 & 8, \\
\hline & 12 & 13,5 & 57 \\
\hline & 11 & 14 & \\
\hline & 9 & 10,5 & 47 \\
\hline & 11,5 & 14,6 & 6,4 \\
\hline & 10,7 & 13,4 & 5,7 \\
\hline & 9,4 & 11,5 & \\
\hline & 11,3 & 13,2 & 8,4 \\
\hline & 10,6 & 12 & 87 \\
\hline & 11,2 & 12,5 & 10,1 \\
\hline & 11,1 & 12,6 & 2 \\
\hline & 11,5 & 13,5 & 8,4 \\
\hline & 10,7 & & 103 \\
\hline & 9,7 & 10,7 & ৪, \\
\hline & 10,6 & 12 & 11,2 \\
\hline & 9,6 & & \\
\hline & 11,4 & 11,7 & 9,5 \\
\hline & 9,5 & 10,7 & \\
\hline & 12 & 14,9 & 7,3 \\
\hline & 10,1 & 11 & 8,7 \\
\hline & 8,5 & 10 &, 4 \\
\hline & 11,7 & 11,4 & 8,5 \\
\hline & 14 & 14,9 & 13 \\
\hline & 12 & 13,3 & \\
\hline & 11,6 & 13,7 & 10,3 \\
\hline & 12,4 & 13,6 & \\
\hline & 10,8 & 13 & 10 \\
\hline & 11,1 & 11,4 & \\
\hline & 11,6 & 12,4 & \\
\hline & 11,1 & 11,6 & \\
\hline & 12,8 & 14,8 & \\
\hline
\end{tabular}




\begin{tabular}{|c|c|c|c|c|c|c|c|c|c|c|c|}
\hline PA02 & S-4/N-1/C-2 & $\mathrm{Vpc}$ & 11,8 & 13,7 & 11,2 & PA02 & $\mathrm{S}-4 / \mathrm{N}-1 / \mathrm{C}-2$ & $V p c$ & 11,4 & 12,7 & 11,7 \\
\hline PA02 & $\mathrm{S}-4 / \mathrm{N}-1 / \mathrm{C}-2$ & $\mathrm{Vpc}$ & 13 & 15 & 11,6 & PA02 & $\mathrm{S}-4 / \mathrm{N}-1 / \mathrm{C}-2$ & Vpc & 10,6 & 11,2 & 9,8 \\
\hline PA02 & $\mathrm{S}-4 / \mathrm{N}-1 / \mathrm{C}-2$ & $\mathrm{Vpc}$ & 10,5 & 13 & 9,3 & PA02 & $\mathrm{S}-4 / \mathrm{N}-1 / \mathrm{C}-2$ & $\mathrm{Vpc}$ & 13,5 & 15,2 & 11,5 \\
\hline PA02 & S-4/N-1/C-2 & $\mathrm{Vpc}$ & 11,4 & 11,8 & 11,8 & PA02 & $\mathrm{S}-4 / \mathrm{N}-1 / \mathrm{C}-2$ & $\mathrm{Vpc}$ & 12,1 & 12,5 & 11,5 \\
\hline PA02 & S-4/N-1/C-2 & $\mathrm{Vpc}$ & 11,5 & 12 & 11,8 & PA02 & $\mathrm{S}-4 / \mathrm{N}-1 / \mathrm{C}-2$ & Vpc & 11,6 & 12,4 & 11,1 \\
\hline PA02 & S- $4 / N-1 / C-2$ & $\mathrm{Vpc}$ & 10,4 & 12,5 & 10,2 & PA02 & $\mathrm{S}-4 / \mathrm{N}-1 / \mathrm{C}-2$ & Vpc & 10,2 & 10,9 & 9,8 \\
\hline PA02 & $\mathrm{S}-4 / \mathrm{N}-1 / \mathrm{C}-2$ & $\mathrm{Vpc}$ & 11,3 & 12,7 & 7,9 & PA02 & $\mathrm{S}-4 / \mathrm{N}-1 / \mathrm{C}-2$ & Vpc & 9,9 & 10,8 & 8,7 \\
\hline PA02 & $\mathrm{S}-4 / \mathrm{N}-1 / \mathrm{C}-2$ & $\mathrm{Vpc}$ & 12,4 & 13,7 & 8,5 & PA02 & $\mathrm{S}-4 / \mathrm{N}-1 / \mathrm{C}-2$ & $\mathrm{Vpc}$ & 12 & 13,4 & 12,7 \\
\hline PA02 & S-4/N-1/C-2 & $\mathrm{Vpc}$ & 11,1 & 11,7 & 9 & PA02 & $\mathrm{S}-4 / \mathrm{N}-1 / \mathrm{C}-2$ & Vpc & 11,2 & 13,4 & 11 \\
\hline PA02 & S- $4 / N-1 / C-2$ & $\mathrm{Vpc}$ & 11,4 & 12,6 & 9,5 & PA02 & $\mathrm{S}-4 / \mathrm{N}-1 / \mathrm{C}-2$ & Vpc & 13,5 & 14,6 & 12,9 \\
\hline PA02 & S-4/N-1/C-2 & $\mathrm{Vpc}$ & 17,1 & 20,1 & 12,4 & PA02 & $S-5 / N-2 / C-3$ & Vpc & 12,7 & 13,9 & 12,4 \\
\hline PA02 & $S-4 / N-1 / C-2$ & $\mathrm{Vpc}$ & 11,8 & 12,4 & 11,8 & PA02 & $\mathrm{S}-4 / \mathrm{N}-1 / \mathrm{C}-2$ & $\mathrm{Vpc}$ & 11 & 13 & 10,2 \\
\hline PA02 & S-4/N-1/C-2 & $\mathrm{Vpc}$ & 11,4 & 14,1 & 11,8 & PA02 & $\mathrm{S}-4 / \mathrm{N}-1 / \mathrm{C}-2$ & Vpc & 12,5 & 13,5 & 10,8 \\
\hline PA02 & $\mathrm{S}-4 / \mathrm{N}-1 / \mathrm{C}-2$ & $\mathrm{Vpc}$ & 14,2 & 15,3 & 13,6 & PA02 & $S-5 / N-2 / C-3$ & $V p c$ & 11,6 & 11,9 & 11,5 \\
\hline PA02 & $\mathrm{S}-4 / \mathrm{N}-1 / \mathrm{C}-2$ & $\mathrm{Vpc}$ & 8,8 & 9,7 & 8 & PA02 & $S-5 / N-2 / C-3$ & $\mathrm{Vpc}$ & 9,5 & 10,9 & 8,8 \\
\hline PA02 & S-4/N-1/C-2 & $\mathrm{Vpc}$ & 10,8 & 9,8 & 12,2 & PA02 & $S-5 / N-2 / C-3$ & $\mathrm{Vpc}$ & 10,8 & 11,5 & 11,9 \\
\hline PA02 & $\mathrm{S}-4 / \mathrm{N}-1 / \mathrm{C}-2$ & $\mathrm{Vpc}$ & 9,4 & 11,3 & 10,2 & PA02 & $S-5 / N-2 / C-3$ & Vpc & 11,6 & 12,4 & 11,3 \\
\hline PA02 & $\mathrm{S}-4 / \mathrm{N}-1 / \mathrm{C}-2$ & $\mathrm{Vpc}$ & 13,8 & 14,7 & 12,9 & PA02 & $S-5 / N-2 / C-3$ & Vpc & 11,6 & 12,8 & 9,9 \\
\hline PA02 & $\mathrm{S}-4 / \mathrm{N}-1 / \mathrm{C}-2$ & $\mathrm{Vpc}$ & 11,3 & 12,9 & 11,8 & PA02 & $S-5 / N-2 / C-3$ & $\mathrm{Vpc}$ & 11,5 & 12,8 & 10,1 \\
\hline PA02 & $\mathrm{S}-4 / \mathrm{N}-1 / \mathrm{C}-2$ & $\mathrm{Vpc}$ & 9,9 & 10,7 & 8 & PA02 & $S-5 / N-2 / C-3$ & $\mathrm{Vpc}$ & 11 & 13,1 & 10,5 \\
\hline PA02 & $\mathrm{S}-4 / \mathrm{N}-1 / \mathrm{C}-2$ & $\mathrm{Vpc}$ & 10,9 & 11,4 & 12 & PA02 & $S-5 / N-2 / C-3$ & $\mathrm{Vpc}$ & 14,6 & 16,1 & \\
\hline PA02 & $\mathrm{S}-4 / \mathrm{N}-1 / \mathrm{C}-2$ & $\mathrm{Vpc}$ & 10,8 & 14,7 & 10,5 & PA02 & $S-5 / N-2 / C-3$ & $\mathrm{Vpc}$ & 13,9 & 17 & 16,3 \\
\hline PA02 & $S-4 / N-1 / C-2$ & $\mathrm{Vpc}$ & 11,6 & 13,1 & 9,9 & PA02 & $S-5 / N-2 / C-3$ & Vpc & 10,6 & 11,4 & 10,3 \\
\hline PA02 & $\mathrm{S}-4 / \mathrm{N}-1 / \mathrm{C}-2$ & Vpc & 10 & 10,8 & 10,5 & PA02 & $S-5 / N-2 / C-3$ & $V p c$ & 10,7 & 12,1 & 8,9 \\
\hline PA02 & $\mathrm{S}-4 / \mathrm{N}-1 / \mathrm{C}-2$ & $\mathrm{Vpc}$ & 10,4 & 11,5 & 9,9 & PA02 & $S-5 / N-2 / C-3$ & $V p c$ & 15,2 & 15,5 & 14,5 \\
\hline PA02 & $\mathrm{S}-4 / \mathrm{N}-1 / \mathrm{C}-2$ & $\mathrm{Vpc}$ & 13,8 & 15 & 12,1 & PA02 & $S-5 / N-2 / C-3$ & $\mathrm{Vpc}$ & 14 & 14 & 13,1 \\
\hline PA02 & S-4/N-1/C-2 & $\mathrm{Vpc}$ & 11,7 & 12,9 & 11,3 & PA02 & $S-5 / N-2 / C-3$ & $\mathrm{Vpc}$ & 12,6 & 13,7 & 12,6 \\
\hline PA02 & $\mathrm{S}-4 / \mathrm{N}-1 / \mathrm{C}-2$ & $\mathrm{Vpc}$ & 14,8 & 13,8 & 5,9 & PA02 & $S-5 / N-2 / C-3$ & $\mathrm{Vpc}$ & 13 & 13,3 & 12,2 \\
\hline PA02 & S-4/N-1/C-2 & $\mathrm{Vpc}$ & 12,9 & & & PA02 & $S-5 / N-2 / C-3$ & Vpc & 10,6 & 11,9 & 9,1 \\
\hline PA02 & $\mathrm{S}-4 / \mathrm{N}-1 / \mathrm{C}-2$ & $\mathrm{Vpc}$ & 10,8 & 12,4 & 10 & PA02 & $S-5 / N-2 / C-3$ & $\mathrm{Vpc}$ & 11,1 & 11,8 & 10,6 \\
\hline PA02 & S-4/N-1/C-2 & $\mathrm{Vpc}$ & 11,7 & 12,8 & 11 & PA02 & $S-5 / N-2 / C-3$ & Vpc & 12,1 & 13,8 & 11,6 \\
\hline PA02 & $\mathrm{S}-4 / \mathrm{N}-1 / \mathrm{C}-2$ & $\mathrm{Vpc}$ & 12,1 & 12,8 & 11,6 & PA02 & $S-5 / N-2 / C-3$ & $\mathrm{Vpc}$ & 14,1 & 14,6 & 13,7 \\
\hline PA02 & S-4/N-1/C-2 & $\mathrm{Vpc}$ & 11,2 & 12,3 & 11,1 & PA02 & $S-5 / N-2 / C-3$ & $\mathrm{Vpc}$ & 12,9 & 12,8 & 13,1 \\
\hline PA02 & $\mathrm{S}-4 / \mathrm{N}-1 / \mathrm{C}-2$ & $\mathrm{Vpc}$ & 13,3 & 14,6 & 13,1 & PA02 & $S-5 / N-2 / C-3$ & $\mathrm{Vpc}$ & 11,6 & 13,6 & 6,9 \\
\hline PA02 & S-4/N-1/C-2 & $\mathrm{Vpc}$ & 11,3 & 12,6 & 8,8 & PA02 & $S-5 / N-2 / C-3$ & $\mathrm{Vpc}$ & 12,3 & 13,8 & 6,1 \\
\hline PA02 & $\mathrm{S}-4 / \mathrm{N}-1 / \mathrm{C}-2$ & $\mathrm{Vpc}$ & 10,4 & 12,1 & 8,9 & PA02 & $S-5 / N-2 / C-3$ & $V p c$ & 10,9 & 11,6 & 10,6 \\
\hline PA02 & S-4/N-1/C-2 & $\mathrm{Vpc}$ & 12,6 & 14,7 & 11,4 & PA02 & $S-5 / N-2 / C-3$ & $\mathrm{Vpc}$ & 10,9 & 13 & 11,1 \\
\hline PA02 & $\mathrm{S}-4 / \mathrm{N}-1 / \mathrm{C}-2$ & $\mathrm{Vpc}$ & 12,4 & 14,1 & 10 & PA02 & $S-5 / N-2 / C-3$ & $\mathrm{Vpc}$ & 10,2 & 10,8 & 9,6 \\
\hline PA02 & S-4/N-1/C-2 & $\mathrm{Vpc}$ & 11,1 & 12,6 & 7,7 & PA02 & $S-5 / N-2 / C-3$ & $\mathrm{Vpc}$ & 12,1 & 12,5 & 10,5 \\
\hline PA02 & S-4/N-1/C-2 & $\mathrm{Vpc}$ & 11,5 & 13 & 11,1 & PA02 & $S-5 / N-2 / C-3$ & Vpc & 13,4 & 13,9 & 13,4 \\
\hline PA02 & $\mathrm{S}-4 / \mathrm{N}-1 / \mathrm{C}-2$ & $\mathrm{Vpc}$ & 12,2 & 13,7 & 10,9 & PA02 & $S-5 / N-2 / C-3$ & Vpc & 13 & 13,6 & 13,4 \\
\hline PA02 & S-4/N-1/C-2 & $\mathrm{Vpc}$ & 12,2 & 13 & 7,3 & PA02 & $S-5 / N-2 / C-3$ & Vpc & 12,7 & 13,6 & 12,1 \\
\hline PA02 & $\mathrm{S}-4 / \mathrm{N}-1 / \mathrm{C}-2$ & $\mathrm{Vpc}$ & 14,2 & 15,1 & 12,8 & PA02 & $S-5 / N-2 / C-4$ & $V p c$ & 10,2 & 10,3 & \\
\hline PA02 & S-5/N-2/C-4 & $V p c$ & 10,8 & & 9 & PA02 & $S-5 / N-2 / C-4$ & $\mathrm{Vpc}$ & 10,2 & 11,4 & 8,7 \\
\hline PA02 & $\mathrm{S}-5 / \mathrm{N}-2 / \mathrm{C}-4$ & $\mathrm{Vpc}$ & & & 9,5 & PA02 & S-5/N-2/C-4 & Vpc & 11,7 & 12,9 & 8,9 \\
\hline
\end{tabular}




\begin{tabular}{|c|c|c|c|c|c|c|c|c|c|c|c|}
\hline PA02 & $\mathrm{S}-5 / \mathrm{N}-2 / \mathrm{C}-4$ & $\mathrm{Vpc}$ & 11,6 & 11,8 & 12,3 & PA02 & S-5/N-2/C-4 & $\mathrm{Vpc}$ & 10,8 & 12,3 & 9,3 \\
\hline PA02 & S-5/N-2/C-4 & Vpc & 10,3 & 11 & 8,8 & PA02 & $\mathrm{S}-5 / \mathrm{N}-2 / \mathrm{C}-4$ & Vpc & 12,2 & & \\
\hline PA02 & $S-5 / N-2 / C-4$ & $\mathrm{Vpc}$ & 13,7 & 12,7 & 13,4 & PA02 & $\mathrm{S}-5 / \mathrm{N}-2 / \mathrm{C}-4$ & $\mathrm{Vpc}$ & 11,1 & 12,4 & 9,9 \\
\hline PA02 & S-5/N-2/C-4 & $\mathrm{Vpc}$ & 10,1 & 11,6 & 9,4 & PA02 & S-5/N-2/C-4 & $\mathrm{Vpc}$ & & & 11,4 \\
\hline PA02 & S-5/N-2/C-4 & $\mathrm{Vpc}$ & 12,2 & 13,4 & & PA02 & $S-5 / N-2 / C-4$ & $\mathrm{Vpc}$ & 11,2 & & \\
\hline PA02 & S-5/N-2/C-4 & $\mathrm{Vpc}$ & & & 9,5 & PA02 & $S-5 / N-2 / C-4$ & Vpc & 11,6 & & \\
\hline PA02 & S-5/N-2/C-4 & $\mathrm{Vpc}$ & 9,9 & 11,6 & 8,7 & PA02 & $S-5 / N-2 / C-4$ & $\mathrm{Vpc}$ & 10,6 & 12 & \\
\hline PA02 & $S-5 / N-2 / C-4$ & Vpc & 13,2 & 14,3 & 11 & PA02 & $\mathrm{S}-5 / \mathrm{N}-2 / \mathrm{C}-4$ & Vpc & 10,1 & 10,8 & 9,6 \\
\hline PA02 & S-5/N-2/C-4 & $\mathrm{Vpc}$ & 12,7 & 14,1 & 9,6 & PA02 & $\mathrm{S}-5 / \mathrm{N}-2 / \mathrm{C}-4$ & Vpc & 11,3 & 12,4 & 10,1 \\
\hline PA02 & $S-5 / N-2 / C-4$ & $\mathrm{Vpc}$ & 11,5 & 12,1 & 11,4 & PA02 & $\mathrm{S}-5 / \mathrm{N}-2 / \mathrm{C}-4$ & $\mathrm{Vpc}$ & & & 10,3 \\
\hline PA02 & S-5/N-2/C-4 & $\mathrm{Vpc}$ & 9,9 & 9,7 & & PA02 & $S-5 / N-2 / C-4$ & Vpc & 10,3 & 12,5 & 9 \\
\hline PA02 & $S-5 / N-2 / C-4$ & $\mathrm{Vpc}$ & 11,2 & 11,2 & 10,6 & PA02 & $\mathrm{S}-5 / \mathrm{N}-2 / \mathrm{C}-4$ & $\mathrm{Vpc}$ & 10 & 11,5 & 10,1 \\
\hline PA02 & $S-5 / N-2 / C-4$ & $\mathrm{Vpc}$ & 11,4 & 11,9 & & PA02 & $S-5 / N-2 / C-4$ & Vpc & & & 8,6 \\
\hline PA02 & $\mathrm{S}-5 / \mathrm{N}-2 / \mathrm{C}-4$ & $\mathrm{Vpc}$ & 10,8 & 10,8 & 9,9 & PA02 & $S-5 / N-2 / C-4$ & $\mathrm{Vpc}$ & 10,9 & 12,5 & \\
\hline PA02 & S-5/N-2/C-4 & $\mathrm{Vpc}$ & 11,7 & 12,7 & 7,1 & PA02 & S-5/N-2/C-4 & Vpc & & & 12,5 \\
\hline PA02 & $S-5 / N-2 / C-4$ & $\mathrm{Vpc}$ & 11,2 & 13 & 12,8 & PA02 & $S-5 / N-2 / C-4$ & Vpc & 9,2 & 11 & \\
\hline PA02 & $S-5 / N-2 / C-4$ & $\mathrm{Vpc}$ & 10,6 & 11 & 10,2 & PA02 & $S-5 / N-2 / C-4$ & $\mathrm{Vpc}$ & & & 10,7 \\
\hline PA02 & $\mathrm{S}-5 / \mathrm{N}-2 / \mathrm{C}-4$ & $\mathrm{Vpc}$ & 10,2 & & & PA02 & $S-5 / N-2 / C-4$ & Vpc & 10,9 & 11,6 & 8,7 \\
\hline PA02 & $\mathrm{S}-5 / \mathrm{N}-2 / \mathrm{C}-4$ & $\mathrm{Vpc}$ & 11,4 & 12,5 & 10,8 & PA02 & $S-5 / N-2 / C-4$ & $\mathrm{Vpc}$ & & & 9,9 \\
\hline PA02 & S-5/N-2/C-4 & $\mathrm{Vpc}$ & 10,9 & 11 & 10,4 & PA02 & S-5/N-2/C-4 & Vpc & 11,5 & 14 & 6,5 \\
\hline PA02 & $S-5 / N-2 / C-4$ & $\mathrm{Vpc}$ & 10,1 & 11,5 & & PA02 & $S-5 / N-2 / C-4$ & $\mathrm{Vpc}$ & & & 9,3 \\
\hline PA02 & $S-5 / N-2 / C-4$ & $\mathrm{Vpc}$ & 10,7 & 12,6 & 9,7 & PA02 & $S-5 / N-2 / C-4$ & Vpc & 11,7 & 12,4 & \\
\hline PA02 & $S-5 / N-2 / C-4$ & $\mathrm{Vpc}$ & & & 11,6 & PA02 & S-5/N-2/C-4 & $\mathrm{Vpc}$ & 11,3 & 10,8 & 9,1 \\
\hline PA02 & S-5/N-2/C-4 & $\mathrm{Vpc}$ & 10,9 & 11,8 & 7,9 & PA02 & $S-5 / N-2 / C-4$ & $\mathrm{Vpc}$ & 9,7 & 11,7 & 8,3 \\
\hline PA02 & $\mathrm{S}-5 / \mathrm{N}-2 / \mathrm{C}-4$ & $\mathrm{Vpc}$ & 12,2 & 13,1 & 11,5 & PA02 & $S-5 / N-2 / C-4$ & $\mathrm{Vpc}$ & 9,3 & 10 & 3,9 \\
\hline PA02 & S-5/N-2/C-4 & $\mathrm{Vpc}$ & 10,2 & 12,6 & 6,3 & PA02 & S-5/N-2/C-4 & Vpc & 10,9 & 12,1 & 3,6 \\
\hline PA02 & $\mathrm{S}-5 / \mathrm{N}-2 / \mathrm{C}-4$ & $\mathrm{Vpc}$ & & & 11,5 & PA02 & $S-5 / N-2 / C-4$ & Vpc & 11,7 & 13,6 & 4,6 \\
\hline PA02 & S-5/N-2/C-4 & $\mathrm{Vpc}$ & & & 7,5 & PA02 & $S-5 / N-2 / C-4$ & Vpc & 10,4 & 10,5 & 5,2 \\
\hline PA02 & $S-5 / N-2 / C-4$ & $\mathrm{Vpc}$ & 10,6 & 11,7 & 11,1 & PA02 & $S-5 / N-2 / C-4$ & $\mathrm{Vpc}$ & 9,3 & 10,9 & 5,7 \\
\hline PA02 & $\mathrm{S}-5 / \mathrm{N}-2 / \mathrm{C}-4$ & $\mathrm{Vpc}$ & 10,7 & 11,6 & 9,9 & PA02 & $S-5 / N-2 / C-4$ & $\mathrm{Vpc}$ & 9,6 & 13 & 5,5 \\
\hline PA02 & S-5/N-2/C-4 & $\mathrm{Vpc}$ & 10,1 & 11,6 & 10,7 & PA02 & $\mathrm{S}-5 / \mathrm{N}-2 / \mathrm{C}-4$ & Vpc & & 11,7 & 6,9 \\
\hline PA02 & S-5/N-2/C-4 & $\mathrm{Vpc}$ & 11 & 11,9 & 9,9 & PA02 & $\mathrm{S}-5 / \mathrm{N}-2 / \mathrm{C}-4$ & Vpc & 12,5 & 12,8 & 11,2 \\
\hline PA02 & S-5/N-2/C-3 & $\mathrm{Vpc}$ & 10 & 12,6 & 10 & PA02 & S-5/N-2/C-4 & Vpc & 11,1 & 11,9 & 11 \\
\hline PA02 & $S-5 / N-2 / C-3$ & $\mathrm{Vpc}$ & 11,5 & 14 & 6,7 & PA02 & $S-5 / N-2 / C-4$ & Vpc & & & 8,7 \\
\hline PA02 & S-5/N-2/C-4 & $\mathrm{Vpc}$ & 10,2 & 11,3 & 9,7 & PA02 & $S-5 / N-2 / C-4$ & Vpc & 11,3 & 12,2 & 7 \\
\hline PA02 & S-5/N-2/C-4 & $\mathrm{Vpc}$ & 11 & 12,2 & 10,3 & PA02 & $\mathrm{S}-5 / \mathrm{N}-2 / \mathrm{C}-4$ & Vpc & 11,3 & 12,1 & 10,8 \\
\hline PA02 & S-5/N-2/C-4 & $\mathrm{Vpc}$ & 12,6 & 12,7 & 10,5 & PA02 & S-5/N-2/C-4 & Vpc & 13,1 & 14,3 & 9,7 \\
\hline PA02 & S-5/N-2/C-4 & $\mathrm{Vpc}$ & 9,9 & 11,1 & 8 & PA02 & $\mathrm{S}-5 / \mathrm{N}-2 / \mathrm{C}-4$ & Vpc & 11,8 & 12,7 & 10,9 \\
\hline PA02 & S-5/N-2/C-4 & $\mathrm{Vpc}$ & 9,5 & 10,9 & 9,5 & PA02 & $S-5 / N-2 / C-4$ & $\mathrm{Vpc}$ & & & 10,5 \\
\hline PA02 & S-5/N-2/C-4 & $\mathrm{Vpc}$ & 11,4 & 12,6 & 9,6 & PA02 & $S-5 / N-2 / C-4$ & $\mathrm{Vpc}$ & & & 7,4 \\
\hline PA02 & S-5/N-2/C-4 & $\mathrm{Vpc}$ & 11,5 & 12,3 & 10,8 & PA02 & $S-5 / N-2 / C-4$ & Vpc & 11,3 & 12,8 & 11,7 \\
\hline PA02 & S-5/N-2/C-4 & $\mathrm{Vpc}$ & & 11,9 & 8,3 & PA02 & $S-5 / N-2 / C-4$ & Vpc & 13,1 & 12,8 & 13,2 \\
\hline PA02 & S-5/N-2/C-4 & $\mathrm{Vpc}$ & 11 & 13 & 10,8 & PA02 & S-5/N-2/C-4 & Vpc & 10,3 & 11,5 & 7,9 \\
\hline PA02 & S-5/N-2/C-4 & $\mathrm{Vpc}$ & 9,2 & & & PA02 & S-5/N-2/C-4 & Vpc & 11,4 & 12,9 & 12,6 \\
\hline PA02 & $\mathrm{S}-5 / \mathrm{N}-2 / \mathrm{C}-4$ & Vpc & 11 & 12,3 & 10,2 & PA02 & $\mathrm{S}-5 / \mathrm{N}-2 / \mathrm{C}-4$ & $\mathrm{Vpc}$ & 14,5 & 15,3 & 14,3 \\
\hline
\end{tabular}




\begin{tabular}{|c|c|c|c|c|c|c|c|c|c|c|c|}
\hline PA02 & S-5/N-2/C-4 & $\mathrm{Vpc}$ & 10,4 & 11,1 & 9,2 & PA02 & S-5/N-2/C-4 & $\mathrm{Vpc}$ & 13,5 & 13,8 & 13,7 \\
\hline PA02 & S-5/N-2/C-4 & $V p c$ & 8,6 & 9,1 & & PA02 & $\mathrm{S}-5 / \mathrm{N}-2 / \mathrm{C}-4$ & $V p c$ & 13,2 & 14,3 & 13,7 \\
\hline PA02 & S-5/N-2/C-4 & $\mathrm{Vpc}$ & 11,2 & & 10,6 & PA02 & S-5/N-2/C-4 & Vpc & 12,6 & 13,4 & 12,8 \\
\hline PA02 & $\mathrm{S}-5 / \mathrm{N}-2 / \mathrm{C}-4$ & $\mathrm{Vpc}$ & 9,8 & 12,5 & 8,5 & PA02 & S-5/N-2/C-4 & $\mathrm{Vpc}$ & 11,6 & 11,7 & 10,4 \\
\hline PA02 & S-5/N-2/C-4 & $\mathrm{Vpc}$ & 12,6 & 13,6 & 10,6 & PA02 & S-5/N-2/C-4 & $\mathrm{Vpc}$ & 11,5 & 12 & 11,8 \\
\hline PA02 & S-5/N-2/C-4 & $\mathrm{Vpc}$ & 10,9 & 12,6 & 10,2 & PA02 & $\mathrm{S}-5 / \mathrm{N}-2 / \mathrm{C}-4$ & Vpc & 11,1 & 11,6 & 11,8 \\
\hline PA02 & S-5/N-2/C-4 & $\mathrm{Vpc}$ & 12,8 & 13,5 & & PA02 & S-5/N-2/C-4 & Vpc & 13,7 & 15,2 & 12,3 \\
\hline PA02 & $S-5 / N-2 / C-4$ & $\mathrm{Vpc}$ & 12,3 & 13,7 & 11,6 & PA02 & $\mathrm{S}-5 / \mathrm{N}-2 / \mathrm{C}-4$ & $\mathrm{Vpc}$ & & & 8,8 \\
\hline PA02 & S-5/N-2/C-4 & $\mathrm{Vpc}$ & 10,1 & 11 & 11,1 & PA02 & S-5/N-2/C-4 & Vpc & 11,8 & 12,6 & 9,8 \\
\hline PA02 & S-5/N-2/C-4 & $\mathrm{Vpc}$ & 12,5 & 12,4 & 12,3 & PA02 & $\mathrm{S}-5 / \mathrm{N}-2 / \mathrm{C}-4$ & Vpc & 10,4 & 11,7 & 8,9 \\
\hline PA02 & S-5/N-2/C-4 & $\mathrm{Vpc}$ & 12,5 & 14 & 13 & PA02 & S-5/N-2/C-4 & Vpc & 10 & 11,6 & 9,3 \\
\hline PA02 & S-5/N-2/C-4 & $\mathrm{Vpc}$ & 10,4 & 12,2 & & PA02 & S-5/N-2/C-4 & Vpc & 12,2 & 13,7 & 10,6 \\
\hline PA02 & S-5/N-2/C-4 & $\mathrm{Vpc}$ & 12,3 & 12,4 & 8,3 & PA02 & S-5/N-2/C-4 & $\mathrm{Vpc}$ & 10,7 & 11 & 10,2 \\
\hline PA02 & S-5/N-2/C-4 & $\mathrm{Vpc}$ & 11,6 & 12,7 & 9,6 & PA02 & S-5/N-2/C-4 & Vpc & 11 & 11,2 & 10,4 \\
\hline PA02 & S-5/N-2/C-4 & $\mathrm{Vpc}$ & 10,9 & 11,1 & 10,3 & PA02 & S-5/N-2/C-4 & $\mathrm{Vpc}$ & 11,4 & 12,6 & \\
\hline PA02 & S-5/N-2/C-4 & $\mathrm{Vpc}$ & 11,9 & 12,7 & 11 & PA02 & S-5/N-2/C-4 & Vpc & 10,8 & 11,9 & 9,2 \\
\hline PA02 & $S-5 / N-2 / C-4$ & $\mathrm{Vpc}$ & 12,4 & 12,6 & 9,9 & PA02 & S-5/N-2/C-4 & $\mathrm{Vpc}$ & 12,8 & 13,6 & 11,2 \\
\hline PA02 & S-5/N-2/C-4 & $\mathrm{Vpc}$ & 11,2 & 12,5 & 10,8 & PA02 & S-5/N-2/C-4 & $\mathrm{Vpc}$ & 11,4 & 12,6 & 11,5 \\
\hline PA02 & S-5/N-2/C-4 & $V p c$ & 9 & 9,9 & 8,3 & PA02 & S-5/N-2/C-4 & $\mathrm{Vpc}$ & 12,2 & 13 & 10,4 \\
\hline PA02 & S-5/N-2/C-4 & $\mathrm{Vpc}$ & 10,6 & 11,6 & 8,2 & PA02 & S-5/N-2/C-4 & $\mathrm{Vpc}$ & 13,4 & 13,1 & 12,1 \\
\hline PA02 & S-5/N-2/C-4 & $\mathrm{Vpc}$ & 9,6 & 11,4 & 8,3 & PA02 & S-5/N-2/C-4 & Vpc & 10,4 & 10,6 & 9,5 \\
\hline PA02 & $S-5 / N-2 / C-4$ & $\mathrm{Vpc}$ & 9,8 & 10,7 & 8,7 & PA02 & $S-5 / N-2 / C-4$ & Vpc & 10,8 & & \\
\hline PA02 & S-5/N-2/C-4 & $\mathrm{Vpc}$ & 10,3 & 11,7 & 6,1 & PA02 & S-5/N-2/C-4 & Vpc & 9,6 & 10,2 & 9,7 \\
\hline PA02 & S-5/N-2/C-4 & $\mathrm{Vpc}$ & 10,8 & 12,2 & 11,2 & PA02 & S-5/N-2/C-4 & $\mathrm{Vpc}$ & & & 10,1 \\
\hline PA02 & S-5/N-2/C-4 & $\mathrm{Vpc}$ & 12,4 & 13,8 & 10,1 & PA02 & S-5/N-2/C-4 & Vpc & 9,2 & 9,9 & 7,4 \\
\hline PA02 & $S-5 / N-2 / C-4$ & $\mathrm{Vpc}$ & 10,3 & 11,4 & 10,3 & PA02 & S-5/N-2/C-4 & $\mathrm{Vpc}$ & 11,3 & 12,4 & 12,1 \\
\hline PA02 & S-5/N-2/C-4 & $\mathrm{Vpc}$ & 11,9 & 11,6 & 12,4 & PA02 & S-5/N-2/C-4 & Vpc & 10,9 & & \\
\hline PA02 & $\mathrm{S}-5 / \mathrm{N}-2 / \mathrm{C}-4$ & $\mathrm{Vpc}$ & 12,7 & 13,5 & 10,6 & PA02 & $\mathrm{S}-5 / \mathrm{N}-2 / \mathrm{C}-4$ & Vpc & & & 8,4 \\
\hline PA02 & S-5/N-2/C-4 & $\mathrm{Vpc}$ & 11,9 & 13,6 & 10,8 & PA02 & S-5/N-2/C-4 & Vpc & 11,5 & 12,1 & 11,9 \\
\hline PA02 & $\mathrm{S}-5 / \mathrm{N}-2 / \mathrm{C}-4$ & $\mathrm{Vpc}$ & 11,6 & 12,7 & 9 & PA02 & S-5/N-2/C-4 & $\mathrm{Vpc}$ & 12 & 12,1 & 12,4 \\
\hline PA02 & S-5/N-2/C-4 & $\mathrm{Vpc}$ & 10,9 & 12,5 & 6,1 & PA02 & S-5/N-2/C-4 & $\mathrm{Vpc}$ & 12,8 & 13,4 & 12 \\
\hline PA02 & $\mathrm{S}-5 / \mathrm{N}-2 / \mathrm{C}-4$ & $\mathrm{Vpc}$ & 12 & 12,9 & 11,3 & PA02 & S-5/N-2/C-4 & Vpc & 11,2 & 11,8 & 11,7 \\
\hline PA02 & S-5/N-2/C-4 & $\mathrm{Vpc}$ & 12,1 & 13,5 & 12,8 & PA02 & $S-5 / N-2 / C-4$ & Vpc & 11,2 & 12,8 & 10,8 \\
\hline PA02 & S-5/N-2/C-4 & $\mathrm{Vpc}$ & 10,7 & 12,6 & 6,9 & PA02 & $\mathrm{S}-5 / \mathrm{N}-2 / \mathrm{C}-4$ & Vpc & 13,3 & 13,4 & 13,8 \\
\hline PA02 & S-5/N-2/C-4 & $\mathrm{Vpc}$ & 11,2 & 12,3 & 11,9 & PA02 & $\mathrm{S}-5 / \mathrm{N}-2 / \mathrm{C}-4$ & $\mathrm{Vpc}$ & 10,9 & 11,7 & 9,4 \\
\hline PA02 & S-5/N-2/C-4 & $\mathrm{Vpc}$ & 12,2 & 13,1 & 11,7 & PA02 & S-5/N-2/C-4 & $\mathrm{Vpc}$ & 11,4 & 12,5 & 9,8 \\
\hline PA02 & S-5/N-2/C-4 & $\mathrm{Vpc}$ & 11,5 & 11,9 & 6,8 & PA02 & S-5/N-2/C-4 & $\mathrm{Vpc}$ & 11,1 & 12,2 & 10,5 \\
\hline PA02 & S-5/N-2/C-4 & $\mathrm{Vpc}$ & 12,5 & 12,6 & 11,7 & PA02 & S-5/N-2/C-4 & Vpc & 11,9 & 12,5 & 11,4 \\
\hline PA02 & $S-5 / N-2 / C-4$ & $\mathrm{Vpc}$ & 10,4 & 10,5 & 10,2 & PA02 & $S-5 / N-2 / C-4$ & Vpc & 11,2 & 10,5 & 10,2 \\
\hline PA02 & S-5/N-2/C-4 & $\mathrm{Vpc}$ & 12,9 & 16,2 & 7,7 & PA02 & S-5/N-2/C-4 & Vpc & 14,5 & 15,8 & 11,6 \\
\hline PA02 & S-5/N-2/C-4 & $V p c$ & 10,5 & 11,8 & 9,4 & PA02 & S-5/N-2/C-4 & $V p c$ & 14 & 15,6 & 11,5 \\
\hline PA02 & S-5/N-2/C-4 & $\mathrm{Vpc}$ & 13 & 13,8 & 12,1 & PA02 & S-5/N-2/C-4 & $\mathrm{Vpc}$ & 11,3 & 11,6 & 11,1 \\
\hline PA02 & S-5/N-2/C-4 & $\mathrm{Vpc}$ & 10,8 & 12,2 & 11,3 & PA02 & $\mathrm{S}-5 / \mathrm{N}-2 / \mathrm{C}-4$ & Vpc & 13,9 & 13,6 & 13,8 \\
\hline PA02 & S-5/N-2/C-4 & $\mathrm{Vpc}$ & 11,6 & 11,8 & 11,2 & PA02 & $S-5 / N-2 / C-4$ & Vpc & 10,8 & 10,5 & 11,2 \\
\hline PA02 & $\mathrm{S}-5 / \mathrm{N}-2 / \mathrm{C}-4$ & $V p c$ & 12,5 & 13,1 & 12,4 & PA02 & $S-5 / N-2 / C-4$ & $\mathrm{Vpc}$ & 10,8 & 11,4 & 11,5 \\
\hline
\end{tabular}




\begin{tabular}{|c|c|c|c|c|c|c|c|c|c|c|c|}
\hline PA02 & S-5/N-2/C-4 & $\mathrm{Vpc}$ & 11,4 & 11,9 & 9,4 & PA02 & $\mathrm{S}-5 / \mathrm{N}-2 / \mathrm{C}-4$ & $\mathrm{Vpc}$ & 13,8 & 13,9 & 12,5 \\
\hline PA02 & S-5/N-2/C-4 & Vpc & 12,9 & 13,7 & 13,7 & PA02 & $\mathrm{S}-5 / \mathrm{N}-2 / \mathrm{C}-4$ & Vpc & 11,1 & 10,7 & 10,4 \\
\hline PA02 & S-5/N-2/C-4 & $\mathrm{Vpc}$ & 12,9 & 13,7 & & PA02 & $\mathrm{S}-5 / \mathrm{N}-2 / \mathrm{C}-4$ & $V p c$ & 11,3 & 12,3 & 11,1 \\
\hline PA02 & S-5/N-2/C-4 & $\mathrm{Vpc}$ & 10,8 & 11,6 & 9,9 & PA02 & S-5/N-2/C-4 & $\mathrm{Vpc}$ & 12,4 & & 9,4 \\
\hline PA02 & S-5/N-2/C-4 & $\mathrm{Vpc}$ & 12,2 & 13,5 & 11,7 & PA02 & $S-5 / N-3 / C-6$ & Vpc & 10,1 & 10,1 & 10,7 \\
\hline PA02 & S-5/N-2/C-4 & $\mathrm{Vpc}$ & 11,5 & 11,2 & 12,3 & PA02 & $S-5 / N-3 / C-6$ & Vpc & 12,9 & 12,2 & 11,5 \\
\hline PA02 & S-5/N-2/C-4 & $\mathrm{Vpc}$ & 10,8 & 12,1 & 10,1 & PA02 & S-5/N-3/C-6 & Vpc & 9,7 & 11,3 & 8,6 \\
\hline PA02 & S-5/N-2/C-4 & Vpc & 10,8 & 11,8 & 10,1 & PA02 & $\mathrm{S}-5 / \mathrm{N}-3 / \mathrm{C}-6$ & $\mathrm{Vpc}$ & 9,4 & 11 & 8,1 \\
\hline PA02 & S-5/N-3/C-6 & $\mathrm{Vpc}$ & 12 & 13,6 & 6,6 & PA02 & S-D/C-5 & Vpc & 14,9 & 16,2 & 8,4 \\
\hline PA02 & S-5/N-3/C-6 & $\mathrm{Vpc}$ & 14,1 & 14,3 & 13,6 & PA02 & S-D/C-5 & Vpc & 16,7 & 18,7 & 15,5 \\
\hline PA02 & S-5/N-3/C-6 & $\mathrm{Vpc}$ & 13,6 & 14,1 & 12,9 & PA02 & $S-D / C-5$ & Vpc & 13,7 & 14,6 & 12,2 \\
\hline PA02 & S-5/N-3/C-6 & $\mathrm{Vpc}$ & 9,7 & 10,4 & 8,9 & PA02 & $S-D / C-5$ & $\mathrm{Vpc}$ & 15 & 15,3 & 14,1 \\
\hline PA02 & S-5/N-3/C-6 & $\mathrm{Vpc}$ & 12,6 & 14,3 & 11,2 & PA02 & S-D/C-5 & Vpc & 15 & 15,6 & 14,3 \\
\hline PA02 & S-5/N-3/C-6 & $\mathrm{Vpc}$ & 13,8 & 16,5 & 12,2 & PA02 & S-D/C-5 & $V p c$ & 15,9 & 18,9 & 13,8 \\
\hline PA02 & S-5/N-3/C-6 & $\mathrm{Vpc}$ & 9,2 & 10,3 & 9,2 & PA02 & S-D/C-5 & $\mathrm{Vpc}$ & 11,3 & 12 & 10,8 \\
\hline PA02 & S-5/N-3/C-6 & $\mathrm{Vpc}$ & 14,4 & 16,4 & 12 & PA02 & S-D/C-5 & Vpc & 17,1 & 18,9 & 15,8 \\
\hline PA02 & S-5/N-3/C-6 & $\mathrm{Vpc}$ & 10,3 & 11,4 & 9,3 & PA02 & S-D/C-5 & $V p c$ & 11,7 & 13,3 & 9,9 \\
\hline PA02 & S-5/N-3/C-6 & $\mathrm{Vpc}$ & 11,2 & 12 & 11,1 & PA02 & S-D/C-5 & Vpc & 13,3 & 14,3 & 14 \\
\hline PA02 & S-5/N-3/C-6 & $\mathrm{Vpc}$ & 15,3 & 16,1 & 14,5 & PA02 & S-D/C-5 & $V p c$ & 10,1 & 11,6 & 8,8 \\
\hline PA02 & S-5/N-3/C-6 & $\mathrm{Vpc}$ & 13,6 & 16,5 & 12,4 & PA02 & S-D/C-5 & Vpc & 14,5 & 16,3 & 11,8 \\
\hline PA02 & S-5/N-3/C-6 & $\mathrm{Vpc}$ & 13,1 & 13,8 & 12,6 & PA02 & $S-D / C-5$ & $V p c$ & 12,5 & 13,8 & 12,1 \\
\hline PA02 & S-5/N-3/C-6 & $\mathrm{Vpc}$ & 13,5 & 13,8 & 12,5 & PA02 & S-D/C-5 & $\mathrm{Vpc}$ & 13,3 & 15,1 & 13 \\
\hline PA02 & S-5/N-3/C-6 & $\mathrm{Vpc}$ & 11,5 & 12 & 12,1 & PA02 & S-D/C-5 & $V p c$ & 12,7 & 12,3 & 12,3 \\
\hline PA02 & S-5/N-3/C-6 & $\mathrm{Vpc}$ & 14,6 & 15,3 & 10,8 & PA02 & S-D/C-5 & $V p c$ & 14,7 & 15,2 & 13,8 \\
\hline PA02 & S-5/N-3/C-6 & $\mathrm{Vpc}$ & 12 & 12,9 & 11,1 & PA02 & $S-D / C-5$ & $V p c$ & 15 & 15,8 & 11,1 \\
\hline PA02 & S-6/N-2/C-3 & $\mathrm{Vpc}$ & & 10,9 & & PA02 & S-D/C-5 & Vpc & 12,3 & 13,2 & 12 \\
\hline PA02 & $\mathrm{S}-8 / \mathrm{N}-2 / \mathrm{C}-3$ & $\mathrm{Vpc}$ & 13,4 & & 11,8 & PA02 & $S-D / C-5$ & $V p c$ & 13,7 & 16,4 & 10,8 \\
\hline PA02 & $\mathrm{S}-8 / \mathrm{N}-2 / \mathrm{C}-3$ & $\mathrm{Vpc}$ & 13,8 & 14 & 11,6 & PA02 & S-D/C-5 & $\mathrm{Vpc}$ & 11,7 & 13,6 & 10 \\
\hline PA02 & $S-B / C-3$ & $\mathrm{Vpc}$ & 15,6 & 17,4 & 8 & PA02 & S-D/C-5 & $V p c$ & 10,6 & 11,3 & 11,3 \\
\hline PA02 & $S-B / C-3$ & $\mathrm{Vpc}$ & 14,5 & 16,7 & 10,7 & PA02 & $S-D / C-5$ & Vpc & 11,5 & 12,6 & 9,9 \\
\hline PA02 & S-B/C-4 & $\mathrm{Vpc}$ & 12 & 12,3 & 11,6 & PA02 & S-D/C-5 & Vpc & 12,1 & 12 & 7 \\
\hline PA02 & $\mathrm{S}-\mathrm{C} / \mathrm{C}-3$ & $\mathrm{Vpc}$ & 16,7 & 16,6 & 15,6 & PA02 & $S-D / C-5$ & $V p c$ & 14 & 15,3 & 12,5 \\
\hline PA02 & S-D/C-5 & $\mathrm{Vpc}$ & 15 & 17 & 14,7 & PA02 & S-D/C-5 & $V p c$ & 12,8 & 13,5 & 12,5 \\
\hline PA02 & S-D/C-5 & $\mathrm{Vpc}$ & 12,5 & 14,3 & 10 & PA02 & S-D/C-5 & $V p c$ & 12,4 & 14,1 & 10,2 \\
\hline PA02 & S-D/C-5 & $V p c$ & 11,7 & 12,8 & 12,7 & PA02 & S-D/C-5 & $V p c$ & 11,4 & 11,4 & 11,9 \\
\hline PA02 & S-D/C-5 & $\mathrm{Vpc}$ & 10,7 & 12,2 & 11,2 & PA02 & S-D/C-5 & $V p c$ & 11,3 & 12,8 & 10,8 \\
\hline PA02 & S-D/C-5 & $V p c$ & 11,6 & 13,6 & 11,9 & PA02 & S-D/C-5 & Vpc & 13,5 & 13,8 & 11,7 \\
\hline PA02 & S-D/C-5 & $\mathrm{Vpc}$ & 11,7 & 12,2 & 12,2 & PA02 & S-D/C-5 & $V p c$ & 10,8 & 11,7 & 10,6 \\
\hline PA02 & S-D/C-5 & $\mathrm{Vpc}$ & 11,7 & 12,9 & 10 & PA02 & S-D/C-5 & Vpc & 11,5 & 11,9 & 6,7 \\
\hline PA02 & S-D/C-5 & $V p c$ & 13,9 & & 13,8 & PA02 & S-D/C-5 & $V p c$ & 7,7 & 8,5 & 7,5 \\
\hline PA02 & S-D/C-5 & $\mathrm{Vpc}$ & 12,4 & 12,7 & 12,1 & PA02 & S-D/C-5 & Vpc & 10,3 & 12,5 & 10,3 \\
\hline PA02 & S-D/C-5 & $\mathrm{Vpc}$ & 10,6 & 10,5 & 10,9 & PA02 & S-D/C-5 & Vpc & 9,8 & 10,8 & 10,3 \\
\hline PA02 & S-D/C-5 & $V p c$ & 12,7 & 13 & 12,6 & PA02 & S-D/C-5 & $V p c$ & 9,4 & 10,5 & 7,7 \\
\hline PA02 & S-D/C-5 & $V p c$ & 10,2 & 11,1 & 10,1 & PA02 & S-D/C-5 & Vpc & 11,3 & 12,5 & 10,4 \\
\hline PA02 & S-D/C-5 & $V p c$ & 10,7 & 11,4 & 11,4 & PA02 & S-D/C-5 & Vpc & 13,6 & 14,5 & 13,4 \\
\hline
\end{tabular}




\begin{tabular}{|c|c|c|c|c|c|c|c|c|c|c|c|}
\hline PA02 & S-D/C-5 & $\mathrm{Vpc}$ & 12,3 & 12,9 & 11,9 & PA02 & S-D/C-5 & $V p c$ & 11 & 12,2 & 10,2 \\
\hline PA02 & S-D/C-5 & $V p c$ & 11,5 & 12,6 & 11,9 & PA02 & S-D/C-5 & $V p c$ & 14,1 & 16,1 & 13,7 \\
\hline PA02 & S-D/C-5 & $V p c$ & 15,2 & 18,5 & 11,1 & PA02 & S-D/C-5 & Vpc & 11,6 & 12,4 & 11 \\
\hline PA02 & S-D/C-5 & $V p c$ & 12,8 & 12,5 & 11,9 & PA02 & S-D/C-5 & $V p c$ & 12,8 & 12,5 & 11,9 \\
\hline PA02 & S-D/C-5 & $\mathrm{Vpc}$ & 13 & 13,4 & 11 & PA02 & S-D/C-5 & Vpc & 11,4 & 13,1 & 9,4 \\
\hline PA02 & S-D/C-5 & $V p c$ & 13,3 & 14,6 & 13 & PA02 & S-D/C-5 & Vpc & 10,9 & 12,2 & 9,5 \\
\hline PA02 & S-D/C-5 & $\mathrm{Vpc}$ & 11,4 & 11,6 & 11,6 & PA02 & S-D/C-5 & Vpc & 10 & 10,6 & 9,6 \\
\hline PA02 & S-D/C-5 & $\mathrm{Vpc}$ & 11,3 & 13,4 & 10,4 & PA02 & S-D/C-5 & $V p c$ & 10,6 & 11,3 & 10 \\
\hline PA02 & S-D/C-5 & $\mathrm{Vpc}$ & 12,7 & 13,7 & & PA02 & S-D/C-5 & Vpc & 11,3 & 12,1 & 11,2 \\
\hline PA02 & S-D/C-5 & $\mathrm{Vpc}$ & 13,4 & 15 & 11,2 & PA02 & S-D/C-5 & $V p c$ & 9,9 & 9,9 & 10,6 \\
\hline PA02 & S-D/C-5 & $\mathrm{Vpc}$ & 14 & 14,4 & 14,2 & PA02 & S-D/C-5 & Vpc & 11,7 & 12,8 & 4,2 \\
\hline PA02 & S-D/C-5 & $\mathrm{Vpc}$ & 11,2 & 12,8 & 11,4 & PA02 & S-D/C-5 & Vpc & 11,7 & 13,7 & 93,5 \\
\hline PA02 & S-D/C-5 & $\mathrm{Vpc}$ & 11,9 & 12,2 & 11,5 & PA02 & S-D/C-5 & $V p c$ & 9,3 & 10,9 & 8,3 \\
\hline PA02 & S-D/C-5 & $\mathrm{Vpc}$ & 13,1 & 13,7 & 13,6 & PA02 & S-D/C-5 & Vpc & 11,7 & 12,3 & 5,5 \\
\hline PA02 & S-D/C-5 & $\mathrm{Vpc}$ & 11,5 & 12,3 & 11,2 & PA02 & S-D/C-5 & $V p c$ & 10 & 12,9 & 4,3 \\
\hline PA02 & S-D/C-5 & $\mathrm{Vpc}$ & 12,7 & 14,2 & 11,7 & PA02 & S-D/C-5 & Vpc & 10,5 & 11,7 & 9,4 \\
\hline PA02 & S-D/C-5 & $\mathrm{Vpc}$ & 13 & 14 & 11,3 & PA02 & S-D/C-5 & Vpc & 10,9 & 13 & 8,9 \\
\hline PA02 & S-D/C-5 & $\mathrm{Vpc}$ & 12,2 & 12,7 & 12,1 & PA02 & S-D/C-5 & $V p c$ & 14,3 & 15,4 & 5,3 \\
\hline PA02 & S-D/C-5 & $V p c$ & 11,7 & 12,1 & 11,5 & PA02 & S-D/C-5 & $V p c$ & 16,6 & 18 & 15,5 \\
\hline PA02 & S-D/C-5 & $V p c$ & 11,5 & 13,2 & 10,4 & PA02 & S-D/C-5 & $V p c$ & 11,2 & 12,5 & 9,8 \\
\hline PA02 & S-D/C-5 & $V p c$ & 12,2 & 13 & 11,1 & PA02 & S-D/C-5 & Vpc & 10,6 & 11,3 & 9,1 \\
\hline PA02 & S-D/C-5 & $\mathrm{Vpc}$ & 12 & 13,7 & 8,6 & PA02 & S-D/C-5 & Vpc & 12,3 & 13,9 & 11,5 \\
\hline PA02 & S-D/C-5 & $V p c$ & 11 & 10,8 & & PA02 & S-D/C-5 & Vpc & 16,8 & 18,3 & 16,1 \\
\hline PA02 & S-D/C-5 & $\mathrm{Vpc}$ & 8,9 & 10,1 & 9,4 & PA02 & S-D/C-5 & $V p c$ & 12,1 & 13,4 & 11,5 \\
\hline PA02 & S-D/C-5 & $V p c$ & 9,5 & 10,1 & 8,4 & PA02 & S-D/C-5 & Vpc & 15 & 15,7 & 13,1 \\
\hline PA02 & S-D/C-5 & $V p c$ & 9,5 & 11 & 8,3 & PA02 & S-D/C-5 & $V p c$ & 14,7 & 17,2 & 10,5 \\
\hline PA02 & S-D/C-5 & $\mathrm{Vpc}$ & 12,6 & 14,2 & 11,7 & PA02 & S-D/C-5 & Vpc & 13,9 & 14,1 & 12,4 \\
\hline PA02 & S-D/C-5 & $\mathrm{Vpc}$ & 12,1 & 13,8 & 7,2 & PA02 & S-D/C-5 & Vpc & 15,5 & 17,6 & 16,5 \\
\hline PA02 & S-D/C-5 & $\mathrm{Vpc}$ & 11,8 & 12,8 & 9,8 & PA02 & S-D/C-5 & $V p c$ & 12,1 & 12,8 & 5,6 \\
\hline PA02 & S-D/C-5 & $\mathrm{Vpc}$ & 16,6 & 20,3 & 14,1 & PA02 & S-D/C-5 & $V p c$ & 12,8 & & 12,3 \\
\hline PA02 & S-D/C-5 & $\mathrm{Vpc}$ & 10 & 10,7 & 10,5 & PA02 & S-D/C-5 & $V p c$ & 10,7 & 12,2 & 10,5 \\
\hline PA02 & S-D/C-5 & $V p c$ & 10,8 & 12,3 & 8,4 & PA02 & S-D/C-5 & Vpc & 10,8 & 12,4 & 8,8 \\
\hline PA02 & S-D/C-5 & $\mathrm{Vpc}$ & & & 9,1 & PA02 & S-D/C-5 & Vpc & 11,1 & 12,7 & 10,4 \\
\hline PA02 & S-D/C-5 & $\mathrm{Vpc}$ & 11,3 & 11,7 & 11,1 & PA02 & S-D/C-5 & Vpc & 9,7 & 11,5 & 6 \\
\hline PA02 & S-D/C-5 & $\mathrm{Vpc}$ & 12,7 & 13,9 & & PA02 & S-D/C-5 & $V p c$ & 11,9 & 12,6 & 12,1 \\
\hline PA02 & S-D/C-5 & $\mathrm{Vpc}$ & 14,4 & 15,3 & 13,9 & PA02 & S-D/C-5 & Vpc & 10 & 10,7 & 10,2 \\
\hline PA02 & S-D/C-5 & $\mathrm{Vpc}$ & 12,2 & 13,1 & 12,1 & PA02 & S-D/C-5 & $V p c$ & 12,2 & 13,6 & 9,4 \\
\hline PA02 & S-D/C-5 & $\mathrm{Vpc}$ & 15,9 & 16,8 & 15,8 & PA02 & S-D/C-5 & Vpc & & & 12,1 \\
\hline PA02 & S-D/C-5 & $\mathrm{Vpc}$ & 15,5 & 17,6 & 15,7 & PA02 & S-D/C-5 & $V p c$ & 9,2 & 11,8 & 8,4 \\
\hline PA02 & S-D/C-5 & $\mathrm{Vpc}$ & 11,4 & 12,4 & 10 & PA02 & S-D/C-5 & $V p c$ & 10 & 11 & 9,7 \\
\hline PA02 & S-D/C-5 & $V p c$ & 13,3 & 14 & 11,7 & PA02 & S-D/C-5 & $V p c$ & 11,7 & 13 & 9,4 \\
\hline PA02 & S-D/C-5 & $\mathrm{Vpc}$ & 11,6 & 12,7 & 11,3 & PA02 & S-D/C-5 & $V p c$ & 11,7 & 12 & 10,8 \\
\hline PA02 & S-D/C-5 & $\mathrm{Vpc}$ & 10,7 & 12 & 9,6 & PA02 & S-D/C-5 & Vpc & 10,3 & 11,6 & 6,8 \\
\hline PA02 & S-D/C-5 & $V p c$ & 9 & 9,9 & 4,3 & PA02 & S-D/C-5 & $V p c$ & 11,6 & 12,5 & 9,7 \\
\hline PA02 & S-D/C-5 & $\mathrm{Vpc}$ & 9,4 & 10 & 8,8 & PA02 & S-D/C-5 & Vpc & 13 & 13,6 & 12,6 \\
\hline
\end{tabular}




\begin{tabular}{|c|c|c|c|c|c|c|c|c|c|c|c|}
\hline PA02 & S-D/C-5 & Vpc & 9,5 & 10,1 & 9,8 & PA02 & S-D/C-5 & Vpc & 10,4 & 9,9 & 10,4 \\
\hline PA02 & S-D/C-5 & Vpc & 11,3 & 12,8 & 8,9 & PA02 & S-D/C-5 & Vpc & 11,6 & 12,7 & 10,8 \\
\hline PA02 & S-D/C-5 & Vpc & & & 14 & PA02 & $S-D / C-5$ & $\mathrm{Vpc}$ & 10,5 & 13,7 & 5,9 \\
\hline PA02 & S-D/C-5 & Vpc & 11,3 & 12,2 & 10,5 & PA02 & $S-D / C-5$ & Vpc & 11,5 & 12,9 & 6,6 \\
\hline PA02 & S-D/C-5 & Vpc & 9,5 & 10,7 & 8,5 & PA02 & $S-D / C-5$ & $\mathrm{Vpc}$ & 8,4 & 10 & 5 \\
\hline PA02 & $S-D / C-5$ & Vpc & 12,8 & 14 & 11,4 & PA02 & S-D/C-5 & $\mathrm{Vpc}$ & 8,5 & 9,9 & 5 \\
\hline PA02 & S-D/C-5 & Vpc & 12,6 & 12,8 & & PA02 & S-D/C-5 & Vpc & 11,8 & 12,9 & 12,3 \\
\hline PA02 & S-D/C-5 & Vpc & 10,8 & 10,9 & 10,1 & PA02 & $S-D / C-5$ & Vpc & & 14,5 & \\
\hline PA02 & S-D/C-5 & Vpc & 10,7 & 11 & 9,9 & PA02 & S-D/C-5 & Vpc & 11,9 & 13,2 & 10,5 \\
\hline PA02 & $S-D / C-5$ & Vpc & 10,9 & 12 & 12,4 & PA02 & $S-D / C-5$ & Vpc & 11,5 & 12,5 & 10,8 \\
\hline PA02 & S-D/C-5 & Vpc & 9,9 & 10,2 & & PA02 & S-D/C-5 & $\mathrm{Vpc}$ & 10,7 & 11,8 & 10 \\
\hline PA02 & S-D/C-5 & Vpc & 12,4 & 13 & 12,6 & PA02 & S-D/C-5 & Vpc & 11,2 & 11,7 & 10,5 \\
\hline PA02 & S-D/C-5 & Vpc & 10,4 & 11,2 & 11,2 & PA02 & S-D/C-5 & Vpc & 13,6 & 13,2 & 11,4 \\
\hline PA02 & S-D/C-5 & Vpc & 12 & 13,8 & 12,5 & PA02 & $S-D / C-5$ & Vpc & 11,1 & 12,9 & 5,5 \\
\hline PA02 & S-D/C-5 & Vpc & 12,9 & 13,2 & 12,1 & PA02 & S-D/C-5 & Vpc & 12,1 & 12,2 & 12,5 \\
\hline PA02 & $S-D / C-5$ & Vpc & 9,7 & 10 & 9,6 & PA02 & $S-D / C-5$ & Vpc & 11,8 & 12,1 & 9,5 \\
\hline PA02 & S-D/C-5 & Vpc & 9,6 & 10,9 & 9,1 & PA02 & S-D/C-5 & $\mathrm{Vpc}$ & 9,3 & 10,7 & 8 \\
\hline PA02 & $S-D / C-5$ & Vpc & 12 & 12,6 & 11,7 & PA02 & S-D/C-5 & Vpc & 10,4 & 12,2 & 9,4 \\
\hline PA02 & S-D/C-5 & Vpc & 10,8 & 11,7 & 9,7 & PA02 & S-D/C-5 & Vpc & 11,8 & 12,9 & \\
\hline PA02 & S-D/C-5 & Vpc & 9,6 & 11,2 & 7,9 & PA02 & S-D/C-5 & Vpc & 13,9 & 16,5 & 11,2 \\
\hline PA02 & S-D/C-5 & Vpc & 9,8 & 10,6 & 8 & PA02 & $S-D / C-5$ & $\mathrm{Vpc}$ & 13,7 & 13,5 & 13 \\
\hline PA02 & $S-D / C-5$ & Vpc & & & 12,2 & PA02 & S-D/C-5 & Vpc & 11,3 & 13,4 & 9,4 \\
\hline PA02 & S-D/C-5 & Vpc & 11,9 & 12,8 & 11,7 & PA02 & S-D/C-5 & Vpc & 12,1 & 12,8 & 5,1 \\
\hline PA02 & S-D/C-5 & Vpc & 11,6 & 12,4 & 10,5 & PA02 & S-D/C-5 & Vpc & 13 & 13,2 & 13,1 \\
\hline PA02 & S-D/C-5 & Vpc & 9,5 & 10,2 & 9,1 & PA02 & $S-D / C-5$ & $\mathrm{Vpc}$ & 12,6 & 13,3 & 13,7 \\
\hline PA02 & $S-D / C-5$ & Vpc & 10,6 & 12,4 & 9,4 & PA02 & S-D/C-5 & Vpc & 10,6 & 11,8 & 11 \\
\hline PA02 & S-D/C-5 & Vpc & 10 & 10,6 & 10 & PA02 & $S-D / C-5$ & $\mathrm{Vpc}$ & 11,4 & 13,1 & 9,5 \\
\hline PA02 & $S-D / C-5$ & Vpc & 11,1 & 12,2 & 10,6 & PA02 & S-D/C-5 & Vpc & 9,4 & 10,7 & 7,9 \\
\hline PA02 & S-D/C-5 & Vpc & 13,2 & 12,6 & 12,6 & PA02 & S-D/C-5 & Vpc & 8,6 & 9,6 & 9,7 \\
\hline PA02 & S-D/C-5 & Vpc & 10,3 & 11,7 & 9,4 & PA02 & $S-D / C-5$ & Vpc & 10,6 & 11,2 & 10,3 \\
\hline PA02 & S-D/C-5 & Vpc & 13,2 & 13,7 & 13,3 & PA02 & S-D/C-5 & $\mathrm{Vpc}$ & 10,2 & 11,3 & 6,3 \\
\hline PA02 & $S-D / C-5$ & Vpc & 10,5 & 12,1 & 10,1 & PA02 & S-D/C-5 & Vpc & 10,3 & 11,2 & 8,1 \\
\hline PA02 & S-D/C-5 & Vpc & 11,8 & 13,4 & 11,2 & PA02 & S-D/C-5 & $\mathrm{Vpc}$ & 10,4 & 11,2 & 8,7 \\
\hline PA02 & $S-D / C-5$ & Vpc & 12,3 & 12,8 & 12,4 & PA02 & S-D/C-5 & Vpc & 11,4 & 12,5 & 10,9 \\
\hline PA02 & S-D/C-5 & $\mathrm{Vpc}$ & 11,7 & 12,4 & 12,8 & PA02 & S-D/C-5 & $\mathrm{Vpc}$ & 13 & 15,8 & 7,5 \\
\hline PA02 & $S-D / C-5$ & Vpc & 11,1 & 11,8 & 10,4 & PA02 & S-D/C-5 & Vpc & 10,3 & 11 & 10,8 \\
\hline PA02 & S-D/C-5 & Vpc & 10,7 & 11,5 & 12 & PA02 & S-D/C-5 & Vpc & & 10,9 & \\
\hline PA02 & S-D/C-5 & Vpc & 11 & 11,3 & 8,1 & PA02 & $S-D / C-5$ & $\mathrm{Vpc}$ & 11,5 & 11,5 & 11,4 \\
\hline PA02 & S-D/C-5 & Vpc & 11,9 & 13,5 & 11,2 & PA02 & S-D/C-5 & $\mathrm{Vpc}$ & & & 10 \\
\hline PA02 & S-D/C-5 & Vpc & 10,8 & 12,3 & 9,9 & PA02 & S-D/C-5 & Vpc & 7,7 & 8,4 & 7 \\
\hline PA02 & S-D/C-5 & Vpc & 14 & & 11,4 & PA02 & S-D/C-5 & Vpc & 8,8 & 10,4 & 7,8 \\
\hline PA02 & $S-D / C-5$ & Vpc & 11 & 12,1 & 8,7 & PA02 & S-D/C-5 & $\mathrm{Vpc}$ & 11 & 11,7 & 10,8 \\
\hline PA02 & S-D/C-5 & Vpc & 11,5 & 12,1 & 12,5 & PA02 & $S-D / C-5$ & $\mathrm{Vpc}$ & 9,6 & 10 & 10,7 \\
\hline PA02 & S-D/C-5 & Vpc & 10,4 & 12,2 & 9,2 & PA02 & S-D/C-5 & Vpc & & & 11,1 \\
\hline PA02 & S-D/C-5 & Vpc & 11,4 & 11,9 & 11,4 & PA02 & S-D/C-5 & Vpc & 11,3 & 11,8 & \\
\hline
\end{tabular}




\begin{tabular}{|c|c|c|c|c|c|c|c|c|c|c|c|}
\hline PA02 & S-D/C-5 & $\mathrm{Vpc}$ & 11,7 & 12,9 & 10,9 & PA02 & S-D/C-5 & $V p c$ & 10,8 & 11,6 & \\
\hline PA02 & S-D/C-5 & $V p c$ & 13,1 & 13 & 13,9 & PA02 & S-D/C-5 & $V p c$ & 13,9 & 15,1 & 14 \\
\hline PA02 & S-D/C-5 & $V p c$ & 11,2 & 12,1 & 12,1 & PA02 & S-D/C-5 & Vpc & 11,8 & 13,2 & 11,3 \\
\hline PA02 & S-D/C-5 & $V p c$ & 13,6 & 14,4 & 11,6 & PA02 & S-D/C-5 & $V p c$ & 11 & 12,5 & 10,1 \\
\hline PA02 & S-D/C-5 & $V p c$ & 11,5 & 12,8 & 12,4 & PA02 & S-D/C-5 & $V p c$ & 12 & 13,5 & 10,4 \\
\hline PA02 & S-D/C-5 & $\mathrm{Vpc}$ & 12,6 & 14,5 & 10,9 & PA02 & S-D/C-5 & Vpc & 10,3 & 11,7 & 10,8 \\
\hline PA02 & S-D/C-5 & $V p c$ & 14,4 & 15,5 & 14 & PA02 & S-D/C-5 & Vpc & 12,8 & 13,1 & 12,5 \\
\hline PA02 & S-D/C-5 & $V p c$ & 11 & 11 & 10,7 & PA02 & $S-D / C-5$ & $V p c$ & & 13,5 & \\
\hline PA02 & S-D/C-5 & $V p c$ & 10,7 & 11,2 & 11,7 & PA02 & S-D/C-5 & Vpc & 11,5 & 13 & 10 \\
\hline PA02 & S-D/C-5 & $V p c$ & 12,3 & 13,1 & 11,5 & PA02 & S-D/C-5 & Vpc & & 16,1 & 13,1 \\
\hline PA02 & S-D/C-5 & $\mathrm{Vpc}$ & 11,6 & 12,8 & 11,9 & PA02 & S-D/C-5 & Vpc & 10,5 & 12,4 & 9,5 \\
\hline PA02 & S-D/C-5 & $\mathrm{Vpc}$ & 12,6 & 12,4 & 12,9 & PA02 & S-D/C-5 & $V p c$ & 12,9 & 13,7 & 13,3 \\
\hline PA02 & S-D/C-5 & $\mathrm{Vpc}$ & 11,2 & 12,5 & 10,7 & PA02 & S-D/C-5 & Vpc & 12,5 & 13,1 & 10 \\
\hline PA02 & S-D/C-5 & $V p c$ & 12,8 & 14,5 & 11,5 & PA02 & S-D/C-5 & $V p c$ & 13,6 & 16,1 & 11,9 \\
\hline PA02 & S-D/C-5 & $\mathrm{Vpc}$ & 11,7 & 12,4 & 11,7 & PA02 & S-D/C-5 & Vpc & 10,2 & 11,5 & 10,9 \\
\hline PA02 & S-D/C-5 & $\mathrm{Vpc}$ & 9,8 & 10,6 & 9 & PA02 & S-D/C-5 & Vpc & 12,9 & 13 & 13,9 \\
\hline PA02 & $S-D / C-5$ & $\mathrm{Vpc}$ & 12,3 & 12,7 & 12,8 & PA02 & S-D/C-5 & Vpc & 11,5 & 12,4 & 8,6 \\
\hline PA02 & S-D/C-5 & $V p c$ & 13 & 13,6 & 10,4 & PA02 & S-D/C-5 & Vpc & 13,6 & 14,1 & 13,7 \\
\hline PA02 & S-D/C-5 & $V p c$ & 10,8 & 11,9 & 11,5 & PA02 & $S-D / C-5$ & Vpc & 13,6 & 13,4 & 11,3 \\
\hline PA02 & S-D/C-5 & Vpc & 10,9 & 11,2 & 9,3 & PA02 & S-D/C-5 & Vpc & 11,6 & 11,5 & 10,3 \\
\hline PA02 & S-D/C-5 & $V p c$ & 9,8 & 10,6 & 7,8 & PA02 & S-D/C-5 & $V p c$ & 13 & 12,9 & 11,4 \\
\hline PA02 & S-D/C-5 & $\mathrm{Vpc}$ & 11,3 & 12,2 & 11,9 & PA02 & S-D/C-5 & Vpc & 13,5 & 14 & 11,9 \\
\hline PA02 & S-D/C-5 & $\mathrm{Vpc}$ & 12,6 & 14,2 & 13,5 & PA02 & S-D/C-5 & $\mathrm{Vpc}$ & 10,2 & 11,4 & 8,3 \\
\hline PA02 & S-D/C-5 & $V p c$ & 10,7 & 11,9 & 9,4 & PA02 & S-D/C-5 & $\mathrm{Vpc}$ & 10,9 & 11 & 11,4 \\
\hline PA02 & S-D/C-5 & $\mathrm{Vpc}$ & 11,9 & 13,2 & 11,9 & PA02 & S-D/C-5 & $V p c$ & 12,5 & 13,6 & 12,8 \\
\hline PA02 & S-D/C-5 & $V p c$ & 13,1 & 13,1 & 13,6 & PA02 & S-D/C-5 & $\mathrm{Vpc}$ & 10 & 11,7 & 8,6 \\
\hline PA02 & S-D/C-5 & $\mathrm{Vpc}$ & 11,2 & 13,1 & 10,2 & PA02 & S-D/C-5 & Vpc & 13,1 & 14,3 & 13,6 \\
\hline PA02 & S-D/C-5 & $\mathrm{Vpc}$ & 13,2 & 16,8 & 5,1 & PA02 & S-D/C-5 & Vpc & 12,2 & 13,6 & 12,4 \\
\hline PA02 & S-D/C-5 & $V p c$ & 9,9 & 10,5 & 4 & PA02 & S-D/C-5 & Vpc & 13,9 & 13,5 & 12,9 \\
\hline PA02 & S-D/C-5 & $V p c$ & 15,3 & 17,6 & 14,3 & PA02 & S-D/C-5 & $V p c$ & 12,9 & 13,9 & 11,6 \\
\hline PA02 & S-D/C-5 & $V p c$ & 14,5 & 14,8 & 13,7 & PA02 & S-D/C-5 & Vpc & 11,5 & 14,3 & 10,3 \\
\hline PA02 & S-D/C-5 & $\mathrm{Vpc}$ & 13,5 & 15 & 12,1 & PA02 & S-D/C-5 & Vpc & 10,6 & 12 & 11,8 \\
\hline PA02 & S-D/C-5 & $V p c$ & 11,8 & 12,2 & 12,3 & PA02 & S-D/C-5 & $V p c$ & 11 & 11,2 & 11,7 \\
\hline PA02 & S-D/C-5 & $\mathrm{Vpc}$ & 13,8 & 14,5 & 14 & PA02 & S-D/C-5 & Vpc & 11,8 & 13,9 & 11,3 \\
\hline PA02 & S-D/C-5 & $V p c$ & 11,1 & 11,9 & 10 & PA02 & $S-D / C-5$ & Vpc & 10,2 & 11,9 & 9,8 \\
\hline PA02 & S-D/C-5 & $V p c$ & 11,7 & 11,7 & 11,5 & PA02 & S-D/C-5 & $\mathrm{Vpc}$ & 9,9 & 10,4 & 9,2 \\
\hline PA02 & S-D/C-5 & $\mathrm{Vpc}$ & 11,3 & 10,1 & 10,4 & PA02 & S-D/C-5 & Vpc & 10,7 & 11,6 & 10,4 \\
\hline PA02 & S-D/C-5 & $V p c$ & 13,5 & 13,8 & 13,2 & PA02 & S-D/C-5 & Vpc & 12,9 & 12,9 & 12,3 \\
\hline PA02 & S-D/C-5 & $\mathrm{Vpc}$ & 10,8 & 11,7 & 11,7 & PA02 & S-D/C-5 & $V p c$ & 12 & 11,9 & 11,7 \\
\hline PA02 & S-D/C-5 & $\mathrm{Vpc}$ & 13,2 & 13,2 & 12,3 & PA02 & S-D/C-5 & Vpc & 13,6 & & \\
\hline PA02 & S-D/C-5 & $V p c$ & 12,5 & 12,8 & 12,4 & PA02 & $S-D / C-5$ & Vpc & 10,8 & & 10,9 \\
\hline PA02 & S-D/C-5 & $V p c$ & 10,8 & 12,3 & 11,4 & PA02 & S-D/C-5 & $V p c$ & 10 & 9,8 & 10 \\
\hline PA02 & S-D/C-5 & $V p c$ & 10,9 & 11,5 & 11,3 & PA02 & S-D/C-5 & $V p c$ & 10,9 & 12,6 & 10,9 \\
\hline PA02 & S-D/C-5 & $\mathrm{Vpc}$ & 10,9 & 12,2 & 9,7 & PA02 & S-D/C-5 & Vpc & 11,9 & 12,4 & 9,7 \\
\hline PA02 & S-D/C-5 & $\mathrm{Vpc}$ & 11,5 & 12,2 & 11,7 & PA02 & S-D/C-5 & Vpc & 11,1 & 12 & 9,1 \\
\hline
\end{tabular}




\begin{tabular}{|c|c|c|c|c|c|c|c|c|c|c|c|}
\hline PA02 & S-D/C-5 & $\mathrm{Vpc}$ & 13,2 & 13,3 & 11,8 & PA02 & S-D/C-5 & $\mathrm{Vpc}$ & 10,4 & 11,6 & 11,1 \\
\hline PA02 & S-D/C-5 & Vpc & 12,4 & 14,1 & 9,3 & PA02 & $S-D / C-5$ & Vpc & 11,8 & 12,3 & 11 \\
\hline PA02 & S-D/C-5 & $V p c$ & 13,2 & 13,9 & 10,6 & PA02 & S-D/C-5 & Vpc & 13,3 & 14,4 & 11,6 \\
\hline PA02 & S-D/C-5 & Vpc & 12,2 & 12 & & PA02 & S-D/C-5 & Vpc & 14,4 & 14,9 & \\
\hline PA02 & S-D/C-5 & $V p c$ & 12,8 & 12,9 & 12,2 & PA02 & S-D/C-5 & $\mathrm{Vpc}$ & 12,7 & 12,4 & 13,1 \\
\hline PA02 & S-D/C-5 & $\mathrm{Vpc}$ & 11,6 & 12 & 11,9 & PA02 & S-D/C-5 & $\mathrm{Vpc}$ & 12,5 & 14,1 & 10,1 \\
\hline PA02 & S-D/C-5 & $V p c$ & 10,5 & 10,6 & 10,8 & PA02 & $S-D / C-5$ & Vpc & 12,9 & 15,7 & 10,6 \\
\hline PA02 & S-D/C-5 & $V p c$ & 12,4 & 14,3 & 12,9 & PA02 & $S-D / C-5$ & Vpc & 11,2 & 11,2 & 9,6 \\
\hline PA02 & S-D/C-5 & $\mathrm{Vpc}$ & 11,3 & 12,6 & 11,6 & PA02 & S-D/C-5 & Vpc & 8,8 & 9,5 & 8,5 \\
\hline PA02 & S-D/C-5 & $V p c$ & 13 & 13,8 & 10,7 & PA02 & S-D/C-5 & $\mathrm{Vpc}$ & 11,7 & 13,4 & 9,6 \\
\hline PA02 & S-D/C-5 & $V p c$ & 12,3 & 12,1 & 12,4 & PA02 & S-D/C-5 & $\mathrm{Vpc}$ & 11,8 & 12,1 & 10,7 \\
\hline PA02 & S-D/C-5 & Vpc & 11,7 & 12,1 & 10,6 & PA02 & $S-D / C-5$ & Vpc & 12 & 12,1 & 12,3 \\
\hline PA02 & S-D/C-5 & $V p c$ & 12,7 & 15,1 & 10 & PA02 & $S-D / C-5$ & $\mathrm{Vpc}$ & 11,2 & 11,7 & 11 \\
\hline PA02 & S-D/C-5 & $V p c$ & 11,9 & 12,5 & 11,9 & PA02 & $S-D / C-5$ & Vpc & 10,3 & 11,1 & 9,6 \\
\hline PA02 & S-D/C-5 & $\mathrm{Vpc}$ & 14,6 & 15,1 & 13,2 & PA02 & S-D/C-5 & Vpc & 10 & 10,4 & 9,5 \\
\hline PA02 & S-D/C-5 & $V p c$ & 11 & 11,9 & 11 & PA02 & $S-D / C-5$ & Vpc & 11 & 11,4 & 10,3 \\
\hline PA02 & S-D/C-5 & $\mathrm{Vpc}$ & 11,2 & 11,7 & 11,8 & PA02 & $S-D / C-5$ & Vpc & 12 & 13,1 & 9,5 \\
\hline PA02 & S-D/C-5 & $\mathrm{Vpc}$ & 12,7 & 15,1 & 9,6 & PA02 & $S-D / C-5$ & Vpc & 11 & 11,8 & 10,5 \\
\hline PA02 & S-D/C-5 & $V p c$ & 12,6 & 14,1 & 11,2 & PA02 & S-D/C-5 & $V p c$ & 11,9 & 12,2 & 11,3 \\
\hline PA02 & S-D/C-5 & $V p c$ & 10,2 & 10,8 & 11,4 & PA02 & S-D/C-5 & Vpc & 10,8 & 11,2 & 10,1 \\
\hline PA02 & S-D/C-5 & $\mathrm{Vpc}$ & 13,4 & 14,9 & 10,5 & PA02 & S-D/C-5 & $\mathrm{Vpc}$ & 10,9 & 11,7 & 9,4 \\
\hline PA02 & $S-D / C-5$ & $V p c$ & 13,7 & 15,5 & 13,7 & PA02 & $S-D / C-5$ & $\mathrm{Vpc}$ & 11,2 & 12,8 & 10 \\
\hline PA02 & S-D/C-5 & $V p c$ & 11,8 & 12,7 & 13,1 & PA02 & $S-D / C-5$ & Vpc & 11 & 11,8 & 11,6 \\
\hline PA02 & $S-D / C-5$ & Vpc & 11,7 & 13,9 & 10,1 & PA02 & S-D/C-5 & $\mathrm{Vpc}$ & 11,9 & 11,3 & 11,9 \\
\hline PA02 & S-D/C-5 & $V p c$ & 11,6 & 11,8 & 12,2 & PA02 & $S-D / C-5$ & $\mathrm{Vpc}$ & 10,1 & 11,1 & 9,6 \\
\hline PA02 & S-D/C-5 & $\mathrm{Vpc}$ & 11,8 & 12,9 & 12,2 & PA02 & $S-D / C-5$ & Vpc & 13,2 & 16,4 & 9,9 \\
\hline PA02 & S-D/C-5 & $V p c$ & 11,9 & 13,6 & 11,4 & PA02 & $S-D / C-5$ & Vpc & 13 & 13,6 & 13,4 \\
\hline PA02 & $S-D / C-5$ & $\mathrm{Vpc}$ & 11,6 & 12,7 & 7,9 & PA02 & $S-D / C-5$ & $\mathrm{Vpc}$ & 10,4 & 11,3 & 10,6 \\
\hline PA02 & S-D/C-5 & $V p c$ & 12,5 & 12,9 & 12,3 & PA02 & S-D/C-5 & Vpc & 13 & 13,5 & 12 \\
\hline PA02 & $S-D / C-5$ & $\mathrm{Vpc}$ & 15,2 & 16,3 & 12,6 & PA02 & $S-D / C-5$ & Vpc & 11,4 & 11,6 & 11,1 \\
\hline PA02 & S-D/C-5 & $V p c$ & 12,7 & 14,4 & 13,7 & PA02 & S-D/C-5 & $\mathrm{Vpc}$ & 11,1 & 12,3 & 11,5 \\
\hline PA02 & S-D/C-5 & $\mathrm{Vpc}$ & 13,4 & 13,1 & 12,1 & PA02 & $S-D / C-5$ & Vpc & 10,4 & 10,8 & 10,2 \\
\hline PA02 & S-D/C-5 & $V p c$ & 13,8 & 15,2 & 13,4 & PA02 & $S-D / C-5$ & $\mathrm{Vpc}$ & 11,5 & 12,9 & 12,3 \\
\hline PA02 & S-D/C-5 & Vpc & 13,5 & 14,6 & 13,7 & PA02 & S-D/C-5 & Vpc & 10,8 & 11,9 & 10,8 \\
\hline PA02 & S-D/C-5 & $V p c$ & 13 & 14,1 & 12,1 & PA02 & S-D/C-5 & $\mathrm{Vpc}$ & 11,4 & 11,8 & 11,6 \\
\hline PA02 & $S-D / C-5$ & $\mathrm{Vpc}$ & 13,6 & 14,4 & 12,1 & PA02 & $S-D / C-5$ & Vpc & 10,2 & 10,4 & 9,6 \\
\hline PA02 & S-D/C-5 & $V p c$ & 14,6 & 14,5 & 12,7 & PA02 & S-D/C-5 & $\mathrm{Vpc}$ & 11,7 & 12,9 & 10,5 \\
\hline PA02 & S-D/C-5 & $V p c$ & 11,2 & 12,2 & 11,9 & PA02 & $S-D / C-5$ & Vpc & 12 & 14,6 & 10 \\
\hline PA02 & S-D/C-5 & $V p c$ & 11,9 & 14,8 & 9,8 & PA02 & S-D/C-5 & $\mathrm{Vpc}$ & 11,3 & 12,5 & 11,5 \\
\hline PA02 & S-D/C-5 & $\mathrm{Vpc}$ & 16,9 & 18,3 & 15,5 & PA02 & S-D/C-5 & Vpc & 11,4 & 12,7 & 11,1 \\
\hline PA02 & S-D/C-5 & $\mathrm{Vpc}$ & 11,6 & 12,5 & 11,5 & PA02 & S-D/C-5 & Vpc & 11,9 & 13 & 9,4 \\
\hline PA02 & S-D/C-5 & $V p c$ & 11,6 & 12,6 & 11 & PA02 & S-D/C-5 & Vpc & 11,4 & 12,2 & 12 \\
\hline PA02 & S-D/C-5 & $V p c$ & 10,8 & 12,3 & 11,3 & PA02 & $S-D / C-5$ & Vpc & 11 & 12,8 & 10,3 \\
\hline PA02 & S-D/C-5 & $\mathrm{Vpc}$ & 13,4 & 14,2 & 10,7 & PA02 & $S-D / C-5$ & $\mathrm{Vpc}$ & 10,9 & 11,2 & 12 \\
\hline PA02 & S-D/C-5 & Vpc & 11,9 & 12,8 & 11,8 & PA02 & S-D/C-5 & $V p c$ & 12,2 & 12,1 & 12,6 \\
\hline
\end{tabular}




\begin{tabular}{|c|c|c|c|c|c|c|c|c|c|c|c|}
\hline PA02 & S-D/C-5 & $V p c$ & 13,1 & 13,5 & 13,4 & PA02 & S-D/C-5 & $V p c$ & 14,1 & 14,9 & 15 \\
\hline PA02 & S-D/C-5 & $\mathrm{Vpc}$ & 13,3 & 16,3 & 10,6 & PA02 & S-D/C-5 & $V p c$ & 11,6 & 12 & 9,9 \\
\hline PA02 & S-D/C-5 & $\mathrm{Vpc}$ & 12,7 & 14,1 & 12,7 & PA02 & S-D/C-5 & $V p c$ & 11 & 12,4 & 10,8 \\
\hline PA02 & S-D/C-5 & $V p c$ & 12,6 & 13,7 & 12,4 & PA02 & S-D/C-5 & $V p c$ & 9,5 & 10,9 & 7,8 \\
\hline PA02 & S-D/C-5 & $V p c$ & 13,4 & 15,2 & 13,1 & PA02 & S-D/C-5 & $V p c$ & 12,9 & & \\
\hline PA02 & S-D/C-5 & $V p c$ & 11,4 & 12,2 & 11,1 & PA02 & S-D/C-5 & $V p c$ & 10,7 & 11,7 & 8,4 \\
\hline PA02 & S-D/C-5 & $\mathrm{Vpc}$ & 11,2 & 12,3 & 10,8 & PA02 & S-D/C-5 & Vpc & 10,7 & 11,8 & 8,8 \\
\hline PA02 & S-D/C-5 & $\mathrm{Vpc}$ & 12,2 & 13,6 & 8,4 & PA02 & S-D/C-5 & $V p c$ & 10,6 & 11,3 & 9,9 \\
\hline PA02 & S-D/C-5 & $V p c$ & 11,6 & 12,5 & 10 & PA02 & S-D/C-5 & $V p c$ & 9,2 & 9,6 & 9,3 \\
\hline PA02 & S-D/C-5 & $V p c$ & 10,5 & 10,8 & 10 & PA02 & S-D/C-5 & $V p c$ & 9,6 & 10,7 & 8,2 \\
\hline PA02 & S-D/C-5 & $V p c$ & 9,2 & 10,7 & 8 & PA02 & S-D/C-5 & $V p c$ & 11,6 & 12,3 & 10 \\
\hline PA02 & S-D/C-5 & $V p c$ & 11,7 & 12,4 & 8,7 & PA02 & S-D/C-5 & $V p c$ & 11,5 & 13,2 & 10,9 \\
\hline PA02 & S-D/C-5 & $V p c$ & 13,2 & 15,6 & 11,9 & PA02 & S-D/C-5 & $V p c$ & 15,6 & 15,8 & 14,7 \\
\hline PA02 & S-D/C-5 & $\mathrm{Vpc}$ & 10,5 & 11,5 & 9,9 & PA02 & S-D/C-5 & $V p c$ & 14,3 & 14,3 & 13,1 \\
\hline PA02 & S-D/C-5 & $V p c$ & 8,7 & 9,8 & 7,9 & PA02 & S-D/C-5 & Vpc & 14,4 & 14,7 & 12,9 \\
\hline PA02 & S-D/C-5 & $V p c$ & 14,1 & & 13,3 & PA02 & S-D/C-5 & $V p c$ & 14,4 & 15,5 & 13,5 \\
\hline PA02 & S-D/C-5 & $\mathrm{Vpc}$ & 10,6 & 12,5 & 9,4 & PA02 & S-D/C-5 & $V p c$ & 15,4 & 17,7 & 10,8 \\
\hline PA02 & S-D/C-5 & $\mathrm{Vpc}$ & 11,1 & 13,6 & 10 & PA02 & S-D/C-5 & $V p c$ & 13,3 & 13,9 & 13 \\
\hline PA02 & S-D/C-5 & $V p c$ & 10,9 & 11,3 & 10,7 & PA02 & S-D/C-5 & $V p c$ & 13,9 & 15,9 & 12,2 \\
\hline PA02 & S-D/C-5 & $V p c$ & 10,1 & 11,5 & 8,8 & PA02 & S-D/C-5 & $V p c$ & 14,4 & 14,7 & 14,8 \\
\hline PA02 & S-D/C-5 & $V p c$ & 9,2 & 10,1 & 9,7 & PA02 & S-D/C-5 & $V p c$ & 17,3 & 18,6 & 15 \\
\hline PA02 & S-D/C-5 & $\mathrm{Vpc}$ & 10,5 & 10,5 & & PA02 & S-D/C-5 & $V p c$ & 12,5 & 13,5 & 11 \\
\hline PA02 & S-D/C-5 & $\mathrm{Vpc}$ & 10,9 & 13,2 & & PA02 & S-D/C-5 & Vpc & 15,3 & 16,2 & 14,5 \\
\hline PA02 & S-D/C-5 & $\mathrm{Vpc}$ & 11,3 & 12,4 & & PA02 & S-D/C-5 & $V p c$ & 13,3 & 15,1 & \\
\hline PA02 & S-D/C-5 & $\mathrm{Vpc}$ & 11,2 & 12,6 & 9,3 & PA02 & S-D/C-5 & $V p c$ & & 18,8 & 18 \\
\hline PA02 & S-D/C-5 & $V p c$ & 10,8 & 11,2 & 11,2 & PA02 & S-D/C-5 & $V p c$ & 9,3 & 9,6 & 8,7 \\
\hline PA02 & S-D/C-5 & $\mathrm{Vpc}$ & 10,2 & 11,8 & 9,9 & PA02 & S-D/C-5 & Vpc & 9 & 9,6 & 7,9 \\
\hline PA02 & S-D/C-5 & $\mathrm{Vpc}$ & 9,5 & 10,6 & 9,5 & PA02 & S-D/C-5 & Vpc & 9,9 & 10,9 & 9,1 \\
\hline PA02 & S-D/C-5 & $V p c$ & 12,1 & 12,7 & 10 & PA02 & S-D/C-5 & $V p c$ & 11 & 11,1 & 10,5 \\
\hline PA02 & S-D/C-5 & $\mathrm{Vpc}$ & 11,6 & 12,5 & 9,9 & PA02 & S-D/C-5 & Vpc & 9,2 & 9,5 & 7,7 \\
\hline PA02 & S-D/C-5 & $V p c$ & 12,5 & 13,8 & 12 & PA02 & S-D/C-5 & $V p c$ & & 12,8 & 8,8 \\
\hline PA02 & S-D/C-5 & $V p c$ & 12 & 12,6 & 12,4 & PA02 & S-D/C-5 & $V p c$ & 12,2 & 13,4 & 9,6 \\
\hline PA02 & S-D/C-5 & $V p c$ & 11,7 & 12,7 & 11,3 & PA02 & S-D/C-5 & $V p c$ & 11 & 11,6 & \\
\hline PA02 & S-D/C-5 & $\mathrm{Vpc}$ & 12 & 12,3 & 12,1 & PA02 & S-D/C-5 & $V p c$ & 12,1 & 14,4 & 7,2 \\
\hline PA02 & S-D/C-5 & $\mathrm{Vpc}$ & 10,8 & 11,2 & 11,5 & PA02 & S-D/C-5 & Vpc & 8,9 & 9,5 & 7,4 \\
\hline PA02 & S-D/C-5 & $\mathrm{Vpc}$ & 10,9 & 11,5 & 10,5 & PA02 & S-D/C-5 & Vpc & 10,3 & 10,8 & 9,9 \\
\hline PA02 & S-D/C-5 & $\mathrm{Vpc}$ & 11,1 & 11,9 & 11,1 & PA02 & S-D/C-5 & $V p c$ & & & \\
\hline PA02 & S-D/C-5 & $\mathrm{Vpc}$ & 11,7 & 14,2 & & PA02 & S-D/C-5 & $V p c$ & 9,7 & 11,4 & 8,5 \\
\hline PA02 & S-D/C-5 & $V p c$ & 10,1 & 11 & 8,5 & PA02 & S-D/C-5 & $V p c$ & & 11,3 & \\
\hline PA02 & S-D/C-5 & $\mathrm{Vpc}$ & & & 10,2 & PA02 & S-D/C-5 & $V p c$ & 9,4 & 10,9 & \\
\hline PA02 & S-D/C-5 & $\mathrm{Vpc}$ & 10,5 & 10,8 & 8,2 & PA02 & S-D/C-5 & $V p c$ & 8,4 & 9,9 & \\
\hline PA02 & S-D/C-5 & $V p c$ & 10,3 & 12,1 & & PA02 & S-D/C-5 & $V p c$ & 11,6 & 12,6 & 12,5 \\
\hline PA02 & S-D/C-5 & $V p c$ & 11,1 & 11,1 & 9,4 & PA02 & S-D/C-5 & $V p c$ & 12,2 & 12,7 & 5,5 \\
\hline PA02 & S-D/C-5 & $V p c$ & & & 11,9 & PA02 & S-D/C-5 & $V p c$ & 11 & 12,1 & 5 \\
\hline PA02 & S-D/C-5 & $V p c$ & 10,6 & 11,9 & 8,7 & PA02 & S-D/C-5 & $V p c$ & 10,1 & 11,9 & 3,3 \\
\hline
\end{tabular}




\begin{tabular}{|c|c|c|c|c|c|c|c|c|c|c|c|}
\hline PA02 & S-D/C-5 & $\mathrm{Vpc}$ & 11 & 11,9 & 11,1 & PA02 & $S-D / C-5$ & Vpc & 11,3 & 11,8 & 6,2 \\
\hline PA02 & S-D/C-5 & $\mathrm{Vpc}$ & 10,9 & 12,1 & 10,6 & PA02 & S-D/C-5 & Vpc & 10,3 & 11,2 & 9,6 \\
\hline PA02 & S-D/C-5 & $V p c$ & 8,1 & 9,4 & 7,6 & PA02 & S-D/C-5 & Vpc & 11,4 & 11,7 & 12,4 \\
\hline PA02 & S-D/C-5 & $V p c$ & 12,6 & 13,5 & 9,8 & PA02 & $S-D / C-5$ & Vpc & 10,6 & 13 & 10,7 \\
\hline PA02 & S-D/C-5 & $\mathrm{Vpc}$ & 14,1 & 15,3 & 14,5 & PA02 & S-D/C-5 & $V p c$ & 12 & 12,8 & 10,8 \\
\hline PA02 & $S-D / C-5$ & $V p c$ & 9,3 & 9,6 & 9,5 & PA02 & $S-D / C-5$ & Vpc & 10,7 & 12,1 & 9,4 \\
\hline PA02 & S-D/C-5 & $V p c$ & 9,5 & 10,3 & 6,3 & PA02 & S-D/C-5 & Vpc & 10,5 & 11,3 & 10,2 \\
\hline PA02 & S-D/C-5 & $V p c$ & 9,8 & 11,3 & 6,1 & PA02 & $S-D / C-5$ & Vpc & 12,2 & 13,9 & 12,9 \\
\hline PA02 & S-D/C-5 & Vpc & 9,6 & 11,5 & 6,7 & PA02 & S-D/C-5 & $\mathrm{Vpc}$ & 9,9 & 10,1 & 6,4 \\
\hline PA02 & S-D/C-5 & $\mathrm{Vpc}$ & 10,5 & 12 & 7 & PA02 & S-D/C-5 & Vpc & 12,8 & 12,9 & 11,4 \\
\hline PA02 & S-D/C-5 & $V p c$ & 9,7 & 11,6 & 5,6 & PA02 & $S-D / C-5$ & Vpc & 10,2 & 11,6 & 10,7 \\
\hline PA02 & S-D/C-5 & $\mathrm{Vpc}$ & 9,3 & 10,7 & 8,3 & PA02 & S-D/C-5 & Vpc & 12,8 & 14 & 11,1 \\
\hline PA02 & S-D/C-5 & $V p c$ & 13 & 13,2 & 12,5 & PA02 & S-D/C-5 & $\mathrm{Vpc}$ & 8,5 & 10,6 & 6,2 \\
\hline PA02 & S-D/C-5 & $V p c$ & 13,2 & 14,7 & 11,2 & PA02 & $S-D / C-5$ & Vpc & 11,2 & 12,8 & 6,8 \\
\hline PA02 & S-D/C-5 & $V p c$ & 11,6 & 13,4 & 7,4 & PA02 & S-D/C-5 & $V p c$ & 10,8 & 12,4 & 10,1 \\
\hline PA02 & S-D/C-5 & $\mathrm{Vpc}$ & 11,3 & 12,5 & 8,9 & PA02 & S-D/C-5 & $V p c$ & 11,1 & 11,4 & 11,6 \\
\hline PA02 & S-D/C-5 & $V p c$ & 9,7 & 10,4 & 5,7 & PA02 & S-D/C-5 & $\mathrm{Vpc}$ & 9,1 & 10,2 & 7,2 \\
\hline PA02 & S-D/C-5 & $V p c$ & 8,7 & 9,6 & 9,2 & PA02 & S-D/C-5 & $\mathrm{Vpc}$ & 9 & 9,5 & 3,7 \\
\hline PA02 & S-D/C-5 & $\mathrm{Vpc}$ & 11,4 & 11,9 & 11,9 & PA02 & $S-D / C-5$ & Vpc & 11,8 & 11,6 & 4,8 \\
\hline PA02 & S-D/C-5 & $\mathrm{Vpc}$ & 10,9 & 11,2 & 11,3 & PA02 & S-D/C-5 & $\mathrm{Vpc}$ & 10,9 & 11,8 & 4,8 \\
\hline PA02 & S-D/C-5 & $\mathrm{Vpc}$ & 12,4 & 11,8 & 13,3 & PA02 & S-D/C-5 & Vpc & 13,5 & 16,4 & \\
\hline PA02 & S-D/C-5 & $\mathrm{Vpc}$ & 11 & 11 & 11,3 & PA02 & S-D/C-5 & $\mathrm{Vpc}$ & & & 8,4 \\
\hline PA02 & S-D/C-5 & $\mathrm{Vpc}$ & 11,8 & 13,5 & 9,7 & PA02 & S-D/C-5 & Vpc & 10,4 & & 6,2 \\
\hline PA02 & S-D/C-5 & $V p c$ & 10,4 & 12,1 & 8,2 & PA02 & S-D/C-5 & Vpc & 11,6 & 12,2 & 5,8 \\
\hline PA02 & S-D/C-5 & $V p c$ & 11,9 & 13,4 & 10,4 & PA02 & S-D/C-5 & $\mathrm{Vpc}$ & 10,2 & 11,1 & 8,7 \\
\hline PA02 & S-D/C-5 & Vpc & 11,5 & 13,3 & 11,2 & PA02 & $S-D / C-5$ & Vpc & 12,9 & 14,6 & 9,2 \\
\hline PA02 & S-D/C-5 & $V p c$ & 12,3 & 13,1 & 12,2 & PA02 & S-D/C-5 & $V p c$ & 11 & 13,7 & 9 \\
\hline PA02 & $S-D / C-5$ & $\mathrm{Vpc}$ & 10,9 & 11 & 10,6 & PA02 & $S-D / C-5$ & $\mathrm{Vpc}$ & 10 & 11,4 & 8,6 \\
\hline PA02 & S-D/C-5 & $V p c$ & 11,5 & 13,1 & 11,1 & PA02 & S-D/C-5 & $\mathrm{Vpc}$ & 10,2 & 11,1 & 8,8 \\
\hline PA02 & S-D/C-5 & Vpc & 12 & & 11,8 & PA02 & S-D/C-5 & Vpc & & & 12,9 \\
\hline PA02 & S-D/C-5 & $V p c$ & 11,7 & 12,7 & 12,3 & PA02 & S-D/C-5 & $\mathrm{Vpc}$ & 11,6 & 12,3 & \\
\hline PA02 & S-D/C-5 & $\mathrm{Vpc}$ & 12,1 & 11,1 & 10,6 & PA02 & S-D/C-5 & Vpc & 9,5 & 10,8 & 9,2 \\
\hline PA02 & S-D/C-5 & $V p c$ & 11,2 & 11,7 & 10,1 & PA02 & S-D/C-5 & Vpc & 10,9 & 12,3 & 12,3 \\
\hline PA02 & S-D/C-5 & $\mathrm{Vpc}$ & 11,8 & 13,3 & 11,5 & PA02 & S-D/C-5 & Vpc & 12,3 & 12,8 & 10 \\
\hline PA02 & S-D/C-5 & $V p c$ & 13,3 & 14,6 & & PA02 & S-D/C-5 & Vpc & 10,8 & 11,6 & 10,9 \\
\hline PA02 & S-D/C-5 & $V p c$ & 10,5 & 12,3 & 11,3 & PA02 & S-D/C-5 & Vpc & 11,6 & 12,4 & 6,3 \\
\hline PA02 & S-D/C-5 & $V p c$ & 10,3 & 10,7 & 10,8 & PA02 & S-D/C-5 & $\mathrm{Vpc}$ & & & 11,2 \\
\hline PA02 & S-D/C-5 & $V p c$ & 9,4 & 10,4 & 7,8 & PA02 & S-D/C-5 & $\mathrm{Vpc}$ & 10,8 & 13,5 & 10,4 \\
\hline PA02 & $S-D / C-5$ & $\mathrm{Vpc}$ & 10,3 & 12,9 & 8,9 & PA02 & $S-D / C-5$ & $\mathrm{Vpc}$ & 9 & 9,4 & 8 \\
\hline PA02 & S-D/C-5 & $V p c$ & 10,9 & 12 & 10,1 & PA02 & S-D/C-5 & Vpc & 11,8 & 13,4 & 12,1 \\
\hline PA02 & S-D/C-5 & $\mathrm{Vpc}$ & & & 7,7 & PA02 & S-D/C-5 & Vpc & 12,3 & 13,4 & 11,5 \\
\hline PA02 & S-D/C-5 & $V p c$ & 11 & 12 & 9 & PA02 & S-D/C-5 & Vpc & 10,7 & 12,8 & 9,1 \\
\hline PA02 & S-D/C-5 & $\mathrm{Vpc}$ & 10,2 & 10,9 & & PA02 & S-D/C-5 & Vpc & 10,8 & 11,8 & 10,7 \\
\hline PA02 & S-D/C-5 & $\mathrm{Vpc}$ & 10,9 & & & PA02 & S-D/C-5 & Vpc & 10,6 & 11 & 11,2 \\
\hline PA02 & S-D/C-5 & $V p c$ & 9,8 & 11,1 & 9,2 & PA02 & S-D/C-5 & $V p c$ & 12,1 & 14,7 & 10 \\
\hline
\end{tabular}




\begin{tabular}{|c|c|c|c|c|c|c|c|c|c|c|c|}
\hline PA02 & S-D/C-5 & $\mathrm{Vpc}$ & 9,7 & 10,1 & 9,4 & PA02 & S-D/C-5 & $V p c$ & & & 14,3 \\
\hline PA02 & S-D/C-5 & $V p c$ & 9 & 10,7 & 9 & PA02 & S-D/C-5 & $V p c$ & 11,1 & 11,8 & 10,2 \\
\hline PA02 & S-D/C-5 & $V p c$ & 11,6 & 11,2 & 11,9 & PA02 & S-D/C-5 & Vpc & 9,8 & 11,6 & 9,4 \\
\hline PA02 & S-D/C-5 & $\mathrm{Vpc}$ & 9,2 & 10 & & PA02 & S-D/C-5 & Vpc & 9,6 & 11 & 7,7 \\
\hline PA02 & S-D/C-5 & $\mathrm{Vpc}$ & 10,5 & 11,7 & 8,2 & PA02 & S-D/C-5 & Vpc & 10,2 & 11,4 & 10 \\
\hline PA02 & S-D/C-5 & $V p c$ & 10,2 & 11,5 & 8,7 & PA02 & S-D/C-5 & Vpc & 11,2 & 12,2 & 9,1 \\
\hline PA02 & S-D/C-5 & $\mathrm{Vpc}$ & 11 & 11,7 & 8,9 & PA02 & S-D/C-5 & Vpc & 11,5 & 12,3 & 9,4 \\
\hline PA02 & S-D/C-5 & $\mathrm{Vpc}$ & 10 & 10,1 & 9,4 & PA02 & S-D/C-5 & $V p c$ & 11,5 & 12,8 & 12,1 \\
\hline PA02 & S-D/C-5 & $\mathrm{Vpc}$ & 10,7 & 10,7 & 10,1 & PA02 & S-D/C-5 & Vpc & 10,3 & 10,6 & 10,2 \\
\hline PA02 & S-D/C-5 & $\mathrm{Vpc}$ & 8,6 & 10,4 & 7,2 & PA02 & S-D/C-5 & Vpc & 10,5 & 11 & 8,2 \\
\hline PA02 & S-D/C-5 & $\mathrm{Vpc}$ & 8,6 & 10,3 & 4 & PA02 & S-D/C-5 & Vpc & 9,3 & 10,9 & 9,5 \\
\hline PA02 & S-D/C-5 & $\mathrm{Vpc}$ & 10,3 & 11,4 & 10,5 & PA02 & S-D/C-5 & Vpc & 10,9 & 12,9 & 6,4 \\
\hline PA02 & S-D/C-5 & $\mathrm{Vpc}$ & 8,9 & 9,8 & 8,1 & PA02 & S-D/C-5 & Vpc & 10,2 & 11,7 & 7,7 \\
\hline PA02 & S-D/C-5 & $\mathrm{Vpc}$ & 10,4 & 11,1 & 8,6 & PA02 & S-D/C-5 & Vpc & 11,9 & 12,6 & 9,8 \\
\hline PA02 & S-D/C-5 & $\mathrm{Vpc}$ & 10,2 & 10,4 & 10,3 & PA02 & S-D/C-5 & $V p c$ & 11,2 & 11,8 & 10,7 \\
\hline PA02 & S-D/C-5 & $\mathrm{Vpc}$ & 12,5 & 13,2 & & PA02 & S-D/C-5 & Vpc & 11,4 & 11,4 & 9 \\
\hline PA02 & S-D/C-5 & $\mathrm{Vpc}$ & 7,6 & 9,4 & 4,9 & PA02 & S-D/C-5 & $V p c$ & 12,8 & 13,2 & 12,2 \\
\hline PA02 & S-D/C-5 & $\mathrm{Vpc}$ & 9,6 & 10,4 & 9,2 & PA02 & S-D/C-5 & $V p c$ & 10,5 & 11,8 & 9,3 \\
\hline PA02 & S-D/C-5 & $\mathrm{Vpc}$ & 10,4 & 11,9 & 4,7 & PA02 & S-D/C-5 & $V p c$ & 10,9 & 11,7 & \\
\hline PA02 & S-D/C-5 & $\mathrm{Vpc}$ & 9,6 & 10,9 & 7,9 & PA02 & S-D/C-5 & Vpc & 10,7 & 11,5 & 10,7 \\
\hline PA02 & S-D/C-5 & $V p c$ & 9,9 & 12,8 & 4,6 & PA02 & S-D/C-5 & Vpc & 10,9 & 11,9 & 9,6 \\
\hline PA02 & S-D/C-5 & $\mathrm{Vpc}$ & 11,8 & 14,2 & 5,4 & PA02 & S-D/C-5 & Vpc & 11,3 & 12,8 & 7,2 \\
\hline PA02 & S-D/C-5 & $\mathrm{Vpc}$ & 10 & 10,9 & 10,5 & PA02 & S-D/C-5 & Vpc & 10,3 & 12,7 & 8,7 \\
\hline PA02 & S-D/C-5 & $\mathrm{Vpc}$ & 10,5 & 12,9 & 10,6 & PA02 & S-D/C-5 & Vpc & 12,8 & 13,9 & 11,2 \\
\hline PA02 & S-D/C-5 & $V p c$ & 12,6 & 14,4 & 7,4 & PA02 & S-D/C-5 & Vpc & 11 & 12,3 & 6,5 \\
\hline PA02 & S-D/C-5 & $V p c$ & 11,3 & 12,3 & 11 & PA02 & S-D/C-5 & $V p c$ & 12,1 & 12,1 & 12,3 \\
\hline PA02 & S-D/C-5 & $\mathrm{Vpc}$ & 10,5 & 11,5 & 6,2 & PA02 & S-D/C-5 & Vpc & 12,5 & 14,7 & 10 \\
\hline PA02 & S-D/C-5 & $\mathrm{Vpc}$ & 11,1 & 11 & 10 & PA02 & S-D/C-5 & $V p c$ & 13,3 & 13,9 & 12,9 \\
\hline PA02 & S-D/C-5 & $\mathrm{Vpc}$ & 11,5 & 11,8 & 10,4 & PA02 & S-D/C-5 & Vpc & 12,1 & 12,5 & 11,2 \\
\hline PA02 & S-D/C-5 & $\mathrm{Vpc}$ & 10,9 & 10,6 & 10,5 & PA02 & S-D/C-5 & $V p c$ & 11,1 & 12,1 & 11,5 \\
\hline PA02 & S-D/C-5 & $\mathrm{Vpc}$ & 9,3 & 11,1 & 8,3 & PA02 & S-D/C-5 & $V p c$ & 13,4 & 13,2 & 12,2 \\
\hline PA02 & S-D/C-5 & $\mathrm{Vpc}$ & 10,3 & 11,5 & 8,9 & PA02 & S-D/C-5 & Vpc & 13,8 & 14,2 & 11,8 \\
\hline PA02 & S-D/C-5 & $\mathrm{Vpc}$ & 11,8 & 13,4 & 9,5 & PA02 & S-D/C-5 & Vpc & 12,1 & 13,5 & 10,6 \\
\hline PA02 & S-D/C-5 & $V p c$ & 10,2 & 11,4 & 6,5 & PA02 & S-D/C-5 & Vpc & 13,6 & 14,6 & 12,6 \\
\hline PA02 & S-D/C-5 & $\mathrm{Vpc}$ & 11,4 & 13,6 & 9,9 & PA02 & S-D/C-5 & Vpc & 11,4 & 12,1 & 11,7 \\
\hline PA02 & S-D/C-5 & $\mathrm{Vpc}$ & 9,4 & 9,6 & 9,6 & PA02 & S-E/C-2 & Vpc & 10,5 & 11,7 & 8,5 \\
\hline PA02 & S-D/C-5 & $\mathrm{Vpc}$ & 9,8 & 11,6 & 12,3 & PA02 & S-E/C-4 & $V p c$ & 14,3 & 16,7 & 13,6 \\
\hline PA02 & S-D/C-5 & $\mathrm{Vpc}$ & 11,3 & 11,1 & 10,8 & PA02 & S-E/C-4 & Vpc & 14,1 & 13,4 & 13 \\
\hline PA02 & S-D/C-5 & $\mathrm{Vpc}$ & 12,4 & 13,3 & 10,3 & PA02 & S-E/C-4 & $V p c$ & 15,8 & 17,2 & 13,8 \\
\hline PA02 & S-D/C-5 & $\mathrm{Vpc}$ & 10,3 & 10,4 & 11,1 & PA02 & S-G/C-3 & $V p c$ & 10,8 & 11,1 & 9,7 \\
\hline PA02 & S-D/C-5 & $\mathrm{Vpc}$ & 10,4 & 11,6 & 11,2 & PA02 & S-G/C-3 & $V p c$ & 13,8 & 15,1 & 12,1 \\
\hline PA02 & S-D/C-5 & $\mathrm{Vpc}$ & 9 & 10,1 & 6 & PA02 & $\mathrm{S}-\mathrm{H} / \mathrm{C}-2$ & $V p c$ & 13,5 & 15,4 & 9,9 \\
\hline PA02 & S-D/C-5 & $V p c$ & 12,6 & 12,4 & 12,2 & PA02 & $\mathrm{S}-\mathrm{I} / \mathrm{C}-3$ & Vpc & 11,2 & 13,8 & 8,6 \\
\hline PA02 & $S-J / C-3$ & $\mathrm{Vpc}$ & & & 11,2 & PA02 & S- Ñ/C-2 & $V p c$ & 11,8 & 12,7 & 9,7 \\
\hline PA02 & S-K/C-3 & $\mathrm{Vpc}$ & 12,9 & 13,6 & 13,1 & PA02 & S-Ñ/C-2 & $V p c$ & 10,5 & 13,2 & 8,9 \\
\hline
\end{tabular}




\begin{tabular}{|c|c|c|c|c|c|c|c|c|c|c|c|}
\hline PA02 & S-K/C-3 & $V p c$ & 11,9 & 12,3 & 11,2 & PA02 & S-Ñ /C-2 & $V p c$ & 11,3 & 12,7 & 10,5 \\
\hline PA02 & S-K/C-3 & $V p c$ & 10,4 & 10,9 & 11,1 & PA02 & S- $-\tilde{N} / C-2$ & $V p c$ & 10,6 & 11,3 & 10,9 \\
\hline PA02 & S-K/C-4 & $V p c$ & 11,2 & 12,6 & 9,9 & PA02 & S-Ñ/C-2 & Vpc & 9,6 & 10,6 & 10,1 \\
\hline PA02 & S-K/C-4 & $\mathrm{Vpc}$ & 10,2 & 11,8 & 11 & PA02 & S-Ñ/C-2 & Vpc & 10,9 & 12,3 & 12 \\
\hline PA02 & S-K/C-4 & $V p c$ & 10,9 & 12,8 & 9,8 & PA02 & S-Ñ/C-2 & $V p c$ & 11 & 12,4 & 9,3 \\
\hline PA02 & S-K/C-4 & $V p c$ & 12,3 & 11,9 & 12,5 & PA02 & S-Ñ/C-2 & Vpc & 12,5 & 13,4 & \\
\hline PA02 & S-K/C-4 & $V p c$ & 12,9 & 14,7 & 11,7 & PA02 & S-Ñ/C-2 & Vpc & 11,6 & 12,6 & 9,1 \\
\hline PA02 & S-K/C-4 & $V p c$ & 11,1 & 12,1 & 4,4 & PA02 & S-Ñ/C-2 & $\mathrm{Vpc}$ & & & 13,4 \\
\hline PA02 & S-K/C-6 & $V p c$ & 12,3 & 13,5 & 13,5 & PA02 & S-Ñ /C-2 & $V p c$ & 11,3 & 13,2 & 10,3 \\
\hline PA02 & S-K/C-6 & $V p c$ & 11,9 & 13,1 & 10,6 & PA02 & S-Ñ/C-2 & Vpc & 11 & 12,6 & 9,3 \\
\hline PA02 & S-K/C-6 & $\mathrm{Vpc}$ & 11,1 & 13 & 11,2 & PA02 & S-Ñ/C-2 & $V p c$ & 10,1 & 10,7 & 9,3 \\
\hline PA02 & S-K/C-6 & $\mathrm{Vpc}$ & 10,5 & 11 & 11 & PA02 & S-Ñ /C-2 & Vpc & 11,5 & 12,3 & 11,4 \\
\hline PA02 & S-K/C-6 & $V p c$ & 11,5 & 12,1 & 11,3 & PA02 & S-Ñ $/ C-2$ & Vpc & 11,5 & 13 & 9,7 \\
\hline PA02 & S-K/C-6 & $\mathrm{Vpc}$ & & & 8,1 & PA02 & S-Ñ/C-2 & Vpc & & & 11,2 \\
\hline PA02 & S-K/C-6 & $V p c$ & 10 & 11,9 & 9,4 & PA02 & S-Ñ/C-2 & $V p c$ & 9 & 10,5 & 8,2 \\
\hline PA02 & S-K/C-6 & $V p c$ & 9,6 & 10 & 7,7 & PA02 & S-Ñ $/ C-2$ & Vpc & 14,4 & 13,1 & 13,9 \\
\hline PA02 & S-K/C-6 & $V p c$ & & & 7,5 & PA02 & S-Ñ/C-2 & Vpc & 12,5 & 12,2 & 11,7 \\
\hline PA02 & S-K/C-6 & $V p c$ & 9,4 & 9,9 & 8,8 & PA02 & S-Ñ/C-2 & Vpc & 11,6 & 13,6 & 9,4 \\
\hline PA02 & S-K/C-6 & $V p c$ & 10,9 & 11,5 & 10,4 & PA02 & S-Ñ/C-2 & $V p c$ & 11,7 & 12,9 & \\
\hline PA02 & S-K/C-6 & $V p c$ & 13,3 & 13,6 & 12,2 & PA02 & S-ÑNC-2 & $V p c$ & & & 8,3 \\
\hline PA02 & S-K/C-6 & $V p c$ & 10,3 & 11,7 & 10,9 & PA02 & S-Ñ $/ C-2$ & $V p c$ & & & 10,5 \\
\hline PA02 & S-K/C-6 & $\mathrm{Vpc}$ & 11,2 & 12,3 & 8,5 & PA02 & S-Ñ $/ C-2$ & $V p c$ & & & 6,8 \\
\hline PA02 & S-K/C-6 & $V p c$ & 11,1 & 11,9 & 12,1 & PA02 & S-Ñ/C-2 & Vpc & 13,5 & 17,1 & 8,2 \\
\hline PA02 & S-K/C-6 & $V p c$ & 10,9 & 11,9 & 9,7 & PA02 & S-Ñ/C-2 & Vpc & 13,5 & 15,6 & 7,7 \\
\hline PA02 & S-N/C-3 & $V p c$ & 12,8 & 14,3 & 9,9 & PA02 & S-Ñ/C-2 & Vpc & 10,6 & 12,2 & 4,4 \\
\hline PA02 & S-N/C-5 & $V p c$ & 8,7 & 10,1 & & PA02 & S-Ñ/C-2 & Vpc & 11,3 & 12,7 & 8,7 \\
\hline PA02 & S-Ñ/C-2 & $V p c$ & 11,2 & 13,1 & 10,6 & PA02 & S-Ñ/C-2 & Vpc & 11,2 & 12,9 & 11,3 \\
\hline PA02 & S-Ñ $/ C-2$ & $V p c$ & 11,6 & 12,8 & & PA02 & S-Ñ/C-2 & $V p c$ & 13,1 & 12,8 & 12 \\
\hline PA02 & S-Ñ/C-2 & $V p c$ & 14,1 & 14,9 & 14,5 & PA02 & S-Ñ/C-2 & Vpc & 9,9 & 10,5 & 10,9 \\
\hline PA02 & S-Ñ/C-2 & $V p c$ & 15,1 & 15,4 & 15,2 & PA02 & S-Ñ/C-2 & Vpc & 12 & 13,4 & 10 \\
\hline PA02 & S-Ñ $/ C-2$ & $V p c$ & 13,9 & 14,7 & 12,7 & PA02 & S-Ñ $/ C-2$ & $V p c$ & 12,6 & 13,7 & 12,6 \\
\hline PA02 & S-Ñ $/ C-2$ & $V p c$ & 11,8 & 13,7 & 12,2 & PA02 & S-Ñ $/ C-2$ & Vpc & 12,8 & 14,3 & 12,6 \\
\hline PA02 & S-Ñ $/ C-2$ & $V p c$ & 12,7 & 15,4 & 12,7 & PA02 & S-Ñ $/ C-2$ & Vpc & 15,2 & 15,2 & 14,7 \\
\hline PA02 & S-Ñ/C-2 & $V p c$ & 12,1 & 13,4 & 8 & PA02 & S-Ñ/C-2 & Vpc & 12,3 & 12,6 & 12,4 \\
\hline PA02 & S-Ñ/C-2 & $\mathrm{Vpc}$ & 11,3 & 12,8 & 11,5 & PA02 & S-Ñ/C-2 & $\mathrm{Vpc}$ & 12 & 12,8 & 11,2 \\
\hline PA02 & S-Ñ/C-2 & $\mathrm{Vpc}$ & 10,2 & 12,5 & 6,2 & PA02 & S-Ñ $/ C-2$ & Vpc & 10,5 & 11 & 10,9 \\
\hline PA02 & S-Ñ/C-2 & $V p c$ & & & 9,6 & PA02 & S-ÑNC-2 & Vpc & 11,4 & 11,9 & 10,6 \\
\hline PA02 & S- $-\tilde{N} / C-2$ & $V p c$ & 13,6 & & & PA02 & S-Ñ/C-2 & Vpc & 12,4 & 13,5 & 11,9 \\
\hline PA02 & S-Ñ/C-2 & $\mathrm{Vpc}$ & & & 10,3 & PA02 & S-Ñ/C-2 & $V p c$ & 13,2 & 14,7 & 11,6 \\
\hline PA02 & S- $\tilde{N} / C-2$ & $\mathrm{Vpc}$ & 9,9 & 10,8 & 8,8 & PA02 & $S-\tilde{N} / C-2$ & Vpc & 13,6 & 15,7 & \\
\hline PA02 & S-Ñ/C-2 & $V p c$ & & & 10,6 & PA02 & S-Ñ/C-2 & Vpc & 12,8 & 13,3 & 11,7 \\
\hline PA02 & S-Ñ $/ C-2$ & $V p c$ & 11,6 & 13,1 & 9,7 & PA02 & S-Ñ $/ C-2$ & Vpc & & 11,1 & \\
\hline PA02 & S-Ñ/C-2 & $V p c$ & 11 & 12,5 & 11,1 & PA02 & S-Ñ/C-2 & $V p c$ & 14 & 15,1 & 13,3 \\
\hline PA02 & S- $\tilde{N} / C-2$ & $V p c$ & 10,7 & 12,7 & 9,2 & PA02 & S-Ñ $/ C-2$ & Vpc & 12,4 & 15,4 & 10 \\
\hline PA02 & S- $-\tilde{N} / C-2$ & $V p c$ & 11,6 & 12,9 & & PA02 & S-Ñ/C-2 & $V p c$ & 12,9 & 13,8 & 12,4 \\
\hline
\end{tabular}




\begin{tabular}{|c|c|c|c|c|c|c|c|c|c|c|c|}
\hline PA02 & S-Ñ/C-2 & $\mathrm{Vpc}$ & & & 9,3 & PA02 & S-Ñ/C-2 & Vpc & 13,5 & 14,9 & 10,7 \\
\hline PA02 & S-Ñ/C-2 & $V p c$ & 10,4 & 11,2 & 8,4 & PA02 & S-Ñ/C-2 & Vpc & 8,6 & 10,6 & 7,1 \\
\hline PA02 & S-Ñ/C-2 & Vpc & & & 9,5 & PA02 & S-Ñ/C-2 & Vpc & 10,8 & 13,6 & 9 \\
\hline PA02 & S-Ñ/C-2 & $V p c$ & 9,9 & 11,7 & & PA02 & $\mathrm{S}-\mathrm{O} / \mathrm{C}-2$ & Vpc & 12,1 & 13 & 12,6 \\
\hline PA02 & S-Ñ/C-2 & Vpc & & & 7,9 & PA02 & $\mathrm{S}-\mathrm{O} / \mathrm{C}-2$ & Vpc & 11,2 & 11,6 & 8,4 \\
\hline PA02 & S-Ñ/C-2 & $\mathrm{Vpc}$ & & & 7 & PA02 & $\mathrm{S}-\mathrm{O} / \mathrm{C}-2$ & Vpc & 11,2 & 11,6 & 10,3 \\
\hline PA02 & S-Ñ/C-2 & Vpc & & & 14 & PA02 & $\mathrm{S}-\mathrm{O} / \mathrm{C}-2$ & Vpc & 9,7 & 10,2 & 10,1 \\
\hline PA02 & S-Ñ/C-2 & $\mathrm{Vpc}$ & & & 7,7 & PA02 & $\mathrm{S}-\mathrm{O} / \mathrm{C}-2$ & Vpc & 10,4 & 11,7 & 8,3 \\
\hline PA02 & S-Ñ/C-2 & Vpc & 11,6 & 13,1 & & PA02 & $\mathrm{S}-\mathrm{O} / \mathrm{C}-2$ & Vpc & 11,2 & 12,5 & 9,5 \\
\hline PA02 & S-Ñ/C-2 & $V p c$ & 11,3 & 12 & 10,2 & PA02 & $\mathrm{S}-\mathrm{O} / \mathrm{C}-2$ & Vpc & 11 & 13,1 & 9,9 \\
\hline PA02 & S-Ñ/C-2 & $\mathrm{Vpc}$ & 11,9 & 13,4 & 10,5 & PA02 & $\mathrm{S}-\mathrm{O} / \mathrm{C}-2$ & Vpc & 11,4 & 13,1 & 10,4 \\
\hline PA02 & S-Ñ/C-2 & $\mathrm{Vpc}$ & 16,2 & 16,5 & 15,6 & PA02 & S-O/C-2 & Vpc & 11,6 & 12,5 & 6,3 \\
\hline PA02 & S-Ñ/C-2 & $V p c$ & 12,8 & 13,3 & 13,3 & PA02 & $\mathrm{S}-\mathrm{O} / \mathrm{C}-2$ & Vpc & 11,1 & 12,4 & 8,9 \\
\hline PA02 & S-Ñ/C-2 & $\mathrm{Vpc}$ & 11,7 & 12,3 & 11,6 & PA02 & $\mathrm{S}-\mathrm{O} / \mathrm{C}-2$ & Vpc & 11,6 & 13 & 10,8 \\
\hline PA02 & S-Ñ/C-2 & $V p c$ & & & 13,4 & PA02 & $\mathrm{S}-\mathrm{O} / \mathrm{C}-2$ & Vpc & 12,2 & 13 & 12,1 \\
\hline PA02 & S-Ñ/C-2 & Vpc & 13,2 & 16,8 & 13,5 & PA02 & $\mathrm{S}-\mathrm{O} / \mathrm{C}-2$ & Vpc & 12,4 & & 12,9 \\
\hline PA02 & S-Ñ/C-2 & $V p c$ & 15 & 15,3 & 15,1 & PA02 & $\mathrm{S}-\mathrm{O} / \mathrm{C}-2$ & $V p c$ & 12,6 & 12,7 & 12,3 \\
\hline PA02 & S-Ñ/C-2 & $\mathrm{Vpc}$ & 14,3 & 15,5 & 13,7 & PA02 & $\mathrm{S}-\mathrm{O} / \mathrm{C}-2$ & Vpc & 13,9 & 14,2 & 14,4 \\
\hline PA02 & S-Ñ/C-2 & $\mathrm{Vpc}$ & 12,3 & 12,5 & 10,8 & PA02 & $\mathrm{S}-\mathrm{O} / \mathrm{C}-2$ & Vpc & 12,2 & 12,6 & 11,3 \\
\hline PA02 & S-Ñ/C-2 & $\mathrm{Vpc}$ & 13,9 & 15,5 & 12,7 & PA02 & $\mathrm{S}-\mathrm{O} / \mathrm{C}-2$ & $V p c$ & 11,2 & 12,5 & 10 \\
\hline PA02 & S-Ñ/C-2 & $\mathrm{Vpc}$ & 11,6 & 13,2 & 11,8 & PA02 & $\mathrm{S}-\mathrm{O} / \mathrm{C}-2$ & Vpc & 11,3 & 11,3 & 7,1 \\
\hline PA02 & S-Ñ/C-2 & $\mathrm{Vpc}$ & 9,8 & 12,1 & 6,1 & PA02 & $\mathrm{S}-\mathrm{O} / \mathrm{C}-2$ & Vpc & 11,3 & 12,8 & 10,5 \\
\hline PA02 & S-Ñ/C-2 & $\mathrm{Vpc}$ & 9,6 & 9,6 & 10,2 & PA02 & $\mathrm{S}-\mathrm{O} / \mathrm{C}-2$ & Vpc & 10,4 & 12,1 & 9 \\
\hline PA02 & S-Ñ/C-2 & $V p c$ & 9,3 & 10,4 & 8,1 & PA02 & $\mathrm{S}-\mathrm{O} / \mathrm{C}-2$ & Vpc & 8,1 & 9,5 & \\
\hline PA02 & S-Ñ/C-2 & $V p c$ & 9,9 & 9,6 & 10 & PA02 & $\mathrm{S}-\mathrm{O} / \mathrm{C}-2$ & $V p c$ & 13 & 13,8 & 12,9 \\
\hline PA02 & S-Ñ/C-2 & $\mathrm{Vpc}$ & 9,5 & 9,4 & & PA02 & $\mathrm{S}-\mathrm{O} / \mathrm{C}-2$ & $V p c$ & 11,3 & 12,1 & 9,4 \\
\hline PA02 & S-Ñ/C-2 & Vpc & 12,9 & 15,6 & 12 & PA02 & $\mathrm{S}-\mathrm{O} / \mathrm{C}-2$ & Vpc & 8,3 & 9,2 & 7,6 \\
\hline PA02 & S-Ñ/C-2 & $\mathrm{Vpc}$ & 11,9 & 14,1 & 7 & PA02 & $\mathrm{S}-\mathrm{O} / \mathrm{C}-2$ & Vpc & 13,6 & 15,3 & 12,5 \\
\hline PA02 & S-Ñ/C-2 & $\mathrm{Vpc}$ & 14,1 & 14,5 & 12,8 & PA02 & S-O/C-2 & Vpc & 11,5 & 13 & 6,8 \\
\hline PA02 & S-Ñ/C-2 & $\mathrm{Vpc}$ & 10,2 & 10,7 & 9,8 & PA02 & $\mathrm{S}-\mathrm{O} / \mathrm{C}-2$ & Vpc & 11,6 & 13,6 & 10,8 \\
\hline PA02 & S-Ñ/C-2 & $V p c$ & 13,8 & 14,7 & 6,9 & PA02 & $\mathrm{S}-\mathrm{O} / \mathrm{C}-2$ & Vpc & 9,9 & 11 & 9,5 \\
\hline PA02 & S-Ñ/C-2 & $\mathrm{Vpc}$ & 11,5 & 13,7 & 12,1 & PA02 & $\mathrm{S}-\mathrm{O} / \mathrm{C}-2$ & Vpc & 10,8 & 12,1 & 9,7 \\
\hline PA02 & S-Ñ/C-2 & $\mathrm{Vpc}$ & 10,9 & 12,7 & 9,4 & PA02 & $\mathrm{S}-\mathrm{O} / \mathrm{C}-2$ & Vpc & 10,9 & 12,8 & 11,4 \\
\hline PA02 & S-Ñ/C-2 & $\mathrm{Vpc}$ & 10,2 & 11,1 & 9,9 & PA02 & $\mathrm{S}-\mathrm{O} / \mathrm{C}-2$ & Vpc & 11,3 & 12,2 & 10,2 \\
\hline PA02 & S-Ñ/C-2 & $\mathrm{Vpc}$ & 10,3 & 11,5 & 11,1 & PA02 & $\mathrm{S}-\mathrm{O} / \mathrm{C}-2$ & $V p c$ & 12,3 & 13,3 & 12,1 \\
\hline PA02 & S-Ñ/C-2 & $\mathrm{Vpc}$ & 9,5 & & 10,2 & PA02 & $\mathrm{S}-\mathrm{O} / \mathrm{C}-2$ & Vpc & 11,8 & 11,2 & 9,2 \\
\hline PA02 & S-Ñ/C-2 & $\mathrm{Vpc}$ & & 11,9 & 8,9 & PA02 & $\mathrm{S}-\mathrm{O} / \mathrm{C}-2$ & $V p c$ & 12 & 13,8 & 11,7 \\
\hline PA02 & S-Ñ/C-2 & $\mathrm{Vpc}$ & 11,8 & 11,4 & 10,9 & PA02 & $\mathrm{S}-\mathrm{O} / \mathrm{C}-2$ & Vpc & 10,2 & 11 & 9,6 \\
\hline PA02 & S-Ñ/C-2 & $\mathrm{Vpc}$ & & & 8,3 & PA02 & $\mathrm{S}-\mathrm{O} / \mathrm{C}-2$ & Vpc & 10,6 & 11,6 & 9,1 \\
\hline PA02 & S-Ñ/C-2 & Vpc & & & 8,5 & PA02 & $\mathrm{S}-\mathrm{O} / \mathrm{C}-2$ & $V p c$ & 12,4 & 12,4 & 12 \\
\hline PA02 & S-Ñ/C-2 & $V p c$ & 12,3 & 14,1 & 9,5 & PA02 & S-O/C-2 & $V p c$ & 10,8 & 11,7 & 8,8 \\
\hline PA02 & S-Ñ/C-2 & $\mathrm{Vpc}$ & 11,7 & 13,1 & 12,8 & PA02 & $\mathrm{S}-\mathrm{O} / \mathrm{C}-2$ & $V p c$ & 12,5 & 12,3 & 12,3 \\
\hline PA02 & S-Ñ/C-2 & Vpc & 12,1 & 14,1 & 10,1 & PA02 & $\mathrm{S}-\mathrm{O} / \mathrm{C}-2$ & Vpc & 10,7 & 11,3 & 9,9 \\
\hline PA02 & S-Ñ/C-2 & $\mathrm{Vpc}$ & 11,9 & 13 & 11,8 & PA02 & $\mathrm{S}-\mathrm{O} / \mathrm{C}-2$ & Vpc & 10,7 & 12,5 & 11,5 \\
\hline PA02 & $\mathrm{S}-\mathrm{O} / \mathrm{C}-2$ & $\mathrm{Vpc}$ & 11,4 & 13,4 & 10,7 & PA02 & $\mathrm{S}-\mathrm{O} / \mathrm{C}-2$ & Vpc & 12 & 13,5 & 12,3 \\
\hline
\end{tabular}




\begin{tabular}{|c|c|c|c|c|c|c|c|c|c|c|c|}
\hline PA02 & $\mathrm{S}-\mathrm{O} / \mathrm{C}-2$ & $V p c$ & 11,8 & 12,5 & 9,5 & PA02 & $\mathrm{S}-\mathrm{O} / \mathrm{C}-2$ & $V p c$ & 10,8 & 12,1 & 9,4 \\
\hline PA02 & $\mathrm{S}-\mathrm{O} / \mathrm{C}-2$ & $V p c$ & 10,8 & 12,4 & 9 & PA02 & $\mathrm{S}-\mathrm{O} / \mathrm{C}-2$ & Vpc & 11,6 & 11,6 & 10,6 \\
\hline PA02 & $\mathrm{S}-\mathrm{O} / \mathrm{C}-2$ & $\mathrm{Vpc}$ & 10,4 & 12,1 & 8,7 & PA02 & $\mathrm{S}-\mathrm{O} / \mathrm{C}-2$ & Vpc & 11,1 & 12,1 & 9,6 \\
\hline PA02 & $\mathrm{S}-\mathrm{O} / \mathrm{C}-2$ & $\mathrm{Vpc}$ & 13 & 13,8 & 13,5 & PA02 & $\mathrm{S}-\mathrm{O} / \mathrm{C}-2$ & Vpc & 9,5 & 9,8 & 10 \\
\hline PA02 & $\mathrm{S}-\mathrm{O} / \mathrm{C}-2$ & $\mathrm{Vpc}$ & 10,8 & & 10,1 & PA02 & $\mathrm{S}-\mathrm{O} / \mathrm{C}-2$ & Vpc & 13,8 & 15,4 & 12,3 \\
\hline PA02 & $\mathrm{S}-\mathrm{O} / \mathrm{C}-2$ & $V p c$ & 11,6 & 12,3 & 9,8 & PA02 & $\mathrm{S}-\mathrm{O} / \mathrm{C}-2$ & Vpc & 12 & 12,8 & 10,8 \\
\hline PA02 & $\mathrm{S}-\mathrm{O} / \mathrm{C}-2$ & $V p c$ & 11,4 & 12 & 11,9 & PA02 & $\mathrm{S}-\mathrm{O} / \mathrm{C}-2$ & Vpc & 12,3 & 12,9 & 11,6 \\
\hline PA02 & $\mathrm{S}-\mathrm{O} / \mathrm{C}-2$ & Vpc & 11,3 & 12,8 & 10,3 & PA02 & $\mathrm{S}-\mathrm{O} / \mathrm{C}-2$ & Vpc & 12,2 & 13,1 & 13,6 \\
\hline PA02 & $\mathrm{S}-\mathrm{O} / \mathrm{C}-2$ & $\mathrm{Vpc}$ & 10,6 & & 10,8 & PA02 & $\mathrm{S}-\mathrm{O} / \mathrm{C}-2$ & Vpc & 11,1 & 12,5 & 9,6 \\
\hline PA02 & $\mathrm{S}-\mathrm{O} / \mathrm{C}-2$ & $\mathrm{Vpc}$ & 10,1 & 10,5 & 5,8 & PA02 & $\mathrm{S}-\mathrm{O} / \mathrm{C}-2$ & Vpc & 12,8 & 12,6 & 12,8 \\
\hline PA02 & $\mathrm{S}-\mathrm{O} / \mathrm{C}-2$ & $\mathrm{Vpc}$ & 9,7 & 11,1 & 8,1 & PA02 & $\mathrm{S}-\mathrm{O} / \mathrm{C}-2$ & Vpc & 12,5 & 14,5 & 11,1 \\
\hline PA02 & $\mathrm{S}-\mathrm{O} / \mathrm{C}-2$ & Vpc & 9,7 & 10,3 & & PA02 & $\mathrm{S}-\mathrm{O} / \mathrm{C}-2$ & Vpc & 11,7 & 12,1 & 11,7 \\
\hline PA02 & $\mathrm{S}-\mathrm{O} / \mathrm{C}-2$ & $\mathrm{Vpc}$ & 10,4 & 11,3 & 6,5 & PA02 & $\mathrm{S}-\mathrm{O} / \mathrm{C}-2$ & Vpc & 10,8 & 11,6 & 10,7 \\
\hline PA02 & $\mathrm{S}-\mathrm{O} / \mathrm{C}-2$ & $\mathrm{Vpc}$ & 10,6 & 11,9 & 9,7 & PA02 & $\mathrm{S}-\mathrm{O} / \mathrm{C}-2$ & Vpc & & 10,5 & 13,4 \\
\hline PA02 & $\mathrm{S}-\mathrm{O} / \mathrm{C}-2$ & $\mathrm{Vpc}$ & 10,6 & 12,1 & 9,8 & PA02 & $\mathrm{S}-\mathrm{O} / \mathrm{C}-2$ & $V p c$ & & 10,6 & 12,5 \\
\hline PA02 & $\mathrm{S}-\mathrm{O} / \mathrm{C}-2$ & $\mathrm{Vpc}$ & 12,3 & 12,5 & 12,3 & PA02 & $\mathrm{S}-\mathrm{O} / \mathrm{C}-2$ & Vpc & 9,8 & 13,3 & 5,5 \\
\hline PA02 & $\mathrm{S}-\mathrm{O} / \mathrm{C}-2$ & $\mathrm{Vpc}$ & 14,4 & 16,2 & 14,1 & PA02 & $\mathrm{S}-\mathrm{O} / \mathrm{C}-2$ & Vpc & 11,8 & 13 & 9,9 \\
\hline PA02 & $\mathrm{S}-\mathrm{O} / \mathrm{C}-2$ & $V p c$ & 13,8 & 15,3 & 13,4 & PA02 & $\mathrm{S}-\mathrm{O} / \mathrm{C}-2$ & Vpc & 10,9 & 12,2 & 8,8 \\
\hline PA02 & $\mathrm{S}-\mathrm{O} / \mathrm{C}-2$ & $\mathrm{Vpc}$ & 12,6 & 13,4 & 12,5 & PA02 & $\mathrm{S}-\mathrm{O} / \mathrm{C}-2$ & Vpc & 12,5 & 14,4 & 11 \\
\hline PA02 & $\mathrm{S}-\mathrm{O} / \mathrm{C}-2$ & $\mathrm{Vpc}$ & 13,4 & 14,7 & 12,4 & PA02 & $\mathrm{S}-\mathrm{O} / \mathrm{C}-2$ & Vpc & 12,2 & 13 & 9,6 \\
\hline PA02 & $\mathrm{S}-\mathrm{O} / \mathrm{C}-2$ & $\mathrm{Vpc}$ & 12,5 & 13,6 & 13 & PA02 & $\mathrm{S}-\mathrm{O} / \mathrm{C}-2$ & Vpc & 12,4 & 12,8 & 12,7 \\
\hline PA02 & $\mathrm{S}-\mathrm{O} / \mathrm{C}-2$ & $\mathrm{Vpc}$ & 10,6 & 12 & 9,7 & PA02 & $\mathrm{S}-\mathrm{O} / \mathrm{C}-2$ & Vpc & 11,8 & 11 & 8 \\
\hline PA02 & $\mathrm{S}-\mathrm{O} / \mathrm{C}-2$ & $\mathrm{Vpc}$ & 9,9 & 12,3 & 8,4 & PA02 & $\mathrm{S}-\mathrm{O} / \mathrm{C}-2$ & Vpc & 10,8 & 11,7 & 9,2 \\
\hline PA02 & $\mathrm{S}-\mathrm{O} / \mathrm{C}-2$ & $V p c$ & 10,5 & 11,8 & 6,8 & PA02 & $\mathrm{S}-\mathrm{O} / \mathrm{C}-2$ & Vpc & 12 & 12 & 11,8 \\
\hline PA02 & $\mathrm{S}-\mathrm{O} / \mathrm{C}-2$ & $\mathrm{Vpc}$ & 10,5 & 10,7 & 8,8 & PA02 & $\mathrm{S}-\mathrm{O} / \mathrm{C}-2$ & Vpc & 10,7 & 11 & 10,6 \\
\hline PA02 & $\mathrm{S}-\mathrm{O} / \mathrm{C}-2$ & $V p c$ & 11,8 & 13,4 & 11,2 & PA02 & $\mathrm{S}-\mathrm{O} / \mathrm{C}-2$ & Vpc & 13 & 13,7 & 13,6 \\
\hline PA02 & $\mathrm{S}-\mathrm{O} / \mathrm{C}-2$ & $\mathrm{Vpc}$ & 11,9 & 12,6 & 7,9 & PA02 & $\mathrm{S}-\mathrm{O} / \mathrm{C}-2$ & Vpc & 10,9 & 11,5 & 10,8 \\
\hline PA02 & $\mathrm{S}-\mathrm{O} / \mathrm{C}-2$ & $\mathrm{Vpc}$ & 9,4 & 10,5 & 8,7 & PA02 & $\mathrm{S}-\mathrm{O} / \mathrm{C}-2$ & Vpc & 9,8 & 11 & 11,2 \\
\hline PA02 & $\mathrm{S}-\mathrm{O} / \mathrm{C}-2$ & $\mathrm{Vpc}$ & 10,8 & 12,4 & 11,8 & PA02 & $\mathrm{S}-\mathrm{O} / \mathrm{C}-2$ & Vpc & 11,4 & 12,6 & 9,5 \\
\hline PA02 & $\mathrm{S}-\mathrm{O} / \mathrm{C}-2$ & $\mathrm{Vpc}$ & 10,5 & 11,6 & 8,8 & PA02 & $\mathrm{S}-\mathrm{O} / \mathrm{C}-2$ & Vpc & 11,6 & 11,9 & 10,9 \\
\hline PA02 & $\mathrm{S}-\mathrm{O} / \mathrm{C}-2$ & $V p c$ & 11,3 & 11 & 11 & PA02 & $\mathrm{S}-\mathrm{O} / \mathrm{C}-2$ & Vpc & 10,8 & 12,1 & 12,3 \\
\hline PA02 & $\mathrm{S}-\mathrm{O} / \mathrm{C}-2$ & $\mathrm{Vpc}$ & & & 11,3 & PA02 & $\mathrm{S}-\mathrm{O} / \mathrm{C}-2$ & Vpc & 9,7 & 10,1 & 9,7 \\
\hline PA02 & $\mathrm{S}-\mathrm{O} / \mathrm{C}-2$ & $\mathrm{Vpc}$ & 13,5 & 14,8 & 12,1 & PA02 & $\mathrm{S}-\mathrm{O} / \mathrm{C}-2$ & Vpc & 9,1 & 9,3 & 8,4 \\
\hline PA02 & $\mathrm{S}-\mathrm{O} / \mathrm{C}-2$ & $\mathrm{Vpc}$ & 12,5 & 12,4 & 11,7 & PA02 & $\mathrm{S}-\mathrm{O} / \mathrm{C}-2$ & Vpc & 10,8 & 11,4 & 11,5 \\
\hline PA02 & $\mathrm{S}-\mathrm{O} / \mathrm{C}-2$ & $V p c$ & 11,8 & 12,1 & 11,6 & PA02 & $\mathrm{S}-\mathrm{O} / \mathrm{C}-2$ & Vpc & 12,5 & 12,9 & 12,6 \\
\hline PA02 & $\mathrm{S}-\mathrm{O} / \mathrm{C}-2$ & $\mathrm{Vpc}$ & 12,1 & 13,5 & 11,2 & PA02 & $\mathrm{S}-\mathrm{O} / \mathrm{C}-2$ & Vpc & 11,5 & 11,8 & 10,5 \\
\hline PA02 & $\mathrm{S}-\mathrm{O} / \mathrm{C}-2$ & $\mathrm{Vpc}$ & 10,2 & 12 & 9,2 & PA02 & $\mathrm{S}-\mathrm{O} / \mathrm{C}-2$ & Vpc & 11,8 & 11,8 & 12,1 \\
\hline PA02 & $\mathrm{S}-\mathrm{O} / \mathrm{C}-2$ & $\mathrm{Vpc}$ & 11,5 & 12,4 & 11 & PA02 & $\mathrm{S}-\mathrm{O} / \mathrm{C}-2$ & Vpc & 12,5 & 12,5 & 12,2 \\
\hline PA02 & $\mathrm{S}-\mathrm{O} / \mathrm{C}-2$ & $\mathrm{Vpc}$ & 11,3 & 12,2 & 10,4 & PA02 & $\mathrm{S}-\mathrm{O} / \mathrm{C}-2$ & Vpc & 11,1 & 12,4 & \\
\hline PA02 & $\mathrm{S}-\mathrm{O} / \mathrm{C}-2$ & $V p c$ & 12,3 & 13,1 & 12,3 & PA02 & $\mathrm{S}-\mathrm{O} / \mathrm{C}-2$ & Vpc & 12,3 & 13,4 & 7,8 \\
\hline PA02 & $\mathrm{S}-\mathrm{O} / \mathrm{C}-2$ & $\mathrm{Vpc}$ & 10,4 & 11 & 8,9 & PA02 & $\mathrm{S}-\mathrm{O} / \mathrm{C}-2$ & Vpc & 9,9 & 10,9 & 9 \\
\hline PA02 & $\mathrm{S}-\mathrm{O} / \mathrm{C}-2$ & $V p c$ & 11,7 & 13,2 & 12,2 & PA02 & $\mathrm{S}-\mathrm{O} / \mathrm{C}-2$ & Vpc & 10,3 & 10,8 & 11,3 \\
\hline PA02 & $\mathrm{S}-\mathrm{O} / \mathrm{C}-2$ & $V p c$ & 11,3 & 12,5 & 10 & PA02 & $\mathrm{S}-\mathrm{O} / \mathrm{C}-2$ & Vpc & 11,7 & 12,1 & 9,2 \\
\hline PA02 & $\mathrm{S}-\mathrm{O} / \mathrm{C}-2$ & $V p c$ & 12,6 & 13 & 13,4 & PA02 & $\mathrm{S}-\mathrm{O} / \mathrm{C}-2$ & Vpc & 11,6 & 12,4 & 11,9 \\
\hline PA02 & $\mathrm{S}-\mathrm{O} / \mathrm{C}-2$ & $V p c$ & 10,4 & 10,9 & 9,1 & PA02 & $\mathrm{S}-\mathrm{O} / \mathrm{C}-2$ & Vpc & 9,8 & 10,7 & \\
\hline
\end{tabular}




\begin{tabular}{|c|c|c|c|c|c|c|c|c|c|c|c|}
\hline PA02 & $\mathrm{S}-\mathrm{O} / \mathrm{C}-2$ & $V p c$ & 12,5 & 13,1 & 13 & PA02 & $\mathrm{S}-\mathrm{O} / \mathrm{C}-2$ & $\mathrm{Vpc}$ & 11,7 & 12,5 & 11,7 \\
\hline PA02 & $\mathrm{S}-\mathrm{O} / \mathrm{C}-2$ & $\mathrm{Vpc}$ & 11,8 & 12 & 10,6 & PA02 & $\mathrm{S}-\mathrm{O} / \mathrm{C}-2$ & $V p c$ & 10,8 & 12,2 & 9,2 \\
\hline PA02 & $\mathrm{S}-\mathrm{O} / \mathrm{C}-2$ & $\mathrm{Vpc}$ & 12,3 & 14,3 & 13 & PA02 & $\mathrm{S}-\mathrm{O} / \mathrm{C}-2$ & $V p c$ & 12,1 & 12 & 10,6 \\
\hline PA02 & $\mathrm{S}-\mathrm{O} / \mathrm{C}-2$ & $V p c$ & 13,2 & 14,8 & 11,6 & PA02 & $\mathrm{S}-\mathrm{O} / \mathrm{C}-2$ & $V p c$ & 10,2 & 11 & 10,3 \\
\hline PA02 & $\mathrm{S}-\mathrm{O} / \mathrm{C}-2$ & $V p c$ & 11,8 & 12,5 & 13,4 & PA02 & $\mathrm{S}-\mathrm{O} / \mathrm{C}-2$ & $V p c$ & 11,2 & 12,6 & 4,9 \\
\hline PA02 & $\mathrm{S}-\mathrm{O} / \mathrm{C}-2$ & $\mathrm{Vpc}$ & 10,9 & 11,5 & 8,5 & PA02 & $\mathrm{S}-\mathrm{O} / \mathrm{C}-2$ & $\mathrm{Vpc}$ & 10,7 & 11,9 & 11,8 \\
\hline PA02 & $\mathrm{S}-\mathrm{O} / \mathrm{C}-2$ & $\mathrm{Vpc}$ & 12,3 & 12,7 & 12,1 & PA02 & $\mathrm{S}-\mathrm{O} / \mathrm{C}-2$ & $V p c$ & 10,6 & 11,7 & 9,6 \\
\hline PA02 & $\mathrm{S}-\mathrm{O} / \mathrm{C}-2$ & $\mathrm{Vpc}$ & 11,5 & 11,8 & 10,4 & PA02 & $\mathrm{S}-\mathrm{O} / \mathrm{C}-2$ & $V p c$ & 10,7 & 11,7 & 10,7 \\
\hline PA02 & $\mathrm{S}-\mathrm{O} / \mathrm{C}-2$ & $V p c$ & 11,9 & 13,5 & 12,1 & PA02 & $\mathrm{S}-\mathrm{O} / \mathrm{C}-2$ & $V p c$ & 11,7 & 12,6 & 11,4 \\
\hline PA02 & $\mathrm{S}-\mathrm{O} / \mathrm{C}-2$ & $V p c$ & 12,4 & 13,2 & 13,8 & PA02 & $\mathrm{S}-\mathrm{O} / \mathrm{C}-2$ & $\mathrm{Vpc}$ & 9,8 & 10,8 & 10,5 \\
\hline PA02 & $\mathrm{S}-\mathrm{O} / \mathrm{C}-2$ & $V p c$ & 13,1 & 14,1 & 14 & PA02 & $\mathrm{S}-\mathrm{O} / \mathrm{C}-2$ & $V p c$ & 11,9 & 13 & 10,6 \\
\hline PA02 & $\mathrm{S}-\mathrm{O} / \mathrm{C}-2$ & $V p c$ & 12,3 & 13,5 & 11,2 & PA02 & $\mathrm{S}-\mathrm{O} / \mathrm{C}-2$ & $V p c$ & & 10,7 & 10,8 \\
\hline PA02 & $\mathrm{S}-\mathrm{O} / \mathrm{C}-2$ & $V p c$ & 12 & 13,6 & 11,7 & PA02 & $\mathrm{S}-\mathrm{O} / \mathrm{C}-2$ & $V p c$ & 9,5 & 10 & 9,5 \\
\hline PA02 & $\mathrm{S}-\mathrm{O} / \mathrm{C}-2$ & $V p c$ & 12,5 & 13,4 & 11,9 & PA02 & $\mathrm{S}-\mathrm{O} / \mathrm{C}-2$ & $V p c$ & 10,6 & 11,6 & 9,1 \\
\hline PA02 & S-O/C-2 & $V p c$ & 12,3 & 12,4 & 12,1 & PA02 & $\mathrm{S}-\mathrm{O} / \mathrm{C}-2$ & $V p c$ & 12,9 & 13,5 & 13,7 \\
\hline PA02 & $\mathrm{S}-\mathrm{O} / \mathrm{C}-2$ & $V p c$ & 11,1 & 11,9 & 11,3 & PA02 & $\mathrm{S}-\mathrm{O} / \mathrm{C}-2$ & $\mathrm{Vpc}$ & 10,7 & 11,8 & 9,3 \\
\hline PA02 & $\mathrm{S}-\mathrm{O} / \mathrm{C}-2$ & $\mathrm{Vpc}$ & 12,1 & 12,5 & 13,4 & PA02 & $\mathrm{S}-\mathrm{O} / \mathrm{C}-2$ & $\mathrm{Vpc}$ & 9,7 & 10,9 & 10,2 \\
\hline PA02 & $\mathrm{S}-\mathrm{O} / \mathrm{C}-2$ & $\mathrm{Vpc}$ & & & 9,5 & PA02 & $\mathrm{S}-\mathrm{O} / \mathrm{C}-2$ & $V p c$ & 10,4 & 11,2 & 8,8 \\
\hline PA02 & $\mathrm{S}-\mathrm{O} / \mathrm{C}-2$ & $V p c$ & 12,2 & 12,6 & 12 & PA02 & $\mathrm{S}-\mathrm{O} / \mathrm{C}-2$ & $V p c$ & & & 10,7 \\
\hline PA02 & $\mathrm{S}-\mathrm{O} / \mathrm{C}-2$ & $V p c$ & 11,9 & 14,2 & 10,9 & PA02 & $\mathrm{S}-\mathrm{O} / \mathrm{C}-2$ & $V p c$ & 11,3 & 11,6 & 10,1 \\
\hline PA02 & $\mathrm{S}-\mathrm{O} / \mathrm{C}-2$ & $V p c$ & 8,9 & 10,3 & 5,4 & PA02 & $\mathrm{S}-\mathrm{O} / \mathrm{C}-2$ & $V p c$ & 12,8 & 15,1 & 11,9 \\
\hline PA02 & $\mathrm{S}-\mathrm{O} / \mathrm{C}-2$ & $\mathrm{Vpc}$ & 9,3 & 10,3 & 8,9 & PA02 & $\mathrm{S}-\mathrm{O} / \mathrm{C}-2$ & $V p c$ & 13,3 & 14,9 & 13,8 \\
\hline PA02 & $\mathrm{S}-\mathrm{O} / \mathrm{C}-2$ & $\mathrm{Vpc}$ & 11,6 & 12,5 & 9,8 & PA02 & $\mathrm{S}-\mathrm{O} / \mathrm{C}-2$ & $\mathrm{Vpc}$ & 12,8 & 14,6 & 12,9 \\
\hline PA02 & $\mathrm{S}-\mathrm{O} / \mathrm{C}-2$ & $\mathrm{Vpc}$ & 8,7 & 9,7 & 8 & PA02 & $\mathrm{S}-\mathrm{O} / \mathrm{C}-2$ & $V p c$ & 10,4 & 11,6 & 9,4 \\
\hline PA02 & $\mathrm{S}-\mathrm{O} / \mathrm{C}-2$ & $\mathrm{Vpc}$ & 9,3 & 9,8 & 8,9 & PA02 & $\mathrm{S}-\mathrm{O} / \mathrm{C}-2$ & $V p c$ & 13 & 13,3 & 13,1 \\
\hline PA02 & $\mathrm{S}-\mathrm{O} / \mathrm{C}-2$ & $\mathrm{Vpc}$ & 11,6 & 12,4 & & PA02 & $\mathrm{S}-\mathrm{O} / \mathrm{C}-2$ & $V p c$ & & & 11,9 \\
\hline PA02 & $\mathrm{S}-\mathrm{O} / \mathrm{C}-2$ & $\mathrm{Vpc}$ & & & 6,1 & PA02 & $\mathrm{S}-\mathrm{O} / \mathrm{C}-2$ & $\mathrm{Vpc}$ & 10,2 & 12,8 & 5,8 \\
\hline PA02 & $\mathrm{S}-\mathrm{O} / \mathrm{C}-2$ & $\mathrm{Vpc}$ & 10,6 & 12,1 & 7,9 & PA02 & $\mathrm{S}-\mathrm{O} / \mathrm{C}-2$ & $\mathrm{Vpc}$ & 10,4 & 11,1 & 11,6 \\
\hline PA02 & $\mathrm{S}-\mathrm{O} / \mathrm{C}-2$ & $V p c$ & 10,7 & 11,8 & 11,6 & PA02 & $\mathrm{S}-\mathrm{O} / \mathrm{C}-2$ & $V p c$ & 11,8 & 12,4 & 11,2 \\
\hline PA02 & $\mathrm{S}-\mathrm{O} / \mathrm{C}-2$ & $\mathrm{Vpc}$ & 8,7 & 9,9 & 7,8 & PA02 & $\mathrm{S}-\mathrm{O} / \mathrm{C}-2$ & $\mathrm{Vpc}$ & 12 & 13,1 & 10,5 \\
\hline PA02 & $\mathrm{S}-\mathrm{O} / \mathrm{C}-2$ & $V p c$ & 12 & 13 & 11,1 & PA02 & $\mathrm{S}-\mathrm{O} / \mathrm{C}-2$ & $V p c$ & 12,2 & 11,8 & 12,9 \\
\hline PA02 & $\mathrm{S}-\mathrm{O} / \mathrm{C}-2$ & $V p c$ & 9,8 & 10,4 & 10,1 & PA02 & $\mathrm{S}-\mathrm{O} / \mathrm{C}-2$ & $V p c$ & 12,5 & 12,7 & 12,6 \\
\hline PA02 & $\mathrm{S}-\mathrm{O} / \mathrm{C}-2$ & $V p c$ & 9,3 & 10,2 & 8,9 & PA02 & $\mathrm{S}-\mathrm{O} / \mathrm{C}-2$ & $V p c$ & 12,4 & 13,2 & 12,5 \\
\hline PA02 & $\mathrm{S}-\mathrm{O} / \mathrm{C}-2$ & $\mathrm{Vpc}$ & 10,5 & 12,2 & 9,6 & PA02 & $\mathrm{S}-\mathrm{O} / \mathrm{C}-2$ & $V p c$ & & & 11,5 \\
\hline PA02 & $\mathrm{S}-\mathrm{O} / \mathrm{C}-2$ & $\mathrm{Vpc}$ & 11,1 & 11,6 & 11,3 & PA02 & $\mathrm{S}-\mathrm{O} / \mathrm{C}-2$ & $\mathrm{Vpc}$ & 13 & 14,1 & 12,8 \\
\hline PA02 & $\mathrm{S}-\mathrm{O} / \mathrm{C}-2$ & $\mathrm{Vpc}$ & 10,4 & 10,4 & 10,5 & PA02 & $\mathrm{S}-\mathrm{O} / \mathrm{C}-2$ & $\mathrm{Vpc}$ & 11,8 & 11,9 & 11,7 \\
\hline PA02 & $\mathrm{S}-\mathrm{O} / \mathrm{C}-2$ & $\mathrm{Vpc}$ & 10,2 & & 8,3 & PA02 & $\mathrm{S}-\mathrm{O} / \mathrm{C}-2$ & $V p c$ & 10,5 & 10,9 & 10,6 \\
\hline PA02 & $\mathrm{S}-\mathrm{O} / \mathrm{C}-2$ & $\mathrm{Vpc}$ & 12 & 12,4 & 12,2 & PA02 & $\mathrm{S}-\mathrm{O} / \mathrm{C}-2$ & $V p c$ & 11 & 11,9 & 11,1 \\
\hline PA02 & $\mathrm{S}-\mathrm{O} / \mathrm{C}-2$ & $V p c$ & 9,4 & 9,6 & 8,9 & PA02 & $\mathrm{S}-\mathrm{O} / \mathrm{C}-2$ & $V p c$ & & & 5,3 \\
\hline PA02 & $\mathrm{S}-\mathrm{O} / \mathrm{C}-2$ & $\mathrm{Vpc}$ & 12,2 & 13,6 & 12 & PA02 & $\mathrm{S}-\mathrm{O} / \mathrm{C}-2$ & $V p c$ & 10,6 & 12,8 & 9,2 \\
\hline PA02 & $\mathrm{S}-\mathrm{O} / \mathrm{C}-2$ & $V p c$ & 11,3 & 12 & 10,2 & PA02 & $\mathrm{S}-\mathrm{O} / \mathrm{C}-2$ & $V p c$ & 10,5 & 11,3 & 5,3 \\
\hline PA02 & $\mathrm{S}-\mathrm{O} / \mathrm{C}-2$ & $V p c$ & 13,3 & 14,3 & 11,8 & PA02 & $\mathrm{S}-\mathrm{O} / \mathrm{C}-2$ & $V p c$ & 9,5 & 9,4 & \\
\hline PA02 & $\mathrm{S}-\mathrm{O} / \mathrm{C}-2$ & $V p c$ & & & 11,5 & PA02 & $\mathrm{S}-\mathrm{O} / \mathrm{C}-2$ & $V p c$ & 10,8 & 12,6 & 9,4 \\
\hline PA02 & $\mathrm{S}-\mathrm{O} / \mathrm{C}-2$ & $V p c$ & 10 & 11,7 & 8,6 & PA02 & $\mathrm{S}-\mathrm{O} / \mathrm{C}-2$ & $V p c$ & 10,5 & 11,8 & 8,4 \\
\hline PA02 & $\mathrm{S}-\mathrm{O} / \mathrm{C}-2$ & $\mathrm{Vpc}$ & 11,6 & 12,2 & 9,9 & PA02 & $\mathrm{S}-\mathrm{O} / \mathrm{C}-2$ & $V p c$ & 11,4 & 13,6 & 9,8 \\
\hline
\end{tabular}




\begin{tabular}{|c|c|c|c|c|c|c|c|c|c|c|c|}
\hline PA02 & $\mathrm{S}-\mathrm{O} / \mathrm{C}-2$ & Vpc & 12,1 & 13,1 & 11 & PA02 & $\mathrm{S}-\mathrm{O} / \mathrm{C}-2$ & Vpc & 9,4 & 11,2 & 5,8 \\
\hline PA02 & $\mathrm{S}-\mathrm{O} / \mathrm{C}-2$ & Vpc & & & 11,1 & PA02 & $\mathrm{S}-\mathrm{O} / \mathrm{C}-2$ & Vpc & 11,8 & 12,9 & 10,4 \\
\hline PA02 & $\mathrm{S}-\mathrm{O} / \mathrm{C}-2$ & Vpc & 10,8 & 11,6 & 11,5 & PA02 & $\mathrm{S}-\mathrm{O} / \mathrm{C}-2$ & Vpc & 12,5 & 13,3 & 12,9 \\
\hline PA02 & $\mathrm{S}-\mathrm{O} / \mathrm{C}-2$ & Vpc & 11,1 & 12,8 & 10,7 & PA02 & $\mathrm{S}-\mathrm{O} / \mathrm{C}-2$ & Vpc & 12,4 & 12,2 & 12,2 \\
\hline PA02 & $\mathrm{S}-\mathrm{O} / \mathrm{C}-2$ & Vpc & 12,8 & 13,7 & 13,1 & PA02 & $\mathrm{S}-\mathrm{O} / \mathrm{C}-2$ & $V p c$ & 12,5 & 12,3 & 12,5 \\
\hline PA02 & $\mathrm{S}-\mathrm{O} / \mathrm{C}-2$ & $V p c$ & 9,6 & 11 & 9 & PA02 & $\mathrm{S}-\mathrm{O} / \mathrm{C}-2$ & Vpc & 11,7 & 12,8 & 11,5 \\
\hline PA02 & $\mathrm{S}-\mathrm{O} / \mathrm{C}-2$ & Vpc & 11,8 & 14,2 & 5,4 & PA02 & $\mathrm{S}-\mathrm{O} / \mathrm{C}-2$ & Vpc & 9,6 & 10,9 & \\
\hline PA02 & $\mathrm{S}-\mathrm{O} / \mathrm{C}-2$ & Vpc & 13,4 & 11 & 9,9 & PA02 & $\mathrm{S}-\mathrm{O} / \mathrm{C}-2$ & Vpc & & & 10,6 \\
\hline PA02 & $\mathrm{S}-\mathrm{O} / \mathrm{C}-2$ & Vpc & 11,3 & & 8,7 & PA02 & $\mathrm{S}-\mathrm{O} / \mathrm{C}-2$ & Vpc & 10,5 & 11,6 & 8,9 \\
\hline PA02 & $\mathrm{S}-\mathrm{O} / \mathrm{C}-2$ & Vpc & 10,7 & 11,8 & 9,4 & PA02 & $\mathrm{S}-\mathrm{O} / \mathrm{C}-2$ & Vpc & 10,2 & 11,6 & 9 \\
\hline PA02 & $\mathrm{S}-\mathrm{O} / \mathrm{C}-2$ & Vpc & 11,4 & 11,6 & 10,9 & PA02 & $\mathrm{S}-\mathrm{O} / \mathrm{C}-2$ & Vpc & 12,3 & 13,6 & 10 \\
\hline PA02 & $\mathrm{S}-\mathrm{O} / \mathrm{C}-2$ & Vpc & 11,6 & 13 & 11,4 & PA02 & $\mathrm{S}-\mathrm{O} / \mathrm{C}-2$ & Vpc & 11,7 & 13,8 & 11,1 \\
\hline PA02 & $\mathrm{S}-\mathrm{O} / \mathrm{C}-2$ & Vpc & 11,8 & 12,7 & 9,5 & PA02 & $\mathrm{S}-\mathrm{O} / \mathrm{C}-2$ & Vpc & 13,1 & 13,6 & 12,3 \\
\hline PA02 & $\mathrm{S}-\mathrm{O} / \mathrm{C}-2$ & Vpc & & & 13,2 & PA02 & $\mathrm{S}-\mathrm{O} / \mathrm{C}-2$ & $\mathrm{Vpc}$ & 12,5 & 13,5 & 13,2 \\
\hline PA02 & $\mathrm{S}-\mathrm{O} / \mathrm{C}-2$ & Vpc & 12,6 & 13 & 12,8 & PA02 & $\mathrm{S}-\mathrm{O} / \mathrm{C}-2$ & $V p c$ & 9,2 & 9,1 & 8,5 \\
\hline PA02 & $\mathrm{S}-\mathrm{O} / \mathrm{C}-2$ & $V p c$ & 11,5 & 12,4 & 12,3 & PA02 & $\mathrm{S}-\mathrm{O} / \mathrm{C}-2$ & Vpc & & & 11,5 \\
\hline PA02 & $\mathrm{S}-\mathrm{O} / \mathrm{C}-2$ & Vpc & 11,8 & 12 & & PA02 & $\mathrm{S}-\mathrm{O} / \mathrm{C}-2$ & $V p c$ & 13 & 13,8 & 13,3 \\
\hline PA02 & $\mathrm{S}-\mathrm{O} / \mathrm{C}-2$ & Vpc & 10,9 & 11,7 & 9,7 & PA02 & $\mathrm{S}-\mathrm{O} / \mathrm{C}-2$ & Vpc & 11,6 & 11,7 & 11,3 \\
\hline PA02 & $\mathrm{S}-\mathrm{O} / \mathrm{C}-2$ & Vpc & 11,1 & 11,8 & 10 & PA02 & S-R/C-6 & Vpc & 8,7 & 9,5 & 7,8 \\
\hline PA02 & $\mathrm{S}-\mathrm{O} / \mathrm{C}-2$ & Vpc & 13,5 & 13,8 & 13,8 & PA02 & S-R/C-6 & Vpc & 8,6 & 9,4 & 7,8 \\
\hline PA02 & $\mathrm{S}-\mathrm{O} / \mathrm{C}-2$ & $V p c$ & 10,7 & 12,6 & 9,8 & PA02 & S-R/C-6 & $V p c$ & 9,3 & 9,9 & 8,5 \\
\hline PA02 & $\mathrm{S}-\mathrm{O} / \mathrm{C}-2$ & Vpc & 11,2 & 11,9 & 10,6 & PA02 & S-R/C-6 & Vpc & 8,8 & 9,2 & 3,6 \\
\hline PA02 & $\mathrm{S}-\mathrm{O} / \mathrm{C}-2$ & $V p c$ & 14,6 & 16,4 & 14,3 & PA02 & S-R/C-6 & Vpc & & & 8,9 \\
\hline PA02 & $\mathrm{S}-\mathrm{O} / \mathrm{C}-2$ & Vpc & 11,3 & 12,1 & 11,5 & PA02 & S-R/C-6 & Vpc & 10,6 & 12,6 & \\
\hline PA02 & $\mathrm{S}-\mathrm{O} / \mathrm{C}-2$ & $\mathrm{Vpc}$ & 11,2 & 12,2 & 9,9 & PA02 & S-R/C-6 & Vpc & 8,7 & 9,5 & \\
\hline PA02 & $\mathrm{S}-\mathrm{O} / \mathrm{C}-2$ & Vpc & 10,7 & 12,8 & 9,7 & PA02 & S-R/C-6 & Vpc & 9,2 & 9,3 & \\
\hline PA02 & $\mathrm{S}-\mathrm{O} / \mathrm{C}-2$ & Vpc & 12,9 & 14,1 & 14 & PA02 & $S-R / C-6$ & Vpc & 9 & 9,5 & 3,9 \\
\hline PA02 & S-R/C-2 & Vpc & 11,2 & 12 & 10,7 & PA02 & S-R/C-6 & Vpc & 8,7 & 9,3 & 5,3 \\
\hline PA02 & $S-R / C-3$ & Vpc & 12,7 & 13,7 & 11,6 & PA02 & S-R/C-6 & Vpc & 8,3 & 9,4 & 4,7 \\
\hline PA02 & S-R/C-3 & Vpc & 10,7 & 13,3 & 6,9 & PA02 & S-R/C-6 & Vpc & 10,8 & 12,1 & 11,7 \\
\hline PA02 & $S-R / C-3$ & Vpc & 11,5 & 1,9 & 10,1 & PA02 & $S-R / C-6$ & $\mathrm{Vpc}$ & 10,9 & 11,5 & 11,7 \\
\hline PA02 & S-R/C-6 & $\mathrm{Vpc}$ & 9,6 & 9,9 & 9,4 & PA02 & S-R/C-6 & Vpc & 10,9 & 11,9 & 11,6 \\
\hline PA02 & S-R/C-6 & Vpc & 9,6 & 10,4 & 9,2 & PA02 & S-R/C-6 & Vpc & 10,8 & 12,1 & 11,1 \\
\hline PA02 & S-R/C-6 & $V p c$ & 9,1 & 10 & 8,1 & PA02 & S-R/C-6 & Vpc & 9 & 10,1 & 8,1 \\
\hline PA02 & S-R/C-6 & Vpc & 10,7 & 12,1 & 11,4 & PA02 & S-R/C-6 & $\mathrm{Vpc}$ & 11,6 & 12,9 & 9,8 \\
\hline PA02 & S-R/C-6 & Vpc & 9,3 & 9,8 & 9,4 & PA02 & S-R/C-6 & $\mathrm{Vpc}$ & 10,8 & 11,6 & 10 \\
\hline PA02 & S-R/C-6 & Vpc & 9,8 & 10,2 & 9,3 & PA02 & S-R/C-6 & $V p c$ & 9,4 & 9,6 & 8,8 \\
\hline PA02 & $S-R / C-6$ & Vpc & 10,9 & 11,3 & 10,1 & PA02 & $S-R / C-6$ & Vpc & 9,6 & 10,5 & 9,9 \\
\hline PA02 & S-R/C-6 & Vpc & 10,5 & 10,7 & 10,6 & PA02 & S-R/C-6 & $\mathrm{Vpc}$ & 10,9 & 12,1 & 12 \\
\hline PA02 & S-R/C-6 & Vpc & 9,1 & 9,9 & 9 & PA02 & $S-R / C-6$ & $\mathrm{Vpc}$ & 10,8 & 11,7 & 11 \\
\hline PA02 & S-R/C-6 & Vpc & 9,6 & 9,7 & 9,8 & PA02 & S-R/C-6 & $\mathrm{Vpc}$ & 10,4 & 11,8 & 10,1 \\
\hline PA02 & S-R/C-6 & Vpc & 9,9 & 10,6 & 8,6 & PA02 & S-R/C-6 & Vpc & 11,6 & 13,6 & 8,9 \\
\hline PA02 & S-R/C-6 & $V p c$ & 9,3 & 9,8 & 9,2 & PA02 & S-R/C-6 & $V p c$ & 10,9 & 12,3 & 11,6 \\
\hline PA02 & S-R/C-6 & $V p c$ & 10,4 & 11,9 & 10,1 & PA02 & S-R/C-6 & $V p c$ & 12 & 12,8 & 11,1 \\
\hline PA02 & S-R/C-6 & Vpc & 9,5 & 9,6 & 9,3 & PA02 & S-R/C-7 & Vpc & 12 & 12,3 & 11,7 \\
\hline
\end{tabular}




\begin{tabular}{|c|c|c|c|c|c|c|c|c|c|c|c|}
\hline PA02 & S-R/C-6 & $\mathrm{Vpc}$ & 10,8 & 11,2 & 10,2 & PA02 & S-R/C-7 & $V p c$ & 11,1 & 12,2 & \\
\hline PA02 & S-R/C-6 & $V p c$ & 9,5 & 9,5 & 9,4 & PA02 & S-R/C-7 & $V p c$ & 10,7 & 12,8 & 8,9 \\
\hline PA02 & S-R/C-6 & $V p c$ & 10,8 & 11,9 & 9,6 & PA02 & S-R/C-7 & Vpc & 12 & 12,7 & 11,6 \\
\hline PA02 & S-R/C-6 & $V p c$ & 11,8 & 12,7 & 10,9 & PA02 & S-R/C-7 & $V p c$ & 11,4 & 12,5 & \\
\hline PA02 & $S-R / C-6$ & $V p c$ & 12,1 & 12,8 & 12 & PA02 & S-R/C-7 & Vpc & 12 & 12,6 & \\
\hline PA02 & S-R/C-6 & $\mathrm{Vpc}$ & 8,7 & 9,9 & & PA02 & S-W/C-4 & $V p c$ & 11,6 & 12,1 & 8,9 \\
\hline PA02 & S-R/C-6 & $V p c$ & 9,3 & 9,7 & 9,5 & PA02 & S-W/C-4 & Vpc & 10 & 10,2 & 9,4 \\
\hline PA02 & $S-R / C-6$ & $V p c$ & 9,1 & 9,9 & 9,2 & PA02 & S-W/C-4 & Vpc & 11,4 & 11,6 & 9,8 \\
\hline PA02 & S-R/C-6 & $V p c$ & 9,6 & 10,3 & 9,3 & PA02 & S-W/C-4 & Vpc & 13,7 & 13,8 & 13,2 \\
\hline PA02 & $S-R / C-6$ & $V p c$ & 9,3 & 11,3 & 9,2 & $A R$ & $\mathrm{C}-10 / \mathrm{N}-4$ & Vpc & 11,4 & 12,1 & 11,6 \\
\hline PA02 & S-R/C-6 & $\mathrm{Vpc}$ & 9 & 9,5 & 6,2 & AR & $\mathrm{S}-5 / \mathrm{C}-4 / \mathrm{N}-3$ & Vpc & 12,9 & 14 & 11,4 \\
\hline PA02 & S-R/C-6 & $\mathrm{Vpc}$ & 9,3 & 9,9 & 7,8 & $A R$ & $\mathrm{~S}-5 / \mathrm{C}-4 / \mathrm{N}-3$ & Vpc & 14,9 & 16,2 & 16 \\
\hline PA02 & S-R/C-6 & $V p c$ & 8,6 & 10,4 & 8,3 & $A R$ & $\mathrm{~S}-5 / \mathrm{C}-4 / \mathrm{N}-3$ & Vpc & 11,4 & 12,2 & 10,9 \\
\hline PA02 & $S-R / C-6$ & $V p c$ & 9,4 & 9,8 & 8,7 & $A R$ & $\mathrm{~S}-5 / \mathrm{C}-4 / \mathrm{N}-3$ & Vpc & 10,9 & 13,4 & 12,3 \\
\hline PA02 & S-R/C-6 & $\mathrm{Vpc}$ & 10,5 & 11,1 & 9,5 & AR & S-5/C-4/N-3 & Vpc & 9,3 & 10,7 & 8,4 \\
\hline PA02 & $S-R / C-6$ & $\mathrm{Vpc}$ & 9,1 & 10 & 8,2 & $A R$ & $S-5 / C-4 / N-3$ & $\mathrm{Vpc}$ & 13,1 & 14,6 & 11,4 \\
\hline PA02 & $S-R / C-6$ & $\mathrm{Vpc}$ & 9,3 & 10 & 8,6 & AR & S-6/C-5/N-3 & $\mathrm{Vpc}$ & 9,2 & 10,2 & \\
\hline PA02 & $S-R / C-6$ & $\mathrm{Vpc}$ & 10,8 & 11,7 & & $A R$ & S-6/C-5/N-3 & $V p c$ & 10,3 & 11,2 & 10,2 \\
\hline PA02 & $S-R / C-6$ & $\mathrm{Vpc}$ & 9,3 & 10,3 & 8,5 & AR & S-6/C-5/N-3 & Vpc & 13,5 & 13,8 & 11,8 \\
\hline PA02 & S-R/C-6 & Vpc & 10,5 & 10,6 & 6,4 & AR & S-6/C-5/N-3 & Vpc & 12,4 & 12,2 & 13,1 \\
\hline PA02 & $S-R / C-6$ & $\mathrm{Vpc}$ & 8,9 & 9,1 & 5,5 & $A R$ & S-6/C-5/N-3 & $\mathrm{Vpc}$ & 10,9 & 11,1 & 10,6 \\
\hline PA02 & $S-R / C-6$ & $\mathrm{Vpc}$ & 8,5 & 9,3 & 7,9 & $A R$ & S-6/C-5/N-3 & $V p c$ & 9 & 10,1 & 4,5 \\
\hline PA02 & $S-R / C-6$ & $\mathrm{Vpc}$ & 10,9 & 12,2 & 12,2 & AR & S-6/C-5/N-3 & $V p c$ & 10 & 10,6 & 7,6 \\
\hline $\mathrm{AR}$ & S-6/C-5/N-3 & $\mathrm{Vpc}$ & 13 & 13,9 & 10,6 & AR & $\mathrm{S}-7 / \mathrm{C}-8 / \mathrm{N}-3$ & Vpc & 10,2 & 11,4 & 8,7 \\
\hline$A R$ & S-6/C-5/N-3 & $\mathrm{Vpc}$ & 13,6 & 14,5 & 12,6 & AR & $\mathrm{S}-7 / \mathrm{C}-8 / \mathrm{N}-3$ & $V p c$ & 9,7 & 10,2 & 10 \\
\hline$A R$ & S-6/C-5/N-3 & $\mathrm{Vpc}$ & 14,3 & 14,2 & 13,5 & $A R$ & $\mathrm{~S}-7 / \mathrm{C}-8 / \mathrm{N}-3$ & $V p c$ & 10,9 & 11,7 & 10,2 \\
\hline$A R$ & S-6/C-5/N-3 & $\mathrm{Vpc}$ & 10,9 & 11,7 & 11,4 & AR & $\mathrm{S}-7 / \mathrm{C}-8 / \mathrm{N}-3$ & $V p c$ & 10,3 & 11,8 & \\
\hline$A R$ & S-6/C-5/N-3 & $\mathrm{Vpc}$ & 12,9 & 13,7 & 10,9 & $A R$ & $\mathrm{~S}-7 / \mathrm{C}-8 / \mathrm{N}-3$ & $\mathrm{Vpc}$ & 10 & 10,3 & 7,7 \\
\hline$A R$ & S-6/C-5/N-3 & $\mathrm{Vpc}$ & 10 & 10,1 & 10,7 & $A R$ & $\mathrm{~S}-7 / \mathrm{C}-8 / \mathrm{N}-3$ & $V p c$ & 9,9 & 10,4 & 10,5 \\
\hline$A R$ & $S-6 / C-5 / N-3$ & $V p c$ & 10,9 & 11,6 & 10,7 & $A R$ & $\mathrm{~S}-7 / \mathrm{C}-8 / \mathrm{N}-3$ & Vpc & 9,5 & 11,1 & 9,3 \\
\hline AR & S-6/C-5/N-3 & $\mathrm{Vpc}$ & 10,2 & 11,4 & 10,7 & AR & $\mathrm{S}-7 / \mathrm{C}-8 / \mathrm{N}-3$ & $V p c$ & 10,1 & 11,3 & 11,2 \\
\hline $\mathrm{AR}$ & S-6/C-5/N-3 & $\mathrm{Vpc}$ & 10,3 & 11,7 & 10,2 & AR & $\mathrm{S}-7 / \mathrm{C}-8 / \mathrm{N}-3$ & $V p c$ & 10,4 & 10,9 & 10,9 \\
\hline$A R$ & S-6/C-5/N-3 & $\mathrm{Vpc}$ & 12,7 & 14,6 & 11,6 & AR & $\mathrm{S}-7 / \mathrm{C}-8 / \mathrm{N}-3$ & $V p c$ & 10,2 & 12,3 & 9,3 \\
\hline AR & S-6/C-5/N-3 & $\mathrm{Vpc}$ & 9,2 & 10 & 7,4 & $A R$ & $\mathrm{~S}-7 / \mathrm{C}-8 / \mathrm{N}-3$ & $V p c$ & 10,9 & 13,1 & 10,3 \\
\hline$A R$ & S-6/C-5/N-3 & $\mathrm{Vpc}$ & 13,5 & 14,4 & 11,7 & AR & $\mathrm{S}-7 / \mathrm{C}-8 / \mathrm{N}-3$ & Vpc & 12,3 & 13,7 & 9,1 \\
\hline$A R$ & S-6/C-5/N-3 & $\mathrm{Vpc}$ & 10,9 & 13,1 & & $A R$ & $\mathrm{~S}-7 / \mathrm{C}-8 / \mathrm{N}-3$ & $\mathrm{Vpc}$ & 11 & 11,2 & 10,5 \\
\hline AR & S-6/C-5/N-3 & $\mathrm{Vpc}$ & 13,4 & 13,5 & 10,8 & $A R$ & $\mathrm{~S}-7 / \mathrm{C}-8 / \mathrm{N}-3$ & $V p c$ & 12 & 12 & 12,2 \\
\hline AR & S-6/C-5/N-3 & $\mathrm{Vpc}$ & 13,1 & 14,6 & 11,6 & AR & $\mathrm{S}-7 / \mathrm{C}-8 / \mathrm{N}-3$ & Vpc & 10,2 & 10,4 & 10,9 \\
\hline$A R$ & S-6/C-5/N-3 & $\mathrm{Vpc}$ & 10,5 & 11,7 & 9,8 & $A R$ & $\mathrm{~S}-7 / \mathrm{C}-8 / \mathrm{N}-3$ & Vpc & 9,3 & 10,3 & 8,5 \\
\hline AR & $\mathrm{S}-6 / \mathrm{C}-5 / \mathrm{N}-3$ & $\mathrm{Vpc}$ & 8,9 & 10,1 & 8,3 & AR & $\mathrm{S}-7 / \mathrm{C}-8 / \mathrm{N}-3$ & $V p c$ & 14,4 & 14,9 & 12,9 \\
\hline$A R$ & S-6/C-5/N-3 & $\mathrm{Vpc}$ & 9,4 & 9,7 & 8 & AR & $\mathrm{S}-7 / \mathrm{C}-8 / \mathrm{N}-3$ & Vpc & 10,3 & 11,6 & 9 \\
\hline$A R$ & S-6/C-5/N-3 & Vpc & 9,8 & 9,9 & 9,4 & AR & $\mathrm{S}-7 / \mathrm{C}-8 / \mathrm{N}-3$ & Vpc & 11,1 & 13,5 & 11,3 \\
\hline AR & S-6/C-5/N-3 & $\mathrm{Vpc}$ & 12,4 & 13,9 & 6,8 & AR & $\mathrm{S}-7 / \mathrm{C}-8 / \mathrm{N}-3$ & $V p c$ & 11 & 11,5 & 10,6 \\
\hline$A R$ & S-6/C-5/N-3 & $\mathrm{Vpc}$ & 12,1 & 13,2 & 10,9 & AR & $\mathrm{S}-7 / \mathrm{C}-8 / \mathrm{N}-3$ & $\mathrm{Vpc}$ & 9,9 & 12,3 & 9,2 \\
\hline$A R$ & S-6/C-5/N-3 & $\mathrm{Vpc}$ & 11,1 & 12 & 9 & $A R$ & $\mathrm{~S}-7 / \mathrm{C}-8 / \mathrm{N}-3$ & $V p c$ & 10,8 & 12,4 & 11,5 \\
\hline
\end{tabular}




\begin{tabular}{|c|c|c|c|c|c|c|c|c|c|c|c|}
\hline AR & $\mathrm{S}-6 / \mathrm{C}-5 / \mathrm{N}-3$ & $\mathrm{Vpc}$ & & & 7,9 & AR & S-7/C-8/N-3 & Vpc & 10,5 & 12,5 & 9,6 \\
\hline AR & S-6/C-5/N-3 & $\mathrm{Vpc}$ & 10,3 & 11,4 & 10,6 & AR & S-7/C-8/N-3 & Vpc & 12,1 & 13,2 & 12,8 \\
\hline AR & S-6/C-5/N-3 & $\mathrm{Vpc}$ & 12,9 & 14,9 & 12,4 & $A R$ & $S-7 / C-8 / N-3$ & Vpc & 12,2 & 12,7 & 12,7 \\
\hline$A R$ & $\mathrm{~S}-6 / \mathrm{C}-5 / \mathrm{N}-3$ & $\mathrm{Vpc}$ & 12,1 & 14,1 & 11,2 & $A R$ & $\mathrm{~S}-7 / \mathrm{C}-8 / \mathrm{N}-3$ & Vpc & 11,8 & 12,8 & 11,9 \\
\hline AR & $\mathrm{S}-6 / \mathrm{C}-5 / \mathrm{N}-3$ & $\mathrm{Vpc}$ & 9,3 & 10,5 & 9,4 & AR & S-7/C-8/N-3 & Vpc & 10,9 & 11,9 & 11,9 \\
\hline AR & S-6/C-5/N-3 & $\mathrm{Vpc}$ & 9,9 & 10,6 & 8,6 & AR & $\mathrm{S}-7 / \mathrm{C}-8 / \mathrm{N}-3$ & Vpc & 10,9 & 12 & 11,7 \\
\hline AR & $\mathrm{S}-6 / \mathrm{C}-5 / \mathrm{N}-3$ & $\mathrm{Vpc}$ & 9,6 & 11,4 & 5,8 & AR & S-7/C-8/N-3 & Vpc & 11,6 & 12,9 & 12,3 \\
\hline AR & S-6/C-5/N-3 & $\mathrm{Vpc}$ & 8,9 & 10,3 & 4,4 & AR & $S-7 / C-8 / N-3$ & Vpc & 11,9 & 12,4 & 12,2 \\
\hline AR & $\mathrm{S}-7 / \mathrm{C}-8 / \mathrm{N}-3$ & $\mathrm{Vpc}$ & 10,1 & 10,1 & 10,4 & AR & $\mathrm{S}-7 / \mathrm{C}-8 / \mathrm{N}-3$ & Vpc & 11 & 11,3 & \\
\hline AR & $\mathrm{S}-7 / \mathrm{C}-8 / \mathrm{N}-3$ & $\mathrm{Vpc}$ & 10,3 & 11,6 & 8,2 & AR & S-7/C-8/N-3 & Vpc & 9,6 & 10,1 & 9,8 \\
\hline AR & $\mathrm{S}-7 / \mathrm{C}-8 / \mathrm{N}-3$ & $\mathrm{Vpc}$ & 10 & 10,5 & 8,7 & AR & $\mathrm{S}-7 / \mathrm{C}-8 / \mathrm{N}-3$ & Vpc & 9,7 & 9,6 & 3,5 \\
\hline AR & $\mathrm{S}-7 / \mathrm{C}-8 / \mathrm{N}-3$ & $\mathrm{Vpc}$ & 10,6 & 11,9 & 10,3 & AR & S-7/C-8/N-3 & Vpc & 11,1 & 12,7 & 7,2 \\
\hline$A R$ & $\mathrm{~S}-7 / \mathrm{C}-8 / \mathrm{N}-3$ & $\mathrm{Vpc}$ & 10,4 & 11,6 & 8,9 & $A R$ & $\mathrm{~S}-7 / \mathrm{C}-8 / \mathrm{N}-3$ & Vpc & 9,2 & 12,2 & 5,6 \\
\hline$A R$ & $\mathrm{~S}-7 / \mathrm{C}-8 / \mathrm{N}-3$ & $\mathrm{Vpc}$ & 11,7 & 13 & 12,7 & $A R$ & $S-7 / C-8 / N-3$ & Vpc & 10,4 & 10,7 & 10,9 \\
\hline$A R$ & $\mathrm{~S}-7 / \mathrm{C}-8 / \mathrm{N}-3$ & $\mathrm{Vpc}$ & 12,4 & 14,2 & 12 & AR & $\mathrm{S}-7 / \mathrm{C}-8 / \mathrm{N}-3$ & $\mathrm{Vpc}$ & 10,2 & 11,6 & 11,1 \\
\hline$A R$ & $\mathrm{~S}-7 / \mathrm{C}-8 / \mathrm{N}-3$ & $\mathrm{Vpc}$ & 12,9 & 14,6 & 11,7 & $A R$ & S-7/C-8/N-3 & Vpc & 9,9 & 11,8 & 9,7 \\
\hline$A R$ & $\mathrm{~S}-7 / \mathrm{C}-8 / \mathrm{N}-3$ & $\mathrm{Vpc}$ & 13,1 & 14 & 11,8 & AR & S-7/C-8/N-3 & Vpc & 9,4 & 10,6 & 9,4 \\
\hline$A R$ & $\mathrm{~S}-7 / \mathrm{C}-8 / \mathrm{N}-3$ & $\mathrm{Vpc}$ & 9,7 & 12,3 & 6,2 & AR & S-7/C-8/N-3 & Vpc & 9,7 & 11,2 & 8,7 \\
\hline$A R$ & $\mathrm{~S}-7 / \mathrm{C}-8 / \mathrm{N}-3$ & $\mathrm{Vpc}$ & 8,1 & 9,2 & 3,4 & AR & S-7/C-8/N-3 & Vpc & 10,4 & 12 & 10,3 \\
\hline$A R$ & $\mathrm{~S}-7 / \mathrm{C}-8 / \mathrm{N}-3$ & $\mathrm{Vpc}$ & 9,7 & 10,6 & 4,2 & AR & $\mathrm{S}-7 / \mathrm{C}-8 / \mathrm{N}-3$ & Vpc & 11 & 11,6 & 11,2 \\
\hline$A R$ & S-7/C-8/N-3 & $\mathrm{Vpc}$ & 10 & 10,6 & 4,4 & AR & S-7/C-8/N-3 & Vpc & 9,7 & 10,4 & 8,5 \\
\hline$A R$ & $\mathrm{~S}-7 / \mathrm{C}-8 / \mathrm{N}-3$ & $\mathrm{Vpc}$ & 9,8 & 10,3 & 9,8 & AR & $\mathrm{S}-7 / \mathrm{C}-8 / \mathrm{N}-3$ & Vpc & 10,9 & 11,8 & 10,4 \\
\hline$A R$ & $\mathrm{~S}-7 / \mathrm{C}-8 / \mathrm{N}-3$ & $\mathrm{Vpc}$ & 9,6 & 10,6 & 9,2 & $A R$ & S-7/C-8/N-3 & Vpc & 10,7 & 11,8 & 10 \\
\hline$A R$ & $\mathrm{~S}-7 / \mathrm{C}-8 / \mathrm{N}-3$ & $\mathrm{Vpc}$ & 10,4 & 10,4 & 9,5 & $A R$ & S-7/C-8/N-3 & Vpc & 11,3 & 13,1 & 12,1 \\
\hline$A R$ & $\mathrm{~S}-7 / \mathrm{C}-8 / \mathrm{N}-3$ & $\mathrm{Vpc}$ & 10,8 & 11,3 & 9,9 & $A R$ & S-7/C-8/N-3 & Vpc & 10,9 & 12,9 & 10,2 \\
\hline$A R$ & $\mathrm{~S}-7 / \mathrm{C}-8 / \mathrm{N}-3$ & $\mathrm{Vpc}$ & 10,6 & 12,6 & 10,6 & AR & S-7/C-8/N-3 & Vpc & 10,4 & 12,1 & 6,7 \\
\hline$A R$ & $\mathrm{~S}-7 / \mathrm{C}-8 / \mathrm{N}-3$ & $\mathrm{Vpc}$ & 10,8 & 11,8 & 11 & $A R$ & S-7/C-8/N-3 & Vpc & 11 & 13,3 & 7,3 \\
\hline$A R$ & $\mathrm{~S}-7 / \mathrm{C}-8 / \mathrm{N}-3$ & $\mathrm{Vpc}$ & 10,8 & 11,8 & 11,1 & AR & S-7/C-8/N-3 & Vpc & 10,2 & 11,9 & 10,2 \\
\hline$A R$ & $\mathrm{~S}-7 / \mathrm{C}-8 / \mathrm{N}-3$ & $\mathrm{Vpc}$ & 10,2 & 12,2 & 5 & TA & S2/Conchero 5/C1 & Vpc & 13,7 & 12,8 & 13,5 \\
\hline$A R$ & $\mathrm{~S}-7 / \mathrm{C}-8 / \mathrm{N}-3$ & $\mathrm{Vpc}$ & 10 & 11,7 & 7,8 & TA & S2/Conchero 5/C2 & Vpc & 13,2 & 12,6 & 11,9 \\
\hline$A R$ & $\mathrm{~S}-7 / \mathrm{C}-8 / \mathrm{N}-3$ & $\mathrm{Vpc}$ & 10,2 & 12,8 & 9,1 & TA & S2/Conchero 5/C2 & Vpc & 14,9 & 11,8 & 10,7 \\
\hline$A R$ & $\mathrm{~S}-7 / \mathrm{C}-8 / \mathrm{N}-3$ & $\mathrm{Vpc}$ & 10,7 & 12,3 & 8 & TA & S2/Conchero 5/C2 & Vpc & 13,6 & & 8,4 \\
\hline$A R$ & $\mathrm{~S}-7 / \mathrm{C}-8 / \mathrm{N}-3$ & $\mathrm{Vpc}$ & 10,2 & 11,7 & 7,9 & TA & S2/Conchero 5/C3 & Vpc & 10,8 & 11,6 & 10,1 \\
\hline$A R$ & $\mathrm{~S}-7 / \mathrm{C}-8 / \mathrm{N}-3$ & $\mathrm{Vpc}$ & 11,1 & 13,7 & 9 & TA & S1/Conchero 5b/UE1 & Vpc & 17,9 & 15,1 & \\
\hline$A R$ & $\mathrm{~S}-7 / \mathrm{C}-8 / \mathrm{N}-3$ & $\mathrm{Vpc}$ & 10,1 & 12 & 5,5 & TA & S1/Conchero 5b/UE1 & Vpc & 9,7 & 11,1 & 8,6 \\
\hline$A R$ & $\mathrm{~S}-7 / \mathrm{C}-8 / \mathrm{N}-3$ & $\mathrm{Vpc}$ & 10,9 & 11,7 & 9,2 & TA & S1/Conchero 5b/UE1 & Vpc & 12,8 & 11,4 & 11,9 \\
\hline$A R$ & $\mathrm{~S}-7 / \mathrm{C}-8 / \mathrm{N}-3$ & $\mathrm{Vpc}$ & 10,6 & 11 & 8 & TA & S1/Conchero 5b/UE1 & Vpc & 11,4 & 13,1 & \\
\hline$A R$ & $\mathrm{~S}-7 / \mathrm{C}-8 / \mathrm{N}-3$ & $\mathrm{Vpc}$ & 10,9 & 12,3 & 8,3 & TA & S1/Conchero 5b/UE1 & Vpc & & 13,4 & 10,3 \\
\hline$A R$ & $\mathrm{~S}-7 / \mathrm{C}-8 / \mathrm{N}-3$ & $\mathrm{Vpc}$ & 11,6 & 11,8 & 10,3 & TA & S1/Conchero 5b/UE1 & Vpc & & 17,5 & \\
\hline AR & $\mathrm{S}-7 / \mathrm{C}-8 / \mathrm{N}-3$ & $\mathrm{Vpc}$ & 11,5 & 13,2 & 10,2 & TA & S1/Conchero 5b/UE1 & $\mathrm{Vpc}$ & & & 8,2 \\
\hline$A R$ & $\mathrm{~S}-7 / \mathrm{C}-8 / \mathrm{N}-3$ & $\mathrm{Vpc}$ & 8,9 & 9,3 & 5,8 & TA & S1/Conchero 5b/UE2 & Vpc & 11,9 & 14,4 & 12,2 \\
\hline$A R$ & $\mathrm{~S}-7 / \mathrm{C}-8 / \mathrm{N}-3$ & $\mathrm{Vpc}$ & 11,7 & 12,9 & 12,3 & TA & S1/Conchero 5b/UE2 & Vpc & 13,1 & 12,4 & 12,9 \\
\hline$A R$ & $\mathrm{~S}-7 / \mathrm{C}-8 / \mathrm{N}-3$ & $\mathrm{Vpc}$ & 11,8 & 12,5 & 13 & TA & S1/Conchero 5b/UE2 & Vpc & 11,5 & 11 & 10,4 \\
\hline$A R$ & $\mathrm{~S}-7 / \mathrm{C}-8 / \mathrm{N}-3$ & $\mathrm{Vpc}$ & 10,8 & 12,2 & 11,3 & TA & S1/Conchero 5b/UE2 & Vpc & & & 10,6 \\
\hline$A R$ & $\mathrm{~S}-8 / \mathrm{C}-3 / \mathrm{N}-2$ & $\mathrm{Vpc}$ & 11 & 12 & 10,2 & TA & S1/Conchero 5b/UE2 & Vpc & & 10,8 & 8,5 \\
\hline
\end{tabular}




\begin{tabular}{|c|c|c|c|c|c|c|c|c|c|c|c|}
\hline$A R$ & S-8/C-4/N-2 & $\mathrm{Vpc}$ & 9,4 & 9,9 & 7,4 & TA & S1/Conchero 3/1R & Vpc & 10,1 & 12,5 & 5,7 \\
\hline$A R$ & $\mathrm{~S}-8 / \mathrm{C}-4 / \mathrm{N}-2$ & Vpc & 11 & 10,9 & 10,7 & TA & S1/Conchero 3/1R & Vpc & 10,7 & & 4,1 \\
\hline AR & $\mathrm{S}-8 / \mathrm{C}-4 / \mathrm{N}-2$ & Vpc & 12,4 & 13 & 10,7 & TA & S1/Conchero 3/1R & Vpc & 10,7 & 11,3 & 5,1 \\
\hline$A R$ & $\mathrm{~S}-8 / \mathrm{C}-4 / \mathrm{N}-2$ & Vpc & 13 & 14,8 & 16,5 & TA & S1/Conchero 3/1R & Vpc & 10,9 & 11,3 & 9 \\
\hline$A R$ & $\mathrm{~S}-8 / \mathrm{C}-4 / \mathrm{N}-3$ & Vpc & & & 8,6 & TA & S1/Conchero 3/1R & Vpc & & 13,2 & \\
\hline TA & S1/Conchero 3/UE1 & Vpc & 13,2 & 13,8 & 11,9 & TA & S1/Conchero 3/1R & Vpc & 10,5 & 11 & 8 \\
\hline TA & S1/Conchero 3/UE1 & Vpc & 12,6 & 13,4 & 12,2 & TA & S1/Conchero 3/1R & Vpc & & & 8,6 \\
\hline TA & S1/Conchero 3/UE1 & Vpc & 13,3 & 15,8 & 12,1 & TA & S1/Conchero 3/UE2 & Vpc & 13,5 & 14,7 & 12,4 \\
\hline TA & S1/Conchero 3/UE1 & Vpc & 12 & 12,1 & 12 & TA & S1/Conchero 3/UE2 & Vpc & 12,5 & 13,4 & \\
\hline TA & S1/Conchero 3/UE1 & Vpc & 12,7 & 13,1 & 10,4 & TA & S1/Conchero 3/UE2 & Vpc & 12,6 & 13,7 & \\
\hline TA & S1/Conchero 3/UE1 & $\mathrm{Vpc}$ & 13,9 & 15,5 & 13,8 & TA & S1/Conchero 3/UE2 & Vpc & 11,3 & 12 & 10,5 \\
\hline TA & S1/Conchero 3/UE1 & Vpc & 12,2 & 13,8 & 12,2 & TA & S1/Conchero 3/UE2 & Vpc & 11,1 & 13 & 9,1 \\
\hline TA & S1/Conchero 3/UE1 & $\mathrm{Vpc}$ & & & 9,7 & TA & S1/Conchero 3/UE2 & Vpc & 12,1 & 12,2 & 11,5 \\
\hline TA & S1/Conchero 3/UE1 & Vpc & & & 13,1 & TA & S1/Conchero 3/UE2 & Vpc & 13,1 & 14,3 & 11,3 \\
\hline TA & S1/Conchero 3/UE1 & $\mathrm{Vpc}$ & & & 10,9 & TA & S1/Conchero 3/UE2 & Vpc & 11,8 & 12,8 & 11,2 \\
\hline TA & S1/Conchero 3/UE1 & Vpc & & & 10,8 & TA & S1/Conchero 3/UE2 & Vpc & & 15,7 & 11,2 \\
\hline TA & S1/Conchero 3/UE1 & Vpc & 11,4 & 13,5 & 11 & TA & S1/Conchero 3/UE2 & Vpc & 11,2 & 12,9 & 10,5 \\
\hline TA & S1/Conchero 3/UE1 & Vpc & 11,4 & 14,2 & 14,4 & TA & S1/Conchero 3/UE2 & Vpc & 13,6 & 13,2 & 10,3 \\
\hline TA & S1/Conchero 3/UE1 & Vpc & 11,7 & 13,4 & 11,4 & TA & S1/Conchero 3/UE2 & Vpc & 11,9 & 12,4 & 10,6 \\
\hline TA & S1/Conchero 3/UE1 & $\mathrm{Vpc}$ & 12,9 & 14,8 & 13,1 & TA & S1/Conchero 3/UE2 & Vpc & 11,6 & 12,3 & 10,8 \\
\hline TA & S1/Conchero 3/UE1 & Vpc & & & 12,7 & TA & S1/Conchero 3/UE2 & Vpc & 10,3 & 12 & 9,7 \\
\hline TA & S1/Conchero 3/UE1 & Vpc & 13,2 & 14,2 & 11,1 & TA & S1/Conchero 3/UE2 & Vpc & 11,5 & 13,4 & 9,2 \\
\hline TA & S1/Conchero 3/UE1 & Vpc & 11,4 & 12,5 & 11,8 & TA & S1/Conchero 3/UE2 & Vpc & & & 13,3 \\
\hline TA & S1/Conchero 3/UE1 & Vpc & 11,2 & 12,8 & 10,2 & TA & S1/Conchero 3/UE2 & Vpc & 9,8 & 11,6 & 9,9 \\
\hline TA & S1/Conchero 3/UE1 & Vpc & & & 11 & TA & S1/Conchero 3/UE2 & Vpc & & 12 & 10,7 \\
\hline TA & S2/Conchero $1 / 1 \mathrm{R}$ & Vpc & 13,2 & 13,2 & 12,1 & TA & S1/Conchero 3/UE2 & Vpc & & & 12,2 \\
\hline TA & S2/Conchero $1 / 1 \mathrm{R}$ & Vpc & 13 & 12,5 & 13,7 & TA & S1/Conchero 3/UE2 & Vpc & & & 11,1 \\
\hline TA & S2/Conchero 5/C1 & Vpc & 14,8 & 15,7 & 14,5 & TA & S1/Conchero 3/UE2 & Vpc & 11 & 13,7 & 6,2 \\
\hline TA & S2/Conchero 5/C1 & Vpc & 12,8 & 13,1 & 11,5 & TA & S1/Conchero 3/UE2 & Vpc & 13,7 & 14,2 & 11,6 \\
\hline TA & S2/Conchero 5/C1 & Vpc & 12,5 & 13,1 & 11,5 & TA & S1/Conchero 3/UE2 & Vpc & 11,8 & 13,8 & 9,3 \\
\hline TA & S2/Conchero 5/C1 & Vpc & 13,5 & 13,1 & 13,8 & TA & S1/Conchero 3/UE2 & Vpc & 15,8 & 16,3 & 14 \\
\hline TA & S2/Conchero 5/C1 & Vpc & 12,6 & 13,1 & 11,3 & TA & S1/Conchero 3/UE2 & Vpc & & & 9,7 \\
\hline TA & S2/Conchero 5/C1 & Vpc & 13,2 & 10,7 & 8,9 & TA & S1/Conchero 3/UE2 & Vpc & 13,8 & 14,6 & 12,4 \\
\hline TA & S1/Conchero 3/UE2 & Vpc & 12,6 & 14,4 & 12,6 & TA & S1/Conchero 3/UE1 & Vpc & 13,1 & 14,5 & 13,5 \\
\hline TA & S1/Conchero 3/UE2 & Vpc & 11,4 & 13,2 & 11,4 & TA & S1/Conchero 3/UE1 & Vpc & 13,2 & 13,1 & 12,6 \\
\hline TA & S1/Conchero 3/UE2 & Vpc & 13,6 & & 12,9 & TA & S1/Conchero 3/UE1 & Vpc & 14,9 & & 11,9 \\
\hline TA & S1/Conchero 3/UE2 & Vpc & 13,6 & 14,4 & 12,3 & TA & S1/Conchero 3/UE1 & Vpc & 13,2 & 15,8 & 12,9 \\
\hline TA & S1/Conchero 3/UE2 & Vpc & 12,7 & 13,2 & 12,4 & TA & S1/Conchero 3/UE1 & Vpc & 12,2 & 14,7 & 11,4 \\
\hline TA & S1/Conchero 3/UE2 & Vpc & 11,7 & 12 & 9,9 & TA & S1/Conchero 3/UE1 & Vpc & 11,7 & 13,6 & 10,4 \\
\hline TA & S1/Conchero 3/UE2 & Vpc & 11,8 & 14,4 & 11,6 & TA & S1/Conchero 3/UE1 & Vpc & 13,9 & 14,9 & 12,3 \\
\hline TA & S1/Conchero 3/UE2 & Vpc & 11,6 & 14,1 & 11,7 & TA & S1/Conchero 3/UE1 & Vpc & 12,8 & 14,7 & 10,2 \\
\hline TA & S1/Conchero 3/UE2 & $\mathrm{Vpc}$ & 13,6 & 12 & 11,4 & TA & S1/Conchero 3/UE1 & Vpc & 12,2 & 14 & 9,6 \\
\hline TA & S1/Conchero 3/UE2 & Vpc & 12,8 & 12,3 & 13,1 & TA & S1/Conchero 3/UE1 & Vpc & 14 & 15,5 & 13,6 \\
\hline TA & S1/Conchero 3/UE2 & Vpc & 13,6 & 12,5 & 15,1 & TA & S1/Conchero 3/UE1 & Vpc & 11,4 & 12,5 & 8,7 \\
\hline TA & S1/Conchero 3/UE2 & Vpc & 13,3 & 15,7 & 11 & TA & S1/Conchero 3/UE1 & Vpc & 13,3 & 14,5 & 11 \\
\hline
\end{tabular}




\begin{tabular}{|c|c|c|c|c|c|c|c|c|c|c|c|}
\hline TA & S1/Conchero 3/UE2 & Vpc & 11,1 & 14 & 10,8 & TA & S1/Conchero 3/UE1 & Vpc & 14,1 & 15,4 & 14,2 \\
\hline TA & S1/Conchero 3/UE2 & $\mathrm{Vpc}$ & 11,9 & 14,3 & 11,8 & TA & S1/Conchero 3/UE1 & $\mathrm{Vpc}$ & 10,7 & 11,3 & 9,4 \\
\hline TA & S1/Conchero 3/UE2 & $\mathrm{Vpc}$ & 9,9 & 11,3 & 8,4 & TA & S1/Conchero 3/UE1 & $V p c$ & 12,3 & 13,6 & 7,7 \\
\hline TA & S1/Conchero 3/UE2 & $\mathrm{Vpc}$ & 11,5 & 11,6 & 9,8 & TA & S1/Conchero 3/UE1 & Vpc & 13,7 & 16,3 & 10,6 \\
\hline TA & S1/Conchero 3/UE2 & Vpc & 13,6 & 14,4 & 10 & TA & S1/Conchero 3/UE1 & Vpc & 12,4 & 12,6 & 11,8 \\
\hline TA & S1/Conchero 3/UE2 & $\mathrm{Vpc}$ & 11,8 & & 11,6 & TA & S1/Conchero 3/UE1 & Vpc & & & 12,8 \\
\hline TA & S1/Conchero 3/UE2 & $\mathrm{Vpc}$ & 10,1 & 12,3 & 8,7 & TA & S1/Conchero 3/UE1 & $\mathrm{Vpc}$ & & & 11,4 \\
\hline TA & S1/Conchero 3/UE2 & $\mathrm{Vpc}$ & 11,2 & 12,8 & 8,9 & TA & S1/Conchero 3/UE1 & Vpc & & 9,6 & 8,8 \\
\hline TA & S1/Conchero 3/UE2 & $\mathrm{Vpc}$ & 11,1 & 12,1 & 9,7 & TA & S1/Conchero 3/UE1 & Vpc & 13 & 15,7 & 12,7 \\
\hline TA & S1/Conchero 3/UE2 & Vpc & 13,2 & 13,6 & 11,9 & TA & S1/Conchero 3/UE1 & Vpc & 14,2 & 15,7 & 14,7 \\
\hline TA & S1/Conchero 3/UE2 & Vpc & 10,5 & 11,4 & 10,6 & TA & S1/Conchero 3/UE1 & Vpc & 14,2 & 14,5 & 13,5 \\
\hline TA & S1/Conchero 3/UE2 & Vpc & 15,1 & 16,2 & 14,4 & TA & S1/Conchero 3/UE1 & Vpc & 13,6 & 15,5 & 12,6 \\
\hline TA & S1/Conchero 3/UE2 & $\mathrm{Vpc}$ & 11,9 & 13,8 & 9,3 & TA & S1/Conchero 3/UE1 & Vpc & 12,1 & 14,7 & 11,6 \\
\hline TA & S1/Conchero 3/UE2 & Vpc & 10,9 & 12,6 & 10,7 & TA & S1/Conchero 3/UE1 & Vpc & 12,8 & 14,9 & 8,5 \\
\hline TA & S1/Conchero 3/UE1 & $\mathrm{Vpc}$ & 11,7 & 13,6 & 11,5 & TA & S1/Conchero 3/UE1 & Vpc & 12,6 & 13,6 & 12,2 \\
\hline TA & S1/Conchero 3/UE1 & $\mathrm{Vpc}$ & 15,2 & 16,7 & 13,6 & TA & S1/Conchero 3/UE1 & Vpc & 11,9 & 13,6 & \\
\hline TA & S1/Conchero 3/UE1 & $\mathrm{Vpc}$ & 15,6 & 16,3 & 14,1 & TA & S1/Conchero 3/UE1 & Vpc & 12 & 12,1 & 10,7 \\
\hline TA & S1/Conchero 3/UE1 & $\mathrm{Vpc}$ & & & 13,6 & TA & S1/Conchero 3/UE1 & Vpc & 14,1 & 15,3 & 14,7 \\
\hline TA & S1/Conchero 3/UE1 & $\mathrm{Vpc}$ & 13,4 & 14,7 & 14,5 & TA & S1/Conchero 3/UE1 & Vpc & 14,1 & 14,7 & 13,2 \\
\hline TA & S1/Conchero 3/UE1 & Vpc & 13,8 & 14,8 & 13,9 & TA & S1/Conchero 3/UE1 & Vpc & 11,5 & 11,9 & 10,8 \\
\hline TA & S1/Conchero 3/UE1 & $\mathrm{Vpc}$ & 14 & 13,1 & 12,7 & TA & S1/Conchero 3/UE1 & Vpc & 11,5 & 12,5 & \\
\hline TA & S1/Conchero 3/UE1 & Vpc & 14,1 & 14,4 & 10,5 & TA & S1/Conchero 3/UE1 & Vpc & 14,3 & 14,8 & 12 \\
\hline TA & S1/Conchero 3/UE1 & $\mathrm{Vpc}$ & 14,1 & 13,9 & 13,6 & TA & S1/Conchero 3/UE1 & Vpc & 12,9 & 14,4 & 12,3 \\
\hline TA & S1/Conchero 3/UE1 & $\mathrm{Vpc}$ & 14,5 & 14,9 & 13,6 & TA & S1/Conchero 3/UE1 & Vpc & 12,2 & 14 & 12,9 \\
\hline TA & S1/Conchero 3/UE1 & $\mathrm{Vpc}$ & 14,5 & 14,8 & 15 & TA & S1/Conchero 3/UE1 & Vpc & 12,1 & 12,5 & 12 \\
\hline TA & S1/Conchero 3/UE1 & $\mathrm{Vpc}$ & 11,1 & 13,7 & 5,6 & TA & S1/Conchero 3/UE1 & Vpc & 13,7 & 16,9 & 13,5 \\
\hline TA & S1/Conchero 3/UE1 & $\mathrm{Vpc}$ & 12,8 & 15,2 & 7,1 & TA & S1/Conchero 3/UE1 & Vpc & 11 & 12,1 & 10,6 \\
\hline TA & S1/Conchero 3/UE1 & $\mathrm{Vpc}$ & 13 & 14,5 & 6 & TA & S1/Conchero 3/UE1 & Vpc & 13 & 14,9 & 12 \\
\hline TA & S1/Conchero 3/UE1 & $\mathrm{Vpc}$ & 12,4 & 13,6 & 10,8 & TA & S1/Conchero 3/UE1 & $\mathrm{Vpc}$ & 12,1 & 14,3 & 10,9 \\
\hline TA & S1/Conchero 3/UE1 & $\mathrm{Vpc}$ & 14 & 14,7 & 12,8 & TA & S1/Conchero 3/UE1 & Vpc & 13 & 14,9 & 10,2 \\
\hline TA & S1/Conchero 3/UE1 & Vpc & 14,5 & 15,7 & 12,1 & TA & S1/Conchero 3/UE1 & $\mathrm{Vpc}$ & 12,7 & 13,3 & 11,9 \\
\hline TA & S1/Conchero 3/UE1 & Vpc & 13,9 & 14 & 12,2 & TA & S1/Conchero 3/UE1 & Vpc & 10,6 & 11,9 & 9,4 \\
\hline TA & S1/Conchero 3/UE1 & Vpc & 12,5 & 13,8 & 12,9 & TA & S1/Conchero 3/UE1 & Vpc & 13,3 & 15,1 & 7,4 \\
\hline TA & S1/Conchero 3/UE1 & $\mathrm{Vpc}$ & 15,4 & 15,7 & 14,6 & TA & S1/Conchero 3/UE1 & Vpc & 10,7 & 12,9 & 10,4 \\
\hline TA & S1/Conchero 3/UE1 & $\mathrm{Vpc}$ & 12,5 & 15,2 & 10,7 & TA & S1/Conchero 5/UE1 & Vpc & 11,3 & 12,6 & 10,3 \\
\hline TA & S1/Conchero 3/UE1 & Vpc & 15,6 & 17,3 & 13,1 & TA & S1/Conchero 5/UE2 & Vpc & 12,6 & 15 & 10,2 \\
\hline TA & S1/Conchero 3/UE1 & Vpc & 15,4 & 16,1 & 14 & TA & S1/Conchero 5/UE2 & Vpc & & & 9,5 \\
\hline TA & S1/Conchero 3/UE1 & $\mathrm{Vpc}$ & 15,5 & 15,9 & 16 & MO & MU040712I01/03 & Vpc & & & 8,5 \\
\hline PA02 & $\mathrm{S}-2 / \mathrm{N}-2 / \mathrm{C}-3$ & Vca & & 12,4 & 14,5 & AR & S-7/C-8/N-3 & Vca & 12,6 & 14,5 & 17 \\
\hline PA02 & $\mathrm{S}-2 / \mathrm{N}-2 / \mathrm{C}-3$ & Vca & 11 & 12,6 & 15 & TA & S1/Conchero 3/UE1 & Vca & 11,5 & 14,6 & 17,2 \\
\hline PA02 & $\mathrm{S}-5 / \mathrm{N}-2 / \mathrm{C}-4$ & Vca & 9 & 9,4 & 12,9 & TA & S1/Conchero 3/UE1 & Vca & 10,9 & 11,5 & 10,5 \\
\hline PA02 & $S-5 / N-2 / C-4$ & Vca & 10,5 & 11,5 & 9,5 & TA & S1/Conchero 3/UE1 & Vca & 10,5 & 11,4 & \\
\hline PA02 & S-D/C-5 & Vca & 10,6 & 11,8 & 9,3 & TA & S1/Conchero 3/UE1 & Vca & 10,9 & 13,8 & 16,4 \\
\hline PA02 & $S-D / C-5$ & Vca & 9,6 & 10 & 8,9 & TA & S1/Conchero 3/UE1 & Vca & 10,4 & 10,8 & \\
\hline PA02 & S-D/C-5 & Vca & 12,8 & & 10,7 & TA & S1/Conchero 3/UE1 & Vca & 10,8 & 10,5 & \\
\hline
\end{tabular}




\begin{tabular}{|c|c|c|c|c|c|c|c|c|c|c|c|}
\hline PA02 & S-D/C-5 & Vca & 9,6 & 10,9 & & TA & S2/Conchero 5/C2 & Vca & 9,6 & 9,6 & 9,1 \\
\hline PA02 & S-D/C-5 & Vca & 8,4 & 9,5 & 8,6 & TA & S1/Conchero 5b/UE1 & Vca & 11,6 & & 14,8 \\
\hline PA02 & S-D/C-5 & Vca & 11,2 & & 9,8 & TA & S1/Conchero 3/UE2 & Vca & 11,6 & 13,4 & 11,8 \\
\hline PA02 & S-G/C-3 & Vca & 9,5 & 10 & 10,3 & TA & S2/Conchero $1 / 1 \mathrm{R}$ & Vca & 11,8 & 12,1 & 10,6 \\
\hline PA02 & $\mathrm{S}-1 / \mathrm{C}-3$ & Vca & & & 10,7 & TA & S2/Conchero 5/2R & Vca & 7,5 & 8,4 & 8 \\
\hline PA02 & $\mathrm{S}-\mathrm{O} / \mathrm{C}-2$ & Vca & 10,8 & 11,8 & 9,1 & ON & UE31 & Vca & 15 & 16,5 & \\
\hline PA02 & $\mathrm{S}-\mathrm{O} / \mathrm{C}-2$ & Vca & 10,6 & 12,2 & 9,8 & MO & MU040712101/03 & Vca & & & 2,3 \\
\hline PA02 & $\mathrm{S}-\mathrm{R} / \mathrm{C}-7$ & Vca & 11,3 & 12,1 & 10,5 & MO & 2004/C2/UE502 & Vca & 10 & 11,2 & 7,9 \\
\hline$A R$ & $\mathrm{~S}-6 / \mathrm{C}-5 / \mathrm{N}-3$ & Vca & 9,7 & 9,8 & 12,3 & MV & Muestra 1 & Vca & 3 & 2,7 & 4,8 \\
\hline$A R$ & $\mathrm{~S}-7 / \mathrm{C}-8 / \mathrm{N}-3$ & Vca & 9,4 & 10 & & RF & 2004/C2/UE502 & Vca & 10 & 11,2 & 7,9 \\
\hline
\end{tabular}

\section{Pollachius Pollachius}

\begin{tabular}{|c|c|c|c|c|c|c|c|c|c|c|c|c|c|}
\hline Yac. & Referencia & $D / S$ & Tipo & M1 & M2 & M3 & Yac. & Referencia & $D / S$ & Tipo & M1 & M2 & M3 \\
\hline PAC & C-1 & $\mathrm{D}$ & $\mathrm{Cdr}$ & & 7,5 & & PAC & $C-2$ & & $\mathrm{Vpc}$ & 10,8 & 13,7 & 10 \\
\hline PAC & B-1 & D & Dnt & & 7,1 & & PAC & $C-2$ & & $\mathrm{Vpc}$ & & & 7,6 \\
\hline PAC & $\mathrm{S}-1 / \mathrm{N}-2 / \mathrm{C}-5$ & S & Dnt & & & 6,9 & PAC & $\mathrm{S}-1 / \mathrm{N}-2 / \mathrm{C}-5$ & & $\mathrm{Vpc}$ & 7,5 & & 7,5 \\
\hline PAC & $\mathrm{C}-2$ & $S$ & Dnt & & & 3,5 & PA02 & S-G/C-3 & & $\mathrm{Vpc}$ & 12,8 & 15,1 & 9,8 \\
\hline PA02 & $\mathrm{S}-\mathrm{H} / \mathrm{C}-2$ & D & Dnt & & 11,1 & & PAC & C-1 & & Vca & 7,6 & 7,6 & 7,6 \\
\hline PAC & B-1 & & Oto & & 6,7 & & PAC & $\mathrm{C}-2$ & & Vca & 12 & 14,4 & 11 \\
\hline PAC & $\mathrm{S}-2 / \mathrm{N}-2 / \mathrm{C}-5$ & D & Pmx & & 11,5 & 13,1 & PAC & $\mathrm{S}-1 / \mathrm{N}-2 / \mathrm{C}-5$ & & Vca & 7,4 & 9,4 & 6,6 \\
\hline AR & S-6/C-5/N-3 & $\mathrm{D}$ & Max & & 9,3 & & PAC & B-1 & & Vca & 8,2 & 8,6 & 8,2 \\
\hline PAC & A-1 & & $\mathrm{Vpc}$ & & & 6,5 & PAC & $\mathrm{S}-1 / \mathrm{N}-2 / \mathrm{C}-5$ & & Vca & 10,9 & 11,9 & 10,3 \\
\hline PAC & $A-1$ & & $\mathrm{Vpc}$ & 8,1 & 9,3 & 8,5 & PAC & $A-2$ & & Vca & 5,6 & 6,1 & 6,9 \\
\hline
\end{tabular}

\section{Trisopterus luscus}

\begin{tabular}{|c|c|c|c|c|c|c|c|c|c|c|c|c|c|}
\hline Yac. & Referencia & $D / S$ & Tipo & M1 & M2 & M3 & Yac. & Referencia & $\mathrm{D} / \mathrm{S}$ & Tipo & M1 & M2 & M3 \\
\hline TA & S1/Conchero 9/1R & D & Max & & 2,4 & & TA & S2/Conchero 5/1R & & $\mathrm{Vpc}$ & 3,5 & 3,3 & 2,2 \\
\hline TA & S2/Conchero 1/1R & $S$ & Pmx & & & 5,2 & MO & MU040510J01/01 & & $\mathrm{Vpc}$ & 2,6 & 2,8 & 2,9 \\
\hline TA & S1/Conchero 9/1R & D & Pst & 3,2 & & & MO & MU040510J01/01 & & $\mathrm{Vpc}$ & 2,9 & 2,9 & 3,1 \\
\hline TA & S1/Conchero 9/1R & $S$ & Pst & 2,6 & & & MO & MU040510J01/01 & & $\mathrm{Vpc}$ & 3 & 3,4 & 3,2 \\
\hline MO & MU040510J01/04 & $S$ & Dnt & 14,2 & 10,7 & & MO & MU040510J01/01 & & $\mathrm{Vpc}$ & 3,4 & 3,7 & 4 \\
\hline MO & MU040510J01/01 & $S$ & Eph & 6,5 & 4,1 & & MO & MU040510J01/01 & & $\mathrm{Vpc}$ & 3,1 & 3,1 & 3,4 \\
\hline MO & MU040629B01/01 & & Oto & 9,8 & 4,9 & & MO & MU040510J01/01 & & $\mathrm{Vpc}$ & 3,6 & 3,7 & 3,9 \\
\hline MO & MU040426I01/02 & & Oto & & 4,1 & & MO & MU040510J01/02 & & $\mathrm{Vpc}$ & 3,1 & 2,8 & 3,3 \\
\hline MO & MU040426I01/05 & & Oto & & 3,8 & & MO & MU040510J01/02 & & $\mathrm{Vpc}$ & 3,5 & 3,5 & 4,2 \\
\hline MO & MU040510J01/04 & & Oto & 3,4 & 7,7 & & MO & MU040510J01/02 & & $\mathrm{Vpc}$ & 2,8 & 2,2 & 1,8 \\
\hline MV & Muestra 1 & & Oto & 8,6 & 4,3 & & MO & MU040510J01/03 & & $\mathrm{Vpc}$ & 3,6 & 3,7 & 4,4 \\
\hline MV & Muestra 1 & & Oto & 11,1 & 5,7 & & MO & MU040510J01/03 & & $\mathrm{Vpc}$ & 3 & 3,5 & 3,2 \\
\hline TA & S1/Conchero 9/1R & & $\mathrm{Vpc}$ & 3,3 & 3,2 & 1,8 & MO & MU040510J01/03 & & $\mathrm{Vpc}$ & 2,6 & 2,5 & 2,7 \\
\hline TA & $\mathrm{S} 2 /$ Conchero $1 / 2 \mathrm{R}$ & & $\mathrm{Vpc}$ & 2,7 & 2,8 & 3 & MO & MU040510J01/04 & & $\mathrm{Vpc}$ & 2,7 & 2,4 & 3,2 \\
\hline TA & S2/Conchero 5/1R & & $\mathrm{Vpc}$ & 2,5 & 3,5 & 1,8 & MO & MU040510J01/04 & & $\mathrm{Vpc}$ & 2,8 & 3 & 3,1 \\
\hline MO & MU040510J01/04 & & $V p c$ & 2,4 & 2,5 & 2,8 & PAC & $A-1$ & & Vca & 5,2 & 5,6 & \\
\hline MO & MU040510J01/04 & & $\mathrm{Vpc}$ & 3,8 & 4 & 3,6 & TA & S1/Conchero 9/1R & & Vca & 2,5 & 2,1 & 3 \\
\hline
\end{tabular}




\begin{tabular}{|c|c|c|c|c|c|c|c|c|c|c|c|}
\hline MO & MU040510J01/04 & Vpc & 3,2 & 3,1 & 3,5 & TA & S1/Conchero 9/1R & Vca & & & 3 \\
\hline MO & MU040712J02/01 & $\mathrm{Vpc}$ & 1,8 & 1,8 & & TA & S1/Conchero 9/1R & Vca & & 2,1 & \\
\hline MO & MU040712J02/02 & $\mathrm{Vpc}$ & 2,8 & 2,6 & 3 & TA & S1/Conchero 9/1R & Vca & 2,4 & & \\
\hline MO & MU040426I01/01 & $\mathrm{Vpc}$ & 3,1 & 3,4 & 3,3 & TA & S2/Conchero 5/1R & Vca & 3,1 & 3,1 & 4,3 \\
\hline MO & MU040426I01/01 & $\mathrm{Vpc}$ & 3,4 & 3,8 & 3,7 & TA & S2/Conchero 5/1R & Vca & 2,5 & 2,4 & 2,9 \\
\hline MO & MU040426I01/01 & $\mathrm{Vpc}$ & 2,8 & 2,8 & 3,4 & MO & MU040426I01/03 & Vca & & 2,5 & \\
\hline MO & MU040426I01/02 & $\mathrm{Vpc}$ & 2,9 & 2,9 & 3,4 & MO & MU040510J01/04 & Vca & 2,8 & 2,9 & 3,7 \\
\hline MO & MU040426I01/02 & Vpc & 2,8 & 2,8 & 3,1 & $\mathrm{MO}$ & MU040510J01/01 & Vca & 2,5 & 2,2 & \\
\hline MO & MU040426I01/03 & $\mathrm{Vpc}$ & 2,8 & 3,1 & 3,2 & MO & MU040629B01/02 & Vca & 2,1 & & \\
\hline MO & MU040426I01/03 & $\mathrm{Vpc}$ & 4 & 3,9 & & MO & MU040510J01/03 & Vca & 2,6 & 2,7 & 3,3 \\
\hline MO & MU040426I01/03 & $\mathrm{Vpc}$ & 2,7 & 3,1 & 3,6 & MO & MU040426I01/05 & Vca & 2,5 & 2,7 & 3,6 \\
\hline MO & MU040426I01/04 & $\mathrm{Vpc}$ & 2,9 & 3,2 & 3,3 & MV & Muestra 1 & Vca & 2,8 & 2,7 & \\
\hline MO & MU040426I01/04 & $\mathrm{Vpc}$ & 2,5 & 3,1 & 2,1 & MV & Muestra 1 & Vca & & & 2,4 \\
\hline MO & MU040426I01/05 & $\mathrm{Vpc}$ & 3,4 & 3,6 & 3,8 & MV & Muestra 1 & Vca & 2,3 & 1,9 & 2,9 \\
\hline MO & MU040426I01/06 & $\mathrm{Vpc}$ & 2,9 & 3,4 & 3,7 & MV & Muestra 1 & Vca & & & 3 \\
\hline MO & MU040629B01/03 & $\mathrm{Vpc}$ & 2,6 & 2,7 & 2,8 & MV & Muestra 1 & Vca & 2,1 & 1,9 & 2,9 \\
\hline MO & MU040629B01/03 & $\mathrm{Vpc}$ & 3,1 & 3,4 & 3,3 & MV & Muestra 1 & Vca & 2,1 & 2 & \\
\hline MV & Muestra 1 & $\mathrm{Vpc}$ & 4,3 & 4,6 & 4,7 & MV & Muestra 1 & Vca & 2,4 & 2,1 & 2,8 \\
\hline AL & M100728B01/078 & $\mathrm{Vpc}$ & 4,8 & 4,7 & 4,9 & MV & Muestra 1 & Vca & 3,6 & 3,6 & 4,4 \\
\hline AL & M100813B06/152 & $\mathrm{Vpc}$ & 3,7 & 3,9 & 4,3 & MV & Muestra 1 & Vca & 3,9 & 3,8 & 4,5 \\
\hline$A L$ & M100810b03/078 & Vpc & 3,3 & 3,2 & 3,7 & $A L$ & M100813B06/152 & Vca & 3,3 & 3,6 & 4,1 \\
\hline$A L$ & M100810b03/078 & $\mathrm{Vpc}$ & 4,6 & 5,1 & 5 & $\mathrm{AL}$ & M100831B02/152 & Vca & 3,4 & 3,7 & 4,2 \\
\hline AL & M100831B02/152 & $\mathrm{Vpc}$ & 3,1 & 3,3 & 3,4 & $\mathrm{AL}$ & M100831B02/152 & Vca & 3,5 & 3,6 & 4,2 \\
\hline AL & M100826B01/152-184 & $\mathrm{Vpc}$ & & & 3 & AL & M100826B01/152-184 & Vca & 3,4 & 3,6 & 4,2 \\
\hline AL & M100826B01/152-184 & $\mathrm{Vpc}$ & 4,8 & 5,7 & 2,5 & $A L$ & M100826B01/152-184 & Vca & 3,5 & 3,7 & 4,2 \\
\hline$A L$ & M100826B01/152-184 & $\mathrm{Vpc}$ & 3,8 & 4 & 3,6 & AL & M100826B01/152-184 & Vca & 3,7 & 3,7 & 4,4 \\
\hline AL & M100727B02/078 & Vpc & 4,1 & 4,5 & 4,6 & & & & & & \\
\hline
\end{tabular}

\section{Zeus faber}

\begin{tabular}{|c|c|c|c|c|c|c|c|c|c|c|c|c|c|}
\hline Yac. & Referencia & $D / S$ & Tipo & M1 & M2 & M3 & Yac. & Referencia & $D / S$ & Tipo & M1 & M2 & M3 \\
\hline PA02 & $\mathrm{S}-4 / \mathrm{N}-1 / \mathrm{C}-2$ & $S$ & Pmx & & 86,8 & & $A R$ & $\mathrm{~S}-7 / \mathrm{C}-8 / \mathrm{N}-3$ & D & Max & & 13,3 & \\
\hline AR & $\mathrm{S}-7 / \mathrm{C}-8 / \mathrm{N}-3$ & $S$ & Max & & 12,6 & & AR & $\mathrm{S}-8 / \mathrm{C}-5 / \mathrm{N}-2$ & D & Pop & & 10 & \\
\hline
\end{tabular}

\section{Dicentrarchus labrax}

\begin{tabular}{|c|c|c|c|c|c|c|c|c|c|c|c|c|c|}
\hline Yac. & Referencia & $D / S$ & Tipo & M1 & M2 & M3 & Yac. & Referencia & $D / S$ & Tipo & M1 & M2 & M3 \\
\hline PAC & $A-2$ & & Crh & 8,4 & & & MO & MU040426I01/03 & & Vca & 3,4 & 3,7 & \\
\hline PAC & $A-2$ & S & Max & & 6,9 & & MO & MU040712I01/03 & & Vca & 1,8 & 1,6 & \\
\hline PAC & B-1 & & Oto & 11,9 & 5,4 & & MO & MU040712I01/01 & & Vca & 2,6 & & 3,2 \\
\hline ON & UE 36 & $\mathrm{D}$ & Cdr & 25,8 & 8,4 & 24,4 & MO & MU040712I01/01 & & Vca & 2,2 & 1,8 & \\
\hline MO & MU040426I01/02 & & $\mathrm{Vpc}$ & 5,3 & 5,5 & 6,4 & MO & MU040629B01/02 & & Vca & 4,1 & 4 & 6,3 \\
\hline MO & MU040510J01/04 & & $\mathrm{Vpc}$ & 3,8 & 3,8 & 5,1 & MO & MU040510J01/01 & & Vca & 4,9 & 4,4 & \\
\hline MV & Muestra 1 & & $\mathrm{Vpc}$ & 2,6 & 2,7 & 3,3 & MV & Muestra 1 & & Vca & 3,5 & 3,6 & 4,6 \\
\hline AR & $\mathrm{S}-4 / \mathrm{C}-4 / \mathrm{N}-3$ & & Vca & 9,1 & 10,4 & 12,7 & MV & Muestra 1 & & Vca & 3,2 & & 5 \\
\hline
\end{tabular}




\begin{tabular}{|c|c|c|c|c|c|c|c|c|c|c|}
\hline AR & $S-4 / C-4 / N-3$ & Vca & 9,4 & 11 & 12,7 & MV & Muestra 1 & Vca & 1,5 & 1,5 \\
\hline$A R$ & $\mathrm{~S}-4 / \mathrm{C}-4 / \mathrm{N}-3$ & Vca & 9,6 & 10,7 & 12 & MV & Muestra 1 & Vca & 2,9 & 3,2 \\
\hline AR & $\mathrm{S}-4 / \mathrm{C}-4 / \mathrm{N}-3$ & Vca & & 10,4 & 12,8 & ON & UENEI04058 & Vca & 2 & 2 \\
\hline
\end{tabular}

Trachurus trachurus

\begin{tabular}{|c|c|c|c|c|c|c|c|c|c|c|c|c|c|}
\hline Yac. & Referencia & $D / S$ & Tipo & M1 & M2 & M3 & Yac. & Referencia & $D / S$ & Tipo & M1 & M2 & M3 \\
\hline PA02 & $\mathrm{S}-\mathrm{H} / \mathrm{C}-4$ & S & Cdr & & 1,9 & & PA02 & $\mathrm{S}-\mathrm{H} / \mathrm{C}-3$ & & Vca & 2,5 & 2,2 & 5,4 \\
\hline PA02 & $\mathrm{S}-\mathrm{H} / \mathrm{C}-4$ & $S$ & $\mathrm{Hmd}$ & 4,7 & 5,7 & & PA02 & $\mathrm{S}-\mathrm{H} / \mathrm{C}-3$ & & Vca & & & 5,4 \\
\hline PA02 & S-G/C-5 & S & Pmx & & 5,2 & 2,5 & PA02 & $\mathrm{S}-\mathrm{H} / \mathrm{C}-3$ & & Vca & 2,8 & 2,8 & 5,2 \\
\hline PA02 & S-G/C-5 & $\mathrm{D}$ & Pmx & & 5,3 & 2,5 & PA02 & $\mathrm{S}-\mathrm{H} / \mathrm{C}-3$ & & Vca & & & 3,4 \\
\hline PA02 & S-G/C-5 & $\mathrm{D}$ & Pmx & & 5,8 & 2,7 & PA02 & $\mathrm{S}-\mathrm{H} / \mathrm{C}-3$ & & Vca & & & 3,1 \\
\hline PA02 & $\mathrm{S}-\mathrm{H} / \mathrm{C}-3$ & $\mathrm{D}$ & Pmx & & 6,4 & 3 & PA02 & $\mathrm{S}-\mathrm{H} / \mathrm{C}-3$ & & Vca & 4,6 & 5,5 & \\
\hline PA02 & $\mathrm{S}-\mathrm{H} / \mathrm{C}-3$ & S & Pmx & & 5,9 & 2,2 & $A R$ & $\mathrm{~S}-4 / \mathrm{C}-4 / \mathrm{N}-3$ & & Vca & 5 & 5,5 & 10,9 \\
\hline$A L$ & M100813B06/152 & & Oto & 6,1 & 3,3 & & AR & $\mathrm{S}-4 / \mathrm{C}-4 / \mathrm{N}-3$ & & Vca & 5,2 & 5,4 & 10,8 \\
\hline PAC & B-1 & & Vpc & 3,1 & 3,4 & 6,9 & $A L$ & M100810b03/078 & & Vca & 3,4 & 3,8 & 7,3 \\
\hline PA02 & S-G/C-5 & & $\mathrm{Vpc}$ & 2,7 & 2,7 & 5 & $\mathrm{AL}$ & M100810b03/078 & & Vca & 3,9 & 3,8 & 7,1 \\
\hline PA02 & S-G/C-5 & & $\mathrm{Vpc}$ & 2,1 & & & $A L$ & M100827B07/184 & & Vca & 4,4 & 9,4 & 5,1 \\
\hline PA02 & S-G/C-5 & & $\mathrm{Vpc}$ & 2,3 & 2,2 & 4,5 & $\mathrm{AL}$ & M100827B07/184 & & Vca & 3,8 & 2,5 & \\
\hline PA02 & S-G/C-5 & & $\mathrm{Vpc}$ & 2,1 & 2,2 & 4 & $\mathrm{AL}$ & M100827B07/184 & & Vca & 3,3 & 3,5 & 6,6 \\
\hline PA02 & S-G/C-5 & & $V p c$ & 2,2 & 2,2 & 4,2 & $\mathrm{AL}$ & М100827B07/184 & & Vca & 4 & 4,3 & 8,3 \\
\hline PA02 & S-G/C-5 & & $\mathrm{Vpc}$ & 2,1 & 2,2 & 4,2 & $\mathrm{AL}$ & М100827B07/184 & & Vca & 3,8 & 4,1 & 8,6 \\
\hline PA02 & S-G/C-5 & & Vpc & 2,3 & 2,3 & 4,7 & $\mathrm{AL}$ & M100831B02/152 & & Vca & 6,3 & 7,6 & 11 \\
\hline PA02 & S-G/C-5 & & $\mathrm{Vpc}$ & 2 & 2,1 & 4,4 & $\mathrm{AL}$ & M100810b03/078 & & Vca & 2,9 & 2,8 & 6,3 \\
\hline PA02 & S-G/C-5 & & $\mathrm{Vpc}$ & 1,9 & 1,8 & 2,9 & $\mathrm{AL}$ & M100827B04/184 & & Vca & & & 6,6 \\
\hline PA02 & S-G/C-5 & & Vpc & 2,5 & 2,3 & 3,8 & $\mathrm{AL}$ & M100728B01/078 & & Vca & 3,1 & 3,1 & 6,1 \\
\hline PA02 & $\mathrm{S}-\mathrm{H} / \mathrm{C}-3$ & & $\mathrm{Vpc}$ & 2,1 & 2,1 & 4 & $\mathrm{AL}$ & M100810b03/078 & & Vca & 2,9 & 2,7 & \\
\hline PA02 & $\mathrm{S}-\mathrm{H} / \mathrm{C}-3$ & & Vpc & 1,8 & 1,8 & 3,3 & $\mathrm{AL}$ & M100827B04/184 & & Vca & 3,3 & 3,3 & 6,3 \\
\hline PA02 & $\mathrm{S}-\mathrm{H} / \mathrm{C}-3$ & & $\mathrm{Vpc}$ & 2,4 & 2,4 & 4,4 & $A L$ & M100810b03/078 & & Vca & 3,5 & 3,8 & 6,8 \\
\hline AL & M100827B04/184 & & Vpc & 3,3 & 3,2 & 6 & $\mathrm{AL}$ & M100728B01/078 & & Vca & 2,4 & 2,4 & 4,7 \\
\hline AL & M100827B04/184 & & $\mathrm{Vpc}$ & 2,9 & 3,1 & & $\mathrm{AL}$ & M100810b03/078 & & Vca & 2,4 & 2,5 & 4,8 \\
\hline $\mathrm{AL}$ & M100810b03/078 & & Vpc & 2,9 & 3,1 & 5,5 & $\mathrm{AL}$ & M100810b03/078 & & Vca & 2,5 & 2,5 & 5 \\
\hline $\mathrm{AL}$ & M100810b03/078 & & $\mathrm{Vpc}$ & & & 4,1 & $\mathrm{AL}$ & M100810b03/078 & & Vca & 3 & 3,1 & 5,8 \\
\hline $\mathrm{AL}$ & M100810b03/078 & & $\mathrm{Vpc}$ & 2,8 & 3,1 & 5,4 & $\mathrm{AL}$ & M100810b03/078 & & Vca & 3,2 & 3,4 & 6,1 \\
\hline AL & M100810b03/078 & & $\mathrm{Vpc}$ & 2,9 & 3,2 & 5,3 & $A L$ & M100810b03/078 & & Vca & 3,7 & 4,3 & 7,4 \\
\hline $\mathrm{AL}$ & M100810b03/078 & & $\mathrm{Vpc}$ & 3,1 & 3,1 & 5,5 & $\mathrm{AL}$ & M100810b03/078 & & Vca & 3,4 & 3,5 & 5,6 \\
\hline $\mathrm{AL}$ & M100810b03/078 & & Vpc & 2,9 & 3,2 & 5,1 & $\mathrm{AL}$ & M100810b03/078 & & Vca & 2,3 & 2,5 & 4,5 \\
\hline AL & M100810b03/078 & & $\mathrm{Vpc}$ & 2,8 & 3,2 & 5,5 & $A L$ & M100810b03/078 & & Vca & 2,9 & 2,7 & 5,9 \\
\hline PAC & A-2 & & Vca & 3,5 & & & AL & M100810b03/078 & & Vca & 2,5 & & \\
\hline PAC & $A-2$ & & Vca & 3,7 & 3,8 & & $A L$ & M100728B01/078 & & Vca & 3,9 & 3,6 & \\
\hline PAC & $A-1$ & & Vca & 4,7 & 4 & 2,8 & $\mathrm{AL}$ & M100813B06/152 & & Vca & 4,4 & & 7,9 \\
\hline PAC & $A-1$ & & Vca & 3,6 & 3,7 & 7,2 & $\mathrm{AL}$ & М100827B04/184 & & Vca & 3,2 & & \\
\hline PAC & $A-1$ & & Vca & 4,1 & 4,6 & 8,3 & $A L$ & М100827B04/184 & & Vca & 2,9 & 2,8 & \\
\hline PAC & B-1 & & Vca & 4 & 4 & 7,2 & $\mathrm{AL}$ & M100827B04/184 & & Vca & & & 6 \\
\hline PAC & B-1 & & Vca & 4,9 & 4,8 & & $A L$ & M100810b03/078 & & Vca & 2,7 & 2,7 & 5,1 \\
\hline
\end{tabular}




\begin{tabular}{|c|c|c|c|c|c|c|c|c|c|c|c|}
\hline PAC & B-1 & Vca & 4,9 & 4,8 & & $\mathrm{AL}$ & M100827B04/184 & Vca & & & 6,4 \\
\hline PA02 & $S-R / C-3$ & Vca & 3,2 & 3,6 & 7,1 & $A L$ & M100810b03/078 & Vca & 2,3 & 2,5 & 4,6 \\
\hline PA02 & $S-D / C-5$ & Vca & 2,1 & 2,1 & 2,4 & AL & M100827B04/184 & Vca & & & 5,8 \\
\hline PA02 & $\mathrm{S}-\mathrm{H} / \mathrm{C}-3$ & Vca & 4,4 & 4,5 & 8,4 & $A L$ & M100827B04/184 & Vca & 3,4 & 3,6 & 6,8 \\
\hline PA02 & $\mathrm{S}-\mathrm{H} / \mathrm{C}-3$ & Vca & 4,2 & 4,4 & & $A L$ & M100827B04/184 & Vca & & & 4,8 \\
\hline PA02 & S-G/C-5 & Vca & 2,1 & 2,2 & 4,6 & $A L$ & M100827B04/184 & Vca & 3,3 & 3,2 & 7,3 \\
\hline PA02 & S-G/C-5 & Vca & 2,8 & 2,4 & 4,8 & $A L$ & M100827B04/184 & Vca & 3,6 & 3,4 & 6,3 \\
\hline
\end{tabular}

\section{Sparus aurata}

\begin{tabular}{|c|c|c|c|c|c|c|c|c|c|c|c|c|c|}
\hline Yac. & Referencia & $D / S$ & Tipo & M1 & M2 & M3 & Yac. & Referencia & $D / S$ & Tipo & M1 & M2 & M3 \\
\hline PAC & B-1 & & Oto & 6,9 & 3,7 & & MO & MU040629B01/03 & & Vca & 2,5 & 2,4 & 4,2 \\
\hline PA02 & S-Ñ/C-2 & & Pal & 18,9 & 4,3 & & MO & MU040510J01/02 & & Vca & 2,6 & 3,2 & 4,5 \\
\hline MO & MU040510J01/01 & & Vpc & 7,1 & 6,7 & 9,2 & MO & MU040426I01/04 & & Vca & 6,9 & 6,3 & 9,2 \\
\hline PAC & B-1 & & Vca & 4,8 & 4,8 & 6,4 & & & & & & & \\
\hline
\end{tabular}

\section{Pagrus pagrus}

\begin{tabular}{|c|c|c|c|c|c|c|c|c|c|c|c|c|c|}
\hline Yac. & Referencia & $\mathrm{D} / \mathrm{S}$ & Tipo & M1 & M2 & M3 & Yac. & Referencia & $\mathrm{D} / \mathrm{S}$ & Tipo & M1 & M2 & M3 \\
\hline PAC & S-1/N-2/C-5 & S & Art & 29,8 & & & PAC & B-1 & & $\mathrm{Vpc}$ & & & 2,7 \\
\hline $\mathrm{AL}$ & M100722B02/078 & $S$ & Art & & & 6,7 & PAC & $A-2$ & & $\mathrm{Vpc}$ & 6,4 & 6,3 & 9,4 \\
\hline PAC & $C-2$ & $S$ & $\mathrm{Cdr}$ & & 3,9 & & PA02 & $S-R / C-3$ & & $\mathrm{Vpc}$ & 9 & 9,1 & \\
\hline PAC & $B-2$ & $S$ & $\mathrm{Hmd}$ & 10,5 & 8,8 & & $\mathrm{AL}$ & MU100630B02/16 & & Vpc & 6,8 & 7,1 & 7,8 \\
\hline PAC & $S-1 / N-2 / C-5$ & D & Max & & 11,9 & & PAC & B-2 & & Vca & 4,1 & 4,2 & 6,3 \\
\hline AL & M100722B02/078 & $S$ & Max & & 19,3 & & PAC & B-2 & & Vca & 5,2 & 4,7 & 7,4 \\
\hline AL & M100827B07/184 & D & Max & & 6,7 & & PAC & $A-2$ & & Vca & 4,9 & 5,2 & 8,1 \\
\hline PAC & B-1 & & Oto & 6,9 & 3,7 & & PAC & C-1 & & Vca & 6,1 & 6,3 & 8,8 \\
\hline PAC & $A-2$ & D & Pal & 16 & 3,1 & & PAC & B-1 & & Vca & 4,8 & 4,8 & 6,4 \\
\hline PAC & B-1 & & Pal & 11,5 & 2,5 & & PAC & B-1 & & Vca & & 3,9 & \\
\hline PA02 & S-Ñ/C-2 & & Pal & 18,9 & 4,3 & & PAC & B-2 & & Vca & & & 9,6 \\
\hline PA02 & S-D/C-5 & D & Pmx & 8,4 & & & $\mathrm{AL}$ & M100813B06/152 & & Vca & 7,5 & 7,4 & 10,9 \\
\hline PAC & $\mathrm{S}-1 / \mathrm{N}-2 / \mathrm{C}-5$ & D & Pmx & 27,4 & & 12,9 & AL & M100810b03/078 & & Vca & 3,7 & 3,8 & 6,1 \\
\hline PA02 & S-Ñ/C-2 & D & Pmx & 40,8 & & 19,6 & $\mathrm{AL}$ & M100810b03/078 & & Vca & 6,1 & 6,3 & 8,6 \\
\hline AL & M100831B02/152 & $S$ & Pmx & 29,7 & & 13,8 & $\mathrm{AL}$ & M100831B02/152 & & Vca & 6,1 & 6,8 & \\
\hline $\mathrm{AL}$ & M100813B06/152 & D & Crh & 21,5 & 12,9 & & & & & & & & \\
\hline
\end{tabular}

\section{Diplodus sp.}

\begin{tabular}{|c|c|c|c|c|c|c|c|c|c|c|c|c|c|}
\hline Yac. & Referencia & $D / S$ & Tipo & M1 & M2 & M3 & Yac. & Referencia & $\mathrm{D} / \mathrm{S}$ & Tipo & M1 & M2 & M3 \\
\hline $\mathrm{AL}$ & M100831B02/152 & & Vca & 4 & 4,5 & 6,2 & & & & & & & \\
\hline
\end{tabular}




\section{Diplodus sargus}

\begin{tabular}{|c|c|c|c|c|c|c|c|c|c|c|c|c|c|}
\hline Yac. & Referencia & $D / S$ & Tipo & M1 & M2 & M3 & Yac. & Referencia & $D / S$ & Tipo & M1 & M2 & M3 \\
\hline$A L$ & M100727B02/078 & & $\mathrm{Fbr}$ & 4,7 & 9,9 & & $A L$ & M100810b03/078 & & $\mathrm{Vpc}$ & 5,6 & 5,4 & 7,2 \\
\hline AL & M100826B01/152-184 & & $\mathrm{Cbr}$ & 2,8 & & & $\mathrm{AL}$ & M100810b03/078 & & $\mathrm{Vpc}$ & 3,8 & 4,6 & 0 \\
\hline MO & MU040510J01/01 & & $\mathrm{Cbr}$ & 3 & & & $A L$ & MU100630B02/16 & & $\mathrm{Vpc}$ & 5,6 & 5 & 4 \\
\hline MV & Muestra 1 & & $\mathrm{Cbr}$ & & 1,5 & & MO & MU040426I01/02 & & $\mathrm{Vpc}$ & 4,4 & 4,8 & 3,1 \\
\hline MV & Muestra 1 & & $\mathrm{Cbr}$ & & 2 & & MO & MU040712J02/04 & & $\mathrm{Vpc}$ & 2,4 & 2,3 & 3,8 \\
\hline $\mathrm{MV}$ & Muestra 1 & & $\mathrm{Cbr}$ & & 1,8 & & MO & MU040712J02/03 & & $V p c$ & 2,4 & 2,2 & 4,3 \\
\hline MV & Muestra 1 & & $\mathrm{Cbr}$ & 6,6 & 1,3 & & PAC & $A-2$ & & Vca & 2,4 & 2,2 & 3,9 \\
\hline $\mathrm{MV}$ & Muestra 1 & $S$ & Cdr & & 2,8 & & $A R$ & $A-5$ & & Vca & 4,6 & 4,1 & 6,6 \\
\hline MV & Muestra 1 & & Pal & 8,8 & 1,1 & & $\mathrm{AL}$ & M100831B02/152 & & Vca & 2,8 & 3,3 & 4,5 \\
\hline MV & Muestra 1 & $S$ & Pmx & 2,4 & & 11,3 & MO & MU040426I01/06 & & Vca & 2,4 & 2,1 & 3,5 \\
\hline$A R$ & $A-5$ & & Pal & 14,3 & 2,5 & & MV & Muestra 1 & & Vca & 2,9 & 3 & 4,7 \\
\hline MO & MU040510J01/01 & $S$ & Eph & 5,3 & 4,4 & & & & & & & & \\
\hline
\end{tabular}

\section{Diplodus vulgaris}

\begin{tabular}{|c|c|c|c|c|c|c|c|c|c|c|c|c|c|}
\hline Yac. & Referencia & $D / S$ & Tipo & M1 & M2 & M3 & Yac. & Referencia & $D / S$ & Tipo & M1 & M2 & M3 \\
\hline MV & Muestra 1 & & Vca & 2,2 & 2,4 & & & & & & & & \\
\hline
\end{tabular}

\section{Pagellus acarne}

\begin{tabular}{|c|c|c|c|c|c|c|c|c|c|c|c|c|c|}
\hline Yac. & Referencia & $D / S$ & Tipo & M1 & M2 & M3 & Yac. & Referencia & $\mathrm{D} / \mathrm{S}$ & Tipo & M1 & M2 & M3 \\
\hline PAC & $\mathrm{S}-2 / \mathrm{N}-2 / \mathrm{C}-5$ & $S$ & Pmx & 22,4 & & & AR & $\mathrm{S}-7 / \mathrm{C}-8 / \mathrm{N}-3$ & & Vca & 2,8 & 2,7 & 5,2 \\
\hline$A L$ & M100827B07/184 & D & Pal & 9,8 & 2,9 & & $A R$ & S-6/C-5/N-3 & & Vca & 3,4 & 3,4 & 5,6 \\
\hline PA02 & S-G/C-2 & & $\mathrm{Vpc}$ & 1,6 & 1,9 & 3,8 & TA & S2/Conchero $1 / 3 \mathrm{R}$ & & Vca & 2,2 & 2,2 & 3,7 \\
\hline PA02 & S-G/C-2 & & $\mathrm{Vpc}$ & 2,2 & 2 & 4,7 & TA & S2/Conchero 5/1R & & Vca & & 2,8 & 5,1 \\
\hline PA02 & S-G/C-2 & & $\mathrm{Vpc}$ & 2,6 & 2,7 & 5,3 & TA & S2/Conchero 5/1R & & Vca & 2,8 & 2,7 & 5 \\
\hline PAC & $A-2$ & & $\mathrm{Vpc}$ & 2,7 & 3,1 & 5,6 & AL & M100827B04/184 & & Vca & 2,8 & 2,6 & 4,1 \\
\hline PAC & $A-1$ & & $\mathrm{Vpc}$ & 2,8 & 3 & 5,7 & $\mathrm{AL}$ & M100827B04/184 & & Vca & 3,1 & 2,8 & 4,6 \\
\hline AL & M100827B04/184 & & $\mathrm{Vpc}$ & 2,9 & 3,1 & 5,3 & $A L$ & MU100630B02/16 & & Vca & 4,6 & 3,7 & 6,1 \\
\hline AL & M100827B04/184 & & $\mathrm{Vpc}$ & 2,9 & 3,2 & 5 & $\mathrm{AL}$ & M100827B04/184 & & Vca & 2,3 & 2,6 & 4 \\
\hline $\mathrm{AL}$ & MU100630B02/16 & & $\mathrm{Vpc}$ & 3,7 & 3,5 & 5,3 & $\mathrm{AL}$ & M100827B07/184 & & Vca & 2,8 & 2,8 & \\
\hline$A L$ & M100827B04/184 & & $\mathrm{Vpc}$ & 3,3 & 5,2 & & $A L$ & M100827B07/184 & & Vca & 3,2 & 2,9 & 4,5 \\
\hline PA02 & S-G/C-2 & & Vca & 2,1 & 2,1 & 4,4 & $\mathrm{AL}$ & M100827B07/184 & & Vca & 3,1 & & 4,4 \\
\hline PA02 & S-R/C-6 & & Vca & 5,3 & 6,3 & 8,4 & $A L$ & M100827B07/184 & & Vca & 3,4 & 3,8 & 6,5 \\
\hline PAC & $\mathrm{C}-2$ & & Vca & 3,5 & 3 & & $\mathrm{AL}$ & M100827B07/184 & & Vca & 3,2 & 3,1 & 5,2 \\
\hline PAC & C-1 & & Vca & 3,1 & & 5,7 & $\mathrm{AL}$ & M100831B02/152 & & Vca & 2,6 & 2,6 & 4,2 \\
\hline
\end{tabular}

\section{Pagellus bogaraveo}

\begin{tabular}{|c|c|c|c|c|c|c|c|c|c|c|c|c|c|}
\hline Yac. & Referencia & $\mathrm{D} / \mathrm{S}$ & Tipo & M1 & M2 & M3 & Yac. & Referencia & $\mathrm{D} / \mathrm{S}$ & Tipo & M1 & M2 & M3 \\
\hline MV & Muestra 1 & $\mathrm{D}$ & Max & & 6,6 & & TA & S1/Conchero 9/2R & & Oto & 5,3 & & \\
\hline $\mathrm{AL}$ & M100827B04/184 & $S$ & Pmx & & & 4,1 & $A L$ & M100826B01/152-184 & D & Crh & 5,8 & 11,1 & \\
\hline
\end{tabular}




\begin{tabular}{|c|c|c|c|c|c|c|c|c|c|c|c|c|c|}
\hline MO & MU040510J01/03 & $\mathrm{D}$ & Pmx & & & 5,8 & $A L$ & M100827B07/184 & $S$ & Eph & 8,4 & 7 & \\
\hline $\mathrm{MV}$ & Muestra 1 & $S$ & Pmx & & & 3,3 & PAC & $A-3$ & & Vpc & 4,5 & 5 & 3,1 \\
\hline PAC & $A-1$ & $\mathrm{D}$ & $\mathrm{Cdr}$ & & 4,8 & & AR & $\mathrm{S}-7 / \mathrm{C}-8 / \mathrm{N}-3$ & & $\mathrm{Vpc}$ & 2,2 & 2,1 & 3,8 \\
\hline TA & S2/Conchero 5/3R & $S$ & $\mathrm{Cdr}$ & & 2,1 & & TA & S1/Conchero 3/1R & & $\mathrm{Vpc}$ & 2,3 & 2,2 & 3,3 \\
\hline$A L$ & M100827B04/184 & $\mathrm{S}$ & $\mathrm{Cdr}$ & & 2,1 & & TA & S2/Conchero 1/1R & & $\mathrm{Vpc}$ & 2,9 & 2,5 & 2,1 \\
\hline MV & Muestra 1 & $\mathrm{D}$ & $\mathrm{Cdr}$ & & 2,3 & & TA & S2/Conchero 5/1R & & $\mathrm{Vpc}$ & 3,8 & 3,2 & 3,1 \\
\hline AL & M100810b03/078 & $\mathrm{S}$ & $\mathrm{Hmd}$ & 10,6 & 7,6 & & AL & M100827B07/184 & & $\mathrm{Vpc}$ & 3,4 & 3,3 & 5,6 \\
\hline $\mathrm{AL}$ & M100813B06/152 & $S$ & $\mathrm{Hmd}$ & 11,4 & 7,5 & & $A L$ & M100827B07/184 & & $\mathrm{Vpc}$ & 3,3 & 3,2 & 5,1 \\
\hline AR & S-6/C-5/N-3 & $\mathrm{S}$ & Pop & & 3,9 & & $A L$ & M100827B07/184 & & $\mathrm{Vpc}$ & 3,7 & 3,3 & 4,7 \\
\hline PAC & $A-1$ & & Pal & 17,7 & 3,1 & & AL & M100827B07/184 & & $\mathrm{Vpc}$ & 3,8 & 3,7 & 3,1 \\
\hline TA & S1/Conchero 9/2R & $\mathrm{D}$ & Pal & 5,7 & 1,3 & & AL & M100827B07/184 & & $\mathrm{Vpc}$ & 2,7 & 2,5 & 4,4 \\
\hline TA & S2/Conchero 1/1R & $\mathrm{S}$ & Pal & 7,9 & 2,1 & & $A L$ & M100728B01/078 & & $\mathrm{Vpc}$ & 2,8 & 2,9 & 4,6 \\
\hline TA & S2/Conchero 5/1R & $\mathrm{D}$ & Pal & 5,3 & 1,1 & & $A L$ & MU100630B02/16 & & $\mathrm{Vpc}$ & 2,7 & 2,6 & 4,4 \\
\hline$A L$ & M100810b03/078 & $\mathrm{S}$ & Pal & 9,3 & 2,7 & & $A L$ & M100827B04/184 & & $\mathrm{Vpc}$ & 3,5 & 3,8 & 5,9 \\
\hline MV & Muestra 1 & & Pal & 4,5 & 1 & & AL & M100827B04/184 & & $\mathrm{Vpc}$ & 3,4 & 3,9 & 5,7 \\
\hline PA02 & S-K/C-4 & & Oto & 7,2 & & & AL & M100827B04/184 & & $\mathrm{Vpc}$ & 3,2 & 3,7 & 7,2 \\
\hline PAC & $\mathrm{C}-2$ & & Oto & 7,3 & & & $A L$ & M100728B01/078 & & $\mathrm{Vpc}$ & 2,5 & 2,4 & 3,9 \\
\hline PAC & $\mathrm{C}-2$ & & Oto & 7,1 & & & MV & Muestra 1 & & $\mathrm{Vpc}$ & 2,6 & 2,6 & 4,3 \\
\hline PAC & $A-2$ & & Oto & 11,5 & & & MV & Muestra 1 & & $\mathrm{Vpc}$ & & & 3,4 \\
\hline PAC & $A-1$ & & Oto & 10,4 & & & PAC & $A-2$ & & Vca & 3,2 & 3,5 & 5,3 \\
\hline PAC & $\mathrm{C}-3$ & & Vca & 3,2 & 2,7 & 5,2 & $A L$ & M100827B07/184 & & Vca & 3,6 & 3,5 & 5,4 \\
\hline PA02 & $S-R / C-6$ & & Vca & 2,1 & 1,9 & 3,4 & AL & M100827B07/184 & & Vca & 3 & 3 & 4,8 \\
\hline PA02 & $S-E / C-2$ & & Vca & 2,2 & 2,3 & 3,9 & MO & MU040510J01/01 & & Vca & 1,8 & 1,8 & 3,3 \\
\hline PA02 & $S-5 / N-2 / C-4$ & & Vca & 2,3 & 2,7 & 4,6 & MO & MU040510J01/01 & & Vca & & & 3,5 \\
\hline TA & S1/Conchero 9/1R & & Vca & 1,7 & 1,4 & 3 & MO & MU040510J01/02 & & Vca & 2,5 & 2,2 & 3,8 \\
\hline TA & S2/Conchero 1/1R & & Vca & 2,9 & & & MO & MU040510J01/03 & & Vca & 2,8 & 2,4 & \\
\hline TA & S2/Conchero 1/1R & & Vca & 1,9 & 2,1 & 2,3 & MO & MU040510J01/04 & & Vca & 2,6 & 2,6 & 3,9 \\
\hline TA & S2/Conchero 5/2R & & Vca & 2,1 & & 3,6 & MO & MU040510J01/04 & & Vca & 2,4 & 2,1 & 3,5 \\
\hline TA & S2/Conchero 5/2R & & Vca & 2,9 & 2,3 & 4 & MO & MU040712J02/01 & & Vca & 4 & 4,4 & 6,3 \\
\hline $\mathrm{AL}$ & M100827B07/184 & & Vca & 3,6 & & 6 & MO & MU040712J02/02 & & Vca & 1,9 & 2,3 & 3,6 \\
\hline$A L$ & M100827B07/184 & & Vca & 2,9 & 2,7 & 4,6 & MO & MU040712I01/02 & & Vca & 1,9 & 1,8 & \\
\hline $\mathrm{AL}$ & M100813B06/152 & & Vca & 2,8 & 2,5 & 4,1 & MO & MU040712I01/02 & & Vca & 2,5 & 2,2 & \\
\hline $\mathrm{AL}$ & M100810b03/078 & & Vca & 2,3 & 2,2 & 3,3 & MO & MU040712I01/06 & & Vca & 3 & 3,2 & \\
\hline$A L$ & M100827B04/184 & & Vca & 3,1 & 2,9 & & MO & MU040426I01/02 & & Vca & 2,5 & & \\
\hline $\mathrm{AL}$ & M100827B04/184 & & Vca & 3,1 & 3,3 & 4,1 & MO & MU040426I01/03 & & Vca & 2,4 & 2,3 & \\
\hline $\mathrm{AL}$ & M100827B04/184 & & Vca & 3 & 2,5 & 3,8 & MO & MU040426I01/03 & & Vca & 2,6 & 2,5 & 3,9 \\
\hline $\mathrm{AL}$ & M100810b03/078 & & Vca & 2,7 & 2,6 & 4 & MO & MU040629B01/01 & & Vca & 2,5 & 2,1 & 3,7 \\
\hline $\mathrm{AL}$ & M100728B01/078 & & Vca & 2,9 & 3,1 & 5,3 & MO & MU040707B02 & & Vca & 2,3 & 2,3 & 3,5 \\
\hline$A L$ & M100728B01/078 & & Vca & 2,5 & 2,4 & 4 & MV & Muestra 1 & & Vca & 1,7 & 1,4 & 2,7 \\
\hline$A L$ & M100810b03/078 & & Vca & 3,1 & 3,2 & 4,8 & MV & Muestra 1 & & Vca & 2 & 2 & \\
\hline AL & M100827B07/184 & & Vca & 3,1 & 2,9 & 4,8 & MV & Muestra 1 & & Vca & 2,9 & 2,9 & 4,7 \\
\hline AL & M100810b03/078 & & Vca & 2,5 & 2,6 & 3,2 & MV & Muestra 1 & & Vca & 2,7 & 2,7 & 4,4 \\
\hline AL & M100827B07/184 & & Vca & 3,2 & & 5,2 & MV & Muestra 1 & & Vca & 3,8 & 3,8 & 6,3 \\
\hline$A L$ & M100827B07/184 & & Vca & 3,1 & 3,1 & 4,5 & & & & & & & \\
\hline
\end{tabular}




\section{Labrus bergylta}

\begin{tabular}{|c|c|c|c|c|c|c|c|c|c|c|c|c|c|}
\hline Yac. & Referencia & $D / S$ & Tipo & M1 & M2 & M3 & Yac. & Referencia & $D / S$ & Tipo & M1 & M2 & M3 \\
\hline PA02 & $S-R / C-6$ & & Art & 21,7 & 19,8 & & PAC & $\mathrm{S}-1 / \mathrm{N}-4 / \mathrm{C}-5$ & & $\mathrm{Cbr}$ & 34,5 & & \\
\hline PA02 & $\mathrm{S}-5 / \mathrm{N}-2 / \mathrm{C}-4$ & D & Max & 33,8 & 13 & & PAC & $\mathrm{S}-1 / \mathrm{N}-2 / \mathrm{C}-5$ & & $\mathrm{Cbr}$ & 33,2 & & \\
\hline PA02 & S-Ñ/C-2 & D & Max & 40,6 & 10,4 & & PAC & $S-1 / N-2 / C-5$ & & $\mathrm{Cbr}$ & 48 & & \\
\hline PAC & S-1/N-2/C-5 & D & Pmx & & 47,3 & 17,4 & PA02 & $\mathrm{S}-4 / \mathrm{N}-2 / \mathrm{C}-3$ & & $\mathrm{Cbr}$ & 16,1 & & \\
\hline PA02 & $S-R / C-6$ & $S$ & Pmx & & 36 & 12,7 & PAC & $A-2$ & & $\mathrm{Cbr}$ & 21,1 & 35,9 & \\
\hline PA02 & S-Ñ/C-2 & $S$ & Pmx & 24,7 & & & PAC & $\mathrm{S}-1 / \mathrm{N}-2 / \mathrm{C}-5$ & & $\mathrm{Cbr}$ & 51,4 & & \\
\hline PA02 & $S-R / C-6$ & $S$ & Pmx & 23,1 & 32,4 & 11,6 & PAC & B-2 & & $\mathrm{Cbr}$ & 19,3 & & \\
\hline PA02 & $S-3 / C-3$ & $S$ & Pmx & 29,2 & & 16,4 & PAC & $A-2$ & & $\mathrm{Cbr}$ & 15,9 & 25,3 & \\
\hline PAC & $A-2$ & $S$ & Pmx & & 34,3 & 12,4 & PAC & $A-2$ & & $\mathrm{Cbr}$ & 18 & & \\
\hline PAC & $A-2$ & D & $\mathrm{Hmd}$ & 14,3 & 12,6 & & PAC & B-2 & & $\mathrm{Cbr}$ & & 28,2 & \\
\hline PA02 & $\mathrm{S}-8 / \mathrm{N}-3 / \mathrm{C}-8$ & D & $\mathrm{Hmd}$ & 15,2 & 13,2 & & PA02 & S-W/C-4 & & $\mathrm{Cbr}$ & & 37,4 & \\
\hline PAC & $\mathrm{S}-1 / \mathrm{N}-2 / \mathrm{C}-5$ & $\mathrm{D}$ & $\mathrm{Hmd}$ & 14,4 & 10,3 & 28,6 & PAC & $\mathrm{S}-1 / \mathrm{N}-2 / \mathrm{C}-5$ & & $\mathrm{Cbr}$ & 34,9 & & \\
\hline $\mathrm{AL}$ & M100827B04/184 & $S$ & $\mathrm{Hmd}$ & 9 & 6 & & PAC & $\mathrm{S}-1 / \mathrm{N}-2 / \mathrm{C}-5$ & & $\mathrm{Cbr}$ & 47,8 & & \\
\hline$A L$ & M100827B07/184 & $S$ & $\mathrm{Hmd}$ & 16 & 10,3 & & PAC & $\mathrm{S}-1 / \mathrm{N}-2 / \mathrm{C}-5$ & & $\mathrm{Cbr}$ & 21,1 & & \\
\hline PAC & $A-2$ & $\mathrm{D}$ & Pop & & 8,8 & & PA02 & S-F/C-3 & & $\mathrm{Cbr}$ & & 43,1 & \\
\hline$A L$ & M100831B02/152 & D & Pop & & 8,9 & & PA02 & S-K/C-4 & & $\mathrm{Cbr}$ & & 25,9 & \\
\hline PA02 & S-G/C-3 & & $\mathrm{Fbr}$ & 18,3 & 9,6 & & PA02 & S-Ñ/C-2 & & $\mathrm{Cbr}$ & & 34,7 & \\
\hline PAC & B-1 & & $\mathrm{Fbr}$ & 8,7 & 10,2 & & PA02 & $\mathrm{S}-\mathrm{H} / \mathrm{C}-2$ & & $\mathrm{Cbr}$ & 22,2 & 37,9 & \\
\hline PA02 & $S-5 / N-2 / C-3$ & & $\mathrm{Fbr}$ & 15,9 & 16,5 & & PA02 & $S-R / C-5$ & & $\mathrm{Cbr}$ & & 42,4 & \\
\hline PAC & $A-2$ & & $\mathrm{Fbr}$ & 14,9 & 10 & & PAC & $C-2$ & $S$ & Eph & 11,6 & 8,2 & \\
\hline PAC & $A-2$ & & $\mathrm{Cbr}$ & 18,4 & 30,6 & & PAC & $A-2$ & & Eph & 15,3 & 8,1 & \\
\hline PA02 & $\mathrm{S}-2 / \mathrm{N}-2 / \mathrm{C}-3$ & & $\mathrm{Cbr}$ & & 36,5 & & $\mathrm{AL}$ & M100827B07/184 & D & Eph & 10,5 & 9,3 & \\
\hline$A L$ & M100827B04/184 & $\mathrm{D}$ & Eph & 6,9 & 5,3 & & PAC & $A-3$ & & Vca & 3,8 & 4,3 & \\
\hline$A L$ & M100728B01/078 & $S$ & Eph & 11 & 8,4 & & PAC & B-2 & & Vca & 3,8 & 3,6 & 4,1 \\
\hline$A L$ & M100827B04/184 & $\mathrm{D}$ & Crh & & 6,7 & & PAC & $C-2$ & & Vca & 4,5 & 4,2 & 4,6 \\
\hline PAC & $A-2$ & $S$ & $\mathrm{Cdr}$ & & 6,9 & & PAC & $\mathrm{C}-2$ & & Vca & 3,6 & & \\
\hline$A L$ & M100827B04/184 & $\mathrm{D}$ & $\mathrm{Cdr}$ & & 4,8 & & PA02 & S-Ñ/C-2 & & Vca & 3,5 & 3,3 & 3,6 \\
\hline PAC & $A-2$ & & Pal & 9,7 & 1,6 & & PAC & $C-2$ & & Vca & 4,7 & 5,1 & 5,1 \\
\hline PAC & $A-2$ & $\mathrm{D}$ & Pal & 15 & 2,8 & & $A L$ & M100827B07/184 & & Vca & 5,4 & 5,4 & 5,9 \\
\hline$A R$ & $\mathrm{~S}-7 / \mathrm{C}-8 / \mathrm{N}-3$ & & Pal & 7,8 & 1,7 & & $\mathrm{AL}$ & M100804B03/064 & & Vca & 4,4 & 4,4 & 4,3 \\
\hline$A L$ & M100728B01/078 & $\mathrm{D}$ & Pal & 11,9 & 2,5 & & $A L$ & M100810b03/078 & & Vca & 2,4 & 2,2 & 2,7 \\
\hline$A L$ & M100813B06/152 & $\mathrm{S}$ & Pal & 10,4 & 2,2 & & $A L$ & M100810b03/078 & & Vca & 6,2 & 6,9 & 6,3 \\
\hline PAC & B-2 & & $\mathrm{Vpc}$ & 6,1 & 5,8 & 2,9 & $A L$ & M100810b03/078 & & Vca & 2,4 & 2,4 & 2,6 \\
\hline PAC & $B-2$ & & Vpc & 7,6 & 8,7 & 6,4 & $A L$ & M100728B01/078 & & Vca & 3 & 3 & 3,4 \\
\hline PAC & $A-2$ & & Vpc & 10,3 & 9,4 & 4,4 & $A L$ & M100728B01/078 & & Vca & 2,7 & 2,3 & 3 \\
\hline PAC & $A-2$ & & $\mathrm{Vpc}$ & 10,7 & 10,6 & 4,8 & $A L$ & M100827B07/184 & & Vca & 3,6 & 3,4 & 4,1 \\
\hline PAC & $A-2$ & & $\mathrm{Vpc}$ & 9,7 & 9,8 & 5,8 & $A L$ & М100827B07/184 & & Vca & 3,6 & 3,4 & 4 \\
\hline PAC & $A-2$ & & Vpc & 4,9 & 4,8 & 3,9 & $A L$ & M100827B07/184 & & Vpc & 4 & 3,6 & 2,5 \\
\hline PAC & $A-2$ & & Vpc & 4,4 & 4,7 & 4,6 & $A L$ & M100827B07/184 & & $\mathrm{Vpc}$ & 4,8 & 5,3 & 3,3 \\
\hline PAC & $C-1$ & & $\mathrm{Vpc}$ & & 3,8 & 3,4 & $A L$ & M100827B07/184 & & $\mathrm{Vpc}$ & 4 & 3,5 & 2,7 \\
\hline PAC & $C-2$ & & Vpc & 4,8 & 5,8 & 4,9 & $A L$ & M100827B04/184 & & Vpc & 3 & 3,3 & 3,1 \\
\hline PA02 & $\mathrm{S}-5 / \mathrm{N}-2 / \mathrm{C}-4$ & & Vpc & 2,6 & 2,9 & 2,4 & $A L$ & M100827B04/184 & & Vpc & 3,1 & 3,3 & 3,2 \\
\hline
\end{tabular}




\begin{tabular}{|c|c|c|c|c|c|c|c|c|c|c|c|}
\hline PA02 & S-D/C-5 & Vpc & 11,6 & 10,9 & 7,6 & $\mathrm{AL}$ & M100810b03/078 & $\mathrm{Vpc}$ & 7,1 & 6,4 & 4,5 \\
\hline PA02 & $S-R / C-6$ & Vpc & 7,7 & 7,9 & 6 & $A L$ & M100810b03/078 & Vca & 3,4 & 3,3 & 3,6 \\
\hline PAC & B-1 & Vpc & & 8,4 & 4,1 & $A L$ & M100827B07/184 & Vca & 5,5 & 5,7 & 5,8 \\
\hline $\mathrm{AL}$ & M100827B07/184 & Vpc & 7,1 & 6,5 & 5,3 & $A L$ & M100827B07/184 & Vca & 6,3 & 6,7 & 6,6 \\
\hline$A L$ & M100831B02/152 & Vpc & 4,9 & 5,8 & 5,2 & $A L$ & M100827B07/184 & Vca & 5,6 & 5,8 & 6 \\
\hline $\mathrm{AL}$ & M100831B02/152 & Vpc & 3,3 & 3,3 & 3,5 & $A L$ & M100831B02/152 & Vca & 3,9 & 3,9 & 3,9 \\
\hline $\mathrm{AL}$ & M100827B04/184 & Vpc & 5,3 & 5,9 & 5,6 & $A L$ & M100831B02/152 & Vca & 3,9 & 3,9 & 4,1 \\
\hline $\mathrm{AL}$ & M100827B04/184 & Vpc & 5,9 & 6,2 & 6 & $A L$ & M100831B02/152 & Vca & 5,1 & 5,5 & 5,5 \\
\hline$A L$ & M100728B01/078 & Vpc & 6 & 5,5 & 4,1 & $A L$ & M100827B07/184 & Vca & 4,4 & 4,3 & 4,7 \\
\hline $\mathrm{AL}$ & M100728B01/078 & Vpc & 5,2 & 5,2 & 5,3 & $A L$ & M100827B04/184 & Vca & 3 & & 3,6 \\
\hline $\mathrm{AL}$ & M100827B04/184 & Vpc & 6 & 6,5 & & $A L$ & M100827B04/184 & Vca & & & 3,2 \\
\hline $\mathrm{AL}$ & M100827B04/184 & Vpc & 3,9 & 4 & 3,7 & $A L$ & M100827B04/184 & Vca & 3,1 & 2,8 & 3,2 \\
\hline $\mathrm{AL}$ & M100827B07/184 & Vpc & 8,3 & 9,2 & 5,6 & $\mathrm{AL}$ & M100827B04/184 & Vca & 2,9 & 2,8 & 3,2 \\
\hline $\mathrm{AL}$ & M100827B07/184 & Vpc & 7,2 & 7,3 & 4,6 & $A L$ & M100827B04/184 & Vca & 3,4 & 3,1 & 3,9 \\
\hline $\mathrm{AL}$ & M100827B07/184 & Vpc & 7,9 & 7,7 & 4,5 & $\mathrm{AL}$ & M100827B04/184 & Vca & 3,4 & 3,5 & 3,8 \\
\hline$A L$ & M100810b03/078 & Vpc & 7,2 & 7,7 & 4,7 & $A L$ & M100827B04/184 & Vca & 3,6 & 3,6 & 3,9 \\
\hline $\mathrm{AL}$ & M100827B04/184 & Vpc & 2,9 & 3,1 & 3,1 & $A L$ & M100810b03/078 & Vca & 6,1 & 6,7 & 6,2 \\
\hline $\mathrm{AL}$ & M100827B07/184 & Vpc & 6,5 & 6,8 & 6 & $A L$ & M100827B04/184 & Vca & 2,8 & 2,7 & 3,2 \\
\hline MO & MU040712I01/03 & Vpc & 5 & & 3,3 & $A L$ & M100813B06/152 & Vca & 5,9 & 6,8 & \\
\hline MO & MU040712J02/03 & Vpc & 6 & 5,3 & 4,2 & $A L$ & M100827B04/184 & Vca & 3,2 & 3 & 3,8 \\
\hline PAC & $A-2$ & Vca & 6,2 & 6,5 & 6,6 & $A L$ & M100827B04/184 & Vca & 3,1 & 2,9 & 3,2 \\
\hline PAC & $A-2$ & Vca & 5,3 & 5,4 & 5,5 & $A L$ & M100827B04/184 & Vca & 4,2 & 4,1 & 4,3 \\
\hline PAC & $A-2$ & Vca & 4,4 & 4,2 & 4,7 & $\mathrm{AL}$ & M100827B04/184 & Vca & 2,9 & 2,7 & 3,2 \\
\hline PAC & $A-2$ & Vca & 4,6 & 4,4 & 4,8 & $A L$ & M100827B04/184 & Vca & 3 & 2,8 & 3,2 \\
\hline PAC & $A-2$ & Vca & 4,5 & 4,5 & 5 & $A L$ & M100827B04/184 & Vca & 3,3 & 3,1 & 3,8 \\
\hline PAC & $A-2$ & Vca & 4 & 3,7 & 4,2 & MO & MU040712I01/05 & Vca & 4,6 & 4,4 & 4,4 \\
\hline PAC & $A-2$ & Vca & 3,3 & 3 & 3,2 & & & & & & \\
\hline
\end{tabular}

\section{Symphodus melops}

\begin{tabular}{|c|c|c|c|c|c|c|c|c|c|c|c|c|c|}
\hline Yac. & Referencia & $D / S$ & Tipo & M1 & M2 & M3 & Yac. & Referencia & $D / S$ & Tipo & M1 & M2 & M3 \\
\hline$A L$ & M100827B07/184 & $S$ & Dnt & 6,6 & 3,9 & 1,8 & PA02 & S-G/C-2 & & Vca & 1,5 & 1,3 & 1,6 \\
\hline PA02 & S-G/C-2 & $S$ & Pmx & & & 2,1 & PA02 & S-Ñ/C-2 & & Vca & 2,2 & 2,1 & 2,5 \\
\hline PA02 & S-G/C-2 & $S$ & $\mathrm{Cdr}$ & 5,6 & 1,2 & & PA02 & S-Ñ/C-2 & & Vca & 2,5 & 2,4 & 3,1 \\
\hline AL & M100827B07/184 & D & Eph & 4,8 & 3,2 & & $A L$ & M100827B07/184 & & Vca & 2,3 & 2,2 & 3,1 \\
\hline AL & M100827B04/184 & D & Eph & 4,7 & 5,4 & & $A L$ & M100827B07/184 & & Vca & 2,2 & 2 & 2,8 \\
\hline $\mathrm{AL}$ & M100826B01/152-184 & $S$ & $\mathrm{Hmd}$ & 5,5 & 3,6 & & $A L$ & M100827B07/184 & & Vca & 2,1 & 2 & 2,7 \\
\hline$A L$ & M100827B07/184 & & $\mathrm{Cbr}$ & & 13,3 & & $\mathrm{AL}$ & M100827B07/184 & & Vca & 2,8 & 2,4 & 3,3 \\
\hline AL & M100827B07/184 & & $\mathrm{Cbr}$ & & 13,6 & & $A L$ & M100827B07/184 & & Vca & 2,1 & 2 & 2,6 \\
\hline AL & M100810b03/078 & & $\mathrm{Cbr}$ & 8,5 & 10,5 & & AL & M100827B07/184 & & Vca & 2 & 1,9 & 2,4 \\
\hline AL & M100831B02/152 & & $\mathrm{Cbr}$ & & 15,2 & & $\mathrm{AL}$ & M100810b03/078 & & Vca & 1,8 & 1,8 & 2,4 \\
\hline AL & M100827B07/184 & & $\mathrm{Vpc}$ & 2,4 & 2,8 & 3,5 & $A L$ & M100810b03/078 & & Vca & 1,9 & 1,9 & 2,4 \\
\hline AL & М100827B07/184 & & $\mathrm{Vpc}$ & 2,1 & 2,1 & 1,7 & $\mathrm{AL}$ & M100827B07/184 & & Vca & 1,9 & 1,7 & 2,3 \\
\hline$A L$ & M100827B07/184 & & $\mathrm{Vpc}$ & 2,8 & 2,4 & 2,6 & $A L$ & M100827B07/184 & & Vca & 2,7 & 2,4 & 3,3 \\
\hline $\mathrm{AL}$ & M100827B07/184 & & $\mathrm{Vpc}$ & 2,7 & 2,7 & 2,6 & $\mathrm{AL}$ & M100827B04/184 & & Vca & 2,7 & 2,5 & 3,1 \\
\hline
\end{tabular}




\begin{tabular}{|c|c|c|c|c|c|c|c|c|c|c|c|}
\hline AL & M100827B07/184 & Vpc & 2,8 & 2,7 & 3,2 & $\mathrm{AL}$ & M100827B07/184 & Vca & 2,1 & 2 & 2,6 \\
\hline AL & M100827B07/184 & Vpc & 3,1 & 2,9 & 3,4 & $\mathrm{AL}$ & M100827B07/184 & Vca & 1,9 & 1,8 & 2,5 \\
\hline$A L$ & M100827B07/184 & Vpc & 3,6 & 3,9 & 3,3 & $\mathrm{AL}$ & M100827B07/184 & Vca & 3,3 & 3,3 & 3,9 \\
\hline $\mathrm{AL}$ & M100827B07/184 & Vpc & 3,3 & 3,6 & 3,7 & $\mathrm{AL}$ & M100827B07/184 & Vca & 3,2 & 3,4 & 4 \\
\hline $\mathrm{AL}$ & M100810b03/078 & Vpc & 2,8 & 2,8 & 3,3 & $\mathrm{AL}$ & M100827B07/184 & Vca & 3,6 & 3,4 & 4 \\
\hline AL & M100831B02/152 & Vpc & 3 & 3,3 & 3,3 & $\mathrm{AL}$ & M100810b03/078 & Vca & 2,4 & 2,3 & 3 \\
\hline AL & M100826B01/152-184 & Vpc & 3,1 & 3,1 & 4 & $\mathrm{AL}$ & M100813B06/152 & Vca & 2,5 & 2,6 & 3,5 \\
\hline $\mathrm{AL}$ & M100827B07/184 & Vpc & 2,8 & 2,8 & 3,5 & $\mathrm{AL}$ & MU100630B02/16 & Vca & 2,1 & 2 & 2,8 \\
\hline $\mathrm{AL}$ & M100827B04/184 & Vpc & 2,3 & 2,1 & 2,8 & $\mathrm{AL}$ & MU100630B02/16 & Vca & 1,9 & 1,7 & 2,3 \\
\hline $\mathrm{AL}$ & M100826B01/183 & Vpc & 1,8 & 2,1 & 1,8 & $\mathrm{AL}$ & M100727B02/078 & Vca & 2,6 & 2,1 & 2,9 \\
\hline $\mathrm{AL}$ & M100728B01/078 & Vpc & 1,3 & 1,3 & 1,5 & $\mathrm{AL}$ & M100728B01/078 & Vca & 2,4 & 2,4 & 3,5 \\
\hline $\mathrm{AL}$ & M100728B01/078 & Vpc & 2,6 & 2,7 & 3,5 & $\mathrm{AL}$ & M100728B01/078 & Vca & 2,9 & 2,9 & 3,6 \\
\hline $\mathrm{AL}$ & M100728B01/078 & Vpc & 2 & 2 & 2,6 & $\mathrm{AL}$ & M100728B01/078 & Vca & 2,7 & 2,5 & 3,4 \\
\hline$A L$ & M100813B06/152 & Vpc & 2,3 & 2,3 & 2,7 & $\mathrm{AL}$ & M100728B01/078 & Vca & 2,2 & 2,1 & 2,7 \\
\hline $\mathrm{AL}$ & M100813B06/152 & Vpc & 3,2 & 3,1 & 3 & $\mathrm{AL}$ & M100728B01/078 & Vca & 2,9 & 3,1 & 3,6 \\
\hline$A L$ & M100827B04/184 & Vpc & 2,3 & 2,2 & 2,8 & $\mathrm{AL}$ & M100827B07/184 & Vca & 2,7 & 2,8 & 3,4 \\
\hline AL & M100827B04/184 & Vpc & 2,6 & 2,7 & 3,5 & $\mathrm{AL}$ & M100813B06/152 & Vca & 2,1 & 1,7 & 2,4 \\
\hline$A L$ & M100827B04/184 & Vpc & 2,2 & 2,1 & 2,9 & $\mathrm{AL}$ & M100831B02/152 & Vca & 2,4 & 2,4 & 3,1 \\
\hline AL & M100810b03/078 & Vpc & 3,3 & 4,2 & 4,4 & $\mathrm{AL}$ & M100813B06/152 & Vca & 2,3 & 2,3 & 3,1 \\
\hline$A L$ & M100827B04/184 & Vpc & 3,4 & 3,3 & 3,3 & $\mathrm{AL}$ & M100831B02/152 & Vca & & & 3,5 \\
\hline AL & M100810b03/078 & Vpc & 3,6 & 4,4 & 4,3 & $\mathrm{AL}$ & M100827B07/184 & Vca & 2,1 & 1,9 & 2,5 \\
\hline$A L$ & M100827B04/184 & Vpc & 2,7 & 2,9 & 3,4 & $\mathrm{AL}$ & M100827B04/184 & Vca & 2,1 & 2,1 & 2,9 \\
\hline $\mathrm{AL}$ & M100827B04/184 & Vpc & 2,4 & 2,5 & 1,8 & $\mathrm{AL}$ & M100827B04/184 & Vca & 2,5 & 2,1 & 3 \\
\hline$A L$ & M100827B04/184 & Vpc & 2,7 & 2,3 & 1,8 & $\mathrm{AL}$ & M100827B04/184 & Vca & 2,4 & 2,3 & 2,9 \\
\hline$A L$ & M100810b03/078 & Vpc & 1,4 & 1,5 & 1,5 & $\mathrm{AL}$ & M100813B06/152 & Vca & 2,4 & 2,2 & 2,8 \\
\hline AL & M100810b03/078 & Vpc & 2,4 & 2,6 & 3 & $\mathrm{AL}$ & M100831B02/152 & Vca & 2,8 & 2,7 & 3,3 \\
\hline $\mathrm{AL}$ & M100722B02/078 & Vpc & 2,9 & 2,7 & 2,9 & $\mathrm{AL}$ & M100827B04/184 & Vca & & & 2,2 \\
\hline AL & M100810b03/078 & Vpc & 2,3 & 2,3 & 3,1 & $\mathrm{AL}$ & M100827B04/184 & Vca & 2 & 1,9 & 2,6 \\
\hline $\mathrm{AL}$ & M100727B02/078 & Vpc & 2,9 & 3 & 3,8 & $\mathrm{AL}$ & M100827B04/184 & Vca & 2,2 & 2 & 2,7 \\
\hline$A L$ & M100810b03/078 & Vpc & 3,9 & 4,1 & 4,1 & $\mathrm{AL}$ & M100827B04/184 & Vca & 2,1 & 2,5 & 2,7 \\
\hline AL & M100827B04/184 & Vpc & 3,4 & 2,2 & 2,9 & & & & & & \\
\hline
\end{tabular}

Scomber scombrus

\begin{tabular}{|c|c|c|c|c|c|c|c|c|c|c|c|c|c|}
\hline Yac. & Referencia & $D / S$ & Tipo & M1 & M2 & M3 & Yac. & Referencia & $D / S$ & Tipo & M1 & M2 & M3 \\
\hline MO & MU040806B01 & D & $\mathrm{Hmd}$ & 7,9 & & & MO & MU040510J01/03 & & Vca & 3,1 & 3,3 & 4,8 \\
\hline $\mathrm{AL}$ & M100813B06/152 & & $\mathrm{Vpc}$ & 3,2 & 3,3 & 6,2 & MO & MU040510J01/01 & & Vca & 3,2 & 3,3 & 5,4 \\
\hline PA02 & S-Ñ/C-2 & & Vca & 4,8 & 6,1 & 9,9 & $\mathrm{MV}$ & Muestra 1 & & Vca & 2,7 & 3 & \\
\hline PAC & B-1 & & Vca & & & 4,9 & & & & & & & \\
\hline
\end{tabular}

\section{Scomber japonicus}

\begin{tabular}{|c|c|c|c|c|c|c|c|c|c|c|c|c|c|}
\hline Yac. & Referencia & $D / S$ & Tipo & M1 & M2 & M3 & Yac. & Referencia & $D / S$ & Tipo & M1 & M2 & M3 \\
\hline PAC & B-2 & D & $\mathrm{Hmd}$ & 15,4 & 11,2 & & PAC & $\mathrm{S}-1 / \mathrm{N}-2 / \mathrm{C}-5$ & & Vca & 11,2 & 13,1 & 18,3 \\
\hline PA02 & S-G/C-5 & & Vpc & 2,8 & 3,2 & & PAC & A-3 & & Vca & 5,7 & & 9,2 \\
\hline
\end{tabular}




\begin{tabular}{|c|c|c|c|c|c|c|c|c|c|c|c|}
\hline PA02 & $\mathrm{S}-\mathrm{O} / \mathrm{C}-2$ & Vpc & 3,5 & 3,5 & 6,6 & PAC & $A-1$ & Vca & 4,3 & 3,1 & \\
\hline PAC & $N-3 / C-4$ & Vpc & 3,7 & 3,6 & 7,1 & PAC & $A-1$ & Vca & 3,5 & 4 & 6,5 \\
\hline PAC & $\mathrm{C}-3$ & Vpc & 3,2 & 3,5 & 5,2 & $\mathrm{AL}$ & M100813B06/152 & Vca & & & 5,3 \\
\hline PAC & $C-2$ & Vpc & 4,4 & 5,1 & 8,7 & AL & M100813B06/152 & Vca & 3,3 & 3,6 & \\
\hline PAC & B-1 & Vpc & 3,4 & 3,7 & 6,6 & $A L$ & M100827B07/184 & Vca & & & 6,8 \\
\hline PAC & B-1 & Vpc & 3,2 & 3,5 & & $A L$ & M100827B07/184 & Vca & 4,4 & & 6,6 \\
\hline PAC & B-1 & Vpc & 3,2 & 3,8 & 6,3 & AL & M100827B07/184 & Vca & 3,9 & & 6,4 \\
\hline $\mathrm{AL}$ & M100810b03/078 & Vpc & 2,7 & 2,9 & & $\mathrm{AL}$ & M100831B02/152 & Vca & & & 5,9 \\
\hline \multirow[t]{2}{*}{$\mathrm{AL}$} & M100826B01/152-184 & Vpc & 3,8 & 4,1 & 6,7 & AL & M100826B01/152-184 & Vca & 3,8 & 4 & 7,8 \\
\hline & & & & & & MV & Muestra 1 & Vca & 3,2 & 3,1 & \\
\hline
\end{tabular}

\section{Trigla lyra}

\begin{tabular}{|c|c|c|c|c|c|c|c|c|c|c|c|c|c|}
\hline Yac. & Referencia & $D / S$ & Tipo & M1 & M2 & M3 & Yac. & Referencia & $D / S$ & Tipo & M1 & M2 & M3 \\
\hline$A R$ & $\mathrm{~S}-6 / \mathrm{C}-5 / \mathrm{N}-3$ & $D$ & Dnt & & & 5,7 & AR & S-6/C-5/N-3 & D & Max & & & 8,6 \\
\hline$A R$ & $\mathrm{~S}-6 / \mathrm{C}-5 / \mathrm{N}-3$ & $D$ & $\mathrm{Hmd}$ & 15,1 & 9,1 & 39,4 & AR & S-6/C-5/N-3 & & $\mathrm{Vpc}$ & 5 & 5,5 & 5,3 \\
\hline$A R$ & $\mathrm{~S}-6 / \mathrm{C}-5 / \mathrm{N}-3$ & D & Opc & & & 5,6 & $A R$ & S-6/C-5/N-3 & & Vpc & 4,9 & 5,6 & 5,3 \\
\hline$A R$ & $\mathrm{~S}-6 / \mathrm{C}-5 / \mathrm{N}-3$ & $\mathrm{D}$ & Opc & & & 4,6 & AR & S-6/C-5/N-3 & & $V p c$ & 4,5 & 5,2 & 5,6 \\
\hline
\end{tabular}

Salmo sp.

\begin{tabular}{|c|c|c|c|c|c|c|c|c|c|c|c|c|c|}
\hline Yac. & Referencia & $D / S$ & Tipo & M1 & M2 & M3 & Yac. & Referencia & $D / S$ & Tipo & M1 & M2 & M3 \\
\hline PAC & B-1 & & Vpc & & 4,3 & 4,3 & & & & & & & \\
\hline
\end{tabular}

\section{Ammodytidae}

\begin{tabular}{|c|c|c|c|c|c|c|c|c|c|c|c|c|c|}
\hline Yac. & Referencia & $D / S$ & Tipo & M1 & M2 & M3 & Yac. & Referencia & $D / S$ & Tipo & M1 & M2 & M3 \\
\hline AL & M100810b03/078 & & Vpc & & 2,7 & 3,8 & TA & S2/Conchero 5/3R & & Vpc & 1,7 & 1,8 & 3 \\
\hline $\mathrm{AL}$ & M100810b03/078 & & Vpc & & 2,7 & 3,3 & & & & & & & \\
\hline
\end{tabular}


